\title{
Classification of Vegetation
}

\section{on the Nevada Test Site}

\section{WORK PERFORMED UNDER \\ CONTRACT NO. DE-AC08-96NV11718}

\section{Submitted to}

U.S. Department of Energy

Nevada Operations Office

Environment, Safety, and Health Division

P.O. Box 98518

Las Vegas, NV 89193-8518

Prepared by

Bechtel Nevada Ecological Services

P.O. Box 98521

Las Vegas, Nevada 89193-8521

December 2000 


\section{DISCLAIMER STATEMENT}

Reference herein to any specific commercial product, process, or service by trade name, trademark, manufacture, or otherwise does not necessarily constitute or imply its endorsement, recommendation, or favoring by the U.S. Government or any agency thereof or its contractors or subcontractors.

\section{AVAILABILITY STATEMENT}

Available for sale to the public from:

U.S. Department of Commerce

National Technical Information Service

5285 Port Royal Road

Springfield, VA 22161-0002

Telephone: 800-553-8647 or 703-487-4650.

Fax: 703-605-6900

E-mail: orders@ntis.fedworld.gov

Online ordering: http://www.doe.gov/bridge

Available for a processing fee to U.S. Department of Energy and its contractors, in paper, from:

U.S. Department of Energy

Office of Scientific and Technical Information

P.O. Box 62

Oak Ridge, TN 37831-0062

Telephone: 865-576-8401

Fax: 865-576-5728

E-mail: reports@adonis.osti.gov 


\title{
Classification of Vegetation on the Nevada Test Site
}

By

\author{
W. Kent Ostler \\ Dennis J. Hansen \\ David C. Anderson \\ Derek B. Hall
}

December 6, 2000

WORK PERFORMED UNDER

CONTRACT NO. DE-AC08-96NV11718

Submitted to

U.S. Department of Energy

Nevada Operations Office

Environment, Safety, and Health Division

P.O. Box 98518

Las Vegas, NV 89193-8518 


\section{ACKNOWLEDGMENTS}

Robert Furlow of the U.S. Department of Energy, Nevada Operations Office, Las Vegas, provided support and encouragement for the project.

Prior work and herbarium specimens by Janice Beatley were instrumental in guiding the mapping efforts and helpful in identifying and describing plant species found on the Nevada Test Site.

Brad W. Schultz, Desert Research Institute, Reno, Nevada, performed vegetation sampling on portions of Area 15 on the Nevada Test Site adjacent to Nellis Air Force Range complex.

Bechtel Nevada scientists and staff who contributed to this report were: Cathy A. Wills, Paul D. Greger, Ashley V. Housewright, James Beckett, Sr., and Camilla Deckert.

R. Brent Colledge, Applied Ecological Services, Logan, Utah, provided assistance with Geographic Information Systems scripts for ArcView ${ }^{\mathrm{TM}}$.

Numerous technicians that assisted with collection of field data. 


\section{CONTENTS}

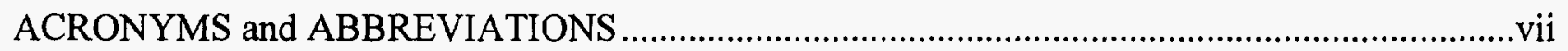

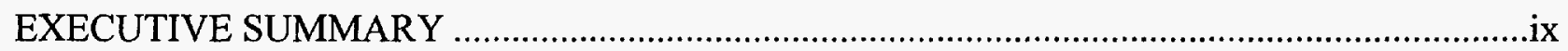

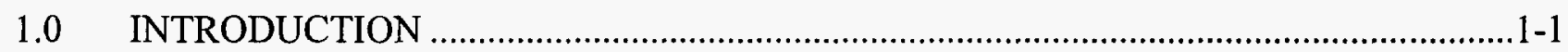

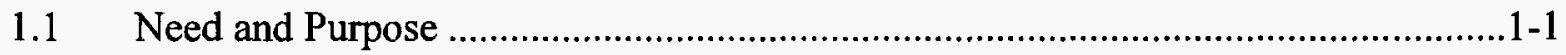

1.2 Goals and Objectives ............................................................................... $1-2$

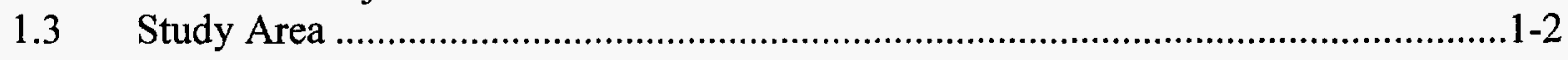

2.0 LITERATURE REVIEW .......................................................................

2.1 Previous Classifications of NTS Vegetation............................................2-1

2.1.1 1957 Vegetation Classification ...................................................2-1

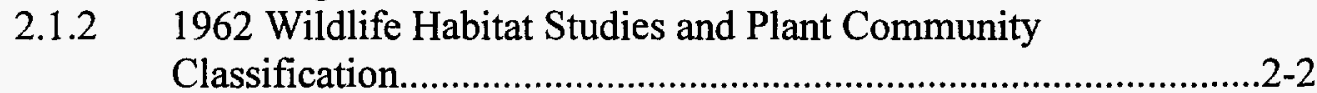

2.1.3 1976 Vegetation Classification .................................................2-2

2.1.4 1999 Vegetation Classification of Yucca Mountain Area ..............2-6

2.2 Vegetation Studies on the NTS ............................................................

2.2.1 Past Climatic Vegetation Changes.............................................2-6

2.2.2 Nevada Applied Ecological Group Studies .................................2-8

2.2.3 Basic Environmental Compliance and Monitoring Program Studies (BECAMP)............................................................2-8

2.2.4 Endangered and Threatened Species Studies................................2-8

2.2.5 Wetland Studies ..................................................................2-9

2.3 Vegetation Classification in the Western United States .............................2-9

2.3.1 Vegetation in Deserts is Strongly Influenced by Water and Soils............................................................................2-12

2.3.2 Soil Surveys Help Identify Plant Communities ...........................2-12

2.3.3 Landforms Are Correlated With Soil Types................................2-13

2.3.4 Ecological Landform Units..................................................2-13

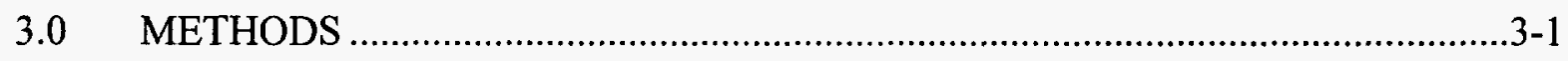

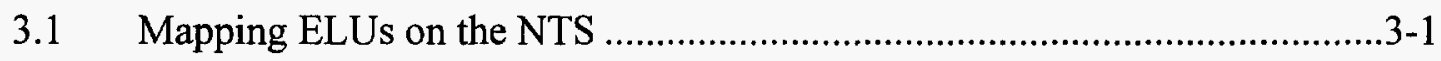

3.1.1 Geographic Information System Techniques ..............................3-1

3.1.2 Image Analysis............................................................... $3-5$ 


\section{CONTENTS}

3.2 Plant Identification............................................................................ 3-5

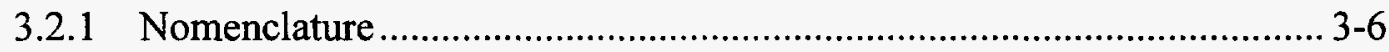

3.2.2 Voucher Specimens …………........................................................... 3-6

3.3 Field Survey Techniques......................................................................... 3-6

$3.4 \quad$ Laboratory Soil Analyses.......................................................................... 3-7

3.5 Statistical Data Analyses............................................................................ 3-7

3.6 Tabular Data Management..................................................................... 3-8

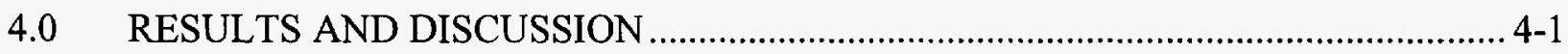

4.1 Vegetation Cluster Analyses........................................................................... 4-1

4.2 Distribution and Description of Plant Alliances ............................................. 4-1

4.2.1 Mojave Desert............................................................................... 4-6

4.2.1.1 Lycium shockleyi-Lycium pallidum Shrubland Alliance .......................................................................... 4-6

4.2.1.2 Larrea tridentata/Ambrosia dumosa Shrubland Alliance ............................................................................ 4-6

4.2.1.3 Atriplex confertifolia-Ambrosia dumosa Shrubland Alliance ............................................................................... 4-7

4.2.2 Transition Zone ............................................................................... 4-7

4.2.2.1 Hymenoclea-Lycium Shrubland Alliance................................ 4-7

4.2.2.2 Ephedra nevadensis Shrubland Alliance................................ 4-7

4.2.2.3 Coleogyne ramosissima Shrubland Alliance .......................... 4-8

4.2.3 Great Basin Desert ............................................................................. 4-

4.2.3.1 Atriplex spp. Shrubland Alliance............................................. 4-8

4.2.3.2 Chrysothamnus-Ericameria Shrubland Alliance...................... 4-8

4.2.3.3 Artemisia spp. Shrubland Alliance ........................................ 4-9

4.2.3.4 Pinus monophylla/Artemisia spp. Woodland Alliance........... 4-9

4.3 Distribution and Description of Plant Associations.......................................... 4-9

4.3.1 Lycium shockleyi-Lycium pallidum Shrubland ................................... 4-13

4.3.2 Larrea tridentata/Ambrosia dumosa Shrubland .................................... 4-15

4.3.3 Atriplex confertifolia-Ambrosia dumosa Shrubland .............................. 4-17

4.3.4 Lycium andersonii-Hymenoclea salsola Shrubland................................ 4-19

4.3.5 Hymenoclea salsola-Ephedra nevadensis Shrubland............................... 4-21

4.3.6 Menodora spinescens-Ephedra nevadensis Shrubland ........................... 4-23

4.3.7 Krascheninnikovia lanata-Ephedra nevadensis Shrubland ....................... 4-25

4.3.8 Eriogonum fasciculatum-Ephedra nevadensis Shrubland ...................... 4-27 


\section{CONTENTS}

4.3.9 Ephedra nevadensis-Grayia spinosa Shrubland....................................4-29

4.3.10 Coleogyne ramosissima-Ephedra nevadensis Shrubland ..........................4-31

4.3.11 Atriplex confertifolia-Kochia americana Shrubland ...............................4-33

4.3.12 Atriplex canescens-Krascheninnikovia lanata Shrubland ........................4-35

4.3.13 Chrysothamnus viscidiflorus-Ephedra nevadensis Shrubland .................4-37

4.3.14 Ericameria nauseosa-Ephedra nevadensis Shrubland .............................4-39

4.3.15 Ephedra viridis-Artemisia tridentata Shrubland ......................................4-41

4.3.16 Artemisia tridentata-Chrysothamnus viscidiflorus Shrubland ..................4-43

4.3.17 Artemisia nova-Chrysothamnus viscidiflorus Shrubland...........................4-45

4.3.18 Artemisia nova-Artemisia tridentata Shrubland .......................................4-47

4.3.19 Pinus monophylla/Artemisia nova Woodland........................................4-49

4.3.20 Pinus monophylla/Artemisia tridentata Woodland .................................4-51

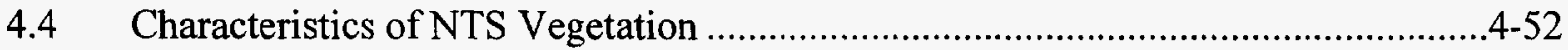

4.4.1 Major Climatic Zones or Ecoregions of the NTS .....................................4-52

4.4.2 Environmental Parameters of Associations Within Ecoregions ....................4-53

4.4.2.1 Composition of Ecoregions by the Number of ELUs .................4-53

4.4.2.2 Species Richness .................................................................4-56

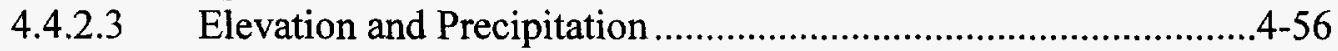

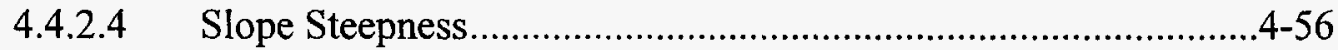

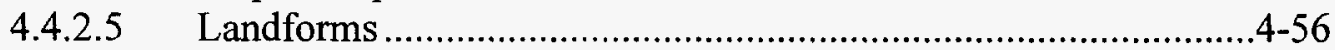

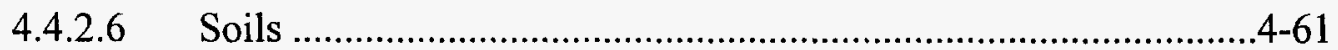

4.4.2.7 Rock Pavement and Clast Size Classes ...................................4-61

4.4.2.8 Microbiotic Crusts .............................................................4-65

4.4.2.9 Productivity of Annual Vegetation ..........................................4-65

4.4.2.10 Invasive Plant Species.....................................................4-65

4.4.2.11 Rodent Activity ...................................................................70

Species Analyses..................................................................................

4.5.1 Species Correlations.....................................................................4-76

4.5.2 Dominant Trees and Shrubs ...........................................................4-76

4.5.3 Dominant Forbs, Grasses, and Succulents ...........................................4-78

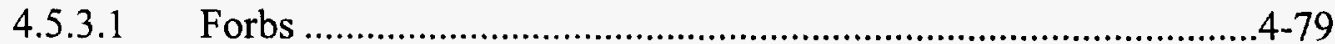

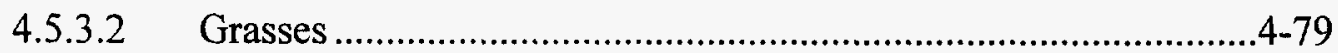

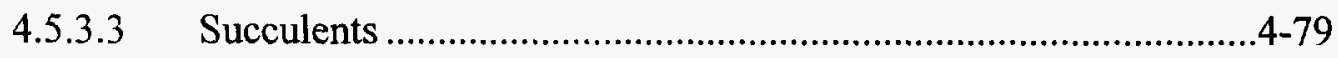

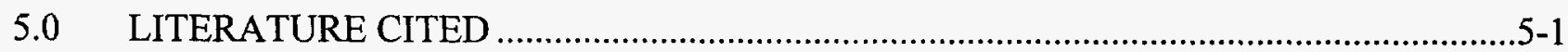

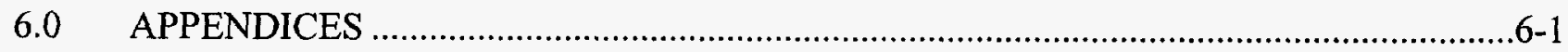

Appendix A Plant Associations on the NTS Recognized by Beatley

Appendix B Plant Species on the NTS

Appendix C List of Common Names, Alphacodes, Scientific Names, and Older Names 


\section{CONTENTS}

Appendix D Percent Abundance of Woody Plants on the NTS by Alliance

Appendix E Percent Abundance of Woody Plants on the NTS by Association

Appendix F Percent Frequency of NTS Plant Species by Alliance

Appendix G Percent Frequency of NTS Plant Species by Association

Appendix H Interspecific Association of Woody Vegetation on the NTS

Appendix I Distribution on the NTS of the Top Dominant Woody Plant

Species Based on Abundance

Appendix J Distribution on the NTS of the Top Dominant Grasses, Forbs, and Succulents Based on the Relative Ranking of Dominance

\section{List of Figures}

Figure 1-1 Major topographic features of the Nevada Test Site ...............................................1-3

Figure 2-1 Plant associations on the NTS according to Beatley (1976)....................................2-5

Figure 2-2 Location of sensitive plant species on the Nevada Test Site .....................................2-10

Figure 2-3 Locations of wetlands on the Nevada Test Site .................................................... -11

Figure 3-1 Landform types and codes for describing landforms on the NTS .............................3-2

Figure 3-2 Example of delineated boundary of an ecological landform unit ...............................3-3

Figure 3-3 Example of a vegetation mapping sampling form .......................................................3-4

Figure 4-1 Results of cluster analyses for ELUs on the NTS ..................................................4-2

Figure 4-2 Distribution of plant alliances on the NTS .......................................................4-4

Figure 4-3 Lycium shockleyi-Lycium pallidum Shrubland ………….....................................4-12

Figure 4-4 Larrea tridentata/Ambrosia dumosa Shrubland ................................................... $4-14$

Figure 4-5 Atriplex confertifolia-Ambrosia dumosa Shrubland ................................................4-16

Figure 4-6 Lycium andersonii-Hymenoclea salsola Shrubland...............................................4-18

Figure 4-7 Hymenoclea salsola-Ephedra nevadensis Shrubland ................................................4-20

Figure 4-8 Menodora spinescens-Ephedra nevadensis Shrubland ...........................................4-22

Figure 4-9 Krascheninnikovia lanata-Ephedra nevadensis Shrubland .......................................4-24

Figure 4-10 Eriogonum fasciculatum-Ephedra nevadensis Shrubland …...................................4-26

Figure 4-11 Ephedra nevadensis-Grayia spinosa Shrubland ......................................................4-28

Figure 4-12 Coleogyne ramosissima-Ephedra nevadensis Shrubland..........................................4-30

Figure 4-13 Atriplex confertifolia-Kochia americana Shrubland.............................................4-32

Figure 4-14 Atriplex canescens-Krascheninnikovia lanata Shrubland...........................................4-34

Figure 4-15 Chrysothamnus viscidiflorus-Ephedra nevadensis Shrubland ....................................4-36

Figure 4-16 Ericameria nauseosa-Ephedra nevadensis Shrubland ..............................................4-38

Figure 4-17 Ephedra viridis-Artemisia tridentata Shrubland ……..........................................4-40

Figure 4-18 Artemisia tridentata-Chrysothamnus viscidiflorus Shrubland ....................................4-42

Figure 4-19 Artemisia nova-Chrysothamnus viscidiflorus Shrubland .........................................4-44

Figure 4-20 Artemisia nova-Artemisia tridentata Shrubland .....................................................4-46

Figure 4-21 Pinus monophylla/Artemisia nova Woodland ......................................................4-48

Figure 4-22 Pinus monophylla/Artemisia tridentata Woodland ..................................................4-50

Figure 4-23 Species richness of ELUs on the NTS ……............................................................4-57

Figure 4-24 Average elevation and precipitation of vegetation associations

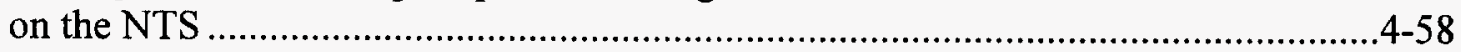

Figure 4-25 Elevation of ELU sampling locations on the NTS................................................4-59

Figure 4-26 Slope steepness at ELU sampling locations on the NTS .........................................4-60 


\section{List of Figures}

Figure 4-27

Figure 4-28

Figure 4-29

Figure 4-30

Figure 4-31

Figure 4-32

Figure 4-33

Figure 4-34

Figure 4-35

Figure 4-36

Figure 4-37

Figure 4-38

Figure 4-39
Landform types in ELUs on the NTS 4-62

Percent of soil surface with rock or pavement in ELUs on the NTS. 4-63 Rock clast size classes in ELUs on the NTS. 4-64 Abundance of biotic crust in ELUs on the NTS $4-66$ Productivity of annual vegetation in ELUs on the NTS 4-67

Relative ranking of dominance of Bromus rubens on the NTS ................................4-68

Relative ranking of dominance of Bromus tectorum on the NTS ............................4-69

Relative ranking of dominance of Schismus arabicus on the NTS............................4-71

Relative ranking of dominance Salsola kali on the NTS .......................................4-72

Relative ranking of dominance of Salsola paulsenii on the NTS .............................4-73

Relative ranking of dominance of Sisymbrium altissimum on the NTS ...................4-74

Rodent activity classes in ELUs on the NTS .......................................................4-75

Percent frequency of succulents on the NTS by elevation (meters) ..........................4-80

\section{List of Tables}

Table 2-1

Table 2-2

Plant associations recognized by Beatley on the NTS in 1976.

Classification of vegetation at Yucca and Little Skull mountains adapted from CRWMS (1998).

Table 4-1

Table 4-2

Table 4-3

Table 4-4

Table 4-5

Vegetation ecoregions, alliances, and associations on the NTS

Characteristics of vegetation alliances on the NTS

Characteristics of the Lycium shockleyi-Lycium pallidum Shrubland

Characteristics of the Larrea tridentata/Ambrosia dumosa Shrubland

Characteristics of the Atriplex confertifolia-Ambrosia dumosa

Shrubland

Table 4-6

Characteri

Table 4-7

Shrubland

Table 4-8

Characteristics of the Menodora spinescens-Ephedra nevadensis

Shrubland

Table 4-9

Characteristic

Table 4-10

Shrubland

Shrubland

Table 4-11

Characteristics of the Ephedra nevadensis-Grayia spinosa Shrubland

Shrubland

Shrubland

Shrubland

Table 4-15

Characteristics of the Chrysothamnus viscidiflorus-Ephedra

nevadensis Shrubland.

Shrubland 


\section{List of Tables}

Table 4-18 Characteristics of the Artemisia tridentata-Chrysothamnus viscidiflorus Shrubland

Table 4-19 Characteristics of the Artemisia nova-Chrysothamnus viscidiflorus

Shrubland.

Table 4-20

Characteristics of the Artemisia nova-Artemisia tridentata Shrubland

Table 4-21

Characteristics of the Pinus monophylla/Artemisia nova Woodland

Table 4-22

Characteristics of the Pinus monophylla/Artemisia tridentata Woodland

Table 4-23

Parameters associated with associations in the Mojave and

Great Basin Deserts and Transition ecoregions on the NTS.

Table 4-24

Percent abundance of dominant species found in associations

in the Mojave and Great Basin Deserts and Transition

Ecoregions on the NTS 


\section{ACRONYMS and ABBREVIATIONS}

$\begin{array}{ll}\text { ac } & \text { acre } \\ \text { BECAMP } & \text { Basic Environmental Compliance and Monitoring Program } \\ \mathrm{cm} & \text { centimeter } \\ \text { CP } & \text { Control Point } \\ \text { CRWMS } & \text { Civilian Radioactive Waste Management System } \\ \text { DOE/NV } & \text { U.S. Department of Energy, Nevada Operations Office } \\ \text { DOE } & \text { U.S. Department of Energy } \\ \text { EC } & \text { electrical conductivity } \\ \text { EGIS } & \text { ecosystem geographical information system } \\ \text { ELU } & \text { Ecological Landform Unit } \\ \text { ESRI } & \text { Environmental Systems Research Institute } \\ \text { ft } & \text { foot } \\ \text { GIS } & \text { Geographic Information System } \\ \text { GPS } & \text { Global Positioning System } \\ \text { ha } & \text { hectare } \\ \text { in } & \text { inch } \\ \text { km } & \\ \text { m } & \text { square kilometer } \\ \text { mi } & \\ \text { mm } & \text { meter } \\ \text { NAEG } & \text { square mile } \\ \text { NRCS } & \text { millimeter } \\ \text { NTS } & \text { Nevada Applied Ecology Group } \\ \text { SPOT } & \text { National Resource Conservation Service } \\ \text { USDA } & \text { Nevada Test Site } \\ \text { USGS } & \text { Satellite Pour L'Observation de la Terre } \\ \text { UTM } & \text { U.S. Department of Agriculture } \\ & \text { Universal Transverse Mercater }\end{array}$




\section{This Page Intentionally Left Blank}




\section{EXECUTIVE SUMMARY}

The Nevada Test Site (NTS) was used for nuclear testing from 1951 to 1992. Despite years of testing only about 7 percent of the 3,567 square kilometers (1,375 square miles) of the site has been disturbed (U.S. Department of Energy, 1996b). Although drastic changes to localized areas due to nuclear testing have occurred, biological resources over much of the NTS remain relatively pristine and undisturbed. Diversification in the mission of the NTS, as described in the recent programmatic NTS Environmental Impact Statement, has created a need to provide detailed information about vegetation for the purposes of National Environmental Policy Act compliance, ecosystem management, ecological monitoring, and resource management planning. Before resources can be effectively managed and preserved, they must first be identified and described. Vegetation classification and mapping are among the first steps in implementing ecosystem management on the NTS. Preparation of an accurate vegetation map and more detailed descriptions of vegetation and wildlife habitat are essential for ecosystem management for new projects or to support expanding existing projects on the NTS.

Mapping of vegetation was initiated by first identifying landforms and delineating their boundaries from prints of aerial photographs (1:24000 scale) of the NTS. These boundaries were traced onto clear plastic sheets registered to the underlying digital prints, as published in 1995 in the NTS Grid Map, A Grid System Photo Locator Map of the NTS. Boundaries of landforms with similar physical and biological properties were then verified in the field and modified to delineate ecological landform units (ELUs). ELUs were delineated on 32 satellite images corresponding in area to the 32 U.S. Geological Survey 7.5 -minute quadrangles that cover the NTS.

The intent was not to subjectively or arbitrarily classify the ELUs as a particular vegetation type or subtype, but rather to delineate all of the basic building blocks or areas that were relatively homogeneous and would respond similarly to management practices. Once the boundaries of these areas were determined, the physical and biological characteristics within these areas were described. Site descriptions were made along 200-meter $(\mathrm{m})$-long (656-foot [ft]-long) linear transects, with observation points located every $20 \mathrm{~m}[65.5 \mathrm{ft}]$ along the transects (i.e., 10 points per transect). At each observation point, the names of the five closest shrubs to the point were recorded, as well as an estimate of the cover of perennial vegetation. The relative abundance of forbs, grasses, cacti, and other important species such as threatened and endangered plant species were also recorded. The names of plants and animals observed, as well as physical conditions of the environment, were described. A total of 1,508 ELUs were sampled during the three-year period of 1996 through 1998.

After the final corrections were made to the delineated boundaries of the ELUs based on the field verification and photomaps, the ELU boundaries were digitized, using Environmental Systems Research Institute, Inc.'s (ESRI's ${ }^{\circledR}$ ) Data Automation Kit ${ }^{\mathrm{TM}}$. Boundaries were verified and then the polygons (ELUs) were labeled with the appropriate ELU number. This coverage was then linked to a Microsoft Access $97{ }^{\circledR}$ database containing the site descriptions using Arcview ${ }^{\circledR} 3.1$ software. Cluster analysis was then used to identify similar ELUs for purposes of classifying the vegetation. Individual ELUs were then assigned to a national vegetation classification category using quantitative characteristics determined from cluster analyses and other statistical tools. A geographic information system was developed to manage and display data collected during the mapping and classification efforts. The resulting system is referred to as the Ecosystem 
Geographic Information System and will ensure that biological information can be readily accessed in a timely and cost-effective manner.

Based on an iterative clustering process, 10 alliances and 20 associations were recognized as occurring on the NTS. Several ELUs did not cluster as groups, but remained as single units because of their unique vegetation. These ELUs were listed together in a miscellaneous category on the final map. Alliances and associations were named after the dominant tree or shrub species based on relative abundance and according to Federal Geographic Data Committee and Ecological Society of America conventions.

Two major vegetation groups or ecoregions, Mojave Desert and Great Basin Desert, can be identified from this classification. Between these two deserts is a broad transition zone that often includes a mixture of species from either major ecoregion. There are three alliances within the Mojave Desert, three within the transition zone, and four within the Great Basin Desert. In terms of total area, the Great Basin Desert occupies approximately 40 percent of the NTS, followed by the transition zone with 37 percent. The Mojave Desert occupies the southern 22 percent of the NTS. Sampling within each major zone was rather even, with the average areas per ELU being 216 hectares (ha) (562 acres [ac]) in the Mojave Desert, 221 ha (575 ac) in the Transition Zone, and 233 ha (606 ac) in the Great Basin Desert.

There were a total of 20 vegetation associations that were recognized, described, and mapped. A distribution map of each association is presented, as well as a brief summary description and photo of each association. In the Mojave Desert, the Larrea tridentata /Ambrosia dumosa Shrubland was the most numerous association, representing about 19 percent of the ELUs on the NTS (18 percent of the total area). No other association in the Mojave Desert represented more than 4 percent of the total ELUs. In the Great Basin Desert, the Artemisia tridentataChrysothamnus viscidiflorus Shrubland was the most numerous association, representing about 11 percent of the ELUs on the NTS (7.5 percent of the total area). No other association in the Great Basin Desert represented more than 7 percent of the total ELUs. In the Transition Ecoregion between these deserts, the Coleogyne ramosissima-Ephedra nevadensis Shrubland was the most numerous association, representing about 22 percent of the ELUs on the NTS (21.6 percent of the total area). No other association in the Transition Ecoregion represented more than 6 percent of the total ELUs.

Analysis of species diversity (richness or the number of species) of perennial trees and shrubs is presented. Species richness of woody species was greatest in the Great Basin Desert associations (mean of 56 species) compared to associations in the Transition Zone (mean of 49 species) and the Mojave Desert (mean of 36 species). Similar species diversity patterns were also observed for all combined perennial species on the NTS.

Summary data of other environmental parameters such as elevation, precipitation, landforms, soil texture, desert pavement, and slope steepness of the ELUs are presented and summarized by plant associations. The presence of visible microbiotic crusts on the soil surface (i.e., nonvascular microorganisms such as algae, fungi, or lichens that are frequently important for enhancing soil fertility and surface stabilization) was noted during the field surveys. Within the NTS, 58 percent of the ELUs sampled had no visual evidence of microbiotic crusts, 28 percent had low visual evidence of crusts, 11 percent had moderate visual evidence of crusts, and only 4 percent had high visual evidence of microbiotic crusts. Visual evidence of crusts was observed to decrease with increases in elevation. Associations with high abundance of crusts also had 
higher percentages of soil fines (clays or silts). Low presence of crusts or their absence was associated with active soil erosional processes (e.g., along washes and steeper unstable slopes).

The presence of annual vegetation (both native and introduced species) and its relative abundance is presented for each vegetation association. Vegetation associations that were more likely to undergo disturbance or are responding to previous disturbances, either natural or anthropogenic, contain higher productivity of annuals. One of the greatest threats to plant diversity in many ecosystems is the invasion of exotic species that have few natural diseases or pests to check their growth and reproduction. Of particular importance on the NTS are those annual species that colonize disturbed soils. Exotic species of concern include foxtail brome, cheatgrass, Arabian schismus, prickly Russian thistle, barbwire Russian thistle, and tumblemustard. By far, the most widely distributed annual grass on the NTS is foxtail brome. It occurs mostly in the Transition Zone and the Mojave Desert, while cheatgrass is the dominant introduced annual grass in the Great Basin Desert.

Distribution on the NTS of the relative abundance of rodent activity is presented. The relative abundance of rodent burrows was found to be inversely correlated with elevation. The Mojave Desert sites may have deeper soils that are more conducive to burrowing, while the rockier soils of the Transition Zone have fewer burrows. The Great Basin Desert sites have shallower soils and more severe winters than the Mojave Desert sites that may reduce burrowing or the abundance of animals likely to burrow.

Perhaps one of the greatest benefits from this study has been the ability to generate maps of each species observed during the field sampling. Because more than 700 species were identified during the survey, only a selected subset of the most characteristic trees, shrubs, forbs, grasses, and succulents are presented and discussed.

Pairwise comparisions of perennial species abundance at a statistical level of significance of $\alpha=0.05$ of the 718 species observed to occur on the NTS indicate that there were 447 positive interspecific associations between species, and only 271 negative interspecific associations. Correlations of percent abundance of woody plant species are presented for approximately 122 species. Causal factors for the positive interspecific associations usually indicate similar ecological needs for related species. They may also suggest species that partition environmental resources sufficiently to allow the coexistence of both species in time or space.

Distributions of the dominant species on the NTS are shown in maps found in Section 4.3 of this report. The spatial distribution of each species results from ecological requirements for the species and the available physical and biological conditions present on NTS landforms. Elevation, as previously mentioned, provides the best single parameter that helps characterize the various plant associations. Each association tends to have only a few dominant species (e.g., two to six), while each species tends to occupy a range of the total elevation gradient ranging from $847 \mathrm{~m}(2,779 \mathrm{ft})$ at the low end of the NTS to $2,292 \mathrm{~m}(7,519 \mathrm{ft})$ at the upper end.

Species most characteristic of the Mojave Desert were (sorted from low to high in elevational position): Shockley's desert thorn, rabbit thorn, white bursage, creosote bush, and range ratany. In the Transition Zone, the most common shrubs were (sorted from low to high in elevational position): spiny menodora, spiny hopsage, winterfat, Anderson's wolfberry, white burrobush, Mojave buckwheat, blackbrush, Cooper's heathgoldenrod, and Nevada jointfir. Species most characteristic of the Great Basin Desert were (sorted from low to high in elevational position): 
bursage, shadscale saltbush, green molly, four-wing saltbush, green rabbitbrush, rubber rabbitbrush, Mormon tea, Stansbury cliffrose, desert bitterbrush, basin big sagebrush, black sagebrush, fuzzy green rabbitbrush, granite prickly gilia, Utah Juniper, antelope bitterbrush, and singleleaf pinyon.

All non-woody plant species encountered during the field surveys on the NTS were ranked according to relative dominance in all ELUs. The top five species in each of the three categories (forbs, grasses, and succulents) are discussed and distribution maps provided.

Several appendices are presented that provide details of vegetation on the NTS, including lists of all species that have been recorded on the NTS and the vegetation alliances where they are commonly found, relative abundance and frequency values for species in vegetation alliances and associations, and species names and codes. 


\subsection{INTRODUCTION}

Although the Nevada Test Site (NTS) was used for nuclear testing from 1951 to 1992, only about 7 percent of the 3,567 square kilometer $\left(\mathrm{km}^{2}\right)\left(1,375\right.$ square miles [mi $\left.\left.{ }^{2}\right]\right)$ of the site has been disturbed (U.S. Department of Energy [DOE], 1996b). Despite drastic changes to localized areas due to nuclear testing, biological resources over much of the NTS remain relatively pristine and undisturbed. The abuses of overgrazing by livestock, land degradation due to uncontrolled recreational uses, industrial pollution, and other disturbances common to public lands have been minor or absent on the NTS. Protection of its biological resources has been strengthened by DOE Policy 430.1 (DOE, 1996a) which mandated that land management practices incorporate ecosystem management principles. DOE also pledged to preserve viable populations of native plants and animals in its Resource Management Plan (DOE, 1998) for the NTS.

Before resources can be effectively managed and preserved, they must first be identified and described. Vegetation classification and mapping are among the first steps in implementing ecosystem management on the NTS. Mapping efforts are supported by state and federal laws that protect threatened and endangered species of plants and animals. Additionally, some habitats (i.e., an assemblage of plants and animals, and their environments) such as critical habitat for threatened and endangered species, jurisdictional wetlands, and waters of the United States are also protected by law. Inventories and spatial mapping are useful tools to ensure that these sensitive species and habitats are adequately described, located, and protected.

\subsection{Need and Purpose}

Recent diversification in the mission of the NTS, as described in the recent programmatic NTS Environmental Impact Statement (DOE, 1996b), has created a need to provide detailed information about vegetation for the purposes of National Environmental Policy Act compliance, ecosystem management, ecological monitoring, and resource management planning. Preparation of an accurate vegetation map and more detailed descriptions of vegetation and wildlife habitat are also required to facilitate the siting of new projects and to support expanding existing projects on the NTS. Such mapping facilitates delineation of boundaries of sensitive habitats and identifies areas that are already disturbed or better suited for new uses.

While numerous studies have been conducted on the NTS historically, there has been no attempt to map biological resources in a systematic manner nor to organize information needed for ecosystem management. Previous mapping of vegetation on the NTS was incomplete and inadequate for today's purposes. Furthermore, previous mapping efforts were not in compliance with recent federal standards for classification of biological resources and plant communities (Federal Geographic Data Committee, 1996). Because of inconsistencies in plant nomenclature, data form and structure, and method of documenting findings (e.g., spatial metadata standards), the information collected in the past is of marginal use to NTS managers, other stakeholders, government agencies, and scientific personnel.

The purpose of this project was to identify and classify the biological resources of the NTS and, through development of an ecosystem geographical information system, to facilitate the use of information in the form of vegetation maps, habitat descriptions, and other data needed to ensure 
compliance and to facilitate the transfer of data to other land managers in the region. Another substantial benefit from these efforts will be significant savings associated with retrieval of information, especially compared to older methods of collecting data and preparing environmental assessments, clearance surveys, and monitoring reports. Information organized through these efforts will facilitate the management of NTS ecosystems and ensure the continued protection of its biological resources.

\subsection{Goals and Objectives}

The goal of this project was to collect essential biological information needed to fulfill the stewardship role accepted by the DOE to manage the NTS resources using ecosystem management principles in compliance with state and federal laws, standards, and biological opinions designed to protect rare or sensitive biological resources. The development of an ecosystem geographical information system (EGIS) as part of this goal will ensure that biological information can be readily accessed in a timely and cost-effective manner.

Specific objectives of the project were to:

- Identify, survey, classify, and describe plant communities on the NTS consistent with national classification standards.

- Develop a series of detailed vegetation maps showing boundaries of delineated vegetation types and distribution of key plant species.

- Establish sensitivity rankings for NTS habitat areas based on species diversity, physical characteristics of the site, previous disturbance, and sensitivity to disturbance.

- Develop an EGIS to organize information, facilitate retrieval, and simplify the preparation of graphics and reports.

- Document and archive data internally and externally through appropriate metadata procedures to ensure data transfer in the future.

\subsection{Study Area}

The NTS is located in Nye County in south-central Nevada and encompasses $3,567 \mathrm{~km}^{2}$ $\left(1,375 \mathrm{mi}^{2}\right)$. The NTS is divided into 27 areas for administration and management (Figure 1-1). Access to the site is strictly controlled. Land along the eastern boundary of the NTS is comanaged by the U.S. Air Force (Nellis Air Force Range) and the Desert National Wildlife Refuge (O'Farrell and Emery, 1976). Land to the north and west also is part of the Nellis Air Force Range. The U.S. Bureau of Land Management manages most land directly south and southwest of the NTS.

Three large valleys or basins dominate the southern two-thirds of the NTS: Yucca, Frenchman, and Jackass flats (Figure 1-1). Mountain ridges and hills rise above gradually sloping alluvial fans (bajadas) and enclose these basins. During years of high precipitation, surface water collects and forms shallow lakes in the closed basins of Yucca and Frenchman Flats.

Jackass Flats is an open basin and drains to the southwest via Fortymile Wash. Mercury, Rock, Topopah, and Mid Valleys are smaller basins and also have drainage outlets. Pahute Mesa and 


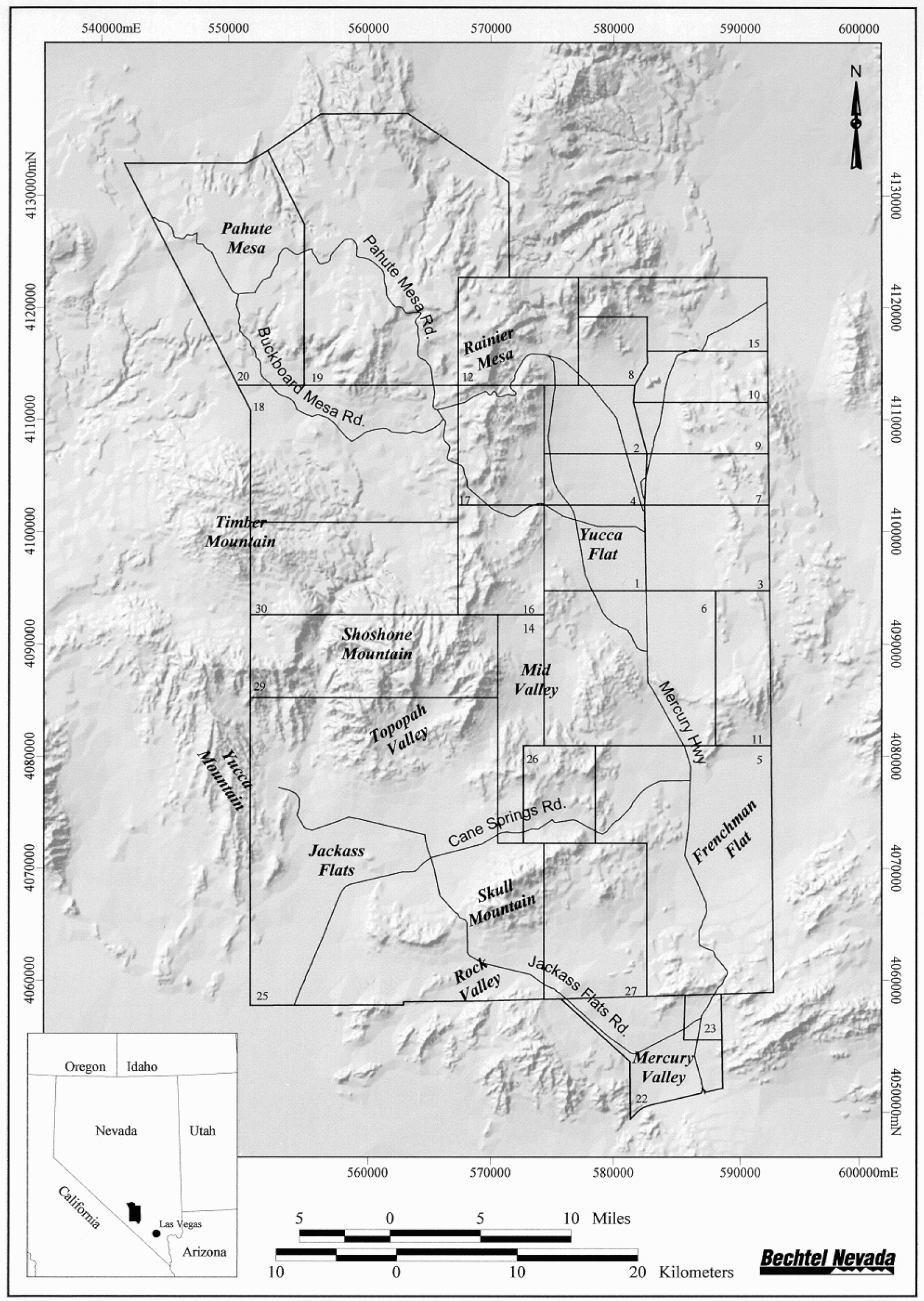

Figure 1-1 Major roads, topographic features, and administrative areas of the Nevada Test Site 
Timber and Shoshone mountains dominate the northern, northwestern, and west central sections of the NTS. Elevation on the NTS ranges from less than 1,000 meters $(\mathrm{m})(3,281$ feet [ft]) above sea level in Frenchman Flat and Jackass Flats to about 2,340 m (7,600 ft) on Rainier Mesa.

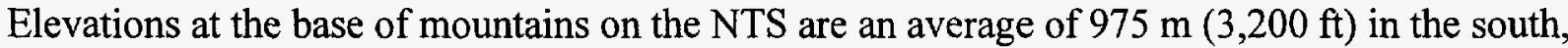
$1,370 \mathrm{~m}(4,500 \mathrm{ft})$ in the central region, and $1,600 \mathrm{~m}(5,250 \mathrm{ft})$ in the northern part of the NTS. Mountain peaks range from $1,400 \mathrm{~m}$ to $1,800 \mathrm{~m}(4,600$ to $5,900 \mathrm{ft})$ in the south and $2,100 \mathrm{~m}$ to $2,300 \mathrm{~m}(6,890$ to $7,550 \mathrm{ft})$ in the north (O'Farrell and Emery, 1976). Associated with these elevation increases are the northern boundary of the Mojave Desert and the southern boundary of the Great Basin Desert within a broad east-west corridor of transition (Beatley, 1976).

NTS has a climate characteristic of high deserts with little precipitation, very hot summers, mild winters, and large diurnal temperature ranges. Monthly average temperatures on the NTS range from $7{ }^{\circ} \mathrm{Celsius}(\mathrm{C})\left(44^{\circ} \mathrm{Farenheit}[\mathrm{F}]\right)$ in January to $32^{\circ} \mathrm{C}\left(90^{\circ} \mathrm{F}\right)$ in July (DOE, 1996b). The average annual precipitation on the NTS ranges from 15 centimeters $(\mathrm{cm})(6$ inches [in]) at the lower elevations to $23 \mathrm{~cm}$ ( 9 in) at the higher elevations (DOE, 1996b). About 60 percent of this precipitation occurs from September through March. Winter precipitation frequently occurs as snow, which persists in northern Yucca Flat and to the north. Higher mountains commonly are snow-covered much of the winter. Snow seldom persists for more than a few hours in the southern valleys.

The NTS is located in an area of southern Nevada that lies between the Great Basin Desert and the Mojave Desert as defined by Jaeger (1957). Within the site boundaries are found both of these desert types, with the northern end of the site being Great Basin Desert and the southern end of the site being Mojave Desert. Transitional areas between the two desert types are also present having been created by gradients in precipitation, temperature, and soils. Unique combinations of physical site conditions have created different vegetation patterns on the NTS that have challenged development of a simple classification system. Because of the remoteness of this area and the restricted access to the test site, little work in classification of vegetation was done prior to1958. 


\subsection{LITERATURE REVIEW}

\subsection{Previous Classifications of NTS Vegetation}

Descriptions of NTS vegetation types consist of three major classification efforts. Two of these efforts were done between 1958 and 1963. The third was published in 1976 and was the standard used until now. A description of these classification efforts follows.

\subsubsection{Vegetation Classification}

In 1957, work was undertaken by New Mexico Highlands University to appraise the extent of nuclear effects on vegetation at the NTS. Objectives of the study were to:

- Measure changes in vegetative cover and floristic composition in relation to topographic, climatic, and edaphic factors;

- Evaluate plant succession around nuclear detonation points;

- Correlate soil properties with plant distribution;

- Evaluate genetic changes in surviving vegetation; and

- Document the nature and extent of injury to plants from radioactive matter.

Specimens of 106 plant species were collected for the herbarium, and Shields (1958) defined nine vegetation zones. A total of 23 plots $(100 \mathrm{ft} \times 100 \mathrm{ft})$ were sampled, with only one to three plots per each vegetation zone. Soil $\mathrm{pH}, \mathrm{Kjeldahl}$ nitrogen, and electrical conductivity (EC) (millimhos $/ \mathrm{cm}^{2}$ at $25^{\circ} \mathrm{C}$ ) of saturated soil paste extract generally decreased with increasing elevation. Jackass Flats and Pahute Mesa were added as nuclear test areas in 1958 and 1964, respectively, and were not surveyed for vegetation during the earlier study. Other minor vegetation patterns were described for these basins and for the mesas to the north. The zones within these basins included:

\section{Frenchman Flat}

- Atriplex confertifolia Zone (10 to 14 percent vegetative cover, mean soil $\mathrm{pH}=8.5, \mathrm{EC}=24$ )

- Lycium Zone (11 percent vegetative cover, mean soil $\mathrm{pH}=8.6, \mathrm{EC}=15$ )

- Larrea Zone (6 to 16 percent vegetative cover, mean soil $\mathrm{pH}=8.2, \mathrm{EC}=12$ )

- Coleogyne ramosissima Zone (18 percent vegetative cover, mean soil $\mathrm{pH}=8.2, \mathrm{EC}=8$ )

\section{Yucca Flat}

- Atriplex confertifolia-Kochia vestita Zone (12 to 17 percent vegetative cover, mean soil $\mathrm{pH}=$ $8.4, \mathrm{EC}=41)$

- Atriplex confertifolia-Eurotia lanata Zone (14 percent vegetative cover, mean soil $\mathrm{pH}=8.5$, $\mathrm{EC}=20$ )

- Tetradymia canescens Zone (10 to 23 percent vegetative cover, mean soil $\mathrm{pH}=8.9, \mathrm{EC}=23$ )

- Coleogyne ramosissima Zone (23 percent vegetative cover, mean soil $\mathrm{pH}=8.1, \mathrm{EC}=11$ )

- Pinus monophylla Zone (44 percent vegetative cover, mean soil $\mathrm{pH}=7.0, \mathrm{EC}=10$ ) 
Subsequently, Shields et al. (1959) and Shields and Rickard (1960) established an additional 60 permanent study plots, and extended the number of species in their study plots from 106 to 238. The study areas were expanded to include Jackass Flats; they also redefined these zones as vegetation types.

\subsubsection{Wildlife Habitat Studies and Plant Community Classification}

Ecological surveys of the fauna and associated wildlife habitat were initiated in 1959 by Brigham Young University scientists and continued through 1962. These surveys were designed to determine the effects of past nuclear detonations that began at the NTS in 1951 on biota at the site (Allred et al., 1963a). Principal objectives of the project were to determine the kinds, population, seasonal occurrence, geographic and ecological distribution, migration, home range, and related habits of native animals in these areas. Seven plant communities were recognized and briefly described:

- Larrea-Ambrosia (Franseria) (included smaller areas dominated by Atriplex confertifolia, Atriplex canescens, and Lycium shockleyi [rickardii])

- Grayia-Lycium

- Coleogyne

- Atriplex-Kochia

- Salsola

- Pinyon-Juniper

- Mixed Communities (included mountainous areas, natural springs, reservoirs, and playas)

Community boundaries were not delineated, nor was a vegetation map produced. Predominant plant species in each plant community were identified. A listing of some of the more common plants found in several communities were given in the appendix of their report, listing vertebrate and invertebrate animals by plant community type. Seasonal occurrence and relative abundance data of these animals were also presented.

A supplemental paper (Allred et al., 1963b) to the original research report (Allred et al., 1963a) described approximate locations (e.g., "2.9 miles NE of Mercury along Mercury Highway, thence 0.3 mile E") of 297 sampling sites. The report listed 28 species of predominant plant species within the seven plant communities.

\subsubsection{Vegetation Classification}

Collection of plants was also begun by the University of California, Los Angeles in 1959 and continued through 1975. Beatley (1976) provided the most detailed description of vegetation on the NTS up to that time, based on field observations recorded at the time of collection of herbarium specimens, and data from 68 permanent study sites on the NTS surveyed during the period of 1962 to 1975. Sites were selected as representative of the major kinds of ecosystems in the region. Vegetation and environmental data, including percent cover by perennial plant species, plant density, rainfall, temperature, soil texture, and soil moisture were also collected and summarized. Beatley (1976) recognized 23 plant associations (Table 2-1). Descriptions of plant associations were provided in a narrative form that makes comparison of similarities and differences between plant associations difficult (Appendix A). 
Table 2-1 Plant associations recognized by Beatley on the NTS in 1976

MOJAVE DESERT REGION

Bajadas

1. Larrea-Ambrosia

2. Larrea-Lycium-Grayia

3. Larrea-Atriplex

Mountains

4. Mountain

Arroyos

5. Arroyo

Spring and Seepage Areas

6. Ash-Screwbean-Baccharis

7. Atriplex and Atriplex-Haplopappus

8. Mesquite (Prosopis)

\section{TRANSITION DESERT REGION}

Upper Bajada

9. Coleogyne

10. Larrea-Grayia-Lycium

Lower Bajada (playas or valley bottoms)

11. Grayia-Lycium

12. Lycium pallidum-Grayia

13. Lycium shockleyi-Atriplex

\section{GREAT BASIN DESERT REGION}

Atriplex

14. Atriplex confertifolia

15. Atriplex-Kochia*

16. Atriplex-Ceratoides*

17. Atriplex-Sarcobatus*

Artemisia

18. Atriplex canescens*

19. Artemisia tridentata*

20. Artemisia nova*

21. Artemisia-Pinyon-Juniper

22. Artemisia-Cercocarpus

White fir

23. White fir (Abies concolor) [does not occur on the NTS]

* Mapping unit not differentiated from other map units. 
There has been no major effort to map the vegetative resources of the NTS in the past. The only complete vegetation map for the NTS prior to 1997 was a $51 / 2$ " $\times 7$ " map produced by Janice Beatley in 1976 (Beatley, 1976). By contrast, this same area is covered by 37 U.S. Geological Survey (USGS) $71 \frac{1}{2}$-minute quadrangle maps. Reasons why no detailed mapping was done include: 1) work scopes did not require identification of vegetation types and detailed mapping, 2) mapping would be a major effort because the NTS consisted of more than 1,300 square miles of area, and 3) field work was difficult logistically because nuclear testing in the past limited access in areas that were already relatively inaccessible due to a lack of roads.

Beatley's vegetation map, showing location of plant associations and study sites, is only approximate and recognizes that "all boundaries are generalized and approximate." The vegetation map was highly simplified and lacked desirable cartographic qualities such as color, distinguishable type symbols and boundaries, and detail needed for interpretive use. The cartography was not corrected for proper orientation relative to acceptable coordinate systems such as decimal degrees, Universal Transverse Mercator (UTM), State Plane, or longitude and latitude. Enhancements to Beatley's original map were provided by O'Farrell and Emery (1976) by refining symbol patterns and correcting legend and symbol ambiguities. O'Farrell and Emery further described the NTS vegetation; however, no vegetation classification was made.

Boundary information from Beatley's original map (Beatley, 1976) and from that enhanced by O'Farrell and Emery (1976) was positioned by hand on clear overlays to LANDSAT georeferenced images to provide a vegetation map that was orthographically correct and georeferenced. Minor editing was done to ensure that boundaries coincided with mountain ranges, major drainages, and playas that were apparent from Beatley's original published and enhanced maps. Color coding was added and boundaries digitized for Geographic Information System (GIS) use to enhance visual interpretation and correlation with other GIS themes. Figure 2-1 shows Beatley's GIS-enhanced map.

The inherent diversity of these 23 plant communities was also noted. According to Beatley (1976): "The communities . . a are extremely diverse with respect to floristic composition; on no two sites is species composition the same (as documented from 20 to 75 species in $1,000 \mathrm{~m}^{2}$ )." Because the vegetation patterns in the Mojave Desert and Transition Desert relate so well with physiographic features and other landforms, Beatley chose to name these vegetation patterns after them (e.g., bajadas, mountains, arroyos, and springs and seeps). However, she used the predominant species of shrubs or trees to name the communities in the Great Basin Desert (e.g., Atriplex confertifolia, Atriplex canescens, Artemisia tridentata, Artemisia nova, and Artemisia-Pinyon-Juniper) where there appeared to be greater uniformity in vegetation patterns than in the former desert types. Beatley concluded that in the Great Basin Desert, "The pattern of its vegetation... is relatively simple and clearly defined" and that "in general, all the plant associations are characterized by increased representation of herbaceous perennials and decreased representation of annual species, as compared with the Mojave and transition deserts; these characteristics are associated with the higher rainfall and lower temperatures of the higher elevations" (Beatley, 1976).

Beatley also provided descriptions of other minor plant communities such as disturbed sites, introduced species, and endangered and threatened species. Because the study area extended beyond the boundaries of the NTS to include central-southern Nevada, four additional plant 


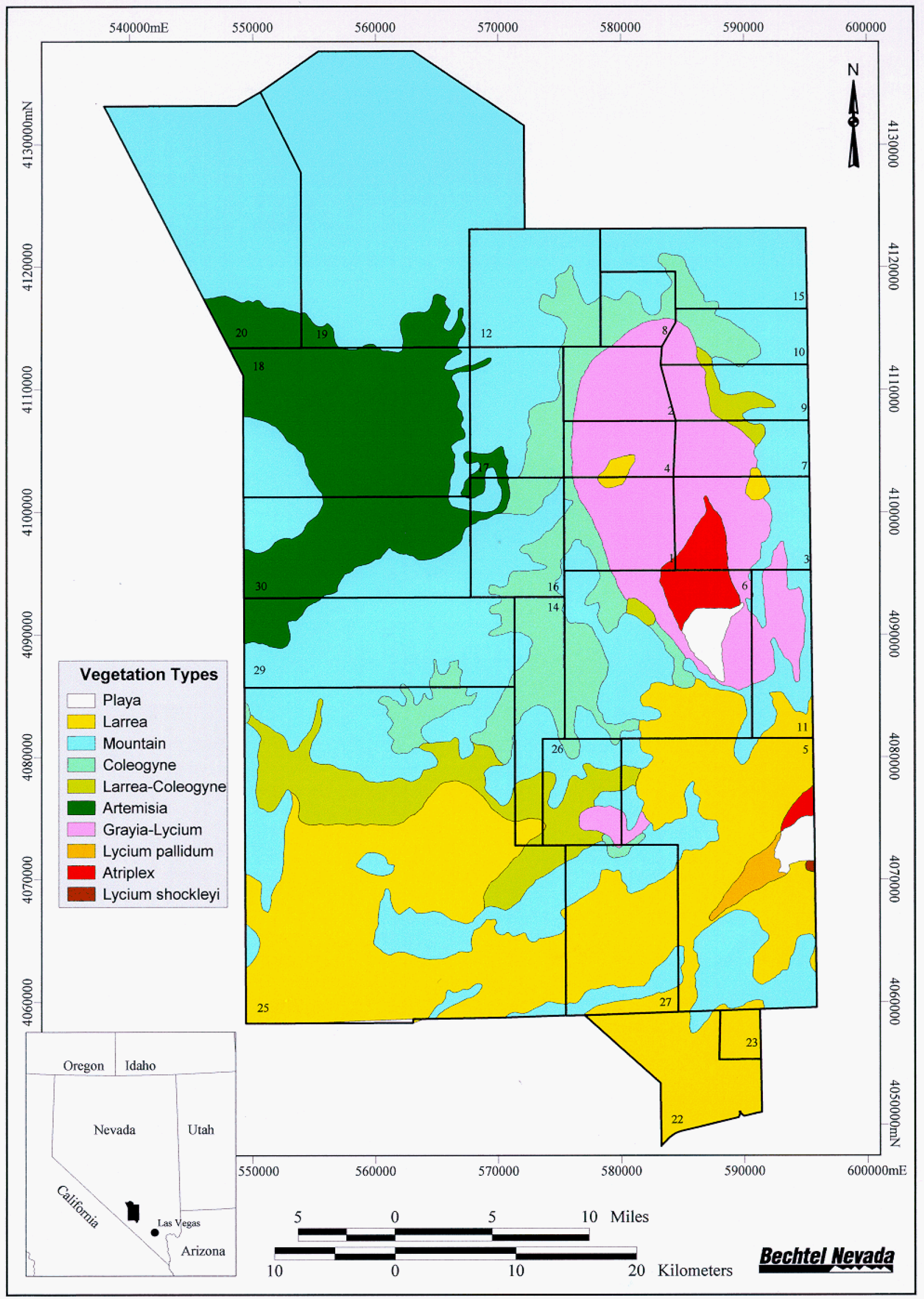

Figure 2-1 Plant associations on the Nevada Test Site according to Janice Beatley (1976) 
communities were described that do not occur on the NTS (e.g., white fir, Atriplex-Sarcobatus, mesquite, and Artemisia-Cercocarpus). Beatley (1976) provided descriptions of plant associations in a narrative form that makes comparison of similarities and differences between plant associations difficult.

\subsubsection{Vegetation Classification of Yucca Mountain Area}

From 1997 through 1999, DOE's Office of Civilian Radioactive Waste Management funded a mapping effort at Yucca Mountain and Little Skull Mountain in the southwestern part of the NTS. It extended into the adjacent U.S. Bureau of Land Management- and U.S. Air Force-managed lands to the west (Civilian Radioactive Waste Management System [CRWMS] Management and Operating Contractor, 1998). This mapping effort covered approximately $173 \mathrm{~km}^{2}\left(67 \mathrm{mi}^{2}\right)$ at Yucca Mountain and $50 \mathrm{~km}^{2}\left(19 \mathrm{mi}^{2}\right)$ at Little Skull Mountain in southern Jackass Flats. The vegetation mapping techniques were derived from those that were currently being used to map vegetation on the NTS for this study (Hansen et al., 1999, Ostler et al., 1999). A total of 259 vegetation sampling units, referred to as Ecological Landform Units (ELUs), were sampled in 1997 at Yucca Mountain and an additional 99 ELUs were sampled at Little Skull Mountain in 1998. Cluster analysis was used to classify ELU samples into groups with similar species composition using PC-ORD software (McCune and Mefford, 1995). Euclidean distance was used as a measure of dissimilarity, and Ward's method was used to agglomerate clusters because it reduced chaining. This quantitative classification grouped ELUs into nine associations that fell into five alliances and two formations. Alliances and associations were named after dominant species according to proposed guidelines by the Federal Geographic Data Committee in conjunction with the Vegetation Classification Panel of the Ecological Society of America (Federal Geographic Data Committee, 1996).

The two formations that were recognized in this mapping were the Mojave Desert Formation and the Great Basin Desert Formation. Alliances, associations, and subdominant species are provided in Table $2-2$.

In addition to maps of the vegetation associations, the authors provide narrative descriptions for each of the associations recognized, including data on topography, surface soil textures, slope, common species, and relative cover of annuals.

\subsection{Vegetation Studies on the NTS}

\subsubsection{Past Climatic Vegetation Changes}

Vegetation patterns in response to changing climatic conditions have been studied extensively on the NTS and documented through the analyses of several packrat-midden sites (Spaulding, 1985). Vegetation patterns suggest that about 45,000 years before present (k yr BP), the NTS had cooler and wetter conditions than currently; dominant plants included littleleaf mountain mahogany (Cercocarpus ledifolius), Utah juniper (Juniperus osteosperma), sagebrush (Artemisia), and horsebrush (Tetradymia spp). By $35 \mathrm{k}$ yr BP, limber pine (Pinus flexilis) and four-wing saltbush (Atriplex canescens) had established at the site. By $25 \mathrm{k}$ yr BP, shadscale saltbush (Atriplex confertifolia), snowberry (Symphoricarpos longiflorus), and Utah Fendlerbush (Fendlerella utahensis) became more common. By $10 \mathrm{k} \mathrm{yr} \mathrm{BP,} \mathrm{limber} \mathrm{pine} \mathrm{was} \mathrm{no} \mathrm{longer} \mathrm{found}$ 
Table 2-2 Classification of vegetation at Yucca and Little Skull mountains adapted from CRWMS (1998)

\section{CLASSIFICATION LEVEL}

ASSOCLATION SUBDOMINANTS

\section{MOJAVE DESERT FORMATION}

A. Ambrosia dumosa-Larrea tridentata Alliance

1. Ambrosia dumosa-Larrea tridentata

Hymenoclea salsola

Ericameria nauseosa

2. Ambrosia dumosa

Ephedra nevadensis

Lycium pallidum

Krameria erecta

3. Larrea tridentata-Ephedra nevadensis

Ambrosia dumosa

Krameria erecta

B. Ephedra nevadensis-Ambrosia dumosa Alliance

1. Ambrosia dumosa-Atriplex confertifolia

Ericameria teretifolia

Eriogonum fasciculatum

2. Ephedra nevadensis-Ambrosia dumosa

Krameria erecta

Larrea tridentata

3. Menodora spinescens

Ambrosia dumosa

Ephedra nevadensis

Krameria erecta

\section{GREAT BASIN DESERT FORMATION}

A. Eriogonum fasciculatum-Ericameria teretifolia Alliance

1. Eriogonum fasciculatum-Ericameria teretifolia

Ephedra nevadensis

Gutierrezia sarothrae

B. Artemisia Alliance

1. Artemisia tridentata

Ephedra nevadensis

Ericameria teretifolia

C. Coleogyne ramosissima Alliance

1. Coleogyne ramosissima

Ephedra nevadensis

Ericameria teretifolia

in packrat midden samples and was replaced by the presence of singleleaf pinyon (Pinus monophylla) and an increase in the abundance of Utah Juniper. Goldenweed (Haplopappus nanus), Dorr's sage (Salvia dorii), and grizzlybear pricklypear (Opuntia erinacea) became more prevalent.

During the past $5 \mathrm{k}$ yr BP, creosote bush (Larrea tridentata), white bursage (Ambrosia dumosa), and other species characteristic of the Mojave Desert established within the NTS area as 
temperatures increased and precipitation decreased. It was estimated that many Great Basin Desert trees and shrubs were displaced about 457 to $610 \mathrm{~m}$ (1,500 to 2,000 ft) upward in elevation to what they historically had been as the climate changed (Spaulding, 1985). This climate change opened new niches for colonization by other species such as blackbrush (Coleogyne ramosissima). Ecotonal species are often adapted to a wide change in climatic conditions such as freezing temperatures, as well as hot, droughty climate.

Hereford and Longpre (2000) evaluated the climate history of the Mojave Desert Region from 1892 to 1996 . They concluded that from about 1905 to 1940 , precipitation was slightly above normal. From 1940 to 1978 , precipitation was slightly below normal and that, more recently, from 1978 to 1996 that precipitation was slightly above normal, although individual years of greater than or less than normal precipitation were also reported during these three longer periods of recent climate.

\subsubsection{Nevada Applied Ecological Group Studies}

In 1970, DOE Nevada Operations Office (DOE/NV) established the Nevada Applied Ecology Group (NAEG) to conduct studies of radionuclides in the environment on and near the NTS. Over the next 16 years, this group studied various ecosystem components to determine the fate of radionuclides in these desert environments. Over 540 reports and papers were prepared during this period. The group compiled and published ten collections of progress and research reports through 1983. While much of these progress reports dealt with radionuclide dynamics, valuable information was presented on the vegetation of many areas on the NTS and impacts of various DOE activities on vegetation. Friesen (1992) has made a final descriptive summary of this work.

\subsubsection{Basic Environmental Compliance and Monitoring Program Studies (BECAMP)}

In 1987, DOE/NV established a follow-on group to NAEG to monitor environmental conditions on the NTS. The objectives of the BECAMP program were to ensure compliance to environmental regulations and monitor potential impacts of DOE activities on biota. Although no vegetation maps were produced from these studies, numerous plots were established and sampled that described both undisturbed and disturbed vegetation on the NTS and monitored changes over the next seven to eight years. Annual reports containing the data sampled from vegetation monitoring plots from 1987 to 1994 were published (Hunter and Medica, 1989; Hunter, 1994a,b,c, 1995).

\subsubsection{Endangered and Threatened Species Studies}

Numerous surveys have been conducted on the NTS over the past 25 years to determine the distribution and abundance of plant species that were candidates for listing under the Endangered Species Act. In 1977, Beatley (1977) produced the first reports on the status of endangered and threatened species on the NTS. Later that year, Rhoads and Williams (1977) also produced a report on the endangered species on the NTS and, in 1978, published on the threatened species on the NTS (Rhoads et al., 1978). Between 1991 and 1998, extensive field surveys were made on species that remained as candidates for listing as threatened and endangered. Blomquist $e t$ al. $(1992,1995)$ and Anderson (1998) published results of these surveys. While none of these 
efforts mapped vegetation on the NTS, they did contribute to our knowledge of the flora of the NTS by documenting species distribution, species collections, and providing habitat descriptions (Figure 2-2).

\subsubsection{Wetland Studies}

A study of potential wetlands and waters of the United States was conducted by Bechtel Nevada scientists during 1996-1997. A report documenting wetlands on the NTS was published by Hansen et al. (1997), including a map of wetlands sites (Figure 2-3). Vegetation from these areas was described, as was water flow and water quality parameters.

\subsection{Vegetation Classification in the Western United States}

Vegetation in the western United States has been traditionally classified using three land classification schemes: (1) habitat type, (2) range site, and (3) community type (Hironaka, 1986; Ferguson et al., 1989). Because the first two of these schemes are based on climax or potential vegetation and do not recognize current vegetation, disturbances, or rare plant associations, they are of limited use in classifying vegetation on the NTS. A brief description of each scheme follows to facilitate comparisons among the classification schemes. Only the community type classification is deemed appropriate for the NTS vegetation.

Habitat type is a hierarchical ecological classification based on climax vegetation used primarily for forests (e.g., the U.S. Forest Service) in the western United States. The habitat type is the aggregate land area that presently supports, or until recently supported, and presumably is again capable of supporting the same climax vegetation. From a mapping viewpoint, all land that supports or supported the same specific climax vegetation is of the same habitat type. Classification by habitat types has not been very helpful in preserving very rare plant associations because classifications usually do not include the rare associations (Wellner, 1989). It does not recognize disturbed vegetation. The mapping of habitat types (based on vegetation) should not be confused with wildlife habitat, the abiotic and biotic components of an animal's environment. Computer models have been developed to relate these latter habitat components which have been reviewed by Berry (1986).

The second land classification scheme used primarily for shrublands and grasslands (e.g., the U.S. Bureau of Land Management and the Natural Resources Conservation Service) in the western United States is the range site classification. The range site is also an ecological classification based on climax vegetation. It is based on site productivity and/or species composition uniformity due to site differences within climax vegetation (Dyksterhuis, 1949). The range site is believed by many to be a homogeneous subdivision of a habitat type based on uniformity of productivity or species composition. The range site has been compared to the habitat type phase (Hironaka, 1986).

The third classification scheme is the community type (Mueller-Dombois and Ellenberg, 1974). It is an ecological classification based on current vegetation without regard to its successional status. It recognizes disturbed and rare plant associations and is considered the most appropriate of the three classification schemes for use on the NTS. The Nature Conservancy, under contract 


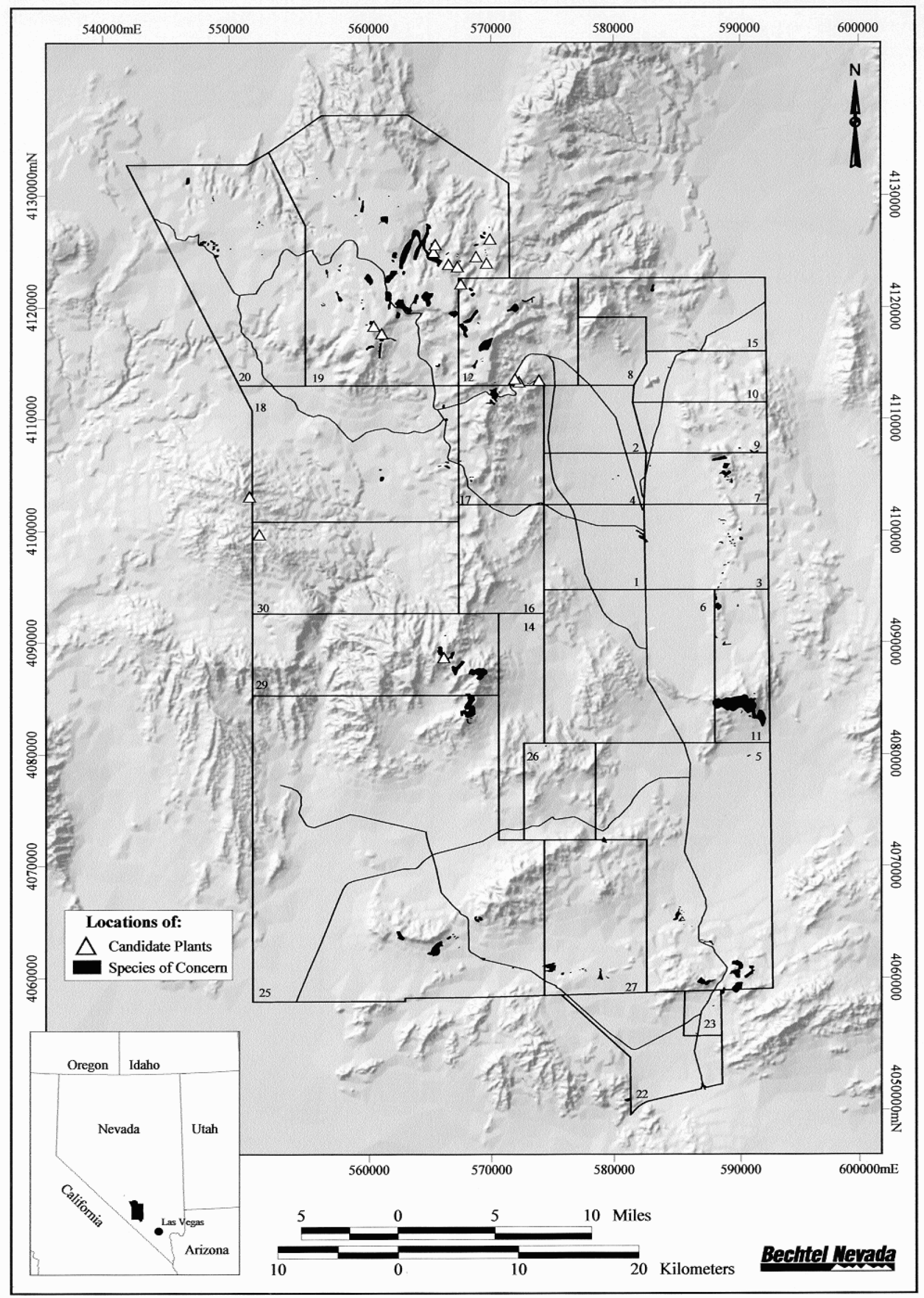

Figure 2-2 Location of sensitive plant species on the Nevada Test Site 


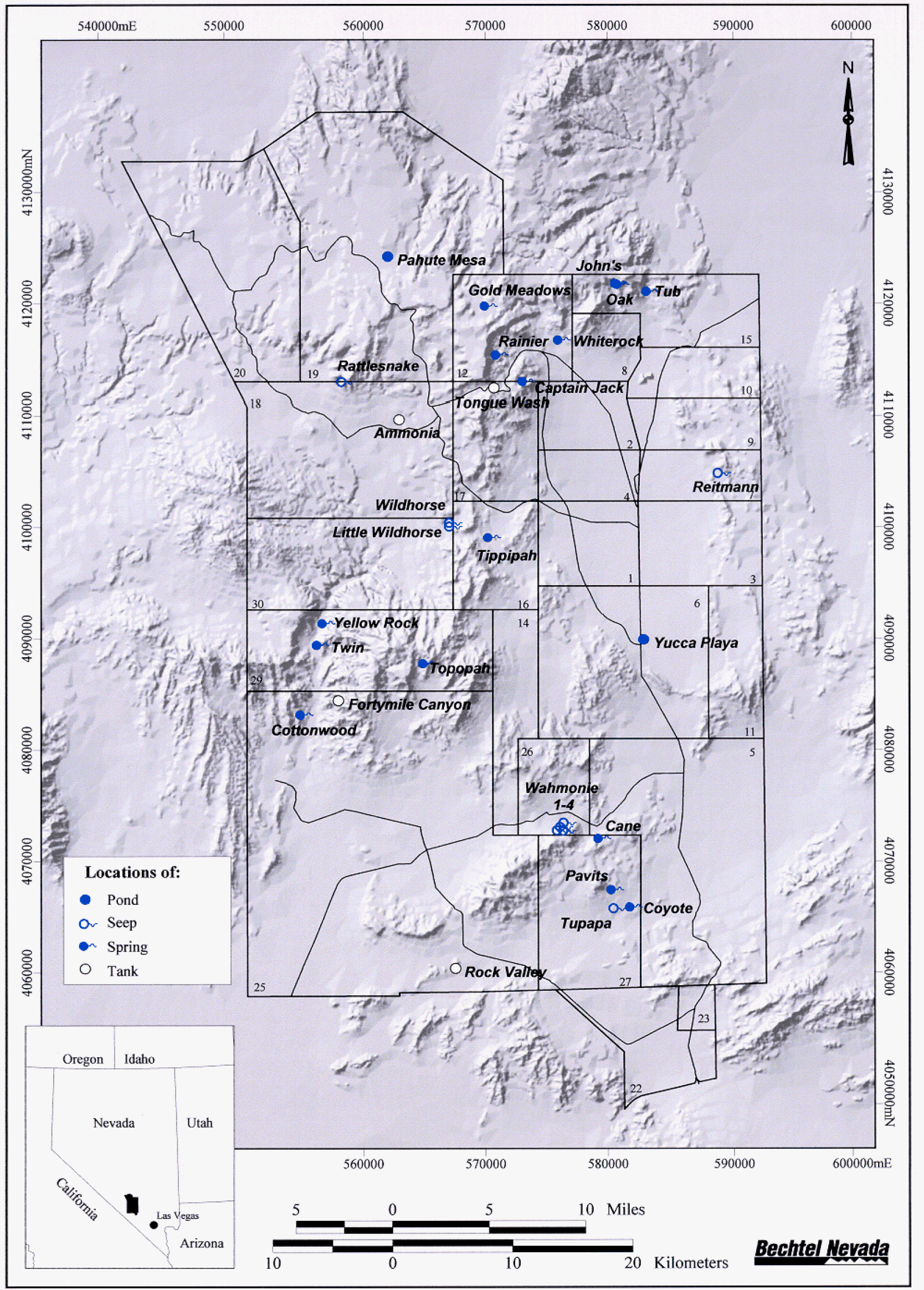

Figure 2-3 Location of wetlands on the Nevada Test Site 
with the U.S. Geological Survey (USGS), has prepared a Standardized National Vegetation Classification based on hierarchical community types (Federal Geographic Data Committee, 1996; Grossman et al., 1998). All federal agencies are encouraged to use this new classification. Accordingly, vegetation classification and mapping efforts on the NTS were aligned with these new standards.

\subsubsection{Vegetation in Deserts is Strongly Influenced by Water and Soils}

The distribution of vegetation on the earth's surface, especially in desert areas, is controlled more by the availability of water than by any other single factor (U.S. Congress, 1983; Kramer, 1969). Primarily climate and soils influence water availability. Climatological changes in desert areas over decades of time alter local availability of water, which has been shown to be highly correlated with changes in vegetation (Hastings and Turner, 1972). Rainfall and temperature determine to a large measure potential evapotranspiration, which has also been shown to correlate with habitat patterns and life zones of the world (Transeau, 1905; Holdridge, 1962). Soils in these habitats play a major role in determining water percolation, water retention, availability of plant nutrients, and ultimately in influencing the growth and vegetation patterns of an area.

\subsubsection{Soil Surveys Help Identify Plant Communities}

The U.S. Natural Resources Conservation Service (formerly the Soil Conservation Service) routinely performs soil surveys for the purpose of identifying the kinds and locations of unique soil types. Because soils persist in areas for very long periods of time ranging from thousands to millions of years, natural selection favors the growth of plants that are best adapted to the physical and chemical conditions peculiar to that soil. Therefore, soil surveys are also useful in identifying associated native vegetation (Gates et al., 1956).

One of the most detailed soil surveys, and also most useful in identifying associated vegetation, identifies phases of a soil series and is referred to as an Order 1 Soil Survey. This survey identifies individual soils referred to as soil consociations (i.e., a single soil component in contrast to an "association" comprised of many soil types or soil components). The mapping unit (a spatial representation of the soil consociation boundaries) may also have occasional allowable complexes. The minimum size of delineated mapping units is usually less than 0.4 hectare (ha) (1.0 acre [ac]) in size, ranging from 0.1 to $1.0 \mathrm{ha}(0.25$ to $2.5 \mathrm{ac})$ in size (Peterson, 1981). The scale of such maps is often greater than 1:10,000. These mapping units are identified by air photo interpretation and validated by transecting and traversing the soil unit. Validation consists of positioning carefully constructed transects across the area, digging soil pits at regularly spaced intervals, and describing the physical and chemical characteristics of the soil profile.

Because a significant effort and cost is required to conduct an Order 1 Survey, this type of mapping is usually restricted to intensely managed agricultural lands or mining lands where segregation and salvage of topsoil is required for revegetation of the land. On large areas that are not intensely managed (like the NTS), soils surveys with less detail are performed where minimum size of soil units are larger, for example: 0.4 to 3.6 ha $(1.0$ to $9.0 \mathrm{ac})$ - Order 2 Survey, 3.6 to 25.9 ha ( 9.0 to $64 \mathrm{ac}$ ) - Order 3 Survey, 14.6 to 63.1 ha (36 to $156 \mathrm{ac}$ ) - Order 4 Survey, and 63.1 to $4,046.9$ ha (156 to 10,000 ac) - Order 5 Survey (Peterson, 1981). 
Aerial color and infrared photography at a scale of $1: 10,000$ to $1: 24,000$ are powerful tools in identifying boundaries of soil consociations. Although at a much smaller scale, satellite imagery with multispectral band wavelengths, such as the French SPOT (Satellite Pour L'Observation de la Terre) is an additional tool in identifying such consociation boundaries. This is because interpretation of the band wavelengths help identify subtle differences in soil moisture, desert pavement (surface armoring by eroded gravel), and mineral types (e.g., caliche layers or cementation layers) which strongly influence root development and plant growth.

\subsubsection{Landforms are Correlated with Soil Types}

Landforms are three-dimensional parts of the general land surface, which are distinctive and repeat themselves frequently across the landscape in fairly consistent positions with respect to surrounding landforms. Examples of landforms are hills, sideslopes, alluvial fans, stream terraces, ballena, flood plains, and playas. In desert areas of Nevada, many of these landforms are composed of distinctive materials and are highly correlated with soil consociations (Peterson, 1981). Because the landforms can be readily discerned from aerial photography, their boundaries can be recognized with a high degree of accuracy. Soils of a particular landform are frequently quite uniform and can be used to approximate the boundaries for soil consociation; however, they may occasionally vary along spatial gradients. For example, this might occur along an alluvial fan outwash slope where coarse materials are deposited near the top of the fan and finer-textured materials are carried to the lower, downslope positions. Such landforms may contain two or more consociations referred to as a soil "association." The only means of discerning the boundaries of these consociations may be differences in spectral properties (photographic hues or textures) or by differences in the plant communities occupying these soils. Landforms provide a means of rapidly identifying boundaries of soil consociations which, in turn, are highly correlated with plant communities or wildlife habitats.

\subsubsection{Ecological Landform Units}

When the landscape is delineated into small mapping units ( 0.4 to 4.0 ha [ 1 to $10 \mathrm{ac}])$ using aerial photography and multispectral satellite imagery, the area is divided into a mosaic of land features that closely approximate an Order 2 Soil Survey (Bailey et al., 1994). This corresponds to the minimum size delineation which is approximately $0.4 \mathrm{~cm}^{2}(1 / 4$-inch square) (about $2.3 \mathrm{ha}$ [5.7 ac] at 1:24,000 scale) (Holdorf, 1989). When these landform units are visited in the field by trained scientists, observations can be made of the delineated areas to determine if the vegetation is relatively homogeneous over the unit or if a mosaic of vegetation patterns exists within the mapping unit. When landform units with mosaics are divided into subunits that have relatively homogeneous plant communities, then these resulting landform units have been referred to as ELUs by Bechtel Nevada biologists. The physical (e.g., soils, slope, geology, and hydrology) and biological (e.g., plant community composition and structure) environmental parameters also strongly influence the types of animals (e.g., insects, birds, mammals, and reptiles) that will also be found in these ELUs. Because the soils, slope, geology, hydrology, vegetation, and animals are all relatively uniform and homogeneous within these ELUs, they represent a meaningful mapping unit that can be hierarchically combined with other similar units into a statistically defensible (e.g., dendrogram based on cluster analyses) collection of plant community types for 
the purpose of mapping plant communities, determining wildlife habitat, and establishing plant species ranges. The strong correlation between landforms and wildlife habitat was also recognized by Berry (1979) and used to model habitat relationships of terrestrial vertebrates. 


\subsection{METHODS}

\subsection{Mapping ELUs on the NTS}

Mapping of stands within plant communities (associations) was initiated by first identifying landforms (Figure 3-1) and delineating their boundaries from prints of aerial photographs (1:24,000 scale) (Figure 3-2). These boundaries were traced onto clear plastic sheets registered to the underlying digital prints as published in the NTS Grid Map, A Grid System Photo Locator Map of the NTS (DOE, 1995). Boundaries of landforms with similar physical and biological properties were then verified in the field and modified to delineate ELUs.

In theory, each area within an ELU has approximately the same slope, soils, and vegetation. The intent was not to subjectively and arbitrarily classify the ELU as a particular vegetation type or subtype, but rather to delineate all of the basic building blocks or areas that were relatively homogeneous and would perhaps respond similarly to management practices. Once the boundaries of these areas were determined, the physical and biological characteristics within these areas were described. A description of the ELU was made by selecting representative areas, visiting the area, and recording information about the ELU on field data sheets (Figure 3-3).

While most ELUs were several hectares in size, some having rather unique environmental conditions were sampled and delineated in areas as small as a hectare in size. UTM (Universal Transverse Mercator) land coordinates (NAD27) and one or more representative photographs were taken to document the location and appearance of the vegetation and landscape at that transect location.

Statistical tools such as cluster analysis were then used to identify similar ELUs for purposes of classifying the vegetation, consistent with national vegetation classification standards. Individual ELUs were then assigned to a national vegetation classification category using quantitative characteristics determined from cluster analyses and other statistical tools. This removed many of the problems of having to subjectively decide in the field which classification category the ELU falls into without having seen all the sites, comparing sites, or having field data to support the classification decision.

\subsubsection{Geographic Information System Techniques}

A geographic information system was developed to manage and display data collected during the mapping and classification efforts. The resulting system was referred to as the EGIS. It was developed using Environmental Systems Research Institute, Inc.'s (ESRI) ArcView ${ }^{\text {TM }} 3.2$. Metadata conformed to proposed Content Standard for National Biological Information Infrastructure Metadata (National Biological Service, 1995). 


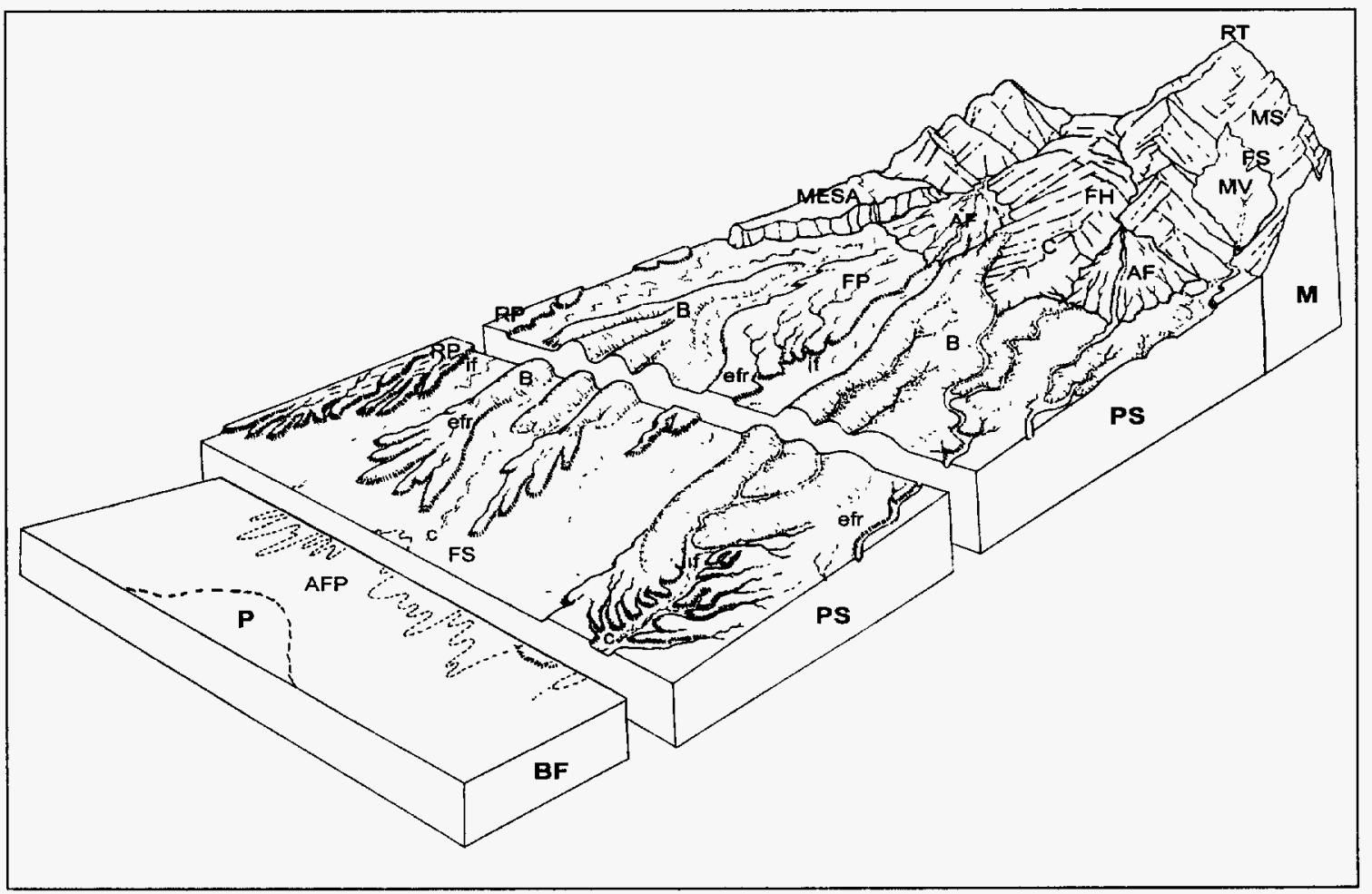

CODES: M: RT,MESA (fr, if),MS,FS,FH (c,s, if),MV (fr,in) PS: RP,B,AF,FP (efr,c), FS (c) BF:AFP,P

MOUNTAIN (M)

Ridge Top (RT)
Mesa (MESA)
fan remnants (fr)
inset fan (if)
Mid Slope (MS)
Foot Slope (FS)
Foothills (FH)
crest (c)
slope (s)
inset fan (ff)
Mountain Valley (MV)
fan remnants (fr)
inset fan (if)

\section{STEEP TERRAIN WITH EXPOSED BEDROCK AT HIGHER ELEVATIONS}

\author{
Mountain tops or crest of broad-ridged mountains \\ Flat-topped mountains \\ Sloping erosional features of Mesas \\ Drainage channels of Mesas \\ Middle elevation sections of mountain slopes \\ Bottom elevation sections of mountain slopes \\ Rolling hills with exposed bedrock at lower elevations \\ Tops of Foothills \\ Sides of Foothills \\ Drainage channels within Foothills \\ Valleys bounded by Mountains at higher elevations \\ Sloping erosional features of Mountain Valleys \\ Drainage channels withın Mountain Valleys
}

PIEDMONT SLOPE (PS) LAND FORMED BY SOIL DEPOSITION AT LOWER ELEVATIONS
Rock Piedmont (RP)
Ballena (B)
Alluvial Fan (AF)
Fan Piedmont (FP)
erosional fan remnant (efr)
inset fan (ii)
channel (c)
Fan Skirt (FS)
channel (c)
An erosional surface cut across bedrock (rare on NTS)
Round-topped ridgeline remnants of fan alluvium
Semiconical fans deposited in drainages below Mountains
Slightly undulating depositional areas below Alluvial Fans Gradually sloping upland areas of a Fan Piedmont Drainage channels within a Fan Piedmont Drainage channels within a Fan Piedmont
Relatively flat slopes below coalescing Fan Piedmonts Drainage channels withın Fan Skirts

BASIN FLOOR (BF)

BOTTOM OF A BASIN THAT COLLECTS WATER AND SEDIMENTS

Alluvial Flat/Plain (AFP) Playa $(P)$
Relatively flat vegetated areas upslope of barren playas Barren flats with fine-textured soils that are occasionally inundated

Figure 3-1 Landform types and codes for describing landforms on the Nevada Test Site 


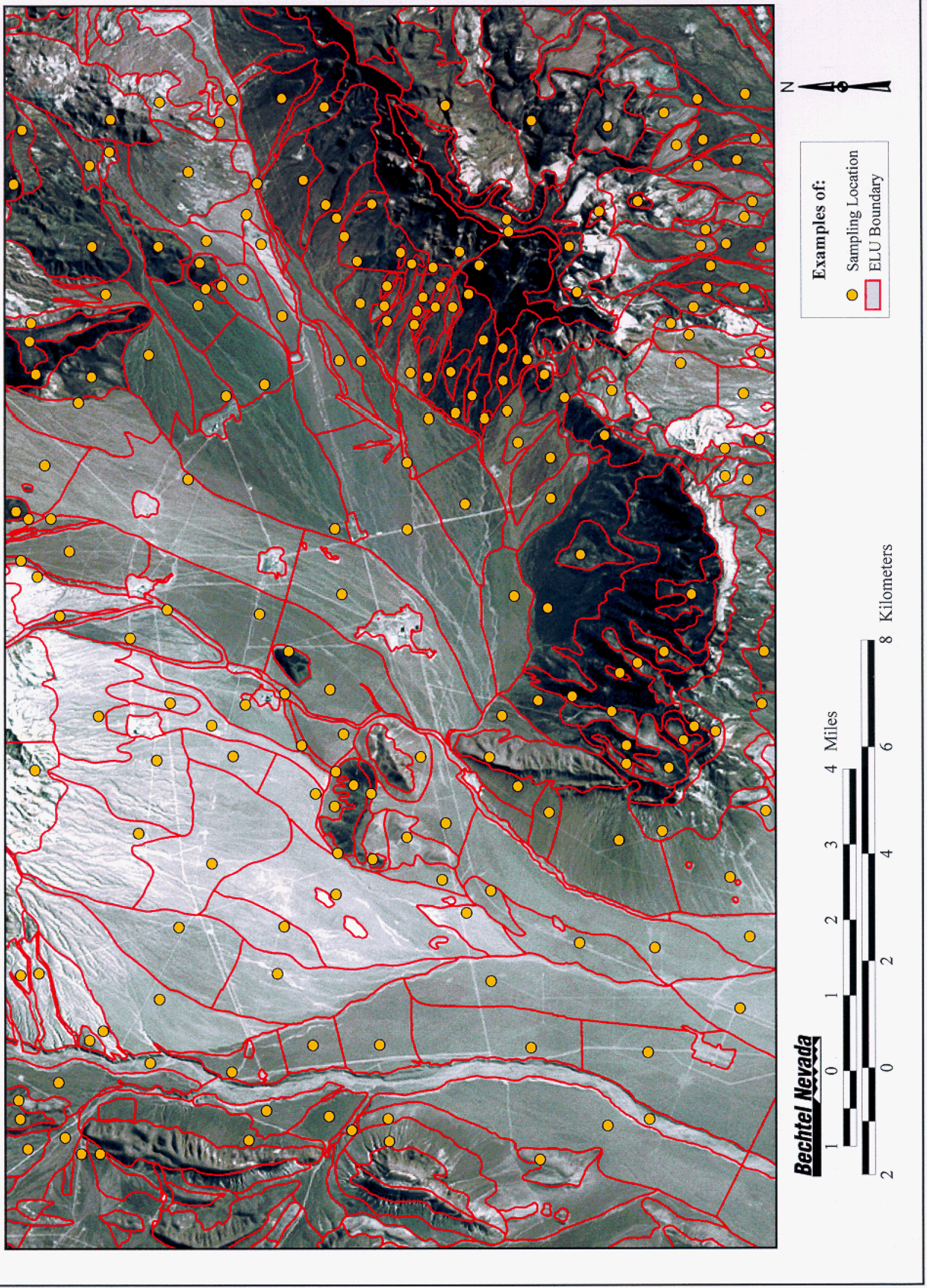

Figure 3-2 Example of delineated boundaries of an Ecological Landform Unit on the Nevada Test Site 


\section{BECHTEL NEVADA 1998 VEGETATION MAPPING SAMPLING FORM}

SITE NO.

DATE_9/

198

TIME GRID MAP NO.

COLLECTORS_WKO DJH USGS QUAD NAME PHOTOS \# GPS COORDINATES_5E, $\quad-4$ N

ELEV (m) SLOPE (') ASPECT (Degrees)

LANDFORM I II III IV V

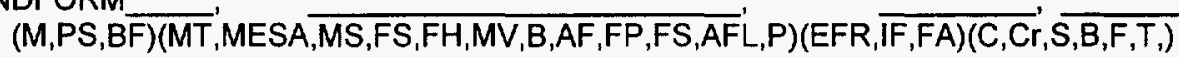
GEOLOGY SOILS EROSION PAVEMT COVER \%

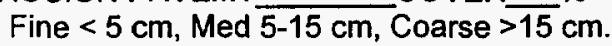

RODENT ACTVTY CRYPTOS ANN. PROD HORSE SIGN $(1-5,1=$ none, $5=$ very abundant $)(1-4,1=\overline{\text { none, } 4=h i g h})(1-5,1=\overline{\text { low, } 5=h i g h})(1-3,1=$ none, $3=$ alot $)$ P COVER 1 DOM TREES/SHRUBS (Relative density, circle dominant species, put "W" if wash species)

\begin{tabular}{|c|c|c|c|c|}
\hline ARNO4 & CORA & ERNAH_ & HYSA & _PUTR2. \\
\hline ARTRT & EPNE_ & ERPA30 & _JuOS_ & RHTR_ \\
\hline ARCA2 & _EPVI__ & _ERTE18_ & _KRLA2 & _SYLO \\
\hline ATCO & ERFA2 & _GRSP & _LYAN_ & _TEAX_ \\
\hline CHVI8_ & ERMI4 & GUSA2 & _PIMO_ & _TECA2 \\
\hline CHVIP4_ & ERNAL & ERCO23 & _PUST_ & _YUBAV \\
\hline
\end{tabular}
( PUST YUBAV

IMPORTANT FORBS
1)
2)
3)
4)
5)
6)
7)
8)
9)
10)

IMPORTANT GRASSES

1) 2)

3)

4)

5)

OTHER IMPORTANT SPECIES (Cacti, T\&E)

1) 2)

3) TOTAL PER. SPECIES

ECOLOGICAL NOTES:

Figure 3-3 Example of a vegetation mapping sampling form 


\subsubsection{Image Analysis}

Landform units were delineated on 32 French satellite images corresponding in area to the 32 USGS 7.5-minute quadrangles that cover the NTS. The digital images were produced by combining $30-\mathrm{m}$ (98-ft) resolution SPOT color digital imagery with $10-\mathrm{m}(32.8-\mathrm{ft})$ resolution SPOT black and white imagery and then printed to maps. Boundaries of landforms were distinguished by image differences in texture and color.

Boundaries were drawn in ink onto clear acetate overlays attached to and registered with the underlying map image. When available, clear overlays of USGS topographic maps were inserted between the image base and the upper overlay to assist in interpreting slope and aspects.

In addition to the SPOT images, 240 photomaps of the NTS and surrounding areas were used to provide greater detail for photo interpretation. The NTS Grid Map collection was obtained by aerial photographic mapping missions that were flown in August and September 1994 by the DOE's Remote Sensing Laboratory located at Nellis Air Force Base in Las Vegas, Nevada. The missions were flown at $488 \mathrm{~m}(16,000 \mathrm{ft})$ above ground level using two photogrammetric cameras with normal color film and infrared color film. The grid map atlas was printed from the normal color photography at a scale of roughly 1:24,000. Registration of latitude and longitude was only approximate, with apparent discrepancies observed from sheet to sheet. Maps were considered accurate to $\pm 30.5 \mathrm{~m}$ (100 ft). Prints of selected images (i.e., photo negatives) were made to provide higher resolution for distinguishing textural differences due to differences in shrub types and cover. These photographic prints were used in the field.

After the final corrections were made to the delineated boundaries of the ELUs based on the field verification and photomaps, the ELU boundaries were digitized using ESRI's Data Automation $\mathrm{Kit}^{\mathrm{TM}}$. Boundaries were verified and then the polygons (ELUs) were labeled with the appropriate ELU number. This coverage was then linked to a Microsof ${ }^{\circledR}$ Access 97 database using ArcView $^{\mathrm{TM}} 3.1$ software.

\subsection{Plant Identification}

Plant species were identified using several published floras (Kartesz, 1988; Hickman, 1993; Welsh et al., 1993; and Cronquist et al., 1994). When the phenological stage of the plant was less than optimal for identification (e.g., before or after flowering when the plant lacked key taxonomic features), then species or varieties were determined as best as possible from taxonomic keys. Final assignment of identification was made by taking into account these features and which species were most commonly reported (e.g., Beatley, 1976) to occur in that community type. On rare occasions, some collections were sent to taxonomists who specialized in the identification of certain species or varieties (e.g., Dr. Stanley Welsh at Brigham Young University, Provo, Utah). 


\subsubsection{Nomenclature}

Plant nomenclature used on the NTS up to 1997 generally followed Beatley (1976). However, with the taxonomic revision of some phylogenetic relationships and subsequent reassignment of a few plants into more appropriate genus and species names, a need arose to reflect current nomenclature. In 1996, the Biota of North America Program under the direction of Dr. John Kartesz, published a revised list of plant names, both scientific and vernacular (common) for North America (U.S. Department of Agriculture [USDA], National Resource Conservation Service [NRCS], 1996). Alphanumeric plant symbols were also assigned to each species or subspecies. The alphanumeric codes were generally comprised of the first two letters of the genus name followed by the first two letters of the species name (e.g., Artemisia tridentata $=$ ARTR). To distinguish between species or subspecies with potentially the same alphanumeric codes (e.g., Artemisia nova and Artemisia norvegica), additional letters or numbers were used (e.g., Artemisia norvegica $=\mathrm{ARNO}$ and Artemisia nova $=\mathrm{ARNO}$ ). This list became the standard to be used by all federal agencies. Starting in 1997, plant nomenclature on the NTS was changed to reflect those of the National Plant Data Center (USDA NRCS, 1996). Synonyms were retained in the database as a crosswalk to the earlier nomenclature of Beatley (1976).

\subsubsection{Voucher Specimens}

Since 1957, plant voucher specimens have been collected, mounted, and stored in the herbarium at Mercury on the NTS. Duplicate specimens were also sent to the herbarium at the University of Nevada at Las Vegas. Additionally, selected specimens were deposited at the herbariums at the University of California in Los Angeles; the New Mexico Highlands University in Las Vegas, New Mexico; and Brigham Young University in Provo, Utah.

Plant collections made during field sampling were identified and mounted, and are also stored in the herbarium at Mercury.

\subsection{Field Survey Techniques}

Data were recorded on the sampling form previously shown (Figure 3-3). The collector reviewed data sheets for inconsistencies or deficiencies. Occasionally, global positioning system (GPS) readings could not be received in the field because of proximity to hills or topographic obstructions. Geographical location data were then estimated from USGS 7.5-minute topographic maps.

Site descriptions were made along 200-m- (656-ft)-long linear transects, with observation points located every $20 \mathrm{~m}(65.5 \mathrm{ft})$ along the transects (i.e., 10 points per transect). At each observation point, the names (alphacodes) of the five closest shrubs to the point were recorded. The relative abundance of forbs, grasses, cacti, and other important species such as threatened and endangered plant species were also recorded and ranked (the most abundant species received a ranking of 1 , the second most abundance species received a ranking of 2 , etc.). The names of plants and animals observed as well as physical conditions of the environment were described.

Not all ELUs were sampled. Based on ground observations, areas that appeared similar in physical and biological characteristics to an adjacently sampled area were not sampled, but 
merely assigned the same characterization values by referencing the sampled site and its recorded attributes. ELUs that were remote or inaccessible were coded either as unsampled or assigned the closest and most comparable sampled ELU. Approximately 1,508 ELUs were sampled.

Two or more transects were used to document the species change on long slopes where species composition of the vegetation changed in response to environmental gradients like increase in soil texture or soil moisture along an elevation gradient. Arbitrary boundaries between the two sampling points were drawn on the map (straight lines half way between the two transect midpoints) to suggest that the upper polygon was most closely described by the transect in the upper reaches of the slope, while the lower polygon was most closely described by the transect in the lower reaches of the slope.

\subsection{Laboratory Soil Analyses}

Laboratory analyses consisted of determining soil texture. Soil samples were taken from representative portions of the area being sampled (i.e., the ELU), usually from the surface soil just under the perimeter of the shrub canopy. Atypical areas such as rocky outcrops, rodent diggings, desert pavement, or disturbances were avoided. The intent was to sample soil in an area that represented the most likely microsite for germinating seeds. Large rocks and plant litter were carefully removed from the surface exposing the surface soil. Approximately 100 milliliters of soil was scooped into small plastic containers. Samples were labeled with the number of the site and returned to the laboratory in Mercury, Nevada, for processing (usually the same day they were collected in the field).

Soil samples were then sieved through a 2-millimeter ( $\mathrm{mm}$ )-sized sieve to remove gravel and plant debris. Screened samples were then wetted with tap water to gradually moisten the sample. The palm-sized sample was kneaded in the hand to mix the soil and water thoroughly. A textural particle size class was then assigned based on the ribbon and grit properties of the sample. Brady (1974) describes the procedure more fully. The textural analysis is only approximate, but appears to offer a quick method for distinguishing between the major textural classes that are often correlated with vegetation patterns.

\subsection{Statistical Data Analyses}

Field data were organized into data tables using Microsoft Access ${ }^{\mathrm{TM}}$ and Excel $^{\mathrm{TM}}$. Descriptive statistics were used to summarize and describe data. MiniTab ${ }^{\mathrm{TM}}$ and Systat $5.0^{\mathrm{TM}}$ software were used to provide statistical analyses such as cluster analyses, discriminate analyses, multiple regression analyses, and chi-square tests. Cluster analysis was used to identify similar ELUs for purposes of classifying vegetation, consistent with national vegetation classification standards.

The clustering program utilized squared Euclidean distance and average linkage to separate unique cluster groups. Clustering was based on the quantitative characteristics of only shrubs

and trees recorded along each transect. Forbs and grasses were not used in this analysis. Cluster groups were assigned to a national vegetation classification category based on the dominant shrubs and trees in each group. ELUs were assigned a number based on the cluster group in 
which they occurred. These groups were used to produce a vegetation map of the NTS. This removed many of the problems of having to subjectively decide in the field which classification category the ELU fell into without having seen all of the site, comparing sites, or having field data to support the classification decision.

\subsection{Tabular Data Management}

After an initial review of field data sheets for accuracy, data were entered into custom data forms using Microsoft Access $97^{\mathrm{TM}}$ software. Field values were subjected to validation rules to ensure that entries were within given size ranges and of proper data type (e.g., alphanumeric vs. numeric or logical). The relational database consisted of five main data forms: (1) site data entry form, (2) shrub and tree data entry form, (3) herb and grass data entry form, (4) cacti and other species (e.g., threatened and endangered plant species), and (5) plant nomenclature data entry form. Data entry items that were not legible or clear were marked for review by the collector (field scientist) and data entered, corrected, or reentered. Data tables were exported for use in Microsoft Excel $97^{\mathrm{TM}}$ and ESRI ArcView 3.1 ${ }^{\mathrm{TM}}$ software. Plant species alphanumeric symbol codes were also checked for accuracy using voucher specimens and other taxonomic aids. 


\subsection{RESULTS AND DISCUSSION}

\subsection{Vegetation Cluster Analyses}

Results from the cluster analysis are shown in Figure 4-1. Assignment of ELUs to cluster groups (alliance and associations) was an iterative process. Initial clustering used the 75 percent similarity level and yielded 11 cluster groups (alliances). Three of these groups were very large and contained a diverse group of ELUs. Site data and pictures taken at each ELU were subsequently evaluated. It was decided to increase the similarity level to recognize additional associations within these three groups. Increasing the similarity level to 85 percent yielded only 13 cluster groups but still did not recognize the pinyon woodland plant communities that occur on the NTS. However, at the 90 percent similarity level, these woodlands were separated from cluster groups dominated by sagebrush. This level also recognized five associations within the group characterized by Nevada jointfir (Ephedra nevadensis). These associations had Nevada jointfir as a subdominant species and other species as dominants. Field observations also tended to support the need to recognize these as separate associations.

Based on this iterative clustering process, 10 alliances and 20 associations were recognized as occurring on the NTS. Several ELUs did not cluster as groups, but remained as single units because of their unique vegetation. These ELUs were listed together in a miscellaneous category on the final map. Alliances and associations were named after the dominant tree or shrub species based on relative abundance and according to Federal Geographic Data Committee and Ecological Society of America conventions (Grosman et al., 1998; Anderson et al., 1998). Results of the classification are shown in Table 4-1.

Two major vegetation groups or ecoregions, Mojave Desert and Great Basin Desert, can be identified from this classification. Between these two deserts is a broad transition zone that often includes a mixture of species from either major ecoregion. Beatley (1976) refers to this climatic zone as the "Transition Desert" and recognized several plant associations within this zone. These climatic zones or ecoregions are discussed more thoroughly in Section 4.4.1. The dominant plant association that typifies this zone is the Coleogyne ramosissima-Ephedra nevadensis Shrubland Alliance. In our cluster analysis, ELUs containing blackbrush clustered together, quite clearly showing the unique nature of this vegetation alliance. Several authors (Beatley, 1976; Brown et al., 1980; Turner, 1982a,b; Holland, 1986) recognize a blackbrush vegetation association, but there is disagreement about whether it should be classified in the Mojave Desert or Great Basin Desert.

\subsection{Distribution and Description of Plant Alliances}

Figure 4-2 shows the distribution of plant alliances on the NTS. Also shown are the generalized boundaries for the Mojave Desert, Great Basin Desert, and the transition region between these deserts. Plant species that dominate alliances within this transition have been historically associated with either desert and, in some cases, listed as a minor species in both deserts. Characteristics of plant alliances on the NTS are shown in Table 4-2. 


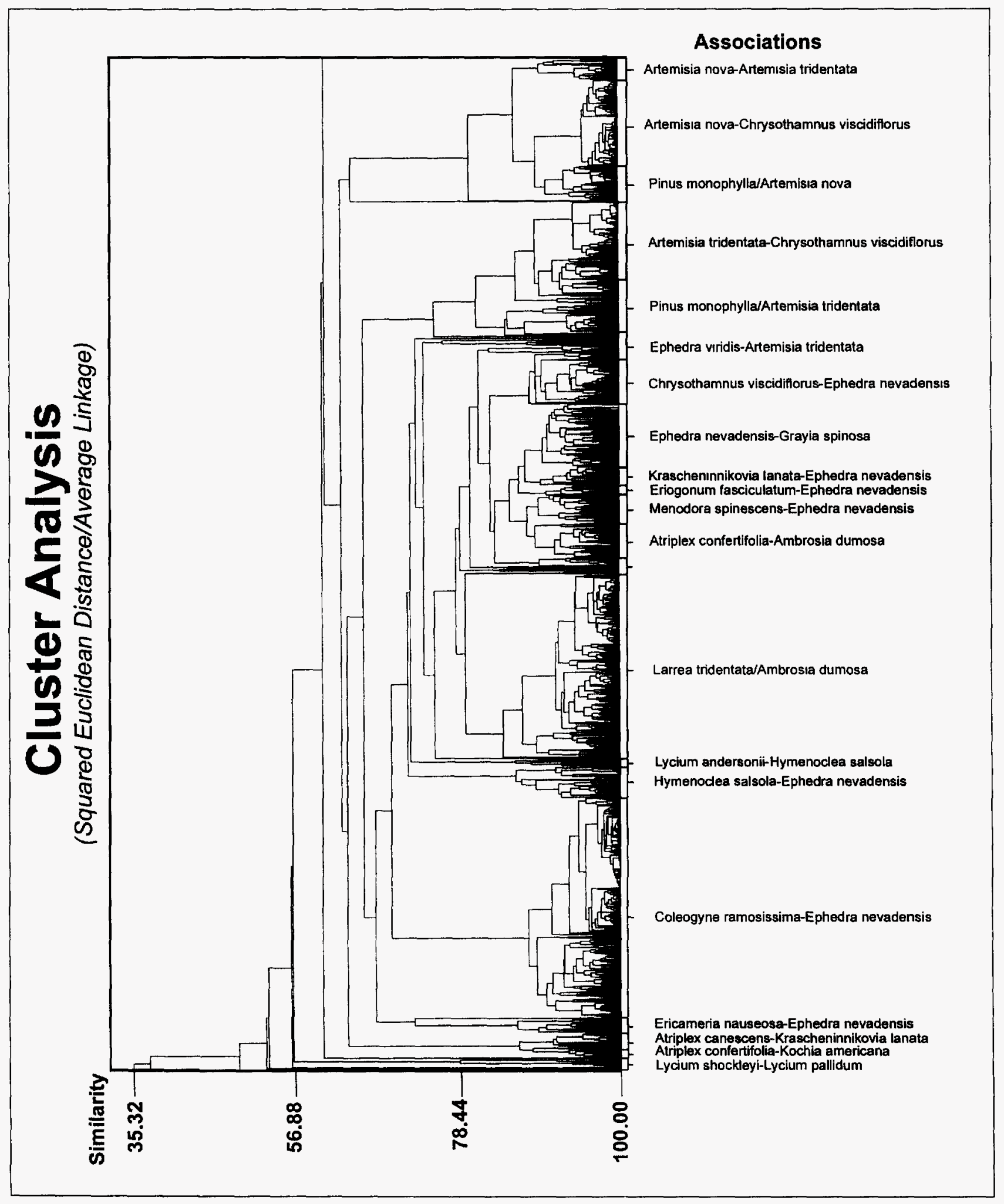

Figure 4-1 Results of cluster analyses for ELUs on the Nevada Test Site 
Table 4-1 Vegetation ecoregions, alliances, and associations on the Nevada Test Site

\begin{tabular}{|c|c|c|}
\hline Ecoregion & Alliance & Association \\
\hline \multirow{3}{*}{ Mojave Desert } & Lycium spp. Shrubland Alliance & Lycium shockleyi-Lycium pallidum Shrubland \\
\hline & $\begin{array}{l}\text { Larrea tridentata/Ambrosia dumosa } \\
\text { Shrubland Alliance }\end{array}$ & Larrea tridentata/Ambrosia dumosa Shrubland \\
\hline & $\begin{array}{l}\text { Atriplex confertifolia-Ambrosia dumosa } \\
\text { Shrubland Alliance }\end{array}$ & $\begin{array}{l}\text { Atriplex confertifolia-Ambrosia dumosa } \\
\text { Shrubland }\end{array}$ \\
\hline \multirow{6}{*}{ Transition Zone } & \multirow[t]{2}{*}{ Hymenoclea-Lycium Shrubland Alliance } & $\begin{array}{l}\text { Lycium andersonii-Hymenoclea salsola } \\
\text { Shrubland }\end{array}$ \\
\hline & & $\begin{array}{l}\text { Hymenoclea salsola-Ephedra nevadensis } \\
\text { Shrubland }\end{array}$ \\
\hline & \multirow{3}{*}{ Ephedra nevadensis Shrubland Alliance } & $\begin{array}{l}\text { Menodora spinescens-Ephedra nevadensis } \\
\text { Shrubland }\end{array}$ \\
\hline & & $\begin{array}{l}\text { Krascheninnikovia lanata-Ephedra nevadensis } \\
\text { Shrubland }\end{array}$ \\
\hline & & $\begin{array}{l}\text { Eriogonum fasciculatum-Ephedra nevadensis } \\
\text { Shrubland } \\
\text { Ephedra nevadensis-Grayia spinosa Shrubland }\end{array}$ \\
\hline & $\begin{array}{l}\text { Coleogyne ramosissima Shrubland } \\
\text { Alliance }\end{array}$ & $\begin{array}{l}\text { Coleogyne ramosissima-Ephedra nevadensis } \\
\text { Shrubland }\end{array}$ \\
\hline \multirow{10}{*}{$\begin{array}{l}\text { Great Basin } \\
\text { Desert }\end{array}$} & \multirow[t]{2}{*}{ Atriplex spp. Shrubland Alliance } & $\begin{array}{l}\text { Atriplex confertifolia-Kochia americana } \\
\text { Shrubland }\end{array}$ \\
\hline & & $\begin{array}{l}\text { Atriplex canescens-Krascheninnikovia lanata } \\
\text { Shrubland }\end{array}$ \\
\hline & \multirow{2}{*}{$\begin{array}{l}\text { Chrysothamnus-Ericameria Shrubland } \\
\text { Alliance }\end{array}$} & $\begin{array}{l}\text { Chrysothamnus viscidiflorus-Ephedra } \\
\text { nevadensis Shrubland }\end{array}$ \\
\hline & & $\begin{array}{l}\text { Ericameria nauseosa-Ephedra nevadensis } \\
\text { Shrubland }\end{array}$ \\
\hline & \multirow{4}{*}{ Artemisia spp. Shrubland Alliance } & Ephedra viridis-Artemisia tridentata Shrubland \\
\hline & & $\begin{array}{l}\text { Artemisia tridentata-Chrysothamnus viscidiflorus } \\
\text { Shrubland }\end{array}$ \\
\hline & & $\begin{array}{l}\text { Artemisia nova-Chrysothamnus viscidiflorus } \\
\text { Shrubland }\end{array}$ \\
\hline & & Artemisia nova-Artemisia tridentata Shrubland \\
\hline & \multirow[b]{2}{*}{$\begin{array}{l}\text { Pinus monophylla/Artemisia spp. } \\
\text { Woodland Alliance }\end{array}$} & Pinus monophylla/Artemisia nova Woodland \\
\hline & & Pinus monophylla/Artemisia tridentata Woodland \\
\hline
\end{tabular}




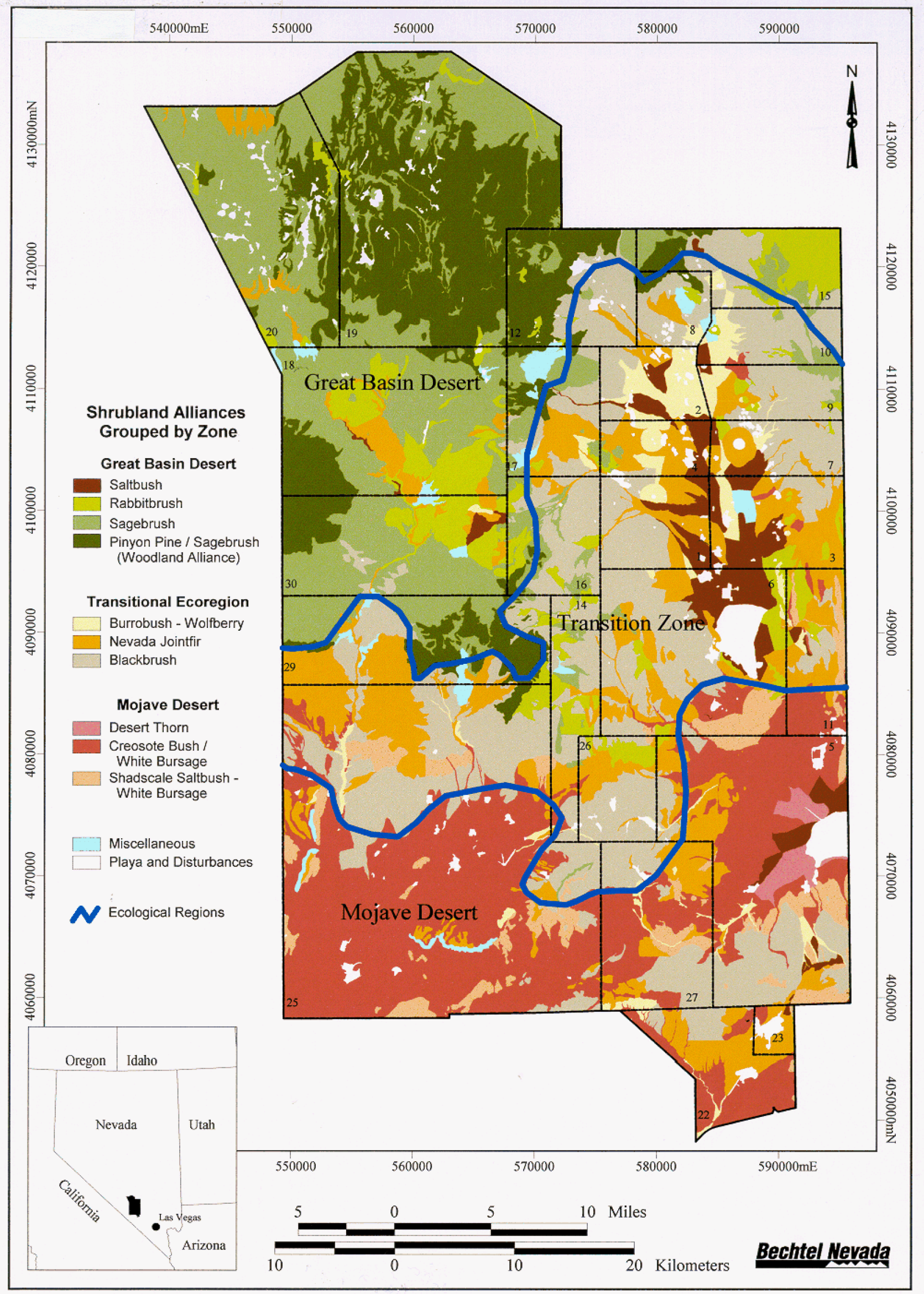

Figure 4-2 Distribution of plant alliances on the Nevada Test Site 


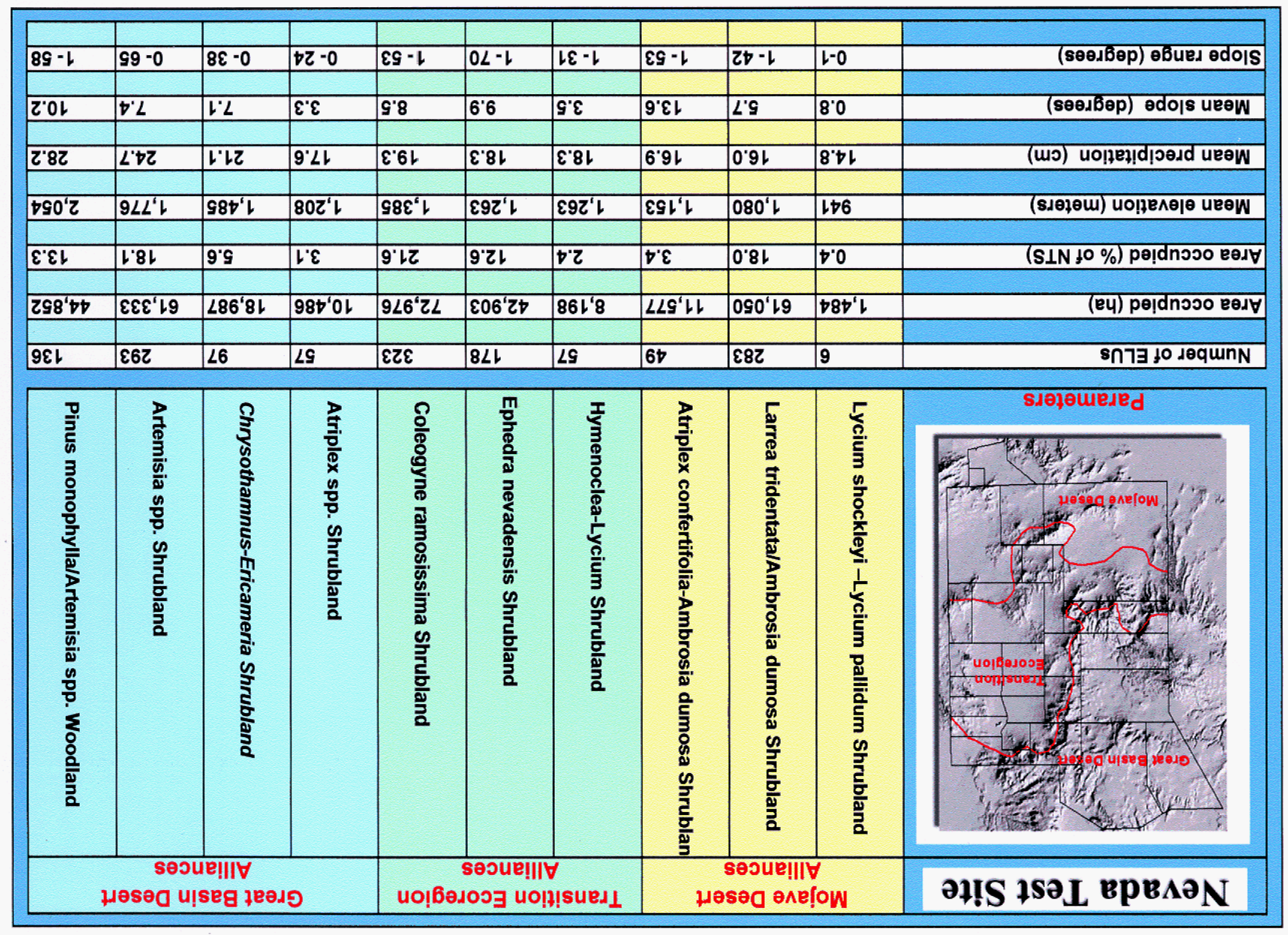


Ten alliances were recognized as occurring on the NTS. These alliances contain diagnostic species or genera that dominate and provide the nomenclature as per the national classification system guidelines. About 4 percent of the 1,508 ELUs sampled were classified as "miscellaneous" because they were unique vegetation types, burned, scraped, or disturbed by nuclear testing. There are three alliances within the Mojave Desert, three within the transition zone, and four within the Great Basin Desert. In terms of total area, the Great Basin Desert occupies approximately 40 percent of the NTS, followed by the transition zone with 37 percent. The Mojave Desert occupies the southern 22 percent of the NTS. Sampling within each major zone was rather even, with the average areas per ELU being 216 ha $(540 \mathrm{ac})$ in the Mojave Desert, 221 ha $(553 \mathrm{ac})$ in the Transition Zone, and $233 \mathrm{ha}(583 \mathrm{ac})$ in the Great Basin Desert.

\subsubsection{Mojave Desert}

There are three alliances in the Mojave Desert ecoregion of the NTS. These alliances contained 338 ELUs, which occurred on 74,111 ha $(185,278 \mathrm{ac})$ or 21.8 percent of the total area of the NTS.

\subsubsection{Lycium shockleyi-Lycium pallidum Shrubland Alliance}

This shrubland alliance consists of a single association that is restricted to the Frenchman Flat area on the NTS. It is the smallest alliance recognized on the NTS, consisting of slightly under 1,500 ha $(3,750 \mathrm{ac})$ or 0.4 percent of the area of the NTS. The dominant species in this alliance is Shockley's desert thorn (Lycium shockleyi), which is a southern Nevada endemic that is restricted to the broad transition desert in southern Nevada. Rabbit thorn (Lycium pallidum), a co-dominant species, has a much greater distribution but is still restricted to the Mojave Desert. It reaches its northern limits of distribution at the NTS. Beatley (1976) states that this community occurs in this area because of the cold air drainage that prohibits invasion by creosote bush. Our observations do not support that hypothesis (e.g., solitary 25-year-old patches of creosote bush along excavated pipelines within the playa where cold air drainage should have killed all plants); rather, its distribution on the NTS appears to be more closely related to soil chemistry, texture, and moisture relations.

\subsubsection{Larrea tridentata/Ambrosia dumosa Shrubland Alliance}

A single association, Larrea tridentata/Ambrosia dumosa Shrubland, is found within this alliance. There were 283 ELUs that were sampled and clustered within this alliance. It is one of the largest associations on the NTS, with over 61,000 ha $(152,500 \mathrm{ac})$ or 18 percent of the total area on the NTS. The dominant species in this alliance is creosote bush, which is the dominant shrub type within the Mojave Desert. On the NTS, white burrobush (Ambrosia dumosa) is the most common co-dominant, but this varies in other areas of the Mojave Desert where Anderson's wolfberry (Lycium andersonii), spiny hopsage (Grayia spinosa), and shadscale saltbush are codominants. Beatley (1976) recognized three plant communities on the NTS dominated by creosote bush: Larrea-Ambrosia, Larrea-Lycium-Grayia, and Larrea-Atriplex. The first two are included within our Larrea tridentata/Ambrosia dumosa Shrubland and the latter one is closely equivalent to our Atriplex confertifolia-Ambrosia dumosa Shrubland. 


\subsubsection{Atriplex confertifolia-Ambrosia dumosa Shrubland Alliance}

This is the third alliance within the Mojave Desert region of the NTS. It is also comprised of a single association. This alliance occurs on the foothills and mountains of the southern one-third of the NTS. There were 49 ELUs sampled and clustered within this alliance/association. It occurs on over $11,500 \mathrm{ha}(28,750 \mathrm{ac})$ or 3.4 percent of the total area on the NTS. The dominant species in this alliance is shadscale saltbush. Beatley (1976) recognized a Larrea-Atriplex plant community; however, while creosote occurs in this alliance/association as an associated species, it seldom dominates.

\subsubsection{Transition Zone}

There are three alliances represented in the Transition Zone ecoregion. These three comprise over $124,077 \mathrm{ha}(310,193 \mathrm{ac})$ or 36.6 percent of the total area on the NTS. A total of 558 ELUs were sampled in the Transition Zone.

\subsubsection{Hymenoclea-Lycium Shrubland Alliance}

This alliance consists of two associations. It is one of the smaller alliances recognized on the NTS, consisting of slightly over 8,000 ha $(20,000 \mathrm{ac})$ or 2.4 percent of the area of the NTS. The dominant species in this alliance are white burrobush and Anderson's wolfberry. This alliance is generally associated with disturbance, either natural such as drainage channels or man-caused such as fires or aboveground nuclear tests. White burrobush is an early successional species in the desert and often invades on disturbed sites. Anderson's wolfberry is one of the few desert species that resprouts following fires or other surface disturbances. Beatley (1976) did not recognize a similar plant community in her vegetation map, possibly because the focus was on undisturbed or climax plant communities. However, this alliance generally overlaps the area that was identified as Grayia-Lycium andersonii. Since 1976 when, Beatley completed her vegetation map, many of the disturbances in Yucca Flat associated with underground testing have occurred in this type.

\subsubsection{Ephedra nevadensis Shrubland Alliance}

This shrubland alliance consists of four associations. It contains slightly under 43,000 ha $(107,500 \mathrm{ac})$ or 12.6 percent of the area of the NTS. There were a total of 178 ELUs sampled that clustered within this alliance. The co-dominant or subdominant species in this alliance is Nevada jointfir, with several other species (spiny menodora [Menodora spinescens], winterfat [Krascheninnikovia lanata], and eastern Mojave buckwheat [Eriogonum fasciculatum]) that are co-dominants within the associations. This alliance occurs throughout the southern mountains and the upper slopes of the Yucca Flat Basin.

Beatley (1976) did not recognize this as an alliance within the Transition Zone, despite the fact that it represents over 30 percent of that zone on the NTS. She did recognize a similar association that she called Grayia-Lycium andersonii. She states that "the plant association that

most clearly characterizes the desert transition environmentally and vegetationally is GrayiaLycium andersonii." In our current study, spiny hopsage is a minor species and never dominates. 
It may be more susceptible to disturbance because it does not rootsprout and its abundance may have declined over the past 30 years. Also, it may have declined in response to natural changes such as global warming or in response to drought conditions in the late 1980s as reported at Yucca Mountain (Schultz and Ostler, 1995). Beatley (1976) states that this community occurs in basin floors such as Yucca Flat and Groom Lake because of the cold air drainage that prohibits invasion by species characteristic of the Mojave Desert. While the geographic areas overlap between our vegetation maps, the dominant species are quite different. She does identify other associated woody species in the Grayia/Lycium andersonii association, many of which are dominant or co-dominant within this alliance.

\subsubsection{Coleogyne ramosissima Shrubland Alliance}

A single association, Coleogyne ramosissima-Ephedra nevadensis Shrubland, made up this alliance. There were 323 ELUs sampled that clustered within this alliance/association. It is one of the largest associations on the NTS, with nearly 73,000 ha $(182,500 \mathrm{ac})$ or 21.6 percent of the total area on the NTS. The dominant species in this alliance is blackbrush, which represents over 50 percent of the relative abundance of shrubs in this association. Nevada jointfir is the most common associated shrub species; however, blackbrush is often so dominant that it forms almost pure stands. Beatley (1976) recognized this plant association and discussed its transitional role between the Mojave and Great Basin Deserts. She stated that it basically belongs to the Mojave Desert, but almost exclusively occupies sites where rainfall exceeds the tolerance of probably many Mojave species. Much of this association has been disturbed on the NTS from testing and natural or man-caused fires. These disturbed areas do not appear to be returning to a Coleogyne ramosissima Shrubland Alliance; rather they tend to cluster within the Ephedra nevadensis Shrubland Alliance.

\subsubsection{Great Basin Desert}

There are four alliances within the Great Basin Desert, occupying 135,658 ha $(339,145 \mathrm{ac})$ or 40 percent of the total area of the NTS. There were a total of 583 ELUs sampled in the Great Basin Desert region on the NTS.

\subsubsection{Atriplex spp. Shrubland Alliance}

This shrubland alliance consists of two associations. It is one of the smaller alliances recognized on the NTS, consisting of slightly over 10,500 ha $(26,250 \mathrm{ac})$ or 3.1 percent of the area of the NTS. The dominant species in this alliance are shadscale saltbush and four-wing saltbush (Atriplex canescens). This alliance is generally associated with unique soil conditions (either saline, heavy-textured soils, or deep loose sandy soils). Beatley (1976) recognized both associations in her vegetation map.

\subsubsection{Chrysothamnus-Ericameria Shrubland Alliance}

This shrubland alliance is comprised of two associations. It is one of the smaller alliances recognized on the NTS, consisting of just under 19,000 ha $(47,500 \mathrm{ac})$ or 5.6 percent of the area 
of the NTS. The dominant species in this alliance are green rabbitbrush (Chrysothamnus viscidiflorus) and rubber rabbitbrush (Ericameria nauseosa). Beatley (1976) does not recognize this alliance, possibly because much of this alliance occurs in mountainous areas that were not broken out by plant associations in her vegetation map. This alliance also occurs on disturbed sites, particularly burned areas in Mid Valley. The Mid Valley burns occurred in the 1980s after Beatley had published her map.

\subsubsection{Artemisia spp. Shrubland Alliance}

This shrubland alliance is comprised of four associations. It consists of over 61,000 ha $(152,500 \mathrm{ac})$ or 18.1 percent of the area of the NTS. There were a total of 293 ELUs sampled that clustered within this alliance. The dominant species in this alliance are basin big sagebrush (Artemisia tridentata) and black sagebrush (Artemisia nova), with two other species, Mormon tea (Ephedra viridis) and green rabbitbrush, that are co-dominants within the associations. This alliance occurs throughout the central and northwestern mountains. Beatley (1976) did recognize two of the associations that make up this alliance, Artemisia tridentata Shrubland and Artemisia nova Shrubland, but did not recognize the successional Ephedra viridis-Artemisia tridentata Shrubland association, which is the result of recent fires in the Timber Mountain and Fortymile Canyon areas.

\subsubsection{Pinus monophylla/Artemisia spp. Woodland Alliance}

This woodland alliance consists of two associations. It contains just under 45,000 ha $(112,500 \mathrm{ac})$ or 13.3 percent of the area of the NTS. There were a total of 136 ELUs sampled that clustered within this alliance. The dominant species in this alliance is singleleaf pinyon with two other species, basin big sagebrush and black sagebrush, that are co-dominants within the associations. This alliance occurs throughout the central and northwestern mountains and mesas. Beatley (1976) recognized a similar plant association, Artemisia/Pinyon-Juniper. Utah juniper is a common associated species and may be classified as a diagnostic species, but seldom achieves dominance other than in localized conditions at slightly lower elevations such as the northwestern part of Pahute Mesa. Tree densities on the NTS are often not high enough to create closed canopies; rather, the aspect is more of an open woodland type with a mix of shrub and tree cover. This allows for relatively good development of a herbaceous layer particularly perennial grasses.

\subsection{Distribution and Description of Plant Associations}

The largest single vegetation association is the Coleogyne ramosissima-Ephedra nevadensis Shrubland, which occurs on over 21 percent of the total area of the NTS. This is followed by the Larrea tridentata/Ambrosia dumosa Shrubland with 18 percent. Each of the other associations is less than 8 percent of the total area on the NTS.

These 20 associations are similar to those recognized by Beatley (1976), with several exceptions. She recognized 23 associations although 4 of which did not occur on the NTS. She also recognized more associations that included creosote bush and atriplex as major components. She did not recognize Nevada jointfir or white burrobush as major alliances or several other transitional associations such as Menodora spinosa-Ephedra nevadensis Shrubland or 
Eriogonum fasciculatum-Ephedra nevadensis Shrubland. She did recognize two associations related to springs that would be classified in our miscellaneous category because of their small size and unique flora.

A distribution map of each association is presented on the left-hand page. On the right-hand page is presented a brief summary description of the association. 
This Page Intentionally Left Blank 


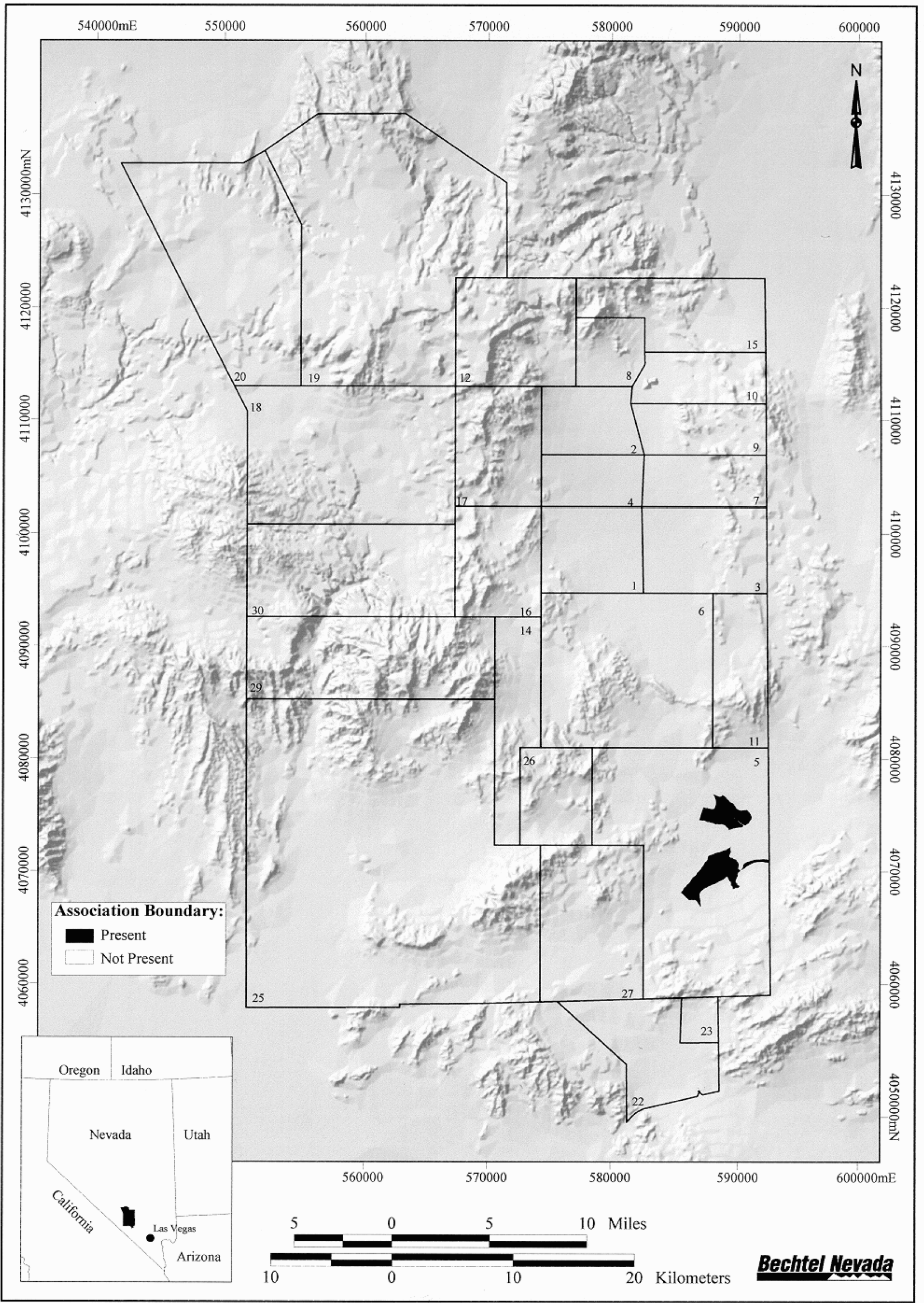

Figure 4-3 Distribution of the Lycium shockleyi - Lycium pallidum Shrubland Association on the Nevada Test Site 


\subsubsection{Lycium shockleyi-Lycium pallidum Shrubland}

This shrubland association is represented by only six ELUs on the NTS which are all located near Frenchman Flat (Figure 4-3). The two Lycium species are separated from each other on a

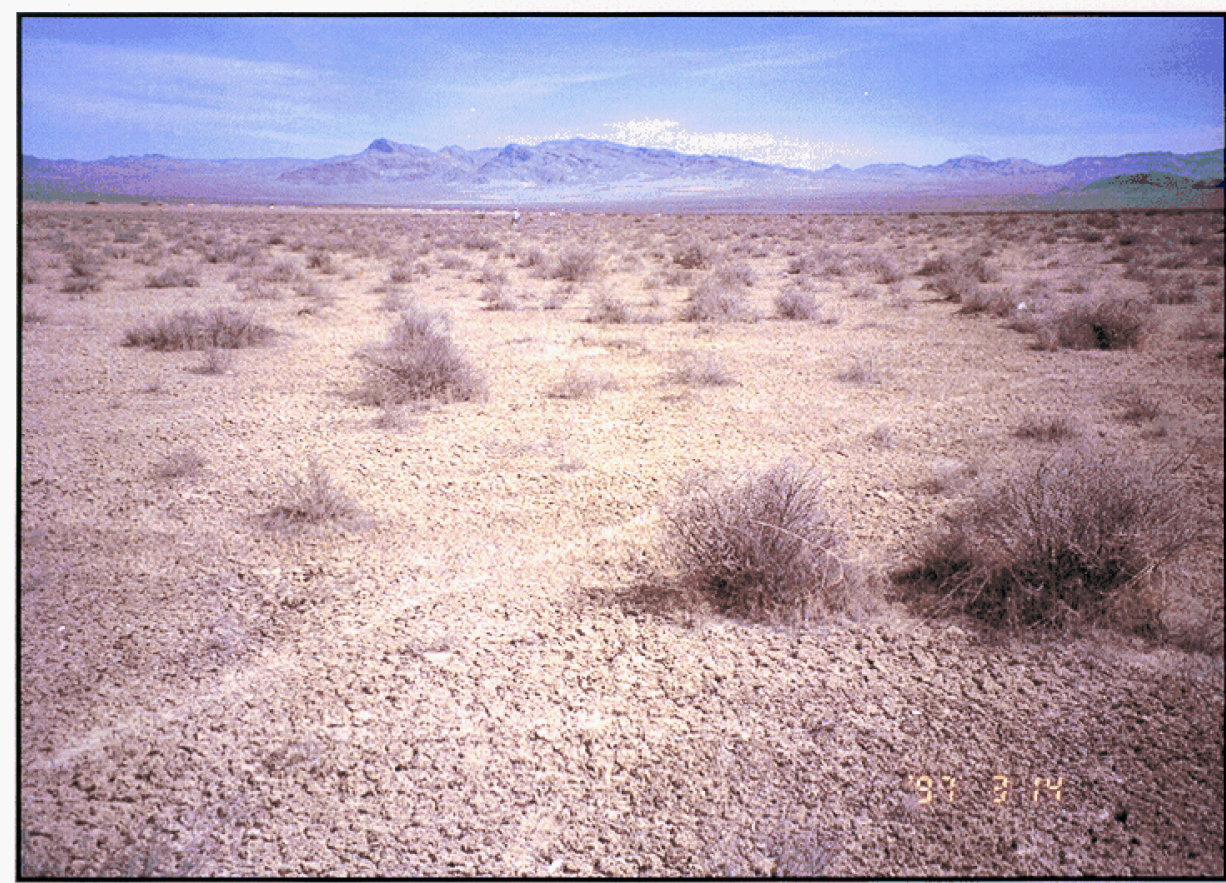

soil texture gradient, with Shockley's desert thorn occurring on clay and clay loam soils originating from limestone materials off of the Mercury Ridge. L. pallidum occurs on sandy soils originating mostly from volcanic materials from the Hampel Hill area and the hills north of Red Mountain. Beatley (1976) recognizes these as two separate vegetation communities with the associated subdominants of shadscale saltbush with

L. shockleyi and spiny hopsage with L. pallidum. Because of their limited size, close proximity, and restricted distribution, we chose to combine them. Of note is that spiny hopsage is present only as a minor component of the ELUs sampled; this condition is noted in other areas where Beatley (1976) has identified this species as being common but is currently uncommon. Summary information for this association is presented in Table 4-3.

Table 4-3 Characteristics of the Lycium shockleyi-Lycium pallidum Shrubland. (Percent relative abundance values for primary and associated species are enclosed in parenthesis.)

\begin{tabular}{|ll}
\hline Primary species: & Shockley's desert thorn (38\%), rabbit thorn $(18 \%)$ \\
Associated species: & White bursage $(18 \%)$, four-wing saltbush $(10 \%)$, and shadscale saltbush (6\%) \\
Species diversity: & 11 species total; averaged 8.8 perennial species/ELU \\
Number of ELUs: & 6 \\
Area of NTS: & 1,484 ha $(0.4 \%)$ \\
Landforms: & Basins, alluvial flats \\
Geology: & Quaternary alluvium \\
Elevation: & Average $941 \mathrm{~m}$, range 940 to $943 \mathrm{~m}$ \\
Precipitation: & Average $14.8 \mathrm{~cm}$ \\
Slopes: & Average $0.8^{\circ}$, range 0 to $1^{\circ}$ \\
Soils: & Clay-clay loams $($ L. shockleyi), sand (L. pallidum) \\
Annuals: & Very low \\
\hline
\end{tabular}




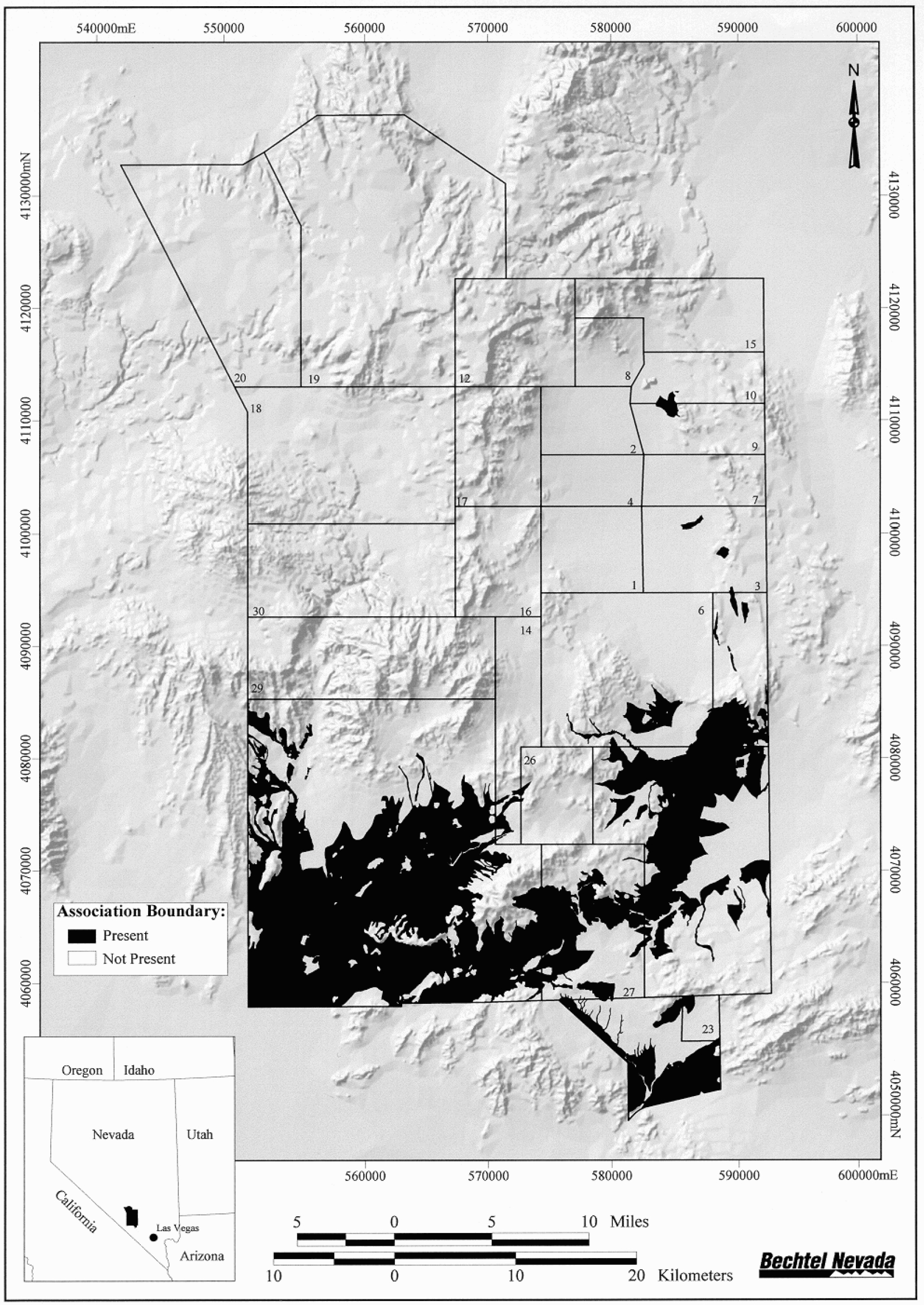

Figure 4-4 Distribution of the Larrea tridentata / Ambrosia dumosa Shrubland Association on the Nevada Test Site 


\subsubsection{Larrea tridentata/Ambrosia dumosa Shrubland}

This association occurs throughout the southern third of the NTS from basin floors to the foothill slopes of the southern mountains (Figure 4-4). Because of the larger size, creosote appears to be the dominant species; however, this association is actually dominated by white bursage when

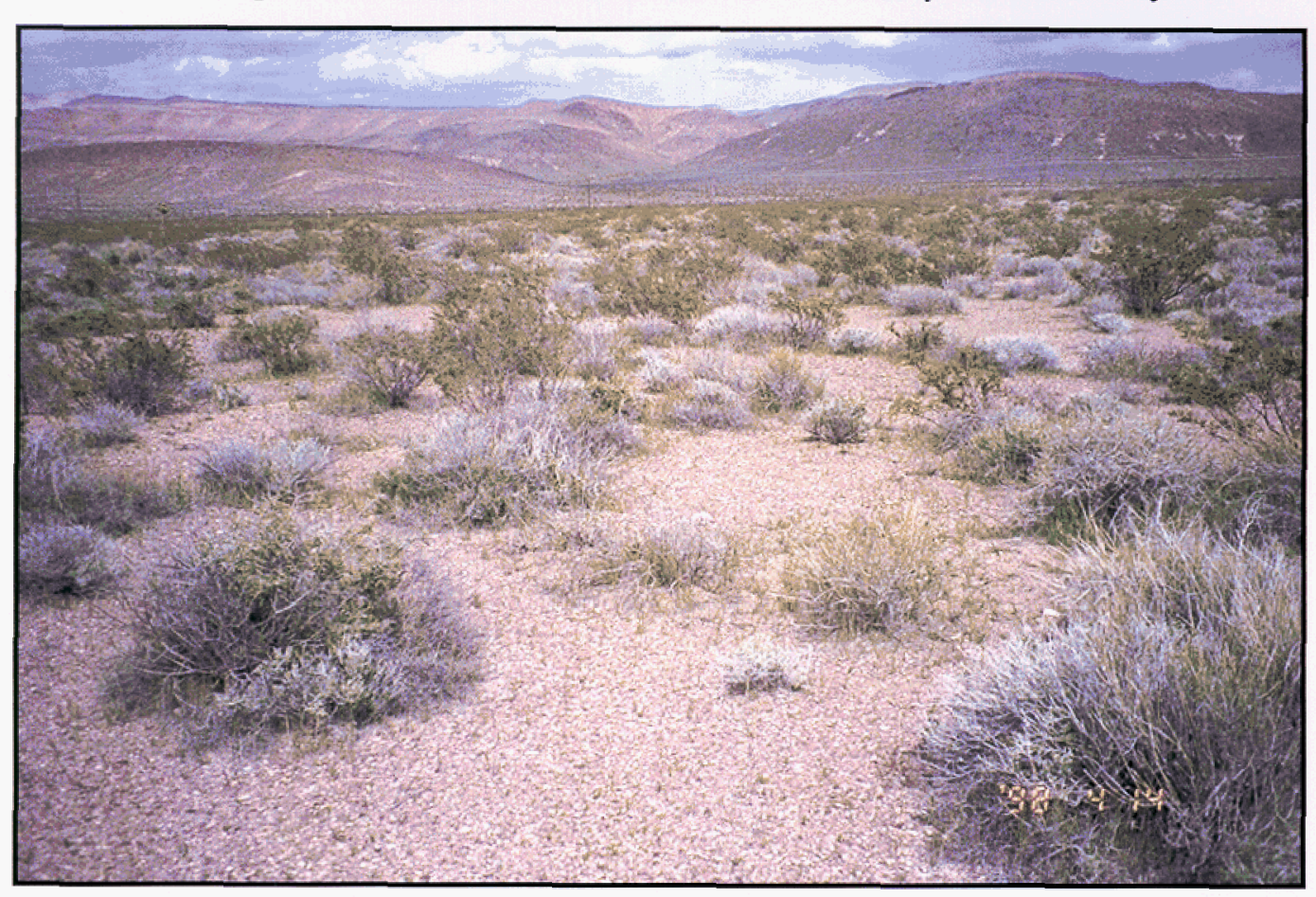

relative abundance, total cover, or total biomass are measured. Soils are generally sands to sandy loams. This association has low perennial species diversity and a high diversity of annual species that germinate in years of abundant moisture, but are absent in most years. Summary information for this association is presented in Table 4-4.

Table 4-4 Characteristics of the Larrea tridentata/Ambrosia dumosa Shrubland. (Percent relative abundance values for primary and associated species are enclosed in parenthesis.)

\begin{tabular}{|ll|}
\hline Primary species: & White bursage (43\%), creosote bush (13\%) \\
Associated species: & Nevada jointfir (7\%), range ratany (Krameria erecta) (7\%), rabbit thorn (6\%) \\
Species diversity: & 49 species total; averaged 13.2 perennial species/ELU \\
Number of ELUs: & 287 \\
Area of NTS: & 61,050 ha $(18.0 \%)$ \\
Landforms: & Variable from basin to foothill slopes of mountains, mostly piedmont slopes \\
Geology: & Quaternary alluvium \\
Elevation: & Average $1,080 \mathrm{~m}$, range 847 to $1,628 \mathrm{~m}$ \\
Precipitation: & Average $16.0 \mathrm{~cm}$ \\
Slopes: & Average $5.7^{\circ}$, range 1 to $42^{\circ}$ \\
Soils: & Primarily sand to sandy loam \\
Annuals: & Very low to moderate \\
\hline
\end{tabular}




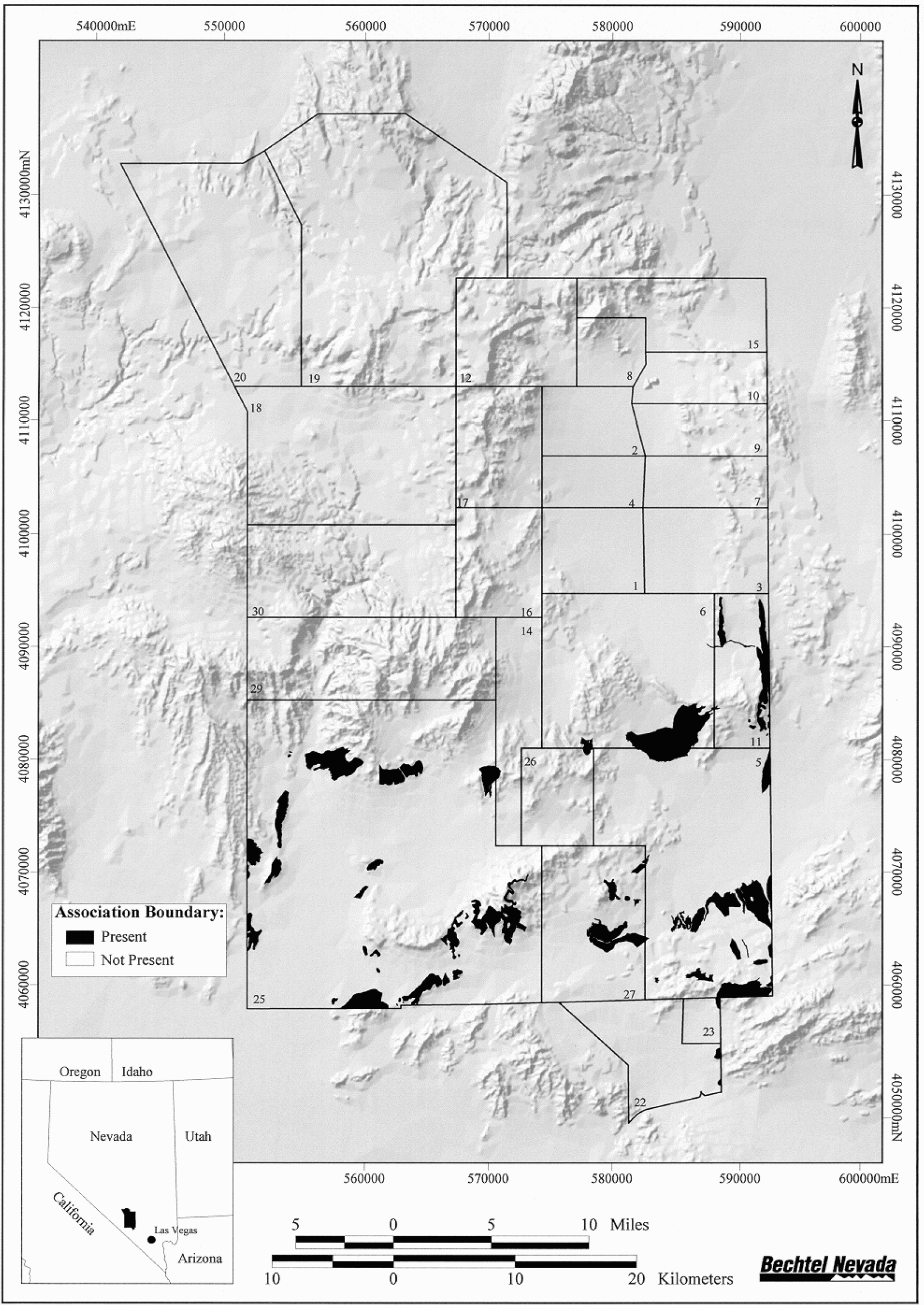

Figure 4-5 Distribution of the Atriplex confertifolia - Ambrosia dumosa Shrubland Association on the Nevada Test Site 


\subsubsection{Atriplex confertifolia-Ambrosia dumosa Shrubland}

This association occurs only in the southern third of the NTS, generally in areas with shallow, often calcareous soils such as in foothill slopes or in the southern mountains, particularly those with limestone or dolomite (Figure 4-5). It is dominated by shadscale saltbush when measured

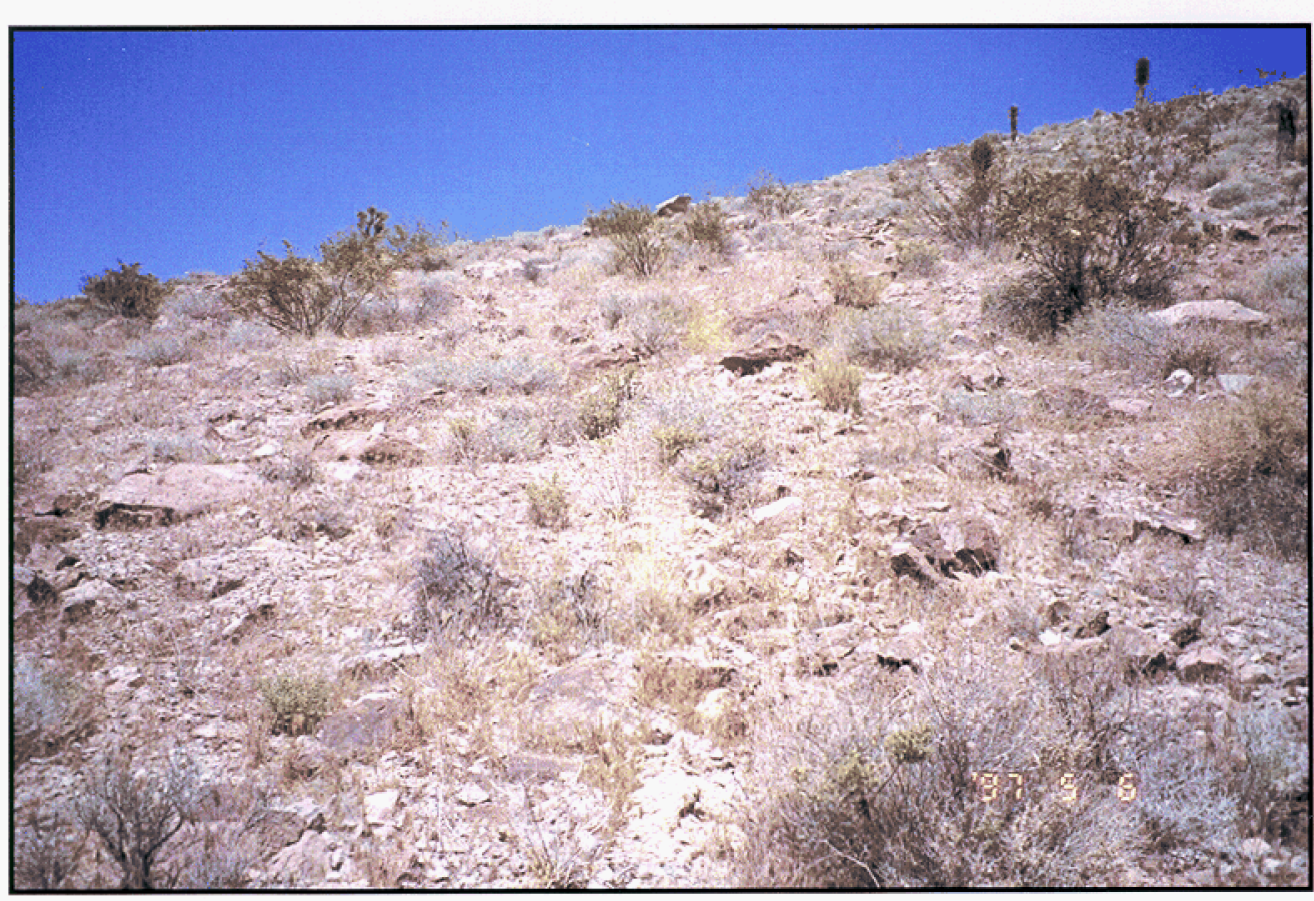

as relative abundance, frequency, or total cover. Soils are generally finer-textured, ranging from loams to sandy loams, but often contain larger fragments and a hardpan or caliche layer that restricts rooting depth. This association has high species diversity, particularly among perennial shrub species and succulents. Summary information for this association is presented in Table 4-5.

Table 4-5 Characteristics of the Atriplex confertifolia-Ambrosia dumosa Shrubland. (Percent relative abundance values for primary and associated species are enclosed in parenthesis.)

\begin{tabular}{|c|c|}
\hline Primary species: & Shadscale saltbush (30\%), white bursage $(20 \%)$ \\
\hline Associated species: & $\begin{array}{l}\text { Nevada jointfir ( } 10 \%) \text {, creosote bush (4\%), range ratany ( } 4 \%) \text {, Anderson's wolfberry } \\
(4 \%)\end{array}$ \\
\hline Species diversity: & 49 species total; averaged 16.2 perennial species/ELU \\
\hline Number of ELUs: & 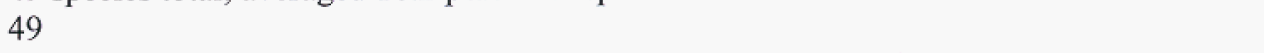 \\
\hline Area of NTS: & 11,577 ha $(3.4 \%)$ \\
\hline Landforms: & Mountains \\
\hline Geology: & $\begin{array}{l}\text { Variable, mostly Quaternary alluvium/colluvium with some older limestones and Tertiary } \\
\text { tuffs }\end{array}$ \\
\hline Elevation: & Average $1,153 \mathrm{~m}$, range 932 to $1,494 \mathrm{~m}$ \\
\hline Precipitation: & Average $16.9 \mathrm{~cm}$ \\
\hline Slopes: & Average $13.6^{\circ}$, range 1 to $53^{\circ}$ \\
\hline Soils: & Primarily sandy loam to loam \\
\hline Annuals: & Very low-moderate \\
\hline
\end{tabular}




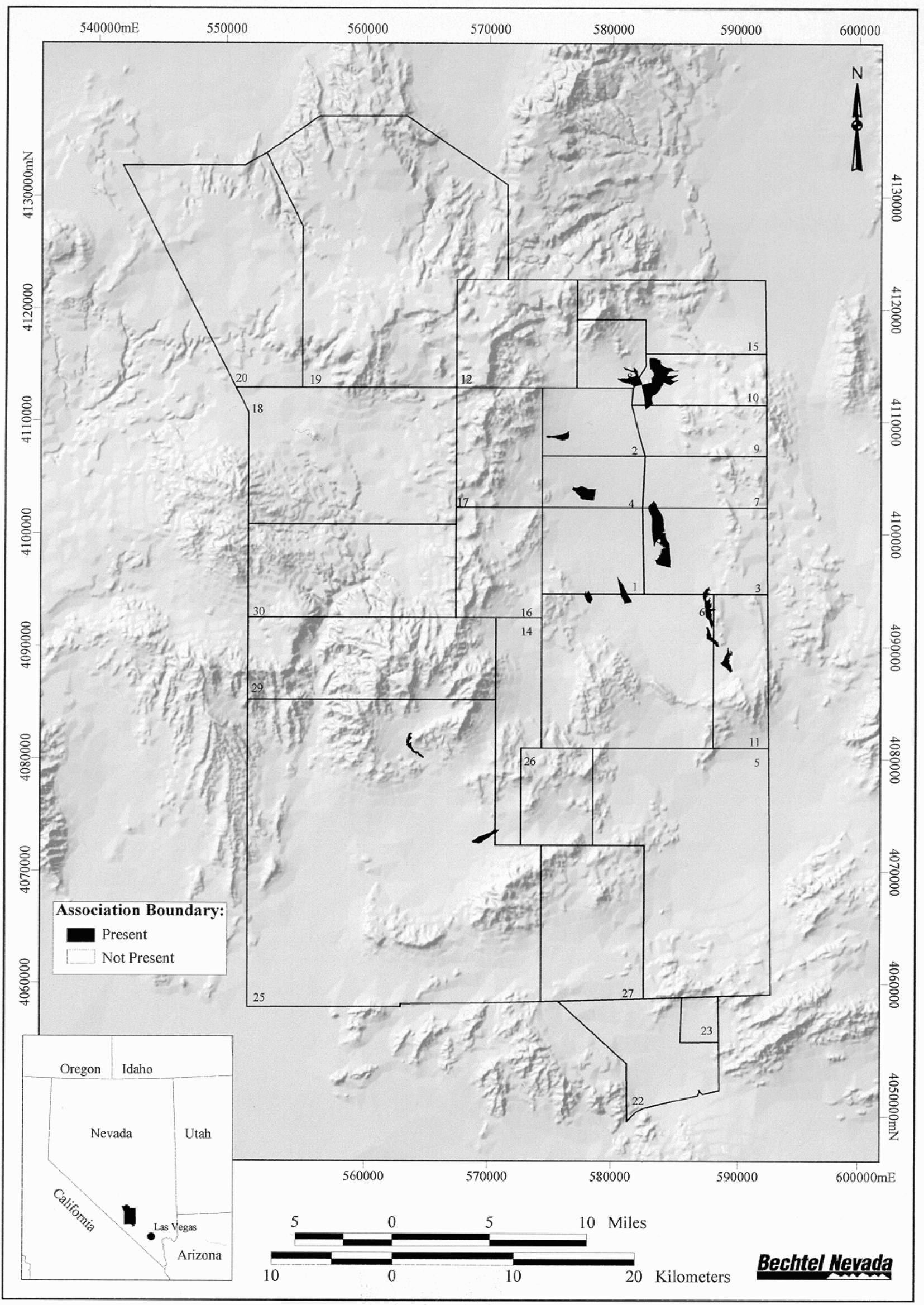

Figure 4-6 Distribution of the Lycium andersonii - Hymenoclea salsola Shrubland Association on the Nevada Test Site 


\subsubsection{Lycium andersonii-Hymenoclea salsola Shrubland}

This association occurs primarily in the lower piedmont slopes of Yucca Flat, often near disturbances (Figure 4-6). It is one of the smallest associations recognized, with slightly under $1,500 \mathrm{ha}(3,750 \mathrm{ac})$ or 0.4 percent of the total area of the NTS. Only 13 ELUs were clustered in this association.

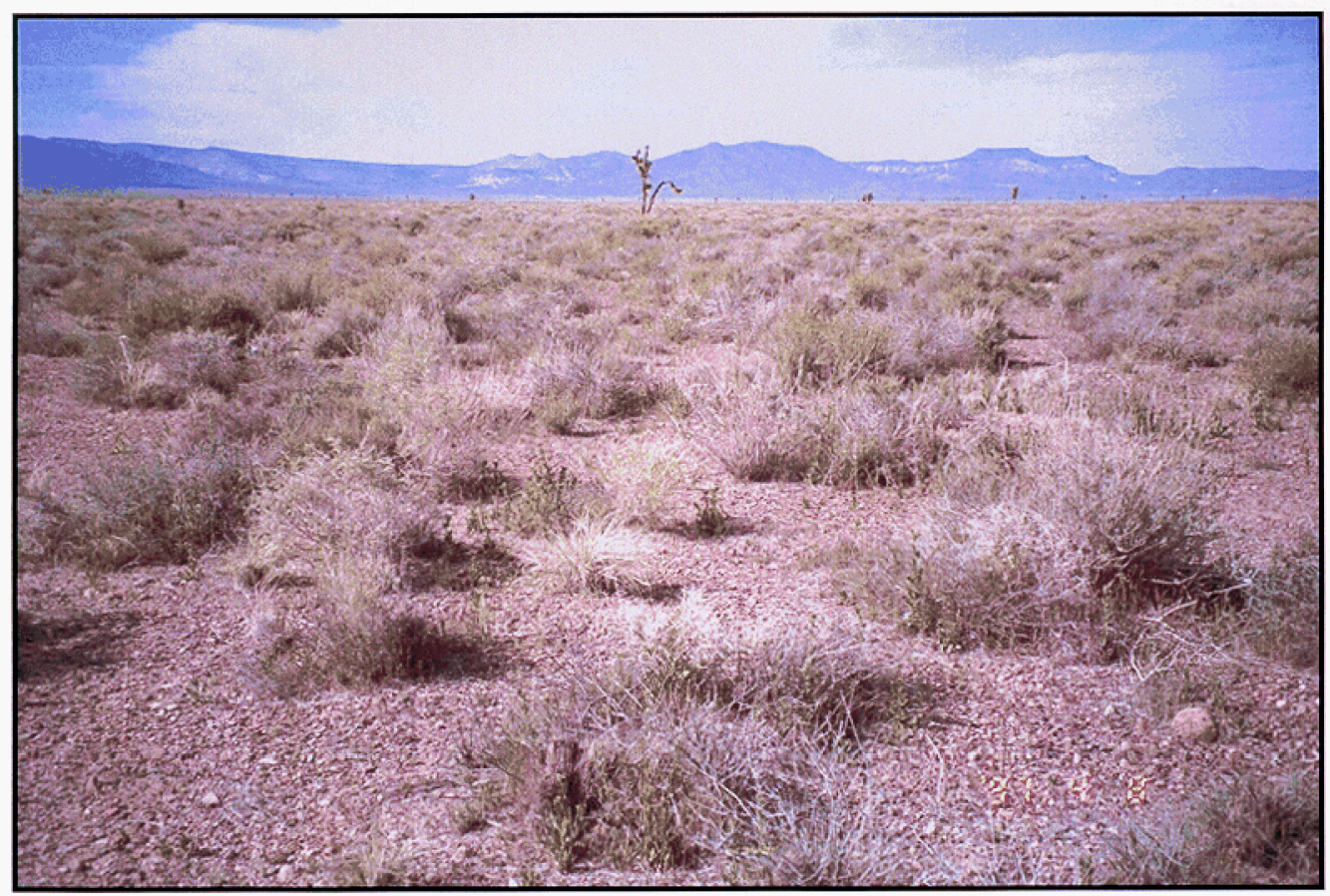
It is dominated by Anderson's wolfberry, representing over 50 percent of the relative abundance of shrub species in this association. Soils are generally sands to sandy loams. This association has low species diversity.

Summary information for this association is presented in Table 4-6.

Table 4-6 Characteristics of the Lycium andersonii-Hymenoclea salsola Shrubland. (Percent relative abundance values for primary and associated species are enclosed in parenthesis.)

\begin{tabular}{|ll|}
\hline Primary species: & Anderson's wolfberry (49\%), white burrobush (Hymenoclea salsola) (9\%) \\
Associated species: & Winterfat (8\%), shadscale (7\%), four-wing saltbush (6\%), Nevada jointfir (5\%) \\
Species diversity: & 23 species total; averaged 12.8 perennial species/ELU \\
Number of ELUs: & 13 \\
Area of NTS: & 1,489 ha $(0.4 \%)$ \\
Landforms: & Mostly lower piedmont slopes, fan piedmont-fan skirt \\
Geology: & Quaternary alluvium \\
Elevation: & Average $1,263 \mathrm{~m}$, range 942 to $1,408 \mathrm{~m}$ \\
Precipitation: & Average $18.3 \mathrm{~cm}$ \\
Slopes: & Average $2.3^{\circ}$, range 1 to $31^{\circ}$ \\
Soils: & Primarily sand to sandy loam \\
Annuals: & Moderate to very high \\
\hline
\end{tabular}




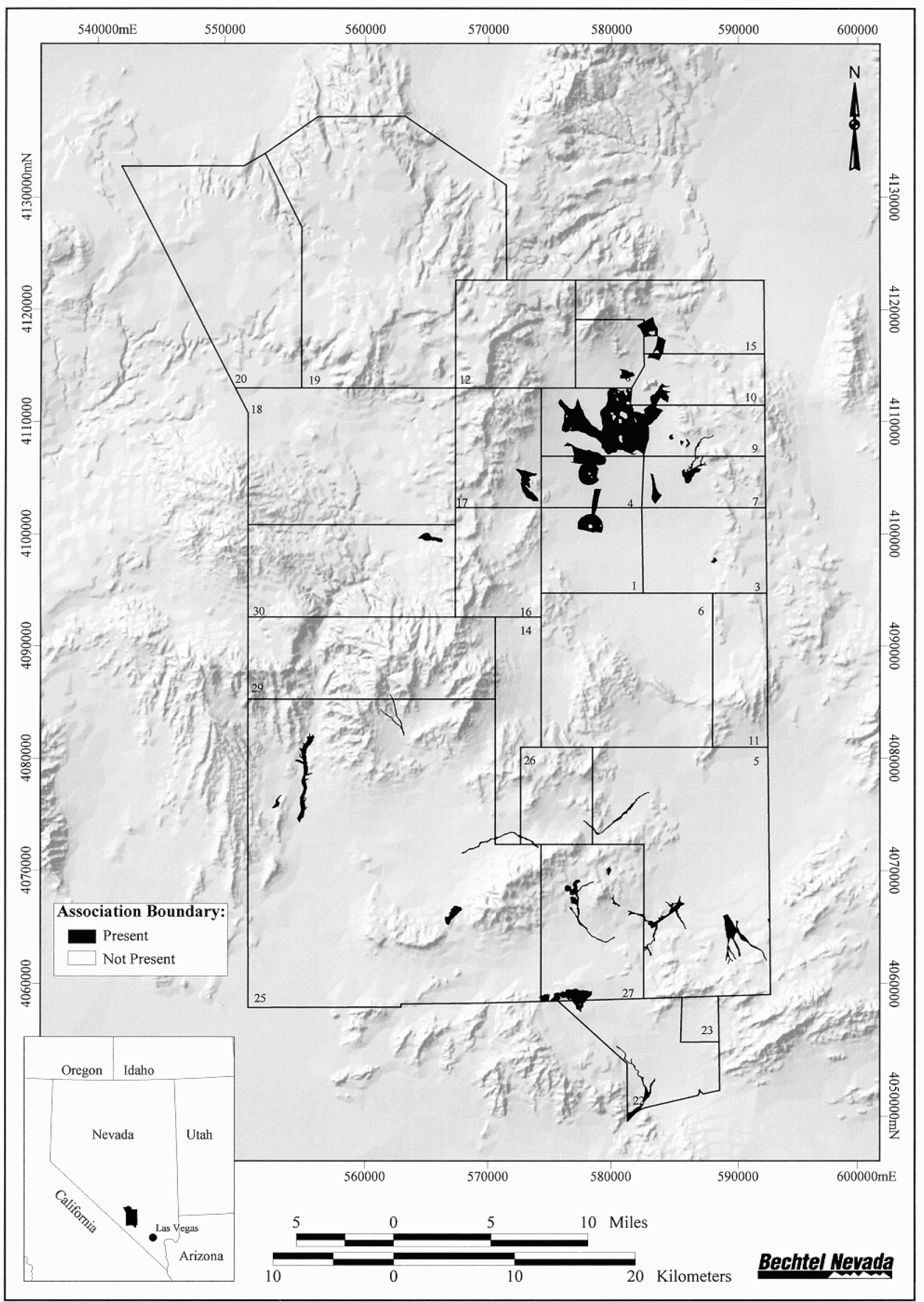

Figure 4-7 Distribution of the Hymenoclea salsola - Ephedra nevadensis Shrubland Association on the Nevada Test Site 


\subsubsection{Hymenoclea salsola-Ephedra nevadensis Shrubland}

This association occurs primarily along drainages in the southern part of the NTS and in disturbed areas in the lower piedmont slopes of Yucca Flat (Figure 4-7). It occupies over 6,700 ha $(15,250 \mathrm{ac})$ or 2.0 percent of the NTS and consists of 44 ELUs. It is dominated by

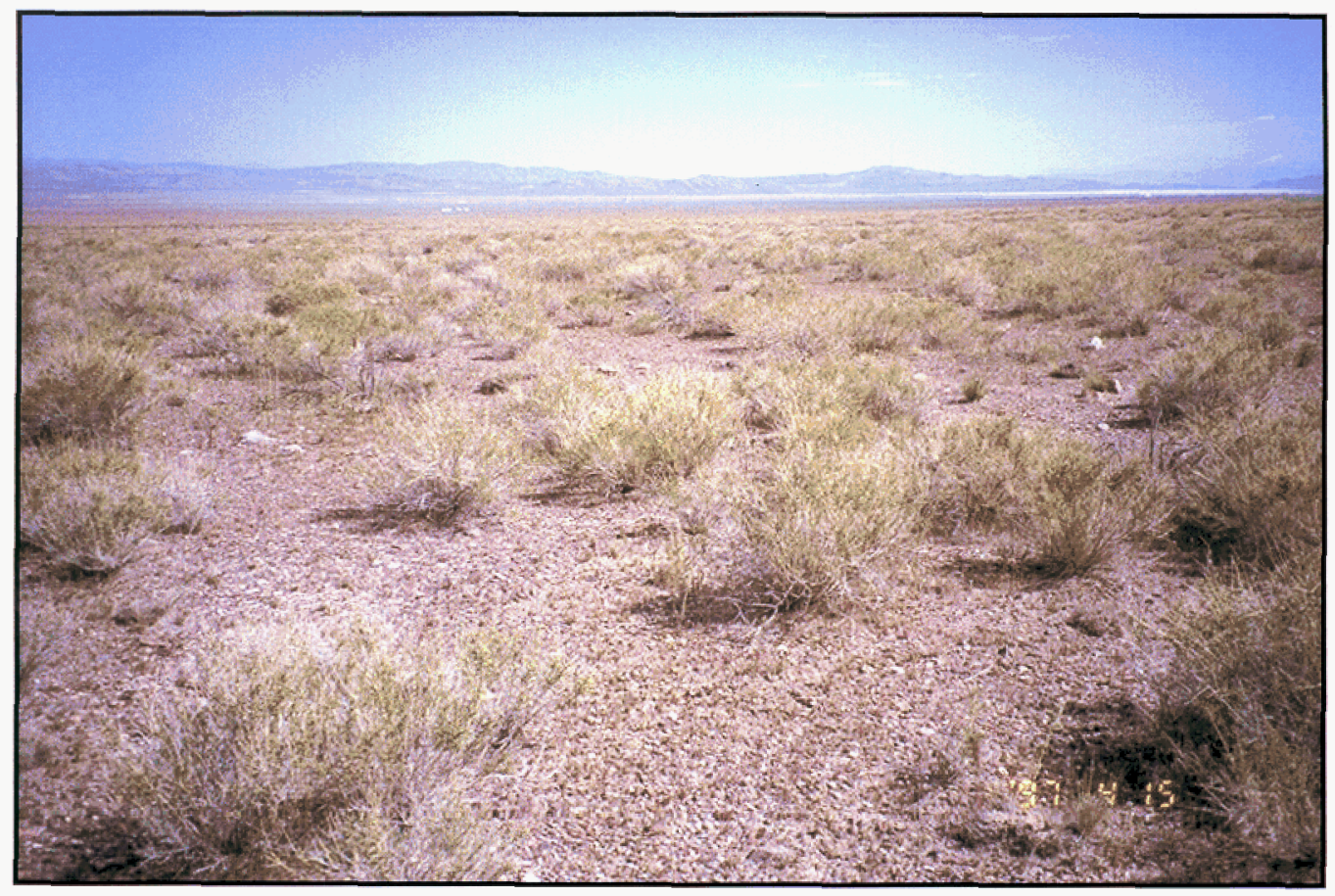

white burrobush that represents over 50 percent of the relative abundance of shrub species in this association. The most commonly associated species is Nevada jointfir. It occurs primarily in disturbed areas, natural or manmade. Soils are generally sand to sandy loams.

This associa-

tion has high species diversity and often has a large number of annual species. Summary information for this association is presented in Table 4-7.

Table 4-7 Characteristics of the Hymenoclea salsola-Ephedra nevadensis Shrubland. (Percent relative abundance values for primary and associated species are enclosed in parenthesis.)

\begin{tabular}{|ll|}
\hline Primary species: & White burrobush (52\%), Nevada jointfir (9\%) \\
Associated species: & Green rabbitbrush (5\%), four-wing saltbush (5\%), Anderson's wolfberry (5\%) \\
Species diversity: & 50 species total; averaged 15.2 perennial species/ELU \\
Number of ELUs: & 44 \\
Area of NTS: & 6,709 ha $(2.0 \%)$ \\
Landforms: & Lower piedmont slopes, fan piedmont-fan skirt \\
Geology: & Quaternary alluvium/colluvium \\
Elevation: & Average $1,263 \mathrm{~m}$, range 950 to $1,530 \mathrm{~m}$ \\
Precipitation: & Average $18.3 \mathrm{~cm}$ \\
Slopes: & Average $3.8^{\circ}$, range 1 to $31^{\circ}$ \\
Soils: & Primarily sand to sandy loam \\
Annuals: & Moderate to very high \\
\hline
\end{tabular}




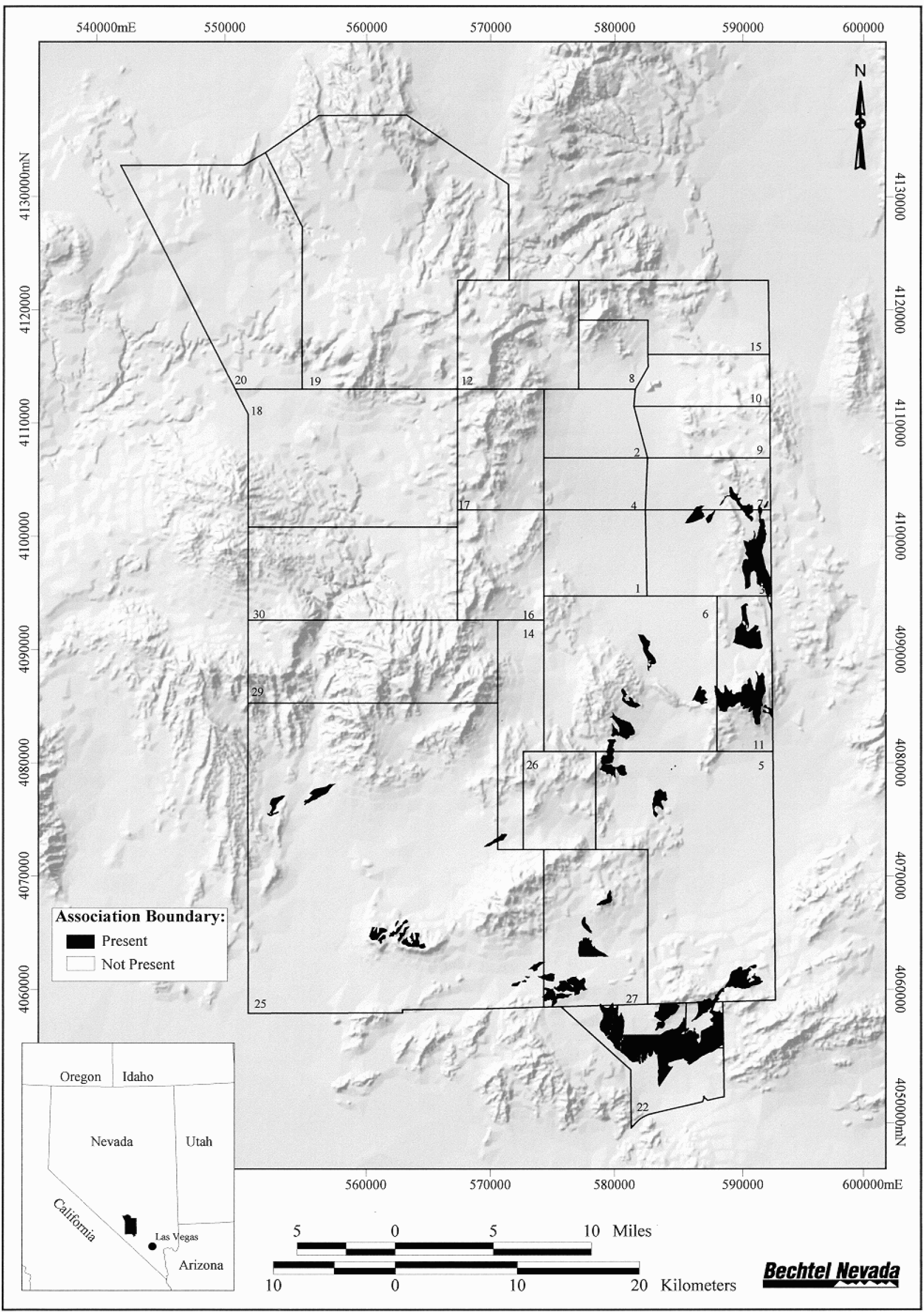

Figure 4-8 Distribution of the Menodora spinescens - Ephedra nevadensis Shrubland Association on the Nevada Test Site 


\subsubsection{Menodora spinescens-Ephedra nevadensis Shrubland}

This association occurs primarily along foothill areas in the southeastern part of the NTS, particularly in northern Mercury Valley (Figure 4-8). It occupies over 8,600 ha (21,500 ac) or 2.5 percent of the NTS and consists of 42 ELUs. It is co-dominated by spiny menodora, Nevada

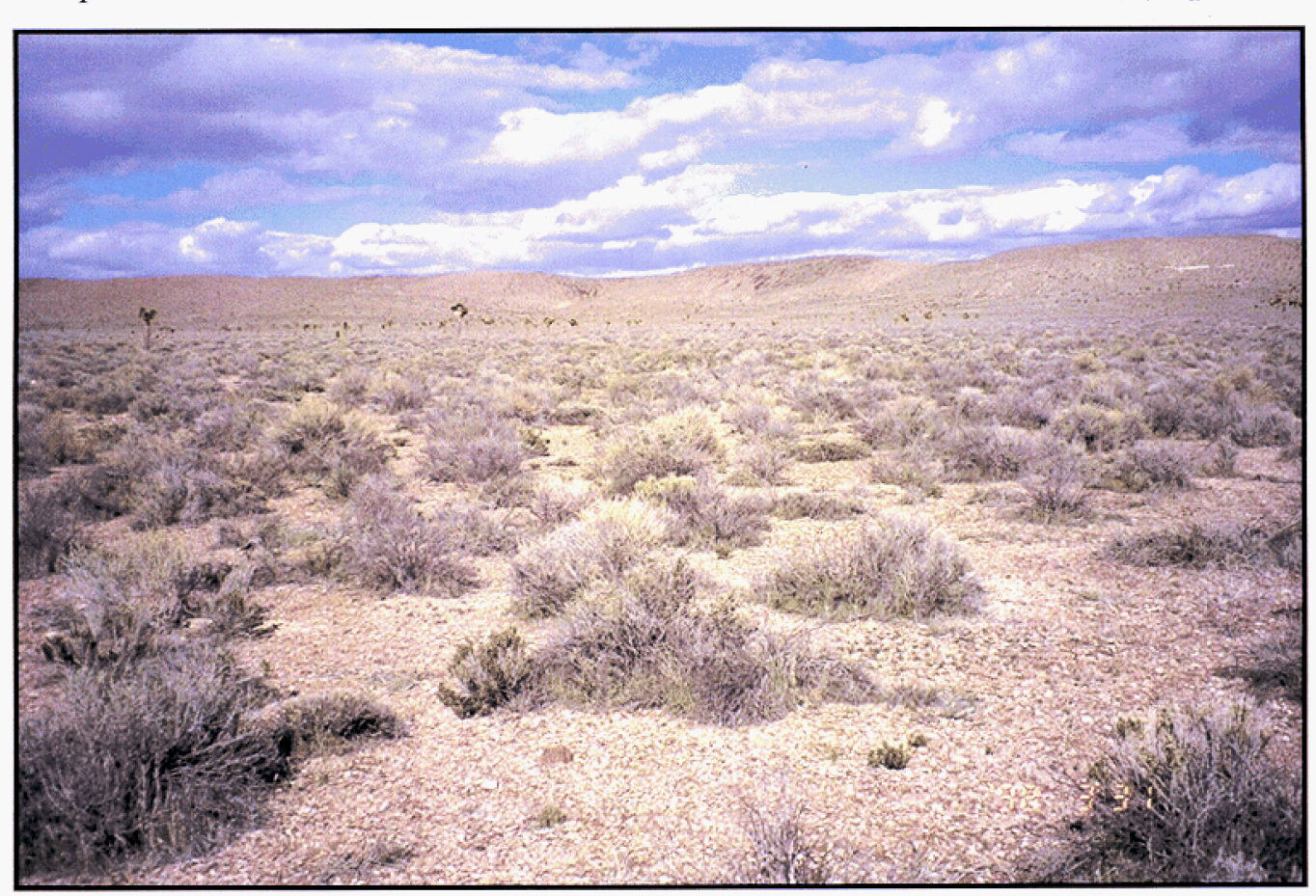

jointfir, and white bursage. The most common associated species is shadscale saltbush. Soils are generally loams to sandy loams. This association has high species diversity, particularly perennial shrubs.

Summary information for this association is presented in Table 4-8.

Table 4-8 Characteristics of the Menodora spinescens-Ephedra nevadensis Shrubland. (Percent relative abundance values for primary and associated species are enclosed in parenthesis.)

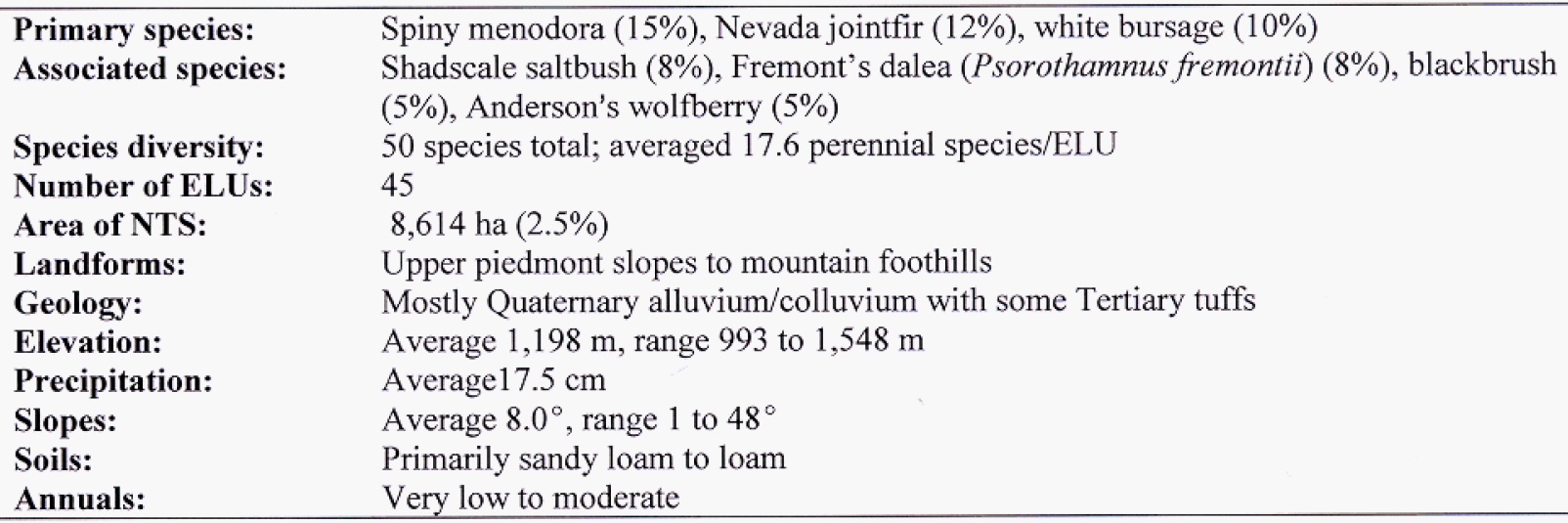




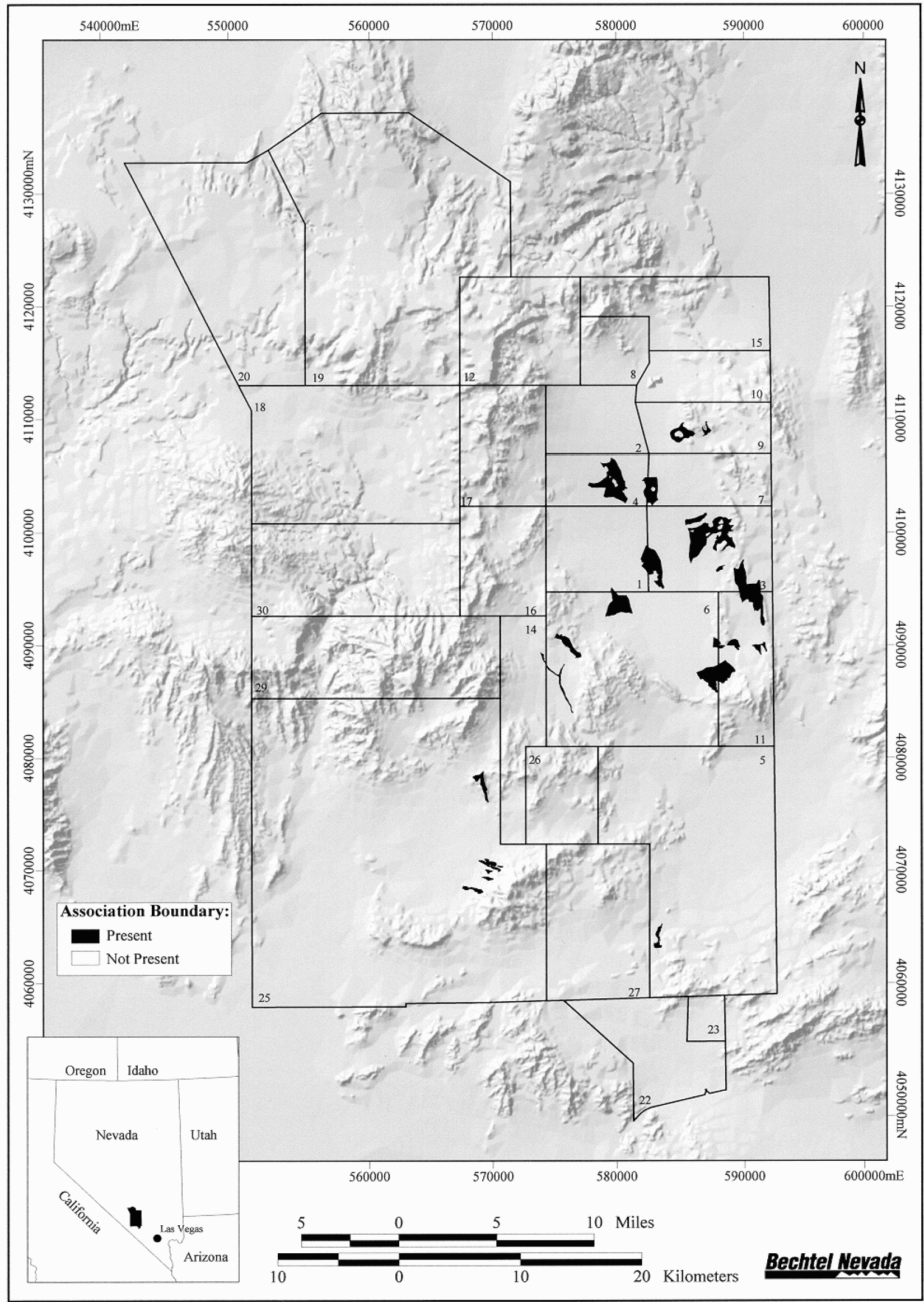

Figure 4-9 Distribution of the Krascheninnikovia lanata - Ephedra nevadensis Shrubland Association on the Nevada Test Site 


\subsubsection{Krascheninnikovia lanata-Ephedra nevadensis Shrubland}

This association occurs primarily on lower piedmont slopes in the southern and central parts of Yucca Flat (Figure 4-9). It occupies over 4,000 ha $(10,000 \mathrm{ac})$ or 1.2 percent of the NTS and consisted of 29 ELUs. It is dominated by winterfat that represents about 30 percent of the

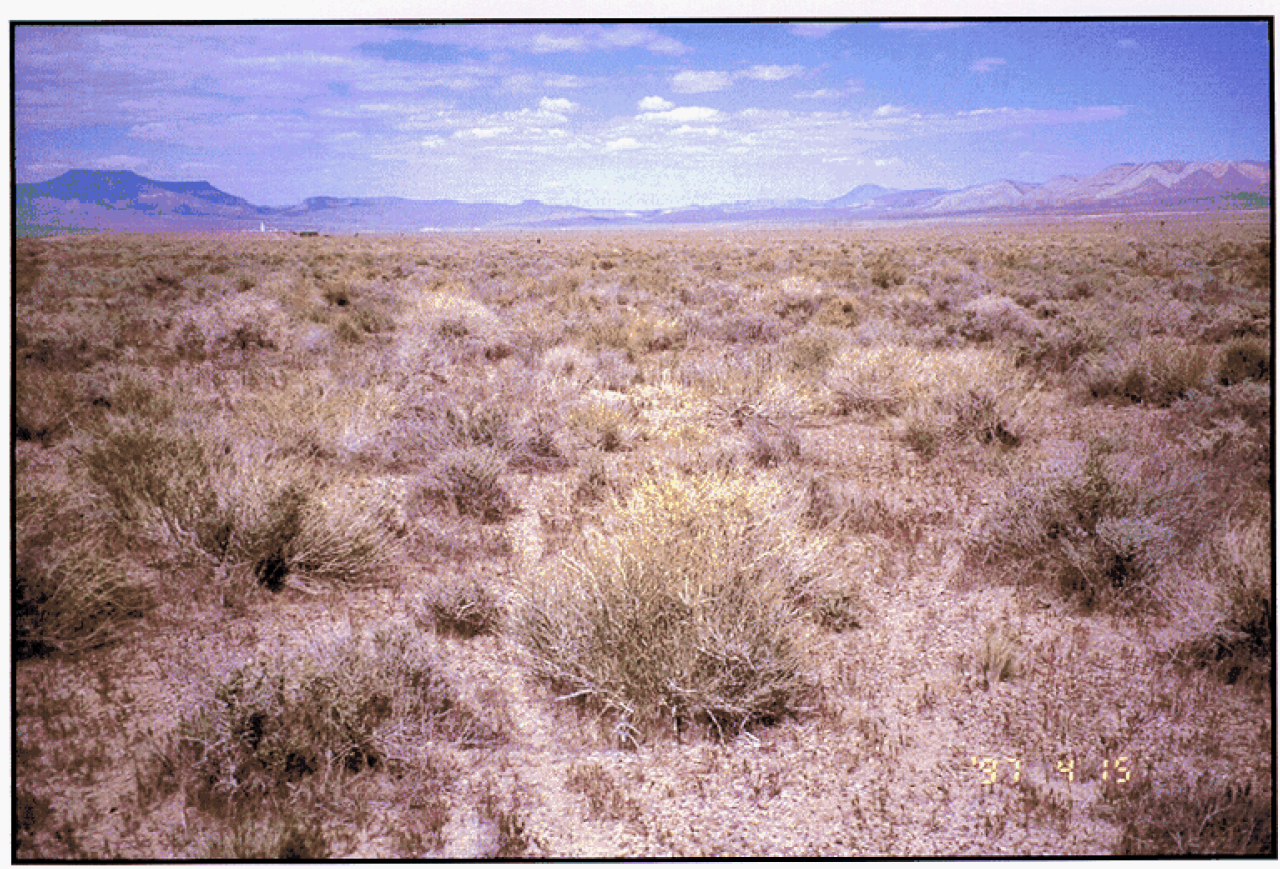

relative abundance of shrub species in this association. The most common associated species are Nevada jointfir and spiny hopsage. Soils are generally loams to sandy loams. This association has high species diversity. Associated species found in Beatley's Larrea/GrayiaLycium are commonly found in this association.

Summary information for this association is presented in Table 4-9.

Table 4-9 Characteristics of the Krascheninnikovia lanata-Ephedra nevadensis Shrubland. (Percent relative abundance values for primary and associated species are enclosed in parenthesis.)

\begin{tabular}{|ll|}
\hline $\begin{array}{l}\text { Primary species: } \\
\text { Associated species: }\end{array}$ & $\begin{array}{l}\text { Winterfat (29\%), Nevada jointfir (12\%) } \\
\text { Spiny hopsage }(8 \%), \text { Anderson's wolfberry }(8 \%), \text { Shockley's goldenhead } \\
\text { (Acamptopappus shockleyi) }(7 \%) \text {, shadscale saltbush }(6 \%)\end{array}$ \\
Species diversity: & 34 species total; averaged 17.6 perennial species/ELU \\
Number of ELUs: & 30 \\
Area of NTS: & 4,046 ha $(1.2 \%)$ \\
Landforms: & Variable, mostly lower piedmont slopes, fan piedmont-fan skirt \\
Geology: & Quaternary alluvium/colluvium \\
Elevation: & Average $1,258 \mathrm{~m}$, range 1,042 to $1,463 \mathrm{~m}$ \\
Precipitation: & Average $18.2 \mathrm{~cm}$ \\
Slopes: & Average $3.6^{\circ}$, range 1 to $14^{\circ}$ \\
Soils: & Primarily loamy sand to loam \\
Annuals: & Moderate \\
\hline
\end{tabular}




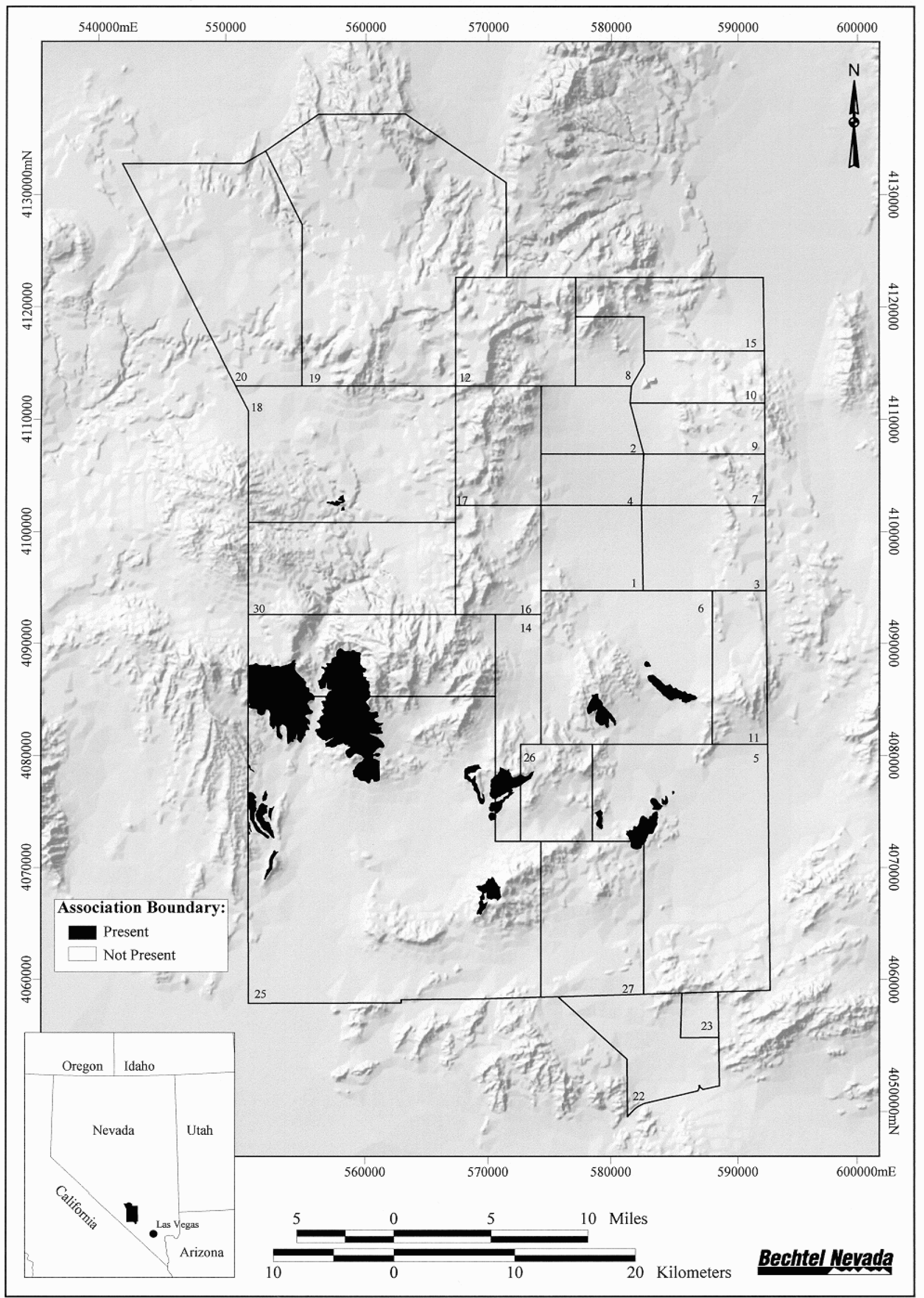

Figure 4-10 Distribution of the Eriogonum fasciculatum - Ephedra nevadensis Shrubland Association on the Nevada Test Site 


\subsubsection{Eriogonum fasciculatum-Ephedra nevadensis Shrubland}

This association occurs primarily in the volcanic tuffaceous mountains in south-central NTS, particularly around Yucca Mountain and the Calico Hills area (Figure 4-10). It occupies over 10,000 ha $(25,000 \mathrm{ac})$ or 3.0 percent of the NTS and consists of 14 ELUs. It is dominated by

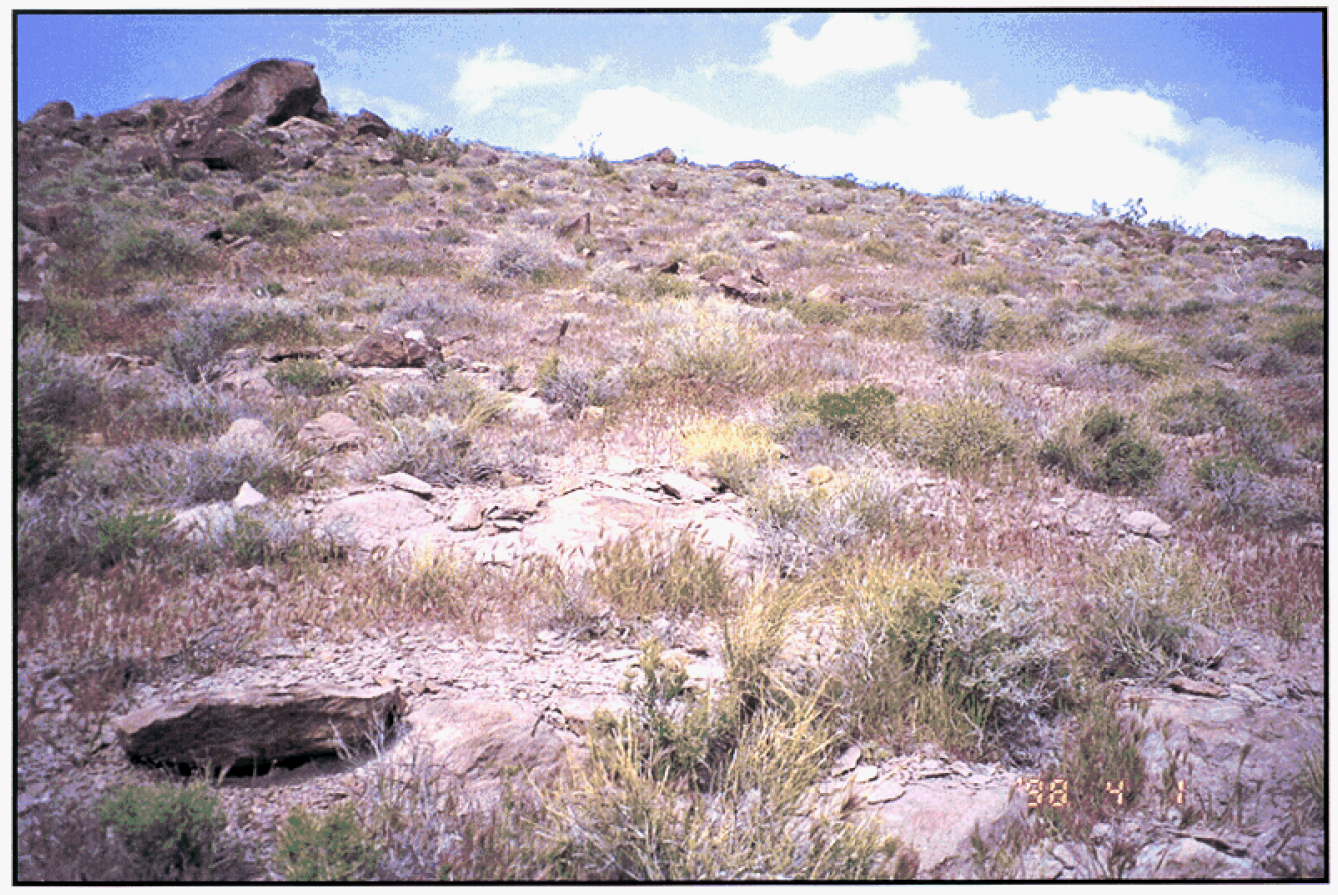

eastern Mojave buckwheat and Nevada jointfir that represent over 42 percent of the relative abundance of shrub species in this association. Soils are poorly developed consisting of shallow sandy loams that are very rocky. This association has high species diversity.

Summary information for this association is presented in Table 4-10.

Table 4-10 Characteristics of the Eriogonum fasciculatum-Ephedra nevadensis Shrubland. (Percent relative abundance values for primary and associated species are enclosed in parenthesis.)

\begin{tabular}{|ll|}
\hline Primary species: & $\begin{array}{l}\text { Eastern Mojave buckwheat (28\%), Nevada jointfir (16\%) } \\
\text { Associated species: }\end{array}$ \\
& $\begin{array}{l}\text { Needle leaf rabbitbrush (Ericameria teretifolia) (12\%), White bursage (5\%), range ratany } \\
(5 \%), \text { spiny hopsage (4\%), winterfat (4\%) }\end{array}$ \\
Species diversity: & 36 species total; averaged 20.4 perennial species/ELU \\
Number of ELUs: & 14 \\
Area of NTS: & 10,176 ha $(3.0 \%)$ \\
Landforms: & Mountains (mostly in southern NTS) \\
Geology: & Tertiary tuffs \\
Elevation: & Average $1,292 \mathrm{~m}$, range 1,140 to $1,579 \mathrm{~m}$ \\
Precipitation: & Average $18.7 \mathrm{~cm}$ \\
Slopes: & Average $36.3^{\circ}, 19$ to $70^{\circ}$ \\
Soils: & Gravel to sandy loam \\
Annuals: & Very low to moderate \\
\hline
\end{tabular}




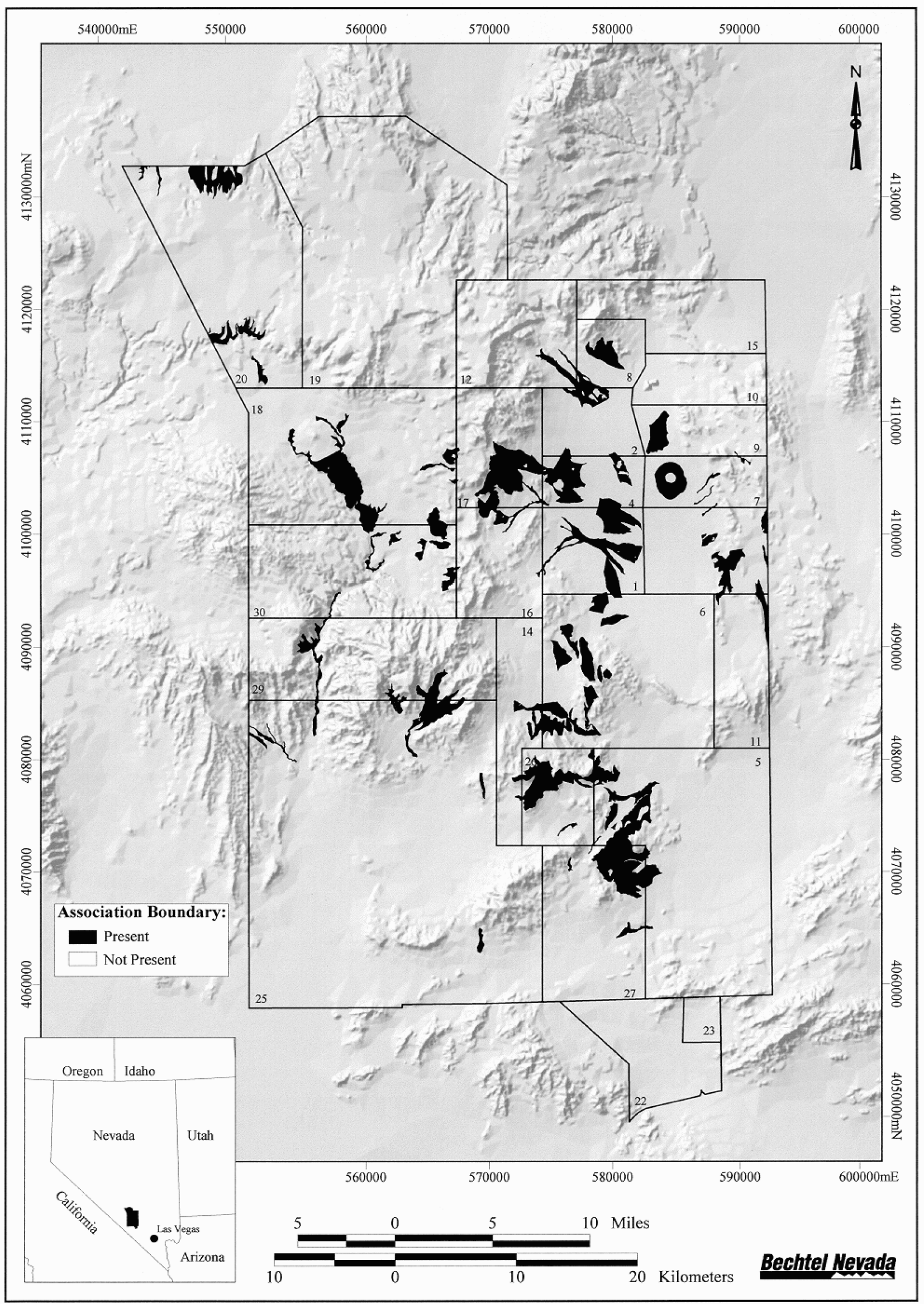

Figure 4-11 Distribution of the Ephedra nevadensis - Grayia spinosa Shrubland Association on the Nevada Test Site 


\subsubsection{Ephedra nevadensis-Grayia spinosa Shrubland}

This association is scattered across much of the central part of the NTS (Figure 4-11). It occurs often along drainages and in other disturbed areas (natural or man-caused) in the upper piedmont slopes and foothills of Yucca Flats. This association is the largest association in this alliance and

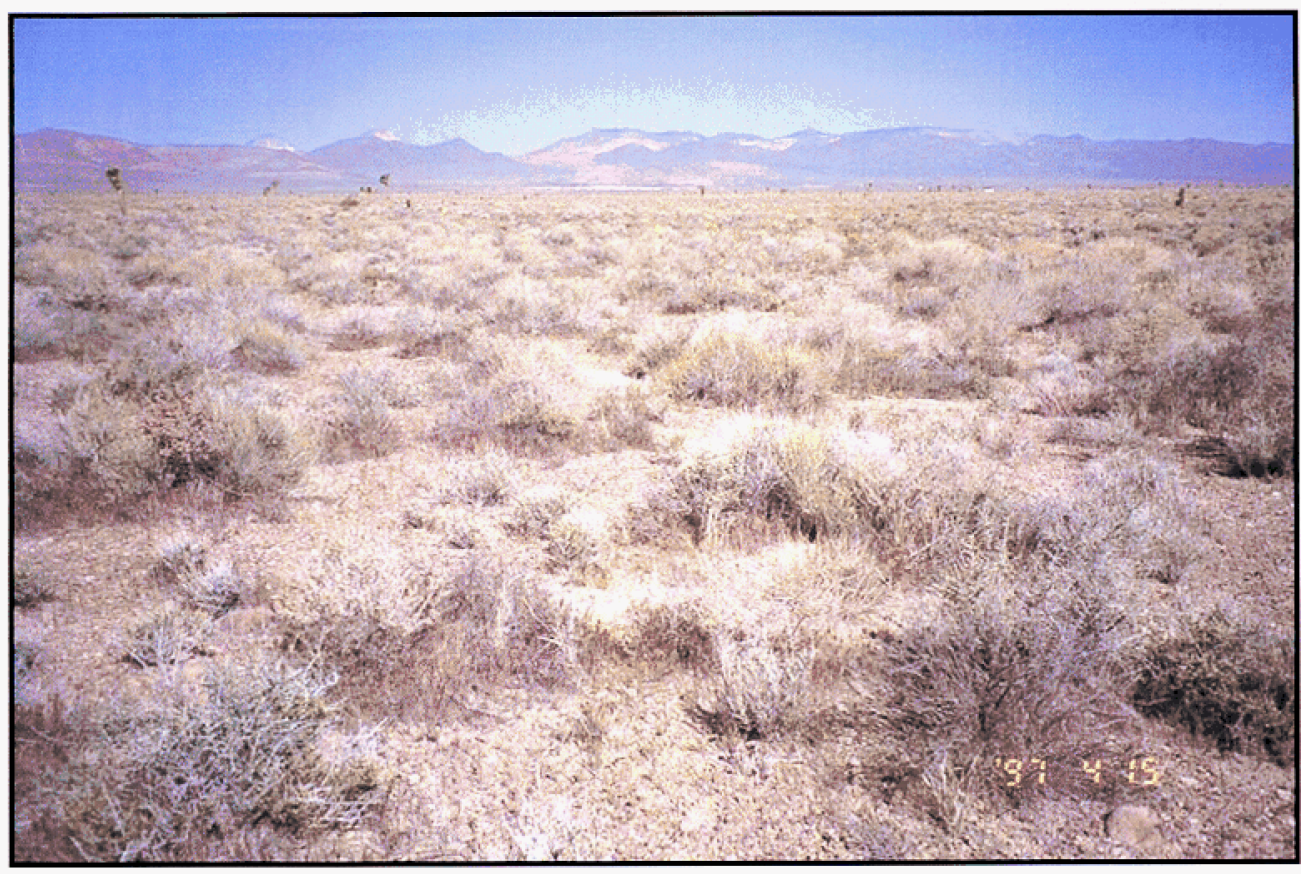

occupies over 20,000 ha $(50,000 \mathrm{ac})$ or 5.9 percent of the NTS. Ninetythree ELUs were clustered and sampled in this association. It is dominated by Nevada jointfir, but has three other co-dominant species, spiny hopsage, fourwing saltbush, and white burrobush. Large areas in Topopah valley that were recently

burned cluster in this association. Soils are generally loams to sandy loams. This association has high species diversity and often has a large number of annuals. Summary information for this association is presented in Table 4-11.

Table 4-11 Characteristics of the Ephedra nevadensis-Grayia spinosa Shrubland. (Percent relative abundance values for primary and associated species are enclosed in parenthesis.)

\begin{tabular}{|ll|}
\hline Primary species: & $\begin{array}{l}\text { Nevada jointfir (24\%), spiny hopsage (8\%), four-wing saltbush (8\%), white burrobush } \\
(8 \%)\end{array}$ \\
Associates species: & $\begin{array}{l}\text { Anderson's wolfberry (6\%), green rabbitbrush (6\%), Cooper's heathgoldenrod } \\
\text { (Ericameria cooperi) }(5 \%), \text { blackbrush }(4 \%)\end{array}$ \\
Species diversity: & 66 species total; averaged 19.7 perennial species/ELU \\
Number of ELUs: & 89 \\
Area of NTS: & 20,067 ha $(5.9 \%)$ \\
Landforms: & Highly variable from basin to mountain \\
Geology: & Mostly Quaternary alluvium/colluvium with some Tertiary tuffs \\
Elevation: & Average $1,413 \mathrm{~m}$, range 988 to $1,884 \mathrm{~m}$ \\
Precipitation: & Average $20.2 \mathrm{~cm}$ \\
Slopes: & Average $8.8^{\circ}$, range 1 to $70^{\circ}$ \\
Soils: & Primarily loamy sand to loam \\
Annuals: & Moderate to very high \\
\hline
\end{tabular}




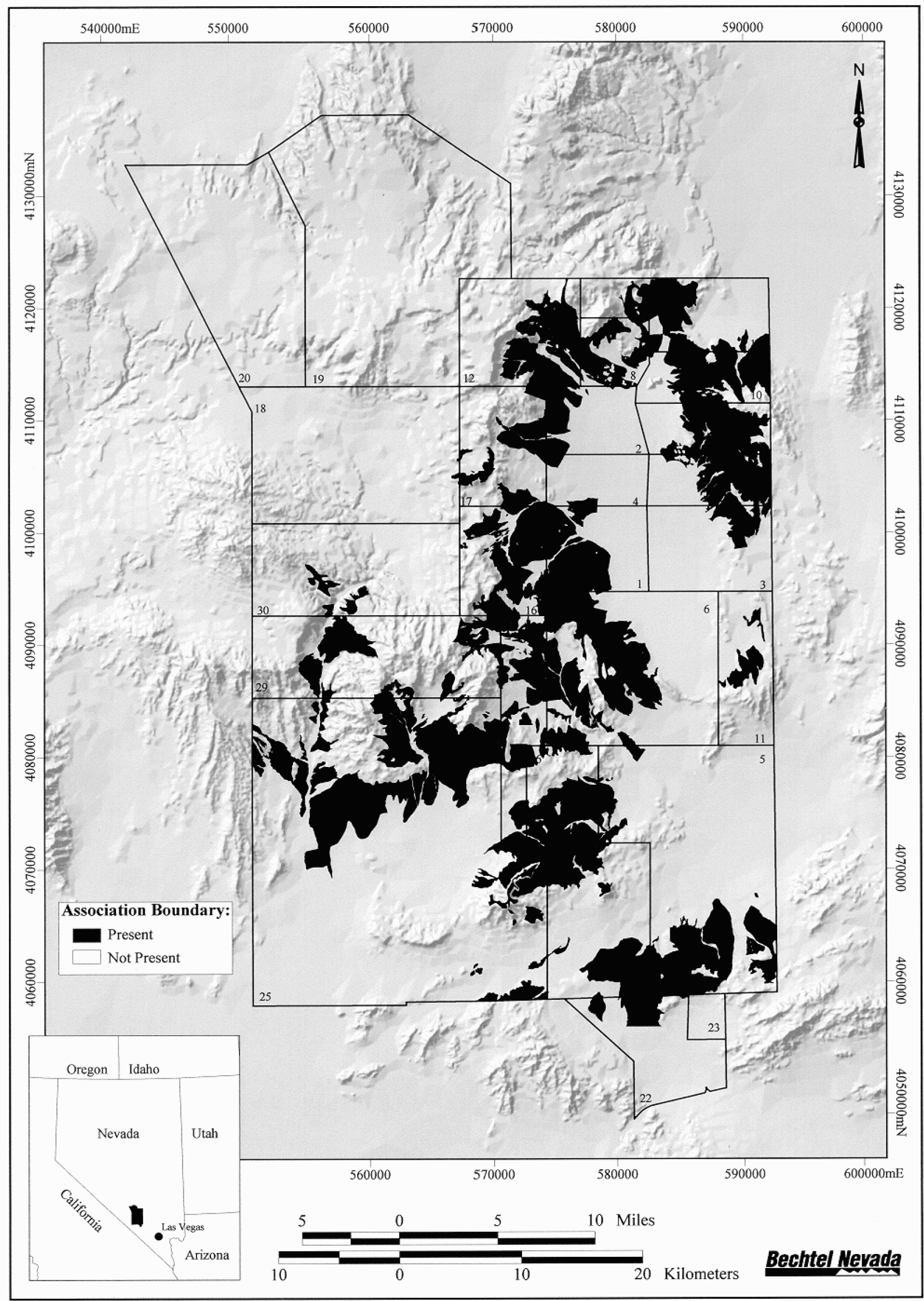

Figure 4-12 Distribution of the Coleogyne ramosissima - Ephedra nevadensis Shrubland Association on the Nevada Test Site 


\subsubsection{Coleogyne ramosissima-Ephedra nevadensis Shrubland}

This association occurs primarily on upper piedmont slopes surrounding Yucca Flat and in Mid Valley and Topopah Valley (Figure 4-12). It occupies nearly 73,000 ha $(182,500 \mathrm{ac}$ ) on the NTS and consisted of 323 ELUs. Despite the large area, this association clustered very tightly

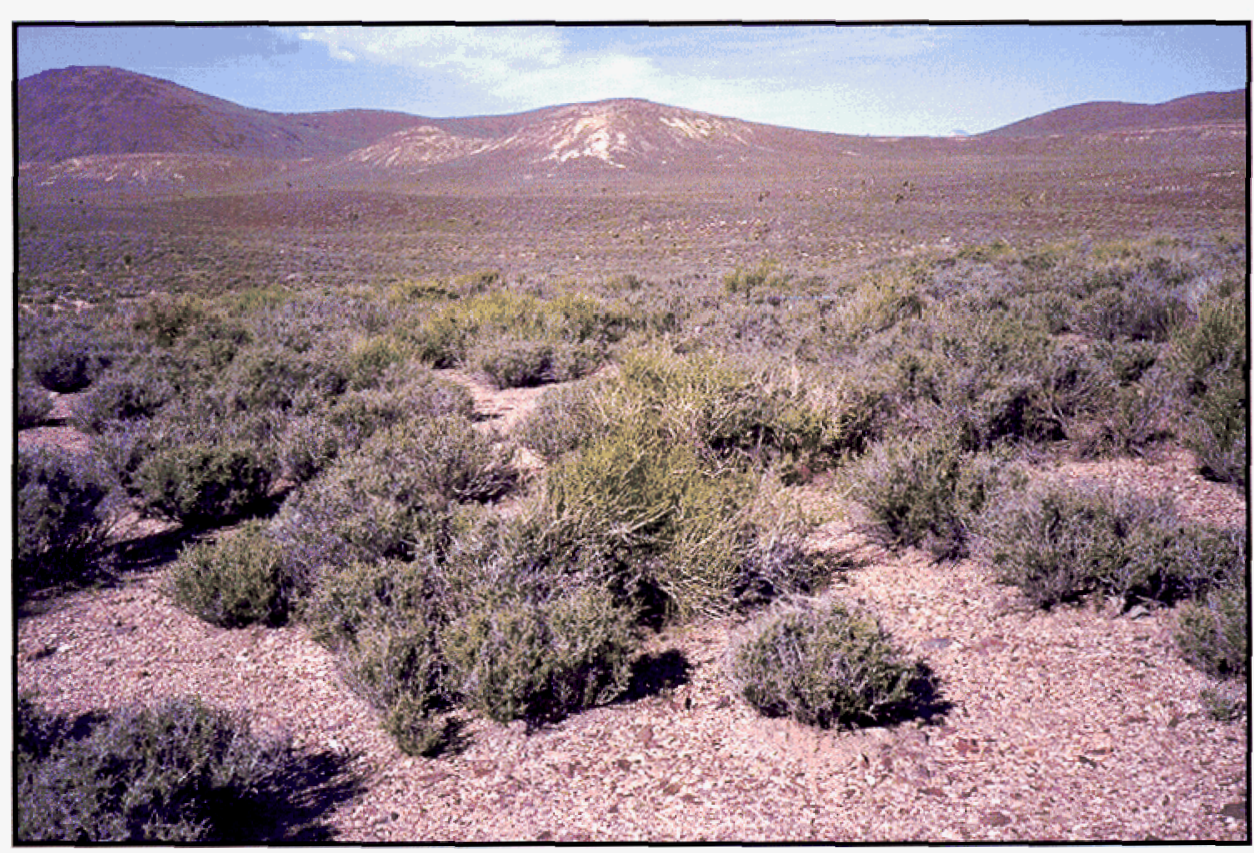

because of its rather unique flora. It is dominated by blackbrush that represents over 50 percent of the relative abundance of shrub species in this association, with few associated shrubs species. Fires have reduced much of the previous blackbrush in the Mid Valley and Topopah Valley. It occurs primarily in undisturbed areas with shallow soils or caliche layers near the soil surface that restricts deep root development. Soils are generally loams to sandy loams. This association has moderate species diversity, but high species richness. Summary information for this association is presented in Table 4-12.

Table 4-12 Characteristics of the Coleogyne ramosissima-Ephedra nevadensis Shrubland. (Percent relative abundance values for primary and associated species are enclosed in parenthesis.)

\begin{tabular}{|ll|}
\hline Primary species: & Blackbrush (56\%), Nevada jointfir (10\%) \\
Associated species: & White burrobush (4\%), Anderson's wolfberry (3\%) \\
Species diversity: & 84 species total; averaged 16.9 perennial species/ELU \\
Number of ELUs: & 323 \\
Area of NTS: & 72,976 ha $(21.6 \%)$ \\
Landforms: & Variable, mostly piedmont slopes to lower slopes of mountains \\
Geology: & Highly variable, mostly quaternary alluvium/colluvium with both older limestones and \\
& some Tertiary tuffs \\
Elevation: & Average $1,385 \mathrm{~m}$, range 981 to $1,865 \mathrm{~m}$ \\
Precipitation: & Average $19.3 \mathrm{~cm}$ \\
Slopes: & Average $8.5^{\circ}$, range 1 to $53^{\circ}$ \\
Soils: & Primarily loamy sand to loam \\
Annuals: & Very low to moderate \\
\hline
\end{tabular}




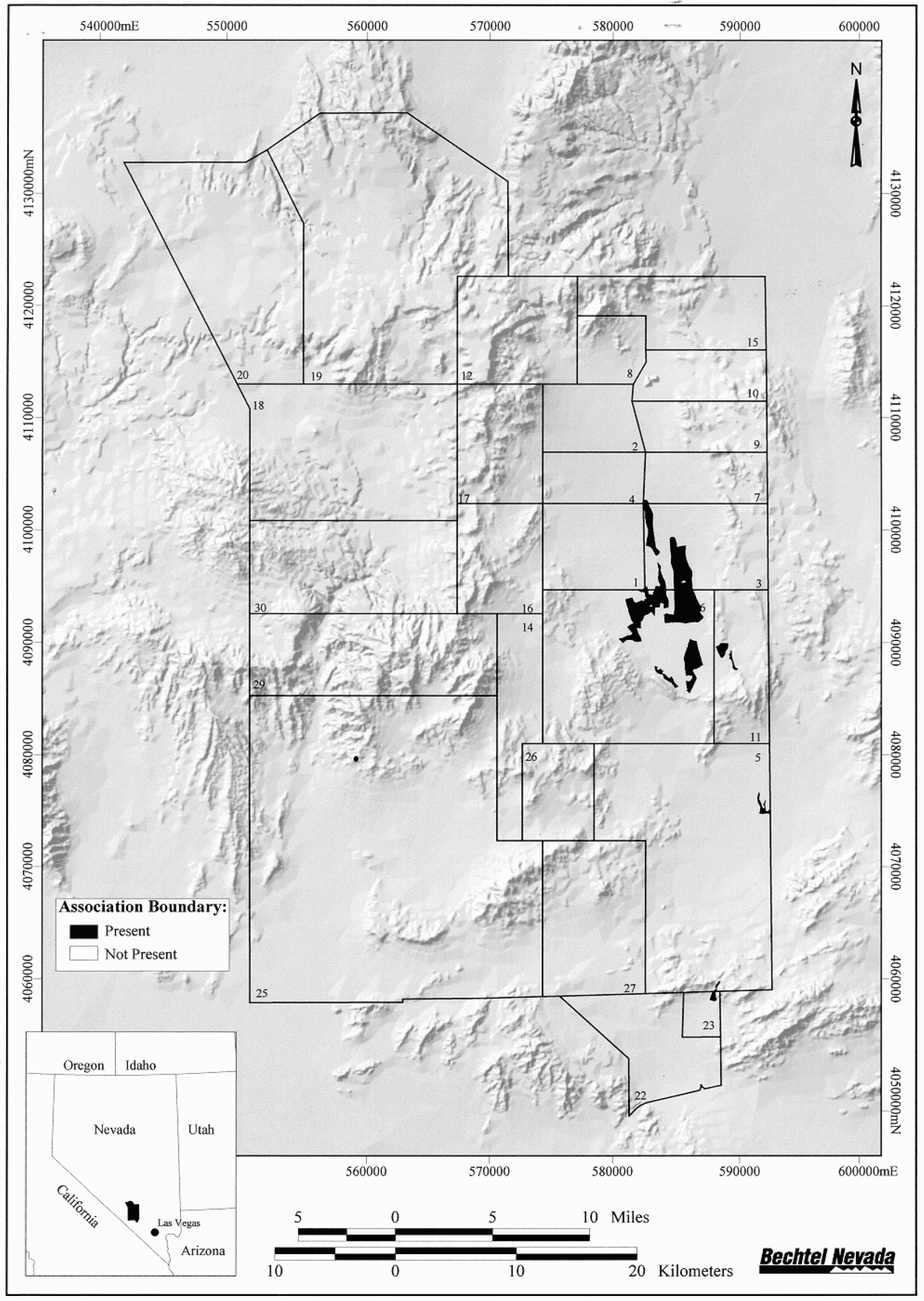

Figure 4-13 Distribution of the Atriplex confertifolia - Kochia americana Shrubland Association on the Nevada Test Site 


\subsubsection{Atriplex confertifolia-Kochia americana Shrubland}

This association is restricted to areas surrounding Yucca and Frenchman lakes (Figure 4-13). It is one of the smaller associations and occupies over 3,200 ha $(8,000 \mathrm{ac})$ or 0.9 percent of the NTS. Nineteen ELUs were sampled and clustered in this association. It is dominated by

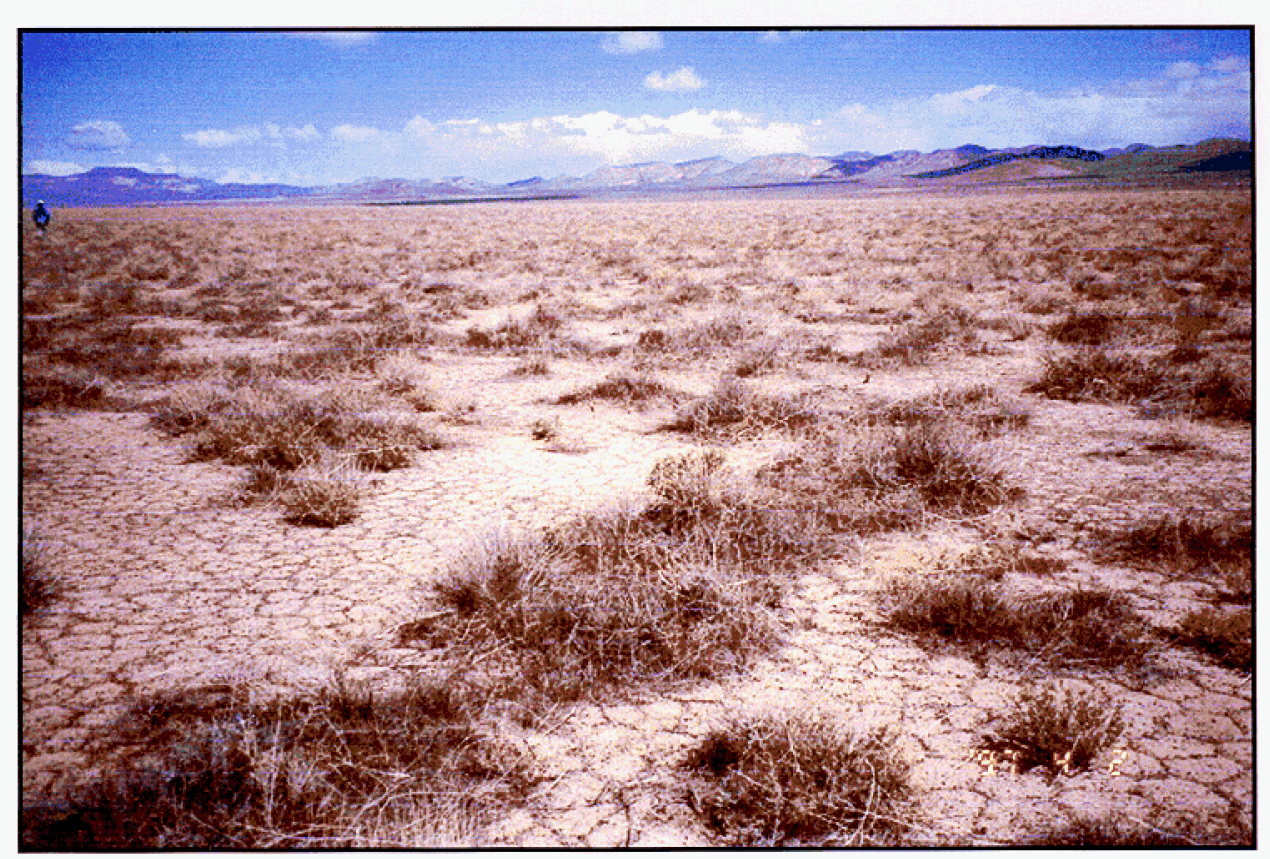

shadscale saltbush that has over 50 percent of the relative shrub abundance, but is often co-dominant with green molly (Kochia americana), particularly in Yucca Flat. In these closed basins, minimum temperatures are lower that the surrounding slopes and, according to Beatley (1976), this area had the "lowest nighttime temperatures" measured at any of the sampled sites. Also, soils tend to contain more silts and clays and have higher salinity levels. Soils are generally clay loams to sandy loams. These conditions exclude most species, resulting in lower species diversity. Summary information for this association is presented in Table 4-13.

Table 4-13 Characteristics of the Atriplex confertifolia-Kochia americana Shrubland. (Percent relative abundance values for primary and associated species are enclosed in parenthesis.)

\begin{tabular}{|ll|}
\hline $\begin{array}{l}\text { Primary species: } \\
\text { Associated species: }\end{array}$ & $\begin{array}{l}\text { Shadscale saltbush (48\%), green molly }(20 \%) \\
\text { Anderson's wolfberry (7\%), Bursage (Artemsia spinescens) (6\%), spiny menodora (5\%), } \\
\text { winterfat }(5 \%)\end{array}$ \\
$\begin{array}{l}\text { Species diversity: } \\
\text { Number of ELUs: }\end{array}$ & 53 species total; averaged 9.2 perennial species/ELU \\
Area of NTS: & 19 \\
Landforms: & 3,211 ha $(0.9 \%)$ \\
Geology: & Basin, alluvial flat \\
Elevation: & Quaternary alluvium \\
Precipitation: & Average $1,208 \mathrm{~m}$, range 940 to $1,382 \mathrm{~m}$ \\
Slopes: & Average $17.6 \mathrm{~cm}$ \\
Soils: & Average $2.7^{\circ}$, range 0 to $20^{\circ}$ \\
Annuals: & Primarily sandy loam to clay loam \\
& Low to moderate
\end{tabular}




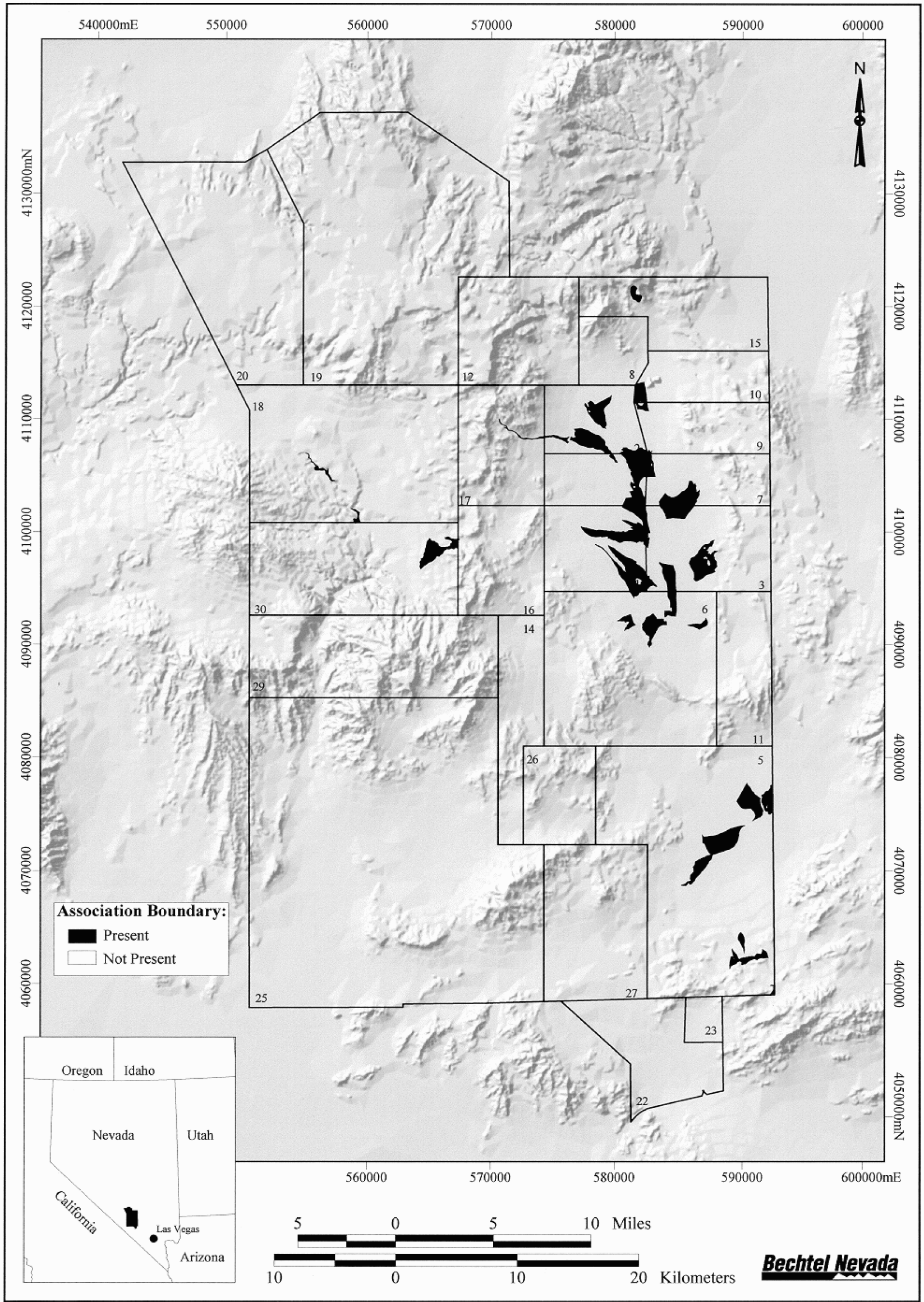

Figure 4-14 Distribution of the Atriplex canescens - Krascheninnikovia lanata Shrubland Association on the Nevada Test Site 


\subsubsection{Atriplex canescens-Krascheninnikovia lanata Shrubland}

This association is most commonly found in the area surrounding Yucca and Frenchman lakes and in disturbed areas within Yucca Flat (Figure 4-14). It is one of the moderate-sized associations and occupies just less than 7,300 ha $(18,250 \mathrm{ac})$ or 2.2 percent of the NTS. Thirty-eight

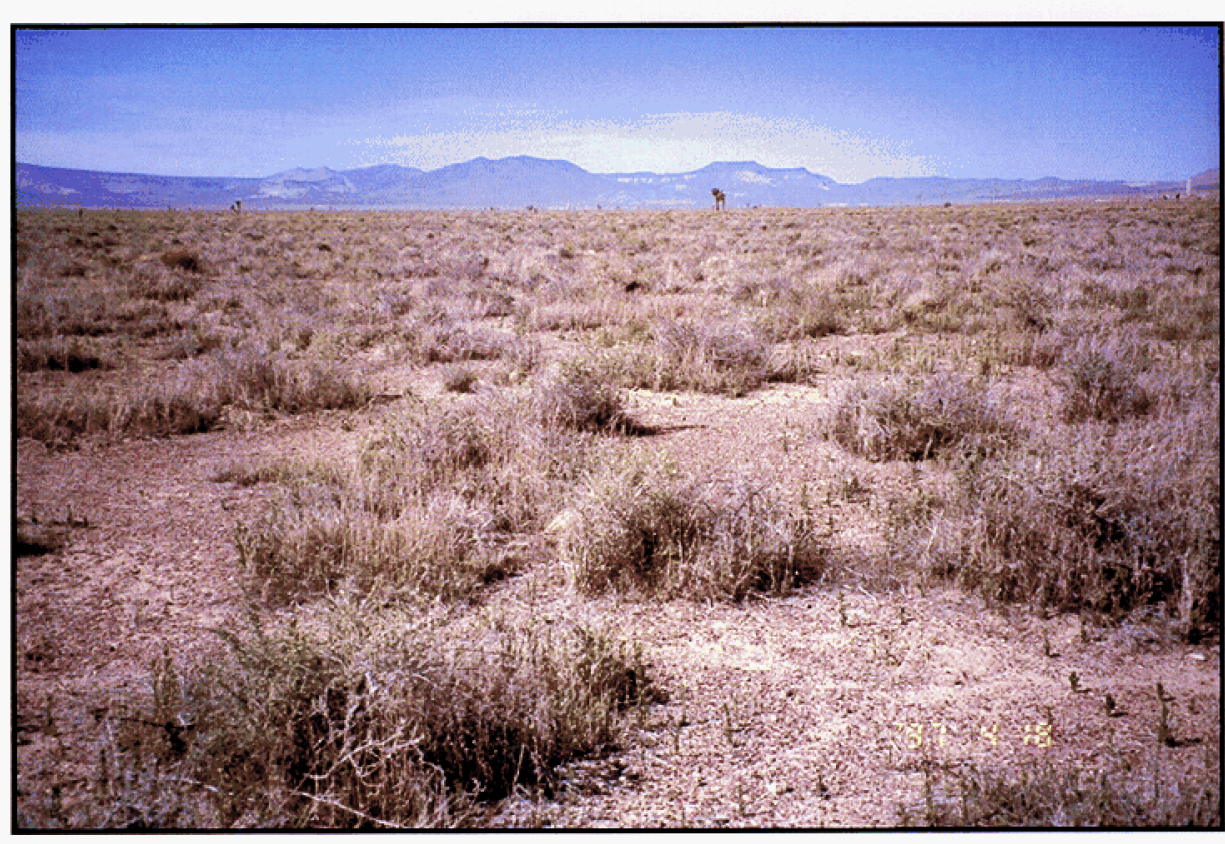

ELUs were recognized and clustered in this association. It is dominated by fourwing saltbush that has 58 percent of the relative shrub abundance. The most common codominant species is winterfat. These sites are also often associated with natural drainage channels. Soils tend to consist of loose deep sands, with little structure or soil development, often with high salinity levels. These conditions tend to exclude most species such that this association has very low species diversity. However, because of the nature of these areas, there are often unique or endemic species such as Gilia nyensis, Eriogonum concinnum, Psorothamnus polydenius, and Eriogonum kearneyi that occur on undisturbed sites. Summary information for this association is presented in Table 4-14.

Table 4-14 Characteristics of the Atriplex canescens-Krascheninnikovia lanata Shrubland. (Percent relative abundance values for primary and associated species are enclosed in parenthesis.)

\begin{tabular}{|ll}
\hline Primary species: & Four-wing saltbush (58\%), winterfat $(11 \%)$ \\
Associated species: & Anderson's wolfberry $(5 \%)$, white burrobush (4\%) \\
Species diversity: & 87 species total; averaged 11.9 perennial species/ELU \\
Number of ELUs: & 38 \\
Area of NTS: & 7,275 ha $(2.2 \%)$ \\
Landforms: & Basin alluvial flats to lower piedmont slopes-fan skirt \\
Geology: & Mostly Quaternary alluvium/colluvium with some Tertiary tuffs \\
Elevation: & Average $1,237 \mathrm{~m}$, range 940 to $1,707 \mathrm{~m}$ \\
Precipitation: & Average $18.0 \mathrm{~cm}$ \\
Slopes: & Average $3.5^{\circ}$, range 0 to $24^{\circ}$ \\
Soils: & Sand to sandy loam \\
Annuals: & Moderate to very high \\
\hline
\end{tabular}




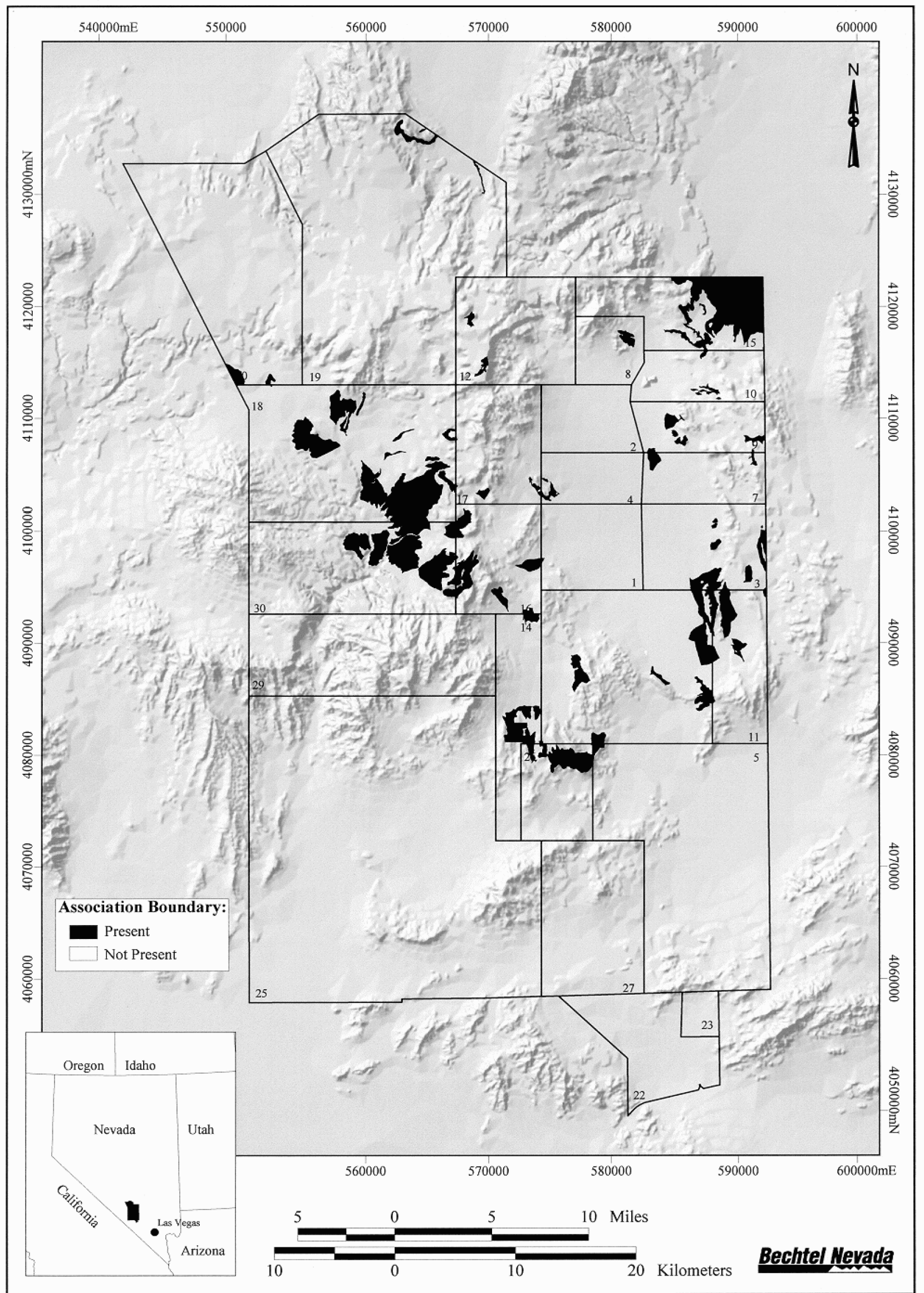

Figure 4-15 Distribution of the Chrysothamnus viscidiflorus - Ephedra nevadensis Shrubland Association on the Nevada Test Site 


\subsubsection{Chrysothamnus viscidiflorus-Ephedra nevadensis Shrubland}

This association is scattered over the central part of the NTS with large areas near Buckboard Mesa, the northeast corner of the NTS near Groom Lake, and Plutonium Valley (Figure 4-15). It is of moderate size, occupying over 16,000 ha $(41,600 \mathrm{ac})$ or $4.8 \%$ of the NTS. Seventy-six

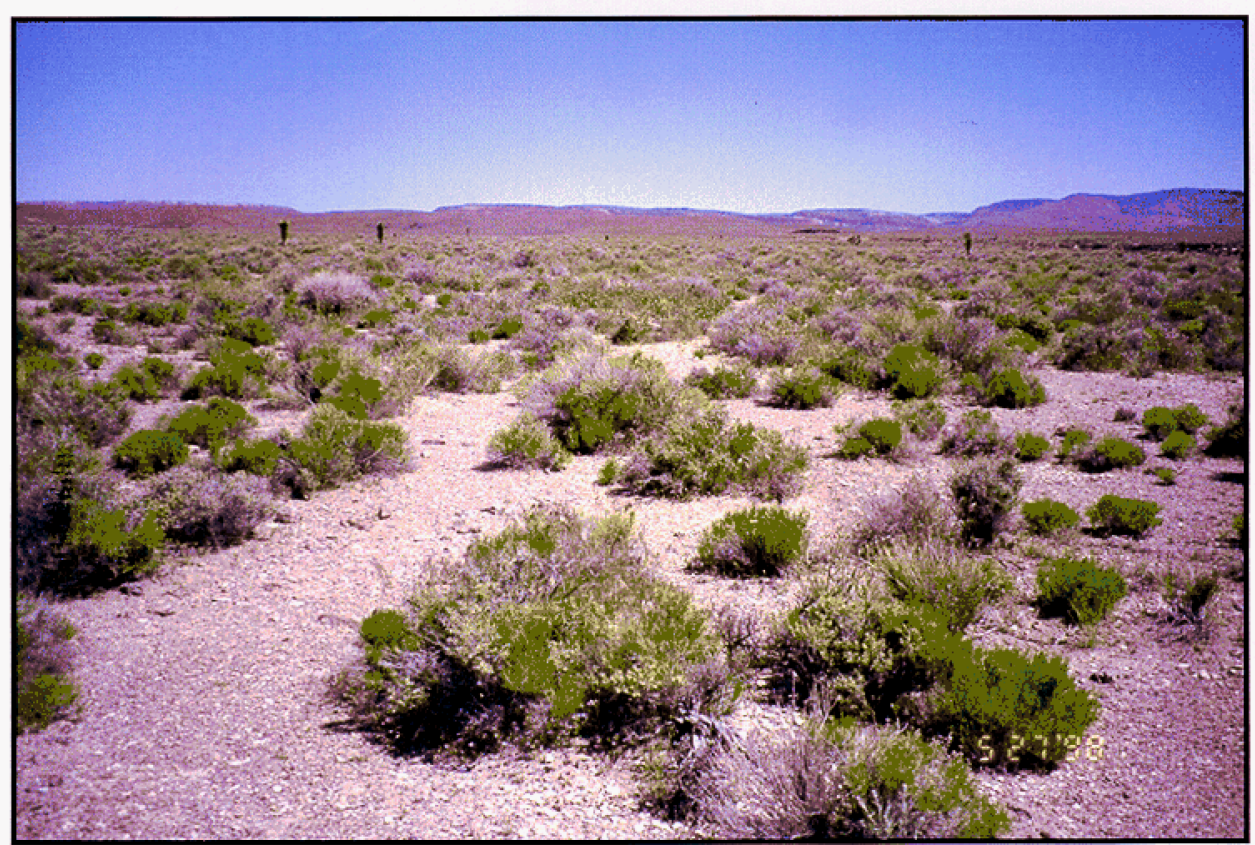

ELUs were clustered and recognized in this association. It is dominated by green rabbitbrush, but has many associated shrub species, the most common of which is Nevada jointfir. It extends as far south as the mountains south of Mid Valley. Soils are generally loamy sands to loams. This association has high species diversity.

Summary information for this association is presented in Table 4-15.

Table 4-15 Characteristics of the Chrysothamnus viscidiflorus-Ephedra nevadensis Shrubland. (Percent relative abundance values for primary and associated species are enclosed in parenthesis.)

\begin{tabular}{|ll|}
\hline Primary species: & Green rabbitbrush (37\%), Nevada jointfir (11\%) \\
Associated species: & Four-wing saltbush (7\%), winterfat $(5 \%)$, spiny hopsage (5\%), basin big sagebrush $(5 \%)$, \\
& Anderson's wolfberry $(5 \%)$, shadscale saltbush (4\%) \\
Species diversity: & 61 species total; averaged 21.4 perennial species/ELU \\
Number of ELUs: & 76 \\
Area of NTS: & 16,114 ha $(4.8 \%)$ \\
Landforms: & Variable, mostly mountains to upper piedmont slopes \\
Geology: & Mostly Quaternary alluvium/colluvium with some Tertiary tuffs \\
Elevation: & Average $1,495 \mathrm{~m}$, range 1,198 to $2,292 \mathrm{~m}$ \\
Precipitation: & Average $21.1 \mathrm{~cm}$ \\
Slopes: & Average $7.1^{\circ}$, range 0 to $38^{\circ}$ \\
Soils: & Primarily loamy sand to loam \\
Annuals: & Low to moderate \\
\hline
\end{tabular}




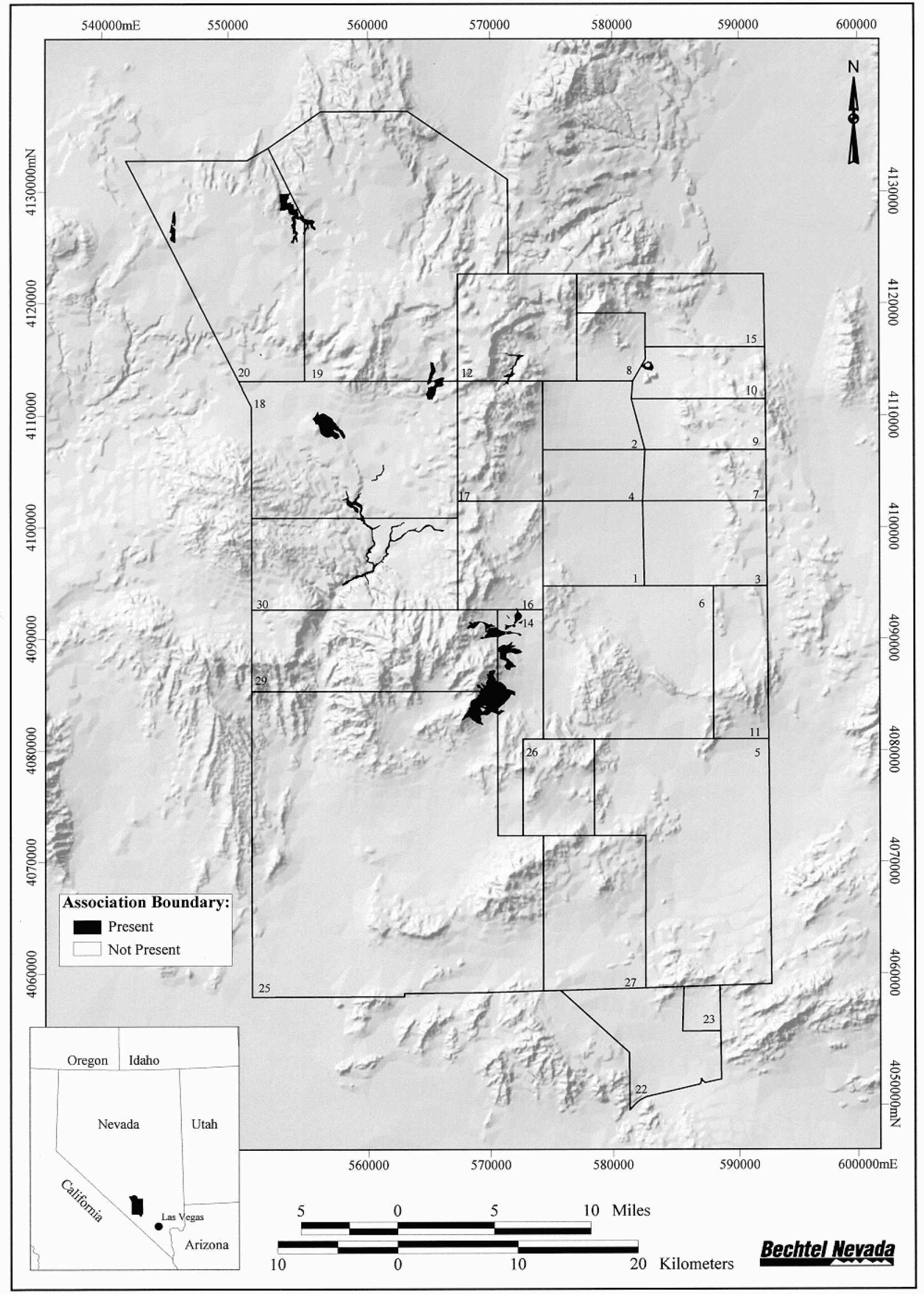

Figure 4-16 Distribution of the Ericameria nauseosa - Ephedra nevadensis Shrubland Association on the Nevada Test Site 


\subsubsection{Ericameria nauseosa-Ephedra nevadensis Shrubland}

This association is scattered over the west-central part of the NTS (Figure 4-16). It is one of smallest associations, occupying just under 3,000 ha $(7,500 \mathrm{ac})$ or 0.8 percent of the NTS. Twenty-one ELUs were clustered and sampled in this association. It is dominated by rubber

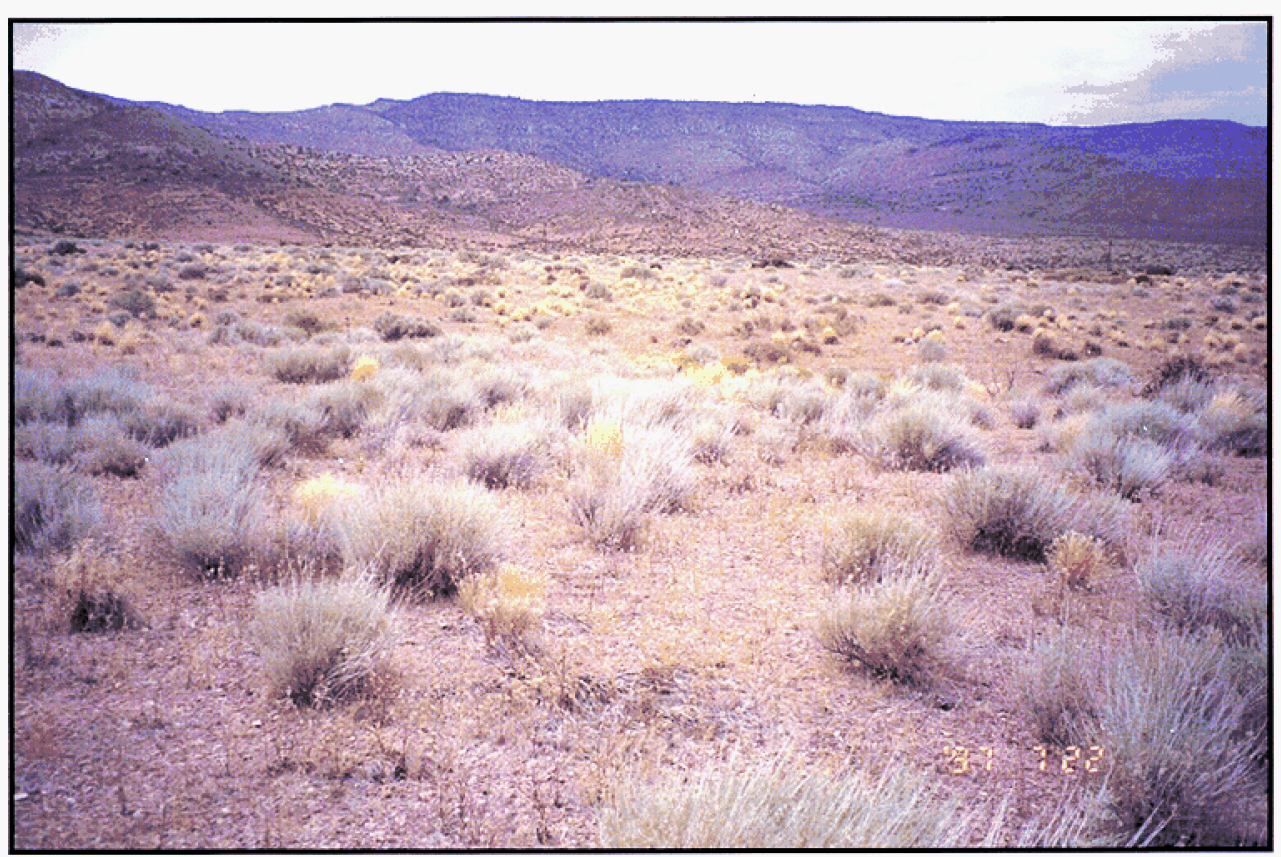

rabbitbrush that has over 50 percent of the relative abundance of shrub species. The most common codominant species is Nevada jointfir. It extends as far south as Mid Valley. This association is associated with disturbance either along natural drainage channels or as the result of man-caused surface disturbance such as fires. This fire succession is particularly noticeable in Mid Valley where rubber rabbitbrush has invaded into areas formerly occupied by blackbrush. Soils are generally sandy loams to sands. This association has moderate species diversity, but high levels of annuals. Summary information for this association is presented in Table 4-16.

Table 4-16 Characteristics of the Ericameria nauseosa-Ephedra nevadensis Shrubland. (Percent relative abundance values for primary and associated species are enclosed in parenthesis.)

\begin{tabular}{|ll|}
\hline Primary species: & Rubber rabbitbrush (52\%), Nevada jointfir (11\%) \\
Associated species: & $\begin{array}{l}\text { Basin big sagebrush (6\%), blackbrush (5\%), four-wing saltbush (5\%), green rabbitbrush } \\
(4 \%)\end{array}$ \\
Species diversity: & 43 species total; averaged 17.1 perennial species/ELU \\
Number of ELUs: & 21 \\
Area of NTS: & $2,873 \mathrm{ha}(0.8 \%)$ \\
Landforms: & Variable, mostly piedmont slopes to mountains \\
Geology: & Mostly Quaternary alluvium/colluvium with some Tertiary tuffs \\
Elevation: & Average $1,563 \mathrm{~m}$, range 1,311 to $2,018 \mathrm{~m}$ \\
Precipitation: & Average $21.1 \mathrm{~cm}$ \\
Slopes: & Average $6.9^{\circ}$, range 1 to $28^{\circ}$ \\
Soils: & Primarily sand to sandy loam \\
Annuals: & Moderate to very high \\
\hline
\end{tabular}




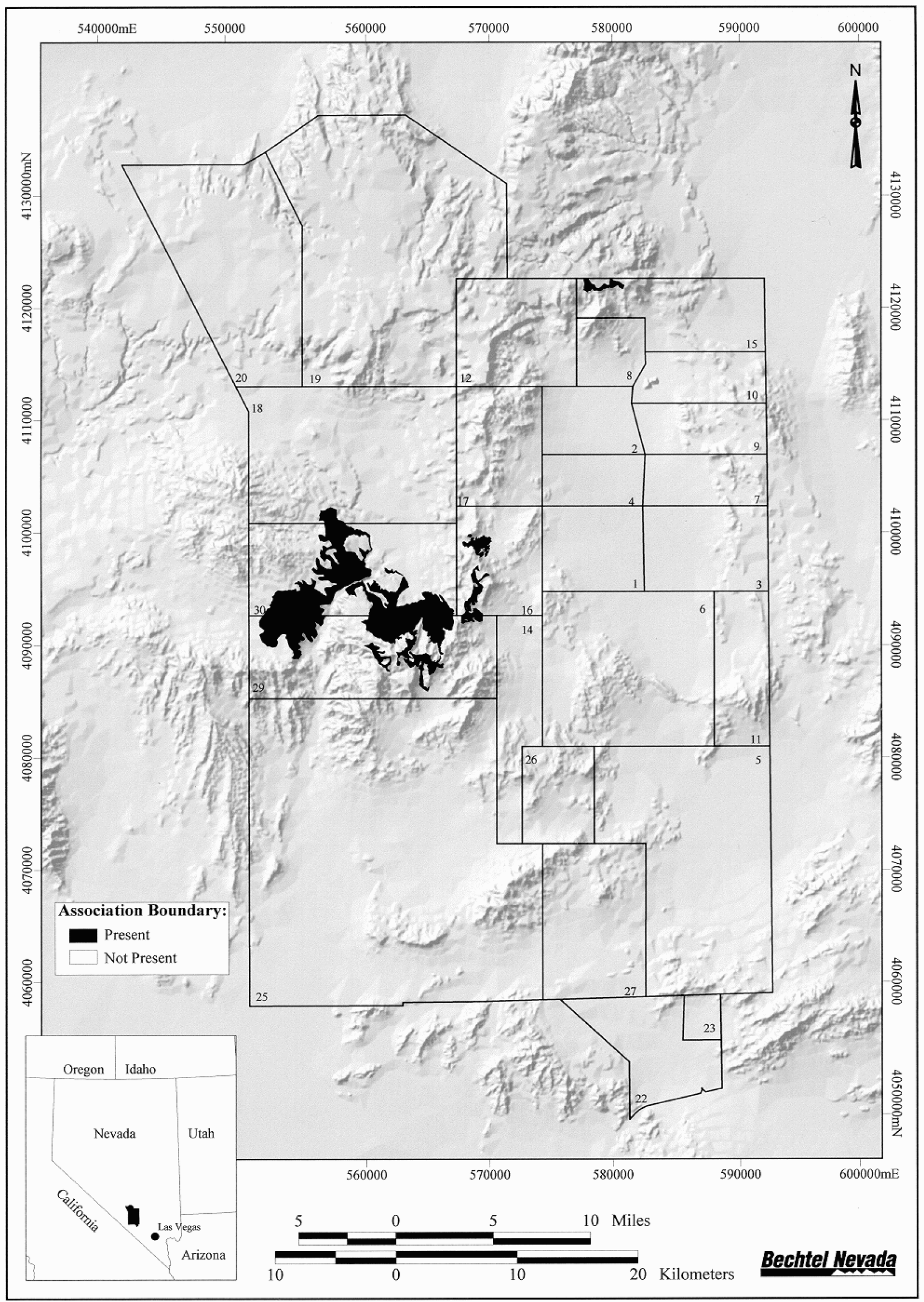

Figure 4-17 Distribution of the Ephedra viridis - Artemisia tridentata Shrubland Association on the Nevada Test Site 


\subsubsection{5}

This association occurs primarily in the southern part of Buckboard Mesa, in upper Fortymile Canyon, and the southern foothills of Timber Mountain (Figure 4-17). It is of moderate size, occupying over 8,500 ha $(21,250 \mathrm{ac})$ or 2.5 percent of the NTS. Twenty ELUs were clustered

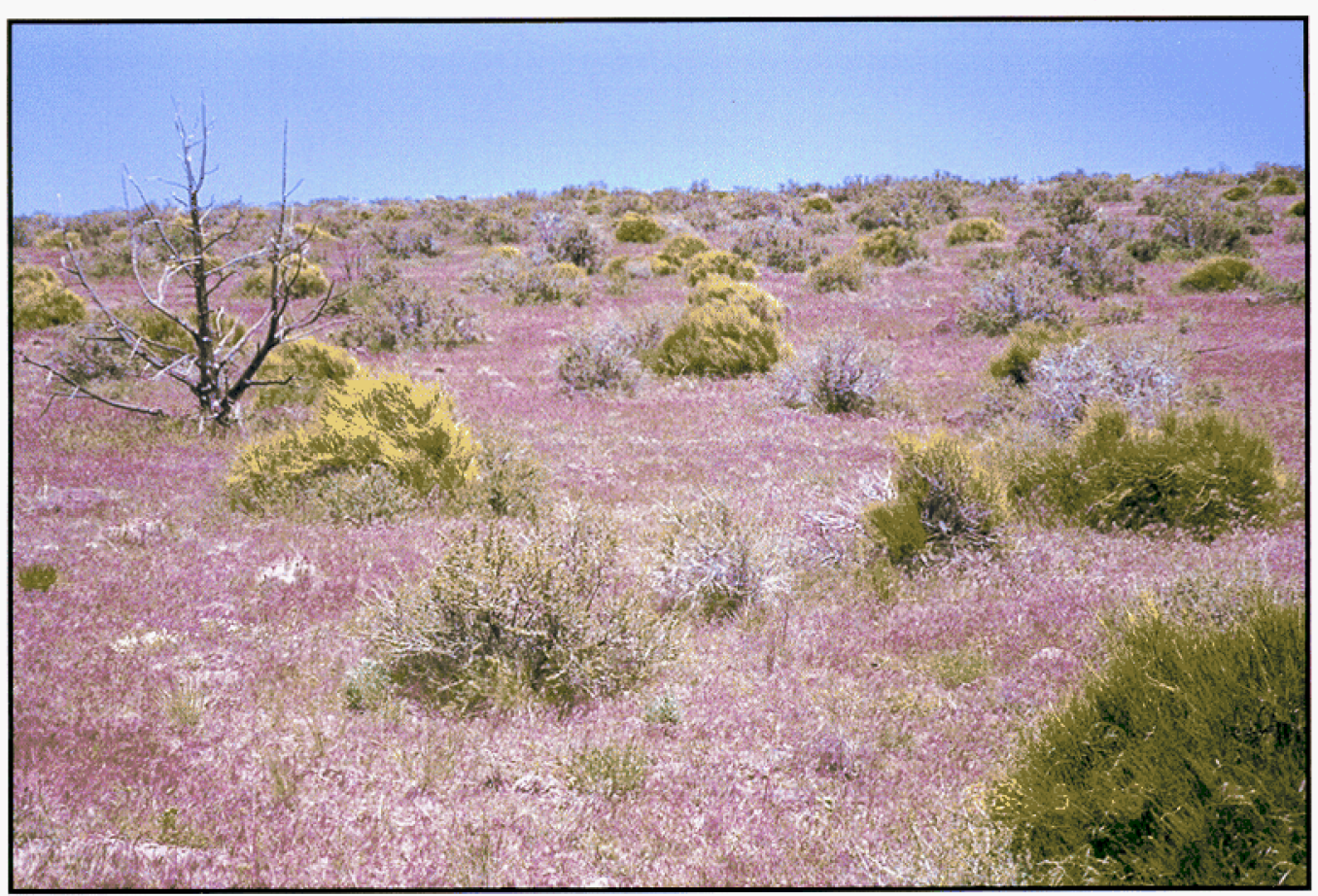

and recognized in this association. It is dominated by Mormon tea, basin big sagebrush, and desert bitterbrush (Purshia glandulosa). It occurs on very steep talus slopes or as a successional type following fire. Soils are sandy loams to silt loams but are very rocky, often with surface talus. This association has very high species diversity. Summary information for this association is presented in Table 4-17.

Table 4-17 Characteristics of the Ephedra viridis-Artemisia tridentata Shrubland. (Percent relative abundance values for primary and associated species are enclosed in parenthesis.)

\begin{tabular}{|ll|}
\hline Primary species: & Mormon tea (20\%), basin big sagebrush (16\%), desert bitterbrush (16\%) \\
Associated species: & $\begin{array}{l}\text { Stansbury cliffrose (Purshia stansburyiana) }(9 \%) \text {, eastern Mojave buckwheat (6\%), } \\
\text { puberulent green rabbitbrush (5\%) }\end{array}$ \\
Species diversity: & 42 species total; averaged 27.0 perennial species/ELU \\
Number of ELUs: & 20 \\
Area of NTS: & 8,585 ha $(2.5 \%)$ \\
Landforms: & Mountains \\
Geology: & Mostly Tertiary tuffs \\
Elevation: & Average $1,721 \mathrm{~m}$, range 1,402 to $2,012 \mathrm{~m}$ \\
Precipitation: & Average $24.0 \mathrm{~cm}$ \\
Slopes: & Average $18.2^{\circ}$, range 4 to $35^{\circ}$ \\
Soils: & Primarily sandy loam to silt loam \\
Annuals: & Moderate to very high \\
\hline
\end{tabular}




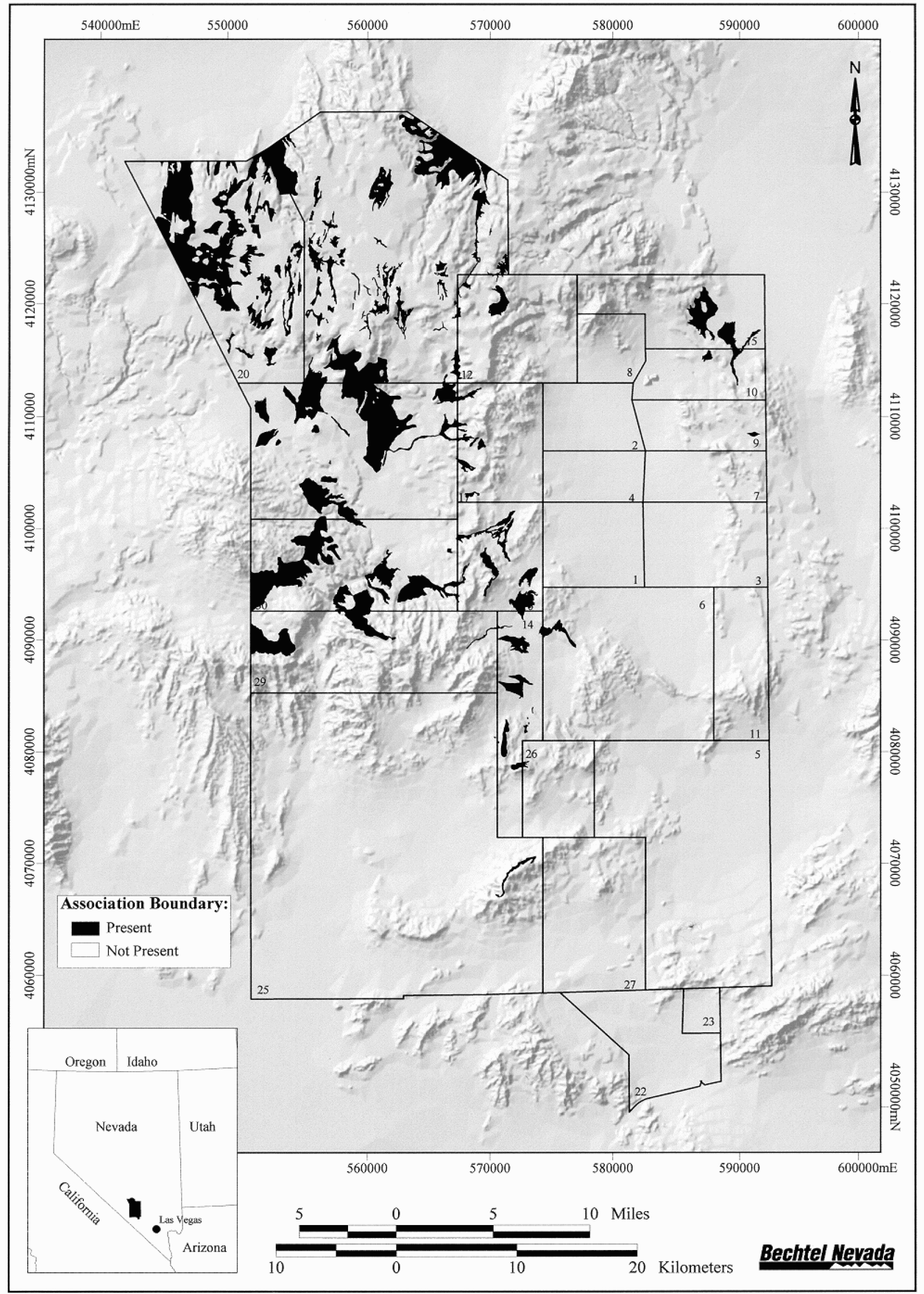

Figure 4-18 Distribution of the Artemisia tridentata - Chrysothamnus viscidiflorus Shrubland Association on the Nevada Test Site 
This association occurs primarily in the northwestern part of the NTS, but does extend as far south as Skull Mountain (Figure 4-18). It is rather large, occupying over 24,700 ha (61,750 ac) or 7.3 percent of the NTS. One hundred thirty-nine ELUs were clustered in this association. It is

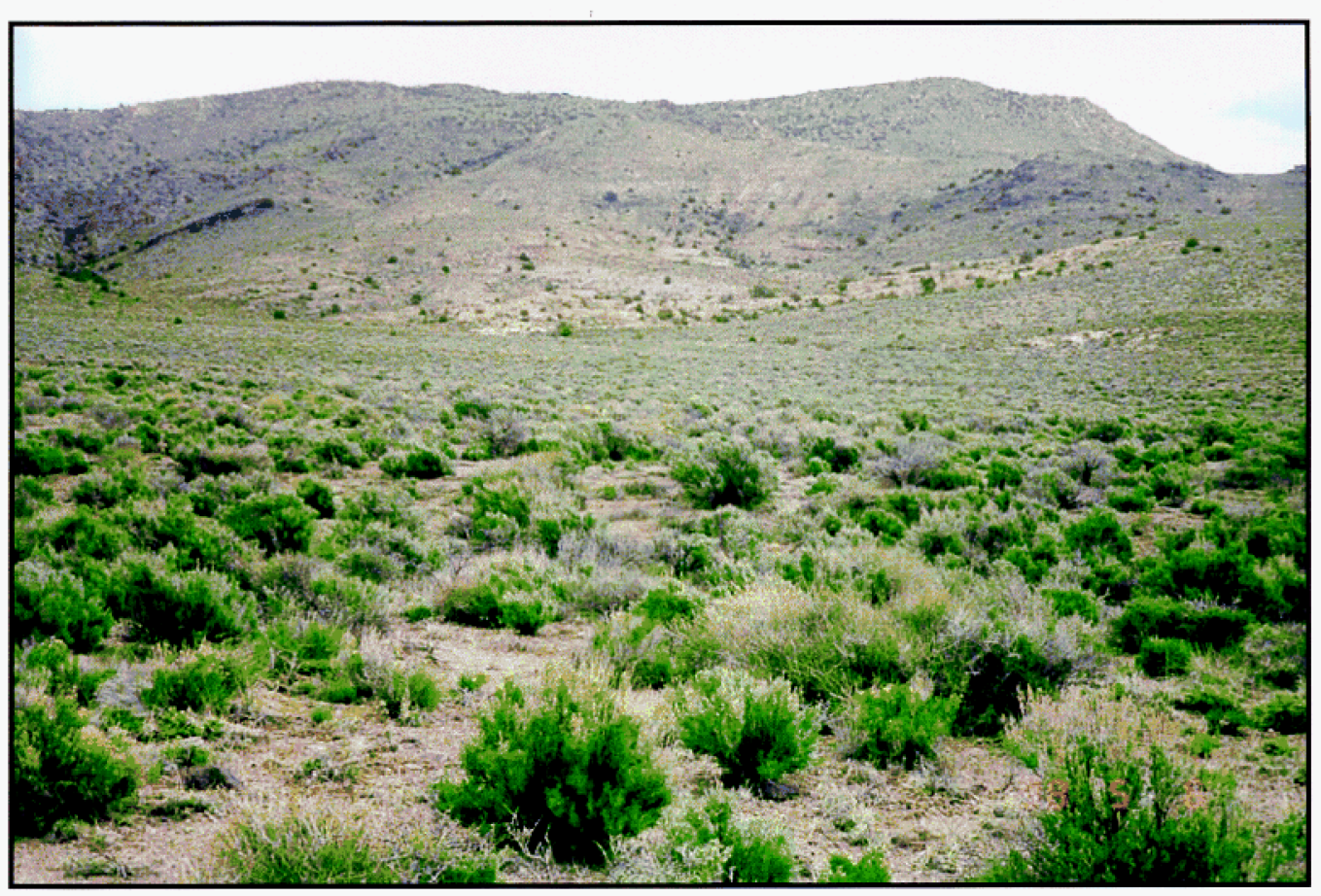
dominated by basin big sagebrush that has 56 percent of the relative abundance of shrub species. There are several other associated species, mainly green rabbitbrush and Nevada jointfir. It occurs on a range of sites from steep slopes to fairly level mountain valleys and mesas. It covers large areas on Pahute Mesa, Buckboard Mesa, and Timber Mountain where soils are relatively deep. Where soils are shallow, it is replaced by black sagebrush. At higher elevations and greater precipitation, it is replaced by pinyon and juniper. Soils are sandy loams to loams. This association has high species diversity. Summary information for this association is presented in Table 4-18.

Table 4-18 Characteristics of the Artemisia tridentata-Chrysothamnus viscidiflorus Shrubland. (Percent relative abundance values for primary and associated species are enclosed in parenthesis.)

\begin{tabular}{|ll|}
\hline Primary species: & Basin big sagebrush (58\%), green rabbitbrush $(9 \%)$ \\
Associated species: & $\begin{array}{l}\text { Nevada jointfir }(8 \%), \text { puberulent green rabbitbrush (Chrysothamnus viscidiflorus ssp. } \\
\text { puberulus) }(3 \%), \text { granite prickly gilia (Leptodactylon pungens) }(3 \%)\end{array}$ \\
Species diversity: & 73 species total; averaged 20.8 perennial species/ELU \\
Number of ELUs: & 139 \\
Area of NTS: & 24,703 ha $(7.3 \%)$ \\
Landforms: & Mostly mountains, some upper piedmont slopes \\
Geology: & Mostly Tertiary tuffs with some Quaternary alluvium/colluvium \\
Elevation: & Average $1,776 \mathrm{~m}$, range 1,298 to $2,225 \mathrm{~m}$ \\
Precipitation: & Average $24.7 \mathrm{~cm}$ \\
Slopes: & Average $5.9^{\circ}$, range 0 to $65^{\circ}$ \\
Soils: & Primarily loamy sand to loam \\
Annuals: & Very low to moderate \\
\hline
\end{tabular}




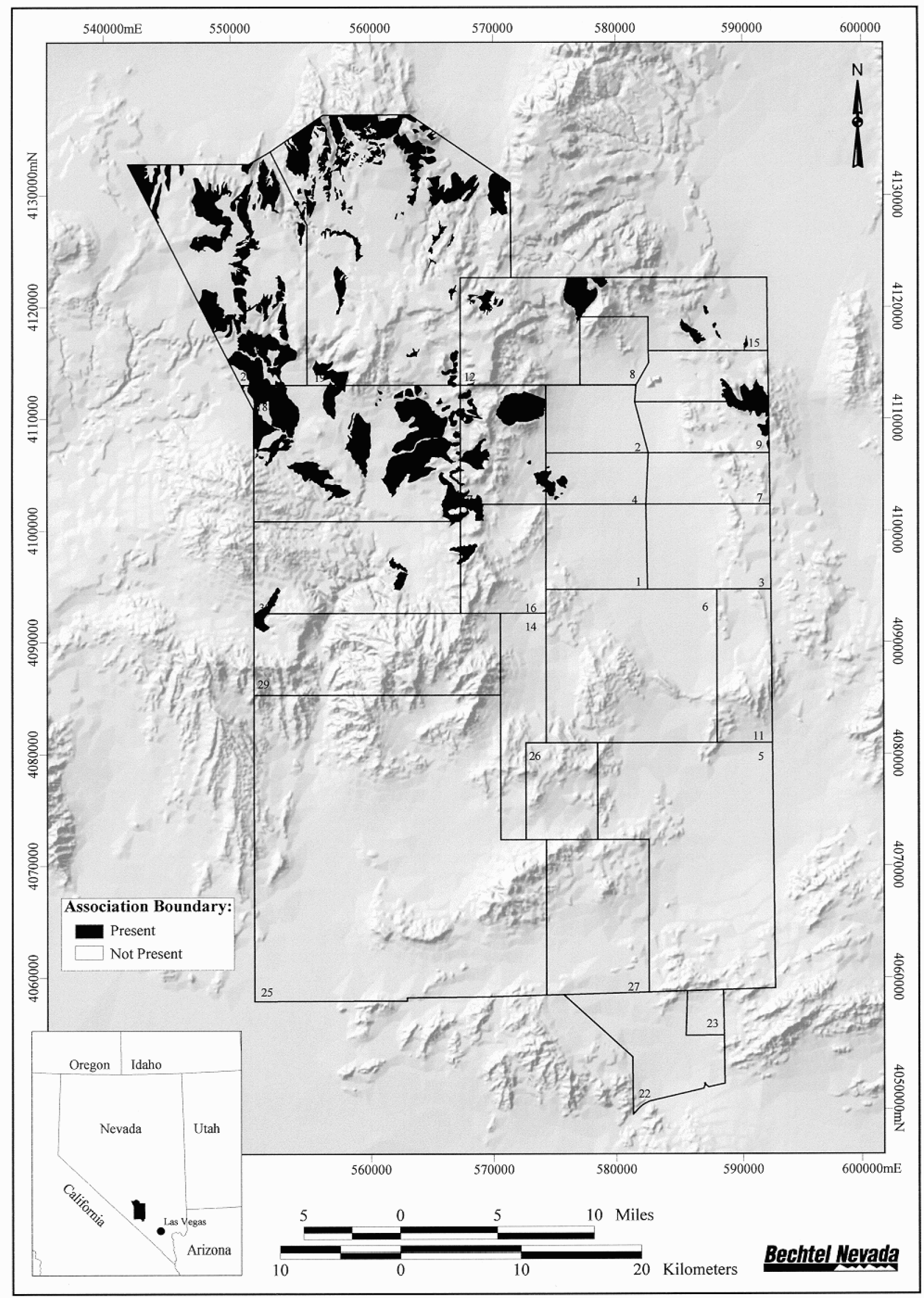

Figure 4-19 Distribution of the Artemisia nova - Chrysothamnus viscidiflorus Shrubland Association on the Nevada Test Site 
This association occurs primarily in the northwestern part of the NTS (Figure 4-19). It is one of the larger associations on the NTS, occupying about 23,500 ha $(58,750 \mathrm{ac})$ or 6.9 percent of the NTS. One hundred four ELUs were clustered and sampled in this association. It is

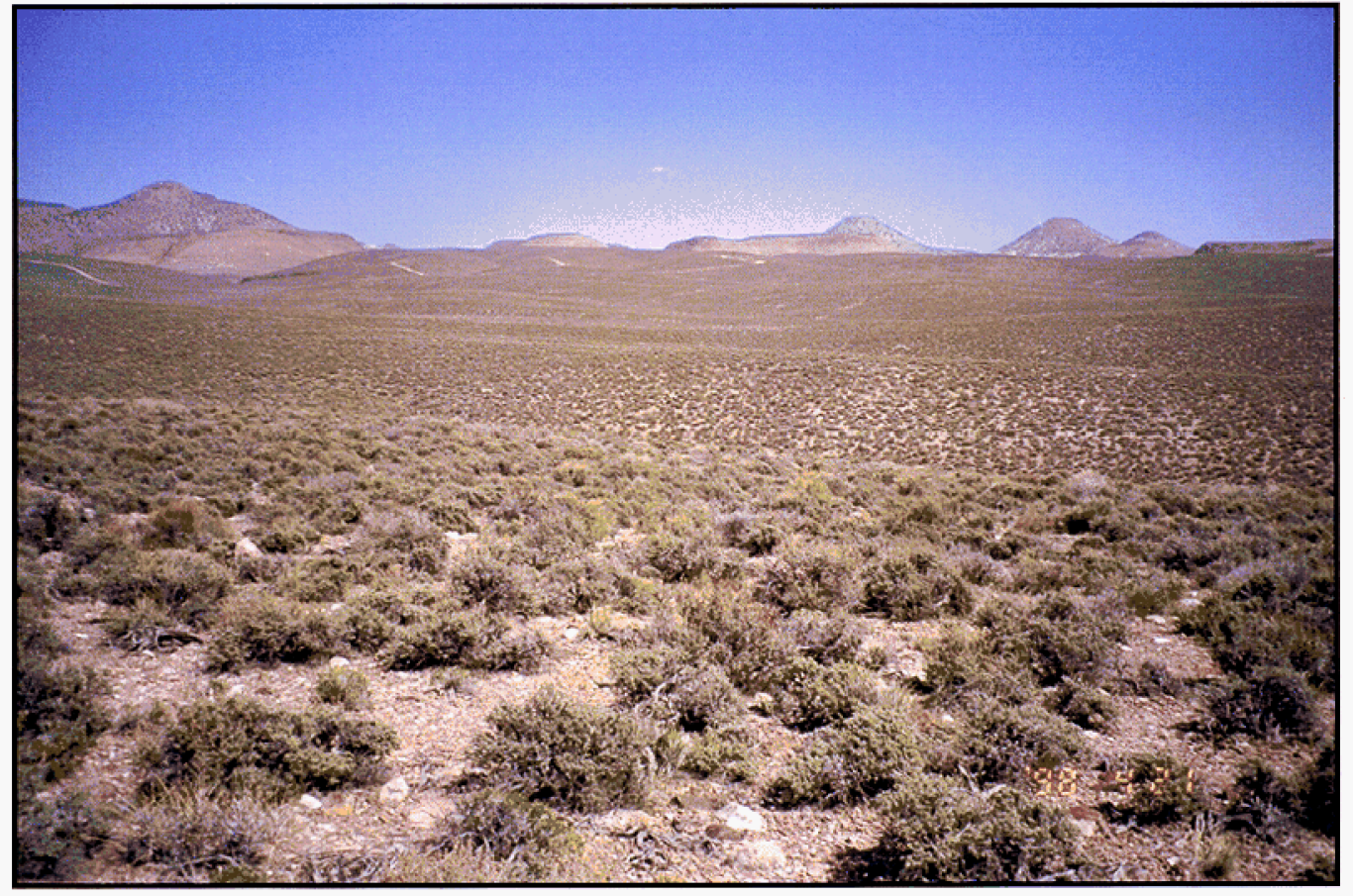

dominated by black sagebrush that contributes 68 percent of the relative abundance of shrub species in this association. Like blackbrush, it often forms nearly pure stands with few other shrub species. It occurs mostly on gently rolling hills or mesa tops. It covers large areas on Pahute and Buckboard mesas where soils are relatively shallow. At higher elevations and greater precipitation, it is replaced by pinyon pine and Utah juniper. Soils are generally residual and consist of sandy loams to loams. This association has high species diversity. Summary information for this association is presented in Table 4-19.

Table 4-19 Characteristics of the Artemisia nova-Chrysothamnus viscidiflorus Shrubland. (Percent relative abundance values for primary and associated species are enclosed in parenthesis.)

\begin{tabular}{|ll|}
\hline Primary species: & Black sagebrush (68\%), green rabbitbrush (5\%) \\
Associated species: & Nevada jointfir (5\%), basin big sagebrush (4\%), puberulent green rabbitbrush (3\%), spiny \\
& hopsage (2\%) \\
Species diversity: & 56 species total; averaged 24.7 perennial species/ELU \\
Number of ELUs: & 104 \\
Area of NTS: & 23,478 ha $(6.9 \%)$ \\
Landforms: & Mostly mountains, foothills, and mesas. \\
Geology: & Mostly Tertiary tuffs with some Quaternary alluvium/colluvium \\
Elevation: & Average $1,805 \mathrm{~m}$, range 1,433 to $2,120 \mathrm{~m}$ \\
Precipitation: & Average $25.1 \mathrm{~cm}$ \\
Slopes: & Average $6.4^{\circ}$, range 0 to $28^{\circ}$ \\
Soils: & Primarily sandy loam to loam \\
Annuals: & Very low to low \\
\hline
\end{tabular}




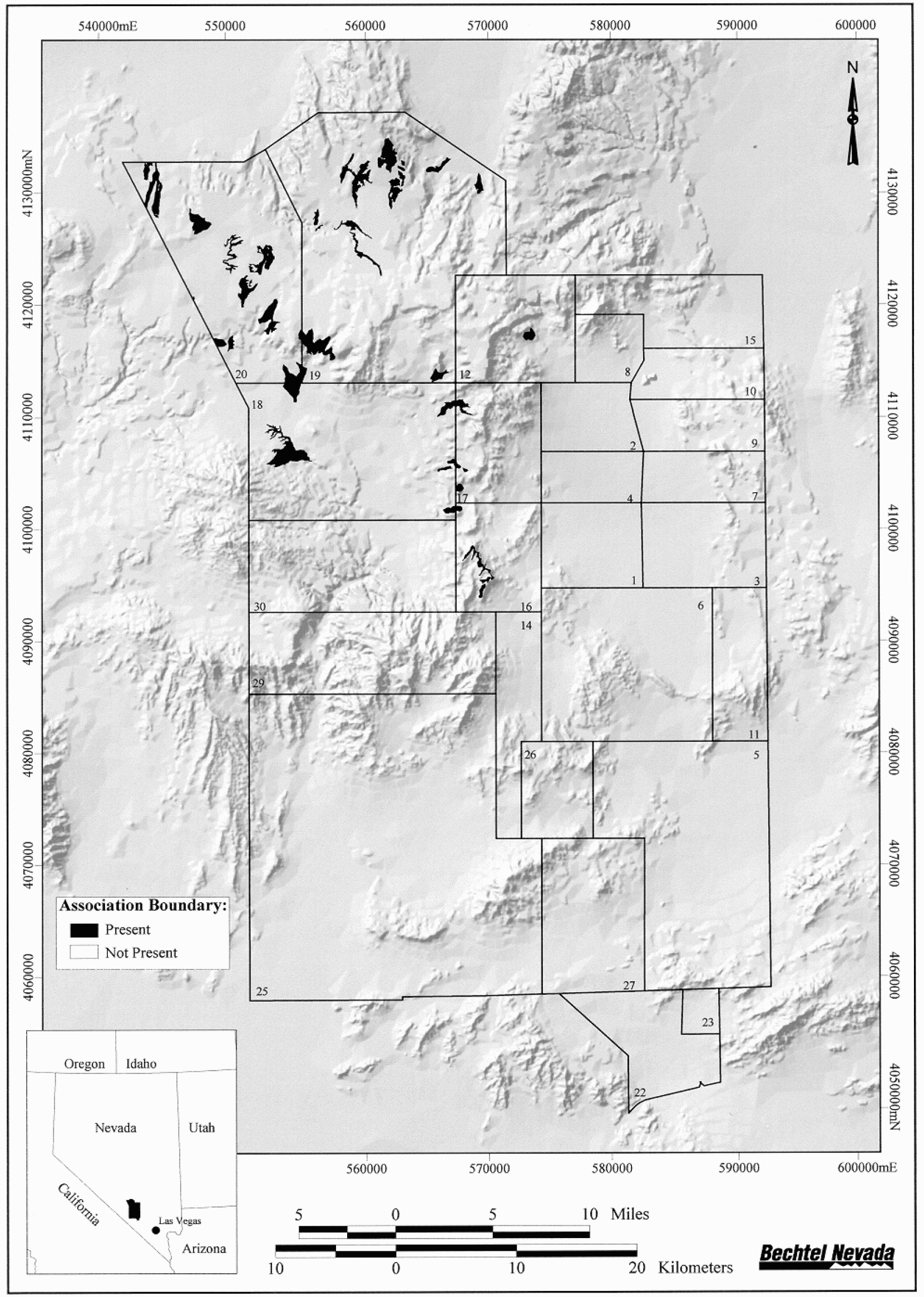

Figure 4-20 Distribution of the Artemisia nova - Artemisia tridentata Shrubland Association on the Nevada Test Site 
This association occurs primarily in the northwestern part of the NTS, but does extend as far south as Shoshone Mountain (Figure 4-20). It occupies over 4,500 ha (11,250 ac) or 1.4 percent of the NTS. Thirty ELUs were recognized and clustered in this association. It is co-dominated

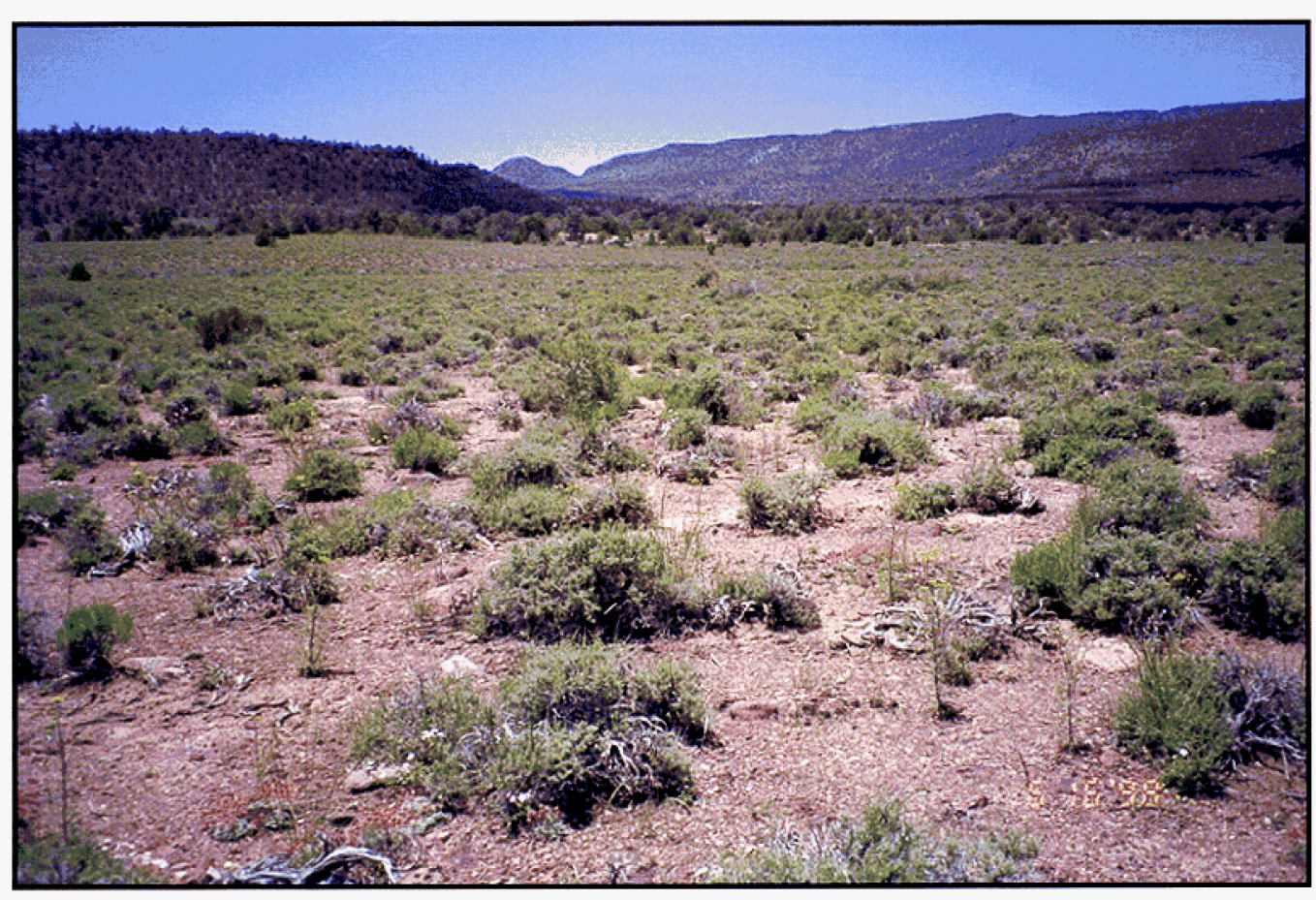

by black

sagebrush and basin big sagebrush in roughly equal numbers. There are several other associated shrub species, mainly puberulent green rabbitbrush, green rabbitbrush, and granite prickly gilia. It occurs in areas with variable slopes with basin big sagebrush occupying areas with deeper soils and black sagebrush along the hillsides and areas with shallower soils. At higher elevations and greater precipitation, it is replaced by Pinus monophylla/Artemisia nova Woodland. Soils are loamy sands to loams. This association has very high species diversity. Summary information for this association is presented in Table 4-20.

Table 4-20 Characteristics of the Artemisia nova-Artemisia tridentata Shrubland. (Percent relative abundance values for primary and associated species are enclosed in parenthesis.)

\begin{tabular}{|ll|}
\hline Primary species: & Black sagebrush (34\%), basin big sagebrush (25\%) \\
Associated species: & Puberulent green rabbitbrush $(8 \%)$, green rabbitbrush (5\%), Nevada jointfir (3\%) \\
Species diversity: & 47 species total; averaged 29.1 perennial species/ELU \\
Number of ELUs: & 30 \\
Area of NTS: & 4,567 ha $(1.4 \%)$ \\
Landforms: & Mountains \\
Geology: & Mostly Tertiary tuffs \\
Elevation: & Average $1,84413 \mathrm{~m}$, range 1,622 to $2,079 \mathrm{~m}$ \\
Precipitation: & Average $25.4 \mathrm{~cm}$ \\
Slopes: & Average $8.6^{\circ}$, range 1 to $38^{\circ}$ \\
Soils: & Primarily loamy sand to loam \\
Annuals: & Very low to moderate \\
\hline
\end{tabular}




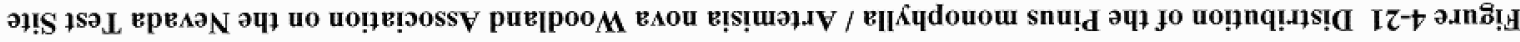

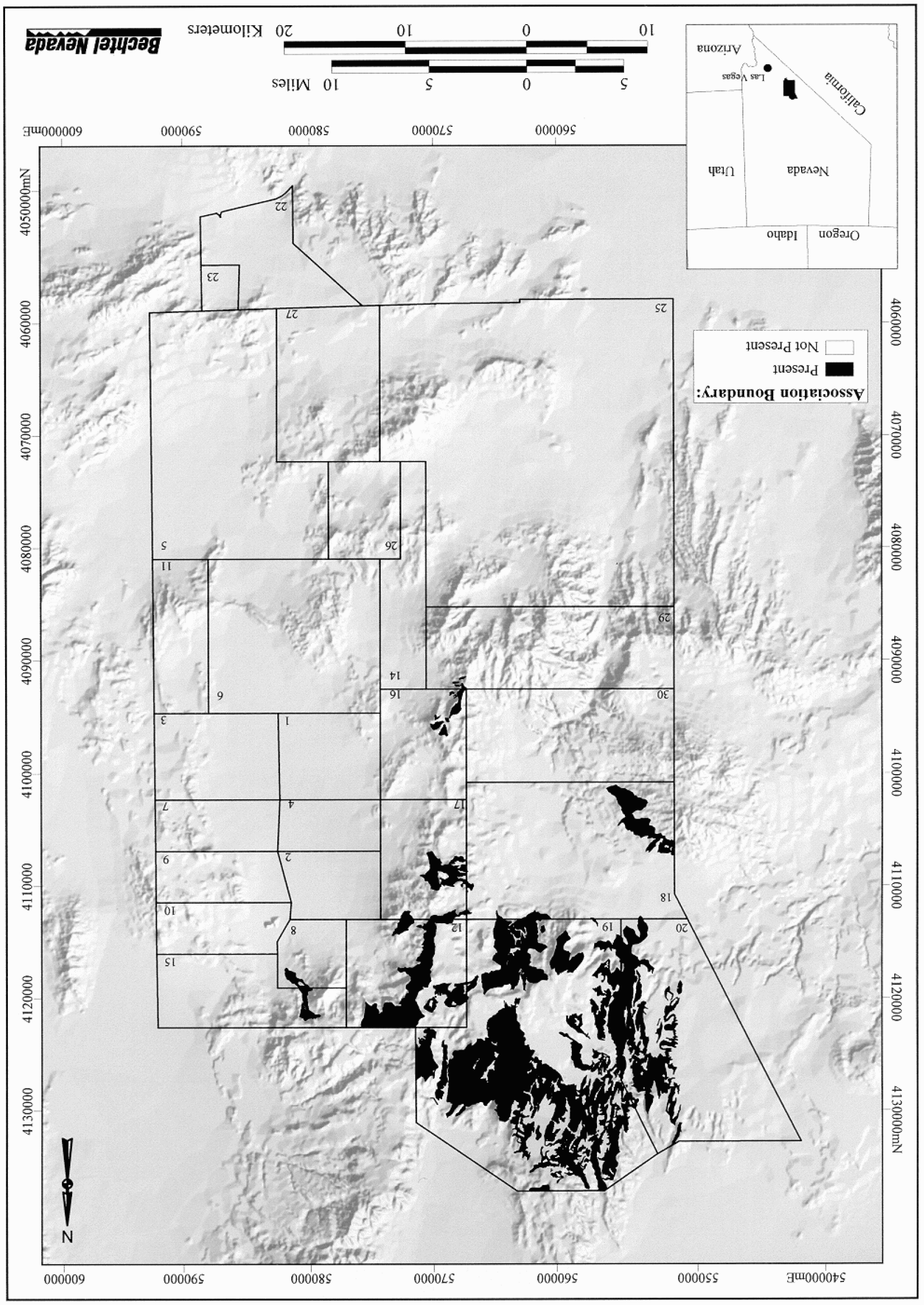




\subsubsection{Pinus monophylla/Artemisia nova Woodland}

This association occurs primarily in the northern part of the NTS, but does extend as far south as Shoshone Mountain (Figure 4-21). It occupies almost 25,000 ha (62,500 ac) or 7.4 percent of the NTS. Seventy-eight ELUs were clustered and recognized in this association. It is co-dominated

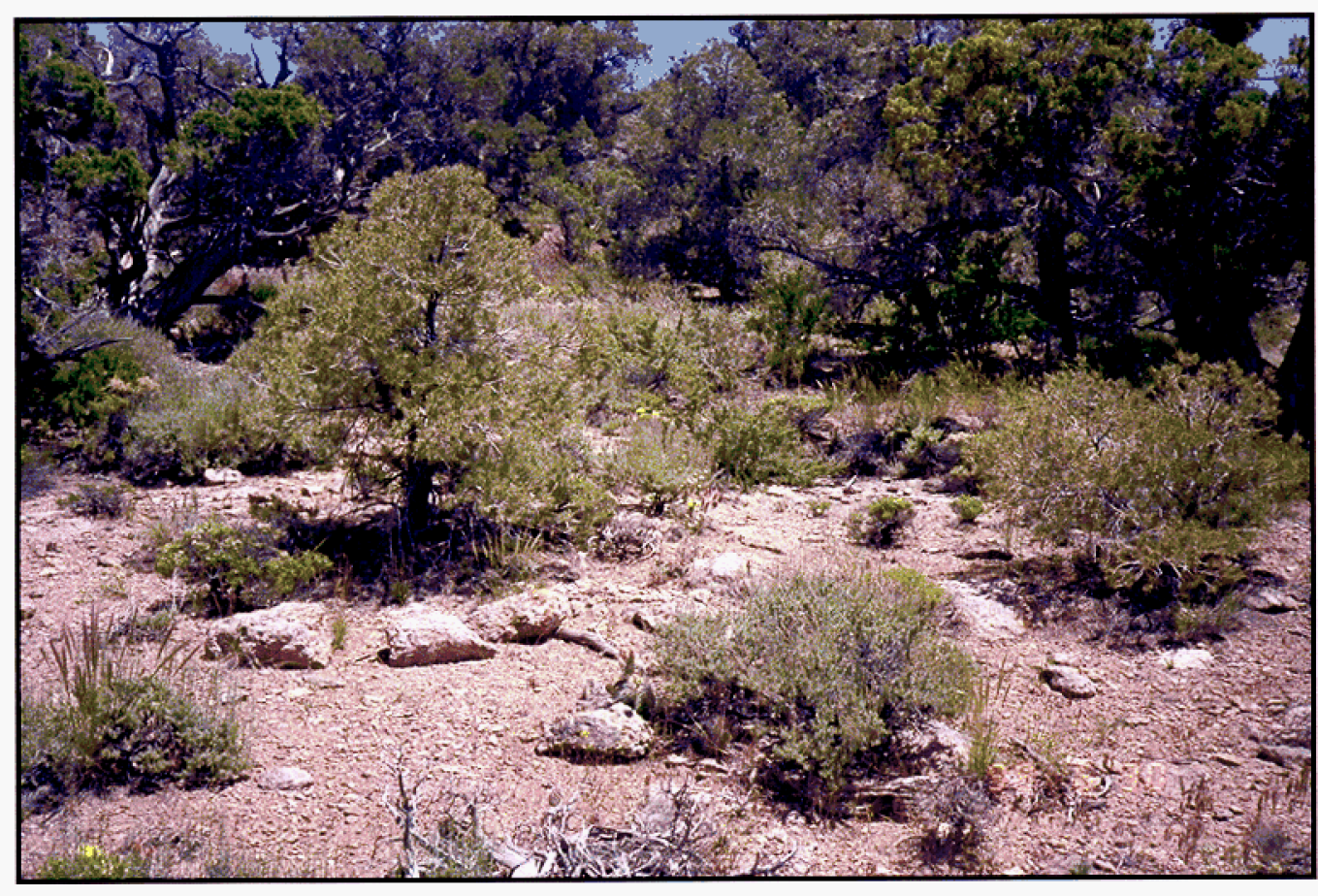

by black sage-

brush and

singleleaf

pinyon. There

are several

other associated shrub and tree species, mainly Utah juniper and green rabbitbrush. It occurs in mountainous areas with variable slopes. At higher elevations or where soils are deeper, it is displaced by

the Pinus monophylla/Artemisia tridentata Woodland. Soils are sandy loams to loams. This association has very high species diversity. Summary information for this association is presented in Table 4-21.

Table 4-21 Characteristics of the Pinus monophyla/Artemisia nova Woodland. (Percent relative abundance values for primary and associated species are enclosed in parenthesis.)

\begin{tabular}{|ll|}
\hline Primary species: & Black sagebrush (55\%), singleleaf pinyon (14\%) \\
Associated species: & $\begin{array}{l}\text { Utah juniper (6\%), green rabbitbrush (4\%), basin big sagebrush (3\%), granite prickly } \\
\text { gilia (3\%) }\end{array}$ \\
Species diversity: & 54 species total; averaged 27.0 perennial species/ELU \\
Number of ELUs: & 78 \\
Area of NTS: & 24,930 ha $(7.4 \%)$ \\
Landforms: & Mountains, mid slopes to mesas \\
Geology: & Mostly Tertiary tuffs \\
Elevation: & Average $1,985 \mathrm{~m}$, range 1,725 to $2,201 \mathrm{~m}$ \\
Precipitation: & Average $27.3 \mathrm{~cm}$ \\
Slopes: & Average $8.1^{\circ}$, range 1 to $58^{\circ}$ \\
Soils: & Primarily sandy loam to loam \\
Annuals: & Very low to low \\
\hline
\end{tabular}




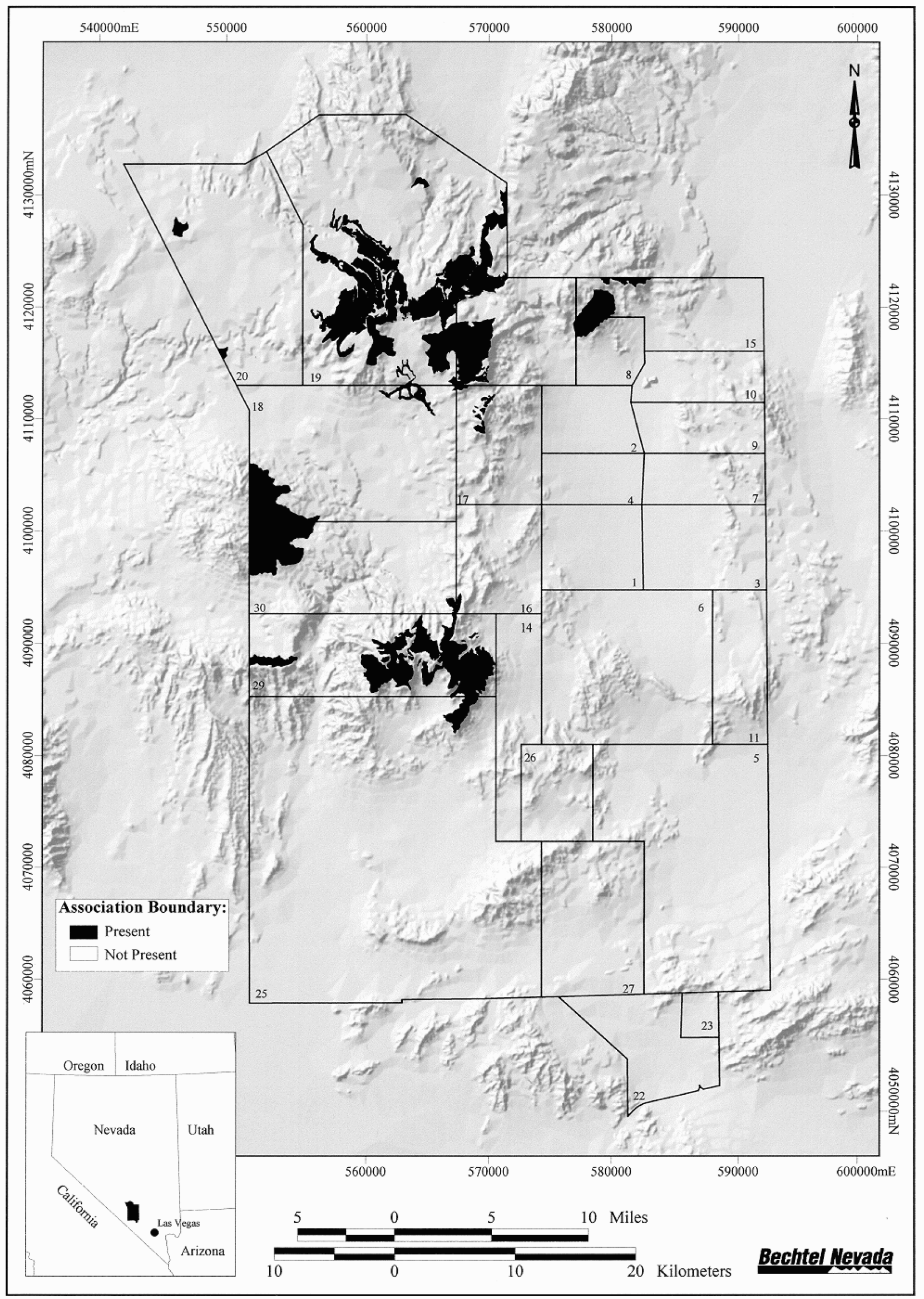

Figure 4-22 Distribution of the Pinus monophylla / Artemisia tridentata Woodland Association on the Nevada Test Site 


\subsubsection{Pinus monophylla/Artemisia tridentata Woodland}

This association occurs primarily in the north and west-central parts of the NTS (Figure 4-22). It occupies just less than 20,000 ha $(50,000 \mathrm{ac})$ or 5.9 percent of the NTS. Fifty-eight ELUs were clustered and recognized in this association. It is co-dominated by singleleaf pinyon and basin

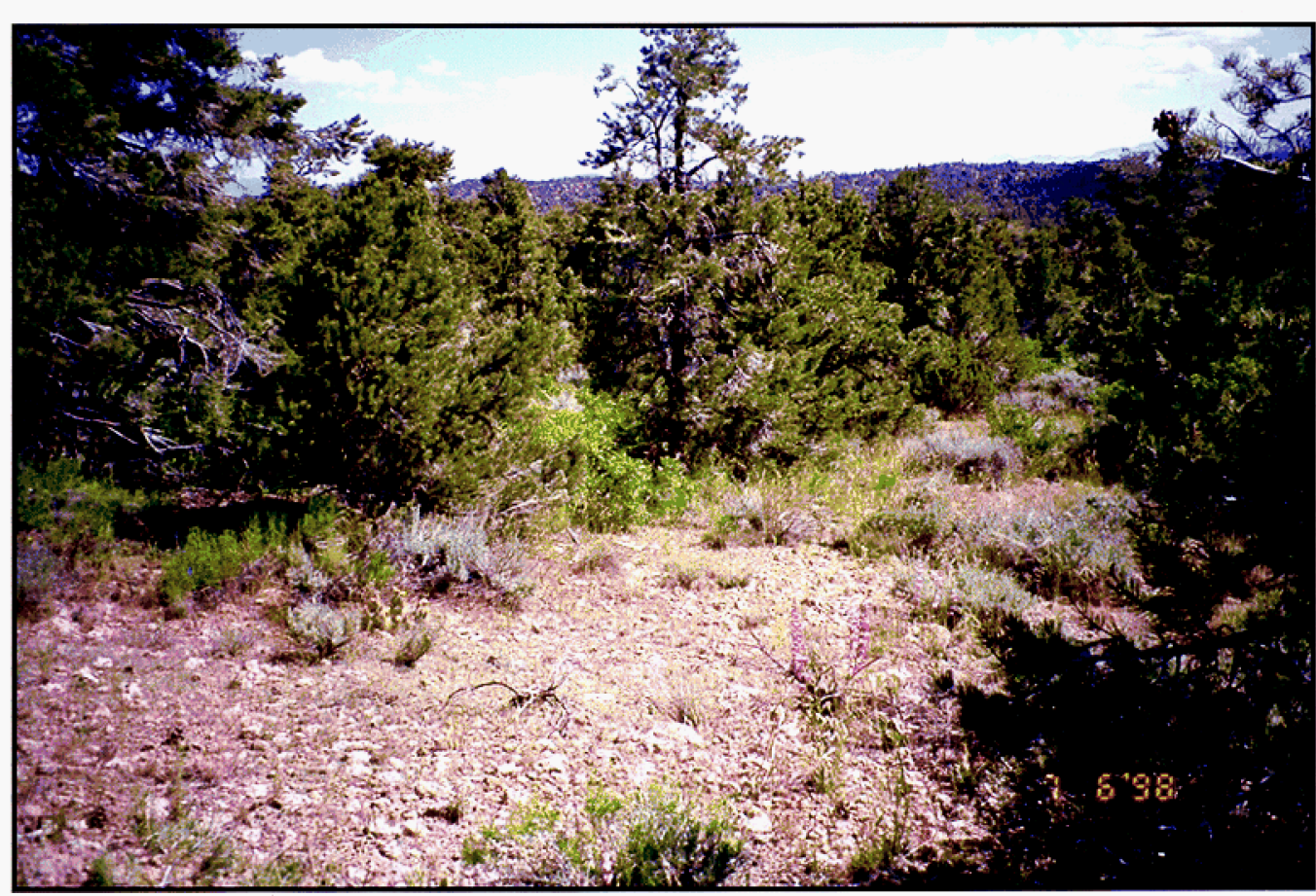

big sagebrush in roughly equal numbers. There are several other associated shrub species, mainly antelope bitterbrush (Purshia tridentata) and Utah juniper. It occurs in mountainous areas with variable slopes. Soils are loamy sands to loams. Because of the better precipitation and deeper soils, this association has very high species diversity. Summary information for this association is presented in Table 4-22.

Table 4-22 Characteristics of the Pinus monophylla/Artemisia tridentata Woodland. (Percent relative abundance values for primary and associated species are enclosed in parenthesis.)

\begin{tabular}{|c|c|}
\hline Primary species: & Singleleaf pinyon (21\%), basin big sagebrush (31\%) \\
\hline Associated species: & $\begin{array}{l}\text { Utah juniper ( } 7 \% \text { ), Antelope bitterbrush ( } 5 \% \text { ), granite prickly gilia (5\%), black sagebrush } \\
(4 \%) \text {, gambel's oak (Quercus gambelii) }(4 \%)\end{array}$ \\
\hline Species diversity: & 47 species total; averaged 28.6 perennial species/ELU \\
\hline Number of ELUs: & 58 \\
\hline Area of NTS: & 19,922 ha $(5.9 \%)$ \\
\hline Landforms: & Mountains, mid slopes to mesas \\
\hline Geology: & Mostly Tertiary tuffs \\
\hline Elevation: & Average $2,054 \mathrm{~m}$, range 1,682 to $2,292 \mathrm{~m}$ \\
\hline Precipitation: & Average $28.2 \mathrm{~cm}$ \\
\hline Slopes: & Average $14.3^{\circ}$, range 1 to $55^{\circ}$ \\
\hline Soils: & Primarily loamy sand to loam \\
\hline Annuals: & Very low to low \\
\hline
\end{tabular}




\subsection{Characteristics of NTS Vegetation}

\subsubsection{Major Climatic Zones or Ecoregions of the NTS}

Topographic features at the NTS create an elevation and moisture gradient formed by relatively cool, moist mountains in the northern part of the NTS and relatively hot, dry valleys in the southern part. Between these two climatic extremes lies an area of land located at intermediate elevations with intermediate climatic conditions. These belts of distinct climate and elevation can be referred to as climatic zones or ecoregions. For the purposes of this report, we use the term "ecoregion" rather loosely to refer to the collection of biotic communities that are determined by climate and often characterized by a distinctive vegetation physiognomy. They have been linked by name to the broader regional physiographic land areas adjacent to the NTS and prior use on the NTS by Beatley (1976).

We do not use the term ecoregion to imply the use of the U.S. Forest Service's ELU classification for the United States (Bailey 1976, 1995). The three major zones or ecoregions on the NTS (Figure 4-2, shown previously) are equivalent to what Beatley (1976) referred to as the "Great Basin Desert Region," the "Mojave Desert Region," and the "Transition Desert Region." Two of these ecoregions, the Great Basin Desert Ecoregion (hereafter referred to as the Great Basin Desert) and the Mojave Desert Ecoregion (hereafter referred to as the Mojave Desert) are representative of land included within the physiographic land areas, or desert biomes, known as the Great Basin Desert (cold-temperate desertland) and the Mojave Desert (warm-temperate desertland) (Brown, 1982). The third ecoregion, the Transition Ecoregion, is a more localized phenomenon restricted to the NTS and is not recognized regionally by others (Brown, 1982; and Bailey, 1976, 1995).

The Transition Ecoregion (i.e., the transition zone between the Great Basin Desert and the Mojave Desert) is of interest because it contains plant species found in both the Great Basin and the Mojave deserts. Species in this ecoregion often have tolerance to freezing as well as drought conditions. Because these species are at the lowermost elevation (i.e., Great Basin Desert species) or uppermost elevation (i.e., Mojave Desert species) boundaries of their tolerance limits, they are very sensitive to climatic fluctuations and other natural perturbations. Plant community composition is often a diverse mixture of shrubs and reflects the recent (last 50 to 100 years) influence of climatic conditions (e.g., freezes and droughts) and other perturbations (e.g., fires and effects of nuclear testing) at the NTS. This ecoregion is located at elevation positions and locations that have been locally disturbed by past nuclear testing. This disturbance encouraged colonization of weedy native and nonnative species.

A study of vegetation within the Transition Ecoregion is valuable to help better understand the differences between the vegetation of the Mojave and the Great Basin deserts. It can also be a useful tool to monitor the effects of global warming, climatic changes, and site disturbances. For these reasons, a discussion of vegetation of the Transition Ecoregion has been included in this report. 


\subsubsection{Environmental Parameters of Associations Within Ecoregions}

\subsubsection{Composition of Ecoregions by the Number of ELUs}

About 23 percent and 37 percent of the ELUs sampled on the NTS were located in the Mojave Desert and Great Basin, respectively (Table 4-23). The remaining 36 percent of the ELUs were located in a Transition Ecoregion between these two deserts. About 4 percent of the 1,508 ELUs sampled were classified as "miscellaneous" because they were unique vegetation types, burned, scraped, or disturbed by nuclear testing.

In the Mojave Desert, the Larrea tridentata /Ambrosia dumosa Shrubland was the most numerous association, representing about 19 percent of the ELUs on the NTS (18 percent of the total area). No other association in the Mojave Desert represented more than 4 percent of the total ELUs.

In the Great Basin Desert, the Artemisia tridentata-Chrysothamnus viscidiflorus Shrubland was the most numerous association, representing about 11 percent of the ELUs on the NTS ( 7.5 percent of the total area). No other association in the Great Basin Desert represented more than 7 percent of the total ELUs.

In the Transition Ecoregion between these deserts, the Coleogyne ramosissima-Ephedra nevadensis Shrubland was the most numerous association, representing about 22 percent of the ELUs on the NTS (21.6 percent of the total area). No other association in the Transition Ecoregion represented more than 6 percent of the total ELUs.

Associations that were considered typical or characteristic of the Mojave Desert were those that contained a presence of Shockley's desert thorn, rabbit thorn, creosote bush, or white bursage, but lacked species characteristic of the Great Basin Desert (Table 4-24). The distribution of white bursage on the NTS (Appendix I) approximates the boundaries for the Mojave Desert on the NTS. Associations that were considered typical of the Great Basin Desert were those that contained a presence of sagebrush, singleleaf pinyon, or Utah juniper, but lacked species characteristic of the Mojave Desert. The distribution of big sagebrush (Artemisia tridentata) on the NTS (Appendix $I$ ) approximates the boundaries of the Great Basin on the NTS. Associations within the Transition Ecoregion were considered to be those that had a mixture of species. Some perennial shrubs such as Ephedra (Ephedra spp.) and blackbrush that occur in the Transition Ecoregion also occur in both the Mojave and Great Basin Desert (Table 4-24). The distribution of blackbrush on the NTS (Appendix I) best approximates the boundaries of the Transition Ecoregion on the NTS, although it is absent from areas with deep soils in the bottomlands (e.g., landform types such as basin floor, alluvial flats and piedmont slope, fan skirts).

Associations that occur in the Transition Ecoregion have shrubs that are often drought deciduous (e.g., blackbrush) or have essentially leafless, photosynthetic stems (e.g., Ephedra spp.), while the most abundant dominant shrubs from associations in the Mojave Desert and Great Basin Desert are frequently evergreen in habit (e.g., creosote bush, big sagebrush, singleleaf pinyon, and Utah juniper). The evolutionary adaptation of leaf reduction or abscission during drought and stress-induced dormancy may help maintain the abundance of blackbrush and Mormon tea in these ecotones. While the abundance of species other than blackbrush 


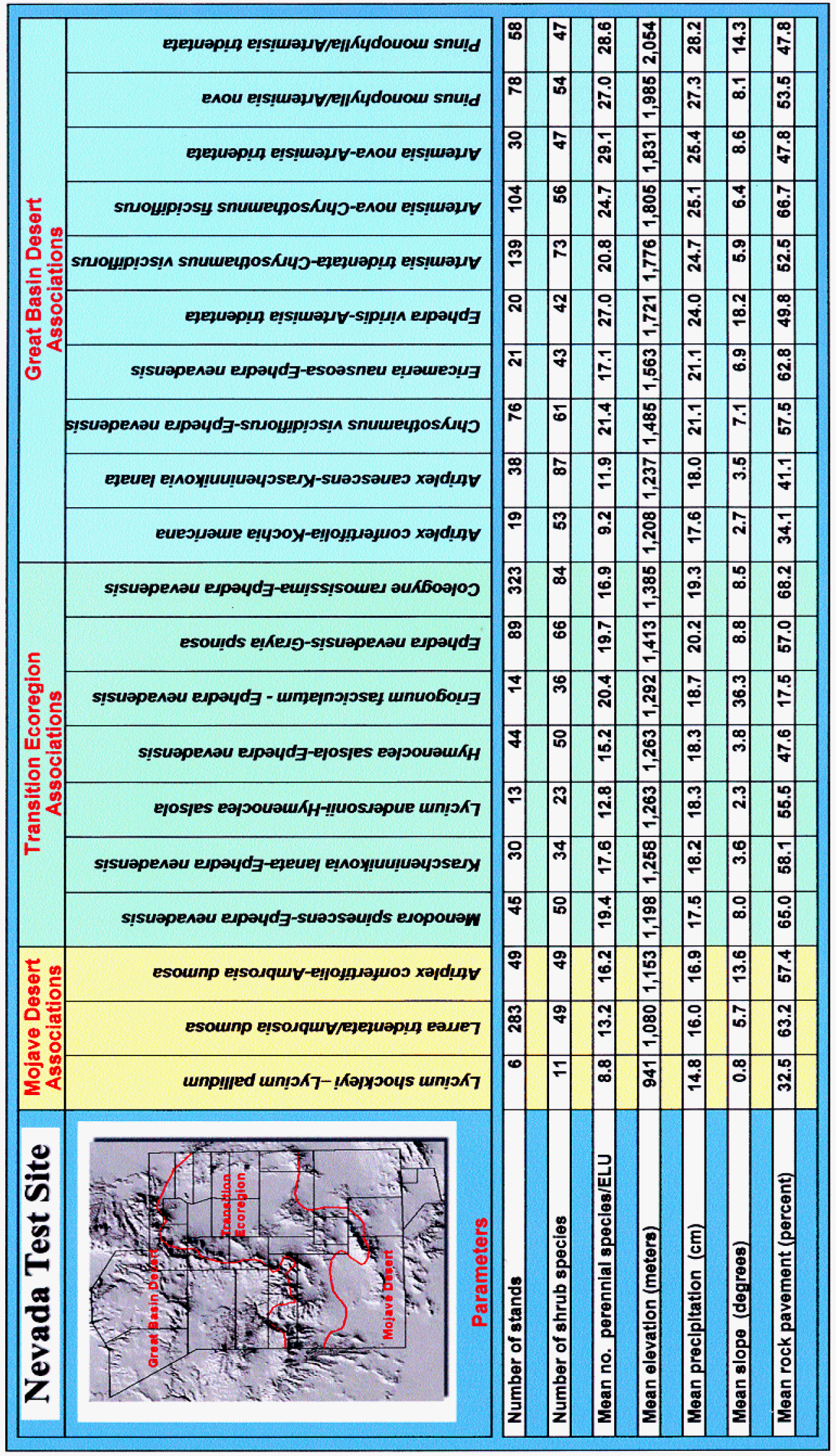

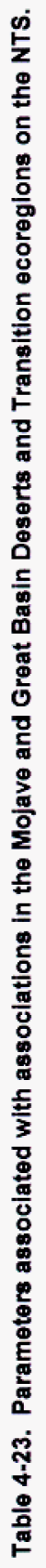




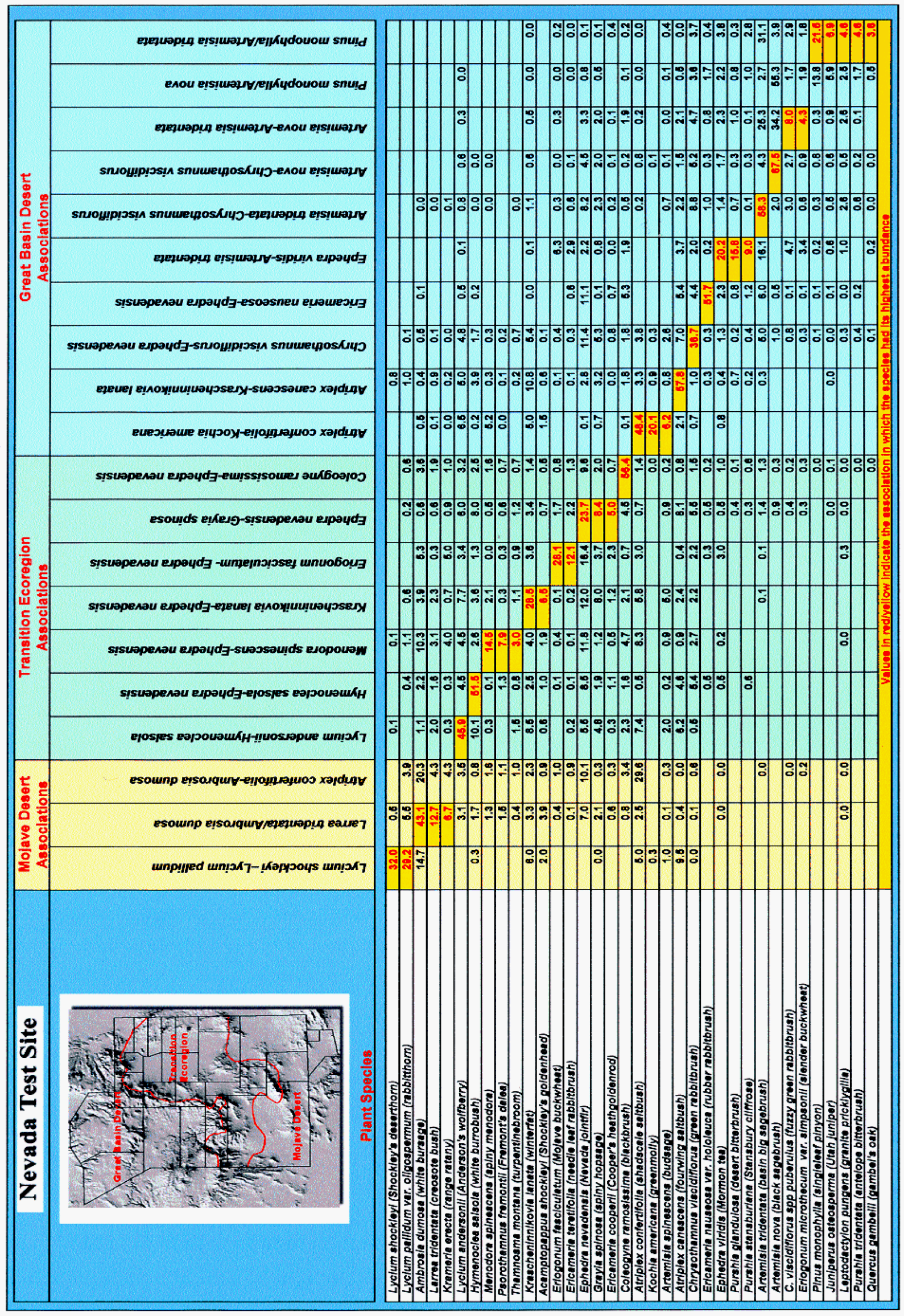

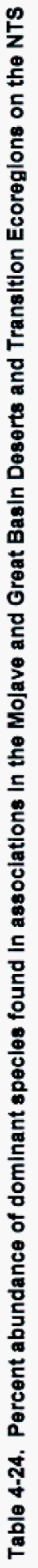


are relatively low in the Coleogyne ramosissima-Ephedra nevadensis Shrubland, they are frequently present in small numbers being found in microrefugia such as small patches where animals have disturbed the soil horizons or fire has reduced competition with blackbrush.

Blackbrush occurs at intermediate elevations. At these elevations, lightning strikes associated with storms blowing from the south, are common during the summer and occasionally fuel loading reaches levels high enough to support wildfires. Once burned, these communities reestablish very slowly; Brown (1982) also reports this phenomenon. The most extensive burn areas on the NTS appear to be anthropogenic in origin (e.g., explosives used in military training or aboveground nuclear events).

\subsubsection{Species Richness}

Species richness or the number of all species in each ELU is shown in Figure 4-23. Species richness for all woody species was greatest in the Great Basin Desert associations (Table 4-23) (mean of 56 species) compared to associations in the Transition Zone (mean of 49 species) and the Mojave Desert (mean of 36 species). Similar species diversity patterns were also observed

for all combined perennial species on the NTS (e.g., Great Basin Desert: 21.7 species per ELU, Transition Zone: 17.4 species per ELU, and Mojave Desert: 12.7 species per ELU).

\subsubsection{Elevation and Precipitation}

Plant associations within the Mojave Desert and Great Basin Desert were ordered according to increasing elevation precipitation (Figure 4-24). Elevation of ELUs is shown in Table 4-23 and Figure 4-25. Mean annual precipitation was determined to be positively correlated $\left(\mathrm{r}^{2}=0.85\right)$ with elevation on the NTS, based on correlation modeling and actual weather recording data (French 1986; other detailed meteorological data are presented by Fransioli and Ambos, 1997). The importance of elevation, slope, and substrate in accounting for statistical variance in shrub species cover was also described for the Nellis Air Force Range consisting of 1,228,355 ha $\left(4,743 \mathrm{mi}^{2}\right)$ of shrubland adjacent to the NTS (Pritchett et al., 1997).

\subsubsection{Slope Steepness}

Slope steepness on the NTS (Table 4-23 and Figure 4-26) was highest in the Transition Zone between the Great Basin Desert and the Mojave Desert and was generally associated with erosion-resistant geological formations such as basalts and tuff deposits. The slopes were often steeper at the boundaries separating these desert zones. Specific geological features include Big and Little Skull mountains, areas around Yucca Mountain and Control Point, and steep slopes associated with Rainier and Paiute Mesas. The Eriogonum fasiculatum-Ephedra nevadensis Shrubland was located on the steepest slopes (36 degrees), with all other associations averaging slopes less than 18 degrees, with a mean slope of 7 degrees. Steeper slopes result in greater runoff during precipitation events and frequently produced greater erosion, leaving behind more of the soil surface covered with larger rocks.

\subsubsection{Landforms}

Landforms are a product of past geological events and erosional processes determined mainly by climatic conditions. Key features include: (1) upland areas such as mountains, foothills, and mesas created by shifts in tectonic plates and volcanic events; (2) piedmont slopes created by 


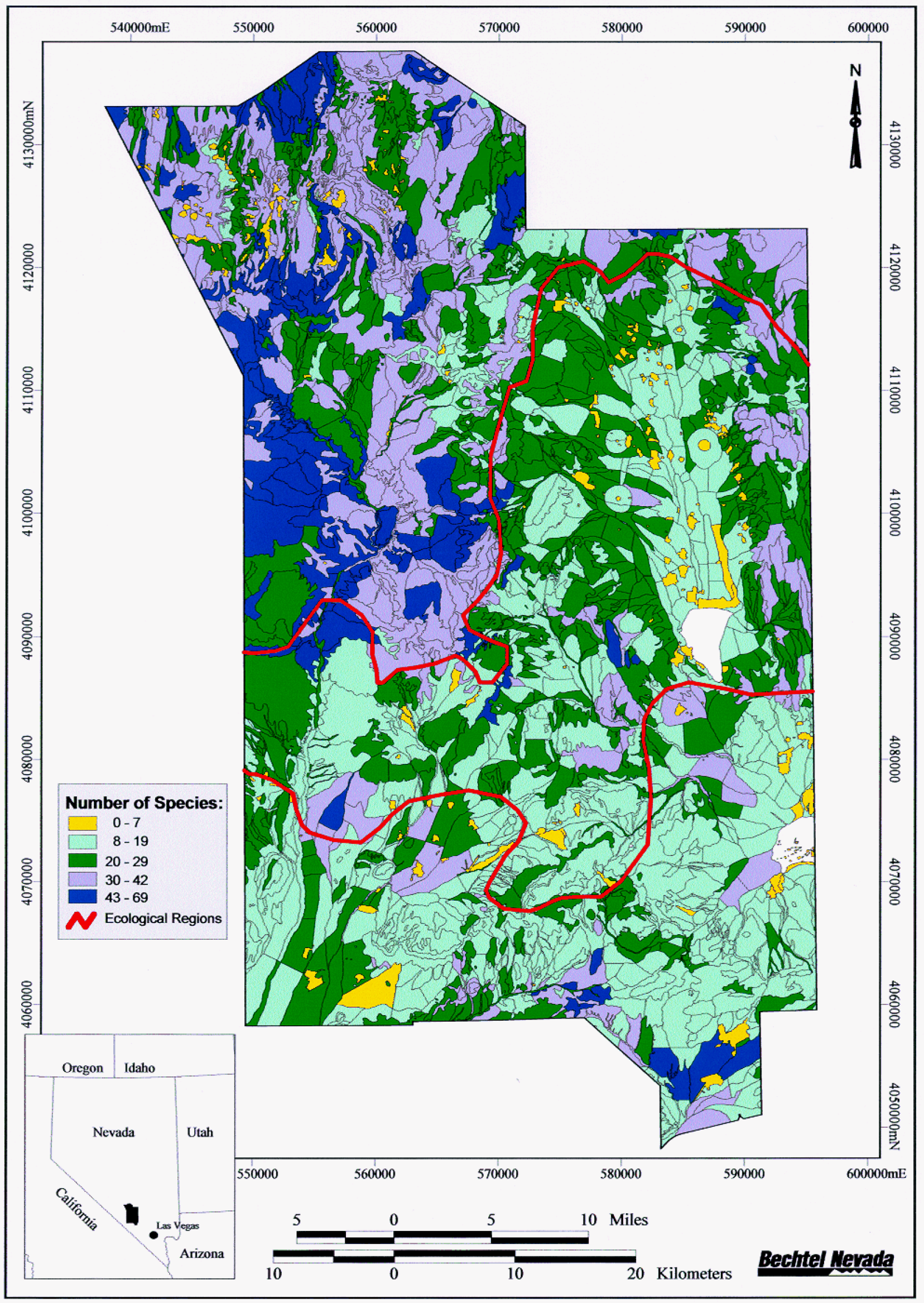

Figure 4-23 Species richness of Ecological Landform Units sampling locations on the Nevada Test Site 


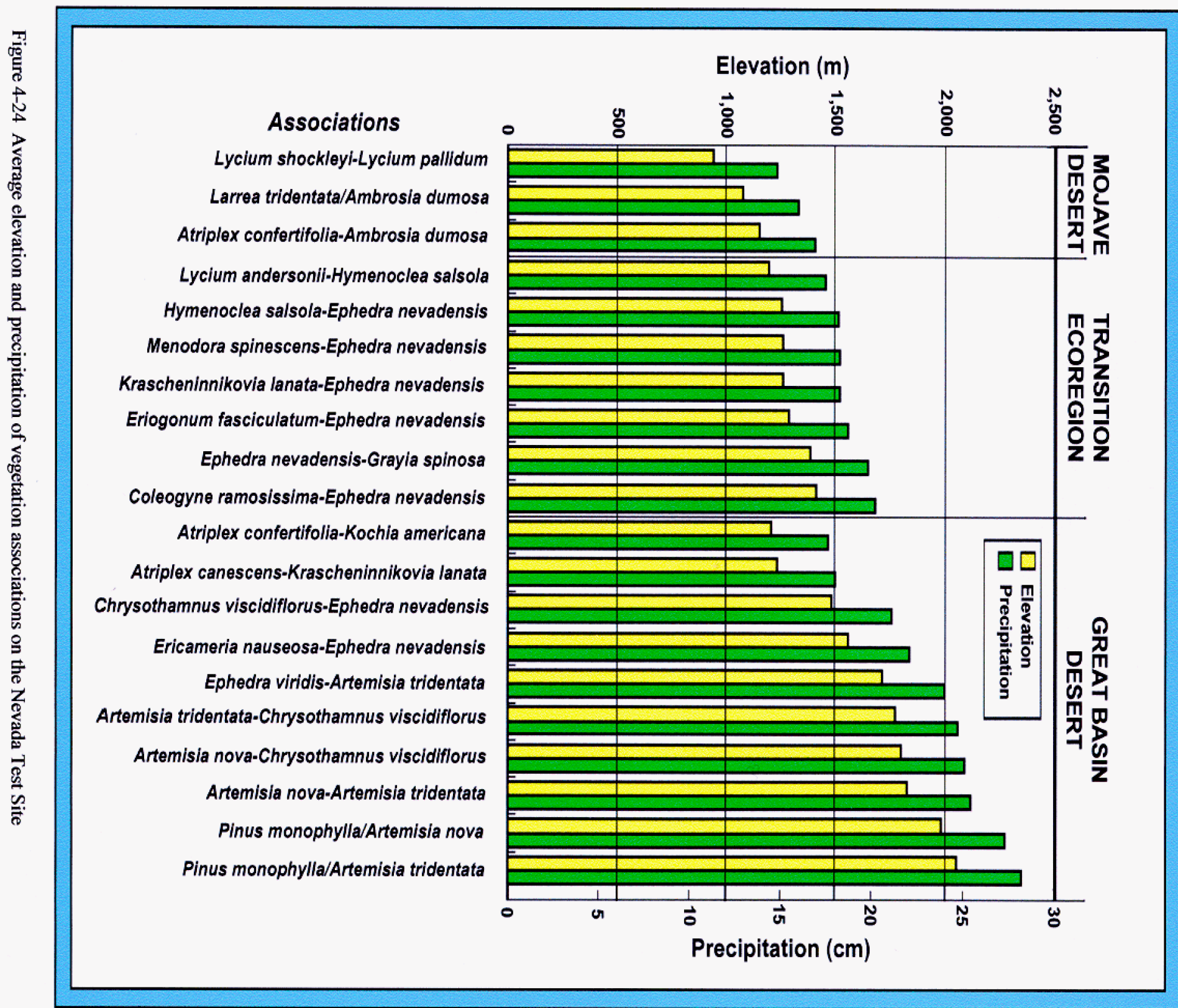




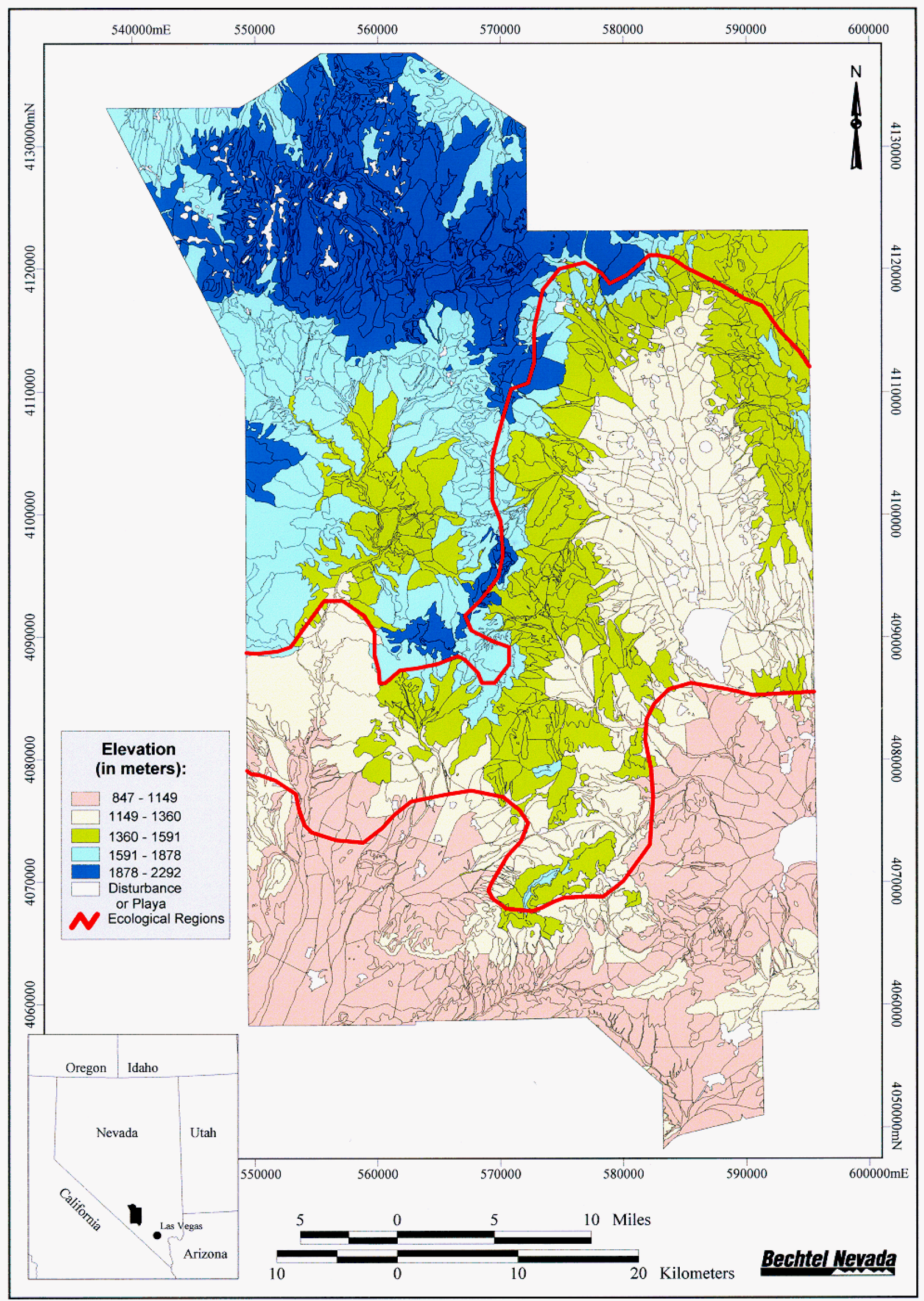

Figure 4-25 Elevation of Ecological Landform Unit sampling locations on the Nevada Test Site 


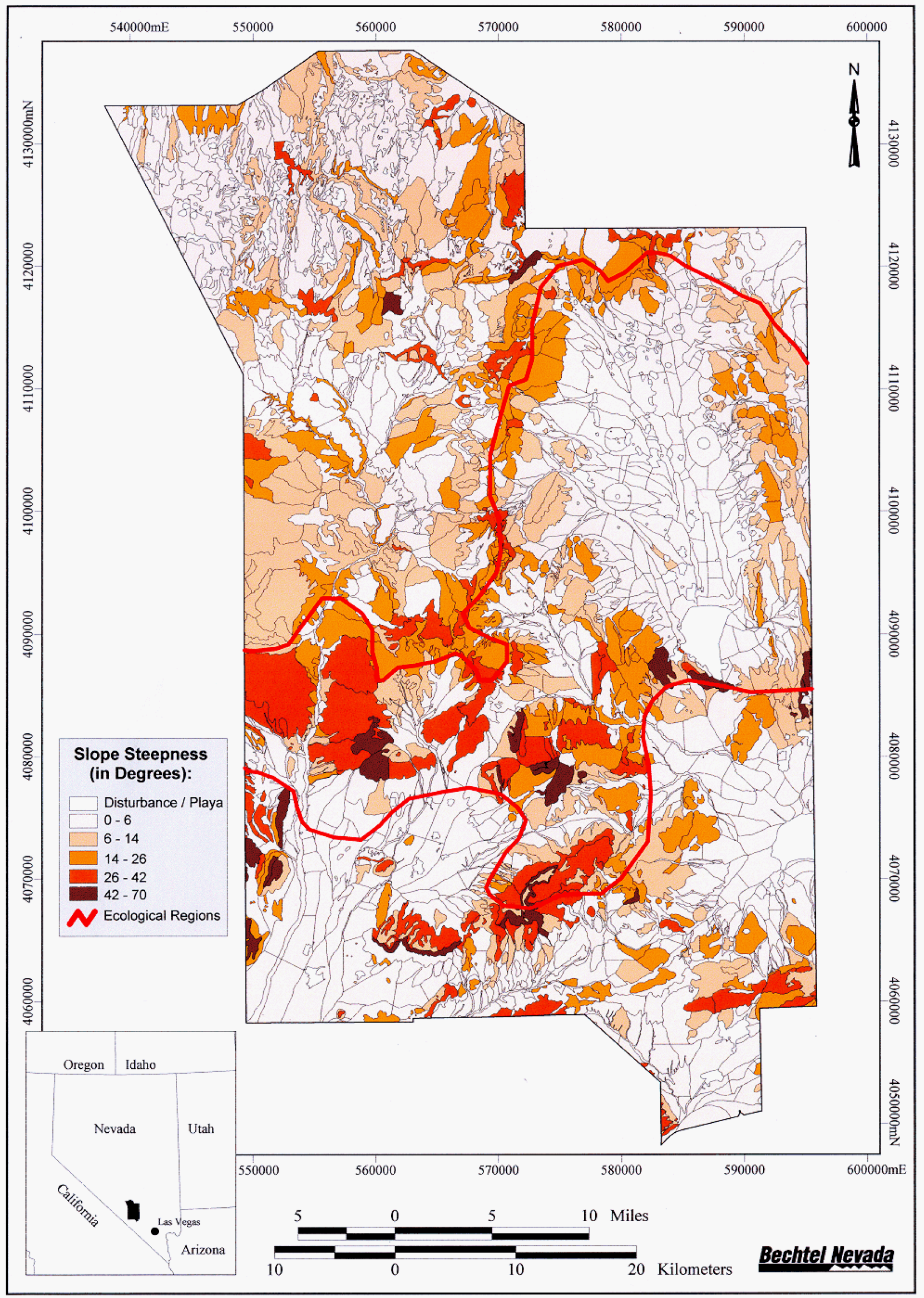

Figure 4-26 Slope steepness of Ecological Landform Unit sampling locations on the Nevada Test Site 
erosion of upland areas; and (3) lowland areas created by deposition of eroded materials into basin floors and playas. Resulting landforms are often correlated with erosion and soil-forming processes as described earlier. Figure 4-27 shows the major landform types found on the NTS. The most commonly occurring landforms in the Great Basin Desert are the mountain and mountain valley landform types at higher elevations. The most commonly occurring landforms of the transitional zone between the Great Basin Desert and the Mojave Desert are the lower elevational mountains, piedmont slopes, and basin floors at intermediate elevations. The most commonly occurring landforms of the Mojave Desert are a mixture of landforms ranging from mountain foothills, piedmont slopes, and basin floor types at lower elevations. Landforms provide additional perspective to landscapes that are not always apparent in elevational maps (e.g., compare the elevational map in Figure 4-25 to the landform map in Figure 4-27).

\subsubsection{Soils}

Texture of surface soils ( 0 to $5 \mathrm{~cm}$ [0 to 2 in]) appeared to differ little among all associations except for two that were correlated with playas and steep mountain slopes. The plant associations associated with playas were the Lycium shockleyi-Lycium pallidum Shrubland and the Atriplex confertifolia-Kochia americana Shrubland. Soil texture of these associations had a greater percentage of clay than other associations. The most abundant soil textures for surface soils of the associations were comprised of three textural types: sandy loam ( 30 percent), loamy sand (18 percent), and loam (14 percent). Soil samples from the remaining 38 percent of associations were classified into more than 30 different textural types.

Despite little difference in soil texture near the soil surface, associations were observed to differ in the type of substrate upon which they most commonly appeared. The Coleogyne ramosissimaEphedra nevadensis Shrubland and Atriplex confertifolia-Ambrosia dumosa Shrubland appeared frequently on shallow soils of limestone-derived parent materials, while most of the associations in the Great Basin Desert occurred in the basalt or tuff formations. Remaining associations occurred in alluvial soils. Creosote bush appeared to be limited by shallow soils or the presence of a caliche layer. Lunt et al. (1973) suggest that big sagebrush and creosote bush have unusually high oxygen requirements, while roots of white bursage appear to require less oxygen.

\subsubsection{Rock Pavement and Clast Size Classes}

Rock fragments on the soil surface have resulted from several erosional and depositional processes such as the chemical and physical weathering of parent material; removal or sorting of weathered substrates; and the accretion of materials by wind, water, or volcanic activity which has rearranged the soil particles and rock fragments to form desert pavements. The percentage of the soil surface covered with rock or desert pavement within ELUs is shown in Figure 4-28, while the rock clast size classes is shown in Figure 4-29. A greater percentage of the surface was covered with rock at higher elevations in steeper areas near mountains than in the flatter areas in the valleys (Table 4-23). The sizes of rock clasts became smaller with greater distance from the mountains, with the smallest sizes often occurring on the surface at playas. Large areas of sandy soils were most common in the Mojave Desert where prevailing winds deposited blowing sands around geological formations such as hills and mesas. True desert pavements (i.e., a rocky surface on top of a deposit of soil fines with relatively few rocks; see Wood et al., 1998) were most common on older soil surfaces where surface erosion was less than in washes and steep slopes. These latter soils were often crunchy when walked on and were characteristically devoid of most vegetation, except brittle spineflower (Chorizanthe spp.). 


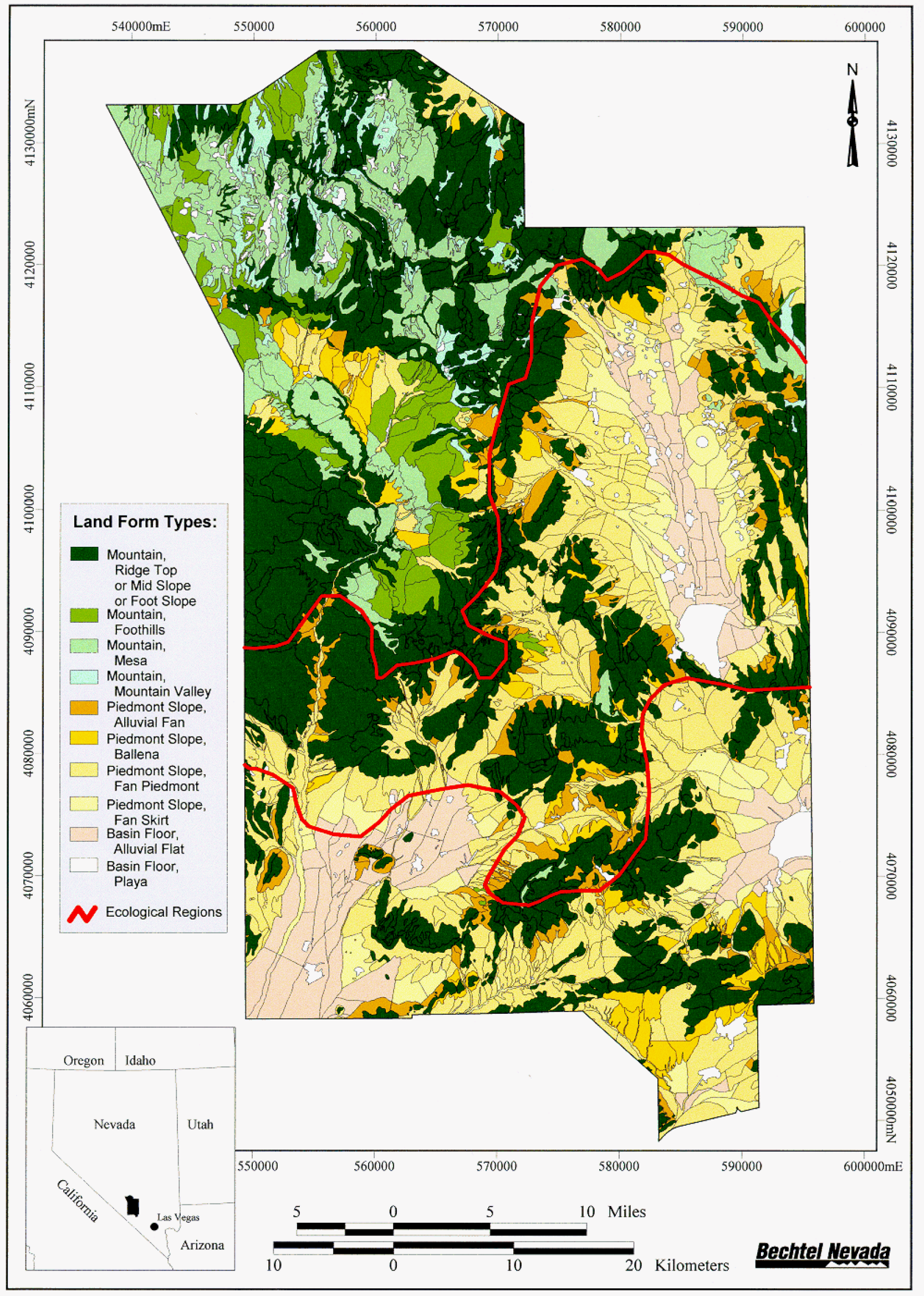

Figure 4-27 Landform types of Ecological Landform Unit sampling locations on the Nevada Test Site 


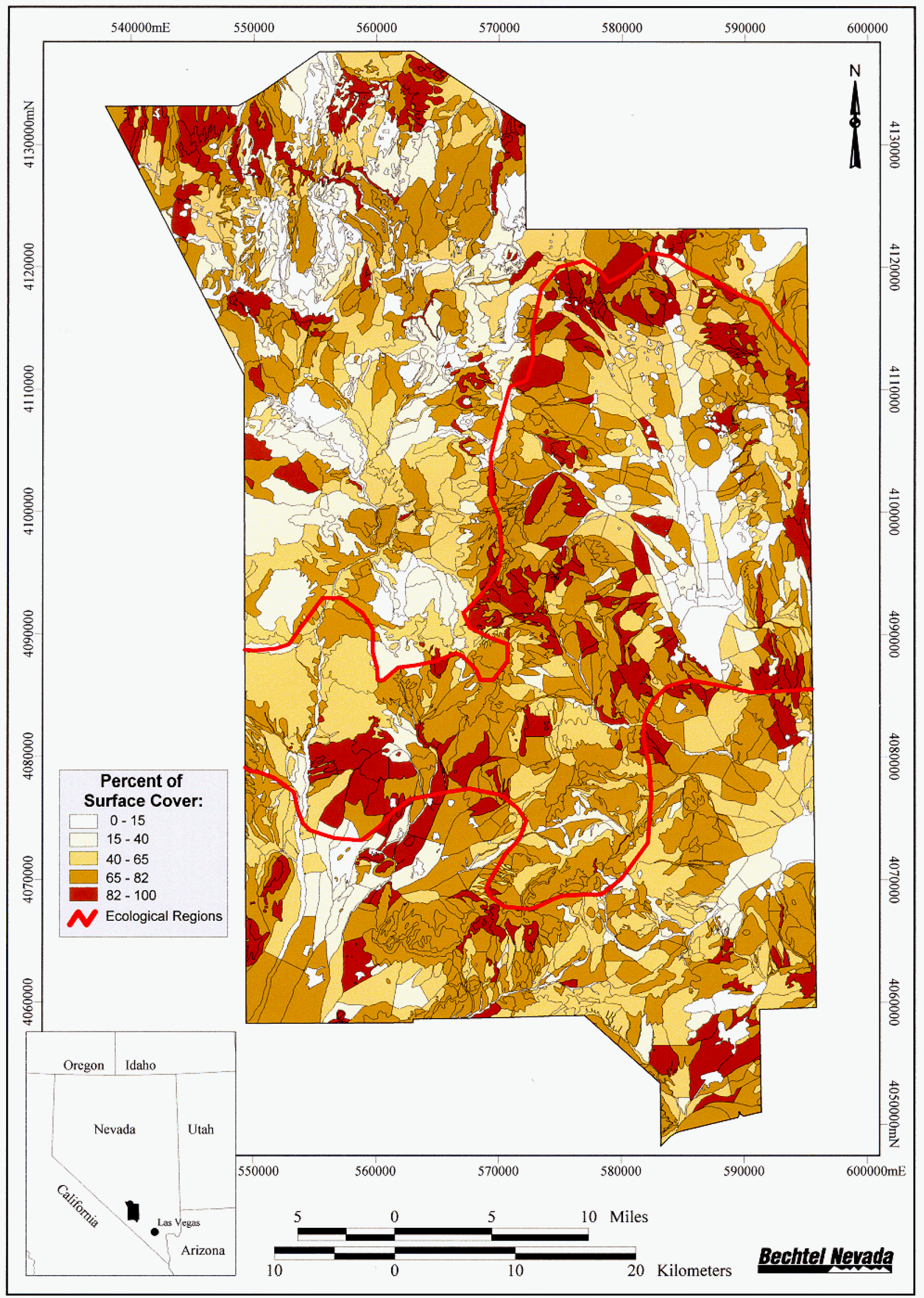

Figure 4-28 Percent of soil surface with rock or pavement cover in Ecological Landform Units on the Nevada Test Site 


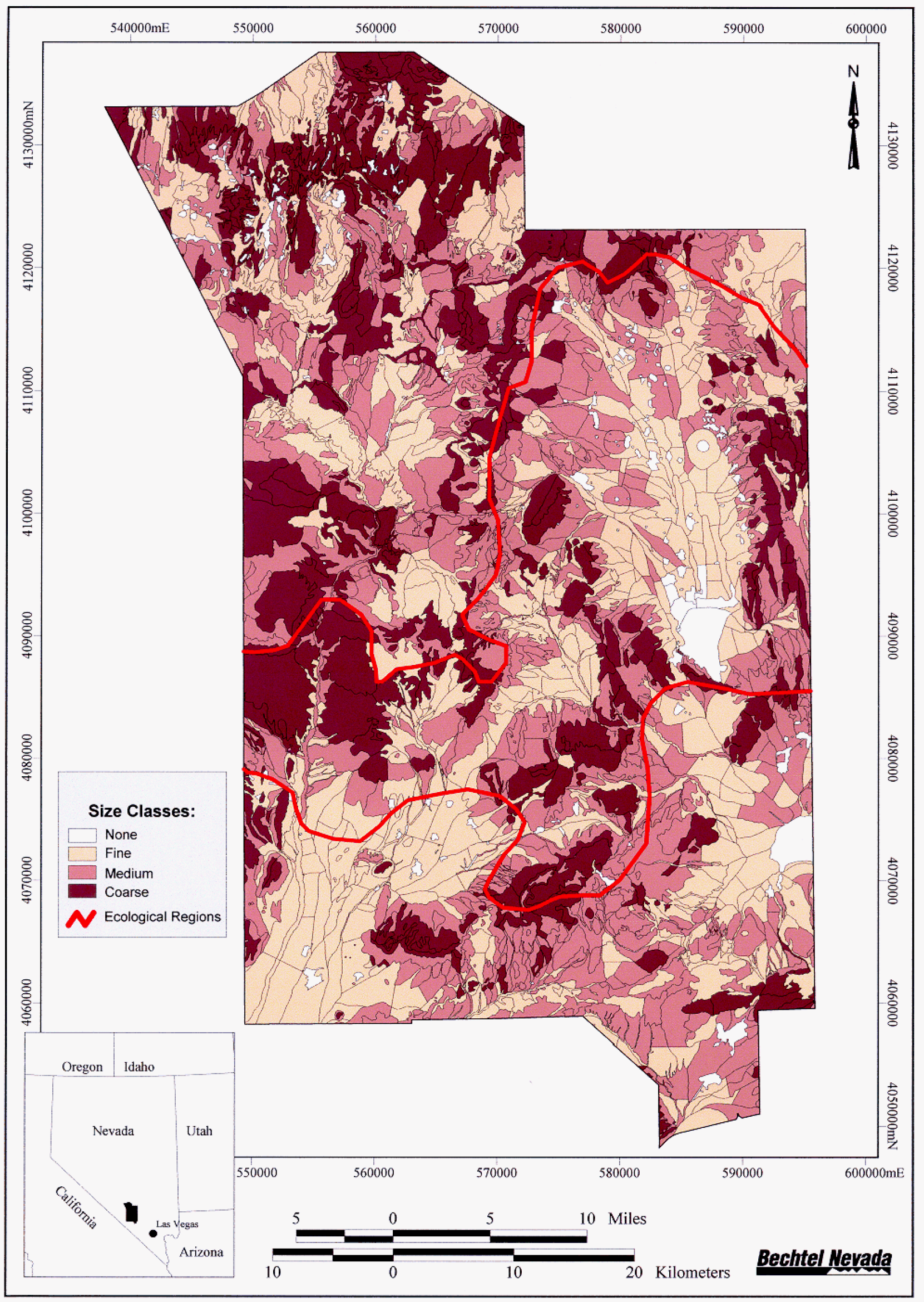

Figure 4-29 Rock clast size classes in Ecological Landform Units on the Nevada Test Site 


\subsubsection{Microbiotic Crusts}

The presence of visible microbiotic crusts on the soil surface (i.e., nonvascular microorganisms such as algae, fungi, or lichens that are frequently important for enhancing soil fertility and surface stabilization) was noted during the field surveys. Within the NTS, 58 percent of the ELUs sampled had no visual evidence of microbiotic crusts, 28 percent had low visual evidence of crusts, 11 percent had moderate visual evidence of crusts, and only 4 percent had high visual evidence of microbiotic crusts (Figure 4-30). Visual evidence of crusts was observed to decrease with increases in elevation. For example, no microbiotic crusts were observed in 31 percent of sites within the Mojave Desert, 43 percent of sites within the Transition Zone, and 50 percent of sites within the Great Basin Desert. Associations with high abundance of crusts also had higher percentages of soil fines (clays or silts). Low presence of crusts or their absence was associated with active soil erosional processes (e.g., along washes and steeper unstable slopes).

\subsubsection{Productivity of Annual Vegetation}

The presence of annual vegetation (both native and introduced species) and its relative abundance is shown in Figure 4-31. Vegetation associations that were more likely to undergo disturbance or are responding to previous disturbances, either natural or anthropogenic, contain higher productivity of annuals (ELUs in the high and very high categories). Three of these associations, Lycium andersonii-Hymenoclea salsola Shrubland, Ericameria nauseosa-Ephedra nevadensis Shrubland, and Ephedra viridis-Artemisia tridentata Shrubland, are mostly successional vegetation that is responding to previous fires. Similarly, Ephedra nevadensis-Grayia spinosa Shrubland sites have experienced tremendous disturbance, although mostly from human activities and nuclear testing. The other vegetation association that ranks high in productivity of annuals, Atriplex canescens-Krashenninkovia lanata Shrubland, contains sites that often experience natural disturbances from soil movement along washes or in very sandy areas. Many of these sites have also been subject to human disturbance from nuclear testing. Some areas, particularly in Frenchman Flat and western Mercury Valley, contain a high productivity of annuals due to impacts from gophers (Hunter et. al., 1980). These areas contain almost no perennial shrubs or forbs, yet often have a carpet of annual grasses and annual forbs, particularly foxtail brome (Bromus rubens).

\subsubsection{Invasive Plant Species}

One of the greatest threats to plant diversity in many ecosystems is the invasion of exotic (i.e., introduced from other countries) species that have few natural diseases or pests to check their growth and reproduction. Of particular importance on the NTS are those annual species that colonize disturbed soils. Species of concern include foxtail brome, cheatgrass (Bromus tectorum), Arabian schismus (Schismus arabicus), prickly Russian thistle (Salsola kali ssp. tragus), barbwire Russian thistle (Salsola paulsenii), and tumblemustard (Sisymbrium altissimum).

By far the most widely distributed annual grass on the NTS is foxtail brome (Figure 4-32). It occurs mostly in the Transition Zone and the Mojave Desert, while cheatgrass is the dominant introduced annual grass in the Great Basin Desert (Figure 4-33). It thrives better in cooler habitats. One interesting observation is its presence in aboveground nuclear test areas (e.g., T2 in Yucca Valley) where foxtail brome is conspicuously absent. Both foxtail brome and 


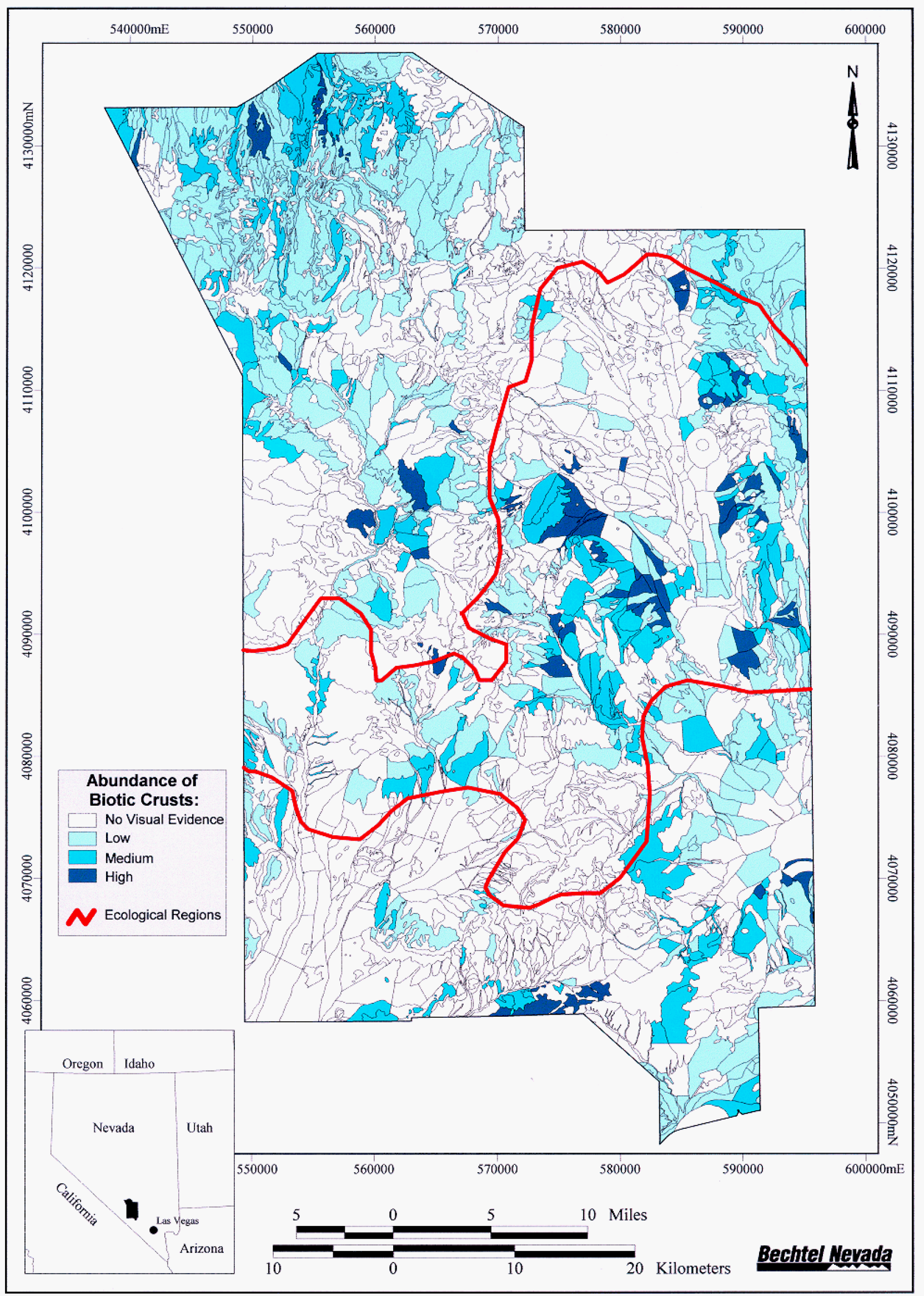

Figure 4-30 Abundance of biotic crusts in Ecological Landform Units on the Nevada Test Site 


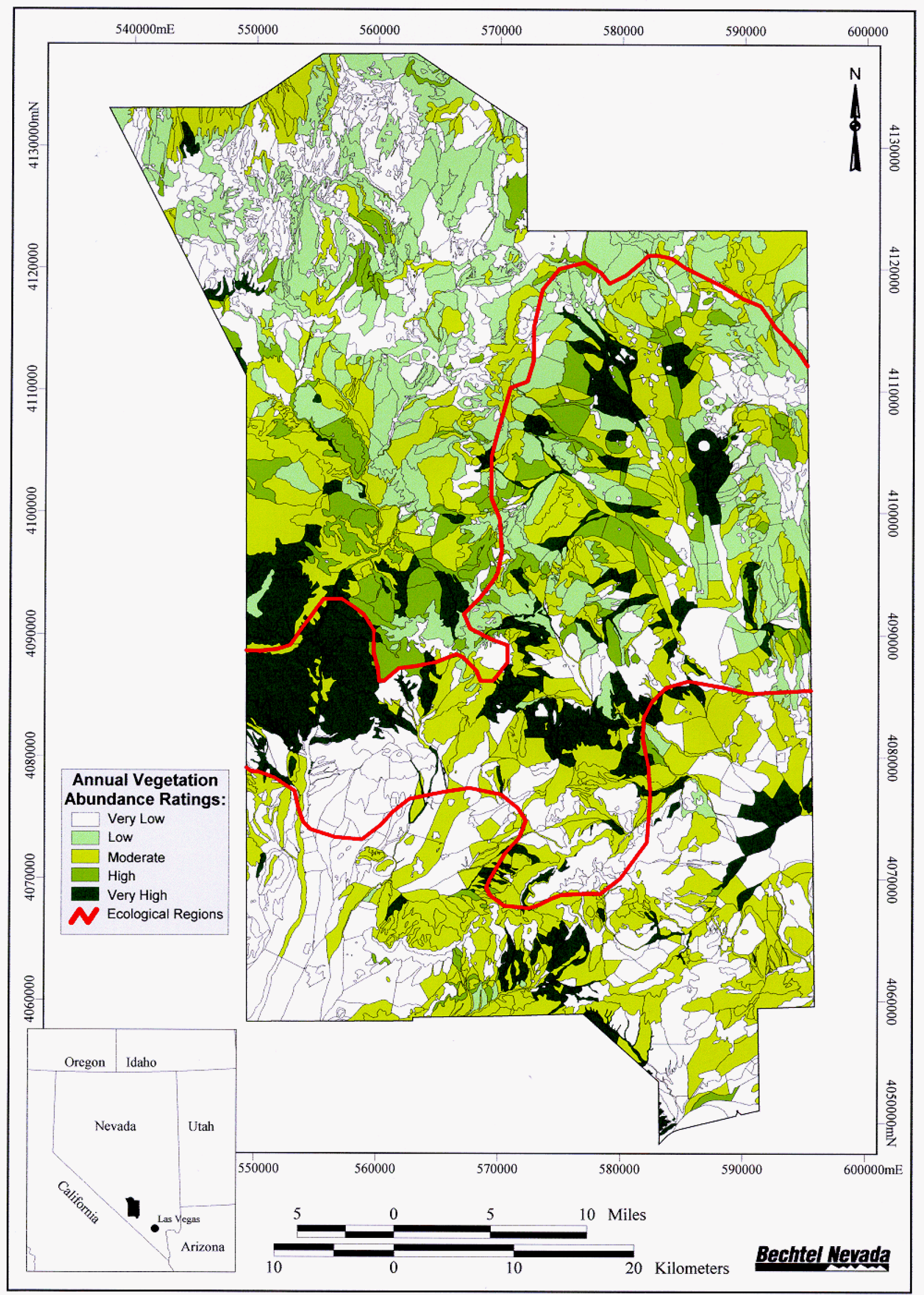

Figure 4-31 Productivity of annual vegetation in Ecological Landform Units on the Nevada Test Site 


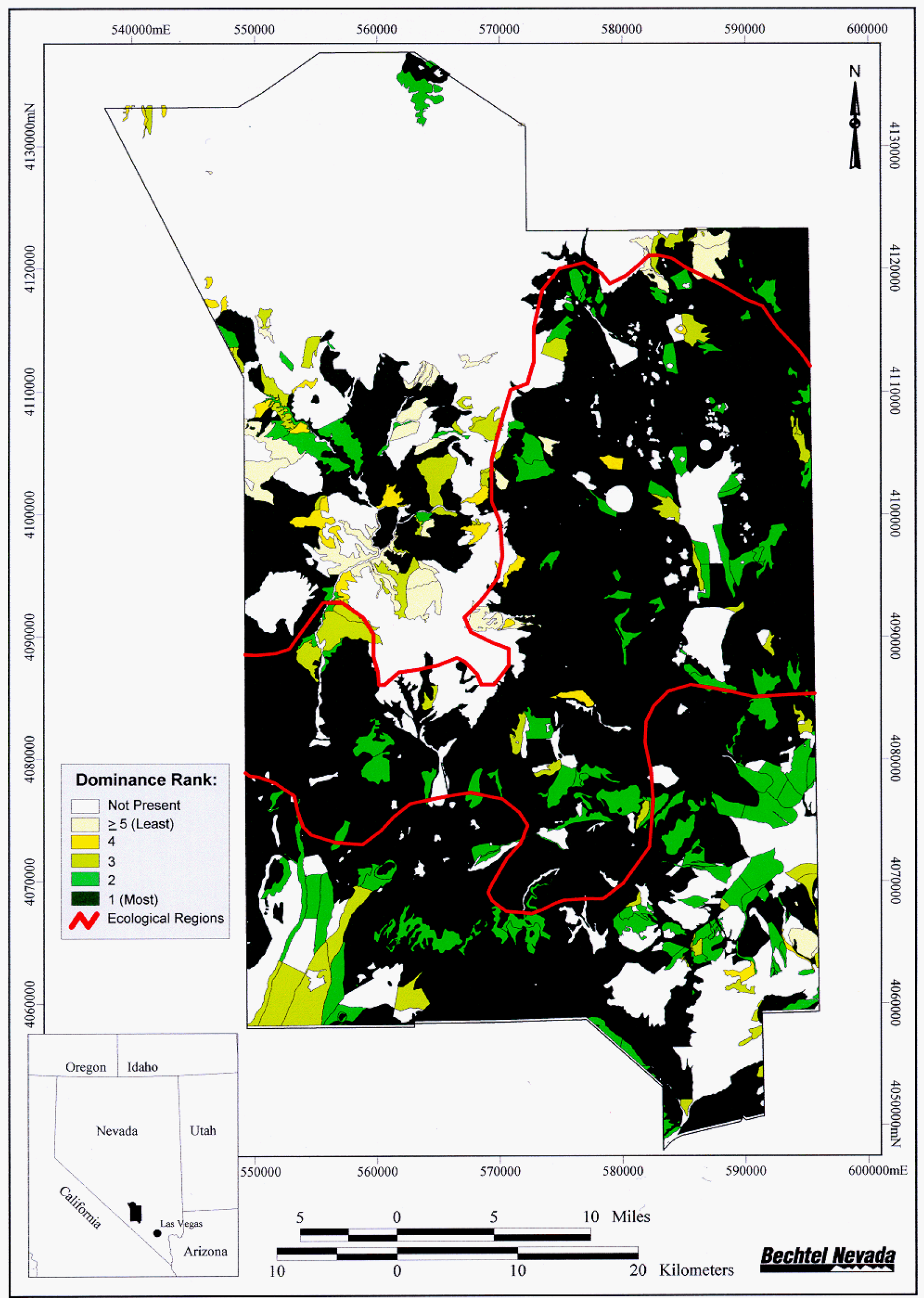

Figure 4-32 Relative ranking of dominance of Bromus rubens in Ecological Landform Units on the Nevada Test Site 


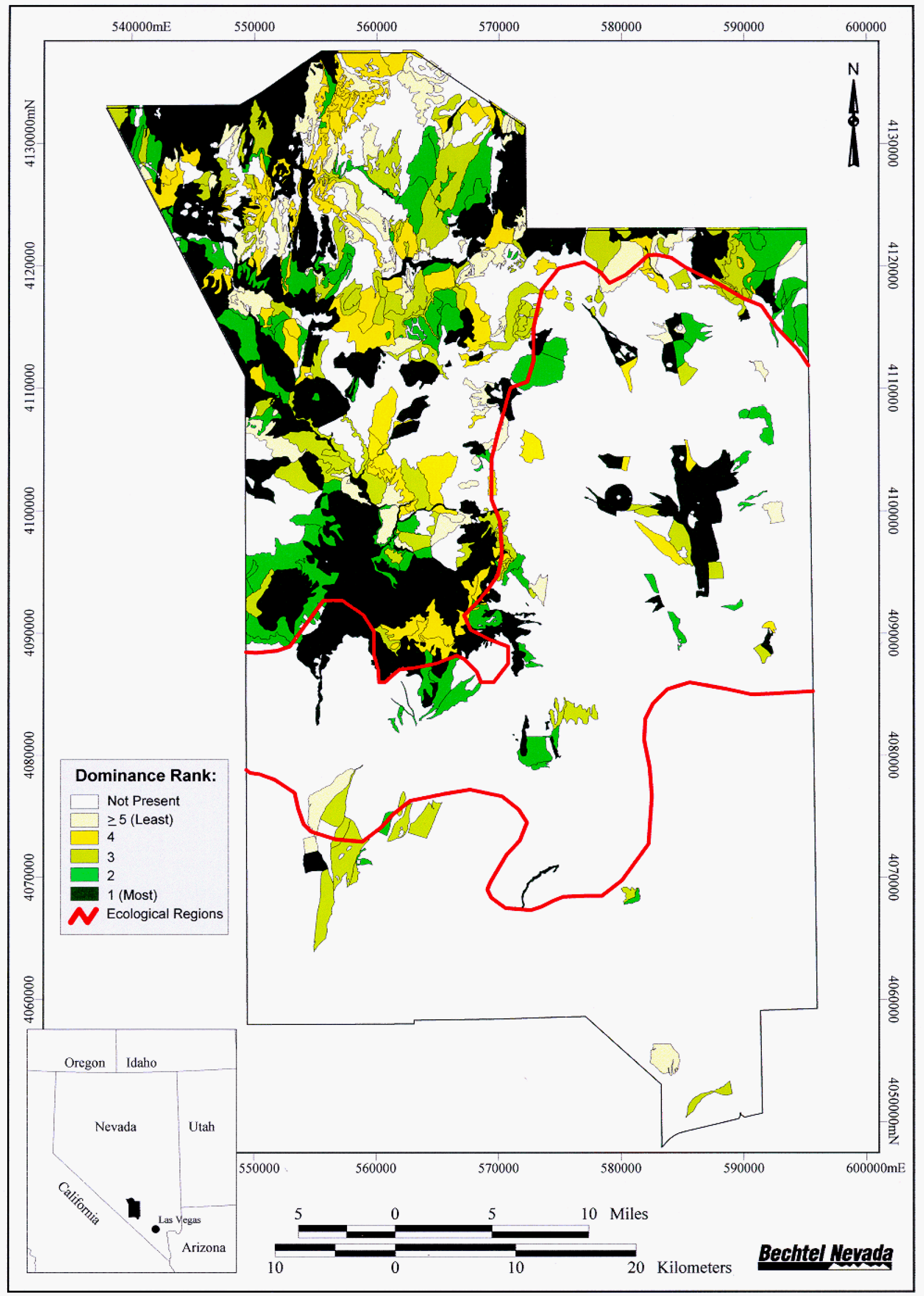

Figure 4-33 Relative ranking of dominance of Bromus tectorum on the Nevada Test Site 
cheatgrass were observed in areas without any apparent human disturbance and no livestock grazing for nearly 50 years. In these sites, their presence appeared to be associated with rodent burrows and predators digging for rodents. No other plants of these species were observed for hundreds of meters surrounding these microsite disturbances. The widespread success of these species appears to lie in their early germination, rapid growth, and ability to displace other species once established. Arabian schismus appears to tolerate heat and drought better than foxtail brome or cheatgrass, and it is found most abundantly in the southwest corner of the NTS (Figure 4-34) in Jackass Flats where foxtail brome ranks low in dominance and cheatgrass is absent.

Prickly Russian thistle, barbwire Russian thistle, and tumblemustard are generally restricted to areas on the NTS (Figures 4-35 through 4-37) where there have been major earthmoving disturbances or aboveground nuclear events. These species appear to thrive best just following soil disturbance when a lack of competition by other plants permits their rapid growth. Without further soil disturbance and with time, the dominance of these species appears to decline as soil nutrients and favorable germination sites are gradually taken over by other native vegetation. These plants were frequently described on sites following aboveground nuclear events.

\subsubsection{Rodent Activity}

Signs indicating burrowing rodents included burrow entrances, excavated soils, or collapsed burrows. These signs give a measure of how disturbed the soil surface is and serve as a crude index of potential for invasive plant species, as well as potential for burrowing by tortoises. For soil to support burrowing by rodents and tortoises, it must have sufficient fines to prevent the burrows from collapsing. For example, soils with all sand-size particles do not support burrowing well, as burrows collapse or fill in with loose particles; they lack the clays, silts, or soil moisture needed to maintain a burrow. Soils must also have sufficient depth before encountering bedrock or caliche to sustain animals through summer heat and winter cold. Distribution on the NTS of sign indicating rodent activity is shown in Figure 4-38. Rodent burrowing sign was found to be inversely correlated with elevation. The Mojave Desert was observed to have a mean of 45 percent of the sites with none to low sign. The Transition Zone was observed to have 59 percent of the sites with none to low sign, and the Great Basin Desert was observed to have 80 percent of the sites with none to low sign. Both the moderate rodent sign and the high to very high rodent sign were also inversely correlated with elevation. The Mojave Desert had 39 percent moderate sign and 16 percent high to very high sign. The Transition Zone had 30 percent moderate sign and 11 percent high to very high sign. The Great Basin Desert had 14 percent moderate sign and 6 percent high to very high sign. The Mojave Desert sites may have deeper soils that are more conducive to burrowing, while the rockier soils of the Transition Zone have fewer burrows. The Great Basin Desert sites have shallower soils and more severe winters than the Mojave Desert sites that may reduce burrowing or the abundance of animals likely to burrow.

\subsection{Species Analyses}

Perhaps one of the greatest benefits from this study has been the ability to generate maps of each species observed during the field sampling. Because of the limited area actually sampled (e.g., only one $200-\mathrm{m}$ [660-ft] transect per each ELU) and variable climatic conditions over the several years of sampling, some speces were overlooked or undersampled. However, the limited sampling was still sufficent to provide a powerful tool to graphically show spatial distribution of 


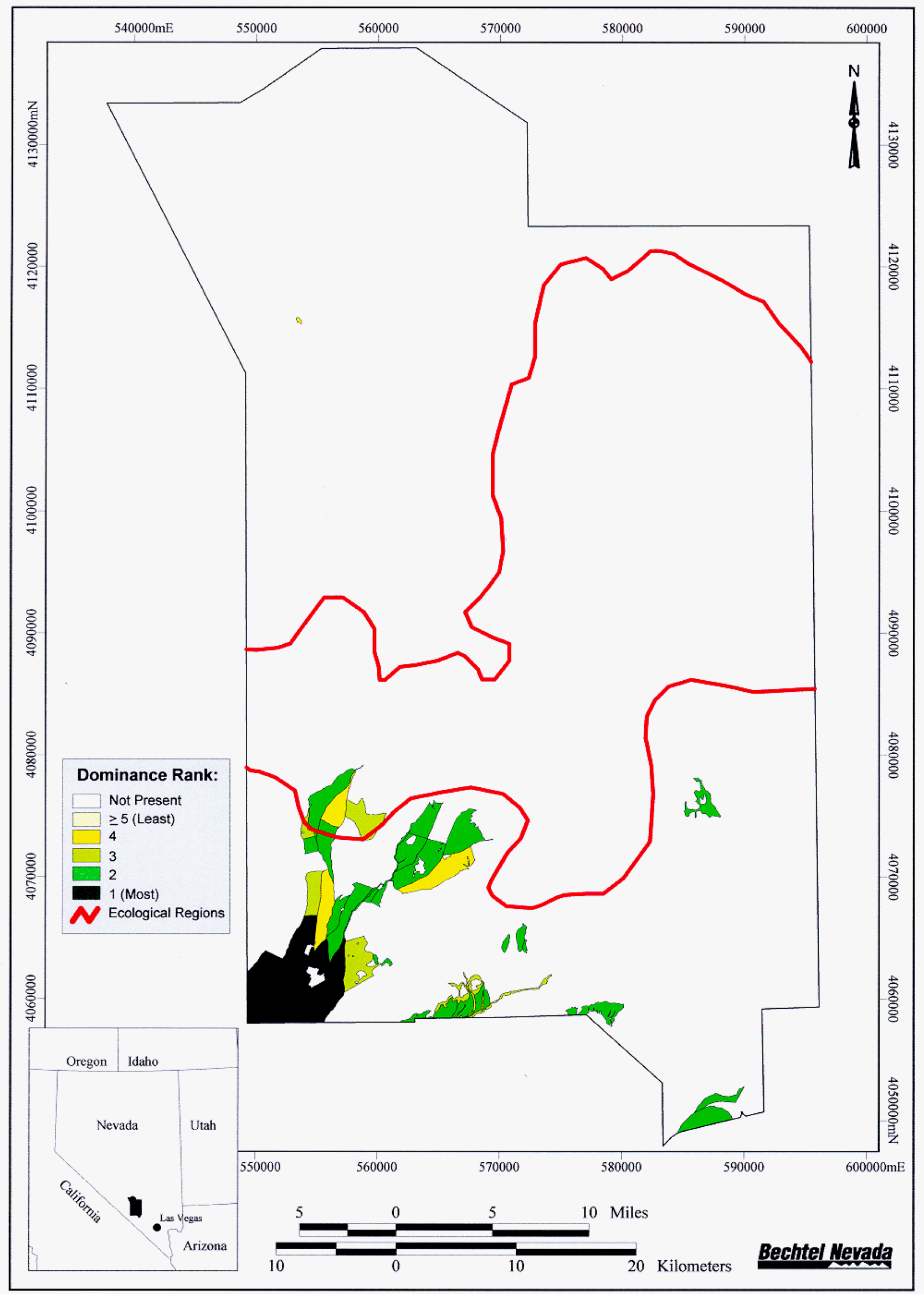

Figure 4-34 Relative ranking of dominance of Schismus arabicus in Ecological Landform Units on the Nevada Test Site 


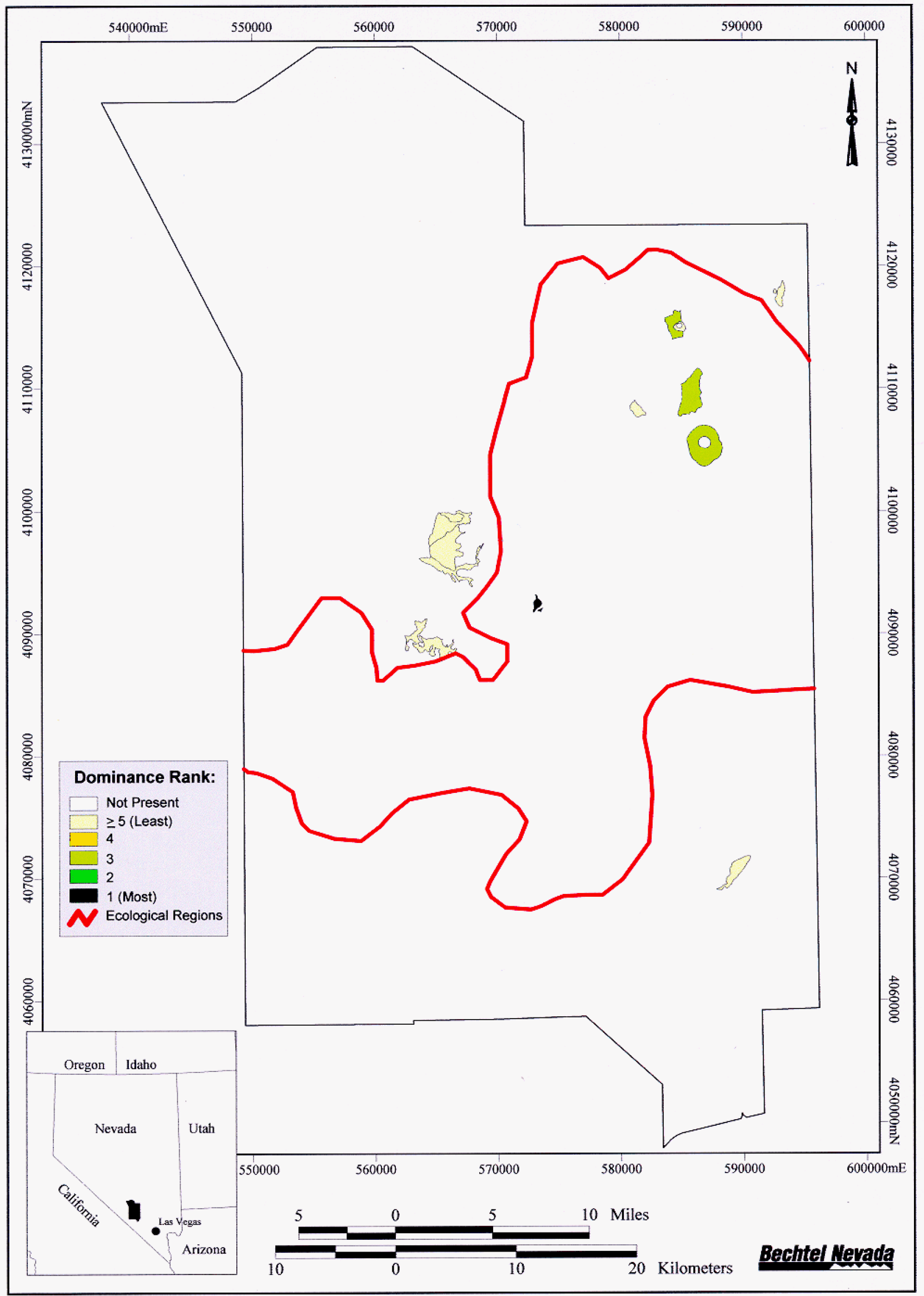

Figure 4-35 Relative ranking of dominance of Salsola kali ssp. tragus in Ecological Landform Units on the Nevada Test Site 


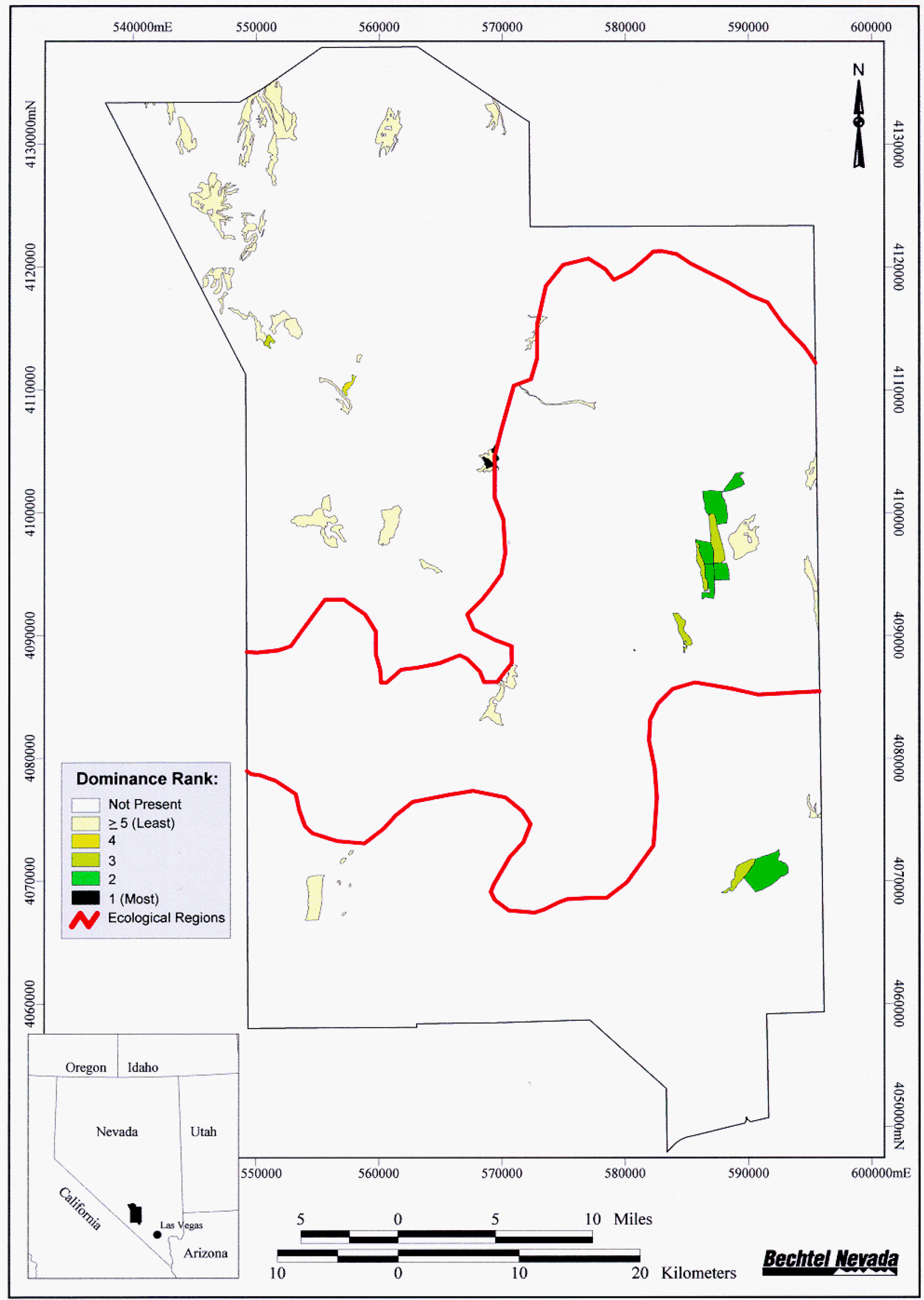

Figure 4-36 Relative ranking of dominance of Salsola paulsenii in Ecological Landform Units on the Nevada Test Site 


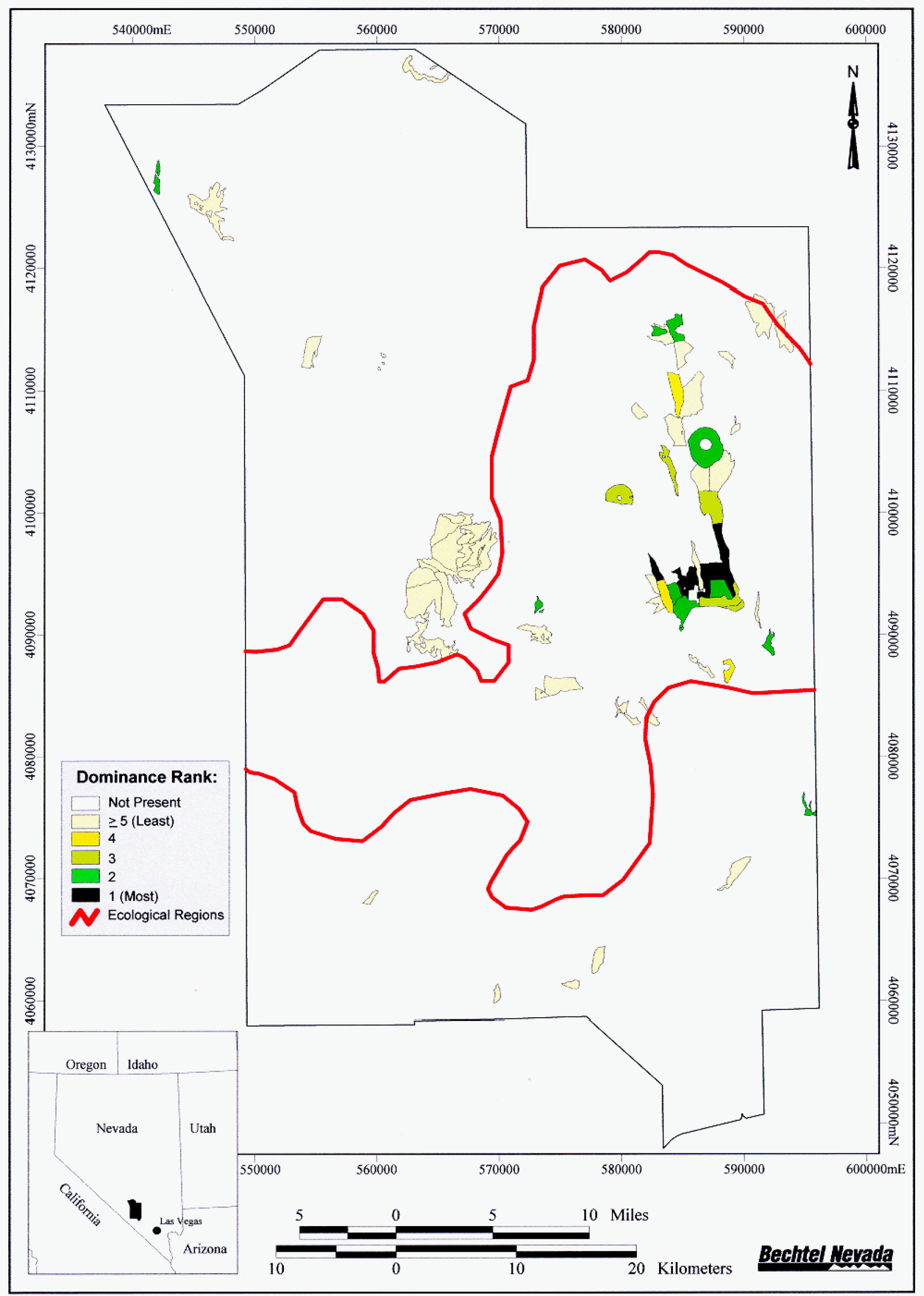

Figure 4-37 Relative ranking of dominance of Sisymbrium altissimum in Ecological Landform Units on the Nevada Test Site 


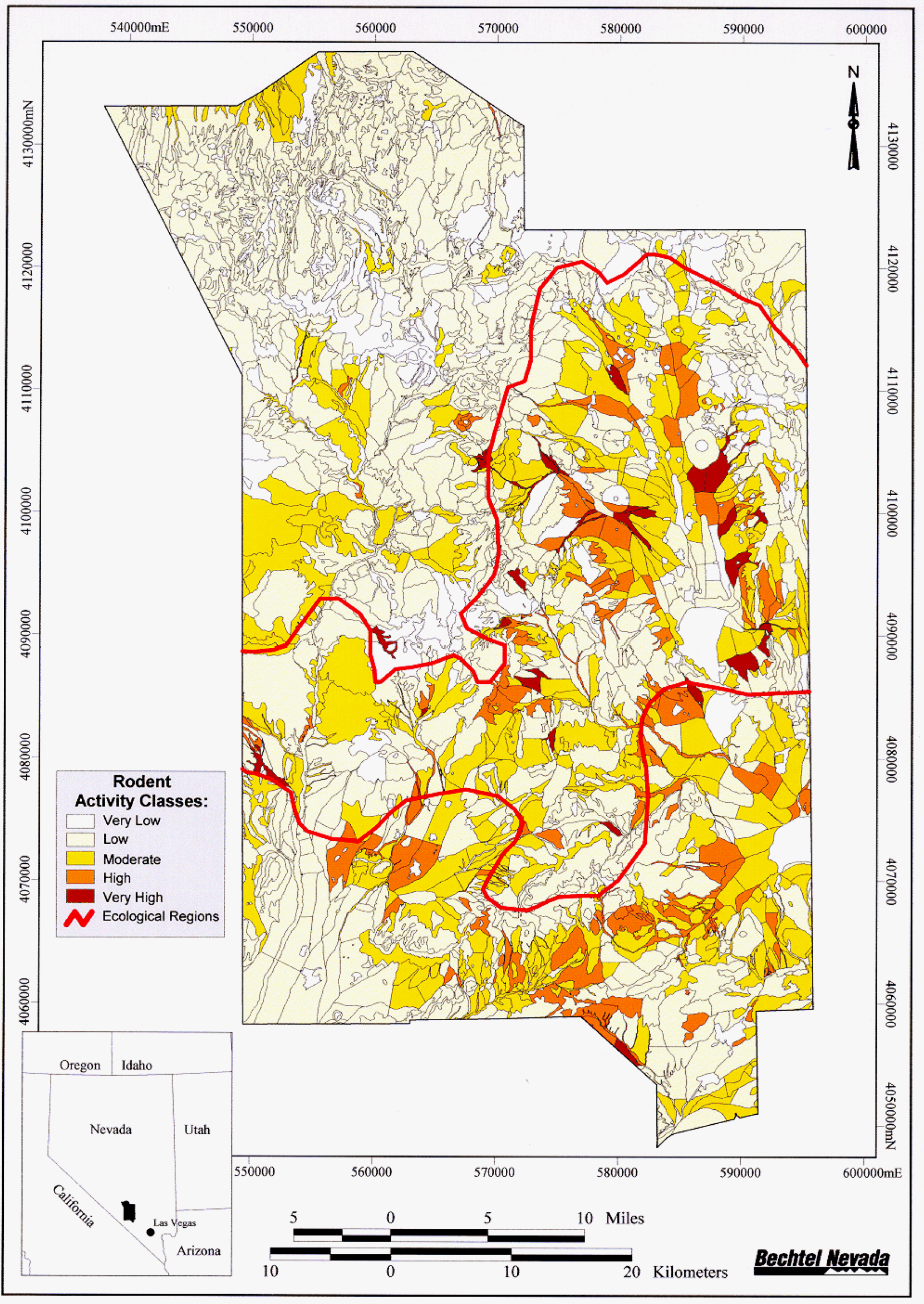

Figure 4-38 Rodent activity classes in Ecological Landform Units on the Nevada Test Site 
species abundance. Because 466 species were identified during the survey, it is not possible to present all of the maps here; rather, a selected subset of the most characteristic trees, shrubs, forbs, grasses, and succulents are presented and discussed.

\subsubsection{Species Correlations}

Pairwise comparisions of perennial species abundance at a statistical level of significance of $\alpha=0.05$ of the 718 species observed to occur on the NTS indicate that there were 447 positive interspecific associations between species and only 271 negative interspecific associations. The negative interspecific associations for the NTS as a whole are less meaningful because they naturally result when two species are not found together as occurs when the two species are from unrelated associations (e.g., species from the Larrea tridentata/Ambrosia dumosa Shrubland and the Pinus monophylla/Artemisia tridentata Woodland). Negative interspecific associations are most meaningful when they are identified within the same association, or closely related associations. The general trend of having more positive associations than negative associations is in

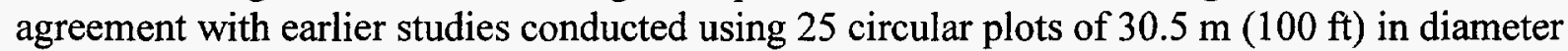
during the late 1960s at the NTS (Wallace and Romney, 1972). Using Chi-squared analyses, Wallace and Romney reported a great many more positive than negative measures of association.

Correlations of percent abundance of woody plant species are presented in Appendix $\mathrm{H}$ for approximately 122 species. Causal factors for the positive interspecific associations usually indicate similar ecological needs for related species. They may also suggest species that partition environmental resources sufficiently to allow the coexistence of both species in time or space. For example, basin big sagebrush and Louisiana sagewort (Artemisia ludoviciana) are positively correlated with each other and probably partition resources. On the other hand, black sagebrush is not positively or negatively correlated with basin big sagebrush or Louisiana sagewort and probably do not partition resources in the same area. Basin big sagebrush is usually found in deep soils, while black sagebrush is found in shallow, rocky soils. Louisiana sagewort is observed in small disturbed patches (e.g., rodent burrows) within the basin big sagebrush sites or on rocky sites at lower elevations where other shrub species (e.g., Eriogonum spp, and Ericameria spp.) appear to exclude the black sagebrush. Information about associations may also be useful to characterize the habitat of selected unique or interesting species such as joshua tree (Yucca brevifolia) or in selecting compatible species while preparing revegetation plans for sites that are to be reseeded or transplanted.

\subsubsection{Dominant Trees and Shrubs}

Thirty-three dominant (based on percent abundance) shrubs and three dominant trees (Utah juniper, gambel's oak, and singleleaf pinyon) were selected to characterize the 20 plant associations on the NTS as previously presented in Table 4-24. These species include the following species (presented alphabetically by scientific name): 
Scientific Name

Acamptopappus shockleyi

Ambrosia dumosa

Artemisia nova

Artemisia spinescens

Artemisia tridentata

Atriplex canescens

Atriplex confertifolia

Chrysothamnus viscidiflorus ssp. puberulus

Chrysothamnus viscidiflorus ssp. viscidiflorus

Coleogyne ramosissima

Ephedra nevadensis

Ephedra viridis

Ericameria cooperi

Ericameria nauseosus

Ericameria teretifolia

Eriogonum fasciculatum

Eriogonum microthecum var. simpsonii

Grayia spinosa

Hymenoclea salsola

Juniperus osteosperma

Kochia americana

Krameria erecta

Krascheninnikovia lanata

Larrea tridentata

Leptodacytylon pungens

Lycium andersonii

Lycium pallidum

Lycium shockleyi

Menodora spinescens

Pinus monophylla

Psorothamnus fremontii

Purshia glandulosa

Purshia stansburiana

Purshia tridentata

Quercus gambelii

Thamnosma montana
Common Name

Shockley goldenhead

white bursage

black sagebrush

budsage

basin big sagebrush

four-wing saltbush

shadscale saltbush

fuzzy green rabbitbrush

sticky green rabbitbrush

blackbrush

Nevada jointfir

Mormon tea

Cooper's heathgoldenrod

rubber rabbitbrush

needle leaf rabbitbrush

eastern Mojave buckwheat

slender buckwheat

spiny hopsage

white burrobrush

Utah juniper

green molly

range ratany

winterfat

creosote bush

granite prickly gilia

Anderson's wolfberry

rabbit thorn

Shockley's desert thorn

spiny menodora

singleleaf pinyon

Fremont's dalea

desert bitterbrush

stansbury cliffrose

antelope bitterbrush

Gambel oak

turpentinebroom

Distributions of the dominant species on the NTS are shown in maps found in Appendix I.

Species associated with these key species are found in Appendix H. Each dominant woody plant species appears to be distributed independently of the other species, although some are found together more frequently than by random chance because of their similar ecological requirements as was discussed previously. For example, creosote bush and white bursage are frequently both found in the same ELUs; however, they achieve their highest dominance in different ELUs. In other words, these species are rarely co-dominant in the sense of having the same percent abundance-one or the other usually has higher dominance, showing slightly better adaptation for conditions within that ELU. Similar patterns are also apparent for closely related species within 
genera such as Artemisia spp., Atriplex spp., Chrysothamnus spp., Ephedra spp., Lycium spp., and Purshia spp. In some cases, the presence of one species meant the exclusion of the other species, especially if the abundance of the first species was rather high. These patterns support the concept of niche partitioning and speciation resulting in reduced interspecific competition.

The spatial distribution of each species results from ecological requirements for the species and the available physical and biological conditions present on NTS landforms. Elevation, as previously mentioned, provides the best single parameter to help characterize the various plant associations. Each association tends to have only a few dominant species (e.g., two to six), while each species tends to occupy a range of the total elevation gradient ranging from $847 \mathrm{~m}(2,779 \mathrm{ft})$ at the low end of the NTS to 2,292 $\mathrm{m}(7,519 \mathrm{ft})$ at the upper end. For some species like Shockley's desert thorn, this range is rather narrow (e.g., $<300 \mathrm{~m}[984 \mathrm{ft}]$ in elevational range) and its presence is limited to a single plant association, suggesting a rather narrow niche width or ecological amplitude. For other species like four-wing saltbush, the range is wide $(>1,200 \mathrm{~m}$ $[3,937 \mathrm{ft}]$ in elevational range), being found in all of the plant associations, which suggests a broader niche width or ecological amplitude.

Species most characteristic of the Mojave Desert were (sorted from low to high in elevational position): Shockley's desert thorn, rabbit thorn, white bursage, creosote bush, and range ratany. Species most characteristic of the Great Basin Desert were (sorted from low to high in elevational position): budsage, shadscale saltbush, green molly, four-wing saltbush, green rabbitbrush, rubber rabbitbrush, Mormon tea, Stansbury cliffrose, desert bitterbrush, basin big sagebrush, black sagebrush, fuzzy green rabbitbrush, slender buskwheat, granite prickly gilia, Utah Juniper, antelope bitterbrush, gambel oak, and singleleaf pinyon. Species that were most characteristic within the Transition Zone between these two deserts were (sorted from low to high in elevational position): spiny menodora, Fremont's dalea, turpentinebroom, spiny hopsage, winterfat, Anderson's wolfberry, white burrobush, eastern Mojave buckwheat, needleleaf rabbitbrush, blackbrush, Cooper's heathgoldenrod, and Nevada jointfir.

\subsubsection{Dominant Forbs, Grasses, and Succulents}

All non-woody plant species on the NTS were ranked according to relative dominance in all ELUs. The top five species in each of the three categories (forbs, grasses, and succulents) were selected for discussion here (see Appendix $J$ for distribution maps). The rankings were limited to five because the ranking was relatively easy for the first five species at a site, but became much more subjective as more species were observed at a site. For example, some sites had more than 30 species and it was impossible to accurately rank them by dominance in any meaningful way past the first five or six species. The top five species in each category include (listed in order of dominance across all ELUs on the NTS):

Scientific Name

Forbs:

Amsinckia tessellata

Sphaeralcea ambigua ssp. ambigua

Chaenactis stevioides

Eriogonum inflatum

Machaeranthera canescens ssp. canescens

\section{Common Name}

bristly fiddleneck

apricot globemallow

Steves duskymaiden

native American pipeweed

hoary aster 


\section{Grasses: \\ Achnatherum hymenoides \\ Bromus rubens \\ Elymus elymoides ssp. elymoides \\ Achnatherum speciosum \\ Bromus tectorum}

\section{Succulents:}

Opuntia echinocarpa var. echinocarpa

Opuntia erinacea var. erinacea

Echinocereus engelmannii

Echinocactus polycephalus

Opuntia polyacantha var. rufispina
Indian ricegrass

foxtail brome

bottlebrush squirreltail

desert needlegrass

cheatgrass

staghorn cholla

Mojave pricklypear

Engelmann's cactus

cottontop barrelcactus

hairspine pricklypear

\subsubsection{Forbs}

The dominant species of forbs on the NTS were distributed along an elevational gradient. In order of decreasing elevation (mean elevation in meters \pm SE mean, number of observations) they were: hoary aster $(1,732 \pm 18, n=244)$, apricot globemallow $(1,295 \pm 13, n=411)$, Steves duskymaiden $(1,492 \pm 15, \mathrm{n}=15)$, bristly fiddleneck $(1,432 \pm 11, \mathrm{n}=435)$, and native American pipeweed $(1,258 \pm 16, \mathrm{n}=201)$.

\subsubsection{Grasses}

The dominant species of grass on the NTS were distributed along an elevational gradient. In order of decreasing elevation (mean elevation in meters \pm SE mean, number of observations) they were: cheatgrass $(1,770 \pm 15, n=320$, bottlebrush squirreltail $(1,740 \pm 13, n=426$, Indian ricegrass $(1,574 \pm 16, n=494)$, desert needlegrass $(1,449 \pm 13, n=326)$, and foxtail brome $(1,346 \pm 10, \mathrm{n}=320)$.

\subsubsection{Succulents}

The five most dominant succulents on the NTS were distributed along an elevational gradient (Figure 4-39). In order of decreasing elevation (mean elevation in meters \pm SE mean, number of observations, species alphacode) they were: hairspine pricklypear $(1,887 \pm 21, n=128$, OPPOR), Mojave pricklypear $(1,837 \pm 180, n=185$, OPERE), Engelmann's cactus $(1,526 \pm 20, n=153$, ECEN), staghorn cholla $(1,392 \pm 13, n=394$, OPECE), and cottontop barrelcactus $(1,302 \pm 16$, $\mathrm{n}=131, \mathrm{ECPO} 2$ ). 


\section{Frequency of Elevation}

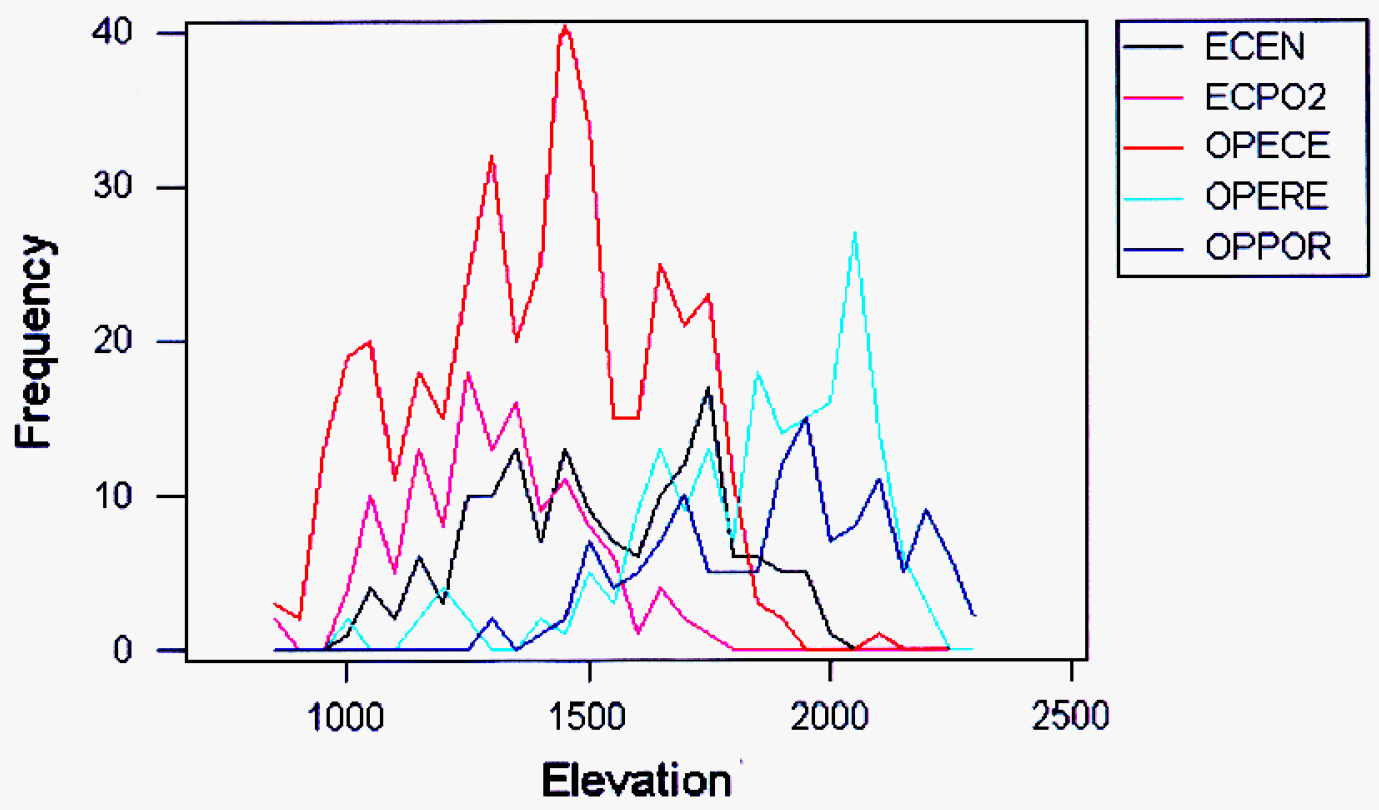

Figure 4-39 Percent frequency of succulents on the NTS by elevation (meters). 


\subsection{LITERATURE CITED}

Allred, D. M., D. E. Beck, and C. D. Jorgensen, 1963a. "Biotic Communities of the Nevada Test Site." Brigham Young University Science Bulletin, Biological Series - Volume II, Number 2, February 1963. $52 \mathrm{pp}$.

— 1963b. "Biotic Communities of the Nevada Test Site." Brigham Young University Science Bulletin, Biological Series - Volume II, Number 4, May 1963. 15 pp.

Anderson, M., P. Bourgeron, M. Bryer, R. Crawford, L. Engelking, D. Faber-Langendoen, M. Gallyoun, K. Goodin, D. Grossman, S. Landaal, K. Metzler, K. Patterson, M. Pyne, M. Reid, L. Sneddon, and A. Weakley, 1998. "International Classification of Ecological Communities: Terrestrial Vegetation of the United States." Volume II. The National Vegetation Classification System: List of Types. The Nature Conservancy, Arlington, Virginia.

Anderson, D. C., 1998. Distribution of Clokey's Eggvetch (Astragalus oophorus var. clokeyanus) on the Nevada Test Site. DOE/NV/11718--262. U.S. Department of Energy, Nevada Operations Office, Las Vegas, Nevada.

Bailey, R. G., 1995. "Description of the Ecoregions of the United States." U.S. Forest Service Miscellaneous Publication 1391 (revised), with separate map at a scale of 1:7,500,000, Washington, D.C.

Bailey, R. G., M. E. Jensen, D. T. Cleland, and P. S. Bourgeron, 1994. "Design and Use of Ecological Mapping Units." In: M. E. Jensen, and P. S. Bourgeron (eds.), Ecosystem Management: Principles and Applications. Gen. Tech. Rep. PNW-318. Portland, Oregon. U.S. Department of Agriculture, Forest Service, Pacific Northwest Research Station: $95-106$.

Bailey, R. G., 1976. Ecoregions of the United States (map). U.S. Forest Service, Intermountain Region, Ogden, Utah. Scale 1:7,500,000.

Beatley, J. C., 1977a. Endangered Plant Species of the Nevada Test Site, Ash Meadows, and Central-Southern Nevada. U.S. Energy Research and Development Administration Topical Report No. C00-2307-11. 77 pp.

- 1977b. Threatened Plant Species of the Nevada Test Site, Ash Meadows, and CentralSouthern Nevada. U.S. Energy Research and Development Administration Topical Report No. C00-2307-12. 66 pp.

- 1976. Vascular Plants of the Nevada Test Site and Central-Southern Nevada: Ecological and Geographic Distributions. TID-26881. Energy Research and Development Administration, Division of Biomedical and Environmental Research. 
Berry, K. H., 1986. "Introduction; Development, Testing, and Application of Wildlife-Habitat Models." In: Jare Verner, Michael L. Morrison, and C. John Ralph (eds.), Wildlife 2000. Modeling Habitat Relationships of Terrestrial Vertebrates: Report of a symposium; October 7-11, 1984. Stanford Sierra Camp, Fallen Leaf Lake, California. University of Wisconsin Press: 3-4, Madison, Wisconsin.

_ 1979. "The East Mojave Desert: An Example of Inventory Design and Habitat Analysis." In: Classification, Inventory and Analysis of Fish and Wildlife Habitat. The proceedings of a National Symposium held at Phoenix, Arizona on January 24-27, 1977. U.S. Department of the Interior, Fish and Wildlife Service, Biological Services Program PB 299240, FWS OBS-78/76.

Blomquist, K. W., T. A. Lindemann, G. E. Lyon, D. C. Steen, C. A. Wills, S. A. Flick, and W. K. Ostler, 1995. Current Distribution, Habitat, and Status of Category 2 Candidate Plant Species On and Near the U.S. Department of Energy's Nevada Test Site. EGG 11265-1149 UC-708. Las Vegas, Nevada. $101 \mathrm{pp}$.

Blomquist, K. W., C. A. Wills, W. K. Ostler, K. R. Rautenstrauch, and T. P. O'Farrell, 1992. Distribution, life history, management, and current status of Astragalus beatleyae on the U. S. Department of Energy's Nevada Test Site. EG\&G/EM Santa Barbara Report No. 10617-2187. $41 \mathrm{pp}$.

Brady, N. C., 1974. The Natural Properties of Soils. Eighth Edition. MacMillan Publishers Co., Inc., New York.

Brown, D. E. (ed.), 1982. "Biotic Communities of the American Southwest-United States and Mexico." Desert Plants Vol. 4, Numbers 1-4. Published by the University of Arizona for the Boyce Thompson Southwestern Arboretum.

Brown, D. E., C. H. Lowe, and C. P. Pase, 1980. A Digitized Systematic Classification for Ecosystems With an Illustrated Summary of the Natural Vegetation of North America. U.S. Department of Agriculture. Forest Service General Technical Report RM-73. Rocky Mountain Forest and Range Experiment Station, Fort Collins, Colorado. 93 pp.

Civilian Radioactive Waste Management System Management and Operating Contractor, 1998. Classification and Map of Vegetation at Yucca and Little Skull Mountains, Nevada. B0000000-01717-5707 REV 00B. Las Vegas, Nevada.

Cronquist, A., A. H. Holmgren, N. H. Holmgren, J. L. Reveal, and P. K. Holmgren, 1994. Intermountain Flora, Vascular Plants of the Intermountain West, U.S.A. Volumes 1-V. The New York Botanical Garden, Bronx, New York.

Dyksterhuis, E. J., 1949. "Condition and Management of Rangeland Based on Quantitative Ecology." Journal of Range Management, 2: 104-115.

Federal Geographic Data Committee, 1996. FGDC Vegetation Classification and Information Standards, June 3, 1996. Vegetation Subcommittee, U.S. Geological Service, Reston, Virginia. http://www.nbs.gov/ mikez/fgdc-veg.htm\#1. Internet retrieval as of 9/05/96. 
Ferguson, D. E., P. Morgan, and F. D. Johnson (compilers), 1989. Proceedings-Land Classifications Based on Vegetation: Applications for Resource Management. Moscow, Idaho, November 17-19, 1987. U.S. Department of Agriculture, Forest Service, General Technical Report INT-257, pp 315.

Fransioli, P. M., and D. S. Ambos, 1997. Engineering Design Climatology and Regional Meterological Conditions Report. B00000000-01717-5707-00066 REV00. TRW Environmental Safety Systems Inc., October 2, 1997. U.S. Department of Energy, Yucca Mountain Site Characterization Office, North Las Vegas, Nevada.

French, R. H., 1986. Daily, Seasonal, and Annual Precipitation at the Nevada Test Site, Nevada. DOE/NV/10384-01. Desert Research Institute, University of Nevada System, Water Resources Center Publication \#45042. U.S. Department of Energy, Nevada Operations Office, Las Vegas, Nevada.

Friesen, H. N., 1992. Summary of the Nevada Applied Ecology Group and Correlative Programs. U.S. Department of Energy Report DOE/NV-357 (Version 2). Las Vegas, Nevada. 136 pp.

Gates, D. H., L. A. Stoddard, and W. C. Cook, 1956. "Soil as a Factor Influencing Plant Distribution on Salt Deserts of Utah." Ecological Monographs 26: 155-175.

Grossman, D. H., D. Faber-Langendoen, A. Weakley, M. Anderson, P. Bourgeron, R. Crawford, K. Goodin, R. Landaal, K. Metzler, K. Patterson, M. Pyne, M. Reid, and L. Sneddon, 1998. "International Classification of Ecological Communities: Terrestrial Vegetation of the United States." Volume I. The National Vegetation Classification System:

Development, Status, and Applications. The Nature Conservancy, Arlington, Virginia.

Hansen, D. J., W. K. Ostler, and D. B. Hall, 1999. "The Transition From Mojave Desert to Great Basin on the Nevada Test Site." In: E. Durant McArthur, W. Kent Ostler, and Carl L. Wambolt (compilers), Proceedings: Shrubland Ecotones. August 12-14, 1998, Ephraim, Utah. Proceedings RMRS-P-000. Ogden, Utah. U.S. Department of Agriculture, Forest Service, Rocky Mountain Research Station. pp 148-158.

Hansen, D. J., P. D. Greger, C. A Wills, and W. K. Ostler. 1997. Nevada Test Site Wetlands Assessment. DOE/NV/11718-124. U.S. Department of Energy, Nevada Operations Office, Las Vegas, Nevada.

Hastings, J. R., and R. M. Turner, 1972. The Changing Mile, An Ecological Study of Vegetation Change with Time in the Lower Mile of an Arid and Semiarid Region. The University of Arizona Press, Tucson, Arizona. pp 317.

Hereford, R., and C. Longpre, 2000. "Climate History of the Mojave Desert Region, 1892 1996," including data from 48 long-term Weather Stations and an Overview of Regional Climate Variation. http://www-wmc.wr.usgs.gov/mojave/climate-history/main.html. Internet retrieval as of $8 / 16 / 2000$.

Hickman, J. C. (ed.), 1993. The Jepson Manual, Higher Plants of California. University of California Press, Berkeley, California. 
Hironaka, M., 1986. "Habitat Type, Range Site, and Community Type." In: ProceedingsSymposium on the Biology of Artemisia and Chrysothamnus. Provo, Utah, July 9-13, 1984. U.S. Department of Agriculture, Forest Service, General Technical Report INT-200, March 1986.

Holdorf, H. D., 1989. "Designing Mapping Projects." In: Proceedings-Land Classifications Based on Vegetation: Applications for Resource Management, Moscow, Idaho, November 17-19, 1987. Compilers: Dennis E. Ferguson, Penelope Morgan, and Frederick D. Johnson. U.S. Department of Agriculture, Forest Service, General Technical Report INT-257, pp 87-89.

Holdridge, L. R., 1962. "The Determination of Atmospheric Water Movements." Ecology 42:1-9.

Holland, R. F., 1986. "Preliminary Descriptions of the Terrestrial Natural Communities of California." California Department of Fish and Game, pp. 1-146.

Hunter, R. B. (compiler), 1995. Status of the Flora and Fauna on the Nevada Test Site, 1994. U.S. Department of Energy Report DOE/NV/11432-195, UC-721. Las Vegas, Nevada. $363 \mathrm{p}$.

- 1994a. Status of the Flora and Fauna on the Nevada Test Site, 1989-91. U.S. Department of Energy Report DOE/NV/11432-57. Las Vegas, Nevada. 377 pp.

- 1994b. Status of the Flora and Fauna on the Nevada Test Site, 1992. U.S. Department of Energy Report DOE/NV/11432-58. Las Vegas, Nevada. 207 pp.

- 1994c. Status of the Flora and Fauna on the Nevada Test Site, 1993. U.S. Department of Energy Report DOE/NV/11432-162. Las Vegas, Nevada. 296 pp.

Hunter, R. B., and P.A. Medica, 1989. Status of the Flora and Fauna on the Nevada Test Site in 1987. U.S. Department of Energy Report DOE/NV/10630-2. Las Vegas, Nevada. $103 \mathrm{pp}$.

Hunter, R. B., E. M. Romney, and A. Wallace, 1980. "Rodent-denuded areas of the northern Mojave Desert." Great Basin Naturalist Memoirs No. 4. Soil-Plant-Animal Relationships Bearing on Revegetation and Land Reclamation in Nevada Deserts. Brigham Young University, Provo, Utah. pp-208-211.

Jaeger, E. C., 1957. The North American Deserts. Stanford University Press, Stanford, California. $308 \mathrm{pp}$.

Kartesz, J. T., 1988. A Flora of Nevada. Parts 1-3. University Microfilms International, Ann Arbor, Michigan.

Kramer, P. J., 1969. Plant \& Soil Water Relationships: A Modern Synthesis. McGraw-Hill Book Company, New York. pp 482. 
Lunt, O. R., J. Letey, and S. B. Clark, 1973. "Oxygen Requirements for Root Growth in Three Species of Desert Shrubs." Ecology, Vol. 54, No. 6, pp 1356-1362.

McCune, B., and M. J. Mefford, 1995. "PC-ORD. Multivariate Analysis of Ecological Data," Version 2.1. Gleneden Beach, Oregon: MjM Software Design.

Mueller-Dombois, D., and H. Ellenberg, 1974. Aims and Methods of Vegetation Ecology. John Wiley and Sons, New York. 547 p.

National Biological Service, 1995. Draft Content Standard for National Biological Information Infrastructure Metadata. December 1995. U.S. Department of the Interior, Washington, D.C.

O'Farrell, T. P., and L. A. Emery, 1976. Ecology of the Nevada Test Site: A Narrative Summary and Annotated Bibliography. NVO-167. U.S. Energy Research and Development Administration, Nevada Operations Office. National Technical Information Services, Springfield, Virginia.

Ostler, W. K., D. J. Hansen, and D. J. Hall, 1999. "The Classification of Shrublands on the Nevada Test Site." In : E. Durant McArthur, W. Kent Ostler, and Carl. L. Wambolt, (compilers), Proceedings: Shrubland Ecotones. August 12-14, 1998, Ephriam, Utah. Proceedings RMRS-P-000. Ogden, Utah. U.S. Department of Agriculture, Forest Service, Rocky Mountain Research Station. pp 137-147.

Peterson, F. F., 1981. Landforms of the Basin \& Range Province Defined for Soil Survey. Technical Bulletin 28, Nevada Agricultural Experimentation, University of Nevada Reno, January 1981.

Pritchett, D., T. Knight, and F. Smith, 1997. "An Inventory for Rare, Threatened, Endangered, and Endemic Plants and Unique Communities on Nellis Air Force Bombing and Gunnery Range, Clark, Lincoln, and Nye Counties, Nevada." The Nature Conservancy, U.S. Department of Defense, Legacy Resource Management Program, Nellis Air Force Base, Nevada.

Rhoads, W. A., S. Cochrane, and M. P. Williams, 1978. Status of Endangered and Threatened Plant Species on Nevada Test Site -A Survey. Part 1: Threatened Species. EG\&G/EM Santa Barbara Report No. 1183-2356.

Rhoads, W. A., and M. P. Williams, 1977. Status of Endangered and Threatened Plant Species on Nevada Test Site -A Survey. Part 1: Endangered Species. EG\&G/EM Santa Barbara Report No. 1183-2356. 102 pp.

Schultz, B. W., and W. K. Ostler, 1995. "Effects of Prolonged Drought on Vegetation Associations in the Northern Mojave Desert." In: B. A. Roundy, E. D. McArthur, J. S. Haley, and D. K. Mann (compilers), Proceedings: Wildland Shrub and Arid Land Restoration Symposium. October 1993, Las Vegas, Nevada. GenTech Report INT-GTR315, Ogden, Utah. U.S. Department of Agriculture, Forest Service, Intermountain Research Station. pp 228-235. 
Shields, L. M., and W. H. Rickard, 1960. "A Botanical Study of Nuclear Effects at the Nevada Test Site, 1959." Annual report of New Mexico Highlands University to U.S. Atomic Energy Commission.

Shields, L. M., W. H. Rickard, and F. Drouet, 1959. "A Botanical Study of Nuclear Effects at the Nevada Test Site, 1958." Annual report of New Mexico Highlands University to U.S. Atomic Energy Commission. $160 \mathrm{pp}$.

Shields, L. M., 1958. "A Botanical Study of Nuclear Effects at the Nevada Test Site, 1957." Annual report of New Mexico Highlands University to U.S. Atomic Energy Commission. pp 109.

Spaulding, W. G., 1985. Vegetation and Climates of the Last 45,000 Years in the Vicinity of the Nevada Test Site, South-Central Nevada. U.S. Geological Survey Professional Paper 1329. U.S. Department of the Interior in cooperation with the U.S. Department of Energy. $83 \mathrm{pp}$.

Transeau, E. N, 1905. "Forest Centers of Eastern North America." American Naturalist 39:875889.

Turner, R. M., 1982a. 152.1 "Great Basin Desertscrub." In: Desert Plants, Biotic Communities of the American Southwest-United States and Mexico. David E. Brown, Editor, Volume 4, Numbers 1-4, pp. 144-155.

—, 1982b. 153.1 "Mohave Desertscrub." In: Desert Plants, Biotic Communities of the American Southwest-United States and Mexico. David E. Brown, Editor, Volume 4, Numbers 1-4, pp. 157-168.

U.S. Department of Agriculture, 1996. The PLANTS Database. National Plant Data Center, Baton Rouge, Louisiana. 70874-4490 USA. (Also available via the Internet: Natural Resource Conservation Service, Biological Conservation Sciences Division, http://trident.ftc.nrcs.usda.gov/npde/30hm-pg.html. Internet retrieval as of 9/10/1996.

U.S. Congress, 1983. Water-Related Technologies for Sustainable Agriculture in the U.S. Arid/Semiarid Lands. OTA-F-212. U.S. Congress, Office of Technology Assessment, October 1983. Washington, D.C. pp 412.

U.S. Department of Energy, 1998. Nevada Test Site Resource Management Plan. DOE/NV-518. Nevada Operations Office, Las Vegas, Nevada.

— 1996a. DOE Policy 430.1, "Land and Facility Use Planning." Washington, D.C.

- 1996b. Final Environmental Impact Statement for the Nevada Test Site and Off-Site Locations in the State of Nevada, Volume 1, Chapters 1-9. DOE/EIS 0243. U.S. Department of Energy, Nevada Operations Office, Las Vegas, Nevada, August 1996.

- 1995. Nevada Test Site Grid Map, A Grid System Photo Locator Map of the Nevada Test Site. U.S. Department of Energy, Remote Sensing Laboratory, Nellis Air Force Base, Las Vegas, Nevada. 
Wallace, A., and E. M. Romney, 1972. Radioecology and Ecophysiology of Desert Plants at the Nevada Test Site. TID-25954. U.S. Atomic Energy Commission, Office of Information Services, Library of Congress Catalog Card Number 72-600110.

Wellner, C. A., 1989. "Classification of Habitat Types in the Western United States." In: Proceedings-Land Classifications Based on Vegetation: Applications for Resource Management, Moscow, Idaho, November 17-19, 1987. Compiled by Dennis E. Ferguson, Penelope Morgan, and Frederic D. Johnson. U.S. Department of Agriculture, Forest Service, General Technical Report INT-257. pp 87-89.

Welsh, S. L., N. D. Atwood, S. Goodrich, and L. C. Higgins (eds.), 1993. A Utah Flora. Brigham Young University, Print Services, Provo, Utah.

Wood, Y. A., R. C. Graham, and S. G. Wells, 1998. "Mesoscale Patterns and Linkages of Clast Mosaics, Biota and Soils on a Pleistocene Desert Pavement." In: New Research Directions in Desert Surficial Processes and Landscape Dynamics on Military Lands. Conference sponsored by: U.S. Army Research Office, and Desert Research Institute, April 25 - May 1, 1998. Zzyzx, California. 
This Page Intentionally Left Blank 


\subsection{APPENDICES}

Appendix A Plant Associations on the NTS Recognized by Beatley

Appendix B Plant Species on the NTS

Appendix C List of Common Names, Alphacodes, Scientific Names, and Older Names

Appendix D Percent Abundance of Woody Plants on the NTS by Alliance

Appendix E Percent Abundance of Woody Plants on the NTS by Association

Appendix F Percent Frequency of NTS Plant Species by Alliance

Appendix G Percent Frequency of NTS Plant Species by Association

Appendix H Interspecific Association of Woody Vegetation on the NTS

Appendix I Distribution on the NTS of the Top Dominant Woody Plant Species

Based on Abundance

Appendix J Distribution on the NTS of the Top Dominant Grasses, Forbs, and Succulents Based on the Relative Ranking of Dominance 
This Page Intentionally Left Blank 


\section{Appendix A}

\section{Plant Associations on the NTS Recognized by Beatley}

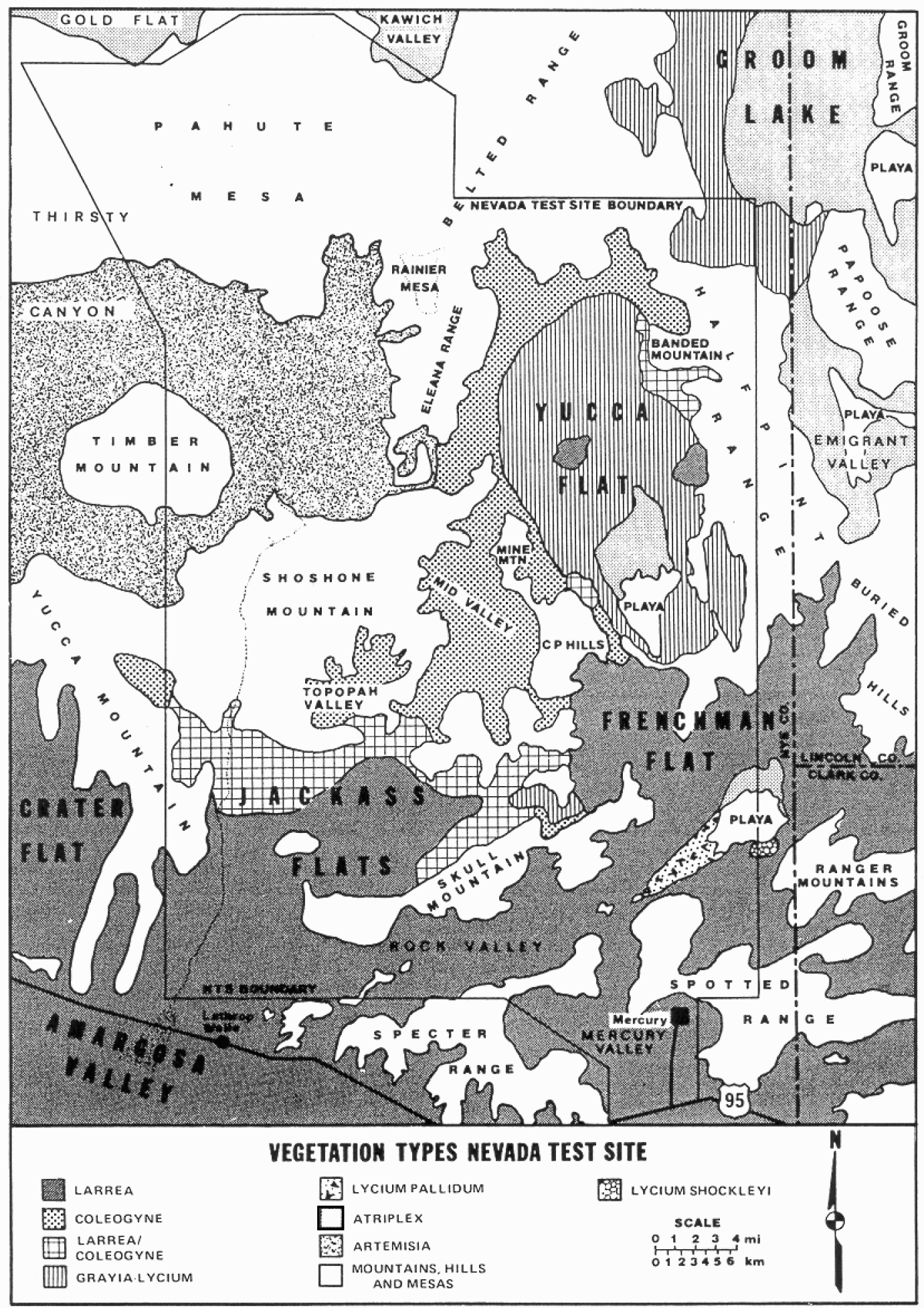


This Page Intentionally Left Blank 
APPENDIX A. PLANT ASSOCIATIONS ON THE NTS RECOGNIZED BY BEATLEY

1. Artemisia nova Association

2. Artemisia tridentata Association

3. Atriplex canescens Association

4. Atriplex - Ceratoides Association

5. Atriplex confertifolia Association

6. Coleogyne Association

7. Grayia - Lycium Association

8. Larrea - Ambrosia Association

9. Larrea - Atriplex Association

10. Larrea - Lycium - Grayia Association

11. Lycium andersonii - Grayia Association

12. Lycium pallidum - Grayia Association

13. Lycium shockleyi - Atriplex Association

14. Pinus - Juniperus - Artemisia Association 
This Page Intentionally Left Blank

$6 \mathrm{~A}-4$ 


\section{ARTEMISIA NOVA ASSOCIATION}

\author{
Regional Type: \\ Landform Type: \\ Series Name: \\ Association Name: \\ Beatley Type: \\ Prevailing Location:
}

Elevation:

Geology:

Soils:

Hydrology/drainage:

Precipitation:

Temperature:

Veg. Cover (\%):

\section{Distinguishing Conditions:}

Predominant Species:

Associate Species:
Great Basin Desertscrub Biome

Mountains and Uplands

Sagebrush

Artemisia nova

Artemisia nova

Large areas occur on northwestern Pahute Mesa and eastern Fortymile Canyon. Occurs in aspects and on soil types similar to Coleogyne but at higher elevations.

$5,000 \mathrm{ft}$ to $6,000 \mathrm{ft}(1,524 \mathrm{~m}$ to $1,829 \mathrm{~m})$. At its lower altitudinal limits, the species is present in narrow ecotones with Coleogyne and Atriplex-Ceratoides. At its upper altitudinal limit, it is replaced by Pinyon-Juniper-Artemisia associations.

(Not described, but reported to occur on volcanic and limestone mountain areas.)

The soils, unlike those of Artemisia tridentata associations, are residual, stony, and usually a thin mantle of various size rock particles over the underlying rock.

Mountains, mesas, foothills, or rolling uplands.

Mean rainfall was $8.0 \mathrm{in}$. (203 mm), and annually varied from 5.3 to $17.9 \mathrm{in}$. (135 to $455 \mathrm{~mm}$ ). The mean precipitation/mean temperature $(P / T)$ ratio was 16.6 .

Mean minimum temperature was $29.8^{\circ} \mathrm{F}\left(-1.2^{\circ} \mathrm{C}\right)$, and the extreme minimum temperature was $-3^{\circ} \mathrm{F}\left(-19.4^{\circ} \mathrm{C}\right)$; mean maximum temperature was $78.5^{\circ} \mathrm{F}\left(25.8^{\circ} \mathrm{C}\right)$, and the extreme maximum was $108^{\circ} \mathrm{F}\left(42.2^{\circ} \mathrm{C}\right)$. On the $A$. nova site, nighttime temperatures are much higher and daytime temperatures are lower than in the nearby lowland $A$. tridentata; moreover, the nights appear to be considerably warmer than in the lowlands of Frenchman and Yucca Flats, at 2,000 to $3,000 \mathrm{ft}$ lower elevation.

Plants are dark-stemmed, uniformly of low height (average $0.3 \mathrm{~m}$ ), closely spaced, and make up about 90 percent of the total shrub cover ( 37.3 percent, as measured). Maximum cover by herbaceous perennials was 3.8 percent, most of which was due to the grass Sitanion hystrix and lesser numbers of Stipa speciosum and Oryzopsis hymenoides. Winter annuals, represented by 10 species, had a maximum density of 73.8 plants $/ \mathrm{m}^{2}$ and cover of 5.3 percent.

Artemisia nova is the dominant species on stony and thin soils at elevations between $5,000 \mathrm{ft}$ to $6,000 \mathrm{ft}(1,524 \mathrm{~m}$ to $1,829 \mathrm{~m})$ with more moderate temperatures than A. tridentata associations.

Artemisia nova is the dominant species.

As in Coleogyne, Ephedra nevadensis and Yucca baccata are rather consistently, if sparingly, present in these communities below $6,000 \mathrm{ft}$. $(1,829 \mathrm{~m})$. The most predictable shrub associate is Chrysothamnus viscidiflorus ssp. puberulus. Several cacti are characteristic of this plant association: Coryphantha vivipara var. rosea, Echinocereus engelmannii var. chrysocentrus, and $E$. triglochidiatus vars. melanachanthus and mojavensis.

As in A. tridentata communities, there is a large number of herbaceous species associated with the $A$. nova communities of the region as a whole. Those species characteristic of $A$. nova vegetation (including the washes), or of interest because of their rarity or

$$
6 \mathrm{~A}-5
$$


uncommon occurrence in this association somewhere in the region (indicated by an asterisk), are the following:

\author{
Allium nevadense \\ Arabis dispar* \\ Arabis holboellii var. pinetorum \\ Arabis pulchra var. gracilis \\ Arabis shockleyui ${ }^{\star}$ \\ Aristida fendleriana \\ Astragalus beatleyae* \\ Astragalus calycosus \\ Astragalus casei \\ Astragalus purshii var. tinctus \\ Balsamorhiza hookeri var. \\ neglecta \\ Calochortus flexuosus \\ Camissonia pterosperma \\ Cleomella hillmanii \\ Cryptantha humilis var. ovina* \\ Delphinium andersonii \\ Dichelostemma pulchellum \\ Eriastrum sparsiflorum \\ Erigeron aphanactis*
}

Erigeron pumilus ssp. concinnoides

Eriogonum beatleyae *

Eriogonum ovalifolium var. multiscapum*

Eriogonum shockleyi*

Eriogonum rupinum*

Euphorbia fendleri

Gayophytum racemosum

Gilia aliquanta*

Gilia malior*

Gilia ophthalmoides

Hilaria jamesii

Hymenoxys cooperi

Lomatium nevadense

Lupinus brevicaulis

Lupinus uncialis*

Microsteris gracilis ssp. humilis

Microseris linearifolia

Mirabilis bigelovii
Munroa squarrosa

Orobanche corymbosa

Orobanche fasciculata

Pectocarya setosa

Phlox lanata*

Phoenicaulis cheiranthoides

Plantago purshii var. oblonga

Poa sandbergii

Polygala subspinosa var.

subspinosa

Senecio multilobatus

Sitanion hystrix

Sphaeralcea ambigua ssp.

monticola

Stylocline micropoides

Syntrichopappus fremontii

Tricardia watsonii

Viguiera multiflora var.

nevadensis 


\section{ARTEMISIA TRIDENTATA ASSOCIATION}

\section{Regional Type:}

Landform Type:

Series Name:

Association Name:

Beatley Type:

Prevailing Location:

Elevation:

Geology:

Soils:

Hydrology/drainage:

Precipitation:

Temperature:

Veg. Cover (\%):

\section{Distinguishing \\ Conditions:}

Predominant Species:

Associate Species:
Great Basin Desertscrub Biome

Upper Bajadas

Sagebrush

Artemisia tridentata

Artemisia tridentata

Occurs on large areas of Pahute Mesa, small areas on Rainier Mesa, and in the Fortymile Canyon drainage in nearly pure stands.

$5,000 \mathrm{ft}$ to $6,000 \mathrm{ft}(1,524 \mathrm{~m}$ to $1,829 \mathrm{~m})$. At its lower altitudinal limits, the species is present in narrow ecotones with Coleogyne and Atriplex-Ceratoides. At its upper altitudinal limit, it is replaced by Pinyon-Juniper-Artemisia associations.

(Not described.)

Soils may be either alluvial or residual, and are usually sandy and deep. In most areas, they are found in mosaics with Artemisia nova associations which are found on shallower and drier soils than Artemisia tridentata associations.

Upper bajadas and closed drainage basins.

Mean rainfall was $8.0 \mathrm{in}$. (203 $\mathrm{mm}$ ), and annually varied from 5.1 to $17.0 \mathrm{in}$. (130 to $432 \mathrm{~mm}$ ), as measured in the eastern Fortymile Canyon drainage, west of rainier Mesa at $5,740 \mathrm{ft}(1,750 \mathrm{~m})$. The mean P/T ratio was 17.3 .

Mean minimum temperature was $25.9^{\circ} \mathrm{F}\left(-3.4^{\circ} \mathrm{C}\right)$, and the extreme minimum temperature was $-10^{\circ} \mathrm{F}\left(-23.3^{\circ} \mathrm{C}\right)$; mean maximum temperature on this topographic site was $80.7^{\circ} \mathrm{F}$ $\left(27.0^{\circ} \mathrm{C}\right)$, and the extreme maximum was $110^{\circ} \mathrm{F}\left(43.3^{\circ} \mathrm{C}\right)$. Mean minimum temperature was $26.0^{\circ} \mathrm{F}\left(-3.3^{\circ} \mathrm{C}\right)$, and the extreme minimum was $-10^{\circ} \mathrm{F}\left(-23.3^{\circ} \mathrm{C}\right)$. Mean maximum temperature was $82.0^{\circ} \mathrm{F}\left(27.8^{\circ} \mathrm{C}\right)$, and the extreme summer temperature was $111^{\circ} \mathrm{F}$ $\left(43.8^{\circ} \mathrm{C}\right)$.

Shrub cover was 32.6 percent, 95 percent of which was due to Artemisia tridentata. Average height was $0.6 \mathrm{~m}$, but the shrubs are commonly as much as $0.9 \mathrm{~m}$ tall.

Artemisia tridentata is the dominant species on deep, usually sandy soils at elevations between $5,000 \mathrm{ft}$ to $6,000 \mathrm{ft}(1,524 \mathrm{~m}$ to $1,829 \mathrm{~m})$.

Artemisia tridentata is the dominant species.

Shrub species, usually sparingly represented in these communities, may be Ceratoides lanata, Chrysothamnus viscidiflonus spp. viscidiflorus and ssp. Stenophyllus, $C$. Nauseosus ssp. leiospermus, Ephedra viridis, Tetradymia glabrata, Eriogonum microthecum var. foliosum, Opuntia echinocarpa, and Echinocereus engelmannii var. amatus. In some areas, as on Pahute Mesa, Cowania mexicana var. stansburiana is prominently associated. Especially along washes or around low rock outcrops, Amelanchier utahensis, Purshia glandulosa, Symphoricarpos longiflorus, and Artemisia ludoviciana ssp. incompta are predictable. Of limited distributions along washes of volcanic areas are Prunus andersonii and Eriogonum umbellatum var. vemum, and along the major washes in limestone areas Lepidospartum latisquamum and Fallugia paradoxa are often common. Peraphyllum ramosissimum, rare and local on the Nevada Test Site (NTS), around calcareous rock outcrops in the Eleana and Halfpint Ranges, is common in washes (and on slopes) of the limestone Spring Mountains.

$6 \mathrm{~A}-7$ 
Herbaceous perennials are represented in these communities by a large number of species because there is great diversity in the origin of the soil materials over the region as a whole. However, except for the grasses, they are seldom present as more than occasional plants on any given site. As measured, their maximum cover was 6.6 percent, nearly all of which was due to the perennial grasses Stipa comata and Sitanion hystrix. Winter annuals are not consistently associated with this kind of vegetation (as measured, maximum density of 34.4 plants $/ \mathrm{m}^{2}$ [nine species], and cover of 7.7 percent), because low temperatures are limiting to germination most years. In total however, a number of winter annual species occur in Artemisia tridentata vegetation, and these, together with the herbaceous perennials that are more or less frequent in this shrub type (or of particular interest because they are rare or uncommon in this region, indicated by an asterisk), are the following (including the washes):

Abronia elliptica

Anisocoma acaulis

Anthimhinum kingii

Astragalus lentiginosus var. fremontii

Astragalus minthomiae var. villosus

Astragalus purshii var. tinctus

Astragalus beckwithii var.

purpureus

Astragalus newberryi

Baileya pleniradiata

Brickellia oblongifolia var. linifolia

Camissonia parvula*

Camissonia heterochroma

Camissonia claviformis ssp.

integrior

Camissonia boothii ssp.

intermedia

Caulanthus pilosus

Caulanthus glaber

Caulanthus crassicaulis

Chaenactis xantiana

Chenopodium leptophyllum

Chenopodium incanum

Cymopterus ripleyi

Dalea seartsiae

Descurania pinnata ssp.

halictorum
Eriastrum wilcoxii

Eriastrum sparsiflorum

Erigeron aphanactis*

Erigeron breweri var.

porphyreticus*

Eriogonum nutans*

Eriogonum hooker

Eriogonum deflexum var.

nevadense

Eriogonum deflexum var.

baratum

Eriogonum concinnum *

Eriogonum cemuum var.

viminale

Eriogonum brachyanthum

Eriogonum ovalifolium var.

ovalifolium

Eriogonum saxatile

Euphorbia albomarginata

Gayophytum ramosissimum

Gilia sinuata

Gilia modocensis

Gilia leptomeria

Gilia hutchinsifolia

Gilia brecciarum

Hilaria jamesil

Lathyrus hitchcockianus *

Leucelene ericoides

Linum lewisii
Lupinus caudatus

Lupinus holmgrenanus*

Lupinus aridus*

Malacothrix sonchoides

Mentzelia veatchiana

Mentzelia albicaulis

Nama densum *

Oenothera avita

Orobanche corymbosa

Orobanche fasiculata

Oryzopsis hymenoides

Oxybaphus comata

Oxytheca dendroidea*

Penstemon floridus

Phacelia bicolor

Phacelia crenulata var. funerea

Phlox stansburyi

Plagiobothrys kingii

Sitanion hystrix

Sphaeralcea ambigua ssp.

monticola

Sphaeralcea emoyi var.

variabilis

Sporobolus cryptandrus

Stanleya elata

Stanleya pinnata var. pinnata

Stephanomeria exigua

Stipa comata 


\section{ATRIPLEX CANESCENS ASSOCIATION}

\section{Regional Type:}

Landform Type:

Series Name:

Association Name:

Beatley Type:

Prevailing Location:

Elevation:

Geology:

Soils:

Hydrology/drainage:

Precipitation:

Temperature:

Veg. Cover (\%):
Great Basin Desertscrub Biome

Basin Floors or Lower Bajadas

Shadscale

Atriplex canescens

Atriplex canescens

The plant assemblages are the middle-elevation equivalents of the Lamea Ambrosia association of edaphically similar sites at the lower elevations. Occurs on the sandy soils of the southern and eastern Fortymile Canyon drainage; the north slope of the Shoshone Mountain; the west side of the Eleana Range, southern Groom Lake, southwestern Penoyer Valley, the Cane Spring of west Frenchman Flat and, to a lesser extent, at the middle elevations of southeastern Fortymile Canyon uplands west of the Sugar Loaves. Atriplex canescens (four-wing saltbush) also occurs in mosaic with Lycium pallidiumGrayia association and Atriplex confertifolia in the Frenchman Flat lowlands, at elevations around 2,000 ft $(610 \mathrm{~m})$.

Middle elevations of the region at $4,500 \mathrm{ft}(1,372 \mathrm{~m})$ to $5,500 \mathrm{ft}(1,676 \mathrm{~m})$.

Derived from volcanic tuffs and other geologic strata.

Deep loose sands.

Middle elevation bajadas.

At the middle elevations, mean annual rainfall, as measured on the southeastern Fortymile Canyon uplands west of the Sugar Loaves, was 7.2 in. (183 mm) and varied from 3.3 to 14.5 in. (84 to $368 \mathrm{~mm}$ ). The mean annual $P / T$ ratio was 16.8 . At the lower elevations, mean annual rainfall was $5.0 \mathrm{in} .(127 \mathrm{~mm})$ and varied among the years from 3.2 to 7.7 in. (81 to $196 \mathrm{~mm}$ ). The $P / T$ ratio was 9.3

At the middle elevations, mean minimum temperature for the 11-year period of record was $26.5^{\circ} \mathrm{F}\left(-3.0^{\circ} \mathrm{C}\right)$, with $-9^{\circ} \mathrm{F}\left(-22.8^{\circ} \mathrm{C}\right)$, the lowest temperature recorded in 11 winter seasons. Year-round mean maximum was $77.0^{\circ} \mathrm{F}\left(25.0^{\circ} \mathrm{C}\right)$, and the highest summer temperature was $108^{\circ} \mathrm{F}\left(42.2^{\circ} \mathrm{C}\right)$. At the lower elevations, mean minimum temperature was $25.7^{\circ} \mathrm{F}\left(-3.5^{\circ} \mathrm{C}\right)$, and the all-time low temperature reading for the NTS, $-18^{\circ} \mathrm{F}$ $\left(-27.8^{\circ} \mathrm{C}\right)$, was set in the winter of 1970 . Mean maximum temperature was $86.8^{\circ} \mathrm{F}$ $\left(30.4^{\circ} \mathrm{C}\right)$, and the all-time high temperature reading for the Test Site, $121^{\circ} \mathrm{F}\left(49.4^{\circ} \mathrm{C}\right)$, was set in 1969.

The middle- and lower-elevation communities have in common low shrub cover and small winter annual populations but, because of the large difference in mean rainfall, are dissimilar with respect to the representation of herbaceous perennials. In the middle elevations, shrub cover was around 15 percent, about two-thirds of which was the suffrutescent Eriogonum keameyi var. keameyi. Cover by herbaceous perennials fluctuated between 6 and 23 percent during the years 1963 to 1975, reflecting large fluctuations in rainfall during this period. Most of the cover was due to Oryzopsis hymenoides, but also to Dalea (petalostemum) seartsiae and Cymopterus ripleyi, both widely distributed species of sandy soils in this region, and especially Oenothera pallida which some years contributes as much as 5 percent to the total cover. Only in certain years are winter annuals present. Maximum winter annual density, in the six years of measurement, was 15 plants $/ \mathrm{m}^{2}$ (seven species), and maximum cover was 3.5 percent. 


\section{Distinguishing Conditions:}

Predominant Species:

Associate Species:
The lower-elevation communities are characterized by around 5.4 percent shrub cover, consisting almost entirely of Atriplex canescens. Cover by herbaceous perennials, including perennial grasses, was comparable to that elsewhere in lowland communities of the Mojave Desert; maximum was 2.1 percent (six species, all generally present in the Frenchman Flat lowlands). Maximum cover by winter annuals was 1.6 percent, with a maximum density of 20 plants $/ \mathrm{m}^{2}$ (two species).

Atriplex canescens is the dominant species located on deep loose sands at middle elevations.

Atriplex canescens is the dominant species.

Associated shrub species were Eriogonum keameyi var. keameyi, Chrysothamnus viscidiflorus ssp. viscidiflorus, Psorothamnus polydenius, and Ephedra viridis. Two endemic taxa have been described from this association: Gilia nyensis and Erogonum concinnum. In addition, the known ranges of some species are greatly extended by their occurrence on the sands of this area, including Lesquerella Iudoviciana and Oenothera pallida. In the Cane Spring of west Frenchman Flat $(4,000 \mathrm{ft}$ or 1,219 $\mathrm{m})$, Camissonia megalantha is reported to be an endemic species.

The following are the characteristic herbaceous species of the middle-elevation Atriplex canescens association; those which occur also in either the lower elevation Atriplex canescens or Larrea-Ambrosia associations are indicated with an asterisk.

\author{
Abronia turbinata \\ Ambrosia acanthicarpa \\ Anisocoma acaulis \\ Baileya pleniradiata \\ Camissonia heterochroma \\ Camissonia megalantha* \\ Chaetadelphia wheeleri \\ Chenopodium desiccatum var. \\ leptophylloides \\ Coldenia plicata \\ Coldenia nuttallii \\ Cryptantha micrantha \\ Cymopterus nipleyi \\ Dalea searisiae*
}

Eriastrum eremicum
Eriogonum concinnum*
Eniogonum brachyanthum*
Eriogonum hooker*
Gilia leptomeria
Gilia campanulata
Gilia nyensis*
Ipomopsis depressa
Iva nevadensis
Langloisia schottii
Lesquella ludoviciana*
Lupinus shockleyi
Lupinus pusillus var.
intemontanus*

\author{
Machaeranthera canescens \\ Malacothrix sonchoides \\ Mentzelia nitens \\ Nama aretioides \\ Oenothera pallida* \\ Orobanche fasciculata * \\ Oryzopsis hymenoides \\ Penstemon venosus ${ }^{*}$ \\ Phacelia bicolor \\ Prenanthella exigua \\ Stephanomeria exigua
}




\section{ATRIPLEX - CERATOIDES ASSOCIATION}

\section{Regional Type:}

Landform Type:

Series Name:

Association Name:

Beatley Type:

Prevailing Location:

\section{Elevation:}

\section{Geology:}

Soils:

Hydrology/drainage:

Precipitation:

Temperature:

Veg. Cover (\%):

\section{Distinguishing Conditions:}

Predominant Species:

Associate Species:
Great Basin Desertscrub Biome

Drainage Basins

Shadscale

Atriplex - Ceratoides

Atriplex - Ceratoides

Is the most widely represented of the shadscale series and is considered to be the association from which the other Atriplex associations are derived in this region. Occurs in southern Yucca Flat which is intermediate in elevation between the Atriplex - Kochia americana association (occurs next to the playa) and the Grayia - Lycium communities at slightly higher elevations.

(Not stated, but inferred to be $>4,000 \mathrm{ft}$ or $1,219 \mathrm{~m}$ ).

(Not stated, but usually basin floors.)

Soils of fine particles and sandy loams, better drained than the Atriplex confertifolia association and less sandy than the Atriplex canescens association.

Relatively level drainage basins.

Mean rainfall for the ten-year period was $7.0 \mathrm{in} .(178 \mathrm{~mm})$, varying annually from 1.9 to 16.7 in. (48 to $424 \mathrm{~mm}$ ). The mean $P / T$ ratio was 14.6 .

Mean minimum temperature was $26.0^{\circ} \mathrm{F}\left(-3.3^{\circ} \mathrm{C}\right)$, and the extreme minimum was $-10^{\circ} \mathrm{F}$ $\left(-23.3^{\circ} \mathrm{C}\right)$. Mean maximum temperature was $82.0^{\circ} \mathrm{F}\left(27.8^{\circ} \mathrm{C}\right)$, and the extreme summer temperature was $111^{\circ} \mathrm{F}\left(43.8^{\circ} \mathrm{C}\right)$.

Shrub cover varied from 17.5 percent in 1963 to 25.6 percent in 1975 on the same site, in part reflecting the effects of 16.7 in. $(425 \mathrm{~mm}$ ) of rainfall in 1969 . Percentage of the shrubs that were Atriplex confertifolia and Ceratoides lanata (74 percent), however, remained unchanged. The number of herbaceous species and individuals present was higher than species in the Atriplex - Kochia association. Maximum cover by herbaceous perennials was 2.4 percent (consisting of Astragalus lentiginosus var. fremontii, Mirabilis pudica, and Oryzopsis hymenoides); maximum winter annual density was 76.4 plants $/ \mathrm{m}^{2}$ (nine species), and 8.3 percent cover.

Atriplex confertifolia and Ceratoides lanata are the dominant species located in drainage basins higher in elevation than the Atriplex confertifolia association.

Atriplex confertifolia and Ceratoides lanata are the dominant species.

Other associated shrub species include Artemisia spinescens, Grayia spinosa, Lycium andersonii, and Tetradymia glabrata. Chrysothamnus greenei ssp. filifolius and C. viscidiflorus ssp. stenophyllus are predominant associates or co-dominants over large disturbed areas in the drainage basins to the north. The introduced annuals Halogeton glomeratus and Salsola species are common weeds in disturbed areas of this association.

Herbaceous species (and cacti) that either characterize the Atriplex communities as a whole or are of special interest because they are known in the region only in the Atriplex vegetation are the following: 
Astragalus lentiginosus var. Camissonia boothii ssp.

intermedia

Camissonia clavivormis ssp.

Integrior

Caulanthus pilosus

Chenopodium nevadense

Chenopodium incanum

Cleome semulata

Eriogonum deflexum var. nevadense

Euphorbia albomarginata

Hermidium alipes fremontii

Hilaria jamesii

Ipomopsis depressa

Iva nevadensis

Langloisia punctata

Lepidium montanum ssp.

canescens

Machaeranthera canescens

Mentzelia torreyi

Oenothera caespitosa ssp.

crinita

Opuntia pulchella

Oryzopsis hymenoides
Blepharidachne kingii

Penstemon venosus

Penstemon arenarius

Psathyrotes annua

Psoralea lanceolata ssp. scabra

Sclerocactus polyancirstrus

Scleropogon brevifolius

Sphaeralcea ambigua ssp.

monticola

Sporobolus cryptandrus 


\section{ATRIPLEX CONFERTIFOLIA ASSOCIATION}

Regional Type:

Landform Type:

Series Name:

Association Name:

Beatley Type:

Prevailing Location:

\section{Elevation:}

\section{Geology:}

Soils:

Hydrology/drainage:

Precipitation:

Temperature:

Veg. Cover (\%):

\section{Distinguishing Conditions:}

Predominant Species:

Associate Species:

\author{
Great Basin Desertscrub Biome
}

Closed Drainage Basins

Shadscale

\section{Atriplex confertifolia}

Atriplex confertifolia

Occurs over many square miles of the basin floors of Gold Flat, Kawich Valley, Groom Lake, and other basins to the north. Lowland Atriplex communities in the corridor of desert transition, or in the Mojave Desert, are usually restricted to discrete areas in the vicinity of playas, from which the Mojave Larrea communities are inferred to be excluded by the low temperatures of the lowlands. In Frenchman Flat of the NTS, the association is represented by a nearly pure stand of Atriplex in a discrete, roughly triangular-shaped area north of the playa. The Lycium pallidum - Grayia and Atriplex canescens communities extend to the southwest, and the Lycium shockleyi communities are along the south playa margin.

(Not stated.)

(Not stated, but usually basin floors.)

Soils on or near playas of fine particles and higher soil salinity levels than soils of other associations.

Drainage basins and lower bajadas.

Mean rainfall was $5.1 \mathrm{in.}(129 \mathrm{~mm}$ ), annual rainfalls ranged from 3.2 to $7.9 \mathrm{in}$. (81 to $201 \mathrm{~mm}$ ). The mean $\mathrm{P} / \mathrm{T}$ ratio was 9.4 .

Mean minimum temperature on the north side of the playa at Frenchman Flat, was $26.6^{\circ} \mathrm{F}$ $\left(-3.0^{\circ} \mathrm{C}\right)$, and the extreme for all winters was $-8^{\circ} \mathrm{F}\left(-22.2^{\mathrm{C}} \mathrm{C}\right)$. Maximum temperatures in these lowlands are among the highest in the region: Mean maximum was $85.9^{\circ} \mathrm{F}$ $\left(29.9^{\circ} \mathrm{C}\right)$, and the highest summer temperature recorded was $120^{\circ} \mathrm{F}\left(48.8^{\circ} \mathrm{C}\right)$.

Shrub cover is the lowest in the regional vegetation mosaic (5.5 percent), and likewise the number of herbaceous species represented. Number of individuals of the few species is variable. As measured, maximum cover by herbaceous perennials was 1.1 percent (consisting of two species, Sphaeralcea panifolia and Oryzopsis hymenoides); for the winter annuals, maximum density was 2.6 plans $/ \mathrm{m}^{2}$, and 0.9 percent cover (five species), which is the lowest maximum occurrence (over a six-year period) of winter annuals in any kind of vegetation in the region.

Atriplex confertifolia is the dominant species located in drainage basins on fine-textured soils or droughty soil conditions.

Atriplex confertifolia is the dominant species.

Spaeralcea parvifolia and Oryzopsis hymenoides are the key perennials species. Many species appear to be excluded from these sites because of extremes in temperatures and adverse soil conditions such as fine particle sizes and higher soil-salt contents. Herbaceous species (and cacti) that either characterize the Atriplex communities as a whole or are of special interest because they are known in the region only in the Atriplex vegetation are the following:

$$
6 \mathrm{~A}-13
$$


Astragalus lentiginosus var. fremontii

Blepharidachne kingii

Camissonia boothii ssp.

intermedia

Camissonia clavivormis ssp.

Integrior

Caulanthus pilosus

Chenopodium nevadense

Chenopodium incanum

Cleome semulata

Eriogonum deflexum var. nevadense
Euphorbia albomarginata Hemidium alipes

Hilaria jamesii

Ipomopsis depressa

Iva nevadensis

Langloisia punctata

Lepedium montanum ssp.

canescens

Machaeranthera canescens

Mentzelia torreyi

Oenothera caespitosa ssp.

crinita

Opuntia puichella
Oryzopsis hymenoides

Penstemon venosus

Penstemon arenarius

Psathyrotes annua

Psoralea lanceolata ssp. scabra

Sclerocactus polyancirstrus

Scleropogon brevifolius

Sphaeralcea ambigua ssp.

monticola

Sporobolus cryptandrus 


\title{
6. COLEOGYNE ASSOCIATION
}

\author{
Regional Type: \\ Great Basin Desertscrub Biome \\ Landform Type: \\ Upper Bajadas (and lower foothills) \\ Series Name: \\ Blackbrush \\ Association Name: \\ Coleogyne \\ Beatley Type: \\ Coleogyne
}

Prevailing Location: The upper bajadas of the north and east slopes of Jackass Flats, the east slope of Frenchman Flat, much of the western and northern Yucca Flat, and the entire basin floors of Topopah Valley and Mid Valley. It also occurs on the upper bajadas below the Spring Mountains.

\section{Elevation:}

Geology:

Solis:

Hydrology/drainage:

Precipitation:

Temperature:

Veg. Cover (\%):

\section{Distinguishing Conditions:}

Predominant Species:
Between 4,000 ft $(1,219 \mathrm{~m})$ elevation to $5,000 \mathrm{ft}(1,524 \mathrm{~m})$.

Soils derived from calcareous rocks or dolomite hills.

Soils are usually shallow, contain many gravels, boulders of various size, or rocky outcrops, and have a predominantly sand matrix. On the floors of the middle-elevation open drainage basins, where the vegetation may cover many square miles, alluvial deposits are deeper and there are fewer large rock fragments in the surface and subsurface soils. Nearly everywhere they occur, however, these communities are associated with soils that would be characterized as stony or rocky soils.

Upper bajadas or lower foothills.

The lower precipitation range is around $6.4 \mathrm{in} .(160 \mathrm{~mm})$ mean annual rainfall, although the mean annual rainfall, as measured for 10 years, was about 8.9 to $9.5 \mathrm{in}$. (225 to $240 \mathrm{~m}$ ) in areas where Coleogyne is best developed (in Topopah and Mid Valleys and on upper bajadas of northwestern Yucca Flat below the Eleana Range). Average rainfall amounts were reported to vary from 3.7 to $19.9 \mathrm{in}$. (94 to $505 \mathrm{~mm}$ ). The upper range of mean rainfall is about $7.2 \mathrm{in}$. $(180 \mathrm{~mm})$. Variation of annual rainfall in ecotones of Larrea/Coleogyne ranged from 2.0 to $17.6 \mathrm{in.}(51$ to $447 \mathrm{~mm})$. Mean P/T ratios are in the range of 14.7 to 17.0 .

The year-round mean minimum air temperature ranged from 33.0 to $35.4^{\circ} \mathrm{F}\left(0.8\right.$ to $\left.1.9^{\circ} \mathrm{C}\right)$, with an extreme minimum air temperature of $-7^{\circ} \mathrm{F}\left(-21.7^{\circ} \mathrm{C}\right)$. The year-round mean maximum air temperature ranged from 81.8 to $83.7^{\circ} \mathrm{F}\left(27.7\right.$ to $\left.28.7^{\circ} \mathrm{C}\right)$, with an extreme maximum air temperature of $118.0^{\circ} \mathrm{F}\left(47.7^{\circ} \mathrm{C}\right)$. Temperature parameters alone do not distinguish the blackbrush environments from that of the creosote environments.

Percent shrub cover reaches its highest value in the region in the nearly pure stands of Coleogyne (as measured, 45 to 51 percent cover), in a large part reflecting the high rainfall. The populations are uniform in height (average around $15 \mathrm{in}$. [37 cm]) nearly everywhere they occur in the region. The plants are closely spaced and are scarcely or not at all in clumps.

Maximum cover values for native winter annuals for the period 1963 to 1968 was 7.8 percent cover and 97.6 plants $/ \mathrm{m}^{2}$ (density). Maximum cover value for herbaceous perennials was 0.4 percent, and on most sites was $<0.1$ percent, with the perennial grasses uniformly scarcely represented, except in the ecotones with other kinds of vegetation.

Coleogyne is the dominant species on upper bajadas and lower foothills on rocky and sandy soils with no or few co-dominant species.

Coleogyne ramosissima is the dominant species. 
Associate Species:

The single predictable associated shrub is the sparingly represented Ephedra nevadensis. Around rocky outcrops Chrysothamnus teretifolius is also predictable. Toward its lower altitudinal limits, especially in the ecotones with Larrea, Yucca brevifolia (Joshua Tree) is often prominent, and towards its upper altitudinal limits, especially in the ecotones with Artemisia, Yucca baccata is often represented. Otherwise, occasional plants of Opuntia echinocarpa (Golden Cholla) are commonly all that breaks the uniformity of this welldefined plant association.

In the broad ecotones, other species are associated, principally Larrea tridentata, Lycium andersonii, and Grayia spinosa. These species, and other shrubs such as Ephedra nevadensis, occur in discrete clumps within the matrix of closely spaced Coleogyne plants. Where Atriplex confertifolia shares dominance of the site with Coleogyne, as is commonly the case on the upper bajadas below limestone hills or mountain ranges, or site dominance is shared with Menodora spinescens, as occurs across the whole of the upper north slope of Jackass Flats, there is also a marked tendency for Coleogyne and the second shrub species to be somewhat segregated in their local distribution. The ecotonal communities are therefore mosaics, more or less, of two plant associations, each with its own soil environment and herbaceous flora.

Although many herbaceous species occur in the Coleogyne communities, they are seldom present in large numbers, except in the ecotones. The introduced winter annual, Bromus rubens, has become thoroughly integrated into the Coleogyne vegetation of certain areas with densities as high as 1,500 plants $/ \mathrm{m}^{2}$ and cover as much as 30 percent, largely due to fire and man-caused disturbances. A number of herbaceous species, are predictable in this association, even if present in small numbers including:

Amaranthus fimbriatus

Arabis pulchra var. munciensis

Astragalus layneae

Astragalus acutirostris

Astragalus casei

Balsamorhiza hookeri var. neglecta

Calochortus flexuosus

Calycoseris parryi

Castilleja chromosa

Chelanthes covillei

Chorizanthe watsonii

Chorizanthe thurberi

Cymopterus globosus

Delphinium parishii
Dicholostemma pulchellum

Emmenanthe pendulifiora

Eriogonum howellianum

Euphorbia serpyllifolia

Euphorbia setiloba

Euporbia micromera

Gilia aliquanta

Gilia malior

Linanthus dichotomus

Lomatium nevadense

Lotus humistratus

Lupinus brevicaulis

Mentzelia veatchiana

Microseris linearifolia

Oenothera primiveris
Pectocarya setosa

Penstemon utahensis

Plagiobothrys arizonicus

Plantago purshii var. oblonga

Sitanion hystrix

Sitanion jubatum

Stephanomeria pamyi

Stipa speciosum

Stylocline micropoides

Suntrichopappus fremontii

Thysanocarpus curvipes var. eradiatus

Tricardia watsonii 


\title{
7. GRAYIA - LYCIUM ASSOCIATION
}

\author{
Regional Type: $\quad$ Mojave Desertscrub Biome \\ Landform Type: $\quad$ Closed Drainage Basins \\ Series Name: $\quad$ Lycium \\ Association Name: Lycium andersonii - Grayia \\ Beatley Type: Grayia-Lycium
}

Prevailing Location: Located on large areas of the floors of closed drainage basins and locally on upper bajadas or near drainage divides (as in the upper Cane Spring Wash area of the NTS) and lower mountain slopes of the transition region. On the long, low-gradient basin floor of Yucca Flat (and that of southern Groom Lake to the north), the communities are well developed over many square miles where the lowlands are under the influence of cool or cold air accumulations.
Elevation:
Between $4,000 \mathrm{ft}(1,219 \mathrm{~m})$ and $5,000 \mathrm{ft}(1,524 \mathrm{~m})$ elevation.
Geology:
Variable geologic origin of parent materials in closed drainage basins.

Soils:

Silt loams or sandy loams on the lower bajadas that are derived from usually deep alluvial deposits.

Hydrology/drainage: Primarily on closed drainage basins and lower bajadas.

Precipitation:

Mean rainfall is regionally intermediate, on the sites of measurements being in the range of 6.5 to $7.1 \mathrm{in}$. (164 to $179 \mathrm{~mm}$ ). Annual rainfalls varied from 1.7 to $16.4 \mathrm{in}$. (43 to $417 \mathrm{~mm}$ ).

Temperature:

Minimum temperatures are comparable to those in the Great Basin Desert of central and northern Nevada. Year-round mean minimums were from 25.6 to $28.3^{\circ} \mathrm{F}\left(-3.6\right.$ to $\left.2.1^{\circ} \mathrm{C}\right)$, and extreme minimums of the 10 -year record were -14 to $-12^{\circ} \mathrm{F}\left(-25.5\right.$ to $\left.-24.4^{\circ} \mathrm{C}\right)$.

Maximum temperatures are similar to those of the Mojave Desert in the south: Mean maximum temperatures were from 82.1 to $83.6^{\circ} \mathrm{F}\left(27.8\right.$ to $\left.28.6^{\circ} \mathrm{C}\right)$, and the extreme maximums recorded were from 111 to $116^{\circ} \mathrm{F}\left(43.8\right.$ to $\left.46.6^{\circ} \mathrm{C}\right)$. Mean $\mathrm{P} / \mathrm{T}$ ratios varied from 13.1 to 13.5 .

Veg. Cover (\%):

Total shrub cover is from 32 to 37 percent, with 40 to 60 percent of this being attributable to the two dominant species, Lycium andersonii and Grayia spinosa, which grow in close association in usually well-developed clumps. Average shrub height is 0.4 to $0.5 \mathrm{~m}$. In most seasons, Oryzopsis hymenoides or Sitanion hystrix have cover values less than 0.2 percent. Winter annuals, although limited in most years by soil temperature, have cover up to 19 percent, with densities up to 200 plants $/ \mathrm{m}^{2}$ and as many as 20 species $/ 100 \mathrm{~m}^{2}$.

\section{Distinguishing Conditions:}

Predominant Species:

Associate Species:
Lycium andersonii and Grayia spinosa are the two co-dominants located in closed drainage basins where cold air accumulates on silt or sandy loam soils.

Grayia spinosa and Lycium andersonii are the two co-dominants.

Ceratoides lanata is prominently represented (locally may be numerical dominant). In some areas, Tetradymia glabrata, Artemisia spinescens, Atriplex canescens, or Acamptopappus shockleyi are numerically important constituents. Other associated woody species are especially Chrysothamnus viscidiflorus ssp. stenophyllus, Ephedra nevadensis, Tetradymia axillaris, Yucca brevifolia, and Opuntia echinocarpa. Opuntia stanlyi var. prishii is known only from this kind of vegetation.

Among the herbaceous perennials, Mirabilis pudica (endemic to the desert transition region of southern Nevada), Sphaeralcea ambigua ssp. monticola, and Stephanomeria parryi are more or less consistently present in significant numbers in the undisturbed 
communities. Oryzopsis hymenoides or Sitanion hystrix are predictable constituents. Herbaceous species generally predictable in this association are as follows:

Amaranthus fimbriatus Amsinckia tessellata Arabis glaucovalvula Astragalus acutirostris Astragalus lentiginosus var. fremontii

Calycoseris wrightii

Camissonia boothii ssp. condensata

Camissonia claviformis ssp.

Integrior

Caulanthus cooperi

Caulanthus lasiophyllus

Chaenactis stevioides

Chaenactis macrantha

Chenopodium incanum

Cryptanta recurvata

Cryptantha nevadensis

Cryptantha pterocarya
Cryptantha circumscissa

Delphinium parishii

Descurainia pinnata ssp. glabra

Eriastrum eremicum

Eriogonum nidularium

Eriogonum deflexum var.

nevadense

Eriogonum maculatum

Eriophyllum pringlei

Euphorbia albomarginata

Euphorbia micromera

Gilia cana ssp. triceps

Glyptopleura marginata

Ipmopsis polycladon

Langloisia schottii

Lupinus flavoculatus

Machaeranthera tortilifolia var.

tortifolia

Malacothrix glabrata
Mentzelia obscura

Mentzelia albicaulis

Mirabilis pudica

Oryzopsis hymenoides

Oxytheca perfoliata

Pectis papposa

Phacelia fremontii

Phacelia vallis-mortae

Polygala subspinosa var.

heteromyncha

Prenanthella exigua

Rafinesquia neomexicana

Sitanion hystrix

Sphaeralcea ambigua ssp. monticola

Stanleya pinnata var. pinnata

Stephanomeria parryi

Streptanthella longirostris 


\section{LARREA - AMBROSIA ASSOCIATION}

Regional Type:

Landform Type:

Series Name:

Association Name:

Beatley Type:

Prevailing Location:

Elevation:

Geology:

Soils:

Hydrology/drainage:

Precipitation:

Temperature:

Veg. Cover (\%):

\section{Distinguishing Conditions:}

\section{Predominant Species:}

Associate Species:
Mojave Desertscrub Biome

Bajada

Creosote

Lamea-Ambrosia

Larrea-Ambrosia

The long, low-gradient bajada extending from Shoshone Mountain in northwestern Jackass Flats, south into Amargosa Valley, and in the deep sands in the northeastern Frenchman Flat south and west of the Buried Hills; elsewhere, the sands below the Striped Hills and the Big Dune area of the northern Amargosa Valley are large areas that are edaphically similar.

Below 4,000 ft $(1,219 \mathrm{~m}$ ) elevation (lower elevations of NTS is at about $2,780 \mathrm{ft}$ or $850 \mathrm{~m}$ ).

(Not described.)

Deep, loose sands without a surface pavement.

Low-gradient bajadas.

All Associations within the Creosote Series - Mean rainfall as low as $4.61 \mathrm{in}$. (117 mm) 10 -year mean annual rainfall, ranging from 1.9 to 12.7 in. (49 to $324 \mathrm{~mm}$ ). Sixty to sixtyfive percent of rain comes between the middle of September and late March (autumn and winter). Mean $\mathrm{P} / \mathrm{T}$ ratios varied from 7.4 to 10.1 .

All Associations within the Creosote Series - Mean maximum temperatures for all seasons were 81.1 to $87.4^{\circ} \mathrm{F}\left(27.2\right.$ to $\left.30.7^{\circ} \mathrm{C}\right)$, and mean minimums were from 29.1 to $39.8^{\circ} \mathrm{F}(-1.6$ to $4.3^{\circ} \mathrm{C}$ ). The extreme maximum temperature recorded for these communities during the 10 -year period was $117^{\circ} \mathrm{F}\left(47.2^{\circ} \mathrm{C}\right)$, and the extreme minimum was $-8^{\circ} \mathrm{F}\left(-22.2^{\circ} \mathrm{C}\right)$.

All Associations within the Creosote Series - Total shrub cover on the Bajadas of the NTS varies from 7.2 to 23.1 percent, and average height of all shrubs varies from $1.6 \mathrm{ft}$ $(0.2 \mathrm{~m})$, where Larrea is scarcely represented and all shrubs are of low stature, to $3.0 \mathrm{ft}$ $(0.9 \mathrm{~m})$, where most of the shrubs are large Larrea plants.

Larrea tridentata and Ambrosia dumosa are dominants at lower elevations with perennial grasses on deep loose sands without surface pavement.

Larrea tridentata and Ambrosia dumosa (bursage) are the usual co-dominants.

Common shrub associates are Psorothamnus (Dalea) fremontii, Krameria parvifolia, Ephedra nevadensis, Ceratoides lanata and, in some areas, Acamptopappus shockleyi or Menodora spinescens. In extreme cases, as for example in the Lathrop Wells area and below the red cinder cone of the northern Amargosa Valley, oniy Larrea is represented.

Perennial grasses (especially Oryzopsis hymenoides) are characteristic of this association. A number of other herbaceous species characterize the communities as a whole, but most are of more or less restricted distribution and only some are predictable everywhere. Among these species are the following:

\author{
Abronia turbinata \\ Anisocoma acaulis \\ Astragalus didymocarpus var. \\ dispermus \\ Astragalus lentiginuosus var. \\ micans
}

\author{
Calyptridium monandrum \\ Camissonia brevipes ssp. \\ brevipes \\ Chaenactis fremontii \\ Chaetadelphia wheeleri \\ Coldenia nuttallii
}

\author{
Coldenia plicata \\ Cryptantha micrantha \\ Cympterus ripleyi \\ Dalea mollissima \\ Eremalche exilis \\ Eremalche rotundifolia
}


Eriastrum eremicum Eriogonum insigne Eriophyllum pringlei Euphorbia parishii Gerea canescens Gilia campanulata Glyptopleura setulosa Langloisia schottii

Linanthus arenicola Lupinus shockleyi
Malacotrix sonchoides

Monoptilon bellioides

Monoptilon bellidiforme

Nama aretioides

Nama depressum

Nemacladus rubescens

Oenothera deltoides

Oryzopsis hymenoides

Penstemon thurberi var. anestius
Penstemon albomarginatus Polygala subspinosa var. heteromyncha

Sphaeralcea emoryi var. variabilis

Sporobolus flexuosus Stephanomeria exigua Stillingia spinulosa

Streptanthella longirostris 


\title{
9. LARREA - ATRIPLEX ASSOCIATION
}

\author{
Regional Type: $\quad$ Mojave Desertscrub Biome \\ Landform Type: Bajada \\ Series Name: $\quad$ Creosote \\ Association Name: $\quad$ Larrea - Atriplex \\ Beatley Type: $\quad$ Larrea - Atriplex
}

Prevailing Location: Found on the bajadas of probably the major part of the Mojave area and at elevations of usually less than $4,000 \mathrm{ft}(1,219 \mathrm{~m})$. $\begin{array}{ll}\text { Elevation: } & \text { Between } 3,500 \mathrm{ft}(1,067 \mathrm{~m}) \text { to } 4,000 \mathrm{ft}(1,219 \mathrm{~m}) \text { elevation (higher elevations than the } \\ & \text { Lamrea-Ambrosia Association Type). }\end{array}$

Geology: $\quad$ Found where soils are calcareous originating in the limestone-dolomite mountain ranges and foothills.

Soils: $\quad$ On soils having a well-developed surface pavement, and the soil matrix is generally finertextured (fine sandy or silt loams) associated nearly everywhere with gravels or larger fragments in the root zone. A more or less hardened calcareous hardpan (caliche) is commonly near the surface and restrictive to root depth.

Hydrology/drainage: Bajadas

Precipitation: $\quad$ All Associations in the Creosote Series - Mean rainfall as low as $4.61 \mathrm{in}$. (117 $\mathrm{mm}$ ) 10-year mean annual rainfall, ranging from 1.9 to $12.7 \mathrm{in}$. (49 to $324 \mathrm{~mm}$ ). Sixty to sixtyfive percent of rain comes between the middle of September and late March (autumn and winter). Mean $\mathrm{P} / \mathrm{T}$ ratios varied from 7.4 to 10.1 .

Temperature:

All Associations in the Creosote Series - Mean maximum temperatures for all seasons were 81.1 to $87.4^{\circ} \mathrm{F}\left(27.2\right.$ to $\left.30.7^{\circ} \mathrm{C}\right)$, and mean minimums were from 29.1 to $39.8^{\circ} \mathrm{F}(-1.6$ to $\left.4.3^{\circ} \mathrm{C}\right)$. The extreme maximum temperature recorded for these communities during the 10-year period was $117^{\circ} \mathrm{F}\left(47.2^{\circ} \mathrm{C}\right)$, and the extreme minimum was $-8^{0} \mathrm{~F}\left(-22.2^{\circ} \mathrm{C}\right)$.

Veg. Cover (\%):

All Associations in the Creosote Series - Total shrub cover on the Bajadas of the NTS varies from 7.2 to 23.1 percent, and average height of all shrubs varies from $0.7 \mathrm{ft}(0.2 \mathrm{~m})$, where Larrea is scarcely represented and all shrubs are of low stature, to $3.0 \mathrm{ft}(0.9 \mathrm{~m})$, where most of the shrubs are large Larrea plants.

\section{Distinguishing} Conditions:

Predominant Species:

Associate Species:
Larrea tridentata and Atriplex confertifolia are the co-dominants at slightly higher elevations than Larrea-Ambrosia Association with well-developed surface pavement, generally without a hardpan near the surface, and with a fine sandy or silty loam matrix with gravels and larger rock fragments in the root zone.

Larrea tridentata and Atriplex confertifolia are consistent co-dominants. The communities are regionally those with the greatest floristic diversity. Species composition varies with the mountain range or part of the range, the soil materials, and accordingly the plant distribution boundaries are often sharply defined. On many bajadas, the communities occur in mosaic with Larrea-Ambrosia, and Larrea-Ambrosia-Atriplex is a well-defined variant of certain bajadas.

In most communities, Psorothamnus fremontii and Krameria panivolia are prominently represented. In certain ones, Ephedra torreyana or E. funerea is numerically prominent, both of which have highly restricted and nonoverlapping distributions in the region. In other areas, the ecological equivalent is the widely distributed $E$. nevadensis. Either Lycium shockleyi or L. pallidum may be co-dominants in this association, although neither is exclusively identified with it. Yucca schidigera (Mojave Yucca) occurs in certain areas, where it may be associated with either Lamea-Atriplex or Larrea-Ambrosia vegetation and often has the status of a community dominant. Opuntia ramosissima is known only from 
this kind of vegetation; $O$. basilaris, perhaps the most widely distributed cactus of the region, is frequently in these communities. Suffrutescent perennials essentially restricted to these communities are Sphaeralcea ambigua ssp. ambigua and Stephanomeria pauciflora.

Herbaceous species most characteristic of this association, or restricted to it, are the following:

\author{
Allionia incamata \\ Androstephium brevifiorum \\ Anthirrhinum filipes \\ Astragalus tidestromii \\ Atrichoseris platyphylla \\ Bouteloua barbata \\ Camissonia boothii ssp. \\ condensata \\ Camissonia brevipes ssp. \\ pallidula \\ Camissonia munzii \\ Chaenactis carphoclinia \\ Chorizanthe rigida \\ Cryptantha augustifolia \\ Cryptantha decipiens \\ Cryptantha recurvata
}

Cryptantha virginensis

Eriogonum bifurcatum

Eriogonum defiexum var.

deflexum

Eriogonum inflatum

Erioneuron pulchellum

Eriogonum rixfordii

Eriogonum trichopes

Gilia clokeyi

Gilia filiformis

Gilia transmontana

Hilaria rigida

Langloisia setosissima

Lepidium flavum

Lepidium fremontii

Mimulus parryi
Nama pusillum

Nemacladus glanduliferus var.

orientalis

Nemacladus sigmoideus

Oenothera primiveris

Orobanche cooperi

Pectocarya heterocarpa

Pectocarya platycarpa

Pectocarya recunata

Phacelia crenulata var. crenulata

Plantago insularis var. fastigiata

Selinocarpus diffusus

Tidestromia oblongifolia

Vulpia octoflora 


\title{
10. LARREA - LYCIUM - GRAYIA ASSOCIATION
}

\author{
Regional Type: Mojave Desertscrub Biome \\ Landform Type: Bajada \\ Series Name: Creosote \\ Association Name: Larrea - Lycium - Grayia \\ Beatley Type: $\quad$ Larrea - Lycium - Grayia
}

Prevailing Location: Found on the lower north and east slopes of Jackass Flats and much of the western half of Frenchman Flat where soils are derived from volcanic mountains and hills. The association occurs elsewhere in the region where there is similar origin of soil materials and at elevations of usually less than $4,000 \mathrm{ft}(1,219 \mathrm{~m})$.

Elevation:

Between $3,500 \mathrm{ft}(1,067 \mathrm{~m})$ to $4,000 \mathrm{ft}(1,219 \mathrm{~m})$ elevation (higher elevations than the Larrea-Ambrosia Association Type).

\section{Geology:}

Soils:

Hydrology/drainage:

Precipitation:

Temperature:

Veg. Cover (\%):

\section{Distinguishing Conditions:}

Predominant Species:

Associate Species:
Found where soils are derived from volcanic mountains and hills.

On soils having a more or less imperfectly developed surface pavement, generally without a hardpan near the surface, and with a sandy loam matrix with larger rock fragments scattered throughout.

\section{Bajadas}

All Associations in the Creosote Series - Mean rainfall as low as $4.61 \mathrm{in}$. (117 mm) 10-year mean annual rainfall, ranging from 1.9 to 12.7 in. (49 to $324 \mathrm{~mm}$ ). Sixty to sixtyfive percent of rain comes between the middle of September and late March (autumn and winter). Mean $\mathrm{P} / \mathrm{T}$ ratios varied from 7.4 to 10.1 .

All Associations in the Creosote Series - Mean maximum temperatures for all seasons were 81.1 to $87.4^{\circ} \mathrm{F}\left(27.2\right.$ to $\left.30.7^{\circ} \mathrm{C}\right)$, and mean minimums were from 29.1 to $39.8^{\circ} \mathrm{F}(-1.6$ to $4.3^{\circ} \mathrm{C}$ ). The extreme maximum temperature recorded for these communities during the 10 -year period was $117^{\circ} \mathrm{F}\left(47.2^{\circ} \mathrm{C}\right)$, and the extreme minimum was $-8^{\circ} \mathrm{F}\left(-22.2^{\circ} \mathrm{C}\right)$.

All Associations in the Creosote Series - Total shrub cover on the Bajadas of the NTS varies from 7.2 to 23.1 percent, and average height of all shrubs varies from $0.7 \mathrm{ft}$ $(0.2 \mathrm{~m})$, where Larrea is scarcely represented and all shrubs are of low stature, to $3.0 \mathrm{ft}$ $(0.9 \mathrm{~m})$, where most of the shrubs are large Larrea plants.

Larrea tridentata, Lycium andersonii, and Grayia spinosa are co-dominants at slightly higher elevations than Larrea-Ambrosia Association with imperfectly developed surface pavement, generally without a hardpan near the surface, and with a sandy loam matrix with larger rock fragments scattered throughout.

Lamea tridentata, Lycium andersonii, and Grayia spinosa are co-dominants with all degrees of numerical co-dominance.

The associated species are those of the Larrea-Ambrosia communities including: shrub species such as Psorothamnus (Dalea) fremontii, Krameria parvifolia, Ephedra nevadensis, Ceratoides lanata and, in some areas, Acamptopappus shockleyi or Menodora spinescens. Additionally, Haplopappus cooperi may be prominent, and a conspicuous associate in some areas is Yucca brevifolia (Joshua tree) which adds a third stratum to the shrub community when it is present. It is in these communities that there are large biennial populations of Astragalus lentiginosus, associated with mass germination in occasional years. Characteristic herbaceous species of the communities that make up the association are the most widely distributed species in the northern Mojave Desert and include: 
Amsinckia tessellata

Arabis glaucovalvula

Astragalus lentiginosus var.

fremontii

Astragalus acutirostris

Calycoseris wrightii

Camissonia kemensis ssp.

gilmanii

Caulanthus lasiophyllus

Caulanthus coopen

Chaenactis stevioides

Chaenactis macrantha

Chorizanthe brevicomu var.

brevicomu

Cryptantha nevadensis
Cryptantha recurvata

Cryptantha dumetorum

Cryptantha circamscissa

Cryptantha pterocarya

Delphinium parishii

Descurainia pinnata ssp. glabra

Eriogonum deflexum var.

nevadense

Eriogonum maculatum

Eriogonum reniforme

Eriogonum nidularium

Eschscholzia glyptosperma

Gilia cana ssp. speciformis

Gilia cana ssp. triceps

Glyptopleura marginata
Ipomopsis polycladon

Lepidium lasiocarpum

Linanthus demissus

Linanthus jonesii

Lupinus flavoculatus

Malacotrix glabrata

Mentzelia obscura

Nama demissum

Oryzopsis hymenoides

Oxytheca perfoliata

Phacelia vallis-mortae

Phacelia fremontii

Rafinesquia neomexicana 


\section{LYCIUM ANDERSONII - GRAYIA ASSOCIATION}

\section{Regional Type:}

Landform Type:

Series Name:

Association Name:

Beatley Type:

Prevailing Location:

Elevation:

Geology:

Soils:

Hy drology/drainage:

Precipitation:

Temperature:

Veg. Cover (\%):

Distinguishing Conditions:

Predominant Species:

Associate Species:
Mojave Desertscrub Biome

Closed Drainage Basins

Lycium

Lycium andersonii - Grayia

Grayia - Lycium

Located on large areas of the floors of closed drainage basins and locally on upper bajadas or near drainage divides (as in the upper Cane Spring Wash area of the NTS) and lower mountain slopes of the transition region. On the long, low-gradient basin floor of Yucca Flat (and that of southern Groom Lake to the north), the communities are well developed over many square miles where the lowlands are under the influence of cool or cold air accumulations.

Between 4,000 ft $(1,219 \mathrm{~m})$ and $5,000 \mathrm{ft}(1,524 \mathrm{~m})$ elevation.

Variable geologic origin of parent materials in closed drainage basins.

Silt loams or sandy loams on the lower bajadas that are derived from usually deep alluvial deposits.

Primarily on closed drainage basins and lower bajadas.

Mean rainfall is regionally intermediate, on the sites of measurements being in the range of 6.5 to $7.1 \mathrm{in}$. (164 to $179 \mathrm{~mm}$ ). Annual rainfalls varied from 1.7 to 16.4 in. (43 to $417 \mathrm{~mm})$.

Minimum temperatures are comparable to those in the Great Basin Desert of central and northem Nevada. Year-round mean minimums were from 25.6 to $28.3^{\circ} \mathrm{F}\left(-3.6\right.$ to $\left.2.1^{\circ} \mathrm{C}\right)$, and extreme minimums of the 10 -year record were -14 to $-12^{\circ} \mathrm{F}\left(-25.5\right.$ to $\left.-24.4^{\circ} \mathrm{C}\right)$. Maximum temperatures are similar to those of the Mojave Desert in the south: Mean maximum temperatures were from 82.1 to $83.6^{\circ} \mathrm{F}\left(27.8\right.$ to $\left.28.6^{\circ} \mathrm{C}\right)$, and the extreme maximums recorded were from 111 to $116^{\circ} \mathrm{F}\left(43.8\right.$ to $\left.46.6^{\circ} \mathrm{C}\right)$. Mean $\mathrm{P} / \mathrm{T}$ ratios varied from 13.1 to 13.5 .

Total shrub cover is from 32 to 37 percent, with 40 to 60 percent of this being attributable to the two dominant species, Lycium andersonii and Grayia spinosa, which grow in close association in usually well-developed clumps. Average shrub height is 0.4 to $0.5 \mathrm{~m}$. In most seasons, Oryzopsis hymenoides or Sitanion hystrix have cover values less than 0.2 percent. Winter annuals, although limited in most years by soil temperature, have cover up to 19 percent, with densities up to 200 plants $/ \mathrm{m}^{2}$ and as many as 20 species $/ 100 \mathrm{~m}^{2}$.

Lycium andersonii and Grayia spinosa are the two co-dominants located in closed drainage basins where cold air accumulates on silt or sandy loam soils.

Lycium andersonii and Grayia spinosa are the two co-dominants.

Ceratoides lanata is prominently represented (locally may be numerical dominant). In some areas, Tetradymia glabrata, Artemisia spinescens, Atriplex canescens, or Acamptopappus shockleyi are numerically important constituents. Other associated woody species are especially Chrysothamnus viscidiflorus ssp. stenophyllus, Ephedra nevadensis, Tetradymia axillaris, Yucca brevifolia, and Opuntia echinocama. Opuntia stanlyi var. parishii is known only from this kind of vegetation.

Among the herbaceous perennials, Mirabilis pudica (endemic to the desert transition region of southern Nevada), Sphaeralcea ambigua ssp. monticola, and Stephanomeria parryi are more or less consistently present in significant numbers in the undisturbed 
communities. Oryzopsis hymenoides or Sitanion hystrix are predictable constituents. Herbaceous species generally predictable in this association are as follows:

Amaranthus fimbriatus

Amsinckia tessellata

Arabis glaucovalvula

Astragalus acutirostris

Astragalus lentiginosus var. fremontii

Calycoseris wrightii

Camissonia boothii ssp.

condensata

Camissonia claviformis ssp.

Integrior

Caulanthus cooperi

Caulanthus lasiophyllus

Chaenactis stevioides

Chaenactis macrantha

Chenopodium incanum

Cryptanta recurvata

Cryptantha nevadensis

Cryptantha pterocarya
Cryptantha circumscissa

Delphinium parishii

Descurainia pinnata ssp. glabra

Eriastrum eremicum

Eriogonum nidularium

Eriogonum deflexum var.

nevadense

Eriogonum maculatum

Eriophyllum pringlei

Euphorbia albomarginata

Euphorbia micromera

Gilia cana ssp. triceps

Glyptopleura marginata

Ipmopsis polycladon

Langloisia schottii

Lupinus flavoculatus

Machaeranthera tortilifolia var.

tortifolia

Malacothrix glabrata
Mentzelia obscura

Mentzelia albicaulis

Mirabilis pudica

Oryzopsis hymenoides

Oxytheca perfoliata

Pectis papposa

Phacelia fremontii

Phacelia vallis-mortae

Polygala subspinosa var.

heterorhyncha

Prenanthella exigua

Rafinesquia neomexicana

Sitanion hystrix

Sphaeralcea ambigua ssp.

monticola

Stanleya pinnata var. pinnata

Stephanomeria pamyi

Streptanthella longirostris 


\section{LYCIUM PALLIDUM - GRAYIA ASSOCIATION}

\author{
Regional Type: \\ Landform Type: \\ Series Name: \\ Association Name: \\ Beatley Type: \\ Mojave Desertscrub Biome \\ Closed Drainage Basins \\ Lycium \\ Lycium pallidum - Grayia \\ Lycium pallidum - Grayia
}

Prevailing Location:

Elevation:

Geology:

Soils:

Hydrology/drainage:

Precipitation:

Temperature:

Veg. Cover (\%):

Distinguishing
Conditions:

Predominant Species:

Located on closed drainage basins, it is one of the most conspicuous vegetation features of the NTS, extending southwest from the playa in Frenchman Flat, in an area about $41 / 2$ miles long and 2 miles wide ( 7 by $3 \mathrm{~km}$ ).

Between 3,100 ft (945 m) and 3,250 ft (991 m) elevation.

Variable geologic origin of parent materials in closed drainage basins.

Soils in southwestern Frenchman Flat are derived from materials from the north face of the limestone Spotted Range (Mercury Ridge and Red Mountain) and the east end of the volcanic Skull Mountain. They are comprised of sands without a surface pavement, which distinguishes the zone of Lycium pallidum - Grayia, but not the Larrea boundaries.

The association boundaries are correlated with low nocturnal temperatures of cold air lake in the Frenchman Flat lowlands, a closed drainage basin.

Mean annual rainfall in the Frenchman Flat over a ten-year period averaged 4.8 in. $(121 \mathrm{~mm})$, with the annual rainfall varying from 2.6 to $10.0 \mathrm{in}$. (66 to $254 \mathrm{~mm}$ ). Mean annual rainfall is lower in this association than in the Lycium andersonii - Grayia association.

Mean minimum temperature for 10 years was $27.0^{\circ} \mathrm{F}\left(-2.8^{\circ} \mathrm{C}\right)$, and the extreme minimum was $-110^{\circ} \mathrm{F}\left(-23.9^{\circ} \mathrm{C}\right)$. Mean maximum temperature was $86.0^{\circ} \mathrm{F}\left(30.0^{\circ} \mathrm{C}\right)$, and the extreme maximum was $119^{\circ} \mathrm{F}\left(48.3^{\circ} \mathrm{C}\right)$. Although daytime temperatures are somewhat higher than in the Lycium andersonii - Grayia communities of the Yucca Flat lowlands (at 1,000-ft higher elevation) the similarity of the temperature regimes in the two plant associations is apparent. The mean PIT ratio was 8.9.

Shrub cover was reported as 75 percent Lycium pallidum var. oligospermum and 20 percent Grayia spinosa.

Lycium andersonii and Grayia spinosa are the two co-dominants located in closed drainage basins where cold air accumulates on silt or sandy loam soils.

Lycium palladium and Grayia spinosa are the two co-dominants. These two species are prominent constituents of the surrounding Larrea vegetation of southwestern Frenchman Flat. Lycium pallidium continues in the Larrea vegetation to the southwest, on the sandy soils below the south face of the volcanic Skull Mountain and across the crest of the limestone Specter Range, where soils have physical properties in notable contrast. Occurrence of the species in this region is inferred to be correlated with soil chemical properties. In this association at Frenchman Flat, Lycium pallidium is the ecological equivalent of Lycium andersonii in the Lycium andersonii - Grayia association of Yucca Flat, and the two associations are in fundamental ways ecological equivalents in the two drainage basins.

Associate Species: $\quad$ Atriplex canescens which becomes the dominant shrub in local areas of the lowlands, and Psorothamnus (Dalea) polydenius are associated with Lycium pallidium and Grayia spinosa. The environment is marginal for herbaceous species of the Mojave Desert because of the low nighttime temperatures. Of interest in this association is the lowland occurrence of Machaeranthera canescens, Gilia hutchinsifolia, and G. sinuata, all species of the higher elevations in this region; the narrowly restricted endemics, Mirabilis pudica 
and Polygala subspinosa var. heteromynca; the occurrence of Abronia turbinata, a species of restricted distribution and associated elsewhere in the region with Larrea Ambrosia communities; and Peteria thompsonae, known from the region elsewhere only from the Goldfield Hills.

According to Beatley, "most of the species that occur in the Lycium andersonii - Grayia association, especially those of more sandy soils, also occur in this association." Based on this statement, herbaceous species generally predictable in this association are inferred to be:

Amaranthus fimbriatus Amsinckia tessellata Arabis glaucovalvula Astragalus acutirostris Astragalus lentiginosus var. fremontii

Calycoseris wrightii

Camissonia boothii ssp.

condensata

Camissonia claviformis ssp. Integrior

Caulanthus cooperi

Caulanthus lasiophyllus

Chaenactis stevioides

Chaenactis macrantha

Chenopodium incanum

Cryptanta recurvata

Cryptantha nevadensis

Cryptantha pterocarya
Cryptantha circumscissa

Delphinium parishii

Descurainia pinnata ssp. glabra

Eniastrum eremicum

Eriogonum nidularium

Eriogonum deflexum var.

nevadense

Eriogonum maculatum

Eriophyllum pringlei

Euphorbia albomarginata

Euphorbia micromera

Gilia cana ssp. triceps

Glyptopleura marginata

Ipmopsis polycladon

Langloisia schottii

Lupinus flavoculatus

Machaeranthera tortilifolia var.

tortifolia

Malacothrix glabrata
Mentzelia obscura

Mentzelia albicaulis

Mirabilis pudica

Oryzopsis hymenoides

Oxytheca perfoliata

Pectis papposa

Phacelia fremontii

Phacelia vallis-mortae

Polygala subspinosa var.

heteromyncha

Prenanthella exigua

Rafinesquia neomexicana

Sitanion hystrix

Sphaeralcea ambigua ssp.

monticola

Stanleya pinnata var. pinnata

Stephanomeria parryi

Streptanthella longirostris 


\section{LYCIUM SHOCKLEYI - ATRIPLEX ASSOCIATION}

$\begin{array}{ll}\text { Regional Type: } & \text { Mojave Desertscrub Biome } \\ \text { Landform Type: } & \text { Lowlands and Uplands } \\ \text { Series Name: } & \text { Lycium } \\ \text { Association Name: } & \text { Lycium shockleyi - Atriplex } \\ \text { Beatley Type: } & \text { Lycium shockleyi - Atriplex }\end{array}$

Prevailing Location: Distribution of Lycium shockleyi is defined by the area of bajada soils originating from the northwest face of the Ranger Mountains in southeastern Frenchman Flat, where it occurs from the playa margin to the base of the mountains, mostly in otherwise Larrea - Atriplex vegetation. It also occurs in lowlands elsewhere, especially in the Mud Lake area to the north, but is equally identifiable with middle and upper bajadas. The largest known area over which it predominates is in Stonewall Flat, on the south slope below the Goldfield Hills and west slope of the Cactus Range.

Elevation:

Geology:

Soils:

Hydrology/drainage:

Precipitation:

Temperature:

Veg. Cover (\%):

Distinguishing

Conditions:

Predominant Species:

Associate Species:
Between 2,600 ft $(792 \mathrm{~m})$ below Skeleton Hills of the northern Amargosa Valley, to $3,100 \mathrm{ft}(945 \mathrm{~m})-4,000 \mathrm{ft}(1,219 \mathrm{~m})$ near the southern boundary of the NTS, to $5,200 \mathrm{ft}$ $(1,585 \mathrm{~m})$ elevation in Ralston Valley to the north.

Variable geologic origin of parent materials, both limestone and volcanic.

Soils appear to span the range of physical characteristics.

Lowlands as well as middle and upper bajadas.

Mean annual rainfall, as measured on four sites in southeastern Frenchman Flat, was 4.9 to 5.4 in. (124 to $137 \mathrm{~mm}$ ). Extreme annual rainfall ranged from 2.3 to 9.9 in. (58 to $251 \mathrm{~mm}$ ).

Its best development on the NTS, at the edge of the playa, is where the year-round mean minimums were from 26.2 to $29.1^{\circ} \mathrm{F}\left(-3.2\right.$ to $\left.-1.6^{\circ} \mathrm{C}\right)$, and the extreme minimums were -11 to $-8^{\circ} \mathrm{F}\left(-23.9\right.$ to $\left.22.2^{\circ} \mathrm{C}\right)$, as in other communities lying near the bottom of the cold air lakes. The mean maximum temperatures are those of the Mojave Desert: Mean maximums were from 83.2 to $85.5^{\circ} \mathrm{F}\left(28.4\right.$ to $\left.29.7^{\circ} \mathrm{C}\right)$, and the extremes were from 112 to $116^{\circ} \mathrm{F}\left(44.4\right.$ to $\left.46.6^{\circ} \mathrm{C}\right)$. (No mean annual $\mathrm{P} / \mathrm{T}$ ratio was reported.)

Shrub cover for Lycium shockleyi ranged from 7.8 to 10.1 percent.

Lycium shockleyi and Atriplex confertifolia are the two co-dominants located in lowlands or in uplands.

Lycium shockleyi and Atriplex confertifolia are the two co-dominants. Lycium shockleyi is endemic to southern Nevada and does not occur in adjacent states.

No herbaceous species are known to distinguish the association. Since the species is nearly always a co-dominant with Atriplex confertifolia in both upland and lowland communities, and with Larrea or Sarcobatus, as well, the herbaceous component of the communities is that of the basic community types. 


\section{PINUS - JUNIPERUS - ARTEMISIA ASSOCIATION}

\author{
Regional Type: \\ Landform Type: \\ Series Name: \\ Association Name: \\ Beatley Type: \\ Prevailing Location:

\section{Great Basin Desertscrub Biome} \\ Mountains \\ Pinyon - Juniper \\ Pinus - Juniperus - Artemisia \\ Artemisia - Pinyon - Juniper \\ Located on Pahute Mesa and the upper Thirsty Canyon uplands. Trees are localized and \\ discontinuous around low cliffs or rock outcrops, or along shallow drainage courses, in \\ what is otherwise Artemisia vegetation. In local but discrete areas, juniper may occur \\ almost to the exclusion of pinyon pine, as on the "Juniper Flats" of northwest Pahute Mesa \\ and, in other areas, the pine may be in essentially pure stands. On mountain slopes, the \\ community may be pinyon - juniper, without either of the Artemisia species in the shrub \\ layer.
}

Elevation:

Geology:

Soils:

Hydrology/drainage:

Precipitation:

Temperature:

Veg. Cover (\%):

\section{Distinguishing Conditions:}

Predominant Species:

$6,000 \mathrm{ft}$ to $8,000 \mathrm{ft}(1,829 \mathrm{~m}$ to $2,438 \mathrm{~m})$.

(Not described, but reported to occur on volcanic ranges.)

Soils are variable in composition and thickness.

Mountains, mesas, and foothills.

Mean annual precipitation on sites from 6,100 to $7,500 \mathrm{ft}(1,860$ to $2,286 \mathrm{~m})$ elevation was from 10.3 to 11.3 in (261 to $286 \mathrm{~mm}$ ); lowest and highest annual rainfalls on the sites were 5.1 and 26.1 in. (130 and $663 \mathrm{~mm}$ ), both recorded on the high-elevation site (Rainer Mesa). The mean $P / T$ ratios were from 22.2 to 32.5 .

Mean minimum temperature were from 24.6 to $29.3^{\circ} \mathrm{F}\left(-4.1\right.$ to $\left.-1.5^{\circ} \mathrm{C}\right)$, and the extreme low minimum was $-17^{0} \mathrm{~F}\left(-27.2^{\circ} \mathrm{C}\right)$. The extremes of the minimums were all recorded on the site at $7,500 \mathrm{ft}(2,286 \mathrm{~m})$, and the extreme low temperature was $1^{\circ} \mathrm{F}$ higher than the all-time low temperature of $-18^{\circ} \mathrm{F}\left(-27,8^{\circ} \mathrm{C}\right)$ recorded at $4,400 \mathrm{ft}(1,341 \mathrm{~m})$ lower elevation in the Frenchman Flat lowlands. Mean maximum temperature varied from 71.1 to $79.5^{\circ} \mathrm{F}$ $\left(21.7\right.$ to $\left.26.4^{\circ} \mathrm{C}\right)$, and the high maximum of the record was $108^{\circ} \mathrm{F}\left(42.2^{\circ} \mathrm{C}\right)$.

Total tree and shrub cover varied from 34.8 percent (where much of the surface was outcropping bedrock) to 43.9 percent. Maximum herbaceous perennial cover varied among the sites from 7.0 to 31.1 percent (to 19 species $/ 1,000 \mathrm{~m}^{2}$ ), with 69 to 99 percent of the cover due to perennial grasses, especially species of Stipa (S. comata, $S$. pinetorum, or $S$. thurberiana). Winter annuals are represented usually only near the lower limits of the association where on one site, one year, they were present in a density of $35.6 \mathrm{plant} / \mathrm{m}^{2}$ (10 species), and cover of 15.7 percent reflecting the large size of plants in areas of high rainfall.

Pinus monophylla, Junipenus osteosperma, and Artemisia spp. are the dominant species in mountainous areas at elevations between 6,000 to $8,000 \mathrm{ft}(1,829 \mathrm{~m}$ to $2,438 \mathrm{~m})$.

Pinus monophylla, Juniperus osteosperma, and Artemisia spp. are the dominant species. Because of variable soil conditions, any of the three dominant species may be found in nearly pure stands without the other species. In order of increasing drought tolerance, the species could be ranked Artemisia, Juniperus, and Pinus. Artemisia also occurs in drier sites interspersed within the trees and sometimes without trees. Juniper is found at slightly lower elevations than pinyon pine, often occurring first as scattered small trees on the Artemisia slopes, followed by pinyon pine within 200 to $300 \mathrm{ft}(70$ to $90 \mathrm{~m})$ increase in elevation; at the upper limits of the association, pinyon pine continues up slope in the white fir communities usually a few hundred feet after juniper has disappeared. 
Associate Species: $\quad$ About half of the plant species in the whole region are known to occur somewhere in this association. The great diversity of geologic substrates and erosional and depositional features result in environmental conditions that encourage high species diversity. Because this association includes Artemisia spp., many herbaceous species listed as occurring in the Artemisia tridentata and Artemisia nova associations can also be found here and are not included in this list.

Commonly occurring species include:

Trees, Shrubs, and Cacti

Amelanchier utahensis

Arctostaphylos pungens

Artemisia nova

Artemisia tridentata

Berberis fremontii

Ceanothus cordulatus

Ceanothus greggii var. vestitus

Cercocarpus ledifolius

Chrysothamnus nauseosus ssp.

hololeucus

Chrysothamnus parryi ssp.

nevadensis

Chrysothamnus viscidiflorus ssp. puberulus

Chrysothamnus viscidiflorus ssp. viscidifforus

Coryphantha vivipara var. rosea

Cowania mexicana var.

stansburiana

Echinocereus engelmannii var.

chysocentrus

Echinocereus triglochidiatus var. melanacanthus

Echinocereus triglochidiatus var. mojavensis

Ephedra viridis

Eriodictyon angustifolium

\section{Herbs}

Achillea millefolium var. lanulosa Agoseris glauca var. laciniata

Agropyron spicatum

Agropyron vaseyi

Allium atrorubens

Antennaria dimorpha

Antennaria rosea

Arabis fendleri

Arabis hirsuta var. pycnocarpa

Arabis holboellii var. retofracta

Arabis microphylla

Arabis pendulina

Arabis pulchra var. gracilis

Arenaria congesta var.

subcongesta

Argemone munita

Aristida longiseta var. robusta

Artemisia dracunculus

Astragalus aequalis

Astragalus inyoensis

Astragalus nuttallianus var.

imperfectus
Eriogonum microthecum var.

foliosum

Eriogonum caespitosum

Enogonum microthecum var. lapidicola

Eriogonum microthecum var. laxiflorum

Eriogonum umbellatum var. dichrocephalum

Eriogonum umbellatum var. subaridum

Eriogonum umbellatum var.

versicolor

Forsellesia nevadensis

Galium hypotrichium ssp.

nevadense

Galium multiflorum

Galium parishii

Gamya flavescens

Gutierrezia sarothrae

Holodiscus microphyllus

Juniperus osteosperma

Keckiella rothrockii

Leptodactylon pungens ssp.

puchriflorum

Linanthus nuttallii

Lupinus excubitus

Astragalus oophorus var. clokeyanus

Astragalus oophorus var.

oophorus

Astragalus purshii var. purshii

Bouteloua gracilis

Brickellia califomica

Brickellia microphylla var. scabra

Bromus anomalus

Bromus carinatus

Calocortus bruneaunis

Calyptridium parryi var.

nevadense

Carex occidentalis

Castelleja linariaefolia

Castelleja martinii var. clokeyi

Chaenactis douglasii

Chenopodium atrovirens

Chenopodium bertandieri var.

zschackei

Chenopodium fremontii

Chenopodium missouriense
Opuntia chlorotica

Opuntia erinacea var. erinacea

Opuntia phaeacantha var. major

Opuntia polyacantha var.

rufispina

Peraphyllum ramosissimum

Perityle megalocephala var.

megalocephala

Petradoria discoidea

Petradoria pumila

Pinus monophylla

Polygala subspinosa var.

subspinosa

Purshia tridentata

Quercus gambelii

Rhus trilobata var. Anisophylla

Ribes cereum

Ribes niveum

Ribes velutinum

Salvia dormi ssp. argentea

Sclerocactus polyancistrus

Stephanomeria spinosa

Symphoricarpos longifforus

Symphoricarpos parishii

Tetradymia canescens

Viguiera multiflora var.

nevadensis

Chenopodium gigantospermum Chenopodium leptophyllum

Chorizanthe brevicomu var.

spathulata

Collinsia callosa

Comandra umbellata ssp.

californica

Crepis intermedia

Crepis occidentalis

Cryptantha ambigua

Cryptantha confertiflora

Cryptantha flavoculata

Cryptantha gracilis

Cryptantha jamesii var. abortiva

Cryptantha torreyana

Cryptantha scoparia

Cryptantha virginensis

Cryptantha watsonii

Elymus cinereus

Eriogonum baileyi

Eriogonum cemuum var.

cemuum 
Eriogonum esmeraldense

Eriogonum palmerianum

Eriogonum panamintense

Eriogonum racemosum

Erysimum asperum var. purshii

Frasera albomarginata

Frasera pahutensis

Fritillaria atropurpurea

Fritillaria pinetorum

Galium bifolium

Galium hilendiae ssp. hilendiae

Galium hilendiae ssp.

kingstonense

Gayophytum decipiens

Gayophytum ramosissimum

Haplopappus acaulis

Hulsea vestita ssp. inyoensis

Hymenopappus filifolius var.

megacephalus

Ipomopsis aggregata

Ipomopsis congesta

Ivesia sabulosa

Koeleria cristata

Lappula occidentalis

Lesquerella kingii ssp. kingii

Lesquerella kingii ssp. latifolia

Linanthus septentrionalis

Lithospermum ruderale
Lomatium paryi

Lupinus alpestris

Lupinus argenteus var. tenellus

Lupinus palmeri

Lygodesmia dianthopsis

Machaeranthera canescens

Melica stricta

Mentzelia congesta

Mentzelia laevicaulis

Mentzelia montana

Mimulus densus

Mimulus pilosus

Mimulus rubellus

Mirabilis froebelii

Monolepis spathulata

Muhlenbergia richardsonis

Nicotiana attenuata

Oenothera caespitosa ssp.

marginata

Oryzopsis micrantha

Pallaea truncata

Pedicularis semibarbata

Pellaea mucronata

Penstemon bridgesii

Penstemon confusus

Penstemon eatonii

Penstemon humilis

Penstemon kingii
Penstemon pahutensis

Penstemon palmeri

Penstemon thompsoniae

Phacelia affinis

Phacelia curvipes

Phacelia hastata

Phacelia lemmonii

Phacelia tetramera

Physalia hederaefolia var.

cordifolia

Physaria chambersii

Pityrogramma triangularis

Poa fendleriana

Polanisia trachysperma

Ranunculus andersonii

Scrophularia desertorum

Silene verecunda ssp.

andersonii

Stipa arida

Stipa coronata var. depauperata

Stipa pinetorum

Stipa thurberiana

Streptanthus cordatus

Thalictrum fendleri

Vulpia microstachya var.

pauciflora

Species of volcanic flatrock areas (especially Rainer Mesa, southern Pahute Mesa, and northern Fortymile Canyon drainage, but also similar areas of different rock substrate elsewhere in the region, e.g., near the base of the northern Belted Range) include:

Arabis holboelii var. pinetorum

Camissonia pterosperma

Camissonia pusilla

Carex douglasii

Chorizanthe watsonii

Collinsia parviflora

Cryptantha humilis var. ovina

Delphinium andersonii

Draba cuneifolia var. cuneifolia

Eriogonum caespitosum

Eriogonum microthecum var. lapidicola

Gayophytum diffusum ssp.

parviflorum
Gilia aliquanta

Gilia brecciarum

Haplopappus nanus

Hymenoxys cooperi

Ivesia sabulosa

Lesquerella kingii ssp. kingii

Lewisia rediviva

Lithophragma tenellum

Lomatium foeniculaceum ssp.

fimbriatum

Microsteris gracilis ssp. humilis

Mimulus densus

Mimulus suksdorfii

Navarretia breweri

Species of cliff ledges and crevices include:

Eniogonum heermannii var. argense

Halimolobos diffusa var. jaegen

Haplopappus cuneatus

Haplopappus watsonii
Heterotheca villosa var. hispida

Montia perfoliata

Petrophytum caespitosum

Phacelia mustelina

Phacelia peirsoniana
Phacelia saxicola

Plantago purshii var. oblonga

Poa sandbergii

Polygonum douglasii var.

johnstonii

Stipa pinetorum

Townsendia scapigera

Trifolium andersonii ssp.

beatleyae

Zigadenus paniculatus
Pityrogramma triangularis

Purpusia saxosa

Thelypodium laxiflorum 
Species of springs and seepage areas include:

Trees and shrubs

Chrysothamnus nauseosus ssp. albicaulis

Prunus virginiana var.

melanocarpa

Ribes aureum

Herbs

Agrostis scabra

Agrostis exarata var. monolepis

Allium bisceptrum

Alopecurus aequalis

Amaranthus blitoides

Angelica kingii

Apocynum sibericum var.

salignum

Aquilegia shockleyi

Amica parryi ssp. sonnen

Artemisia biennis

Aster adscendens

Carex alma

Carex aurea

Carex douglasii

Carex lanuginosa

Carex microptera

Carex nebrascensis

Carex scopularum

Cleome lutea

Conzya canadensis

Descurainia californica

Descurainia obtusa

Eleocharis macrostachya

Eleochanis parishii

Elymus cinereus
Clematis ligusticifolia

Populus fremontii

Rosa woodsii

Salix exigua var. stenophylla

Salix lasiolepis

Elymus triticoides

Epilobium ciliatum

Epilobium glandulosum var.

tenue

Erigeron divergens

Equisetum hyemale

Equisetum laevigatum

Geum macrophyllum

Gilia tenerrima

Hordeum brachyantherum

Hordeum jubatum

Hutchinsia procumbens

Iris missouriensis

Juncus balticus

Juncus bufonius

Juncus ensifolius

Juncus longistylis

Juncus nodosus

Lemna minuta

Leptodactylon caespitosum

Mimulus guttatus

Monolepis nuttalliana

Montia chamissoi

Oenothera hookeri ssp.

angustifolia

Osmorhiza occidentalis
Populus trichocarpa

Salix rigida var. watsonii

Plagiobothry scouleri var. penicillatus

Poa nevadensis

Potentilla gracilis ssp. nuttallii

Potentilla biennis

Ranunculus cymbalaria var. saximontanus

Rumex salicifolius

Sagina saginoides

Scirpus microcarpus

Senecio integerrimus var.

exaltatus

Sisyrinchium halophilum

Smilacina stellata

Solanum triflorum

Trifolium andersonii ssp.

beatleyae

Trifolium ciliatum

Trifolium monanthum

Trifolium wormskioldii

Urtica holosericea

Verbena bracteata

Veronica americana

Viola neprophylla

Zannichellia palustris 
This Page Intentionally Left Blank 


\section{Appendix B}

\section{Plant Species on the NTS}

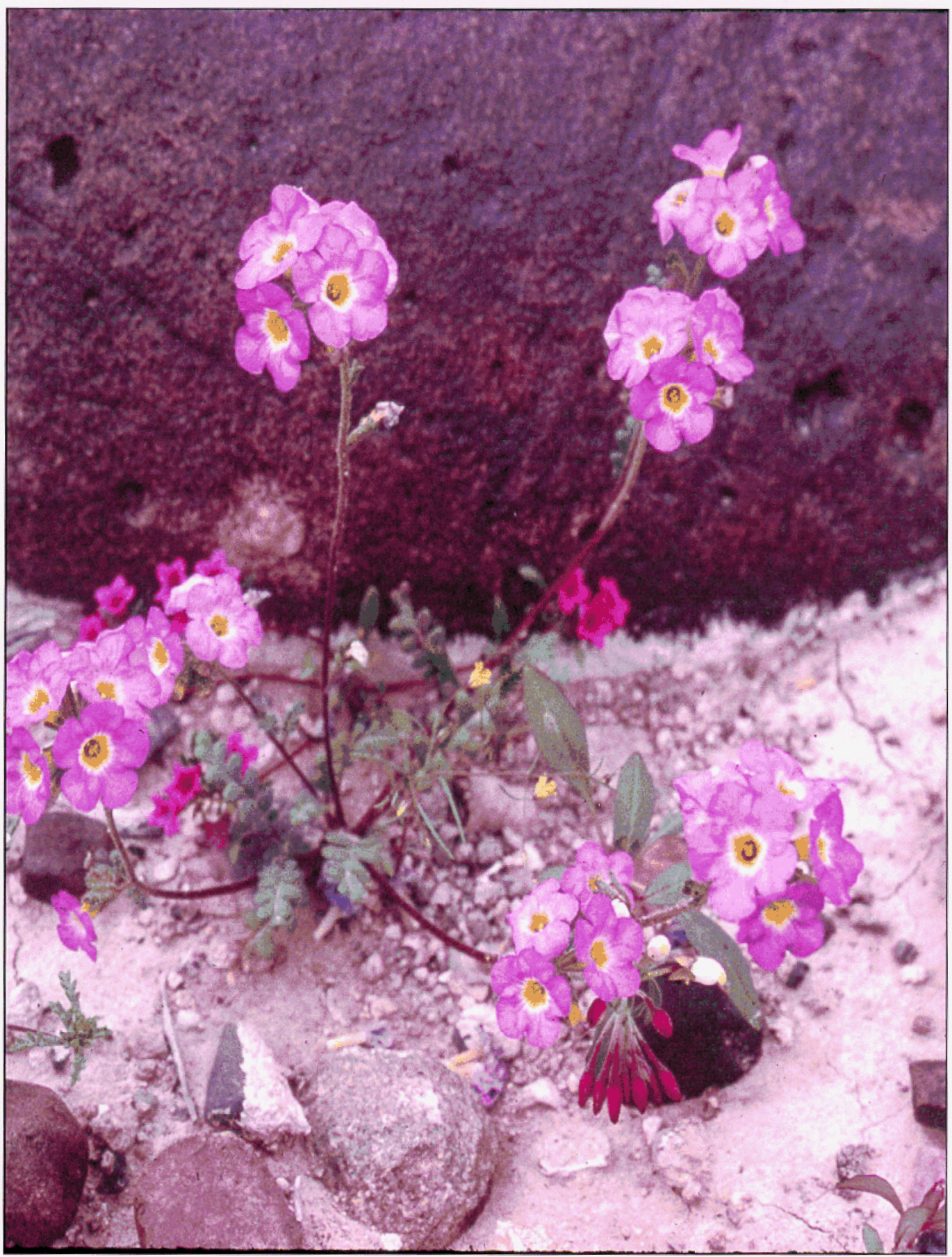

Fremont's phacelia (Phacelia fremontii) [Photo by Susan Cochrane] 
This Page Intentionally Left Blank 
LEGEND: A=1999 Survey; Bardditional species listed in the 1976 Beatley Survey; 1 = Lyclum spp. Shrubland Alliance; 2 E Larrea tridentata/Ambroela dumoes Shrubland Alliance; 3 = Atriplex confertffolla/Ambrosia dumosa Shrubland Alliance; 4 $=$ Hymenoclea-Lyclum Shrubland Alliance; 5 = Ephedra nevadensls Shrubland Alliance; 6 = Coleogyne rammosiseima Shrubland Alliance; 7 = Atriplox spp. Shrubland Alliance; $8=$ Chrysothamnus-Ericameria Shrubland Allance; 9 = Artemisia spp. Shrubland Alliance; 10 = Pinus monophylla/Artemisia ssp. Woodland Alliance; 11= Miscellaneous

\begin{tabular}{|c|c|c|c|c|c|c|c|c|c|c|c|c|c|}
\hline s.p. & and & inscenano & \pm & 3 & 8 & $I$ & 巡 & J & $\Phi$ & 0 & 8 & aㅡ & \\
\hline Code & Genus & Species & 1 & 2 & 3 & 4 & 5 & 6 & 7 & 8 & 9 & 10 & 11 \\
\hline ABEL & Abronia & elliptice & & $\mathbf{A}$ & & & A & & & A & A & A & \\
\hline ABTU & Abronia & turbinata & $\mathbf{B}$ & B & & & & & B & A & & & \\
\hline ACAR14 & Achnatherum & arida & & & & & & A & & & $\mathbf{A}$ & A & \\
\hline ACCO21 & Achnatherum & coronata & & & & & & A & & & A & A & \\
\hline ACHY & Achnatherum & hymenoides & $\mathbf{B}$ & $\mathbf{A}$ & A & A & A & A & A & A & A & A & \\
\hline ACMIL3 & Achillea & millefolium var. lanulosa & & & & & & & & & & $\mathbf{B}$ & \\
\hline ACPA13 & Achnathorum & parishii & & & & & & & & & & & B \\
\hline ACPAP & Achnatherum & parishii var. parishii & & & & & & & & & & & B \\
\hline ACPI2 & Achnatherum & pinetorum & & & & & & & & A & & $\mathbf{B}$ & \\
\hline ACROP & Acroptilon & repens & & & & & & & & & & & B \\
\hline ACSH & Acamptopappus & shockleyi & A & A & A & A & $\mathbf{A}$ & $\mathbf{A}$ & A & A & & & B \\
\hline ACSP12 & Achnatherum & speciosa & & $\mathbf{A}$ & A & A & A & A & A & A & A & A & \\
\hline ACTH7 & Achnatherum & thurberiana & & & & & & & & & A & $\mathbf{A}$ & \\
\hline ADCO2 & Adenophyllum & coopeni & & A & & $\mathbf{A}$ & $\mathbf{A}$ & A & & A & A & & \\
\hline AGCR & Agropyron & cristatum & & & & & & & & & & B & B \\
\hline AGEMX2 & Agrostis & exarata var. monolepis & & & & & & & & & & & B \\
\hline ACGLL & Agoseris & glauca var. laciniata & & & & & & & & A & A & A & \\
\hline ACSE2 & Agrostis & semiverticillata & & & & & & & & & & $\mathbf{B}$ & $\mathbf{B}$ \\
\hline AGUTE & Agave & utahensis var. eborispina & & & & & & & & & & & $\mathbf{B}$ \\
\hline ALIN & Allionia & incarnata & & & B & & & & & & & & \\
\hline ALNE & Allium & nevadense & & & & & A & $A$ & & & $\mathbf{A}$ & A & \\
\hline ALSC3 & Allium & scorodoprasum & & & & & & & & & & & $\mathbf{B}$ \\
\hline AMAC2 & Ambrosia & acanthicarpa & & $\mathbf{B}$ & & & A & A & B & A & A & $\mathbf{A}$ & \\
\hline AMAL & Amaranthus & albus & & & & & B & & & & B & $\mathbf{B}$ & \\
\hline AMBL & Amaranthus & blitoides & & & & & & $\mathbf{B}$ & & & $\mathbf{B}$ & $\mathbf{B}$ & \\
\hline AMCA & Amaranthus & californicus & & $\mathbf{B}$ & & & & & & & & & \\
\hline AMDU2 & Ambrosia & dumosa & A & A & A & A & A & A & $\mathbf{A}$ & A & A & & \\
\hline AMER & Ambrosia & eriocentra & & A & & $\mathbf{A}$ & $\mathbf{A}$ & A & & & B & & B \\
\hline AMFI & Amaranthus & fimbriatus & & $\mathbf{B}$ & & B & $\mathbf{B}$ & B & & & & & \\
\hline AMFRF & Amphipappus & fremontii var. fremontii & & & & & & & & & & & $\mathbf{B}$ \\
\hline AMPA2 & Amelanchier & pallida & & & & & & & & & & A & B \\
\hline AMTE3 & Amsinckia & tessellata & $\mathbf{A}$ & $\mathbf{A}$ & A & A & $\mathbf{A}$ & A & A & A & A & A & \\
\hline AMTO2 & Amsonia & tomentosa & & & B & & & & & & & & \\
\hline AMUT & Amelanchier & utahensis & & & & & & & & $\mathbf{A}$ & $\mathbf{A}$ & A & B \\
\hline
\end{tabular}


LEGEND: A=1999 Survey; Bandditional species llsted in the 1976 Beatley Survey; 1 = Lycium spp. Shrubland Alliance; 2 = Larrea tridentata/Ambrosia dumoea Shrubland Alliance; 3 = Atriplex confertifolla/Ambrosla dumosa Shrubland Alliance; 4 = Hymenoclea-Lycium Shrubland Alliance; 5 = Ephedra nevadensis Shrubland Alliance; 6 = Coleogyne rammosissima Shrubland Allance; 7 = Atriplex spp. Shrubland Allance; $8=$ Chrysothamnus-Ericameria Shrubland Allance; 9 = Artemisia spp. Shrubland Alliance; 10 = Pinus monophylla/Artemisia sep. Woodland Alliance; $11=$ Mlecellaneous

\begin{tabular}{|c|c|c|c|c|c|c|c|c|c|c|c|c|c|}
\hline Code & Genus & Species & 1 & 2 & 3 & 4 & 5 & 6 & 7 & 8 & 9 & 10 & 11 \\
\hline ANAC & Anisocoma & acaulis & & A & & & A & A & B & A & A & A & \\
\hline ANBR4 & Androstephium & brevifiorum & B & $\mathbf{B}$ & $\mathbf{B}$ & & & B & & & & & \\
\hline AND12 & Antennaria & dimorpha & & & & & & & & A & $\mathbf{A}$ & A & \\
\hline ANRO2 & Antennaria & rosea & & & & & & & & & & $\mathbf{A}$ & \\
\hline ANTU & Anemone & tuberosa & & & & & & B & & & & & \\
\hline APGR2 & Apium & graveolens & & & & & & & & & & $\mathbf{B}$ & \\
\hline AQFOF & Aquilogia & formosa var. formosa & & & & & & & & & & $\mathbf{B}$ & B \\
\hline ARAD & Aristida & adscensionis & & $\mathbf{B}$ & B & & & & & & & & \\
\hline ARAR6 & Aristida & arizonica & & & & & & & & & & & B \\
\hline ARBI3 & Artemisia & bigelovii & & & & & & A & & & & & \\
\hline ARCO6 & Angemone & corymbosa & $\mathbf{B}$ & & & & & & & & & $\mathbf{A}$ & \\
\hline ARCOS2 & Arenaria & congesta var. subcongesta & & & & & A & A & & A & A & A & B \\
\hline ARDI & Arabis & dispar & & & & & & & & & B & $\mathbf{B}$ & \\
\hline ARDI3 & Arcouthobium & divaricatum & & & & & & & & & & A & \\
\hline ARDR4 & Artemisia & dracunculus & & & & & A & & A & A & A & A & $\mathbf{B}$ \\
\hline ARGL2 & Arabis & glaucovalvula & $\mathbf{B}$ & B & $\mathbf{B}$ & B & $\mathbf{B}$ & & & & & & \\
\hline ARHOP3 & Arabis & holboellii var. pinetorum & & & & & & A & & & A & A & B \\
\hline ARIN & Arabis & inyoensis & & & & & & A & & A & A & $\mathbf{B}$ & \\
\hline ARJO2 & Argyrochosma & jonosii & & & & & & & & & & & B \\
\hline ARKIC & Arenaria & kingii ssp compacta & & & & & & $\mathbf{B}$ & & & & A & \\
\hline ARLU & Artemisia & Iudoviciana & & & & & A & $\mathbf{A}$ & & & A & A & $\mathbf{0}$ \\
\hline ARLU12 & Antemisia & Iudoviciana ssp. incompta & & & & & & B & & & $\mathbf{B}$ & $\mathbf{B}$ & \\
\hline ARMA3 & Arenaria & macradenia & & & A & & $\mathbf{A}$ & A & & A & A & A & \\
\hline ARMAF & Arenaria & macradenia ssp. ferrisiae & & & & & & $\mathbf{B}$ & & & $\mathbf{B}$ & $\mathbf{B}$ & \\
\hline ARMAM4 & Arenaria & macradenia ssp. macradenia ver. macrade & & & $\mathbf{B}$ & & B & $\mathbf{B}$ & & & & B & \\
\hline ARME2 & Arctomecon & meniamii & & B & A & & & & A & & & & B \\
\hline ARMUR & Argemone & munita ssp. rotundata & & & & & & A & B & A & A & B & \\
\hline ARNO4 & Artemisia & nova & & & & & A & $\mathbf{A}$ & & A & A & A & \\
\hline ARPE & Arabis & pendulina & & & & & & & & & & $\mathbf{B}$ & $\mathbf{B}$ \\
\hline ARPE2 & Arabis & perennans & & $\mathbf{B}$ & $\mathbf{B}$ & & & & & & $\mathbf{B}$ & $\mathbf{B}$ & \\
\hline ARPUS & Aristida & purpurea & & A & A & & A & A & & A & A & A & \\
\hline ARPUF & Aristida & purpurea var. fondleriana & & & & & B & & & & B & B & \\
\hline ARPUG & Arabis & pulchra var. gracilis & & & & & A & A & & A & A & A & \\
\hline ARPUL & Aristiola & purpurea var. longisete & & & & A & & $\mathbf{B}$ & & $\mathbf{A}$ & $\mathbf{B}$ & $\mathbf{B}$ & \\
\hline
\end{tabular}




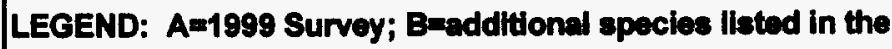
1976 Beatley Survey; 1 = Lyclum spp. Shrubland Alliance; 2 = Larrea tridentata/Ambrosia dumoea Shrubland Alliance; 3 = Atriplex confertifolia/Ambrosia dumosea Shrubland Allance; 4 = Hymenoclea-Lycium Shrubland Alliance; 5 = Ephodra nevadensis Shrubland Alliance; 6 = Coleogyne rammosissima Shrubland Alliance; 7 = Atriplex spp. Shrubland Allance; $8=$ Chrysothamnus-Ericameria Shrubland Alliance; $9=$ Artemisia spp. Shrubland Alliance; 10 = Pinus monophylla/Artemisla ssp. Woodland Alliance; 11= Miscellaneous

\begin{tabular}{|c|c|c|c|c|c|c|c|c|c|c|c|c|c|}
\hline Code & Genus & Species & 1 & 2 & 3 & 4 & 5 & \begin{tabular}{l|l}
6 & 7 \\
\end{tabular} & 78 & 8 & 9 & 10 & 11 \\
\hline ARPUM & Arabis & pulchra var. munciensis & A & $\mathbf{A}$ & A & A & A & A & & $\mathbf{A}$ & A & $\mathbf{A}$ & \\
\hline ARPUN & Aristida & purpurea var. nealleyi & & B & B & & & $\mathbf{B}$ & & & & & \\
\hline ARPUW & Aristida & purpurea var. wrightii & & & & & & $\mathbf{B}$ & & & & & \\
\hline ARSH & Arabis & shockleyi & & & & & & A & & & B & $\mathbf{B}$ & \\
\hline ARSP5 & Artemisia & spinescens & A & $\mathbf{A}$ & A & A & A & A & A & $\mathbf{A}$ & A & A & \\
\hline ARTRT & Artemisia & tridentata ssp. tridentata & & & A & & & $\mathbf{A}$ & A & A & A & A & $\mathbf{B}$ \\
\hline ASAC3 & Astragalus & acutirostris & B & A & & B & A & $\mathbf{A}$ & A & $\mathbf{A}$ & A & A & \\
\hline ASBE3 & Astragalus & beckwithii & & & & & & & & & A & A & \\
\hline ASBE5 & Astragalus & beatleyae & & & & & & & & & $\mathbf{A}$ & A & \\
\hline ASCA14 & Astragalus & casei & & & & & A & A & A & & A & $\mathbf{B}$ & \\
\hline ASCAC5 & Astragalus & calycosus var. calycosus & & & & & & & & $\mathbf{A}$ & A & A & $\mathbf{B}$ \\
\hline ASDID & Astragalus & didymocarpus var. dispermus & & A & & & & A & & & & & \\
\hline ASER2 & Asclepias & erose & & A & & & B & A & & & A & $\mathbf{B}$ & \\
\hline ASFU3 & Astragalus & funereus & & & & & & & & $\mathbf{A}$ & A & & $\mathbf{B}$ \\
\hline ASLA8 & Astragalus & layneae & & A & A & $\mathbf{A}$ & A & A & & & & & \\
\hline ASLEF2 & Astragalus & lentiginosus var. fremontii & $\mathbf{A}$ & $\mathbf{A}$ & A & A & $\mathbf{A}$ & A & A & A & $\mathbf{A}$ & A & \\
\hline ASLEM3 & Astragalus & lontiginosus var. micans & & $\mathbf{B}$ & B & & & & & & B & & \\
\hline ASLEV & Astragalus & letiginosus var. variabilis & & & & & & & & & & & $\mathbf{B}$ \\
\hline ASNIV & Astragalus & minthomiae var. villosus & & & & & & B & & & $\mathbf{A}$ & $\mathbf{B}$ & \\
\hline ASMONA & Astragalus & mohavensis var. mohavensis & & $\mathbf{B}$ & & & & B & & & & & \\
\hline ASNE6 & Astragalus & newbermi & & & & & & & & & A & A & \\
\hline ASNEC & Astragalus & nowberryi var. castoreus & & & & & & & & & & & $\mathbf{B}$ \\
\hline ASNEN & Astragalus & newberryi var. newberyi & & & & & & & & & B & B & $\mathbf{B}$ \\
\hline ASNY2 & Astragalus & nyensis & & & & & & & & & & & B \\
\hline AsO002 & Astragalus & oophorus var. oophorus & & & & & & & & & & $\mathbf{B}$ & \\
\hline ASPUL2 & Astragalus & purshii var. loctulus & & & & & & & & & & & $\mathbf{B}$ \\
\hline ASPUT & Astragalus & purshii var, tinctus & & & & & A & A & A & A & A & A & \\
\hline ASTI & Astragalus & tidestromii & & A & B & & A & & $\mathbf{A}$ & & & & $\mathbf{B}$ \\
\hline ATARE & Atriplex & argentea ssp. expanse & & & & & & & & & & & $\mathbf{B}$ \\
\hline ATCAC & Atriplex & canescens var. canescens & $\mathbf{A}$ & A & A & $\mathbf{A}$ & A & A & A & $\mathbf{A}$ & A & A & $\mathbf{B}$ \\
\hline ATCO & Atriplex & confertifolia & $\mathbf{A}$ & A & A & A & A & $\mathbf{A}$ & A & A & A & A & \\
\hline ATELF & Atriplex & elegans var. fasciculata & & & & & & & & & & & $\mathbf{B}$ \\
\hline ATHY & Atriplex & hymenelytra & & $\mathbf{A}$ & A & & & & & & & & \\
\hline ATLEL & Atriplex & lentiformis ssp. lentiformis & & & & & & & & & & & B \\
\hline
\end{tabular}


LEGEND: $A=1999$ Survey; Bradditional species liated in the 1976 Beatley Survey; 1 = Lycium spp. Shrubland Allance; $2=$ Larrea tridentata/Ambrosia dumoea Shrubland Alliance; 3 = Atriplex confertifolla/Ambrosia dumosa Shrubland Alliance; 4 $=$ Hymenoclea-Lycium Shrubland Alliance; 5 = Ephedra nevadensis Shrubland Allance; 6 = Coleogyne rammosiseima Shrubland Alliance; 7 = Atriplex spp. Shrubland Alliance; $8=$ Chrysothamnus-Ericameria Shrubland Alliance; $9=$ Artemisia spp. Shrubland Alliance; 10 = Pinus monophylla/Artemisia ssp. Woodland Alliance; $11=$ Miscellaneous

\begin{tabular}{|c|c|c|c|c|c|c|c|c|c|c|c|c|c|}
\hline & & & & & & & & & & & & & \\
\hline Code & Genus & Species & 1 & 2 & 3 & 4 & 5 & 6 & 7 & 8 & 9 & 10 & 11 \\
\hline ATPL & Atrichoseris & platyphylla & & & $\mathbf{B}$ & & A & & & & & & \\
\hline ATPO & Atriplex & polycarpa & & $\mathbf{A}$ & B & $\mathbf{A}$ & & & & & & & \\
\hline AVSA & Avena & sativa & & & & & & & & & & & $\mathbf{B}$ \\
\hline BAEM & Baccharis & emoryi & & & & & & & & & & & $\mathbf{B}$ \\
\hline BAHON & Balsamorhiza & hookeri var. neglecta & & & & & & $\mathbf{B}$ & & & A & A & \\
\hline BAHY & Bassia & hyssopifolia & & & & & & & $\mathbf{B}$ & & & B & \\
\hline BAMU & Baileya & multiradiata & $\mathbf{A}$ & A & A & $\mathbf{A}$ & $\mathbf{A}$ & A & $A$ & A & & & \\
\hline BAPL3 & Baileya & pleniradiata & B & $\mathbf{B}$ & & & B & A & B & $\mathbf{A}$ & & & \\
\hline BEER & Berula & erecta & & & & & & & & & & & $\mathbf{B}$ \\
\hline BLKI & Blepharidachne & kingii & & $\mathbf{B}$ & & & $\mathbf{B}$ & & B & & & & $\mathbf{B}$ \\
\hline BOBA2 & Bouteloua & barbata & & B & $\mathbf{B}$ & & B & B & B & & & & \\
\hline BOGR2 & Bouteloua & gracilis & & & & & $\mathbf{A}$ & A & $\mathbf{B}$ & $\mathbf{A}$ & $\mathbf{A}$ & A & \\
\hline BORO5 & Bolboschoonus & robustus & & & & & & & & & & & $\mathbf{B}$ \\
\hline BOTR2 & Bouteloua & trifida & & $\mathbf{B}$ & & & & $\mathbf{B}$ & & & & & \\
\hline BRAN & Bromus & anomalus & & & & & & & & & & $\mathbf{B}$ & $\mathbf{B}$ \\
\hline BRAT & Brickellia & atractyloides & & $\mathbf{A}$ & A & $\mathbf{A}$ & $\mathbf{A}$ & $\mathbf{A}$ & & A & & & \\
\hline BRAR2 & Brickellia & arguta & & & & & & & & & & & $\mathbf{B}$ \\
\hline BRBE2 & Bromus & berterianus & & & & & & $\mathbf{A}$ & $\mathbf{B}$ & A & & & $\mathbf{B}$ \\
\hline BRCA3 & Brickellia & califomica & & & & & & & & & A & $\mathbf{B}$ & \\
\hline BRCA5 & Bromus & carinatus & & & & & & & & & & $\mathbf{B}$ & $\mathbf{B}$ \\
\hline BRCA6 & Bromus & catharticus & & $\mathbf{A}$ & $\mathbf{B}$ & A & $\mathbf{A}$ & $\mathbf{A}$ & & & A & B & \\
\hline BRDE3 & Brickellia & desertorum & & $\mathbf{B}$ & & & & & & & & & \\
\hline BRDI3 & Bromus & diandrus & & & & & & & & & & & $\mathbf{B}$ \\
\hline BRGE & Brassica & geniculata & & & & & & & & & & & \\
\hline BRIN & Brickellia & incana & & $\mathbf{B}$ & & A & & & & & & & \\
\hline BRJA & Bromus & japonicus & & & & & & & & & & & $\mathbf{B}$ \\
\hline BRLO & Brickellia & Iongifolia & & & & & & & & & & & $\mathbf{B}$ \\
\hline BRLOM & Brickellia & longifolia var. multifiora & & & A & & & & & & & & \\
\hline BRMIS & Brickellia & microphylla var. scabra & & & & & & & B & A & A & $\mathbf{B}$ & \\
\hline BRMIW & Brickellia & microphylla var. watsonii & & $\mathbf{A}$ & A & & A & $\mathbf{A}$ & & A & & A & \\
\hline BROBL & Brickellia & oblongifolia var. linifolia & & & & A & A & $\mathbf{A}$ & & A & A & $\mathbf{B}$ & $\mathbf{B}$ \\
\hline BRRU2 & Bromus & rubens & A & $\mathbf{A}$ & A & A & $\mathbf{A}$ & $\mathbf{A}$ & A & A & A & A & \\
\hline BRTE & Bromus & tectorum & & A & & A & $\mathbf{A}$ & A & A & A & A & A & \\
\hline BUUT & Buddleja & utahensis & & $\mathbf{B}$ & A & & & $\mathbf{A}$ & & & & & \\
\hline
\end{tabular}


LEGEND: $A=1999$ Survey; Bredditional species llated in the 1976 Beatley Survey; 1 = Lycium spp. Shrubland Allance; 2E Larrea tridentata/Ambrosia dumosa Shrubland Alliance; 3 = Atriplex confertifolla/Ambroela dumosa Shrubland Alliance; 4 = Hymenocles-Lyclum Shrubland Allance; 5 = Ephodra nevadensis Shrubland Alliance; 6 a Coleogyne rammoelsaima Shrubland Alliance; 7 = Atriplox spp. Shrubland Allianco; $8=$ Chrysothamnus-Ericameria Shrubland Alliance; $9=$ Artemisia spp. Shrubland Alliance; 10 = Pinus monophylla/Artemisia ssp. Woodiand Allance; 11 = Miscellaneous

\begin{tabular}{|c|c|c|c|c|c|c|c|c|c|c|c|c|c|}
\hline Code & Genus & Species & 1 & 2 & 3 & 4 & 5 & 6 & 7 & 8 & 9 & 10 & 11 \\
\hline CAAL7 & Carex & alma & & & & & & & & & & $\mathbf{B}$ & \\
\hline CAAP4 & Cestilloja & applegatei & & A & A & A & A & A & A & $\mathbf{A}$ & $\mathbf{A}$ & A & B \\
\hline CAAPM & Castilloja & applegatei ssp. martinii & & A & & A & A & & & & & $\mathbf{B}$ & B \\
\hline CABOC & Camissonia & boothii ssp. condensata & B & A & A & A & A & A & & & & $\mathbf{A}$ & \\
\hline CABOI & Camissonia & boothii ssp. intermedia & & & & & & & B & A & A & B & \\
\hline CABRA & Calochortus & bruneaunis & & & & & & & & & & B & \\
\hline CABRB4 & Camissonia & brevipes ssp. brevipes & & A & A & A & B & A & A & $\mathbf{A}$ & A & A & $\mathbf{B}$ \\
\hline CABRP & Camissonia & brevipes ssp. pallidula & & $\mathbf{B}$ & A & & & & & & & & \\
\hline CACA32 & Camissonia & celiformica & & & & & & & & & $\mathbf{B}$ & & B \\
\hline CACH12 & Camissonia & chamaenerioides & & $\mathbf{B}$ & B & & B & & & & & & \\
\hline CACLI & Camissonia & claviformis ssp. integrior & $\mathbf{B}$ & $\mathbf{A}$ & & B & A & A & $\mathbf{B}$ & $\mathbf{A}$ & A & A & \\
\hline CACO18 & Caulanthus & cooperi & B & A & & B & B & B & & & & & \\
\hline CACRG & Caulanthus & crassicaulis var. glaber & & & & & & & & & $\mathbf{A}$ & A & \\
\hline CADO2 & Carex & douglasii & & & & & & & & & & A & \\
\hline CAFL & Calochortus & flexuosus & & A & & A & A & A & A & A & A & A & \\
\hline CAHE12 & Camissonia & heterochroma & & A & & & A & A & $\mathbf{B}$ & & $\mathbf{B}$ & $\mathbf{B}$ & \\
\hline CAKEG & Camissonia & kemensis ssp. gilmanii & & $\mathbf{A}$ & A & A & A & A & A & A & A & & \\
\hline CALI & Castilloja & Iinariaefolia & & & & & & A & & A & A & A & B \\
\hline CAME16 & Camissonia & megalantha & & & & & & A & A & A & & & B \\
\hline CAMU14 & Camissonia & munzii & & & B & & & & & & & & \\
\hline CAOC2 & Carex & occidentalis & & & & & & & & & & A & \\
\hline CAPA39 & Camissonia & parvula & & & & & & & & & A & $\mathbf{B}$ & \\
\hline CAPA7 & Calycoseris & pamyi & & & & & A & A & A & A & A & A & \\
\hline CAPK & Caulanthus & pilosus & & A & & A & A & & B & A & A & & \\
\hline CAPR5 & Carex & praogracilis & & & & & & & B & & & B & B \\
\hline CAPT & Camissonia & pterosperma & & & & & A & B & & A & $\mathbf{A}$ & A & \\
\hline CAPU16 & Camissonia & pusilla & & & & & & & & & A & $\mathbf{A}$ & \\
\hline CARE2 & Camissonia & refracta & & A & A & & & & & A & A & & \\
\hline CAWAT & Camissonia & walkeri ssp. tortilis & & & B & & & $\mathbf{B}$ & & & & & \\
\hline CAWR & Calycoseris & wrightii & $\mathbf{B}$ & B & & A & B & $\mathbf{B}$ & & & & & \\
\hline CEGRV2 & Ceanothus & greggii ssp. vestitus & & & & & & A & & & A & A & $\mathbf{B}$ \\
\hline CEIN7 & Cercocarpus & intricatus & & & & & & $\mathbf{B}$ & & & & A & B \\
\hline CELEL & Cercocarpus & ledifolius var. ledifolius & & & & & & $\mathbf{A}$ & & & & A & B \\
\hline CETH3 & Centrostegia & thurberi & A & A & & & A & A & A & A & A & $\mathbf{A}$ & \\
\hline
\end{tabular}


LEGEND: $A=1999$ Survey; Bradditional species liated in the 1976 Beatley Survey; 1 = Lycium spp. Shrubland Alliance; $2=$ Larrea tridentata/Ambrosla dumosa Shrubland Alliance; 3 = Atriplex confertffolla/Ambroela dumoes Shrubland Alliance; 4 = Hymenoclea-Lycium Shrubland Alliance; 5 = Ephedra nevadenais Shrubland Alliance; 6 = Coloogyne rammosissima Shrubland Alliance; 7 = Atriplex spp. Shrubland Alliance; $8=$ Chrysothamnus-Ericameria Shrubland Alliance; $9=$ Artemisia spp. Shrubland Allance; 10 = Pinus monophylla/Artomisia ssp. Woodland Allance; $11=$ Miscellaneous

\begin{tabular}{|c|c|c|c|c|c|c|c|c|c|c|c|c|c|}
\hline p. & 19 & Hilscella & $\exists$ & 5 & 5 & $\mathbf{I}$ & 出 & डั & 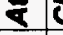 & 0 & $\$$ & $\bar{a}$ & $E$ \\
\hline Code & Genus & Species & 1 & 2 & 3 & 4 & 5 & 6 & 7 & 8 & 9 & 10 & 11 \\
\hline CHAL11 & Chamaesyco & albomarginata & A & A & $\mathbf{A}$ & A & A & A & A & $\mathbf{A}$ & $\mathbf{A}$ & A & \\
\hline CHAL7 & Chenopodium & album & & & & & & & A & & $\mathbf{A}$ & A & $\mathbf{B}$ \\
\hline CHALM2 & Chenopodium & album var. missouriense & & & & & & & & & & $\mathbf{B}$ & \\
\hline CHAT & Chenopodium & atrovirens & & & & & & & & & & B & \\
\hline CHBES & Chenopodium & bertandieri var. sinuatum & & & & & & & & & & $\mathbf{B}$ & \\
\hline CHBEZ & Chenopodium & bertandieri var. zschacke $i$ & & & & & & B & & & & B & \\
\hline CHBRB & Chorizanthe & brevicomu var. brovicomu & & A & & A & A & A & A & & A & & \\
\hline CHBRS & Chorizanthe & brevicomu var. spathulata & & & & & & & & & & $\mathbf{B}$ & \\
\hline CHCA & Chaenactis & carphoclinia & & A & A & & B & A & & & & & \\
\hline $\mathrm{CHCO4}$ & Cheilanthes & covillei & & & & & & B & & & & & \\
\hline CHDO & Chaenactis & douglasii & & & & & & & & & A & A & B \\
\hline CHER2 & Leucelene & ericoides & & & & & B & $\mathbf{B}$ & $\mathbf{B}$ & A & $\mathbf{A}$ & $\mathbf{B}$ & \\
\hline CHFE3 & Chameesyce & fendleri & & & & & & & & & $\mathbf{B}$ & B & $\mathbf{B}$ \\
\hline CHFR & Chaenactis & fremontii & A & $\mathbf{A}$ & A & A & A & A & A & $\mathbf{A}$ & $\mathbf{A}$ & & \\
\hline CHFR3 & Chenopodium & fermontii & & & & & & & & & & $\mathbf{B}$ & \\
\hline CHGR13 & Chrysothamnus & gramineus & & & & & & & & & $\mathbf{A}$ & A & $\mathbf{B}$ \\
\hline CHGR6 & Chrysothamnus & greenei & & & & & A & A & B & A & A & A & \\
\hline CHIN2 & Chenopodium & incanum & & B & & B & B & $\mathbf{B}$ & B & & $\mathbf{A}$ & A & \\
\hline CHLE4 & Chenopodium & leptophyllum & & & & & & & & A & A & A & \\
\hline CHMA & Chaenactis & macrantha & $\mathbf{B}$ & A & A & B & A & A & A & A & A & A & \\
\hline CHMI2 & Chamaebatiaria & millefolium & & & & & & & & & & B & \\
\hline CHMI7 & Chamaesyce & micromera & B & B & $\mathbf{B}$ & B & B & B & B & & $\mathbf{B}$ & & \\
\hline CHPA30 & Chamaesyce & parishii & & B & & & & & & & & & \\
\hline CHPA4 & Cheilanthos & pamyi & & & $\mathbf{B}$ & & & & & & & & \\
\hline CHPR5 & Chenopodium & pratericola & & $\mathbf{B}$ & & & & & B & & & & \\
\hline CHRI & Chorizanthe & rigida & & A & A & & A & A & A & A & $\mathbf{A}$ & & \\
\hline CHSE8 & Chamaesyce & sotiloba & & & & & $\mathbf{B}$ & B & & & $\mathbf{B}$ & & \\
\hline CHSES & Chamaesyce & serpyllifolia ssp. serpyllifolia & & B & & & A & B & B & $\mathbf{A}$ & A & $\mathbf{B}$ & \\
\hline CHSI2 & Chenopodium & simplex & & & & & & & & & & B & \\
\hline CHST & Chaenactis & stevioides & A & A & A. & A & A & A & $\mathbf{A}$ & $\mathbf{A}$ & A & A & \\
\hline CHSTG2 & Chenopodium & strictum ssp. glaucophyllum & & & & & & & & & & B & \\
\hline CHVM & Chloris & virgata & & & & & & & & & & B & \\
\hline CHVIP4 & Chrysothamnus & viscidiflorus ssp. puberulus & & & A & & A & A & $\mathbf{B}$ & A & A & A & $\mathbf{B}$ \\
\hline CHVIS5 & Chrysothamnus & viscidiflorus ssp. viscidifiorus & byllus & & & $\mathbf{B}$ & A & $\mathbf{B}$ & $\mathbf{B}$ & & $\mathbf{A}$ & $\mathbf{B}$ & \\
\hline
\end{tabular}


LEGEND: $A=1999$ Survey; Bandditional species listed in the 1976 Beatley Survey; 1 = Lycium spp. Shrubland Allance; 2 = Larrea tridentata/Ambrosla dumosa Shrubland Allance; 3 = Atriplex confertifolia/Ambrocia dumosa Shrubland Allance; 4 = Hymenoclea-Lycium Shrubland Allance; 5 = Ephedra nevadensls Shrubland Allance; 6 = Coleogyne rammoalacima Shrubland Alliance; 7 = Atriplex spp. Shrubland Allance; $8=$ Chrysothamnus-Ericamerla Shrubland Alliance; 9 = Artemisia spp. Shrubland Allance; 10 = Pinus monophylla/Artemisia ssp. Woodland Alliance; 11 = Miscellaneous

\begin{tabular}{|c|c|c|c|c|c|c|c|c|c|c|c|c|c|}
\hline Code & Genus & Species & 1 & 2 & 3 & 4 & 5 & 6 & 78 & 8 & 9 & 10 & 11 \\
\hline CHVIV2 & Chrysothamnus & viscidiflorus ssp. viscidifiorus & A & A & A & A & A & $\mathbf{A}$ & A & A & A & A & $B$ \\
\hline CHWA2 & Chorizanthe & watsonii & & & & & A & A & & $\mathbf{A}$ & A & $\mathbf{A}$ & \\
\hline CHWH & Chaetedelphia & Wheelen & & B & & & $\mathbf{B}$ & & B & & & & \\
\hline CHXA & Chaenactis & xantiana & & & & & & & & & A & A & B \\
\hline CinO4 & Cistanthe & monandra & & B & & & & & & & & & B \\
\hline CINE & Cirsium & neomexicanum & & A & & & A & A & & A & $\mathbf{A}$ & A & \\
\hline CIPAN & Cistenthe & parnyi var. nevadense & & & & & & A & & & A & B & \\
\hline CLLU2 & Cleome & Iutea & & & & & & & $\mathbf{B}$ & & & $\mathbf{B}$ & \\
\hline CLPAU2 & Claytonia & perfoliata ssp. perfoliata & & & & & & A & & & A & A & \\
\hline COAR4 & Convolvulus & arvensis & & & & & & & & & & & B \\
\hline COCA5 & Conyza & canadensis & & & B & & & B & & & & $\mathbf{B}$ & \\
\hline COPA3 & Collinsia & parvifiora & & & & & & A & & & & A & \\
\hline CORA & Coleogyne & ramosissima & & $\mathbf{A}$ & $\mathbf{A}$ & A & A & A & A & A & A & A & \\
\hline COTE & Collomia & tenella & & & & & & B & & & & B & \\
\hline CRAM3 & Cryptanthe & ambigua & & & & & A & & & & A & $\mathbf{A}$ & \\
\hline CRAN4 & Cryptantha & angustifolia & & B & B & & & & & & & & \\
\hline CRBA5 & Cryptantha & barbigera & & & & & & $\mathbf{B}$ & & & & & \\
\hline CRCI2 & Cryptantha & circumscissa & $\mathbf{A}$ & A & $\mathbf{A}$ & A & $\mathbf{A}$ & $\mathbf{A}$ & $\mathbf{A}$ & A & A & A & \\
\hline CRCO12 & Cryptantha & confertiflora & & & & & A & A & $\mathbf{A}$ & $\mathbf{A}$ & $\mathbf{A}$ & A & \\
\hline CRDE & Cryptanthe & decipiens & & $\mathbf{B}$ & B & & & & & & A & & \\
\hline CRDU & Cryptanthe & dumotorum & & $\mathbf{B}$ & & & & & & & & & \\
\hline CRFL6 & Cryptanthe & flavoculata & & & A & & A & A & & A & A & A & \\
\hline CRGR3 & Cryptantha & gracilis & & & & & $\mathbf{A}$ & $\mathbf{A}$ & & A & A & $\mathbf{A}$ & \\
\hline CRHU2 & Cryptantha & humilis & & & & & & & & & B & $\mathbf{A}$ & \\
\hline CRIN4 & Crepis & intermodia & & & & & & & & & & A & $\mathbf{B}$ \\
\hline CRMAT & Cryptantha & maritima & & $\mathbf{A}$ & & & A & & & & & & $\mathbf{B}$ \\
\hline CRMII & Cryptantha & micrantha & & A & A & A & A & $\mathbf{A}$ & $\mathbf{A}$ & A & $\mathbf{A}$ & A & \\
\hline CRNEN & Cryptantha & nevadensis var. nevadensis & A & A & A & A & A & A & A & A & A & A & B \\
\hline CROCO2 & Cropis & occidentalis ssp. occidentalis & & & & & A & A & & & A & A & \\
\hline CRPT & Cryptantha & pterocarya & A & $\mathbf{A}$ & & A & $\mathbf{A}$ & A & $\mathbf{A}$ & A & A & A & \\
\hline CRRA2 & Cryptantha & racermosa & & B & & & & & & & & & \\
\hline CRRE5 & Cryptantha & recurvata & B & A & B & $\mathbf{B}$ & A & A & B & A & A & & \\
\hline CRRUH & Cropis & runcinata ssp. hallii & & & & & & & & & & & B \\
\hline $\mathrm{CRSC}_{2}$ & Cryptantha & scoparia & & & & & & & & & & $\mathbf{B}$ & \\
\hline
\end{tabular}


LEGEND: A=1999 Survey; Bradditional specles lieted in the 1976 Beatloy Survey; 1 = Lycium spp. Shrubland Alliance; 2 = Larrea tridentata/Ambrosia dumoea Shrubland Alliance; 3 = Atriplex confertfolla/Ambroela dumoca Shrubland Allance; 4 = Hymenoclea-Lyclum Shrubland Alliance; 5 = Ephodra nevadenals Shrubland Alliance; 6 = Coloogyne rammosiesima Shrubland Alliance; 7 = Atriplox spp. Shrubland Allance; $8=$ Chrysothamnus-Ericameria Shrubland Alliance; 9 = Artemisia spp. Shrubland Allance; 10 = Pinus monophylla/Artemisia ssp. Woodland Allance; 11= Mlscellaneous

\begin{tabular}{|c|c|c|c|c|c|c|c|c|c|c|c|c|c|}
\hline Code & Genus & Species & 1 & 2 & 3 & 4 & 5 & 6 & 7 & 8 & 9 & 10 & 11 \\
\hline CRUT & Cryptantha & utahensis & & A & A & & A & $\mathbf{A}$ & A & $\mathbf{A}$ & A & A & \\
\hline CRV15 & Cryptanthe & virginensis & & A & $\mathbf{A}$ & A & $\mathbf{A}$ & $\mathbf{A}$ & A & $\mathbf{A}$ & A & A & \\
\hline CRWA2 & Cryptanthe & watsonii & & & & & & & & & & $\mathbf{B}$ & \\
\hline CUDE2 & Cuscuta & denticulata & & & & & & & & & & & B \\
\hline CUDEV & Cuscuta & denticulate var. vetchii & & $\mathbf{A}$ & & & & A & & & & & B \\
\hline CYAB & Cymopterus & aboriginum & & & & & & A & & & B & A & \\
\hline CYDA & Cynodon & dectyion & & & & & & & & & & & B \\
\hline CYGI & Cymopterus & gilmanii & & & & & & $\mathbf{B}$ & & & & & \\
\hline CYGL2 & Cymopterus & globosus & & & & A & A & A & A & $\mathbf{A}$ & A & & B \\
\hline CYPU & Cymopterus & purpurascens & & & & & A & A & & & A & $\mathbf{B}$ & \\
\hline CYRI2 & Cymopterus & nipleyi & & $\mathbf{B}$ & & A & A & A & B & $\mathbf{A}$ & A & $\mathbf{B}$ & \\
\hline CYUT & Cynanchum & utahense & & B & & & & & & & & & \\
\hline DACA6 & Daucus & carota & & & & & & & & & & & B \\
\hline DAGL & Dactylis & glomerata & & & & & & & & & & & $\mathbf{B}$ \\
\hline DAMO2 & Dalea & mollissima & & A & & & & & B & & & & \\
\hline DASE3 & Dalea & searlsiae & & & & & & $\mathbf{B}$ & $\mathbf{B}$ & $\mathbf{A}$ & B & $\mathbf{B}$ & \\
\hline DAWR2 & Datura & wrightii & & & & & & & B & & & & \\
\hline DEAN & Dolphinium & andersonii & & $\mathbf{A}$ & A & & A & A & & & $\mathbf{A}$ & A & \\
\hline DECA18 & Deschampsia & caespitosa & & & & & & & & & & & B \\
\hline DEDA & Deschampsia & danthonioides & & & & & & B & & & & & \\
\hline DEPAP3 & Delphinium & parishii ssp. parishii & $\mathbf{B}$ & A & A & A & A & A & A & $\mathbf{A}$ & $\mathbf{A}$ & $A$ & \\
\hline DEPIG & Descurainia & pinnata ssp. giabra & A & A & A & B & A & A & A & A & A & A & \\
\hline DEPIH & Descurainia & pinnata ssp. halictorum & & & & & & & & & $\mathbf{B}$ & $\mathbf{B}$ & B \\
\hline DESO2 & Descurainia & sophia & $\mathbf{A}$ & A & B & & A & A & & & & $\mathbf{B}$ & \\
\hline DIPU3 & Dichelostermma & pulchellum & & A & & A & A & $\mathbf{A}$ & & $\mathbf{A}$ & A & A & \\
\hline DISA & Digitaria & sanguinalis & & & & & & & & & & & B \\
\hline DISP & Distichlis & spicata & & & & & & & B & & & & \\
\hline DRCUC & Draba & cuneifolia var. cuneifolia & & & & & & & & & B & $\mathbf{B}$ & \\
\hline DRCUI & Draba & cuneifolia var. integrifolia & & & & & & B & & & & & \\
\hline DYPEB & Dyssodia & pentachaeta var. belenidium & & & & & & $\mathbf{B}$ & & & & & \\
\hline ECCR & Echinochloa & crusgalli & & & & & & & & & & & $\mathbf{B}$ \\
\hline ECEN & Echinocereus & engelmannii & & A & A & A & $\mathbf{A}$ & A & A & A & A & $\mathbf{A}$ & \\
\hline ECENA2 & Echinocereus & engelmannii var. armatus & & & & & & & & & B & & \\
\hline ECENC & Echinocereus & engelmannii var. chysocentrus & & & & & & & & & & $\mathbf{B}$ & \\
\hline
\end{tabular}


LEGEND: $A=1999$ Survey; $B$ andditional species listed in the 1976 Beatley Survey; 1 = Lycium spp. Shrubland Alliance; 2 = Larrea tridentata/Ambrosia dumosa Shrubland Allance; 3 = Atriplex confertifolla/Ambroela dumoea Shrubland Alliance; 4 = Hymenoclea-Lycium Shrubland Alliance; 5 = Ephedra nevadenais Shrubland Allance; 6 = Coloogyne rammosiasima Shrubland Alliance; 7 = Atriplox spp. Shrubland Alliance; $8=$ Chrysothamnus-Ericameria Shrubland Allance; $9=$ Artemisia spp. Shrubland Allance; 10 = Pinus monophylla/Artomisia ssp. Woodland Alliance; $11=$ Miscellaneous

\begin{tabular}{|c|c|c|c|c|c|c|c|c|c|c|c|c|c|}
\hline Code & Genus & Species & 1 & 2 & 3 & 4 & 5 & 6 & 7 & 8 & 9 & 10 & 11 \\
\hline ECENE & Echinocereus & engelmannii var. engelmannii & & & $\mathbf{B}$ & & $\mathbf{A}$ & A & & A & & & \\
\hline ECPO2 & Echinocectus & polycephalus & & $\mathbf{A}$ & $A$ & A & $\mathbf{A}$ & A & A & A & & & \\
\hline ECTRM & Echinocerous & triglochictiatus var. melanacanthus & & $\mathbf{A}$ & & & A & B & & & A & A & \\
\hline ELELE & Elymus & elymoides ssp. elymoids & A & A & A & A & A & A & A & A & A & A & \\
\hline ELMAS & Eleocheris & macrostachya & & & & & & & & & & $\mathbf{B}$ & \\
\hline ELMU3 & Elymus & multisetus & & & & & & $\mathbf{B}$ & & & & & $\mathbf{B}$ \\
\hline ELPA3 & Eleocharis & paulustris & & & & & & & & & & & $\mathbf{B}$ \\
\hline ELPA4 & Eloocharis & parishii & & & & & & & & & & B & $\mathbf{B}$ \\
\hline ENNUN & Encoliopsis & nudicaulis var. nudicaulis & & & & A & A & & & & $\mathbf{B}$ & & \\
\hline ENVIV & Encelia & virginensis var. vinginensis & & A & $\mathbf{A}$ & A & $\mathbf{A}$ & A & A & A & A & & \\
\hline EPCI & Epilobium & ciliatum & & & & & & $\mathbf{B}$ & & & & A & \\
\hline EPFU & Ephedra & funerea & & $\mathbf{A}$ & $\mathbf{A}$ & & $\mathbf{A}$ & A & & & & & \\
\hline EPGL & Epilobium & glabemimum & & & & & & & & & & & $\mathbf{B}$ \\
\hline EPNE & Ephodra & nevadensis & & $\mathbf{A}$ & A & A & B & A & A & A & A & $\mathbf{A}$ & \\
\hline EPTO & Ephedra & tomeyana & & A & $\mathbf{A}$ & & $\mathbf{A}$ & A & A & & & & \\
\hline EPV & Ephedra & vinidis & & A & A & A & $\mathbf{A}$ & A & A & A & A & $\mathbf{A}$ & \\
\hline ERAP & Erigeron & aphanactis & & & & & & & & A & A & $\mathbf{A}$ & $\mathbf{B}$ \\
\hline ERBA2 & Eragrostis & bamelieni & & & & & & & & & & & $\mathbf{B}$ \\
\hline ERBAB & Eniogonum & baileyi var. baileyi & & & & & & & & & & & $\mathbf{B}$ \\
\hline ERBR7 & Eriogonum & brachyanthum & & & & & & A & B & & $\mathbf{A}$ & $\mathbf{A}$ & \\
\hline ERBR8 & Eniogonum & brachypodum & & & $\mathbf{B}$ & & & $\mathbf{B}$ & & & & & \\
\hline ERBRP & Erigeron & breweri var. porphyreticus & & & & & & & & & B & & \\
\hline ERCA2 & Eriogonum & califomicum & & & & & & & & & A & A & B \\
\hline ERCA8 & Eriogonum & caespitosum & & & & & & $\mathbf{A}$ & & & $\mathbf{A}$ & $\mathbf{B}$ & \\
\hline ERCEC & Eriogonum & cemuum ver. cermuum & & & & & & & & & & $B$ & B \\
\hline ERCEV & Eriogonum & comuum var. viminale & & & & & & & & & B & $\mathbf{B}$ & \\
\hline ERCl6 & Erodium & cicutarium & & A & A & A & A & $\mathbf{A}$ & A & A & A & A & \\
\hline ERCO18 & Eriogonum & concinnum & & & & & & & B & & A & $\mathbf{B}$ & \\
\hline ERCO23 & Ericemeria & coopeni & & A & A & A & A & A & A & $\mathbf{A}$ & $A$ & A & \\
\hline ERCOC3 & Erigeron & concinnus var. concinnus & & A & A & & A & $A$ & A & A & A & A & \\
\hline ERCUC & Ericameria & cuneatus & & & & & & A & & & $\mathbf{B}$ & $\mathbf{B}$ & \\
\hline ERDE6 & Eriogonum & defiexum & & A & A & A & A & A & A & A & A & $A$ & \\
\hline ERDEB & Eriogonum & deffexum var. baratum & & & & & & $\mathbf{B}$ & & & $\mathbf{B}$ & $\mathbf{B}$ & \\
\hline ERDED4 & Eriogonum & deflexum ver. deffexum & & $\mathbf{B}$ & B & & & & & & & B & \\
\hline
\end{tabular}


LEGEND: A=1999 Survey; Bandditional species llated in the 1976 Beatley Survey; 1 = Lycium spp. Shrubland Alliance; 2 = Larrea tridentata/Ambrosia dumosa Shrubland Alliance; 3 = Atriplex confertfolla/Ambroalia dumosa Shrubland Alliance; 4 $=$ Hymenoclea-Lyclum Shrubland Alliance; 5 = Ephedra nevadensis Shrubland Allance; 6 = Coleogyne rammosiasima Shrubland Alllance; 7 = Atriplex spp. Shrubland Alliance; 8 = Chrysothamnus-Ericameria Shrubland Allance; $9=$ Artemisia spp. Shrubland Allance; 10 = Pinus monophylla/Artemisia ssp. Woodland Alliance; 11= Mlscellaneous

\begin{tabular}{|c|c|c|c|c|c|c|c|c|c|c|c|c|c|}
\hline Code & Genus & Species & 1 & 2 & 3 & 4 & 5 & 6 & 7 & 8 & 9 & 10 & 11 \\
\hline ERDEN & Eriogonum & deflexum var. nevadense & B & $\mathbf{B}$ & & $\mathbf{B}$ & $\mathbf{B}$ & B & $\mathbf{B}$ & & B & $\mathbf{B}$ & \\
\hline ERDI4 & Erigeron & divergens & & & & & A & A & & A & $\mathbf{A}$ & A & \\
\hline ERER2 & Eriastrum & eremicum & A & A & A & A & A & A & A & A & A & A & \\
\hline ERESE & Eriogonum & esmeraldense var. esmeraldense & & & & & $\mathbf{A}$ & & & & A & A & B \\
\hline EREX3 & Eremalche & exilis & & B & & & & & & & & & B \\
\hline ERFAP & Eriogonum & fasciculatum var. polifolium & & A & A & A & A & A & A & A & $\mathbf{A}$ & A & \\
\hline ERGLA & Eriogonum & glandulosum & & & B & & & A & & & & & \\
\hline ERHEA & Eriogonum & heermannii var. argense & & & & & & A & & & A & B & \\
\hline ERHEH2 & Eriogonum & hoermannii var. heermannii & & & A & & A & A & & & & & $\mathbf{B}$ \\
\hline ERHES2 & Eriogonum & heermannii var. sulcatum & & & & & & & & & & & $\mathbf{B}$ \\
\hline ERHO12 & Eriogonum & howellianum & & & & & & $\mathbf{B}$ & & & & & \\
\hline ERHO6 & Eriogonum & hookeri & & & & & & & $\mathbf{B}$ & $\mathbf{A}$ & A & & \\
\hline ERIN10 & Eriogonum & insigne & & $\mathbf{B}$ & & & & & & & & & \\
\hline ERIN4 & Eriogonum & inflatum & $\mathbf{A}$ & A & A & A & $\mathbf{A}$ & A & A & A & A & A & \\
\hline ERLI6 & Ericameria & linearifolius & & & & & A & A & & A & A & A & \\
\hline ERMA2 & Eniogonum & maculatum & A & A & A & B & B & A & B & & A & & \\
\hline ERMIL & Eriogonum & microthecum var. lapidicola & & & & & & A & & & A & A & \\
\hline ERMIS2 & Eriogonum & microthecum var. simpsonii & & & A & & A & A & & A & A & A & \\
\hline ERNA10 & Enicamenia & nauseosus & & & B & & A & A & $\mathbf{B}$ & A & A & A & B \\
\hline ERNAT & Enicemeria & nanus & & & & & A & B & A & A & A & A & \\
\hline ERNAH & Ericameria & nauseosus ssp. nauseosus var. hololeuca & & & B & $\mathbf{A}$ & A & A & $\mathbf{A}$ & $\mathbf{A}$ & A & A & \\
\hline ERNAL & Ericameria & nauseosus ssp consimilis var. loiosperma & & A & A & A & A & A & A & A & A & A & \\
\hline ERNH4 & Eriogonum & nidularium & A & A & A & A & A & A & A & A & A & A & \\
\hline ERNU4 & Eriogonum & nummulare & & & & & $\mathbf{A}$ & A & B & A & A & & \\
\hline ERNUN2 & Eriogonum & nutans var nutans & & & & & & & & & B & B & \\
\hline EROVO5 & Eriogonum & ovalifolium var. ovalifolium & & & & A & A & A & & A & A & A & \\
\hline ERPA11 & Eriogonum & palmerianum & & & & & & B & & & B & A & \\
\hline ERPA29 & Ericameria & paniculata & & A & & A & $\mathbf{A}$ & & & & $\mathbf{A}$ & A & B \\
\hline ERPAN2 & Enicameria & pamyi var. nevadensis & & & & & & & & & A & A & \\
\hline ERPI6 & Enioneuron & pilosum & & & & & & & & & B & & \\
\hline ERPR4 & Eriophyllum & pringlei & B & A & A & A & $\mathbf{A}$ & A & $\mathbf{A}$ & A & A & & \\
\hline ERPU6 & Eriogonum & pusillum & & A & & A & $\mathbf{B}$ & A & A & A & A & & \\
\hline ERPU8 & Erioneuron & puichellum & & A & A & A & $\mathbf{A}$ & A & A & A & A & & \\
\hline ERRA3 & Eriogonum & racemosum & & A & & & & & & A & $\mathbf{A}$ & A & $\mathbf{B}$ \\
\hline
\end{tabular}


LEGEND: $A=1999$ Survey; Barddltional species listad in the 1976 Beatley Survoy; 1 = Lycium spp. Shrubland Alliance; 2 = Larrea tridentata/Ambrosla dumosa Shrubland Alliance; 3 = Atriplex confortfolia/Ambroeia dumosa Shrubland Alliance; 4 = Hymenoclea-Lycium Shrubland Alliance; 5 = Ephodra nevadensis Shrubland Alliance; 6 = Coleogyne rammosisaima Shrubland Alliance; $7=$ Atriplex app. Shrubland Alliance; 8 = Chrysothamnus-Ericameria Shrubland Allance; $9=$ Artemisia spp. Shrubland Alliance; 10 = Pinus monophylla/Artemisia ssp. Woodland Alliance; $11=$ Miscellaneous

\begin{tabular}{|c|c|c|c|c|c|c|c|c|c|c|c|c|c|}
\hline Code & Genus & Species & 1 & 2 & 3 & 4 & 5 & 6 & 7 & 8 & 9 & 10 & 11 \\
\hline ERRE3 & Eriogonum & reniforme & B & B & & & $\mathbf{A}$ & & & & & & \\
\hline ERROB & Eremalche & rotundifolia & & B & B & & & & & & & & \\
\hline ERSA6 & Eriogonum & saxatile & & & & & A & A & & A & A & A & \\
\hline ERSP3 & Eniastrum & sparsiflorum & & A & A & & & A & & A & A & A & \\
\hline ERTE18 & Ericameria & teretifolia & & A & A & A & A & A & A & A & A & A & \\
\hline ERTH & Eriogonum & thomasii & & $\mathbf{A}$ & A & & & A & & A & & & \\
\hline ERTRB & Eriogonum & trichopes & & A & B & & & A & & & B & & \\
\hline ERUM & Eriogonum & umbollatum & & & & & A & A & A & A & A & A & \\
\hline ERUMD3 & Eriogonum & umbellatum var. dichrocephalum & & & & & & & & & B & B & \\
\hline ERUMS2 & Eriogonum & umbellatum var. subaridum & & & & & & & & & & $\bar{A}$ & B \\
\hline ERUMV & Eriogonum & umbellatum var. vermum & & & & & & & & & B & A & \\
\hline ERUIMV2 & Eriagonum & umbellatum var. versicolor & & & & & & & & & A & A & B \\
\hline ERWA8 & Ericameria & watsonii & & A & & & & & & & A & $\mathbf{A}$ & \\
\hline ERM & Eriastrum & wilcoxii & & & & & & & & & A & $\mathbf{A}$ & \\
\hline ERWRS & Eriogonum & wrightii var. subscaposum & & & & & & & & & & & B \\
\hline ESGL & Eschscholzia & glyptosperma & A & A & A & & A & A & A & & & & \\
\hline ESMI & Eschscholzia & minutifiora & & A & B & & A & B & B & & A & & \\
\hline ESMIC2 & Eschscholzia & multifiora ssp. covillei & & B & B & & & B & & & & & \\
\hline ESVID & Escobaria & vivipara var. deserti & & & & & A & A & & A & A & $\mathbf{B}$ & \\
\hline ESVIR2 & Escobaria & vivipara var. rosea & & & A & & A & A & A & & A & A & \\
\hline EUMI2 & Eucrypta & micrantha & & & B & & & B & & & & & \\
\hline EUUR & Eucnide & urens & & & & & & & & & & & B \\
\hline FAPA & Fallugia & paradoxa & & & & & & B & & & B & B & \\
\hline FEPR & Festuca & pretensis & & & & & & & & & & & B \\
\hline FEUT & Fendlerella & utahensis & & & & & & B & & & & B & \\
\hline FOPUP & Forestiora & pubescens ver, pubescens & & & B & & & & & & & & B \\
\hline FRAL5 & Frasera & albomarginata & & & & & & & & & & & B \\
\hline FRALM & Frasera & pahutensis & & & & & & & & & & A & \\
\hline FRAN2 & Fraxinus & anomala & & & & & & & & & & & B \\
\hline FRAT & Fritillaria & atropurpurea & & & & & & & & & A & B & \\
\hline FRVE2 & Fraxinus & velutina & & & & & & & & & & & B \\
\hline GAAP2 & Galium & aparine & & & & & & & & & & B & \\
\hline GABI & Galium & bifolium & & & & & & & & & & B & \\
\hline GACOS & Gaura & cocciner & & B & B & & & B & & & & & \\
\hline
\end{tabular}


LEGEND: $A=1999$ Survey; $B$ andditional species liated in the 1976 Beatley Survey; 1 = Lyclum spp. Shrubland Alliance; 2 = Larrea tridentata/Ambrosia dumoea Shrubland Alliance; 3 = Atriplex confertffolia/Ambroeia dumosa Shrubland Alliance; 4 = Hymenoclea-Lycium Shrubland Alliance; 5 = Ephedra nevadensis Shrubland Alliance; 6 = Coloogyne rammoelesima Shrubland Alliance; $7=$ Atriplex spp. Shrubland Allance; $8=$ Chrysothamnus-Ericameria Shrubland Allance; 9 = Artemisia spp. Shrubland Allance; 10 = Pinus monophylla/Artomisia ssp. Woodland Allance; $11=$ Miscellaneous

\begin{tabular}{|c|c|c|c|c|c|c|c|c|c|c|c|c|c|}
\hline \multicolumn{3}{|c|}{ ssp. Woodland } & \multirow{2}{*}{$\begin{array}{l}J \\
1\end{array}$} & \multirow{2}{*}{$\begin{array}{l}3 \\
2\end{array}$} & \multirow{2}{*}{\begin{tabular}{|l} 
\\
\end{tabular}} & \multirow{2}{*}{$\frac{I}{4}$} & \multirow{2}{*}{$\frac{\pi}{5}$} & \multirow{2}{*}{$\frac{0}{6}$} & \multirow{2}{*}{8} & \multirow{2}{*}{$\begin{array}{l}0 \\
8\end{array}$} & \multirow{2}{*}{$\frac{8}{9}$} & \multirow{2}{*}{$\frac{a}{10}$} & \multirow{2}{*}{11} \\
\hline Code & Gonus & Species & & & & & & & & & & & \\
\hline GADE2 & Gayophytum & decipiens & & & & & & & & & & $\mathbf{B}$ & \\
\hline GADIP & Gayophytum & diffusum ssp. parvifiorum & & & & & & & & & A & A & \\
\hline GAHIH & Galium & hilendiae ssp. hilendiae & & & & & & & & & & $\mathbf{B}$ & \\
\hline GAHIK & Galium & hilendiae ssp. kingstonense & & & & & & & & & & $\mathbf{B}$ & \\
\hline GAMA3 & Galium & magnifolium & & & & & & $\mathbf{B}$ & & & & & \\
\hline GARA & Gayophytum & racomosum & & & & & $\mathbf{A}$ & & & & A & B & $\mathbf{B}$ \\
\hline GARA2 & Gayophytum & ramosissimum & & & & & & & & & A & $\mathbf{B}$ & \\
\hline GAST & Gelium & stellatum & & B & A & & & & & & & & \\
\hline GECA2 & Geraea & canescens & & & B & & & & & & & & \\
\hline GIALB & Gilia & aliquanta ssp. breviloba & & & & & & A & & & B & B & \\
\hline GIBRB & Gilia & brecciarum ssp. brecciarum & & A & A & & A. & A & A & A & A & A & \\
\hline GICA2 & Gilia & campanulata & B & B & B & & & & B & & & & \\
\hline GICAS & Gilia & cana ssp. speciformis & & $\mathbf{A}$ & A & & $\mathbf{B}$ & B & & & & & \\
\hline GICAT & Gilia & cana ssp. triceps & B & $\mathbf{A}$ & & B & A & B & B & & & & \\
\hline GICL2 & Gilia & clokeyi & & $\mathbf{B}$ & $\mathbf{B}$ & & & B & & & & & \\
\hline GIFI2 & Gilia & filiformis & & & B & & & & & & & & \\
\hline GIHU & Gilia & hutchinsifolia & B & B & & & & A & & & A & A & \\
\hline GIN2 & Gilia & inconspicua & & & & $\mathbf{A}$ & A. & A & A & A & A & A & $\mathbf{B}$ \\
\hline GILA2 & Gilia & Iatifolia & & B & $\mathbf{B}$ & & & A & & & & & \\
\hline GILE3 & Gilia & leptomeria & & $\mathbf{A}$ & & & & B & B & & B & B & \\
\hline GIMA & Gilia & malior & & & & & & B & & & B & & \\
\hline GIMO & Gilia & modocensis & & & & & & & & & $\mathbf{B}$ & B & \\
\hline GINY & Gilia & nyensis & & & & & & & $\mathbf{B}$ & & A & A & \\
\hline GIOP & Gilia & ophthalmoides & & & & & & A & & A & $\mathbf{B}$ & $\mathbf{B}$ & \\
\hline GIR/2 & Gilia & ripleyi & & & & & & & & & & & B \\
\hline GISC & Gilia & scopulorum & & A & B & & A & A & & & & & \\
\hline GISI & Gilia & sinuata & & & & $\mathbf{B}$ & & & & A & A & & \\
\hline GIST & Gilia & stollata & & $\mathbf{B}$ & & $\mathbf{B}$ & & & & & & & \\
\hline GITR & Gilia & transmontana & & & B & & & & & & & & \\
\hline GLMA2 & Glyptopleura & marginata & $\mathbf{B}$ & $\mathbf{B}$ & & B & A 1 & B & B & & & & \\
\hline GLSPA & Forsellesia & nevadensis & & & & & A & A & & & $\mathbf{A}$ & A & B \\
\hline GNPA & Gnaphalium & palustro & & & & & & & & & $\mathbf{B}$ & $\mathbf{B}$ & \\
\hline GRSP & Grayia & spinosa & A & A & A & A & A & A & A & $\mathbf{A}$ & A & A & \\
\hline GRSQS & Grindelia & squarrosa var. semulata & & & B & & & & & & & & \\
\hline
\end{tabular}


LEGEND: $A=1999$ Survey; Bandditional species listed in the 1978 Beatley Survey; 1 = Lycium spp. Shrubland Alliance; $2=$ Larrea tridentata/Ambrosia dumoea Shrubland Alliance; 3 = Atriplex confertifolia/Ambroela dumosa Shrubland Alliance; 4 = Hymenoclea-Lycium Shrubland Alliance; 5 = Ephedra nevadensis Shrubland Allance; 6 = Coleogyne rammosissima Shrubland Alliance; 7 = Atriplox spp. Shrubland Allance; $8=$ Chrysothamnus-Ericameria Shrubland Alliance; 9 = Artemisla spp. Shrubland Alliance; 10 = Pinus monophylla/Artemisia ssp. Woodland Allance; 11= Miscellaneous

\begin{tabular}{|c|c|c|c|c|c|c|c|c|c|c|c|c|c|}
\hline Code & Genus & Species & 1 & 2 & 3 & 4 & 5 & 6 & 7 & 8 & 9 & 10 & 11 \\
\hline GULA4 & Guillenia & Iassiophylla & $\mathbf{B}$ & $\mathbf{B}$ & & $\mathbf{B}$ & B & $\mathbf{B}$ & & & & & \\
\hline GUMA & Gutierrezia & microcephala & & & B & & $\mathbf{B}$ & B & $\mathbf{B}$ & & $\mathbf{B}$ & $\mathbf{B}$ & \\
\hline GUSA2 & Gutierrezia & sarothrae & & A & A & $\mathbf{A}$ & A & A & $\mathbf{A}$ & $\mathbf{A}$ & A & $A$ & B \\
\hline HABR3 & Hazardia & brickellioides & & & & & & & & & & & B \\
\hline HAGL & Halogeton & glomeratus & & & A & & A & A & $\mathbf{A}$ & & A & & \\
\hline HEAN3 & Helianthus & annuus & & & & & & & & & & & $\mathbf{B}$ \\
\hline HECOC8 & Hesporostipe & comata ssp. comata & & & & & A & $\mathbf{A}$ & & A & A & A & $\mathbf{B}$ \\
\hline HENUN & Heliomeris & multifiora var. nevadensis & & $\mathbf{A}$ & & $\mathbf{A}$ & A & $\mathbf{A}$ & $\mathbf{A}$ & A & A & A & \\
\hline HENAC & Hedeoma & nanum ssp. califomicum & & & & & & & & & & & $\mathbf{B}$ \\
\hline HEPEF & Helianthus & potiolaris ssp. fallax & & & & & & & & & & & $\mathbf{B}$ \\
\hline HEPEP & Helianthus & petiolaris ssp. petiolaris & & & & & & & & & & & B \\
\hline HESH & Hecastocteis & shockleyi & & & & & & $\mathbf{B}$ & & & & & \\
\hline HEVIH & Heterothoca & villosa var. hispida & & & & & & & & & & $\mathbf{B}$ & \\
\hline HIIN3 & Hirschfeldia & incana & & & & & & & & & & & B \\
\hline HODI & Holodiscus & discolor & & & & & & & & A & & A & $\mathbf{B}$ \\
\hline HOJU & Hordeum & jubatum & & & & & & B & & & $\mathbf{A}$ & $\mathbf{B}$ & \\
\hline HOMUG & Hordeum & murinum ssp. glaucum & & & & & & & & & & & $\mathbf{B}$ \\
\hline HUVEI & Hulsea & vestita ssp. inyoensis & & & & & & & $\mathbf{B}$ & A & A & A & \\
\hline HYCOC2 & Hymenoxys & cooperi var. cooperi & & & & & & & & & A & A & \\
\hline HYFIM & Hymenopappus & filifolius var. megacophalus & & & & & & & & & & A & \\
\hline HYSA & Hymenoclea & salsola & $\mathbf{A}$ & A & A & A & $\mathbf{A}$ & $\mathbf{A}$ & A & $\mathbf{A}$ & A & & \\
\hline IPCO5 & Ipomopsis & congesta & & & & & & & B & & A & A & $\mathbf{B}$ \\
\hline IPDE & Ipomopsis & depressa & $\mathbf{B}$ & & B & & & $\mathbf{B}$ & $\mathbf{B}$ & & & $\mathbf{A}$ & \\
\hline IPPO2 & Ipomopsis & polycladon & $\mathbf{A}$ & A & A & A & $\mathbf{A}$ & A & A & A & A & A & \\
\hline ISACA2 & Isocoma & acradenius var. eremophilus & & & & & & & & & & & B \\
\hline IVARS & Ivesia & arizonica var. saxosa & & & & & & & & & & $\mathbf{B}$ & \\
\hline IVNE & Iva & novadensis & & & & & & & $\mathbf{B}$ & & & & \\
\hline IVSA & Ivesia & sabulosa & & & & & & & & & & $\mathbf{B}$ & $\mathbf{B}$ \\
\hline JUBA & Juncus & balticus & & & B & & & B & $\mathbf{B}$ & & A & $\mathbf{B}$ & \\
\hline JULO & Juncus & longistylis & & & & & & & & & & & B \\
\hline Juos & Juniperus & osteosperma & & & & & A & A & A & $\mathbf{A}$ & A & A & $\mathbf{B}$ \\
\hline JUSA & Juncus & saximontanus & & & & & & & & & & & B \\
\hline KEROR & Keckiella & rothrockii ssp. rothrockii & & & & & & & & & & $\mathbf{A}$ & \\
\hline KOAM & Kocthia & americana & $\mathbf{A}$ & & & & & A & A & $\mathbf{A}$ & A & & B \\
\hline
\end{tabular}


LEGEND: A=1999 Survey; Bandditional species listed in the 1976 Beatley Survey; 1 = Lyclum spp. Shrubland Alliance; 2 = Larrea tridentata/Ambrosia dumosa Shrubland Alliance; 3 = Atriplex confertifolia/Ambrosia dumosa Shrubland Allance; 4 = Hymenoclea-Lycium Shrubland Alliance; 5 = Ephedra nevadensis Shrubland Alliance; $6=$ Coleogyne rammosissima Shrubland Alliance; $7=$ Atriplex spp. Shrubland Alliance; $8=$ Chrysothamnus-Ericameria Shrubland Alliance; $9=$ Artomisia spp. Shrubland Alliance; 10 = Pinus monophylla/Artemisia ssp. Woodland Alliance; $11=$ Miscellaneous

\begin{tabular}{|c|c|c|c|c|c|c|c|c|c|c|c|c|c|}
\hline Code & Genus & Species & 1 & 2 & 3 & 4 & 5 & 6 & 7 & 8 & 9. & 10 & 11 \\
\hline KOIR & Kochia & iranica & & & & & & & & & B & $\mathbf{B}$ & \\
\hline KOMA & Koeleria & macrantha & & & & & & & & A & A & A & \\
\hline kosc & Kochia & scoparia & & & & & & & & & & & B \\
\hline KRER & Krameria & erecta & & $\mathbf{A}$ & $\mathbf{A}$ & A & A & $\mathbf{A}$ & A & A & & & \\
\hline KRLA2 & Krascheninnikovia & Janata & A & A & A & A & A & A & A & A & A & A & \\
\hline LAHI4 & Lathyrus & hitchcockianus & & & & & & & & & B & $\mathbf{B}$ & \\
\hline LAOCO & Lappula & occidentalis var. occidentalis & A & & & & A & A & & A & $\mathbf{A}$ & A & B \\
\hline LASE & Lactuce & semiola & & A & B & $\mathbf{A}$ & & A & & & & & \\
\hline LASE3 & Langloisia & setosissima & A & A & $\mathbf{B}$ & $\mathbf{A}$ & $\mathbf{A}$ & A & B & A & & & \\
\hline LASEP & Langloisia & selossima ssp. punctata & & & & & & & $\mathbf{B}$ & & & & \\
\hline LATR2 & Lamea & tridentata & & $\mathbf{B}$ & $\mathbf{A}$ & $\mathbf{A}$ & A & A & A & A & $\mathbf{A}$ & & B \\
\hline LECI & Leymus & cinereus & & & & & & $\mathbf{A}$ & A & A & $\mathbf{A}$ & A & B \\
\hline LEFLF2 & Lepidium & flavum var flavum & & A & $\mathbf{B}$ & & & A & & & & & B \\
\hline LEFR2 & Lepidium & fremontii & & $\mathbf{A}$ & A & $\mathbf{A}$ & A & A & $\mathbf{A}$ & A & A] & & \\
\hline LEKIK & Lesquerella & kingii ssp. kingii & & & & & & & & & A & A & B \\
\hline LELA & Lepidium & lasiocarpum & A & A & A & A & $A$ & A & A & A & A & A & \\
\hline LELU & Lesquerella & Iudoviciana & & & & & & & B & & & $\mathbf{B}$ & \\
\hline LEMOC & Lepidium & montanum var. canescens & & A & & & & & B & & & & B \\
\hline LEPE2 & Lepidium & perfoliatum & & & & & & & & & & & B \\
\hline LEPU & Leptodactylon & pungens & & A & A & & A & $\mathbf{A}$ & & A & A & A & B \\
\hline LEREM & Lewisia & rediviva var. minor & & & & & & & & & A & $\mathbf{A}$ & \\
\hline LETR5 & Leymus & triticoides & & & & & & B & & & & $\mathbf{B}$ & \\
\hline LEUN2 & Leptochloe & uninervia & & & & & & & & & & & B \\
\hline LIIAR2 & Linanthus & arenicola & & $\mathbf{B}$ & & & & & & & & & \\
\hline LIIBI2 & Linanthus & bigelovii & & $\mathbf{B}$ & & & & & & & A & & \\
\hline LIDE2 & Linanthus & demissus & & A & & & & A & & & & & \\
\hline LIDI2 & Linanthus & dichotomus & & A & & & & A & & A & B & A & \\
\hline LIIJO & Linanthus & jonesii & & B & $\mathbf{B}$ & & & B & & & & & \\
\hline LILE3 & Linum & lewisii & & & & A & A & A & A & A & A & A & \\
\hline LINUN & Linanthus & nuttallii ssp nuttallii & & & & & & & & & A & A & B \\
\hline LIRU4 & Lithospermum & ruderale & & & & & & & & & B & A & \\
\hline LLISE & Linanthus & septentrionalis & & & & & & & & & & B & \\
\hline LITE4 & Lithophragma & tenellum & & & & & & & & & & $\mathbf{B}$ & \\
\hline LOAR10 & Lolium & arundinacea & & & & & & & & & & & B \\
\hline
\end{tabular}


LEGEND: $A=1999$ Survey; Bandditional species listod in the 1976 Beatley Survey; 1 = Lycium spp. Shrubland Allance; 2 = Larroa tridentata/Ambrosia dumosa Shrubland Alliance; 3 = Atriplex confertifolla/Ambrosia dumosa Shrubland Alliance; 4 = Hymenoclea-Lycium Shrubland Alliance; 5 = Ephedra nevadensis Shrubland Allance; 6 = Coloogyne rammosisaima Shrubland Alliance; 7 = Atriplex spp. Shrubland Alliance; $8=$ Chrysothamnus-Ericameria Shrubland Allance; $9=$ Artemisia spp. Shrubland Alliance; $10=$ Pinus monophylla/Artemisia ssp. Woodland Alliance; 11= Miscellaneous

\begin{tabular}{|c|c|c|c|c|c|c|c|c|c|c|c|c|c|}
\hline se. & ind & Ai & $\exists$ & 3 & $\frac{\pi}{8}$ & $\underline{z}$ & Uี & 8 & $>c$ & J & के & $\bar{a}$ & 5 \\
\hline Code & Genus & Species & 1 & 2 & 3 & 4 & 5 & 6 & 7 & 8 & 9 & 10 & 11 \\
\hline LOFOF & Lomatium & foeniculaceum ssp. fimbriatum & & & & & & & & & B & $\mathbf{A}$ & \\
\hline LOHU2 & Lotus & humistratus & & A & $A$ & & A & A & & $\mathbf{A}$ & $\mathbf{A}$ & & \\
\hline LONEN & Lomatium & novadonse var. novadense & & & & & A & A & & $\mathbf{A}$ & A & $\mathbf{A}$ & \\
\hline LOPEM2 & Lolium & perenne ssp. multifiorum & & & & & & & & & & & $\mathbf{B}$ \\
\hline Losc 3 & Lomatium & scabrum & & A & & & A & A & & $\mathbf{A}$ & & & \\
\hline Losc6 & Loeseliastrum & schottii & $\mathbf{B}$ & $\mathbf{A}$ & & $\mathbf{B}$ & A & A & $\mathbf{B}$ & $\mathbf{A}$ & $\mathbf{B}$ & & \\
\hline LUART & Lupinus & aridus & & & & & & & & & $\mathbf{B}$ & & \\
\hline LUARLS & Lupinus & langenteus ssp. artenteus var. laxiflons & & & & & & & & A & $\mathbf{A}$ & A & $\mathbf{B}$ \\
\hline LUBR2 & Lupinus & brevicaulis & $\mathbf{B}$ & $\mathbf{A}$ & & & A & A & A & $\mathbf{A}$ & $\mathbf{A}$ & A & \\
\hline LUCA & Lupinus & caudatus & & & & & & & & & $\mathbf{B}$ & A & \\
\hline LUCOO2 & Lupinus & concinnus ssp. orcuttii & & & & & & A & & & A & & $\mathbf{B}$ \\
\hline LUFL & Lupinus & fiavoculatus & $\mathbf{B}$ & $\mathbf{A}$ & & B & $\mathbf{A}$ & A & $\mathbf{A}$ & A & $\mathbf{A}$ & $\mathbf{A}$ & \\
\hline LUHO & Lupinus & holmgrenanus & & & & & & & & & $\mathbf{B}$ & & \\
\hline LUMI & Lupinus & microcarpus & & & & & & & & & $\mathbf{A}$ & & \\
\hline LUPA3 & Lupinus & palmeri & & & & & & & & & & $\mathbf{A}$ & \\
\hline LUSH & Lupinus & shockleyi & & A & A & A & A & A & A & A & A & A & \\
\hline LUSU10 & Lupinus & subvexus & & & & & & & & & $\mathbf{A}$ & & \\
\hline LUUN & Lupinus & uncialis & & & & & & & & & $\mathbf{B}$ & & \\
\hline LYAN & Lycium & andersonii & & $\mathbf{A}$ & A & A & A & $\mathbf{A}$ & A & $\mathbf{A}$ & A & $\mathbf{A}$ & \\
\hline LYDI4 & Lygodesmia & dianthopsis & & & & & & & & & $\mathbf{B}$ & $\mathbf{B}$ & \\
\hline LYPAO & Lycium & pallidum var. oligospermum & A & A & A & A & A & $\mathbf{A}$ & A & A & & & $\mathbf{B}$ \\
\hline LYSH & Lycium & shockleyi & $\mathbf{A}$ & A & A & A & A & & A & & & $\mathbf{B}$ & $\mathbf{B}$ \\
\hline MAAF & Malcolmia & africana & & & & & & & & & & & $\mathbf{B}$ \\
\hline MACAC & Machaeranthera & canescens ssp. canescens & $\mathbf{A}$ & A & A & A & A & A & A & A & A & $\mathbf{A}$ & \\
\hline MACO3 & Malacothrix & coulteri & & $\mathbf{B}$ & B & & & B & & & & & \\
\hline MAGL3 & Malacothrix & glabrata & A & A & A & A & A & $A$ & A & A & A & A & \\
\hline MAGR10 & Machaeranthera & gracilis & & & & & & & & & & & $\mathbf{B}$ \\
\hline MAPAS & Matva & panvifiora & & & & & & & & & & & $\mathbf{B}$ \\
\hline MAPIG2 & Machaeranthere & gooddingii & & & & & & & & & & & $\mathbf{B}$ \\
\hline MASO & Malacothrix & sonchoides & & A & & & A & A & $\mathbf{B}$ & A & A & A & \\
\hline MATE4 & Mammillania & tetrancistra & & $\mathbf{A}$ & & & A & A & & & A & A & $\mathbf{B}$ \\
\hline MAVU & Marrubium & vulgare & & & & & & & & & & B & \\
\hline MEAL6 & Mentzelia & albicaulis & A & A & $A$ & B & A & $\mathbf{A}$ & A & A & A & A & \\
\hline MECO2 & Mentzelia & congesta & & & & & & A & & & A & $\mathbf{A}$ & \\
\hline
\end{tabular}


LEGEND: A=1999 Survoy; B-additional species listod in the 1976 Beatley Survey; 1 = Lycium spp. Shrubland Alliance; 2 = Larrea tridentata/Ambrosia dumosa Shrubland Alliance; 3 = Atriplex confertffolia/Ambrosia dumosa Shrubland Alliance; 4 $=$ Hymenoclea-Lyclum Shrubland Allance; 5 = Ephedra nevadensls Shrubland Alliance; 6 = Coleogyne rammosisaima Shrubland Alliance; 7 = Atriplex spp. Shrubland Alliance; $8=$ Chrysothamnus-Ericameria Shrubland Alliance; 9 = Artemisia spp. Shrubland Allance; 10 = Pinus monophylla/Artemisia ssp. Woodland Allance; 11 = Miscellaneous

\begin{tabular}{|c|c|c|c|c|c|c|c|c|c|c|c|c|c|}
\hline $\mathrm{sep}$ & and $A$ & Mis & $\exists$ & 9 & 8 & $\mathbf{\Sigma}$ & Uิ & 0 & 810 & $\overline{0}$ & 8 & $a$ & 2 \\
\hline Code & Genus & Species & 1 & 2 & 3 & 4 & 5 & 6 & 7 & 8 & 9 & 10 & 11 \\
\hline MEIN2 & Molibtus & indicus & & & & & & B & & & & $\mathbf{B}$ & \\
\hline MEMO4 & Mentzelia & montana & & & & & & B & & & $\mathbf{B}$ & B & \\
\hline MENI2 & Mentzelia & nitens & & B & & & & A & $\mathbf{B}$ & & & & \\
\hline MEOB3 & Mentzelia & obscura & $\mathbf{B}$ & $\mathbf{A}$ & A & A & A & A & A & A & $\mathbf{A}$ & & \\
\hline MEOF & Molilotus & officinalis & & & & & & & & & & & $\mathbf{B}$ \\
\hline MEOR3 & Mentzelia & oreophila & & & & & & & & & & & $\mathbf{B}$ \\
\hline MERE & Mentzelia & reflexa & & B & & & & & & & & & \\
\hline MESA & Medicego & sativa & & & & & & & & & & & B \\
\hline MESP2 & Menodora & spinescens & & A & A & A & A & A & A & A & A & & \\
\hline MEVES & Mentzelia & veatchiana & & A & & A & A & A & A & A & A & A & \\
\hline Mals & Mirabillis & bigelovii & & $\mathbf{A}$ & A & A & A & A & A & A & A & A & \\
\hline MIBIB & Mirabillis & bigelovii var. bigelovii & & $\mathbf{B}$ & & & A & & & & & & \\
\hline MBBIB2 & Mimulus & bigelovii var. bigelovii & & $\mathbf{B}$ & B & & A & B & & & & & \\
\hline MICO15 & Oxybaphus & comatus & & & & & & B & & & $\mathbf{B}$ & B & $\mathbf{B}$ \\
\hline MIDE2 & Mimulus & densus & & & & & & & & & $\mathbf{B}$ & $\mathbf{B}$ & \\
\hline MGU & Mimulus & guttatus & & & & & & B & & & & B & $\mathbf{B}$ \\
\hline MIMO2 & Mimulus & montioides & & B & B & & & & & & & & \\
\hline MIMUG & Mirabillis & multifiora var. glandulosa & & & & & A & B & & & A & A & \\
\hline MIPI5 & Mimetanthe & pilosus & & & & & & & & & & $\mathbf{B}$ & \\
\hline MIPU5 & Mirabillis & pudica & A & $\mathbf{A}$ & A & A & A & A & A & A & A & & \\
\hline MIRU & Mimulus & rubellus & & & & & & & & & & & $\mathbf{B}$ \\
\hline MISP & Mimulus & spissus & $\mathbf{B}$ & & & & A & A & A & A & A & A & \\
\hline MIsU2 & Mimulus & suksolorfii & & & & & A & A & & $\mathbf{A}$ & A & A & \\
\hline MOBE & Monoption & bellidiforme & $\mathbf{B}$ & A & B & & A & A & & $\mathbf{A}$ & & & \\
\hline MOBE2 & Monoption & bellioides & & A & & & & & & & & & \\
\hline MOBR & Mohavea & brevifiora & & B & B & & & & & & & & \\
\hline MOCE & Mollugo & cerviana & & B & & & $\mathbf{B}$ & & & & & & \\
\hline MOGL & Monardella & glauca & & & & & & & & & & & B \\
\hline MOSP & Monolepis & spathulata & & & & & & & & & & $\mathbf{B}$ & \\
\hline MOSQ & Monnoa & squarrosa & & & & & & & & & $\mathbf{B}$ & $\mathbf{B}$ & \\
\hline MoUT & Mortonia & utahensis & & & & & & & & & & & B \\
\hline MUPO2 & Muhlenbergia & porteri & & & $\mathbf{B}$ & & B & B & & & & & \\
\hline MURI & Muhlenbergia & richardsonis & & & & & & & & & & B & \\
\hline NAAR & Nama & aretioides & & B & & & & & $\mathbf{B}$ & & A & & \\
\hline
\end{tabular}


LEGEND: $A=1999$ Survey; Badditional species lleted in the 1976 Bentley Survey; 1 = Lycium spp. Shrubland Alliance; 2 = Larrea tridentata/Ambroela dumoen Shrubland Allance; 3 = Atriplex confertffolia/Ambroela dumosa Shrubland Alliance; 4 $=$ Hymenoclea-Lyclum Shrubland Alliance; 5 = Ephedra nevadenais Shrubland Alllance; 6 = Coleogyne rammoaissima Shrubland Alliance; $7=$ Atriplox spp. Shrubland Allance; $8=$ Chrysothamnus-Ericameria Shrubland Alliance; $9=$ Artemisia spp. Shrubland Allance; $10=$ Pinus monophylla/Artemisia ssp. Woodland Allance; 11= Miscellaneous

\begin{tabular}{|c|c|c|c|c|c|c|c|c|c|c|c|c|c|}
\hline Code & Genus & Species & 1 & 2 & 3 & 4 & 5 & 6 & 7 & 8 & 9 & 10 & 11 \\
\hline NABR & Naverretia & breweri & & & & & & & & & A & A & \\
\hline NADE2 & Nama & densum & & & & & & & & & B & $\mathbf{B}$ & \\
\hline NADE3 & Name & depressum & & $\mathbf{B}$ & & & & & & & & & \\
\hline NADED & Name & demissum var. demissum & & A & & $\mathbf{B}$ & $\mathbf{B}$ & A & A & $\mathbf{A}$ & A & $\mathbf{B}$ & \\
\hline NAPU & Nama & pusillum & & $\mathbf{A}$ & B & A & $\mathbf{A}$ & A & & $\mathbf{A}$ & A & $\mathbf{A}$ & \\
\hline NEFI & Noogaentinum & filipes & & B & B & & & & & & & & \\
\hline NECLO & Nemacladus & glandulifenus var. orientalis & & A & $\mathbf{B}$ & & & A & & & B & & \\
\hline NERU & Nemacladus & rubescens & $\mathbf{B}$ & $\mathbf{B}$ & & & & & & & & & \\
\hline NESI & Nemacladus & sigmoideus & & $\mathbf{B}$ & & & & $\mathbf{B}$ & & & & & \\
\hline NIAT & Nicotiana & attenuata & & & $\mathbf{A}$ & & $\mathbf{A}$ & & B & & & $\mathbf{B}$ & \\
\hline NITRT & Nicotiana & trigonophylla var. trigonophylla & & $\mathbf{B}$ & & & & & & & & & \\
\hline OECA2 & Oenothera & californica spp avita & $\mathbf{A}$ & A & & & & & & & A & & $\mathbf{B}$ \\
\hline OECEMH & Oenothera & caespitosa ssp. marginata & & $A$ & & A & A & $\mathbf{A}$ & A & $\mathbf{A}$ & A & A & \\
\hline OEDED4 & Oenothera & detoides ssp. deltoides & & A & A & & & & & & & & \\
\hline OEPAP & Oenothera & pallida ssp. pallida & & & & & A & A & B & A & A & A & \\
\hline OEPR & Oenothera & primivenis & A & A & B & & A & $\mathbf{B}$ & A & & A & & \\
\hline OPBAB2 & Opuntia & basilaris var. basilaris & & $A$ & $\mathbf{A}$ & A & A & A & A & $\mathbf{A}$ & A & $\mathbf{B}$ & \\
\hline OPECE & Opuntia & ochinocarpa var. ochinocarpa & & A & A & A & A & $\mathbf{A}$ & A & $\mathbf{A}$ & A & A & \\
\hline OPERE & Opuntia & eninacea var. erinacea & & $\mathbf{A}$ & A & A & A & A & A & $\mathbf{A}$ & A & A & \\
\hline OPERU & Opuntia & erinacea var. ursina & & & & & A & $\mathbf{B}$ & & & $\mathbf{A}$ & $\mathbf{B}$ & \\
\hline OPPOR & Opuntia & polyacantha var. rufispina & & & & & A & $\mathbf{A}$ & A & A & A & A & \\
\hline OPPU & Opuntia & pulchella & & & & A & A & A & B & & A & & $\mathbf{B}$ \\
\hline OPRA & Opuntia & ramosissima & & A & A & & A & A & & & A & & \\
\hline ORCO4 & Orobanche & cooperi & & $\mathbf{B}$ & $\mathbf{B}$ & & & & & & & $A$ & \\
\hline ORCO5 & Orobanche & corymbosa & & & & & & & & & A & $\mathbf{B}$ & \\
\hline ORFA & Orobanche & fasciculata & & & & & & A & $\mathbf{B}$ & A & A & $\mathbf{A}$ & \\
\hline OXPE2 & Oxythece & perfoliata & A & A & A & A & A & A & A & A & A & & \\
\hline PASM & Pascopyrum & smithii & & & & & & & & & & & \\
\hline PEAL3 & Penstemon & albomarginatus & & $\mathbf{B}$ & & & & & & & & & \\
\hline PEANV & Penstemon & angustifolius var. venosus & & & & & & & $\mathbf{B}$ & & & & \\
\hline PECA12 & Potrophytum & caespitosum & & & & & & $\mathbf{B}$ & & & & $\mathbf{B}$ & $\mathbf{B}$ \\
\hline PEFLA2 & Penstemon & floridus var. austinii & & & & & A & $\mathbf{A}$ & & A & A & A & \\
\hline PEFRA & Penstemon & fruticiformis ssp. amargosae & & B & $\mathbf{B}$ & & & $\mathbf{B}$ & & & & & \\
\hline PEHE & Pectocarya & heterocarpa & & B & B & & & & & & & & \\
\hline
\end{tabular}


LEGEND: $A=1999$ Survey; $B=$-additional species listed in the 1976 Beatley Survey; 1 = Lycium spp. Shrubland Alliance; 2 = Larrea tridentata/Ambrosia dumoea Shrubland Alliance; 3 = Atriplex confertifolia/Ambrosia dumosa Shrubland Alliance; 4 = Hymenoclea-Lyclum Shrubland Alliance; 5 = Ephedra nevadensis Shrubland Alliance; 6 = Coloogyne rammosisaima Shrubland Alliance; $7=$ Atriplox spp. Shrubland Allance; $8=$ Chrysothamnus-Ericameria Shrubland Allance; $9=$ Artemisia spp. Shrubland Alliance; 10 = Pinus monophylla/Artemisia ssp. Woodland Allance; 11 = Mlscellaneous

\begin{tabular}{|c|c|c|c|c|c|c|c|c|c|c|c|c|c|}
\hline p. & and & Mls & $\Xi$ & 9 & $\geq$ & $\overline{\mathbf{x}}$ & 过 & 0 & 8 & 3 & 7 & $\bar{a}$ & $\geq$ \\
\hline Code & Genus & Specles & 1 & 2 & 3 & 4 & 5 & 6 & 7 & 8 & 9 & 10 & 11 \\
\hline PEHUH & Penstemon & humilis ssp humilis & & & & & & & & A & A & A & \\
\hline PEMEI & Penityle & megalocephala var. intricata & & & & & & & & & & & $\mathbf{B}$ \\
\hline PEMEM & Perityle & megalocephela var. megalocephala & & & & & & & & & B & $\mathbf{B}$ & \\
\hline PEMUM & Pollaea & mucronata ssp. mucronata & & & & & & $\mathbf{B}$ & & & & $\mathbf{B}$ & \\
\hline PENI & Petalonyx & nitidus & & & & A & A & A & & & A & & \\
\hline PEPA2 & Pectis & papposa & B & & & $\mathbf{B}$ & B & B & & & & A & \\
\hline PEPA23 & Penstemon & pahutensis & & & & & & & & A & A & B & \\
\hline PEPAB & Penstemon & palmeri & & & & A & & A & & & A & A & $\mathbf{B}$ \\
\hline PEPE13 & Penstemon & potiolatus & & & $\mathbf{B}$ & & & B & & & & & \\
\hline PEPL & Pectocarya & platycarpa & & $\mathbf{A}$ & A & & A & A & & A & A & A & \\
\hline PEPU7 & Petradoria & pumila & & & & & & & & & A & A & $\mathbf{B}$ \\
\hline PERA4 & Peraphyllum & ramosissimum & & & & & & A & & & A & $\mathbf{B}$ & \\
\hline PERE & Pectocarya & recurvata & & A & B & & & A & & & & & \\
\hline PERO10 & Penstemon & rostriflorus & & & & & & & & A & & A & B \\
\hline PESC4 & Poucephytlum & schottii & & B & & & & & & & & & \\
\hline PESE & Pectocarya & setosa & & $\mathbf{A}$ & A & A & A & A & & A & A & A & \\
\hline PETH3 & Penstemon & thurberi & & B & & & & & & & & & \\
\hline PETH5 & Peteria & thompsonae & $\mathbf{B}$ & B & & & & & & & & & $\mathbf{B}$ \\
\hline PETHT & Potalonyx & thurberi ssp. thurberi & & $\mathbf{B}$ & & & & & & & & & \\
\hline PETR3 & Pellaea & truncata & & & & & & B & & & & $\mathbf{B}$ & \\
\hline PETR7 & Pentagama & triangularis & & & & & & & & & & A & $\mathbf{B}$ \\
\hline PETRT & Pentagrama & triangularis ssp. triangularis & & & & & & B & & & B & B & \\
\hline PHAF & Phacelia & affinis & & & & & & & & & & A & \\
\hline PHAMB & Phacelia & ambigua & & & & & & & & & & & $\mathbf{B}$ \\
\hline PHBE3 & Phacelia & beatleyae & & & & & & B & & & & & \\
\hline PHEI & Phacelia & bicolor & & $\mathbf{B}$ & & & & & B & & A & B & \\
\hline PHCA2 & Phacelia & cathifolia & & & & & A & & & & & & $\mathbf{B}$ \\
\hline PHCH2 & Physaria & chambersii & & & & & & & & A & $\mathbf{B}$ & A & $\mathbf{B}$ \\
\hline PHCR2 & Phacolia & cryptantha & & & & & & & & & & & $\mathbf{B}$ \\
\hline PHCR4 & Physalis & crassifolia & & $\mathbf{B}$ & $\mathbf{B}$ & & & & & & & & \\
\hline PHCRC3 & Phacalia & crenulata var. crenulata & & A & A & A & A & A & A & A & A & A & \\
\hline PHCU & Phacelia & curvipes & & & & & & A & & & A & A & \\
\hline PHDI & Phacolia & distans & & & & & & & & & & & $\mathbf{B}$ \\
\hline PHFR2 & Phacelia & fremontii & $\mathbf{B}$ & $\mathbf{A}$ & A & $\mathbf{A}$ & $\mathbf{A}$ & A & A & A & A & A & \\
\hline
\end{tabular}


LEGEND: A=1999 Survey; Badditional specles listed in the 1976 Beatley Survoy; 1 = Lycium spp. Shrubland Alliance; 2 E Larrea tridentata/Ambroela dumosa Shrubland Allance; 3 = Atriplex confortifolla/Ambroala dumoea Shrubland Allance; 4 = Hymenoclea-Lycium Shrubland Alliance; 5 = Ephedra nevadensis Shrubland Allanco; 6 = Coleogyne rammosiseima Shrubland Alliance; 7 = Atriplox spp. Shrubland Allance; $8=$ Chrysothamnus-Ericameria Shrubland Alliance; $9=$ Artemisia spp. Shrubland Alliance; 10 = Pinus monophylla/Artemisia ssp. Woodland Alliance; 11= Miscellaneous
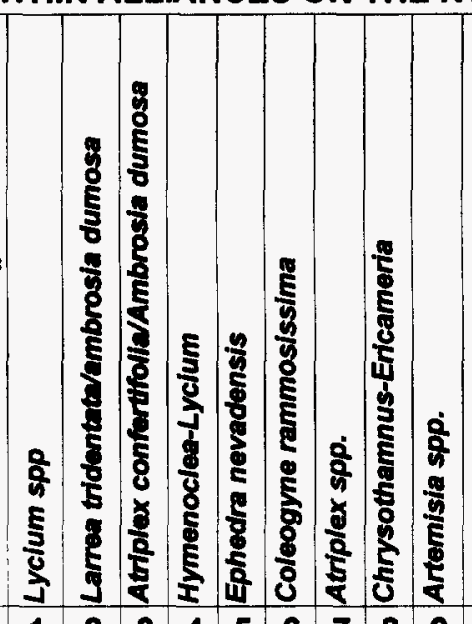

\begin{tabular}{|c|c|c|c|c|c|c|c|c|c|c|c|c|c|}
\hline Code & Genus & Species & 1 & 2 & 3 & 4 & 5 & 6 & 7 & 8 & 9 & 10 & 11 \\
\hline PHGRH & Phlox & gracilis ssp. humilis & & & A & & A & A & & A & A & A & \\
\hline PHHOL & Phlox & hoodii ssp. lanata & & & & & & & & A & A & A & \\
\hline PHJU & Phoradendron & juniperinum & & & & & & & & & & B & \\
\hline PHLE & Phacelia & lemmonii & & & & & & & & & & & B \\
\hline PHMU & Phacelia & mustelina & & & B & & & B & & & A & B & \\
\hline PHPA2 & Phacelia & parishii & & & A & & & & & & & & B \\
\hline PHPE & Phacelia & pedicellata & & & B & & & & & & & & \\
\hline PHPE2 & Phacelia & peirsoniana & & & & & & & & & & A & \\
\hline PHRO2 & Phacelia & rotundifolia & & B & B & & & B & & & & & \\
\hline PHSA & Phacelia & saxicola & & A & & & A & A & B & A & A & A & \\
\hline PHST11 & Phiox & stansburyi & & & A & A & A & A & A & A & A & A & \\
\hline PHTE & Phacolia & tetramera & & & & & & & & & & B & \\
\hline PHVAV2 & Phacelia & vallis-mortae var. vallis-mortae & B & A & A & A & $\mathbf{A}$ & $\mathbf{A}$ & & $\mathbf{A}$ & A & A & \\
\hline PIMIT & Piptathenum & micrantha & & & & & & & & & & B & \\
\hline PIMO & Pinus & monophylla & & & & & & A & & A & A & A & B \\
\hline PLAR & Plagiobothrys & arizonicus & & & & & & B & & & B & & \\
\hline PLJA & Plauraphis & jamesii & & & & A & A & A & $A$ & A & $\mathbf{A}$ & A & \\
\hline PLJO & Plagiobothrys & jonesii & & B & & & & & & & & & \\
\hline PLKI & Plagiobothrys & kingii & & & & & & & & & B & & \\
\hline PLOV & Plantago & ovata & & A & A & A & A & A & & & & & \\
\hline PLPA2 & Plantago & patagonica & & & & & A & A & A & A & A & A & \\
\hline PLPL & Plourocoronis & pluriseta & & B & & & & & & & & & \\
\hline PLRI3 & Plouraphis & rigida & & A & A & A & A & A & & & & & \\
\hline POAN & Poa & annua & & & & & & & & & & & B \\
\hline POAR5 & Polygonum & argyrocoleon & & & & & & & & & & & B \\
\hline POAV & Polygonum & aviculare & & & & & & & & & & & B \\
\hline POBI & Poa & bigelovii & & & & & & & & & & & B \\
\hline POB17 & Potentilla & biennis & & & & & & B & & & B & B & \\
\hline PODOJ2 & Polygonum & douglasii ssp. johnstonii & & & & & & & & & & B & B \\
\hline POFE & Poa & fendleriana & & & & & & A & A & A & A & A & $\mathbf{B}$ \\
\hline POFRF3 & Populus & fremontii ssp. fremontii & & & & & & & & & & B & B \\
\hline POGR5 & Porophyllum & gracile & & B & & & & & & & & & \\
\hline POHE7 & Polygala & heterorinyncha & B & B & B & B & B & & B & & A & A & \\
\hline POIN7 & Polypogon & interruptus & & & & & & & & & & & $\mathbf{B}$ \\
\hline
\end{tabular}


LEGEND: A=1999 Survey; Baradditional species listed in the 1976 Beatley Survey; 1 = Lycium spp. Shrubland Alliance; 2 = Larrea tridentata/Ambrosia dumosa Shrubland Allance; 3 = Atriplex confertifolia/Ambroela dumosa Shrubland Alliance; 4 = Hymonoclea-Lyclum Shrubland Alliance; 5 = Ephodra nevadensis Shrubland Alliance; 6 = Coleogyne rammosisaima Shrubland Alliance; 7 = Atriplex app. Shrubland Allance; $8=$ Chrysothamnus-Ericameria Shrubland Alliance; $9=$ Artemisia spp. Shrubland Alliance; 10 = Pinus monophylla/Artemisia ssp. Woodland Alliance; 11 = Miscellaneous

\begin{tabular}{|c|c|c|c|c|c|c|c|c|c|c|c|c|c|}
\hline Code & Genus & Species & 1 & 2 & 3 & 4 & 5 & 6 & 7 & 8 & 9 & 10 & 11 \\
\hline POMO5 & Polypogon & monspelionsis & & & & & & B & B & & & B & \\
\hline POPE2 & Polygonum & pensylvanicum & & & & & & & & & & & B \\
\hline POPE6 & Potamogeton & pectinatus & & & & & & & & & & & B \\
\hline POPR & Poa & pratensis & & & & & & & & & B & & \\
\hline POSE & Poa & socunda & & B & A & & A & A & A & A & A & A & \\
\hline POSU & Polygala & subspinosa & A & $\mathbf{A}$ & A & A & A & A & A & A & A & $\mathbf{A}$ & \\
\hline POVI8 & Polypogon & vinidis & & & & & & & & & & & B \\
\hline PREX & Prenanthella & exigua & B & A & & B & B & A & B & & & & \\
\hline PRFA & Prunus & fesciculata & & & A & A & A & A & & A & A & A & \\
\hline PRGLT & Prosopis & glandulosa var. torreyana & & & & & & & & & & & B \\
\hline PSAN & Psathyrotes & annua & & B & & & A & A & A & A & B & & \\
\hline PSCO2 & Psilostrophe & cooperi & & & & & & B & & & & & \\
\hline PSFRF & Psorothamnus & fremontii var. fremontii & & A & $\mathbf{A}$ & A & A & A & A & A & & & \\
\hline PSPO & Psorothamnus & polydenius & 8 & $\mathbf{A}$ & A. & A & A & $\mathbf{A}$ & A & A & A & & \\
\hline PSRA & Psathyrotes & ramosissima & & B & & & & & & & & & \\
\hline PSSTT & Pseudognaphalium & straminoum & & & & & & & & & & & B \\
\hline PTHE & Pteryxia & hendersonii & & & & & & & & & & & B \\
\hline PUDI & Puccinellia & distans & & & & & & & & & & & B \\
\hline PUGL2 & Purshia & glandulosa & & & & & A & A & $\mathbf{A}$ & A & A & $\mathbf{A}$ & \\
\hline PUST & Purshia & stansburiane & & & & A & A & A & A & A & A & A & \\
\hline PUTR2 & Purshia & Iridentata & & & & & & A & & A & A & A & \\
\hline QUGA & Quercus & gambelii & & & & & & & & A & A & A & \\
\hline RAAN & Ranunculus & andersonii & & & & & & & & & & B & B \\
\hline RANE & Rafinesquia & necmexicana & $\mathbf{B}$ & A & $\mathbf{A}$ & B & $A$ & A & & A & & & \\
\hline RHTRA & Rhus & trilobata var. anisophylla & & & & A & & A & & & A & A & \\
\hline RICEC2 & Ribes & cereum var. cereum & & & & & & & & & A & A & B \\
\hline RIVEV & Ribes & velutinum var. velutinum & & & & & & A & & A & A & A & B \\
\hline ROWO & Rosa & woodsii & & & & & & & & & & B & B \\
\hline RUCR & Rumex & crispus & & & & & & & & & B & B & \\
\hline RUSA & Rumex & salicifolius & & & & & & B & & & & B & \\
\hline SACOC & Salvia & columbariae var. columbariae & & A & B & & A & A & A & A & A & B & \\
\hline SADOD3 & Salvia & donii ssp. domii var. domii & & & & A & A & A & & A & A & $\mathbf{A}$ & \\
\hline SAEX & Salix & exigua & & & & & & B & & & & B & \\
\hline SAGO & Salix & gooddingii & & & & & & & B & & & $\mathbf{B}$ & B \\
\hline
\end{tabular}


LEGEND: A=1998 Survey; Bandditional species listed in the 1976 Beatiey Survey; 1 = Lyclum spp. Shrubland Alliance; 2 = Larrea tridentata/Ambroela dumoea Shrubland Alliance; 3 = Atriplex confertifolla/Ambroeia dumoea Shrubland Allance; 4 = Hymenoclea-Lycium Shrubland Alliance; 5 = Ephedra nevadensis Shrubland Alliance; 6 = Coloogyno rammoslasima Shrubland Alliance; 7 = Atriplox spp. Shrubland Alliance; 8 = Chrysothamnus-Ericameria Shrubland Allance; 9 = Artemiaia spp. Shrubland Alliance; 10 = PInus monophylla/Artemisia ssp. Woodland Alliance; 11= Miscellaneous

\begin{tabular}{|c|c|c|c|c|c|c|c|c|c|c|c|c|c|}
\hline sp & ind & Ulscellat & $\exists$ & 3 & ₹ & $\mathbf{I}$ & 过 & 0 & 8 & 0 & 8 & $\pi$ & $\underline{3}$ \\
\hline Code & Gonus & Species & 1 & 2 & 3 & 4 & 5 & 6 & 7 & 8 & 9 & 10 & 11 \\
\hline SAKAT3 & Salsola & kali ssp. tragus & & & & A & A & A & A & A & A & & \\
\hline SAKI & Saircocarpus & kingii & & & & & & $\mathbf{B}$ & & & $\mathbf{B}$ & B & B \\
\hline SAME & Salazaria & mexicana & & $\mathbf{A}$ & A & $\mathbf{A}$ & A & A & A & A & A & & \\
\hline SAPAB & Selsola & paulsenii & A & A & & A & A & $\mathbf{A}$ & A & A & $\mathbf{A}$ & A & B \\
\hline SCACA & Schoenoplectus & acutus var. acutus & & & & & & & & & & & \\
\hline SCAR & Schismus & arabicus & & $\mathbf{A}$ & A & A & & A & & & & & \\
\hline SCDE & Scrophularia & desertorum & & & & & & & & & & $\mathbf{B}$ & \\
\hline SCPO4 & Sclerocactus & polyancistrus & & & & & A & $\mathbf{A}$ & A & A & A & $\mathbf{A}$ & \\
\hline SCRI2 & Scopulophila & rixfordii & & & $\mathbf{B}$ & & & & & & & & \\
\hline SEDI3 & Selinocarpus & novadensis & & B & B & & & & & & & & \\
\hline SEINE & Senecio & integenimus var. exaltatus & & & & & & & & & & B & \\
\hline SEMU3 & Senecio & multilobatus & & & & & A & A & & A & A & A & B \\
\hline SENE5 & Senecio & fleccidus var. douglasii & & $\mathbf{B}$ & A & & A & A & & & & & \\
\hline SEPU8 & Sotaria & pumila & & & & & & & & & & & $\mathbf{B}$ \\
\hline SESP3 & Senecio & spartioides & & & & & & & & & $\mathbf{A}$ & A & B \\
\hline SIAL2 & Sisymbrium & altissimum & & A & A & A & A & A & A & A & A & B & \\
\hline SIIR & Sisymbrium & ino & & $\mathbf{B}$ & & & & & & & & & \\
\hline SIRO & Sibara & rosulata & & & & & & & & & & & B \\
\hline SIVEA & Silene & verecunda ssp. andersonii & & & & & & & & A & A & A & B \\
\hline SOAS & Sonchus & asper & & & & & & & & & & & B \\
\hline SOHA & Sorghum & halepense & & & & & & B & & & & & \\
\hline SONO3 & Solanum & nodifiorum & & & & & & & & & & & B \\
\hline SPAMA & Sphaeralcea & ambigua ssp. ambigua & A & A & A & A & A & $\mathbf{A}$ & A & A & $\mathbf{A}$ & A & \\
\hline SPAMM & Sphaeralcea & ambigua ssp. monticola & B & $\mathbf{B}$ & & B & A & $\mathbf{A}$ & A & A & $\mathbf{A}$ & A & \\
\hline SPAMR & Spheoralcea & ambigua var. rugosa & & $\mathbf{A}$ & A & A & $\mathbf{A}$ & A & & A & A & & \\
\hline SPCR & Sporobolus & cryptandrus & & $\mathbf{B}$ & & & A & & B & A & A & A & B \\
\hline SPEM & Sphaeralcea & emoryi & B & & & & & & & & B & & \\
\hline SPFL2 & Sporobolus & flexuosus & & $\mathbf{B}$ & & & & & & & & & \\
\hline SPGRP2 & Sphaeralcea & grossulariaefolia ssp. podata & & A & A & A & A & A & A & A & A & A & \\
\hline SPPA2 & Sphaeralcea & panvifolia & $\mathbf{B}$ & & & & & & $\mathbf{B}$ & & & & \\
\hline STCOC & Streptanthus & cordatus var. condatus & & $A$ & & & $\mathbf{A}$ & A & & $\mathbf{A}$ & A & $A$ & $\mathbf{B}$ \\
\hline STEL & Stanlaya & elata & & & & A & A & $\mathbf{A}$ & B & A & A & & \\
\hline STEXE & Stephanomeria & exigua ssp. exigua & B & $A$ & A & A & A & $\mathbf{A}$ & A. & A & A & $\mathbf{A}$ & \\
\hline STLO4 & Streptanthella & longirostris & $\mathbf{B}$ & A & & B & A & A & & A & $\mathbf{A}$ & $\mathbf{A}$ & \\
\hline
\end{tabular}


LEGEND: $A=1999$ Survey; Bradditional species listed in the 1976 Beatley Survey; 1 = Lyclum spp. Shrubland Alliance; 2 = Larrea tridentata/Ambrosia dumoea Shrubland Allance; 3 = Atriplex confertifolla/Ambroala dumosa Shrubland Alliance; 4 = Hymenoclea-Lycium Shrubland Alliance; 5 = Ephedra nevadenais Shrubland Alliance; 6 = Coleogyne rammosiseima Shrubland Alliance; 7 = Atriplox spp. Shrubland Allance; 8 = Chrysothamnus-Ericameria Shrubland Alliance; 9 = Artemisia spp. Shrubland Allance; 10 = Pinus monophylla/Artemisla ssp. Woodland Alllance; 11= Miscellaneous

\begin{tabular}{|c|c|c|c|c|c|c|c|c|c|c|c|c|c|}
\hline 18 & nd & Mrcellan & $\Xi$ & $\boldsymbol{d}$ & ₹ & $\mathbf{I}$ & 过 & $\tilde{u}$ & 8 & 0 & 8 & $\bar{a}$ & $E$ \\
\hline Code & Genus & Species & 1 & 2 & 3 & 4 & 5 & 6 & 7 & 8 & 9 & 10 & 11 \\
\hline STMI2 & Stylocline & micropoides & & & & & & $\mathbf{A}$ & & & $\mathbf{A}$ & $\mathbf{B}$ & \\
\hline STPA3 & Stephanomeria & paryi & $\mathbf{B}$ & A & A & A & A & A & & A & A & & B \\
\hline STPA4 & Stephanomeria & paucifiora & A & $\mathbf{A}$ & A & A & A & $\mathbf{A}$ & A & A & A & A & \\
\hline STPIP & Stanloya & pinnata var. pinnata & A & A & A & A & A & A & A & A & A & A & B \\
\hline STPS & Stylocline & psibcarphoides & & & & & & & & & & & $\mathbf{B}$ \\
\hline STSP & Stillingia & spinulosa & & B & & & & & & & & A & \\
\hline STSP6 & Stephanomeria & spinosa & & & & & & & & A & A & B & B \\
\hline sumo & Suaeda & moquinii & & & $\mathbf{B}$ & & & & B & & & & $\mathbf{B}$ \\
\hline SYFR & Syntrichopappus & fremontii & & A & $\mathbf{A}$ & A & A & A & A & A & $\mathbf{A}$ & A & \\
\hline SYLO & Symphoricarpos & longifforus & & & & & A & A & A & A & A & A & \\
\hline SYROP & Symphoricarpos & rotundifolius var. parishii & & & & & & & & & & B & $\mathbf{B}$ \\
\hline TARA & Tamarix & ramosissima & & & & & & & & & & & $\mathbf{B}$ \\
\hline TEAXA & Tetradymia & axillaris var. axillaris & A & A & $\mathbf{A}$ & A & A & $\mathbf{A}$ & A & A & A & A & \\
\hline TECA2 & Tetradymia & canescens & & $\mathbf{A}$ & A & A & A & A & A & A & A & $\mathbf{A}$ & $\mathbf{B}$ \\
\hline TEGL & Tetredymia & glabrata & & $\mathbf{A}$ & & $\mathbf{B}$ & A & A & B & A & A & A & \\
\hline THCU & Thysanocarpus & curvipes & & & & & & A & & & A & A & \\
\hline THLA3 & Thysanocarpus & laciniatus & & & & & A & & & & & & B \\
\hline THLA4 & Thelypodium & laxifionum & & & & & A & & & & & B & \\
\hline THMO & Thamnosma & montana & & A & A & A & A & A & A & A & A & & \\
\hline THPEB & Thymphylla & pentechaeta ver. belenidium & & & A & & & A & & & & & \\
\hline TICAC & Tiquilia & canescens var. canescens & & & & & & & & & & & $\mathbf{B}$ \\
\hline TINU2 & Tiquilia & nuttallii & & $\mathbf{B}$ & & & & A & $\mathbf{B}$ & & $\mathbf{A}$ & $\mathbf{B}$ & \\
\hline TIOBO & Tidestromia & oblongifolia ssp. oblongifolia & & $\mathbf{B}$ & & & & & & & & & \\
\hline TIPL2 & Tiquilie & plicata & & $\mathbf{B}$ & & & & & $\mathbf{B}$ & & & & \\
\hline Tosc & Townsendia & scapigera & & & & & & & & & A & $\mathbf{A}$ & \\
\hline TRAN & Trifolium & andersonii & & & & & & & & & B & $\mathbf{A}$ & \\
\hline TRMU & Tridens & muticus & & B & $\mathbf{B}$ & & & B & & & & & \\
\hline TRTE & Tribulus & terrestris & & B & & & & & & & & & \\
\hline TRWA2 & Tricardia & watsonii & & & & & A & $\mathbf{B}$ & & & A & $\mathbf{A}$ & \\
\hline TrDO & Typha & domingensis & & & & $\mathbf{B}$ & B & $\mathbf{B}$ & & & & & \\
\hline TYLA & Typha & latifolia & & & & & & & & & & & $\mathbf{B}$ \\
\hline ULMI & Uimus & minor & & & & & & $\mathbf{B}$ & & & & $\mathbf{B}$ & \\
\hline ULPA & Uimus & parvifolia & & & & & & & & & & & B \\
\hline URLI2 & Uropappus & lineanifolia & & & & & A & $\mathbf{A}$ & A & A & $\mathbf{A}$ & $\mathbf{A}$ & \\
\hline
\end{tabular}


LEGEND: A=1999 Survey; Bradditional species listed in the 1976 Beatley Survey; 1 = Lycium spp. Shrubland Alliance; 2 = Larrea tridentata/Ambroela dumoes Shrubland Alliance; 3 = Atriplex confortffolla/Ambrosia dumoes Shrubland Alliance; 4 - Hymenoclea-Lyclum Shrubland Alliance; 5 = Ephedra nevadenois Shrubland Allance; $6=$ Coleogyne rammosiesima Shrubland Alliance; 7 = Atriplex spp. Shrubland Alliance; $8=$ Chrysothamnus-Ericameria Shrubland Alliance; $9=$ Artemisia spp. Shrubland Alliance; 10 = Pinus monophylla/Artemisia ssp. Woodland Alliance; $11=$ Miscellaneous

\begin{tabular}{|c|c|c|c|c|c|c|c|c|c|c|c|c|c|}
\hline Code & Genus & Species & 1 & 2 & 3 & 4 & 5 & 6 & 7 & 8 & 9 & 10 & 11 \\
\hline VEAM2 & Veronica & americana & & & & & & & & & & $\mathbf{B}$ & \\
\hline VEAN2 & Veronica & anagallis-aquatica & & & & & & & & & & B & \\
\hline VEBR & Verbena & bracteata & & & & & & & & & & $\mathbf{B}$ & $\mathbf{B}$ \\
\hline VEPEX2 & Veronica & peregrina ssp. xalapensis & & B & & & & $\mathbf{B}$ & & & & B & \\
\hline VUMI & Vulpia & microstachys & A & & & & & A & & & A & A & $\mathbf{B}$ \\
\hline VUMY & Vulpia & myuros & & & & & & B & & & & & \\
\hline VuOC & Vulpia & octofiora & & A & A & A & A & A & A & $\mathbf{A}$ & A & A & \\
\hline XASTC & Xanthium & strumarium var. canadense & & & & & & & & & & & $\mathbf{B}$ \\
\hline XYTOT & Xylorhiza & tortifolia var. imberbis & B & A & A & A & A & A & & $\mathbf{A}$ & & A & \\
\hline YUBAV & Yucca & baccete var. vespertina & & & A & & A & A & A & A & A & $\mathbf{A}$ & \\
\hline YUBR & Yucca & brevifolia & & $\mathbf{A}$ & A & $\mathbf{A}$ & A & A & A & A & $\mathbf{A}$ & $A$ & \\
\hline Yusc2 & Yucca & schidigera & & A & A & A & A & A & A & & & & \\
\hline ZAPA & Zannichellia & palustris & & & & & & B & & & & $\mathbf{B}$ & $\mathbf{B}$ \\
\hline ZIPA2 & Zigadenus & paniculatus & & & & & & & & & A & A & \\
\hline 9/20/1999 & & G:IEMACIVEGWATALEGIS & The & $s 1 B$ & Dist & $i /{ }^{2}$ & Asso & cWt: & tslist & $2 . x / 5$ & & & \\
\hline
\end{tabular}


This Page Intentionally Left Blank 


\section{Appendix C}

List of Common Names, Alphacodes, Scientific Names, and Older Names

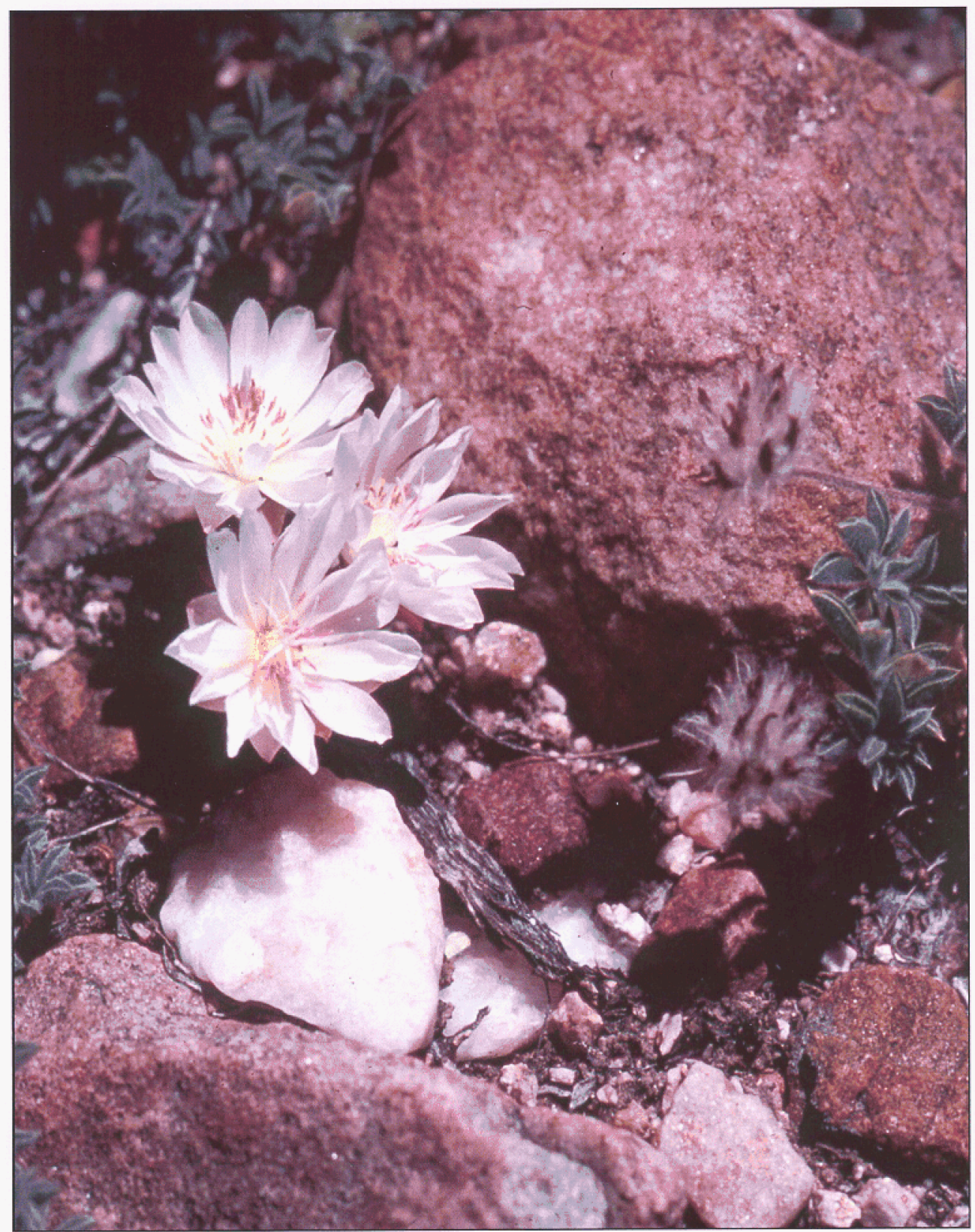

Oregon bitterroot (Lewisia rediviva) [photo by Susan Cochrane] 
This Page Intentionally Left Blank

$6 \mathrm{C}-2$ 


\begin{tabular}{|c|c|c|c|c|}
\hline Common Name & Code & Genus & Species & Older Name Used by Beatley \\
\hline acorn buckw heat & EREL4 & Eriogonum & glandulosum & \\
\hline African mustard & TIAAF & Malcomia & africana & \\
\hline alfalia & WESA & Medicago & sativa & \\
\hline akalbulrush & E0:05 & Borboschoonus & robustus & Scripus robusfus, Scirpus maritinus \\
\hline akain goddenbush & ISACA2 & Isocoma & acradenius var. eremophilus & Isocoma acadenia ssp. eremophilus \\
\hline American black nightshade & SOAM & Solanum & americanum & \\
\hline American speedwell & VEAL 2 & Veronica & americana & \\
\hline Anderson's buttercup & RAAN & Ranunculus & andersonil & \\
\hline Anderson's campion & SIVEA & Silene & verecunda ssp. andersonit & \\
\hline Anderson's wolfberry & LYAN & Lycium & andersonii & \\
\hline annualbhegrass & POAN & Pos & annua & \\
\hline annualhairgrass & DEDA & Deschampsia & danthonioides & \\
\hline annual psathyrotes & PBSAN & Psathyrotes & annua & \\
\hline annual rabbisfoot grass & Po'sos & Polypogon & monspeliensis & \\
\hline annual toothleaf & STSP & Stillingia & spinulosa & \\
\hline annual yelow sweelclover & WEN & Melitoks & indicus & \\
\hline antelope bitterbrush & PUTE2 & Purshia & tridentata & \\
\hline Antelope sland skeletonplant & LYAH & Lygodesmia & dianthopsis & \\
\hline Apache plume & FAPA & Fallugia & paradoxa & \\
\hline apricot globemalow & SPA'TA & Spheoralcea & ambigua ssp. ambigua & \\
\hline Arabian schismus & SCAR & Schismus & arabicus & \\
\hline Argus btazingstar & IIEoins & Mentzelia & orecphila & \\
\hline arid neediograss & ACARiR & Achnatiorum & ande & Stipe arida \\
\hline Arizona honeysw eet & TKO:O & Tidestromia & कblongifolia ssp. oblongifolia & \\
\hline Arizona popcornflower & PLAR & Plagiobothrys & arizonicus & \\
\hline Arzona threeawn & ARARE & Aristida & arizonica & \\
\hline Austin's beardtongue & PEDAR & Penstemon & fioridus var. austinii & Penstemon fioridus ssp. austinii \\
\hline backoot groundsmoke & GARA & Gayophytum & racemosum & \\
\hline Baiby's buckw heat & ER:AB & Eriogonum & bailey var. bailey & \\
\hline ballead githa & IPCOS & Tpomopsis & congesta & \\
\hline Balicic rush & JUEA & Juncus & balticus & \\
\hline banana yucca & YUEAV & Yucca & baccata var. vespertina & \\
\hline barbw ire Russian thiste & SAPAB & Salsola & paulsenit & \\
\hline baretwig stylocine & STPS & Styocline & psilocarphoides & \\
\hline barnyard grass & ECCR & Echinochloa & crusgalli & \\
\hline bashful four o'clock & MIIPUS & Mirabilis & pudica & \\
\hline basin big sagebrush & ARIRI & Artemisia & tridentata ssp. tridentata & \\
\hline basin catseye & CRAII3 & Cryptantha & ambigua & \\
\hline basin widrye & LECF & Leymus & cinereus & Eymus cinereus \\
\hline basin yellow catseye & CFicor2 & Cryptantha & contertitiora & \\
\hline bastardsage & ENWRS & Erigonum & wrightii var. subscaposum & \\
\hline
\end{tabular}

$$
\text { 6C-3 }
$$


t-09

\begin{tabular}{|c|c|c|c|c|}
\hline & en6!xe & enequeued & xتyd & 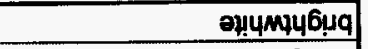 \\
\hline "1se6puq vomelsued & snopynsos & nowersued & 0lOy & uoueqsued e6pug \\
\hline 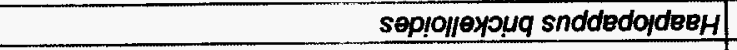 & sepio!nexpuq & B!p/BZ8H & E्avH & 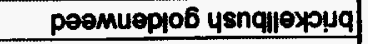 \\
\hline & עөмелq & EnaUEABN & 8QYN & eñueneu s,samajg \\
\hline & snopeskydjod je^ yemeiq & nove6y & dygyg & oueqrey s,omejg \\
\hline & eu!iss!soure & Equndo & Fdo & enoup noued poypuesq \\
\hline xyis/4 uo!ub!! & spyouk/e dss sepiouk/e & snw/B & تาตาㅋ & 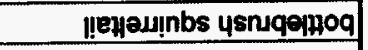 \\
\hline unzse6uos вunurisojeypa & un॥өy\%nd & euweisoyeup!a & Endia & xipen|q \\
\hline & yөujed & snuidn7 & EVdח7 & ouidn| peuuoqenja \\
\hline 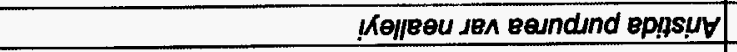 & 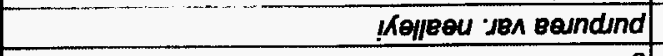 & EppsuY & Nndy $y$ & umeeosup onjq \\
\hline & 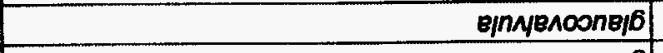 & s!qesy & 270y & ssaroxpos pod anja \\
\hline & s!!!oen6 & Bnopernog & 22008 & ewes6 enıg \\
\hline & & Byozuew & ZINEW & Jeis6uịze|q \\
\hline & Biejnolued & Bueuropy & 6zVd) & usnuquqqes unezspee1q \\
\hline & Bu!nss!soures & ouk60eyos & VeO0 & ysnuqæeja \\
\hline & BAou & e!s!wop/ & honey & 4snuquoes xoeja \\
\hline & Bqeuatonu dss afouaronu & Boenled & wnind & өxesqup joojpu!q \\
\hline & unuepnp!u & unuoboug & thea & jeermpong reou p!!q \\
\hline & 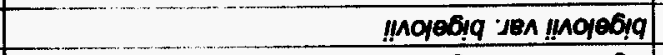 & snpnutw & zgingim & Jemoufoxyou $8, \mathrm{moj} 6 ! \mathrm{g}$ \\
\hline esedse 'J8A !nO/e6!q s!!!qu!W & 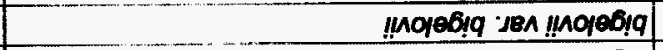 & sumqaun & gigim & Fopp,o Jnol s, moi6!a \\
\hline & !n०106!q & snupueur7 & 21917 & spodunupesep s,moi6!a \\
\hline & BपpURPBW & spposuesuo & ทัHว & uepieukiqsnp peoubịq \\
\hline & 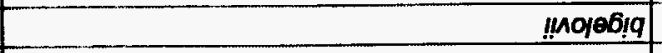 & Bșuey & EIgy & 4snuqe6es moje6!1: \\
\hline & 8)80108/q & euequen & gegn & euequen pesq6ịq \\
\hline unpeqn! uọuru!s & smpes!ynu & snuxig & Enผ79 & 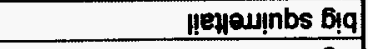 \\
\hline & s!uvomuvi dss s!uwomuel & $x \in d u p$ & 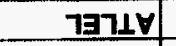 & 4snqpes $6 ! 9$ \\
\hline вр!6ч вивин & $8 p ! 6 ! 4$ & s!yoternetd & E187d & 뤼케e6 6!9 \\
\hline & s!uuv!q & enpuepod & Ll8Od & piojenbup jęuue!̣ \\
\hline & Uо/४рвp & nopouks & valo & ssed6 epnuweg \\
\hline & 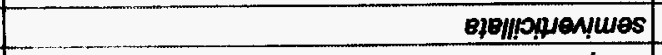 & spgsalb & 29S9V & ssej6\}ueq \\
\hline & ezejnuedureo & B!ा!9 & Zพจ|จ & E!n!6 edeus |əq \\
\hline & sueydpoep & BqquBidKo & تৈบ0 & әкәszes 6u!!n6eq \\
\hline & 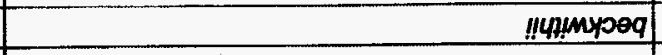 & snpofansy & Ëgsv & 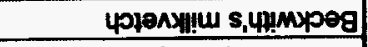 \\
\hline & 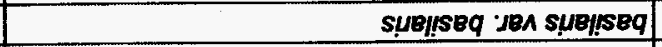 & Bqundo & zeVEdo & 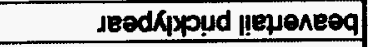 \\
\hline & Biejnypeds & sydejociow & dSOW & sidejouou seneəq \\
\hline & $\theta \theta र \theta p в \theta q$ & Bye0e4d & Eaghd & pormuoidioos s,Repeeg \\
\hline & eexeppeq & snje6ensy & 9ggsv & 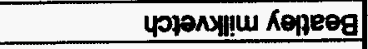 \\
\hline sep!oo!!n snuk, & sep!oompu & $\operatorname{snuK\theta 7}$ & sy137 & oxppim sseipieeq \\
\hline & ese6!queq & equuejdKo & sveyo & әкөsqeo papieaq \\
\hline 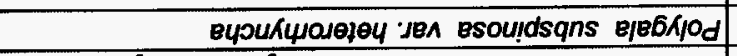 & 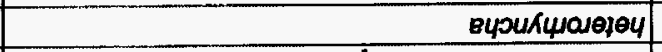 & $8 / 861 / O_{d}$ & LIHOd & eje6kjod Ku!ds pəyyeaq \\
\hline Kejpeeg Kq pesn eureN Jepio & selpeds & snues & opos & ouEN UowWos \\
\hline
\end{tabular}




\begin{tabular}{|c|c|c|c|c|}
\hline 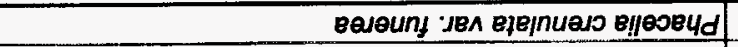 & 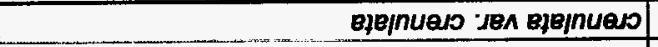 & $8 ! 10084 d$ & EOy & 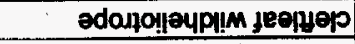 \\
\hline & unpв!10yed & un!pide 7 & 2อd 97 & promuadded 6uldsep \\
\hline & esodded & s!poed & ZYdad & plo6yeuplyey peom4рu! \\
\hline & edresorejey & B/1800p00d & BHבd & persquos enempnup \\
\hline & Byoyned & snuin & Vd]n & سule әseu!u? \\
\hline & snuвueyeq & snwos & żEya & sseyp uee!! \\
\hline & ENOYNBD & BAYEW & sVdYw & Molfeu poemeseeup \\
\hline & unvopes & snwoug & ت148 & ssed6̧ee40 \\
\hline & "IsuequBup & eunesR4d & ZHOHd & podumy s,jequeuD \\
\hline & suepoenes & unidy & cyodv & Nuejeo \\
\hline & Bdreokpod & xeyduqy & OdIV & 4snques eqfieo \\
\hline & 10580 & snje6eqsy & HLVOSY & 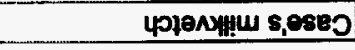 \\
\hline & Bpeufousu & Buneydoydug & สบบาอ & peesenteo \\
\hline ejeurl xo14d & Bjeug dss upoou & $x 014 d$ & 7OHHd & xoyd yodies \\
\hline & șsuepeues & EzRuOS & Sv000 & peemessou ueipeuej \\
\hline & esuepeues jen unueunns & unnupuex & 215VX & unqaypos epeues \\
\hline & 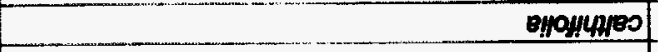 & oneosud & ZVoHd & peemuropdrose jecpinies \\
\hline & Bjensal & eueq!s & oyls & 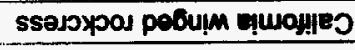 \\
\hline ByıB BNoypoueO & 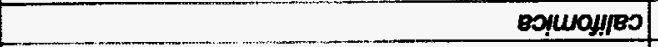 & B!noss!unes & ZEVOVO & dnouns e!̣uof!es \\
\hline & eejequnjos jes erjequnjos & e!nes & joगvs & 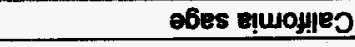 \\
\hline & unopuayjes dss unubu & Buroper & ONNGH & 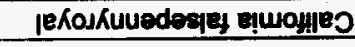 \\
\hline & BỵA dds вoyuoyjeo & Euepoveo & ZVDEO & 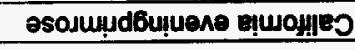 \\
\hline & snjeupeo & snwarg & 9vวyg & awosq 부열 \\
\hline & 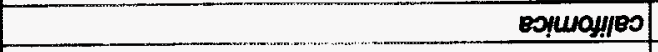 & e!llexpug & Evวyg & ysnqu|expyq equomes \\
\hline & snopuaypes & snupueseung & VowV & 4puesewe ęuayje? \\
\hline & esomeoses & Bupuejd/No & ZYXYO & OKesqeo Kusnq \\
\hline & unvojounp & supusidko & noy & exosjeo Bupnopysnq \\
\hline & yoyod & 8!6requerunw & zodnu & Kiynu ysnq \\
\hline & Ejesunfd & siluarooaneid & $7 d 7 d$ & jeeqmaue ysnq \\
\hline & snuвppoosypy! & snuxupe7 & HHY & әu!neəd uig]unow Boulng \\
\hline & suesseu!ds & esspuent & SdSYy & ysnuqe6es png 'e6espnq \\
\hline & șuneeunq & snyoupopes & tugvo & A 1 !1 Bsodyeu neeung \\
\hline & Broysned & Buouroueyders & WdIs & 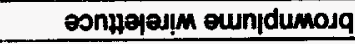 \\
\hline & 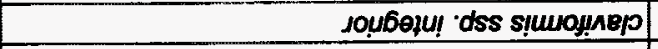 & B!uOssiumo & 17วVว & sekeumosq \\
\hline & sepyopreds & openes & EdSas & |Pspunos6 woosq \\
\hline & 8!|gㅛㄹ & eudk1 & $\nabla \mu$ & 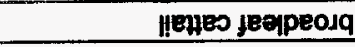 \\
\hline & ed/80:48jd & 8/1800100d & $7 d B d$ & poesquoo unupeosq \\
\hline snsouen uowejsued & snsouen jeA sn!o!nsnbur & nourejsued & ANVEd & en6uoupueeq pueeqpeosq \\
\hline & Bpejnupeds jea nuroouavq & enpuezuous & SygHO & Jomoyouids omyq \\
\hline & nwos!1esq 'seя nwoo!1esq & onpuszyous & EบgHว & Jemoyouids eptuq \\
\hline & Bp!ds!! 'Jen esol!n & 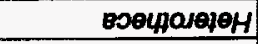 & нIи캐 & Jejseuep|06 R!̣eч Rpsuq \\
\hline & 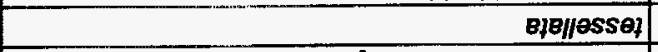 & B!You!sW甘 & EaInV & xoueippy Kpsug \\
\hline Kelpeeg Kq pesn eueN JepIo & sẹpods & snues & opos & 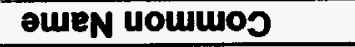 \\
\hline
\end{tabular}




\begin{tabular}{|c|c|c|c|c|}
\hline & !zunw & E!uoss!uBg & $\operatorname{tnnwy}$ & 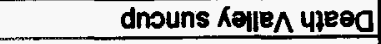 \\
\hline & 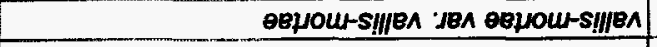 & Bne084d & zAVAHd & Biposud Keㄹㅅ 4peeg \\
\hline & Eesoung & espeydg & $n+d \exists$ & espoude Ke\#len yleeg \\
\hline & 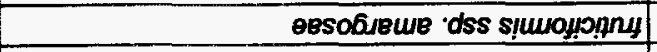 & nowejsued & VPAEd & 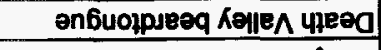 \\
\hline & ouwoypp! & nopdonow & 380w & Jęsyesap Ksiep \\
\hline & 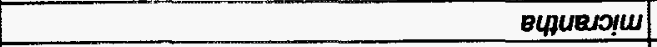 & BydRong & ziwng & paesep! џ עesep Kquịep \\
\hline & Epอบ丶 & enieg & 49ᄏ9 & dịussedieqem jeeqno \\
\hline & essposunou! & eqpubiddo & z1כ४ว & Oxesteo uoḷ4sno \\
\hline & 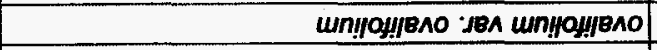 & unuoboyg & sonoy & peoumponq uo!usno \\
\hline & B]8Nnכes & expeopoed & 피리 & peesquos inuenno \\
\hline & 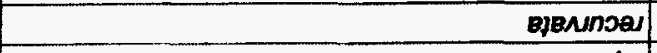 & supusidico & 9эะมว & exesqeo qnuenuno \\
\hline & Bleinues jon esauenbs & enepung & sosyo & peemun6 dnokuno \\
\hline & snds 40 & xouny & yony & жоp K \\
\hline & snyouper 'sen snyoyper & sndreo00100 & 79790 & Kue6ouew upepunow jeenpno \\
\hline 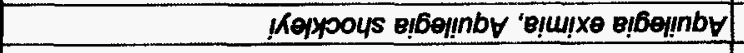 & Bsomioy ren esouwoy & eybenby & $\pm 0 \pm 0 \mathrm{~V}$ & ouqqunjoo uoswip \\
\hline & unnpisus & vaukdany & पODV & 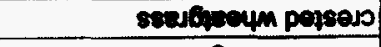 \\
\hline unjeuONOO Bd!ns & Eq8uaros & unNoupouypy & 120027 & striboypeou isess \\
\hline & eqejuepy & BauB7 & 2y+7) & 4enq 01050010 \\
\hline & epenuene & BuenoOMN & IVIN & 0008901090100 \\
\hline & lempaos & serpuenters & ЮOHO & wojdy s,elf, \\
\hline 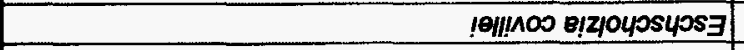 & Ielin100 dos arounynu & B121040s40s3 & zolms & Kddoduepio6 s,ajinoo \\
\hline & snjeydeoxpod & snperooulupg & 2OdD & snpeopouseq dojuonos \\
\hline & ب0d000 & sn4puejneo & 8lojvo & Obeqq00 pim s,jodooo \\
\hline & yedoos jen yedoos & sAxovouKh & $2000 \Lambda \mathrm{H}$ & shxoueun 4 s,jodoo? \\
\hline yedoos snddedojdeH & nedooo & 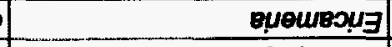 & Ezopdg & posueppobypey s,jodooj \\
\hline yedooo e!posska & nedoos & unykydouepy & 2000y & peem6op sjodooj \\
\hline & snssids & sninuin & dSin & semoykoyuoul pedu100 \\
\hline suejno!juel dsssnnuus sn4pus!leH & snnuue & snцqueneH & ENVEH & somoutuns youmboo \\
\hline & sulysnyned & șe400e19 & EYd7 & ysnuoxyds uoutuos \\
\hline sulsnied surupoeg & Ex408150108W & ș184000日 & sทพาย & 4snexids youminos \\
\hline & exuppores & E!zaueqng & ZVsno & poomoyeus voutuoo \\
\hline unupueuow wn!puyd/185 & B.puBuow & expUE?5!O & towio & smedksend uounuros \\
\hline & BApes & Buent & VSAY & teo noumbos \\
\hline & Bubdoos & 8!y00) & osoy & E!1400y uoumuos \\
\hline & ens!̣uenel & BบenIUWEW & venvin & 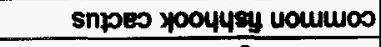 \\
\hline & snjeyexe jen snumuebelul & apoves & בNIIaS & lespuno16 eigunjos \\
\hline 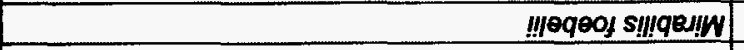 & 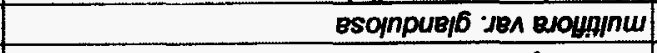 & s!llqen! W & onvin & жpop, o dnol opesolo? \\
\hline & !Knqsueqs & $x 014 d$ & HLISHd & xolyd yesepploo \\
\hline & syporiboend & $x \otimes 180$ & sydvo & o6pes piey pejejsnjo \\
\hline & BiBjno!osef & өyourq0u & VJyO & odesuroasq pesejsnp \\
\hline & !Кеуоур & B!IIO & 27010 & 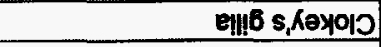 \\
\hline eleouno jen вjeouno snddedojdeH & snjeouno & 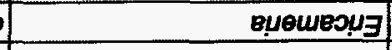 & onoy日 & posueppo64peeч झщр \\
\hline Repeeg Kq pesn euren Jeplo & sejpods & snues & өpoo & oureN uounuos \\
\hline
\end{tabular}




\begin{tabular}{|c|c|c|c|c|}
\hline Common Name & Code & Genus & Species & Older Name Used by Beatley \\
\hline deceptive ground smoke & GADE2 & Gayophytum & decipiens & \\
\hline depressed fiddleleaf & NADE3 & Nama & depressum & \\
\hline depressed skyrocket & IPDE & Ipomopsis & depressa & \\
\hline desert almond & PRFA & Prunus & fasciculate & \\
\hline desert bear poppy & ARINE2 & Anctomecon & merriamï & \\
\hline desert biscuitroot & LOFOF & Lomatium & foeniculaceum ssp. fimbriatum & \\
\hline desert bifterbrush & PUGL2 & Purshia & glandulosa & \\
\hline desert brickellbush & BRDE3 & Brickellia & desertorum & \\
\hline desert broomrape & ORCO4 & Orobanche & cooperi & \\
\hline desert dodder & CUDE2 & Cuscuta & denticulata & \\
\hline desert elkwoed & FRALS & Frasera & albomarginata & Swartia albomarginata \\
\hline desert eveningprimrose & OEPR & Oenothera & primiveris & \\
\hline desert figwort & SCDE & Scrophularia & desertorum & \\
\hline desert fivespot & ERRO8 & Eremalche & rotundifolia & \\
\hline desert globemallow & SPAMT & Sphearalcea & ambigua ssp. monticola & \\
\hline desert goldenpoppy & ESGL & Eschscholzia & glyptosperma & \\
\hline desert gooseberry & RIVEV & Ribes & velutinum var. velutinum & \\
\hline desert goosefoot & CHPR5 & Chenopodium & pratericola & Chenopodium desiccatum var leptophylloides \\
\hline desert holly & ATHY & Atriplex & hymenelytra & \\
\hline desert Indianwheat & PLOV & Plantago & ovata & Plantago insularis var. fastigiata \\
\hline desert lupine & LUAR7 & Lupinus & anidus & \\
\hline desert marigold & BANU & Bailoya & multiradiata & \\
\hline desert milkweed & ASER2 & Asclepias & erose & \\
\hline desert noedigrass & ACSP12 & Achnetherum & speciosa & Stipa speciosum \\
\hline desert pale gilia & GIHU & Gilia & hutchinsifolia & \\
\hline desert peppenweed & LEFR2 & Lepidium & fremontii & \\
\hline desert princasplume & STPP & Stanioya & pinnata var. pinnata & \\
\hline desert rockcress & ARPUG & Arabis & pulchra var. gracilis & \\
\hline desert snowbeny & SYLO & Symphoricarpos & longifiorus & \\
\hline desert spinystar & ESVD & Escobaria & vivipara var. deserti & \\
\hline desert stickseed & LAOCO & Lappula & occidentalis var. occidentalis & \\
\hline desert stingbush & EUUR & Eucnide & urens & \\
\hline desert threadplant & NERU & Nemacladus & rubescens & \\
\hline desert tobacco & NTTRT & Nicotiana & trigonophylla var. trigonophylla & \\
\hline desert woolstar & ERER2 & Eniastrum & eremicum & \\
\hline desertsnow & LIDE2 & Linanthus & demissus & \\
\hline devil's spineflower & CHRI & Chorizanthe & rigida & \\
\hline difinuse mountain trumpet & COTE & Collomia & tenella & \\
\hline distant phacelia & PHDI & Phacelia & distans & \\
\hline ditch polypogon & POIN7 & Polypogon & intermuptus & \\
\hline Dorr's sage & SADOD3 & Salvia & donii ssp. domii var. dorrii & Salvia domii ssp. argentea, Salvia domii ssp. gilmanii \\
\hline Douglas' dustymaiden & CHDO & Chaenactis & douglasii & \\
\hline
\end{tabular}

6C-7 


\begin{tabular}{|c|c|c|c|c|}
\hline & BUB!nuex & sposuer40 & VXHO & uol!ysnou!d jo|0ousey \\
\hline & s!!!quuen Jen snsou!binuel & snjebensy & $\Lambda \exists 7 S V$ & чріелҮ\|!U ре|хрен \\
\hline & esoquikioo & өypurqajo & 90080 & odeswoosq dopey \\
\hline & edJeo! & B!sasquy & zOVIV & peambes unq ou!dsqey \\
\hline & unxeyep :ra unxeyep & unuo6049 & rogayg & jeoympnq umorgley \\
\hline & unjereq jвл unхејер & unuo6oug & gecya & zeoumspnq umorpley \\
\hline & wnxeyep & unuo6oug & 9э0у크 & peoumpnq umorjey \\
\hline & вұвpumpar 'dss вұunu & euoweany & ynimy & Kddod AIxpyd pnqpey \\
\hline & yUOSłeM & oqpuezyous & ZVMHO & Jemoyeu!ds ypoojeny \\
\hline & "luosiepue & wn! ${ }_{1} \mu_{\perp}$ & NVy. & 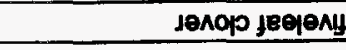 \\
\hline & EnaydossKu & e!sseg & 삼 & peameupous woyeny \\
\hline \multirow[t]{2}{*}{ 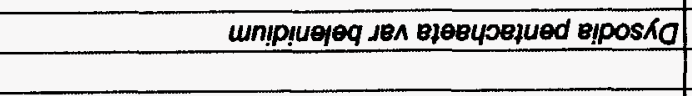 } & 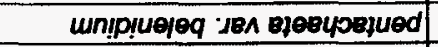 & 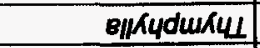 & gadHI & jeakㅅoud apeou ony \\
\hline & sn/84doos6ou ven snyogyy & snddedouounth & $m+\lambda H$ & snddedousuk 4 feopeuy \\
\hline \multirow[t]{4}{*}{ sed!ly unu!uщ! } & sed!ly & unu!umeo60eN & $\mathbf{H} \mathbf{B N}$ & Uo6eupdeus sed!!! \\
\hline & sisuene & snpnyoukos & tyYoo & poompu!q ploy \\
\hline & orisuwej dss elueperobu & ouguery & sViey & Hompues, sues \\
\hline & unyojej!u & вupineqeeweyo & ZI:HS & joems yesep 'yenq uej \\
\hline 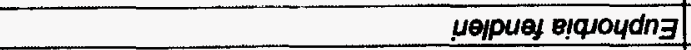 & yeypues & eokseouruO & \&ะHO & teupues s,jeppued \\
\hline \multirow[t]{3}{*}{ 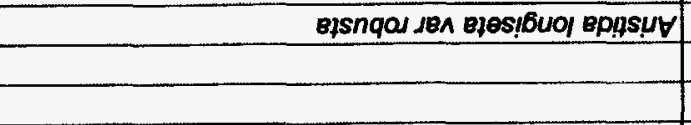 } & Bles!buof jeA reandind & eppsuy & Indy $y$ & umbearif seppues \\
\hline & Busuejpuef joA Baindind & eppsuy & Indy & umeeesut jepued \\
\hline & 8j86!!n & ș0140 & HAHO & ssej6rebuy 1eupea \\
\hline Bipoijd в!uep/os & BqBoyd & B!nnby & हाdा1 & feweqyuy jeequej \\
\hline \multirow[t]{7}{*}{ Bsol!d sninu!n } & snsond & oqpuBioun:N & SIdIw & JamoyKoxyou es|ej \\
\hline & Esauenbs & Baulu & Osow & ssejbojeynq өs|ej \\
\hline & 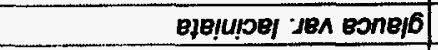 & sueso6y & $7700 y$ & șyosobe ostej \\
\hline & sepiou/purido & B!!!9 & dOID & e!! 6 peरe \\
\hline & snwoloyo!p & snupueu!n & 지믹 & Mous6u!uene \\
\hline & esuepjejouse jen esueplejeuse & unuo6oug & 코플 & Jeoumponq epposous \\
\hline & & unuo6oug & solya & unuo6oye \\
\hline \multirow[t]{6}{*}{ 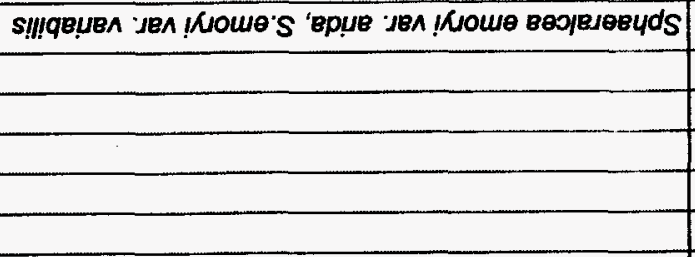 } & Krome & Bepposeouds & mads & Monleweqo16 s,Now] \\
\hline & Mrowe & surypoeg & nV & syeupoeq s,Noul \\
\hline & unu!snd & BWEN & ndVN & jeojeippy jeej66e \\
\hline & snjoydoo jen snuoydoo & snje6eqsy & $20005 y$ & 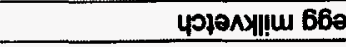 \\
\hline & unypyjpod Jen wnyejnọosey & unuo6oyg & dVy & 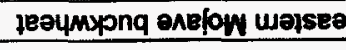 \\
\hline & snuweds!p jen sndresoukpip & snje6ensy & alasy & 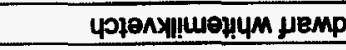 \\
\hline s!numy dss s!!!oes6 suevaro!w & s!luuny dss sulpeib & $x 014 d$ & HYOHd & xо14d yемp \\
\hline \multirow[t]{4}{*}{ Bueu snddedojdeH } & snueu & 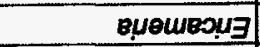 & LWNa & pojuәрі064реөч уемр \\
\hline & surinu & unuo6oug & zNnNyg & jeeympng kem6ng \\
\hline & unพ어 $\times 81$ & un!podKreuL & WHH & Kpodkieup semoudooup \\
\hline & !ssej6nop & xevej & zodvs & o6pes, sej6nog \\
\hline "ysejbnop opoeues & !sej6nop :jen snp!ooey & opoues & gENES & jespunod6 sej6nog \\
\hline Kepeeg Kq pesn eureN Jepio & sejpeds & snues & epoo & outeN Uownos \\
\hline
\end{tabular}




\begin{tabular}{|c|c|c|c|c|}
\hline Common Name & Code & Genus & Species & Older Name Used by Beatley \\
\hline foothill bladderpod & LELU & Lesquerella & ludoviciana & \\
\hline foothill deathcamas & ZIPA2 & Zigadenus & paniculatus & \\
\hline foothill deervetch & LOHU2 & Lotus & humistratus & \\
\hline four o'clock & MICO15 & Oxybaphus & comatus & Mirabilis comatus \\
\hline fourpart scorpionweed & PHTE & Phacelia & tetramera & \\
\hline fourwing saltbush & ATCAC & Atriplex & canescens var. canescens & \\
\hline foxtail barley & HOJU & Hordeum & jubatum & \\
\hline foxtail brome & BRRU2 & Bromus & rubens & \\
\hline Fremont chaffbush & AIIFRF & Amphipappus & fremontii var. fremontii & \\
\hline Fremont's cottonwood & POFRF3 & Populus & fremontii ssp. fremontii & \\
\hline Fremont's dalea & PSFRF & Psorothamnus & fremontii var. fremontii & \\
\hline Fremont's goosefoot & CHFR3 & Chenopodium & fremontii & \\
\hline Fremont's milkvetch & ASLEF2 & Astragalus & lentiginosus var. fremontii & \\
\hline Fremont's phacelia & PHFR2 & Phacelia & fremontii & \\
\hline fringed amaranth & ALiFT & Amaranthus & fimbriatus & \\
\hline Funeral Mountain milkvetch & ASFU3 & Astraga/us & funereus & \\
\hline galleta grass & PLJA & Plouraphis & jamesii & Hilania jamesii \\
\hline Gambel oak & QUGA & Quercus & gambelif & \\
\hline gilia & GILIA & Gilia & & \\
\hline Gilman's springparsley & CYGI & Cymopterus & gilmanii & \\
\hline Gilman's suncup & CAKEG & Camissonia & kemensis ssp. gilmanii & \\
\hline glandular brickellbush & BRAR2 & Brickellia & arguta & \\
\hline glandular threadplant & NEGLO & Nemacladus & glanduliferus var. orientalis & \\
\hline globe springparsley & CYGL2 & Cymopterus & globosus & \\
\hline golden desertsnapdragon & MOER & Mohaves & breviitora & \\
\hline golden suncup & CABRBA & Camissonia & brevipes ssp. brevipes & \\
\hline Goodding's aster & MAPIC2 & Machaeranthera & gooddingii & Haplopappus pinnatifida ssp. gooddingii var. gooddingii \\
\hline Goodding's willow & SAGO & Salix & gooddingii & Salix gooddingii var. googgingii \\
\hline gooseberryleaf globemallow & SPGRP2 & Sphaeralcea & grossulariaefolia ssp. pedata & Sphaeralcea grossulariffolia var. pedata \\
\hline granite pricklygilia & LEPU & Leptodactylon & pungens & Leptodactylon pungens ssp.pulchrifiorum, L. p. ssp. hallii \\
\hline grassy rockgoldenrod & PEPU7 & Petradoria & pumila & \\
\hline gray coldenia & TICAC & Tiquilia & canescens ver. cenescens & Coldenia canescens var canescens \\
\hline Great Basin langloisia & LASEP & Langloisia & setossima ssp. punctata & Langloisia punctata \\
\hline Great Basin popcornflower & PLKI & Plagiobothrys & kingii & \\
\hline Great Basin woolstar & ERSP3 & Eriastrum & sparsifiorum & \\
\hline green rabbitbrush & CHVIP4 & Chrysothamnus & viscidifiorus ssp. puberulus & \\
\hline green rabbitbrush & CHVS6 & Chrysothamnus & viscidifiorus ssp. viscidiflorus var. stenophyllus & \\
\hline green rabbitbrush & CHVV2 & Chrysothamnus & viscidifiorus ssp. viscidiflorus & \\
\hline Greene's rabbitbrush & CHGR6 & Chrysothamnus & greenei & \\
\hline greenmolly & KOAM & Kochia & americana & Kochia americanavar vestita \\
\hline grizzlybear pricklypear & OPERE & Opuntia & erinacea var. erinacea & \\
\hline
\end{tabular}

6C-9 


\begin{tabular}{|c|c|c|c|c|}
\hline Common Name & Code & Genus & Species & Older Name Used by Beatley \\
\hline grizzlybear pricklypear & OPERU & Opuntia & erinacea var. ursina & \\
\hline ground nama & NAAR & Nama & aretioides & \\
\hline Guadalupe catseye & CRMA7 & Cryptantha & maritima & \\
\hline hairspine pricklypear & OPPOR & Opuntia & polyacantha var. nufispina & \\
\hline hairy crabgrass & DISA & Digitaria & sanguinalis & \\
\hline hairy desert sunflower & GECA2 & Geraea & canescens & \\
\hline hairy purslane speedwell & VEPEX2 & Veronica & peregrina ssp. xalapensis & \\
\hline hairy wild cabbage & CAPI4 & Caulanthus & pilosus & \\
\hline hairy willowherb & EPCI & Epilobium & cillatum & \\
\hline hairy woollygrass & ERPI5 & Erioneuron & pilosum & \\
\hline hairyloaf caulanthus & GULA4 & Guillenia & lasiophylla & Caulanthus lasiophyllus \\
\hline Hall's hawksbeard & CRRUH & Cropis & runcinata ssp. hallii & \\
\hline halogeton & HAGL & Halogeton & glomeratus & \\
\hline handsome scorpionweed & PHPE2 & Phacelia & poirsoniana & \\
\hline handheads & ACRE3 & Acroption & repens & Centaurea repens \\
\hline hardstem bulrush & SCACA & Schoonoplectus & acutus var. acutus & Scirpus acutus \\
\hline heartleaf twistilower & STCOC & Streptanthus & cordatus var. cordatus & \\
\hline hedgehog cactus & ECENE & Echinocereus & engelmannii var. engolmannii & \\
\hline Heermann's buckwheat & ERHEA & Eriogonum & heermannii var. argense & \\
\hline Heermann's buckwheat & ERHEH2 & Eriogonum & hoermannil var. heermannï & \\
\hline Heermann's buckwheat & ERHES2 & Eriogonum & hoermannii var. sulcatum & \\
\hline Henderson"s desertparsley & PTHE & Pteryxia & hendersonii & \\
\hline herb sophia & DESO2 & Doscurainia & sophia & \\
\hline hiddenflower scorpionweed & PHCR2 & Phacolia & cryptantha & \\
\hline Hilend's bedstraw & GAHIH & Galium & hilendiae ssp. hilendiae & \\
\hline Hilend's bedtetraw & GAHIK & Galium & hilendien ssp. kingstonense & \\
\hline hoary aster & MACAC & Machaoranthera & canescens ssp. canescens & \\
\hline hoary buckwheat & ERSA6 & Eriogonum & saxatile & \\
\hline Holboelf's rockcress & ARHOP3 & Arabis & holboellii var. pinetorum & \\
\hline Holmgren's lupine & LUHO & Lupinus & holmgrenanus & \\
\hline Hooker's buckwheat & ERHO6 & Eniogonum & hookeri & \\
\hline horehound & Mave & Marnubium & vulgare & \\
\hline homed pondweed & ZAPA & Zannichellia & palustris & \\
\hline Howell's buckwheat & ERHO12 & Eriogonum & howellianum & \\
\hline inchhigh lupine & LUUN & Lupinus & uncialis & \\
\hline Indian ricegrass & ACHY & Achnatherum & hymenoides & Oryzopsis hymenoides \\
\hline Indian springparsley & CYAB & Cymopterus & aboriginum & \\
\hline inland saltgrass & DISP & Distichlis & spicata & \\
\hline intermediate suncup & CABOI & Camissonia & boothii ssp. intermedia & \\
\hline Intermountain mousetail & IVSA & Ivesia & sabulosa & \\
\hline Inyo rockcress & ARIN & Arabis & inyoensis & \\
\hline
\end{tabular}

6C-10 


\begin{tabular}{|c|c|c|c|c|}
\hline Common Name & Code & Genus & Species & Older Name Used by Beatley \\
\hline Iranian kochia & KOIR & Kochia & iranica & \\
\hline Island fringepod & THLA3 & Thysanocarpus & laciniatus & Thysanocarpus laciniatus var. hitchcockif \\
\hline Italian ryegrass & LOPEM2 & Lolium & perenne ssp. multifionum & \\
\hline Japanese brome & BRJA & Bromus & japonicus & \\
\hline Johnsongrass & SOHA & Sorghum & halepense & \\
\hline Johnston's knotweed & PODOJ2 & Polygonum & douglasii ssp. johnstonii & Polygonum douglasii var. johnstonii \\
\hline Jones' deserttrumpets & LWO & Linanthus & jonesii & \\
\hline Jones' falsecloak fern & ARWO2 & Argyrochosma & jonesii & Notholaena jonesii \\
\hline Joshua tree & YUBR & Yucca & brevifolia & \\
\hline juniper mistletoe & PHJU & Phoradendron & juniperinum & \\
\hline Kentucky bluegrass & POPR & POA & pratensis & \\
\hline kidney leaf buckwheat & ERRE3 & Eriogonum & reniforme & \\
\hline Kings bladderpod & LEKIK & Lesqueralla & kingii ssp. kingii & \\
\hline King's compact sandwort & ARKKC & Aronaria & kingii ssp. Compacta & Arenaria congesta var. kingii \\
\hline King's oyolash grass & BLKI & Blephanidachne & kingii & \\
\hline King's snapdragon & SAK & Saircocarpus & kingii & Anthimhium kingii \\
\hline ladder buckwheat & ERIN10 & Eriogonum & insigne & \\
\hline lambsquarters & CHALI2 & Chenopodium & album var. missouriense & Chenopodium missouriense \\
\hline largeflower hawksbeard & $\mathrm{CROCO}_{2}$ & Cropis & occidentalis ssp. occidentalis & \\
\hline largefiower suncup & CAKET6 & Camissonia & megalantha & \\
\hline largeleaf bedstraw & GAIM3 & Galium & megnifolium & \\
\hline larkspur & DEAN & Delphinium & andersonii & \\
\hline latefiowering goosefoot & CHSTG2 & Chenopodium & strictum ssp. glaucophyllum & \\
\hline leafy nama & NADE2 & Name & densum & \\
\hline leafy nama & NADED & Nama & demissum var. demissum & \\
\hline Lemmon's sconpionweed & PHLE & Phacolia & lemmonii & \\
\hline Lemmon's scorpionweed & POA & Pos & bigalovii & \\
\hline Lewis River suncup & CAPA30 & Camissonia & parvula & \\
\hline limestone hawksbeard & CRIN & Cropis & intermedia & \\
\hline limestone rockdaisy & PEIIEM & Perityle & megalocephala var. megalocephala & \\
\hline limestone scorpionweed & PHAF & Phacolia & affinis & \\
\hline little deserttrumpet & ERTR8 & Eriogonum & trichopes & \\
\hline little wiry suncup & CAPU16 & Camissonia & pusilla & \\
\hline Iittleleaf horsebrush & TEGL & Tetradymia & glabrata & \\
\hline littleleaf mountain mahogany & CEIN7 & Cercocarpus & intricatus & \\
\hline lobeleaf groundsel & SENU3 & Senecio & multilobatus & \\
\hline Londonrocket & SIIR & Sisymbrium & inio & \\
\hline long capsule suncup & CACH12 & Camissonia & chameenerioides & \\
\hline longbeak streptanthella & STLO4 & Streptantholla & longirostris & \\
\hline longleaf brickellbush & BRLO & Brickellia & longifolia & \\
\hline longleaf brickellbush & BRLOM & Brickellia & longifolia var. multifiora & \\
\hline longspine horsebush & TEAXA & Tetradymia & axillaris var. axillaris & \\
\hline
\end{tabular}

6C-11 


\begin{tabular}{|c|c|c|c|c|}
\hline & Bqdwoou! dss BuBp!nopn & B!s!weyt & $\operatorname{zin} 8 y$ & pome6es u!ejunow \\
\hline \multirow[t]{6}{*}{ suesseues dss wnubjuou un!p!do7 } & suesseues jen wnuejuou & unipplde7 & Soma7 & peamedded uịęunou \\
\hline & sepyopuou & sn!nu!n & zomine & 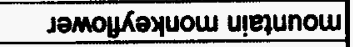 \\
\hline & emiss!sojes & Bistoj6u87 & EasV7 & e!ș이말 ypow \\
\hline & esoles & BNBP00100d & ISEd & persquos y;om \\
\hline & sppy!n & Eupeyd引 & nda & Ee? uounow \\
\hline & s!dejouow jen elejexe & s!sauby & 2XW39V & Ssejb\}uaq șidgouom \\
\hline \multirow[t]{2}{*}{ 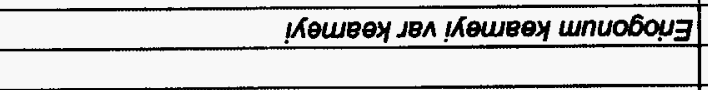 } & evejnuwnu & unuo6oug & InNY9 & peeumyonq Kouou \\
\hline & exe6!p!yos & eson从 & $205 n$ & EOSnK anelow \\
\hline 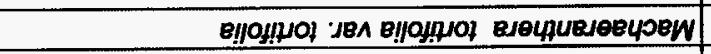 & 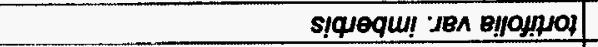 & вzчuокx & $1014 x$ & 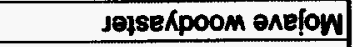 \\
\hline \multirow{9}{*}{ 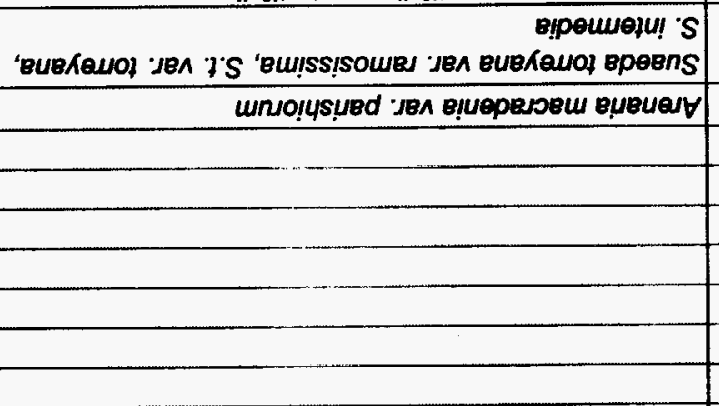 } & !u!nbow & epeens & Owns & 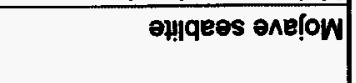 \\
\hline & 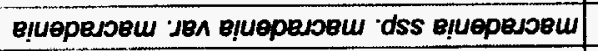 & вuвueaty & minyy & Hompues әne!ow \\
\hline & в!uepersen & вuвuady & EVwy & HOMpUES әNEFOW \\
\hline & esoqu/N100 & ovome6ny & $9058 \mathrm{Y}$ & Addod APYPYYd OAETOW \\
\hline & !nsevon & scuppoquibeld & ornd & Jemounuosdod enefow \\
\hline & 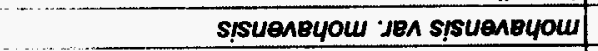 & snpobensy & wonst & чрjony!n axe[ow \\
\hline & sep!oingeq & uopgdourow & 2380w & IE7suอsep әмefom \\
\hline & snmsen dss \#66ed6 & snupouees & 2Аษอรว & snupuees exefow \\
\hline & s!suesopout & 8!I!O & Ovio & E!!!6 ropow \\
\hline \multirow[t]{2}{*}{ 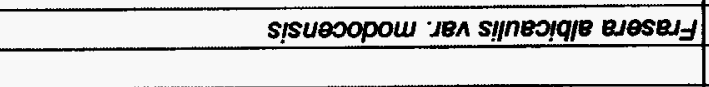 } & sisueinyed & enesey & wרry & peemyie sopow \\
\hline & 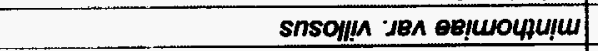 & snie6ans $\forall$ & Niss & 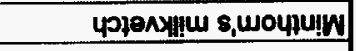 \\
\hline \multirow[t]{11}{*}{ s!sueyejn dss QJoy!ned B!yuOW } & 87E!yoyed dss biejpyed & 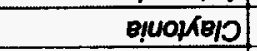 & zกษdาว & conła ssou!w \\
\hline & omounun & $8014001 d \theta 7$ & 2Nnכ7 & dojabuesds uesixew \\
\hline & 8UBग!x日u & BURZZB/BS & Iuvs & egessoppelq uesixew \\
\hline & snsonxey & sniogarods & 27dds & poesdoup esem \\
\hline & بө:1อบвq & sqsaberg & zVgug & ssej6encq usoueneypew \\
\hline & unuesu! & ungpodoueyo & ZNIHO & $700 j 05006$ Ripew \\
\hline & sisuejerd & eonisey & ydझt & onssej Mopeem \\
\hline & unsoycseres & wnuoboug & 8४วУ9 & je84mxnq ponzu \\
\hline & unsoydsero & umprydonged & ZLVOZd & Bendsspos yeul \\
\hline & s!uospreypy & eigreque/4nW & Panw & Apynu zew \\
\hline & seppoyla & snunusseury & 7gavy & quesewe jew \\
\hline !Кеуор дем !U! & !!! & efon!mseo & Mavro & $\begin{array}{r}\text { usnuqui!ed } \\
\text { ue!pul geequem s,uguew }\end{array}$ \\
\hline \multirow[t]{7}{*}{ unuwedsoiue6! $B$ unypodoueyo } & xejdu!s & unipodoueyo & ZISHO & 700 jos006 jea|eydem \\
\hline & uорерокjod & s!sdowodf & 20ddl & en! 6 poypuejqאuem \\
\hline & un//eyjynd & uanneuoy & 8ndy & sses 6 K॥оO M MO| \\
\hline & Budrow!p & вивuนвjuy & zlany & seor-Kssnd MOl \\
\hline & s!l!wny dss s.!!wny & nowersued & HกHتd & inbuoppueeq $\mathrm{mol}$ \\
\hline & 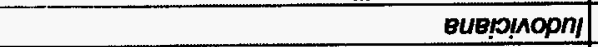 & 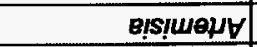 & nTy & poma6es Eue!șno7 \\
\hline & s!nर4! & snoune & o7nr & 4sn1 941456uol \\
\hline Kepeeg Kq pesn ouleN sepio & se!peds & snues & epos & OULEN UOUumos \\
\hline
\end{tabular}




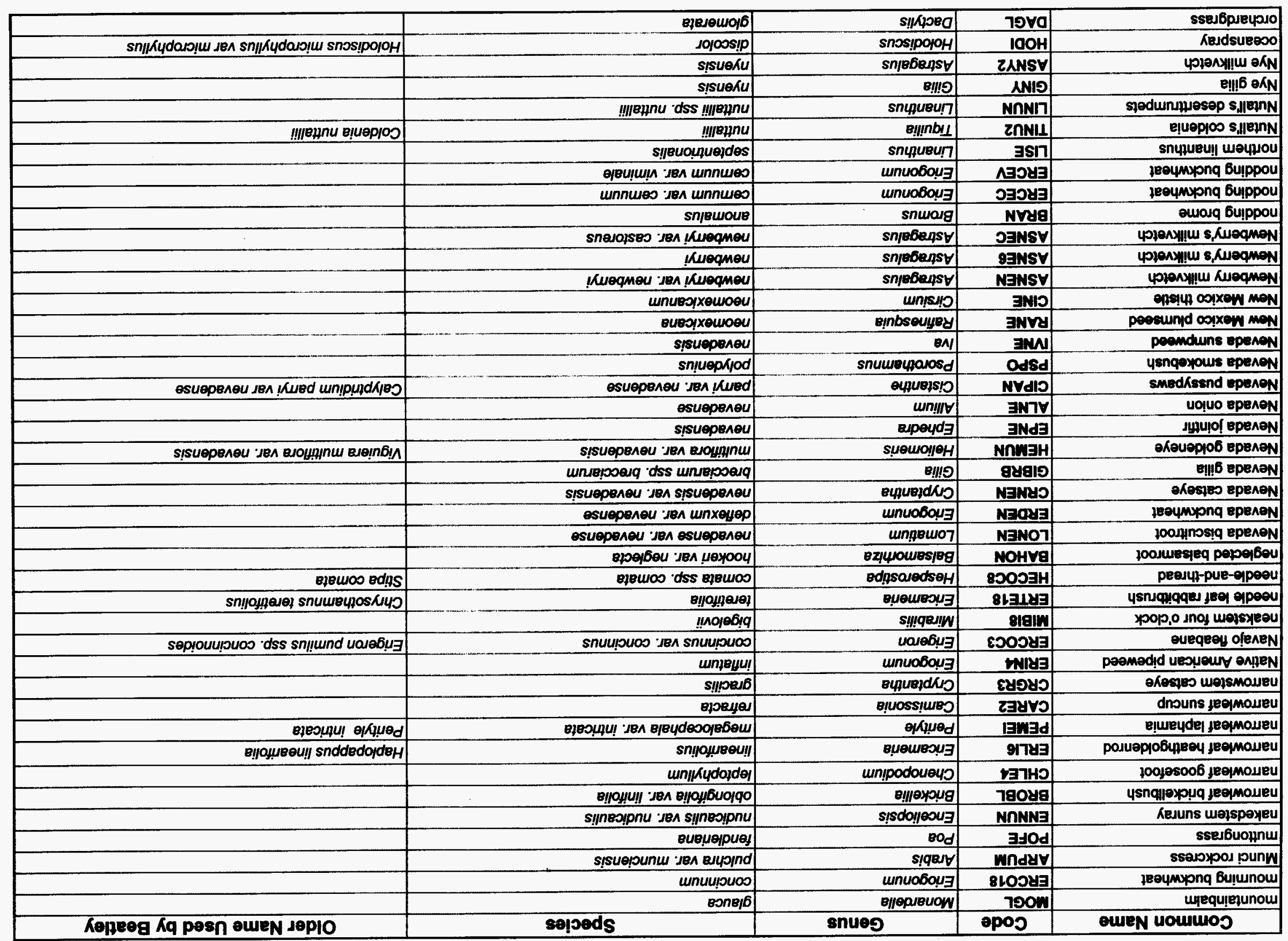




\begin{tabular}{|c|c|c|c|c|}
\hline & Jeds!p & s!qe & IOQY & ssajoxpos uoku!d \\
\hline . & unuissisoures & unjkiydokes & ZVYVD & exouspunos6 uoKu!d \\
\hline & suennouB & unypodoue40 & Iทับว & zoojesoo6 uoku!d \\
\hline & unyesuenp & un!qoupneau & EIay & oołensị jemp uokuid \\
\hline \multirow[t]{5}{*}{ s!suepenou вцичвіd/10 } & equedoos & 84puejd/10 & zosyo & axesyes yesep uoKuld \\
\hline & unjolp!l84 dss eqeuu!d & B!u!eunoseg & Hldea & puefsnuksuet eqeuu!d \\
\hline & euqe/6 dss вleuuld & B!u!eunoseg & Pld & puefsnuksuel o\}euu!d \\
\hline & Eond!IIIe & B!uauqf & 7gav & euequenpues yu!d \\
\hline & unNoy^arq & un! & tyany & Sulnouun yuịd \\
\hline \multirow[t]{10}{*}{ unuoleu!d Bdins } & unnoleuid & unNeupeuYP & Zldov & ssed6eipoeu spoomeu!d \\
\hline & Inuoway & sppeuesuo & 배이 & JaMOy uO!ysnou!d \\
\hline & unq/e & unypodoueuo & LTVHO & sueprenbequiei 'poombind \\
\hline & snjejoned & noweisued & \&bझdᄏd & enbuolpuseq ejejoned \\
\hline & suruuered & s!qery & CEdy & ssesoppos jeịuuesed \\
\hline & & nowersued & 1SNEd & nowalsuad \\
\hline & unopuenfsued & unvookyod & zedOd & poemyeurs eịuenksuued \\
\hline & E)B\|80!pod & eneosud & 3dHd & poomuoidjoos өqE\#poiped \\
\hline & B!u!jpoyd/80 & s!notueruo & УОHO & uoịsnou!d ajqqed \\
\hline & KLUBd & eyououryders & EVd1S & eопнерачм s,kued \\
\hline s!suepeneu dds !Kued snuweups/uY & s!suepвneи 'J81 !Kuвd & 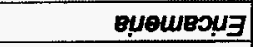 & zNYdQ日 & 4snuquqqes s,Kued \\
\hline \multirow[t]{3}{*}{ 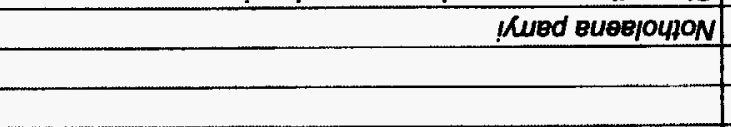 } & !Kued & serqueyeus & WDHO & weyd!n s,Kued \\
\hline & unpodkupesq & unuo6oug & gygeg & jeoumxpnq s,kued \\
\hline & „14sued & sus400013 & Wd7a & 4snuexyds s,4sped \\
\hline \multirow[t]{2}{*}{ "yysued sodjeououduxs } & 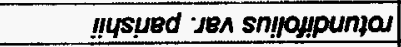 & sodveoyouduks & doyגs & Aueqmous s,4sied \\
\hline & 114șed & B!le0e4d & ZVdHd & peomuoịdioos s,4sued \\
\hline \multirow[t]{5}{*}{ "lysued a!quoydng } & "nysued & eofseeurey & OEVdHO & leupues s,ysued \\
\hline & „14sued J81 !ysued & แnNoupauYo & dVdOY & ssed6eipoou s, usued \\
\hline & "nysurded & unveupauypy & ElYdoY & sseubopoou s,4sued \\
\hline & "14sued dss „lysued & un!u!yd/eg & EdVdヨa & Indsyej s,4syed \\
\hline & B\|Kud/4Bjd & suesoypü & 7dIV & juejd eqnupesed \\
\hline \multirow[t]{6}{*}{ Eep!oos!p вuоредеd } & snou!wes6 & snuweypos 1140 & ЕเУОНО & posuep106 xpos fuimeued \\
\hline & ej8jo & exojueis & 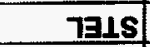 & aunjdsoouyd fu!ueued \\
\hline & Byomsn6us & eqpuejd/10 & twras & axasjes quiueued \\
\hline & yew/ed & noweisued & 8YdZd & Uoweisuad s,jewjed \\
\hline & unueuew/ed & unuo6oug & HVdY日 & zeeumyonq s,joujed \\
\hline & elnp!lied dss sedunauq & E!UOSSIUEO & dyavo & dnouns p!|led \\
\hline \multirow[t]{5}{*}{ 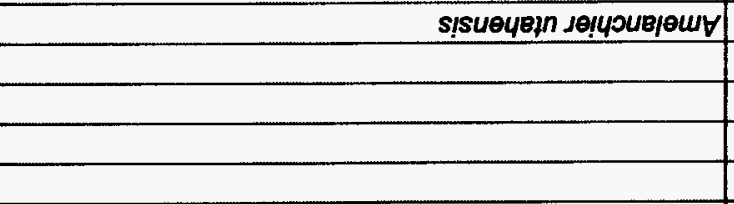 } & Bp!j]Ed & seiчouejour & zVduV & Kueqeoinas ejed \\
\hline & Bp!lied dss вp!lled & Eseypoue & dVdBo & 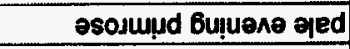 \\
\hline & șisueynyed & noweysued & EZYdBd & on6uojpueeq eyn!ed \\
\hline & aunosqo & e!equew & EgOEx & Jezs6uizzejq oỵped \\
\hline & 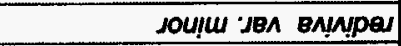 & $\theta ! \operatorname{sim} \theta$ & लำ & joouenq uo6ejo \\
\hline "lnnojo jen snuu!ouos snu!dn7 & Innayo dss snuu!ouos & snu!dn7 & zooगnา & ou!dn! s.jposo \\
\hline Kepeeg Kq pesn eureN Jeplo & selpeds & snues & epos & outeN Hounos \\
\hline
\end{tabular}




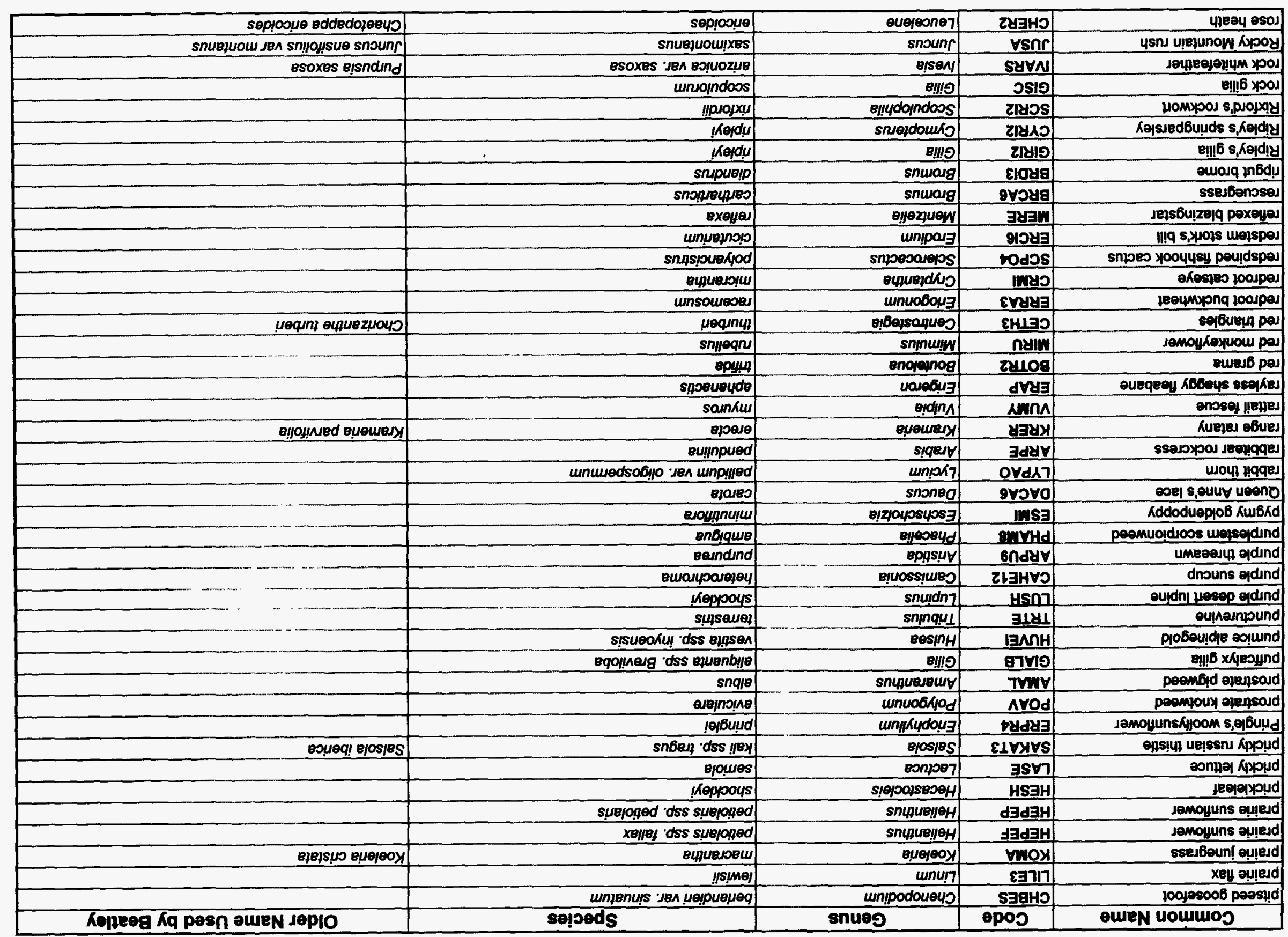




\begin{tabular}{|c|c|c|c|c|}
\hline & unчрuекцวвиq & unuo6oug & Lygyg & JeOumpnq Jemourous \\
\hline & KepYooys & s!qest & HSYV & 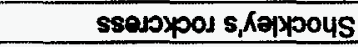 \\
\hline & ! אorpous & un!OK 7 & HSA7 & woumpesep s, Rejæpous \\
\hline & Kelpooys & snddedoydurest & HSOV & 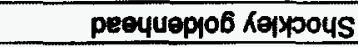 \\
\hline & snppyu & $x(140181 \theta d$ & INBd & juejd jodedpues jeejku! \\
\hline & sue!!u & enezuew & ZINEW & Ięs6uizzejq 6u!nu!4s \\
\hline & sulsaunnos & snjebens & EOYSV & ypienyu!u pooy dueys \\
\hline & undurso!s8! & un!pyde7 & ที7 & 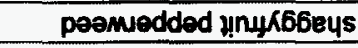 \\
\hline & 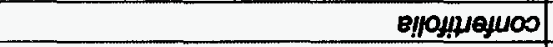 & xepduty & ODLV & ysnques ojeospeys \\
\hline \multirow[t]{3}{*}{ 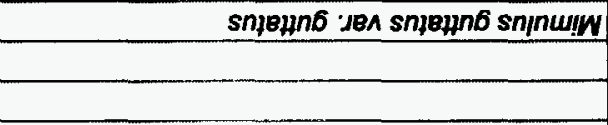 } & snjenn6 & snnump & nom & semoykeyuoul deas \\
\hline & $\theta \theta i s \mu \theta \theta s$ & $B \theta j B O$ & Eəsva & Jenopey!lesd, suees \\
\hline & !noyos & unjkydeoned & tos $3 d$ & 1epeokufịd s, noups \\
\hline \multirow[t]{2}{*}{ !noyos в!syoj6ue7 } & Imo4os & unusejeseo7 & 90507 & oOfleo s,pOYOS \\
\hline & s!sueyeqn & Bunuejdko & Inyo & OKosqeo pequeos \\
\hline \multirow[t]{4}{*}{ sneu!0000 jen snou!jo000 snese00u! 409} & 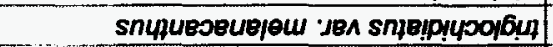 & snavesou!40 & 12103 & smpes Goye6pey lepeos \\
\hline & Beu10000 & euneg & soovg & wossogqeaq 1ejueos \\
\hline & s!ynese & eurososing & ONY & pnqejess \\
\hline & ejoopuas & snupueu! & z\&VI7 & sledunnuesep eunppues \\
\hline 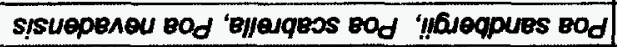 & epunses & eod & 3SOd & sseuBenjq s,6ueqpues \\
\hline \multirow[t]{2}{*}{ e\|kydouels jen enbixe dss enbixe xyes } & enọxe & 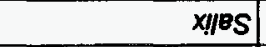 & xavs & molt!m seqpues \\
\hline & unserdopanoss & $u n ! / \|$ & sอsาษ & yөer pues \\
\hline \multirow[t]{11}{*}{ snje!peje jen sediluno snodiejoues 141} & sodinno & sndiroourskin & nOH $\perp$ & podebuly pues \\
\hline & snupuejdKus & snjogarods & YOdS & peosdoup pues \\
\hline & Buissisomes & xurus 1 & VYVI & sepoones \\
\hline & snquesos 140 jen nuusuje6ue & snereooum40 & ONBD & snpes squ!es \\
\hline & 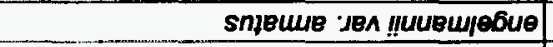 & snevesoulyog & ¿ทำ & snpes squịes \\
\hline & !nueuje6ue & snevesoulupg & NقS习 & snpes squies \\
\hline & smpunpod & volebourepod & 9gdOd & paempuod obes \\
\hline & Bleypind & equindo & nddo & Enoup ysnjqo6es \\
\hline & m460um & Eumieg & zamva & aqddeurou peroes \\
\hline & eso6n & Beopereouds & yivis & mo|feweq어 \\
\hline & Buwedsole/ den sylumsuoo dss snsoesneu & виешвон日 & 7NR: & ysniqugges jogqni \\
\hline \multirow[t]{10}{*}{ snonejojou dds snsoesneu snumb4loskuy } & eonejoyou jen snsoesneu dss snsoesneu & вионвочи & HVNag & usnuquqqeJ Jeqqn \\
\hline & snsoesneu & вионивон & OLVNY & usnuquqqes seqqn \\
\hline & s!numu & equuejdRo & zntryo & afesqeo expdspunos \\
\hline & elfoypunjas & Bnpos4d & 2OYHd & peamuoịduoss jeeipunos \\
\hline & efe!loyed & $8004 \beta 1 \times 0$ & $\overline{Z J X O}$ & pesqainpound feejpunos \\
\hline & Bqejnooney & equepidas & 97-180 & әKespeo poesubnos \\
\hline & unuqeos & unpewo7 & 80507 & Kejsueduesep y6nos \\
\hline & esqeos usa ejkцdar!u & Emexpug & smeg & 4snquexpiqq 46nos \\
\hline & 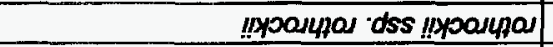 & Byppoex & УOYFX & uoweisued s,yposupoy \\
\hline & eesal & 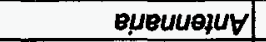 & zoyNY & seot-Kssnd asol \\
\hline Kepeeg Kq pesn oureN deplo & selpeds & snues & อpos & ounEN UOUHOOS \\
\hline
\end{tabular}




\begin{tabular}{|c|c|c|c|c|}
\hline & Bqeoun? & $\theta \theta \theta \theta_{d}$ & Ey19d & exesqup Ku!ds \\
\hline & suesseubo. & в!шरреде 1 & ZVOJ1 & ysnuqesiou ssejeu!ds \\
\hline & 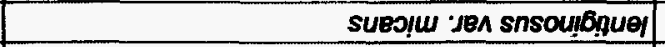 & snje6ensy & 8พ⿻75\% & 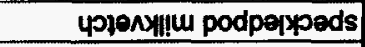 \\
\hline & 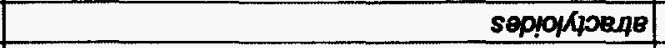 & E!llexpug & IV8g & usnq\|expuq jeepseeds \\
\hline & sepyoypuos & XULPOOEJ日W & osvin & uo!|еpuepuesep өpsiцmos \\
\hline & s!sue6u!uop & $8 y d K_{I}$ & oon1 & leңes weupnos \\
\hline \multirow[t]{6}{*}{ 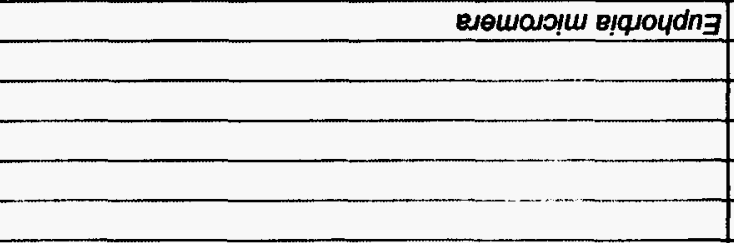 } & ENewaryu & esḱseruryo & $\angle M H O$ & jeupues uejouos \\
\hline & Bu!ssu!fow & eejeg & zowva & Jenopou! iesd yos \\
\hline & yeynos & xu4poserew & coovin & peou s,oypus \\
\hline & soumu & snuIn & แmก & une jeequpous \\
\hline & unu!ueqej6 & uniqoydg & 7Odg & poommonim ypoous \\
\hline & eqeuqej6 & xuLpoogrw & EาวทN & youppuepyesop ypoous \\
\hline \multirow[t]{4}{*}{ unगnej6 wneproH } & unonej6 dss unuinu & unepюн & ONसон & Kepeq upoous \\
\hline & effoyned & Beoperepuds & ZVdds & monfeuegoj6 jemouneus \\
\hline & BNoyned & Busumpos & EVdOO & Kuew peKe enjq semoumeurs \\
\hline & enoixe dos enoixe & Buewourydors & EXE15 & sonner-aym neus \\
\hline \multirow[t]{5}{*}{ unquUero!u sisdoz } & expuespiu & unverpeydy & 느리 & sseu6eo! pavemon neus \\
\hline & shyousaroin & Brolnn & mens & enosey Ilews \\
\hline & snopnul & suepuI & nmyt & suepul w!!s \\
\hline & un //euel & Bubauydount & tำा & Iezspuejpoom sepuejs \\
\hline & 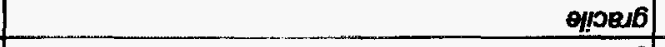 & unnkyodanod & 9yood & jeejajod sepuers \\
\hline \multirow[t]{8}{*}{ s!l!ous 6 snddedojdeH } & s!!!วen6 & Bronureerpen & oเมOVN & poemueplo6 sepuejs \\
\hline & ejooppidel j81 unoeypopy & unuoboug & 그로 & 1Eeumponq sepuegs \\
\hline & 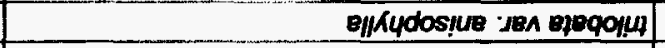 & $\operatorname{sn} 48$ & VIHY & Deuns usnqpunys \\
\hline & esoyopso & Bidnn & sonn & onosey syoomx!s \\
\hline & s!̣uọsueospo & eppsyy & avey & 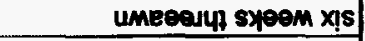 \\
\hline & $B, B q / B q$ & enopanog & zveog & Busej6 sypen x!s \\
\hline & enkydouou & snu!d & omid & uokuid jegieibui!s \\
\hline & Biswous & snuixers & ENVA & yse jeㅇ-여uㅣㄴ \\
\hline \multirow[t]{3}{*}{ unso!jog jeA unooufas!u unuo6ug } & 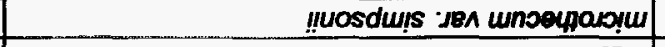 & unvo6oyg & zsineg & peeumpnq s,uosdun!s \\
\hline & 40010001K6/8 & unuobryad & gyvod & peamyoury upeousionit:s \\
\hline & esuedxe dss bejuebur & xejduny & تYVIV & 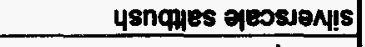 \\
\hline \multirow[t]{8}{*}{ 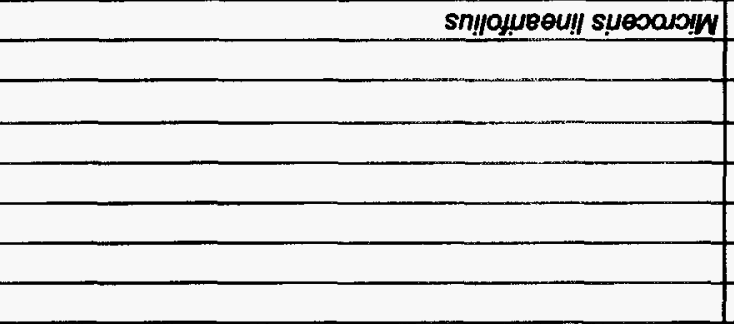 } & e!noyseou! & snddedaun & ziาyn & Hnd sexp!s \\
\hline & snepyowbis & snpeperuen & ISFN & zue|dpear47 pioubịs \\
\hline & enoydsuoou! & B!IS & ZNIIO & e!!!6 Kus \\
\hline & 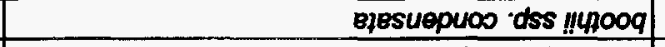 & ẹuoss!umeo & oogvo & dnsuns 6u!ppai4s \\
\hline & soleoul dss eueo & B!ा! & IVOIT & Bin!6 Kmous \\
\hline & silumoypods dos eubo & 8!n! & SVOIอ & ein6 Amous \\
\hline & s!yneग!^esq & snuydn7 & zyan7 & ouidn| weisyous \\
\hline & Bueou! & E!prejupsunH & ENIIH & pueqsnu pochuous \\
\hline вUеоц! в!p|өјчоs!!H & eiepnọue6 & Bopssesg & ت989 & puezenu pochious \\
\hline Keppeg Kq pesn outeN Jepio & selpeds & snues & อpos & OuEN UowwoJ \\
\hline
\end{tabular}




\begin{tabular}{|c|c|c|c|c|}
\hline & $\mu \theta q n \varphi_{7} d s s \mu \theta q n 47$ & $x$ xuopeled & IHLId & jue|d Jededpues s,Jequnul \\
\hline sn!̣seub JeA unqunut vourelsued & עoqunul & uowepsued & EHLIS & uourisued s,jequny 1 \\
\hline \multirow[t]{7}{*}{ unuevequnul edus } & BuBuequn4] & 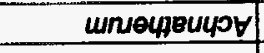 & $\angle H \perp O Y$ & ssejbejpoou s,jeqnu41 \\
\hline & "yuospiem & 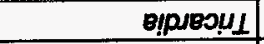 & zYMU1 & syeəu-ə2J4] \\
\hline & BUEMNOD & $\alpha 6 n / 10 w$ & 300m & peampedies urepspeesul] \\
\hline & ejeydeoavilu & B!izeuenng & uno & poemoxpeus jeeipeasut \\
\hline & Bsouids & Buewouryders & 9dSIS & peamuoje|pys woy 1 \\
\hline & eruosdurouf & euejed & SHIJd & eyeqed s,uosduoul \\
\hline & "IssuOU & unuo6oug & HLYa & zeoumponq, sewoy 1 \\
\hline jeqej6 synneopssero sn4quejnej & Jegej6 jen sypnespssejo & snчpuepros & อบวิว & 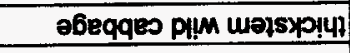 \\
\hline \multirow[t]{10}{*}{ uneosuppune eonłsey } & Boosulpunis & unipo7 & oเมvo7 & envsef 씨 \\
\hline & snjepneo & snuidn7 & vonา & eu!dn! dnO|!e] \\
\hline & unpenequin & unuo6oug & mny & fEeumpnqpim Inudins \\
\hline & sojoọsien jen unpenequn & unuoboug & zNMnY9 & leoymxng semoyeudins \\
\hline & unwen jen unzenequn & unuoboug & NinYg & feoumpnq semoufeydins \\
\hline & unpueqns je^ unpeyequn & unuoboug & zenny & jeoumpnq jomoyoudjns \\
\hline & unjeydeoarypp seя unjenequn & unuodoug & sounap & Pecumpnq semoupoudins \\
\hline & بyopsyns & snmulw & znsil & Lemoukoyuow syopsyns \\
\hline & Bjsebuoogns 'j81 eqse6uros & Byeuen & ZSODYY & Lompues efso6uoogns \\
\hline & eu/e & $x \theta 190$ & Lาทช & o6pos Kpunts \\
\hline 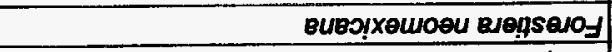 & sueosegnd jen sueosegnd & Quensaroy & dndos & Ruequpians \\
\hline \multirow[t]{6}{*}{ uneuiueqs un!jeydeug } & uneupurus & unyeydeubopnesd & LSSd & poompnoesjey Mens \\
\hline & $8 / 001 \times 8 \mathrm{~S}$ & B!je084d & VSHd & peomuoịdioos dopouojs \\
\hline & OuUBde & unyeg & ZdVNo & AnImixp!?s \\
\hline & sepyoineys & sppeuesuo & ISHO & Uep!EuKXysnp senels \\
\hline & unjeneps & unures & 18VO & мejspeq Auris \\
\hline & $87 \theta \| \theta 15$ & B!IIO & 1819 & En!6 Jełs \\
\hline \multirow[t]{4}{*}{ 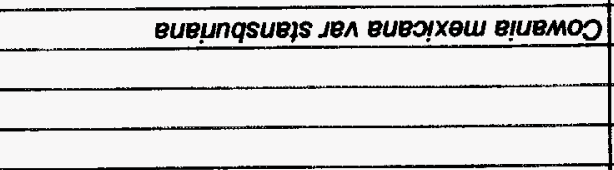 } & Bueunqsueps & Bilusind & Lind & esoump KunqsuetS \\
\hline & 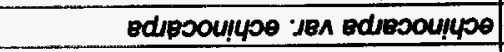 & egundo & تOFdO & Enoup woy6ęs \\
\hline & unuouned dss unsnщ!p & unnlydorisg & dlave & expouspunas6 6uipeess \\
\hline & unu!ss! sours & wn\|kydeued & megd & adde menbs \\
\hline snuo|y XE| 'J81 snejuebse dss snejue6/8 snu!dn7 & snuoy!xel jen snejuəye dss snequebje & snuidn 7 & s7yพn7 & ou!dn! Jnds \\
\hline \multirow[t]{6}{*}{ s!suepenөu 'dss snsny!p sndiejou!les } & sisuepeneu & sndresoulles & g1035 & poduooul 6u!peesds \\
\hline & suebjenpp & vore6ug & thay & oueqeey buypeedds \\
\hline & eeundindans & 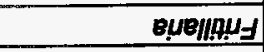 & IVys & s\|धquo!ss!̣u penods \\
\hline & unjejnoew & unuoboug & expy & feoumxonq ponods \\
\hline & Besol jen esrodyy & Bueq00s & renusg & Ję̧sKu!̣ds \\
\hline & jedse & snyours & svos & Ons!̣umos Ruids \\
\hline \multirow[t]{3}{*}{ Bsoujdsqns 'jen Bsoundsqns Bje6/10d } & Esoupdsqns & $8 j 86 \times 10 \mathrm{~d}$ & nsod & eje6אjod Auids \\
\hline & sueoseutds & Bropouew & ZdS9M & ejopoueu Kuids \\
\hline & esouids & B!KBUS & dSYO & Obesdou Kuids \\
\hline 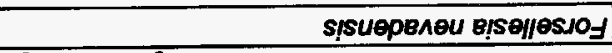 & unpule jen suesseulds & vojeledossolo & VdS7อ & 4snqoseeu6 Ku!ds \\
\hline Kelpeeg Kq pesn oureN Jeplo & selpeds & snues & epos & outeN uowuos \\
\hline
\end{tabular}




\begin{tabular}{|c|c|c|c|c|}
\hline Common Name & Code & Genus & Species & Older Name Used by Beatley \\
\hline thymeleaf sandmat & CHSES & Chameesyce & serpyllifolia ssp. serpylifolia & Euphorbia serpyllifolia \\
\hline Tidestrom's milkvetch & ASTI & Astragalus & tidestromii & \\
\hline Torrey milkvetch & ASCAC5 & Astragalus & calycosus var. calycosus & \\
\hline Torrey's jointfir & EPTO & Ephodra & torreyana & \\
\hline trailing windmilis & ALIN & Allionia & incamata & \\
\hline transmontane gilia & GITR & Gilia & transmontana & \\
\hline transmontane sandverbena & ABTU & Abronia & turbinata & \\
\hline triangle eveningprimrose & OEDED4 & Denothera & deltoides ssp. deltoides & \\
\hline tuber anemone & ANTU & Anemone & tuberasa & \\
\hline tufted eveningprimrose & OECENM & Oenothera & caespitosa ssp. marginata & \\
\hline tufted hairgrass & DECA18 & Deschampsia & ceospitosa & \\
\hline tufted townsend daisy & TOSC & Townsendia & scapigera & \\
\hline tumblemustard & SIAL2 & Sisymbrium & altissimum & \\
\hline turpentinobroom & THMO & Thamnosma & montana & \\
\hline twinleaf bedstraw & GABI & Galium & bifolium & \\
\hline two color phacelia & PHEI & Phacelia & bicolor & \\
\hline united blazingstar & MECO2 & Mentzelia & congesta & \\
\hline Utah agave & AGUTE & Agave & utahensis var. eborispina & \\
\hline Utah butterflybush & BUUT & Buddloja & utahensis & \\
\hline Utah fendlerbush & FEUT & Fendlenella & utahensis & \\
\hline Utah juniper & JUOS & Juniperus & osteosperma & \\
\hline Utah mortonia & MOUT & Mortonia & utahensis & \\
\hline Utah serviceberry & AMUT & Amolanchier & utahensis & \\
\hline Utah swallowmort & CruT & Cynanchum & utahense & \\
\hline valley lupine & LUM & Lupinus & microcarpus & \\
\hline valley lupine & LUSU10 & Lupinus & subvexus & Lupinus microcarpus \\
\hline variegatedbract blazingstar & MEMO4 & Mantzelia & montana & \\
\hline velvet ash & FRVE2 & Fraxinus & velutina & Fraxinus velutinavar coriacea \\
\hline velvet turtieback & PSRA & Psathyrotes & ramosissima & \\
\hline Vetch's dodder & CUDEV & Cuscuta & denticulate var. vetchii & \\
\hline Virgin River brittlebush & ENVIV & Encelia & virginensis var. virginensis & \\
\hline Virgin River catseye & CRVis & Cryptantha & vinginensis & \\
\hline Walker's suncup & CAWAT & Camissonia & walkeri ssp. tortilis & \\
\hline Washoe scorpionweed & PHCU & Phacalia & curvipes & \\
\hline water speedwell & VEAN2 & Veronica & anagallis-aquatica & \\
\hline Watson's bricklebush & BRIIW & Brickellia & microphylla var. watsonii & \\
\hline Watson's catseye & CRWA2 & Cryptantha & watsonii & \\
\hline Watson's heathgoldenrod & ERWA8 & Ericameria & watsonii & Haplopappus watsonii \\
\hline wavyleaf Indian paintbrush & CAAP4 & Castilleja & applegatej & Castelleja angustifolia. Castelleja chromosa \\
\hline wax currant & RICEC2 & Ribes & ceroum var. cereum & \\
\hline weasel scorpionweed & PHMU & Phacelia & mustelina & \\
\hline
\end{tabular}

6C-19 


\begin{tabular}{|c|c|c|c|c|}
\hline Common Name & Code & Genus & Species & Older Name Used by Beatley \\
\hline wedge leaf whitiow grass & DRCUC & Draba & cuneifolia var. cuneifolia & \\
\hline wedgeleaf whitiow grass & DRCUI & Draba & cunelfolia var. integnília & \\
\hline weeping alkaligrass & PUDI & Puccinellia & distans & \\
\hline western goldfern & PETR7 & Pentagama & triangularis & \\
\hline westem goldfern & PETRT & Pentagrama & triangularis ssp. triangularis & Pitymogramma triangularis $v$ ar. triangularis \\
\hline westem gromwell & LIRU4 & Lithospermum & ruderale & ( \\
\hline westem honey mesquite & PRGLT & Prosopis & glandulosa var. torreyana & \\
\hline westem marsh curdweed & GNPA & Gnaphalium & palustre & \\
\hline western sedge & CAOC2 & Carex & occidentalis & \\
\hline westem wheatgrass & PASM & Pascopyrum & smithii & Agropyrum smithii \\
\hline Wheeler's skeletonweed & CFWH & Chaetadolphia & whoeleri & \\
\hline wheelscale saltbush & ATELF & Atriplex & elegans var. fasciculata & \\
\hline white burrobrush & HYSA & Hymenoclea & salsola & \\
\hline white bursage & AMDU2 & Ambrosia & dumasa & \\
\hline white mallow & EREX3 & Eremalche & exilis & \\
\hline white tackstem & CAWR & Calycoseris & wrightii & \\
\hline whitemargin beardtongue & PEAL3 & Penstemon & albomerginatus & \\
\hline whitemargin sandmat & CHALI1 & Chamaesyce & albomarginata & Euphorbia albomarginata \\
\hline whitestem blazingstar & MEAL6 & Mentzelia & albicaulis & \\
\hline whitestom blazingstar & MEVES & Mentzelia & veatchiana & \\
\hline whitestem paperflower & PSCO2 & Psilostrophe & cooposi & \\
\hline widewing springparsley & CYPU & Cymoptorus & purpurascens & \\
\hline widows milkvetch & ASLA8 & Astregatus & laynere & \\
\hline Wilcox's woolstar & ERW & Eriastrum & wikcoxii & \\
\hline willow dock & RUSA & Rumex & salicifolius & \\
\hline winding mariposa lity & CAFL & Calochortus & fiexuasus & \\
\hline wingfruit suncup & CAPT & Camissonia & pterosperma & \\
\hline wingnut catseye & CRPT & Cryptantha & pterocarya & \\
\hline winterfat & KRDAZ & Kraschoninnikovia & Tanata & Ceratoides lanala, Eurotia lanata \\
\hline Woods' rose & ROWO & Rosa & moodsii & \\
\hline woolleypod milkvetch & ASPUL2 & Astragalus & purshii var. lectulus & \\
\hline woolly bluestar & AMTO2 & Amsonia & tomentosa & \\
\hline woolly brickellbush & BRIN & Brickellia & incana & \\
\hline woolly desert marigold & BAPL3 & Baileya & pleniradiata & \\
\hline woolly fruit burr ragweed & AMER & Ambrosia & eriocentra & \\
\hline woolly plantain & PLPA2 & Plantago & patagonica & Plantagopurshii var. oblonga \\
\hline woollyhead neststraw & STMI2 & Stylocline & micropoides & \\
\hline woollypod milkvetch & ASPUT & Astragalus & purshii var. tinctus & \\
\hline wormwood & ARDR4 & Artemisia & dracunculus & \\
\hline Wright threeawn & ARPUW & Anistida & purpurea var. wrightii & Aristida purpurea wrightif \\
\hline Wyoming Indian paintbrush & CALI4 & Castilleja & linariaefolia & \\
\hline yarrow, milfoil & ACIIL3 & Achillea & millefolium var. lanulosa & \\
\hline
\end{tabular}

6C-20 


\begin{tabular}{|c|c|c|c|c|}
\hline Common Name & Code & Genus & Species & Older Name Used by Beatley \\
\hline yellow and purple monkeyfiower & MIDE2 & Mimulus & densus & \\
\hline yellow bristiegrass & SEPU8 & Sotaria & pumila & Setaria glauca \\
\hline yellow gilia & GIFI2 & Gilia & filiformis & \\
\hline yellow nightshade & PHCR4 & Physalis & crassifolia & \\
\hline yellow pepperweed & LEFLF2 & Lepidium & fiavum var. flavum & \\
\hline yellow spiderflower & CLLU2 & Cleome & lutea & \\
\hline yellow sweetclover & NEOF & Moliotus & oficinalis & Melilotus albe \\
\hline yellow tackstem & CAPA7 & Calycoseris & paryi & \\
\hline yellow turbans & ERPU6 & Eriogonum & pusillum & \\
\hline yelloweyes & LUFL & Lupinus & fiavoculatus & \\
\hline yellowray fremontsgold & SYFR & Syntrichopappus & fremontï & \\
\hline Yuma sandmat & CHSE8 & Chamaesyce & setiloba & Chamaesyce setiloba \\
\hline Zschack's goosefoot & CHBEZ & Chenopodium & berlandieri var. zschackei & \\
\hline 21-Sep-99 & & & G:IEMACIVEGLATAEGISIRER & LstCommNamesiComnName.x/s \\
\hline
\end{tabular}


This Page Intentionally Left Blank 


\section{Appendix D}

Percent Abundance of Woody Plants on the NTS by Alliance

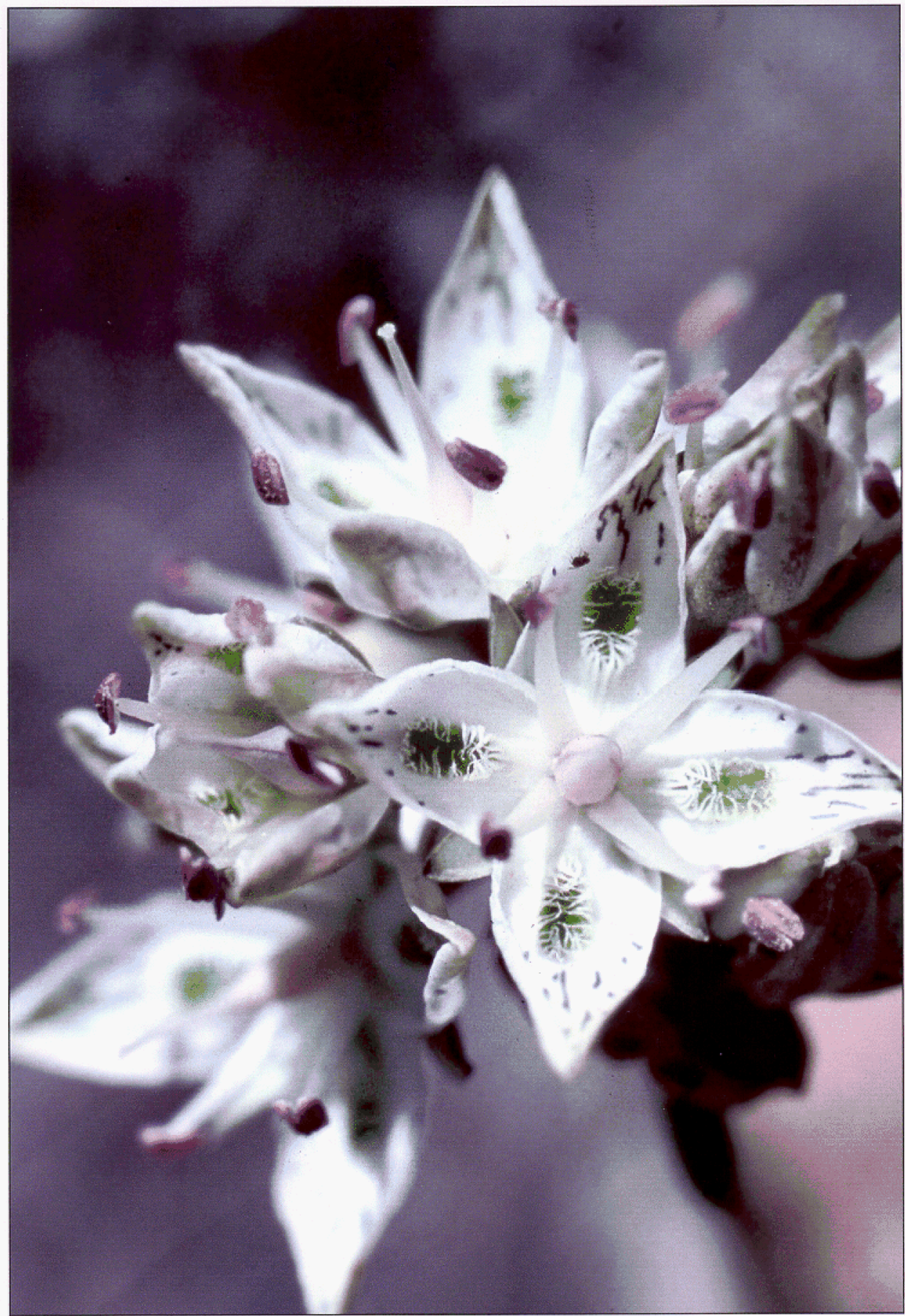

Modoc elkweed (Frasera pahutensis) [photo by Susan Cochrane] 
This Page Intentionally Left Blank

$6 \mathrm{D}-2$ 


\section{Appendix D}

\section{Percent Abundance of Woody Plants on the NTS by Alliance}

Lifeform Longevity ACODE

Lycium spp. Shrubland Alliance

Short Shrubs (0.5-2 m)

$\begin{array}{lll}\text { Perennial } & \text { LYSH } & \text { Lycium } \\ \text { Perennial } & \text { LYPAO } & \text { Lycium } \\ \text { Perennial } & \text { AMDU2 } & \text { Ambrosia } \\ \text { Perennial } & \text { ATCAC } & \text { Atriplex } \\ \text { Perennial } & \text { KRLA2 } & \text { Krascheninnikovia } \\ \text { Perennial } & \text { ATCO } & \text { Atriplex } \\ \text { Perennial } & \text { ACSH } & \text { Acamptopappus } \\ \text { Perennial } & \text { HYSA } & \text { Hymenoclea } \\ \text { Perennial } & \text { CHVIV2 } & \text { Chrysothamnus } \\ \text { Perennial } & \text { GRSP } & \text { Grayia } \\ \text { Perennial } & \text { STPIP } & \text { Stanleya } \\ \text { Perennial } & \text { TEAXA } & \text { Tetradymia }\end{array}$

Dwarf Shrubs (<0.5 m)

$\begin{array}{lll}\text { Perennial } & \text { ARSP5 } & \text { Artemisia } \\ \text { Perennial } & \text { KOAM } & \text { Kochia }\end{array}$

Species

Abundance

$\begin{array}{lc}\text { shockleyi } & 32.0 \% \\ \text { pallidum var. oligospermum } & 29.2 \% \\ \text { dumosa } & 14.7 \% \\ \text { canescens var. canescens } & 9.5 \% \\ \text { lanata } & 6.0 \% \\ \text { confertifolia } & 5.0 \% \\ \text { shockleyi } & 2.0 \% \\ \text { salsola } & 0.3 \% \\ \text { viscidiflorus ssp. viscidiflorus } & 0.0 \% \\ \text { spinosa } & 0.0 \% \\ \text { pinnata var. pinnata } & 0.0 \% \\ \text { axillaris var. axillaris } & 0.0 \%\end{array}$

spinescens

$1.0 \%$

$0.3 \%$ 
Lifeform Longevity ACODE Genus Species Abundance

\section{Larrea tridentata/Ambrosia dumosa Shrubland Alliance}

\section{Tall Shrubs (2-5 m)}

Perennial LATR2 Lamea tridentata

Short Shrubs $(0.5-2 \mathrm{~m})$

\begin{tabular}{|c|c|c|}
\hline Perennial & AMDU2 & Ambrosia \\
\hline Perennial & EPNE & Ephedra \\
\hline Perennial & LYPAO & Lycium \\
\hline Perennial & $\mathrm{ACSH}$ & Acamptopappus \\
\hline Perennial & KRLA2 & Krascheninnikovia \\
\hline Perennial & LYAN & Lycium \\
\hline Perennial & ATCO & Atriplex \\
\hline Perennial & GRSP & Grayia \\
\hline Perennial & HYSA & Hymenoclea \\
\hline Perennial & PSFRF & Psorothamnus \\
\hline Perennial & CORA & Coleogyne \\
\hline Perennial & ERCO23 & Ericameria \\
\hline Perennial & LYSH & Lycium \\
\hline Perennial & ERFAP & Eriogonum \\
\hline Perennial & ATCAC & Atriplex \\
\hline Perennial & THMO & Thamnosma \\
\hline Perennial & ENVIV & Encelia \\
\hline Perennial & SAME & Salazaria \\
\hline Perennial & LEFR2 & Lepidium \\
\hline Perennial & EPFU & Ephedra \\
\hline Perennial & GUSA2 & Gutierrezia \\
\hline Perennial & PSPO & Psorothamnus \\
\hline Perennial & ATPO & Atriplex \\
\hline Perennial & CHVIV2 & Chrysothamnus \\
\hline Perennial & ERTE18 & Ericameria \\
\hline Perennial & TEAXA & Tetradymia \\
\hline
\end{tabular}

dumosa
nevadensis
pallidum var. oligospermum
shockleyi
lanata
andersonii
confertifolia
spinosa
salsola
fremontii var. fremontii
ramosissima
cooperi
shockleyi
fasciculatum var. polifolium
canescens var. canescens
montana
virginensis var. virginensis
mexicana
fremontii
funerea
sarothrae
polydenius
polycarpa
viscidiflorus ssp. viscidiflorus
teretifolia
axillaris var. axillaris

$43.1 \%$

$7.0 \%$

$5.2 \%$

$3.9 \%$

$3.3 \%$

$3.1 \%$

$2.5 \%$

$2.1 \%$

$1.7 \%$

$1.4 \%$

$0.8 \%$

$0.6 \%$

$0.5 \%$

$0.4 \%$

$0.4 \%$

$0.4 \%$

$0.3 \%$

$0.3 \%$

$0.2 \%$

$0.2 \%$

$0.2 \%$

$0.1 \%$

$0.1 \%$

$0.1 \%$

$0.0 \%$

$0.0 \%$

Wednesday, January 05, 2000 


\begin{tabular}{ccll} 
Lifeform & Longevity & ACODE & \multicolumn{1}{c}{ Genus } \\
Perennial & AMER & Ambrosia \\
Perennial & EPTO & Ephedra \\
Perennial & EPVI & Ephedra \\
Perennial & ERPA29 & Ericameria \\
Perennial & TECA2 & Tetradymia \\
Perennial & STPIP & Stanleya \\
Perennial & BRMIW & Brickellia \\
Perennial & ATHY & Atriplex \\
Perennial & TEGL & Tetradymia \\
Perennial & ERNAL & Ericameria
\end{tabular}

\section{Species}

eriocentra

torreyana

viridis

paniculata

pinnata var. pinnata

microphylla var. watsonii

hymenelytra

glabrata

nauseosus ssp. consimilis var. canescens

Abundance

$0.0 \%$

$0.0 \%$

$0.0 \%$

$0.0 \%$

$0.0 \%$

$0.0 \%$

$0.0 \%$

$0.0 \%$

$0.0 \%$

$0.0 \%$

\section{Dwarf Shrubs (<0.5 m)}

$\begin{array}{lll}\text { Perennial } & \text { KRER } & \text { Krameria } \\ \text { Perennial } & \text { MESP2 } & \text { Menodora } \\ \text { Perennial } & \text { ARSP5 } & \text { Artemisia } \\ \text { Perennial } & \text { LEPU } & \text { Leptodactylon }\end{array}$

erecta

$6.7 \%$

spinescens

$1.3 \%$

spinescens

$0.1 \%$

pungens

$0.0 \%$

\section{Forbs}

$\begin{array}{lll}\text { Perennial } & \text { BRAT } & \text { Brickellia } \\ \text { Perennial } & \text { STPA3 } & \text { Stephanomeria }\end{array}$

atractyloides

$0.0 \%$

parryi

$0.0 \%$

\section{Succulents}

$\begin{array}{lll}\text { Perennial } & \text { YUSC2 } & \text { Yucca } \\ \text { Perennial } & \text { YUBR } & \text { Yucca } \\ \text { Perennial } & \text { OPECE } & \text { Opuntia } \\ \text { Perennial } & \text { OPRA } & \text { Opuntia }\end{array}$

$0.2 \%$

$0.1 \%$

$0.0 \%$

$0.0 \%$ 
Lifeform Longevity ACODE Genus Species Abundance

Atriplex confertifolia-Ambrosia dumosa Shrubland Alliance

Tall Shrubs (2-5 m)

$\begin{array}{lllll}\text { Perennial } & \text { LATR2 } & \text { Larrea } & \text { tridentata } & 4.3 \% \\ \text { Perennial } & \text { ARTRT } & \text { Artemisia } & \text { tridentata ssp. tridentata } & 0.0 \%\end{array}$

\section{Short Shrubs (0.5-2 m)}

\begin{tabular}{lll} 
Perennial & ATCO & Atriplex \\
Perennial & AMDU2 & Ambrosia \\
Perennial & EPNE & Ephedra \\
Perennial & LYPAO & Lycium \\
Perennial & LYAN & Lycium \\
Perennial & CORA & Coleogyne \\
Perennial & KRLA2 & Krascheninnikovia \\
Perennial & GUSA2 & Gutierrezia \\
Perennial & LEFR2 & Lepidium \\
Perennial & ERFAP & Eriogonum \\
Perennial & PSFRF & Psorothamnus \\
Perennial & THMO & Thamnosma \\
Perennial & EPTO & Ephedra \\
Perennial & ERTE18 & Ericameria \\
Perennial & ACSH & Acamptopappus \\
Perennial & SAME & Salazaria \\
Perennial & HYSA & Hymenoclea \\
Perennial & ENVIV & Encelia \\
Perennial & CHVIV2 & Chrysothamnus \\
Perennial & ATHY & Atriplex \\
Perennial & BRLOM & Brickellia \\
Perennial & BRMIW & Brickellia \\
Perennial & GRSP & Grayia \\
Perennial & ERCO23 & Ericameria \\
Perennial & TEAXA & Tetradymia \\
& & \\
\hline
\end{tabular}

confertifolia
dumosa
nevadensis
pallidum var. oligospermum
andersonii
ramosissima
lanata
sarothrae
fremontii
fasciculatum var. polifolium
fremontii var. fremontii
montana
torreyana
teretifolia
shockleyi
mexicana
salsola
virginensis var. virginensis
viscidiflorus ssp. viscidiflorus
hymenelytra
longifolia var. multifora
microphylla var. watsonii
spinosa
coopeni
axillaris var. axillaris

$29.6 \%$

$20.3 \%$

$10.1 \%$

$3.9 \%$

$3.5 \%$

$3.4 \%$

$2.3 \%$

$1.9 \%$

$1.8 \%$

$1.0 \%$

$1.0 \%$

$1.0 \%$

$0.9 \%$

$0.9 \%$

$0.9 \%$

$0.9 \%$

$0.8 \%$

$0.7 \%$

$0.6 \%$

$0.4 \%$

$0.4 \%$

$0.4 \%$

$0.3 \%$

$0.2 \%$

$0.2 \%$

Wednesday, January 05, 2000

Page 4 of 24 


\begin{tabular}{|c|c|c|c|c|c|}
\hline \multirow[t]{15}{*}{ Lifeform } & Longevity & $A C O D E$ & Genus & Species & Abundance \\
\hline & Perennial & ERMIS2 & Eriogonum & microthecum var. simpsonii & $0.2 \%$ \\
\hline & Perennial & PSPO & Psorothamnus & polydenius & $0.2 \%$ \\
\hline & Perennial & ERHEH2 & Eriogonum & heermannii var. heermannii & $0.1 \%$ \\
\hline & Perennial & EPFU & Ephedra & funerea & $0.1 \%$ \\
\hline & Perennial & BUUT & Buddleja & utahensis & $0.1 \%$ \\
\hline & Perennial & SENE5 & Senecio & flaccidus var. douglasii & $0.1 \%$ \\
\hline & Perennial & TECA2 & Tetradymia & canescens & $0.1 \%$ \\
\hline & Perennial & STPIP & Stanleya & pinnata var. pinnata & $0.0 \%$ \\
\hline & Perennial & EPVI & Ephedra & viridis & $0.0 \%$ \\
\hline & Perennial & ATCAC & Atriplex & canescens var. canescens & $0.0 \%$ \\
\hline & Perennial & ERNAL & Ericameria & nauseosus ssp. consimilis var. & $0.0 \%$ \\
\hline & Perennial & LYSH & Lycium & shockleyi & $0.0 \%$ \\
\hline & Perennial & PRFA & Prunus & fasciculata & $0.0 \%$ \\
\hline & Perennial & CHVIP4 & Chrysothamnus & viscidifforus ssp. puberulus & $0.0 \%$ \\
\hline
\end{tabular}

\section{Dwarf Shrubs (<0.5 m)}

$\begin{array}{lll}\text { Perennial } & \text { KRER } & \text { Krameria } \\ \text { Perennial } & \text { MESP2 } & \text { Menodora } \\ \text { Perennial } & \text { ARSP5 } & \text { Artemisia } \\ \text { Perennial } & \text { LEPU } & \text { Leptodactylon }\end{array}$

erecta

spinescens

spinescens

pungens
$4.3 \%$

$1.5 \%$

$0.3 \%$

$0.0 \%$

\section{Forbs}

$\begin{array}{lll}\text { Perennial } & \text { BRAT } & \text { Brickellia } \\ \text { Perennial } & \text { GAST } & \text { Galium }\end{array}$

atractyloides

$0.2 \%$

stellatum

$0.0 \%$

\section{Succulents}

$\begin{array}{lll}\text { Perennial } & \text { YUSC2 } & \text { Yucca } \\ \text { Perennial } & \text { YUBR } & \text { Yucca } \\ \text { Perennial } & \text { YUBAV } & \text { Yucca }\end{array}$

schidigera

$0.7 \%$

brevifolia

$0.1 \%$

baccata var. vespertina

$0.0 \%$ 
Lifeform Longevity ACODE Genus Species

Abundance

Hymenoclea-Lycium Shrubland Alliance

Tall Shrubs (2-5 m)

$1.6 \%$

Short Shrubs (0.5-2 m)

\begin{tabular}{lll} 
Perennial & HYSA & Hymenoclea \\
Perennial & LYAN & Lycium \\
Perennial & EPNE & Ephedra \\
Perennial & ATCAC & Atriplex \\
Perennial & CHVIV2 & Chrysothamnus \\
Perennial & KRLA2 & Krascheninnikovia \\
Perennial & GRSP & Grayia \\
Perennial & ATCO & Atriplex \\
Perennial & AMDU2 & Ambrosia \\
Perennial & CORA & Coleogyne \\
Perennial & ENVIV & Encelia \\
Perennial & LEFR2 & Lepidium \\
Perennial & PSFRF & Psorothamnus \\
Perennial & SAME & Salazaria \\
Perennial & THMO & Thamnosma \\
Perennial & ERCO23 & Ericameria \\
Perennial & ACSH & Acamptopappus \\
Perennial & ERPA29 & Ericameria \\
Perennial & PUST & Purshia \\
Perennial & EPVI & Ephedra \\
Perennial & PSPO & Psorothamnus \\
Perennial & ERNAH & Ericameria \\
Perennial & SADOD3 & Salvia \\
Perennial & TEAXA & Tetradymia \\
Perennial & STPIP & Stanleya \\
Perennial & LYPAO & Lycium \\
& & \\
\hline
\end{tabular}

$\begin{array}{lr}\text { salsola } & 41.3 \% \\ \text { andersonii } & 15.2 \% \\ \text { nevadensis } & 7.7 \% \\ \text { canescens var. canescens } & 4.9 \% \\ \text { viscidiflorus ssp. viscidiflorus } & 4.2 \% \\ \text { lanata } & 3.9 \% \\ \text { spinosa } & 2.5 \% \\ \text { confertifolia } & 2.0 \% \\ \text { dumosa } & 1.9 \% \\ \text { ramosissima } & 1.7 \% \\ \text { virginensis var. virginensis } & 1.3 \% \\ \text { fremontii } & 1.1 \% \\ \text { fremontii var. fremontii } & 1.0 \% \\ \text { mexicana } & 0.9 \% \\ \text { montana } & 0.9 \% \\ \text { cooperi } & 0.9 \% \\ \text { shockleyi } & 0.9 \% \\ \text { paniculata } & 0.8 \% \\ \text { stansburiana } & 0.5 \% \\ \text { viridis } & 0.4 \% \\ \text { polydenius } & 0.4 \% \\ \text { nauseosus ssp. nauseosus var. } & 0.3 \% \\ \text { dorii ssp. dorrii var. dornii } & 0.3 \% \\ \text { axillaris var. axillaris } & 0.3 \% \\ \text { pinnata var. pinnata } & 0.3 \% \\ \text { pallidum var. oligospermum } & 0.3 \% \\ & \end{array}$

Wednesday, January 05, 2000

Page 6 of 24 
Lifeform Longevity ACODE

Genus

Perennial

Perennial

Perennial

Perennial

Perennial

Perennial

Perennial

Perennial

Perennial

Perennial

Perennial

Perennial

Perennial

Perennial
AMER

GUSA2

Ambrosia

Gutierrezia

Atriplex

Prunus

Brickellia

Ericameria

Tetradymia

Ericameria

Brickellia

Eriogonum

Lycium

Rhus

Petalonyx

Stanleya

\section{Species}

eriocentra

sarothrae

polycarpa

fasciculata

oblongifolia var. linifolia

canescens

teretifolia

incana

fasciculatum var. polifolium

shockleyi

trilobata var. anisophylla

nitidus

elata nauseosus ssp. consimilis var.

Abundance

$0.2 \%$

$0.1 \%$

$0.1 \%$

$0.1 \%$

$0.1 \%$

$0.1 \%$

$0.1 \%$

$0.1 \%$

$0.1 \%$

$0.0 \%$

$0.0 \%$

$0.0 \%$

$0.0 \%$

$0.0 \%$

\section{Dwarf Shrubs (<0.5 m)}

$\begin{array}{lll}\text { Perennial } & \text { ARSP5 } & \text { Artemisia } \\ \text { Perennial } & \text { KRER } & \text { Krameria } \\ \text { Perennial } & \text { MESP2 } & \text { Menodora }\end{array}$

spinescens

$0.6 \%$

erecta

$0.3 \%$

spinescens

$0.2 \%$

\section{Forbs}

$\begin{array}{lll}\text { Perennial } & \text { ADCO2 } & \text { Adenophyllum } \\ \text { Perennial } & \text { BRAT } & \text { Brickellia } \\ \text { Perennial } & \text { POSU } & \text { Polygala }\end{array}$

cooperi

$0.2 \%$

atractyloides

$0.0 \%$

subspinosa

$0.0 \%$

\section{Succulents}

$\begin{array}{lll}\text { Perennial } & \text { YUBR } & \text { Yucca } \\ \text { Perennial } & \text { YUSC2 } & \text { Yucca }\end{array}$

brevifolia

$0.1 \%$

schidigera

$0.0 \%$ 


\section{Ephedra nevadensis Shrubland Alliance}

\section{Trees (>5 m)}

Perennial JuOS Juniperus

osteosperma

$0.0 \%$

\section{Tall Shrubs (2-5 $\mathrm{m})$}

$\begin{array}{llllr}\text { Perennial } & \text { LATR2 } & \text { Larrea } & \text { tridentata } & 1.5 \% \\ \text { Perennial } & \text { ARTRT } & \text { Artemisia } & \text { tridentata ssp. tridentata } & 0.7 \%\end{array}$

\section{Short Shrubs (0.5-2 m)}

\begin{tabular}{lll} 
Perennial & EPNE & Ephedra \\
Perennial & KRLA2 & Krascheninnikovia \\
Perennial & GRSP & Grayia \\
Perennial & LYAN & Lycium \\
Perennial & HYSA & Hymenoclea \\
Perennial & ATCAC & Atriplex \\
Perennial & CHVIV2 & Chrysothamnus \\
Perennial & AMDU2 & Ambrosia \\
Perennial & CORA & Coleogyne \\
Perennial & ATCO & Atriplex \\
Perennial & ERFAP & Eriogonum \\
Perennial & ERCO23 & Ericameria \\
Perennial & PSFRF & Psorothamnus \\
Perennial & ERTE18 & Ericameria \\
Perennial & ACSH & Acamptopappus \\
Perennial & THMO & Thamnosma \\
Perennial & SAME & Salazana \\
Perennial & ENVIV & Encelia \\
Perennial & GUSA2 & Gutierrezia \\
Perennial & TEAXA & Tetradymia \\
Perennial & LEFR2 & Lepidium \\
Perennial & EPVI & Ephedra \\
& & \\
\hline
\end{tabular}

nevadensis
lanata
spinosa
andersonii
salsola
canescens var. canescens
viscidiflorus ssp. viscidiflorus
dumosa
ramosissima
confertifolia
fasciculatum var. polifolium
cooperi
fremontii var. fremontii
teretifolia
shockleyi
montana
mexicana
virginensis var. virginensis
sarothrae
axillaris var. axillaris
fremontii
viridis




\begin{tabular}{|c|c|c|c|c|c|}
\hline \multirow[t]{32}{*}{ Lifeform } & Longevity & $A C O D E$ & Genus & Species & Abundance \\
\hline & Perennial & LYPAO & Lycium & pallidum var, oligospermum & $0.5 \%$ \\
\hline & Perennial & ARNO4 & Artemisia & nova & $0.4 \%$ \\
\hline & Perennial & TECA2 & Tetradymia & canescens & $0.4 \%$ \\
\hline & Perennial & ERNAL & Ericameria & nauseosus ssp. consimilis var. & $0.4 \%$ \\
\hline & Perennial & CHVIS5 & Chrysothamnus & viscidiflorus ssp. viscidifforus var. & $0.4 \%$ \\
\hline & Perennial & STPIP & Stanleya & pinnata var. pinnata & $0.3 \%$ \\
\hline & Perennial & ERNAH & Ericameria & nauseosus ssp. nauseosus var. & $0.3 \%$ \\
\hline & Perennial & PSPO & Psorothamnus & polydenius & $0.3 \%$ \\
\hline & Perennial & PUGL2 & Purshia & glandulosa & $0.2 \%$ \\
\hline & Perennial & CHVIP4 & Chrysothamnus & viscidiflorus ssp. puberulus & $0.2 \%$ \\
\hline & Perennial & SYLO & Symphoricarpos & longiflorus & $0.2 \%$ \\
\hline & Perennial & EPFU & Ephedra & funerea & $0.2 \%$ \\
\hline & Perennial & ERMIS2 & Eriogonum & microthecum var. simpsonii & $0.1 \%$ \\
\hline & Perennial & PUST & Purshia & stansburiana & $0.1 \%$ \\
\hline & Perennial & EPTO & Ephedra & torreyana & $0.1 \%$ \\
\hline & Perennial & ERNA10 & Ericameria & nauseosus & $0.1 \%$ \\
\hline & Perennial & BRMIW & Brickellia & microphylla var. watsonii & $0.1 \%$ \\
\hline & Perennial & CHGR6 & Chrysothamnus & greenei & $0.1 \%$ \\
\hline & Perennial & STEL & Stanleya & elata & $0.1 \%$ \\
\hline & Perennial & TEGL & Tetradymia & glabrata & $0.1 \%$ \\
\hline & Perennial & PENI & Petalonyx & nitidus & $0.1 \%$ \\
\hline & Perennial & ERLI6 & Ericameria & linearifolius & $0.1 \%$ \\
\hline & Perennial & SADOD3 & Salvia & dorii ssp. domii var. dormii & $0.0 \%$ \\
\hline & Perennial & BROBL & Brickellia & oblongifolia var. linifolia & $0.0 \%$ \\
\hline & Perennial & ERPA29 & Ericameria & paniculata & $0.0 \%$ \\
\hline & Perennial & LYSH & Lycium & shockleyi & $0.0 \%$ \\
\hline & Perennial & ERNA7 & Ericameria & nanus & $0.0 \%$ \\
\hline & Perennial & ERHEH2 & Eriogonum & heermannii var. heermannii & $0.0 \%$ \\
\hline & Perennial & AMER & Ambrosia & eriocentra & $0.0 \%$ \\
\hline & Perennial & GLSPA & Glossopetalon & spinescens var. aridum & $0.0 \%$ \\
\hline & Perennial & PRFA & Prunus & fasciculata & $0.0 \%$ \\
\hline
\end{tabular}




\section{Dwarf Shrubs (<0.5 m)}

$\begin{array}{lll}\text { Perennial } & \text { MESP2 } & \text { Menodora } \\ \text { Perennial } & \text { KRER } & \text { Krameria } \\ \text { Perennial } & \text { ARSP5 } & \text { Artemisia } \\ \text { Perennial } & \text { LEPU } & \text { Leptodactylon }\end{array}$

$\begin{array}{ll}\text { spinescens } & 3.8 \% \\ \text { erecta } & 2.0 \% \\ \text { spinescens } & 1.5 \% \\ \text { pungens } & 0.0 \%\end{array}$

Forbs

$\begin{array}{lllll}\text { Perennial } & \text { ERSA6 } & \text { Eriogonum } & \text { saxatile } & 0.1 \% \\ \text { Perennial } & \text { ARLU } & \text { Artemisia } & \text { ludoviciana } & 0.0 \% \\ \text { Perennial } & \text { BRAT } & \text { Brickellia } & \text { atractyloides } & 0.0 \% \\ \text { Perennial } & \text { ERNU4 } & \text { Eniogonum } & \text { nummulare } & 0.0 \%\end{array}$

\section{Succulents}

$\begin{array}{lll}\text { Perennial } & \text { YUBR } & \text { Yucca } \\ \text { Perennial } & \text { OPECE } & \text { Opuntia } \\ \text { Perennial } & \text { YUSC2 } & \text { Yucca } \\ \text { Perennial } & \text { YUBAV } & \text { Yucca } \\ \text { Perennial } & \text { OPERU } & \text { Opuntia } \\ \text { Perennial } & \text { ECENE } & \text { Echinocereus } \\ \text { Perennial } & \text { OPBAB2 } & \text { Opuntia } \\ \text { Perennial } & \text { OPPOR } & \text { Opuntia } \\ \text { Perennial } & \text { OPRA } & \text { Opuntia }\end{array}$

$\begin{array}{ll}\text { brevifolia } & 0.5 \% \\ \text { echinocarpa var. echinocarpa } & 0.1 \% \\ \text { schidigera } & 0.1 \% \\ \text { baccata var. vespertina } & 0.0 \% \\ \text { erinacea var. ursina } & 0.0 \% \\ \text { engelmannii var. engelmannii } & 0.0 \% \\ \text { basilaris var. basilaris } & 0.0 \% \\ \text { polyacantha var. rufispina } & 0.0 \% \\ \text { ramosissima } & 0.0 \%\end{array}$




\section{Coleogyne ramosissima Shrubland Alliance}

Trees (>5 m)

$\begin{array}{lll}\text { Perennial } & \text { JUOS } & \text { Juniperus } \\ \text { Perennial } & \text { PIMO } & \text { Pinus }\end{array}$

osteosperma

$0.1 \%$

Perennial PIMO Pinus

monophylla

$0.0 \%$

Tall Shrubs (2-5 m)

$\begin{array}{lll}\text { Perennial } & \text { LATR2 } & \text { Larrea } \\ \text { Perennial } & \text { ARTRT } & \text { Artemisia } \\ \text { Perennial } & \text { CELEL } & \text { Cercocarpus } \\ \text { Perennial } & \text { CEGRV2 } & \text { Ceanothus }\end{array}$

$\begin{array}{ll}\text { tridentata } & 1.9 \% \\ \text { tridentata ssp. tridentata } & 1.3 \% \\ \text { ledifolius var. ledifolius } & 0.0 \% \\ \text { greggir ssp. vestitus } & 0.0 \%\end{array}$

Short Shrubs (0.5-2 m)

$\begin{array}{lll}\text { Perennial } & \text { CORA } & \text { Coleogyne } \\ \text { Perennial } & \text { EPNE } & \text { Ephedra } \\ \text { Perennial } & \text { AMDU2 } & \text { Ambrosia } \\ \text { Perennial } & \text { LYAN } & \text { Lycium } \\ \text { Perennial } & \text { HYSA } & \text { Hymenoclea } \\ \text { Perennial } & \text { GRSP } & \text { Grayia } \\ \text { Perennial } & \text { CHVIV2 } & \text { Chrysothamnus } \\ \text { Perennial } & \text { KRLA2 } & \text { Krascheninnikovia } \\ \text { Perennial } & \text { ATCO } & \text { Atriplex } \\ \text { Perennial } & \text { ERTE18 } & \text { Ericameria } \\ \text { Perennial } & \text { EPVI } & \text { Ephedra } \\ \text { Perennial } & \text { ATCAC } & \text { Atriplex } \\ \text { Perennial } & \text { ERCO23 } & \text { Ericameria } \\ \text { Perennial } & \text { ERFAP } & \text { Eriogonum } \\ \text { Perennial } & \text { THMO } & \text { Thamnosma } \\ \text { Perennial } & \text { PUST } & \text { Purshia } \\ \text { Perennial } & \text { ERNAL } & \text { Ericameria } \\ \text { Perennial } & \text { ENVIV } & \text { Encelia } \\ \text { Perennial } & \text { PSFRF } & \text { Psorothamnus }\end{array}$

$\begin{array}{lr}\text { ramosissima } & 56.4 \% \\ \text { nevadensis } & 9.6 \% \\ \text { dumosa } & 3.5 \% \\ \text { andersonii } & 3.2 \% \\ \text { salsola } & 2.5 \% \\ \text { spınosa } & 2.0 \% \\ \text { viscidiflorus ssp. viscidiflorus } & 1.5 \% \\ \text { lanata } & 1.4 \% \\ \text { confertifolia } & 1.4 \% \\ \text { teretifolia } & 1.3 \% \\ \text { virndis } & 1.0 \% \\ \text { canescens var. canescens } & 0.8 \% \\ \text { cooperi } & 0.7 \% \\ \text { fasciculatum var. polifolium } & 0.7 \% \\ \text { montana } & 0.7 \% \\ \text { stansburiana } & 0.6 \% \\ \text { nauseosus ssp. consimilis var. } & 0.6 \% \\ \text { virginensis var. virginensis } & 0.5 \% \\ \text { fremontii var. fremontii } & 0.5 \%\end{array}$

Wednesday, January 05, 2000

Page 11 of 24 


\begin{tabular}{|c|c|c|c|c|c|}
\hline Lifeform & Longevity & $A C O D E$ & Genus & Species & Abundance \\
\hline & Perennial & $\mathrm{ACSH}$ & Acamptopappus & shockleyi & $0.5 \%$ \\
\hline & Perennial & LYPAO & Lycium & pallidum var. oligospermum & $0.4 \%$ \\
\hline & Perennial & TEAXA & Tetradymia & axillaris var. axillaris & $0.3 \%$ \\
\hline & Perennial & SAME & Salazaria & mexicana & $0.3 \%$ \\
\hline & Perennial & ARNO4 & Artemisia & nova & $0.3 \%$ \\
\hline & Perennial & ERMIS2 & Eriogonum & microthecum var. simpsonii & $0.2 \%$ \\
\hline & Perennial & TECA2 & Tetradymia & canescens & $0.2 \%$ \\
\hline & Perennial & ERNAH & Ericameria & nauseosus ssp. nauseosus var. & $0.2 \%$ \\
\hline & Perennial & GUSA2 & Gutierrezia & sarothrae & $0.2 \%$ \\
\hline & Perennial & CHVIP4 & Chrysothamnus & viscidiflorus ssp. puberulus & $0.2 \%$ \\
\hline & Perennial & LEFR2 & Lepidium & fremontii & $0.1 \%$ \\
\hline & Perennial & SYLO & Symphoricarpos & longiflorus & $0.1 \%$ \\
\hline & Perennial & EPFU & Ephedra & funerea & $0.1 \%$ \\
\hline & Perennial & PSPO & Psorothamnus & polydenius & $0.1 \%$ \\
\hline & Perennial & ERLI6 & Ericameria & Innearifolius & $0.1 \%$ \\
\hline & Perennial & ERNA10 & Ericameria & nauseosus & $0.1 \%$ \\
\hline & Perennial & PRFA & Prunus & fasciculata & $0.1 \%$ \\
\hline & Perennial & PUGL2 & Purshia & glandulosa & $0.1 \%$ \\
\hline & Perennial & BRMIW & Brickellia & microphylla var. watsonii & $0.1 \%$ \\
\hline & Perennial & STPIP & Stanleya & pinnata var. pinnata & $0.1 \%$ \\
\hline & Perennial & STEL & Stanleya & elata & $0.0 \%$ \\
\hline & Perennial & EPTO & Ephedra & torreyana & $0.0 \%$ \\
\hline & Perennial & TEGL & Tetradymia & glabrata & $0.0 \%$ \\
\hline & Perennial & AMER & Ambrosia & eriocentra & $0.0 \%$ \\
\hline & Perennial & ARBI3 & Artemisia & bigelovii & $0.0 \%$ \\
\hline & Perennial & SADOD3 & Salvia & dorii ssp. domii var. domii & $0.0 \%$ \\
\hline & Perennial & ERHEH2 & Eriogonum & heermannii var. heermannii & $0.0 \%$ \\
\hline & Perennial & ERHEA & Eriogonum & heermannii var. argense & $0.0 \%$ \\
\hline & Perennial & PERA4 & Peraphyllum & ramosissimum & $0.0 \%$ \\
\hline & Perennial & PENI & Petalonyx & nitidus & $0.0 \%$ \\
\hline & Perennial & RHTRA & Rhus & trilobata var. anisophylla & $0.0 \%$ \\
\hline & Perennial & BROBL & Brickellia & oblongifolia var. linifolia & $0.0 \%$ \\
\hline & Perennial & CHGR6 & Chrysothamnus & greenei & $0.0 \%$ \\
\hline
\end{tabular}




\begin{tabular}{clll} 
Lifeform & Longevity & ACODE & \multicolumn{1}{c}{ Genus } \\
& Perennial & BUUT & Buddleja \\
Perennial & ERCUC & Ericameria \\
Perennial & GLSPA & Glossopetalon \\
Perennial & PUTR2 & Purshia \\
Perennial & RIVEV & Ribes
\end{tabular}

\section{Species}

utahensis

cuneatus

spinescens var. anidum

tridentata

velutinum var. velutinum
Abundance

$0.0 \%$

$0.0 \%$

$0.0 \%$

$0.0 \%$

$0.0 \%$

\section{Dwarf Shrubs (<0.5 m)}

$\begin{array}{lll}\text { Perennial } & \text { MESP2 } & \text { Menodora } \\ \text { Perennial } & \text { KRER } & \text { Krameria } \\ \text { Perennial } & \text { ARSP5 } & \text { Artemisia } \\ \text { Perennial } & \text { LEPU } & \text { Leptodactylon } \\ \text { Perennial } & \text { KOAM } & \text { Kochia }\end{array}$

$\begin{array}{ll}\text { spinescens } & 1.3 \% \\ \text { erecta } & 1.0 \% \\ \text { spinescens } & 0.2 \% \\ \text { pungens } & 0.0 \% \\ \text { americana } & 0.0 \%\end{array}$

Forbs

$\begin{array}{lll}\text { Perennial } & \text { ARLU } & \text { Artemisia } \\ \text { Perennial } & \text { ERSA6 } & \text { Eriogonum } \\ \text { Perennial } & \text { BRAT } & \text { Brickellia } \\ \text { Perennial } & \text { ERNU4 } & \text { Eriogonum }\end{array}$

ludoviciana

saxatile

atractyloides

nummulare

$0.0 \%$

$0.0 \%$

$0.0 \%$

$0.0 \%$

\section{Succulents}

$\begin{array}{lll}\text { Perennial } & \text { YUBR } & \text { Yucca } \\ \text { Perennial } & \text { YUSC2 } & \text { Yucca } \\ \text { Perennial } & \text { YUBAV } & \text { Yucca } \\ \text { Perennial } & \text { OPECE } & \text { Opuntia } \\ \text { Perennial } & \text { OPRA } & \text { Opuntia } \\ \text { Perennial } & \text { ECPO2 } & \text { Echinocactus } \\ \text { Perennial } & \text { ECENE } & \text { Echinocereus } \\ \text { Perennial } & \text { OPPOR } & \text { Opuntia }\end{array}$


Atriplex spp. Shrubland Alliance

Trees (>5 m)

Perennial JUOS

Juniperus

osteosperma

$0.0 \%$

Tall Shrubs (2-5 m)

$\begin{array}{lll}\text { Perennial } & \text { LATR2 } & \text { Lamea } \\ \text { Perennial } & \text { ARTRT } & \text { Artemisia }\end{array}$

tridentata

$0.6 \%$

tridentata ssp. tridentata

$0.2 \%$

Short Shrubs (0.5-2 m)

$\begin{array}{lll}\text { Perennial } & \text { ATCAC } & \text { Atriplex } \\ \text { Perennial } & \text { ATCO } & \text { Atriplex } \\ \text { Perennial } & \text { KRLA2 } & \text { Krascheninnikovia } \\ \text { Perennial } & \text { LYAN } & \text { Lycium } \\ \text { Perennial } & \text { HYSA } & \text { Hymenoclea } \\ \text { Perennial } & \text { GRSP } & \text { Grayia } \\ \text { Perennial } & \text { EPNE } & \text { Ephedra } \\ \text { Perennial } & \text { CORA } & \text { Coleogyne } \\ \text { Perennial } & \text { LEFR2 } & \text { Lepidium } \\ \text { Perennial } & \text { ACSH } & \text { Acamptopappus } \\ \text { Perennial } & \text { CHVIV2 } & \text { Chrysothamnus } \\ \text { Perennial } & \text { LYPAO } & \text { Lycium } \\ \text { Perennial } & \text { EPVI } & \text { Ephedra } \\ \text { Perennial } & \text { LYSH } & \text { Lycium } \\ \text { Perennial } & \text { PUGL2 } & \text { Purshia } \\ \text { Perennial } & \text { AMDU2 } & \text { Ambrosia } \\ \text { Perennial } & \text { ERNAH } & \text { Ericamenia } \\ \text { Perennial } & \text { TECA2 } & \text { Tetradymia } \\ \text { Perennial } & \text { TEAXA } & \text { Tetradymia } \\ \text { Perennial } & \text { ERNAL } & \text { Ericameria } \\ \text { Perennial } & \text { PUST } & \text { Purshia } \\ \text { Perennial } & \text { THMO } & \text { Thamnosma }\end{array}$

canescens var. canescens
confertifolia
lanata
andersonii
salsola
spinosa
nevadensis
ramosissima
fremontii
shockleyi
viscidiflorus ssp. viscidiflorus
pallidum var. oligospermum
vindis
shockleyi
glandulosa
dumosa
nauseosus ssp. nauseosus var.
canescens
axillaris var. axillaris
nauseosus ssp. consimilis var.
stansburiana
montana

$39.2 \%$

$18.3 \%$

$8.9 \%$

$5.5 \%$

$2.7 \%$

$2.4 \%$

$1.9 \%$

$1.2 \%$

$1.1 \%$

$0.9 \%$

$0.9 \%$

$0.7 \%$

$0.6 \%$

$0.5 \%$

$0.5 \%$

$0.5 \%$

$0.2 \%$

$0.2 \%$

$0.1 \%$

$0.1 \%$

$0.1 \%$

$0.1 \%$

Wednesday, January 05, 2000

Page 14 of 24 


\begin{tabular}{|c|c|c|c|c|c|}
\hline \multirow[t]{13}{*}{ Lifeform } & Longevity & $A C O D E$ & Genus & Species & Abundance \\
\hline & Perennial & ERFAP & Eriogonum & fasciculatum var. polifolium & $0.1 \%$ \\
\hline & Perennial & EPTO & Ephedra & torreyana & $0.0 \%$ \\
\hline & Perennial & PSFRF & Psorothamnus & fremontii var. fremontii & $0.0 \%$ \\
\hline & Perennial & STPIP & Stanleya & pinnata var. pinnata & $0.0 \%$ \\
\hline & Perennial & ERTE18 & Ericameria & teretifolia & $0.0 \%$ \\
\hline & Perennial & GUSA2 & Gutierrezia & sarothrae & $0.0 \%$ \\
\hline & Perennial & PSPO & Psorothamnus & polydenius & $0.0 \%$ \\
\hline & Perennial & ENVIV & Encelia & virginensis var. virginensis & $0.0 \%$ \\
\hline & Perennial & ERCO23 & Ericameria & cooperi & $0.0 \%$ \\
\hline & Perennial & ERNA7 & Ericameria & nanus & $0.0 \%$ \\
\hline & Perennial & SAME & Salazaria & mexicana & $0.0 \%$ \\
\hline & Perennial & SYLO & Symphoricarpos & longiflorus & $0.0 \%$ \\
\hline
\end{tabular}

\section{Dwarf Shrubs (<0.5 m)}

$\begin{array}{lll}\text { Perennial } & \text { KOAM } & \text { Kochia } \\ \text { Perennial } & \text { ARSP5 } & \text { Artemisia } \\ \text { Perennial } & \text { MESP2 } & \text { Menodora } \\ \text { Perennial } & \text { KRER } & \text { Krameria }\end{array}$

americana $7.3 \%$

spinescens $2.6 \%$

spinescens $1.9 \%$

$\begin{array}{ll}\text { erecta } & 0.1 \%\end{array}$

Forbs

$\begin{array}{llll}\text { Perennial POSU } & \text { Polygala } & \text { subspinosa } & 0.1 \%\end{array}$

\section{Succulents}

$\begin{array}{lll}\text { Perennial } & \text { YUBR } & \text { Yucca } \\ \text { Perennial } & \text { OPECE } & \text { Opuntia } \\ \text { Perennial } & \text { YUSC2 } & \text { Yucca } \\ \text { Perennial } & \text { OPBAB2 } & \text { Opuntia } \\ \text { Perennial } & \text { YUBAV } & \text { Yucca }\end{array}$

brevifolia
echinocarpa var. echinocarpa
schidigera
basilaris var. basilaris
baccata var. vespertina




\section{Chrysothamnus-Ericameria Shrubland Alliance}

\section{Trees (>5 m)}

$\begin{array}{lll}\text { Perennial } & \text { QUGA } & \text { Quencus } \\ \text { Perennial } & \text { PIMO } & \text { Pinus } \\ \text { Perennial } & \text { JUOS } & \text { Juniperus }\end{array}$

gambelii

monophylla

osteosperma
$0.1 \%$

$0.1 \%$

$0.0 \%$

Tall Shrubs (2-5 m)

$\begin{array}{lll}\text { Perennial } & \text { ARTRT } & \text { Artemisia } \\ \text { Perennial } & \text { LATR2 } & \text { Larrea } \\ \text { Perennial } & \text { AMUT } & \text { Amelanchier }\end{array}$

tridentata ssp. tridentata

tridentata

$0.1 \%$

utahensis

$0.0 \%$

\section{Short Shrubs (0.5-2 m)}

$\begin{array}{lll}\text { Perennial } & \text { CHVIV2 } & \text { Chrysothamnus } \\ \text { Perennial } & \text { ERNAH } & \text { Ericameria } \\ \text { Perennial } & \text { EPNE } & \text { Ephedra } \\ \text { Perennial } & \text { ATCAC } & \text { Atriplex } \\ \text { Perennial } & \text { KRLA2 } & \text { Krascheninnikovia } \\ \text { Perennial } & \text { GRSP } & \text { Grayia } \\ \text { Perennial } & \text { LYAN } & \text { Lycium } \\ \text { Perennial } & \text { ATCO } & \text { Atriplex } \\ \text { Perennial } & \text { CORA } & \text { Coleogyne } \\ \text { Perennial } & \text { EPVI } & \text { Ephedra } \\ \text { Perennial } & \text { HYSA } & \text { Hymenoclea } \\ \text { Perennial } & \text { ARNO4 } & \text { Artemisia } \\ \text { Perennial } & \text { ERCO23 } & \text { Ericameria } \\ \text { Perennial } & \text { ERNAL } & \text { Ericameria } \\ \text { Perennial } & \text { TECA2 } & \text { Tetradymia } \\ \text { Perennial } & \text { CHVIP4 } & \text { Chrysothamnus } \\ \text { Perennial } & \text { PUST } & \text { Purshia } \\ \text { Perennial } & \text { THMO } & \text { Thamnosma } \\ \text { Perennial } & \text { GUSA2 } & \text { Gutierrezia }\end{array}$

viscidiflorus ssp. viscidiflorus
nauseosus ssp. nauseosus var.
nevadensis
canescens var. canescens
lanata
spinosa
andersonii
confertifolia
ramosissima
viridis
salsola
nova
cooperi
nauseosus ssp. consimilis var.
canescens
viscidiflorus ssp. puberulus
stansburiana
montana
sarothrae

$29.7 \%$

$11.5 \%$

$11.3 \%$

$6.5 \%$

$4.2 \%$

$4.2 \%$

$3.8 \%$

$2.9 \%$

$2.6 \%$

$1.6 \%$

$1.3 \%$

$0.9 \%$

$0.8 \%$

$0.7 \%$

$0.7 \%$

$0.7 \%$

$0.6 \%$

$0.6 \%$

$0.5 \%$ 


\begin{tabular}{|c|c|c|c|c|c|}
\hline \multirow[t]{28}{*}{ Lifeform } & Longevity & $A C O D E$ & Genus & Species & Abundance \\
\hline & Perennial & PSPO & Psorothamnus & polydenius & $0.5 \%$ \\
\hline & Perennial & AMDU2 & Ambrosia & dumosa & $0.4 \%$ \\
\hline & Perennial & ERTE18 & Ericameria & teretifolia & $0.4 \%$ \\
\hline & Perennial & ERLI6 & Ericameria & linearifolius & $0.4 \%$ \\
\hline & Perennial & PUGL2 & Purshia & glandulosa & $0.4 \%$ \\
\hline & Perennial & PUTR2 & Purshia & tridentata & $0.4 \%$ \\
\hline & Perennial & ENVIV & Encelia & virginensis var. virginensis & $0.3 \%$ \\
\hline & Perennial & STPIP & Stanleya & pinnata var. pinnata & $0.3 \%$ \\
\hline & Perennial & ERFAP & Eriogonum & fasciculatum var. polifolium & $0.3 \%$ \\
\hline & Perennial & ERNA10 & Ericameria & nauseosus & $0.3 \%$ \\
\hline & Perennial & SYLO & Symphoricarpos & longiflorus & $0.2 \%$ \\
\hline & Perennial & ERMIS2 & Eriogonum & microthecum var. simpsonii & $0.2 \%$ \\
\hline & Perennial & TEAXA & Tetradymia & axillaris var. axillaris & $0.2 \%$ \\
\hline & Perennial & TEGL & Tetradymia & glabrata & $0.2 \%$ \\
\hline & Perennial & LEFR2 & Lepidium & fremontii & $0.2 \%$ \\
\hline & Perennial & PSFRF & Psorothamnus & fremontii var. fremontii & $0.1 \%$ \\
\hline & Perennial & LYPAO & Lycium & pallidum var. oligospermum & $0.1 \%$ \\
\hline & Perennial & $\mathrm{ACSH}$ & Acamptopappus & shockleyi & $0.1 \%$ \\
\hline & Perennial & RIVEV & Ribes & velutinum var. velutinum & $0.1 \%$ \\
\hline & Perennial & CHGR6 & Chrysothamnus & greenei & $0.0 \%$ \\
\hline & Perennial & SAME & Salazaria & mexicana & $0.0 \%$ \\
\hline & Perennial & BRMIW & Brickellia & microphylla var. watsonii & $0.0 \%$ \\
\hline & Perennial & ERNA7 & Ericameria & nanus & $0.0 \%$ \\
\hline & Perennial & HODI & Holodiscus & discolor & $0.0 \%$ \\
\hline & Perennial & PRFA & Prunus & fasciculata & $0.0 \%$ \\
\hline & Perennial & SADOD3 & Salvia & doni ssp. domii var. domii & $0.0 \%$ \\
\hline & Perennial & STEL & Stanleya & elata & $0.0 \%$ \\
\hline
\end{tabular}

\section{Dwarf Shrubs (<0.5 m)}

$\begin{array}{lll}\text { Perennial } & \text { ARSP5 } & \text { Artemisia } \\ \text { Perennial } & \text { MESP2 } & \text { Menodora } \\ \text { Perennial } & \text { KOAM } & \text { Kochia } \\ \text { Perennial } & \text { LEPU } & \text { Leptodactyion }\end{array}$

$\begin{array}{ll}\text { spinescens } & 2.1 \% \\ \text { spinescens } & 0.2 \% \\ \text { americana } & 0.2 \% \\ \text { pungens } & 0.2 \%\end{array}$


Lifeform Longevity ACODE

Genus

Perennial KRER Krameria

Forbs

$\begin{array}{lll}\text { Perennial } & \text { ERNU4 } & \text { Eriogonum } \\ \text { Perennial } & \text { ERSA6 } & \text { Eriogonum } \\ \text { Perennial } & \text { STPA3 } & \text { Stephanomeria }\end{array}$

nummulare

$0.5 \%$

saxatile

parryi

$0.3 \%$

$0.0 \%$

\section{Succulents}

$\begin{array}{lll}\text { Perennial } & \text { YUBR } & \text { Yucca } \\ \text { Perennial } & \text { OPECE } & \text { Opuntia } \\ \text { Perennial } & \text { ECENE } & \text { Echinocereus } \\ \text { Perennial } & \text { OPERE } & \text { Opuntia } \\ \text { Perennial } & \text { OPPOR } & \text { Opuntia } \\ \text { Perennial } & \text { YUBAV } & \text { Yucca }\end{array}$

brevifolia

$0.5 \%$

echinocarpa var. echinocarpa

$0.1 \%$

engelmannii var. engelmannii

$0.0 \%$

erinacea var. erinacea

$0.0 \%$

polyacantha var. rufispina

$0.0 \%$

baccata var. vespertina

$0.0 \%$ 
Artemisia spp. Shrubland Alliance

Trees (>5 m)

$\begin{array}{lll}\text { Perennial } & \text { JUOS } & \text { Juniperus } \\ \text { Perennial } & \text { PIMO } & \text { Pinus } \\ \text { Perennial } & \text { QUGA } & \text { Quercus }\end{array}$

osteosperma

$0.6 \%$

monophylla

$0.5 \%$

QUGA

gambelii

$0.0 \%$

Tall Shrubs (2-5 m)

$\begin{array}{lll}\text { Perennial } & \text { ARTRT } & \text { Artemisia } \\ \text { Perennial } & \text { AMUT } & \text { Amelanchier } \\ \text { Perennial } & \text { CEGRV2 } & \text { Ceanothus } \\ \text { Perennial } & \text { LATR2 } & \text { Larrea }\end{array}$

tridentata ssp. tridentata

$33.0 \%$

utahensis

$0.1 \%$

greggii ssp. vestitus

$0.0 \%$

tridentata

$0.0 \%$

\section{Short Shrubs (0.5-2 m)}

\begin{tabular}{|c|c|c|}
\hline Perennial & ARNO4 & Artemisia \\
\hline Perennial & CHVIV2 & Chrysothamnus \\
\hline Perennial & EPNE & Ephedra \\
\hline Perennial & CHVIP4 & Chrysothamnus \\
\hline Perennial & EPVI & Ephedra \\
\hline Perennial & GRSP & Grayia \\
\hline Perennial & ATCAC & Atriplex \\
\hline Perennial & PUGL2 & Purshia \\
\hline Perennial & ERMIS2 & Eriogonum \\
\hline Perennial & KRLA2 & Krascheninnikovia \\
\hline Perennial & PUST & Purshia \\
\hline Perennial & ERNAH & Ericameria \\
\hline Perennial & ERFAP & Eriogonum \\
\hline Perennial & LYAN & Lycium \\
\hline Perennial & CORA & Coleogyne \\
\hline Perennial & GUSA2 & Gutierrezia \\
\hline Perennial & ERTE18 & Ericameria \\
\hline Perennial & ERNA7 & Ericameria \\
\hline
\end{tabular}

nova
viscidiflorus ssp. viscidiflorus
nevadensis
viscidiflorus ssp. puberulus
viridis
spinosa
canescens var. canescens
glandulosa
microthecum var. simpsonii
lanata
stansburiana
nauseosus ssp. nauseosus var.
fasciculatum var. polifolium
andersonii
ramosissima
sarothrae
teretifolia
nanus




\begin{tabular}{|c|c|c|c|c|c|}
\hline Lifeform & Longevity & ACODE & Genus & Species & Abundance \\
\hline & Perennial & ERNAL & Ericameria & nauseosus ssp. consimilis var. & $0.5 \%$ \\
\hline & Perennial & ATCO & Atriplex & confentifolia & $0.4 \%$ \\
\hline & Perennial & TEGL & Tetradymia & glabrata & $0.4 \%$ \\
\hline & Perennial & TECA2 & Tetradymia & canescens & $0.3 \%$ \\
\hline & Perennial & PUTR2 & Purshia & tridentata & $0.3 \%$ \\
\hline & Perennial & SYLO & Symphoricarpos & longiflorus & $0.2 \%$ \\
\hline & Perennial & ERLI6 & Ericameria & linearifolius & $0.2 \%$ \\
\hline & Perennial & ERCO23 & Ericameria & cooperi & $0.1 \%$ \\
\hline & Perennial & TEAXA & Tetradymia & axıllanis var. axillaris & $0.1 \%$ \\
\hline & Perennial & ERNA10 & Ericameria & nauseosus & $0.1 \%$ \\
\hline & Perennial & CHGR6 & Chrysothamnus & greenei & $0.1 \%$ \\
\hline & Perennial & PRFA & Prunus & fasciculata & $0.0 \%$ \\
\hline & Perennial & RIVEV & Ribes & velutinum var. velutinum & $0.0 \%$ \\
\hline & Perennial & PSPO & Psorothamnus & polydenius & $0.0 \%$ \\
\hline & Perennial & PERA4 & Peraphyllum & ramosissimum & $0.0 \%$ \\
\hline & Perennial & ENVIV & Encelia & virginensis var. virginensis & $0.0 \%$ \\
\hline & Perennial & HYSA & Hymenoclea & salsola & $0.0 \%$ \\
\hline & Perennial & CHVIS5 & Chrysothamnus & viscidiflorus ssp. viscidiflorus var. & $0.0 \%$ \\
\hline & Perennial & GLSPA & Glossopetalon & spinescens var. aridum & $0.0 \%$ \\
\hline & Perennial & RICEC2 & Ribes & cereum var. cereum & $0.0 \%$ \\
\hline & Perennial & ERHEA & Eriogonum & heermannii var. argense & $0.0 \%$ \\
\hline & Perennial & SAME & Salazaria & mexicana & $0.0 \%$ \\
\hline & Perennial & ERPA29 & Ericameria & paniculata & $0.0 \%$ \\
\hline & Perennial & LEFR2 & Lepidium & fremontii & $0.0 \%$ \\
\hline & Perennial & AMDU2 & Ambrosia & dumosa & $0.0 \%$ \\
\hline & Perennial & BROBL & Brickellia & oblongifolia var. linifolia & $0.0 \%$ \\
\hline & Perennial & ERPAN2 & Ericameria & parryi var. nevadensis & $0.0 \%$ \\
\hline & Perennial & RHTRA & Rhus & trilobata var. anisophylla & $0.0 \%$ \\
\hline & Perennial & SADOD3 & Salvia & dorii ssp. domii var. domii & $0.0 \%$ \\
\hline & Perennial & STPIP & Stanleya & pinnata var. pinnata & $0.0 \%$ \\
\hline & Perennial & STEL & Stanleya & elata & $0.0 \%$ \\
\hline & Perennial & THMO & Thamnosma & montana & $0.0 \%$ \\
\hline & Perennial & PENI & Petalonyx & nitidus & $0.0 \%$ \\
\hline
\end{tabular}

Wednesday, January 05, 2000

Page 20 of 24 
Lifeform Longevity ACODE Genus Species Abundance

Dwarf Shrubs ( $<0.5 \mathrm{~m})$

$\begin{array}{lll}\text { Perennial } & \text { LEPU } & \text { Leptodactylon } \\ \text { Perennial } & \text { ARSP5 } & \text { Artemisia } \\ \text { Perennial } & \text { KOAM } & \text { Kochia } \\ \text { Perennial } & \text { MESP2 } & \text { Menodora }\end{array}$

pungens

$1.7 \%$

spinescens

$0.4 \%$

$0.0 \%$

americana

$0.0 \%$

\section{Forbs}

$\begin{array}{lll}\text { Perennial } & \text { ERNU4 } & \text { Eriogonum } \\ \text { Perennial } & \text { ARLU } & \text { Artemisia } \\ \text { Perennial } & \text { ERSA6 } & \text { Eriogonum } \\ \text { Perennial } & \text { ERUM } & \text { Eriogonum } \\ \text { Perennial } & \text { CHGR13 } & \text { Chrysothamnus } \\ \text { Perennial } & \text { HYCOC2 } & \text { Hymenoxys } \\ \text { Perennial } & \text { ERUMV2 } & \text { Eriogonum } \\ \text { Perennial } & \text { ARDR4 } & \text { Artemisia } \\ \text { Perennial } & \text { BRCA3 } & \text { Brickellia } \\ \text { Perennial } & \text { ERCA8 } & \text { Eriogonum } \\ \text { Perennial } & \text { POSU } & \text { Polygala }\end{array}$

nummulare
ludoviciana
saxatile
umbellatum
gramineus
cooperi var. cooperi
umbellatum var. versicolor
dracunculus
califomica
caespitosum
subspinosa

$0.2 \%$

$0.1 \%$

$0.1 \%$

$0.0 \%$

$0.0 \%$

$0.0 \%$

$0.0 \%$

$0.0 \%$

$0.0 \%$

$0.0 \%$

$0.0 \%$

\section{Succulents}

$\begin{array}{lll}\text { Perennial } & \text { OPECE } & \text { Opuntia } \\ \text { Perennial } & \text { YUBAV } & \text { Yucca } \\ \text { Perennial } & \text { YUBR } & \text { Yucca } \\ \text { Perennial } & \text { OPPOR } & \text { Opuntia }\end{array}$

echinocarpa var. echinocarpa

$0.1 \%$

baccata var. vespertina

$0.1 \%$

brevifolia

$0.1 \%$

polyacantha var. rufispina

$0.0 \%$ 
Lifeform Longevity ACODE Genus Species

Abundance

\section{Pinus monophylla/Artemisia spp. Woodland Alliance}

\section{Trees (>5 m)}

$\begin{array}{lll}\text { Perennial } & \text { PIMO } & \text { Pinus } \\ \text { Perennial } & \text { JUOS } & \text { Juniperus } \\ \text { Perennial } & \text { QUGA } & \text { Quercus }\end{array}$

monophylla

$17.0 \%$

$6.3 \%$

$1.8 \%$

\section{Tall Shrubs (2-5 m)}

$\begin{array}{lll}\text { Perennial } & \text { ARTRT } & \text { Artemisia } \\ \text { Perennial } & \text { AMUT } & \text { Amelanchier } \\ \text { Perennial } & \text { CEGRV2 } & \text { Ceanothus } \\ \text { Perennial } & \text { AMPA2 } & \text { Amelanchier } \\ \text { Perennial } & \text { CEIN7 } & \text { Cercocarpus } \\ \text { Perennial } & \text { CELEL } & \text { Cercocarpus }\end{array}$

$\begin{array}{lr}\text { tridentata ssp. tridentata } & 14.7 \% \\ \text { utahensis } & 0.3 \% \\ \text { greggii ssp. vestitus } & 0.0 \% \\ \text { pallida } & 0.0 \% \\ \text { intricatus } & 0.0 \% \\ \text { ledifolius var. ledifolius } & 0.0 \%\end{array}$

Short Shrubs (0.5-2 m)

$\begin{array}{lll}\text { Perennial } & \text { ARNO4 } & \text { Artemisia } \\ \text { Perennial } & \text { CHVIV2 } & \text { Chrysothamnus } \\ \text { Perennial } & \text { PUTR2 } & \text { Purshia } \\ \text { Perennial } & \text { EPVI } & \text { Ephedra } \\ \text { Perennial } & \text { CHVIP4 } & \text { Chrysothamnus } \\ \text { Perennial } & \text { ERMIS2 } & \text { Eriogonum } \\ \text { Perennial } & \text { PUST } & \text { Purshia } \\ \text { Perennial } & \text { ERNA7 } & \text { Ericameria } \\ \text { Perennial } & \text { SYLO } & \text { Symphoricarpos } \\ \text { Perennial } & \text { PUGL2 } & \text { Purshia } \\ \text { Perennial } & \text { EPNE } & \text { Ephedra } \\ \text { Perennial } & \text { SADOD3 } & \text { Salvia } \\ \text { Perennial } & \text { ERNAL } & \text { Ericameria } \\ \text { Perennial } & \text { ATCAC } & \text { Atriplex } \\ \text { Perennial } & \text { GRSP } & \text { Grayia } \\ \text { Perennial } & \text { GUSA2 } & \text { Gutierrezia }\end{array}$

nova
viscidiflorus ssp. viscidiflorus
tridentata
viridis
viscidiflorus ssp. puberulus
microthecum var. simpsonii
stansburiana
nanus
longiflorus
glandulosa
nevadensis
dorii ssp. domii var. domii
nauseosus ssp. consimilis var.
canescens var. canescens
spinosa
sarothrae

$33.6 \%$

$3.7 \%$

$2.9 \%$

$2.9 \%$

$2.2 \%$

$1.9 \%$

$1.8 \%$

$1.2 \%$

$1.1 \%$

$0.6 \%$

$0.5 \%$

$0.5 \%$

$0.5 \%$

$0.3 \%$

$0.3 \%$

$0.3 \%$ 


\begin{tabular}{|c|c|c|c|c|c|}
\hline \multirow[t]{24}{*}{ Lifeform } & Longevity & $A C O D E$ & Genus & Species & Abundance \\
\hline & Perennial & ERNA10 & Ericameria & nauseosus & $0.2 \%$ \\
\hline & Perennial & RICEC2 & Ribes & cereum var. cereum & $0.2 \%$ \\
\hline & Perennial & ERLI6 & Ericameria & linearifolius & $0.2 \%$ \\
\hline & Perennial & CORA & Coleogyne & ramosissima & $0.2 \%$ \\
\hline & Perennial & ERCO23 & Ericameria & cooperi & $0.2 \%$ \\
\hline & Perennial & CHGR6 & Chrysothamnus & greenei & $0.1 \%$ \\
\hline & Perennial & RIVEV & Ribes & velutinum var. velutinum & $0.1 \%$ \\
\hline & Perennial & ERFAP & Eriogonum & fasciculatum var. polifolium & $0.1 \%$ \\
\hline & Perennial & TEGL & Tetradymia & glabrata & $0.1 \%$ \\
\hline & Perennial & ERNAH & Ericameria & nauseosus ssp. nauseosus var. & $0.1 \%$ \\
\hline & Perennial & KRLA2 & Krascheninnikovia & lanata & $0.0 \%$ \\
\hline & Perennial & RHTRA & Rhus & trilobata var. anisophylla & $0.0 \%$ \\
\hline & Perennial & ATCO & Atriplex & confertifolia & $0.0 \%$ \\
\hline & Perennial & ERPAN2 & Ericameria & paryi var. nevadensis & $0.0 \%$ \\
\hline & Perennial & TECA2 & Tetradymia & canescens & $0.0 \%$ \\
\hline & Perennial & ERPA29 & Ericameria & paniculata & $0.0 \%$ \\
\hline & Perennial & HODI & Holodiscus & discolor & $0.0 \%$ \\
\hline & Perennial & PRFA & Prunus & fasciculata & $0.0 \%$ \\
\hline & Perennial & ERTE18 & Ericameria & teretifolia & $0.0 \%$ \\
\hline & Perennial & GLSPA & Glossopetalon & spinescens var. aridum & $0.0 \%$ \\
\hline & Perennial & LYAN & Lycium & andersonii & $0.0 \%$ \\
\hline & Perennial & STPIP & Stanleya & pinnata var. pinnata & $0.0 \%$ \\
\hline & Perennial & TEAXA & Tetradymia & axtllaris var. axillaris & $0.0 \%$ \\
\hline
\end{tabular}

\section{Dwarf Shrubs ( $<0.5 \mathrm{~m})$}

$\begin{array}{lll}\text { Perennial } & \text { LEPU } & \text { Leptodactyion } \\ \text { Perennial } & \text { ARSP5 } & \text { Artemisia } \\ \text { Perennial } & \text { ERMIL } & \text { Eriogonum }\end{array}$

pungens

\section{Forbs}

$\begin{array}{lll}\text { Perennial } & \text { CHGR13 } & \text { Chrysothamnus } \\ \text { Perennial } & \text { PEPU7 } & \text { Petradonia } \\ \text { Perennial } & \text { ERUMS2 } & \text { Eriogonum }\end{array}$

gramineus
pumila
umbellatum var. subaridum


Lifeform Longevity ACODE

Genus

$\begin{array}{lll}\text { Perennial } & \text { ERSA6 } & \text { Eriogonum } \\ \text { Perennial } & \text { ARLU } & \text { Artemisia } \\ \text { Perennial } & \text { ERUM } & \text { Eriogonum } \\ \text { Perennial } & \text { ERUMV } & \text { Eriogonum } \\ \text { Perennial } & \text { ERUMV2 } & \text { Eriogonum }\end{array}$

\section{Succulents}

$\begin{array}{lll}\text { Perennial } & \text { OPPOR } & \text { Opuntia } \\ \text { Perennial } & \text { YUBAV } & \text { Yucca } \\ \text { Perennial } & \text { OPERE } & \text { Opuntia } \\ \text { Perennial } & \text { OPECE } & \text { Opuntia } \\ \text { Perennial } & \text { YUBR } & \text { Yucca }\end{array}$

\section{Species}

saxatile

ludoviciana

umbellatum

umbellatum var. vermum

umbellatum var. versicolor
Abundance

$0.0 \%$

$0.0 \%$

$0.0 \%$

$0.0 \%$

$0.0 \%$
$0.3 \%$
$0.1 \%$
$0.0 \%$
$0.0 \%$
$0.0 \%$ 


\section{Appendix E}

\section{Percent Abundance of Woody Plants on the NTS by Association}

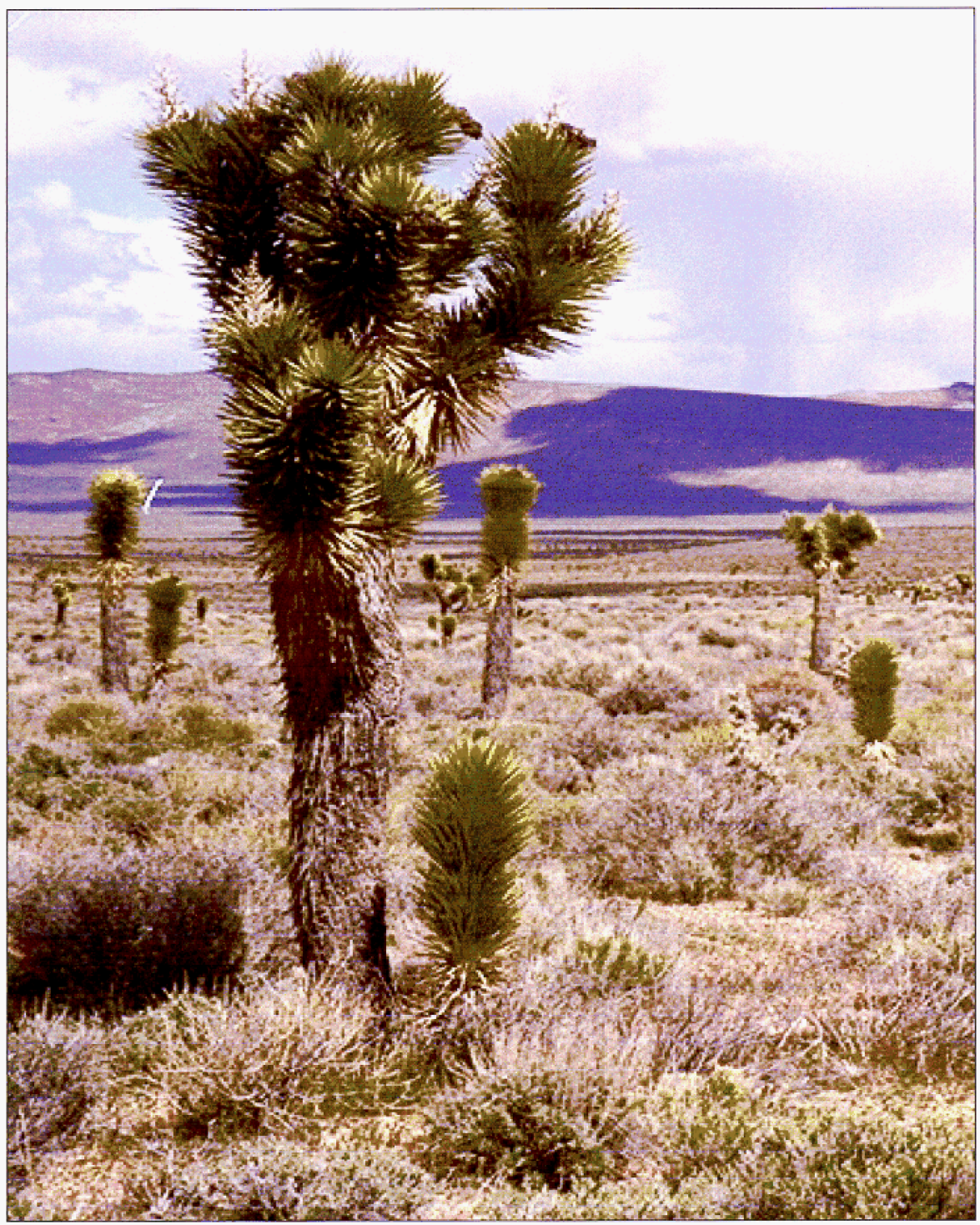

Joshua tree (Yucca brevifolia) and other woody plants near Yucca Flat [photo by W. Kent Ostler] 
This Page Intentionally Left Blank 


\section{Appendix E}

Percent Abundance of Woody Plants on the NTS by Association

Association Longevity ACODE2

Genus

Species

Abundance

\section{Lycium shockleyi-Lycium pallidum Shrubland}

Short Shrubs (0.5-2 m)

$\begin{array}{lll}\text { Perennial } & \text { LYSH } & \text { Lycium } \\ \text { Perennial } & \text { LYPAO } & \text { Lycium } \\ \text { Perennial } & \text { AMDU2 } & \text { Ambrosia } \\ \text { Perennial } & \text { ATCAC } & \text { Atriplex } \\ \text { Perennial } & \text { KRLA2 } & \text { Krascheninnikovia } \\ \text { Perennial } & \text { ATCO } & \text { Atriplex } \\ \text { Perennial } & \text { ACSH } & \text { Acamptopappus } \\ \text { Perennial } & \text { HYSA } & \text { Hymenoclea } \\ \text { Perennial } & \text { CHVIV2 } & \text { Chrysothamnus } \\ \text { Perennial } & \text { GRSP } & \text { Grayia } \\ \text { Perennial } & \text { STPIP } & \text { Stanleya } \\ \text { Perennial } & \text { TEAXA } & \text { Tetradymia }\end{array}$

shockleyi
pallidum var. oligospermum
dumosa
canescens var. canescens
lanata
confertifolia
shockleyi
salsola
viscidiflorus ssp. viscidiflorus
spinosa
pinnata var. pinnata
axillaris var. axillaris

Dwarf Shrubs ( $<0.5 \mathrm{~m})$

$\begin{array}{lll}\text { Perennial } & \text { ARSP5 } & \text { Artemisia } \\ \text { Perennial } & \text { KOAM } & \text { Kochia }\end{array}$

spinescens

$1.0 \%$

americana

$0.3 \%$ 


\section{Larrea Tridentata/Ambrosia dumosa Shrubland}

Tall Shrubs (2-5 m)

Perennial LATR2 Lamea

Short Shrubs (0.5-2 m)

\begin{tabular}{|c|c|c|}
\hline Perennial & AMDU2 & Ambrosia \\
\hline Perennial & EPNE & Ephedra \\
\hline Perennial & LYPAO & Lycium \\
\hline Perennial & $\mathrm{ACSH}$ & Acamptopappus \\
\hline Perennial & KRLA2 & Krascheninnikovia \\
\hline Perennial & LYAN & Lycium \\
\hline Perennial & ATCO & Atriplex \\
\hline Perennial & GRSP & Grayia \\
\hline Perennial & HYSA & Hymenoclea \\
\hline Perennial & PSFRF & Psorothamnus \\
\hline Perennial & CORA & Coleogyne \\
\hline Perennial & ERCO23 & Ericameria \\
\hline Perennial & LYSH & Lycium \\
\hline Perennial & ERFAP & Eriogonum \\
\hline Perennial & ATCAC & Atriplex \\
\hline Perennial & THMO & Thamnosma \\
\hline Perennial & ENVIV & Encelia \\
\hline Perennial & SAME & Salazaria \\
\hline Perennial & LEFR2 & Lepidium \\
\hline Perennial & EPFU & Ephedra \\
\hline Perennial & GUSA2 & Gutierrezia \\
\hline Perennial & PSPO & Psorothamnus \\
\hline Perennial & ATPO & Atriplex \\
\hline Perennial & CHVIV2 & Chrysothamnus \\
\hline Perennial & ERTE18 & Ericameria \\
\hline Perennial & TEAXA & Tetradymia \\
\hline
\end{tabular}

tridentata

$12.7 \%$

dumosa
nevadensis
pallidum var. oligospermum
shockleyi
lanata
andersonii
confertifolia
spinosa
salsola
fremontii var. fremontii
ramosissima
cooperi
shockleyi
fasciculatum var. polifolium
canescens var. canescens
montana
virginensis var. virginensis
mexicana
fremontii
funerea
sarothrae
polydenius
polycarpa
viscidiflorus ssp. viscidiflorus
teretifolia
axillaris var. axillaris

$43.1 \%$

$7.0 \%$

$5.2 \%$

$3.9 \%$

$3.3 \%$

$3.1 \%$

$2.5 \%$

$2.1 \%$

$1.7 \%$

$1.4 \%$

$0.8 \%$

$0.6 \%$

$0.5 \%$

$0.4 \%$

$0.4 \%$

$0.4 \%$

$0.3 \%$

$0.3 \%$

$0.2 \%$

$0.2 \%$

$0.2 \%$

$0.1 \%$

$0.1 \%$

$0.1 \%$

$0.0 \%$

$0.0 \%$

Page 2 of 44 


$\begin{array}{lll}\text { Perennial } & \text { AMER } & \text { Ambrosia } \\ \text { Perennial } & \text { EPTO } & \text { Ephedra } \\ \text { Perennial } & \text { EPVI } & \text { Ephedra } \\ \text { Perennial } & \text { ERPA29 } & \text { Ericameria } \\ \text { Perennial } & \text { TECA2 } & \text { Tetradymia } \\ \text { Perennial } & \text { STPIP } & \text { Stanleya } \\ \text { Perennial } & \text { BRMIW } & \text { Brickellia } \\ \text { Perennial } & \text { ATHY } & \text { Atriplex } \\ \text { Perennial } & \text { TEGL } & \text { Tetradymia } \\ \text { Perennial } & \text { ERNAL } & \text { Ericameria }\end{array}$

eriocentra
torreyana
viridis
paniculata
canescens
pinnata var. pinnata
microphylla var. watsonii
hymenelytra
glabrata
nauseosus ssp. consimilis var.
leiosperma

$0.0 \%$

$0.0 \%$

$0.0 \%$

$0.0 \%$

$0.0 \%$

$0.0 \%$

$0.0 \%$

$0.0 \%$

$0.0 \%$

$0.0 \%$

\section{Dwarf Shrubs (<0.5 m)}

$\begin{array}{lll}\text { Perennial } & \text { KRER } & \text { Krameria } \\ \text { Perennial } & \text { MESP2 } & \text { Menodora } \\ \text { Perennial } & \text { ARSP5 } & \text { Artemisia } \\ \text { Perennial } & \text { LEPU } & \text { Leptodactylon }\end{array}$

erecta

$6.7 \%$

spinescens

$1.3 \%$

spinescens

$0.1 \%$

pungens

$0.0 \%$

Forbs

$\begin{array}{lll}\text { Perennial } & \text { BRAT } & \text { Brickellia } \\ \text { Perennial } & \text { STPA3 } & \text { Stephanomeria }\end{array}$

atractyloides

$0.0 \%$

parryi

$0.0 \%$

\section{Succulents}

$\begin{array}{lll}\text { Perennial } & \text { YUSC2 } & \text { Yucca } \\ \text { Perennial } & \text { YUBR } & \text { Yucca } \\ \text { Perennial } & \text { OPECE } & \text { Opuntia } \\ \text { Perennial } & \text { OPRA } & \text { Opuntia }\end{array}$

schidigera
brevifolia
echinocarpa var. echinocarpa
ramosissima


Association Longevity ACODE2 Genus Species Abundance

Atriplex confertifolia-Ambrosia dumosa Shrubland

Tall Shrubs $(2-5 \mathrm{~m})$

$\begin{array}{lll}\text { Perennial } & \text { LATR2 } & \text { Larrea } \\ \text { Perennial } & \text { ARTRT } & \text { Artemisia }\end{array}$

tridentata

$4.3 \%$

Perennial

ARTRT Artemisia

tridentata ssp. tridentata

$0.0 \%$

\section{Short Shrubs (0.5-2 m)}

\begin{tabular}{|c|c|c|}
\hline Perennial & ATCO & Atriplex \\
\hline Perennial & AMDU2 & Ambrosia \\
\hline Perennial & EPNE & Ephedra \\
\hline Perennial & LYPAO & Lycium \\
\hline Perennial & LYAN & Lycium \\
\hline Perennial & CORA & Coleogyne \\
\hline Perennial & KRLA2 & Krascheninnikovia \\
\hline Perennial & GUSA2 & Gutierrezia \\
\hline Perennial & LEFR2 & Lepidium \\
\hline Perennial & ERFAP & Eriogonum \\
\hline Perennial & PSFRF & Psorothamnus \\
\hline Perennial & THMO & Thamnosma \\
\hline Perennial & EPTO & Ephedra \\
\hline Perennial & ERTE18 & Ericameria \\
\hline Perennial & $\mathrm{ACSH}$ & Acamptopappus \\
\hline Perennial & SAME & Salazaria \\
\hline Perennial & HYSA & Hymenoclea \\
\hline Perennial & ENVIV & Encelia \\
\hline Perennial & CHVIV2 & Chrysothamnus \\
\hline Perennial & ATHY & Atriplex \\
\hline Perennial & BRLOM & Brickellia \\
\hline Perennial & BRMIW & Brickellia \\
\hline Perennial & GRSP & Grayia \\
\hline Perennial & ERCO23 & Ericameria \\
\hline Perennial & TEAXA & Tetradymia \\
\hline
\end{tabular}

confertifolia
dumosa
nevadensis
pallidum var. oligospermum
andersonii
ramosissima
lanata
sarothrae
fremontii
fasciculatum var. polifolium
fremontii var. fremontii
montana
torreyana
teretifolia
shockleyi
mexicana
salsola
virginensis var. virginensis
viscidiflorus ssp. viscidiflorus
hymenelytra
longifolia var. multiflora
microphylla var. watsonii
spinosa
cooperi
axillaris var. axillaris
for

$29.6 \%$

$20.3 \%$

$10.1 \%$

$3.9 \%$

$3.5 \%$

$3.4 \%$

$2.3 \%$

$1.9 \%$

$1.8 \%$

$1.0 \%$

$1.0 \%$

$1.0 \%$

$0.9 \%$

$0.9 \%$

$0.9 \%$

$0.9 \%$

$0.8 \%$

$0.7 \%$

$0.6 \%$

$0.4 \%$

$0.4 \%$

$0.4 \%$

$0.3 \%$

$0.2 \%$

$0.2 \%$

Thursday, September 09, 1999

Page 4 of 44 


$\begin{array}{lll}\text { Perennial } & \text { ERMIS2 } & \text { Eriogonum } \\ \text { Perennial } & \text { PSPO } & \text { Psorothamnus } \\ \text { Perennial } & \text { ERHEH2 } & \text { Eriogonum } \\ \text { Perennial } & \text { EPFU } & \text { Ephedra } \\ \text { Perennial } & \text { BUUT } & \text { Buddleja } \\ \text { Perennial } & \text { SENE5 } & \text { Senecio } \\ \text { Perennial } & \text { TECA2 } & \text { Tetradymia } \\ \text { Perennial } & \text { STPIP } & \text { Stanleya } \\ \text { Perennial } & \text { EPVI } & \text { Ephedra } \\ \text { Perennial } & \text { ATCAC } & \text { Atriplex } \\ \text { Perennial } & \text { ERNAL } & \text { Ericameria } \\ \text { Perennial } & \text { LYSH } & \text { Lycium } \\ \text { Perennial } & \text { PRFA } & \text { Prunus } \\ \text { Perennial } & \text { CHVIP4 } & \text { Chrysothamnus }\end{array}$

microthecum var. simpsonii
polydenius
heermannii var. heermannii
funerea
utahensis
flaccidus var. douglasii
canescens
pinnata var. pinnata
viridis
canescens var. canescens
nauseosus ssp. consimilis var.
leiosperma
shockleyi
fasciculata
viscidiflorus ssp. puberulus

\section{Dwarf Shrubs (<0.5 m)}

$\begin{array}{lll}\text { Perennial } & \text { KRER } & \text { Krameria } \\ \text { Perennial } & \text { MESP2 } & \text { Menodora } \\ \text { Perennial } & \text { ARSP5 } & \text { Artemisia } \\ \text { Perennial } & \text { LEPU } & \text { Leptodactylon }\end{array}$

erecta $4.3 \%$

spinescens

spinescens

pungens
$1.5 \%$

$0.3 \%$

$0.0 \%$

atractyloides

$0.2 \%$

stellatum

$0.0 \%$

\section{Succulents}

$\begin{array}{lll}\text { Perennial } & \text { YUSC2 } & \text { Yucca } \\ \text { Perennial } & \text { YUBR } & \text { Yucca } \\ \text { Perennial } & \text { YUBAV } & \text { Yucca }\end{array}$

schidigera

$0.7 \%$

brevifolia

$0.1 \%$

baccata var. vespertina

$0.0 \%$ 
Association Longevity ACODE2 Genus Species Abundance

\section{Lycium andersonii-Hymenoclea salsola Shrubland}

Tall Shrubs (2-5 m)

tridentata

$2.0 \%$

Short Shrubs (0.5-2 m)

$\begin{array}{lll}\text { Perennial } & \text { LYAN } & \text { Lycium } \\ \text { Perennial } & \text { HYSA } & \text { Hymenoclea } \\ \text { Perennial } & \text { KRLA2 } & \text { Krascheninnikovia } \\ \text { Perennial } & \text { ATCO } & \text { Atriplex } \\ \text { Perennial } & \text { ATCAC } & \text { Atriplex } \\ \text { Perennial } & \text { EPNE } & \text { Ephedra } \\ \text { Perennial } & \text { GRSP } & \text { Grayia } \\ \text { Perennial } & \text { CORA } & \text { Coleogyne } \\ \text { Perennial } & \text { THMO } & \text { Thamnosma } \\ \text { Perennial } & \text { AMDU2 } & \text { Ambrosia } \\ \text { Perennial } & \text { ACSH } & \text { Acamptopappus } \\ \text { Perennial } & \text { CHVIV2 } & \text { Chrysothamnus } \\ \text { Perennial } & \text { ENVIV } & \text { Encelia } \\ \text { Perennial } & \text { ERCO23 } & \text { Ericameria } \\ \text { Perennial } & \text { TEAXA } & \text { Tetradymia } \\ \text { Perennial } & \text { ERTE18 } & \text { Ericameria } \\ \text { Perennial } & \text { AMER } & \text { Ambrosia } \\ \text { Perennial } & \text { LEFR2 } & \text { Lepidium }\end{array}$

andersonii
salsola
lanata
confertifolia
canescens var. canescens
nevadensis
spinosa
ramosissima
montana
dumosa
shockleyi
viscidiflorus ssp. viscidiflorus
virginensis var. virginensis
cooperi
axillaris var. axillanis
teretifolia
eriocentra
fremontii

$45.9 \%$

$10.1 \%$

$8.5 \%$

$7.4 \%$

$6.2 \%$

$5.5 \%$

$4.8 \%$

$2.3 \%$

$1.5 \%$

$1.1 \%$

$0.6 \%$

$0.5 \%$

$0.3 \%$

$0.3 \%$

$0.2 \%$

$0.2 \%$

$0.0 \%$

$0.0 \%$

\section{Dwarf Shrubs (<0.5 m)}

$\begin{array}{lll}\text { Perennial } & \text { ARSP5 } & \text { Artemisia } \\ \text { Perennial } & \text { KRER } & \text { Krameria } \\ \text { Perennial } & \text { MESP2 } & \text { Menodora }\end{array}$

spinescens

$2.0 \%$

erecta

$0.3 \%$

spinescens

$0.3 \%$

\section{Succulents}

Perennial YUBR Yucca

brevifolia

$0.2 \%$ 
Association Longevity ACODE2 Genus Species

Abundance

\section{Hymenoclea salsola-Ephedra nevadensis Shrubland}

\section{Tall Shrubs (2-5 m)}

tridentata

\section{Short Shrubs (0.5-2 m)}

\begin{tabular}{|c|c|c|}
\hline Perennial & HYSA & Hymenoclea \\
\hline Perennial & EPNE & Ephedra \\
\hline Perennial & CHVIV2 & Chrysothamnus \\
\hline Perennial & ATCAC & Atriplex \\
\hline Perennial & LYAN & Lycium \\
\hline Perennial & KRLA2 & Krascheninnikovia \\
\hline Perennial & AMDU2 & Ambrosia \\
\hline Perennial & GRSP & Grayia \\
\hline Perennial & ENVIV & Encelia \\
\hline Perennial & CORA & Coleogyne \\
\hline Perennial & LEFR2 & Lepidium \\
\hline Perennial & PSFRF & Psorothamnus \\
\hline Perennial & SAME & Salazaria \\
\hline Perennial & $\mathrm{ERCO} 23$ & Ericameria \\
\hline Perennial & ERPA29 & Ericameria \\
\hline Perennial & $\mathrm{ACSH}$ & Acamptopappus \\
\hline Perennial & THMO & Thamnosma \\
\hline Perennial & PUST & Purshia \\
\hline Perennial & EPVI & Ephedra \\
\hline Perennial & PSPO & Psorothamnus \\
\hline Perennial & ERNAH & Ericameria \\
\hline Perennial & ATCO & Atriplex \\
\hline Perennial & SADOD3 & Salvia \\
\hline Perennial & STPIP & Stanleya \\
\hline Perennial & TEAXA & Tetradymia \\
\hline Perennial & LYPAO & Lycium \\
\hline
\end{tabular}

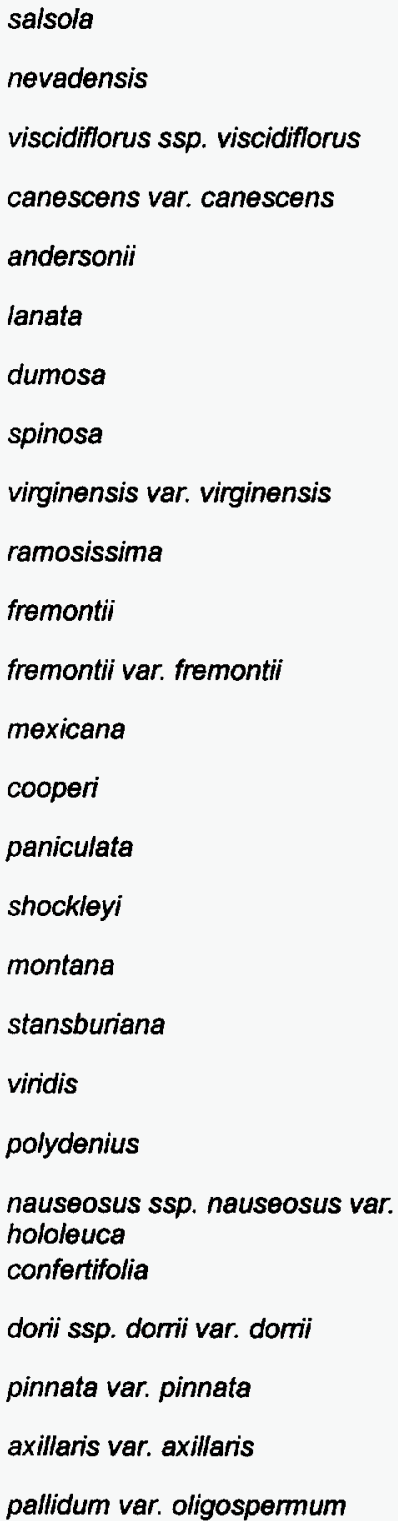

$51.5 \%$

$8.5 \%$

$5.4 \%$

$4.6 \%$

$4.5 \%$

$2.5 \%$

$2.2 \%$

$1.9 \%$

$1.7 \%$

$1.5 \%$

$1.4 \%$

$1.3 \%$

$1.2 \%$

$1.0 \%$

$1.0 \%$

$1.0 \%$

$0.8 \%$

$0.6 \%$

$0.5 \%$

$0.5 \%$

$0.5 \%$

$0.5 \%$

$0.5 \%$

$0.4 \%$

$0.4 \%$

$0.4 \%$

Thursday, September 09, 1999

Page 7 of 44 


$\begin{array}{lll}\text { Perennial } & \text { AMER } & \text { Ambrosia } \\ \text { Perennial } & \text { GUSA2 } & \text { Gutiemezia } \\ \text { Perennial } & \text { ATPO } & \text { Atriplex } \\ \text { Perennial } & \text { PRFA } & \text { Prunus } \\ \text { Perennial } & \text { BROBL } & \text { Brickellia } \\ \text { Perennial } & \text { ERNAL } & \text { Ericameria } \\ \text { Perennial } & \text { TECA2 } & \text { Tetradymia } \\ \text { Perennial } & \text { BRIN } & \text { Brickellia } \\ \text { Perennial } & \text { ERFAP } & \text { Eriogonum } \\ \text { Perennial } & \text { ERTE18 } & \text { Ericameria } \\ \text { Perennial } & \text { RHTRA } & \text { Rhus } \\ \text { Perennial } & \text { LYSH } & \text { Lycium } \\ \text { Perennial } & \text { PENI } & \text { Petalonyx } \\ \text { Perennial } & \text { STEL } & \text { Stanleya }\end{array}$

eniocentra
sarothrae
polycarpa
fasciculata
oblongifolia var. linifolia
nauseosus ssp. consimilis var.
leiosperma
canescens
incana
fasciculatum var. polifolium
teretifolia
trilobata var. anisophylla
shockleyi
nitidus
elata

Dwarf Shrubs $(<0.5 \mathrm{~m})$

$\begin{array}{lll}\text { Perennial } & \text { KRER } & \text { Krameria } \\ \text { Perennial } & \text { ARSP5 } & \text { Artemisia } \\ \text { Perennial } & \text { MESP2 } & \text { Menodora }\end{array}$

erecta $0.3 \%$

spinescens

$0.2 \%$

spinescens

$0.1 \%$

Forbs

$\begin{array}{lll}\text { Perennial } & \text { ADCO2 } & \text { Adenophyllum } \\ \text { Perennial } & \text { BRAT } & \text { Brickellia } \\ \text { Perennial } & \text { POSU } & \text { Polygala }\end{array}$

cooperi

$0.2 \%$

atractyloides

$0.0 \%$

subspinosa

$0.0 \%$

\section{Succulents}

$\begin{array}{lll}\text { Perennial } & \text { YUBR } & \text { Yucca } \\ \text { Perennial } & \text { YUSC2 } & \text { Yucca }\end{array}$

brevifolia

$0.1 \%$

schidigera

$0.0 \%$ 
Association Longevity ACODE2 Genus Species Abundance

\section{Menodora spinescens-Ephedra nevadensis Shrubland}

Tall Shrubs (2-5 m)

Perennial

LATR2 Larrea

tridentata

Short Shrubs $(0.5-2 \mathrm{~m})$

$\begin{array}{lll}\text { Perennial } & \text { EPNE } & \text { Ephedra } \\ \text { Perennial } & \text { AMDU2 } & \text { Ambrosia } \\ \text { Perennial } & \text { ATCO } & \text { Atriplex } \\ \text { Perennial } & \text { PSFRF } & \text { Psorothamnus } \\ \text { Perennial } & \text { CORA } & \text { Coleogyne } \\ \text { Perennial } & \text { LYAN } & \text { Lycium } \\ \text { Perennial } & \text { KRLA2 } & \text { Krascheninnikovia } \\ \text { Perennial } & \text { THMO } & \text { Thamnosma } \\ \text { Perennial } & \text { CHVIV2 } & \text { Chrysothamnus } \\ \text { Perennial } & \text { HYSA } & \text { Hymenoclea } \\ \text { Perennial } & \text { ACSH } & \text { Acamptopappus } \\ \text { Perennial } & \text { ENVIV } & \text { Encelia } \\ \text { Perennial } & \text { CHVIS5 } & \text { Chrysothamnus } \\ \text { Perennial } & \text { GRSP } & \text { Grayia } \\ \text { Perennial } & \text { LEFR2 } & \text { Lepidium } \\ \text { Perennial } & \text { LYPAO } & \text { Lycium } \\ \text { Perennial } & \text { ATCAC } & \text { Atriplex } \\ \text { Perennial } & \text { EPFU } & \text { Ephedra } \\ \text { Perennial } & \text { STPIP } & \text { Stanieya } \\ \text { Perennial } & \text { SAME } & \text { Salazaria } \\ \text { Perennial } & \text { EPTO } & \text { Ephedra } \\ \text { Perennial } & \text { ERCO23 } & \text { Ericameria } \\ \text { Penial } & \text { GUSA2 } & \text { Gutierrezia } \\ \text { TECA2 } & \text { Tetradymia } \\ \text { ERFAP } & \text { Eriogonum } \\ \text { PSPO } & \text { Psorothamnus }\end{array}$

nevadensis

$11.8 \%$

dumosa

$10.3 \%$

confertifolia

$8.3 \%$

fremontii var. fremontii

$7.9 \%$

ramosissima

$4.7 \%$

andersonii

$4.5 \%$

lanata

$4.0 \%$

montana

$3.0 \%$

viscidiflorus ssp. viscidiflorus

$2.7 \%$

salsola

$2.6 \%$

shockleyi

$1.9 \%$

virginensis var. vinginensis

$1.8 \%$

viscidiflorus ssp. viscidiflorus var. stenophyllus

spinosa

$1.5 \%$

$1.2 \%$

fremontii

$1.1 \%$

pallidum var. oligospermum

$1.1 \%$

canescens var. canescens

$0.9 \%$

funerea

$0.6 \%$

pinnata var. pinnata

$0.6 \%$

mexicana

$0.6 \%$

torreyana

$0.5 \%$

cooperi

$0.5 \%$

sarothrae

$0.5 \%$

canescens

$0.5 \%$

fasciculatum var. polifolium

$0.4 \%$

polydenius

$0.4 \%$ 


\section{Association Longevity}

ACODE2

Genus

Species

Abundance

$\begin{array}{lll}\text { Perennial } & \text { TEAXA } & \text { Tetradymia } \\ \text { Perennial } & \text { PENI } & \text { Petalonyx } \\ \text { Perennial } & \text { EPVI } & \text { Ephedra } \\ \text { Perennial } & \text { ERTE18 } & \text { Ericameria } \\ \text { Perennial } & \text { ERHEH2 } & \text { Eriogonum } \\ \text { Perennial } & \text { LYSH } & \text { Lycium } \\ \text { Perennial } & \text { SYLO } & \text { Symphoricarpos } \\ \text { Perennial } & \text { SADOD3 } & \text { Salvia } \\ \text { Perennial } & \text { ERNAL } & \text { Ericameria } \\ \text { Perennial } & \text { STEL } & \text { Stanleya } \\ \text { Perennial } & \text { BRMIW } & \text { Brickellia }\end{array}$

axillaris var. axillaris

$0.4 \%$

nitidus

$0.3 \%$

viridis

$0.2 \%$

teretifolia

$0.1 \%$

heermannii var, heermannii

$0.1 \%$

shockleyi

$0.1 \%$

longifforus

$0.1 \%$

donii ssp. domii var. domii

$0.0 \%$

nauseosus ssp. consimilis var.

leiosperma

elata

$0.0 \%$

$0.0 \%$

microphylla var. watsonii

$0.0 \%$

Dwarf Shrubs ( $<0.5 \mathrm{~m}$ )

$\begin{array}{lll}\text { Perennial } & \text { MESP2 } & \text { Menodora } \\ \text { Perennial } & \text { KRER } & \text { Krameria } \\ \text { Perennial } & \text { ARSP5 } & \text { Artemisia } \\ \text { Perennial } & \text { LEPU } & \text { Leptodactylon }\end{array}$

spinescens

$13.1 \%$

erecta

$4.0 \%$

spinescens

$0.9 \%$

pungens

$0.0 \%$

\section{Succulents}

$\begin{array}{lll}\text { Perennial } & \text { YUBR } & \text { Yucca } \\ \text { Perennial } & \text { YUSC2 } & \text { Yucca } \\ \text { Perennial } & \text { OPECE } & \text { Opuntia } \\ \text { Perennial } & \text { OPERU } & \text { Opuntia } \\ \text { Perennial } & \text { ECENE } & \text { Echinocereus } \\ \text { Perennial } & \text { OPBAB2 } & \text { Opuntia } \\ \text { Perennial } & \text { OPRA } & \text { Opuntia }\end{array}$

brevifolia
schidigera
echinocarpa var. echinocarpa
eninacea var. ursina
engelmannii var. engelmannii
basilaris var. basilaris
ramosissima

$0.9 \%$

$0.3 \%$

$0.2 \%$

$0.1 \%$

$0.1 \%$

$0.0 \%$

$0.0 \%$

Thursday, September 09, 1999 
Krascheninnikovia lanata-Ephedra nevadensis Shrubland

Tall Shrubs (2-5 m)

$\begin{array}{lll}\text { Perennial } & \text { LATR2 } & \text { Larrea } \\ \text { Perennial } & \text { ARTRT } & \text { Artemisia }\end{array}$

Short Shrubs (0.5-2 m)

\begin{tabular}{|c|c|c|}
\hline Perennial & KRLA2 & Krascheninnikovia \\
\hline Perennial & EPNE & Ephedra \\
\hline Perennial & GRSP & Grayia \\
\hline Perennial & LYAN & Lycium \\
\hline Perennial & $\mathrm{ACSH}$ & Acamptopappus \\
\hline Perennial & ATCO & Atriplex \\
\hline Perennial & AMDU2 & Ambrosia \\
\hline Perennial & HYSA & Hymenoclea \\
\hline Perennial & ATCAC & Atriplex \\
\hline Perennial & CHVIV2 & Chrysothamnus \\
\hline Perennial & CORA & Coleogyne \\
\hline Perennial & ERCO23 & Ericameria \\
\hline Perennial & THMO & Thamnosma \\
\hline Perennial & TEAXA & Tetradymia \\
\hline Perennial & LYPAO & Lycium \\
\hline Perennial & ERNAL & Ericameria \\
\hline Perennial & PSFRF & Psorothamnus \\
\hline Perennial & STPIP & Stanleya \\
\hline Perennial & STEL & Stanleya \\
\hline Perennial & LEFR2 & Lepidium \\
\hline Perennial & TECA2 & Tetradymia \\
\hline Perennial & SAME & Salazaria \\
\hline Perennial & ERTE18 & Ericameria \\
\hline Perennial & ERFAP & Eriogonum \\
\hline Perennial & ENVIV & Encelia \\
\hline
\end{tabular}

tridentata
tridentata ssp. tridentata

$2.3 \%$

$0.1 \%$
$28.5 \%$

$12.0 \%$

$8.0 \%$

$7.7 \%$

$6.5 \%$

$5.8 \%$

$3.9 \%$

$3.6 \%$

$2.4 \%$

$2.2 \%$

$2.1 \%$

$1.2 \%$

$1.1 \%$

$1.0 \%$

$0.6 \%$

$0.5 \%$

$0.3 \%$

$0.3 \%$

$0.3 \%$

$0.2 \%$

$0.2 \%$

$0.2 \%$

$0.2 \%$

$0.1 \%$

$0.1 \%$ 


\begin{tabular}{cllllr} 
Association & Longevity & ACODE2 & \multicolumn{1}{c}{ Genus } & \multicolumn{1}{c}{ Species } & Abundance \\
& & & & sarothrae & $0.0 \%$ \\
& Perennial & GUSA2 & Gutierrezia & nitidus & $0.0 \%$ \\
Perennial & PENI & Petalonyx & Iongiflorus & $0.0 \%$ \\
Perennial & SYLO & Symphoricarpos & glabrata & $0.0 \%$
\end{tabular}

\section{Dwarf Shrubs (<0.5 m)}

$\begin{array}{lll}\text { Perennial } & \text { ARSP5 } & \text { Artemisia } \\ \text { Perennial } & \text { MESP2 } & \text { Menodora } \\ \text { Perennial } & \text { KRER } & \text { Krameria }\end{array}$

spinescens

$5.0 \%$

spinescens

$2.1 \%$

erecta

$0.7 \%$

\section{Succulents}

Perennial YUBR Yucca

brevifolia

$0.6 \%$ 
Association Longevity ACODE2 Genus Species Abundance

\section{Eriogonum fasciculatum-Ephedra nevadensis Shrubland}

\section{Tall Shrubs (2-5 m)}

$\begin{array}{lll}\text { Perennial } & \text { LATR2 } & \text { Larrea } \\ \text { Perennial } & \text { ARTRT } & \text { Artemisia }\end{array}$

tridentata

$0.3 \%$

tridentata ssp. tridentata

$0.1 \%$

Short Shrubs (0.5-2 $\mathrm{m})$

\begin{tabular}{|c|c|c|}
\hline Perennial & ERFAP & Eriogonum \\
\hline Perennial & EPNE & Ephedra \\
\hline Perennial & ERTE18 & Ericameria \\
\hline Perennial & AMDU2 & Ambrosia \\
\hline Perennial & GRSP & Grayia \\
\hline Perennial & KRLA2 & Krascheninnikovia \\
\hline Perennial & LYAN & Lycium \\
\hline Perennial & ATCO & Atriplex \\
\hline Perennial & EPVI & Ephedra \\
\hline Perennial & GUSA2 & Gutierrezia \\
\hline Perennial & ERCO23 & Ericameria \\
\hline Perennial & CHVIV2 & Chrysothamnus \\
\hline Perennial & SAME & Salazaria \\
\hline Perennial & HYSA & Hymenoclea \\
\hline Perennial & ENVIV & Encelia \\
\hline Perennial & THMO & Thamnosma \\
\hline Perennial & TEAXA & Tetradymia \\
\hline Perennial & CORA & Coleogyne \\
\hline Perennial & ATCAC & Atriplex \\
\hline Perennial & STPIP & Stanleya \\
\hline Perennial & BRMIW & Brickellia \\
\hline Perennial & ERNAH & Ericameria \\
\hline Perennial & PSFRF & Psorothamnus \\
\hline Perennial & ERNAL & Ericameria \\
\hline Perennial & LEFR2 & Lepidium \\
\hline
\end{tabular}

fasciculatum var. polifolium

$28.1 \%$

nevadensis

$16.4 \%$

teretifolia

$12.1 \%$

dumosa

$5.3 \%$

spinosa

$3.7 \%$

lanata

$3.6 \%$

andersonii

$3.4 \%$

confertifolia

$3.0 \%$

viridis

$3.0 \%$

sarothrae

$2.6 \%$

cooperi

$2.3 \%$

viscidiflorus ssp. viscidiflorus

$2.2 \%$

mexicana

$1.3 \%$

salsola

$1.3 \%$

virginensis var. virginensis

$1.1 \%$

montana

$0.9 \%$

axillaris var. axillaris

$0.9 \%$

ramosissima

$0.7 \%$

canescens var. canescens

$0.4 \%$

pinnata var. pinnata

$0.4 \%$

microphylla var. watsonii

$0.3 \%$

nauseosus ssp. nauseosus var.

$0.3 \%$

$0.3 \%$

nauseosus ssp. consimilis var. leiosperma

$0.1 \%$

fremontii 


$\begin{array}{lll}\text { Perennial } & \text { SYLO } & \text { Symphoricarpos } \\ \text { Perennial } & \text { ERLI6 } & \text { Ericameria } \\ \text { Perennial } & \text { TEGL } & \text { Tetradymia }\end{array}$

longiflorus

linearifolius

glabrata

erecta

$5.0 \%$

pungens

$0.3 \%$

Perennial

LEPU

Leptodactyion

Perennial

MESP2

Menodora

spinescens

$0.0 \%$

Forbs

$\begin{array}{lll}\text { Perennial } & \text { ARLU } & \text { Artemisia } \\ \text { Perennial } & \text { BRAT } & \text { Brickellia }\end{array}$

ludoviciana

$0.1 \%$

atractyloides

$0.0 \%$

\section{Succulents}

Perennial

YUBR

Yucca

brevifolia

$0.1 \%$ 


\section{Ephedra nevadensis-Grayia spinosa Shrubland}

Trees $(>5 \mathrm{~m})$

$$
\text { Perennial JUOS Juniperus }
$$

osteosperma

$0.0 \%$

Tall Shrubs (2-5 m)

$\begin{array}{lll}\text { Perennial } & \text { ARTRT } & \text { Artemisia } \\ \text { Perennial } & \text { LATR2 } & \text { Lamrea }\end{array}$

tridentata ssp. tridentata

$1.4 \%$

tridentata

$0.6 \%$

\section{Short Shrubs (0.5-2 m)}

\begin{tabular}{lll} 
Perennial & EPNE & Ephedra \\
Perennial & GRSP & Grayia \\
Perennial & ATCAC & Atriplex \\
Perennial & HYSA & Hymenoclea \\
Perennial & LYAN & Lycium \\
Perennial & CHVIV2 & Chrysothamnus \\
Perennial & ERCO23 & Ericameria \\
Perennial & CORA & Coleogyne \\
Perennial & KRLA2 & Krascheninnikovia \\
Perennial & ERTE18 & Ericameria \\
Perennial & SAME & Salazaria \\
Perennial & ERFAP & Eriogonum \\
Perennial & THMO & Thamnosma \\
Perennial & ENVIV & Encelia \\
Perennial & ARNO4 & Artemisia \\
Perennial & GUSA2 & Gutierrezia \\
Perennial & ATCO & Atriplex \\
Perennial & ACSH & Acamptopappus \\
Perennial & ERNAL & Ericameria \\
Perennial & TEAXA & Tetradymia \\
Perennial & PSFRF & Psorothamnus \\
& AMDU2 & Ambrosia \\
& TECA2 & Tetradymia \\
\hline
\end{tabular}

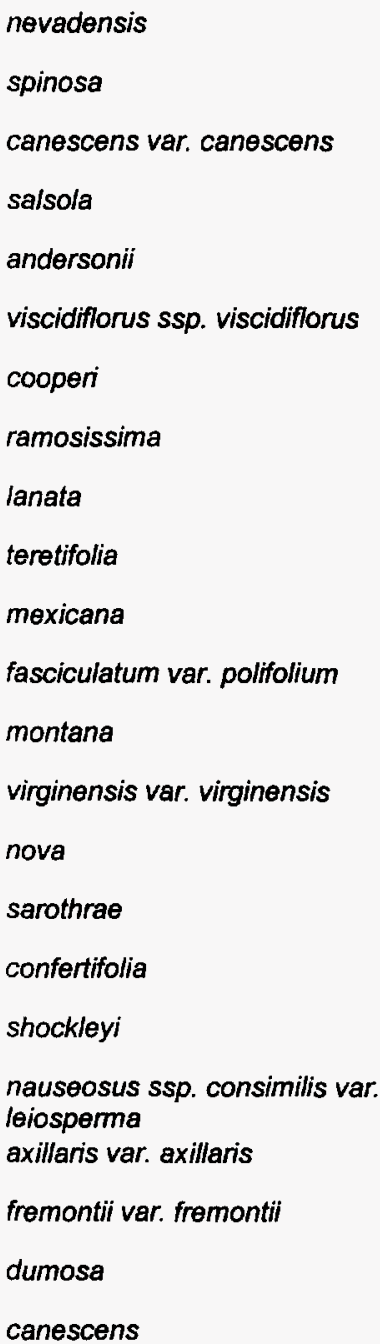

$23.7 \%$ 


\begin{tabular}{|c|c|c|c|c|c|}
\hline Association & Longevity & $A C O D E 2$ & Genus & Species & Abundance \\
\hline & Perennial & ERNAH & Ericameria & $\begin{array}{l}\text { nauseosus ssp. nauseosus var. } \\
\text { hololeuca }\end{array}$ & $0.5 \%$ \\
\hline & Perennial & EPVI & Ephedra & vinidis & $0.5 \%$ \\
\hline & Perennial & LEFR2 & Lepidium & fremontii & $0.5 \%$ \\
\hline & Perennial & PUGL2 & Purshia & glandulosa & $0.4 \%$ \\
\hline & Perennial & CHVIP4 & Chrysothamnus & viscidiflorus ssp. puberulus & $0.4 \%$ \\
\hline & Perennial & PSPO & Psorothamnus & polydenius & $0.3 \%$ \\
\hline & Perennial & SYLO & Symphoricarpos & longiflorus & $0.3 \%$ \\
\hline & Perennial & ERMIS2 & Eriogonum & microthecum var. simpsonii & $0.3 \%$ \\
\hline & Perennial & PUST & Purshia & stansburiana & $0.3 \%$ \\
\hline & Perennial & ERNA10 & Ericameria & nauseosus & $0.3 \%$ \\
\hline & Perennial & CHGR6 & Chrysothamnus & greenei & $0.2 \%$ \\
\hline & Perennial & TEGL & Tetradymia & glabrata & $0.2 \%$ \\
\hline & Perennial & LYPAO & Lycium & pallidum var. oligospermum & $0.2 \%$ \\
\hline & Perennial & STPIP & Stanleya & pinnata var. pinnata & $0.2 \%$ \\
\hline & Perennial & BRMIW & Brickellia & microphylla var. watsonii & $0.2 \%$ \\
\hline & Perennial & ERLI6 & Ericameria & linearifolius & $0.1 \%$ \\
\hline & Perennial & STEL & Stanleya & elata & $0.1 \%$ \\
\hline & Perennial & BROBL & Brickellia & oblongifolia var. linifolia & $0.1 \%$ \\
\hline & Perennial & ERPA29 & Ericameria & paniculata & $0.1 \%$ \\
\hline & Perennial & SADOD3 & Salvia & dorii ssp. domii var. domii & $0.1 \%$ \\
\hline & Perennial & ERNA7 & Ericameria & nanus & $0.0 \%$ \\
\hline & Perennial & AMER & Ambrosia & eriocentra & $0.0 \%$ \\
\hline & Perennial & GLSPA & Glossopetalon & spinescens var. aridum & $0.0 \%$ \\
\hline & Perennial & LYSH & Lycium & shockleyi & $0.0 \%$ \\
\hline & Perennial & ERHEH2 & Eriogonum & heermannii var. heermannii & $0.0 \%$ \\
\hline & Perennial & PRFA & Prunus & fasciculata & $0.0 \%$ \\
\hline
\end{tabular}

\section{Dwarf Shrubs (<0.5 m)}

$\begin{array}{lll}\text { Perennial } & \text { ARSP5 } & \text { Artemisia } \\ \text { Perennial } & \text { KRER } & \text { Krameria } \\ \text { Perennial } & \text { MESP2 } & \text { Menodora } \\ \text { Perennial } & \text { LEPU } & \text { Leptodactylon }\end{array}$

$\begin{array}{ll}\text { spinescens } & 0.9 \% \\ \text { erecta } & 0.9 \% \\ \text { spinescens } & 0.5 \% \\ \text { pungens } & 0.0 \%\end{array}$


Association Longevity ACODE2 Genus Species Abundance

\section{Forbs}

$\begin{array}{lll}\text { Perennial } & \text { ERSA6 } & \text { Eriogonum } \\ \text { Perennial } & \text { ARLU } & \text { Artemisia } \\ \text { Perennial } & \text { ERNU4 } & \text { Eriogonum }\end{array}$

saxatile

$0.2 \%$

ludoviciana

$0.0 \%$

nummulare

$0.0 \%$

\section{Succulents}

$\begin{array}{lll}\text { Perennial } & \text { YUBR } & \text { Yucca } \\ \text { Perennial } & \text { OPECE } & \text { Opuntia } \\ \text { Perennial } & \text { YUBAV } & \text { Yucca } \\ \text { Perennial } & \text { OPPOR } & \text { Opuntia } \\ \text { Perennial } & \text { YUSC2 } & \text { Yucca }\end{array}$

brevifolia

$0.3 \%$

echinocarpa var. echinocarpa

$0.2 \%$

baccata var. vespertina

$0.1 \%$

polyacantha var. rufispina

$0.0 \%$

schidigera

$0.0 \%$ 
Association Longevity ACODE2 Genus Species Abundance

\section{Coleogyne ramosissima-Ephedra nevadensis Shrubland}

Trees $(>5 \mathrm{~m})$

$\begin{array}{lll}\text { Perennial } & \text { JUOS } & \text { Juniperus } \\ \text { Perennial } & \text { PIMO } & \text { Pinus }\end{array}$

osteosperma

$0.1 \%$

Perennial

PIMO

monophylla

$0.0 \%$

\section{Tall Shrubs (2-5 m)}

$\begin{array}{lll}\text { Perennial } & \text { LATR2 } & \text { Larrea } \\ \text { Perennial } & \text { ARTRT } & \text { Artemisia } \\ \text { Perennial } & \text { CELEL } & \text { Cercocarpus } \\ \text { Perennial } & \text { CEGRV2 } & \text { Ceanothus }\end{array}$

tridentata

tridentata ssp. tridentata

ledifolius var. ledifolius

greggii ssp. vestitus
$1.9 \%$

$1.3 \%$

$0.0 \%$

$0.0 \%$

\section{Short Shrubs (0.5-2 m)}

$\begin{array}{lll}\text { Perennial } & \text { CORA } & \text { Coleogyne } \\ \text { Perennial } & \text { EPNE } & \text { Ephedra } \\ \text { Perennial } & \text { AMDU2 } & \text { Ambrosia } \\ \text { Perennial } & \text { LYAN } & \text { Lycium } \\ \text { Perennial } & \text { HYSA } & \text { Hymenoclea } \\ \text { Perennial } & \text { GRSP } & \text { Grayia } \\ \text { Perennial } & \text { CHVIV2 } & \text { Chrysothamnus } \\ \text { Perennial } & \text { KRLA2 } & \text { Krascheninnikovia } \\ \text { Perennial } & \text { ATCO } & \text { Atriplex } \\ \text { Perennial } & \text { ERTE18 } & \text { Ericameria } \\ \text { Perennial } & \text { EPVI } & \text { Ephedra } \\ \text { Perennial } & \text { ATCAC } & \text { Atriplex } \\ \text { Perennial } & \text { ERCO23 } & \text { Ericameria } \\ \text { Perennial } & \text { ERFAP } & \text { Eriogonum } \\ \text { Perennial } & \text { THMO } & \text { Thamnosma } \\ \text { Perennial } & \text { PUST } & \text { Purshia } \\ \text { Perennial } & \text { ERNAL } & \text { Ericameria } \\ \text { Perennial } & \text { ENVIV } & \text { Encelia } \\ \text { Perennial } & \text { PSFRF } & \text { Psorothamnus } \\ \text { Perennial } & \text { ACSH } & \text { Acamptopappus }\end{array}$

ramosissima
nevadensis
dumosa
andersonii
salsola
spinosa
viscidiflorus ssp. viscidiflorus
lanata
confertifolia
teretifolia
viridis
canescens var. canescens
cooperi
fasciculatum var. polifolium
montana
stansburiana
nauseosus ssp. consimilis var.
leiosperma
virginensis var. virginensis
fremontii var. fremontii
shockleyi

$56.4 \%$

$9.6 \%$

$3.5 \%$

$3.2 \%$

$2.5 \%$

$2.0 \%$

$1.5 \%$

$1.4 \%$

$1.4 \%$

$1.3 \%$

$1.0 \%$

$0.8 \%$

$0.7 \%$

$0.7 \%$

$0.7 \%$

$0.6 \%$

$0.6 \%$

$0.5 \%$

$0.5 \%$

$0.5 \%$ 


\begin{tabular}{|c|c|c|c|c|c|}
\hline Association & Longevity & $A C O D E 2$ & Genus & Species & Abundance \\
\hline & Perennial & LYPAO & Lycium & pallidum var. oligospermum & $0.4 \%$ \\
\hline & Perennial & TEAXA & Tetradymia & axillaris var. axillaris & $0.3 \%$ \\
\hline & Perennial & SAME & Salazaria & mexicana & $0.3 \%$ \\
\hline & Perennial & ARNO4 & Artemisia & nova & $0.3 \%$ \\
\hline & Perennial & ERMIS2 & Eriogonum & microthecum var. simpsonii & $0.2 \%$ \\
\hline & Perennial & TECA2 & Tetradymia & canescens & $0.2 \%$ \\
\hline & Perennial & ERNAH & Ericameria & $\begin{array}{l}\text { nauseosus ssp. nauseosus var. } \\
\text { hololeuca }\end{array}$ & $0.2 \%$ \\
\hline & Perennial & GUSA2 & Gutierrezia & sarothrae & $0.2 \%$ \\
\hline & Perennial & CHVIP4 & Chrysothamnus & viscidiflorus ssp. puberulus & $0.2 \%$ \\
\hline & Perennial & LEFR2 & Lepidium & fremontii & $0.1 \%$ \\
\hline & Perennial & SYLO & Symphoricarpos & longiflorus & $0.1 \%$ \\
\hline & Perennial & EPFU & Ephedra & funerea & $0.1 \%$ \\
\hline & Perennial & PSPO & Psorothamnus & polydenius & $0.1 \%$ \\
\hline & Perennial & ERLI6 & Ericameria & linearifolius & $0.1 \%$ \\
\hline & Perennial & ERNA10 & Ericameria & nauseosus & $0.1 \%$ \\
\hline & Perennial & PRFA & Prunus & fasciculata & $0.1 \%$ \\
\hline & Perennial & PUGL2 & Purshia & glandulosa & $0.1 \%$ \\
\hline & Perennial & BRMIW & Brickellia & microphylla var. watsonii & $0.1 \%$ \\
\hline & Perennial & STPIP & Stanleya & pinnata var. pinnata & $0.1 \%$ \\
\hline & Perennial & STEL & Stanleya & elata & $0.0 \%$ \\
\hline & Perennial & EPTO & Ephedra & torreyana & $0.0 \%$ \\
\hline & Perennial & TEGL & Tetradymia & glabrata & $0.0 \%$ \\
\hline & Perennial & AMER & Ambrosia & eriocentra & $0.0 \%$ \\
\hline & Perennial & ARBI3 & Artemisia & bigelovii & $0.0 \%$ \\
\hline & Perennial & SADOD3 & Salvia & dorii ssp. domii var, domii & $0.0 \%$ \\
\hline & Perennial & ERHEH2 & Eriogonum & heermannii var. heermannii & $0.0 \%$ \\
\hline & Perennial & ERHEA & Eriogonum & heermannii var. argense & $0.0 \%$ \\
\hline & Perennial & PERA4 & Peraphyllum & ramosissimum & $0.0 \%$ \\
\hline & Perennial & PENI & Petalonyx & nitidus & $0.0 \%$ \\
\hline & Perennial & RHTRA & Rhus & trilobata var. anisophylla & $0.0 \%$ \\
\hline & Perennial & BROBL & Brickellia & oblongifolia var. linifolia & $0.0 \%$ \\
\hline & Perennial & CHGR6 & Chrysothamnus & greenei & $0.0 \%$ \\
\hline
\end{tabular}


Association

Longevity

$\begin{array}{lll}\text { Perennial } & \text { BUUT } & \text { Buddleja } \\ \text { Perennial } & \text { ERCUC } & \text { Ericameria } \\ \text { Perennial } & \text { GLSPA } & \text { Glossopetalon } \\ \text { Perennial } & \text { PUTR2 } & \text { Purshia } \\ \text { Perennial } & \text { RIVEV } & \text { Ribes }\end{array}$

utahensis

$0.0 \%$

cuneatus

$0.0 \%$

spinescens var. aridum

$0.0 \%$

tridentata

$0.0 \%$

velutinum var. velutinum

$0.0 \%$

\section{Dwarf Shrubs (<0.5 m)}

$\begin{array}{lll}\text { Perennial } & \text { MESP2 } & \text { Menodora } \\ \text { Perennial } & \text { KRER } & \text { Krameria } \\ \text { Perennial } & \text { ARSP5 } & \text { Artemisia } \\ \text { Perennial } & \text { LEPU } & \text { Leptodactylon } \\ \text { Perennial } & \text { KOAM } & \text { Kochia }\end{array}$

$\begin{array}{ll}\text { spinescens } & 1.3 \% \\ \text { erecta } & 1.0 \% \\ \text { spinescens } & 0.2 \% \\ \text { pungens } & 0.0 \% \\ \text { americana } & 0.0 \%\end{array}$

\section{Forbs}

$\begin{array}{lll}\text { Perennial } & \text { ARLU } & \text { Artemisia } \\ \text { Perennial } & \text { ERSA6 } & \text { Eriogonum } \\ \text { Perennial } & \text { BRAT } & \text { Brickellia } \\ \text { Perennial } & \text { ERNU4 } & \text { Eriogonum }\end{array}$

Iudoviciana

saxatile

atractyloides

nummulare
$0.0 \%$

$0.0 \%$

$0.0 \%$

$0.0 \%$

\section{Succulents}

$\begin{array}{lll}\text { Perennial } & \text { YUBR } & \text { Yucca } \\ \text { Perennial } & \text { YUSC2 } & \text { Yucca } \\ \text { Perennial } & \text { YUBAV } & \text { Yucca } \\ \text { Perennial } & \text { OPECE } & \text { Opuntia } \\ \text { Perennial } & \text { OPRA } & \text { Opuntia } \\ \text { Perennial } & \text { ECPO2 } & \text { Echinocactus } \\ \text { Perennial } & \text { ECENE } & \text { Echinocereus } \\ \text { Perennial } & \text { OPPOR } & \text { Opuntia }\end{array}$

brevifolia

$0.3 \%$

schidigera

$0.1 \%$

baccata var. vespertina

$0.1 \%$

echinocarpa var. echinocarpa

$0.0 \%$

ramosissima

$0.0 \%$

polycephalus

$0.0 \%$

engelmannii var. engelmannii

$0.0 \%$

polyacantha var. rufispina

$0.0 \%$ 
Association Longevity ACODE2 Genus Species Abundance

\section{Atriplex confertifolia-Kochia americana Shrubland}

Tall Shrubs (2-5 m)

Perennial LATR2

tridentata

$0.1 \%$

\section{Short Shrubs (0.5-2 m)}

$\begin{array}{lll}\text { Perennial } & \text { ATCO } & \text { Atriplex } \\ \text { Perennial } & \text { LYAN } & \text { Lycium } \\ \text { Perennial } & \text { KRLA2 } & \text { Krascheninnikovia } \\ \text { Perennial } & \text { ATCAC } & \text { Atriplex } \\ \text { Perennial } & \text { ACSH } & \text { Acamptopappus } \\ \text { Perennial } & \text { LEFR2 } & \text { Lepidium } \\ \text { Perennial } & \text { EPV1 } & \text { Ephedra } \\ \text { Perennial } & \text { CHVIV2 } & \text { Chrysothamnus } \\ \text { Perennial } & \text { GRSP } & \text { Grayia } \\ \text { Perennial } & \text { AMDU2 } & \text { Ambrosia } \\ \text { Perennial } & \text { TEAXA } & \text { Tetradymia } \\ \text { Perennial } & \text { HYSA } & \text { Hymenoclea } \\ \text { Perennial } & \text { EPNE } & \text { Ephedra } \\ \text { Perennial } & \text { CORA } & \text { Coleogyne } \\ \text { Perennial } & \text { GUSA2 } & \text { Gutierrezia } \\ \text { Perennial } & \text { EPTO } & \text { Ephedra } \\ \text { Perennial } & \text { ERNA7 } & \text { Ericameria } \\ \text { Perennial } & \text { PSFRF } & \text { Psorothamnus } \\ \text { Perennial } & \text { TECA2 } & \text { Tetradymia }\end{array}$

confertifolia
andersonii
lanata
canescens var. canescens
shockleyi
fremontii
vinidis
viscidiflorus ssp. viscidiflorus
spinosa
dumosa
axillaris var. axillaris
salsola
nevadensis
ramosissima
sarothrae
torreyana
nanus
fremontii var. fremontii
canescens

$48.4 \%$

$6.5 \%$

$5.0 \%$

$2.1 \%$

$1.5 \%$

$0.9 \%$

$0.8 \%$

$0.7 \%$

$0.7 \%$

$0.5 \%$

$0.3 \%$

$0.2 \%$

$0.1 \%$

$0.1 \%$

$0.1 \%$

$0.0 \%$

$0.0 \%$

$0.0 \%$

$0.0 \%$

\section{Dwarf Shrubs (<0.5 m)}

$\begin{array}{lll}\text { Perennial } & \text { KOAM } & \text { Kochia } \\ \text { Perennial } & \text { ARSP5 } & \text { Artemisia } \\ \text { Perennial } & \text { MESP2 } & \text { Menodora } \\ \text { Perennial } & \text { KRER } & \text { Krameria }\end{array}$

americana
spinescens
spinescens
erecta

$20.1 \%$

$6.2 \%$

$5.2 \%$

$0.0 \%$ 


\section{Succulents}

$\begin{array}{lll}\text { Perennial } & \text { OPECE } & \text { Opuntia } \\ \text { Perennial } & \text { YUBR } & \text { Yucca } \\ \text { Perennial } & \text { YUSC2 } & \text { Yucca }\end{array}$

echinocarpa var. echinocarpa

$0.2 \%$

brevifolia

$0.1 \%$

schidigera

$0.0 \%$ 
Association Longevity ACODE2 Genus Species Abundance

\section{Atriplex canescens-Krascheninnikovia lanata Shrubland}

Trees $(>5 \mathrm{~m})$

Perennia

JUOS Juniperus

osteosperma

$0.0 \%$

Tall Shrubs (2-5 $\mathrm{m})$

$\begin{array}{lllll}\text { Perennial } & \text { LATR2 } & \text { Larrea } & \text { tridentata } & 0.9 \% \\ \text { Perennial } & \text { ARTRT } & \text { Artemisia } & \text { tridentata ssp. tridentata } & 0.3 \%\end{array}$

Short Shrubs (0.5-2 $\mathrm{m})$

\begin{tabular}{|c|c|c|}
\hline Perennial & ATCAC & Atriplex \\
\hline Perennial & KRLA2 & Krascheninnikovia \\
\hline Perennial & LYAN & Lycium \\
\hline Perennial & HYSA & Hymenoclea \\
\hline Perennial & ATCO & Atriplex \\
\hline Perennial & GRSP & Grayia \\
\hline Perennial & EPNE & Ephedra \\
\hline Perennial & CORA & Coleogyne \\
\hline Perennial & LEFR2 & Lepidium \\
\hline Perennial & LYPAO & Lycium \\
\hline Perennial & CHVIV2 & Chrysothamnus \\
\hline Perennial & LYSH & Lycium \\
\hline Perennial & PUGL2 & Purshia \\
\hline Perennial & $\mathrm{ACSH}$ & Acamptopappus \\
\hline Perennial & AMDU2 & Ambrosia \\
\hline Perennial & EPVI & Ephedra \\
\hline Perennial & ERNAH & Ericameria \\
\hline Perennial & TECA2 & Tetradymia \\
\hline Perennial & ERNAL & Ericameria \\
\hline Perennial & PUST & Purshia \\
\hline Perennial & THMO & Thamnosma \\
\hline Perennial & ERFAP & Eriogonum \\
\hline Perennial & STPIP & Stanleya \\
\hline
\end{tabular}

canescens var. canescens
lanata
andersonii
salsola
confertifolia
spinosa
nevadensis
ramosissima
fremontii
pallidum var. oligospermum
viscidiflorus ssp. viscidiflorus
shockleyi
glandulosa
shockleyi
dumosa
viridis
nauseosus ssp. nauseosus var.
hololeuca
canescens
nauseosus ssp. consimilis var.
leiosperma
stansburiana
montana
fasciculatum var. polifolium
pinnata var. pinnata

$57.8 \%$

$10.8 \%$

$4.9 \%$

$3.9 \%$

$3.3 \%$

$3.2 \%$

$2.8 \%$

$1.8 \%$

$1.1 \%$

$1.0 \%$

$0.9 \%$

$0.8 \%$

$0.7 \%$

$0.6 \%$

$0.4 \%$

$0.4 \%$

$0.3 \%$

$0.3 \%$

$0.2 \%$

$0.2 \%$

$0.2 \%$

$0.1 \%$

$0.1 \%$

Thursday, September 09, 1999

Page 23 of 44 


\begin{tabular}{cllllr} 
Association & Longevity & ACODE2 & \multicolumn{1}{c}{ Genus } & \multicolumn{1}{c}{ Species } & Abundance \\
& Perennial & EPTO & Ephedra & torreyana & $0.1 \%$ \\
Perennial & PSFRF & Psorothamnus & tremontii var. fremontii & $0.1 \%$ \\
Perennial & ERTE18 & Ericameria & teretifolia & $0.1 \%$ \\
Perennial & PSPO & Psorothamnus & polydenius & axillaris var. axillaris & $0.1 \%$ \\
Perennial & TEAXA & Tetradymia & virginensis var. virginensis & $0.0 \%$ \\
Perennial & ENVIV & Encelia & cooperi & $0.0 \%$ \\
Perennial & ERCO23 & Ericameria & mexicana & $0.0 \%$ \\
Perennial & SAME & Salazaria & longiflorus & $0.0 \%$ \\
Perennial & SYLO & Symphoricarpos & & $0.0 \%$
\end{tabular}

\section{Dwarf Shrubs (<0.5 m)}

$\begin{array}{lll}\text { Perennial } & \text { KOAM } & \text { Kochia } \\ \text { Perennial } & \text { ARSP5 } & \text { Artemisia } \\ \text { Perennial } & \text { MESP2 } & \text { Menodora } \\ \text { Perennial } & \text { KRER } & \text { Krameria }\end{array}$

$\begin{array}{ll}\text { americana } & 0.9 \% \\ \text { spinescens } & 0.8 \% \\ \text { spinescens } & 0.3 \% \\ \text { erecta } & 0.2 \%\end{array}$

\section{Forbs}

$\begin{array}{llll}\text { Perennial POSU } & \text { Polygala } & \text { subspinosa } & 0.1 \%\end{array}$

\section{Succulents}

$\begin{array}{lll}\text { Perennial } & \text { YUBR } & \text { Yucca } \\ \text { Perennial } & \text { YUSC2 } & \text { Yucca } \\ \text { Perennial } & \text { OPBAB2 } & \text { Opuntia } \\ \text { Perennial } & \text { YUBAV } & \text { Yucca }\end{array}$

brevifolia
schidigera
basilaris var. basilaris
baccata var. vespertina

$0.2 \%$

$0.1 \%$

$0.1 \%$

$0.0 \%$ 
Association Longevity ACODE2 Genus Species Abundance

\section{Chrysothamnus viscidiflorus-Ephedra nevadensis Shrubland}

Trees (>5 m)

$\begin{array}{lll}\text { Perennial } & \text { QUGA } & \text { Quercus } \\ \text { Perennial } & \text { PIMO } & \text { Pinus } \\ \text { Perennial } & \text { JUOS } & \text { Juniperus }\end{array}$

gambelii

$0.1 \%$

monophylla

$0.1 \%$

osteosperma

$0.0 \%$

Tall Shrubs (2-5 m)

$\begin{array}{lllll}\text { Perennial } & \text { ARTRT } & \text { Artemisia } & \text { tridentata ssp. tridentata } & 5.0 \% \\ \text { Perennial } & \text { LATR2 } & \text { Larrea } & \text { tridentata } & 0.1 \%\end{array}$

\section{Short Shrubs (0.5-2 m)}

\begin{tabular}{|c|c|c|}
\hline Perennial & CHVIV2 & Chrysothamnus \\
\hline Perennial & EPNE & Ephedra \\
\hline Perennial & ATCAC & Atriplex \\
\hline Perennial & KRLA2 & Krascheninnikovia \\
\hline Perennial & GRSP & Grayia \\
\hline Perennial & LYAN & Lycium \\
\hline Perennial & ATCO & Atriplex \\
\hline Perennial & CORA & Coleogyne \\
\hline Perennial & HYSA & Hymenoclea \\
\hline Perennial & EPVI & Ephedra \\
\hline Perennial & ARNO4 & Artemisia \\
\hline Perennial & TECA2 & Tetradymia \\
\hline Perennial & ERCO23 & Ericameria \\
\hline Perennial & CHVIP4 & Chrysothamnus \\
\hline Perennial & THMO & Thamnosma \\
\hline Perennial & GUSA2 & Gutierrezia \\
\hline Perennial & AMDU2 & Ambrosia \\
\hline Perennial & PUST & Purshia \\
\hline Perennial & PUTR2 & Purshia \\
\hline Perennial & ERFAP & Eriogonum \\
\hline Perennial & STPIP & Stanleya \\
\hline
\end{tabular}

viscidiflorus ssp. viscidiflorus
nevadensis
canescens var. canescens
lanata
spinosa
andersonii
confertifolia
ramosissima
salsola
viridis
nova
canescens
cooperi
viscidiflorus ssp. puberulus
montana
sarothrae
dumosa
stansburiana
tridentata
fasciculatum var. polifolium
pinnata var. pinnata

$36.7 \%$

$11.4 \%$

$6.9 \%$

$5.4 \%$

$5.3 \%$

$4.8 \%$

$3.7 \%$

$1.8 \%$

$1.6 \%$

$1.3 \%$

$1.0 \%$

$0.9 \%$

$0.8 \%$

$0.8 \%$

$0.7 \%$

$0.6 \%$

$0.5 \%$

$0.4 \%$

$0.4 \%$

$0.4 \%$

$0.3 \%$

Thursday, September 09, 1999

Page 25 of 44 


\begin{tabular}{lll} 
Perennial & ERNAH & Ericameria \\
Perennial & ERTE18 & Ericameria \\
Perennial & ERNA10 & Ericameria \\
Perennial & TEAXA & Tetradymia \\
Perennial & ERMIS2 & Eriogonum \\
Perennial & PSPO & Psorothamnus \\
Perennial & ERNAL & Ericameria \\
Perennial & TEGL & Tetradymia \\
Perennial & LEFR2 & Lepidium \\
Perennial & SYLO & Symphoricarpos \\
Perennial & PUGL2 & Purshia \\
Perennial & PSFRF & Psorothamnus \\
Perennial & LYPAO & Lycium \\
Perennial & ACSH & Acamptopappus \\
Perennial & ENVIV & Encelia \\
Perennial & ERLI6 & Ericameria \\
Perennial & CHGR6 & Chrysothamnus \\
Perennial & SAME & Salazaria \\
Perennial & BRMIW & Brickellia \\
Perennial & STEL & Stanleya \\
& & \\
\hline
\end{tabular}

\begin{tabular}{ll}
$\begin{array}{l}\text { nauseosus ssp. nauseosus var. } \\
\text { hololeuca } \\
\text { teretifolia }\end{array}$ & $0.3 \%$ \\
nauseosus & $0.3 \%$ \\
axillaris var. axillaris & $0.3 \%$ \\
microthecum var. simpsonii & $0.3 \%$ \\
polydenius & $0.3 \%$ \\
nauseosus ssp. consimilis var. & $0.3 \%$ \\
leiosperma & $0.3 \%$ \\
glabrata & $0.3 \%$ \\
fremontii & $0.2 \%$ \\
glangiflorus & $0.2 \%$ \\
fremontii var. fremontii & $0.2 \%$ \\
pallidum var. oligospermum & $0.1 \%$ \\
shockleyi & $0.1 \%$ \\
virginensis var. virginensis & $0.1 \%$ \\
linearifolius & $0.1 \%$ \\
greenei & $0.1 \%$ \\
mexicana & $0.1 \%$ \\
microphylla var. watsonii & $0.0 \%$ \\
dorii ssp. dornii var. domii & $0.0 \%$ \\
elata & $0.0 \%$ \\
\hline
\end{tabular}

Dwarf Shrubs (<0.5 m)

$\begin{array}{lll}\text { Perennial } & \text { ARSP5 } & \text { Artemisia } \\ \text { Perennial } & \text { MESP2 } & \text { Menodora } \\ \text { Perennial } & \text { KOAM } & \text { Kochia } \\ \text { Perennial } & \text { LEPU } & \text { Leptodactylon } \\ \text { Perennial } & \text { KRER } & \text { Krameria }\end{array}$

$\begin{array}{ll}\text { spinescens } & 2.6 \% \\ \text { spinescens } & 0.3 \% \\ \text { americana } & 0.3 \% \\ \text { pungens } & 0.3 \% \\ \text { erecta } & 0.0 \%\end{array}$

Forbs

$\begin{array}{lll}\text { Perennial } & \text { ERNU4 } & \text { Eriogonum } \\ \text { Perennial } & \text { ERSA6 } & \text { Eriogonum } \\ \text { Perennial } & \text { STPA3 } & \text { Stephanomeria }\end{array}$

nummulare

$0.6 \%$

saxatile

$0.3 \%$

parryi 


\section{Succulents}

$\begin{array}{lll}\text { Perennial } & \text { YUBR } & \text { Yucca } \\ \text { Perennial } & \text { ECENE } & \text { Echinocereus } \\ \text { Perennial } & \text { OPECE } & \text { Opuntia } \\ \text { Perennial } & \text { OPERE } & \text { Opuntia } \\ \text { Perennial } & \text { OPPOR } & \text { Opuntia } \\ \text { Perennial } & \text { YUBAV } & \text { Yucca }\end{array}$

brevifolia

$0.5 \%$

engelmannii var. engelmannit

echinocarpa var. echinocarpa

erinacea var. erinacea

polyacantha var. rufispina

baccata var. vespertina
$0.1 \%$

$0.0 \%$

$0.0 \%$

$0.0 \%$

$0.0 \%$ 
Association Longevity ACODE2 Genus Species Abundance

\section{Ericameria nauseosa-Ephedra nevadensis Shrubland}

Trees $(>5 \mathrm{~m})$

$\begin{array}{lll}\text { Perennial } & \text { JUOS } & \text { Juniperus } \\ \text { Perennial } & \text { PIMO } & \text { Pinus }\end{array}$

osteosperma

$0.1 \%$

monophylla

$0.1 \%$

Tall Shrubs (2-5 m)

$\begin{array}{lll}\text { Perennial } & \text { ARTRT } & \text { Artemisia } \\ \text { Perennial } & \text { AMUT } & \text { Amelanchier }\end{array}$

tridentata ssp. tridentata

$6.0 \%$

utahensis

$0.0 \%$

\section{Short Shrubs (0.5-2 m)}

\begin{tabular}{|c|c|c|}
\hline Perennial & ERNAH & Ericameria \\
\hline Perennial & EPNE & Ephedra \\
\hline Perennial & CORA & Coleogyne \\
\hline Perennial & ATCAC & Atriplex \\
\hline Perennial & CHVIV2 & Chrysothamnus \\
\hline Perennial & EPVI & Ephedra \\
\hline Perennial & ERNAL & Ericameria \\
\hline Perennial & ERLI6 & Ericameria \\
\hline Perennial & PSPO & Psorothamnus \\
\hline Perennial & PUST & Purshia \\
\hline Perennial & ENVIV & Encelia \\
\hline Perennial & PUGL2 & Purshia \\
\hline Perennial & ERCO23 & Ericameria \\
\hline Perennial & ERTE18 & Ericameria \\
\hline Perennial & ARNO4 & Artemisia \\
\hline Perennial & LYAN & Lycium \\
\hline Perennial & GUSA2 & Gutierrezia \\
\hline Perennial & RIVEV & Ribes \\
\hline Perennial & SYLO & Symphoricarpos \\
\hline Perennial & HYSA & Hymenoclea \\
\hline Perennial & PUTR2 & Purshia \\
\hline Perennial & CHVIP4 & Chrysothamnus \\
\hline
\end{tabular}

nauseosus ssp. nauseosus var.
hololeuca
nevadensis
ramosissima
canescens var. canescens
viscidiflorus ssp. viscidiflorus
viridis
nauseosus ssp. consimilis var.
leiosperma
linearifolius
polydenius
stansburiana
virginensis var. virginensis
glandulosa
cooperi
teretifolia
nova
andersonii
sarothrae
velutinum var. velutinum
longiflorus
salsola
tridentata
viscidiflorus ssp. puberulus

$51.7 \%$

$11.1 \%$

$5.3 \%$

$5.2 \%$

$4.4 \%$

$2.3 \%$

$2.2 \%$

$1.4 \%$

$1.3 \%$

$1.2 \%$

$1.1 \%$

$0.8 \%$

$0.7 \%$

$0.5 \%$

$0.5 \%$

$0.5 \%$

$0.4 \%$

$0.4 \%$

$0.3 \%$

$0.2 \%$

$0.2 \%$

$0.1 \%$ 


\begin{tabular}{clll} 
Association & Longevity & ACODE2 & \multicolumn{1}{c}{ Genus } \\
& Perennial & GRSP & Grayia \\
Perennial & AMDU2 & Ambrosia \\
Perennial & ERMiS2 & Eriogonum \\
Perennial & STPIP & Stanleya \\
Perennial & KRLA2 & Krascheninnikovia \\
Perennial & SAME & Salazaria \\
Perennial & ERNA7 & Ericameria \\
Perennial & HODI & Holodiscus \\
Perennial & LEFR2 & Lepidium \\
Perennial & PRFA & Prunus \\
Perennial & TEAXA & Tetradymia
\end{tabular}

\section{Dwarf Shrubs ( $<0.5 \mathrm{~m})$}

Perennial LEPU

Forbs

Perennial

ERNU4

Eriogonum

\section{Succulents}

$\begin{array}{lll}\text { Perennial } & \text { YUBR } & \text { Yucca } \\ \text { Perennial } & \text { OPECE } & \text { Opuntia } \\ \text { Perennial } & \text { YUBAV } & \text { Yucca }\end{array}$

nummulare

$0.1 \%$ brevifolia

$0.5 \%$

echinocarpa var. echinocarpa

baccata var. vespertina

$0.4 \%$

$0.0 \%$
Abundance
$0.1 \%$
$0.1 \%$
$0.1 \%$
$0.1 \%$
$0.0 \%$
$0.0 \%$
$0.0 \%$
$0.0 \%$
$0.0 \%$
$0.0 \%$
$0.0 \%$

$0.0 \%$

pungens 
Association Longevity ACODE2 Genus Species

Abundance

\section{Ephedra viridis-Artemisia tridentata Shrubland}

\section{Trees $(>5 \mathrm{~m})$}

$\begin{array}{lll}\text { Perennial } & \text { JUOS } & \text { Juniperus } \\ \text { Perennial } & \text { PIMO } & \text { Pinus } \\ \text { Perennial } & \text { QUGA } & \text { Quercus }\end{array}$

osteosperma
monophylla
gambelii

Tall Shrubs (2-5 m)

$\begin{array}{lll}\text { Perennial } & \text { ARTRT } & \text { Artemisia } \\ \text { Perennial } & \text { AMUT } & \text { Amelanchier } \\ \text { Perennial } & \text { CEGRV2 } & \text { Ceanothus }\end{array}$

tridentata ssp. tridentata
utahensis
greggii ssp. vestitus

\section{Short Shrubs (0.5-2 m)}

$\begin{array}{lll}\text { Perennial } & \text { EPVI } & \text { Ephedra } \\ \text { Perennial } & \text { PUGL2 } & \text { Purshia } \\ \text { Perennial } & \text { PUST } & \text { Purshia } \\ \text { Perennial } & \text { ERFAP } & \text { Eriogonum } \\ \text { Perennial } & \text { CHVIP4 } & \text { Chrysothamnus } \\ \text { Perennial } & \text { ATCAC } & \text { Atriplex } \\ \text { Perennial } & \text { ERMIS2 } & \text { Eriogonum } \\ \text { Perennial } & \text { ERTE18 } & \text { Ericameria } \\ \text { Perennial } & \text { EPNE } & \text { Ephedra } \\ \text { Perennial } & \text { ERNAL } & \text { Ericameria } \\ \text { Perennial } & \text { CHVIV2 } & \text { Chrysothamnus } \\ \text { Perennial } & \text { CORA } & \text { Coleogyne } \\ \text { Perennial } & \text { TEGL } & \text { Tetradymia } \\ \text { Perennial } & \text { ERLI6 } & \text { Ericameria } \\ \text { Perennial } & \text { GRSP } & \text { Grayia } \\ \text { Perennial } & \text { GUSA2 } & \text { Gutierrezia } \\ \text { Perennial } & \text { PRFA } & \text { Prunus } \\ \text { Perennial } & \text { TEAXA } & \text { Tetradymia } \\ \text { Perennial } & \text { PERA4 } & \text { Peraphyllum } \\ & \text { TECA2 } & \text { Tetradymia }\end{array}$

viridis
glandulosa
stansburiana
fasciculatum var. polifolium
viscidiflorus ssp. puberulus
canescens var. canescens
microthecum var. simpsonii
teretifolia
nevadensis
nauseosus ssp. consimilis var.
leiosperma
viscidiflorus ssp. viscidiflorus
ramosissima
glabrata
linearifolius
spinosa
sarothrae
fasciculata
axillaris var. axillaris
ramosissimum
canescens

$20.2 \%$

$15.8 \%$

$9.0 \%$

$6.3 \%$

$4.7 \%$

$3.7 \%$

$3.4 \%$

$2.9 \%$

$2.2 \%$

$2.0 \%$

$2.0 \%$

$1.9 \%$

$1.8 \%$

$1.1 \%$

$0.8 \%$

$0.7 \%$

$0.6 \%$

$0.5 \%$

$0.5 \%$

$0.3 \%$

Page 30 of 44

Thursday, September 09, 1999 


\begin{tabular}{cllllr} 
Association & Longevity & ACODE2 & \multicolumn{1}{c}{ Genus } & \multicolumn{1}{c}{ Species } & Abundance \\
Perennial & ERNAH & Ericameria & $\begin{array}{l}\text { nauseosus ssp. nauseosus var. } \\
\text { hololeuca } \\
\text { cereum var. cereum }\end{array}$ & $0.2 \%$ \\
Perennial & RICEC2 & Ribes & virginensis var. virginensis & $0.2 \%$ \\
Perennial & ENVIV & Encelia & andersonii & $0.1 \%$ \\
Perennial & LYAN & Lycium & lanata & $0.1 \%$ \\
Perennial & KRLA2 & Krascheninnikovia & mexicana & $0.1 \%$ \\
Perennial & SAME & Salazania & oblongifolia var. linifolia & $0.1 \%$ \\
Perennial & BROBL & Brickellia & nanus & $0.1 \%$ \\
Perennial & ERNA7 & Ericameria & trilobata var. anisophylla & $0.1 \%$ \\
Perennial & RHTRA & Rhus & longiflorus & $0.0 \%$ \\
Perennial & SYLO & Symphoricarpos & cooperi & $0.0 \%$ \\
Perennial & ERCO23 & Ericameria & nitidus & $0.0 \%$ \\
Perennial & PENI & Petalonyx & $0.0 \%$
\end{tabular}

\section{Dwarf Shrubs ( $<0.5 \mathrm{~m})$}

Perennial LEPU Leptodactylon

pungens

Forbs

Perennial CHGR13 Chrysothamnus

gramineus

$0.1 \%$

\section{Succulents}

$\begin{array}{lll}\text { Perennial } & \text { YUBAV } & \text { Yucca } \\ \text { Perennial } & \text { YUBR } & \text { Yucca }\end{array}$

baccata var. vespertina

$0.1 \%$

brevifolia

$0.0 \%$ 
Association Longevity ACODE2 Genus Species Abundance

Artemisia tridentata-Chrysothamnus viscidiflorus Shrubland

Trees (>5 m)

$\begin{array}{lll}\text { Perennial } & \text { JUOS } & \text { Juniperus } \\ \text { Perennial } & \text { PIMO } & \text { Pinus } \\ \text { Perennial } & \text { QUGA } & \text { Quercus }\end{array}$

osteosperma

$0.5 \%$

monophylla

$0.3 \%$

gambelii

$0.0 \%$

Tall Shrubs (2-5 m)

$\begin{array}{lll}\text { Perennial } & \text { ARTRT } & \text { Artemisia } \\ \text { Perennial } & \text { AMUT } & \text { Amelanchier } \\ \text { Perennial } & \text { LATR2 } & \text { Lamea }\end{array}$

tridentata ssp. tridentata

$58.3 \%$

utahensis

$0.1 \%$

tridentata

$0.0 \%$

\section{Short Shrubs (0.5-2 m)}

$\begin{array}{lll}\text { Perennial } & \text { CHVIV2 } & \text { Chrysothamnus } \\ \text { Perennial } & \text { EPNE } & \text { Ephedra } \\ \text { Perennial } & \text { CHVIP4 } & \text { Chrysothamnus } \\ \text { Perennial } & \text { GRSP } & \text { Grayia } \\ \text { Perennial } & \text { ATCAC } & \text { Atriplex } \\ \text { Perennial } & \text { ARNO4 } & \text { Artemisia } \\ \text { Perennial } & \text { EPVI } & \text { Ephedra } \\ \text { Perennial } & \text { KRLA2 } & \text { Krascheninnikovia } \\ \text { Perennial } & \text { ERNAH } & \text { Ericameria } \\ \text { Perennial } & \text { LYAN } & \text { Lycium } \\ \text { Perennial } & \text { PUGL2 } & \text { Purshia } \\ \text { Perennial } & \text { ERMIS2 } & \text { Eriogonum } \\ \text { Perennial } & \text { ERTE18 } & \text { Ericameria } \\ \text { Perennial } & \text { PUTR2 } & \text { Purshia } \\ \text { Perennial } & \text { GUSA2 } & \text { Gutierrezia } \\ \text { Perennial } & \text { CORA } & \text { Coleogyne } \\ \text { Perennial } & \text { TECA2 } & \text { Tetradymia } \\ \text { Perennial } & \text { ERNAL } & \text { Ericameria } \\ \text { Perennial } & \text { ERFAP } & \text { Eriogonum } \\ \text { Perennial } & \text { TEGL } & \text { Tetradymia }\end{array}$

viscidiflorus ssp. viscidiflorus
nevadensis
viscidiflorus ssp. puberulus
spinosa
canescens var. canescens
nova
viridis
lanata
nauseosus ssp. nauseosus var.
hololeuca
andersonii
glandulosa
microthecum var. simpsonii
teretifolia
tridentata
sarothrae
ramosissima
canescens
nauseosus ssp. consimilis var.
leiosperma
fasciculatum var. polifolium
glabrata

$8.8 \%$

$8.2 \%$

$3.0 \%$

$2.3 \%$

$2.2 \%$

$2.0 \%$

$1.4 \%$

$1.1 \%$

$1.0 \%$

$0.8 \%$

$0.6 \%$

$0.6 \%$

$0.6 \%$

$0.5 \%$

$0.5 \%$

$0.5 \%$

$0.4 \%$

$0.3 \%$

$0.3 \%$

$0.3 \%$

Thursday, September 09, 1999

Page 32 of 44 


\begin{tabular}{lll} 
Perennial & ERLI6 & Ericameria \\
Perennial & ATCO & Atriplex \\
Perennial & SYLO & Symphoricarpos \\
Perennial & ERCO23 & Ericameria \\
Perennial & TEAXA & Tetradymia \\
Perennial & ERNA10 & Ericameria \\
Perennial & PUST & Purshia \\
Perennial & RIVEV & Ribes \\
Perennial & PSPO & Psorothamnus \\
Perennial & ENVIV & Encelia \\
Perennial & HYSA & Hymenoclea \\
Perennial & ERPA29 & Ericameria \\
Perennial & ERNA7 & Ericameria \\
Perennial & AMDU2 & Ambrosia \\
Perennial & ERPAN2 & Ericameria \\
Perennial & ERHEA & Eriogonum \\
Perennial & SAME & Salazaria \\
Perennial & SADOD3 & Salvia \\
Perennial & LEFR2 & Lepidium \\
Perennial & RICEC2 & Ribes \\
Perennial & STEL & Stanleya \\
PHial & STMO & Thamnosma \\
PRFA & Prunus \\
Stanleya \\
\hline
\end{tabular}

\begin{tabular}{ll} 
linearifolius & $0.2 \%$ \\
confertifolia & $0.2 \%$ \\
longiflorus & $0.2 \%$ \\
cooperi & $0.2 \%$ \\
axillaris var. axillanis & $0.1 \%$ \\
nauseosus & $0.1 \%$ \\
stansburiana & $0.1 \%$ \\
velutinum var. velutinum & $0.1 \%$ \\
polydenius & $0.1 \%$ \\
virginensis var. virginensis & $0.0 \%$ \\
salsola & $0.0 \%$ \\
paniculata & $0.0 \%$ \\
nanus & $0.0 \%$ \\
dumosa & $0.0 \%$ \\
parryi var. nevadensis & $0.0 \%$ \\
heermannii var. argense & $0.0 \%$ \\
mexicana & $0.0 \%$ \\
dorii ssp. dorrii var. dornii & $0.0 \%$ \\
fremontii & $0.0 \%$ \\
cereum var. cereum & $0.0 \%$ \\
elata & $0.0 \%$ \\
montana & $0.0 \%$ \\
fasciculata & $0.0 \%$ \\
pinnata var. pinnata & $0.0 \%$ \\
\hline
\end{tabular}

\section{Dwarf Shrubs (<0.5 m)}

$\begin{array}{lll}\text { Perennial } & \text { LEPU } & \text { Leptodactylon } \\ \text { Perennial } & \text { ARSP5 } & \text { Artemisia } \\ \text { Perennial } & \text { MESP2 } & \text { Menodora }\end{array}$

$\begin{array}{ll}\text { pungens } & 2.6 \% \\ \text { spinescens } & 0.6 \% \\ \text { spinescens } & 0.0 \%\end{array}$

\section{Forbs}

$\begin{array}{lll}\text { Perennial } & \text { ERSA6 } & \text { Eriogonum } \\ \text { Perennial } & \text { ERNU4 } & \text { Eriogonum }\end{array}$


Association Longevity ACODE2

Genus

$\begin{array}{lll}\text { Perennial } & \text { ARLU } & \text { Artemisia } \\ \text { Perennial } & \text { ERUM } & \text { Eriogonum } \\ \text { Perennial } & \text { HYCOC2 } & \text { Hymenoxys } \\ \text { Perennial } & \text { CHGR13 } & \text { Chrysothamnus }\end{array}$

\section{Succulents}

$\begin{array}{lll}\text { Perennial } & \text { OPECE } & \text { Opuntia } \\ \text { Perennial } & \text { YUBR } & \text { Yucca } \\ \text { Perennial } & \text { YUBAV } & \text { Yucca } \\ \text { Perennial } & \text { OPPOR } & \text { Opuntia }\end{array}$

Species

ludoviciana

umbellatum

cooperi var. cooperi

gramineus

echinocarpa var. echinocarpa

brevifolia

baccata var. vespertina

polyacantha var. rufispina
$0.2 \%$

$0.1 \%$

Abundance

$0.1 \%$

$0.1 \%$

$0.1 \%$

$0.0 \%$

$0.0 \%$

$0.0 \%$ 


\section{Artemisia nova-Chrysothamnus viscidiflorus Shrubland}

Trees (>5 m)

$\begin{array}{lll}\text { Perennial } & \text { PIMO } & \text { Pinus } \\ \text { Perennial } & \text { JUOS } & \text { Juniperus } \\ \text { Perennial } & \text { QUGA } & \text { Quencus }\end{array}$

monophylla
osteosperma

gambelii

\section{$0.8 \%$ \\ $0.6 \%$ \\ $0.0 \%$}

Tall Shrubs (2-5 m)

\section{Short Shrubs (0.5-2 m)}

\begin{tabular}{|c|c|c|}
\hline Perennial & ARNO4 & Artemisia \\
\hline Perennial & CHVIV2 & Chrysothamnus \\
\hline Perennial & EPNE & Ephedra \\
\hline Perennial & CHVIP4 & Chrysothamnus \\
\hline Perennial & GRSP & Grayia \\
\hline Perennial & EPVI & Ephedra \\
\hline Perennial & ATCAC & Atriplex \\
\hline Perennial & ERNA7 & Ericameria \\
\hline Perennial & ERMIS2 & Eriogonum \\
\hline Perennial & ATCO & Atriplex \\
\hline Perennial & GUSA2 & Gutierrezia \\
\hline Perennial & KRLA2 & Krascheninnikovia \\
\hline Perennial & LYAN & Lycium \\
\hline Perennial & TEGL & Tetradymia \\
\hline Perennial & ERNAL & Ericameria \\
\hline Perennial & ERNAH & Ericameria \\
\hline Perennial & TECA2 & Tetradymia \\
\hline Perennial & PUGL2 & Purshia \\
\hline Perennial & PUST & Purshia \\
\hline Perennial & CHGR6 & Chrysothamnus \\
\hline Perennial & CORA & Coleogyne \\
\hline Perennial & ERNA10 & Ericameria \\
\hline
\end{tabular}

nova
viscidiflorus ssp. viscidiflorus
nevadensis
viscidiflorus ssp. puberulus
spinosa
viridis
canescens var. canescens
nanus
microthecum var. simpsonii
confertifolia
sarothrae
lanata
andersonii
glabrata
nauseosus ssp. consimilis var.
leiosperma
nauseosus ssp. nauseosus var.
hololeuca
canescens
glandulosa
stansburiana
greenei
ramosissima
nauseosus

$67.5 \%$

$5.2 \%$

$4.5 \%$

$2.7 \%$

$2.0 \%$

$1.7 \%$

$1.4 \%$

$0.9 \%$

$0.9 \%$

$0.8 \%$

$0.7 \%$

$0.6 \%$

$0.6 \%$

$0.4 \%$

$0.3 \%$

$0.3 \%$

$0.3 \%$

$0.3 \%$

$0.3 \%$

$0.3 \%$

$0.2 \%$

$0.2 \%$

Page 35 of 44 


$\begin{array}{lll}\text { Perennial } & \text { SYLO } & \text { Symphoricarpos } \\ \text { Perennial } & \text { PUTR2 } & \text { Purshia } \\ \text { Perennial } & \text { ERCO23 } & \text { Ericameria } \\ \text { Perennial } & \text { TEAXA } & \text { Tetradymia } \\ \text { Perennial } & \text { ERTE18 } & \text { Ericameria } \\ \text { Perennial } & \text { GLSPA } & \text { Glossopetalon } \\ \text { Perennial } & \text { HYSA } & \text { Hymenoclea } \\ \text { Perennial } & \text { LEFR2 } & \text { Lepidium } \\ \text { Perennial } & \text { ERHEA } & \text { Eriogonum } \\ \text { Perennial } & \text { ERFAP } & \text { Eriogonum } \\ \text { Perennial } & \text { PRFA } & \text { Prunus } \\ \text { Perennial } & \text { ERL16 } & \text { Ericameria } \\ \text { Perennial } & \text { SADOD3 } & \text { Salvia } \\ \text { Perennial } & \text { RHTRA } & \text { Rhus } \\ \text { Perennial } & \text { RIVEV } & \text { Ribes } \\ \text { Perennial } & \text { STPIP } & \text { Stanleya }\end{array}$

longiflorus
tridentata
cooperi
axillaris var. axillaris
teretifolia
spinescens var. aridum
salsola
fremontii
heermannii var. argense
fasciculatum var. polifolium
fasciculata
linearifolius
donii ssp. dorrii var. domii
trilobata var. anisophylla
velutinum var. velutinum
pinnata var. pinnata

\section{Dwarf Shrubs (<0.5 m)}

$\begin{array}{lll}\text { Perennial } & \text { LEPU } & \text { Leptodactylon } \\ \text { Perennial } & \text { ARSP5 } & \text { Artemisia } \\ \text { Perennial } & \text { KOAM } & \text { Kochia } \\ \text { Perennial } & \text { MESP2 } & \text { Menodora }\end{array}$

$\begin{array}{ll}\text { pungens } & 0.5 \% \\ \text { spinescens } & 0.1 \% \\ \text { americana } & 0.1 \% \\ \text { spinescens } & 0.0 \%\end{array}$

\section{Forbs}

$\begin{array}{lll}\text { Perennial } & \text { ERNU4 } & \text { Eriogonum } \\ \text { Perennial } & \text { ERUMV2 } & \text { Eriogonum } \\ \text { Perennial } & \text { ERCA8 } & \text { Eriogonum } \\ \text { Perennial } & \text { ERSA6 } & \text { Eriogonum } \\ \text { Perennial } & \text { ERUM } & \text { Eriogonum }\end{array}$

nummulare
umbellatum var. versicolor
caespitosum
saxatile
umbellatum

\section{Succulents}

$\begin{array}{lll}\text { Perennial } & \text { YUBAV } & \text { Yucca } \\ \text { Perennial } & \text { OPECE } & \text { Opuntia } \\ \text { Perennial } & \text { YUBR } & \text { Yucca }\end{array}$
baccata var. vespertina




\section{Artemisia nova-Artemisia tridentata Shrubland}

\section{Trees (>5 m)}

$\begin{array}{lll}\text { Perennial } & \text { JUOS } & \text { Juniperus } \\ \text { Perennial } & \text { PIMO } & \text { Pinus }\end{array}$

osteosperma

$0.9 \%$

Perennial

PIMO

monophylla

$0.3 \%$

\section{Tall Shrubs (2-5 m)}

Perennial ARTRT Artemisia

\section{Short Shrubs (0.5-2 m)}

\begin{tabular}{|c|c|c|}
\hline Perennial & ARNO4 & Artemisia \\
\hline Perennial & CHVIP4 & Chrysothamnus \\
\hline Perennial & CHVIV2 & Chrysothamnus \\
\hline Perennial & ERMIS2 & Eriogonum \\
\hline Perennial & EPNE & Ephedra \\
\hline Perennial & EPVI & Ephedra \\
\hline Perennial & ATCAC & Atriplex \\
\hline Perennial & GRSP & Grayia \\
\hline Perennial & CORA & Coleogyne \\
\hline Perennial & ERNA7 & Ericameria \\
\hline Perennial & PUGL2 & Purshia \\
\hline Perennial & ERNAH & Ericameria \\
\hline Perennial & SYLO & Symphoricarpos \\
\hline Perennial & ERNAL & Ericameria \\
\hline Perennial & KRLA2 & Krascheninnikovia \\
\hline Perennial & GUSA2 & Gutierrezia \\
\hline Perennial & LYAN & Lycium \\
\hline Perennial & ERFAP & Eriogonum \\
\hline Perennial & TECA2 & Tetradymia \\
\hline Perennial & CHVIS5 & Chrysothamnus \\
\hline Perennial & ATCO & Atriplex \\
\hline Perennial & TEAXA & Tetradymia \\
\hline Perennial & PUST & Purshia \\
\hline
\end{tabular}

tridentata ssp. tridentata

nova
viscidiflorus ssp. puberulus
viscidiflorus ssp. viscidiflorus
microthecum var. simpsonii
nevadensis
viridis
canescens var. canescens
spinosa
ramosissima
nanus
glandulosa
nauseosus ssp. nauseosus var.
hololeuca
longiflorus
nauseosus ssp. consimilis var.
leiosperma
lanata
sarothrae
andersonii
fasciculatum var. polifolium
canescens
viscidiflorus ssp. viscidiforus
var. stenophyllus
confertifolia
axillaris var. axillaris
stansburiana

Thursday, September 09, 1999 


\begin{tabular}{cllllr} 
Association & Longevity & ACODE2 & \multicolumn{1}{c}{ Genus } & \multicolumn{1}{c}{ Species } & Abundance \\
Perennial & ERCO23 & Ericameria & cooperi & $0.1 \%$ \\
Perennial & PSPO & Psorothamnus & polydenius & $0.1 \%$ \\
Perennial & PUTR2 & Purshia & tridentata & $0.1 \%$ \\
Perennial & RHTRA & Rhus & trilobata var. anisophylla & $0.0 \%$ \\
Perennial & TEGL & Tetradymia & glabrata & $0.0 \%$ \\
Perennial & GLSPA & Glossopetalon & spinescens var. aridum & $0.0 \%$ \\
Perennial & PRFA & Prunus & fasciculata & $0.0 \%$ \\
Perennial & SADOD3 & Salvia & donii ssp. domii var. domii & $0.0 \%$ \\
Perennial & STPIP & Stanleya & pinnata var. pinnata & $0.0 \%$
\end{tabular}

\section{Dwarf Shrubs $(<0.5 \mathrm{~m})$}

$\begin{array}{lll}\text { Perennial } & \text { LEPU } & \text { Leptodactylon } \\ \text { Perennial } & \text { ARSP5 } & \text { Artemisia }\end{array}$

pungens

$2.6 \%$

spinescens

$0.0 \%$

\section{Forbs}

$\begin{array}{lll}\text { Perennial } & \text { ARLU } & \text { Artemisia } \\ \text { Perennial } & \text { ERSA6 } & \text { Eriogonum } \\ \text { Perennial } & \text { ARDR4 } & \text { Artemisia } \\ \text { Perennial } & \text { BRCA3 } & \text { Brickellia } \\ \text { Perennial } & \text { POSU } & \text { Polygala }\end{array}$

Iudoviciana

saxatile

dracunculus

californica

subspinosa

echinocarpa var. echinocarpa

polyacantha var. rufispina

baccata var. vespertina

brevifolia
$0.1 \%$

$0.3 \%$

$0.1 \%$

$0.0 \%$

$0.0 \%$

$0.0 \%$

$0.1 \%$

$0.0 \%$

$0.0 \%$ 
Association Longevity ACODE2 Genus Species Abundance

Pinus monophylla/Artemisia nova Woodland

Trees (>5 m)

$\begin{array}{lll}\text { Perennial } & \text { PIMO } & \text { Pinus } \\ \text { Perennial } & \text { JUOS } & \text { Juniperus } \\ \text { Perennial } & \text { QUGA } & \text { Quercus }\end{array}$

monophylla

$13.8 \%$

osteosperma

$5.9 \%$

gambelii

$0.5 \%$

Tall Shrubs (2-5 m)

$\begin{array}{lll}\text { Perennial } & \text { ARTRT } & \text { Artemisia } \\ \text { Perennial } & \text { AMUT } & \text { Amelanchier }\end{array}$

tridentata ssp. tridentata

$2.7 \%$

utahensis

$0.0 \%$

\section{Short Shrubs (0.5-2 m)}

\begin{tabular}{|c|c|c|}
\hline Perennial & ARNO4 & Artemisia \\
\hline Perennial & CHVIV2 & Chrysothamnus \\
\hline Perennial & EPVI & Ephedra \\
\hline Perennial & ERMIS2 & Eriogonum \\
\hline Perennial & CHVIP4 & Chrysothamnus \\
\hline Perennial & ERNA7 & Ericameria \\
\hline Perennial & PUTR2 & Purshia \\
\hline Perennial & PUST & Purshia \\
\hline Perennial & EPNE & Ephedra \\
\hline Perennial & PUGL2 & Purshia \\
\hline Perennial & ATCAC & Atriplex \\
\hline Perennial & SYLO & Symphoricarpos \\
\hline Perennial & ERNAL & Ericameria \\
\hline Perennial & GRSP & Grayia \\
\hline Perennial & GUSA2 & Gutierrezia \\
\hline Perennial & ERLI6 & Ericameria \\
\hline Perennial & ERNA10 & Ericameria \\
\hline Perennial & CORA & Coleogyne \\
\hline Perennial & TEGL & Tetradymia \\
\hline Perennial & SADOD3 & Salvia \\
\hline Perennial & RIVEV & Ribes \\
\hline
\end{tabular}

\begin{tabular}{ll} 
nova & $55.3 \%$ \\
viscidiflorus ssp. viscidiforus & $3.6 \%$ \\
viridis & $2.2 \%$ \\
microthecum var. simpsonii & $1.9 \%$ \\
viscidiflorus ssp. puberulus & $1.7 \%$ \\
nanus & $1.7 \%$ \\
tridentata & $1.7 \%$ \\
stansburiana & $1.0 \%$ \\
nevadensis & $0.8 \%$ \\
glandulosa & $0.8 \%$ \\
canescens var. canescens & $0.5 \%$ \\
longiflorus & $0.5 \%$ \\
nauseosus ssp. consimilis var. & $0.5 \%$ \\
leiosperma & \\
spinosa & $0.5 \%$ \\
sarothrae & $0.4 \%$ \\
linearifolius & $0.3 \%$ \\
nauseosus & $0.2 \%$ \\
ramosissima & $0.1 \%$ \\
glabrata & $0.1 \%$ \\
dorii ssp. domii var. dorrii & $0.1 \%$ \\
velutinum var. velutinum & $0.0 \%$ \\
\hline
\end{tabular}


Association Longevity ACODE2

$\begin{array}{lll}\text { Perennial } & \text { ERFAP } & \text { Eriogonum } \\ \text { Perennial } & \text { KRLA2 } & \text { Krascheninnikovia } \\ \text { Perennial } & \text { RICEC2 } & \text { Ribes } \\ \text { Perennial } & \text { ERPAN2 } & \text { Ericameria } \\ \text { Perennial } & \text { ATCO } & \text { Atriplex } \\ \text { Perennial } & \text { ERNAH } & \text { Ericameria } \\ \text { Perennial } & \text { ERTE18 } & \text { Ericameria } \\ \text { Perennial } & \text { GLSPA } & \text { Glossopetalon } \\ \text { Perennial } & \text { LYAN } & \text { Lycium } \\ \text { Perennial } & \text { RHTRA } & \text { Rhus } \\ \text { Perennial } & \text { STPIP } & \text { Stanleya } \\ \text { Perennial } & \text { TEAXA } & \text { Tetradymia } \\ \text { Perennial } & \text { TECA2 } & \text { Tetradymia }\end{array}$

\section{Dwarf Shrubs ( $<0.5 \mathrm{~m})$}

$\begin{array}{lll}\text { Perennial } & \text { LEPU } & \text { Leptodactylon } \\ \text { Perennial } & \text { ARSP5 } & \text { Artemisia } \\ \text { Perennial } & \text { ERMIL } & \text { Eriogonum }\end{array}$

\section{Forbs}

$\begin{array}{lll}\text { Perennial } & \text { PEPU7 } & \text { Petradoria } \\ \text { Perennial } & \text { ARLU } & \text { Artemisia } \\ \text { Perennial } & \text { ERSA6 } & \text { Eriogonum } \\ \text { Perennial } & \text { ERUM } & \text { Eriogonum }\end{array}$

\section{Succulents}

$\begin{array}{lll}\text { Perennial } & \text { OPPOR } & \text { Opuntia } \\ \text { Perennial } & \text { YUBAV } & \text { Yucca } \\ \text { Perennial } & \text { OPECE } & \text { Opuntia }\end{array}$

$\begin{array}{ll}\text { fasciculatum var. polifolium } & 0.0 \% \\ \text { lanata } & 0.0 \% \\ \text { cereum var. cereum } & 0.0 \% \\ \text { parnyi var. nevadensis } & 0.0 \% \\ \text { confertifolia } & 0.0 \% \\ \text { nauseosus ssp. nauseosus var. } & 0.0 \% \\ \text { hololeuca } & 0.0 \% \\ \text { teretifolia } & 0.0 \% \\ \text { spinescens var. aridum } & 0.0 \% \\ \text { andersonii } & 0.0 \% \\ \text { trilobata var. anisophylla } & 0.0 \% \\ \text { pinnata var. pinnata } & 0.0 \% \\ \text { axillaris var. axillaris } & 0.0 \% \\ \text { canescens } & \end{array}$

pungens $\quad 2.5 \%$

$\begin{array}{ll}\text { spinescens } & 0.1 \%\end{array}$

microthecum var. lapidicola $\quad 0.0 \%$

$\begin{array}{ll}\text { pumila } & 0.0 \%\end{array}$

ludoviciana $\quad 0.0 \%$

saxatile $\quad 0.0 \%$

umbellatum $\quad 0.0 \%$

polyacantha var. rufispina $\quad 0.4 \%$

baccata var. vespertina $\quad 0.1 \%$

echinocarpa var. echinocarpa $\quad 0.0 \%$ 
Association Longevity ACODE2 Genus Species

Pinus monophylla/Artemisia tridentata Woodland

Trees (>5 m)

$\begin{array}{lll}\text { Perennial } & \text { PIMO } & \text { Pinus } \\ \text { Perennial } & \text { JUOS } & \text { Juniperus } \\ \text { Perennial } & \text { QUGA } & \text { Quercus }\end{array}$

monophylla

$21.5 \%$

osteosperma

$6.9 \%$

gambelii

$3.6 \%$

Tall Shrubs (2-5 $\mathrm{m})$

$\begin{array}{lll}\text { Perennial } & \text { ARTRT } & \text { Artemisia } \\ \text { Perennial } & \text { AMUT } & \text { Amelanchier } \\ \text { Perennial } & \text { CEGRV2 } & \text { Ceanothus } \\ \text { Perennial } & \text { AMPA2 } & \text { Amelanchier } \\ \text { Perennial } & \text { CEIN7 } & \text { Cercocarpus } \\ \text { Perennial } & \text { CELEL } & \text { Cercocarpus }\end{array}$

tridentata ssp. tridentata

$31.1 \%$

utahensis

$0.8 \%$

greggii ssp. vestitus

$0.0 \%$

pallida

$0.0 \%$

intricatus

$0.0 \%$

ledifolius var. ledifolius

$0.0 \%$

\section{Short Shrubs (0.5-2 m)}

$\begin{array}{lll}\text { Perennial } & \text { PUTR2 } & \text { Purshia } \\ \text { Perennial } & \text { ARNO4 } & \text { Artemisia } \\ \text { Perennial } & \text { EPVI } & \text { Ephedra } \\ \text { Perennial } & \text { CHVIV2 } & \text { Chrysothamnus } \\ \text { Perennial } & \text { CHVIP4 } & \text { Chrysothamnus } \\ \text { Perennial } & \text { PUST } & \text { Purshia } \\ \text { Perennial } & \text { SYLO } & \text { Symphoricarpos } \\ \text { Perennial } & \text { ERMIS2 } & \text { Eriogonum } \\ \text { Perennial } & \text { SADOD3 } & \text { Salvia } \\ \text { Perennial } & \text { ERNA7 } & \text { Ericameria } \\ \text { Perennial } & \text { ERNAL } & \text { Ericameria } \\ \text { Perennial } & \text { RICEC2 } & \text { Ribes } \\ \text { Perennial } & \text { ERCO23 } & \text { Ericameria } \\ \text { Perennial } & \text { ERNA10 } & \text { Ericameria } \\ \text { Perennial } & \text { PUGL2 } & \text { Purshia } \\ \text { Perennial } & \text { CHGR6 } & \text { Chrysothamnus } \\ \text { Perennial } & \text { CORA } & \text { Coleogyne }\end{array}$

tridentata
nova
vinidis
viscidiflorus ssp. viscidiflorus
viscidiflorus ssp. puberulus
stansburiana
Jongiflorus
microthecum var. simpsonii
dorii ssp. domii var. domii
nanus
nauseosus ssp. consimilis var.
leiosperma
cereum var. cereum
cooperi
nauseosus
glandulosa
greenei
ramosissima

$4.6 \%$ $3.9 \%$

$3.8 \%$

$3.7 \%$

$2.9 \%$

$2.8 \%$

$1.9 \%$

$1.8 \%$

$1.1 \%$

$0.4 \%$

$0.4 \%$

$0.4 \%$

$0.4 \%$

$0.3 \%$

$0.3 \%$

$0.3 \%$

$0.2 \%$

Thursday, September 09, 1999

Page 42 of 44 


$\begin{array}{lll}\text { Perennial } & \text { RIVEV } & \text { Ribes } \\ \text { Perennial } & \text { ERFAP } & \text { Eriogonum } \\ \text { Perennial } & \text { ERNAH } & \text { Ericameria } \\ \text { Perennial } & \text { GUSA2 } & \text { Gutierrezia } \\ \text { Perennial } & \text { EPNE } & \text { Ephedra } \\ \text { Perennial } & \text { TEGL } & \text { Tetradymia } \\ \text { Perennial } & \text { GRSP } & \text { Grayia } \\ \text { Perennial } & \text { ATCAC } & \text { Atriplex } \\ \text { Perennial } & \text { RHTRA } & \text { Rhus } \\ \text { Perennial } & \text { ATCO } & \text { Atriplex } \\ \text { Perennial } & \text { ERPA29 } & \text { Ericameria } \\ \text { Perennial } & \text { HODI } & \text { Holodiscus } \\ \text { Perennial } & \text { PRFA } & \text { Prunus } \\ \text { Perennial } & \text { TECA2 } & \text { Tetradymia } \\ \text { Perennial } & \text { ERLI6 } & \text { Ericameria } \\ \text { Perennial } & \text { KRLA2 } & \text { Krascheninnikovia } \\ \text { Perennial } & \text { ERPAN2 } & \text { Ericameria } \\ \text { Perennial } & \text { ERTE18 } & \text { Ericameria }\end{array}$

velutinum var. velutinum
fasciculatum var. polifolium
nauseosus ssp. nauseosus var.
hololeuca
sarothrae
nevadensis
glabrata
spinosa
canescens var. canescens
trilobata var. anisophylla
confertifolia
paniculata
discolor
fasciculata
canescens
linearifolius
lanata
parryi var. nevadensis
teretifolia

$0.2 \%$

$0.2 \%$

$0.1 \%$

$0.1 \%$

$0.1 \%$

$0.1 \%$

$0.1 \%$

$0.0 \%$

$0.0 \%$

$0.0 \%$

$0.0 \%$

$0.0 \%$

$0.0 \%$

$0.0 \%$

$0.0 \%$

$0.0 \%$

$0.0 \%$

$0.0 \%$

Dwarf Shrubs (<0.5 m)

$\begin{array}{lll}\text { Perennial } & \text { LEPU } & \text { Leptodactylon } \\ \text { Perennial } & \text { ARSP5 } & \text { Artemisia } \\ \text { Perennial } & \text { ERMIL } & \text { Eriogonum }\end{array}$

pungens

$4.6 \%$

spinescens

$0.4 \%$

microthecum var. lapidicola

$0.0 \%$

\section{Forbs}

$\begin{array}{lll}\text { Perennial } & \text { CHGR13 } & \text { Chrysothamnus } \\ \text { Perennial } & \text { ERUMS2 } & \text { Eriogonum } \\ \text { Perennial } & \text { PEPU7 } & \text { Petradoria } \\ \text { Perennial } & \text { ERSA6 } & \text { Eriogonum } \\ \text { Perennial } & \text { ERUMV } & \text { Eriogonum } \\ \text { Perennial } & \text { ERUMV2 } & \text { Eriogonum }\end{array}$

Thursday, September 09, 1999

Page 43 of 44 


\section{Succulents}

$\begin{array}{lll}\text { Perennial } & \text { OPPOR } & \text { Opuntia } \\ \text { Perennial } & \text { OPERE } & \text { Opuntia } \\ \text { Perennial } & \text { YUBAV } & \text { Yucca } \\ \text { Perennial } & \text { YUBR } & \text { Yucca }\end{array}$

polyacantha var. rufispina

$0.2 \%$

erinacea var. erinacea

$0.1 \%$

baccata var. vespertina

$0.1 \%$

brevifolia

$0.0 \%$ 


\section{This Page Intentionally Left Blank}




\section{Appendix F}

\section{Percent Frequency of NTS Plant Species by Alliance}

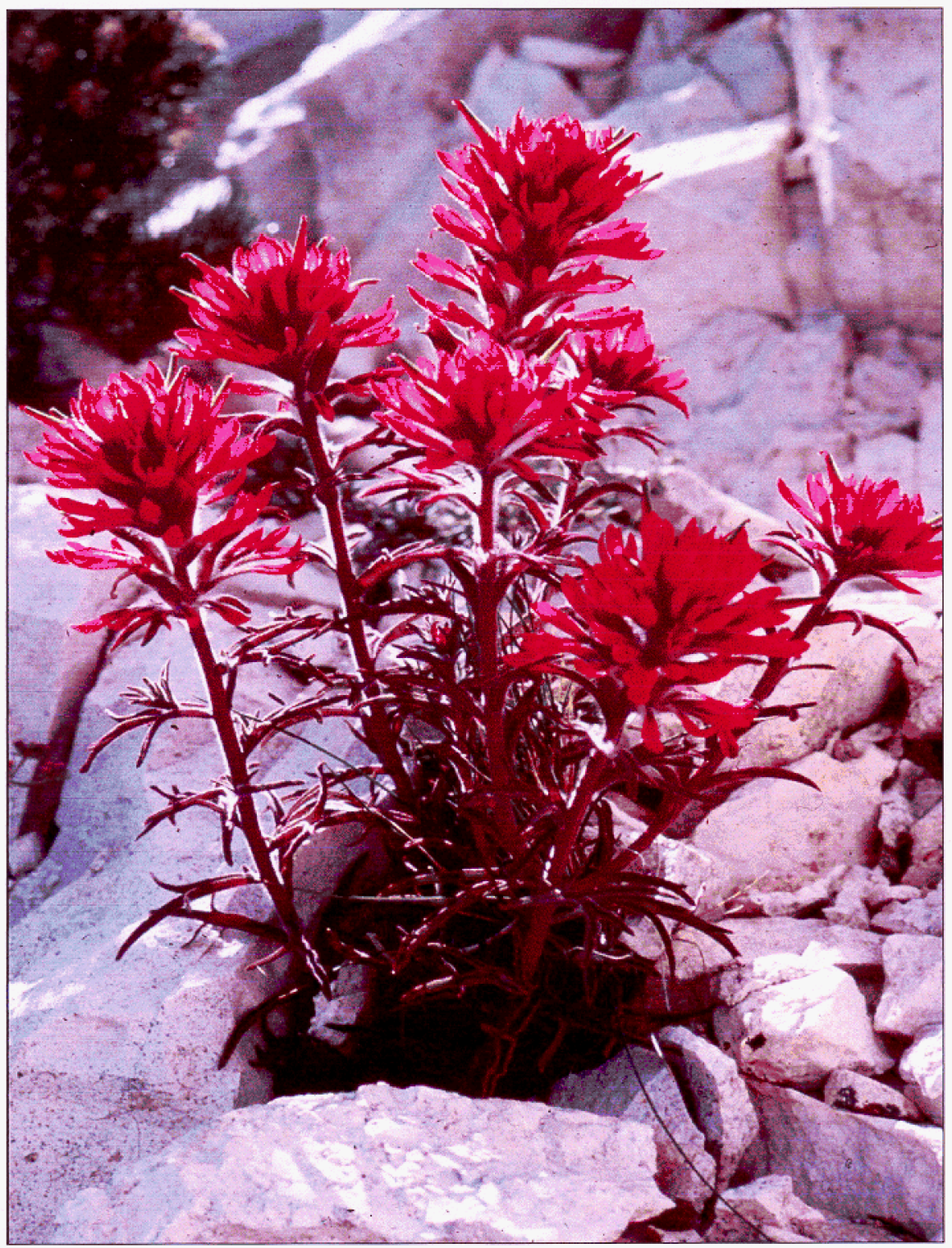

Wavyleaf Indian paintbrush (Castelleja applegatei) [photo by Susan Cochrane] 
This Page Intentionally Left Blank 


\section{Appendix F}

\section{Percent Frequency of NTS Plant Species by Alliance}

Lifeform Longevity ACODE

Genus

Species

Frequency

\section{Lycium spp. Shrubland Alliance}

\section{Short Shrubs (0.5-2 m)}

$\begin{array}{lll}\text { Perennial } & \text { KRLA2 } & \text { Krascheninnikovia } \\ \text { Perennial } & \text { AMDU2 } & \text { Ambrosia } \\ \text { Perennial } & \text { ATCAC } & \text { Atriplex } \\ \text { Perennial } & \text { ATCO } & \text { Atriplex } \\ \text { Perennial } & \text { LYSH } & \text { Lycium } \\ \text { Perennial } & \text { ACSH } & \text { Acamptopappus } \\ \text { Perennial } & \text { HYSA } & \text { Hymenoclea } \\ \text { Perennial } & \text { LYPAO } & \text { Lycium } \\ \text { Perennial } & \text { CHVIV2 } & \text { Chrysothamnus } \\ \text { Perennial } & \text { GRSP } & \text { Grayia } \\ \text { Perennial } & \text { STPIP } & \text { Stanleya } \\ \text { Perennial } & \text { TEAXA } & \text { Tetradymia }\end{array}$

lanata
dumosa
canescens var. canescens
confertifolia
shockleyi
shockleyi
salsola
pallidum var. oligospermum
viscidiflorus ssp. viscidifforus
spinosa
pinnata var. pinnata
axillaris var. axillaris

$80.0 \%$

$60.0 \%$

$60.0 \%$

$60.0 \%$

$60.0 \%$

$40.0 \%$

$40.0 \%$

$40.0 \%$

$20.0 \%$

$20.0 \%$

$20.0 \%$

$20.0 \%$

Dwarf Shrubs ( $<0.5 \mathrm{~m}$ )

$\begin{array}{lll}\text { Perennial } & \text { ARSP5 } & \text { Artemisia } \\ \text { Perennial } & \text { KOAM } & \text { Kochia }\end{array}$

spinescens

$40.0 \%$

americana

$20.0 \%$

\section{Graminoids}

$\begin{array}{lll}\text { Perennial } & \text { ACHY } & \text { Achnatherum } \\ \text { Annual } & \text { BRRU2 } & \text { Bromus } \\ \text { Perennial } & \text { ELELE } & \text { Elymus }\end{array}$

hymenoides
rubens

$100.0 \%$

$80.0 \%$

elymoides ssp. elymoides

\section{Forbs}

$\begin{array}{lll}\text { Annual } & \text { AMTE3 } & \text { Amsinckia } \\ \text { Annual } & \text { ASLEF2 } & \text { Astragalus } \\ \text { Perennial } & \text { BAMU } & \text { Baileya } \\ \text { Annual } & \mathrm{CRCl} 2 & \text { Cryptantha } \\ \text { Annual } & \text { ERER2 } & \text { Eriastrum }\end{array}$

tessellata
lentiginosus var. fremontii
multiradiata
circumscissa
eremicum

$40.0 \%$

$40.0 \%$

$40.0 \%$

$40.0 \%$

$40.0 \%$ 
Lifeform Longevity ACODE

Genus

\begin{tabular}{|c|c|c|}
\hline Perennial & ERIN4 & Eriogonum \\
\hline Annual & LELA & Lepidium \\
\hline Perennial & MACAC & Machaeranthera \\
\hline Annual & MAGL3 & Malacothrix \\
\hline Annual & MEAL6 & Mentzelia \\
\hline Perennial & MIPU5 & Mirabilis \\
\hline Annual & OEPR & Oenothera \\
\hline Perennial & SPAMA & Sphaeralcea \\
\hline Perennial & STPA4 & Stephanomeria \\
\hline Perennial & ARPUM & Arabis \\
\hline Annual & CETH3 & Centrostegia \\
\hline Annual & CHFR & Chaenactis \\
\hline Annual & CHST & Chaenactis \\
\hline Perennial & CHAL11 & Chamaesyce \\
\hline Annual & CRNEN & Cryptantha \\
\hline Annual & CRPT & Cryptantha \\
\hline Annual & DEPIG & Descurainia \\
\hline Annual & DESO2 & Descurainia \\
\hline Annual & ERMA2 & Eriogonum \\
\hline Annual & ERNI4 & Eriogonum \\
\hline Annual & ESGL & Eschscholzia \\
\hline Annual & IPPO2 & Ipomopsis \\
\hline Annual & LASE3 & Langloisia \\
\hline Annual & LAOCO & Lappula \\
\hline Perennial & OECA2 & Oenothera \\
\hline Annual & OXPE2 & Oxytheca \\
\hline Perennial & Posu & Polygala \\
\hline Annual & SAPA8 & Salsola \\
\hline
\end{tabular}

Species

inflatum
lasiocarpum
canescens ssp. canescens
glabrata
albicaulis
pudica
primiveris
ambigua ssp. ambigua
pauciflora
pulchra var. munciensis
thurberi
fremontii
stevioides
albomarginata
nevadensis var. nevadensis
pterocarya
pinnata ssp. glabra
sophia
maculatum
nidularium
glyptosperma
polycladon
setosissima
occidentalis var. occidentalis
califomica spp. avita
perfoliata
subspinosa
paulsenii
pol

Frequency

$40.0 \%$

$40.0 \%$

$40.0 \%$

$40.0 \%$

$40.0 \%$

$40.0 \%$

$40.0 \%$

$40.0 \%$

$40.0 \%$

$20.0 \%$

$20.0 \%$

$20.0 \%$

$20.0 \%$

$20.0 \%$

$20.0 \%$

$20.0 \%$

$20.0 \%$

$20.0 \%$

$20.0 \%$

$20.0 \%$

$20.0 \%$

$20.0 \%$

$20.0 \%$

$20.0 \%$

$20.0 \%$

$20.0 \%$

$20.0 \%$

$20.0 \%$ 
Lifeform Longevity ACODE Genus Species

Frequency

\section{Larrea tridentata/Ambrosia dumosa Shrubland Alliance}

\section{Tall Shrubs (2-5 m)}

$\begin{array}{llll}\text { Perennial LATR2 Larrea } & \text { tridentata }\end{array}$

Short Shrubs (0.5-2 m)

\begin{tabular}{|c|c|c|}
\hline Perennial & AMDU2 & Ambrosia \\
\hline Perennial & EPNE & Ephedra \\
\hline Perennial & KRLA2 & Krascheninnikovia \\
\hline Perennial & LYAN & Lycium \\
\hline Perennial & GRSP & Grayia \\
\hline Perennial & LYPAO & Lycium \\
\hline Perennial & $\mathrm{ACSH}$ & Acamptopappus \\
\hline Perennial & ATCO & Atriplex \\
\hline Perennial & HYSA & Hymenoclea \\
\hline Perennial & PSFRF & Psorothamnus \\
\hline Perennial & CORA & Coleogyne \\
\hline Perennial & SAME & Salazaria \\
\hline Perennial & ENVIV & Encelia \\
\hline Perennial & ERCO23 & Ericameria \\
\hline Perennial & ERFAP & Eriogonum \\
\hline Perennial & THMO & Thamnosma \\
\hline Perennial & LEFR2 & Lepidium \\
\hline Perennial & LYSH & Lycium \\
\hline Perennial & ATCAC & Atriplex \\
\hline Perennial & CHVIV2 & Chrysothamnus \\
\hline Perennial & GUSA2 & Gutierrezia \\
\hline Perennial & TEAXA & Tetradymia \\
\hline Perennial & EPFU & Ephedra \\
\hline Perennial & PSPO & Psorothamnus \\
\hline Perennial & STPIP & Stanleya \\
\hline Perennial & ERTE18 & Ericameria \\
\hline Perennial & ATPO & Atriplex \\
\hline
\end{tabular}

dumosa
nevadensis
lanata
andersonii
spinosa
pallidum var. oligospermum
shockleyi
confertifolia
salsola
fremontii var. fremontii
ramosissima
mexicana
virginensis var. virginensis
cooperi
fasciculatum var. polifolium
montana
fremontii
shockleyi
canescens var. canescens
viscidiflorus ssp. viscidiflorus
sarothrae
axillaris var. axillaris
funerea
polydenius
pinnata var. pinnata
teretifolia
polycarpa

$99.3 \%$

$80.2 \%$

$58.7 \%$

$53.4 \%$

$51.6 \%$

$47.7 \%$

$44.2 \%$

$32.9 \%$

$29.7 \%$

$27.6 \%$

$17.0 \%$

$16.3 \%$

$14.5 \%$

$11.0 \%$

$9.2 \%$

$9.2 \%$

$8.8 \%$

$8.8 \%$

$7.4 \%$

$4.6 \%$

$4.6 \%$

$3.2 \%$

$2.8 \%$

$2.8 \%$

$2.8 \%$

$2.5 \%$

$1.4 \%$

Wednesday, January 05, 2000

Page 3 of 71 
Lifeform Longevity ACODE

$\begin{array}{lll}\text { Perennial } & \text { EPTO } & \text { Ephedra } \\ \text { Perennial } & \text { EPVI } & \text { Ephedra } \\ \text { Perennial } & \text { TECA2 } & \text { Tetradymia } \\ \text { Perennial } & \text { BRMIW } & \text { Brickellia } \\ \text { Perennial } & \text { ERPA29 } & \text { Ericameria } \\ \text { Perennial } & \text { AMER } & \text { Ambrosia } \\ \text { Perennial } & \text { ATHY } & \text { Atriplex } \\ \text { Perennial } & \text { ERNAL } & \text { Ericameria } \\ \text { Perennial } & \text { TEGL } & \text { Tetradymia }\end{array}$

\section{Species}

torreyana
viridis
canescens
microphylla var. watsonii
paniculata
eriocentra
hymenelytra
nauseosus ssp. consimilis var.
glabrata

Frequency
$1.4 \%$
$1.1 \%$
$1.1 \%$
$0.7 \%$
$0.7 \%$
$0.4 \%$
$0.4 \%$
$0.4 \%$
$0.4 \%$

\section{Dwarf Shrubs ( $<0.5 \mathrm{~m})$}

$\begin{array}{lll}\text { Perennial } & \text { KRER } & \text { Krameria } \\ \text { Perennial } & \text { MESP2 } & \text { Menodora } \\ \text { Perennial } & \text { ARSP5 } & \text { Artemisia } \\ \text { Perennial } & \text { ERWA8 } & \text { Ericameria } \\ \text { Perennial } & \text { LEPU } & \text { Leptodactylon }\end{array}$

\section{erecta}

$61.8 \%$

spinescens

$21.2 \%$

spinescens

$4.2 \%$

watsonii

$0.7 \%$

pungens

$0.4 \%$

\section{Graminoids}

$\begin{array}{lll}\text { Annual } & \text { BRRU2 } & \text { Bromus } \\ \text { Perennial } & \text { ACHY } & \text { Achnatherum } \\ \text { Perennial } & \text { ACSP12 } & \text { Achnatherum } \\ \text { Annual } & \text { SCAR } & \text { Schismus } \\ \text { Annual } & \text { VUOC } & \text { Vulpia } \\ \text { Perennial } & \text { ERPU8 } & \text { Erioneuron } \\ \text { Annual } & \text { BRTE } & \text { Bromus } \\ \text { Perennial } & \text { PLRI3 } & \text { Pleuraphis } \\ \text { Perennial } & \text { ELELE } & \text { Elymus } \\ \text { Annual } & \text { BRCA6 } & \text { Bromus } \\ \text { Perennial } & \text { ARPU9 } & \text { Aristida }\end{array}$

rubens
hymenoides
speciosum
arabicus
octoflora
pulchellum
tectorum
rigida
elymoides ssp. elymoides
cartharticus
purpurea

$87.6 \%$

$51.9 \%$

$23.7 \%$

$10.6 \%$

$9.9 \%$

$9.2 \%$

$3.9 \%$

$3.5 \%$

$2.5 \%$

$1.4 \%$

$0.4 \%$

Forbs

$\begin{array}{lll}\text { Annual } & \text { AMTE3 } & \text { Amsinckia } \\ \text { Perennial } & \text { ERIN4 } & \text { Eriogonum } \\ \text { Perennial } & \text { XYTOT } & \text { Xylorhiza }\end{array}$

Wednesday, January 05, 2000 tessellata $\quad 59.4 \%$

inflatum $\quad 51.2 \%$

tortifolia var. imberbis $\quad 33.6 \%$ 


\begin{tabular}{|c|c|c|c|}
\hline Lifeform & Longevity & $A C O D E$ & Genus \\
\hline & Annual & LUSH & Lupinus \\
\hline & Perennial & SPAMA & Sphaeralcea \\
\hline & Annual & MAGL3 & Malacothrix \\
\hline & Annual & CHRI & Chorizanthe \\
\hline & Annual & ERER2 & Eriastrum \\
\hline & Annual & CRNEN & Cryptantha \\
\hline & Annual & CHFR & Chaenactis \\
\hline & Annual & $\mathrm{CRCl} 2$ & Cryptantha \\
\hline & Perennial & ASLA8 & Astragalus \\
\hline & Annual & CRPT & Cryptantha \\
\hline & Annual & CHST & Chaenactis \\
\hline & Annual & LELA & Lepidium \\
\hline & Annual & OXPE2 & Oxytheca \\
\hline & Perennial & DEPAP3 & Delphinium \\
\hline & Annual & LUFL & Lupinus \\
\hline & Annual & PHFR2 & Phacelia \\
\hline & Annual & LASE3 & Langloisia \\
\hline & Annual & DEPIG & Descurainia \\
\hline & Annual & RANE & Rafinesquia \\
\hline & Annual & STEXE & Stephanomeria \\
\hline & Annual & PHVAV2 & Phacelia \\
\hline & Annual & CABRB4 & Camissonia \\
\hline & Annual & $\mathrm{ERCI6}$ & Erodium \\
\hline & Annual & ERPR4 & Eriophyllum \\
\hline & Annual & STLO4 & Streptanthella \\
\hline & Annual & ASLEF2 & Astragalus \\
\hline & Perennial & STPA4 & Stephanomeria \\
\hline & Annual & ASAC3 & Astragalus \\
\hline & Annual & ERTH & Eriogonum \\
\hline & Annual & CABOC & Camissonia \\
\hline & Annual & GILIA & Gilia \\
\hline & Annual & СЕТНЗ & Centrostegia \\
\hline & Annual & MEOB3 & Mentzelia \\
\hline
\end{tabular}

Species

shockleyi

ambigua ssp. ambigua

glabrata

rigida

eremicum

nevadensis var. nevadensis

fremontii

circumscissa

layneae

pterocarya

stevioides

lasiocarpum

perfoliata

parishii ssp. parishii

flavoculatus

fremontii

setosissima

pinnata ssp. glabra

neomexicana

exigua ssp. exigua

vallis-mortae var. vallis-mortae

brevipes ssp. brevipes

cicutarium

pringlei

longimstris

lentiginosus var. fremontii

pauciffora

acutirostris

thomasii

boothii ssp. condensata

thumber

obscura
Frequency

$26.5 \%$

$25.8 \%$

$25.4 \%$

$19.8 \%$

$17.7 \%$

$15.2 \%$

$14.5 \%$

$14.1 \%$

$13.4 \%$

$13.1 \%$

$12.4 \%$

$12.0 \%$

$12.0 \%$

$11.7 \%$

$11.7 \%$

$11.7 \%$

$11.0 \%$

$10.6 \%$

$9.5 \%$

$9.5 \%$

$9.2 \%$

$8.8 \%$

$8.8 \%$

$8.5 \%$

$8.5 \%$

$7.8 \%$

$7.1 \%$

$6.7 \%$

$6.7 \%$

$6.4 \%$

$6.4 \%$

$5.3 \%$

$5.3 \%$

Wednesday, January 05, 2000

Page 5 of 71 


\begin{tabular}{|c|c|c|c|}
\hline \multirow[t]{34}{*}{ Lifeform } & Longevity & $A C O D E$ & Genus \\
\hline & Annual & $\mathrm{CHCA}$ & Chaenactis \\
\hline & Annual & CHBRB & Chorizanthe \\
\hline & Perennial & GIBRB & Gilia \\
\hline & Annual & IPPO2 & Ipomopsis \\
\hline & Perennial & BAMU & Baileya \\
\hline & Perennial & CRUT & Cryptantha \\
\hline & Annual & ERDE6 & Eriogonum \\
\hline & Perennial & MIBI8 & Mirabilis \\
\hline & Annual & PESE & Pectocarya \\
\hline & Perennial & SPAMR & Sphaeralcea \\
\hline & Annual & ESGL & Eschscholzia \\
\hline & Perennial & GICAS & Gilia \\
\hline & Annual & NAPU & Nama \\
\hline & Annual & PLOV & Plantago \\
\hline & Perennial & CHAL11 & Chamaesyce \\
\hline & Annual & CRMI & Cryptantha \\
\hline & Annual & MOBE & Monoptilon \\
\hline & Annual & OEPR & Oenothera \\
\hline & Annual & ESMI & Eschscholzia \\
\hline & Annual & LIDE2 & Linanthus \\
\hline & Annual & MASO & Malacothrix \\
\hline & Perennial & DIPU3 & Dichelostemma \\
\hline & Annual & ERNI4 & Eriogonum \\
\hline & Annual & PEPL & Pectocarya \\
\hline & Perennial & POSU & Polygala \\
\hline & Perennial & STPA3 & Stephanomeria \\
\hline & Perennial & CAPI4 & Caulanthus \\
\hline & Perennial & CRVI5 & Cryptantha \\
\hline & Annual & LOHU2 & Lotus \\
\hline & Perennial & CAFL & Calochortus \\
\hline & Annual & CAKEG & Camissonia \\
\hline & Perennial & CAAP4 & Castilleja \\
\hline & Perennial & LEMOC & Lepidium \\
\hline
\end{tabular}

Wednesday, January 05, 2000

\section{Species}

carphoclinia
brevicormu var. brevicomu
brecciarum ssp. brecciarum
polycladon
multiradiata
utahensis
deflexum
bigelovii
setosa
ambiguua var. rugosa
glyptosperma
cana ssp. speciformis
pusillum
ovata
albomarginata
micrantha
bellidiforme
primiveris
minutiflora
demissus
sonchoides
pulchellum
nidularium
platycarpa
subspinosa
parmyi
pilosus
virginensis
humistratus
flexuosus
kemensis ssp. gilmanii
montanum var. canescens

Frequency

$4.9 \%$

$4.9 \%$

$4.9 \%$

$4.6 \%$

$4.2 \%$

$4.2 \%$

$4.2 \%$

$4.2 \%$

$4.2 \%$

$4.2 \%$

$3.9 \%$

$3.9 \%$

$3.5 \%$

$3.5 \%$

$3.2 \%$

$2.8 \%$

$2.8 \%$

$2.8 \%$

$2.5 \%$

$2.5 \%$

$2.5 \%$

$2.1 \%$

$2.1 \%$

$2.1 \%$

$2.1 \%$

$2.1 \%$

$1.8 \%$

$1.8 \%$

$1.8 \%$

$1.4 \%$

$1.4 \%$

$1.4 \%$

$1.4 \%$

Page 6 of 71 


\section{Genus}

\begin{tabular}{|c|c|c|}
\hline Perennial & MACAC & Machaeranthera \\
\hline Annual & MEAL6 & Mentzelia \\
\hline Annual & PHCRC3 & Phacelia \\
\hline Biennial & SIAL2 & Sisymbrium \\
\hline Perennial & ARPUM & Arabis \\
\hline Annual & ASDID & Astragalus \\
\hline Annual & CACLI & Camissonia \\
\hline Perennial & DEAN & Delphinium \\
\hline Annual & ERSP3 & Eriastrum \\
\hline Annual & ERPU6 & Eriogonum \\
\hline Annual & LUBR2 & Lupinus \\
\hline Annual & MOBE2 & Monoptilon \\
\hline Annual & NEGLO & Nemacladus \\
\hline Annual & ANAC & Anisocoma \\
\hline Perennial & CAAPM & Castilleja \\
\hline Biennial & CINE & Cirsium \\
\hline Perennial & DAMO2 & Dalea \\
\hline Annual & DESO2 & Descurainia \\
\hline Perennial & ERCOC3 & Erigeron \\
\hline Annual & ERMA2 & Eriogonum \\
\hline Annual & ERTR8 & Eriogonum \\
\hline Perennial & GISC & Gilia \\
\hline Perennial & OECA2 & Oenothera \\
\hline Annual & OEDED4 & Oenothera \\
\hline Annual & PHSA & Phacelia \\
\hline Annual & SYFR & Syntrichopappus \\
\hline Perennial & ABEL & Abronia \\
\hline Perennial & $\mathrm{ADCO} 2$ & Adenophyllum \\
\hline Perennial & ASER2 & Asclepias \\
\hline Perennial & ASTI & Astragalus \\
\hline Perennial & BRAT & Brickellia \\
\hline Annual & CAHE12 & Camissonia \\
\hline Annual & CARE2 & Camissonia \\
\hline
\end{tabular}

\section{Species}

canescens ssp. canescens

albicaulis

crenulata var. crenulata

altissimum

pulchra var. munciensis

didymocarpus var. dispermus

claviformis ssp. integrior

andersonii

sparsiflorum

pusillum

brevicaulis

bellioides

glanduliferus var. orientalis

acaulis

applegatei ssp. martinii

neomexicanum

mollissima

sophia

concinnus var. concinnus

maculatum

trichopes

scopulorum

califomica spp. avita

deltoides ssp. deltoides

saxicola

fremontii

elliptica

cooperi

erosa

tidestromii

atractyloides

heterochroma

refracta
Frequency

$1.4 \%$

$1.4 \%$

$1.4 \%$

$1.4 \%$

$1.1 \%$

$1.1 \%$

$1.1 \%$

$1.1 \%$

$1.1 \%$

$1.1 \%$

$1.1 \%$

$1.1 \%$

$1.1 \%$

$0.7 \%$

$0.7 \%$

$0.7 \%$

$0.7 \%$

$0.7 \%$

$0.7 \%$

$0.7 \%$

$0.7 \%$

$0.7 \%$

$0.7 \%$

$0.7 \%$

$0.7 \%$

$0.7 \%$

$0.4 \%$

$0.4 \%$

$0.4 \%$

$0.4 \%$

$0.4 \%$

$0.4 \%$

$0.4 \%$

Wednesday, January 05, 2000

Page 7 of 71 


\begin{tabular}{|c|c|c|c|}
\hline \multirow[t]{23}{*}{ Lifeform } & Longevity & $A C O D E$ & Genus \\
\hline & Annual & CACO18 & Caulanthus \\
\hline & Annual & CHMA & Chaenactis \\
\hline & Annual & CRMA7 & Cryptantha \\
\hline & Annual & CRRE5 & Cryptantha \\
\hline & Perennial & ERRA3 & Eriogonum \\
\hline & Perennial & GICAT & Gilia \\
\hline & Perennial & GILE3 & Gilia \\
\hline & Perennial & HEMUN & Heliomeris \\
\hline & Annual & LEFLF2 & Lepidium \\
\hline & Annual & LIDI2 & Linanthus \\
\hline & Annual & LOSC6 & Loeseliastrum \\
\hline & Perennial & LOSC3 & Lomatium \\
\hline & Annual & MEVE5 & Mentzelia \\
\hline & Perennial & MIPU5 & Mirabilis \\
\hline & Annual & NADED & Nama \\
\hline & Perennial & OECEM4 & Oenothera \\
\hline & Annual & PERE & Pectocarya \\
\hline & Annual & PREX & Prenanthella \\
\hline & Annual & SAPAB & Salsola \\
\hline & Annual & SACOC & Salvia \\
\hline & Perennial & SPGRP2 & Sphaeralcea \\
\hline & Perennial & STCOC & Streptanthus \\
\hline
\end{tabular}

\section{Species}

cooperi

macrantha

maritima

recurvata

racemosum

cana ssp. triceps

leptomeria

multiflora var. nevadensis

flavum var. flavum

dichotomus

schottii

scabrum

veatchiana

pudica

demissum var. demissum

caespitosa ssp. marginata

recurvata

exigua

paulsenii

columbariae var. columbariae

grossulariaefolia ssp. pedata

cordatus var. cordatus

denticulata var. vetchii

Perennial CUDEV Cuscuta

\section{Succulents}

$\begin{array}{lll}\text { Perennial } & \text { OPECE } & \text { Opuntia } \\ \text { Perennial } & \text { OPBAB2 } & \text { Opuntia } \\ \text { Perennial } & \text { YUBR } & \text { Yucca } \\ \text { Perennial } & \text { ECPO2 } & \text { Echinocactus } \\ \text { Perennial } & \text { YUSC2 } & \text { Yucca } \\ \text { Perennial } & \text { ECEN } & \text { Echinocereus }\end{array}$

Wednesday, January 05, 2000

Frequency

$0.4 \%$

$0.4 \%$

$0.4 \%$

$0.4 \%$

$0.4 \%$

$0.4 \%$

$0.4 \%$

$0.4 \%$

$0.4 \%$

$0.4 \%$

$0.4 \%$

$0.4 \%$

$0.4 \%$

$0.4 \%$

$0.4 \%$

$0.4 \%$

$0.4 \%$

$0.4 \%$

$0.4 \%$

$0.4 \%$

$0.4 \%$

$0.4 \%$

\section{Epiphytes}




\section{Lifeform Longevity ACODE Genus}

\section{Species}

Frequency

$\begin{array}{lll}\text { Perennial } & \text { OPRA } & \text { Opuntia } \\ \text { Perennial } & \text { OPERE } & \text { Opuntia } \\ \text { Perennial } & \text { ECTRM } & \text { Echinocereus } \\ \text { Perennial } & \text { MATE4 } & \text { Mammillaria }\end{array}$

ramosissima

$3.5 \%$

erinacea var. erinacea

$1.1 \%$

triglochidiatus var. melanacanthus

$0.4 \%$

tetrancistra

$0.4 \%$

\section{Variable}

$\begin{array}{lll}\text { Variable } & \text { ERIOG } & \text { Eriogonum } \\ \text { Variable } & \text { MENTZ } & \text { Mentzelia }\end{array}$

$2.8 \%$

$1.1 \%$ 


\section{Atriplex confertifolia-Ambrosia dumosa Shrubland Alliance}

\section{Tall Shrubs (2-5 m)}

$\begin{array}{lll}\text { Perennial } & \text { LATR2 } & \text { Larrea } \\ \text { Perennial } & \text { ARTRT } & \text { Artemisia }\end{array}$

tridentata

$73.5 \%$

tridentata ssp. tridentata

$2.0 \%$

\section{Short Shrubs (0.5-2 m)}

\begin{tabular}{|c|c|c|}
\hline Perennial & ATCO & Atriplex \\
\hline Perennial & AMDU2 & Ambrosia \\
\hline Perennial & EPNE & Ephedra \\
\hline Perennial & LYAN & Lycium \\
\hline Perennial & CORA & Coleogyne \\
\hline Perennial & KRLA2 & Krascheninnikovia \\
\hline Perennial & LYPAO & Lycium \\
\hline Perennial & LEFR2 & Lepidium \\
\hline Perennial & PSFRF & Psorothamnus \\
\hline Perennial & $\mathrm{ACSH}$ & Acamptopappus \\
\hline Perennial & ENVIV & Encelia \\
\hline Perennial & THMO & Thamnosma \\
\hline Perennial & GUSA2 & Gutierrezia \\
\hline Perennial & HYSA & Hymenoclea \\
\hline Perennial & CHVIV2 & Chrysothamnus \\
\hline Perennial & ERFAP & Eriogonum \\
\hline Perennial & GRSP & Grayia \\
\hline Perennial & SAME & Salazania \\
\hline Perennial & ERCO23 & Ericameria \\
\hline Perennial & ERTE18 & Ericameria \\
\hline Perennial & ЕРTO & Ephedra \\
\hline Perennial & TEAXA & Tetradymia \\
\hline Perennial & BRMIW & Brickellia \\
\hline Perennial & STPIP & Stanleya \\
\hline Perennial & ATHY & Atriplex \\
\hline Perennial & EPVI & Ephedra \\
\hline
\end{tabular}

\begin{tabular}{l} 
confertifolia \\
dumosa \\
nevadensis \\
andersonii \\
ramosissima \\
lanata \\
pallidum var. oligospermum \\
fremontii \\
fremontii var. fremontii \\
shockleyi \\
virginensis var. virginensis \\
montana \\
sarothrae \\
salsola \\
viscidiflorus ssp. viscidiflorus \\
fasciculatum var. polifolium \\
spinosa \\
mexicana \\
coopen \\
teretifolia \\
torreyana \\
axillaris var. axillaris \\
microphylla var. watsonii \\
pinnata var. pinnata \\
hymenelytra \\
viridis \\
\hline
\end{tabular}

$100.0 \%$

$93.9 \%$

$89.8 \%$

$57.1 \%$

$49.0 \%$

$49.0 \%$

$42.9 \%$

$40.8 \%$

$32.7 \%$

$24.5 \%$

$22.4 \%$

$22.4 \%$

$20.4 \%$

$18.4 \%$

$14.3 \%$

$14.3 \%$

$14.3 \%$

$14.3 \%$

$12.2 \%$

$12.2 \%$

$102 \%$

$10.2 \%$ 


$\begin{array}{lll}\text { Perennial } & \text { ERHEH2 } & \text { Eriogonum } \\ \text { Perennial } & \text { ATCAC } & \text { Atriplex } \\ \text { Perennial } & \text { BRLOM } & \text { Brickellia } \\ \text { Perennial } & \text { BUUT } & \text { Buddleja } \\ \text { Perennial } & \text { CHVIP4 } & \text { Chrysothamnus } \\ \text { Perennial } & \text { EPFU } & \text { Ephedra } \\ \text { Perennial } & \text { ERNAL } & \text { Ericameria } \\ \text { Perennial } & \text { ERMIS2 } & \text { Eriogonum } \\ \text { Perennial } & \text { LYSH } & \text { Lycium } \\ \text { Perennial } & \text { PRFA } & \text { Prunus } \\ \text { Perennial } & \text { PSPO } & \text { Psorothamnus } \\ \text { Perennial } & \text { SENE5 } & \text { Senecio } \\ \text { Perennial } & \text { TECA2 } & \text { Tetradymia }\end{array}$

heermannii var. heermannii
canescens var. canescens
longifolia var. multiflora
utahensis
viscidiflorus ssp. puberulus
funerea
nauseosus ssp. consimilis var.
microthecum var. simpsonii
shockleyi
fasciculata
polydenius
flaccidus var. douglasii
canescens

\section{Dwarf Shrubs ( $<0.5 \mathrm{~m})$}

$\begin{array}{lll}\text { Perennial } & \text { KRER } & \text { Krameria } \\ \text { Perennial } & \text { MESP2 } & \text { Menodora } \\ \text { Perennial } & \text { ARSP5 } & \text { Artemisia } \\ \text { Perennial } & \text { LEPU } & \text { Leptodactylon }\end{array}$

$\begin{array}{lr}\text { erecta } & 65.3 \% \\ \text { spinescens } & 34.7 \% \\ \text { spinescens } & 16.3 \% \\ \text { pungens } & 2.0 \%\end{array}$

\section{Graminoids}

$\begin{array}{lll}\text { Annual } & \text { BRRU2 } & \text { Bromus } \\ \text { Perennial } & \text { ACHY } & \text { Achnatherum } \\ \text { Perennial } & \text { ACSP12 } & \text { Achnatherum } \\ \text { Perennial } & \text { ERPU8 } & \text { Erioneuron } \\ \text { Perennial } & \text { ELELE } & \text { Elymus } \\ \text { Perennial } & \text { PLRI3 } & \text { Pleuraphis } \\ \text { Perennial } & \text { POSE } & \text { Poa } \\ \text { Annual } & \text { SCAR } & \text { Schismus } \\ \text { Perennial } & \text { ARPU9 } & \text { Aristida } \\ \text { Annual } & \text { VUOC } & \text { Vulpia }\end{array}$

rubens
hymenoides
speciosum
pulchellum
elymoides ssp. elymoides
rigida
secunda
arabicus
purpurea
octoflora

$87.8 \%$ 


\section{Forbs}

\begin{tabular}{|c|c|c|}
\hline Perennial & ERIN4 & Eriogonum \\
\hline Perennial & SPAMA & Sphaeralcea \\
\hline Annual & AMTE3 & Amsinckia \\
\hline Annual & CHRI & Chorizanthe \\
\hline Perennial & DEPAP3 & Delphinium \\
\hline Annual & PHFR2 & Phacelia \\
\hline Perennial & STPA4 & Stephanomeria \\
\hline Annual & LELA & Lepidium \\
\hline Annual & MAGL3 & Malacothrix \\
\hline Annual & PLOV & Plantago \\
\hline Annual & CRNEN & Cryptantha \\
\hline Annual & ERDE6 & Eriogonum \\
\hline Annual & $\mathrm{ERCl} 6$ & Erodium \\
\hline Annual & LUSH & Lupinus \\
\hline Annual & PHVAV2 & Phacelia \\
\hline Perennial & BAMU & Baileya \\
\hline Perennial & BRAT & Brickellia \\
\hline Annual & CABOC & Camissonia \\
\hline Annual & CHFR & Chaenactis \\
\hline Annual & CHST & Chaenactis \\
\hline Annual & ERER2 & Eriastrum \\
\hline Perennial & GICAS & Gilia \\
\hline Perennial & MACAC & Machaeranthera \\
\hline Perennial & STPA3 & Stephanomeria \\
\hline Perennial & ARME2 & Arctomecon \\
\hline Annual & CABRB4 & Camissonia \\
\hline Annual & CAKEG & Camissonia \\
\hline Perennial & CHAL11 & Chamaesyce \\
\hline Annual & $\mathrm{CRCl} 2$ & Cryptantha \\
\hline Perennial & CRUT & Cryptantha \\
\hline Annual & DEPIG & Descurainia \\
\hline Annual & ERN/4 & Eriogonum \\
\hline Perennial & GIBRB & Gilia \\
\hline
\end{tabular}

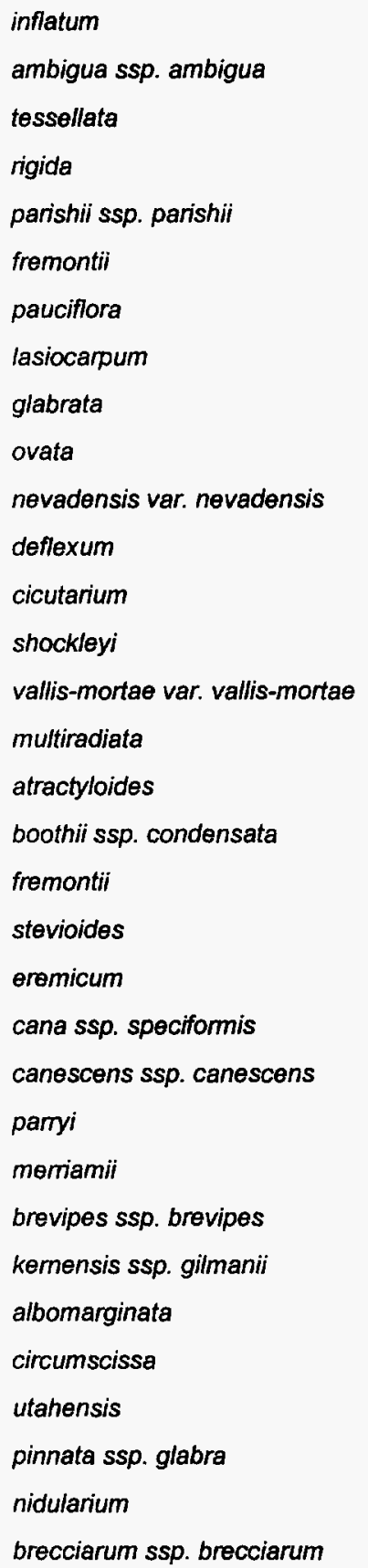


Species

Frequency

\begin{tabular}{|c|c|c|}
\hline Annual & IPPO2 & Ipomopsis \\
\hline Annual & OXPE2 & Oxytheca \\
\hline Annual & PEPL & Pectocarya \\
\hline Annual & PHCRC3 & Phacelia \\
\hline Annual & RANE & Rafinesquia \\
\hline Perennial & SPAMR & Sphaeralcea \\
\hline Perennial & ARPUM & Arabis \\
\hline Perennial & ARMA3 & Arenaria \\
\hline Perennial & ASLA8 & Astragalus \\
\hline Annual & ASLEF2 & Astragalus \\
\hline Annual & CABRP & Camissonia \\
\hline Annual & CARE2 & Camissonia \\
\hline Perennial & CAAP4 & Castilleja \\
\hline Annual & $\mathrm{CHCA}$ & Chaenactis \\
\hline Annual & CHMA & Chaenactis \\
\hline Perennial & CRFL6 & Cryptantha \\
\hline Annual & CRMI & Cryptantha \\
\hline Perennial & CRVI5 & Cryptantha \\
\hline Perennial & DEAN & Delphinium \\
\hline Annual & ERSP3 & Eriastrum \\
\hline Perennial & ERCOC3 & Erigeron \\
\hline Annual & ERMA2 & Eriogonum \\
\hline Annual & ERTH & Eriogonum \\
\hline Annual & ERPR4 & Eriophyllum \\
\hline Annual & ESGL & Eschscholzia \\
\hline Perennial & GAST & Galium \\
\hline Annual & GILIA & Gilia \\
\hline Annual & HAGL & Halogeton \\
\hline Annual & LOHU2 & Lotus \\
\hline Annual & MEAL6 & Mentzelia \\
\hline Annual & MEOB3 & Mentzelia \\
\hline Perennial & MIBI8 & Mirabilis \\
\hline Perennial & MIPU5 & Mirabilis \\
\hline
\end{tabular}

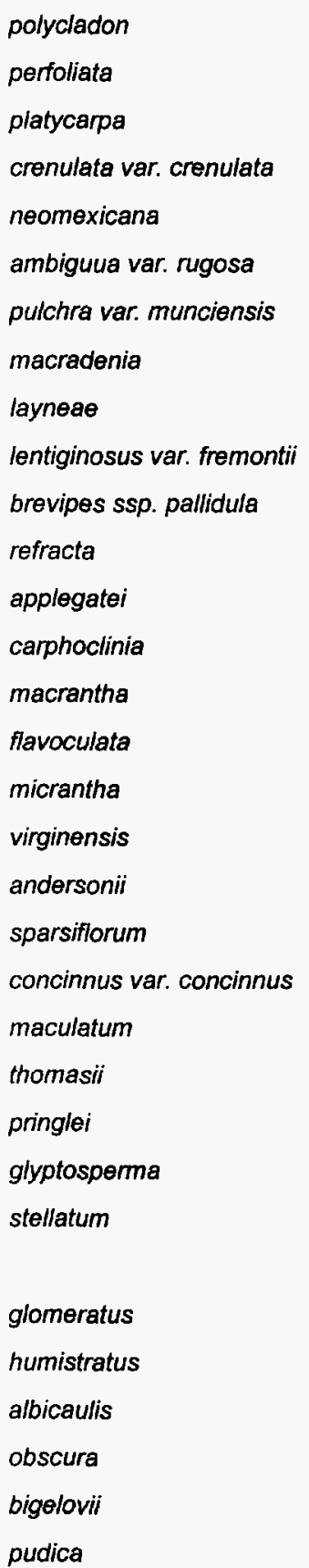

$4.1 \%$

4. $1 \%$

$4.1 \%$

$4.1 \%$

$4.1 \%$

$4.1 \%$

$2.0 \%$

$2.0 \%$

$2.0 \%$

$2.0 \%$

$2.0 \%$

$2.0 \%$

$2.0 \%$

$2.0 \%$

$2.0 \%$

$2.0 \%$

$2.0 \%$

$2.0 \%$

$2.0 \%$

$2.0 \%$

$2.0 \%$

$2.0 \%$

$2.0 \%$

$2.0 \%$

$2.0 \%$

$2.0 \%$

$2.0 \%$

$2.0 \%$

$2.0 \%$

$2.0 \%$

$2.0 \%$

$2.0 \%$

$2.0 \%$

Page 13 of 71 
Lifeform Longevity ACODE
Genus

Species

Annual

NIAT

Nicotiana

Annual

OEDED4

Oenothera

Annual

PESE

Pectocarya

Annual

PHPA2

Perennial

PHGRH

Phacelia

Perennia

PHST11

Phlox

Perennial

POSU

Phlox

Biennial

SIAL2

Perennial

SPGRP2

Annual

STEXE

Annual

SYFR

Polygala

Perennial

THPEB
Sphaeralcea

Stephanomeria

Syntrichopappus

Thymphylla attenuata

deltoides ssp. deltoides

setosa

parishii

gracilis ssp. humilis

stansburyi

subspinosa

altissimum

grossulariaefolia ssp. pedata

exigua ssp. exigua

fremontii

pentachaeta var. belenidium
Frequency

$2.0 \%$

$2.0 \%$

$2.0 \%$

$2.0 \%$

$2.0 \%$

$2.0 \%$

$2.0 \%$

$2.0 \%$

$2.0 \%$

$2.0 \%$

$2.0 \%$

$2.0 \%$

\section{Succulents}

$\begin{array}{lll}\text { Perennial } & \text { ECPO2 } & \text { Echinocactus } \\ \text { Perennial } & \text { YUSC2 } & \text { Yucca } \\ \text { Perennial } & \text { OPBAB2 } & \text { Opuntia } \\ \text { Perennial } & \text { OPECE } & \text { Opuntia } \\ \text { Perennial } & \text { YUBR } & \text { Yucca } \\ \text { Perennial } & \text { ECEN } & \text { Echinocereus } \\ \text { Perennial } & \text { OPERE } & \text { Opuntia } \\ \text { Perennial } & \text { OPRA } & \text { Opuntia } \\ \text { Perennial } & \text { ESVIR2 } & \text { Escobaria } \\ \text { Perennial } & \text { YUBAV } & \text { Yucca }\end{array}$

\section{Variable}

Variable ERIOG Eriogonum

$34.7 \%$

$28.6 \%$

$20.4 \%$

$20.4 \%$

$16.3 \%$

$10.2 \%$

$6.1 \%$

$4.1 \%$

$2.0 \%$

$2.0 \%$

$2.0 \%$ 


\section{Hymenoclea-Lycium Shrubland Alliance}

\section{Tall Shrubs (2-5 m)}

Perennial LATR2 Larrea tridentata

\section{Short Shrubs $(0.5-2 \mathrm{~m})$}

\begin{tabular}{|c|c|c|}
\hline Perennial & HYSA & Hymenoclea \\
\hline Perennial & LYAN & Lycium \\
\hline Perennial & EPNE & Ephedra \\
\hline Perennial & ATCAC & Atriplex \\
\hline Perennial & KRLA2 & Krascheninnikovia \\
\hline Perennial & GRSP & Grayia \\
\hline Perennial & CHVIV2 & Chrysothamnus \\
\hline Perennial & AMDU2 & Ambrosia \\
\hline Perennial & CORA & Coleogyne \\
\hline Perennial & $\mathrm{ACSH}$ & Acamptopappus \\
\hline Perennial & ENVIV & Encelia \\
\hline Perennial & SAME & Salazaria \\
\hline Perennial & $\mathrm{ERCO} 23$ & Ericameria \\
\hline Perennial & TEAXA & Tetradymia \\
\hline Perennial & PSFRF & Psorothamnus \\
\hline Perennial & STPIP & Stanleya \\
\hline Perennial & LEFR2 & Lepidium \\
\hline Perennial & THMO & Thamnosma \\
\hline Perennial & AMER & Ambrosia \\
\hline Perennial & ATCO & Atriplex \\
\hline Perennial & ERNAH & Ericameria \\
\hline Perennial & ERFAP & Eriogonum \\
\hline Perennial & GUSA2 & Gutierrezia \\
\hline Perennial & ERTE18 & Ericameria \\
\hline Perennial & LYPAO & Lycium \\
\hline Perennial & PSPO & Psorothamnus \\
\hline Perennial & PUST & Purshia \\
\hline
\end{tabular}

salsola
andersonii
nevadensis
canescens var. canescens
lanata
spinosa
viscidiflorus ssp. viscidiflorus
dumosa
ramosissima
shockleyi
virginensis var. virginensis
mexicana
cooperi
axillaris var. axillaris
fremontii var. fremontii
pinnata var. pinnata
fremontii
montana
eriocentra
confertifolia
nauseosus ssp. nauseosus var.
fasciculatum var. polifolium
sarothrae
teretifolia
pallidum var. oligospermum
polydenius
stansburiana

$91.4 \%$

$77.6 \%$

$65.5 \%$

$60.3 \%$

$56.9 \%$

$50.0 \%$

$48.3 \%$

$41.4 \%$

$29.3 \%$

$27.6 \%$

$22.4 \%$

$20.7 \%$

$19.0 \%$

$19.0 \%$

$17.2 \%$

$17.2 \%$

$15.5 \%$

$12.1 \%$

$10.3 \%$

$10.3 \%$

$10.3 \%$

$10.3 \%$

$10.3 \%$

$8.6 \%$

$8.6 \%$

$6.9 \%$

$5.2 \%$

Wednesday, January 05, 2000

Page 15 of 71 


\section{Species}

$\begin{array}{lll}\text { Perennial } & \text { ATPO } & \text { Atriplex } \\ \text { Perennial } & \text { ERPA29 } & \text { Ericameria } \\ \text { Perennial } & \text { LYSH } & \text { Lycium } \\ \text { Perennial } & \text { PRFA } & \text { Prunus } \\ \text { Perennial } & \text { TECA2 } & \text { Tetradymia } \\ \text { Perennial } & \text { BRIN } & \text { Brickellia } \\ \text { Perennial } & \text { BROBL } & \text { Brickellia } \\ \text { Perennial } & \text { EPVI } & \text { Ephedra } \\ \text { Perennial } & \text { ERNAL } & \text { Ericameria } \\ \text { Perennial } & \text { PENI } & \text { Petalonyx } \\ \text { Perennial } & \text { RHTRA } & \text { Rhus } \\ \text { Perennial } & \text { SADOD3 } & \text { Salvia } \\ \text { Perennial } & \text { STEL } & \text { Stanleya }\end{array}$

Dwarf Shrubs ( $<0.5 \mathrm{~m}$ )

$\begin{array}{lll}\text { Perennial } & \text { ARSP5 } & \text { Artemisia } \\ \text { Perennial } & \text { KRER } & \text { Krameria } \\ \text { Perennial } & \text { MESP2 } & \text { Menodora }\end{array}$

\section{Graminoids}

$\begin{array}{lll}\text { Annual } & \text { BRRU2 } & \text { Bromus } \\ \text { Perennial } & \text { ACHY } & \text { Achnatherum } \\ \text { Perennial } & \text { ACSP12 } & \text { Achnatherum } \\ \text { Annual } & \text { BRTE } & \text { Bromus } \\ \text { Perennial } & \text { ELELE } & \text { Elymus } \\ \text { Perennial } & \text { PLJA } & \text { Pleuraphis } \\ \text { Perennial } & \text { ERPU8 } & \text { Erioneuron } \\ \text { Perennial } & \text { PLRI3 } & \text { Pleuraphis } \\ \text { Perennial } & \text { ARPUL } & \text { Aristida } \\ \text { Annual } & \text { BRCA6 } & \text { Bromus } \\ \text { Annual } & \text { SCAR } & \text { Schismus } \\ \text { Annual } & \text { VUOC } & \text { Vulpia }\end{array}$

Wednesday, January 05, 2000

$\begin{array}{ll}\text { polycarpa } & 3.4 \% \\ \text { paniculata } & 3.4 \% \\ \text { shockleyi } & 3.4 \% \\ \text { fasciculata } & 3.4 \% \\ \text { canescens } & 3.4 \% \\ \text { incana } & 1.7 \% \\ \text { oblongifolia var. linifolia } & 1.7 \% \\ \text { vinidis } & 1.7 \% \\ \text { nauseosus ssp. consimilis var. } & 1.7 \% \\ \text { nitidus } & 1.7 \% \\ \text { trilobata var. anisophylla } & 1.7 \% \\ \text { dorii ssp. dormi var. dormii } & 1.7 \% \\ \text { elata } & 1.7 \%\end{array}$

spinescens $\quad 15.5 \%$

erecta $12.1 \%$

spinescens $\quad 12.1 \%$

$\begin{array}{lr}\text { rubens } & 87.9 \% \\ \text { hymenoides } & 70.7 \% \\ \text { speciosum } & 62.1 \% \\ \text { tectorum } & 22.4 \% \\ \text { elymoides ssp. elymoides } & 20.7 \% \\ \text { jamesii } & 13.8 \% \\ \text { pulchellum } & 10.3 \% \\ \text { rigida } & 5.2 \% \\ \text { purpurea var. longiseta } & 3.4 \% \\ \text { cartharticus } & 1.7 \% \\ \text { arabicus } & 1.7 \% \\ \text { octoflora } & 1.7 \%\end{array}$


Forbs

\begin{tabular}{|c|c|c|}
\hline Perennial & SPAMA & Sphaeralcea \\
\hline Annual & CHST & Chaenactis \\
\hline Annual & MAGL3 & Malacothrix \\
\hline Annual & ERCI6 & Erodium \\
\hline Perennial & MACAC & Machaeranthera \\
\hline Perennial & CHAL11 & Chamaesyce \\
\hline Perennial & MIPU5 & Mirabilis \\
\hline Perennial & ERIN4 & Eriogonum \\
\hline Annual & ERER2 & Eriastrum \\
\hline Annual & ERDE6 & Eriogonum \\
\hline Annual & OXPE2 & Oxytheca \\
\hline Annual & ERNI4 & Eriogonum \\
\hline Biennial & SIAL2 & Sisymbrium \\
\hline Perennial & $\mathrm{ADCO} 2$ & Adenophyllum \\
\hline Annual & CRNEN & Cryptantha \\
\hline Perennial & DEPAP3 & Delphinium \\
\hline Annual & ERPR4 & Eriophyllum \\
\hline Perennial & POSU & Polygala \\
\hline Annual & STEXE & Stephanomeria \\
\hline Perennial & STPA4 & Stephanomeria \\
\hline Perennial & XYтот & Xylorhiza \\
\hline Perennial & CAFL & Calochortus \\
\hline Annual & PHFR2 & Phacelia \\
\hline Annual & PHVAV2 & Phacelia \\
\hline Perennial & SPGRP2 & Sphaeralcea \\
\hline Annual & ASLEF2 & Astragalus \\
\hline Perennial & BAMU & Baileya \\
\hline Annual & CAKEG & Camissonia \\
\hline Perennial & CAAP4 & Castilleja \\
\hline Perennial & HEMUN & Heliomeris \\
\hline Annual & LELA & Lepidium \\
\hline Annual & MEOB3 & Mentzelia \\
\hline
\end{tabular}

ambigua ssp. ambigua
stevioides
glabrata
cicutarium
canescens ssp. canescens
albomarginata
pudica
inflatum
eremicum
deflexum
perfoliata
nidularium
altissimum
cooperi
nevadensis var. nevadensis
parishii ssp. parishii
pringlei
subspinosa
exigua ssp. exigua
pauciflora
tortifolia var. imberbis
flexuosus
fremontii
vallis-mortae var. vallis-mortae
grossulariaefolia ssp. pedata
lentiginosus var. fremontii
multiradiata
kernensis ssp. gilmanii
applegatei
multifora var. nevadensis
asiocam
al

$55.2 \%$

$43.1 \%$

$34.5 \%$

$31.0 \%$

$25.9 \%$

$22.4 \%$

$22.4 \%$

$20.7 \%$

$19.0 \%$

$19.0 \%$

$17.2 \%$

$13.8 \%$

$13.8 \%$

$10.3 \%$

$10.3 \%$

$8.6 \%$

$8.6 \%$

$8.6 \%$

$8.6 \%$

$8.6 \%$

$8.6 \%$

$6.9 \%$

$6.9 \%$

$6.9 \%$

$6.9 \%$

$5.2 \%$

$5.2 \%$

$5.2 \%$

$5.2 \%$

$5.2 \%$

$5.2 \%$

$5.2 \%$ 
Lifeform Longevity ACODE

Genus

\begin{tabular}{|c|c|c|}
\hline Perennial & ARPUM & Arabis \\
\hline Perennial & ASLAB & Astragalus \\
\hline Perennial & BRAT & Brickellia \\
\hline Annual & CHBRB & Chorizanthe \\
\hline Annual & CRMI & Cryptantha \\
\hline Annual & CRPT & Cryptantha \\
\hline Perennial & GIIN2 & Gilia \\
\hline Annual & LASE3 & Langloisia \\
\hline Perennial & MIBI8 & Mirabilis \\
\hline Perennial & PHST11 & Phlox \\
\hline Perennial & STPA3 & Stephanomeria \\
\hline Annual & CAWR & Calycoseris \\
\hline Annual & CABOC & Camissonia \\
\hline Annual & CABRB4 & Camissonia \\
\hline Perennial & CAAPM & Castilleja \\
\hline Perennial & CAPI4 & Caulanthus \\
\hline Annual & CHFR & Chaenactis \\
\hline Annual & $\mathrm{CRCl} 2$ & Cryptantha \\
\hline Perennial & CRVI5 & Cryptantha \\
\hline Perennial & CYGL2 & Cymopterus \\
\hline Perennial & CYRI2 & Cymopterus \\
\hline Perennial & DIPU3 & Dichelostemma \\
\hline Perennial & ENNUN & Enceliopsis \\
\hline Perennial & EROVO5 & Eriogonum \\
\hline Annual & ERPU6 & Eriogonum \\
\hline Annual & GILIA & Gilia \\
\hline Annual & IPPO2 & Ipomopsis \\
\hline Perennial & LILE3 & Linum \\
\hline Annual & LUSH & Lupinus \\
\hline Annual & MEVE5 & Mentzelia \\
\hline Annual & NAPU & Nama \\
\hline Perennial & OECEM4 & Oenothera \\
\hline Annual & PESE & Pectocarya \\
\hline
\end{tabular}

Species

pulchra var. munciensis

layneae

atractyloides

brevicomu var. brevicomu

micrantha

pterocarya

inconspicua

setosissima

bigelovii

stansburyi

parryi

wrightii

boothii ssp. condensata

brevipes ssp. brevipes

applegatei ssp. martinii

pilosus

fremontii

circumscissa

virginensis

globosus

ripleyi

pulchellum

nudicaulis var. nudicaulis

ovalifolium var. ovalifolium

pusillum

polycladon

lewisii

shockleyi

veatchiana

pusillum

caespitosa ssp. marginata

setosa
Frequency

$3.4 \%$

$3.4 \%$

$3.4 \%$

$3.4 \%$

$3.4 \%$

$3.4 \%$

$3.4 \%$

$3.4 \%$

$3.4 \%$

$3.4 \%$

$3.4 \%$

$1.7 \%$

$1.7 \%$

$1.7 \%$

$1.7 \%$

$1.7 \%$

$1.7 \%$

$1.7 \%$

$1.7 \%$

$1.7 \%$

$1.7 \%$

$1.7 \%$

$1.7 \%$

$1.7 \%$

$1.7 \%$

$1.7 \%$

$1.7 \%$

$1.7 \%$

$1.7 \%$

$1.7 \%$

$1.7 \%$

$1.7 \%$

$1.7 \%$ 


\section{Lifeform Longevity ACODE}

Perennial PENST

Perennial PEPA8

Penstemon

Annual

PHCRC3

Penstemon

Annual

PLOV

Phacelia

Annual

SAKAT3

Plantago

Annual

SAPA8

Salsola

Perennial

SPAMR

Salsola

Annual

SYFR

Sphaeralcea
Syntrichopappus

\section{Species}

palmeri
crenulata var. crenulata
ovata
kali ssp. tragus
paulsenii
ambiguua var. rugosa
fremontii

Frequency

$1.7 \%$

$1.7 \%$

$1.7 \%$

$1.7 \%$

$1.7 \%$

$1.7 \%$

$1.7 \%$

$1.7 \%$

\section{Succulents}

$\begin{array}{lll}\text { Perennial } & \text { YUBR } & \text { Yucca } \\ \text { Perennial } & \text { OPECE } & \text { Opuntia } \\ \text { Perennial } & \text { OPBAB2 } & \text { Opuntia } \\ \text { Perennial } & \text { ECEN } & \text { Echinocereus } \\ \text { Perennial } & \text { YUSC2 } & \text { Yucca } \\ \text { Perennial } & \text { ECPO2 } & \text { Echinocactus } \\ \text { Perennial } & \text { OPERE } & \text { Opuntia } \\ \text { Perennial } & \text { OPPU } & \text { Opuntia }\end{array}$

brevifolia

$27.6 \%$

echinocarpa var. echinocarpa

$24.1 \%$

basilaris var. basilaris

$5.2 \%$

engelmannii

$3.4 \%$

schidigera

$3.4 \%$

polycephalus

$1.7 \%$

erinacea var. erinacea

$1.7 \%$

pulchella

$1.7 \%$ 


\section{Ephedra nevadensis Shrubland Alliance}

\section{Trees $(>5 \mathrm{~m})$}

Perennial JUOS Juniperus

osteosperma

Tall Shrubs (2-5 m)

$\begin{array}{lll}\text { Perennial } & \text { LATR2 } & \text { Larrea } \\ \text { Perennial } & \text { ARTRT } & \text { Artemisia }\end{array}$

tridentata

$31.5 \%$

Perennial

ARTRT Artemisia

tridentata ssp. tridentata

$11.6 \%$

\section{Short Shrubs (0.5-2 m)}

\begin{tabular}{|c|c|c|}
\hline Perennial & EPNE & Ephedra \\
\hline Perennial & LYAN & Lycium \\
\hline Perennial & KRLA2 & Krascheninnikovia \\
\hline Perennial & GRSP & Grayia \\
\hline Perennial & HYSA & Hymenoclea \\
\hline Perennial & ATCAC & Atriplex \\
\hline Perennial & CHVIV2 & Chrysothamnus \\
\hline Perennial & CORA & Coleogyne \\
\hline Perennial & ATCO & Atriplex \\
\hline Perennial & AMDU2 & Ambrosia \\
\hline Perennial & TEAXA & Tetradymia \\
\hline Perennial & $\mathrm{ERCO} 23$ & Ericameria \\
\hline Perennial & $\mathrm{ACSH}$ & Acamptopappus \\
\hline Perennial & PSFRF & Psorothamnus \\
\hline Perennial & SAME & Salazaria \\
\hline Perennial & ERFAP & Eriogonum \\
\hline Perennial & ERTE18 & Ericameria \\
\hline Perennial & THMO & Thamnosma \\
\hline Perennial & ENVIV & Encelia \\
\hline Perennial & STPIP & Stanleya \\
\hline Perennial & TECA2 & Tetradymia \\
\hline Perennial & ERNAL & Ericameria \\
\hline Perennial & LEFR2 & Lepidium \\
\hline
\end{tabular}

nevadensis
andersonii
lanata
spinosa
salsola
canescens var. canescens
viscidiflorus ssp. viscidiflorus
ramosissima
confertifolia
dumosa
axillaris var. axillaris
cooperi
shockleyi
fremontii var. fremontii
mexicana
fasciculatum var. polifolium
teretifolia
montana
virginensis var. virginensis
pinnata var. pinnata
canescens
nauseosus ssp. consimilis var.
fremontii


Lifeform Longevity ACODE

Genus

\begin{tabular}{|c|c|c|}
\hline Perennial & GUSA2 & Gutierrezia \\
\hline Perennial & LYPAO & Lycium \\
\hline Perennial & EPVI & Ephedra \\
\hline Perennial & PUGL2 & Purshia \\
\hline Perennial & ARNO4 & Artemisia \\
\hline Perennial & ERMIS2 & Eriogonum \\
\hline Perennial & STEL & Stanleya \\
\hline Perennial & ERLI6 & Ericameria \\
\hline Perennial & ERNAH & Ericameria \\
\hline Perennial & PSPO & Psorothamnus \\
\hline Perennial & SYLO & Symphoricarpos \\
\hline Perennial & PUST & Purshia \\
\hline Perennial & TEGL & Tetradymia \\
\hline Perennial & CHVIP4 & Chrysothamnus \\
\hline Perennial & BRMIW & Brickellia \\
\hline Perennial & EPTO & Ephedra \\
\hline Perennial & ERHEH2 & Eriogonum \\
\hline Perennial & ERNA7 & Ericameria \\
\hline Perennial & PENI & Petalonyx \\
\hline Perennial & SADOD3 & Salvia \\
\hline Perennial & AMER & Ambrosia \\
\hline Perennial & CHVIS5 & Chrysothamnus \\
\hline Perennial & EPFU & Ephedra \\
\hline Perennial & ERPA29 & Ericameria \\
\hline Perennial & LYSH & Lycium \\
\hline Perennial & SENE5 & Senecio \\
\hline Perennial & BROBL & Brickellia \\
\hline Perennial & CHGR6 & Chrysothamnus \\
\hline Perennial & ERNA10 & Ericameria \\
\hline Perennial & GLSPA & Glossopetalon \\
\hline Perennial & PRFA & Prunus \\
\hline
\end{tabular}

Species

sarothrae
pallidum var. oligospermum
viridis
glandulosa
nova
microthecum var. simpsonii
elata
linearifolius
nauseosus ssp. nauseosus var.
polydenius
longiflorus
stansburiana
glabrata
viscidiflorus ssp. puberulus
microphylla var. watsonii
torreyana
heermannii var. heermannii
nanus
nutidus
dorii ssp. dormi var. dorrii
eriocentra
viscidiflorus ssp. viscidiflorus var.
funerea
paniculata
shockleyi
flaccidus var. douglasii
oblongifolia var. linifolia
greenei
nauseosus
spinescens var. aridum
fasciculata

Frequency

$8.8 \%$

$8.3 \%$

$7.7 \%$

$5.5 \%$

$5.0 \%$

$5.0 \%$

$5.0 \%$

$4.4 \%$

$4.4 \%$

$4.4 \%$

$4.4 \%$

$3.9 \%$

$3.9 \%$

$3.3 \%$

$2.8 \%$

$2.8 \%$

$2.2 \%$

$1.7 \%$

$1.7 \%$

$1.7 \%$

$1.1 \%$

$1.1 \%$

$1.1 \%$

$1.1 \%$

$1.1 \%$

$1.1 \%$

$0.6 \%$

$0.6 \%$

$0.6 \%$

$0.6 \%$

$0.6 \%$ 


\section{Dwarf Shrubs $(<0.5 \mathrm{~m})$}

$\begin{array}{lll}\text { Perennial } & \text { ARSP5 } & \text { Artemisia } \\ \text { Perennial } & \text { KRER } & \text { Krameria } \\ \text { Perennial } & \text { LEPU } & \text { Leptodactylon }\end{array}$

spinescens

$33.7 \%$

$24.9 \%$

\section{Graminoids}

$\begin{array}{lll}\text { Annual } & \text { BRRU2 } & \text { Bromus } \\ \text { Perennial } & \text { ACHY } & \text { Achnatherum } \\ \text { Perennial } & \text { ACSP12 } & \text { Achnatherum } \\ \text { Perennial } & \text { ELELE } & \text { Elymus } \\ \text { Perennial } & \text { PLJA } & \text { Pleuraphis } \\ \text { Annual } & \text { BRTE } & \text { Bromus } \\ \text { Perennial } & \text { ERPU8 } & \text { Erioneuron } \\ \text { Perennial } & \text { POSE } & \text { Poa } \\ \text { Perennial } & \text { ARPU9 } & \text { Aristida } \\ \text { Perennial } & \text { HECOC8 } & \text { Hesperostipa } \\ \text { Annual } & \text { VUOC } & \text { Vulpia } \\ \text { Annual } & \text { BRCA6 } & \text { Bromus } \\ \text { Perennial } & \text { PLRI3 } & \text { Pleuraphis } \\ \text { Perennial } & \text { BOGR2 } & \text { Bouteloua } \\ \text { Perennial } & \text { SPCR } & \text { Sporobolus }\end{array}$

\section{Forbs}

\begin{tabular}{|c|c|c|}
\hline Perennial & SPAMA & Sphaeralcea \\
\hline Annual & AMTE3 & Amsinckia \\
\hline Annual & CHST & Chaenactis \\
\hline Perennial & ERIN4 & Eriogonum \\
\hline Perennial & XYTOT & Xylorhiza \\
\hline Perennial & DEPAP3 & Delphinium \\
\hline Annual & ERCI6 & Erodium \\
\hline Perennial & CAAP4 & Castilleja \\
\hline Annual & ERDE6 & Eriogonum \\
\hline Annual & ERNI4 & Eriogonum \\
\hline
\end{tabular}

$4.4 \%$

erecta

pungens

$88.4 \%$

$58.0 \%$

$52.5 \%$

$33.1 \%$

$20.4 \%$

$16.6 \%$

$9.9 \%$

$5.0 \%$

$3.3 \%$

$3.3 \%$

$2.2 \%$

$1.7 \%$

$1.7 \%$

$1.1 \%$

$0.6 \%$

cryptandrus

$65.2 \%$

$63.5 \%$

$37.0 \%$

$36.5 \%$

$25.4 \%$

$23.8 \%$

$23.2 \%$

$21.5 \%$

$19.3 \%$

$19.3 \%$ 


\begin{tabular}{|c|c|c|c|}
\hline \multirow[t]{34}{*}{ Lifeform } & Longevity & $A C O D E$ & Genus \\
\hline & Perennial & MACAC & Machaeranthera \\
\hline & Perennial & CHAL11 & Chamaesyce \\
\hline & Annual & ERER2 & Eriastrum \\
\hline & Annual & MAGL3 & Malacothrix \\
\hline & Annual & PHFR2 & Phacelia \\
\hline & Annual & ERPR4 & Eriophyllum \\
\hline & Perennial & MIPU5 & Mirabilis \\
\hline & Annual & OXPE2 & Oxytheca \\
\hline & Annual & PHVAV2 & Phacelia \\
\hline & Annual & LELA & Lepidium \\
\hline & Annual & ASLEF2 & Astraga/us \\
\hline & Annual & CRPT & Cryptantha \\
\hline & Perennial & CAFL & Calochortus \\
\hline & Perennial & HEMUN & Heliomeris \\
\hline & Perennial & STPA4 & Stephanomeria \\
\hline & Annual & PHCRC3 & Phacelia \\
\hline & Annual & CHRI & Chorizanthe \\
\hline & Perennial & ARPUM & Arabis \\
\hline & Annual & GILIA & Gilia \\
\hline & Annual & CRNEN & Cryptantha \\
\hline & Perennial & CRUT & Cryptantha \\
\hline & Perennial & PHST11 & Phlox \\
\hline & Biennial & CINE & Cirsium \\
\hline & Annual & DEPIG & Descurainia \\
\hline & Perennial & MIBI8 & Mirabilis \\
\hline & Annual & $\mathrm{CRCl} 2$ & Cryptantha \\
\hline & Perennial & POSU & Polygala \\
\hline & Annual & CABRB4 & Camissonia \\
\hline & Annual & LOHU2 & Lotus \\
\hline & Perennial & ASLA8 & Astragalus \\
\hline & Perennial & BAMU & Baileya \\
\hline & Perennial & GIBRB & Gilia \\
\hline & Annual & LUFL & Lupinus \\
\hline
\end{tabular}

Wednesday, January 05, 2000

Species

canescens ssp. canescens

albomarginata

eremicum

glabrata

fremontii

pringiei

pudica

perfoliata

vallis-mortae var. vallis-mortae

lasiocarpum

lentiginosus var. fremontii

pterocarya

flexuosus

multiflora var. nevadensis

pauciflora

crenulata var. crenulata

rigida

pulchra var. munciensis

nevadensis var. nevadensis

utahensis

stansburyi

neomexicanum

pinnata ssp. glabra

bigelovii

circumscissa

subspinosa

brevipes ssp. brevipes

humistratus

layneae

multiradiata

brecciarum ssp. brecciarum

flavoculatus
Frequency

$19.3 \%$

$17.7 \%$

$17.1 \%$

$16.6 \%$

$16.0 \%$

$13.3 \%$

$13.3 \%$

$13.3 \%$

$12.2 \%$

$11.6 \%$

$10.5 \%$

$9.9 \%$

$9.4 \%$

$9.4 \%$

$8.8 \%$

$8.3 \%$

$7.7 \%$

$7.2 \%$

$7.2 \%$

$6.6 \%$

$6.6 \%$

$6.6 \%$

$6.1 \%$

$6.1 \%$

$6.1 \%$

$5.5 \%$

$5.5 \%$

$5.0 \%$

$5.0 \%$

$4.4 \%$

$4.4 \%$

$4.4 \%$

$4.4 \%$

Page 23 of 71 


\begin{tabular}{|c|c|c|}
\hline Annual & LUSH & Lupinus \\
\hline Annual & PESE & Pectocarya \\
\hline Annual & SAPA8 & Salsola \\
\hline Annual & SACOC & Salvia \\
\hline Biennial & SIAL2 & Sisymbrium \\
\hline Annual & STEXE & Stephanomeria \\
\hline Annual & SYFR & Syntrichopappus \\
\hline Perennial & $\mathrm{ADCO} 2$ & Adenophyllum \\
\hline Annual & CAKEG & Camissonia \\
\hline Annual & CETH3 & Centrostegia \\
\hline Annual & CHFR & Chaenactis \\
\hline Annual & IPPO2 & Ipomopsis \\
\hline Perennial & SPAMR & Sphaeralcea \\
\hline Perennial & DIPU3 & Dichelostemma \\
\hline Perennial & ERCOC3 & Erigeron \\
\hline Perennial & STPA3 & Stephanomeria \\
\hline Annual & CRMI & Cryptantha \\
\hline Annual & ESGL & Eschscholzia \\
\hline Annual & MEAL6 & Mentzelia \\
\hline Perennial & OECEM4 & Oenothera \\
\hline Perennial & PEFLA2 & Penstemon \\
\hline Perennial & SEMU3 & Senecio \\
\hline Annual & STLO4 & Streptanthella \\
\hline Annual & ASAC3 & Astragalus \\
\hline Perennial & ASTI & Astragalus \\
\hline Annual & CACLI & Camissonia \\
\hline Perennial & CAAPM & Castilleja \\
\hline Annual & CHMA & Chaenactis \\
\hline Annual & LASE3 & Langloisia \\
\hline Perennial & LILE3 & Linum \\
\hline Annual & MEOB3 & Mentzelia \\
\hline Annual & OEPR & Oenothera \\
\hline Annual & RANE & Rafinesquia \\
\hline
\end{tabular}

shockleyi

$4.4 \%$

setosa

$4.4 \%$

paulsenii

$4.4 \%$

columbariae var. columbariae

$4.4 \%$

altissimum

$4.4 \%$

exigua ssp. exigua

$4.4 \%$

fremontii

$4.4 \%$

cooperi

$3.9 \%$

kemensis ssp. gilmanii $\quad 3.9 \%$

thurberi

$3.9 \%$

$3.9 \%$

$3.9 \%$

$3.9 \%$

$3.3 \%$

$3.3 \%$

$3.3 \%$

$2.8 \%$

$2.8 \%$

$2.8 \%$

$2.8 \%$

$2.8 \%$

$2.8 \%$

$2.8 \%$

$2.2 \%$

$2.2 \%$

$2.2 \%$

$2.2 \%$

$2.2 \%$

$2.2 \%$

$2.2 \%$

$2.2 \%$

$2.2 \%$

$2.2 \%$ 


\section{Species}

ludoviciana

purshii var. tinctus

parryi

boothii ssp. condensata

pilosus

confertiflora

gracilis

virginensis

sophia

ovalifolium var. ovalifolium

saxatile

minutiflora

inconspicua

occidentalis var. occidentalis

brevicaulis

veatchiana

spissus

pusillum

patagonica

kall ssp. tragus

cordatus var. cordatus

acanthicarpa

pulchra var. gracilis

congesta var. subcongesta

macradenia

dracunculus

casei

atractyloides

heterochroma

brevicomu var. brevicomu

flavoculata

ripleyi

andersonii
Frequency

$1.7 \%$

$1.7 \%$

$1.7 \%$

$1.7 \%$

$1.7 \%$

$1.7 \%$

$1.7 \%$

$1.7 \%$

$1.7 \%$

$1.7 \%$

$1.7 \%$

$1.7 \%$

$1.7 \%$

$1.7 \%$

$1.7 \%$

$1.7 \%$

$1.7 \%$

$1.7 \%$

$1.7 \%$

$17 \%$

$1.7 \%$

$1.1 \%$

$1.1 \%$

$1.1 \%$

$1.1 \%$

$1.1 \%$

$1.1 \%$

$1.1 \%$

$1.1 \%$

$1.1 \%$

$1.1 \%$

$1.1 \%$

$1.1 \%$

Wednesday, January 05, 2000

Page 25 of 71 
Lifeform Longevity ACODE

Genus

\begin{tabular}{|c|c|c|}
\hline Perennial & LONEN & Lomatium \\
\hline Annual & MOBE & Monoptilon \\
\hline Annual & NIAT & Nicotiana \\
\hline Perennial & OEPAP & Oenothera \\
\hline Annual & PHSA & Phacelia \\
\hline Perennial & SPAMM & Sphaeralcea \\
\hline Perennial & SPGRP2 & Sphaeralcea \\
\hline Annual & URLI2 & Uropappus \\
\hline Perennial & ABEL & Abronia \\
\hline Perennial & ALNE & Allium \\
\hline Annual & ANAC & Anisocoma \\
\hline Annual & ATPL & Atrichoseris \\
\hline Annual & CAPT & Camissonia \\
\hline Annual & CHSES & Chamaesyce \\
\hline Annual & CHWA2 & Chorizanthe \\
\hline Perennial & CROCO2 & Crepis \\
\hline Annual & CRAM3 & Cryptantha \\
\hline Annual & CRMA7 & Cryptantha \\
\hline Annual & CRRE5 & Cryptantha \\
\hline Perennial & CYGL2 & Cymopterus \\
\hline Perennial & CYPU & Cymopterus \\
\hline Perennial & ENNUN & Enceliopsis \\
\hline Annual & ERDI4 & Erigeron \\
\hline Annual & ERESE & Eriogonum \\
\hline Perennial & ERNU4 & Eriogonum \\
\hline Annual & ERRE3 & Eriogonum \\
\hline Perennial & ERUM & Eriogonum \\
\hline Annual & GARA & Gayophytum \\
\hline Perennial & GICAT & Gilia \\
\hline Perennial & GISC & Gilia \\
\hline Annual & GLMA2 & Glyptopleura \\
\hline Annual & HAGL & Halogeton \\
\hline Annual & LOSC6 & Loeseliastrum \\
\hline
\end{tabular}

Species

nevadense var. nevadense
bellidiforme
attenuata
pallida ssp. pallida
saxicola
ambigua ssp. monticola
grossulariaefolia ssp. pedata
linearifolia
elliptica
nevadense
acaulis
platyphylla
pterosperma
serpylifolia ssp. serpyllifolia
watsonii
occidentalis ssp. occidentalis
ambigua
maritima
recurvata
globosus
purpurascens
nudicaulis var. nudicaulis
divergens
esmeraldense var. esmeraldense
nummulare
reniforme
umbellatum
racemosum
cana ssp. triceps
scopulorum
marginata
schottii

Frequency

$1.1 \%$

$1.1 \%$

$1.1 \%$

$1.1 \%$

$1.1 \%$

$1.1 \%$

$1.1 \%$

$1.1 \%$

$0.6 \%$

$0.6 \%$

$0.6 \%$

$0.6 \%$

$0.6 \%$

$0.6 \%$

$0.6 \%$

$0.6 \%$

$0.6 \%$

$0.6 \%$

$0.6 \%$

$0.6 \%$

$0.6 \%$

$0.6 \%$

$0.6 \%$

$0.6 \%$

$0.6 \%$

$0.6 \%$

$0.6 \%$

$0.6 \%$

$0.6 \%$

$0.6 \%$

$0.6 \%$

$0.6 \%$

$0.6 \%$ 


\begin{tabular}{|c|c|c|c|}
\hline \multirow[t]{12}{*}{ Lifeform } & Longevity & $A C O D E$ & Genus \\
\hline & Annual & MASO & Malacothrix \\
\hline & Annual & MIBIB2 & Mimulus \\
\hline & Annual & MISU2 & Mimulus \\
\hline & Perennial & MIMUG & Mirabilis \\
\hline & Annual & PEPL & Pectocarya \\
\hline & Annual & PHCA2 & Phacelia \\
\hline & Perennial & PHGRH & Phlox \\
\hline & Annual & PLOV & Plantago \\
\hline & Annual & PSAN & Psathyrotes \\
\hline & Biennial & THLA4 & Thelypodium \\
\hline & Perennial & TRWA2 & Tricardia \\
\hline
\end{tabular}

\section{Species}

sonchoides

bigelovii var. bigelovii

suksdorfii

multiflora var. glandulosa

platycarpa

calthifolia

gracilis ssp. humilis

ovata

annua

laxiflorum

watsonii
Frequency

$0.6 \%$

$0.6 \%$

$0.6 \%$

$0.6 \%$

$0.6 \%$

$0.6 \%$

$0.6 \%$

$0.6 \%$

$0.6 \%$

$0.6 \%$

$0.6 \%$

\section{Succulents}

$\begin{array}{lll}\text { Perennial } & \text { YUBR } & \text { Yucca } \\ \text { Perennial } & \text { OPECE } & \text { Opuntia } \\ \text { Perennial } & \text { ECPO2 } & \text { Echinocactus } \\ \text { Perennial } & \text { OPBAB2 } & \text { Opuntia } \\ \text { Perennial } & \text { ECEN } & \text { Echinocereus } \\ \text { Perennial } & \text { YUSC2 } & \text { Yucca } \\ \text { Perennial } & \text { YUBAV } & \text { Yucca } \\ \text { Perennial } & \text { OPPOR } & \text { Opuntia } \\ \text { Perennial } & \text { OPPU } & \text { Opuntia } \\ \text { Perennial } & \text { ESVIR2 } & \text { Escobaria } \\ \text { Perennial } & \text { OPERE } & \text { Opuntia } \\ \text { Perennial } & \text { OPRA } & \text { Opuntia } \\ \text { Perennial } & \text { SCPO4 } & \text { Sclerocactus } \\ \text { Perennial } & \text { ECENE } & \text { Echinocereus } \\ \text { Perennial } & \text { ECTRM } & \text { Echinocereus } \\ \text { Perennial } & \text { ESVID } & \text { Escobaria } \\ \text { Perennial } & \text { MATE4 } & \text { Mammillaria } \\ \text { Perennial } & \text { OPERU } & \text { Opuntia }\end{array}$

brevifolia
echinocarpa var. echinocarpa
polycephalus
basilaris var. basilaris
engelmannii
schidigera
baccata var. vespertina
polyacantha var. rufispina
pulchella
vivipara var. rosea
erinacea var. erinacea
ramosissima
polyancistrus
engelmannii var. engelmannii
triglochidiatus var. melanacanthus
vivipara var. deserti
tetrancistra
erinacea var. ursina

$48.1 \%$

$35.4 \%$

$15.5 \%$

$13.8 \%$

$13.3 \%$

$7.7 \%$

$5.5 \%$

$3.3 \%$

$3.3 \%$

$2.2 \%$

$1.7 \%$

$1.1 \%$

$1.1 \%$

$0.6 \%$

$0.6 \%$

$0.6 \%$

$0.6 \%$

$0.6 \%$ 
Variable

Variable MENTZ Mentzelia

$0.6 \%$ 


\title{
Coleogyne ramosissima Shrubland Alliance
}

\section{Trees (>5 m)}

$\begin{array}{lll}\text { Perennial } & \text { JUOS } & \text { Juniperus } \\ \text { Perennial } & \text { PIMO } & \text { Pinus }\end{array}$

osteosperma

$6.5 \%$

PIMO Pinus

monophylla

\section{Tall Shrubs (2-5 m)}

$\begin{array}{lll}\text { Perennial } & \text { LATR2 } & \text { Larrea } \\ \text { Perennial } & \text { ARTRT } & \text { Artemisia } \\ \text { Perennial } & \text { CELEL } & \text { Cercocarpus } \\ \text { Perennial } & \text { CEGRV2 } & \text { Ceanothus }\end{array}$

\author{
tridentata \\ tridentata ssp. tridentata \\ ledifolius var. ledifolius \\ greggii ssp. vestitus
}

$33.4 \%$

$13.9 \%$

$0.6 \%$

$0.3 \%$

\section{Short Shrubs (0.5-2 m)}

$\begin{array}{lll}\text { Perennial } & \text { CORA } & \text { Coleogyne } \\ \text { Perennial } & \text { EPNE } & \text { Ephedra } \\ \text { Perennial } & \text { LYAN } & \text { Lycium } \\ \text { Perennial } & \text { GRSP } & \text { Grayia } \\ \text { Perennial } & \text { HYSA } & \text { Hymenoclea } \\ \text { Perennial } & \text { KRLA2 } & \text { Krascheninnikovia } \\ \text { Perennial } & \text { CHVIV2 } & \text { Chrysothamnus } \\ \text { Perennial } & \text { TEAXA } & \text { Tetradymia } \\ \text { Perennial } & \text { AMDU2 } & \text { Ambrosia } \\ \text { Perennial } & \text { ATCAC } & \text { Atriplex } \\ \text { Perennial } & \text { ERTE18 } & \text { Ericameria } \\ \text { Perennial } & \text { ERCO23 } & \text { Ericameria } \\ \text { Perennial } & \text { ENVIV } & \text { Encelia } \\ \text { Perennial } & \text { EPVI } & \text { Ephedra } \\ \text { Perennial } & \text { PUST } & \text { Purshia } \\ \text { Perennial } & \text { SAME } & \text { Salazaria } \\ \text { Perennial } & \text { ACSH } & \text { Acamptopappus } \\ \text { Perennial } & \text { ERNAL } & \text { Ericameria } \\ \text { Perennial } & \text { ATCO } & \text { Atriplex } \\ \text { Perennial } & \text { ERFAP } & \text { Eriogonum } \\ & & \end{array}$

ramosissima
nevadensis
andersonii
spinosa
salsola
lanata
viscidiflorus ssp. viscidiflorus
axillaris var. axillaris
dumosa
canescens var. canescens
teretifolia
cooperi
virginensis var. virginensis
viridis
stansburiana
mexicana
shockleyi
nauseosus ssp. consimilis var.
confertifolia
fasciculatum var. polifolium

$100.0 \%$

$91.3 \%$

$66.6 \%$

$55.4 \%$

$52.6 \%$

$47.1 \%$

$32.2 \%$

$28.5 \%$

$28.2 \%$

$27.6 \%$

$25.4 \%$

$24.5 \%$

$22.0 \%$

$22.0 \%$

$19.2 \%$

$17.6 \%$

$17.0 \%$

$16.7 \%$

$15.5 \%$

$15.2 \%$ 


\begin{tabular}{|c|c|c|}
\hline Perennial & LEFR2 & Lepidium \\
\hline Perennial & PSFRF & Psorothamnus \\
\hline Perennial & THMO & Thamnosma \\
\hline Perennial & TECA2 & Tetradymia \\
\hline Perennial & LYPAO & Lycium \\
\hline Perennial & SYLO & Symphoricarpos \\
\hline Perennial & STPIP & Stanleya \\
\hline Perennial & ERLI6 & Ericameria \\
\hline Perennial & ERNAH & Ericameria \\
\hline Perennial & ERMIS2 & Eriogonum \\
\hline Perennial & STEL & Stanleya \\
\hline Perennial & BRMIW & Brickellia \\
\hline Perennial & CHVIP4 & Chrysothamnus \\
\hline Perennial & GUSA2 & Gutierrezia \\
\hline Perennial & PRFA & Prunus \\
\hline Perennial & PUGL2 & Purshia \\
\hline Perennial & ARNO4 & Artemisia \\
\hline Perennial & TEGL & Tetradymia \\
\hline Perennial & ERNA10 & Ericameria \\
\hline Perennial & PSPO & Psorothamnus \\
\hline Perennial & EPFU & Ephedra \\
\hline Perennial & ERHEH2 & Eriogonum \\
\hline Perennial & PENI & Petalonyx \\
\hline Perennial & EPTO & Ephedra \\
\hline Perennial & RHTRA & Rhus \\
\hline Perennial & AMER & Ambrosia \\
\hline Perennial & BROBL & Brickellia \\
\hline Perennial & CHGR6 & Chrysothamnus \\
\hline Perennial & SADOD3 & Salvia \\
\hline Perennial & ARBI3 & Artemisia \\
\hline Perennial & BUUT & Buddleja \\
\hline Perennial & ERCUC & Ericameria \\
\hline Perennial & ERHEA & Eriogonum \\
\hline
\end{tabular}

fremontii
fremontii var. fremontii
montana
canescens
pallidum var. oligospermum
longiflorus
pinnata var. pinnata
linearifolius
nauseosus ssp. nauseosus var.
microthecum var. simpsonii
elata
microphylla var. watsonii
viscidflorus ssp. puberulus
sarothrae
fasciculata
glandulosa
nova
glabrata
nauseosus
polydenius
funerea
heermannii var. heermannii
nitidus
torreyana
trilobata var. anisophylla
eriocentra
oblongifolia var. linifolia
greenei
donii ssp. domii var. domii
bigelovii
utahensis
cuneatus

$14.6 \%$

$13.9 \%$

$12.7 \%$

$10.8 \%$

$7.4 \%$

$6.8 \%$

$6.5 \%$

$5.9 \%$

$5.6 \%$

$5.6 \%$

$5.6 \%$

$4.6 \%$

$4.3 \%$

$3.7 \%$

$3.7 \%$

$3.1 \%$

$2.8 \%$

$2.5 \%$

$1.5 \%$

$1.5 \%$

$1.2 \%$

$1.2 \%$

$1.2 \%$

$0.9 \%$

$0.9 \%$

$0.6 \%$

$0.6 \%$

$0.6 \%$

$0.6 \%$

$0.3 \%$

$0.3 \%$

$0.3 \%$

$0.3 \%$

Wednesday, January 05, 2000

Page 30 of 71 
Lifeform Longevity ACODE Genus

Perennial GLSPA Glossopetalon

Perennial PERA4 Peraphyllum

Perennial

Perennial

Perennial
PUTR2

Purshia

RIVEV

Ribes

SENE5

Senecio

\section{Species}

spinescens var. aridum

ramosissimum

tridentata

velutinum var. velutinum

flaccidus var. douglasii
Frequency

$0.3 \%$

$0.3 \%$

$0.3 \%$

$0.3 \%$

$0.3 \%$

Dwarf Shrubs (<0.5 m)

$\begin{array}{lll}\text { Perennial } & \text { MESP2 } & \text { Menodora } \\ \text { Perennial } & \text { KRER } & \text { Krameria } \\ \text { Perennial } & \text { ARSP5 } & \text { Artemisia } \\ \text { Perennial } & \text { LEPU } & \text { Leptodactylon } \\ \text { Perennial } & \text { ERMIL } & \text { Eriogonum } \\ \text { Perennial } & \text { KOAM } & \text { Kochia }\end{array}$

spinescens
erecta
spinescens
pungens
microthecum var. lapidicola
americana

\section{Graminoids}

$\begin{array}{lll}\text { Annual } & \text { BRRU2 } & \text { Bromus } \\ \text { Perennial } & \text { ACSP12 } & \text { Achnatherum } \\ \text { Perennial } & \text { ELELE } & \text { Elymus } \\ \text { Perennial } & \text { ACHY } & \text { Achnatherum } \\ \text { Perennial } & \text { POSE } & \text { Poa } \\ \text { Annual } & \text { BRTE } & \text { Bromus } \\ \text { Perennial } & \text { PLJA } & \text { Pleuraphis } \\ \text { Annual } & \text { VUOC } & \text { Vulpia } \\ \text { Perennial } & \text { ERPU8 } & \text { Erioneuron } \\ \text { Perennial } & \text { POFE } & \text { Poa } \\ \text { Perennial } & \text { ARPU9 } & \text { Aristida } \\ \text { Perennial } & \text { HECOC8 } & \text { Hesperostipa } \\ \text { Annual } & \text { SCAR } & \text { Schismus } \\ \text { Perennial } & \text { PLRI3 } & \text { Pleuraphis } \\ \text { Annual } & \text { VUMI } & \text { Vulpia } \\ \text { Perennial } & \text { ACAR14 } & \text { Achnatherum } \\ \text { Perennial } & \text { ACCO21 } & \text { Achnatherum } \\ \text { Perennial } & \text { BOGR2 } & \text { Bouteloua } \\ & & \end{array}$

rubens
speciosum
elymoides ssp. elymoides
hymenoides
secunda
tectorum
jamesii
octoflora
pulchellum
fendleriana
purpurea
comata ssp. comata
arabicus
rigida
microstachys
aridum
coronata
gracilis

$86.7 \%$

$44.9 \%$

$30.7 \%$

$29.1 \%$

$16.1 \%$

$11.5 \%$

$9.0 \%$

$5.9 \%$

$4.0 \%$

$2.8 \%$

$2.2 \%$

$1.5 \%$

$1.2 \%$

$0.9 \%$

$0.9 \%$

$0.6 \%$

$0.3 \%$

$0.3 \%$

Wednesday, January 05, 2000

Page 31 of 71 
Genus

$\begin{array}{lll}\text { Annual } & \text { BRBE2 } & \text { Bromus } \\ \text { Annual } & \text { BRCA6 } & \text { Bromus } \\ \text { Perennial } & \text { LECl4 } & \text { Leymus }\end{array}$

\section{Forbs}

\begin{tabular}{|c|c|c|}
\hline Annual & AMTE3 & Amsinckia \\
\hline Perennial & SPAMA & Sphaeralcea \\
\hline Annual & CHST & Chaenactis \\
\hline Perennial & DEPAP3 & Delphinium \\
\hline Perennial & XYTOT & Xylorhiza \\
\hline Perennial & CAFL & Calochortus \\
\hline Annual & OXPE2 & Oxytheca \\
\hline Annual & PHVAV2 & Phacelia \\
\hline Annual & ERCI6 & Erodium \\
\hline Annual & ERNI4 & Eriogonum \\
\hline Perennial & ERIN4 & Eriogonum \\
\hline Annual & PHFR2 & Phacelia \\
\hline Annual & ERER2 & Eriastrum \\
\hline Perennial & ARPUM & Arabis \\
\hline Annual & CRNEN & Cryptantha \\
\hline Perennial & CAAP4 & Castilleja \\
\hline Annual & MAGL3 & Malacothrix \\
\hline Perennial & MACAC & Machaeranthera \\
\hline Perennial & HEMUN & Heliomeris \\
\hline Annual & ERDE6 & Eriogonum \\
\hline Annual & LUSH & Lupinus \\
\hline Perennial & PHST11 & Phlox \\
\hline Perennial & CHAL11 & Chamaesyce \\
\hline Annual & ERPR4 & Eriophyllum \\
\hline Annual & CHRI & Chorizanthe \\
\hline Perennial & STPA3 & Stephanomeria \\
\hline Annual & SYFR & Syntrichopappus \\
\hline Annual & CRMI & Cryptantha \\
\hline
\end{tabular}

Wednesday, January 05, 2000

\section{Species}

berterianus

cartharticus

cinereus
Frequency

$0.3 \%$

$0.3 \%$

$0.3 \%$

tessellata
ambigua ssp. ambigua
stevioides
parishii ssp. parishii
tortifolia var. imberbis
flexuosus
perfoliata
vallis-mortae var. vallis-mortae
cicutarium
nidularium
inflatum
fremontii
eremicum
pulchra var. munciensis
nevadensis var. nevadensis
applegatei
glabrata
canescens ssp. canescens
multifiora var. nevadensis
deflexum
shockleyi
stansburyi
albomarginata
pringlei
rigida
parryi
fremontii
micrantha

$65.9 \%$

$36.8 \%$

$32.2 \%$

$28.5 \%$

$24.1 \%$

$23.8 \%$

$22.6 \%$

$22.3 \%$

$21.7 \%$

$19.2 \%$

$17.0 \%$

$13.9 \%$

$13.6 \%$

$13.0 \%$

$12.4 \%$

$12.1 \%$

$11.8 \%$

$11.1 \%$

$10.8 \%$

$7.7 \%$

$7.7 \%$

$7.7 \%$

$7.4 \%$

$7.4 \%$

$6.8 \%$

$6.8 \%$

$6.8 \%$

$6.2 \%$ 


\begin{tabular}{|c|c|c|c|}
\hline Lifeform & Longevity & $A C O D E$ & Genus \\
\hline & Annual & PESE & Pectocarya \\
\hline & Annual & STEXE & Stephanomeria \\
\hline & Annual & CRPT & Cryptantha \\
\hline & Annual & GILIA & Gilia \\
\hline & Perennial & GIIN2 & Gilia \\
\hline & Annual & LOHU2 & Lotus \\
\hline & Annual & MEVE5 & Mentzelia \\
\hline & Perennial & ARMA3 & Arenaria \\
\hline & Annual & CAKEG & Camissonia \\
\hline & Annual & CETH3 & Centrostegia \\
\hline & Annual & DEPIG & Descurainia \\
\hline & Annual & LELA & Lepidium \\
\hline & Perennial & STPA4 & Stephanomeria \\
\hline & Perennial & $\mathrm{ADCO} 2$ & Adenophyllum \\
\hline & Perennial & DIPU3 & Dichelostemma \\
\hline & Annual & ASLEF2 & Astragalus \\
\hline & Perennial & ERCOC3 & Erigeron \\
\hline & Perennial & CRUT & Cryptantha \\
\hline & Annual & LASE3 & Langloisia \\
\hline & Annual & LUBR2 & Lupinus \\
\hline & Annual & LUFL & Lupinus \\
\hline & Annual & $\mathrm{CRCl} 2$ & Cryptantha \\
\hline & Perennial & EROVO5 & Eriogonum \\
\hline & Perennial & GIBRB & Gilia \\
\hline & Perennial & ASLA8 & Astragalus \\
\hline & Perennial & LONEN & Lomatium \\
\hline & Annual & RANE & Rafinesquia \\
\hline & Perennial & SPAMR & Sphaeralcea \\
\hline & Annual & ERMA2 & Eriogonum \\
\hline & Annual & IPPO2 & Ipomopsis \\
\hline & Perennial & MIBI8 & Mirabilis \\
\hline & Perennial & CRCO12 & Cryptantha \\
\hline & Perennial & ARCOS2 & Arenaria \\
\hline
\end{tabular}

Species

setosa

exigua ssp. exigua

pterocarya

inconspicua

humistratus

veatchiana

macradenia

kemensis ssp. gilmanii

thurberi

pinnata ssp. glabra

lasiocarpum

pauciflora

cooperi

pulchellum

lentiginosus var. fremontii

concinnus var. concinnus

utahensis

setosissima

brevicaulis

flavoculatus

circumscissa

ovalifolium var. ovalifolium

brecciarum ssp. brecciarum

layneae

nevadense var. nevadense

neomexicana

ambiguua var. rugosa

maculatum

polycladon

bigelovii

confertiflora

congesta var. subcongesta
Frequency

$6.2 \%$

$6.2 \%$

$5.9 \%$

$5.6 \%$

$5.6 \%$

$5.3 \%$

$5.3 \%$

$5.0 \%$

$5.0 \%$

$4.6 \%$

$4.6 \%$

$4.6 \%$

$4.6 \%$

$4.3 \%$

$4.3 \%$

$4.0 \%$

$4.0 \%$

$3.7 \%$

$3.7 \%$

$3.7 \%$

$3.7 \%$

$3.4 \%$

$3.4 \%$

$3.4 \%$

$3.1 \%$

$3.1 \%$

$3.1 \%$

$3.1 \%$

$2.8 \%$

$2.8 \%$

$2.8 \%$

$2.5 \%$

$2.2 \%$ 


\section{Species}

$\begin{array}{lll}\text { Annual } & \text { ASAC3 } & \text { Astragalus } \\ \text { Biennial } & \text { CINE } & \text { Cirsium } \\ \text { Perennial } & \text { MIPU5 } & \text { Mirabilis } \\ \text { Annual } & \text { PLPA2 } & \text { Plantago } \\ \text { Annual } & \text { STLO4 } & \text { Streptanthella } \\ \text { Annual } & \text { CABOC } & \text { Camissonia } \\ \text { Annual } & \text { CHFR } & \text { Chaenactis } \\ \text { Annual } & \text { CHBRB } & \text { Chorizanthe } \\ \text { Annual } & \text { NADED } & \text { Nama } \\ \text { Annual } & \text { URLI2 } & \text { Uropappus } \\ \text { Perennial } & \text { ALNE } & \text { Allium } \\ \text { Perennial } & \text { ARIN } & \text { Arabis } \\ \text { Perennial } & \text { ARLU } & \text { Artemisia } \\ \text { Perennial } & \text { ASPUT } & \text { Astragalus } \\ \text { Annual } & \text { CAPA7 } & \text { Calycoseris } \\ \text { Annual } & \text { CABRB4 } & \text { Camissonia } \\ \text { Perennial } & \text { OECEM4 } & \text { Oenothera } \\ \text { Annual } & \text { PEPL } & \text { Pectocarya } \\ \text { Annual } & \text { PSAN } & \text { Psathyrotes } \\ \text { Biennial } & \text { SIAL2 } & \text { Sisymbrium } \\ \text { Perennial } & \text { SPGRP2 } & \text { Sphaeralcea } \\ \text { Perennial } & \text { ARPUG } & \text { Arabis } \\ \text { Perennial } & \text { BAMU } & \text { Baileya } \\ \text { Perennial } & \text { ERCA8 } & \text { Eriogonum } \\ \text { Annual } & \text { LIDI2 } & \text { Linanthus } \\ \text { Annual } & \text { MEAL6 } & \text { Mentzelia } \\ \text { Annual } & \text { MEOB3 } & \text { Mentzelia } \\ \text { Annial } & \text { PEFLA2 } & \text { Penstemon } \\ \text { A } & \text { SACOC } & \text { Salvia } \\ \text { ASER2 } & \text { Asclepias } \\ \text { CHCA } & \text { Chaenactis } \\ \text { Claytonia } \\ \text { Cymopterus }\end{array}$

acutirostris

neomexicanum

pudica

patagonica

longirostris

boothii ssp. condensata

fremontii

brevicomu var. brevicomu

demissum var. demissum

linearifolia

nevadense

inyoensis

ludoviciana

purshii var. tinctus

parryi

brevipes ssp. brevipes

caespitosa ssp. marginata

platycarpa

annua

altissimum

grossulariaefolia ssp. pedata

pulchra var. gracilis

multiradiata

caespitosum

dichotomus

albicaulis

obscura

floridus var. austinii

columbariae var. columbariae

erosa

carphoclinia

perfoliata ssp. perfoliata

globosus
$2.2 \%$

$2.2 \%$

Frequency

$2.2 \%$

$2.2 \%$

$2.2 \%$

$1.9 \%$

$1.9 \%$

$1.9 \%$

$1.9 \%$

$1.9 \%$

$1.5 \%$

$1.5 \%$

$1.5 \%$

$1.5 \%$

$1.5 \%$

$1.5 \%$

$1.5 \%$

$1.5 \%$

$1.5 \%$

$1.5 \%$

$1.5 \%$

$1.2 \%$

$1.2 \%$

$1.2 \%$

$1.2 \%$

$1.2 \%$

$1.2 \%$

$1.2 \%$

$1.2 \%$

$0.9 \%$

$0.9 \%$

$0.9 \%$

$0.9 \%$ 


\section{Species}

\begin{tabular}{|c|c|c|}
\hline Annual & DESO2 & Descurainia \\
\hline Annual & ERPU6 & Eriogonum \\
\hline Perennial & ERSA6 & Eriogonum \\
\hline Annual & ERTH & Eriogonum \\
\hline Annual & LEFLF2 & Lepidium \\
\hline Annual & LOSC6 & Loesehastrum \\
\hline Annual & MISU2 & Mimulus \\
\hline Annual & MOBE & Monoptilon \\
\hline Annual & PHCRC3 & Phacelia \\
\hline Perennial & POSU & Polygala \\
\hline Perennial & STCOC & Streptanthus \\
\hline Annual & AMAC2 & Ambrosia \\
\hline Perennial & ARHOP3 & Arabis \\
\hline Annual & ASDID & Astragalus \\
\hline Perennial & BRAT & Brickellia \\
\hline Annual & CACLI & Camissonia \\
\hline Annual & CHMA & Chaenactis \\
\hline Perennial & CRFL6 & Cryptantha \\
\hline Annual & CRGR3 & Cryptantha \\
\hline Annual & CRRE5 & Cryptantha \\
\hline Perennial & CYAB & Cymopterus \\
\hline Annual & ERSP3 & Eriastrum \\
\hline Annual & ERDI4 & Erigeron \\
\hline Perennial & ERUM & Eriogonum \\
\hline Annual & ESGL & Eschscholzia \\
\hline Annual & HAGL & Halogeton \\
\hline Annual & LAOCO & Lappula \\
\hline Annual & LIDE2 & Linanthus \\
\hline Annual & MASO & Malacothrix \\
\hline Annual & MENI2 & Mentzelia \\
\hline Annual & NAPU & Nama \\
\hline Perennial & OEPAP & Oenothera \\
\hline Perennial & PHGRH & Phlox \\
\hline
\end{tabular}

sophia

pusillum

saxatile

thomasii

flavum var. flavum

schottii

suksdorfii

bellidiforme

crenulata var. crenulata

subspinosa

cordatus var. cordatus

acanthicarpa

holboellii var. pinetorum

didymocarpus var. dispermus

atractyloides

claviformis ssp. integrior

macrantha

flavoculata

gracilis

recurvata

aboriginum

sparsiflorum

divergens

umbellatum

glyptosperma

giomeratus

occidentalis var. occidentalis

demissus

sonchoides

nitens

pusillum

pallida ssp. pallida

gracilis ssp. humilis
Frequency

$0.9 \%$

$0.9 \%$

$0.9 \%$

$0.9 \%$

$0.9 \%$

$0.9 \%$

$0.9 \%$

$0.9 \%$

$0.9 \%$

$0.9 \%$

$0.9 \%$

$0.6 \%$

$0.6 \%$

$0.6 \%$

$0.6 \%$

$0.6 \%$

$0.6 \%$

$0.6 \%$

$0.6 \%$

$0.6 \%$

$0.6 \%$

$0.6 \%$

$0.6 \%$

$0.6 \%$

$0.6 \%$

$0.6 \%$

$0.6 \%$

$0.6 \%$

$0.6 \%$

$0.6 \%$

$0.6 \%$

$0.6 \%$

$0.6 \%$ 
Lifeform Longevity ACODE

Genus

\begin{tabular}{|c|c|c|}
\hline Perennial & SEMU3 & Senecio \\
\hline Annual & THCU & Thysanocarpus \\
\hline Annual & ANAC & Anisocoma \\
\hline Perennial & ARSH & Arabis \\
\hline Perennial & ARMUR & Argemone \\
\hline Perennial & ASCA14 & Astragalus \\
\hline Annual & BAPL3 & Baileya \\
\hline Annual & CAHE12 & Camissonia \\
\hline Annual & CAME16 & Camissonia \\
\hline Perennial & CALI4 & Castilleja \\
\hline Annual & CHWA2 & Chorizanthe \\
\hline Annual & CIPAN & Cistanthe \\
\hline Annual & COPA3 & Collinsia \\
\hline Perennial & $\mathrm{CROCO} 2$ & Crepis \\
\hline Perennial & CRVI5 & Cryptantha \\
\hline Annual & CRWA2 & Cryptantha \\
\hline Perennial & CYPU & Cymopterus \\
\hline Perennial & CYRI2 & Cymopterus \\
\hline Perennial & DEAN & Delphinium \\
\hline Annual & ERBR7 & Eriogonum \\
\hline Annual & ERGL4 & Eriogonum \\
\hline Perennial & ERNU4 & Eriogonum \\
\hline Annual & ERTR8 & Eriogonum \\
\hline Perennial & GIALB & Gilia \\
\hline Perennial & GIHU & Gilia \\
\hline Perennial & GILA2 & Gilia \\
\hline Perennial & GIOP & Gilia \\
\hline Perennial & GISC & Gilia \\
\hline Perennial & LILE3 & Linum \\
\hline Perennial & LOSC3 & Lomatium \\
\hline Annual & LUCOO2 & Lupinus \\
\hline Annual & MECO2 & Mentzelia \\
\hline Annual & MISP & Mimulus \\
\hline
\end{tabular}

\section{Species}

multilobatus

cunvipes

acaulis

shockleyi

munita ssp. rotundata

casei

pleniradiata

heterochroma

megalantha

linariaefolia

watsonii

parryi var. nevadense

parviflora

occidentalis ssp. occidentalis

virginensis

watsonii

purpurascens

ripleyi

andersonii

brachyanthum

glandulosum

nummulare

trichopes

aliquanta ssp. Breviloba

hutchinsifolia

latifolia

ophthaimoides

scopulorum

lewisii

scabrum

concinnus ssp. orcuttii

congesta

spissus
Frequency

$0.6 \%$

$0.6 \%$

$0.3 \%$

$0.3 \%$

$0.3 \%$

$0.3 \%$

$0.3 \%$

$0.3 \%$

$0.3 \%$

$0.3 \%$

$0.3 \%$

$0.3 \%$

$0.3 \%$

$0.3 \%$

$0.3 \%$

$0.3 \%$

$0.3 \%$

$0.3 \%$

$0.3 \%$

$0.3 \%$

$0.3 \%$

$0.3 \%$

$0.3 \%$

$0.3 \%$

$0.3 \%$

$0.3 \%$

$0.3 \%$

$0.3 \%$

$0.3 \%$

$0.3 \%$

$0.3 \%$

$0.3 \%$

$0.3 \%$

Page 36 of 71 
Lifeform Longevity ACODE

$\begin{array}{lll}\text { Annual } & \text { NEGLO } & \text { Nemacladus } \\ \text { Perennial } & \text { ORFA } & \text { Orobanche } \\ \text { Annual } & \text { PERE } & \text { Pectocarya } \\ \text { Perennial } & \text { PEPA8 } & \text { Penstemon } \\ \text { Annual } & \text { PHCU } & \text { Phacelia } \\ \text { Annual } & \text { PHSA } & \text { Phacelia } \\ \text { Annual } & \text { PLOV } & \text { Plantago } \\ \text { Annual } & \text { PREX } & \text { Prenanthella } \\ \text { Annual } & \text { SAKAT3 } & \text { Salsola } \\ \text { Annual } & \text { SAPA8 } & \text { Salsola } \\ \text { Perennial } & \text { SPAMM } & \text { Sphaeralcea } \\ \text { Annual } & \text { STMI2 } & \text { Stylocline } \\ \text { Perennial } & \text { THPEB } & \text { Thymphylla } \\ \text { Annual } & \text { TINU2 } & \text { Tiquilia }\end{array}$

\section{Epiphytes}

Perennial CUDEV Cuscuta

\section{Succulents}

$\begin{array}{lll}\text { Perennial } & \text { YUBR } & \text { Yucca } \\ \text { Perennial } & \text { OPECE } & \text { Opuntia } \\ \text { Perennial } & \text { ECPO2 } & \text { Echinocactus } \\ \text { Perennial } & \text { YUBAV } & \text { Yucca } \\ \text { Perennial } & \text { ECEN } & \text { Echinocereus } \\ \text { Perennial } & \text { OPBAB2 } & \text { Opuntia } \\ \text { Perennial } & \text { YUSC2 } & \text { Yucca } \\ \text { Perennial } & \text { OPPOR } & \text { Opuntia } \\ \text { Perennial } & \text { OPERE } & \text { Opuntia } \\ \text { Perennial } & \text { OPPU } & \text { Opuntia } \\ \text { Perennial } & \text { ESVIR2 } & \text { Escobaria } \\ \text { Perennial } & \text { ESVID } & \text { Escobaria } \\ \text { Perennial } & \text { OPRA } & \text { Opuntia } \\ \text { Perennial } & \text { SCPO4 } & \text { Sclerocactus }\end{array}$

Wednesday, January 05, 2000

\section{Species}

glanduliferus var. orientalis

fasciculata

recurvata

palmeri

curvipes

saxicola

ovata

exigua

kali ssp. tragus

pau/senii

ambigua ssp. monticola

micropoides

pentachaeta var. belenidium

nuttallii

denticulata var. vetchii

$0.9 \%$

brevifolia
echinocarpa var. echinocarpa
polycephalus
baccata var. vespertina
engelmannii
basilaris var. basilaris
schidigera
polyacantha var. rufispina
erinacea var. erinacea
pulchella
vivipara var. rosea
vivipara var. deserti
ramosissima
polyancistrus

$55.7 \%$

$35.6 \%$

$16.4 \%$

$15.2 \%$

$13.0 \%$

$8.7 \%$

$6.2 \%$

$4.6 \%$

$4.0 \%$

$2.2 \%$

$1.5 \%$

$1.2 \%$

$0.9 \%$

$0.9 \%$ 
Lifeform Longevity ACODE

Perennial

MATE4

Perennial
Genus

Mammillaria

Echinocereus

Variable

Variable

ERIOG
Species

tetrancistra

engelmannii var. engelmannii
Frequency

$0.6 \%$

$0.3 \%$

$0.6 \%$ 


\section{Atriplex spp. Shrubland Alliance}

\section{Trees (>5 m)}

Perennial JUOS Juniperus

osteosperma

Tall Shrubs (2-5 m)

$\begin{array}{lll}\text { Perennial } & \text { LATR2 } & \text { Larrea } \\ \text { Perennial } & \text { ARTRT } & \text { Artemisia }\end{array}$

tridentata

\section{Short Shrubs (0.5-2 m)}

$\begin{array}{lll}\text { Perennial } & \text { ATCAC } & \text { Atriplex } \\ \text { Perennial } & \text { KRLA2 } & \text { Krascheninnikovia } \\ \text { Perennial } & \text { LYAN } & \text { Lycium } \\ \text { Perennial } & \text { ATCO } & \text { Atriplex } \\ \text { Perennial } & \text { EPNE } & \text { Ephedra } \\ \text { Perennial } & \text { GRSP } & \text { Grayia } \\ \text { Perennial } & \text { HYSA } & \text { Hymenoclea } \\ \text { Perennial } & \text { CHVIV2 } & \text { Chrysothamnus } \\ \text { Perennial } & \text { ACSH } & \text { Acamptopappus } \\ \text { Perennial } & \text { TEAXA } & \text { Tetradymia } \\ \text { Perennial } & \text { CORA } & \text { Coleogyne } \\ \text { Perennial } & \text { TECA2 } & \text { Tetradymia } \\ \text { Perennial } & \text { AMDU2 } & \text { Ambrosia } \\ \text { Perennial } & \text { LEFR2 } & \text { Lepidium } \\ \text { Perennial } & \text { EPTO } & \text { Ephedra } \\ \text { Perennial } & \text { LYSH } & \text { Lycium } \\ \text { Perennial } & \text { PSFRF } & \text { Psorothamnus } \\ \text { Perennial } & \text { STPIP } & \text { Stanleya } \\ \text { Perennial } & \text { EPVI } & \text { Ephedra } \\ \text { Perennial } & \text { ERNAH } & \text { Ericameria } \\ \text { Perennial } & \text { LYPAO } & \text { Lycium } \\ \text { Perennial } & \text { ENVIV } & \text { Encelia } \\ \text { Perennial } & \text { ERCO23 } & \text { Ericameria } \\ & & \\ & & \text { AMT }\end{array}$

canescens var. canescens
lanata
andersonii
confertifolia
nevadensis
spinosa
salsola
viscidiflorus ssp. viscidiflorus
shockleyi
axillaris var. axillaris
ramosissima
canescens
dumosa
fremontii
torreyana
shockleyi
fremontii var. fremontii
pinnata var. pinnata
viridis
nauseosus ssp. nauseosus var.
pallidum var. oligospermum
virginensis var. virginensis
cooperi




$\begin{array}{lll}\text { Perennial } & \text { ERNA7 } & \text { Ericameria } \\ \text { Perennial } & \text { ERNAL } & \text { Ericameria } \\ \text { Perennial } & \text { ERTE18 } & \text { Ericameria } \\ \text { Perennial } & \text { ERFAP } & \text { Eriogonum } \\ \text { Perennial } & \text { GUSA2 } & \text { Gutiemezia } \\ \text { Perennial } & \text { PSPO } & \text { Psorothamnus } \\ \text { Perennial } & \text { PUGL2 } & \text { Purshra } \\ \text { Perennial } & \text { PUST } & \text { Purshia } \\ \text { Perennial } & \text { SAME } & \text { Salazaria } \\ \text { Perennial } & \text { SYLO } & \text { Symphoricarpos } \\ \text { Perennial } & \text { THMO } & \text { Thamnosma }\end{array}$

nauseosus ssp. consimilis var.

fasciculatum var. polifolium

montana

Dwarf Shrubs $(<0.5 \mathrm{~m})$

$\begin{array}{lll}\text { Perennial } & \text { ARSP5 } & \text { Artemisia } \\ \text { Perennial } & \text { KOAM } & \text { Kochia } \\ \text { Perennial } & \text { MESP2 } & \text { Menodora } \\ \text { Perennial } & \text { KRER } & \text { Krameria }\end{array}$

spinescens
americana
spinescens
erecte

erecta

\section{Graminoids}

$\begin{array}{lll}\text { Annual } & \text { BRRU2 } & \text { Bromus } \\ \text { Perennial } & \text { ACHY } & \text { Achnatherum } \\ \text { Perennial } & \text { ELELE } & \text { Elymus } \\ \text { Annual } & \text { BRTE } & \text { Bromus } \\ \text { Perennial } & \text { ACSP12 } & \text { Achnatherum } \\ \text { Perennial } & \text { PLJA } & \text { Pleuraphis } \\ \text { Perennial } & \text { ERPU8 } & \text { Erioneuron } \\ \text { Perennial } & \text { POSE } & \text { Poa } \\ \text { Perennial } & \text { LECl4 } & \text { Leymus } \\ \text { Perennial } & \text { POFE } & \text { Poa } \\ \text { Annual } & \text { VUOC } & \text { Vulpia }\end{array}$

\section{Forbs}

$\begin{array}{lll}\text { Annual } & \text { AMTE3 } & \text { Amsinckia } \\ \text { Annual } & \text { CHST } & \text { Chaenactis }\end{array}$


Lifeform Longevity ACODE

\section{Genus}

\begin{tabular}{|c|c|c|}
\hline Perennial & SPAMA & Sphaeralcea \\
\hline Annual & ERDE6 & Eriogonum \\
\hline Perennial & MIPU5 & Mirabilis \\
\hline Biennial & SIAL2 & Sisymbrium \\
\hline Perennial & MACAC & Machaeranthera \\
\hline Annual & ERCI6 & Erodium \\
\hline Annual & SAPAB & Salsola \\
\hline Annual & $\mathrm{CHRI}$ & Chorizanthe \\
\hline Annual & ASLEF2 & Astragalus \\
\hline Perennial & CHAL11 & Chamaesyce \\
\hline Perennial & ERIN4 & Eriogonum \\
\hline Annual & ERPR4 & Eriophyllum \\
\hline Perennial & HEMUN & Heliomeris \\
\hline Annual & MAGL3 & Malacothrix \\
\hline Annual & ERER2 & Eriastrum \\
\hline Annual & MEOB3 & Mentzelia \\
\hline Perennial & MIBI8 & Mirabilis \\
\hline Annual & OXPE2 & Oxytheca \\
\hline Annual & PHFR2 & Phacelia \\
\hline Perennial & BAMU & Baileya \\
\hline Annual & CRMI & Cryptantha \\
\hline Perennial & CYGL2 & Cymopterus \\
\hline Annual & ERNI4 & Eriogonum \\
\hline Perennial & OECEM4 & Oenothera \\
\hline Annual & STEXE & Stephanomeria \\
\hline Perennial & CAFL & Calochortus \\
\hline Annual & CRPT & Cryptantha \\
\hline Annual & MEAL6 & Mentzelia \\
\hline Perennial & CAAP4 & Castilleja \\
\hline Annual & CHMA & Chaenactis \\
\hline Annual & CHBRB & Chorizanthe \\
\hline Perennial & DEPAP3 & Delphinium \\
\hline Annual & DEPIG & Descurainia \\
\hline
\end{tabular}

Species

ambigua ssp. ambigua

deflexum

pudica

altissimum

canescens ssp. canescens

cıcutarium

paulsenii

rigida

lentiginosus var. fremontii

albomarginata

Inflatum

pnnglei

multiflora var. nevadensis

glabrata

eremicum

obscura

bigelovii

perfoliata

fremontii

multiradiata

micrantha

globosus

nidularium

caespitosa ssp. marginata

exigua ssp. exigua

flexuosus

pterocarya

albicaulis

applegatei

macrantha

brevicomu var. brevicomu

parishii ssp. parishii

pinnata ssp. glabra
Frequency

$45.5 \%$

$38.2 \%$

$38.2 \%$

$36.4 \%$

$30.9 \%$

$18.2 \%$

$18.2 \%$

$16.4 \%$

$14.5 \%$

$14.5 \%$

$14.5 \%$

$10.9 \%$

$10.9 \%$

$10.9 \%$

$9.1 \%$

$9.1 \%$

$9.1 \%$

$9.1 \%$

$9.1 \%$

$7.3 \%$

$7.3 \%$

$7.3 \%$

$7.3 \%$

$7.3 \%$

$7.3 \%$

$5.5 \%$

$5.5 \%$

$5.5 \%$

$3.6 \%$

$3.6 \%$

$3.6 \%$

$3.6 \%$

$3.6 \%$ 


\section{Species}

$\begin{array}{lll}\text { Annual } & \text { ERPU6 } & \text { Eriogonum } \\ \text { Annual } & \text { ESGL } & \text { Eschscholzia } \\ \text { Perennial } & \text { GIBRB } & \text { Gilia } \\ \text { Perennial } & \text { GIIN2 } & \text { Gilia } \\ \text { Annual } & \text { HAGL } & \text { Halogeton } \\ \text { Annual } & \text { LELA } & \text { Lepidium } \\ \text { Annual } & \text { LUFL } & \text { Lupinus } \\ \text { Annual } & \text { MISP } & \text { Mimulus } \\ \text { Annual } & \text { PHCRC3 } & \text { Phacelia } \\ \text { Perennial } & \text { PHST11 } & \text { Phlox } \\ \text { Perennial } & \text { POSU } & \text { Polygala } \\ \text { Annual } & \text { SAKAT3 } & \text { Salsola } \\ \text { Perennial } & \text { ARME2 } & \text { Arctomecon } \\ \text { Perennial } & \text { ARDR4 } & \text { Artemisia } \\ \text { Annual } & \text { ASAC3 } & \text { Astragalus } \\ \text { Perennial } & \text { ASCA14 } & \text { Astragalus } \\ \text { Perennial } & \text { ASPUT } & \text { Astragalus } \\ \text { Perennial } & \text { ASTI } & \text { Astragalus } \\ \text { Annual } & \text { CAPA7 } & \text { Calycoseris } \\ \text { Annual } & \text { CABRB4 } & \text { Camissonia } \\ \text { Annual } & \text { CAKEG } & \text { Camissonia } \\ \text { Annual } & \text { CAME16 } & \text { Camissonia } \\ \text { Annual } & \text { CETH3 } & \text { Centrostegia } \\ \text { Annual } & \text { CHFR } & \text { Chaenactis } \\ \text { Annual } & \text { CHAL7 } & \text { Chenopodium } \\ \text { Annual } & \text { CRCI2 } & \text { Cryptantha } \\ \text { Perennial } & \text { CRCO12 } & \text { Cryptantha } \\ \text { Perennial } & \text { CRUT } & \text { Cryptantha } \\ \text { ARPOal } & \text { CRVI5 } & \text { Cryptantha } \\ \text { ERCOC3 } & \text { Erigeron } \\ \text { ERUM } & \text { Eriogonum } \\ \text { Anomsis } \\ \text { ARniantha }\end{array}$

pusillum
glyptosperma
brecciarum ssp. brecciarum
inconspicua
glomeratus
lasiocarpum
flavoculatus
spissus
crenulata var. crenulata
stansburyi
subspinosa
kali ssp. tragus
merriamii
dracunculus
acutirostris
casei
purshii var. tinctus
tidestromii
parryi
brevipes ssp. brevipes
kemensis ssp. gilmanii
megalantha
thurberi
fremontii
album
circumscissa
confertiflora
nevadensis var. nevadensis
utahensis
virginensis
concinnus var. concinnus
umbellatum
polydon
a

Frequency

$3.6 \%$

$3.6 \%$

$3.6 \%$

$3.6 \%$

$3.6 \%$

$3.6 \%$

$3.6 \%$

$3.6 \%$

$3.6 \%$

$3.6 \%$

$3.6 \%$

$3.6 \%$

$1.8 \%$

$1.8 \%$

$1.8 \%$

$1.8 \%$

$1.8 \%$

$1.8 \%$

$1.8 \%$

$1.8 \%$

$1.8 \%$

$1.8 \%$

$1.8 \%$

$1.8 \%$

$1.8 \%$

$1.8 \%$

$1.8 \%$

$1.8 \%$

$1.8 \%$

$1.8 \%$

$1.8 \%$

$1.8 \%$

$1.8 \%$

Page 42 of 71 
Lifeform Longevity ACODE

$\begin{array}{lll}\text { Perennial } & \text { LILE3 } & \text { Linum } \\ \text { Annual } & \text { LUBR2 } & \text { Lupinus } \\ \text { Annual } & \text { LUSH } & \text { Lupinus } \\ \text { Annual } & \text { MEVE5 } & \text { Mentzelia } \\ \text { Annual } & \text { NADED } & \text { Nama } \\ \text { Annual } & \text { OEPR } & \text { Oenothera } \\ \text { Annual } & \text { PLPA2 } & \text { Plantago } \\ \text { Annual } & \text { PSAN } & \text { Psathyrotes } \\ \text { Annual } & \text { SACOC } & \text { Salvia } \\ \text { Perennial } & \text { SPAMM } & \text { Sphaeralcea } \\ \text { Perennial } & \text { SPGRP2 } & \text { Sphaeralcea } \\ \text { Perennial } & \text { STPA4 } & \text { Stephanomeria } \\ \text { Annual } & \text { SYFR } & \text { Syntrichopappus } \\ \text { Annual } & \text { URL12 } & \text { Uropappus }\end{array}$

Species

lewisii

brevicaulis

shockleyi

veatchiana

demissum var. demissum

primiveris

patagonica

annua

columbariae var. columbariae

ambigua ssp. monticola

grossulariaefolia ssp. pedata

pauciflora

fremontii

linearifolia
Frequency

$1.8 \%$

$1.8 \%$

$1.8 \%$

$1.8 \%$

$1.8 \%$

$1.8 \%$

$1.8 \%$

$1.8 \%$

$1.8 \%$

$1.8 \%$

$1.8 \%$

$1.8 \%$

$1.8 \%$

$1.8 \%$

\section{Succulents}

$\begin{array}{lll}\text { Perennial } & \text { YUBR } & \text { Yucca } \\ \text { Perennial } & \text { OPECE } & \text { Opuntia } \\ \text { Perennial } & \text { OPBAB2 } & \text { Opuntia } \\ \text { Perennial } & \text { YUSC2 } & \text { Yucca } \\ \text { Perennial } & \text { ECEN } & \text { Echinocereus } \\ \text { Perennial } & \text { ECPO2 } & \text { Echinocactus } \\ \text { Perennial } & \text { ESVIR2 } & \text { Escobaria } \\ \text { Perennial } & \text { OPERE } & \text { Opuntia } \\ \text { Perennial } & \text { OPPOR } & \text { Opuntia } \\ \text { Perennial } & \text { SCPO4 } & \text { Sclerocactus } \\ \text { Perennial } & \text { YUBAV } & \text { Yucca }\end{array}$

brevifolia

$29.1 \%$

echinocarpa var. echinocarpa

$18.2 \%$

basilaris var. basilaris

$9.1 \%$

schidigera

$5.5 \%$

engelmannii

$3.6 \%$

polycephalus

$1.8 \%$

vivipara var. rosea

$1.8 \%$

erinacea var. erinacea

$1.8 \%$

polyacantha var. rufispina

$1.8 \%$

polyancistrus

$1.8 \%$

baccata var. vespertina

$1.8 \%$ 
Chrysothamnus-Ericameria Shrubland Alliance

Trees $(>5 \mathrm{~m})$

$\begin{array}{lll}\text { Perennial } & \text { PIMO } & \text { Pinus } \\ \text { Perennial } & \text { JUOS } & \text { Juniperus } \\ \text { Perennial } & \text { QUGA } & \text { Quercus }\end{array}$

monophylla

$5.2 \%$

osteosperma

gambelii

$4.1 \%$

$1.0 \%$

Tall Shrubs (2-5 m)

$\begin{array}{lll}\text { Perennial } & \text { ARTRT } & \text { Artemisia } \\ \text { Perennial } & \text { LATR2 } & \text { Larrea } \\ \text { Perennial } & \text { AMUT } & \text { Amelanchier }\end{array}$

tridentata ssp. tridentata

$40.2 \%$

tridentata

$8.2 \%$

utahensis

$1.0 \%$

\section{Short Shrubs (0.5-2 m)}

$\begin{array}{lll}\text { Perennial } & \text { CHVIV2 } & \text { Chrysothamnus } \\ \text { Perennial } & \text { EPNE } & \text { Ephedra } \\ \text { Perennial } & \text { LYAN } & \text { Lycium } \\ \text { Perennial } & \text { KRLA2 } & \text { Krascheninnikovia } \\ \text { Perennial } & \text { GRSP } & \text { Grayia } \\ \text { Perennial } & \text { ATCAC } & \text { Atriplex } \\ \text { Perennial } & \text { CORA } & \text { Coleogyne } \\ \text { Perennial } & \text { ERNAH } & \text { Ericameria } \\ \text { Perennial } & \text { HYSA } & \text { Hymenoclea } \\ \text { Perennial } & \text { STPIP } & \text { Stanleya } \\ \text { Perennial } & \text { ATCO } & \text { Atriplex } \\ \text { Perennial } & \text { TECA2 } & \text { Tetradymia } \\ \text { Perennial } & \text { TEAXA } & \text { Tetradymia } \\ \text { Perennial } & \text { EPVI } & \text { Ephedra } \\ \text { Perennial } & \text { ERCO23 } & \text { Ericameria } \\ \text { Perennial } & \text { LEFR2 } & \text { Lepidium } \\ \text { Perennial } & \text { ERTE18 } & \text { Ericameria } \\ \text { Perennial } & \text { GUSA2 } & \text { Gutierrezia } \\ \text { Perennial } & \text { ERNAL } & \text { Ericameria } \\ \text { Perennial } & \text { PUGL2 } & \text { Purshia }\end{array}$

Wednesday, January 05, 2000
$87.6 \%$

$81.4 \%$

$70.1 \%$

$64.9 \%$

$60.8 \%$

$58.8 \%$

$35.1 \%$

$30.9 \%$

$25.8 \%$

$24.7 \%$

$23.7 \%$

$22.7 \%$

$21.6 \%$

$20.6 \%$

$17.5 \%$

$15.5 \%$

$13.4 \%$

$13.4 \%$

$11.3 \%$

$11.3 \%$

Page 44 of 71 


\section{Species}

Perennial

AMDU2

Ambrosia

Perennial

PUST

Purshia

Perennial

SYLO

Symphoricarpos

Perennial

ARNO4

Artemisia

Perennial

ERMIS2

Eriogonum

Iinearifolius
Perennial

ENVIV

Perennial

PSPO

Perennia

$\mathrm{ACSH}$

Perennia

Perennial

ERLI6

THMO

Perennial

CHVIP4

Perennial

ERFAP

Perennial

PSFRF

Perennial

Perennial

Perennial

Perennial

Perennial

Perennial

Perennial

Perennial

Perennial

Perennial

Perennial

Perennial

Perennial

Perennial

Perennial
SAME

TEGL

ERNA10

PUTR2

LYPAO

BRMIS

BRMIW

BROBL

CHGR6

ERNA7

HODI

PRFA

RIVEV

SADOD3

STEL
Encelra

Psorothamnus

Acamptopappus

Ericameria

Thamnosma

Chrysothamnus

Eriogonum

Psorothamnus

Salazaria

Tetradymia

Ericameria

Purshia

Lycium

Brickellia

Brickellia

Brickellia

Chrysothamnus

Ericameria

Holodiscus

Prunus

Ribes

Salvia

Dwarf Shrubs (<0.5 m)

$\begin{array}{lll}\text { Perennial } & \text { ARSP5 } & \text { Artemisia } \\ \text { Perennial } & \text { MESP2 } & \text { Menodora } \\ \text { Perennial } & \text { LEPU } & \text { Leptodactylon }\end{array}$

dumosa

stansburiana

longiflorus

nova

microthecum var. simpsonii

virginensis var. virginensis

polydenius

shockleyi

montana

viscidiflorus ssp. puberulus

fasciculatum var. polifolium

fremontii var. fremontii

mexicana

glabrata

nauseosus

tridentata

pallidum var. oligospermum

microphylla var. scabra

microphylla var. watsonii

oblongufolia var. linifolia

greenei

nanus

discolor

fasciculata

velutinum var. velutinum

dori ssp. dornii var. domii

elata
Frequency

$10.3 \%$

$10.3 \%$

$10.3 \%$

$9.3 \%$

$9.3 \%$

$8.2 \%$

$8.2 \%$

$7.2 \%$

$7.2 \%$

$7.2 \%$

$6.2 \%$

$5.2 \%$

$5.2 \%$

$5.2 \%$

$5.2 \%$

$3.1 \%$

$3.1 \%$

$2.1 \%$

$1.0 \%$

$1.0 \%$

$1.0 \%$

$1.0 \%$

$1.0 \%$

$1.0 \%$

$1.0 \%$

$1.0 \%$

$1.0 \%$

$1.0 \%$

$40.2 \%$

$11.3 \%$

$8.2 \%$ 


$\begin{array}{lll}\text { Perennial } & \text { KOAM } & \text { Kochia } \\ \text { Perennial } & \text { KRER } & \text { Krameria }\end{array}$

americana

erecta

$4.1 \%$

$2.1 \%$

\section{Graminoids}

\begin{tabular}{lll} 
Perennial & ACHY & Achnatherum \\
Annual & BRRU2 & Bromus \\
Perennial & ELELE & Elymus \\
Annual & BRTE & Bromus \\
Perennial & ACSP12 & Achnatherum \\
Perennial & PLJA & Pleuraphis \\
Perennial & POSE & Poa \\
Perennial & HECOC8 & Hesperostipa \\
Perennial & ARPU9 & Aristida \\
Perennial & ERPU8 & Erioneuron \\
Perennial & POFE & Poa \\
Annual & VUOC & Vulpia \\
Perennial & ACPI2 & Achnatherum \\
Perennial & AGGLL & Agoseris \\
Perennial & ARPUL & Aristida \\
Perennial & BOGR2 & Bouteloua \\
Annual & BRBE2 & Bromus \\
Perennial & KOMA & Koeleria \\
Perennial & LECl4 & Leymus \\
Perennial & SPCR & Sporobolus \\
& & \\
\hline
\end{tabular}

\section{Forbs}

$\begin{array}{lll}\text { Perennial } & \text { SPAMA } & \text { Sphaeralcea } \\ \text { Annual } & \text { AMTE3 } & \text { Amsinckia } \\ \text { Annual } & \text { CHST } & \text { Chaenactis } \\ \text { Perennial } & \text { MACAC } & \text { Machaeranthera } \\ \text { Perennial } & \text { CAAP4 } & \text { Castilleja } \\ \text { Perennial } & \text { DEPAP3 } & \text { Delphinium } \\ \text { Annual } & \text { PHFR2 } & \text { Phacelia }\end{array}$

hymenoides
rubens
elymoides ssp. elymoides
tectorum
speciosum
jamesii
secunda
comata ssp. comata
purpurea
pulchellum
fendleriana
octoflora
pinetorum
glauca var. laciniata
purpurea var. longiseta
gracilis
berterianus
macrantha
cinereus
cryptandrus

stevioides

$51.5 \%$

canescens ssp. canescens

$44.3 \%$

applegatei

$37.1 \%$

parishii ssp. parishii

$37.1 \%$

fremontii 
Lifeform Longevity ACODE

Genus

\begin{tabular}{|c|c|c|}
\hline Annual & ASLEF2 & Astragalus \\
\hline Annual & ERER2 & Eriastrum \\
\hline Annual & $\mathrm{CRCl}_{2}$ & Cryptantha \\
\hline Annual & CRPT & Cryptantha \\
\hline Perennial & GIBRB & Gilia \\
\hline Perennial & ERIN4 & Eriogonum \\
\hline Annual & ERCI6 & Erodium \\
\hline Annual & DEPIG & Descurainia \\
\hline Annual & SYFR & Syntrichopappus \\
\hline Perennial & ARPUM & Arabis \\
\hline Perennial & CAFL & Calochortus \\
\hline Perennial & CHAL11 & Chamaesyce \\
\hline Perennial & PHST11 & Phlox \\
\hline Perennial & ERCOC3 & Erigeron \\
\hline Annual & LELA & Lepidium \\
\hline Annual & ERNi4 & Eriogonum \\
\hline Perennial & HEMUN & Heliomeris \\
\hline Annual & MEAL6 & Mentzelia \\
\hline Annual & ERDE6 & Eriogonum \\
\hline Annual & IPPO2 & Ipomopsis \\
\hline Annual & PHVAV2 & Phacelia \\
\hline Perennial & CRVI5 & Cryptantha \\
\hline Perennial & EROVO5 & Eriogonum \\
\hline Annual & PESE & Pectocarya \\
\hline Annual & CRNEN & Cryptantha \\
\hline Perennial & LILE3 & Linum \\
\hline Annual & MAGL3 & Malacothrix \\
\hline Perennial & OECEM4 & Oenothera \\
\hline Perennial & CRUT & Cryptantha \\
\hline Perennial & DIPU3 & Dichelostemma \\
\hline Perennial & MIBI8 & Mirabilis \\
\hline Annual & OXPE2 & Oxytheca \\
\hline Annual & PHCRC3 & Phacelia \\
\hline
\end{tabular}

\section{Species}

lentiginosus var. fremontii

enemicum

circumscissa

pterocarya

brecciarum ssp. brecciarum

inflatum

cicutarium

pinnata ssp. glabra

fremontii

pulchra var. munciensis

flexuosus

albomarginata

stansburyi

concinnus var. concinnus

lasiocarpum

nidularium

multiflora var. nevadensis

albicaulis

deflexum

polycladon

vallis-mortae var. vallis-mortae

virginensis

ovalifolium var. ovalifolium

setosa

nevadensis var. nevadensis

lewisii

glabrata

caespitosa ssp. marginata

utahensis

pulchellum

bigelovii

perfoliata

crenulata var. crenulata
Frequency

$34.0 \%$

$25.8 \%$

$24.7 \%$

$23.7 \%$

$22.7 \%$

$21.6 \%$

$21.6 \%$

$20.6 \%$

$20.6 \%$

$19.6 \%$

$19.6 \%$

$19.6 \%$

$19.6 \%$

$18.6 \%$

$18.6 \%$

$17.5 \%$

$17.5 \%$

$15.5 \%$

$13.4 \%$

$13.4 \%$

$12.4 \%$

$11.3 \%$

$11.3 \%$

$11.3 \%$

$10.3 \%$

$10.3 \%$

$10.3 \%$

$10.3 \%$

$9.3 \%$

$9.3 \%$

$9.3 \%$

$9.3 \%$

$9.3 \%$ 


\begin{tabular}{|c|c|c|c|}
\hline \multirow[t]{34}{*}{ Lifeform } & Longevity & $A C O D E$ & Genus \\
\hline & Annual & PLPA2 & Plantago \\
\hline & Annual & LUBR2 & Lupinus \\
\hline & Annual & MEVE5 & Mentzelia \\
\hline & Perennial & SEMU3 & Senecio \\
\hline & Annual & CETH3 & Centrostegia \\
\hline & Biennial & CINE & Cirsium \\
\hline & Annual & CABRB4 & Camissonia \\
\hline & Annual & CRMI & Cryptantha \\
\hline & Annual & LUSH & Lupinus \\
\hline & Annual & MEOB3 & Mentzelia \\
\hline & Biennial & SIAL2 & Sisymbrium \\
\hline & Annual & STEXE & Stephanomeria \\
\hline & Perennial & ASPUT & Astragalus \\
\hline & Annual & CAPT & Camissonia \\
\hline & Annual & LOSC6 & Loeseliastrum \\
\hline & Perennial & LONEN & Lomatium \\
\hline & Perennial & MIPU5 & Mirabilis \\
\hline & Perennial & OEPAP & Oenothera \\
\hline & Annual & SAPA8 & Salsola \\
\hline & Perennial & STPA4 & Stephanomeria \\
\hline & Perennial & ABTU & Abronia \\
\hline & Perennial & ARPUG & Arabis \\
\hline & Perennial & ARMA3 & Arenaria \\
\hline & Perennial & CRCO12 & Cryptantha \\
\hline & Perennial & CYRI2 & Cymopterus \\
\hline & Perennial & ERNU4 & Eriogonum \\
\hline & Annual & ERPR4 & Eriophyllum \\
\hline & Annual & LOHU2 & Lotus \\
\hline & Annual & MISP & Mimulus \\
\hline & Annual & MOBE & Monoptilon \\
\hline & Perennial & PEFLA2 & Penstemon \\
\hline & Perennial & POSU & Polygala \\
\hline & Perennial & XYTOT & Xylorhiza \\
\hline
\end{tabular}

\section{Species}

patagonica

brevicaulis

veatchiana

multilobatus

thurberi

neomexicanum

brevipes ssp. brevipes

micrantha

shockleyi

obscura

altissimum

exigua ssp. exigua

purshii var. tinctus

pterosperma

schottii

nevadense var. nevadense

pudica

pallida ssp. pallida

paulsenii

pauciflora

turbinata

pulchra var. gracilis

macradenia

confertifiora

ripleyi

nummulare

pringlei

humistratus

spissus

bellidiforme

floridus var. austinii

subspinosa

tortifolia var. imberbis
Frequency

$9.3 \%$

$8.2 \%$

$8.2 \%$

$8.2 \%$

$7.2 \%$

$7.2 \%$

$6.2 \%$

$6.2 \%$

$6.2 \%$

$6.2 \%$

$6.2 \%$

$6.2 \%$

$5.2 \%$

$5.2 \%$

$5.2 \%$

$5.2 \%$

$5.2 \%$

$5.2 \%$

$5.2 \%$

$5.2 \%$

$4.1 \%$

$4.1 \%$

$4.1 \%$

$4.1 \%$

$4.1 \%$

4. $1 \%$

$4.1 \%$

$4.1 \%$

$4.1 \%$

4.1\%

$4.1 \%$

$4.1 \%$

$4.1 \%$

Wednesday, January 05, 2000

Page 48 of 71 
Lifeform Longevity ACODE

Perennial ADCO2

Annual

ASAC3

Adenophyllum

Perennial

ASCAC5

Astragalus

Perennial

ASFU3

Astragalus

Perennial

BAMU

Astragalus

Annual

CAPA7

Baileya

Annual

CABOI

Calycoseris

Annual

CHRI

Camissonia

Perennial

CRFL6

Chorizanthe

Annual

CRGR3

Cryptantha

Annual

CRRE5

Cryptantha

Perennial

CYGL2

Perennial

DASE3

Cryptantha

Annual

ERDI4

Perennial

GIIN2

Cymopterus

Annual

LASE3

Annual

Annual

MASO

Annual

NAPU

Dalea

Annual

SAKAT3

Erigeron

Perennial

URLI2

Annual

ABEL

AMAC2

Gilia

Langloisia

Malacothrix

Nama

Salsola

Annual

ANAC

Uropappus

Perennial

ARIN

BAPL 3

Annual

Perennial

BRAT

CACLI

Abronia

Annual

CACL

Annual

CAKEG

Ambrosia

Perennial

CAPI4

CHFR

Anisocoma

Annual

CHFR

Annual

CHSES

CHWA2

Annual

ERSP3

Annual

Arabis

Baileya

Brickellia

Camissonia

Camissonia

Caulanthus

Chaenactis

Chamaesyce

Chorizanthe

Eriastrum

\section{Species}

cooperi

acutirostris

calycosus var. calycosus

funereus

multiradiata

parryi

boothii ssp. intermedia

ngida

flavoculata

gracilis

recurvata

globosus

seartsiae

divergens

inconspicua

setosissima

sonchoides

pusillum

kali ssp. tragus

linearifolia

elliptica

acanthicarpa

acaulis

inyoensis

pleniradiata

atractyloides

claviformis ssp. integrior

kernensis ssp. gilmanii

pilosus

fremontii

serpyllifolia ssp. serpyllifolia

watsonii

sparsiflorum
Frequency

$3.1 \%$

$3.1 \%$

$3.1 \%$

$3.1 \%$

$3.1 \%$

$3.1 \%$

$3.1 \%$

$3.1 \%$

$3.1 \%$

$3.1 \%$

$3.1 \%$

$3.1 \%$

$3.1 \%$

$3.1 \%$

$3.1 \%$

$3.1 \%$

$3.1 \%$

$3.1 \%$

$3.1 \%$

$3.1 \%$

$2.1 \%$

$2.1 \%$

$2.1 \%$

$2.1 \%$

$2.1 \%$

$2.1 \%$

$2.1 \%$

$2.1 \%$

$2.1 \%$

$2.1 \%$

$2.1 \%$

$2.1 \%$

$2.1 \%$

Page 49 of 71

Wednesday, January 05, 2000 
Lifeform Longevity ACODE

Genus

Species

Frequency

\begin{tabular}{|c|c|c|}
\hline Annual & ERPUG & Eriogonum \\
\hline Perennial & ERSA6 & Eriogonum \\
\hline Perennial & ERUM & Eriogonum \\
\hline Annual & GILIA & Gilia \\
\hline Perennial & GISI & Gilia \\
\hline Perennial & HUVEI & Hulsea \\
\hline Annual & LAOCO & Lappula \\
\hline Annual & LIDI2 & Linanthus \\
\hline Perennial & LUARL5 & Lupinus \\
\hline Annual & LUFL & Lupinus \\
\hline Annual & RANE & Rafinesquia \\
\hline Annual & SACOC & Salvia \\
\hline Perennial & SPAMR & Sphaeralcea \\
\hline Perennial & STPA3 & Stephanomeria \\
\hline Annual & STLO4 & Streptanthella \\
\hline Perennial & ANDI2 & Antennaria \\
\hline Perennial & ARCOS2 & Arenaria \\
\hline Perennial & ARMUR & Argemone \\
\hline Perennial & ARDR4 & Artemisia \\
\hline Annual & CAME16 & Camissonia \\
\hline Annual & CARE2 & Camissonia \\
\hline Perennial & CALI4 & Castilleja \\
\hline Annual & CHMA & Chaenactis \\
\hline Annual & CHLE4 & Chenopodium \\
\hline Perennial & ERAP & Erigeron \\
\hline Annual & ERHO6 & Eriogonum \\
\hline Perennial & ERRA3 & Eriogonum \\
\hline Annual & ERTH & Eniogonum \\
\hline Perennial & GIOP & Gilia \\
\hline Perennial & CHER2 & Leucelene \\
\hline Perennial & LOSC3 & Lomatium \\
\hline Annual & MISU2 & Mimulus \\
\hline Annual & NADED & Nama \\
\hline
\end{tabular}

pusillum
saxatle
umbellatum
sinuata
vestita ssp. inyoensis
occidentalis var. occidentalis
dichotomus
argenteus ssp. artenteus var. laxiflorus
flavoculatus
neomexicana
columbariae var. columbariae
ambiguua var. rugosa
pamyi
longirostris
dimorpha
congesta var. subcongesta
munita ssp. rotundata
dracunculus
megalantha
refracta
linariaefolia
macrantha
leptophyllum
aphanactis
hookeri
racemosum
thomasii
ophthalmoides
scabrum
suksorfii
demissum
a

$2.1 \%$

$2.1 \%$

$2.1 \%$

$2.1 \%$

$2.1 \%$

$2.1 \%$

$2.1 \%$

$2.1 \%$

$2.1 \%$

$2.1 \%$

$2.1 \%$

$2.1 \%$

$2.1 \%$

$2.1 \%$

$2.1 \%$

$1.0 \%$

$1.0 \%$

$1.0 \%$

$1.0 \%$

$1.0 \%$

$1.0 \%$

$1.0 \%$

$1.0 \%$

$1.0 \%$

$1.0 \%$

$1.0 \%$

$1.0 \%$

$1.0 \%$

$1.0 \%$

$1.0 \%$

$1.0 \%$

$1.0 \%$

$1.0 \%$

Wednesday, January 05, 2000

Page 50 of 71 


\section{Species}

fasciculata

platycarpa

humilis ssp. humilis

pahutensis

rostrifiorus

saxicola

gracilis ssp. humilis

hoodii ssp. lanata

chambersi

annua

verecunda ssp. andersonii

ambigua ssp. monticola

grossulariaefolia ssp. pedata

spinosa

cordatus var. cordatus
Frequency

$1.0 \%$

$1.0 \%$

$1.0 \%$

$1.0 \%$

$1.0 \%$

$1.0 \%$

$1.0 \%$

$1.0 \%$

$1.0 \%$

$1.0 \%$

$1.0 \%$

$10 \%$

$1.0 \%$

$1.0 \%$

$1.0 \%$

\section{Succulents}

$\begin{array}{lll}\text { Perennial } & \text { YUBR } & \text { Yucca } \\ \text { Perennial } & \text { OPECE } & \text { Opuntia } \\ \text { Perennial } & \text { OPERE } & \text { Opuntia } \\ \text { Perennial } & \text { ECEN } & \text { Echinocereus } \\ \text { Perennial } & \text { OPBAB2 } & \text { Opuntia } \\ \text { Perennial } & \text { YUBAV } & \text { Yucca } \\ \text { Perennial } & \text { OPPOR } & \text { Opuntia } \\ \text { Perennial } & \text { SCPO4 } & \text { Sclerocactus } \\ \text { Perennial } & \text { ECPO2 } & \text { Echinocactus } \\ \text { Perennial } & \text { ECENE } & \text { Echinocereus } \\ \text { Perennial } & \text { ESVID } & \text { Escobaria }\end{array}$

brevifolia

$42.3 \%$

echinocarpa var. echinocarpa

$38.1 \%$

eninacea var. erinacea

$14.4 \%$

engelmannii

$12.4 \%$

basilaris var. basilaris

$10.3 \%$

baccata var. vespertina

$8.2 \%$

polyacantha var. rufispina

$6.2 \%$

polyancistrus

$6.2 \%$

polycephalus

$5.2 \%$

engelmannii var. engelmannii

$1.0 \%$

vivipara var. deserti 
Lifeform Longevity ACODE Genus Species

\section{Artemisia spp. Shrubland Alliance}

Trees (>5 m)

$\begin{array}{lll}\text { Perennial } & \text { JUOS } & \text { Juniperus } \\ \text { Perennial } & \text { PIMO } & \text { Pinus } \\ \text { Perennial } & \text { QUGA } & \text { Quercus }\end{array}$

osteosperma

$47.9 \%$

monophylla

$33.2 \%$

gambelii

\section{Tall Shrubs (2-5 m)}

$\begin{array}{lll}\text { Perennial } & \text { ARTRT } & \text { Artemisia } \\ \text { Perennial } & \text { AMUT } & \text { Amelanchier } \\ \text { Perennial } & \text { CEGRV2 } & \text { Ceanothus } \\ \text { Perennial } & \text { LATR2 } & \text { Larrea }\end{array}$

tridentata ssp. tridentata

$80.5 \%$

utahensis

$1.7 \%$

greggii ssp. vestitus

$0.7 \%$

tridentata

$0.3 \%$

\section{Short Shrubs (0.5-2 m)}

$\begin{array}{lll}\text { Perennial } & \text { EPNE } & \text { Ephedra } \\ \text { Perennial } & \text { CHVIV2 } & \text { Chrysothamnus } \\ \text { Perennial } & \text { ARNO4 } & \text { Artemisia } \\ \text { Perennial } & \text { GRSP } & \text { Grayia } \\ \text { Perennial } & \text { ATCAC } & \text { Atriplex } \\ \text { Perennial } & \text { EPVI } & \text { Ephedra } \\ \text { Perennial } & \text { CHVIP4 } & \text { Chrysothamnus } \\ \text { Perennial } & \text { ERMIS2 } & \text { Eriogonum } \\ \text { Perennial } & \text { KRLA2 } & \text { Krascheninnikovia } \\ \text { Perennial } & \text { LYAN } & \text { Lycium } \\ \text { Perennial } & \text { PUGL2 } & \text { Purshia } \\ \text { Perennial } & \text { ERNAL } & \text { Ericameria } \\ \text { Perennial } & \text { GUSA2 } & \text { Gutierrezia } \\ \text { Perennial } & \text { ERNAH } & \text { Ericameria } \\ \text { Perennial } & \text { PUST } & \text { Purshia } \\ \text { Perennial } & \text { SYLO } & \text { Symphoricarpos } \\ \text { Perennial } & \text { ERNA7 } & \text { Ericameria } \\ \text { Perennial } & \text { TEGL } & \text { Tetradymia } \\ \text { Perennial } & \text { CORA } & \text { Coleogyne }\end{array}$

nevadensis
viscidiflorus ssp. viscidiflorus
nova
spinosa
canescens var. canescens
viridis
viscidiflorus ssp. puberulus
microthecum var. simpsonii
lanata
andersonii
glandulosa
nauseosus ssp. consimilis var.
sarothrae
nauseosus ssp. nauseosus var.
stansburiana
longiflorus
nanus
glabrata
ramosissima

$65.8 \%$

$59.9 \%$

$57.9 \%$

$50.0 \%$

$47.6 \%$

$46.6 \%$

$42.1 \%$

$29.1 \%$

$28.1 \%$

$20.5 \%$

$19.2 \%$

$16.1 \%$

$12.7 \%$

$12.3 \%$

$11.6 \%$

$11.6 \%$

$11.0 \%$

$11.0 \%$

$8.6 \%$ 
Lifeform Longevity ACODE

Genus

\begin{tabular}{|c|c|c|}
\hline Perennial & ATCO & Atriplex \\
\hline Perennial & TECA2 & Tetradymia \\
\hline Perennial & ERFAP & Eriogonum \\
\hline Perennial & PUTR2 & Purshia \\
\hline Perennial & ERTE18 & Ericameria \\
\hline Perennial & TEAXA & Tetradymia \\
\hline Perennial & ERCO23 & Ericameria \\
\hline Perennial & ERLI6 & Ericameria \\
\hline Perennial & ERNA10 & Ericameria \\
\hline Perennial & HYSA & Hymenoclea \\
\hline Perennial & RHTRA & Rhus \\
\hline Perennial & ENVIV & Encelia \\
\hline Perennial & GLSPA & Glossopetalon \\
\hline Perennial & SADOD3 & Salvia \\
\hline Perennial & LEFR2 & Lepidium \\
\hline Perennial & PRFA & Prunus \\
\hline Perennial & PSPO & Psorothamnus \\
\hline Perennial & CHGR6 & Chrysothamnus \\
\hline Perennial & ERHEA & Eriogonum \\
\hline Perennial & RICEC2 & Ribes \\
\hline Perennial & RIVEV & Ribes \\
\hline Perennial & SAME & Salazaria \\
\hline Perennial & STPIP & Stanleya \\
\hline Perennial & BROBL & Brickellia \\
\hline Perennial & STEL & Stanleya \\
\hline Perennial & THMO & Thamnosma \\
\hline Perennial & AMDU2 & Ambrosia \\
\hline Perennial & BRMIS & Brickellia \\
\hline Perennial & CHVIS5 & Chrysothamnus \\
\hline Perennial & ERPA29 & Ericameria \\
\hline Perennial & ERPAN2 & Ericameria \\
\hline Perennial & PERA4 & Peraphyllum \\
\hline Perennial & PENI & Petalonyx \\
\hline
\end{tabular}

\section{Species}

confertifolia

canescens

fasciculatum var. polifolium

tridentata

teretifolia

axillaris var. axillaris

cooperi

linearifolius

nauseosus

salsola

trilobata var. anisophylla

virginensis var. virginensis

spinescens var. aridum

dori ssp. dorrii var. dorrii

fremontii

fasciculata

polydenius

greenei

heermannii var. angense

cereum var. cereum

velutinum var. velutinum

mexicana

pinnata var. pinnata

oblongifolia var. linifolia

elata

montana

dumosa

microphylla var. scabra

viscidifforus ssp. viscidifforus var.

paniculata

pamyi var. nevadensis

ramosissimum

nitidus
Frequency

$8.2 \%$

$8.2 \%$

$7.9 \%$

$7.9 \%$

$7.5 \%$

$6.2 \%$

$5.8 \%$

$5.8 \%$

$2.7 \%$

$2.7 \%$

$2.7 \%$

$2.4 \%$

$2.4 \%$

$2.4 \%$

$2.1 \%$

$1.4 \%$

$1.4 \%$

$1.0 \%$

$1.0 \%$

$1.0 \%$

$1.0 \%$

$1.0 \%$

$1.0 \%$

$0.7 \%$

$0.7 \%$

$0.7 \%$

$0.3 \%$

$0.3 \%$

$0.3 \%$

$0.3 \%$

$0.3 \%$

$0.3 \%$

$0.3 \%$ 
Dwarf Shrubs (<0.5 m)

$\begin{array}{lll}\text { Perennial } & \text { LEPU } & \text { Leptodactylon } \\ \text { Perennial } & \text { ARSP5 } & \text { Artemisia } \\ \text { Perennial } & \text { ERMIL } & \text { Eriogonum } \\ \text { Perennial } & \text { MESP2 } & \text { Menodora } \\ \text { Perennial } & \text { ERWA8 } & \text { Ericameria } \\ \text { Perennial } & \text { KOAM } & \text { Kochia }\end{array}$

pungens
spinescens
microthecum var. lapidicola
spinescens
watsonii
americana

\section{Graminoids}

\begin{tabular}{|c|c|c|}
\hline Perennial & ELELE & Elymus \\
\hline Perennial & ACHY & Achnatherum \\
\hline Annual & BRTE & Bromus \\
\hline Perennial & PLJA & Pleuraphis \\
\hline Perennial & POSE & Poa \\
\hline Perennial & HECOC8 & Hesperostipa \\
\hline Annual & BRRU2 & Bromus \\
\hline Perennial & ACSP12 & Achnatherum \\
\hline Perennial & ARPU9 & Aristida \\
\hline Perennial & POFE & Poa \\
\hline Annual & VUOC & Vuipia \\
\hline Perennial & LECl4 & Leymus \\
\hline Annual & VUMI & Vulpia \\
\hline Perennial & AGGLL & Agoseris \\
\hline Perennial & ACTH7 & Achnatherum \\
\hline Perennial & KOMA & Koeleria \\
\hline Perennial & BOGR2 & Bouteloua \\
\hline Annual & BRCA6 & Bromus \\
\hline Perennial & ERPU8 & Erioneuron \\
\hline Perennial & SPCR & Sporobolus \\
\hline Variable & ACHNA & Achnatherum \\
\hline Perennial & ACAR14 & Achnatherum \\
\hline Perennial & $\mathrm{ACCO} 21$ & Achnatherum \\
\hline
\end{tabular}

elymoides ssp. elymoides
hymenoides
tectorum
jamesii
secunda
comata ssp. comata
rubens
speciosum
purpurea
fendleriana
octoflora
cinereus
microstachys
glauca var. laciniata
thurberiana
macrantha
gracilis
cartharticus
pulchellum
cryptandrus
aridum
coronata

$81.8 \%$

$73.3 \%$

$71.9 \%$

$58.6 \%$

$48.3 \%$

$39.7 \%$

$29.8 \%$

$24.3 \%$

$17.5 \%$

$15.8 \%$

$15.1 \%$

$9.2 \%$

$6.5 \%$

$3.1 \%$

$2.1 \%$

$2.1 \%$

$1.0 \%$

$0.7 \%$

$0.7 \%$

$0.7 \%$

$0.3 \%$

$0.3 \%$

$0.3 \%$

Wednesday, January 05, 2000

Page 54 of 71 


$\begin{array}{lll}\text { Perennial } & \text { HOJU } & \text { Hordeum } \\ \text { Perennial } & \text { JUBA } & \text { Juncus }\end{array}$

Perennial JUBA Juncus

balticus

Forbs

\begin{tabular}{|c|c|c|}
\hline Perennial & CAAP4 & Castilleja \\
\hline Perennial & PHST11 & Phlox \\
\hline Perennial & MACAC & Machaeranthera \\
\hline Perennial & SPAMA & Sphaeralcea \\
\hline Perennial & EROVO5 & Eriogonum \\
\hline Perennial & GIBRB & Gilia \\
\hline Annual & ASLEF2 & Astragalus \\
\hline Annual & PHFR2 & Phacelia \\
\hline Annual & $\mathrm{CRCl} 2$ & Cryptantha \\
\hline Annual & DEPIG & Descurainia \\
\hline Perennial & CAFL & Calochortus \\
\hline Annual & CRPT & Cryptantha \\
\hline Annual & SYFR & Syntrichopappus \\
\hline Annual & AMTE3 & Amsinckia \\
\hline Perennial & ERCOC3 & Erigeron \\
\hline Annual & MEAL6 & Mentzelia \\
\hline Perennial & DEPAP3 & Delphinium \\
\hline Annual & CHST & Chaenactis \\
\hline Annual & ERER2 & Eriastrum \\
\hline Annual & CAPT & Camissonia \\
\hline Perennial & ASPUT & Astragalus \\
\hline Annual & CRGR3 & Cryptantha \\
\hline Perennial & SEMU3 & Senecio \\
\hline Annual & ERNI4 & Eriogonum \\
\hline Perennial & ARPUG & Arabis \\
\hline Annual & LUFL & Lupinus \\
\hline Perennial & DEAN & Delphinium \\
\hline Perennial & DIPU3 & Dichelostemma \\
\hline Perennial & LILE3 & Linum \\
\hline
\end{tabular}

applegatei
stansburyi
canescens ssp. canescens
ambigua ssp. ambigua
ovalifolium var. ovalifolium
brecciarum ssp. brecciarum
lentiginosus var. fremontii
fremontii
circumscissa
pinnata ssp. glabra
flexuosus
pterocarya
fremontii
tessellata
concinnus var. concinnus
albicaulis
parishii ssp. parishii
stevioides
eremicum
pterosperma
purshii var. tinctus
gracilis
multilobatus
nidularium
pulchra var. gracilis
flavoculatus
andersonii
pulchellum
lewisii




\section{Lifeform Longevity ACODE}

\begin{tabular}{|c|c|c|}
\hline Perennial & ERCA8 & Eriogonum \\
\hline Annual & PLPA2 & Plantago \\
\hline Annual & CETH3 & Centrostegia \\
\hline Perennial & LONEN & Lomatium \\
\hline Annual & PHCRC3 & Phacelia \\
\hline Perennial & CHAL11 & Chamaesyce \\
\hline Annual & LAOCO & Lappula \\
\hline Annual & LELA & Lepidium \\
\hline Perennial & OECEM4 & Oenothera \\
\hline Annual & CHMA & Chaenactis \\
\hline Perennial & CRFL6 & Cryptantha \\
\hline Annual & ERDI4 & Erigeron \\
\hline Annual & ERCI6 & Erodium \\
\hline Perennial & HEMUN & Heliomeris \\
\hline Annual & PESE & Pectocarya \\
\hline Perennial & CALI4 & Castilleja \\
\hline Perennial & HYCOC2 & Hymenoxys \\
\hline Annual & PHVAV2 & Phacelia \\
\hline Perennial & $\mathrm{CROCO} 2$ & Crepis \\
\hline Annual & LUBR2 & Lupinus \\
\hline Annual & PHSA & Phacelia \\
\hline Perennial & STCOC & Streptanthus \\
\hline Perennial & CHDO & Chaenactis \\
\hline Perennial & SPAMM & Sphaeralcea \\
\hline Annual & CRNEN & Cryptantha \\
\hline Annual & STEXE & Stephanomeria \\
\hline Annual & CHWA2 & Chorizanthe \\
\hline Annual & CAPU16 & Camissonia \\
\hline Perennial & ORFA & Orobanche \\
\hline Perennial & ASCAC5 & Astragalus \\
\hline Biennial & CINE & Cirsium \\
\hline Annual & IPPO2 & Ipomopsis \\
\hline Annual & LUSH & Lupinus \\
\hline
\end{tabular}

\section{Species}

caespitosum

patagonica

thurberi

nevadense var. nevadense

crenulata var. crenulata

albomarginata

occidentalis var. occidentalis

lasjocarpum

caespitosa ssp. marginata

macrantha

flavoculata

divergens

cicutarium

multiflora var. nevadensis

setosa

linariaefolia

cooperi var. cooperi

vallis-mortae var. vallis-mortae

occidentalis ssp. occidentalis

brevicaulis

saxicola

cordatus var. cordatus

douglasii

ambigua ssp. monticola

nevadensis var. nevadensis

exigua ssp. exigua

watsonii

pusilla

fasciculata

calycosus var. calycosus

neomexicanum

polycladon

shockleyi
Frequency

$15.4 \%$

$15.4 \%$

$14.4 \%$

$14.0 \%$

$13.0 \%$

$12.7 \%$

$12.7 \%$

$12.3 \%$

$12.0 \%$

$11.6 \%$

$11.6 \%$

$11.3 \%$

$11.3 \%$

$11.3 \%$

$11.3 \%$

$10.3 \%$

$10.3 \%$

$10.3 \%$

$9.9 \%$

$9.9 \%$

$9.9 \%$

$9.9 \%$

$9.6 \%$

$9.6 \%$

$9.2 \%$

$9.2 \%$

$8.9 \%$

$8.6 \%$

$8.6 \%$

$8.2 \%$

$8.2 \%$

$8.2 \%$

$8.2 \%$

Wednesday, January 05, 2000

Page 56 of 71 


\begin{tabular}{llll} 
Lifeform & Longevity & ACODE & \multicolumn{1}{c}{ Genus } \\
Perennial & ARPUM & Arabis \\
Perennial & ARCOS2 & Arenaria \\
Annual & MISP & Mimulus \\
Annual & MISU2 & Mimulus \\
Perennial & ERUM & Eriogonum \\
Annual & MEVE5 & Mentzelia \\
Perennial & PHGRH & Phlox \\
Annual & MAGL3 & Malacothrix \\
Annual & GILIA & Gilia \\
Annual & LIDI2 & Linanthus \\
Perennial & LUARL5 & Lupinus \\
Perennial & CRCO12 & Cryptantha \\
Annual & SAPA8 & Salsola \\
Perennial & MIBI8 & Mirabilis \\
Perennial & CRUT & Cryptantha \\
Annual & URL12 & Uropappus \\
Perennial & PEPA23 & Penstemon \\
Perennial & TOSC & Townsendia \\
Annual & LOHU2 & Lotus \\
Perennial & CRVI5 & Cryptantha \\
Perennial & PEFLA2 & Penstemon \\
Perennial & ALNE & Alium \\
Perennial & ASNE6 & Astragalus \\
Annual & CABRB4 & Camissonia \\
Perennial & MIMUG & Mirabilis \\
Perennial & CYPU & Cymopterus \\
ERnalacothrix
\end{tabular}

\section{Species}

pulchra var. munciensis

congesta var. subcongesta

spissus

suksdorfii

umbellatum

veatchiana

gracilis ssp. humilis

glabrata

dichotomus

argenteus ssp. artenteus var. laxiflorus

confertiflora

paulsenii

bigelovii

utahensis

linearifolia

scapigera

humistratus

virginensis

floridus var. austinii

nevadense

newberryi

brevipes ssp. brevipes

multiflora var. glandulosa

purpurascens

deflexum

altissimum

ludoviciana

pilosus

saxatile

perfoliata

pahutensis

sonchoides
Frequency

$7.9 \%$

$7.9 \%$

$7.9 \%$

$7.9 \%$

$7.5 \%$

$7.5 \%$

$7.5 \%$

$6.8 \%$

$6.5 \%$

$6.5 \%$

$6.5 \%$

$6.2 \%$

$6.2 \%$

$5.8 \%$

$5.5 \%$

$5.5 \%$

$5.1 \%$

$4.8 \%$

$4.5 \%$

$4.5 \%$

4. $1 \%$

$4.1 \%$

$4.1 \%$

$4.1 \%$

$3.8 \%$

$3.8 \%$

$3.8 \%$

$3.4 \%$

$3.4 \%$

$3.4 \%$

$3.4 \%$

$3.4 \%$

$3.1 \%$

Wednesday, January 05, 2000

Page 57 of 71 
Lifeform Longevity ACODE

$\begin{array}{lll}\text { Annual } & \text { CACLI } & \text { Camissonia } \\ \text { Annual } & \text { CHIN2 } & \text { Chenopodium } \\ \text { Annual } & \text { CRMI } & \text { Cryptantha } \\ \text { Annual } & \text { ERSP3 } & \text { Eriastrum } \\ \text { Perennial } & \text { OEPAP } & \text { Oenothera } \\ \text { Perennial } & \text { STPA4 } & \text { Stephanomeria } \\ \text { Perennial } & \text { ABEL } & \text { Abronia } \\ \text { Annual } & \text { CHXA } & \text { Chaenactis } \\ \text { Perennial } & \text { ERAP } & \text { Erigeron } \\ \text { Perennial } & \text { ERRA3 } & \text { Eriogonum } \\ \text { Perennial } & \text { LEKIK } & \text { Lesquerella } \\ \text { Annual } & \text { ASAC3 } & \text { Astragalus } \\ \text { Annual } & \text { CHBRB } & \text { Chorizanthe } \\ \text { Annual } & \text { ERESE } & \text { Eriogonum } \\ \text { Perennial } & \text { GIN2 } & \text { Gilia } \\ \text { Annual } & \text { PEPL } & \text { Pectocarya } \\ \text { Perennial } & \text { STSP6 } & \text { Stephanomeria } \\ \text { Annual } & \text { AMAC2 } & \text { Ambrosia } \\ \text { Annual } & \text { ANAC } & \text { Anisocoma } \\ \text { Perennial } & \text { ASCA14 } & \text { Astragalus } \\ \text { Annual } & \text { ERBR7 } & \text { Eriogonum } \\ \text { Perennial } & \text { ERIN4 } & \text { Eriogonum } \\ \text { Perennial } & \text { GINY } & \text { Gilia } \\ \text { Annual } & \text { MEOB3 } & \text { Mentzelia } \\ \text { Annual } & \text { NADED } & \text { Nama } \\ \text { Perennial } & \text { ORCO5 } & \text { Orobanche } \\ \text { Perennial } & \text { PEHUH } & \text { Penstemon } \\ \text { Annual } & \text { SACOC } & \text { Salvia } \\ \text { STPA3 } & \text { Stephanomeria } \\ \text { AHCU } & \text { Thysanocarpus } \\ \text { AROI } & \text { Adenophyllum } \\ \text { Camissonia }\end{array}$

Species

claviformis ssp. integrior

incanum

micrantha

sparsifforum

pallida ssp. pallida

pauciflora

elliptica

xantiana

aphanactis

racemosum

kingii ssp. kingii

acutirostris

brevicomu var. brevicomu

esmeraldense var. esmeraldense

inconspicua

platycarpa

spinosa

acanthicarpa

acaulis

casei

brachyanthum

inflatum

nyensis

obscura

demissum var. demissum

corymbosa

humilis ssp. humilis

columbariae var. columbariae

parryi

cunvipes

paniculatus

cooperi

boothii ssp. intermedia
Frequency

$2.7 \%$

$2.7 \%$

$2.7 \%$

$2.7 \%$

$2.7 \%$

$2.7 \%$

$2.4 \%$

$2.4 \%$

$2.4 \%$

$2.4 \%$

$2.4 \%$

$2.1 \%$

$2.1 \%$

$2.1 \%$

$2.1 \%$

$2.1 \%$

$2.1 \%$

$1.7 \%$

$1.7 \%$

$1.7 \%$

$1.7 \%$

$1.7 \%$

$1.7 \%$

$1.7 \%$

$1.7 \%$

$1.7 \%$

$1.7 \%$

$1.7 \%$

$1.7 \%$

$1.7 \%$

$1.7 \%$

$1.4 \%$

$1.4 \%$ 
Lifeform Longevity ACODE

$\begin{array}{lll}\text { Perennial } & \text { CACRG } & \text { Caulanthus } \\ \text { Annual } & \text { CRRE5 } & \text { Cryptantha } \\ \text { Annual } & \text { GADIP } & \text { Gayophytum } \\ \text { Perennial } & \text { GISI } & \text { Gilia } \\ \text { Annual } & \text { HAGL } & \text { Halogeton } \\ \text { Perennial } & \text { CHER2 } & \text { Leucelene } \\ \text { Perennial } & \text { PENST } & \text { Penstemon } \\ \text { Perennial } & \text { POSU } & \text { Polygala } \\ \text { Perennial } & \text { SPGRP2 } & \text { Sphaeralcea } \\ \text { Annual } & \text { STLO4 } & \text { Streptanthella } \\ \text { Perennial } & \text { TRWA2 } & \text { Tricardia } \\ \text { Perennial } & \text { ASFU3 } & \text { Astragalus } \\ \text { Annual } & \text { CARE2 } & \text { Camissonia } \\ \text { Annual } & \text { CHLE4 } & \text { Chenopodium } \\ \text { Annual } & \text { CHRI } & \text { Chorizanthe } \\ \text { Annual } & \text { ERMA2 } & \text { Eriogonum } \\ \text { Perennial } & \text { ERNU4 } & \text { Eriogonum } \\ \text { Perennial } & \text { HUVEI } & \text { Hulsea } \\ \text { Perennial } & \text { LINUN } & \text { Linanthus } \\ \text { Perennial } & \text { MIPU5 } & \text { Mirabilis } \\ \text { Perennial } & \text { PEPU7 } & \text { Petradoria } \\ \text { Annual } & \text { PHCU } & \text { Phacelia } \\ \text { Annual } & \text { STMI2 } & \text { Stylocline } \\ \text { Perennial } & \text { ARMA3 } & \text { Arenaria } \\ \text { Perennial } & \text { ARDR4 } & \text { Artemisia } \\ \text { Perennial } & \text { ASBE5 } & \text { Astragalus } \\ \text { Perennial } & \text { BAHON } & \text { Balsamorhiza } \\ \text { Annual } & \text { CAKEG } & \text { Camissonia } \\ \text { CHAAN } & \text { CHFR } & \text { Camissonia } \\ \text { Chaenactis } \\ \text { CHAL7 } & \text { Chenopodium } \\ \text { Chrysothamnus } \\ \text { Anthe }\end{array}$

Species

crassicaulis var. glaber

recurvata

diffusum ssp. parvifiorum

sinuata

glomeratus

ericoides

subspinosa

grossulariaefolia ssp. pedata

longirostris

watsonii

funereus

refracta

leptophyllum

rigida

maculatum

nummulare

vestita ssp. inyoensis

nuttallii ssp. nuttallii

pudica

pumila

curvipes

micropoides

macradenia

dracunculus

beatleyae

hookeri var. neglecta

kemensis ssp. gilmanii

parvula

fremontii

album

gramineus

parmyi var. nevadense
Frequency

$1.4 \%$

$1.4 \%$

$1.4 \%$

$1.4 \%$

$1.4 \%$

$1.4 \%$

$1.4 \%$

$1.4 \%$

$1.4 \%$

$1.4 \%$

$1.4 \%$

$1.0 \%$

$1.0 \%$

$1.0 \%$

$1.0 \%$

$1.0 \%$

$1.0 \%$

$1.0 \%$

$1.0 \%$

$1.0 \%$

$1.0 \%$

$1.0 \%$

$1.0 \%$

$0.7 \%$

$0.7 \%$

$0.7 \%$

$0.7 \%$

$0.7 \%$

$0.7 \%$

$0.7 \%$

$0.7 \%$

$0.7 \%$

$0.7 \%$

Wednesday, January 05, 2000

Page 59 of 71 
Lifeform Longevity ACODE

Genus

\begin{tabular}{|c|c|c|}
\hline Annual & CLPAU2 & Claytonia \\
\hline Perennial & CYGL2 & Cymopterus \\
\hline Annual & ERWI & Eriastrum \\
\hline Annual & ERCO18 & Eriogonum \\
\hline Annual & ERHO6 & Eriogonum \\
\hline Perennial & IPCO5 & lpomopsis \\
\hline Annual & NABR & Navarretia \\
\hline Annual & SAKAT3 & Salsola \\
\hline Perennial & SIVEA & Silene \\
\hline Perennial & SPAMR & Sphaeralcea \\
\hline Perennial & ANDI2 & Antennaria \\
\hline Perennial & ARHOP3 & Arabis \\
\hline Perennial & ARIN & Arabis \\
\hline Perennial & ARMUR & Argemone \\
\hline Perennial & ASER2 & Asclepias \\
\hline Perennial & ASBE3 & Astragalus \\
\hline Perennial & ASMIV & Astragalus \\
\hline Perennial & BRCA3 & Brickellia \\
\hline Annual & CAPA7 & Calycoseris \\
\hline Annual & CHSES & Chamaesyce \\
\hline Annual & CRAM3 & Cryptantha \\
\hline Annual & CRDE & Cryptantha \\
\hline Perennial & CYRI2 & Cymopterus \\
\hline Annual & ERPU6 & Eriogonum \\
\hline Perennial & ERUMV2 & Eriogonum \\
\hline Annual & ERPR4 & Eriophyllum \\
\hline Annual & ESMI & Eschscholzia \\
\hline Perennial & FRAT & Fritillaria \\
\hline Annual & GARA & Gayophytum \\
\hline Annual & GARA2 & Gayophytum \\
\hline Perennial & GIHU & Gilia \\
\hline Perennial & LEREM & Lewisia \\
\hline Annual & LIBI2 & Linanthus \\
\hline
\end{tabular}

\section{Species}

perfoliata ssp. perfoliata

globosus

wilcoxii

concinnum

hookeri

congesta

breweri

kali ssp. tragus

verecunda ssp. andersonii

ambiguua var. rugosa

dimorpha

holboellii var. pinetorum

inyoensis

munita ssp. rotundata

erosa

beckwithii

minthomiae var. villosus

californica

parryi

serpyllifolia ssp. serpyllifolia

ambigua

decipiens

ripleyi

pusillum

umbellatum var. versicolor

pringlei

minutiflora

atropurpurea

racemosum

ramosissimum

hutchinsifolia

rediviva var. minor

bigelovii
Frequency

$0.7 \%$

$0.7 \%$

$0.7 \%$

$0.7 \%$

$0.7 \%$

$0.7 \%$

$0.7 \%$

$0.7 \%$

$0.7 \%$

$07 \%$

$0.3 \%$

$0.3 \%$

$0.3 \%$

$0.3 \%$

$0.3 \%$

$0.3 \%$

$0.3 \%$

$0.3 \%$

$0.3 \%$

$0.3 \%$

$0.3 \%$

$0.3 \%$

$0.3 \%$

$0.3 \%$

$0.3 \%$

$0.3 \%$

$0.3 \%$

$0.3 \%$

$0.3 \%$

$0.3 \%$

$0.3 \%$

$0.3 \%$

$0.3 \%$ 
Species

concinnus ssp. orcuttii

microcarpus

subvexus

congesta

aretioides

pusillum

californica spp. avita

primiveris

palmeni

bicolor

mustelina

hoodii ssp. lanata

heterorhyncha

spartioides

nuttallii
Frequency

$0.3 \%$

$0.3 \%$

$0.3 \%$

$0.3 \%$

$0.3 \%$

$0.3 \%$

$0.3 \%$

$0.3 \%$

$0.3 \%$

$0.3 \%$

$0.3 \%$

$0.3 \%$

$0.3 \%$

$0.3 \%$

$0.3 \%$

\section{Succulents}

$\begin{array}{lll}\text { Perennial } & \text { OPERE } & \text { Opuntia } \\ \text { Perennial } & \text { OPECE } & \text { Opuntia } \\ \text { Perennial } & \text { OPPOR } & \text { Opuntia } \\ \text { Perennial } & \text { ECEN } & \text { Echinocereus } \\ \text { Perennial } & \text { YUBAV } & \text { Yucca } \\ \text { Perennial } & \text { YUBR } & \text { Yucca } \\ \text { Perennial } & \text { ESVIR2 } & \text { Escobaria } \\ \text { Perennial } & \text { SCPO4 } & \text { Sclerocactus } \\ \text { Perennial } & \text { OPERU } & \text { Opuntia } \\ \text { Perennial } & \text { MATE4 } & \text { Mammillaria } \\ \text { Perennial } & \text { OPBAB2 } & \text { Opuntia } \\ \text { Perennial } & \text { ESVID } & \text { Escobania } \\ \text { Perennial } & \text { OPPU } & \text { Opuntia } \\ \text { Perennial } & \text { ECTRM } & \text { Echinocereus } \\ \text { Perennial } & \text { OPRA } & \text { Opuntia }\end{array}$

erinacea var. erinacea
echinocarpa var. echinocarpa
polyacantha var. rufispina
engelmannii
baccata var. vespertina
brevifolia
vivipara var. rosea
polyancistrus
erinacea var. ursina
tetrancistra
basilaris var. basilaris
vivipara var. deserti
pulchella
triglochidiatus var. melanacanthus
ramosissima

$28.8 \%$

$28.1 \%$

$14.7 \%$

$13.7 \%$

$11.0 \%$

$6.5 \%$

$5.5 \%$

$4.1 \%$

$2.1 \%$

$1.4 \%$

$1.0 \%$

$0.7 \%$

$0.7 \%$

$0.3 \%$

$0.3 \%$

Wednesday, January 05, 2000

Page 61 of 71 
Variable 


\section{Pinus monophylla/Artemisia spp. Woodland Alliance}

Trees (>5 m)

$\begin{array}{lll}\text { Perennial } & \text { PIMO } & \text { Pinus } \\ \text { Perennial } & \text { JUOS } & \text { Juniperus } \\ \text { Perennial } & \text { QUGA } & \text { Quercus }\end{array}$

monophylla

osteosperma

gambelii

$94.9 \%$

$94.2 \%$

$28.5 \%$

\section{Tall Shrubs (2-5 m)}

$\begin{array}{lll}\text { Perennial } & \text { ARTRT } & \text { Artemisia } \\ \text { Perennial } & \text { AMUT } & \text { Amelanchier } \\ \text { Perennial } & \text { CEGRV2 } & \text { Ceanothus } \\ \text { Perennial } & \text { AMPA2 } & \text { Amelanchier } \\ \text { Perennial } & \text { CEIN7 } & \text { Cercocarpus } \\ \text { Perennial } & \text { CELEL } & \text { Cercocarpus }\end{array}$

tridentata ssp. tridentata

$63.5 \%$

utahensis

$5.8 \%$

greggii ssp. vestitus

$1.5 \%$

$0.7 \%$

$0.7 \%$

intricatus

$0.7 \%$

\section{Short Shrubs (0.5-2 m)}

$\begin{array}{lll}\text { Perennial } & \text { ARNO4 } & \text { Artemisia } \\ \text { Perennial } & \text { EPVI } & \text { Ephedra } \\ \text { Perennial } & \text { CHVIV2 } & \text { Chrysothamnus } \\ \text { Perennial } & \text { ERMIS2 } & \text { Eriogonum } \\ \text { Perennial } & \text { PUTR2 } & \text { Purshia } \\ \text { Perennial } & \text { CHVIP4 } & \text { Chrysothamnus } \\ \text { Perennial } & \text { SYLO } & \text { Symphoricarpos } \\ \text { Perennial } & \text { PUST } & \text { Purshia } \\ \text { Perennial } & \text { ERNA7 } & \text { Ericameria } \\ \text { Perennial } & \text { ATCAC } & \text { Atriplex } \\ \text { Perennial } & \text { PUGL2 } & \text { Purshia } \\ \text { Perennial } & \text { EPNE } & \text { Ephedra } \\ \text { Perennial } & \text { GRSP } & \text { Grayia } \\ \text { Perennial } & \text { RIVEV } & \text { Ribes } \\ \text { Perennial } & \text { ERNAL } & \text { Ericameria } \\ \text { Perennial } & \text { SADOD3 } & \text { Salvia } \\ \text { Perennial } & \text { RICEC2 } & \text { Ribes }\end{array}$

Wednesday, January 05, 2000

nova

viridis

viscidiflorus ssp. viscidiflorus

microthecum var. simpsonii

tridentata

viscidiflorus ssp. puberulus

longiflorus

stansburiana

nanus

canescens var. canescens

glandulosa

nevadensis

spinosa

velutinum var. velutinum

nauseosus ssp. consimilis var.

dorii ssp. dorrii var. dorrii

cereum var. cereum
$71.5 \%$

$69.3 \%$

$63.5 \%$

$45.3 \%$

$44.5 \%$

$42.3 \%$

$29.9 \%$

$25.5 \%$

$21.9 \%$

$17.5 \%$

$17.5 \%$

$15.3 \%$

$13.9 \%$

$11.7 \%$

$8.8 \%$

$8.8 \%$

$8.0 \%$

Page 63 of 71 
Lifeform Longevity ACODE

\begin{tabular}{|c|c|c|}
\hline Perennial & GUSA2 & Gutierrezia \\
\hline Perennial & TEGL & Tetradymia \\
\hline Perennial & ERNA10 & Ericameria \\
\hline Perennial & ERLI6 & Ericameria \\
\hline Perennial & ERFAP & Eriogonum \\
\hline Perennial & KRLA2 & Krascheninnikovia \\
\hline Perennial & RHTRA & Rhus \\
\hline Perennial & ATCO & Atriplex \\
\hline Perennial & CHGR6 & Chrysothamnus \\
\hline Perennial & CORA & Coleogyne \\
\hline Perennial & ERNAH & Enicameria \\
\hline Perennial & ERPAN2 & Ericameria \\
\hline Perennial & ERTE18 & Ericameria \\
\hline Perennial & TECA2 & Tetradymia \\
\hline Perennial & BRMIW & Brickellia \\
\hline Perennial & $\mathrm{ERCO} 23$ & Ericameria \\
\hline Perennial & ERPA29 & Ericameria \\
\hline Perennial & GLSPA & Glossopetalon \\
\hline Perennial & HODI & Holodiscus \\
\hline Perennial & KEROR & Keckiella \\
\hline Perennial & LYAN & Lycium \\
\hline Perennial & PRFA & Prunus \\
\hline Perennial & STPIP & Stanleya \\
\hline Perennial & TEAXA & Tetradymia \\
\hline
\end{tabular}

Dwarf Shrubs (<0.5 m)

$\begin{array}{lll}\text { Perennial } & \text { LEPU } & \text { Leptodactylon } \\ \text { Perennial } & \text { ERMIL } & \text { Eriogonum } \\ \text { Perennial } & \text { ARSP5 } & \text { Artemisia } \\ \text { Perennial } & \text { ERWA8 } & \text { Ericameria }\end{array}$

\section{Species}

sarothrae
glabrata
nauseosus
linearifolius
fasciculatum var. polifolium
lanata
trilobata var. anisophylla
confertifolia
greenei
ramosissima
nauseosus ssp. nauseosus var.
pamyi var. nevadensis
teretifolia
canescens
microphylla var. watsonii
cooperi
paniculata
spinescens var. aridum
discolor
rothrockii ssp. rothrockii
andersonii
fasciculata
pinnata var. pinnata
axillaris var. axillaris

Frequency

$5.1 \%$

$4.4 \%$

$3.6 \%$

$2.9 \%$

$2.9 \%$

$2.9 \%$

$2.9 \%$

$1.5 \%$

$1.5 \%$

$1.5 \%$

$1.5 \%$

$1.5 \%$

$1.5 \%$

$1.5 \%$

$0.7 \%$

$0.7 \%$

$0.7 \%$

$0.7 \%$

$0.7 \%$

$0.7 \%$

$0.7 \%$

$0.7 \%$

$0.7 \%$

$0.7 \%$

$59.9 \%$

$9.5 \%$

$2.2 \%$

$0.7 \%$ 


\section{Graminoids}

\begin{tabular}{lll} 
Perennial & ELELE & Elymus \\
Perennial & POSE & Poa \\
Annual & BRTE & Bromus \\
Perennial & ACHY & Achnatherum \\
Perennial & POFE & Poa \\
Perennial & HECOC8 & Hesperostipa \\
Perennial & PLJA & Pleuraphis \\
Perennial & ACTH7 & Achnatherum \\
Perennial & KOMA & Koeleria \\
Perennial & ACSP12 & Achnatherum \\
Perennial & ARPU9 & Aristida \\
Perennial & AGGLL & Agoseris \\
Annual & BRRU2 & Bromus \\
Perennial & LECl4 & Leymus \\
Perennial & ACCO21 & Achnatherum \\
Perennial & ACPI2 & Achnatherum \\
Perennial & ACAR14 & Achnatherum \\
Perennial & BOGR2 & Bouteloua \\
Perennial & CADO2 & Carex \\
Perennial & CAOC2 & Carex \\
Annual & VUOC & Vulpia \\
Perennial & SPCR & Sporobolus \\
Annual & VUMI & Vulpia \\
& & \\
\hline
\end{tabular}

\begin{tabular}{lc} 
elymoides ssp. elymoides & $83.9 \%$ \\
secunda & $81.0 \%$ \\
tectorum & $72.3 \%$ \\
hymenoides & $64.2 \%$ \\
fendleriana & $48.2 \%$ \\
comata ssp. comata & $43.1 \%$ \\
jamesii & $24.8 \%$ \\
thurberiana & $19.0 \%$ \\
macrantha & $19.0 \%$ \\
speciosum & $13.9 \%$ \\
purpurea & $10.9 \%$ \\
glauca var. laciniata & $8.8 \%$ \\
rubens & $3.6 \%$ \\
cinereus & $3.6 \%$ \\
coronata & $2.2 \%$ \\
pinetorum & $2.2 \%$ \\
aridum & $1.5 \%$ \\
gracilis & $1.5 \%$ \\
douglasii & $1.5 \%$ \\
occidentalis & $1.5 \%$ \\
octoflora & $1.5 \%$ \\
cryptandrus & $0.7 \%$ \\
microstachys & $0.7 \%$ \\
\hline
\end{tabular}

Forbs

$\begin{array}{lll}\text { Perennial } & \text { PHST11 } & \text { Phlox } \\ \text { Annual } & \text { ASLEF2 } & \text { Astragalus } \\ \text { Perennial } & \text { STCOC } & \text { Streptanthus } \\ \text { Perennial } & \text { ERCA8 } & \text { Eriogonum } \\ \text { Perennial } & \text { CAAP4 } & \text { Castilleja } \\ \text { Perennial } & \text { GIBRB } & \text { Gilia } \\ \text { Perennial } & \text { ARCOS2 } & \text { Arenaria } \\ \text { Perennial } & \text { SEMU3 } & \text { Senecio } \\ \text { Perennial } & \text { EROVO5 } & \text { Eriogonum }\end{array}$

stansburyi
lentiginosus var. fremontii
cordatus var. cordatus
caespitosum
applegatei
brecciarum ssp. brecciarum
congesta var. subcongesta
multilobatus
ovalifolium var. ovalifolium

$56.2 \%$

$54.7 \%$

$54.0 \%$

$53.3 \%$

$50.4 \%$

$48.2 \%$

$46.7 \%$

$46.7 \%$

$44.5 \%$ 


\begin{tabular}{|c|c|c|c|}
\hline Lifeform & Longevity & $A C O D E$ & Genus \\
\hline & Perennial & CHDO & Chaenactis \\
\hline & Perennial & MACAC & Machaeranthera \\
\hline & Perennial & CAFL & Calochortus \\
\hline & Perennial & ERUM & Eriogonum \\
\hline & Perennial & CRFL6 & Cryptantha \\
\hline & Annual & PHVAV2 & Phacelia \\
\hline & Annual & CRGR3 & Cryptantha \\
\hline & Annual & CAPU16 & Camissonia \\
\hline & Perennial & ASCAC5 & Astragalus \\
\hline & Perennial & PEHUH & Penstemon \\
\hline & Annual & DEPIG & Descurainia \\
\hline & Annual & PHFR2 & Phacelia \\
\hline & Perennial & HYCOC2 & Hymenoxys \\
\hline & Perennial & ASPUT & Astragalus \\
\hline & Perennial & ERCOC3 & Erigeron \\
\hline & Annual & MISP & Mimulus \\
\hline & Annual & ERER2 & Eriastrum \\
\hline & Perennial & CRVI5 & Cryptantha \\
\hline & Perennial & PEFLA2 & Penstemon \\
\hline & Annual & PHSA & Phacelia \\
\hline & Perennial & ARPUG & Arabis \\
\hline & Perennial & $\mathrm{CROCO} 2$ & Crepis \\
\hline & Perennial & DIPU3 & Dichelostemma \\
\hline & Annual & ERDI4 & Enigeron \\
\hline & Perennial & CALI4 & Castilleja \\
\hline & Perennial & DEAN & Delphinium \\
\hline & Annual & $\mathrm{CRCl} 2$ & Cryptantha \\
\hline & Annual & LUSH & Lupinus \\
\hline & Perennial & SPAMA & Sphaeralcea \\
\hline & Perennial & LONEN & Lomatium \\
\hline & Perennial & PEPU7 & Petradoria \\
\hline & Perennial & LEKIK & Lesquerella \\
\hline & Annual & MEVE5 & Mentzelia \\
\hline
\end{tabular}

\section{Species}

douglasii

canescens ssp. canescens

flexuosus

umbellatum

flavoculata

vallis-mortae var. vallis-mortae

gracilis

pusilla

calycosus var. calycosus

humilis ssp. humilis

pinnata ssp. glabra

fremontii

cooperi var. cooperi

purshii var. tinctus

concinnus var. concinnus

spissus

eremicum

virginensis

floridus var. austinii

saxicola

pulchra var. gracilis

occidentalis ssp. occidentalis

puichellum

divergens

linanaefolia

andersonii

circumscissa

shockleyi

ambigua ssp. ambigua

nevadense var. nevadense

pumila

kingii ssp. kingii

veatchiana
Frequency

$43.8 \%$

$41.6 \%$

$40.1 \%$

$36.5 \%$

$35.8 \%$

$34.3 \%$

$32.8 \%$

$29.9 \%$

$28.5 \%$

$27.7 \%$

$27.0 \%$

$26.3 \%$

$24.8 \%$

$24.1 \%$

$24.1 \%$

$23.4 \%$

$22.6 \%$

$21.2 \%$

$20.4 \%$

$20.4 \%$

$19.7 \%$

$19.7 \%$

$19.7 \%$

$19.7 \%$

$19.0 \%$

$19.0 \%$

$18.2 \%$

$18.2 \%$

$17.5 \%$

$16.8 \%$

$16.8 \%$

$16.1 \%$

$15.3 \%$

Page 66 of 71 
Lifeform Longevity ACODE

\begin{tabular}{|c|c|c|}
\hline Annual & MisU2 & Mimulus \\
\hline Perennial & DEPAP3 & Delphinium \\
\hline Perennial & HEMUN & Heliomeris \\
\hline Perennial & PEPA23 & Penstemon \\
\hline Perennial & PHGRH & Phlox \\
\hline Annual & CRPT & Cryptantha \\
\hline Annual & MEAL6 & Mentzelia \\
\hline Annual & AMTE3 & Amsinckia \\
\hline Annual & CAPT & Camissonia \\
\hline Perennial & ERRA3 & Eriogonum \\
\hline Perennial & LILE3 & Linum \\
\hline Perennial & CRCO12 & Cryptantha \\
\hline Perennial & ORFA & Orabanche \\
\hline Annual & CHIN2 & Chenopodium \\
\hline Perennial & OECEM4 & Oenothera \\
\hline Annual & $\mathrm{PHCU}$ & Phacelia \\
\hline Perennial & SPAMM & Sphaeralcea \\
\hline Annual & GILIA & Gilia \\
\hline Perennial & LUARL5 & Lupinus \\
\hline Annual & SYFR & Syntrichopappus \\
\hline Perennial & MIMUG & Mirabilis \\
\hline Annual & ERNI4 & Eriogonum \\
\hline Perennial & ALNE & Allium \\
\hline Annual & CHST & Chaenactis \\
\hline Perennial & LEREM & Lewisia \\
\hline Annual & LIDI2 & Linanthus \\
\hline Annual & MECO2 & Mentzelia \\
\hline Perennial & SIVEA & Silene \\
\hline Biennial & CINE & Cirsium \\
\hline Annual & ERSP3 & Eriastrum \\
\hline Annual & ERESE & Eriogonum \\
\hline Perennial & ERSA6 & Eriogonum \\
\hline Perennial & IPCO5 & Ipomopsis \\
\hline
\end{tabular}

Species

Frequency

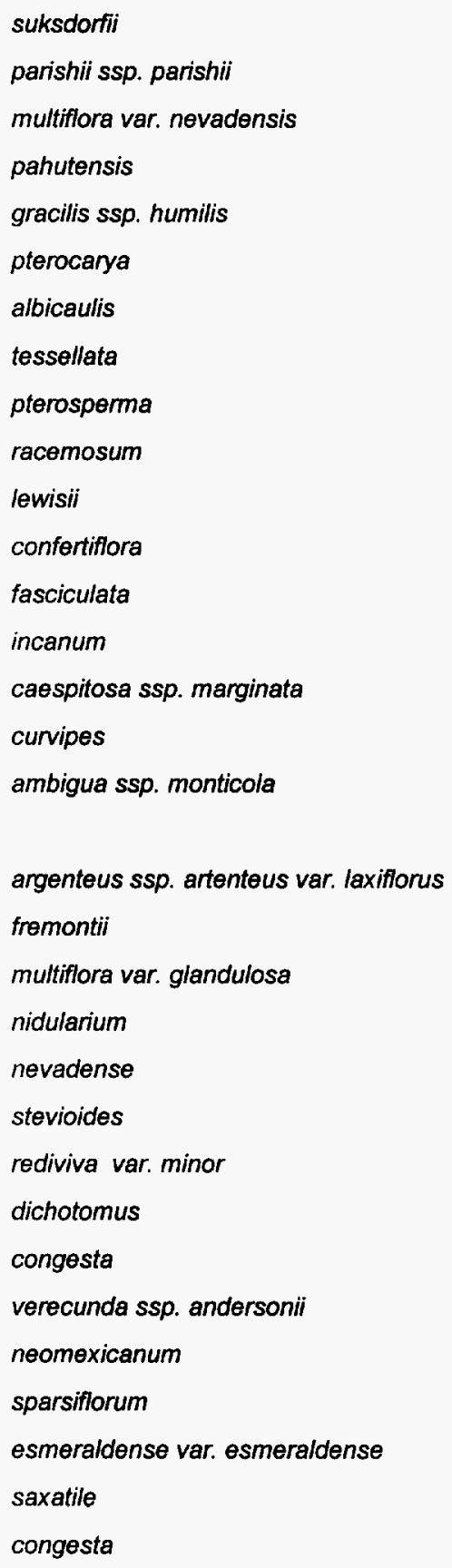

$15.3 \%$

$14.6 \%$

$14.6 \%$

$14.6 \%$

$14.6 \%$

$13.9 \%$

$13.9 \%$

$12.4 \%$

$12.4 \%$

$12.4 \%$

$12.4 \%$

$11.7 \%$

$10.9 \%$

$10.2 \%$

$10.2 \%$

$10.2 \%$

$9.5 \%$

$8.8 \%$

$8.8 \%$

$8.8 \%$

$7.3 \%$

$6.6 \%$

$5.8 \%$

$5.8 \%$

$5.8 \%$

$5.8 \%$

$5.8 \%$

$5.8 \%$

$5.1 \%$

$5.1 \%$

$5.1 \%$

$5.1 \%$

$4.4 \%$

Wednesday, January 05, 2000

Page 67 of 71 


\begin{tabular}{|c|c|c|}
\hline Annual & IPPO2 & Ipomopsis \\
\hline Annual & LAOCO & Lappula \\
\hline Annual & LUFL. & Lupinus \\
\hline Annual & NABR & Navarretia \\
\hline Perennial & STSP6 & Stephanomeria \\
\hline Perennial & ABEL & Abronia \\
\hline Perennial & ASNE6 & Astragalus \\
\hline Perennial & CACRG & Caulanthus \\
\hline Annual & CETH3 & Centrostegia \\
\hline Annual & CHMA & Chaenactis \\
\hline Annual & CHWA2 & Chorizanthe \\
\hline Perennial & HUVEI & Hulsea \\
\hline Annual & PESE & Pectocarya \\
\hline Perennial & PEPA8 & Penstemon \\
\hline Annual & URLI2 & Uropappus \\
\hline Perennial & ZIPA2 & Zigadenus \\
\hline Perennial & ARPUM & Arabis \\
\hline Perennial & ARMA3 & Arenaria \\
\hline Perennial & CHAL11 & Chamaesyce \\
\hline Annual & COPA3 & Collinsia \\
\hline Annual & CRNEN & Cryptantha \\
\hline Perennial & CRUT & Cryptantha \\
\hline Perennial & CYAB & Cymopterus \\
\hline Annual & ERWI & Eriastrum \\
\hline Annual & ERCI6 & Erodium \\
\hline Perennial & GINY & Gilia \\
\hline Perennial & LINUN & Linanthus \\
\hline Annual & LUBR2 & Lupinus \\
\hline Perennial & MIBI8 & Mirabilis \\
\hline Annual & SAPAB & Salsola \\
\hline Annual & STEXE & Stephanomeria \\
\hline Annual & THCU & Thysanocarpus \\
\hline Perennia! & ANDI2 & Antennaria \\
\hline
\end{tabular}

polycladon
occidentalis var. occidentalis
flavoculatus
breweri
spinosa
elliptica
newberryi
crassicaulis var. glaber
thurberi
macrantha
watsonii
vestita ssp. inyoensis
setosa
palmeri
linearifolia
paniculatus
pulchra var. munciensis
macradenia
albomarginata
parviflora
nevadensis var. nevadensis
utahensis
aboriginum
wilcoxii
cicutarium
nyensis
nuttallii ssp. nuttallii
brevicaulis
bigelovii
paulsenii
exigua ssp. exigua
curves
dima




\begin{tabular}{|c|c|c|c|}
\hline Lifeform & Longevity & $A C O D E$ & Genus \\
\hline & Annual & CABRB4 & Camissonia \\
\hline & Annual & CRAM3 & Cryptantha \\
\hline & Annual & GADIP & Gayophytum \\
\hline & Perennial & ORCO5 & Orobanche \\
\hline & Perennial & PENST & Pensteman \\
\hline & Perennial & PER010 & Penstemon \\
\hline & Annual & PHCRC3 & Phacelia \\
\hline & Annual & PLPA2 & Plantago \\
\hline & Perennial & POSU & Polygala \\
\hline & Perennial & SPGRP2 & Sphaeralcea \\
\hline & Perennial & STPA4 & Stephanomeria \\
\hline & Perennial & TOSC & Townsendia \\
\hline & Annual & ANAC & Anisocoma \\
\hline & Perennial & ARKIC & Arenaria \\
\hline & Annual & ASAC3 & Astragalus \\
\hline & Perennial & ASBE5 & Astragalus \\
\hline & Perennial & ASBE3 & Astragalus \\
\hline & Annual & CHAL7 & Chenopodium \\
\hline & Annual & CHLE4 & Chenopodium \\
\hline & Perennial & CHGR13 & Chrysothamnus \\
\hline & Annual & CLPAU2 & Claytonia \\
\hline & Annual & ERDE6 & Eriogonum \\
\hline & Perennial & HYFIM & Hymenopappus \\
\hline & Perennial & LOFOF & Lomatium \\
\hline & Perennial & TRWA2 & Tricardia \\
\hline & Perennial & TRAN & Trifolium \\
\hline & Perennial & XYTOT & Xylorhiza \\
\hline & Annual & AMAC2 & Ambrosia \\
\hline & Perennial & ANRO2 & Antennaria \\
\hline & Perennial & ARHOP3 & Arabis \\
\hline & Perennial & ARCO6 & Argemone \\
\hline & Perennial & ARDR4 & Artemisia \\
\hline & Perennial & ARLU & Artemisia \\
\hline
\end{tabular}

Species

brevipes ssp. brevipes

ambigua

diffusum ssp. parviflorum

corymbosa

rostriflorus

crenulata var. crenulata

patagonica

subspinosa

grossulariaefolia ssp. pedata

pauciflora

scapigera

acaulis

kingii ssp. Compacta

acutirostris

beatleyae

beckwithii

album

leptophyllum

gramineus

perfoliata ssp. perfoliata

deflexum

filifolius var. megacephalus

foeniculaceum ssp. fimbriatum

watsonii

andersonii

tortifolia var. imberbis

acanthicarpa

rosea

holboellii var. pinetorum

carymbosa

dracunculus

Iudoviciana
Frequency

$2.2 \%$

$2.2 \%$

$2.2 \%$

$2.2 \%$

$2.2 \%$

$2.2 \%$

$2.2 \%$

$2.2 \%$

$2.2 \%$

$2.2 \%$

$2.2 \%$

$2.2 \%$

$1.5 \%$

$1.5 \%$

$1.5 \%$

$1.5 \%$

$1.5 \%$

$1.5 \%$

$1.5 \%$

$1.5 \%$

$1.5 \%$

$1.5 \%$

$1.5 \%$

$1.5 \%$

$1.5 \%$

$1.5 \%$

$1.5 \%$

$0.7 \%$

$0.7 \%$

$0.7 \%$

$0.7 \%$

$0.7 \%$

$0.7 \%$

Wednesday, January 05, 2000

Page 69 of 71 


\begin{tabular}{|c|c|c|c|}
\hline \multirow[t]{34}{*}{ Lifeform } & Longevity & $A C O D E$ & Genus \\
\hline & Perennial & BAHON & Balsamorhiza \\
\hline & Annual & CAPA7 & Calycoseris \\
\hline & Annual & CABOC & Camissonia \\
\hline & Annual & CACLI & Camissonia \\
\hline & Annual & $\mathrm{CHXA}$ & Chaenactis \\
\hline & Perennial & CRIN4 & Crepis \\
\hline & Perennial & CRHU2 & Cryptantha \\
\hline & Annual & CRMI & Cryptantha \\
\hline & Perennial & $\mathrm{EPCl}$ & Epilobium \\
\hline & Perennial & ERAP & Erigeron \\
\hline & Annual & ERBR7 & Eriogonum \\
\hline & Perennial & ERIN4 & Eriogonum \\
\hline & Perennial & ERUMS2 & Eriogonum \\
\hline & Perennial & ERUMV & Eriogonum \\
\hline & Perennial & ERUMV2 & Eriogonum \\
\hline & Perennial & FRALM & Frasera \\
\hline & Perennial & GIHU & Gilia \\
\hline & Perennial & GIIN2 & Gilia \\
\hline & Annual & IPDE & Ipomopsis \\
\hline & Annual & LELA & Lepidium \\
\hline & Perennial & LIRU4 & Lithospermum \\
\hline & Perennial & LUCA & Lupinus \\
\hline & Perennial & LUPA3 & Lupinus \\
\hline & Annual & MAGL3 & Malacothrix \\
\hline & Annual & MASO & Malacothrix \\
\hline & Annual & NAPU & Nama \\
\hline & Perennial & OEPAP & Oenothera \\
\hline & Annual & PEPL & Pectocarya \\
\hline & Annual & PHAF & Phacelia \\
\hline & Annual & PHPE2 & Phacelia \\
\hline & Perennial & PHHOL & Phlox \\
\hline & Perennial & $\mathrm{PHCH} 2$ & Physaria \\
\hline & Perennial & POHE? & Polygala \\
\hline
\end{tabular}

\section{Species}

hookeri var. neglecta

parryi

boothii ssp. condensata

claviformis ssp. integrior

xantiana

intermedia

humilis

micrantha

ciliatum

aphanactis

brachyanthum

inflatum

umbellatum var. subaridum

umbellatum var. vernum

umbellatum var. versicolor

pahutensis

hutchinsifolia

inconspicua

depressa

lasiocarpum

ruderale

caudatus

palmeri

glabrata

sonchoides

pusillum

pallida ssp. pallida

platycarpa

affinis

peirsoniana

hoodii ssp. lanata

chambersii

heterorhynche
Frequency

$0.7 \%$

$0.7 \%$

$0.7 \%$

$0.7 \%$

$0.7 \%$

$0.7 \%$

$0.7 \%$

$0.7 \%$

$0.7 \%$

$0.7 \%$

$0.7 \%$

$0.7 \%$

$0.7 \%$

$0.7 \%$

$0.7 \%$

$0.7 \%$

$0.7 \%$

$0.7 \%$

$0.7 \%$

$0.7 \%$

$0.7 \%$

$0.7 \%$

$0.7 \%$

$0.7 \%$

$0.7 \%$

$0.7 \%$

$0.7 \%$

$0.7 \%$

$0.7 \%$

$0.7 \%$

$0.7 \%$

$0.7 \%$

$0.7 \%$

Wednesday, January 05, 2000

Page 70 of 71 
Arceuthobium

divaricatum

$2.2 \%$

\section{Succulents}

$\begin{array}{lll}\text { Perennial } & \text { OPPOR } & \text { Opuntia } \\ \text { Perennial } & \text { OPERE } & \text { Opuntia } \\ \text { Perennial } & \text { YUBAV } & \text { Yucca } \\ \text { Perennial } & \text { ESVIR2 } & \text { Escobaria } \\ \text { Perennial } & \text { ECEN } & \text { Echinocereus } \\ \text { Perennial } & \text { OPECE } & \text { Opuntia } \\ \text { Perennial } & \text { MATE4 } & \text { Mammillaria } \\ \text { Perennial } & \text { ECTRM } & \text { Echinocereus } \\ \text { Perennial } & \text { SCPO4 } & \text { Sclerocactus } \\ \text { Perennial } & \text { YUBR } & \text { Yucca }\end{array}$

\section{Genus}

Perennial

SESP3

Senecio

Annual

STLO4

Streptanthella

Ferns

Perennial PETR7 Pentagama

\section{Species}

spartioides

longirostris

triangularis

$0.7 \%$

\section{Epiphytes}

ARDI3

polyacantha var. rufispina

$51.1 \%$

erinacea var. erinacea

$46.7 \%$

baccata var. vespertina

$17.5 \%$

vivipara var. rosea

$12.4 \%$

engelmannii

$7.3 \%$

echinocarpa var. echinocarpa

$4.4 \%$

tetrancistra

$1.5 \%$

triglochidiatus var. melanacanthus

$0.7 \%$

polyancistrus

$0.7 \%$

brevifolia 
This Page Intentionally Left Blank 


\section{Appendix G}

\section{Percent Frequency of NTS Plant Species by Association}

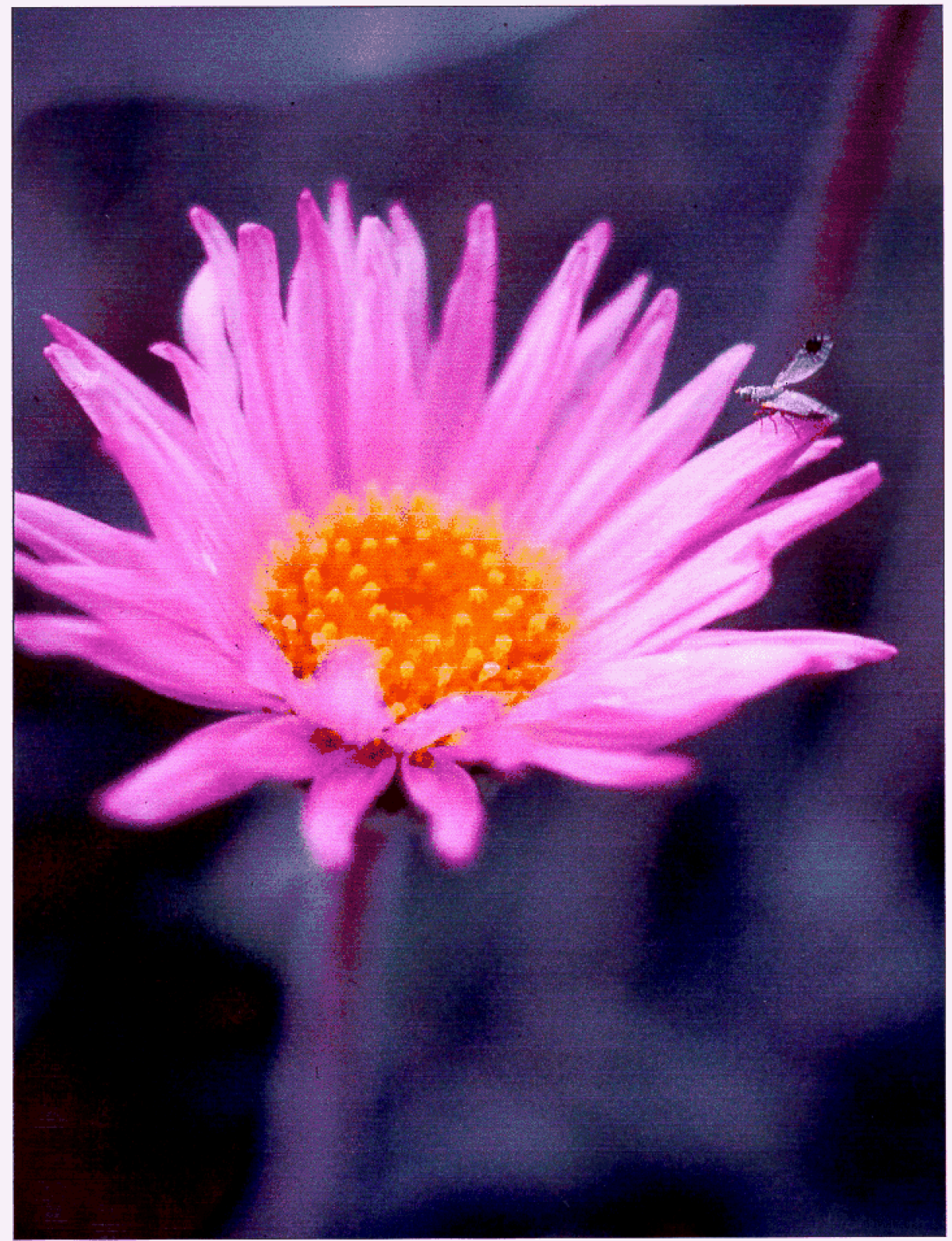

Mojave woodyaster (Xylorhiza tortifolia) [photo by Susan Cochrane] 
This Page Intentionally Left Blank 


\section{Appendix G. Percent Frequency of NTS Plant Species by Association}

Association Longevity ACODE Genus

\section{Lycium shockleyi-Lycium pallidum Shrubland}

Short Shrubs (0.5-2 m)

$\begin{array}{lll}\text { Perennial } & \text { KRLA2 } & \text { Krascheninnikovia } \\ \text { Perennial } & \text { AMDU2 } & \text { Ambrosia } \\ \text { Perennial } & \text { ATCAC } & \text { Atriplex } \\ \text { Perennial } & \text { ATCO } & \text { Atriplex } \\ \text { Perennial } & \text { LYSH } & \text { Lycium } \\ \text { Perennial } & \text { ACSH } & \text { Acamptopappus } \\ \text { Perennial } & \text { HYSA } & \text { Hymenoclea } \\ \text { Perennial } & \text { LYPAO } & \text { Lycium } \\ \text { Perennial } & \text { CHVIV2 } & \text { Chrysothamnus } \\ \text { Perennial } & \text { GRSP } & \text { Grayia } \\ \text { Perennial } & \text { STPIP } & \text { Stanleya } \\ \text { Perennial } & \text { TEAXA } & \text { Tetradymia }\end{array}$

\section{Dwarf Shrubs ( $<0.5 \mathrm{~m})$}

$\begin{array}{lll}\text { Perennial } & \text { ARSP5 } & \text { Artemisia } \\ \text { Perennial } & \text { KOAM } & \text { Kochia }\end{array}$

\section{Graminoids}

$\begin{array}{lll}\text { Perennial } & \text { ACHY } & \text { Achnatherum } \\ \text { Annual } & \text { BRRU2 } & \text { Bromus } \\ \text { Perennial } & \text { ELELE } & \text { Elymus }\end{array}$

\section{Forbs}

$\begin{array}{lll}\text { Annual } & \text { AMTE3 } & \text { Amsinckia } \\ \text { Annual } & \text { ASLEF2 } & \text { Astragalus } \\ \text { Perennial } & \text { BAMU } & \text { Baileya } \\ \text { Annual } & \text { CRCl2 } & \text { Cryptantha } \\ \text { Annual } & \text { ERER2 } & \text { Eriastrum } \\ \text { Perennial } & \text { ERIN4 } & \text { Eriogonum } \\ \text { Annual } & \text { LELA } & \text { Lepidium } \\ \text { Perennial } & \text { MACAC } & \text { Machaeranthera } \\ \text { Annual } & \text { MAGL3 } & \text { Malacothrix }\end{array}$

$\begin{array}{ll}\text { tessellata } & 40.0 \\ \text { lentiginosus var. fremontii } & 40.0 \\ \text { multiradiata } & 40.0 \\ \text { circumscissa } & 40.0 \\ \text { eremicum } & 40.0 \\ \text { inflatum } & 40.0 \\ \text { lasiocarpum } & 40.0 \\ \text { canescens ssp. canescens } & 40.0 \\ \text { glabrata } & 40.0\end{array}$




\begin{tabular}{|c|c|c|c|c|c|}
\hline \multirow{25}{*}{ Association } & Longevity & $A C O D E$ & Genus & Species & \% Frequency \\
\hline & Annual & MEAL6 & Mentzelia & albicaulis & 40.0 \\
\hline & Perennial & MIPU5 & Mirabilis & pudica & 40.0 \\
\hline & Annual & OEPR & Oenothera & primiveris & 40.0 \\
\hline & Perennial & SPAMA & Sphaeralcea & ambigua ssp. ambigua & 40.0 \\
\hline & Perennial & STPA4 & Stephanomeria & pauciflora & 40.0 \\
\hline & Perennial & ARPUM & Arabis & pulchra var. munciensis & 20.0 \\
\hline & Annual & CETH3 & Centrostegia & thurberi & 20.0 \\
\hline & Perennial & CHAL11 & Chamaesyce & albomarginata & 20.0 \\
\hline & Annual & CHFR & Chaenactis & fremontii & 20.0 \\
\hline & Annual & CHST & Chaenactis & stevioides & 20.0 \\
\hline & Annual & CRNEN & Cryptantha & nevadensis var. nevadensis & 20.0 \\
\hline & Annual & CRPT & Cryptantha & pterocarya & 20.0 \\
\hline & Annual & DEPIG & Descurainja & pinnata ssp. glabra & 20.0 \\
\hline & Annual & DESO2 & Descurainia & sophia & 20.0 \\
\hline & Annual & ERMA2 & Eriogonum & maculatum & 20.0 \\
\hline & Annual & ERNI4 & Eriogonum & nidularium & 20.0 \\
\hline & Annual & ESGL & Eschscholzia & glyptosperma & 20.0 \\
\hline & Annual & IPPO2 & Ipomopsis & polycladon & 20.0 \\
\hline & Annual & LAOCO & Lappula & occidentalis var. occidentalis & 20.0 \\
\hline & Annual & LASE3 & Langloisia & setosissima & 20.0 \\
\hline & Perennial & OECA2 & Oenothera & califomica spp avita & 20.0 \\
\hline & Annual & OXPE2 & Oxytheca & perfoliata & 20.0 \\
\hline & Perennial & POSU & Polygala & subspinosa & 20.0 \\
\hline & Annual & SAPA8 & Salsola & paulsenii & 20.0 \\
\hline
\end{tabular}

Thursday, September 09, 1999 


\section{Larrea Tridentata/Ambrosia dumosa Shrubland}

Tall Shrubs (2-5 m)

Perennial LATR2 Larre

tridentata

\section{Short Shrubs (0.5-2 m)}

\begin{tabular}{|c|c|c|}
\hline Perennial & AMDU2 & Ambrosia \\
\hline Perennial & EPNE & Ephedra \\
\hline Perennial & KRLA2 & Krascheninnikovia \\
\hline Perennial & LYAN & Lycium \\
\hline Perennial & GRSP & Grayia \\
\hline Perennial & LYPAO & Lycium \\
\hline Perennial & $\mathrm{ACSH}$ & Acamptopappus \\
\hline Perennial & ATCO & Atriplex \\
\hline Perennial & HYSA & Hymenoclea \\
\hline Perennial & PSFRF & Psorothamnus \\
\hline Perennial & CORA & Coleogyne \\
\hline Perennial & SAME & Salazaria \\
\hline Perennial & ENVIV & Encelia \\
\hline Perennial & ERCO23 & Ericameria \\
\hline Perennial & ERFAP & Eriogonum \\
\hline Perennial & THMO & Thamnosma \\
\hline Perennial & LEFR2 & Lepidium \\
\hline Perennial & LYSH & Lycium \\
\hline Perennial & ATCAC & Atriplex \\
\hline Perennial & CHVIV2 & Chrysothamnus \\
\hline Perennial & GUSA2 & Gutierrezia \\
\hline Perennial & TEAXA & Tetradymia \\
\hline Perennial & EPFU & Ephedra \\
\hline Perennial & PSPO & Psorothamnus \\
\hline Perennial & STPIP & Stanleya \\
\hline Perennial & ERTE18 & Ericameria \\
\hline Perennial & ATPO & Atriplex \\
\hline Perennial & EPTO & Ephedra \\
\hline Perennial & EPVI & Ephedra \\
\hline Perennial & TECA2 & Tetradymia \\
\hline Perennial & BRMIW & Brickellia \\
\hline
\end{tabular}

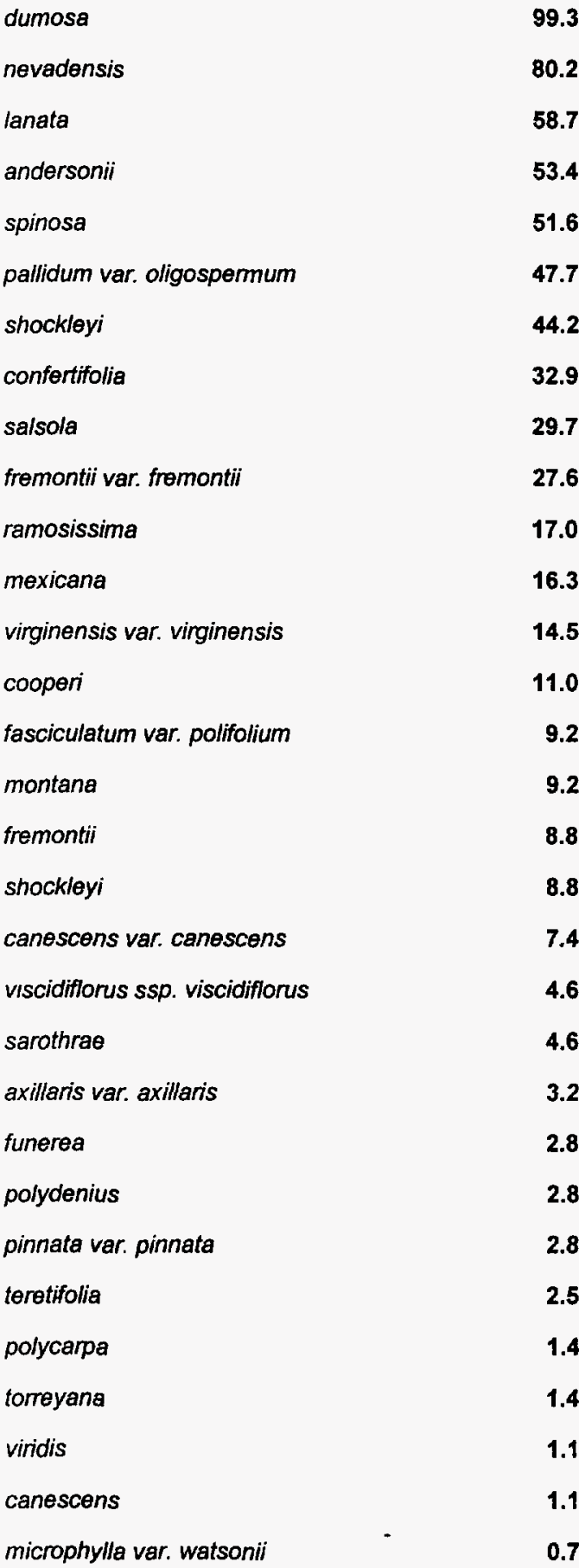




$\begin{array}{rrrl}\text { Association } & \text { Longevity } & \text { ACODE } & \text { Genus } \\ & \text { Perennial } & \text { ERPA29 } & \text { Ericameria } \\ & \text { Perennial } & \text { AMER } & \text { Ambrosia } \\ \text { Perennial } & \text { ATHY } & \text { Atriplex } \\ & \text { Perennial } & \text { ERNAL } & \text { Ericameria } \\ & \text { Perennial } & \text { TEGL } & \text { Tetradymia }\end{array}$

Species $\%$ Fred
paniculata
eriocentra
hymenelytra
nauseosus ssp. consimilis var. leiosperma
glabrata

\section{Dwarf Shrubs ( $<0.5 \mathrm{~m})$}

$\begin{array}{lll}\text { Perennial } & \text { KRER } & \text { Krameria } \\ \text { Perennial } & \text { MESP2 } & \text { Menodora } \\ \text { Perennial } & \text { ARSP5 } & \text { Artemisia } \\ \text { Perennial } & \text { ERWA8 } & \text { Ericameria } \\ \text { Perennial } & \text { LEPU } & \text { Leptodactylon }\end{array}$

erecta
spinescens
spinescens
watsonii
pungens

\section{Graminoids}

$\begin{array}{lcl}\text { Annual } & \text { BRRU2 } & \text { Bromus } \\ \text { Perennial } & \text { ACHY } & \text { Achnatherum } \\ \text { Perennial } & \text { ACSP12 } & \text { Achnatherum } \\ \text { Annual } & \text { SCAR } & \text { Schismus } \\ \text { Annual } & \text { VUOC } & \text { Vulpia } \\ \text { Perennial } & \text { ERPU8 } & \text { Erioneuron } \\ \text { Annual } & \text { BRTE } & \text { Bromus } \\ \text { Perennial } & \text { PLRI3 } & \text { Pleuraphis } \\ \text { Perennial } & \text { ELELE } & \text { Elymus } \\ \text { Annual } & \text { BRCA6 } & \text { Bromus } \\ \text { Perennial } & \text { ARPU9 } & \text { Aristida }\end{array}$

$\begin{array}{lr}\text { rubens } & 87.6 \\ \text { hymenoides } & 51.6 \\ \text { speciasum } & 23.7 \\ \text { arabicus } & 10.6 \\ \text { octoflora } & 9.9 \\ \text { pulchellum } & 9.2 \\ \text { tectorum } & 3.9 \\ \text { rigida } & 3.5 \\ \text { elymoides ssp. elymoides } & 2.5 \\ \text { cartharticus } & 1.4 \\ \text { purpurea } & 0.4\end{array}$

\section{Forbs}

$\begin{array}{lll}\text { Annual } & \text { AMTE3 } & \text { Amsinckia } \\ \text { Perennial } & \text { ERIN4 } & \text { Eniogonum } \\ \text { Perennial } & \text { XYTOT } & \text { Xylorhiza } \\ \text { Annual } & \text { LUSH } & \text { Lupinus } \\ \text { Perennial } & \text { SPAMA } & \text { Sphaeralcea } \\ \text { Annual } & \text { MAGL3 } & \text { Malacothrix } \\ \text { Annual } & \text { CHRI } & \text { Chorizanthe } \\ \text { Annual } & \text { ERER2 } & \text { Eriastrum } \\ \text { Annual } & \text { CRNEN } & \text { Cryptantha } \\ \text { Annual } & \text { CHFR } & \text { Chaenactis }\end{array}$

tessellata
inflatum
tortifolia var. imberbis
shockleyi
ambigua ssp. ambigua
glabrata
rigida
eremicum
nevadensis var. nevadensis
fremontii




\begin{tabular}{|c|c|c|}
\hline Annual & $\mathrm{CRCl} 2$ & Cryptantha \\
\hline Perennial & ASLA8 & Astragalus \\
\hline Annual & CRPT & Cryptantha \\
\hline Annual & CHST & Chaenactis \\
\hline Annual & LELA & Lepidium \\
\hline Annual & OXPE2 & Oxytheca \\
\hline Perennial & DEPAP3 & Delphinium \\
\hline Annual & LUFL & Lupinus \\
\hline Annual & PHFR2 & Phacelia \\
\hline Annual & LASE3 & Langloisia \\
\hline Annual & DEPIG & Descurainia \\
\hline Annual & RANE & Rafinesquia \\
\hline Annual & STEXE & Stephanomeria \\
\hline Annual & PHVAV2 & Phacelia \\
\hline Annual & CABRB4 & Camissonia \\
\hline Annual & ERCl6 & Erodium \\
\hline Annual & ERPR4 & Eriophyllum \\
\hline Annual & STLO4 & Streptanthella \\
\hline Annual & ASLEF2 & Astragalus \\
\hline Perennial & STPA4 & Stephanomeria \\
\hline Annual & ASAC3 & Astragalus \\
\hline Annual & ERTH & Eriogonum \\
\hline Annual & CABOC & Camissonia \\
\hline Annual & GILIA & Gilia \\
\hline Annual & CETH3 & Centrostegia \\
\hline Annual & MEOB3 & Mentzelia \\
\hline Annual & CHBRB & Chorizanthe \\
\hline Annual & $\mathrm{CHCA}$ & Chaenactis \\
\hline Perennial & GIBRB & Gilia \\
\hline Annual & IPPO2 & Ipomopsis \\
\hline Perennial & BAMU & Baileya \\
\hline Perennial & CRUT & Cryptantha \\
\hline Annual & ERDE6 & Eriogonum \\
\hline Perennial & MIBI8 & Mirabilis \\
\hline Annual & PESE & Pectocarya \\
\hline Perennial & SPAMR & Sphaeralcea \\
\hline
\end{tabular}

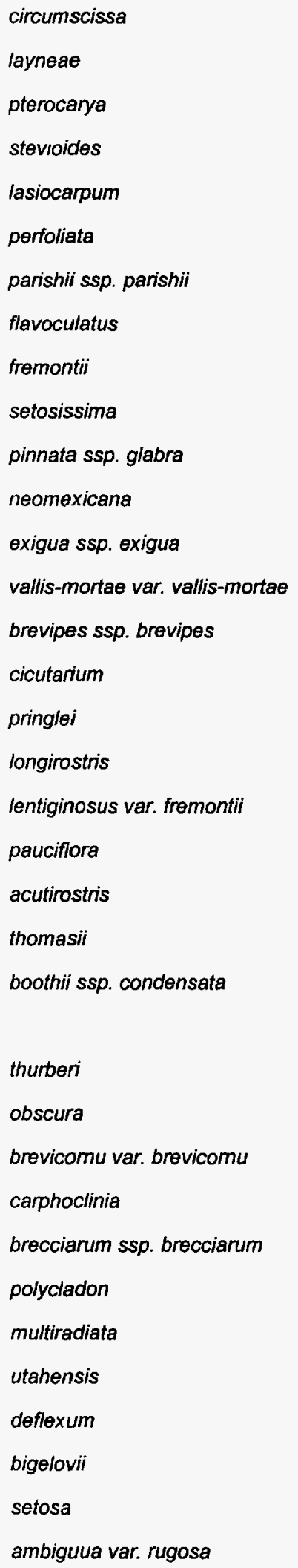




\begin{tabular}{|c|c|c|c|c|c|}
\hline \multirow[t]{37}{*}{ Association } & Longevity & $A C O D E$ & Genus & Species & $\%$ Frequency \\
\hline & Annual & ESGL & Eschscholzia & glyptosperma & 3. \\
\hline & Perennial & GICAS & Gilia & cana ssp. speciformis & 3 \\
\hline & Annual & NAPU & Nama & pusillum & \\
\hline & Annual & PLOV & Plantago & ovata & 3 \\
\hline & Perennial & CHAL11 & Chamaesyce & albomarginata & \\
\hline & Annual & CRMI & Cryptantha & micrantha & 2 \\
\hline & Annual & MOBE & Monoptilon & bellidiforme & \\
\hline & Annual & OEPR & Oenothera & primiveris & 2 \\
\hline & Annual & ESMI & Eschscholzia & minutiflora & 2 \\
\hline & Annual & LIDE2 & Linanthus & demissus & 2 \\
\hline & Annual & MASO & Malacothrix & sonchoides & \\
\hline & Perennial & DIPU3 & Dichelostemma & pulchellum & 2 \\
\hline & Annual & ERN14 & Eriogonum & nidularium & \\
\hline & Annual & PEPL & Pectocarya & platycarpa & 2. \\
\hline & Perennial & POSU & Polygala & subspinosa & 2 \\
\hline & Perennial & STPA3 & Stephanomeria & parryi & \\
\hline & Perennial & CAPI4 & Caulanthus & pilosus & \\
\hline & Perennial & CRVI5 & Cryptantha & virginensis & \\
\hline & Annual & LOHU2 & Lotus & humistratus & 1 \\
\hline & Perennial & CAAP4 & Castilleja & applegatei & $\mathrm{T}$ \\
\hline & Perennial & CAFL & Calochortus & flexuosus & \\
\hline & Annual & CAKEG & Camissonia & kemensis ssp. gilmanii & \\
\hline & Perennial & LEMOC & Lepidium & montanum var. canescens & \\
\hline & Perennial & MACAC & Machaeranthera & canescens ssp. canescens & \\
\hline & Annual & MEAL6 & Mentzelia & albicaulis & \\
\hline & Annual & PHCRC3 & Phacelia & crenulata var. crenulata & \\
\hline & Biennial & SIAL2 & Sisymbrium & altissimum & \\
\hline & Perennial & ARPUM & Arabis & pulchra var. munciensis & \\
\hline & Annual & ASDID & Astragalus & didymocarpus var. dispermus & \\
\hline & Annual & CACLI & Camissonia & claviformis ssp. integrior & \\
\hline & Perennial & DEAN & Delphinium & andersonii & \\
\hline & Annual & ERPU6 & Eriogonum & pusillum & \\
\hline & Annual & ERSP3 & Eriastrum & sparsiflorum & \\
\hline & Annual & LUBR2 & Lupinus & brevicaulis & \\
\hline & Annual & MOBE2 & Monoptilon & bellioides & \\
\hline & Annual & NEGLO & Nemacladus & glanduliferus var. orientalis & \\
\hline
\end{tabular}




\begin{tabular}{|c|c|c|}
\hline Annual & ANAC & Anisocoma \\
\hline Perennial & CAAPM & Castilleja \\
\hline Biennial & CINE & Cirsium \\
\hline Perennial & DAMO2 & Dalea \\
\hline Annual & DESO2 & Descurainia \\
\hline Perennial & ERCOC3 & Enigeron \\
\hline Annual & ERMA2 & Eriogonum \\
\hline Annual & ERTR8 & Eniogonum \\
\hline Perennial & GISC & Gilia \\
\hline Perennial & OECA2 & Oenothera \\
\hline Annual & OEDED4 & Oenothera \\
\hline Annual & PHSA & Phacelia \\
\hline Annual & SYFR & Syntrichopappus \\
\hline Perennial & ABEL & Abronia \\
\hline Perennial & $\mathrm{ADCO} 2$ & Adenophyllum \\
\hline Perennial & ASER2 & Asclepias \\
\hline Perennial & ASTI & Astragalus \\
\hline Perennial & BRAT & Brickellia \\
\hline Annual & CAC018 & Caulanthus \\
\hline Annual & CAHE12 & Camissonia \\
\hline Annual & CARE2 & Camissonia \\
\hline Annual & CHMA & Chaenactis \\
\hline Annual & CRMA7 & Cryptantha \\
\hline Annual & CRRE5 & Cryptantha \\
\hline Perennial & ERRA3 & Eriogonum \\
\hline Perennial & GICAT & Gilia \\
\hline Perennial & GILE3 & Gilia \\
\hline Perennial & HEMUN & Heliomeris \\
\hline Annual & LEFLF2 & Lepidium \\
\hline Annual & LIDI2 & Linanthus \\
\hline Perennial & $\operatorname{LOSC} 3$ & Lomatium \\
\hline Annual & LOSC6 & Loeseliastrum \\
\hline Annual & MEVE5 & Mentzelia \\
\hline Perennial & MIPU5 & Mirabilis \\
\hline Annual & NADED & Nama \\
\hline Perennial & OECEM4 & Oenothera \\
\hline
\end{tabular}

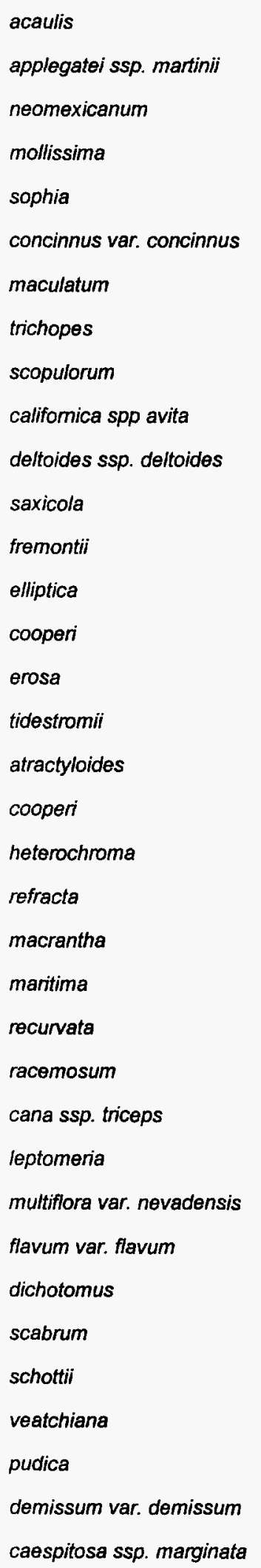




$\begin{array}{lrl}\text { Annual } & \text { PERE } & \text { Pectocarya } \\ \text { Annual } & \text { PREX } & \text { Prenanthella } \\ \text { Annual } & \text { SACOC } & \text { Salvia } \\ \text { Annual } & \text { SAPA8 } & \text { Salsola } \\ \text { Perennial } & \text { SPGRP2 } & \text { Sphaeralcea } \\ \text { Perennial } & \text { STCOC } & \text { Streptanthus }\end{array}$

recurvata
exigua
columbariae var. columbariae
paulsenii
grossulariaefolia ssp. pedate
cordatus var. cordatus

\section{Epiphytes}

Perennial CUDEV Cuscuta

denticulata var. vetchii

\section{Succulents}

$\begin{array}{ccl}\text { Perennial } & \text { OPECE } & \text { Opuntia } \\ \text { Perennial } & \text { OPBAB2 } & \text { Opuntia } \\ \text { Perennial } & \text { YUBR } & \text { Yucca } \\ \text { Perennial } & \text { ECPO2 } & \text { Echinocactus } \\ \text { Perennial } & \text { YUSC2 } & \text { Yucca } \\ \text { Perennial } & \text { ECEN } & \text { Echinocereus } \\ \text { Perennial } & \text { OPRA } & \text { Opuntia } \\ \text { Perennial } & \text { OPERE } & \text { Opuntia } \\ \text { Perennial } & \text { ECTRM } & \text { Echinocereus } \\ \text { Perennial } & \text { MATE4 } & \text { Mammillania }\end{array}$

echinocarpa var. echinocarpa
basilaris var. basilaris
brevifolia
polycephalus
schidigera
engelmannii
ramosissima
erinacea var. erinacea
triglochidiatus var. melanacanthus
tetrancistra

\section{Variable}

$\begin{array}{ccc}\text { Variable } & \text { ERIOG } & \text { Eriogonum } \\ \text { Variable } & \text { MENTZ } & \text { Mentzelia }\end{array}$




\section{Atriplex confertifolia-Ambrosia dumosa Shrubland}

Tall Shrubs (2-5 $\mathrm{m})$

$\begin{array}{lll}\text { Perennial } & \text { LATR2 } & \text { Lamea } \\ \text { Perennial } & \text { ARTRT } & \text { Artemisia }\end{array}$

tridentata

73.5

Perennial ARTRT Artemisia

tridentata ssp. tridentata

\section{Short Shrubs (0.5-2 m)}

\begin{tabular}{|c|c|c|}
\hline Perennial & ATCO & Atriplex \\
\hline Perennial & AMDU2 & Ambrosia \\
\hline Perennial & EPNE & Ephedra \\
\hline Perennial & LYAN & Lycium \\
\hline Perennial & CORA & Coleogyne \\
\hline Perennial & KRLA2 & Krascheninnikovia \\
\hline Perennial & LYPAO & Lycium \\
\hline Perennial & LEFR2 & Lepidium \\
\hline Perennial & PSFRF & Psorothamnus \\
\hline Perennial & $\mathrm{ACSH}$ & Acamptopappus \\
\hline Perennial & ENVIV & Encelia \\
\hline Perennial & THMO & Thamnosma \\
\hline Perennial & GUSA2 & Gutierrezia \\
\hline Perennial & HYSA & Hymenoclea \\
\hline Perennial & CHVIV2 & Chrysothamnus \\
\hline Perennial & ERFAP & Eriogonum \\
\hline Perennial & GRSP & Grayia \\
\hline Perennial & SAME & Salazaria \\
\hline Perennial & ERCO23 & Ericameria \\
\hline Perennial & ERTE18 & Ericameria \\
\hline Perennial & EPTO & Ephedra \\
\hline Perennial & TEAXA & Tetradymia \\
\hline Perennial & BRMIW & Brickellia \\
\hline Perennial & STPIP & Stanleya \\
\hline Perennial & ATHY & Atriplex \\
\hline Perennial & EPVI & Ephedra \\
\hline Perennial & ERHEH2 & Eriogonum \\
\hline Perennial & ATCAC & Atriplex \\
\hline Perennial & BRLOM & Brickellia \\
\hline Perennial & BUUT & Buddleja \\
\hline
\end{tabular}

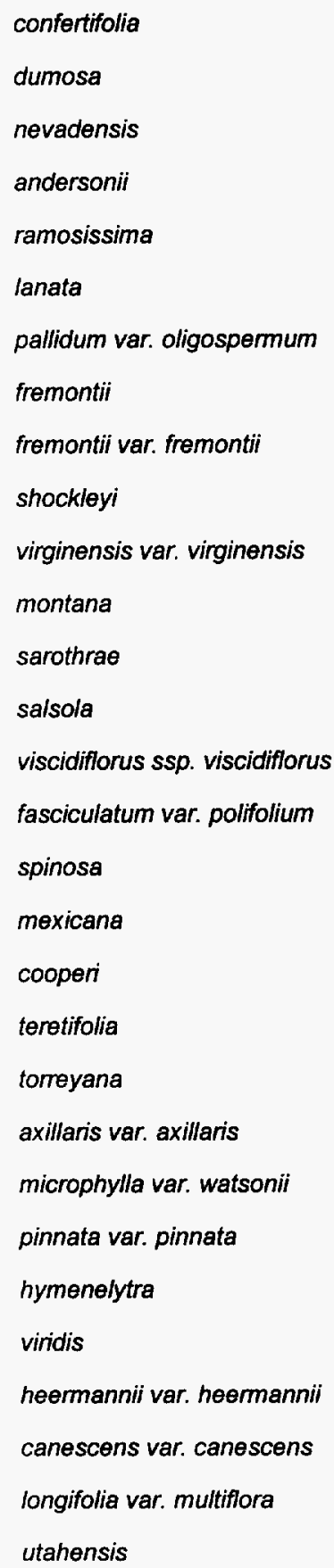

100.0

93.9

89.8

57.1

49.0

49.0

42.9

40.8

32.7

24.5

22.4

22.4

20.4

18.4

14.3

14.3

14.3

14.3

12.2

12.2

10.2

10.2

8.2 


\section{Association Longevity ACODE Genus}

$\begin{array}{ccl}\text { Perennial } & \text { CHVIP4 } & \text { Chrysothamnus } \\ \text { Perennial } & \text { EPFU } & \text { Ephedra } \\ \text { Perennial } & \text { ERMIS2 } & \text { Eriogonum } \\ \text { Perennial } & \text { ERNAL } & \text { Ericameria } \\ \text { Perennial } & \text { LYSH } & \text { Lycium } \\ \text { Perennial } & \text { PRFA } & \text { Prunus } \\ \text { Perennial } & \text { PSPO } & \text { Psorothamnus } \\ \text { Perennial } & \text { SENE5 } & \text { Senecio } \\ \text { Perennial } & \text { TECA2 } & \text { Tetradymia }\end{array}$

\section{Dwarf Shrubs ( $<0.5 \mathrm{~m}$ )}

$\begin{array}{lll}\text { Perennial } & \text { KRER } & \text { Krameria } \\ \text { Perennial } & \text { MESP2 } & \text { Menodora } \\ \text { Perennial } & \text { ARSP5 } & \text { Artemisia } \\ \text { Perennial } & \text { LEPU } & \text { Leptodactylon }\end{array}$

\section{Graminoids}

$\begin{array}{lcl}\text { Annual } & \text { BRRU2 } & \text { Bromus } \\ \text { Perennial } & \text { ACHY } & \text { Achnatherum } \\ \text { Perennial } & \text { ACSP12 } & \text { Achnatherum } \\ \text { Perennial } & \text { ERPU8 } & \text { Erioneuron } \\ \text { Perennial } & \text { ELELE } & \text { Elymus } \\ \text { Perennial } & \text { PLRI3 } & \text { Pleuraphis } \\ \text { Perennial } & \text { POSE } & \text { Poa } \\ \text { Annual } & \text { SCAR } & \text { Schismus } \\ \text { Perennial } & \text { ARPU9 } & \text { Aristida } \\ \text { Annual } & \text { VUOC } & \text { Vulpia }\end{array}$

\section{Forbs}

$\begin{array}{lcl}\text { Perennial } & \text { ERIN4 } & \text { Eriogonum } \\ \text { Perennial } & \text { XYTOT } & \text { Xylorhiza } \\ \text { Perennial } & \text { SPAMA } & \text { Sphaeraicea } \\ \text { Annual } & \text { AMTE3 } & \text { Amsinckia } \\ \text { Annual } & \text { CHRI } & \text { Chorizanthe } \\ \text { Perennial } & \text { DEPAP3 } & \text { Delphinium } \\ \text { Annual } & \text { PHFR2 } & \text { Phacelia } \\ \text { Perennial } & \text { STPA4 } & \text { Stephanomeria }\end{array}$

\section{Species}

\% Frequency

$\begin{array}{ll}\text { viscidiflorus ssp. puberulus } & \mathbf{2 . 0} \\ \text { funerea } & 2.0 \\ \text { microthecum var. simpsonii } & 2.0 \\ \text { nauseosus ssp. consimilis var. leiosperma } & 2.0 \\ \text { shockleyi } & 2.0 \\ \text { fasciculata } & 2.0 \\ \text { polydenius } & 2.0 \\ \text { flaccidus var. douglasii } & 2.0 \\ \text { canescens } & 2.0\end{array}$

erecta

65.3

spinescens

34.7

spinescens

16.3

pungens

$\begin{array}{lc}\text { rubens } & 87.8 \\ \text { hymenoides } & 38.8 \\ \text { speciosum } & 38.8 \\ \text { pulchellum } & 20.4 \\ \text { elymoides ssp. elymoides } & 10.2 \\ \text { rigida } & 6.1 \\ \text { secunda } & 4.1 \\ \text { arabicus } & 4.1 \\ \text { purpurea } & 2.0 \\ \text { octoflora } & 2.0\end{array}$

$\begin{array}{ll}\text { Inflatum } & 73.5 \\ \text { tortifolia var. imberbis } & 57.1 \\ \text { ambigua ssp. ambigua } & 38.8 \\ \text { tessellata } & 30.6 \\ \text { ngida } & 24.5 \\ \text { parishii ssp. parishii } & 18.4 \\ \text { fremontii } & 14.3 \\ \text { pauciflore } & 12.2\end{array}$ 


\begin{tabular}{|c|c|c|}
\hline Annual & LELA & Lepidium \\
\hline Annual & MAGL3 & Malacothrix \\
\hline Annual & PLOV & Plantago \\
\hline Annual & CRNEN & Cryptantha \\
\hline Annual & ERCl6 & Erodium \\
\hline Annual & ERDE6 & Eriogonum \\
\hline Annual & LUSH & Lupinus \\
\hline Annual & PHVAV2 & Phacelia \\
\hline Perennial & BAMU & Baileya \\
\hline Perennial & BRAT & Brickellia \\
\hline Annual & CABOC & Camissonia \\
\hline Annual & CHFR & Chaenactis \\
\hline Annual & CHST & Chaenactis \\
\hline Annual & ERER2 & Eriastrum \\
\hline Perennial & GICAS & Gilia \\
\hline Perennial & MACAC & Machaeranthera \\
\hline Perennial & STPA3 & Stephanomeria \\
\hline Perennial & ARME2 & Arctomecon \\
\hline Annual & CABRB4 & Camissonia \\
\hline Annual & CAKEG & Camissonia \\
\hline Perennial & CHAL11 & Chamaesyce \\
\hline Annual & $\mathrm{CRCl} 2$ & Cryptantha \\
\hline Perennial & CRUT & Cryptantha \\
\hline Annual & DEPIG & Descurainia \\
\hline Annual & ERNI4 & Eriogonum \\
\hline Perennial & GIBRB & Gilia \\
\hline Annual & IPPO2 & Ipomopsis \\
\hline Annual & OXPE2 & Oxytheca \\
\hline Annual & PEPL & Pectocarya \\
\hline Annual & PHCRC3 & Phacelia \\
\hline Annual & RANE & Rafinesquia \\
\hline Perennial & SPAMR & Sphaeralcea \\
\hline Perennial & ARMA3 & Arenaria \\
\hline Perennial & ARPUM & Arabis \\
\hline Perennial & ASLA8 & Astragalus \\
\hline Annual & ASLEF2 & Astragalus \\
\hline
\end{tabular}

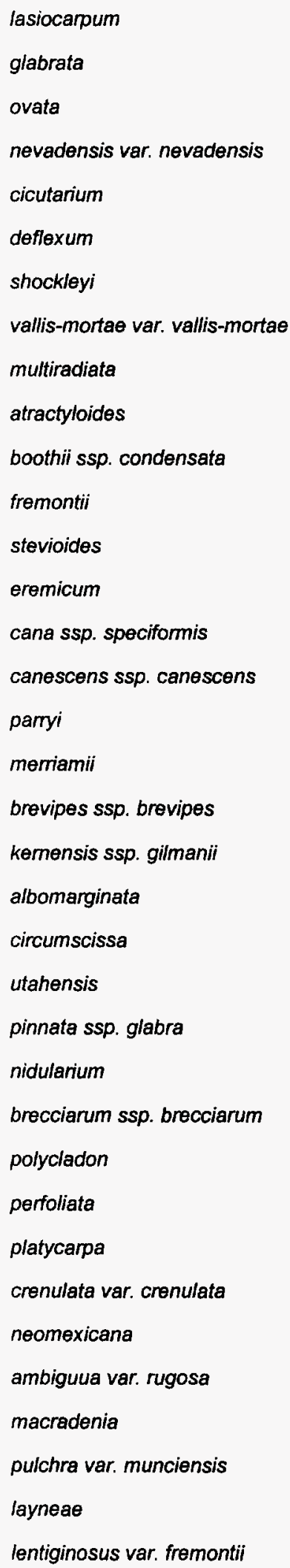




\begin{tabular}{|c|c|c|c|}
\hline \multirow[t]{36}{*}{ Association } & Longevity & $A C O D E$ & Genus \\
\hline & Perennial & CAAP4 & Castilleja \\
\hline & Annual & CABRP & Camissonia \\
\hline & Annual & CARE2 & Camissonia \\
\hline & Annual & $\mathrm{CHCA}$ & Chaenactis \\
\hline & Annual & CHMA & Chaenactis \\
\hline & Perennial & CRFL6 & Cryptantha \\
\hline & Annual & CRMI & Cryptantha \\
\hline & Perennial & CRVI5 & Cryptantha \\
\hline & Perennial & DEAN & Delphinium \\
\hline & Perennial & ERCOC3 & Erigeron \\
\hline & Annual & ERMA2 & Eriogonum \\
\hline & Annual & ERPR4 & Eriophyllum \\
\hline & Annual & ERSP3 & Eriastrum \\
\hline & Annual & ERTH & Eriogonum \\
\hline & Annual & ESGL & Eschscholzia \\
\hline & Perennial & GAST & Galium \\
\hline & Annual & GILIA & Gilia \\
\hline & Annual & HAGL & Halogeton \\
\hline & Annual & LOHU2 & Lotus \\
\hline & Annual & MEAL6 & Mentzelia \\
\hline & Annual & MEOB3 & Mentzelia \\
\hline & Perennial & MIBI8 & Mirabilis \\
\hline & Perennial & MIPU5 & Mirabilis \\
\hline & Annual & NIAT & Nicotiana \\
\hline & Annual & OEDED4 & Oenothera \\
\hline & Annual & PESE & Pectocarya \\
\hline & Perennial & PHGRH & Phlox \\
\hline & Annual & PHPA2 & Phacelia \\
\hline & Perennial & PHST11 & Phlox \\
\hline & Perennial & POSU & Polygala \\
\hline & Biennial & SIAL2 & Sisymbrum \\
\hline & Perennial & SPGRP2 & Sphaeralcea \\
\hline & Annual & STEXE & Stephanomeria \\
\hline & Annual & SYFR & Syntrichopappus \\
\hline & Perennial & THPEB & Thymphylla \\
\hline
\end{tabular}

\section{Species}

\% Frequency

applegate

brevipes ssp. pallidula

2.0

refracta

2.0

carphoclinia

macrantha

flavoculata

2.0

micrantha

2.0

virginensis

andersonii

2.0

concinnus var. concinnus

2.0

maculatum

pringlei

2.0

sparsifforum

2.0

thomasii

2.0

glyptosperma

2.0

stellatum

2.0

2.0

glomeratus

2.0

humistratus

2.0

albicaulis

2.0

obscura

2.0

bigelovii

2.0

pudica

2.0

attenuata

2.0

deltoides ssp. deltoides

2.0

setosa

2.0

gracilis ssp. humilis

2.0

parishii

2.0

stansburyi

2.0

subspinosa

2.0

altissimum

2.0

grossulariaefolia ssp. pedata

2.0

exigua ssp. exigua

2.0

fremontii

2.0

pentachaeta var. belenidium 


\section{Succulents}

$\begin{array}{lll}\text { Perennial } & \text { ECPO2 } & \text { Echinocactus } \\ \text { Perennial } & \text { YUSC2 } & \text { Yucca } \\ \text { Perennial } & \text { OPBAB2 } & \text { Opuntia } \\ \text { Perennial } & \text { OPECE } & \text { Opuntia } \\ \text { Perennial } & \text { YUBR } & \text { Yucca } \\ \text { Perennial } & \text { ECEN } & \text { Echinocereus } \\ \text { Perennial } & \text { OPERE } & \text { Opuntia } \\ \text { Perennial } & \text { OPRA } & \text { Opuntia } \\ \text { Perennial } & \text { ESVIR2 } & \text { Escobaria } \\ \text { Perennial } & \text { YUBAV } & \text { Yucca }\end{array}$

polycephalus
schidigera
basilaris var. basilaris
echinocarpa var. echinocarpa
brevifolia
engelmannii
erinacea var. erinacea
ramosissima
vivipara var. rosea
baccata var. vespertina

34.7

28.6

20.4

20.4

16.3

10.2

6.1

4.1

2.0

2.0

\section{Variable}

Variable ERIOG Eriogonum 
Association Longevity ACODE Genus Species \% Frequency

\section{Lycium andersonii-Hymenoclea salsola Shrubland}

\section{Tall Shrubs (2-5 m)}

Perennial LATR2 Larrea

tridentata

\section{Short Shrubs (0.5-2 m)}

$\begin{array}{lcl}\text { Perennial } & \text { LYAN } & \text { Lycium } \\ \text { Perennial } & \text { KRLA2 } & \text { Krascheninnikovia } \\ \text { Perennial } & \text { HYSA } & \text { Hymenoclea } \\ \text { Perennial } & \text { ATCAC } & \text { Atriplex } \\ \text { Perennial } & \text { CHVIV2 } & \text { Chrysothamnus } \\ \text { Perennial } & \text { EPNE } & \text { Ephedra } \\ \text { Perennial } & \text { GRSP } & \text { Grayia } \\ \text { Perennial } & \text { AMDU2 } & \text { Ambrosia } \\ \text { Perennial } & \text { ACSH } & \text { Acamptopappus } \\ \text { Perennial } & \text { CORA } & \text { Coleogyne } \\ \text { Perennial } & \text { ATCO } & \text { Atriplex } \\ \text { Perennial } & \text { ENVIV } & \text { Encelia } \\ \text { Perennial } & \text { ERCO23 } & \text { Ericameria } \\ \text { Perennial } & \text { TEAXA } & \text { Tetradymia } \\ \text { Perennial } & \text { THMO } & \text { Thamnosma } \\ \text { Perennial } & \text { AMER } & \text { Ambrosia } \\ \text { Perennial } & \text { ERTE18 } & \text { Ericameria } \\ \text { Perennial } & \text { LEFR2 } & \text { Lepidium } \\ \text { Perennial } & \text { LYSH } & \text { Lycium } \\ & & \end{array}$

andersonii
lanata
salsola
canescens var. canescens
viscidiflorus ssp. viscidiflorus
nevadensis
spinosa
dumosa
shockleyi
ramosissima
confertifolia
virginensis var. virginensis
cooperi
axillaris var. axillaris
montana
eriocentra
teretifolia
fremontii
shockleyi

100.0

78.6

64.3

57.1

50.0

50.0

50.0

35.7

28.6

28.6

21.4

21.4

14.3

14.3

14.3

7.1

7.1

7.1

7.1

\section{Dwarf Shrubs ( $<0.5 \mathrm{~m}$ )}

$\begin{array}{ccc}\text { Perennial } & \text { ARSP5 } & \text { Artemisia } \\ \text { Perennial } & \text { MESP2 } & \text { Menodora } \\ \text { Perennial } & \text { KRER } & \text { Krameria }\end{array}$

spinescens

42.9

spinescens

erecta

\section{Graminoids}

$\begin{array}{lcl}\text { Perennial } & \text { ACHY } & \text { Achnatherum } \\ \text { Annual } & \text { BRRU2 } & \text { Bromus } \\ \text { Perennial } & \text { ACSP12 } & \text { Achnatherum } \\ \text { Annual } & \text { BRTE } & \text { Bromus } \\ \text { Perennial } & \text { ELELE } & \text { Elymus }\end{array}$

Thursday, September 09, 1999 hymenoides $\quad 92.9$

$\begin{array}{ll}\text { rubens } & \mathbf{7 8 . 6}\end{array}$

speciosum $\quad \mathbf{4 2 . 9}$

tectorum $\quad 42.9$

elymoides ssp. elymoides $\quad 28.6$ 


$\begin{array}{ccc}\text { Perennial } & \text { PLJA } & \text { Pleuraphis } \\ \text { Perennial } & \text { ERPU8 } & \text { Erioneuron }\end{array}$

\section{Forbs}

\begin{tabular}{|c|c|c|}
\hline Annual & AMTE3 & Amsinckia \\
\hline Perennial & SPAMA & Sphaeralcea \\
\hline Annual & CHST & Chaenactis \\
\hline Annual & MAGL3 & Malacothrix \\
\hline Perennial & MACAC & Machaeranthera \\
\hline Annual & ERDE6 & Eriogonum \\
\hline Perennial & MIPU5 & Mirabilis \\
\hline Biennial & SIAL2 & Sisymbrium \\
\hline Annual & CRNEN & Cryptantha \\
\hline Annual & ERCI6 & Erodium \\
\hline Annual & ERER2 & Eriastrum \\
\hline Annual & ASLEF2 & Astragalus \\
\hline Perennial & CHAL11 & Chamaesyce \\
\hline Annual & MEOB3 & Mentzelia \\
\hline Annual & PHFR2 & Phacelia \\
\hline Perennial & STPA3 & Stephanomeria \\
\hline Perennial & STPA4 & Stephanomeria \\
\hline Perennial & $\mathrm{ADCO} 2$ & Adenophyllum \\
\hline Annual & CAKEG & Camissonia \\
\hline Annual & CRMI & Cryptantha \\
\hline Annual & CRPT & Cryptantha \\
\hline Perennial & CYRI2 & Cymopterus \\
\hline Perennial & DEPAP3 & Delphinium \\
\hline Perennial & ERIN4 & Eriogonum \\
\hline Annual & ERNI4 & Eriogonum \\
\hline Annual & ERPR4 & Eriophyllum \\
\hline Annual & ERPU6 & Eriogonum \\
\hline Perennial & GIIN2 & Gilia \\
\hline Annual & LELA & Lepidium \\
\hline Annual & MEVE5 & Mentzelia \\
\hline Perennial & PENST & Penstemon \\
\hline
\end{tabular}

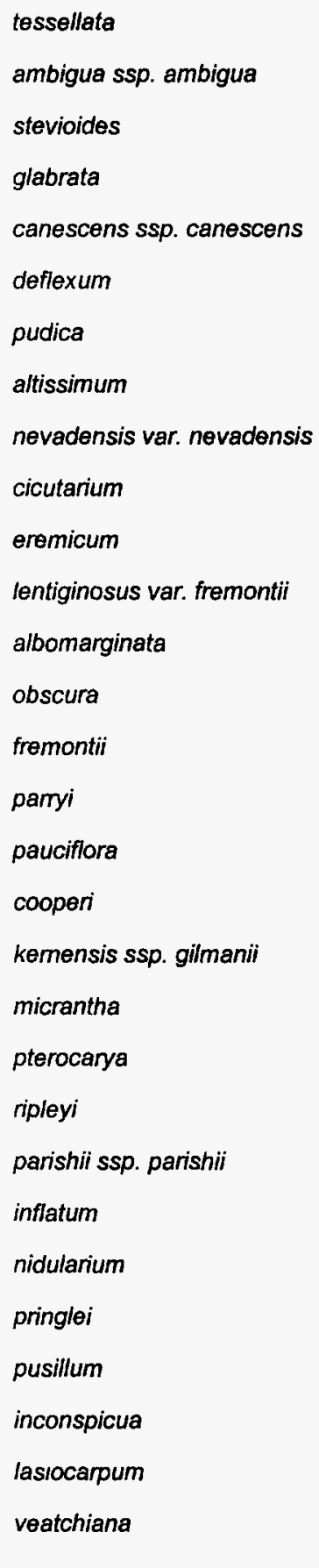

85.7

57.1

50.0

42.9

35.7

28.6

28.6

28.6

21.4

21.4

21.4

14.3

14.3

14.3

14.3

14.3

14.3

7.1

7.1

7.1

7.1

7.1

7.1

7.1

7.1

7.1

7.1

7.1

7.1

7.1

7.1

Thursday, September 09, 1999

Page 15 of 107 
Association Longevity ACODE Genus

Perennial SPGRP2 Sphaeralcea

Annual STEXE Stephanomeria

Perennial XYTOT Xylormiza

\section{Succulents}

$\begin{array}{ccl}\text { Perennial } & \text { YUBR } & \text { Yucca } \\ \text { Perennial } & \text { OPECE } & \text { Opuntia } \\ \text { Perennial } & \text { OPBAB2 } & \text { Opuntia }\end{array}$

\section{Species}

grossulariaefolia ssp. pedata

exigua ssp. exigua

tortifolia var. imberbis

brevifolia

echinocarpa var. echinocarpa

basilaris var. basilaris
35.7

$\%$ Frequency

7.1

7.1

7.1

21.4

7.1 
Association Longevity ACODE Genus Species \% Frequency

Hymenoclea salsola-Ephedra nevadensis Shrubland

Tall Shrubs (2-5 m)

Perennial LATR2 Larrea

tridentata

Short Shrubs (0.5-2 m)

\begin{tabular}{|c|c|c|}
\hline Perennial & HYSA & Hymenoclea \\
\hline Perennial & EPNE & Ephedra \\
\hline Perennial & LYAN & Lycium \\
\hline Perennial & ATCAC & Atriplex \\
\hline Perennial & GRSP & Grayia \\
\hline Perennial & KRLA2 & Krascheninnikovia \\
\hline Perennial & CHVIV2 & Chrysothamnus \\
\hline Perennial & AMDU2 & Ambrosia \\
\hline Perennial & CORA & Coleogyne \\
\hline Perennial & $\mathrm{ACSH}$ & Acamptopappus \\
\hline Perennial & SAME & Salazaria \\
\hline Perennial & ENVIV & Encelia \\
\hline Perennial & PSFRF & Psorothamnus \\
\hline Perennial & STPIP & Stanleya \\
\hline Perennial & ERCO23 & Ericameria \\
\hline Perennial & TEAXA & Tetradymia \\
\hline Perennial & LEFR2 & Lepidium \\
\hline Perennial & ERFAP & Eriogonum \\
\hline Perennial & ERNAH & Ericameria \\
\hline Perennial & GUSA2 & Gutierrezia \\
\hline Perennial & AMER & Ambrosia \\
\hline Perennial & LYPAO & Lycium \\
\hline Perennial & THMO & Thamnosma \\
\hline Perennial & ERTE18 & Ericameria \\
\hline Perennial & PSPO & Psorothamnus \\
\hline Perennial & ATCO & Atriplex \\
\hline Perennial & PUST & Purshia \\
\hline Perennial & ATPO & Atriplex \\
\hline Perennial & ERPA29 & Ericameria \\
\hline Perennial & PRFA & Prunus \\
\hline Perennial & TECA2 & Tetradymia \\
\hline
\end{tabular}

salsola

100.0

nevadensis $\quad 70.5$

andersonii 70.5

canescens var. canescens $\quad 61.4$

spinosa $\quad 50.0$

lanata $\quad \mathbf{5 0 . 0}$

viscidiflorus ssp. viscidiflorus $\quad 47.7$

dumosa $\quad 43.2$

ramosissima 29.5

shockleyi 27.3

mexicana $\quad 27.3$

virginensis var. virginensis $\quad 22.7$

fremontii var. fremontii $\quad 22.7$

pinnata var. pinnata $\quad 22.7$

cooperi 20.5

axillaris var. axillaris $\quad 20.5$

$\begin{array}{ll}\text { fremontii } & 18.2\end{array}$

fasciculatum var. polifolium $\quad 13.6$

nauseosus ssp. nauseosus var. $\quad 13.6$

hololeuca 13.6

sarothrae 13.6

eriocentra $\quad 11.4$

pallidum var. oligospermum $\quad 11.4$

montana $\quad 11.4$

teretifolia $\quad 9.1$

polydenius $\quad 9.1$

confertifolia $\quad 6.8$

$\begin{array}{ll}\text { stansburiana } & 6.8\end{array}$

polycarpa $\quad 4.5$

paniculata $\quad 4.5$

fasciculata $\quad 4.5$

canescens $\quad 4.5$

Thursday, September 09, 1999 


$\begin{array}{ccl}\text { Perennial } & \text { BRIN } & \text { Brickellia } \\ \text { Perennial } & \text { BROBL } & \text { Brickellia } \\ \text { Perennial } & \text { EPVI } & \text { Ephedra } \\ \text { Perennial } & \text { ERNAL } & \text { Ericameria } \\ \text { Perennial } & \text { LYSH } & \text { Lycium } \\ \text { Perennial } & \text { PENI } & \text { Petalonyx } \\ \text { Perennial } & \text { RHTRA } & \text { Rhus } \\ \text { Perennial } & \text { SADOD3 } & \text { Salvia } \\ \text { Perennial } & \text { STEL } & \text { Stanleya }\end{array}$

incana
oblongifolia var. linifolia
viridis
nauseosus ssp. consimilis var. leiosperma
shockleyi
nitidus
trilobata var. anisophylla
dorii ssp. domii var. dorrii
elata

\section{Dwarf Shrubs (<0.5 m)}

$\begin{array}{lll}\text { Perennial } & \text { KRER } & \text { Krameria } \\ \text { Perennial } & \text { MESP2 } & \text { Menodora } \\ \text { Perennial } & \text { ARSP5 } & \text { Artemisia }\end{array}$

erecta

\section{Graminoids}

$\begin{array}{lcl}\text { Annual } & \text { BRRU2 } & \text { Bromus } \\ \text { Perennial } & \text { ACSP12 } & \text { Achnatherum } \\ \text { Perennial } & \text { ACHY } & \text { Achnatherum } \\ \text { Perennial } & \text { ELELE } & \text { Elymus } \\ \text { Annual } & \text { BRTE } & \text { Bromus } \\ \text { Perennial } & \text { PLJA } & \text { Pleuraphis } \\ \text { Perennial } & \text { ERPU8 } & \text { Erioneuron } \\ \text { Perennial } & \text { PLRI3 } & \text { Pleuraphis } \\ \text { Perennial } & \text { ARPUL } & \text { Aristida } \\ \text { Annual } & \text { BRCA6 } & \text { Bromus } \\ \text { Annual } & \text { SCAR } & \text { Schismus } \\ \text { Annual } & \text { VUOC } & \text { Vulpia }\end{array}$

$\begin{array}{lr}\text { rubens } & 90.9 \\ \text { speciosum } & 68.2 \\ \text { hymenoides } & 63.6 \\ \text { elymoides ssp. elymoides } & 18.2 \\ \text { tectorum } & 15.9 \\ \text { jamesii } & 13.6 \\ \text { pulchellum } & 11.4 \\ \text { rigida } & 6.8 \\ \text { purpurea var. longiseta } & 4.5 \\ \text { cartharticus } & 2.3 \\ \text { arabicus } & 2.3 \\ \text { octoflora } & 2.3\end{array}$

\section{Forbs}

$\begin{array}{lrl}\text { Annual } & \text { AMTE3 } & \text { Amsinckia } \\ \text { Perennial } & \text { SPAMA } & \text { Sphaeralcea } \\ \text { Annual } & \text { CHST } & \text { Chaenactis } \\ \text { Annual } & \text { ERCI6 } & \text { Erodium } \\ \text { Annual } & \text { MAGL3 } & \text { Malacothrix } \\ \text { Perennial } & \text { CHAL11 } & \text { Chamaesyce } \\ \text { Perennial } & \text { ERIN4 } & \text { Eriogonum }\end{array}$

tessellata
ambigua ssp. ambigua
stevioides
cicutarium
glabrata
albomarginata
inflatum




\begin{tabular}{|c|c|c|c|}
\hline Association & Longevity & $A C O D E$ & Genus \\
\hline & Perennial & MACAC & Machaeranthera \\
\hline & Annual & OXPE2 & Oxytheca \\
\hline & Perennial & MIPU5 & Mirabilis \\
\hline & Annual & ERER2 & Eriastrum \\
\hline & Annual & ERDE6 & Eriogonum \\
\hline & Annual & ERNI4 & Eriogonum \\
\hline & Perennial & $\mathrm{ADCO} 2$ & Adenophyllum \\
\hline & Perennial & POSU & Polygala \\
\hline & Perennial & CAFL & Calochortus \\
\hline & Perennial & DEPAP3 & Delphinium \\
\hline & Annual & ERPR4 & Eriophyllum \\
\hline & Annual & PHVAV2 & Phacelia \\
\hline & Biennial & SIAL2 & Sisymbrium \\
\hline & Annual & STEXE & Stephanomeria \\
\hline & Perennial & XYTOT & Xylorhiza \\
\hline & Perennial & BAMU & Baileya \\
\hline & Perennial & CAAP4 & Castilleja \\
\hline & Annual & CRNEN & Cryptantha \\
\hline & Perennial & HEMUN & Heliomeris \\
\hline & Perennial & SPGRP2 & Sphaeralcea \\
\hline & Perennial & STPA4 & Stephanomeria \\
\hline & Perennial & ARPUM & Arabis \\
\hline & Perennial & ASLA8 & Astragalus \\
\hline & Perennial & BRAT & Brickellia \\
\hline & Annual & CAKEG & Camissonia \\
\hline & Annual & CHBRB & Chorizanthe \\
\hline & Annual & LASE3 & Langloisia \\
\hline & Annual & LELA & Lepidium \\
\hline & Perennial & MIBI8 & Mirabilis \\
\hline & Annual & PHFR2 & Phacelia \\
\hline & Perennial & PHST11 & Phlox \\
\hline & Annual & ASLEF2 & Astragalus \\
\hline & Perennial & CAAPM & Castilleja \\
\hline & Annual & CABOC & Camissonia \\
\hline & Annual & CABRB4 & Camissonia \\
\hline & Perennial & CAPI4 & Caulanthus \\
\hline
\end{tabular}

$$
\text { Species }
$$

\% Frequency

$\begin{array}{lc}\text { canescens ssp. canescens } & 22.7 \\ \text { perfoliata } & 22.7 \\ \text { pudica } & 20.5 \\ \text { eremicum } & 18.2 \\ \text { deflexum } & 15.9 \\ \text { nidularium } & 15.9 \\ \text { cooperi } & 11.4 \\ \text { subspinosa } & 11.4 \\ \text { flexuosus } & 9.1 \\ \text { parishii ssp. parishii } & 9.1\end{array}$

pringlei $\quad 9.1$

vallis-mortae var. vallis-mortae $\quad 9.1$

altissimum $\quad 9.1$

exigua ssp. exigua $\quad 9.1$

tortifolia var. imberbis $\quad 9.1$

multiradiata $\quad 6.8$

applegatei $\quad 6.8$

nevadensis var. nevadensis $\quad 6.8$

multiflora var. nevadensis $\quad 6.8$

grossulariaefolia ssp. pedata $\quad 6.8$

pauciflora $\quad 6.8$

pulchra var. munciensis $\quad 4.5$

layneae $\quad 4.5$

atractyloides $\quad 4.5$

kernensis ssp. gilmanii $\quad 4.5$

brevicomu var. brevicomu $\quad 4.5$

setosissima $\quad 4.5$

lasiocarpum $\quad 4.5$

bigelovii $\quad 4.5$

fremontii $\quad 4.5$

stansburyi $\quad 4.5$

lentiginosus var. fremontii $\quad 2.3$

applegatei ssp. martinii 2.3

boothii ssp. condensata $\quad 2.3$

brevipes ssp. brevipes $\quad 2.3$

pilosus $\quad 2.3$ 
Association Longevity ACODE Genus

$$
\text { Species }
$$

\% Frequency

$\begin{array}{lcl}\text { Annual } & \text { CAWR } & \text { Calycoseris } \\ \text { Annual } & \text { CHFR } & \text { Chaenactis } \\ \text { Annual } & \text { CRCI2 } & \text { Cryptantha } \\ \text { Annual } & \text { CRMI } & \text { Cryptantha } \\ \text { Annual } & \text { CRPT } & \text { Cryptantha } \\ \text { Perennial } & \text { CRVI5 } & \text { Cryptantha } \\ \text { Perennial } & \text { CYGL2 } & \text { Cymopterus } \\ \text { Perennial } & \text { DIPU3 } & \text { Dichelostemma } \\ \text { Perennial } & \text { ENNUN } & \text { Enceliopsis } \\ \text { Perennial } & \text { EROVO5 } & \text { Eriogonum } \\ \text { Perennial } & \text { GIIN2 } & \text { Gilia } \\ \text { Annual } & \text { GILIA } & \text { Gilia } \\ \text { Annual } & \text { IPPO2 } & \text { Ipomopsis } \\ \text { Perennial } & \text { LILE3 } & \text { Linum } \\ \text { Annual } & \text { LUSH } & \text { Lupinus } \\ \text { Annual } & \text { MEOB3 } & \text { Mentzelia } \\ \text { Annual } & \text { NAPU } & \text { Nama } \\ \text { Perennial } & \text { OECEM4 } & \text { Oenothera } \\ \text { Perennial } & \text { PEPA8 } & \text { Penstemon } \\ \text { Annual } & \text { PESE } & \text { Pectocarya } \\ \text { Annual } & \text { PHCRC3 } & \text { Phacelia } \\ \text { Annual } & \text { PLOV } & \text { Plantago } \\ \text { Annual } & \text { SAKAT3 } & \text { Salsola } \\ \text { Annual } & \text { SAPA8 } & \text { Salsola } \\ \text { Perennial } & \text { SPAMR } & \text { Sphaeralcea } \\ \text { Annual } & \text { SYFR } & \text { Syntrichopappus }\end{array}$

\section{Succulents}

$\begin{array}{lll}\text { Perennial } & \text { OPECE } & \text { Opuntia } \\ \text { Perennial } & \text { YUBR } & \text { Yucca } \\ \text { Perennial } & \text { ECEN } & \text { Echinocereus } \\ \text { Perennial } & \text { OPBAB2 } & \text { Opuntia } \\ \text { Perennial } & \text { YUSC2 } & \text { Yucca } \\ \text { Perennial } & \text { ECPO2 } & \text { Echinocactus } \\ \text { Perennial } & \text { OPERE } & \text { Opuntia } \\ \text { Perennial } & \text { OPPU } & \text { Opuntia }\end{array}$

echinocarpa var. echinocarpa
brevifolia
engelmannii
basilaris var. basilaris
schidigera
polycephalus
erinacea var. erinacea
pulchella

wrightii
fremontii
circumscissa
micrantha
pterocarya
virginensis
globosus
pulchellum
nudicaulis var. nudicaulis
ovalifolium var. ovalifolium
inconspicua
polycladon
lewisii
shockleyi
obscura
pusillum
caespitosa ssp. marginata
setosa
crenulata var. crenulata




\section{Menodora spinescens-Ephedra nevadensis Shrubland}

Tall Shrubs $(2-5 \mathrm{~m})$

Perennial LATR2 Larrea tridentata

60.0

\section{Short Shrubs (0.5-2 m)}

\begin{tabular}{|c|c|c|}
\hline Perennial & EPNE & Ephedra \\
\hline Perennial & ATCO & Atriplex \\
\hline Perennial & AMDU2 & Ambrosia \\
\hline Perennial & HYSA & Hymenoclea \\
\hline Perennial & PSFRF & Psorothamnus \\
\hline Perennial & KRLA2 & Krascheninnikovia \\
\hline Perennial & LYAN & Lycium \\
\hline Perennial & CORA & Coleogyne \\
\hline Perennial & ACSH & Acamptopappus \\
\hline Perennial & GRSP & Grayia \\
\hline Perennial & SAME & Salazaria \\
\hline Perennial & THMO & Thamnosma \\
\hline Perennial & CHVIV2 & Chrysothamnus \\
\hline Perennial & STPIP & Stanleya \\
\hline Perennial & ENVIV & Encelia \\
\hline Perennial & LYPAO & Lycium \\
\hline Perennial & TEAXA & Tetradymia \\
\hline Perennial & LEFR2 & Lepidium \\
\hline Perennial & TECA2 & Tetradymia \\
\hline Perennial & ATCAC & Atriplex \\
\hline Perennial & EPTO & Ephedra \\
\hline Perennial & ERTE18 & Ericameria \\
\hline Perennial & ERCO23 & Ericameria \\
\hline Perennial & STEL & Stanleya \\
\hline Perennial & ERFAP & Eriogonum \\
\hline Perennial & ERHEH2 & Eriogonum \\
\hline Perennial & GUSA2 & Gutierrezia \\
\hline Perennial & CHVIS5 & Chrysothamnus \\
\hline Perennial & EPFU & Ephedra \\
\hline Perennial & PENI & Petalonyx \\
\hline Perennial & PSPO & Psorothamnus \\
\hline
\end{tabular}

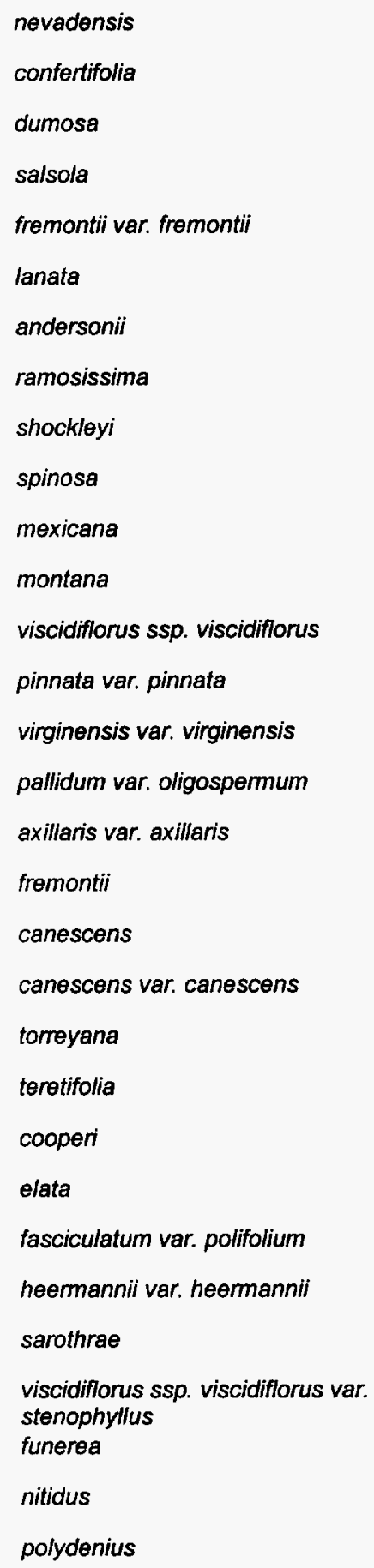

95.6

75.6

71.1

66.7

66.7

64.4

60.0

53.3

40.0

37.8

35.6

26.7

24.4

24.4

22.2

20.0

17.8

17.8

15.6

11.1

11.1

8.9

8.9

6.7

6.7

6.7 


\begin{tabular}{|c|c|c|c|}
\hline \multirow[t]{8}{*}{ Association } & Longevity & $A C O D E$ & Genus \\
\hline & Perennial & SADOD3 & Salvia \\
\hline & Perennial & BRMIW & Brickellia \\
\hline & Perennial & EPVI & Ephedra \\
\hline & Perennial & ERNAL & Ericameria \\
\hline & Perennial & LYSH & Lycium \\
\hline & Perennial & SENE5 & Senecio \\
\hline & Perennial & SYLO & Symphoricarpos \\
\hline
\end{tabular}

\section{Species}

\% Frequency dorii ssp. dorrii var. dorrii $\quad 4.4$

microphylla var. watsonii 2.2

viridis $\quad 2.2$

nauseosus ssp. consimilis var. leiosperma $\quad 2.2$

shockleyi 2.2

flaccidus var. douglasii $\quad 2.2$

longiflorus $\quad 2.2$

$\begin{array}{llll}\text { Perennial MESP2 } & \text { Menodora } & \text { spinescens } & 75.6\end{array}$

$\begin{array}{llll}\text { Perennial KRER } & \text { Krameria } & \text { erecta } & 44.4\end{array}$

$\begin{array}{llll}\text { Perennial ARSP5 Artemisia } & \text { spinescens } & 26.7\end{array}$

$\begin{array}{llll}\text { Perennial LEPU Leptodactylon } & \text { pungens } & 4.4\end{array}$

\section{Graminoids}

$\begin{array}{lcl}\text { Annual } & \text { BRRU2 } & \text { Bromus } \\ \text { Perennial } & \text { ACHY } & \text { Achnatherum } \\ \text { Perennial } & \text { ACSP12 } & \text { Achnatherum } \\ \text { Perennial } & \text { ELELE } & \text { Elymus } \\ \text { Perennial } & \text { ERPU8 } & \text { Erioneuron } \\ \text { Annual } & \text { BRTE } & \text { Bromus } \\ \text { Annual } & \text { BRCA6 } & \text { Bromus } \\ \text { Perennial } & \text { PLJA } & \text { Pleuraphis } \\ \text { Annual } & \text { VUOC } & \text { Vulpia } \\ \text { Perennial } & \text { PLRI3 } & \text { Plouraphis }\end{array}$

rubens
hymenoides
speciosum
elymoides ssp. elymoides
pulchellum
tectorum
cartharticus
jamesii
octoflora
rigida

\section{Forbs}

$\begin{array}{lll}\text { Perennial } & \text { ERIN4 } & \text { Eriogonum } \\ \text { Perennial } & \text { SPAMA } & \text { Sphaeralcea } \\ \text { Perennial } & \text { XYTOT } & \text { Xylomiza } \\ \text { Annual } & \text { AMTE3 } & \text { Amsinckia } \\ \text { Annual } & \text { CHRI } & \text { Chorizanthe } \\ \text { Perennial } & \text { DEPAP3 } & \text { Delphinium } \\ \text { Annual } & \text { PHFR2 } & \text { Phacelia } \\ \text { Perennial } & \text { CRUT } & \text { Cryptantha } \\ \text { Annual } & \text { ERDE6 } & \text { Eriogonum } \\ \text { Annual } & \text { CABRB4 } & \text { Camissonia }\end{array}$

$\begin{array}{ll}\text { inflatum } & 64.4 \\ \text { ambigua ssp. ambigua } & 57.8 \\ \text { tortifolia var. imberbis } & 44.4 \\ \text { tessellata } & 40.0 \\ \text { rigida } & 26.7 \\ \text { parishii ssp. parishii } & 24.4 \\ \text { fremontii } & 22.2 \\ \text { utahensis } & 17.8 \\ \text { deflexum } & 17.8 \\ \text { brevipes ssp. brevipes } & 15.6\end{array}$




\section{Association Longevity ACODE Genus}

\begin{tabular}{|c|c|c|}
\hline Annual & CHST & Chaenactis \\
\hline Perennial & BAMU & Baileya \\
\hline Annual & $\mathrm{ERCl} 6$ & Erodium \\
\hline Annual & GILIA & Gilia \\
\hline Annual & LELA & Lepidium \\
\hline Annual & PHVAV2 & Phacelia \\
\hline Perennial & CAFL & Calochortus \\
\hline Annual & CRNEN & Cryptantha \\
\hline Annual & CRPT & Cryptantha \\
\hline Annual & ERNI4 & Eriogonum \\
\hline Perennial & MACAC & Machaeranthera \\
\hline Annual & MAGL3 & Malacothrix \\
\hline Annual & OXPE2 & Oxytheca \\
\hline Perennial & STPA4 & Stephanomeria \\
\hline Perennial & ARPUM & Arabis \\
\hline Annual & ASLEF2 & Astragalus \\
\hline Perennial & CAAPM & Castilleja \\
\hline Annual & CHFR & Chaenactis \\
\hline Annual & ERER2 & Eriastrum \\
\hline Perennial & MIPU5 & Mirabilis \\
\hline Annual & STLO4 & Streptanthella \\
\hline Perennial & ASTI & Astragalus \\
\hline Perennial & CAAP4 & Castilleja \\
\hline Annual & DEPIG & Descurainia \\
\hline Annual & ESGL & Eschscholzia \\
\hline Perennial & GIBRB & Gilia \\
\hline Annual & IPPO2 & Ipomopsis \\
\hline Annual & MEOB3 & Mentzelia \\
\hline Perennial & MIBI8 & Mirabilis \\
\hline Perennial & POSU & Polygala \\
\hline Perennial & SPAMR & Sphaeralcea \\
\hline Perennial & CAPI4 & Caulanthus \\
\hline Annual & CHBRB & Chorizanthe \\
\hline Perennial & DIPU3 & Dichelostemma \\
\hline Annual & ERPR4 & Eriophyllum \\
\hline Annual & OEPR & Oenothera \\
\hline
\end{tabular}

\section{Species}

\% Frequency

stevioides $\quad 15.6$

multiradiata $\quad 13.3$

cicutarium $\quad 13.3$

13.3

lasiocarpum $\quad 13.3$

vallis-mortae var. vallis-mortae $\quad 13.3$

flexuosus $\quad 11.1$

nevadensis var. nevadensis $\quad 11.1$

pterocarya $\quad 11.1$

nidularium $\quad 11.1$

canescens ssp. canescens $\quad 11.1$

glabrata $\quad 11.1$

perfoliata $\quad 11.1$

pauciflora $\quad 11.1$

pulchra var. munciensis $\quad 8.9$

lentiginosus var. fremontii $\quad 8.9$

applegatei ssp. martinii $\quad 8.9$

fremontii $\quad 8.9$

eremicum $\quad 8.9$

pudica $\quad 8.9$

longirostris $\quad 8.9$

tidestromii $\quad 6.7$

applegatei $\quad 6.7$

pinnata ssp. glabra $\quad 6.7$

glyptosperma $\quad 6.7$

brecciarum ssp. brecciarum $\quad 6.7$

polycladon $\quad 6.7$

obscura $\quad 6.7$

bigelovii $\quad 6.7$

$\begin{array}{ll}\text { subspinosa } & 6.7\end{array}$

ambiguua var. rugosa $\quad 6.7$

prlosus $\quad 4.4$

brevicomu var. brevicomu $\quad 4.4$

pulchellum $\quad 4.4$

pringlei $\quad 4.4$

primiveris $\quad 4.4$ 


\begin{tabular}{|c|c|c|c|}
\hline \multirow[t]{37}{*}{ Association } & Longevity & $A C O D E$ & Genus \\
\hline & Annual & PESE & Pectocarya \\
\hline & Annual & PHCRC3 & Phacelia \\
\hline & Perennial & PHST11 & Phlox \\
\hline & Annual & SAPA8 & Salsola \\
\hline & Biennial & SIAL2 & Sisymbrium \\
\hline & Perennial & STCOC & Streptanthus \\
\hline & Perennial & ALNE & Allium \\
\hline & Perennial & ARCOS2 & Arenaria \\
\hline & Perennial & ARMA3 & Arenaria \\
\hline & Perennial & ASLAB & Astragalus \\
\hline & Perennial & ASPUT & Astragalus \\
\hline & Annual & ATPL & Atrichoseris \\
\hline & Annual & CABOC & Camissonia \\
\hline & Annual & CACLI & Camissonia \\
\hline & Annual & CAHE12 & Camissonia \\
\hline & Annual & CAKEG & Camissonia \\
\hline & Annual & CETH3 & Centrostegia \\
\hline & Perennial & CHAL.11 & Chamaesyce \\
\hline & Annual & CHMA & Chaenactis \\
\hline & Annual & CRAM3 & Cryptantha \\
\hline & Annual & $\mathrm{CRCl} 2$ & Cryptantha \\
\hline & Annual & CRMA7 & Cryptantha \\
\hline & Annual & CRRE5 & Cryptantha \\
\hline & Perennial & CRVI5 & Cryptantha \\
\hline & Perennial & ENNUN & Enceliopsis \\
\hline & Perennial & ERCOC3 & Erigeron \\
\hline & Annual & ERRE3 & Eriogonum \\
\hline & Perennial & ERUM & Eriogonum \\
\hline & Annual & GARA & Gayophytum \\
\hline & Perennial & GISC & Gilia \\
\hline & Annual & LASE3 & Langloisia \\
\hline & Annual & LOHU2 & Lotus \\
\hline & Annual & LOSC6 & Loeseliastrum \\
\hline & Annual & LUFL & Lupinus \\
\hline & Annual & MISP & Mimulus \\
\hline & Annual & MOBE & Monoptilon \\
\hline
\end{tabular}

\section{Species}

\% Frequency

setosa

4.4

crenulata var. crenulata

4.4

stansburyi

4.4

paulsenii

4.4

altissimum

4.4

cordatus var. cordatus

nevadense

congesta var. subcongesta

2.2

macradenia

2.2

layneae

2.2

purshii var. tinctus

2.2

platyphylla

2.2

boothii ssp. condensata

2.2

claviformis ssp. integrior

2.2

heterochroma $\quad 2.2$

kermensis ssp. gilmanii 2.2

thurberi 2.2

albomarginata $\quad 2.2$

macrantha $\quad 2.2$

ambigua $\quad 2.2$

circumscissa $\quad 2.2$

maritima $\quad 2.2$

recurvata 2.2

virginensis $\quad 2.2$

nudicaulis var. nudicaulis $\quad 2.2$

concinnus var. concinnus $\quad 2.2$

reniforme $\quad 2.2$

umbellatum $\quad 2.2$

racemosum $\quad 2.2$

scopulorum $\quad 2.2$

setosissima $\quad 2.2$

humistratus $\quad 2.2$

schottii 2.2

flavoculatus $\quad 2.2$

spissus $\quad 2.2$

bellidiforme $\quad 2.2$

Page 24 of 107 
Association Longevity ACODE Genus

$\begin{array}{lll}\text { Perennial } & \text { OECEM4 } & \text { Oenothera } \\ \text { Perennial } & \text { OEPAP } & \text { Oenothera } \\ \text { Perennial } & \text { PEFLA2 } & \text { Penstemon } \\ \text { Annual } & \text { PHSA } & \text { Phacelia } \\ \text { Annual } & \text { PLOV } & \text { Plantago } \\ \text { Annual } & \text { PSAN } & \text { Psathyrotes } \\ \text { Annual } & \text { RANE } & \text { Rafinesquia } \\ \text { Annual } & \text { SACOC } & \text { Salvia } \\ \text { Perennial } & \text { SPGRP2 } & \text { Sphaeralcea } \\ \text { Annual } & \text { STEXE } & \text { Stephanomeria } \\ \text { Annual } & \text { SYFR } & \text { Syntrichopappus }\end{array}$

\section{Succulents}

$\begin{array}{lll}\text { Perennial } & \text { YUBR } & \text { Yucca } \\ \text { Perennial } & \text { OPECE } & \text { Opuntia } \\ \text { Perennial } & \text { YUSC2 } & \text { Yucca } \\ \text { Perennial } & \text { ECPO2 } & \text { Echinocactus } \\ \text { Perennial } & \text { ECEN } & \text { Echinocereus } \\ \text { Perennial } & \text { OPBAB2 } & \text { Opuntia } \\ \text { Perennial } & \text { ECENE } & \text { Echinocereus } \\ \text { Perennial } & \text { ESVID } & \text { Escobaria } \\ \text { Perennial } & \text { OPERE } & \text { Opuntia } \\ \text { Perennial } & \text { OPERU } & \text { Opuntia } \\ \text { Perennial } & \text { OPPU } & \text { Opuntia } \\ \text { Perennial } & \text { OPRA } & \text { Opuntia }\end{array}$

\section{Species}

caespitosa ssp. marginata

pallida ssp. pallida

floridus var. austinii

saxicola

ovata

annua

neomexicana

columbariae var. columbariae

grossulariaefolia ssp. pedata

exigua ssp. exigua

fremontii
$\%$ Frequency

2.2

2.2

2.2

2.2

2.2

2.2

2.2

2.2

2.2

48.9

brevifolia

35.6

echinocarpa var. echinocarpa

26.7

schidigera

17.8

polycephalus

8.9

engelmannii

6.7

basilaris var. basilaris

2.2

engelmannii var. engelmannii

vivipara var. deserti

2.2

2.2

2.2

puichella

2.2 
Association Longevity ACODE Genus Species \% Frequency

Krascheninnikovia lanata-Ephedra nevadensis Shrubland

Tall Shrubs (2-5 $\mathrm{m})$

$\begin{array}{lll}\text { Perennial } & \text { LATR2 } & \text { Larrea } \\ \text { Perennial } & \text { ARTRT } & \text { Artemisia }\end{array}$

tndentata

40.0

Perennial ARTRT, Artemisia

tridentata ssp. tridentata

\section{Short Shrubs (0.5-2 m)}

\begin{tabular}{|c|c|c|}
\hline Perennial & KRLA2 & Krascheninnikovia \\
\hline Perennial & EPNE & Ephedra \\
\hline Perennial & LYAN & Lycium \\
\hline Perennial & GRSP & Grayia \\
\hline Perennial & HYSA & Hymenoclea \\
\hline Perennial & $\mathrm{ACSH}$ & Acamptopappus \\
\hline Perennial & ATCO & Atriplex \\
\hline Perennial & TEAXA & Tetradymia \\
\hline Perennial & CHVIV2 & Chrysothamnus \\
\hline Perennial & AMDU2 & Ambrosia \\
\hline Perennial & ATCAC & Atriplex \\
\hline Perennial & CORA & Coleogyne \\
\hline Perennial & ERCO23 & Ericameria \\
\hline Perennial & PSFRF & Psorothamnus \\
\hline Perennial & STPIP & Stanleya \\
\hline Perennial & LEFR2 & Lepidium \\
\hline Perennial & TECA2 & Tetradymia \\
\hline Perennial & THMO & Thamnosma \\
\hline Perennial & ENVIV & Encelia \\
\hline Perennial & LYPAO & Lycium \\
\hline Perennial & SAME & Salazaria \\
\hline Perennial & ERFAP & Eriogonum \\
\hline Perennial & ERNAL & Ericameria \\
\hline Perennial & ERTE18 & Ericameria \\
\hline Perennial & GUSA2 & Gutierrezia \\
\hline Perennial & PENI & Petalonyx \\
\hline Perennial & STEL & Stanleya \\
\hline Perennial & SYLO & Symphoricarpos \\
\hline Perennial & TEGL & Tetradymia \\
\hline
\end{tabular}

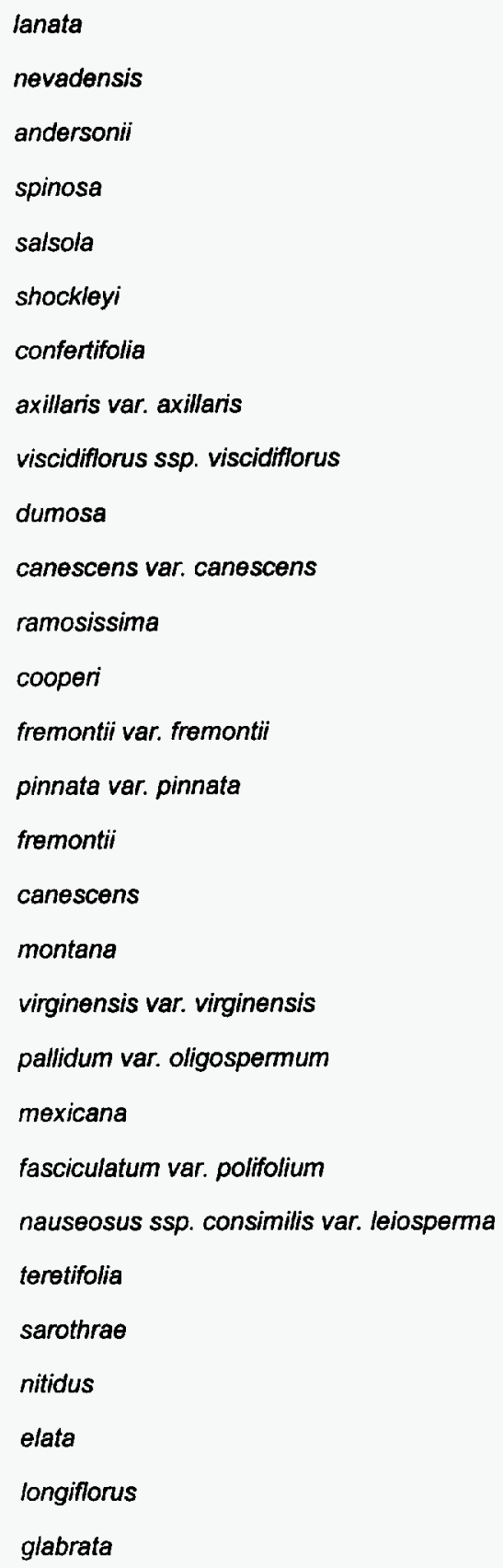

100.0

86.7

86.7

83.3

66.7

60.0

56.7

56.7

53.3

36.7

36.7

26.7

23.3

23.3

23.3

16.7

16.7

13.3

10.0

10.0

10.0

6.7

6.7

3.3

3.3

3.3

3.3

3.3

3.3 
Dwarf Shrubs ( $<0.5 \mathrm{~m})$

$\begin{array}{lll}\text { Perennial } & \text { ARSP5 } & \text { Artemisia } \\ \text { Perennial } & \text { MESP2 } & \text { Menodora } \\ \text { Perennial } & \text { KRER } & \text { Krameria }\end{array}$

spinescens

Perennial

KRER Krameria

spinescens

50.0

erecta

\section{Graminoids}

$\begin{array}{lcl}\text { Annual } & \text { BRRU2 } & \text { Bromus } \\ \text { Perennial } & \text { ACHY } & \text { Achnatherum } \\ \text { Perennial } & \text { ELELE } & \text { Elymus } \\ \text { Perennial } & \text { ACSP12 } & \text { Achnatherum } \\ \text { Annual } & \text { BRTE } & \text { Bromus } \\ \text { Perennial } & \text { ERPU8 } & \text { Erioneuron } \\ \text { Perennial } & \text { ARPU9 } & \text { Aristida } \\ \text { Perennial } & \text { PLJA } & \text { Pleuraphis } \\ \text { Perennial } & \text { PLRI3 } & \text { Pleuraphis } \\ \text { Perennial } & \text { POSE } & \text { Poa } \\ \text { Perennial } & \text { SPCR } & \text { Sporobolus } \\ \text { Annual } & \text { VUOC } & \text { Vulpia }\end{array}$

rubens
hymenoides
elymoides ssp. elymoides
speciosum
tectorum
pulchellum
purpurea
jamesii
rigida
secunda
cryptandrus
octoflora

\section{Forbs}

$\begin{array}{lll}\text { Perennial } & \text { SPAMA } & \text { Sphaeralcea } \\ \text { Annual } & \text { CHST } & \text { Chaenactis } \\ \text { Annual } & \text { AMTE3 } & \text { Amsinckia } \\ \text { Perennial } & \text { ERIN4 } & \text { Eriogonum } \\ \text { Annual } & \text { ERDE6 } & \text { Eriogonum } \\ \text { Annual } & \text { ERPR4 } & \text { Eriophyllum } \\ \text { Annual } & \text { OXPE2 } & \text { Oxytheca } \\ \text { Perennial } & \text { MIPU5 } & \text { Mirabilis } \\ \text { Perennial } & \text { XYTOT } & \text { Xylorhiza } \\ \text { Perennial } & \text { DEPAP3 } & \text { Delphinium } \\ \text { Annual } & \text { ERNI4 } & \text { Eriogonum } \\ \text { Annual } & \text { MAGL3 } & \text { Malacothrix } \\ \text { Annual } & \text { ERER2 } & \text { Eriastrum } \\ \text { Perennial } & \text { POSU } & \text { Polygala } \\ \text { Perennial } & \text { CAAP4 } & \text { Castilleja } \\ \text { Perennial } & \text { MACAC } & \text { Machaeranthera }\end{array}$

$\begin{array}{ll}\text { ambigua ssp. ambigua } & 80.0 \\ \text { stevioides } & 60.0 \\ \text { tessellata } & 56.7 \\ \text { Inflatum } & 36.7 \\ \text { deflexum } & 33.3 \\ \text { pringlei } & 30.0 \\ \text { perfoliata } & 30.0 \\ \text { pudica } & 23.3 \\ \text { tortifolia var. imberbis } & 23.3 \\ \text { parishii ssp. parishii } & 20.0 \\ \text { nidularium } & 20.0 \\ \text { glabrata } & 20.0 \\ \text { eremicum } & 16.7 \\ \text { subspinosa } & 16.7 \\ \text { applegatei } & 13.3 \\ \text { canescens ssp. canescens } & 13.3\end{array}$




\begin{tabular}{|c|c|c|c|c|c|}
\hline \multirow{32}{*}{ Association } & Longevity & $A C O D E$ & Genus & Species & $\%$ Frequency \\
\hline & Annual & PHFR2 & Phacelia & fremontii & \\
\hline & Perennial & GIIN2 & Gilia & inconspicua & \\
\hline & Annual & GILIA & Gilia & & \\
\hline & Annual & LELA & Lepidium & lasiocarpum & 10 \\
\hline & Perennial & ASLA8 & Astragalus & layneae & \\
\hline & Perennial & CHAL 11 & Chamaesyce & albomarginata & \\
\hline & Annual & ERCI6 & Erodium & cicutarium & \\
\hline & Annual & PHVAV2 & Phacelia & vallis-mortae var. vallis-mortae & \\
\hline & Annual & CRMI & Cryptantha & micrantha & \\
\hline & Annual & CRNEN & Cryptantha & nevadensis var. nevadensis & \\
\hline & Perennial & CRUT & Cryptantha & utahensis & \\
\hline & Perennial & DIPU3 & Dichelostemma & pulchellum & \\
\hline & Perennial & ERCOC3 & Erigeron & concinnus var. concinnus & \\
\hline & Annual & ESMI & Eschscholzia & minutiflora & \\
\hline & Perennial & HEMUN & Heliomeris & multiflora var. nevadensis & \\
\hline & Annual & IPPO2 & Ipomopsis & polycladon & \\
\hline & Annual & LUBR2 & Lupinus & brevicaulis & \\
\hline & Annual & LUFL & Lupinus & flavoculatus & \\
\hline & Annual & LUSH & Lupinus & shockleyi & \\
\hline & Annual & MIBIB2 & Mimulus & bigelovii var. bigelovii & \\
\hline & Annual & OEPR & Oenothera & primiveris & \\
\hline & Annual & PHCRC3 & Phacelia & crenulata var. crenulata & \\
\hline & Perennial & PHST11 & Phlox & stansburyi & \\
\hline & Annual & RANE & Rafinesquia & neomexicana & \\
\hline & Annual & SAPAB & Salsola & paulsenii & \\
\hline & Biennial & SIAL2 & Sisymbrium & altissimum & \\
\hline & Perennial & SPAMR & Sphaeralcea & ambiguua var. rugosa & \\
\hline & Perennial & SPGRP2 & Sphaeralcea & grossulariaefolia ssp. pedata & \\
\hline & Annual & STLO4 & Streptanthella & longurostris & \\
\hline & Perennial & STPA4 & Stephanomeria & pauciflora & \\
\hline & Biennial & THLA4 & Thelypodium & laxifforum & \\
\hline
\end{tabular}

\section{Succulents}

$\begin{array}{lcl}\text { Perennial } & \text { YUBR } & \text { Yucca } \\ \text { Perennial } & \text { OPECE } & \text { Opuntia } \\ \text { Perennial } & \text { OPBAB2 } & \text { Opuntia } \\ \text { Perennial } & \text { ECPO2 } & \text { Echinocactus }\end{array}$

brevifolia
echinocarpa var. echinocarpa
basilaris var. basilaris
polycephalus




\begin{tabular}{rrrrrr} 
Association & Longevity & ACODE & \multicolumn{1}{c}{ Genus } & \multicolumn{1}{c}{ Species } & \% Frequency \\
& Perennial & ECEN & Echinocereus & engelmannii & 3.3 \\
Perennial & OPPU & Opuntia & pulchella & 3.3
\end{tabular}


Association Longevity ACODE Genus Species \% Frequency

\section{Eriogonum fasciculatum-Ephedra nevadensis Shrubland}

Tall Shrubs (2-5 $\mathbf{~ m})$

$\begin{array}{lll}\text { Perennial } & \text { LATR2 } & \text { Larrea } \\ \text { Perennial } & \text { ARTRT } & \text { Artemisia }\end{array}$

tridentata

Perennial ARTRT Artemisia

tridentata ssp. tridentata

\section{Short Shrubs (0.5-2 m)}

\begin{tabular}{|c|c|c|}
\hline Perennial & ERFAP & Eriogonum \\
\hline Perennial & LYAN & Lycium \\
\hline Perennial & EPNE & Ephedra \\
\hline Perennial & ERTE18 & Ericameria \\
\hline Perennial & GRSP & Grayia \\
\hline Perennial & KRLA2 & Krascheninnikovia \\
\hline Perennial & AMDU2 & Ambrosia \\
\hline Perennial & ENVIV & Encelia \\
\hline Perennial & SAME & Salazaria \\
\hline Perennial & ATCO & Atriplex \\
\hline Perennial & ERCO23 & Ericameria \\
\hline Perennial & CHVIV2 & Chrysothamnus \\
\hline Perennial & CORA & Coleogyne \\
\hline Perennial & EPVI & Ephedra \\
\hline Perennial & HYSA & Hymenoclea \\
\hline Perennial & THMO & Thamnosma \\
\hline Perennial & TEAXA & Tetradymia \\
\hline Perennial & ATCAC & Atriplex \\
\hline Perennial & BRMIW & Brickellia \\
\hline Perennial & ERNAL & Ericameria \\
\hline Perennial & GUSA2 & Gutierrezia \\
\hline Perennial & PSFRF & Psorothamnus \\
\hline Perennial & STPIP & Stanieya \\
\hline Perennial & ERLI6 & Ericameria \\
\hline Perennial & ERNAH & Ericameria \\
\hline Perennial & LEFR2 & Lepidium \\
\hline Perennial & SYLO & Symphoricarpos \\
\hline Perennial & TEGL & Tetradymia \\
\hline
\end{tabular}

\begin{tabular}{l} 
fasciculatum var. polifolium \\
andersonii \\
nevadensis \\
teretifolia \\
spinosa \\
lanata \\
dumosa \\
virginensis var. virginensis \\
mexicana \\
confertifolia \\
cooperi \\
viscidiflorus ssp. viscidiflorus \\
ramosissima \\
viridis \\
salsola \\
montana \\
axillaris var. axillaris \\
canescens var. canescens \\
microphylla var. watsonii \\
nauseosus ssp. consimilis var. leiosperma \\
sarothrae \\
fremontii var. fremontii \\
pinnata var. pinnata \\
linearifolius \\
nauseosus ssp. nauseosus var. \\
fremololea \\
longiflorus \\
\hline
\end{tabular}

100.0

92.9

85.7

85.7

71.4

71.4

64.3

50.0

50.0

35.7

35.7

28.6

28.6

28.6

28.6

28.6

21.4

14.3

14.3

14.3

14.3

14.3

14.3

7.1

7.1

7.1

7.1

7.1

Thursday, September 09, 1999

Page 30 of 107 
Dwarf Shrubs $(<0.5 \mathrm{~m})$

$\begin{array}{lll}\text { Perennial } & \text { KRER } & \text { Krameria } \\ \text { Perennial } & \text { LEPU } & \text { Leptodactylon } \\ \text { Perennial } & \text { MESP2 } & \text { Menodora }\end{array}$

erecta

\section{Graminoids}

$\begin{array}{lll}\text { Perennial } & \text { ACSP12 } & \text { Achnatherum } \\ \text { Annual } & \text { BRRU2 } & \text { Bromus } \\ \text { Perennial } & \text { ERPU8 } & \text { Erioneuron } \\ \text { Perennial } & \text { ELELE } & \text { Elymus } \\ \text { Perennial } & \text { ACHY } & \text { Achnatherum } \\ \text { Perennial } & \text { ARPU9 } & \text { Aristida } \\ \text { Perennial } & \text { BOGR2 } & \text { Bouteloua } \\ \text { Annual } & \text { BRTE } & \text { Bromus } \\ \text { Perennial } & \text { PLJA } & \text { Pleuraphis }\end{array}$

speciosum
rubens
pulchellum
elymoides ssp. elymoides
hymenoides
purpurea
gracilis
tectorum
jamesii

100.0

\section{Forbs}

$\begin{array}{lll}\text { Perennial } & \text { SPAMA } & \text { Sphaeralcea } \\ \text { Perennial } & \text { XYTOT } & \text { Xylorhiza } \\ \text { Perennial } & \text { ERIN4 } & \text { Eriogonum } \\ \text { Perennial } & \text { DEPAP3 } & \text { Delphinium } \\ \text { Annual } & \text { ERN14 } & \text { Eriogonum } \\ \text { Perennial } & \text { STPA4 } & \text { Stephanomeria } \\ \text { Annual } & \text { AMTE3 } & \text { Amsinckia } \\ \text { Perennial } & \text { CAAP4 } & \text { Castilleja } \\ \text { Perennial } & \text { BRAT } & \text { Brickellia } \\ \text { Biennial } & \text { CINE } & \text { Cirsium } \\ \text { Perennial } & \text { GIBRB } & \text { Gilia } \\ \text { Annual } & \text { LOHU2 } & \text { Lotus } \\ \text { Annual } & \text { PHFR2 } & \text { Phacelia } \\ \text { Annual } & \text { PHVAV2 } & \text { Phacelia } \\ \text { Perennial } & \text { ADCO2 } & \text { Adenophyllum } \\ \text { Perennial } & \text { ARLU } & \text { Artemisia } \\ \text { Perennial } & \text { ARPUM } & \text { Arabis } \\ \text { Annual } & \text { ASAC3 } & \text { Astragalus } \\ \text { Perennial } & \text { ASCA14 } & \text { Astragalus }\end{array}$

78.6 
Association Longevity ACODE Genus

Perennial ASLA8 Astragalus

Annual CABRB4 Camissonia

Annual CAHE12 Camissonia

Annual CAPA7 Calycoseris

Annual CETH3 Centrostegia

Perennial CHAL11 Chamaesyce

Annual CHMA Chaenactis

Annual CHST Chaenactis

Annual CRNEN Cryptantha

Perennial CRUT Cryptantha

Perennial CRVI5 Cryptantha

Annual ERCl6 Erodium

Annual ESGL Eschscholzia

Annual ESMI Eschscholzia

Perennial HEMUN Heliomeris

Annual IPPO2 Ipomopsis

Annual LELA Lepidium

Annual LUSH Lupinus

Annual MEAL6 Mentzelia

Perennial MIPU5 Mirabilis

Annual NAPU Nama

Annual NIAT Nicotiana

Perennial OECEM4 Oenothera

Annual PEPL Pectocarya

Annual PHCRC3 Phacelia

Annual RANE Rafinesquia

Annual SACOC Salvia

Perennial SPAMR Sphaeralcea

\section{Succulents}

$\begin{array}{lcl}\text { Perennial } & \text { ECPO2 } & \text { Echinocactus } \\ \text { Perennial } & \text { ECEN } & \text { Echinocereus } \\ \text { Perennial } & \text { YUBR } & \text { Yucca } \\ \text { Perennial } & \text { OPBAB2 } & \text { Opuntia } \\ \text { Perennial } & \text { MATE4 } & \text { Mammillaria }\end{array}$

\section{Species}

layneae

brevipes ssp. brevipes

heterochroma

parryi

thurberi

albomarginata

macrantha

stevioides

nevadensis var. nevadensis

utahensis

virginensis

cicutarium

glyptosperma

minutifiora

multiflora var. nevadensis

polycladon

lasiocarpum

shockleyi

albicaulis

pudica

pusillum

attenuata

caespitosa ssp. marginata

platycarpa

crenulata var. crenulata

neomexicana

columbariae var. columbariae

ambiguua var. rugosa

polycephalus

engelmannii

brevifolia

basilaris var. basilaris

tetrancistra
64.3

35.7

21.4

7.1

7.1

7.1

7.1

7.1

7.1

7.1

7.1

7.1

7.1

7.1

7.1

7.1

7.1

7.1

7.1

7.1

7.1

7.1

7.1

7.1

7.1

7.1

7.1

7.1

7.1

7.1

7.1

7.1

Thursday, September 09, 1999

Page 32 of 107 


\section{Ephedra nevadensis-Grayia spinosa Shrubland}

\section{Trees (>5 m)}

Perennial JUOS Juniperus

osteosperma

Tall Shrubs (2-5 m)

$\begin{array}{lll}\text { Perennial } & \text { ARTRT } & \text { Artemisia } \\ \text { Perennial } & \text { LATR2 } & \text { Larrea }\end{array}$

tridentata ssp. tridentata

tridentata

\section{Short Shrubs (0.5-2 m)}

\begin{tabular}{|c|c|c|}
\hline Perennial & EPNE & Ephedra \\
\hline Perennial & LYAN & Lycium \\
\hline Perennial & GRSP & Grayia \\
\hline Perennial & ATCAC & Atriplex \\
\hline Perennial & HYSA & Hymenoclea \\
\hline Perennial & KRLA2 & Krascheninnikovia \\
\hline Perennial & CHVIV2 & Chrysothamnus \\
\hline Perennial & CORA & Coleogyne \\
\hline Perennial & ERCO23 & Ericameria \\
\hline Perennial & TEAXA & Tetradymia \\
\hline Perennial & ERFAP & Eriogonum \\
\hline Perennial & ERTE18 & Ericameria \\
\hline Perennial & SAME & Salazaria \\
\hline Perennial & TECA2 & Tetradymia \\
\hline Perennial & THMO & Thamnosma \\
\hline Perennial & ENVIV & Encelra \\
\hline Perennial & ERNAL & Ericameria \\
\hline Perennial & $\mathrm{ACSH}$ & Acamptopappus \\
\hline Perennial & AMDU2 & Ambrosia \\
\hline Perennial & ATCO & Atriplex \\
\hline Perennial & GUSA2 & Gutierrezia \\
\hline Perennial & PUGL2 & Purshia \\
\hline Perennial & STPIP & Stanleya \\
\hline Perennial & ARNO4 & Artemisia \\
\hline Perennial & EPVI & Ephedra \\
\hline Perennial & ERMIS2 & Eriogonum \\
\hline Perennial & PSFRF & Psorothamnus \\
\hline
\end{tabular}

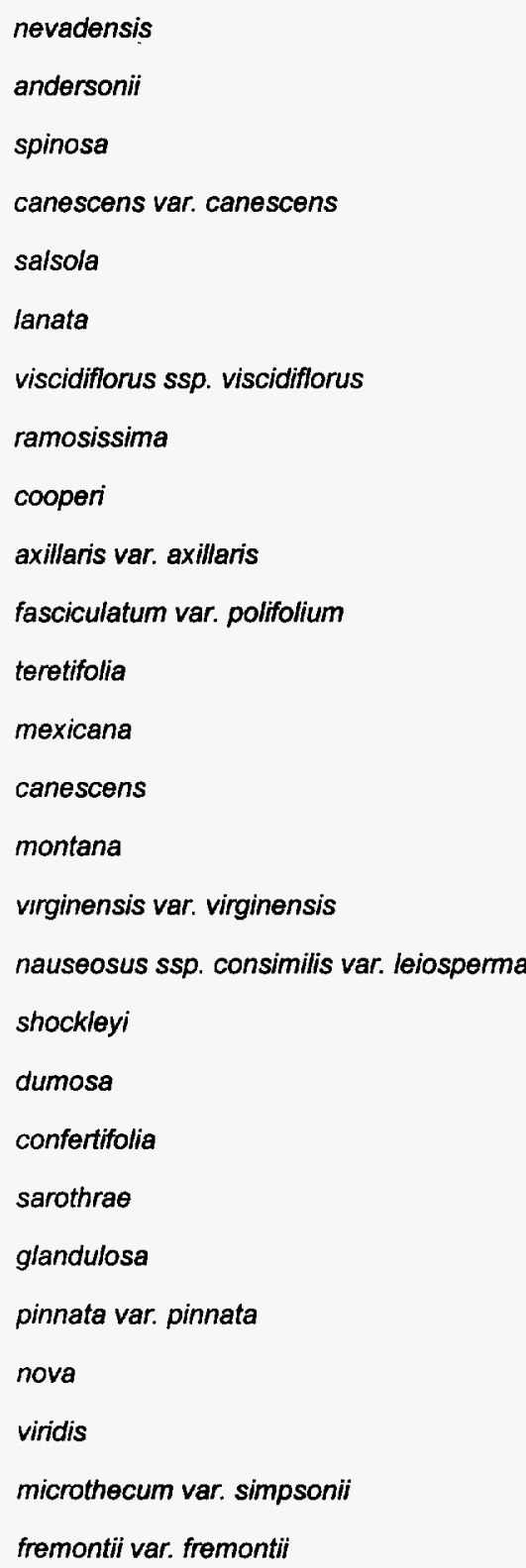

96.7

83.7

78.3

72.8

69.6

67.4

58.7

50.0

44.6

35.9

28.3

27.2

23.9

18.5

18.5

17.4

16.3

13.0

10.9

10.9

10.9

10.9

10.9

9.8

9.8

9.8

9.8 


\begin{tabular}{|c|c|c|c|c|c|}
\hline \multirow[t]{24}{*}{ Association } & Longevity & $A C O D E$ & Genus & Species & $\%$ Frequenc \\
\hline & Perennial & ERLI6 & Ericameria & IInearifolius & \\
\hline & Perennial & ERNAH & Ericameria & $\begin{array}{l}\text { nauseosus ssp. nauseosus var. } \\
\text { hololeuca }\end{array}$ & \\
\hline & Perennial & PUST & Purshia & stansburiana & \\
\hline & Perennial & CHVIP4 & Chrysothamnus & viscidiflorus ssp. puberulus & \\
\hline & Perennial & PSPO & Psorothamnus & polydenius & \\
\hline & Perennial & LEFR2 & Lepidium & fremontii & \\
\hline & Perennial & SYLO & Symphoricarpos & longiflorus & \\
\hline & Perennial & TEGL & Tetradymia & glabrata & \\
\hline & Perennial & STEL & Stanleya & elata & \\
\hline & Perennial & ERNA7 & Ericameria & nanus & \\
\hline & Perennial & AMER & Ambrosia & eriocentra & \\
\hline & Perennial & BRMIW & Brickellia & microphylla var. watsonii & \\
\hline & Perennial & ERPA29 & Ericameria & paniculata & \\
\hline & Perennial & LYPAO & Lycium & pallidum var. oligospermum & \\
\hline & Perennial & BROBL & Brickellia & oblongifolia var. linifolia & \\
\hline & Perennial & CHGR6 & Chrysothamnus & greenei & \\
\hline & Perennial & ERHEH2 & Eriogonum & heermannii var. heermannii & \\
\hline & Perennial & ERNA10 & Ericameria & nauseosus & \\
\hline & Perennial & GLSPA & Glossopetalon & spinescens var. aridum & \\
\hline & Perennial & LYSH & Lycium & shockleyi & \\
\hline & Perennial & PRFA & Prunus & fasciculata & \\
\hline & Perennial & SADOD3 & Salvia & dorii ssp. dornii var. domii & \\
\hline & Perennial & SENE5 & Senecio & flaccidus var. douglasii & \\
\hline
\end{tabular}

\section{Dwarf Shrubs (<0.5 m)}

$\begin{array}{lll}\text { Perennial } & \text { ARSP5 } & \text { Artemisia } \\ \text { Perennial } & \text { MESP2 } & \text { Menodora } \\ \text { Perennial } & \text { KRER } & \text { Krameria } \\ \text { Perennial } & \text { LEPU } & \text { Leptodactylon }\end{array}$

spinescens
spinescens
erecta
pungens

\section{Graminoids}

$\begin{array}{lcl}\text { Annual } & \text { BRRU2 } & \text { Bromus } \\ \text { Perennial } & \text { ACSP12 } & \text { Achnatherum } \\ \text { Perennial } & \text { ACHY } & \text { Achnatherum } \\ \text { Perennial } & \text { ELELE } & \text { Elymus } \\ \text { Perennial } & \text { PLJA } & \text { Pleuraphis } \\ \text { Annual } & \text { BRTE } & \text { Bromus }\end{array}$

rubens
speciosum
hymenoides
elymoides ssp. elymoides
jamesii
tectorum




$\begin{array}{lcl}\text { Perennial } & \text { POSE } & \text { Poa } \\ \text { Perennial } & \text { HECOC8 } & \text { Hesperostipa } \\ \text { Perennial } & \text { ERPU8 } & \text { Erioneuron } \\ \text { Perennial } & \text { ARPU9 } & \text { Aristida } \\ \text { Perennial } & \text { BOGR2 } & \text { Bouteloua } \\ \text { Annual } & \text { BRCA6 } & \text { Bromus } \\ \text { Perennial } & \text { PLRI3 } & \text { Pleuraphis } \\ \text { Annual } & \text { VUOC } & \text { Vulpia }\end{array}$

secunda

comata ssp. comata

pulchellum

purpurea

4.3

gracilis

1.1

cartharticus

1.1

rigida

octoflora

\section{Forbs}

\begin{tabular}{|c|c|c|}
\hline Annual & AMTE3 & Amsinckia \\
\hline Perennial & SPAMA & Sphaeralcea \\
\hline Annual & CHST & Chaenactis \\
\hline Annual & ERCI6 & Erodium \\
\hline Perennial & CAAP4 & Castilleja \\
\hline Perennial & CHAL 11 & Chamaesyce \\
\hline Perennial & MACAC & Machaeranthera \\
\hline Perennial & DEPAP3 & Delphinium \\
\hline Annual & ERER2 & Eriastrum \\
\hline Perennial & ERIN4 & Eriogonum \\
\hline Annual & ERNI4 & Eriogonum \\
\hline Annual & MAGL3 & Malacothrix \\
\hline Annual & ERDE6 & Eriogonum \\
\hline Annual & ASLEF2 & Astragalus \\
\hline Perennial & HEMUN & Heliomeris \\
\hline Annual & CRPT & Cryptantha \\
\hline Annual & ERPR4 & Eriophyllum \\
\hline Annual & PHFR2 & Phacelia \\
\hline Perennial & XYTOT & Xylorhiza \\
\hline Perennial & CAFL & Calochortus \\
\hline Perennial & MIPU5 & Mirabilis \\
\hline Annual & PHVAV2 & Phacelia \\
\hline Annual & LELA & Lepidium \\
\hline Annual & PHCRC3 & Phacelia \\
\hline Annual & OXPE2 & Oxytheca \\
\hline Biennial & CINE & Cirsium \\
\hline Annual & $\mathrm{CRCl} 2$ & Cryptantha \\
\hline
\end{tabular}

tessellata
ambigua ssp. ambigua
stevioides
cicutarium
applegatei
albomarginata
canescens ssp. canescens
parishii ssp. parishii
eremicum
inflatum
nidularium
glabrata
deflexum
lentiginosus var. fremontii
multiflora var. nevadensis
pterocarya
pringlei
fremontii
tortifolia var. imberbis
flexuosus
pudica
vallis-mortae var. vallis-mortae
lasiocarpum
crenulata var. crenulata
neomexicanum
circumscissa
peliata
a

83.7

62.0

44.6

35.9

31.5

30.4

28.3

23.9

23.9

22.8

21.7

20.7

18.5

16.3

16.3

14.1

14.1

14.1

14.1

13.0

13.0

13.0

12.0

12.0

10.9

9.8

9.8 


\begin{tabular}{|c|c|c|c|}
\hline \multirow[t]{37}{*}{ Association } & Longevity & $A C O D E$ & Genus \\
\hline & Perennial & PHST11 & Phlox \\
\hline & Perennial & ARPUM & Arabis \\
\hline & Annual & DEPIG & Descurainia \\
\hline & Perennial & MIBI8 & Mirabilis \\
\hline & Annual & STEXE & Stephanomeria \\
\hline & Annual & SYFR & Syntrichopappus \\
\hline & Perennial & $\mathrm{ADCO} 2$ & Adenophyllum \\
\hline & Annual & CAKEG & Camissonia \\
\hline & Annual & LOHU2 & Lotus \\
\hline & Annual & LUFL & Lupinus \\
\hline & Annual & LUSH & Lupinus \\
\hline & Annual & PESE & Pectocarya \\
\hline & Annual & SACOC & Salvia \\
\hline & Perennial & STPA3 & Stephanomeria \\
\hline & Perennial & STPA4 & Stephanomeria \\
\hline & Annual & CETH3 & Centrostegia \\
\hline & Annual & CRNEN & Cryptantha \\
\hline & Annual & SAPA8 & Salsola \\
\hline & Perennial & SEMU3 & Senecio \\
\hline & Biennial & SIAL2 & Sisymbrium \\
\hline & Perennial & ASLA8 & Astragalus \\
\hline & Annual & CRMI & Cryptantha \\
\hline & Perennial & ERCOC3 & Erigeron \\
\hline & Annual & GILIA & Gilia \\
\hline & Perennial & LILE3 & Linum \\
\hline & Annual & MEAL6 & Mentzelia \\
\hline & Perennial & PEFLA2 & Penstemon \\
\hline & Annual & ASAC3 & Astragalus \\
\hline & Annual & CACLI & Camissonia \\
\hline & Annual & CHFR & Chaenactis \\
\hline & Perennial & CRCO12 & Cryptantha \\
\hline & Annual & CRGR3 & Cryptantha \\
\hline & Annual & $\mathrm{DESO} 2$ & Descurainia \\
\hline & Perennial & DIPU3 & Dichelostemma \\
\hline & Perennial & EROVO5 & Enogonum \\
\hline & Perennial & ERSA6 & Eriogonum \\
\hline
\end{tabular}

\section{Species \\ \% Frequency}

Stansburyi 9.8

pulchra var. munciensis $\quad 8.7$

pinnata ssp. glabra $\quad 8.7$

bigelovii $\quad 8.7$

exigua ssp. exigua $\quad 7.6$

fremontii $\quad \mathbf{7 . 6}$

cooperi $\quad 6.5$

kernensis ssp. gilmanii $\quad 6.5$

humistratus $\quad 6.5$

flavoculatus $\quad 6.5$

shockleyi 6.5

setosa $\quad 6.5$

columbariae var. columbariae $\quad 6.5$

pamyi $\quad 6.5$

pauciflora $\quad 6.5$

thuberi $\quad 5.4$

nevadensis var. nevadensis $\quad 5.4$

paulsenii $\quad 5.4$

multilobatus $\quad 5.4$

altissimum $\quad 5.4$

layneae $\quad 4.3$

micrantha 4.3

concinnus var. concinnus $\quad 4.3$

4.3

lewisii 4.3

albicaulis $\quad 4.3$

floridus var. austinii $\quad 4.3$

acutirostris $\quad 3.3$

claviformis ssp. integrior $\quad 3.3$

fremontii $\quad 3.3$

confertiflora $\quad 3.3$

gracilis $\quad 3.3$

sophia $\quad 3.3$

pulchellum $\quad 3.3$

ovalifolium var. ovalifolium $\quad 3.3$

saxatile $\quad 3.3$ 
Species

\begin{tabular}{|c|c|c|}
\hline Perennial & GIBRB & Gilia \\
\hline Annual & LAOCO & Lappula \\
\hline Annual & LASE3 & Langloisia \\
\hline Annual & MEVE5 & Mentzelia \\
\hline Perennial & OECEM4 & Oenothera \\
\hline Annual & PLPA2 & Plantago \\
\hline Annual & SAKAT3 & Salsola \\
\hline Annual & AMAC2 & Ambrosia \\
\hline Perennial & ARDR4 & Artemisia \\
\hline Perennial & ARLU & Artemisia \\
\hline Perennial & ARPUG & Arabis \\
\hline Perennial & ASPUT & Astragalus \\
\hline Perennial & BAMU & Baileya \\
\hline Annual & CABOC & Camissonia \\
\hline Annual & CAPA7 & Calycoseris \\
\hline Annual & CHMA & Chaenactis \\
\hline Annual & CHRI & Chorizanthe \\
\hline Perennial & CRFL6 & Cryptantha \\
\hline Perennial & CRUT & Cryptantha \\
\hline Perennial & CYRI2 & Cymopterus \\
\hline Perennial & DEAN & Delphinium \\
\hline Annual & IPPO2 & Ipomopsis \\
\hline Perennial & LONEN & Lomatium \\
\hline Annual & LUBR2 & Lupinus \\
\hline Annual & MISP & Mimulus \\
\hline Annual & NAPU & Nama \\
\hline Perenni & POS & Polygala \\
\hline Perennial & SPAMM & Sphaeralcea \\
\hline Perennial & SPAMR & Sphaeralcea \\
\hline Annual & URLI2 & Uropappus \\
\hline Perennial & ABEL & Abronia \\
\hline Annual & ANAC & Anisocoma \\
\hline Perennial & ARCOS2 & Arenaria \\
\hline Perennial & ARMA3 & Arenaria \\
\hline renr & ASCA & Astraga \\
\hline 'erenn & AS & Astr \\
\hline
\end{tabular}

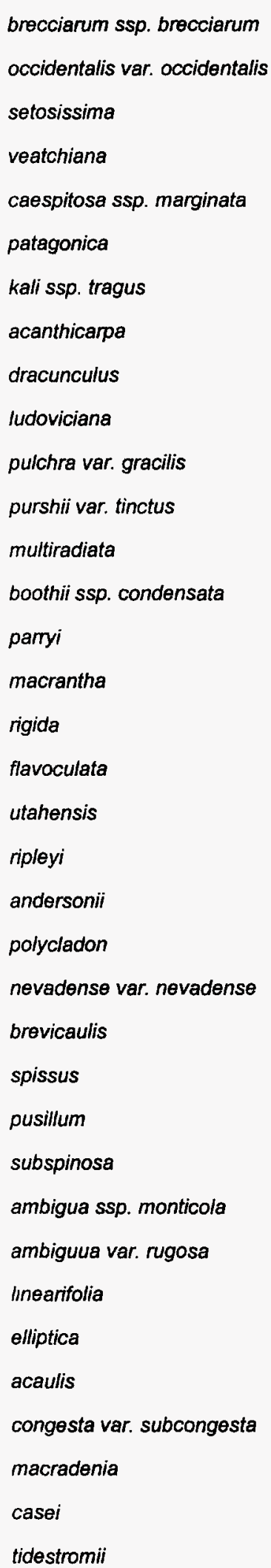

3.3

3.3

3.3

3.3

3.3

2.2

2.2

2.2

2.2

2.2

2.2

2.2

2.2

2.2

2.2

2.2

2.2

2.2

2.2

2.2

2.2

2.2

2.2

2.2

2.2

2.2

2.2

2.2

1.1

1.1

1.1

1.1

1.1

1.1 
Association Longevity ACODE Genus

\begin{tabular}{|c|c|c|}
\hline Annual & CABRB4 & Camissonia \\
\hline Perennial & CAPI4 & Caulanthus \\
\hline Annual & CAPT & Camissonia \\
\hline Annual & CHSES & Chamaesyce \\
\hline Annual & CHWA2 & Chorizanthe \\
\hline Perennial & CROCO2 & Crepis \\
\hline Perennial & CRVI5 & Cryptantha \\
\hline Perennial & CYGL2 & Cymopterus \\
\hline Perennial & CYPU & Cymopterus \\
\hline Annual & ERDI4 & Erigeron \\
\hline Annual & ERESE & Eriogonum \\
\hline Perennial & ERNU4 & Eriogonum \\
\hline Annual & ESGL & Eschscholzia \\
\hline Annual & ESMI & Eschscholzia \\
\hline Perennial & GICAT & Gilia \\
\hline Annual & GLMA2 & Glyptopleura \\
\hline Annual & HAGL & Halogeton \\
\hline Annual & MASO & Malacothrix \\
\hline Annual & MEOB3 & Mentzelia \\
\hline Perennial & MIMUG & Mirabilis \\
\hline Annual & MISU2 & Mimulus \\
\hline Annual & MOBE & Monoptilon \\
\hline Annual & NIAT & Nicotiana \\
\hline Perennial & OEPAP & Oenothera \\
\hline Annual & OEPR & Oenothera \\
\hline Annual & PHCA2 & Phacelia \\
\hline Perennial & PHGRH & Phlox \\
\hline Annual & PHSA & Phacelia \\
\hline Annual & RANE & Rafinesquia \\
\hline Perennial & STCOC & Streptanthus \\
\hline Perennial & TRWA2 & Tricardia \\
\hline
\end{tabular}

\section{Succulents}

$\begin{array}{ccl}\text { Perennial } & \text { YUBR } & \text { Yucca } \\ \text { Perennial } & \text { OPECE } & \text { Opuntia } \\ \text { Perennial } & \text { ECEN } & \text { Echinocereus } \\ \text { Perennial } & \text { OPBAB2 } & \text { Opuntia }\end{array}$

\section{Species}

brevipes ssp. brevipes
pilosus
pterosperma
serpyllifolia ssp. serpylifolia
watsonii
occidentalis ssp. occidentalis
virginensis
globosus
purpurascens
divergens
esmeraldense var. esmeraldense
nummulare
glyptosperma
minutiflora

cana ssp. triceps

marginata

glomeratus

sonchoides

obscura

multiflora var. glandulosa

suksdorfii

bellidiforme

attenuata

pallida ssp. pallida

primiveris

calthifolia

gracilis ssp. humilis

saxicola

neomexicana

cordatus var. cordatus

watsonit

1.1

1.1

1.1

1.1

1.1

1.1

1.1

1.1

1.1

1.1

1.1

1.1

1.1

1.1

1.1

1.1

1.1

1.1

1.1

1.1

1.1

1.1

1.1

1.1

1.1

1.1

1.1

1.1

1.1
44.6

40.2

13.0 


$\begin{array}{ccll}\text { Association } & \text { Longevity } & \text { ACODE } & \text { Genus } \\ & \text { Perennial } & \text { YUBAV } & \text { Yucca } \\ \text { Perennial } & \text { ECPO2 } & \text { Echinocactus } \\ \text { Perennial } & \text { OPPOR } & \text { Opuntia } \\ \text { Perennial } & \text { ESVIR2 } & \text { Escobaria } \\ \text { Perennial } & \text { OPPU } & \text { Opuntia } \\ \text { Perennial } & \text { OPERE } & \text { Opuntia } \\ & \text { Perennial } & \text { SCPO4 } & \text { Sclerocactus } \\ \text { Perennial } & \text { YUSC2 } & \text { Yucca } \\ \text { Perennial } & \text { ECTRM } & \text { Echinocereus } \\ \text { Perennial } & \text { OPRA } & \text { Opuntia }\end{array}$

Species

baccata var. vespertina

polycephalus

polyacantha var. rufispina

vivipara var. rosea

pulchella

erinacea var. erinacea

polyancistrus

schidigera

triglochidiatus var. melanacanthus

ramosissima
\% Frequency

10.9

9.8

5.4

4.3

4.3

2.2

2.2

2.2

1.1

1.1

1.1 
Association Longevity ACODE Genus Species \% Frequency

\section{Coleogyne ramosissima-Ephedra nevadensis Shrubland}

Trees $(>5 \mathrm{~m})$

$\begin{array}{lll}\text { Perennial } & \text { JUOS } & \text { Juniperus } \\ \text { Perennial } & \text { PIMO } & \text { Pinus }\end{array}$

osteosperma

6.5

monophylla

Tall Shrubs (2-5 m)

$\begin{array}{lll}\text { Perennial } & \text { LATR2 } & \text { Larrea } \\ \text { Perennial } & \text { ARTRT } & \text { Artemisia } \\ \text { Perennial } & \text { CELEL } & \text { Cercocarpus } \\ \text { Perennial } & \text { CEGRV2 } & \text { Ceanothus }\end{array}$

tridentata

33.4

tridentata ssp. tridentata

13.9

ledifolius var. ledifolius

greggii ssp. vestitus

Short Shrubs (0.5-2 $\mathrm{m})$

\begin{tabular}{|c|c|c|}
\hline Perennial & CORA & Coleogyne \\
\hline Perennial & EPNE & Ephedra \\
\hline Perennial & LYAN & Lycium \\
\hline Perennial & GRSP & Grayia \\
\hline Perennial & HYSA & Hymenoclea \\
\hline Perennial & KRLA2 & Krascheninnikovia \\
\hline Perennial & CHVIV2 & Chrysothamnus \\
\hline Perennial & TEAXA & Tetradymia \\
\hline Perennial & AMDU2 & Ambrosia \\
\hline Perennial & ATCAC & Atriplex \\
\hline Perennial & ERTE18 & Ericameria \\
\hline Perennial & ERCO23 & Ericameria \\
\hline Perennial & ENVIV & Encelia \\
\hline Perennial & EPVI & Ephedra \\
\hline Perennial & PUST & Purshia \\
\hline Perennial & SAME & Salazaria \\
\hline Perennial & $\mathrm{ACSH}$ & Acamptopappus \\
\hline Perennial & ERNAL & Ericameria \\
\hline Perennial & ATCO & Atriplex \\
\hline Perennial & ERFAP & Eriogonum \\
\hline Perennial & LEFR2 & Lepidium \\
\hline Perennıal & PSFRF & Psorothamnus \\
\hline Perennial & THMO & Thamnosma \\
\hline Perennial & TECA2 & Tetradymia \\
\hline
\end{tabular}

ramosissima
nevadensis
andersonii
spinosa
saisola
lanata
viscidiflorus ssp. viscidiflorus
axillaris var. axillaris
dumosa
canescens var. canescens
teretifolia
cooperi
virginensis var. virginensis
vinidis
stansburiana
mexicana
shockleyi
nauseosus ssp. consimilis var. leiosperma
confertifolia
fasciculatum var. polifolium
fremontii
fremontii var. fremontii
canescens
montana
a

100.0

91.3

66.6

55.4

52.6

47.1

32.2

28.5

28.2

27.6

25.4

24.5

22.0

22.0

19.2

17.6

17.0

16.7

15.5

15.2

14.6

13.9

12.7

10.8 


\begin{tabular}{|c|c|c|c|}
\hline \multirow[t]{35}{*}{ Association } & Longevity & $A C O D E$ & Genus \\
\hline & Perennial & LYPAO & Lycium \\
\hline & Perennial & SYLO & Symphoricarpos \\
\hline & Perennial & STPIP & Stanleya \\
\hline & Perennial & ERLI6 & Ericameria \\
\hline & Perennial & ERMIS2 & Eniogonum \\
\hline & Perennial & ERNAH & Ericameria \\
\hline & Perennial & STEL & Stanleya \\
\hline & Perennial & BRMIW & Brickellia \\
\hline & Perennial & CHVIP4 & Chrysothamnus \\
\hline & Perennial & GUSA2 & Gutierrezia \\
\hline & Perennial & PRFA & Prunus \\
\hline & Perennial & PUGL2 & Purshia \\
\hline & Perennial & ARNO4 & Artemisia \\
\hline & Perennial & TEGL & Tetradymia \\
\hline & Perennial & ERNA10 & Ericameria \\
\hline & Perennial & PSPO & Psorothamnus \\
\hline & Perennial & EPFU & Ephedra \\
\hline & Perennial & ERHEH2 & Eriogonum \\
\hline & Perennial & PENI & Petalonyx \\
\hline & Perennial & EPTO & Ephedra \\
\hline & Perennial & RHTRA & Rhus \\
\hline & Perennial & AMER & Ambrosia \\
\hline & Perennial & BROBL & Brickellia \\
\hline & Perennial & CHGR6 & Chrysothamnus \\
\hline & Perennial & SADOD3 & Salvia \\
\hline & Perennial & ARBI3 & Artemisia \\
\hline & Perennial & BUUT & Buddleja \\
\hline & Perennial & ERCUC & Ericameria \\
\hline & Perennial & ERHEA & Eriogonum \\
\hline & Perennial & GLSPA & Glossopetalon \\
\hline & Perennial & PERA4 & Peraphyllum \\
\hline & Perennial & PUTR2 & Purshia \\
\hline & Perennial & RIVEV & Ribes \\
\hline & Perennial & SENE5 & Senecio \\
\hline
\end{tabular}

Species

pallidum var. oligospermum

longiflorus

pinnata var. pinnata

linearifolius

microthecum var. simpsonii

nauseosus ssp. nauseosus var.

hololeuca

elata

microphylla var. watsonii

viscidiflorus ssp. puberulus

sarothrae

fasciculata

glandulosa

nova

glabrata

nauseosus

polydenius

funerea

heermannii var. heermannii

nitidus

torreyana

trilobata var. anisophylla

eriocentra

oblongifolia var. linifolia

greenei

dorii ssp. dorrii var. domii

bigelovii

utahensis

cuneatus

heermannii var. argense

spinescens var. aridum

ramosissimum

tridentata

velutinum var. velutinum

flaccidus var, douglasii
7.4

6.8

6.5

5.9

5.6

$\%$ Frequency

5.6

5.6

4.6

4.3

3.7

3.7

3.1

2.8

2.5

1.5

1.5

1.2

1.2

1.2

0.9

0.9

0.6

0.6

0.6

0.6

0.3

0.3

0.3

0.3

0.3

0.3

0.3

0.3

0.3

Thursday, September 09, 1999 
Dwarf Shrubs (<0.5 m)

$\begin{array}{lll}\text { Perennial } & \text { MESP2 } & \text { Menodora } \\ \text { Perennial } & \text { KRER } & \text { Krameria } \\ \text { Perennial } & \text { ARSP5 } & \text { Artemisia } \\ \text { Perennial } & \text { LEPU } & \text { Leptodactylon } \\ \text { Perennial } & \text { ERMIL } & \text { Eriogonum } \\ \text { Perennial } & \text { KOAM } & \text { Kochia }\end{array}$

spinescens
erecta
spinescens
pungens
microthecum var. lapidicola
americana

24.8

21.7

11.5

1.5

0.3

0.3

\section{Graminoids}

\begin{tabular}{|c|c|c|}
\hline Annual & BRRU2 & Bromus \\
\hline Perennial & ACSP12 & Achnatherum \\
\hline Perennial & ELELE & Elymus \\
\hline Perennial & $\mathrm{ACHY}$ & Achnatherum \\
\hline Perennial & POSE & Poa \\
\hline Annual & BRTE & Bromus \\
\hline Perennial & PLJA & Pleuraphis \\
\hline Annual & VuOC & Vulpia \\
\hline Perennial & ERPU8 & Erioneuron \\
\hline Perennial & POFE & Poa \\
\hline Perennial & ARPU9 & Aristida \\
\hline Perennial & HECOC8 & Hesperostipa \\
\hline Annual & SCAR & Schismus \\
\hline Perennial & PLRI3 & Pleuraphis \\
\hline Annual & VUMI & Vulpia \\
\hline Perennial & ACAR14 & Achnatherum \\
\hline Perennial & $\mathrm{ACCO} 21$ & Achnatherum \\
\hline Perennial & BOGR2 & Bouteloua \\
\hline Annual & BRBE2 & Bromus \\
\hline Annual & BRCA6 & Bromus \\
\hline Perennial & LECl4 & Leymus \\
\hline
\end{tabular}

\begin{tabular}{l} 
rubens \\
speciosum \\
elymoides ssp. elymoides \\
hymenoides \\
secunda \\
tectorum \\
jamesii \\
octoflora \\
pulchellum \\
fendleriana \\
purpurea \\
comata ssp. comata \\
arabicus \\
rigida \\
microstachys \\
arida \\
coronata \\
gracilis \\
berterianus \\
cartharticus \\
cinereus \\
\hline
\end{tabular}

86.4 44.9 30.7

29.1 16.1 11.5 9.0 5.9 4.0 2.8 2.2 1.5 1.2 0.9 0.9 0.6 0.3 0.3 0.3 0.3 0.3 
Forbs

\begin{tabular}{|c|c|c|}
\hline Annual & AMTE3 & Amsinckia \\
\hline Perennial & SPAMA & Sphaeralcea \\
\hline Annual & CHST & Chaenactis \\
\hline Perennial & DEPAP3 & Delphinium \\
\hline Perennial & XYTOT & Xylorhiza \\
\hline Perennial & CAFL & Calochortus \\
\hline Annual & OXPE2 & Oxytheca \\
\hline Annual & PHVAV2 & Phacelia \\
\hline Annual & ERCl6 & Erodium \\
\hline Annual & ERNI4 & Eriogonum \\
\hline Perennial & ERIN4 & Eriogonum \\
\hline Annual & PHFR2 & Phacelia \\
\hline Annual & ERER2 & Eriastrum \\
\hline Perennial & ARPUM & Arabis \\
\hline Annual & CRNEN & Cryptantha \\
\hline Perennial & CAAP4 & Castilleja \\
\hline Annual & MAGL3 & Malacothrix \\
\hline Perennial & MACAC & Machaeranthera \\
\hline Perennial & HEMUN & Heliomeris \\
\hline Annual & ERDE6 & Eriogonum \\
\hline Annual & LUSH & Lupinus \\
\hline Perennial & PHST11 & Phlox \\
\hline Perennial & CHAL11 & Chamaesyce \\
\hline Annual & ERPR4 & Eriophyllum \\
\hline Annual & $\mathrm{CHRI}$ & Chorizanthe \\
\hline Perennial & STPA3 & Stephanomeria \\
\hline Annual & SYFR & Syntrichopappus \\
\hline Annual & CRMI & Cryptantha \\
\hline Annual & PESE & Pectocarya \\
\hline Annual & STEXE & Stephanomeria \\
\hline Annual & CRPT & Cryptantha \\
\hline Perennial & GIIN2 & Gilia \\
\hline Annual & GILIA & Gilia \\
\hline Annual & LOHU2 & Lotus \\
\hline Annual & MEVE5 & Mentzelia \\
\hline
\end{tabular}

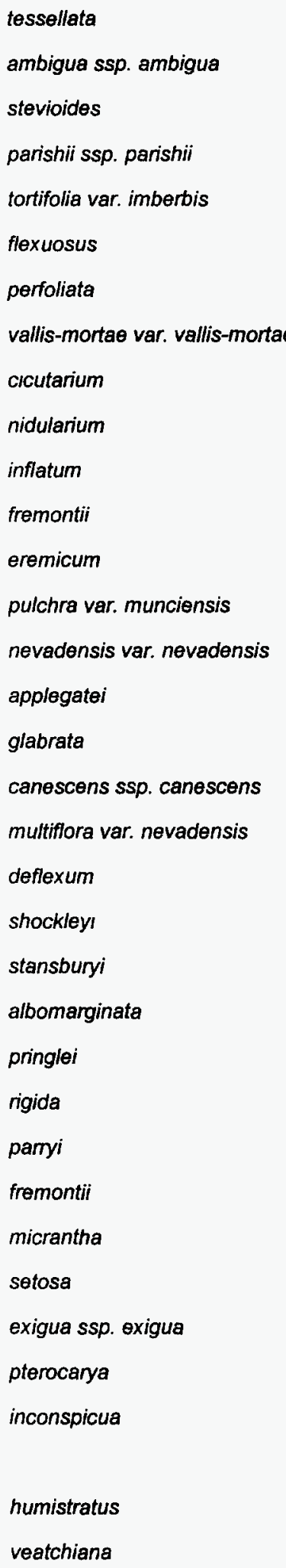




\begin{tabular}{|c|c|c|c|c|c|}
\hline \multirow[t]{38}{*}{ Association } & Longevity & $A C O D E$ & Genus & Species & \% Frequency \\
\hline & Perennial & ARMA3 & Arenaria & macradenia & 5.0 \\
\hline & Annual & CAKEG & Camissonia & kemensis ssp. gilmanii & 5.0 \\
\hline & Annual & CETH3 & Centrostegia & thurberi & 4.6 \\
\hline & Annual & DEPIG & Descurainia & pinnata ssp. glabra & 4.6 \\
\hline & Annual & LELA & Lepidium & lasiocarpum & 4.6 \\
\hline & Perennial & STPA4 & Stephanomeria & pauciflora & 4.6 \\
\hline & Perennial & $\mathrm{ADCO} 2$ & Adenophyllum & cooperi & 4.3 \\
\hline & Perennial & DIPU3 & Dichelostemma & pulchellum & 4.3 \\
\hline & Annual & ASLEF2 & Astragalus & lentiginosus var. fremontii & 4.0 \\
\hline & Perennial & ERCOC3 & Erigeron & concinnus var. concinnus & 4.0 \\
\hline & Perennial & CRUT & Cryptantha & utahensis & 3.7 \\
\hline & Annual & LASE3 & Langloisia & setosissima & 3.7 \\
\hline & Annual & LUBR2 & Lupinus & brevicaulis & 3.7 \\
\hline & Annual & LUFL & Lupinus & flavoculatus & 3.7 \\
\hline & Annual & $\mathrm{CRCl} 2$ & Cryptantha & circumscissa & 3.4 \\
\hline & Perennial & EROVO5 & Eriogonum & ovalifolium var. ovalifolium & 3.4 \\
\hline & Perennial & GIBRB & Gilia & brecciarum ssp. brecciarum & 3.4 \\
\hline & Perennial & ASLA8 & Astragalus & layneae & 3.1 \\
\hline & Perennial & LONEN & Lomatium & nevadense var. nevadense & 3.1 \\
\hline & Annual & RANE & Rafinesquia & neomexicana & 3.1 \\
\hline & Perennial & SPAMR & Sphaeralcea & ambiguua var. rugosa & 3.1 \\
\hline & Annual & ERMA2 & Eriogonum & maculatum & 2.8 \\
\hline & Annual & IPPO2 & Ipomopsis & polycladon & 2.8 \\
\hline & Perennial & MIBI8 & Mirabilis & brgelovii & 2.8 \\
\hline & Perennial & $\mathrm{CRCO} 12$ & Cryptantha & confertiflora & 2.5 \\
\hline & Perennial & ARCOS2 & Arenaria & congesta var. subcongesta & 2.2 \\
\hline & Annual & ASAC3 & Astragalus & acutirostris & 2.2 \\
\hline & Biennial & CINE & Cirsium & neomexicanum & 2.2 \\
\hline & Perennial & MIPU5 & Mirabilis & pudica & 2.2 \\
\hline & Annual & PLPA2 & Plantago & patagonica & 2.2 \\
\hline & Annual & STLO4 & Streptanthella & longirostris & 2.2 \\
\hline & Annual & CABOC & Camissonia & boothii ssp. condensata & 1.9 \\
\hline & Annual & CHBRB & Chorizanthe & brevicomu var. brevicornu & 1.9 \\
\hline & Annual & CHFR & Chaenactis & fremontii & 1.9 \\
\hline & Annual & NADED & Nama & demissum var. demissum & 1.9 \\
\hline & Annual & URLI2 & Uropappus & linearifolia & 1.9 \\
\hline & Perennial & ALNE & Allium & nevadense & 1.5 \\
\hline
\end{tabular}




\begin{tabular}{|c|c|c|c|c|c|}
\hline \multirow{38}{*}{ Association } & Longevity & $A C O D E$ & Genus & Species & $\%$ Frequency \\
\hline & Perennial & ARIN & Arabis & inyoensis & 1.5 \\
\hline & Perennial & ARLU & Artemisia & ludoviciana & 1. \\
\hline & Perennial & ASPUT & Astragalus & purshii var. tinctus & 1. \\
\hline & Annual & CABRB4 & Camissonia & brevipes ssp. brevipes & 1. \\
\hline & Annual & CAPA7 & Calycoseris & parmy! & 1. \\
\hline & Perennial & OECEM4 & Oenothera & caespitosa ssp. marginata & 1. \\
\hline & Annual & PEPL & Pectocarya & platycarpa & 1 \\
\hline & Annual & PSAN & Psathyrotes & annua & 1 \\
\hline & Biennial & SIAL2 & Sisymbrium & altissimum & 1. \\
\hline & Perennial & SPGRP2 & Sphaeralcea & grossulariaefolia ssp. pedata & 1.6 \\
\hline & Perennial & ARPUG & Arabis & pulchra var. gracilis & 1 \\
\hline & Perennial & BAMU & Baileya & multiradiata & 1 \\
\hline & Perennial & ERCA8 & Eriogonum & caespitosum & 1 \\
\hline & Annual & LIDI2 & Linanthus & dichotomus & 1 \\
\hline & Annual & MEAL6 & Mentzelia & albicaulis & 1 \\
\hline & Annual & MEOB3 & Mentzelia & obscura & 1.2 \\
\hline & Perennial & PEFLA2 & Penstemon & floridus var. austinii & \\
\hline & Annual & SACOC & Salvia & columbariae var. columbariae & 1 \\
\hline & Perennial & ASER2 & Asclepias & erosa & 0 \\
\hline & Annual & $\mathrm{CHCA}$ & Chaenactis & carphoclinia & 0. \\
\hline & Annual & CLPAU2 & Claytonia & perfoliata ssp. perfoliata & 0. \\
\hline & Perennial & CYGL2 & Cymopterus & globosus & 0 \\
\hline & Annual & DESO2 & Descurainia & sophia & 0. \\
\hline & Annual & ERPU6 & Eriogonum & pusillum & 0. \\
\hline & Perennial & ERSA6 & Eriogonum & saxatile & 0. \\
\hline & Annual & ERTH & Eriogonum & thomasii & 0. \\
\hline & Annual & LEFLF2 & Lepidium & flavum var. flavum & 0. \\
\hline & Annual & LOSC6 & Loeseliastrum & schottii & 0.5 \\
\hline & Annual & MISU2 & Mimulus & suksdorfii & 0. \\
\hline & Annual & MOBE & Monoptilon & bellidiforme & 0 \\
\hline & Annual & PHCRC3 & Phacelia & crenulata var. crenulata & 0 \\
\hline & Perennial & POSU & Polygala & subspinosa & 列 \\
\hline & Perennial & STCOC & Streptanthus & cordatus var. cordatus & 0 \\
\hline & Annual & AMAC2 & Ambrosia & acanthicarpa & \\
\hline & Perennial & ARHOP3 & Arabis & holboellii var. pinetorum & \\
\hline & Annual & ASDID & Astragalus & didymocarpus var. dispermus & \\
\hline & Perennial & BRAT & Brickellia & atractyloides & \\
\hline
\end{tabular}




\begin{tabular}{|c|c|c|c|c|c|}
\hline \multirow[t]{38}{*}{ Association } & Longevity & $A C O D E$ & Genus & Species & $\%$ Frequency \\
\hline & Annual & CACLI & Camissonia & claviformis ssp integrior & \\
\hline & Annual & CHMA & Chaenactis & macrantha & \\
\hline & Perennial & CRFL6 & Cryptantha & flavoculata & \\
\hline & Annual & CRGR3 & Cryptantha & gracilis & \\
\hline & Annual & CRRE5 & Cryptantha & recurvata & \\
\hline & Perennial & CYAB & Cymopterus & aboriginum & \\
\hline & Annual & ERD14 & Erigeron & divergens & \\
\hline & Annual & ERSP3 & Eriastrum & sparsiflorum & \\
\hline & Perennial & ERUM & Eriogonum & umbellatum & \\
\hline & Annual & ESGL & Eschscholzia & glyptosperma & \\
\hline & Annual & HAGL & Halogeton & glomeratus & \\
\hline & Annual & LAOCO & Lappula & occidentalis var. occidentalis & \\
\hline & Annual & LIDE2 & Linanthus & demissus & \\
\hline & Annual & MASO & Malacothrix & sonchoides & \\
\hline & Annual & MENI2 & Mentzelia & nitens & \\
\hline & Annual & NAPU & Nama & pusillum & \\
\hline & Perennial & OEPAP & Oenothera & pallida ssp. pallida & \\
\hline & Perennial & PHGRH & Phlox & gracilis ssp. humilis & \\
\hline & Perennial & SEMU3 & Senecio & multilobatus & \\
\hline & Annual & THCU & Thysanocarpus & curvipes & \\
\hline & Annual & ANAC & Anisocoma & acaulis & \\
\hline & Perennial & ARMUR & Argemone & munita ssp. rotundata & \\
\hline & Perennial & ARSH & Arabis & shockleyi & \\
\hline & Perennial & ASCA14 & Astragalus & casei & \\
\hline & Annual & BAPL3 & Baileya & pleniradiata & \\
\hline & Annual & CAHE 12 & Camissonia & heterochroma & \\
\hline & Perennial & CALI4 & Castilleja & linariaefolia & \\
\hline & Annual & CAME16 & Camissonia & megalantha & \\
\hline & Annual & CHWA2 & Chorizanthe & watsonii & \\
\hline & Annual & CIPAN & Cistanthe & parryi var. nevadense & \\
\hline & Annual & COPA3 & Collinsia & panvifiora & \\
\hline & Perennial & CROCO2 & Crepis & occidentalis ssp. occidentalis & \\
\hline & Perennial & CRVI5 & Cryptantha & virginensis & \\
\hline & Annual & CRWA2 & Cryptantha & watsonii & \\
\hline & Perennial & CYPU & Cymopterus & purpurascens & \\
\hline & Perennial & CYRI2 & Cymopterus & ripleyi & \\
\hline & Perennial & DEAN & Delphinium & andersonii & \\
\hline
\end{tabular}




\begin{tabular}{|c|c|c|c|c|c|}
\hline \multirow[t]{29}{*}{ Association } & Longevity & $A C O D E$ & Genus & Species & $\%$ Frequency \\
\hline & Annual & ERBR7 & Eriogonum & brachyanthum & \\
\hline & Annual & ERGL4 & Eriogonum & glandulosum & \\
\hline & Perennial & ERNU4 & Eriogonum & nummulare & \\
\hline & Annual & ERTR8 & Eriogonum & trichopes & \\
\hline & Perennial & GIALB & Gilia & aliquanta ssp. Breviloba & \\
\hline & Perennial & GHU & Gilia & hutchinsifolia & \\
\hline & Perennial & GILA2 & Gilia & latifolia & \\
\hline & Perennial & GIOP & Gilia & ophthalmoides & \\
\hline & Perennial & GISC & Gilia & scopulorum & \\
\hline & Perennial & LILE3 & Linum & lewisii & \\
\hline & Perennial & Losc3 & Lomatium & scabrum & \\
\hline & Annual & LUCOO2 & Lupinus & concınnus ssp. orcuttii & \\
\hline & Annual & MECO2 & Mentzelia & congesta & \\
\hline & Annual & MISP & Mimulus & spissus & \\
\hline & Annual & NEGLO & Nemacladus & glanduliferus var. orientalis & \\
\hline & Perennial & ORFA & Orobanche & fasciculata & \\
\hline & Perennial & PEPAB & Penstemon & palmeri & \\
\hline & Annual & PERE & Pectocarya & recunvata & \\
\hline & Annual & PHCU & Phacelia & curvipes & \\
\hline & Annual & PHSA & Phacelia & saxicola & \\
\hline & Annual & PLOV & Plantago & ovata & \\
\hline & Annual & PREX & Prenanthella & exigua & \\
\hline & Annual & SAKAT3 & Salsola & kali ssp. tragus & \\
\hline & Annual & SAPAB & Salsola & paulsenii & \\
\hline & Perennial & SPAMM & Sphaeralcea & ambigua ssp. monticola & \\
\hline & Annual & STM12 & Stylocline & micropoides & \\
\hline & Perennial & THPEB & Thymphylla & pentachaeta var. belenidium & \\
\hline & Annual & TINU2 & Tiquilia & nuttallii & \\
\hline
\end{tabular}

\section{Epiphytes}

Perennial CUDEV Cuscuta

denticulata var. vetchii

\section{Succulents}

$\begin{array}{lcl}\text { Perennial } & \text { YUBR } & \text { Yucca } \\ \text { Perennial } & \text { OPECE } & \text { Opuntia } \\ \text { Perennial } & \text { ECPO2 } & \text { Echinocactus } \\ \text { Perennial } & \text { YUBAV } & \text { Yucca }\end{array}$

brevifolia 


\begin{tabular}{|c|c|c|c|c|c|}
\hline \multirow[t]{13}{*}{ Association } & Longevity & $A C O D E$ & Genus & Species & $\%$ Frequency \\
\hline & Perennial & ECEN & Echinocereus & engelmannii & 13.0 \\
\hline & Perennial & OPBAB2 & Opuntia & basilaris var. basilaris & 8.7 \\
\hline & Perennial & YUSC2 & Yucca & schidigera & 6.2 \\
\hline & Perennial & OPPOR & Opuntia & polyacantha var. rufispina & 4.3 \\
\hline & Perennial & OPERE & Opuntia & eninacea var. erinacea & 4.0 \\
\hline & Perennial & OPPU & Opuntia & pulchella & 2.2 \\
\hline & Perennial & ESVIR2 & Escobaria & vivipara var. rosea & 1.5 \\
\hline & Perennial & ESVID & Escobaria & vivipara var. deserti & 1.2 \\
\hline & Perennial & OPRA & Opuntia & ramosissima & 0.9 \\
\hline & Perennial & SCPO4 & Sclerocactus & polyancistrus & 0.9 \\
\hline & Perennial & MATE4 & Mammillaria & tetrancistra & 0.6 \\
\hline & Perennial & ECENE & Echinocereus & engelmannii var. engelmannii & 0.3 \\
\hline
\end{tabular}

\section{Variable}

Variable ERIOG Eriogonum 
Association Longevity ACODE Genus Species

\% Frequency

Atriplex confertifolia-Kochia americana Shrubland

Tall Shrubs (2-5 $\mathrm{m})$

Perennial LATR2 Larrea

tridentata

Short Shrubs (0.5-2 m)

$\begin{array}{lll}\text { Perennial } & \text { ATCO } & \text { Atriplex } \\ \text { Perennial } & \text { LYAN } & \text { Lycium } \\ \text { Perennial } & \text { KRLA2 } & \text { Krascheninnikovia } \\ \text { Perennial } & \text { ATCAC } & \text { Atriplex } \\ \text { Perennial } & \text { CHVIV2 } & \text { Chrysothamnus } \\ \text { Perennial } & \text { GRSP } & \text { Grayia } \\ \text { Perennial } & \text { HYSA } & \text { Hymenoclea } \\ \text { Perennial } & \text { TEAXA } & \text { Tetradymia } \\ \text { Perennial } & \text { ACSH } & \text { Acamptopappus } \\ \text { Perennial } & \text { EPNE } & \text { Ephedra } \\ \text { Perennial } & \text { AMDU2 } & \text { Ambrosia } \\ \text { Perennial } & \text { LEFR2 } & \text { Lepidium } \\ \text { Perennial } & \text { CORA } & \text { Coleogyne } \\ \text { Perennial } & \text { EPTO } & \text { Ephedra } \\ \text { Perennial } & \text { EPVI } & \text { Ephedra } \\ \text { Perennial } & \text { ERNA7 } & \text { Ericameria } \\ \text { Perennial } & \text { GUSA2 } & \text { Gutierrezia } \\ \text { Perennial } & \text { PSFRF } & \text { Psorothamnus } \\ \text { Perennial } & \text { TECA2 } & \text { Tetradymia } \\ & & \end{array}$

confertifolia
andersonii
lanata
canescens var. canescens
viscidiflorus ssp. viscidiflorus
spinosa
salsola
axillaris var. axillanis
shockleyi
nevadensis
dumosa
fremontii
ramosissima
torreyana
viridis
nanus
sarothrae
fremontii var. fremontii
canescens

100.0

57.9

42.1

36.8

21.1

21.1

21.1

21.1

15.8

15.8

10.5

10.5

\section{Dwarf Shrubs ( $<0.5 \mathrm{~m}$ )}

$\begin{array}{lll}\text { Perennial } & \text { KOAM } & \text { Kochia } \\ \text { Perennial } & \text { ARSP5 } & \text { Artemisia } \\ \text { Perennial } & \text { MESP2 } & \text { Menodora } \\ \text { Perennial } & \text { KRER } & \text { Krameria }\end{array}$

americana
spinescens
spinescens
erecta

\section{Graminoids}

$\begin{array}{lll}\text { Annual } & \text { BRRU2 } & \text { Bromus } \\ \text { Perennial } & \text { ELELE } & \text { Elymus } \\ \text { Perennial } & \text { ACHY } & \text { Achnatherum } \\ \text { Annual } & \text { BRTE } & \text { Bromus }\end{array}$

rubens
elymoides ssp. elymoides
hymenoides
tectorum




$$
\text { Species }
$$

\% Frequency

$\begin{array}{lcl}\text { Annual } & \text { HAGL } & \text { Halogeton } \\ \text { Perennial } & \text { HEMUN } & \text { Heliomeris } \\ \text { Annual } & \text { MEAL6 } & \text { Mentzelia } \\ \text { Perennial } & \text { MIBI8 } & \text { Mirabilis } \\ \text { Annual } & \text { NADED } & \text { Nama } \\ \text { Perennial } & \text { OECEM4 } & \text { Oenothera } \\ \text { Annual } & \text { OXPE2 } & \text { Oxytheca } \\ \text { Perennial } & \text { PHST11 } & \text { Phlox } \\ \text { Annual } & \text { PSAN } & \text { Psathyrotes } \\ \text { Annual } & \text { STEXE } & \text { Stephanomeria }\end{array}$

\section{Succulents}

$\begin{array}{lcl}\text { Perennial } & \text { YUBR } & \text { Yucca } \\ \text { Perennial } & \text { OPBAB2 } & \text { Opuntia } \\ \text { Perennial } & \text { OPECE } & \text { Opuntia } \\ \text { Perennial } & \text { ECEN } & \text { Echinocereus } \\ \text { Perennial } & \text { OPERE } & \text { Opuntia } \\ \text { Perennial } & \text { YUSC2 } & \text { Yucca }\end{array}$

glomeratus
multiflora var. nevadensis
albicaulis
bigelovii
demissum var. demissum
caespitosa ssp. marginata
perfoliata
stansburyi
annua
exigua ssp. exigua

brevifolia
basilaris var. basilaris
echinocarpa var. echinocarpa
engelmannii
eninacea var. erinacea
schidigera


Association Longevity ACODE Genus Species \% Frequency

\section{Atriplex canescens-Krascheninnikovia lanata Shrubland}

\section{Trees (>5 m)}

Perennial JuOS Juniperus

osteosperma

Tall Shrubs (2-5 $\mathrm{m})$

$\begin{array}{lll}\text { Perennial } & \text { ARTRT } & \text { Artemisia } \\ \text { Perennial } & \text { LATR2 } & \text { Larrea }\end{array}$

tridentata ssp. tridentata

Perennial LATR2 Larrea

tridentata

\section{Short Shrubs (0.5-2 m)}

\begin{tabular}{|c|c|c|}
\hline Perennial & ATCAC & Atriplex \\
\hline Perennial & KRLA2 & Krascheninnikovia \\
\hline Perennial & EPNE & Ephedra \\
\hline Perennial & LYAN & Lycium \\
\hline Perennial & GRSP & Grayia \\
\hline Perennial & HYSA & Hymenoclea \\
\hline Perennial & CHVIV2 & Chrysothamnus \\
\hline Perennial & ATCO & Atriplex \\
\hline Perennial & $\mathrm{ACSH}$ & Acamptopappus \\
\hline Perennial & CORA & Coleogyne \\
\hline Perennial & TECA2 & Tetradymia \\
\hline Perennial & TEAXA & Tetradymia \\
\hline Perennial & LYSH & Lycium \\
\hline Perennial & STPIP & Stanleya \\
\hline Perennial & AMDU2 & Ambrosia \\
\hline Perennial & EPTO & Ephedra \\
\hline Perennial & ERNAH & Ericameria \\
\hline Perennial & LEFR2 & Lepidium \\
\hline Perennial & LYPAO & Lycium \\
\hline Perennial & PSFRF & Psorothamnus \\
\hline Perennial & ENVIV & Encelia \\
\hline Perennial & EPVI & Ephedra \\
\hline Perennial & ERCO23 & Ericameria \\
\hline Perennial & ERFAP & Eriogonum \\
\hline Perennial & ERNAL & Ericameria \\
\hline Perennial & ERTE18 & Ericameria \\
\hline Perennial & PSPO & Psorothamnus \\
\hline
\end{tabular}

\begin{tabular}{|c|c|}
\hline canescens var. canescens & 100.0 \\
\hline lanata & 60.5 \\
\hline nevadensis & 52.6 \\
\hline andersonii & 52.6 \\
\hline spinosa & 47.4 \\
\hline salsola & 42.1 \\
\hline viscidiflorus ssp. viscidiflorus & 28.9 \\
\hline confertifolia & 21.1 \\
\hline shockleyi & 15.8 \\
\hline ramosissima & 13.2 \\
\hline canescens & 13.2 \\
\hline axillaris var. axillaris & 10.5 \\
\hline shockleyi & 7.9 \\
\hline pinnata var. pinnata & 7.9 \\
\hline dumosa & 5.3 \\
\hline torreyana & 5.3 \\
\hline $\begin{array}{l}\text { nauseosus ssp. nauseosus var. } \\
\text { hololeuca }\end{array}$ & 5.3 \\
\hline fremontii & 5.3 \\
\hline pallidum var. oligospermum & 5.3 \\
\hline fremontii var. fremontii & 5.3 \\
\hline virginensis var. virginensis & 2.6 \\
\hline viridıs & 2.6 \\
\hline cooperi & 2.6 \\
\hline fasciculatum var. polifolium & 2.6 \\
\hline nauseosus ssp. consimilis var. leiosperma & 2.6 \\
\hline teretifolia & 2.6 \\
\hline polydenius & 2.6 \\
\hline
\end{tabular}




\begin{tabular}{cccl} 
Association & Longevity & ACODE & \multicolumn{1}{c}{ Genus } \\
& Perennial & PUGL2 & Purshia \\
Perennial & PUST & Purshia \\
Perennial & SAME & Salazaria \\
Perennial & SYLO & Symphoricarpos \\
Perennial & THMO & Thamnosma
\end{tabular}

$$
\text { Species }
$$

glandulosa

stansburiana

mexicana

longiflorus

montana

spinescens

28.9

Perennial

$$
\text { ARSP5 Artemisia }
$$

Perennial

KOAM Kochia

Perennial

MESP2 Menodora

Perennial

KRER Krameria

\section{Graminoids}

$\begin{array}{lll}\text { Perennial } & \text { ACHY } & \text { Achnatherum } \\ \text { Annual } & \text { BRRU2 } & \text { Bromus } \\ \text { Annual } & \text { BRTE } & \text { Bromus } \\ \text { Perennial } & \text { ELELE } & \text { Elymus } \\ \text { Perennial } & \text { ACSP12 } & \text { Achnatherum } \\ \text { Perennial } & \text { PLJA } & \text { Pleuraphis } \\ \text { Perennial } & \text { ERPU8 } & \text { Erioneuron } \\ \text { Perennial } & \text { POSE } & \text { Poa } \\ \text { Perennial } & \text { LECI4 } & \text { Leymus } \\ \text { Perennial } & \text { POFE } & \text { Poa } \\ \text { Annual } & \text { VUOC } & \text { Vulpia }\end{array}$

\section{Forbs}

$\begin{array}{lrl}\text { Annual } & \text { AMTE3 } & \text { Amsinckia } \\ \text { Annual } & \text { CHST } & \text { Chaenactis } \\ \text { Perennial } & \text { SPAMA } & \text { Sphaeralcea } \\ \text { Perennial } & \text { MIPU5 } & \text { Mirabilis } \\ \text { Annual } & \text { ERDE6 } & \text { Eriogonum } \\ \text { Perennial } & \text { MACAC } & \text { Machaeranthera } \\ \text { Biennial } & \text { SIAL2 } & \text { Sisymbrium } \\ \text { Annual } & \text { ERCI6 } & \text { Erodium } \\ \text { Perennial } & \text { CHAL11 } & \text { Chamaesyce } \\ \text { Annual } & \text { SAPA8 } & \text { Salsola } \\ \text { Perennial } & \text { HEMUN } & \text { Heliomeris }\end{array}$

americana

spinescens

erecta
10.5

hymenoides $\quad 81.6$

rubens $\quad 71.1$

tectorum $\quad 44.7$

elymoides ssp. elymoides $\quad 36.8$

speciosum $\quad 31.6$

jamesii $\quad 15.8$

pulchellum $\quad 7.9$

secunda $\quad 5.3$

cinereus $\quad 2.6$

fendleriana $\quad 2.6$

octofiora $\quad 2.6$

$\begin{array}{ll}\text { tessellata } & 71.1 \\ \text { stevioides } & 50.0 \\ \text { ambigua ssp. ambigua } & 44.7 \\ \text { pudica } & 42.1 \\ \text { deflexum } & 39.5 \\ \text { canescens ssp. canescens } & 39.5 \\ \text { altissimum } & 23.7 \\ \text { cicutarium } & 21.1 \\ \text { albomarginata } & 18.4 \\ \text { paulsenii } & 15.8 \\ \text { multiflora var. nevadensis } & 13.2\end{array}$




\begin{tabular}{|c|c|c|}
\hline Annual & MEOB3 & Mentzelia \\
\hline Annual & ASLEF2 & Astragalus \\
\hline Annual & ERER2 & Eriastrum \\
\hline Perennial & ERIN4 & Eriogonum \\
\hline Annual & ERNI4 & Eriogonum \\
\hline Annual & ERPR4 & Eriophyllum \\
\hline Annual & MAGL3 & Malacothrix \\
\hline Perennial & MIBI8 & Mirabilis \\
\hline Annual & OXPE2 & Oxytheca \\
\hline Annual & CHRI & Chorizanthe \\
\hline Annual & CRMI & Cryptantha \\
\hline Perennial & OECEM4 & Oenothera \\
\hline Annual & STEXE & Stephanomeria \\
\hline Perennial & BAMU & Baileya \\
\hline Perennial & CAFL & Calochortus \\
\hline Annual & CRPT & Cryptantha \\
\hline Perennial & DEPAP 3 & Delphinium \\
\hline Annual & DEPIG & Descurainia \\
\hline Perennial & GIBRB & Gilia \\
\hline Perennial & GIIN2 & Gilia \\
\hline Annual & LELA & Lepidium \\
\hline Annual & MEAL6 & Mentzelia \\
\hline Annual & MISP & Mimulus \\
\hline Annual & PHCRC3 & Phacelia \\
\hline Annual & PHFR2 & Phacelia \\
\hline Perennial & POSU & Polygala \\
\hline Annual & SAKAT3 & Salsola \\
\hline Perennial & ARDR4 & Artemisia \\
\hline Perennial & ARME2 & Arctomecon \\
\hline Annual & ASAC3 & Astragalus \\
\hline Perennial & ASCA14 & Astragalus \\
\hline Perennial & ASPUT & Astragalus \\
\hline Perennial & CAAP4 & Castilleja \\
\hline Annual & CAKEG & Camissonia \\
\hline Annual & CAPA7 & Calycoseris \\
\hline Annual & CETH3 & Centrostegia \\
\hline
\end{tabular}

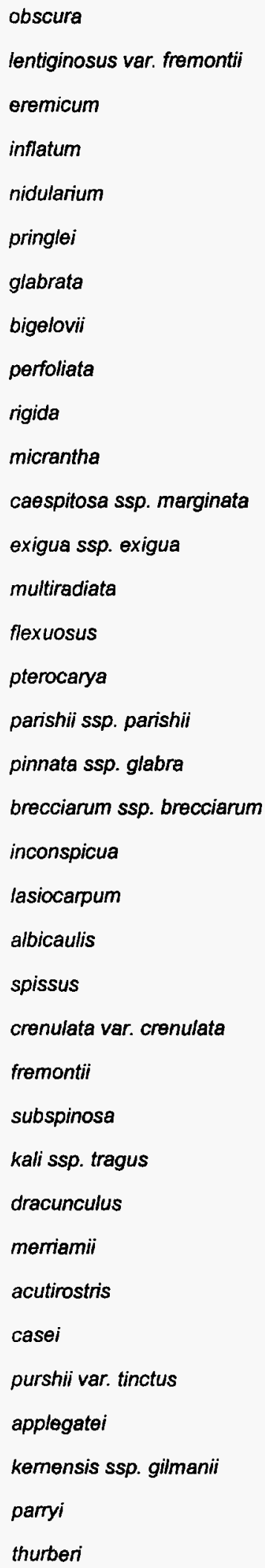




\section{Species}

\% Frequency

\begin{tabular}{|c|c|c|}
\hline Annual & CHAL7 & Chenopodium \\
\hline Annual & CHBRB & Chorizanthe \\
\hline Annual & CHFR & Chaenactis \\
\hline Annual & CHMA & Chaenactis \\
\hline Annual & $\mathrm{CRCl} 2$ & Cryptantha \\
\hline Perennial & CRCO12 & Cryptantha \\
\hline Perennial & CRUT & Cryptantha \\
\hline Perennial & CRVI5 & Cryptantha \\
\hline Perennial & ERCOC3 & Erigeron \\
\hline Annual & ERPU6 & Eriogonum \\
\hline Annual & ESGL & Eschscholzia \\
\hline Annual & HAGL & Halogeton \\
\hline Annual & IPPO2 & Ipomopsis \\
\hline Perennial & LILE3 & Linum \\
\hline Annual & LUBR2 & Lupinus \\
\hline Annual & LUSH & Lupinus \\
\hline Annual & MEVE5 & Mentzelia \\
\hline Annual & OEPR & Oenothera \\
\hline Perennial & PHST11 & Phlox \\
\hline Annual & PLPA2 & Plantago \\
\hline Annual & SACOC & Salvia \\
\hline Perennial & SPAMM & Sphaeralcea \\
\hline Perennial & SPGRP2 & Sphaeralcea \\
\hline Perennial & STPA4 & Stephanomeria \\
\hline Annual & SYFR & Syntric \\
\hline Annua & URLI2 & Uropappus \\
\hline
\end{tabular}

\section{Succulents}

$\begin{array}{lcl}\text { Perennial } & \text { YUBR } & \text { Yucca } \\ \text { Perennial } & \text { OPECE } & \text { Opuntia } \\ \text { Perennial } & \text { OPBAB2 } & \text { Opuntia } \\ \text { Perennial } & \text { YUSC2 } & \text { Yucca } \\ \text { Perennial } & \text { ECEN } & \text { Echinocereus } \\ \text { Perennial } & \text { ECPO2 } & \text { Echinocactus } \\ \text { Perennial } & \text { ESVIR2 } & \text { Escobaria }\end{array}$

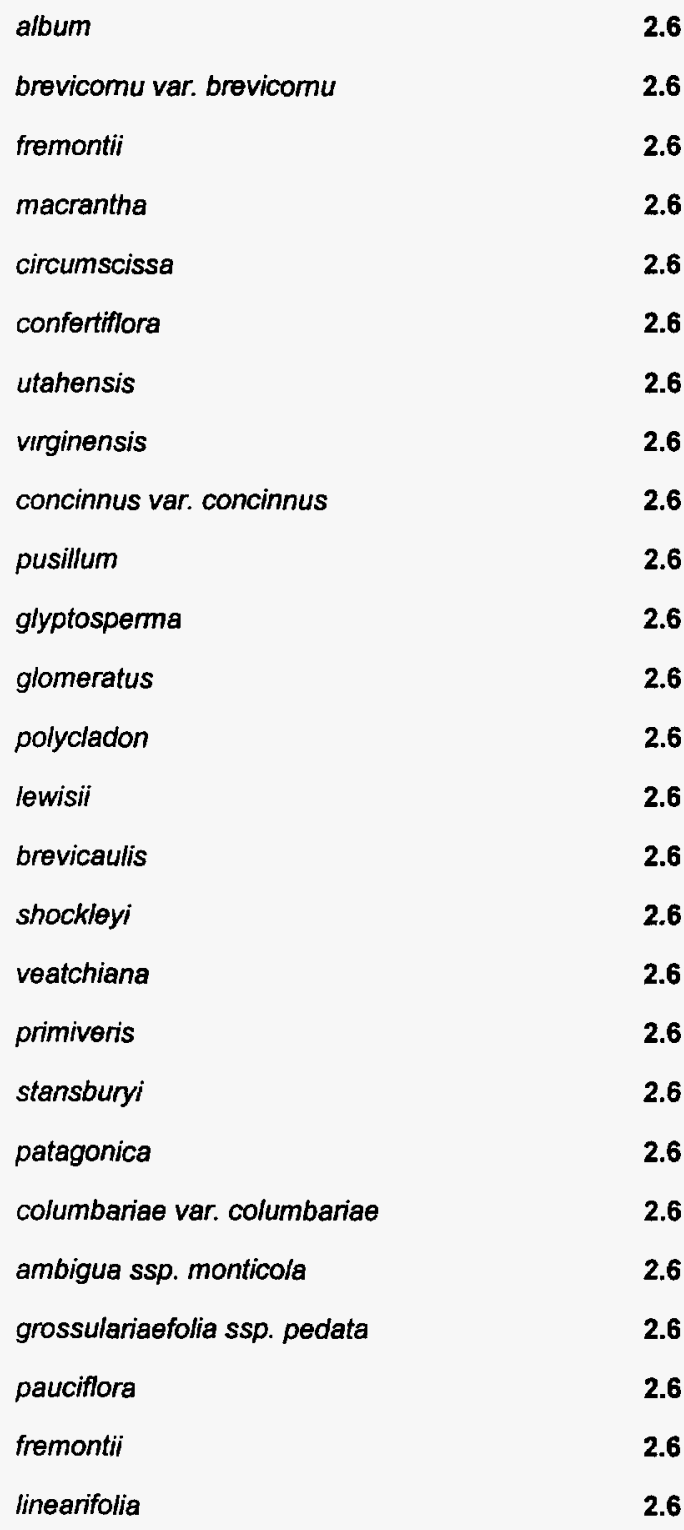

brevifolia

26.3

echinocarpa var. echinocarpa 18.4

basilaris var. basilaris

5.3

schidigera

5.3

engelmannii

polycephalus

vivipara var. rosea

\section{6} 6 .6 .6 2.6 6 2.6 .6 .6 2.6 .6 .6 .6 2.6 2.6 .6 2.6 .6 .6 2.6 2.6 6 2.6 2.6 6 2.6 
Association Longevity ACODE Genus

$\begin{array}{lll}\text { Perennial } & \text { OPPOR } & \text { Opuntia } \\ \text { Perennial } & \text { SCPO4 } & \text { Sclerocactus } \\ \text { Perennial } & \text { YUBAV } & \text { Yucca }\end{array}$

\section{Species}

polyacantha var. rufispina

polyancistrus

baccata var. vespertina
$\%$ Frequency

2.6

2.6

2.6 
Association Longevity ACODE Genus Species

$\%$ Frequency

\section{Chrysothamnus viscidiflorus-Ephedra nevadensis Shrubland}

Trees (>5 m)

$\begin{array}{lll}\text { Perennial } & \text { PIMO } & \text { Pinus } \\ \text { Perennial } & \text { JUOS } & \text { Juniperus } \\ \text { Perennial } & \text { QUGA } & \text { Quercus }\end{array}$

monophylla

osteosperma

2.6

gambelii

Tall Shrubs (2-5 m)

$\begin{array}{lll}\text { Perennial } & \text { ARTRT } & \text { Artemisia } \\ \text { Perennial } & \text { LATR2 } & \text { Larrea }\end{array}$

tridentata ssp. tridentata

Perennial

LATR2 Larrea

tridentata

\section{Short Shrubs (0.5-2 m)}

\begin{tabular}{|c|c|c|}
\hline Perennial & CHVIV2 & Chrysothamnus \\
\hline Perennial & EPNE & Ephedra \\
\hline Perennial & KRLA2 & Krascheninnikovia \\
\hline Perennial & LYAN & Lycium \\
\hline Perennial & GRSP & Grayia \\
\hline Perennial & ATCAC & Atriplex \\
\hline Perennial & CORA & Coleogyne \\
\hline Perennial & ATCO & Atriplex \\
\hline Perennial & HYSA & Hymenoclea \\
\hline Perennial & STPIP & Stanleya \\
\hline Perennial & TECA2 & Tetradymia \\
\hline Perennial & TEAXA & Tetradymia \\
\hline Perennial & ERCO23 & Ericameria \\
\hline Perennial & LEFR2 & Lepidium \\
\hline Perennial & EPVI & Ephedra \\
\hline Perennial & GUSA2 & Gutierrezia \\
\hline Perennial & AMDU2 & Ambrosia \\
\hline Perennial & ERNAH & Ericameria \\
\hline Perennial & SYLO & Symphoricarpos \\
\hline Perennial & ARNO4 & Artemisia \\
\hline Perennial & ERMIS2 & Eriogonum \\
\hline Perennial & ERTE18 & Ericameria \\
\hline Perennial & $\mathrm{ACSH}$ & Acamptopappus \\
\hline Perennial & PUGL2 & Purshia \\
\hline Perennial & THMO & Thamnosma \\
\hline
\end{tabular}

viscidiflorus ssp. viscidiflorus
nevadensis
lanata
andersonii
spinosa
canescens var. canescens
ramosissima
confertifolia
salsola
pinnata var. pinnata
canescens
axillaris var. axillaris
cooperi
fremontii
viridis
sarothrae
dumosa
nauseosus ssp. nauseosus var.
hololeuca
longiflorus
nova
microthecum var. simpsonii
teretifolia
shockleyi
glandulosa
montana




$\begin{array}{lcl}\text { Perennial } & \text { ENVIV } & \text { Encelia } \\ \text { Perennial } & \text { ERNAL } & \text { Ericameria } \\ \text { Perennial } & \text { PSPO } & \text { Psorothamnus } \\ \text { Perennial } & \text { ERFAP } & \text { Eriogonum } \\ \text { Perennial } & \text { PSFRF } & \text { Psorothamnus } \\ \text { Perennial } & \text { PUST } & \text { Purshia } \\ \text { Perennial } & \text { TEGL } & \text { Tetradymia } \\ \text { Perennial } & \text { CHVIP4 } & \text { Chrysothamnus } \\ \text { Perennial } & \text { ERNA10 } & \text { Ericameria } \\ \text { Perennial } & \text { SAME } & \text { Salazaria } \\ \text { Perennial } & \text { ERL16 } & \text { Ericameria } \\ \text { Perennial } & \text { LYPAO } & \text { Lycium } \\ \text { Perennial } & \text { PUTR2 } & \text { Purshia } \\ \text { Perennial } & \text { BRMIS } & \text { Brickellia } \\ \text { Perennial } & \text { BRMIW } & \text { Brickellia } \\ \text { Perennial } & \text { BROBL } & \text { Brickellia } \\ \text { Perennial } & \text { CHGR6 } & \text { Chrysothamnus } \\ \text { Perennial } & \text { SADOD3 } & \text { Salvia } \\ \text { Perennial } & \text { STEL } & \text { Stanleya } \\ & & \end{array}$

$\begin{array}{ll}\text { virginensis var. virginensis } & 7.9 \\ \text { nauseosus ssp. consimilis var. leiosperma } & 7.9 \\ \text { polydenius } & 7.9 \\ \text { fasciculatum var. polifolium } & 6.6 \\ \text { fremontii var. fremontii } & 6.6 \\ \text { stansburiana } & 6.6 \\ \text { glabrata } & 6.6 \\ \text { viscidiflorus ssp. puberulus } & 5.3 \\ \text { nauseosus } & 3.9 \\ \text { mexicana } & 3.9 \\ \text { linearifolius } & 2.6 \\ \text { pallidum var. oligospermum } & 2.6 \\ \text { tridentata } & 2.6 \\ \text { microphylla var. scabra } & 1.3 \\ \text { microphylla var. watsonii } & 1.3 \\ \text { oblongifolia var. linifolia } & 1.3 \\ \text { greenei } & 1.3 \\ \text { dorii ssp. domii var. dorrii } & 1.3 \\ \text { elata } & 1.3\end{array}$

\section{Dwarf Shrubs ( $<0.5 \mathrm{~m})$}

$\begin{array}{lll}\text { Perennial } & \text { ARSP5 } & \text { Artemisia } \\ \text { Perennial } & \text { MESP2 } & \text { Menodora } \\ \text { Perennial } & \text { LEPU } & \text { Leptodactylon } \\ \text { Perennial } & \text { KOAM } & \text { Kochia } \\ \text { Perennial } & \text { KRER } & \text { Krameria }\end{array}$

$\begin{array}{lr}\text { spinescens } & 51.3 \\ \text { spinescens } & 14.5 \\ \text { pungens } & 7.9 \\ \text { americana } & 5.3 \\ \text { erecta } & 2.6\end{array}$

\section{Graminoids}

$\begin{array}{lcl}\text { Annual } & \text { BRRU2 } & \text { Bromus } \\ \text { Perennial } & \text { ACHY } & \text { Achnatherum } \\ \text { Perennial } & \text { ELELE } & \text { Elymus } \\ \text { Perennial } & \text { ACSP12 } & \text { Achnatherum } \\ \text { Perennial } & \text { PLJA } & \text { Pleuraphis } \\ \text { Annual } & \text { BRTE } & \text { Bromus } \\ \text { Perennial } & \text { POSE } & \text { Poa } \\ \text { Perennial } & \text { ARPU9 } & \text { Aristida } \\ \text { Perennial } & \text { HECOC8 } & \text { Hesperostipa }\end{array}$

rubens
hymenoides
elymoides ssp. elymoides
speciosum
jamesii
tectorum
secunda
purpurea
comata ssp. comata




$\begin{array}{clll}\text { Association } & \text { Longevity } & \text { ACODE } & \text { Genus } \\ & \text { Perennial } & \text { ERPUB } & \text { Erioneuron } \\ \text { Annual } & \text { VUOC } & \text { Vulpia } \\ \text { Perennial } & \text { ACPI2 } & \text { Achnatherum } \\ \text { Perennial } & \text { BOGR2 } & \text { Bouteloua } \\ \text { Annual } & \text { BRBE2 } & \text { Bromus } \\ \text { Perennial } & \text { KOMA } & \text { Koeleria } \\ \text { Perennial } & \text { POFE } & \text { Poa } \\ \text { Perennial } & \text { SPCR } & \text { Sporobolus }\end{array}$

\begin{tabular}{lr}
\multicolumn{1}{l}{ Species } & \% Frequency \\
pulchellum & 5.3 \\
octoflora & 2.6 \\
pinetorum & 1.3 \\
gracilis & 1.3 \\
berterianus & 1.3 \\
macrantha & 1.3 \\
fendleriana & 1.3 \\
cryptandrus & 1.3
\end{tabular}

\section{Forbs}

\begin{tabular}{|c|c|c|}
\hline Perennial & SPAMA & Sphaeralcea \\
\hline Annual & CHST & Chaenactis \\
\hline Annual & AMTE3 & Amsinckia \\
\hline Perennial & CAAP4 & Castilleja \\
\hline Perennial & DEPAP3 & Delphinium \\
\hline Perennial & MACAC & Machaeranthera \\
\hline Annual & PHFR2 & Phacelia \\
\hline Annual & ASLEF2 & Astragalus \\
\hline Annual & CRPT & Cryptantha \\
\hline Perennial & GIBRB & Gilia \\
\hline Annual & $\mathrm{CRCl} 2$ & Cryptantha \\
\hline Perennial & ERIN4 & Eriogonum \\
\hline Annual & ERER2 & Eniastrum \\
\hline Annual & LELA & Lepidium \\
\hline Perennial & CHAL11 & Chamaesyce \\
\hline Perennial & ERCOC3 & Erigeron \\
\hline Perennial & CAFL & Calochortus \\
\hline Annual & DEPIG & Descurainia \\
\hline Annual & ERCI6 & Erodium \\
\hline Annual & ERNI4 & Eriogonum \\
\hline Annual & MEAL6 & Mentzelia \\
\hline Perennial & ARPUM & Arabis \\
\hline Perennial & PHST11 & Phlox \\
\hline Annual & SYFR & Syntrichopappus \\
\hline Annual & IPPO2 & Ipomopsis \\
\hline Annual & PHVAV2 & Phacelia \\
\hline Perennial & CRVI5 & Cryptantha \\
\hline
\end{tabular}

ambigua ssp. ambigua
stevioides
tessellata
applegatei
parishii ssp. parishii
canescens ssp. canescens
fremontii
lentiginosus var. fremontii
pterocarya
brecciarum ssp. brecciarum
circumscissa
inflatum
eremicum
lasiocarpum
albomarginata
concinnus var. concinnus
flexuosus
pinnata ssp. glabra
cicutarium
nidularium
albicaulis
pulchra var. munciensis
stansburyi
fremontii
polycladon
vallis-mortae var. vallis-mortae




\begin{tabular}{|c|c|c|c|}
\hline \multirow[t]{37}{*}{ Association } & Longevity & $A C O D E$ & Genus \\
\hline & Annual & CRNEN & Cryptantha \\
\hline & Perennial & HEMUN & Heliomeris \\
\hline & Perennial & EROVO5 & Eriogonum \\
\hline & Perennial & LILE3 & Linum \\
\hline & Perennial & MIBI8 & Mirabilis \\
\hline & Annual & OXPE2 & Oxytheca \\
\hline & Annual & ERDE6 & Eriogonum \\
\hline & Annual & LUBR2 & Lupinus \\
\hline & Annual & PLPA2 & Plantago \\
\hline & Annual & CETH3 & Centrostegia \\
\hline & Annual & PESE & Pectocarya \\
\hline & Annual & PHCRC3 & Phacelia \\
\hline & Annual & CRMI & Cryptantha \\
\hline & Perennial & CRUT & Cryptantha \\
\hline & Perennial & DIPU3 & Dichelostemma \\
\hline & Annual & MEOB3 & Mentzelia \\
\hline & Perennial & OECEM4 & Oenothera \\
\hline & Perennial & SEMU3 & Senecio \\
\hline & Perennial & ASPUT & Astragalus \\
\hline & Annual & CAPT & Camissonia \\
\hline & Biennial & CINE & Cirsium \\
\hline & Annual & LOSC6 & Loeseliastrum \\
\hline & Annual & LUSH & Lupinus \\
\hline & Annual & MAGL3 & Malacothrix \\
\hline & Perennial & MIPU5 & Mirabilis \\
\hline & Perennial & OEPAP & Oenothera \\
\hline & Perennial & ARMA3 & Arenaria \\
\hline & Perennial & ARPUG & Arabis \\
\hline & Annual & CABRB4 & Camissonia \\
\hline & Perennial & CRCO12 & Cryptantha \\
\hline & Perennial & CYRI2 & Cymopterus \\
\hline & Annual & ERPR4 & Eriophyllum \\
\hline & Annual & LOHU2 & Lotus \\
\hline & Annual & MEVE5 & Mentzelia \\
\hline & Annual & MISP & Mimulus \\
\hline & Annual & MOBE & Monoptilon \\
\hline
\end{tabular}

\begin{tabular}{lr}
\multicolumn{1}{c}{ Species } & \% Frequency \\
nevadensis var. nevadensis & 13.2 \\
multiflora var. nevadensis & 13.2 \\
ovalifolium var. ovalifolium & 11.8 \\
lewisii & 11.8 \\
bigelovii & 11.8 \\
perfoliata & 11.8 \\
deflexum & 10.5 \\
brevicaulis & 10.5 \\
patagonica & 10.5
\end{tabular}




\begin{tabular}{|c|c|c|}
\hline Perennial & POSU & Polygala \\
\hline Biennial & SIAL2 & Sisymbrium \\
\hline Perennial & XYTOT & Xylomiza \\
\hline Perennial & ASCAC5 & Astragalus \\
\hline Annual & CABOI & Camissonia \\
\hline Annual & CAPA7 & Calycoseris \\
\hline Annual & $\mathrm{CHRI}$ & Chorizanthe \\
\hline Annual & CRRE5 & Cryptantha \\
\hline Perennial & CYGL2 & Cymopterus \\
\hline Annual & ERDI4 & Erigeron \\
\hline Perennial & ERNU4 & Eriogonum \\
\hline Annual & LASE3 & Langioisia \\
\hline Annual & NAPU & Nama \\
\hline Annual & SAPAB & Salsola \\
\hline Annual & STEXE & Stephanomeria \\
\hline Perennial & ABEL & Abronia \\
\hline Perennial & ABTU & Abronia \\
\hline Annual & AMAC2 & Ambrosia \\
\hline Annual & ANAC & Anisocoma \\
\hline Perennial & ARIN & Arabis \\
\hline Annual & ASAC3 & Astraga/us \\
\hline Annual & CACLI & Camissonia \\
\hline Annual & CAKEG & Camissonia \\
\hline Perennial & CAPl4 & Caulanthus \\
\hline Annual & CHFR & Chaenactis \\
\hline Perennial & CRFL6 & Cryptantha \\
\hline Annual & CRGR3 & Cryptantha \\
\hline Perennial & DASE3 & Dalea \\
\hline Perennial & ERSA6 & Eniogonum \\
\hline Annual & ERSP3 & Eniastrum \\
\hline Perennial & ERUM & Eriogonum \\
\hline Annual & GILIA & Gilia \\
\hline Perennial & HUVEI & Hulsea \\
\hline Annual & LAOCO & Lappula \\
\hline Annual & LIDI2 & Linanthus \\
\hline Perennial & ONEN & Lomatium \\
\hline
\end{tabular}

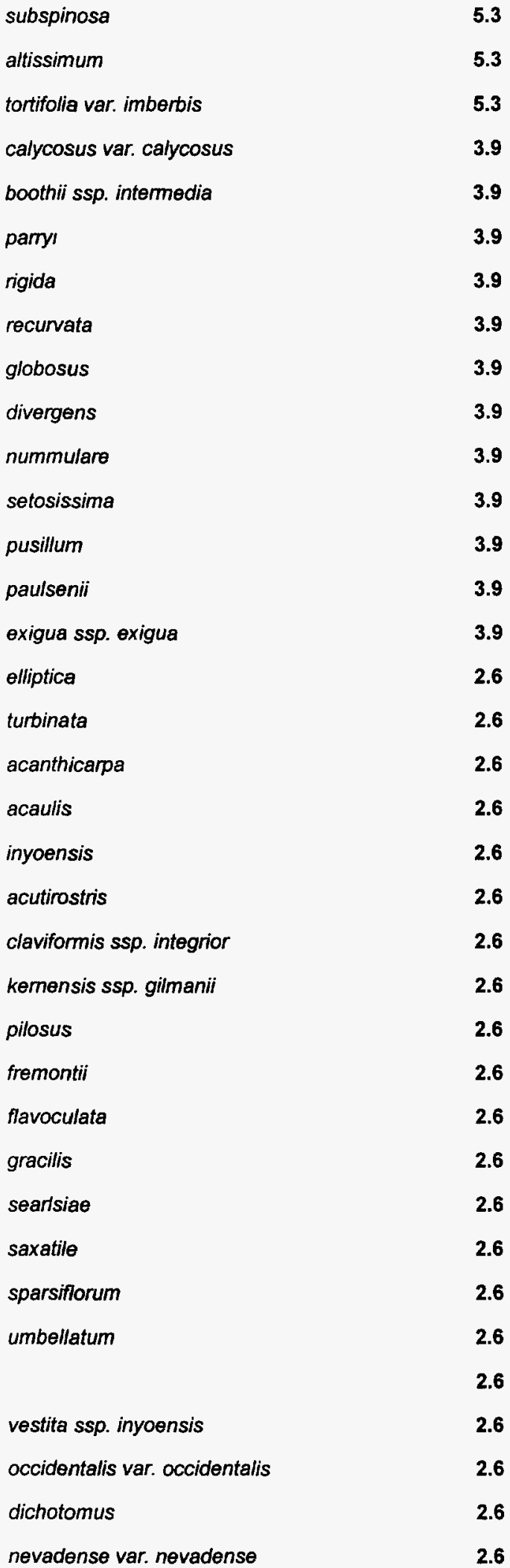




\begin{tabular}{|c|c|c|c|c|c|}
\hline \multirow[t]{37}{*}{ Association } & Longevity & $A C O D E$ & Genus & Species & $n c y$ \\
\hline & Annual & MASO & Malacothrix & sonchoides & 2.6 \\
\hline & Annual & RANE & Rafinesquia & neomexicana & 2.6 \\
\hline & Annual & SACOC & Salvia & columbariae var. columbariae & 2.6 \\
\hline & Perennial & SPAMR & Sphaeralcea & ambiguua var. rugosa & 2.6 \\
\hline & Annual & STLO4 & Streptanthella & longirostris & 2.6 \\
\hline & Perennial & STPA3 & Stephanomeria & parryi & 2.6 \\
\hline & Perennial & STPA4 & Stephanomeria & pauciflora & 2.6 \\
\hline & Annual & URLI2 & Uropappus & linearifolia & 2.6 \\
\hline & Perennial & ADCO2 & Adenophyllum & cooperi & 1.3 \\
\hline & Perennial & ANDI2 & Antennaria & dimorpha & 1.3 \\
\hline & Perennial & ARCOS2 & Arenaria & congesta var. subcongesta & 1.3 \\
\hline & Perennial & ASFU3 & Astragalus & funereus & 1.3 \\
\hline & Perennial & BAMU & Baileya & multiradiata & 1.3 \\
\hline & Annual & BAPL3 & Baileya & pleniradiata & 1.3 \\
\hline & Perennial & BRAT & Brickellia & atractyloides & 1.3 \\
\hline & Perennial & CALI4 & Castilleja & linariaefolia & 1.3 \\
\hline & Annual & CAME16 & Camissonia & megalantha & 1.3 \\
\hline & Annual & CARE2 & Camissonia & refracta & 1.3 \\
\hline & Perennial & CHER2 & Leucelene & ericoides & 1.3 \\
\hline & Annual & CHMA & Chaenactis & macrantha & 1.3 \\
\hline & Annual & CHSES & Chamaesyce & serpyllifolia ssp. serpyllifolia & 1.3 \\
\hline & Annual & CHWA2 & Chorizanthe & watsonii & 1.3 \\
\hline & Annual & ERHO6 & Eriogonum & hookeri & 1.3 \\
\hline & Annual & ERPU6 & Eriogonum & pusillum & 1.3 \\
\hline & Perennial & ERRA3 & Eriogonum & racemosum & 1.3 \\
\hline & Annual & ERTH & Eriogonum & thomasii & 1.3 \\
\hline & Perennial & GIIN2 & Gilia & inconspicua & 1.3 \\
\hline & Perennial & GIOP & Gilia & ophthalmoides & 1.3 \\
\hline & Perennial & GISI & Gilia & sinuata & 1.3 \\
\hline & Perennial & LUARL5 & Lupinus & argenteus ssp. artenteus var. laxiflorus & 1.3 \\
\hline & Annual & LUFL & Lupinus & flavoculatus & 1.3 \\
\hline & Annual & MISU2 & Mimulus & suksdorfii & 1.3 \\
\hline & Annual & NADED & Nama & demissum var. demissum & 1.3 \\
\hline & Perennial & ORFA & Orobanche & fasciculata & 1.3 \\
\hline & Perennial & PEFLA2 & Penstemon & floridus var. austinii & 1.3 \\
\hline & Perennial & PEHUH & Penstemon & humilis ssp. humilis & 1.3 \\
\hline
\end{tabular}




\section{Species}

pahutensis

platycarpa

chambersii

hoodii ssp. lanata

saxicola

kali ssp. tragus

verecunda ssp. andersonii

ambigua ssp. monticola

grossulariaefolia ssp. pedata

cordatus var. cordatus

spinosa
1.3

1.3

1.3

1.3

1.3

1.3

1.3

1.3

1.3

1.3

46.1

brevifolia

35.5

echinocarpa var. echinocarpa

13.2

basilaris var. basilaris

11.8

engelmannii

11.8

erinacea var. erinacea

7.9

polyancistrus

6.6

polycephalus

5.3

polyacantha var. rufispina

5.3

baccata var. vespertina

1.3 


\section{Ericameria nauseosa-Ephedra nevadensis Shrubland}

Trees (>5 m)

$\begin{array}{lll}\text { Perennial } & \text { JUOS } & \text { Juniperus } \\ \text { Perennial } & \text { PIMO } & \text { Pinus }\end{array}$

\section{Tall Shrubs (2-5 m)}

$\begin{array}{lll}\text { Perennial } & \text { ARTRT } & \text { Artemisia } \\ \text { Perennial } & \text { AMUT } & \text { Amelanchier }\end{array}$

tridentata ssp. tridentata

Perennial AMUT Amelanchier

utahensis

\section{Short Shrubs (0.5-2 m)}

\begin{tabular}{|c|c|c|}
\hline Perennial & ERNAH & Ericameria \\
\hline Perennial & EPNE & Ephedra \\
\hline Perennial & ATCAC & Atriplex \\
\hline Perennial & CHVIV2 & Chrysothamnus \\
\hline Perennial & CORA & Coleogyne \\
\hline Perennial & EPVI & Ephedra \\
\hline Perennial & LYAN & Lycium \\
\hline Perennial & ERLI6 & Ericameria \\
\hline Perennial & ERNAL & Ericameria \\
\hline Perennial & ERTE18 & Ericameria \\
\hline Perennial & PUST & Purshia \\
\hline Perennial & PUGL2 & Purshia \\
\hline Perennial & ERCO23 & Ericameria \\
\hline Perennial & GUSA2 & Gutierrezia \\
\hline Perennial & CHVIP4 & Chrysothamnus \\
\hline Perennial & ENVIV & Encelia \\
\hline Perennial & GRSP & Grayia \\
\hline Perennial & HYSA & Hymenoclea \\
\hline Perennial & KRLA2 & Krascheninnikovia \\
\hline Perennial & PSPO & Psorothamnus \\
\hline Perennial & SAME & Salazaria \\
\hline Perennial & AMDU2 & Ambrosia \\
\hline Perennial & ARNO4 & Artemisia \\
\hline Perennial & ERMIS2 & Eriogonum \\
\hline Perennial & ERNA7 & Ericameria \\
\hline Perennial & HODI & Holodiscus \\
\hline
\end{tabular}

\begin{tabular}{|c|c|}
\hline $\begin{array}{l}\text { nausøosus ssp. nauseosus var. } \\
\text { hololeuca } \\
\text { nevadensis }\end{array}$ & $\begin{array}{r}100.0 \\
66.7\end{array}$ \\
\hline canescens var. canescens & 57.1 \\
\hline viscidiflorus ssp. viscidiflorus & 47.6 \\
\hline ramosissima & 42.9 \\
\hline viridis & 42.9 \\
\hline andersonii & 33.3 \\
\hline linearifolius & 23.8 \\
\hline nauseosus ssp. consimilis var. leiosperma & 23.8 \\
\hline teretifolia & 23.8 \\
\hline stansburiana & 23.8 \\
\hline glandulosa & 19.0 \\
\hline cooperi & 14.3 \\
\hline sarothrae & 14.3 \\
\hline viscidiflorus ssp. puberulus & 9.5 \\
\hline virginensis var. virginensis & 9.5 \\
\hline spinosa & 9.5 \\
\hline salsola & 9.5 \\
\hline lanata & 9.5 \\
\hline polydenius & 9.5 \\
\hline mexicana & 9.5 \\
\hline dumosa & 4.8 \\
\hline nova & 4.8 \\
\hline microthecum var. simpsonii & 4.8 \\
\hline nanus & 4.8 \\
\hline discolor & 4.8 \\
\hline
\end{tabular}

Thursday, September 09, 1999 


\section{Association Longevity ACODE Genus}

$\begin{array}{lll}\text { Perennial } & \text { LEFR2 } & \text { Lepidium } \\ \text { Perennial } & \text { PRFA } & \text { Prunus } \\ \text { Perennial } & \text { PUTR2 } & \text { Purshia } \\ \text { Perennial } & \text { RIVEV } & \text { Ribes } \\ \text { Perennial } & \text { STPIP } & \text { Stanleya } \\ \text { Perennial } & \text { SYLO } & \text { Symphoricarpos } \\ \text { Perennial } & \text { TEAXA } & \text { Tetradymia }\end{array}$

fremontii
fasciculata
tridentata
velutinum var. velutinum
pinnata var. pinnata
longifiorus
axillanis var. axillaris

\section{Dwarf Shrubs (<0.5 m)}

Perennial LEPU Leptodactylon

pungens

\section{Graminoids}

$\begin{array}{lcl}\text { Perennial } & \text { ACHY } & \text { Achnatherum } \\ \text { Annual } & \text { BRTE } & \text { Bromus } \\ \text { Perennial } & \text { ELELE } & \text { Elymus } \\ \text { Perennial } & \text { ACSP12 } & \text { Achnatherum } \\ \text { Annual } & \text { BRRU2 } & \text { Bromus } \\ \text { Perennial } & \text { POSE } & \text { Poa } \\ \text { Perennial } & \text { HECOC8 } & \text { Hesperostipa } \\ \text { Perennial } & \text { PLJA } & \text { Pleuraphis } \\ \text { Perennial } & \text { AGGLL } & \text { Agoseris } \\ \text { Perennial } & \text { ARPUL } & \text { Aristida } \\ \text { Perennial } & \text { LECl4 } & \text { Leymus } \\ \text { Perennial } & \text { POFE } & \text { Poa }\end{array}$

hymenoides
tectorum
elymoides ssp. elymoides
speciosum
rubens
secunda
comata ssp. comata
jamesii
glauca var. laciniata
punpurea var. longiseta
cinereus
fendleriana

\section{Forbs}

$\begin{array}{lrl}\text { Annual } & \text { AMTE3 } & \text { Amsinckia } \\ \text { Perennial } & \text { SPAMA } & \text { Sphaeraicea } \\ \text { Perennial } & \text { MACAC } & \text { Machaeranthera } \\ \text { Annual } & \text { ASLEF2 } & \text { Astragalus } \\ \text { Annual } & \text { ERER2 } & \text { Eriastrum } \\ \text { Perennial } & \text { HEMUN } & \text { Heliomenis } \\ \text { Annual } & \text { ERCI6 } & \text { Erodium } \\ \text { Annual } & \text { SYFR } & \text { Syntrichopappus } \\ \text { Perennial } & \text { ARPUM } & \text { Arabis } \\ \text { Annual } & \text { CHST } & \text { Chaenactis } \\ \text { Annual } & \text { CRCI2 } & \text { Cryptantha }\end{array}$

tessellata
ambigua ssp. ambigua
canescens ssp. canescens
lentiginosus var. fremontii
eremicum
multiflora var. nevadensis
cicutarium
fremontii
pulchra var. munciensis
stevioides
circumscissa


Association Longevity ACODE Genus

\begin{tabular}{|c|c|c|}
\hline Annual & DEPIG & Descurainia \\
\hline Annual & ERDE6 & Eriogonum \\
\hline Annual & MAGL3 & Malacothrix \\
\hline Perennial & PHST11 & Phlox \\
\hline Perennial & CAFL & Calochortus \\
\hline Annual & MEVE5 & Mentzelia \\
\hline Perennial & OECEM4 & Oenothera \\
\hline Annual & PESE & Pectocarya \\
\hline Annual & PHFR2 & Phacelia \\
\hline Perennial & CHAL11 & Chamaesyce \\
\hline Annual & CRPT & Cryptantha \\
\hline Perennial & CRUT & Cryptantha \\
\hline Perennial & DIPU3 & Dichelostemma \\
\hline Perennial & LONEN & Lomatium \\
\hline Perennial & PEFLA2 & Penstemon \\
\hline Annual & STEXE & Stephanomeria \\
\hline Perennial & STPA4 & Stephanomeria \\
\hline Perennial & ABTU & Abronia \\
\hline Perennial & $\mathrm{ADCO} 2$ & Adenophyllum \\
\hline Perennial & ASFU3 & Astragalus \\
\hline Perennial & BAMU & Baileya \\
\hline Annual & CABRB4 & Camissonia \\
\hline Biennial & CINE & Cirsium \\
\hline Perennial & ERCOC3 & Erigeron \\
\hline Perennial & ERIN4 & Eriogonum \\
\hline Annual & ERNI4 & Eriogonum \\
\hline Perennial & EROVO5 & Eriogonum \\
\hline Perennial & GIBRB & Gilia \\
\hline Perennial & GIIN2 & Gilia \\
\hline Annual & PHCRC3 & Phacelia \\
\hline Annual & SAKAT3 & Salsola \\
\hline Annual & SAPAB & Salsola \\
\hline Perennial & SEMU3 & Senecio \\
\hline Biennial & SIAL2 & Sisymbrium \\
\hline Perennial & ARDR4 & Artemisia \\
\hline Perennial & ARMUR & Argemone \\
\hline
\end{tabular}

\section{Species}

pinnata ssp. glabra

23.8

deflexum

23.8

glabrata

23.8

stansburyi

23.8

flexuosus

19.0

veatchiana

19.0

caespitosa ssp. manginata

19.0

setosa

19.0

fremontii

19.0

albomarginata $\quad 14.3$

pterocarya $\quad 14.3$

utahensis $\quad 14.3$

pulchellum $\quad 14.3$

nevadense var. nevadense $\quad 14.3$

floridus var. austinii $\quad 14.3$

exigua ssp. exigua $\quad 14.3$

pauciflora $\quad 14.3$

turbinata $\quad 9.5$

cooperi $\quad 9.5$

funereus $\quad 9.5$

multiradiata $\quad 9.5$

brevipes ssp. brevipes $\quad 9.5$

neomexicanum $\quad 9.5$

concinnus var. concinnus $\quad 9.5$

inflatum $\quad 9.5$

nidularium $\quad 9.5$

ovalifolium var. ovalifolium $\quad 9.5$

brecciarum ssp. brecciarum $\quad 9.5$

inconspicua $\quad 9.5$

crenulata var. crenulata $\quad 9.5$

kali ssp. tragus $\quad 9.5$

paulsenii $\quad 9.5$

multilobatus $\quad 9.5$

altissimum $\quad 9.5$

dracunculus $\quad 4.8$

munita ssp. rotundata $\quad 4.8$ 


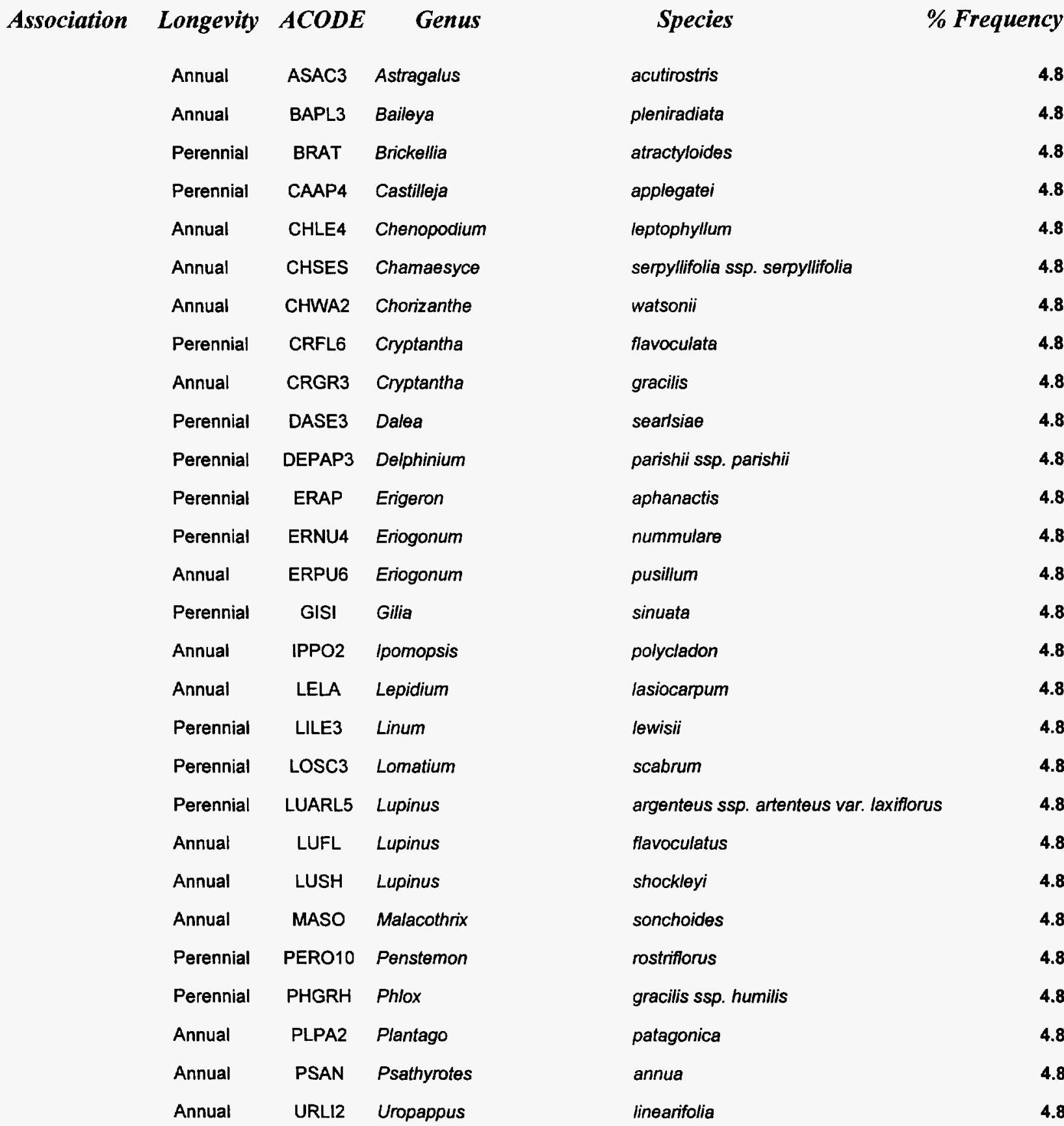

\section{Succulents}

$\begin{array}{lcl}\text { Perennial } & \text { OPECE } & \text { Opuntia } \\ \text { Perennial } & \text { YUBR } & \text { Yucca } \\ \text { Perennial } & \text { OPERE } & \text { Opuntia } \\ \text { Perennial } & \text { ECEN } & \text { Echinocereus } \\ \text { Perennial } & \text { YUBAV } & \text { Yucca } \\ \text { Perennial } & \text { ESVID } & \text { Escobaria } \\ \text { Perennial } & \text { OPPOR } & \text { Opuntia }\end{array}$

Thursday, September 09, 1999 
Association Longevity ACODE Genus Species \% Frequency

\section{Ephedra viridis-Artemisia tridentata Shrubland}

\section{Trees (>5 m)}

$\begin{array}{lll}\text { Perennial } & \text { PIMO } & \text { Pinus } \\ \text { Perennial } & \text { JUOS } & \text { Juniperus } \\ \text { Perennial } & \text { QUGA } & \text { Quercus }\end{array}$

monophylla
osteosperma
gambelii

Tall Shrubs (2-5 m)

$\begin{array}{ccl}\text { Perennial } & \text { ARTRT } & \text { Artemisia } \\ \text { Perennial } & \text { AMUT } & \text { Amelanchier } \\ \text { Perennial } & \text { CEGRV2 } & \text { Ceanothus }\end{array}$

\section{Short Shrubs (0.5-2 m)}

\begin{tabular}{|c|c|c|}
\hline Perennial & EPVI & Ephedra \\
\hline Perennial & CHVIP4 & Chrysothamnus \\
\hline Perennial & ERFAP & Eriogonum \\
\hline Perennial & PUGL2 & Purshia \\
\hline Perennial & ATCAC & Atriplex \\
\hline Perennial & ERTE18 & Ericameria \\
\hline Perennial & PUST & Purshia \\
\hline Perennial & CHVIV2 & Chrysothamnus \\
\hline Perennial & EPNE & Ephedra \\
\hline Perennial & ERLI6 & Ericameria \\
\hline Perennial & ERMIS2 & Eriogonum \\
\hline Perennial & CORA & Coleogyne \\
\hline Perennial & ERNAL & Ericameria \\
\hline Perennial & ENVIV & Encelia \\
\hline Perennial & LYAN & Lycium \\
\hline Perennial & RHTRA & Rhus \\
\hline Perennial & SYLO & Symphoricarpos \\
\hline Perennial & TEAXA & Tetradymia \\
\hline Perennial & ERCO23 & Ericameria \\
\hline Perennial & GRSP & Grayia \\
\hline Perennial & GUSA2 & Gutierrezia \\
\hline Perennial & KRLA2 & Krascheninnikovia \\
\hline Perennial & SAME & Salazaria \\
\hline Perennial & TECA2 & Tetradymia \\
\hline
\end{tabular}

\begin{tabular}{|c|c|}
\hline viridis & 100.0 \\
\hline viscidiflorus ssp. puberulus & 65.0 \\
\hline fasciculatum var. polifolium & 55.0 \\
\hline glandulosa & 55.0 \\
\hline canescens var. canescens & 45.0 \\
\hline teretifolia & 40.0 \\
\hline stansburiana & 40.0 \\
\hline viscidifforus ssp. viscidiflorus & 35.0 \\
\hline nevadensis & 35.0 \\
\hline linearifolius & 35.0 \\
\hline microthecum var. simpsonii & 35.0 \\
\hline ramosissima & 30.0 \\
\hline nauseosus ssp. consimilis var. leiosperma & 25.0 \\
\hline virginensis var. virginensis & 15.0 \\
\hline andersonii & 15.0 \\
\hline trilobata var. anisophylla & 15.0 \\
\hline longiflorus & 15.0 \\
\hline axillaris var. axillaris & 15.0 \\
\hline cooperi & 10.0 \\
\hline spinosa & 10.0 \\
\hline sarothrae & 10.0 \\
\hline lanata & 10.0 \\
\hline mexicana & 10.0 \\
\hline canescens & \\
\hline
\end{tabular}




$\begin{array}{lcl}\text { Perennial } & \text { TEGL } & \text { Tetradymia } \\ \text { Perennial } & \text { BROBL } & \text { Brickellia } \\ \text { Perennial } & \text { ERNA7 } & \text { Ericameria } \\ \text { Perennial } & \text { ERNAH } & \text { Ericameria } \\ \text { Perennial } & \text { PENI } & \text { Petalonyx } \\ \text { Perennial } & \text { PERA4 } & \text { Peraphyllum } \\ \text { Perennial } & \text { PRFA } & \text { Prunus } \\ \text { Perennial } & \text { RICEC2 } & \text { Ribes }\end{array}$

$\begin{array}{ll}\text { glabrata } & 10.0 \\ \text { oblongifolia var. linifolia } & 5.0 \\ \text { nanus } & 5.0 \\ \text { nauseosus ssp. nauseosus var. } & 5.0 \\ \text { hololeuca } & \\ \text { nitidus } & 5.0 \\ \text { ramosissimum } & 5.0 \\ \text { fasciculata } & 5.0 \\ \text { cereum var. cerøum } & 5.0\end{array}$

Dwarf Shrubs (<0.5 m)

$\begin{array}{llll}\text { Perennial } & \text { LEPU } & \text { Leptodactylon } & \text { pungens } \\ \text { Perennial } & \text { ERMIL } & \text { Eriogonum } & \text { microthecum var. Iapidicola }\end{array}$

\section{Graminoids}

$\begin{array}{lll}\text { Annual } & \text { BRTE } & \text { Bromus } \\ \text { Perennial } & \text { ELELE } & \text { Elymus } \\ \text { Perennial } & \text { POSE } & \text { Poa } \\ \text { Perennial } & \text { ACHY } & \text { Achnatherum } \\ \text { Perennial } & \text { PLJA } & \text { Pleuraphis } \\ \text { Perennial } & \text { ACSP12 } & \text { Achnatherum } \\ \text { Annual } & \text { BRRU2 } & \text { Bromus } \\ \text { Perennial } & \text { POFE } & \text { Poa } \\ \text { Perennial } & \text { ARPU9 } & \text { Aristida } \\ \text { Perennial } & \text { HECOC8 } & \text { Hesperostipa } \\ \text { Perennial } & \text { LECI4 } & \text { Leymus } \\ \text { Variable } & \text { ACHNA } & \text { Achnatherum } \\ \text { Annual } & \text { BRCA6 } & \text { Bromus } \\ \text { Annual } & \text { VUMI } & \text { Vulpia } \\ \text { Annual } & \text { VUOC } & \text { Vulpia }\end{array}$

tectorum
elymoides ssp. elymoides
secunda
hymenoides
jamesii
speciosum
rubens
fendieriana
purpurea
comata ssp. comata
cinereus
cartharticus
microstachys
octofiora

100.0

90.0

80.0

50.0

50.0

45.0

40.0

35.0

20.0

20.0

10.0

\section{Forbs}

$\begin{array}{lcl}\text { Annual } & \text { AMTE3 } & \text { Amsinckia } \\ \text { Perennial } & \text { PHST11 } & \text { Phlox } \\ \text { Annual } & \text { ERCI6 } & \text { Erodium } \\ \text { Perennial } & \text { HEMUN } & \text { Heliomeris } \\ \text { Perennial } & \text { MACAC } & \text { Machaeranthera } \\ \text { Perennial } & \text { CAAP4 } & \text { Castilleja }\end{array}$

tessellata
stansburyi
cicutarium
multifiora var. nevadensis
canescens ssp. canescens
applegatei




\begin{tabular}{|c|c|c|c|c|c|}
\hline Association & Longevity & $A C O D E$ & Genus & Species & ency \\
\hline & Annual & ERNI4 & Eriogonum & nidularium & 50.0 \\
\hline & Perennial & GIBRB & Gilia & brecciarum ssp. brecciarum & 50.0 \\
\hline & Annual & SYFR & Syntrichopappus & fremontii & 50.0 \\
\hline & Perennial & DEPAP3 & Delphinium & parishii ssp. parishii & 45.0 \\
\hline & Perennial & ERCAB & Eriogonum & caespitosum & 45.0 \\
\hline & Perennial & SPAMA & Sphaeralcea & ambigua ssp. ambigua & 45.0 \\
\hline & Perennial & ERCOC3 & Erigeron & concinnus var. concinnus & 40.0 \\
\hline & Perennial & EROVO5 & Eriogonum & ovalifolium var. ovalifolium & 40.0 \\
\hline & Annual & PHFR2 & Phacelia & fremontii & 40.0 \\
\hline & Annual & PHVAV2 & Phacelia & vallis-mortae var. vallis-mortae & 40.0 \\
\hline & Perennial & CHAL11 & Chamaesyce & albomarginata & 35.0 \\
\hline & Biennial & CINE & Cirsium & neomexicanum & 35.0 \\
\hline & Annual & DEPIG & Descurainia & pinnata ssp. glabra & 35.0 \\
\hline & Perennial & SEMU3 & Senecio & multilobatus & 35.0 \\
\hline & Annual & CHST & Chaenactis & stevioides & 30.0 \\
\hline & Annual & CRPT & Cryptantha & pterocarya & 30.0 \\
\hline & Perennial & STCOC & Streptanthus & cordatus var. cordatus & 30.0 \\
\hline & Perennial & $\mathrm{CROCO} 2$ & Crepis & occidentalis ssp. occidentalis & 25.0 \\
\hline & Annual & MEVE5 & Mentzelia & veatchiana & 25.0 \\
\hline & Annual & PESE & Pectocarya & setosa & 25.0 \\
\hline & Annual & PHCRC3 & Phacelia & crenulata var. crenulata & 25.0 \\
\hline & Annual & PLPA2 & Plantago & patagonica & 25.0 \\
\hline & Annual & STEXE & Stephanomeria & exigua ssp. exigua & 25.0 \\
\hline & Perennial & CAFL & Calochortus & flexuosus & 20.0 \\
\hline & Perennial & DIPU3 & Dichelostemma & pulchellum & 20.0 \\
\hline & Annual & ERDI4 & Erigeron & divergens & 20.0 \\
\hline & Perennial & ERRA3 & Eriogonum & racemosum & 20.0 \\
\hline & Annual & LOHU2 & Lotus & humistratus & 20.0 \\
\hline & Perennial & LONEN & Lomatium & nevadense var. nevadense & 20.0 \\
\hline & Perennial & LUARL5 & Lupinus & argenteus ssp. artenteus var. laxiflorus & 20.0 \\
\hline & Perennial & MIBI8 & Mirabilis & bigelovii & 20.0 \\
\hline & Perennial & OECEM4 & Oenothera & caespitosa ssp. marginata & 20.0 \\
\hline & Annual & THCU & Thysanocarpus & curvipes & 20.0 \\
\hline & Annual & ASLEF2 & Astragalus & lentiginosus var. fremontii & 15.0 \\
\hline & Annual & $\mathrm{CRCl} 2$ & Cryptantha & cincumscissa & 15.0 \\
\hline & Annual & CRNEN & Cryptantha & nevadensis var. nevadensis & 15.0 \\
\hline
\end{tabular}




\begin{tabular}{|c|c|c|c|c|c|}
\hline \multirow[t]{37}{*}{ Association } & Longevity & $A C O D E$ & Genus & Species & $\%$ Frequency \\
\hline & Perennial & ERSA6 & Eriogonum & saxatile & 15.0 \\
\hline & Annual & LUBR2 & Lupinus & brevicaulis & 15.0 \\
\hline & Annual & MEAL6 & Mentzelia & albicaulis & 15.0 \\
\hline & Perennial & MIMUG & Mirabilis & multiflora var. glandulosa & 15.0 \\
\hline & Annual & MISP & Mimulus & spissus & 15.0 \\
\hline & Perennial & PEFLA2 & Penstemon & floridus var. austinii & 15.0 \\
\hline & Perennial & PEPA23 & Penstemon & pahutensis & 15.0 \\
\hline & Biennial & SIAL2 & Sisymbrium & altissimum & 15.0 \\
\hline & Perennial & SPAMM & Sphaeralcea & ambigua ssp. monticola & 15.0 \\
\hline & Annual & URLI2 & Uropappus & linearifolia & 15.0 \\
\hline & Perennial & ARCOS 2 & Arenaria & congesta var. subcongesta & 10.0 \\
\hline & Perennial & ARPUG & Arabis & pulchra var. gracilis & 10.0 \\
\hline & Perennial & ARPUM & Arabis & pulchra var. munciensis & 10.0 \\
\hline & Annual & ASAC3 & Astragalus & acutirostris & 10.0 \\
\hline & Perennial & ASPUT & Astragalus & purshii var. tinctus & 10.0 \\
\hline & Perennial & $\mathrm{CHDO}$ & Chaenactıs & douglasii & 10.0 \\
\hline & Annual & CHMA & Chaenactis & macrantha & 10.0 \\
\hline & Annual & CHWA2 & Chorizanthe & watsonii & 10.0 \\
\hline & Annual & CLPAU2 & Claytonia & perfoliata ssp. perfoliata & 10.0 \\
\hline & Annual & CRGR3 & Cryptantha & gracilis & 10.0 \\
\hline & Perennial & CRUT & Cryptantha & utahensis & 10.0 \\
\hline & Annual & ERER2 & Eriastrum & eremicum & 10.0 \\
\hline & Annual & LELA & Lepidium & lasiocarpum & 10.0 \\
\hline & Perennial & MIPU5 & Mirabilis & pudica & 10.0 \\
\hline & Annual & $\mathrm{PHCU}$ & Phacelia & curvipes & 10.0 \\
\hline & Annual & PHSA & Phacelia & saxicola & 10.0 \\
\hline & Annual & SACOC & Salvia & columbariae var. columbariae & 10.0 \\
\hline & Perennial & ARLU & Artemisia & ludoviciana & 5.0 \\
\hline & Perennial & ARMUR & Argemone & munita ssp. rotundata & 5.0 \\
\hline & Perennial & ASCA14 & Astragalus & caset & 5.0 \\
\hline & Annual & CABOI & Camissonia & boothii ssp. intermedia & 5.0 \\
\hline & Annual & CACLI & Camissonia & claviformis ssp. integrior & 5.0 \\
\hline & Perennial & CACRG & Caulanthus & crassicaulis var. glaber & 5.0 \\
\hline & Annual & CHBRB & Chorizanthe & brevicornu var. brevicornu & 5.0 \\
\hline & Perennial & CHGR13 & Chrysothamnus & gramineus & 5.0 \\
\hline & Annual & CHIN2 & Chenopodium & incanum & 5.0 \\
\hline
\end{tabular}




\begin{tabular}{|c|c|c|c|c|c|}
\hline \multirow[t]{19}{*}{ Association } & Longevity & $A C O D E$ & Genus & Species & $\%$ Frequency \\
\hline & Annual & CHXA & Chaenactis & xantiana & 5.0 \\
\hline & Annual & CRAM3 & Cryptantha & ambigua & 5.0 \\
\hline & Perennial & ERUM & Eriogonum & umbellatum & 5.0 \\
\hline & Annual & GILIA & Gilia & & 5.0 \\
\hline & Perennial & GINY & Gilia & nyensis & . \\
\hline & Perennial & HUVEI & Huisea & vestita ssp. inyoensis & 5.0 \\
\hline & Perennial & LEKIK & Lesquerella & kingii ssp. kingii & 5. \\
\hline & Perennial & LEREM & Lewisia & rediviva var. minor & $5 .($ \\
\hline & Annual & LIDI2 & Linanthus & dichotomus & $5 .($ \\
\hline & Annual & LUCOO2 & Lupinus & concinnus ssp. orcuttii & 5. \\
\hline & Annual & LUSH & Lupinus & shockleyi & 5. \\
\hline & Annual & LUSU10 & Lupinus & subvexus & 5. \\
\hline & Annual & MECO2 & Mentzelia & congesta & 5. \\
\hline & Perennial & ORFA & Orobanche & fasciculata & $5 .($ \\
\hline & Perennial & PEPU7 & Petradoria & pumila & 5. \\
\hline & Annual & SAKAT3 & Salsola & kali ssp. tragus & 5 \\
\hline & Perennial & STPA3 & Stephanomeria & parryi & 5. \\
\hline & Perennial & TRWA2 & Tricardia & watsonii & \\
\hline
\end{tabular}

\section{Succulents}

$\begin{array}{ccl}\text { Perennial } & \text { OPPOR } & \text { Opuntia } \\ \text { Perennial } & \text { ECEN } & \text { Echinocereus } \\ \text { Perennial } & \text { OPERE } & \text { Opuntia } \\ \text { Perennial } & \text { OPECE } & \text { Opuntia } \\ \text { Perennial } & \text { YUBAV } & \text { Yucca } \\ \text { Perennial } & \text { OPBAB2 } & \text { Opuntia } \\ \text { Perennial } & \text { YUBR } & \text { Yucca }\end{array}$

polyacantha var. rufispina
engelmannii
erinacea var. erinacea
echinocarpa var. echinocarpa
baccata var. vespertina
basilaris var. basilaris
brevifolia


Association Longevity ACODE Genus Species \% Frequency

Artemisia tridentata-Chrysothamnus viscidiflorus Shrubland

Trees (>5 m)

$\begin{array}{lll}\text { Perennial } & \text { JUOS } & \text { Juniperus } \\ \text { Perennial } & \text { PIMO } & \text { Pinus } \\ \text { Perennial } & \text { QUGA } & \text { Quercus }\end{array}$

osteosperma

40.3

Perennial QUGA Quercus

monophylla

23.7

gambelii

Tall Shrubs (2-5 $\mathrm{m})$

$\begin{array}{lll}\text { Perennial } & \text { ARTRT } & \text { Artemisia } \\ \text { Perennial } & \text { AMUT } & \text { Amelanchier } \\ \text { Perennial } & \text { LATR2 } & \text { Larrea }\end{array}$

tridentata ssp. tridentata

97.8

utahensis

0.7

tridentata

\section{Short Shrubs (0.5-2 $\mathrm{m})$}

$\begin{array}{ccl}\text { Perennial } & \text { CHVIV2 } & \text { Chrysothamnus } \\ \text { Perennial } & \text { EPNE } & \text { Ephedra } \\ \text { Perennial } & \text { GRSP } & \text { Grayia } \\ \text { Perennial } & \text { ATCAC } & \text { Atriplex } \\ \text { Perennial } & \text { CHVIP4 } & \text { Chrysothamnus } \\ \text { Perennial } & \text { EPVI } & \text { Ephedra } \\ \text { Perennial } & \text { ARNO4 } & \text { Artemisia } \\ \text { Perennial } & \text { KRLA2 } & \text { Krascheninnikovia } \\ \text { Perennial } & \text { LYAN } & \text { Lyclum } \\ \text { Perennial } & \text { ERMIS2 } & \text { Eriogonum } \\ \text { Perennial } & \text { ERNAH } & \text { Ericameria } \\ \text { Perennial } & \text { PUGL2 } & \text { Purshia } \\ \text { Perennial } & \text { PUTR2 } & \text { Purshia } \\ \text { Perennial } & \text { ERNAL } & \text { Ericameria } \\ \text { Perennial } & \text { TEGL } & \text { Tetradymia } \\ \text { Perennial } & \text { CORA } & \text { Coleogyne } \\ \text { Perennial } & \text { ERTE18 } & \text { Ericameria } \\ \text { Perennial } & \text { GUSA2 } & \text { Gutierrezia } \\ \text { Perennial } & \text { PUST } & \text { Purshia } \\ \text { Perennial } & \text { TECA2 } & \text { Tetradymia } \\ \text { SYLO } & \text { Symphoricaroos } \\ \text { ERCO23 } & \text { Ericamenia } \\ \text { ERFA } & \text { Ericameria } \\ \text { Priagonum } \\ \text { Peren }\end{array}$

viscidiflorus ssp. viscidiflorus
nevadensis
spinosa
canescens var. canescens
viscidiflorus ssp. puberulus
viridis
nova
lanata
andersonii
microthecum var. simpsonii
nauseosus ssp. nauseosus var.
hololeuca
glandulosa
tridentata
nauseosus ssp. consimilis var. leiosperma
glabrata
ramosissima
sarothrae
stansburiana
longiflorus
teretifolia
canescens
cooperi
fasciculatum var. polifolium
linearifolius
a

69.8

61.9

46.0

41.0

33.1

29.5

25.9

23.0

18.7

18.0

15.1

12.9

12.2

10.8

10.1

9.4

8.6

8.6

8.6

7.9

7.2

6.5

5.8

5.0

Thursday, September 09, 1999

Page 73 of 107 


\begin{tabular}{|c|c|c|c|c|c|}
\hline \multirow[t]{23}{*}{ Association } & Longevity & $A C O D E$ & Genus & Species & $\%$ Frequency \\
\hline & Perennial & ATCO & Atriplex & confentifolia & 4.3 \\
\hline & Perennial & ERNA7 & Ericameria & nanus & 3.6 \\
\hline & Perennial & TEAXA & Tetradymia & axillaris var. axillaris & 3.6 \\
\hline & Perennial & ENVIV & Encelia & virginensis var. virginensis & 2.9 \\
\hline & Perennial & HYSA & Hymenoclea & salsola & 2.9 \\
\hline & Perennial & ERNA10 & Ericameria & nauseosus & 2.2 \\
\hline & Perennial & PSPO & Psorothamnus & polydenius & 2.2 \\
\hline & Perennial & SADOD3 & Salvia & donii ssp. domii var. dornii & 2.2 \\
\hline & Perennial & LEFR2 & Lepidium & fremontii & 1.4 \\
\hline & Perennial & RICEC2 & Ribes & cereum var. cereum & 1.4 \\
\hline & Perennial & RIVEV & Ribes & velutinum var. velutinum & 1.4 \\
\hline & Perennial & STEL & Stanleya & elata & 1.4 \\
\hline & Perennial & THMO & Thamnosma & montana & 1.4 \\
\hline & Perennial & AMDU2 & Ambrosia & dumosa & 0.7 \\
\hline & Perennial & BRMIS & Brickellia & microphylla var. scabra & 0.7 \\
\hline & Perennial & BROBL & Brickellia & oblongifolia var. linifolia & 0.7 \\
\hline & Perennial & ERHEA & Eriogonum & heermannii var. argense & 0.7 \\
\hline & Perennial & ERPA29 & Ericameria & paniculata & 0.7 \\
\hline & Perennial & ERPAN2 & Ericameria & parryi var. nevadensis & 0.7 \\
\hline & Perennial & PRFA & Prunus & fasciculata & 0.7 \\
\hline & Perennial & SAME & Salazaria & mexicana & 0.7 \\
\hline & Perennial & STPIP & Stanleya & pinnata var. pinnata & .7 \\
\hline
\end{tabular}

\section{Dwarf Shrubs (<0.5 m)}

$\begin{array}{lll}\text { Perennial } & \text { LEPU } & \text { Leptodactylon } \\ \text { Perennial } & \text { ARSP5 } & \text { Artemisia } \\ \text { Perennial } & \text { ERMIL } & \text { Eriogonum } \\ \text { Perennial } & \text { MESP2 } & \text { Menodora }\end{array}$

pungens
spinescens
microthecum var. lapidicola
spinescens

\section{Graminoids}

$\begin{array}{lll}\text { Perennial } & \text { ELELE } & \text { Elymus } \\ \text { Perennial } & \text { ACHY } & \text { Achnatherum } \\ \text { Annual } & \text { BRTE } & \text { Bromus } \\ \text { Perennial } & \text { PLJA } & \text { Pleuraphis } \\ \text { Perennial } & \text { HECOC8 } & \text { Hesperostipa } \\ \text { Perennial } & \text { POSE } & \text { Poa } \\ \text { Annual } & \text { BRRU2 } & \text { Bromus }\end{array}$

elymoides ssp. elymoides
hymenoides
tectorum
jamesii
comata ssp. comata
secunda
rubens




\begin{tabular}{cccl} 
Association & Longevity & ACODE & \multicolumn{1}{c}{ Genus } \\
Perennial & ACSP12 & Achnatherum \\
Perennial & ARPU9 & Aristida \\
Perennial & LECI4 & Leymus \\
Perennial & POFE & Poa \\
Annual & VUOC & Vulpia \\
Annual & VUMI & Vulpia \\
Perennial & AGGLL & Agoseris \\
Perennial & KOMA & Koeleria \\
Perennial & BOGR2 & Bouteloua \\
Perennial & ERPU8 & Erioneuron \\
Perennial & SPCR & Sporobolus \\
Perennial & ACTH7 & Achnatherum \\
& Annual & BRCA6 & Bromus \\
Perennial & JUBA & Juncus
\end{tabular}

\begin{tabular}{lr}
\multicolumn{1}{c}{ Species } & \% Frequency \\
speciosum & 20.9 \\
purpurea & 13.7 \\
cinereus & 13.7 \\
fendleriana & 11.5 \\
octoflora & 8.6 \\
microstachys & 7.9 \\
glauca var. laciniata & 5.8 \\
macrantha & 2.9 \\
gracilis & 2.2 \\
pulchellum & 1.4 \\
cryptandrus & 1.4 \\
thumeriana & 0.7 \\
cartharticus & 0.7 \\
balticus & 0.7
\end{tabular}

\section{Forbs}

\begin{tabular}{lcl} 
Perennial & SPAMA & Sphaeralcea \\
Annual & ASLEF2 & Astragalus \\
Perennial & MACAC & Machaeranthera \\
Annual & CRCI2 & Cryptantha \\
Perennial & CAAP4 & Castilleja \\
Perennial & PHST11 & Phlox \\
Perennial & GIBRB & Gilia \\
Annual & DEPIG & Descurainia \\
Annual & CRPT & Cryptantha \\
Annual & PHFR2 & Phacelia \\
Perennial & EROVO5 & Eriogonum \\
Annual & MEAL6 & Mentzelia \\
Annual & SYFR & Syntrichopappus \\
Annual & AMTE3 & Amsinckia \\
Annual & ERER2 & Eriastrum \\
Annual & CHST & Chaenactis \\
Perennial & ERCOC3 & Erigeron \\
Perennial & DEPAP3 & Delphinium \\
Annual & CAPT & Camissonia \\
Perennial & CAFL & Calochortus \\
Perennial & SEMU3 & Senecio \\
& & \\
\hline
\end{tabular}

ambigua ssp. ambigua
lentiginosus var. fremontii
canescens ssp. canescens
circumscissa
applegatei
stansburyi
brecciarum ssp. brecciarum
pinnata ssp. glabra
pterocarya
fremontii
ovalifolium var. ovalifolium
albicaulis
fremontii
tessellata
eremicum
stevioides
concinnus var. concinnus
parishii ssp. parishii
pterosperma
flexuosus
multilobatus




\begin{tabular}{|c|c|c|c|c|c|}
\hline Association & Longevity & $A C O D E$ & Genus & Species & $n c y$ \\
\hline & Annual & ERNI4 & Eniogonum & nidularium & 21.6 \\
\hline & Annual & СЕТНЗ & Centrostegia & thumberi & 20.1 \\
\hline & Annual & CRGR3 & Cryptantha & gracilis & 20.1 \\
\hline & Perennial & DEAN & Delphinium & andersonii & 20.1 \\
\hline & Perennial & ASPUT & Astragalus & purshii var. tinctus & 19.4 \\
\hline & Annual & LUFL & Lupinus & flavoculatus & 19.4 \\
\hline & Annual & PLPA2 & Plantago & patagonica & 17.3 \\
\hline & Perennial & DIPU3 & Dichelostemma & pulchellum & 15.8 \\
\hline & Annual & PHCRC3 & Phacelia & crenulata var. crenulata & 15.8 \\
\hline & Perennial & CHAL11 & Chamaesyce & albomarginata & 14.4 \\
\hline & Perennial & $\mathrm{CHDO}$ & Chaenactis & douglasii & 13.7 \\
\hline & Perennial & HEMUN & Heliomeris & multiflora var. nevadensis & 12.9 \\
\hline & Perennial & ARPUG & Arabis & pulchra var. gracilis & 12.2 \\
\hline & Annual & CAPU16 & Camissonia & pusilla & 12.2 \\
\hline & Perennial & CRFL6 & Cryptantha & flavoculata & 12.2 \\
\hline & Annual & LAOCO & Lappula & occidentalis var. occidentalis & 12.2 \\
\hline & Annual & CHMA & Chaenactis & macrantha & 11.5 \\
\hline & Annual & LELA & Lepidium & lasiocarpum & 11.5 \\
\hline & Annual & MISP & Mimulus & spissus & 11.5 \\
\hline & Annual & PESE & Pectocarya & setosa & 11.5 \\
\hline & Perennial & CALI4 & Castilleja & linariaefolia & 10.8 \\
\hline & Annual & ERDI4 & Erigeron & divergens & 10.8 \\
\hline & Perennial & LILE3 & Linum & lewisii & 10.8 \\
\hline & Perennial & OECEM4 & Oenothera & caespitosa ssp. marginata & 10.8 \\
\hline & Perennial & PHGRH & Phlox & gracilis ssp. humilis & 10.8 \\
\hline & Annual & CHWA2 & Chorizanthe & watsonii & 10. \\
\hline & Perennial & LONEN & Lomatium & nevadense var. nevadense & 10.1 \\
\hline & Annual & LUBR2 & Lupinus & brevicaulis & 10.1 \\
\hline & Annual & LUSH & Lupinus & shockleyi & 10.1 \\
\hline & Perennial & ARPUM & Arabis & pulchra var. munciensis & 9.4 \\
\hline & Perennial & ASCAC5 & Astragalus & calycosus var. calycosus & \\
\hline & Annual & IPPO2 & Ipomopsis & polycladon & 9 \\
\hline & Perennial & LUARL5 & Lupinus & argenteus ssp. artenteus var. laxiflorus & 9.4 \\
\hline & Annual & MAGL3 & Malacothrix & glabrata & 9.4 \\
\hline & Annual & CRNEN & Cryptantha & nevadensis var. nevadensis & 8.6 \\
\hline & Perennial & ERCA8 & Eriogonum & caespitosum & 8.6 \\
\hline
\end{tabular}




\section{Association Longevity ACODE Genus}

\begin{tabular}{|c|c|c|}
\hline Annual & ERCI6 & Erodium \\
\hline Perennial & ERUM & Eriogonum \\
\hline Annual & GILIA & Gilia \\
\hline Perennial & HYCOC2 & Hymenoxys \\
\hline Annual & LIDI2 & Linanthus \\
\hline Annual & MEVE5 & Mentzelia \\
\hline Annual & SAPAB & Salsola \\
\hline Perennial & $\mathrm{CROCO} 2$ & Crepis \\
\hline Annual & STEXE & Stephanomeria \\
\hline Perennial & ARCOS2 & Arenaria \\
\hline Perennial & CRVI5 & Cryptantha \\
\hline Annual & ERDE6 & Eriogonum \\
\hline Annual & MISU2 & Mimulus \\
\hline Perennial & ORFA & Orobanche \\
\hline Annual & PHVAV2 & Phacelia \\
\hline Perennial & SPAMM & Sphaeralcea \\
\hline Perennial & STCOC & Streptanthus \\
\hline Perennial & CRUT & Cryptantha \\
\hline Annual & URLI2 & Uropappus \\
\hline Annual & CABRB4 & Camissonia \\
\hline Biennial & CINE & Cirsium \\
\hline Annual & ERSP3 & Eriastrum \\
\hline Annual & LOHU2 & Lotus \\
\hline Perennial & MIBI8 & Mirabilis \\
\hline Annual & PHSA & Phacelia \\
\hline Perennial & STPA4 & Stephanomeria \\
\hline Perennial & CRCO12 & Cryptantha \\
\hline Annual & MASO & Malacothrix \\
\hline Perennial & OEPAP & Oenothera \\
\hline Perennial & PEPA23 & Penstemon \\
\hline Biennial & SIAL2 & Sisymbrium \\
\hline Perennial & ABEL & Abronia \\
\hline Perennial & CAPI4 & Caulanthus \\
\hline Annual & ERESE & Eriogonum \\
\hline Annual & MEOB3 & Mentzelia \\
\hline Perennial & MIMUG & Mirabilis \\
\hline
\end{tabular}

\section{Species}

\% Frequency

cicutarium

umbellatum

cooperi var. cooperi $\quad 8.6$

dichotomus $\quad 8.6$

veatchiana $\quad 8.6$

paulsenii $\quad 8.6$

occidentalis ssp. occidentalis $\quad 7.9$

exigua ssp. exigua $\quad 7.9$

congesta var. subcongesta $\quad 6.5$

virginensis $\quad 6.5$

deflexum $\quad 6.5$

suksdorfii $\quad 6.5$

fasciculata $\quad 6.5$

vallis-mortae var. vallis-mortae $\quad 6.5$

ambigua ssp. monticola $\quad 6.5$

cordatus var. cordatus $\quad 6.5$

utahensis $\quad 5.8$

Inearifolia $\quad 5.8$

brevipes ssp. brevipes $\quad 5.0$

neomexicanum $\quad 5.0$

sparsifforum $\quad \mathbf{5 . 0}$

humistratus $\quad \mathbf{5 . 0}$

bigelovii $\quad \mathbf{5 . 0}$

saxicola $\quad 5.0$

pauciflora $\quad 5.0$

confertiflora $\quad 4.3$

sonchoides $\quad 4.3$

pallida ssp. pallida $\quad 4.3$

pahutensis $\quad 4.3$

altissimum 4.3

elliptica $\quad 3.6$

pilosus $\quad 3.6$

esmeraldense var. esmeraldense $\quad 3.6$

obscura $\quad 3.6$

multiflora var. glandulosa $\quad 3.6$ 


\begin{tabular}{|c|c|c|c|c|c|}
\hline \multirow[t]{37}{*}{ Association } & Longevity & $A C O D E$ & Genus & Species & \% Frequency \\
\hline & Perennial & PEFLA2 & Penstemon & floridus var. austinii & 3.6 \\
\hline & Perennial & STSP6 & Stephanomeria & spinosa & 3.6 \\
\hline & Perennial & ALNE & Allium & nevadense & 2.9 \\
\hline & Perennial & ARLU & Artemisia & ludoviciana & 2.9 \\
\hline & Perennial & ASCA14 & Astragalus & casei & 2.9 \\
\hline & Annual & CACLI & Camissonia & claviformis ssp. integrior & 2.9 \\
\hline & Annual & CHBRB & Chorizanthe & brevicornu var. brevicomu & 2.9 \\
\hline & Annual & $\mathrm{CHXA}$ & Chrenactis & xantiana & 2.9 \\
\hline & Annual & CRMI & Cryptantha & micrantha & 2.9 \\
\hline & Annual & CRRE5 & Cryptantha & recurvata & 2.9 \\
\hline & Perennial & ERSA6 & Eriogonum & saxatile & 2.9 \\
\hline & Perennial & GIIN2 & Gilia & inconspicua & 2.9 \\
\hline & Annual & NADED & Nama & demissum var. demissum & 2.9 \\
\hline & Annual & PEPL & Pectocarya & platycarpa & 2.9 \\
\hline & Perennial & $\mathrm{ADCO} 2$ & Adenophyllum & cooperi & 2.2 \\
\hline & Annual & ANAC & Anisocoma & acaulis & 2.2 \\
\hline & Perennial & ASFU3 & Astragalus & funereus & 2.2 \\
\hline & Annual & CHLE4 & Chenopodium & leptophyllum & 2.2 \\
\hline & Perennial & ERAP & Erigeron & aphanactis & 2.2 \\
\hline & Annual & GADIP & Gayophytum & diffusum ssp. parviflorum & 2.2 \\
\hline & Perennial & GINY & Gilia & nyensis & 2.2 \\
\hline & Perennial & ORCO5 & Orobanche & corymbosa & 2.2 \\
\hline & Perennial & SPGRP2 & Sphaeralcea & grossulariaefolia ssp. pedata & 2.2 \\
\hline & Perennial & TOSC & Townsendia & scapigera & 2.2 \\
\hline & Annual & AMAC2 & Ambrosia & acanthicarpa & 1.4 \\
\hline & Annual & ASAC3 & Astragalus & acutirostris & 1.4 \\
\hline & Annual & CHAL7 & Chenopodium & album & 1.4 \\
\hline & Annual & CHFR & Chaenactis & fremontii & 1.4 \\
\hline & Annual & CHIN2 & Chenopodium & incanum & 1.4 \\
\hline & Perennial & CYGL2 & Cymopterus & globosus & 1.4 \\
\hline & Perennial & CYPU & Cymopterus & purpurascens & 1.4 \\
\hline & Annual & ERBR7 & Eriogonum & brachyanthum & 1.4 \\
\hline & Perennial & ERIN4 & Eriogonum & inflatum & 1.4 \\
\hline & Annual & ERMA2 & Eriogonum & maculatum & 1.4 \\
\hline & Perennial & ERNU4 & Eriogonum & nummulare & 1.4 \\
\hline & Perennial & ERRA3 & Eriogonum & racemosum & 1.4 \\
\hline
\end{tabular}




\begin{tabular}{|c|c|c|}
\hline Annual & ERWI & Eriastrum \\
\hline Perennial & GISI & Gilia \\
\hline Perennial & HUVEI & Hulsea \\
\hline Perennial & LEKIK & Lesquerella \\
\hline Perennial & LINUN & Linanthus \\
\hline Annual & OXPE2 & Oxytheca \\
\hline Perennial & PEHUH & Penstemon \\
\hline Annual & SACOC & Salvia \\
\hline Annual & STLO4 & Streptanthella \\
\hline Annual & STMI2 & Stylocline \\
\hline Perennial & STPA3 & Stephanomeria \\
\hline Perennial & TRWA2 & Tricardia \\
\hline Perennial & ARMA3 & Arenaria \\
\hline Perennial & ASER2 & Asclepias \\
\hline Perennial & ASNE6 & Astragalus \\
\hline Annual & CABOI & Camissonia \\
\hline Annual & CAKEG & Camissonia \\
\hline Annual & CAPA39 & Camissonia \\
\hline Annual & CARE2 & Camissonia \\
\hline Perennial & CHER2 & Leucelene \\
\hline Perennial & CHGR13 & Chrysothamnus \\
\hline Annual & CHRI & Chorizanthe \\
\hline Annual & CHSES & Chamaesyce \\
\hline Annual & CIPAN & Cistanthe \\
\hline Perennial & CYRI2 & Cymopterus \\
\hline Annual & ERHO6 & Eriogonum \\
\hline Perennial & FRAT & Fritillaria \\
\hline Annual & GARA2 & Gayophytum \\
\hline Perennial & IPCO5 & Ipomopsis \\
\hline Annual & LUMI & Lupinus \\
\hline Perennial & MIPU5 & Mirabilis \\
\hline Annual & NABR & Navarretia \\
\hline Perennial & OECA2 & Oenothera \\
\hline Perennial & PENST & Penstemon \\
\hline Perennial & PEPA8 & Penstemon \\
\hline Annua & PHBI & Phacelia \\
\hline
\end{tabular}

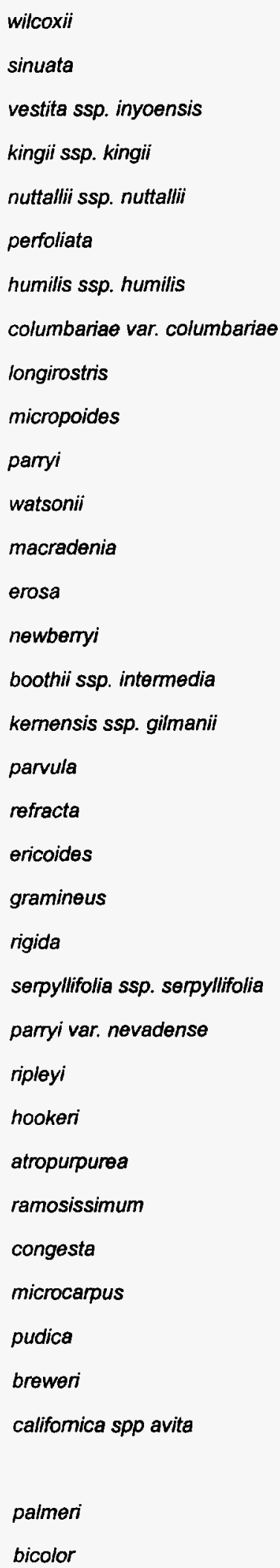

1.4

1.4

1.4

1.4

1.4

1.4

1.4

1.4

1.4

1.4

1.4

1.4

0.7

0.7

0.7

0.7

0.7

0.7

0.7

0.7

0.7

0.7

0.7

0.7

0.7

0.7

0.7

0.7

0.7

0.7

0.7

0.7

0.7

0.7

0.7

0.7 
Association Longevity ACODE Genus

$\begin{array}{lcl}\text { Annual } & \text { PHCU } & \text { Phacelia } \\ \text { Perennial } & \text { PHHOL } & \text { Phlox } \\ \text { Perennial } & \text { POSU } & \text { Polygala } \\ \text { Annual } & \text { SAKAT3 } & \text { Salsola } \\ \text { Perennial } & \text { SIVEA } & \text { Silene } \\ \text { Perennial } & \text { SPAMR } & \text { Sphaeralcea } \\ \text { Annual } & \text { THCU } & \text { Thysanocarpus } \\ \text { Perennial } & \text { ZIPA2 } & \text { Zigadenus }\end{array}$

\section{Succulents}

$\begin{array}{lll}\text { Perennial } & \text { OPECE } & \text { Opuntia } \\ \text { Perennial } & \text { OPERE } & \text { Opuntia } \\ \text { Perennial } & \text { OPPOR } & \text { Opuntia } \\ \text { Perennial } & \text { ECEN } & \text { Echinocereus } \\ \text { Perennial } & \text { YUBR } & \text { Yucca } \\ \text { Perennial } & \text { YUBAV } & \text { Yucca } \\ \text { Perennial } & \text { ESVIR2 } & \text { Escobaria } \\ \text { Perennial } & \text { SCPO4 } & \text { Sclerocactus } \\ \text { Perennial } & \text { MATE4 } & \text { Mammillaria } \\ \text { Perennial } & \text { ESVID } & \text { Escobaria } \\ \text { Perennial } & \text { OPBAB2 } & \text { Opuntia } \\ \text { Perennial } & \text { OPERU } & \text { Opuntia } \\ \text { Perennial } & \text { OPPU } & \text { Opuntia } \\ \text { Perennial } & \text { OPRA } & \text { Opuntia }\end{array}$

\section{Variable}

Variable MENTZ Mentzelia
\% Frequency

curvipes

0.7

hoodii ssp. lanata $\quad 0.7$

subspinosa $\quad 0.7$

kali ssp. tragus $\quad 0.7$

verocunda ssp. andersonii $\quad 0.7$

$\begin{array}{ll}\text { ambiguua var. rugosa } & 0.7\end{array}$

$\begin{array}{ll}\text { curvipes } & 0.7\end{array}$

$\begin{array}{ll}\text { paniculatus } & 0.7\end{array}$

$\begin{array}{lr}\text { echinocarpa var. echinocarpa } & 27.3 \\ \text { erinacea var. erinacea } & 15.8 \\ \text { polyacantha var. rufispina } & 15.8 \\ \text { engelmannii } & 11.5 \\ \text { brevifolia } & 8.6 \\ \text { baccata var. vespertina } & 3.6 \\ \text { vivipara var. rosea } & 2.9 \\ \text { polyancistrus } & 2.9 \\ \text { tetrancistra } & 1.4 \\ \text { vivipara var. deserti } & 0.7 \\ \text { basilaris var. basilaris } & 0.7 \\ \text { erinacea var. ursina } & 0.7 \\ \text { pulchella } & 0.7 \\ \text { ramosissima } & 0.7\end{array}$

15.8

15.8

11.5

8.6

3.6

2.9

.9

1.4

0.7

0.7

0.7

0.7

0.7

0.7 
Association Longevity ACODE Genus Species \% Frequency

\section{Artemisia nova-Chrysothamnus viscidiflorus Shrubland}

Trees $(>5 \mathrm{~m})$

$\begin{array}{lll}\text { Perennial } & \text { JUOS } & \text { Juniperus } \\ \text { Perennial } & \text { PIMO } & \text { Pinus } \\ \text { Perennial } & \text { QUGA } & \text { Quercus }\end{array}$

osteosperma $\quad \mathbf{5 6 . 3}$

monophylla $\quad 39.8$

Tall Shrubs (2-5 m)

Perennial ARTRT Artemisia

tridentata ssp. tridentata

50.5

\section{Short Shrubs (0.5-2 m)}

$\begin{array}{lll}\text { Perennial } & \text { ARNO4 } & \text { Artemisia } \\ \text { Perennial } & \text { EPNE } & \text { Ephedra } \\ \text { Perennial } & \text { GRSP } & \text { Grayia } \\ \text { Perennial } & \text { EPVI } & \text { Ephedra } \\ \text { Perennial } & \text { ATCAC } & \text { Atriplex } \\ \text { Perennial } & \text { CHVIV2 } & \text { Chrysothamnus } \\ \text { Perennial } & \text { CHVIP4 } & \text { Chrysothamnus } \\ \text { Perennial } & \text { KRLA2 } & \text { Krascheninnikovia } \\ \text { Perennial } & \text { ERMIS2 } & \text { Eriogonum } \\ \text { Perennial } & \text { LYAN } & \text { Lycium } \\ \text { Perennial } & \text { ERNA7 } & \text { Ericameria } \\ \text { Perennial } & \text { PUGL2 } & \text { Purshia } \\ \text { Perennial } & \text { ERNAL } & \text { Ericameria } \\ \text { Perennial } & \text { ATCO } & \text { Atriplex } \\ \text { Perennial } & \text { GUSA2 } & \text { Gutierrezia } \\ \text { Perennial } & \text { TEGL } & \text { Tetradymia } \\ \text { Perennial } & \text { SYLO } & \text { Symphoricarpos } \\ \text { Perennial } & \text { PUST } & \text { Purshia } \\ \text { Perennial } & \text { ERNAH } & \text { Ericameria } \\ \text { Perennial } & \text { TEAXA } & \text { Tetradymia } \\ \text { Perennial } & \text { ERCO23 } & \text { Ericameria } \\ \text { ERNA10 } & \text { Ericameria } \\ \text { PECA2 } & \text { Tetradymia } \\ \text { Pepidium }\end{array}$

nova
nevadensis
spinosa
viridis
canescens var. canescens
viscidiflorus ssp. viscidiflorus
viscidiflorus ssp. puberulus
lanata
microthecum var. simpsonii
andersonii
nanus
glandulosa
nauseosus ssp. consimilis var. leiosperma
confertifolia
sarothrae
glabrata
longiflorus
stansburiana
nauseosus ssp. nauseosus var.
hololeuca
canescens
spinescens var. aridum
axillaris var. axillaris
cooperi
nauseosus
salsola
fremontii

100.0

76.7

63.1

55.3

52.4

52.4

44.7

37.9

34.0

24.3

19.4

19.4

18.4

16.5

15.5

12.6

11.7

10.7

8.7

7.8

5.8

5.8

4.9

4.9

3.9

3.9

Thursday, September 09, 1999

Page 81 of 107 


$\begin{array}{lll}\text { Perennial } & \text { PUTR2 } & \text { Purshia } \\ \text { Perennial } & \text { CHGR6 } & \text { Chrysothamnus } \\ \text { Perennial } & \text { CORA } & \text { Coleogyne } \\ \text { Perennial } & \text { ERLI6 } & \text { Ericameria } \\ \text { Perennial } & \text { ERTE18 } & \text { Ericamenia } \\ \text { Perennial } & \text { SADOD3 } & \text { Salvia } \\ \text { Perennial } & \text { ERHEA } & \text { Eriogonum } \\ \text { Perennial } & \text { RHTRA } & \text { Rhus } \\ \text { Perennial } & \text { ERFAP } & \text { Eriogonum } \\ \text { Perennial } & \text { PRFA } & \text { Prunus } \\ \text { Perennial } & \text { RIVEV } & \text { Ribes } \\ \text { Perennial } & \text { STPIP } & \text { Stanleya }\end{array}$

$\begin{array}{ll}\text { tridentata } & 3.9 \\ \text { greenei } & 2.9 \\ \text { ramosissima } & 2.9 \\ \text { linearifolius } & 2.9 \\ \text { teretifolia } & 2.9 \\ \text { dorii ssp. domii var. dorrii } & 2.9 \\ \text { heermannii var. argense } & 1.9 \\ \text { trilobata var. anisophylla } & 1.9 \\ \text { fasciculatum var. polifolium } & 1.0 \\ \text { fasciculata } & 1.0 \\ \text { velutinum var. velutinum } & 1.0 \\ \text { pınnata var. pinnata } & 1.0\end{array}$

\section{Dwarf Shrubs ( $<0.5 \mathrm{~m}$ )}

$\begin{array}{lll}\text { Perennial } & \text { LEPU } & \text { Leptodactylon } \\ \text { Perennial } & \text { ARSP5 } & \text { Artemisia } \\ \text { Perennial } & \text { ERMIL } & \text { Eriogonum } \\ \text { Perennial } & \text { KOAM } & \text { Kochia } \\ \text { Perennial } & \text { MESP2 } & \text { Menodora }\end{array}$

pungens
spinescens
microthecum var. lapidicola
americana
spinescens

\section{Graminoids}

$\begin{array}{lll}\text { Perennial } & \text { ELELE } & \text { Elymus } \\ \text { Perennial } & \text { ACHY } & \text { Achnatherum } \\ \text { Annual } & \text { BRTE } & \text { Bromus } \\ \text { Perennial } & \text { PLJA } & \text { Pleuraphis } \\ \text { Perennial } & \text { POSE } & \text { Poa } \\ \text { Annual } & \text { BRRU2 } & \text { Bromus } \\ \text { Perennial } & \text { HECOC8 } & \text { Hesperostipa } \\ \text { Perennial } & \text { ACSP12 } & \text { Achnatherum } \\ \text { Perennial } & \text { ARPU9 } & \text { Aristida } \\ \text { Annual } & \text { VUOC } & \text { Vulpia } \\ \text { Perennial } & \text { POFE } & \text { Poa } \\ \text { Annual } & \text { VUMI } & \text { Vulpia } \\ \text { Perennial } & \text { ACTH7 } & \text { Achnatherum } \\ \text { Perennial } & \text { KOMA } & \text { Koeleria } \\ \text { Perennial } & \text { ACCO21 } & \text { Achnatherum } \\ \text { Perennial } & \text { LECI4 } & \text { Leymus }\end{array}$

elymoides ssp. elymoides
hymenoides
tectorum
jamesii
secunda
rubens
comata ssp. comata
speciosum
purpurea
octoflora
fendleriana
microstachys
thurberiana
macrantha
coronata
cinereus




\section{Forbs}

\begin{tabular}{|c|c|c|}
\hline Perennial & CAAP4 & Castilleja \\
\hline Perennial & PHST11 & Phlox \\
\hline Perennial & CAFL & Calochortus \\
\hline Annual & PHFR2 & Phacelia \\
\hline Perennial & EROVO5 & Eriogonum \\
\hline Perennial & SPAMA & Sphaeralcea \\
\hline Perennial & GIBRB & Gilia \\
\hline Annual & DEPIG & Descurainia \\
\hline Perennial & MACAC & Machaeranthera \\
\hline Perennial & ERCOC3 & Erigeron \\
\hline Annual & ASLEF2 & Astragalus \\
\hline Annual & CAPT & Camissonia \\
\hline Annual & $\mathrm{CRCl} 2$ & Cryptantha \\
\hline Annual & SYFR & Syntrichopappus \\
\hline Perennial & ASPUT & Astragalus \\
\hline Annual & CRPT & Cryptantha \\
\hline Annual & CRGR3 & Cryptantha \\
\hline Annual & AMTE3 & Amsinckia \\
\hline Perennial & ARPUG & Arabis \\
\hline Perennial & DEPAP3 & Delphinium \\
\hline Annual & MEAL6 & Mentzelia \\
\hline Annual & CHST & Chaenactis \\
\hline Perennial & DIPU3 & Dichelostemma \\
\hline Perennial & LILE3 & Linum \\
\hline Annual & LUFL & Lupinus \\
\hline Perennial & LONEN & Lomatium \\
\hline Perennial & SEMU3 & Senecio \\
\hline Perennial & DEAN & Delphinium \\
\hline Annual & ERER2 & Eriastrum \\
\hline Perennial & ERCA8 & Eniogonum \\
\hline Annual & ERNI4 & Eriogonum \\
\hline Annual & LAOCO & Lappula \\
\hline Annual & LELA & Lepidium \\
\hline Annual & PHSA & Phacelia \\
\hline Annual & CHMA & Chaenactis \\
\hline
\end{tabular}

\begin{tabular}{|c|c|}
\hline applegatei & 68.9 \\
\hline stansburyi & 62.1 \\
\hline flexuosus & 61.2 \\
\hline fremontii & $\mathbf{5 7 . 3}$ \\
\hline ovalifolium var. ovalifolium & 56.3 \\
\hline ambigua ssp. ambigua & 52.4 \\
\hline brecciarum ssp. brecciarum & 50.5 \\
\hline pinnata ssp. glabra & 47.6 \\
\hline canescens ssp. canescens & 47.6 \\
\hline concinnus var. concinnus & 44.7 \\
\hline lentiginosus var. fremontii & 43.7 \\
\hline oterosperma & 40.8 \\
\hline circumscissa & 39.8 \\
\hline fremontii & 39.8 \\
\hline purshii var. tinctus & 38.8 \\
\hline pterocarya & 35.0 \\
\hline gracilis & 32.0 \\
\hline tessellata & 31.1 \\
\hline pulchra var. gracilis & 30.1 \\
\hline parishii ssp. parishii & 30.1 \\
\hline albicaulis & 26.2 \\
\hline stevioides & 24.3 \\
\hline pulchellum & 24.3 \\
\hline lewisii & 24.3 \\
\hline flavoculatus & 22.3 \\
\hline nevadense var. nevadense & 21.4 \\
\hline multilobatus & 21.4 \\
\hline andersonii & 20.4 \\
\hline eremicum & \\
\hline caespitosum & 19.4 \\
\hline nidularium & 17.5 \\
\hline occidentalis var. occidentalis & 14.6 \\
\hline lasiocarpum & \\
\hline saxicola & 13.6 \\
\hline macrantha & 1 \\
\hline
\end{tabular}




\begin{tabular}{|c|c|c|c|c|c|}
\hline Association & Longevity & $A C O D E$ & Genus & Species & $\%$ Frequency \\
\hline & Annual & MISU2 & Mimulus & suksdorfii & 12 \\
\hline & Perennial & OECEM4 & Oenothera & caespitosa ssp. marginata & \\
\hline & Perennial & CALI4 & Castilleja & Inariaefolia & 10 \\
\hline & Perennial & CRFL6 & Cryptantha & flavoculata & \\
\hline & Perennial & HYCOC2 & Hymenoxys & cooperi var. cooperi & 10 \\
\hline & Annual & PLPA2 & Plantago & patagonica & 10. \\
\hline & Perennial & STCOC & Streptanthus & cordatus var. cordatus & \\
\hline & Perennial & ARCOS2 & Arenaria & congesta var. subcongesta & \\
\hline & Annual & ERDI4 & Erigeron & divergens & \\
\hline & Perennial & ASNE6 & Astragalus & newberryi & \\
\hline & Annual & CRNEN & Cryptantha & nevadensis var. nevadensis & \\
\hline & Perennial & $\mathrm{CROCO} 2$ & Crepis & occidentalis ssp. occidentalis & 8. \\
\hline & Perennial & CYPU & Cymopterus & purpurascens & \\
\hline & Annual & LUBR2 & Lupinus & brevicaulis & \\
\hline & Perennial & SPAMM & Sphaeralcea & ambigua ssp. monticola & \\
\hline & Perennial & TOSC & Townsendia & scapigera & \\
\hline & Annual & CETH3 & Centrostegia & thurberi & \\
\hline & Annual & IPPO2 & Ipomopsis & polycladon & \\
\hline & Annual & PESE & Pectocarya & setosa & \\
\hline & Annual & PHCRC3 & Phacelia & crenulata var. crenulata & \\
\hline & Annual & PHVAV2 & Phacelia & vallis-mortae var. vallis-mortae & \\
\hline & Annual & ERCl6 & Erodium & cicutarium & \\
\hline & Perennial & ERUM & Eriogonum & umbellatum & \\
\hline & Perennial & ORFA & Orobanche & fasciculata & \\
\hline & Annual & OXPE2 & Oxytheca & perfoliata & 6. \\
\hline & Perennial & PHGRH & Phlox & gracilis ssp. humilis & \\
\hline & Perennial & ALNE & Allium & nevadense & \\
\hline & Perennial & ARPUM & Arabis & pulchra var. munciensis & O. \\
\hline & Perennial & ASCAC5 & Astragalus & calycosus var. calycosus & \\
\hline & Annual & CHWA2 & Chorizanthe & watsonii & \\
\hline & Perennial & $\mathrm{CRCO} 12$ & Cryptantha & confertiflora & \\
\hline & Perennial & CRUT & Cryptantha & ufahensis & \\
\hline & Annual & LUSH & Lupinus & shockleyi & \\
\hline & Annual & MAGL3 & Malacothrix & glabrata & \\
\hline & Annual & CABRB 4 & Camissonia & brevipes ssp. brevipes & \\
\hline & Perennial & CAPI4 & Caulanthus & pilosus & \\
\hline
\end{tabular}




\begin{tabular}{|c|c|c|c|c|c|}
\hline \multirow[t]{37}{*}{ Association } & Longevity & $A C O D E$ & Genus & Species & \% Frequency \\
\hline & Perennial & CHAL11 & Chamaesyce & albomarginata & 4.9 \\
\hline & Biennial & CINE & Cirsium & neomexicanum & 4.9 \\
\hline & Annual & SAPAB & Salsola & paulsenii & 4.9 \\
\hline & Annual & CAPU16 & Camissonia & pusilla & 3.9 \\
\hline & Perennial & $\mathrm{CHDO}$ & Chaenactis & douglasii & 3.9 \\
\hline & Annual & LIDI2 & Linanthus & dichotomus & 3.9 \\
\hline & Annual & STEXE & Stephanomeria & exigua ssp. exigua & 3.9 \\
\hline & Perennial & CHER2 & Leucelene & encoides & 2.9 \\
\hline & Annual & GILIA & Gilia & & 2.9 \\
\hline & Annual & HAGL & Halogeton & glomeratus & 2.9 \\
\hline & Perennial & LEKIK & Lesquerella & kingii ssp. kingii & 2.9 \\
\hline & Annual & LOHU2 & Lotus & humistratus & 2.9 \\
\hline & Annual & MASO & Malacothrix & sonchoides & 2.9 \\
\hline & Annual & MEVE5 & Mentzelia & veatchiana & 2.9 \\
\hline & Annual & URL12 & Uropappus & linearifolia & 2.9 \\
\hline & Perennial & ZIPA2 & Zigadenus & paniculatus & 2.9 \\
\hline & Annual & ANAC & Anisocoma & acaulis & 1.9 \\
\hline & Annual & ASAC3 & Astragalus & acutirostris & 1.9 \\
\hline & Perennial & ASBE5 & Astragalus & beatleyae & 1.9 \\
\hline & Perennial & BAHON & Balsamorhiza & hookeri var. neglecta & 1.9 \\
\hline & Annual & CABOI & Camissonia & boothii ssp. intermedia & 1.9 \\
\hline & Annual & CACLI & Camissonia & claviformis ssp. integrior & 1.9 \\
\hline & Annual & CARE2 & Camissonia & refracta & 1.9 \\
\hline & Annual & CHIN2 & Chenopodium & incanum & 1.9 \\
\hline & Annual & CHRI & Chorizanthe & rigida & 1.9 \\
\hline & Annual & CRMI & Cryptantha & micrantha & 1.9 \\
\hline & Perennial & CRVI5 & Cryptantha & virginensis & 1.9 \\
\hline & Perennial & ERAP & Erigeron & aphanactis & 1.9 \\
\hline & Annual & ERCO18 & Eriogonum & concinnum & 1.9 \\
\hline & Annual & ERDE6 & Eriogonum & deflexum & 1.9 \\
\hline & Perennial & ERIN4 & Eriogonum & inflatum & 1.9 \\
\hline & Perennial & GISI & Gilia & sinuata & 1.9 \\
\hline & Perennial & HEMUN & Heliomeris & multiflora var. nevadensis & 1.9 \\
\hline & Perennial & MIBI8 & Mirabilis & bigelovii & 1. \\
\hline & Annual & MISP & Mimulus & spissus & 1.9 \\
\hline & Perennial & OEPAP & Oenothera & pallida ssp. pallida & 1.9 \\
\hline
\end{tabular}




\begin{tabular}{|c|c|c|c|c|c|}
\hline \multirow[t]{37}{*}{ Association } & Longevity & $A C O D E$ & Genus & Species & $\%$ Frequency \\
\hline & Perennial & ORCO5 & Orobanche & corymbosa & 1.9 \\
\hline & Perennial & PEFLA2 & Penstemon & floridus var. austinii & 1.9 \\
\hline & Perennial & PEPU7 & Petradoria & pumila & 1.9 \\
\hline & Perennial & POSU & Polygala & subspinosa & 1.9 \\
\hline & Biennial & SIAL2 & Sisymbrium & altissimum & 1.9 \\
\hline & Perennial & STPA3 & Stephanomeria & parryi & 1.9 \\
\hline & Perennial & ABEL & Abronia & elliptica & 1.0 \\
\hline & Perennial & ARHOP3 & Arabis & holboellii var. pinetorum & 1.0 \\
\hline & Perennial & ARIN & Arabis & inyoensis & 1.0 \\
\hline & Perennial & ARMA3 & Arenaria & macradenia & 1.0 \\
\hline & Perennial & ASBE3 & Astragalus & beckwithii & 1.0 \\
\hline & Perennial & ASMIV & Astragalus & minthorniae var. villosus & 1.0 \\
\hline & Perennial & CACRG & Caulanthus & crassicaulis var. glaber & 1.0 \\
\hline & Annual & CAPA39 & Camissonia & parvula & 1.0 \\
\hline & Annual & CAPA7 & Calycoseris & parryi & 1.0 \\
\hline & Annual & CHBRB & Chorizanthe & brevicornu var. brevicomu & 1.0 \\
\hline & Annual & $\mathrm{CHXA}$ & Chaenactis & xantiana & 1.0 \\
\hline & Annual & CIPAN & Cistanthe & pamyi var. nevadense & 1.0 \\
\hline & Annual & CRDE & Cryptantha & decipiens & 1.0 \\
\hline & Annual & ERBR7 & Eriogonum & brachyanthum & 1.0 \\
\hline & Annual & ERESE & Eriogonum & esmeraldense var. esmeraldense & 1.0 \\
\hline & Annual & ERMA2 & Eriogonum & maculatum & 1.0 \\
\hline & Perennial & ERNU4 & Eriogonum & nummulare & 1.0 \\
\hline & Annual & ERPR4 & Eriophyllum & pringlei & 1.0 \\
\hline & Annual & ERPU6 & Eriogonum & pusillum & 1.0 \\
\hline & Perennial & ERRA3 & Eriogonum & racemosum & 1.0 \\
\hline & Perennial & ERSA6 & Eriogonum & saxatile & 1.0 \\
\hline & Annual & ERSP3 & Eriastrum & sparsiflorum & 1.0 \\
\hline & Perennial & ERUMV2 & Eriogonum & umbellatum var. versicolor & 1.0 \\
\hline & Annual & ESMI & Eschscholzia & minutiffora & 1.0 \\
\hline & Annual & GARA & Gayophytum & racemosum & 1.0 \\
\hline & Perennial & GIHU & Gilia & hutchinsifolia & 1.0 \\
\hline & Perennial & GIIN2 & Gilia & inconspicua & 1.0 \\
\hline & Perennial & GINY & Gilia & nyensis & 1.0 \\
\hline & Annual & LIBI2 & Linanthus & bigelovii & 1.0 \\
\hline & Perennial & LINUN & Linanthus & nuttallii ssp. nuttallii & 1.0 \\
\hline
\end{tabular}




$\begin{array}{lll}\text { Perennial } & \text { LUARL5 } & \text { Lupinus } \\ \text { Perennial } & \text { MIMUG } & \text { Mirabilis } \\ \text { Annual } & \text { NAAR } & \text { Nama } \\ \text { Annual } & \text { NADED } & \text { Nama } \\ \text { Annual } & \text { NAPU } & \text { Nama } \\ \text { Annual } & \text { OEPR } & \text { Oenothera } \\ \text { Perennial } & \text { PEHUH } & \text { Penstemon } \\ \text { Perennial } & \text { PENST } & \text { Penstemon } \\ \text { Perennial } & \text { PEPA23 } & \text { Penstemon } \\ \text { Perennial } & \text { POHE7 } & \text { Polygala } \\ \text { Annual } & \text { SACOC } & \text { Salvia } \\ \text { Perennial } & \text { SESP3 } & \text { Senecio } \\ \text { Perennial } & \text { SIVEA } & \text { Silene } \\ \text { Perennial } & \text { SPAMR } & \text { Sphaeralcea } \\ \text { Perennial } & \text { SPGRP2 } & \text { Sphaeralcea } \\ \text { Annual } & \text { STLO4 } & \text { Streptanthella } \\ \text { Annual } & \text { STMI2 } & \text { Stylocline } \\ \text { Perennial } & \text { TRWA2 } & \text { Tricardia }\end{array}$

$\begin{array}{ll}\text { argenteus ssp. artenteus var. laxiflorus } & 1.0 \\ \text { multiflora var. glandulosa } & 1.0 \\ \text { aretioides } & 1.0 \\ \text { demissum var. demissum } & 1.0 \\ \text { pusillum } & 1.0 \\ \text { primiveris } & 1.0 \\ \text { humilis ssp. humilis } & 1.0 \\ & 1.0 \\ \text { pahutensis } & 1.0 \\ \text { heteromyncha } & 1.0 \\ \text { columbariae var. columbariae } & 1.0 \\ \text { spartioides } & 1.0 \\ \text { verecunda ssp. andersonii } & 1.0 \\ \text { ambiguua var. rugosa } & 1.0 \\ \text { grossulariaefolia ssp. pedata } & 1.0 \\ \text { longirostris } & 1.0 \\ \text { micropoides } & 1.0 \\ \text { watsonii } & 1.0\end{array}$

\section{Succulents}

$\begin{array}{lll}\text { Perennial } & \text { OPERE } & \text { Opuntia } \\ \text { Perennial } & \text { OPECE } & \text { Opuntia } \\ \text { Perennial } & \text { YUBAV } & \text { Yucca } \\ \text { Perennial } & \text { ECEN } & \text { Echinocereus } \\ \text { Perennial } & \text { OPPOR } & \text { Opuntia } \\ \text { Perennial } & \text { ESVIR2 } & \text { Escobania } \\ \text { Perennial } & \text { SCPO4 } & \text { Sclerocactus } \\ \text { Perennial } & \text { YUBR } & \text { Yucca } \\ \text { Perennial } & \text { OPERU } & \text { Opuntia } \\ \text { Perennial } & \text { MATE4 } & \text { Mammillaria } \\ \text { Perennial } & \text { ECTRM } & \text { Echinocereus } \\ \text { Perennial } & \text { OPBAB2 } & \text { Opuntia }\end{array}$

erinacea var. erinacea
echinocarpa var. echinocarpa
baccata var. vespertina
engelmannii
polyacantha var. rufispina
vivipara var. rosea
polyancistrus
brevifolia
erinacea var. ursina
tetrancistra
triglochidiatus var. melanacanthus
basilaris var. basilaris




\section{Artemisia nova-Artemisia tridentata Shrubland}

\section{Trees (>5 m)}

$\begin{array}{lll}\text { Perennial } & \text { JUOS } & \text { Juniperus } \\ \text { Perennial } & \text { PIMO } & \text { Pinus }\end{array}$

Perennial PIMO Pinus

monophylla

Tall Shrubs (2-5 m)

Perennial ARTRT Artemisia

tridentata ssp. tridentata

Short Shrubs (0.5-2 m)

\begin{tabular}{|c|c|c|}
\hline Perennial & ARNO4 & Artemisia \\
\hline Perennial & EPNE & Ephedra \\
\hline Perennial & ATCAC & Atriplex \\
\hline Perennial & CHVIP4 & Chrysothamnus \\
\hline Perennial & EPVI & Ephedra \\
\hline Perennial & ERMIS2 & Eriogonum \\
\hline Perennial & CHVIV2 & Chrysothamnus \\
\hline Perennial & GRSP & Grayia \\
\hline Perennial & KRLA2 & Krascheninnikovia \\
\hline Perennial & ERNAL & Ericameria \\
\hline Perennial & GUSA2 & Gutierrezia \\
\hline Perennial & PUGL2 & Purshia \\
\hline Perennial & SYLO & Symphoricarpos \\
\hline Perennial & ERNA7 & Ericameria \\
\hline Perennial & LYAN & Lycium \\
\hline Perennial & ERNAH & Ericameria \\
\hline Perennial & TEAXA & Tetradymia \\
\hline Perennial & TECA2 & Tetradymia \\
\hline Perennial & CORA & Coleogyne \\
\hline Perennial & ERFAP & Eriogonum \\
\hline Perennial & PUST & Purshia \\
\hline Perennial & RHTRA & Rhus \\
\hline Perennial & TEGL & Tetradymia \\
\hline Perennial & PUTR2 & Purshia \\
\hline Perennial & ATCO & Atriplex \\
\hline Perennial & CHVIS5 & Chrysothamnus \\
\hline Perennial & ERCO23 & Ericameria \\
\hline
\end{tabular}

nova

100.0

nevadensis

66.7

canescens var. canescens

63.3

viscidiflorus ssp. puberulus

60.0

viridis

60.0

microthecum var. simpsonii

60.0

viscidifforus ssp. viscidifforus

56.7

spinosa

50.0

lanata

30.0

nauseosus ssp. consimilis var. leiosperma

26.7

sarothrae

23.3

glandulosa

23.3

longiflorus

23.3

nanus

20.0

andersonii

20.0

nauseosus ssp. nauseosus var.

16.7

hololeuca

axillaris var. axillaris

13.3

canescens

ramosissima

10.0

fasciculatum var. polifolium

10.0

stansburiana

10.0

trilobata var. anisophylla

10.0

glabrata

10.0

tridentata

6.7

confertifolia

viscidiflorus ssp. viscidiflorus var. 


$\begin{array}{ccl}\text { Perennial } & \text { GLSPA } & \text { Glossopetalon } \\ \text { Perennial } & \text { PRFA } & \text { Prunus } \\ \text { Perennial } & \text { PSPO } & \text { Psorothamnus } \\ \text { Perennial } & \text { SADOD3 } & \text { Salvia } \\ \text { Perennial } & \text { STPIP } & \text { Stanleya }\end{array}$

spinescens var. anidum

Dwarf Shrubs ( $<0.5 \mathrm{~m})$

$\begin{array}{lll}\text { Perennial } & \text { LEPU } & \text { Leptodactylon } \\ \text { Perennial } & \text { ARSP5 } & \text { Artemisia } \\ \text { Perennial } & \text { ERWA8 } & \text { Ericameria }\end{array}$

pungens

spinescens

56.7

watsonii

\section{Graminoids}

$\begin{array}{lcl}\text { Perennial } & \text { ELELE } & \text { Elymus } \\ \text { Perennial } & \text { ACHY } & \text { Achnatherum } \\ \text { Perennial } & \text { PLJA } & \text { Pleuraphis } \\ \text { Annual } & \text { BRTE } & \text { Bromus } \\ \text { Perennial } & \text { HECOC8 } & \text { Hesperostipa } \\ \text { Perennial } & \text { POSE } & \text { Poa } \\ \text { Perennial } & \text { POFE } & \text { Poa } \\ \text { Annual } & \text { VUOC } & \text { Vulpia } \\ \text { Perennial } & \text { ACSP12 } & \text { Achnatherum } \\ \text { Annual } & \text { BRRU2 } & \text { Bromus } \\ \text { Perennial } & \text { ARPU9 } & \text { Aristida } \\ \text { Perennial } & \text { LECI4 } & \text { Leymus } \\ \text { Perennial } & \text { ACTH7 } & \text { Achnatherum } \\ \text { Perennial } & \text { ACAR14 } & \text { Achnatherum } \\ \text { Perennial } & \text { AGGLL } & \text { Agoseris } \\ \text { Perennial } & \text { HOJU } & \text { Hondeum } \\ \text { Annual } & \text { VUMI } & \text { Vulpia }\end{array}$

\section{Forbs}

$\begin{array}{lcl}\text { Perennial } & \text { EROVO5 } & \text { Eriogonum } \\ \text { Perennial } & \text { MACAC } & \text { Machaeranthera } \\ \text { Perennial } & \text { CAAP4 } & \text { Castilleja } \\ \text { Perennial } & \text { PHST11 } & \text { Phlox } \\ \text { Annual } & \text { ASLEF2 } & \text { Astragalus } \\ \text { Perennial } & \text { CAFL } & \text { Calochortus }\end{array}$

$\begin{array}{lr}\text { elymoides ssp. elymoides } & 90.0 \\ \text { hymenoides } & 80.0 \\ \text { jamesii } & 76.7 \\ \text { tectorum } & 70.0 \\ \text { comata ssp. comata } & 66.7 \\ \text { secunda } & 63.3 \\ \text { fendleriana } & 33.3 \\ \text { octoflora } & 30.0 \\ \text { speciosum } & 23.3 \\ \text { rubens } & 20.0 \\ \text { purpurea } & 16.7 \\ \text { cinereus } & 16.7 \\ \text { thurberiana } & 10.0 \\ \text { arida } & 3.3 \\ \text { glauca var. laciniata } & 3.3 \\ \text { jubatum } & 3.3 \\ \text { microstachys } & 3.3\end{array}$

ovalifolium var. ovalifolium $\quad 76.7$

canescens ssp. canescens $\quad 63.3$

applegatei $\quad 60.0$

$\begin{array}{ll}\text { stansburyi } \quad 60.0 & \end{array}$

lentiginosus var, fremontii $\quad 56.7$

flexuosus $\quad 56.7$ 


\section{Species}

\% Frequency

\begin{tabular}{|c|c|c|}
\hline Annual & PHFR2 & Phacelia \\
\hline Annual & $\mathrm{CRCl} 2$ & Cryptantha \\
\hline Perennial & GIBRB & Gilia \\
\hline Perennial & ERCOC3 & Erigeron \\
\hline Annual & ERER2 & Eriastrum \\
\hline Perennial & SPAMA & Sphaeralcea \\
\hline Annual & AMTE3 & Amsinckia \\
\hline Annual & MEAL6 & Mentzelia \\
\hline Perennial & ARPUG & Arabis \\
\hline Annual & CRPT & Cryptantha \\
\hline Perennial & DEPAP3 & Delphinium \\
\hline Annual & DEPIG & Descurainia \\
\hline Annual & ERNI4 & Eriogonum \\
\hline Perennial & SEMU3 & Senecio \\
\hline Annual & CHST & Chaenactis \\
\hline Annual & CRGR3 & Cryptantha \\
\hline Perennial & LILE3 & Linum \\
\hline Annual & LUFL & Lupinus \\
\hline Perennial & ASPUT & Astragalus \\
\hline Perennial & ORFA & Orobanche \\
\hline Annual & CAPT & Camissonia \\
\hline Perennial & HYCOC2 & Hymenoxys \\
\hline Perennial & SPAMM & Sphaeralcea \\
\hline Annual & STEXE & Stephanomeria \\
\hline Annual & SYFR & Syntrichopappus \\
\hline Annual & CETH3 & Centrostegia \\
\hline Perennial & $\mathrm{CRCO} 12$ & Cryptantha \\
\hline Perennial & CRFL6 & Cryptantha \\
\hline Annual & PHSA & Phacelia \\
\hline Perennial & ARLU & Artemisia \\
\hline Perennial & ASCAC5 & Astragalus \\
\hline Perennial & CHAL11 & Chamaesyce \\
\hline Biennial & CINE & Cirsium \\
\hline Perennial & DEAN & Delphinium \\
\hline Annual & LAOCO & Lappula \\
\hline Annual & PHVAV2 & Phacelia \\
\hline
\end{tabular}

fremontii $\quad 53.3$

$\begin{array}{ll}\text { circumscissa } & \mathbf{5 0 . 0}\end{array}$

brecciarum ssp. brecciarum $\quad 50.0$

$\begin{array}{ll}\text { concinnus var. concinnus } & 46.7\end{array}$

eremicum $\quad 46.7$

ambigua ssp. ambigua $\quad 43.3$

tessellata $\quad 40.0$

albicaulis $\quad \mathbf{4 0 . 0}$

pulchra var. gracilis $\quad 36.7$

pterocarya $\quad 36.7$

parishii ssp. parishii $\quad 36.7$

pinnata ssp. glabra $\quad 36.7$

nidularium $\quad 36.7$

multilobatus $\quad 36.7$

stevioides $\quad 33.3$

gracilis $\quad 33.3$

lewisii 33.3

$\begin{array}{ll}\text { flavoculatus } & \mathbf{3 0 . 0}\end{array}$

purshii var. tinctus $\quad 26.7$

fasciculata $\quad 26.7$

pterosperma 23.3

cooperi var. cooperi 23.3

ambigua ssp. monticola $\quad 23.3$

exigua ssp. exigua $\quad 23.3$

fremontii 23.3

$\begin{array}{ll}\text { thurberi } & 20.0\end{array}$

confertiflora $\quad 20.0$

flavoculata $\quad 20.0$

$\begin{array}{ll}\text { saxicola } & 20.0\end{array}$

ludoviciane $\quad 16.7$

calycosus var. calycosus $\quad 16.7$

albomarginata $\quad 16.7$

neomexicanum $\quad 16.7$

$\begin{array}{ll}\text { andersonii } & 16.7\end{array}$

occidentalis var. occidentalis $\quad 16.7$

vallis-mortae var. vallis-mortae $\quad 16.7$ 
Association Longevity ACODE Genus

\section{Species}

$\begin{array}{ll}\text { patagonica } & 16.7\end{array}$

\begin{tabular}{|c|c|c|}
\hline Annual & PLPA2 & Plantago \\
\hline Perennial & CALI4 & Castilleja \\
\hline Annual & CAPU16 & Camissonia \\
\hline Annual & CHWA2 & Chorizanthe \\
\hline Perennial & CROCO2 & Crepis \\
\hline Perennial & ERCAB & Eriogonum \\
\hline Annual & ERDI4 & Erigeron \\
\hline Annual & LELA & Lepidium \\
\hline Perennial & MIBI8 & Mirabilis \\
\hline Perennial & OECEM4 & Oenothera \\
\hline Annual & PESE & Pectocarya \\
\hline Annual & AMAC2 & Ambrosia \\
\hline Perennial & $\mathrm{CHDO}$ & Chaenactis \\
\hline Annual & CHIN2 & Chenopodium \\
\hline Annual & CHMA & Chaenactis \\
\hline Annual & CRNEN & Cryptantha \\
\hline Perennial & DIPU3 & Dichelostemma \\
\hline Annual & GILIA & Gilia \\
\hline Annual & IPPO2 & Ipomopsis \\
\hline Annual & LUBR2 & Lupinus \\
\hline Annual & LUSH & Lupinus \\
\hline Perennial & MIMUG & Mirabilis \\
\hline Perennial & PEFLA2 & Penstemon \\
\hline Annual & PHCRC3 & Phacelia \\
\hline Perennial & STCOC & Streptanthus \\
\hline Perennial & TOSC & Townsendia \\
\hline Perennial & ALNE & Allium \\
\hline Perennial & ARCOS2 & Arenaria \\
\hline Perennial & ARDR4 & Artemisia \\
\hline Perennial & ARPUM & Arabis \\
\hline Perennial & ASNE6 & Astragalus \\
\hline Perennial & CACRG & Caulanthus \\
\hline Annual & CRMI & Cryptantha \\
\hline Perennial & CRVI5 & Cryptantha \\
\hline Perennial & ERAP & Erigeron \\
\hline Annual & ERBR7 & Eriogonum \\
\hline
\end{tabular}

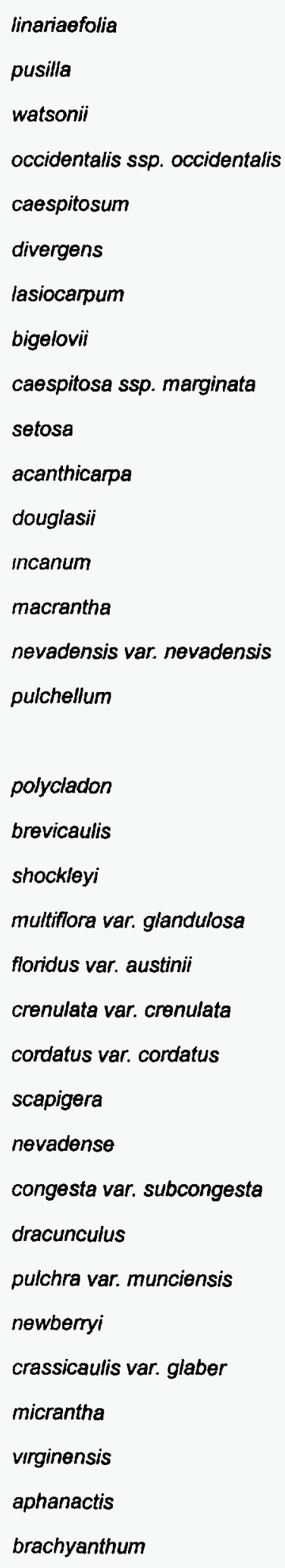

13.3

13.3

13.3

13.3

13.3

13.3

13.3

13.3

13.3

13.3

10.0

10.0

10.0

10.0

10.0

10.0

10.0

10.0

10.0

10.0

10.0

10.0

10.0

10.0

10.0

6.7

6.7

6.7

6.7

6.7

6.7

6.7

6.7

6.7

6.7 


\begin{tabular}{|c|c|c|c|c|c|}
\hline \multirow[t]{37}{*}{ Association } & Longevity & $A C O D E$ & Genus & Species & Frequency \\
\hline & Annual & ERCI6 & Erodium & cicutarium & 6.7 \\
\hline & Perennial & ERSA6 & Eriogonum & saxatile & 6.7 \\
\hline & Perennial & ERUM & Eriogonum & umbellatum & 6.7 \\
\hline & Perennial & HEMUN & Heliomeris & multifiora var. nevadensis & 6.7 \\
\hline & Annual & LIDI2 & Linanthus & dichotomus & 6.7 \\
\hline & Annual & MEVE5 & Mentzelia & veatchiana & 6.7 \\
\hline & Annual & MISP & Mimulus & spissus & 6.7 \\
\hline & Perennial & PEHUH & Penstemon & humilis ssp. humilis & 6.7 \\
\hline & Perennial & PENST & Penstemon & & 6.7 \\
\hline & Annual & PEPL & Pectocarya & platycarpa & 6.7 \\
\hline & Annual & URLI2 & Uropappus & Inearifolia & 6.7 \\
\hline & Perennial & ABEL & Abronia & elliptica & 3.3 \\
\hline & Perennial & $\mathrm{ADCO} 2$ & Adenophyllum & cooperi & 3.3 \\
\hline & Perennial & ANDI2 & Antennaria & dimorpha & 3.3 \\
\hline & Perennial & BRCA3 & Brickellia & califomica & 3.3 \\
\hline & Annual & CACLI & Camissonia & claviformis ssp. integrior & 3.3 \\
\hline & Annual & CAKEG & Camissonia & kermensis ssp. gilmanii & 3.3 \\
\hline & Annual & CHXA & Chaenactis & xantiana & 3.3 \\
\hline & Annual & ERHO6 & Eriogonum & hookeri & 3.3 \\
\hline & Perennial & ERIN4 & Eriogonum & inflatum & 3.3 \\
\hline & Annual & GADIP & Gayophytum & diffusum ssp. parviflorum & 3.3 \\
\hline & Perennial & GIIN2 & Gilia & inconspicua & 3.3 \\
\hline & Annual & HAGL & Halogeton & glomeratus & 3.3 \\
\hline & Perennial & IPCO5 & Ipomopsis & congesta & 3.2 \\
\hline & Perennial & LEKIK & Lesquerella & kingii ssp. kingii & 3.3 \\
\hline & Perennial & LONEN & Lomatium & nevadense var. nevadense & 3.3 \\
\hline & Perennial & LUARL5 & Lupinus & argenteus ssp. artenteus var. laxiflorus & 3.3 \\
\hline & Annual & MAGL3 & Malacothrix & glabrata & 3.3 \\
\hline & Annual & MISU2 & Mimulus & suksdorfii & 3.3 \\
\hline & Annual & NABR & Navarretia & breweri & 3.3 \\
\hline & Annual & OXPE2 & Oxytheca & perfoliata & 3.3 \\
\hline & Annual & PHMU & Phacelia & mustelina & 3.3 \\
\hline & Perennial & Posu & Polygala & subspinosa & 3.3 \\
\hline & Annual & SAPAB & Salsola & paulsenii & 3.3 \\
\hline & Annual & STLO4 & Streptanthella & longirostris & 3.3 \\
\hline & Perennial & STPA4 & Stephanomeria & pauciflora & 3.3 \\
\hline
\end{tabular}




\begin{tabular}{|c|c|c|c|}
\hline Association & Longevity & $A C O D E$ & Genus \\
\hline & Perennial & STSP6 & Stephanomeria \\
\hline & Annual & TINU2 & Tiquilia \\
\hline & Perennial & ZIPA2 & Zigadenus \\
\hline Su & cculents & & \\
\hline & Perennial & OPERE & Opuntia \\
\hline & Perennial & OPECE & Opuntia \\
\hline & Perennial & YUBAV & Yucca \\
\hline & Perennial & ECEN & Echinocereus \\
\hline & Perennial & OPERU & Opuntia \\
\hline & Perennial & SCPO4 & Sclerocactus \\
\hline & Perennial & ESVID & Escobaria \\
\hline & Perennial & ESVIR2 & Escobaria \\
\hline & Perennial & OPPOR & Opuntia \\
\hline & Perennial & OPPU & Opuntia \\
\hline & Perennial & YUBR & Yucca \\
\hline
\end{tabular}

$$
\text { Species }
$$

spinosa

nuttallii

paniculatus

3.3

erinacea var. erinacea
echinocarpa var. echinocarpa
baccata var. vespertina
engelmannii
erinacea var. ursina
polyancistrus
vivipara var. deserti
vivipara var. rosea
polyacantha var. rufispina
pulchella
brevifolia

53.3

26.7

13.3

10.0

6.7

6.7

3.3

3.3

3.3

3.3

3.3 


\section{Pinus monophylla/Artemisia nova Woodland}

\section{Trees $(>5 \mathrm{~m})$}

$\begin{array}{lll}\text { Perennial } & \text { JUOS } & \text { Juniperus } \\ \text { Perennial } & \text { PIMO } & \text { Pinus } \\ \text { Perennial } & \text { QUGA } & \text { Quercus }\end{array}$

Perennial

monophylla

gambelii

Tall Shrubs (2-5 m)

$\begin{array}{ccl}\text { Perennial } & \text { ARTRT } & \text { Artemisia } \\ \text { Perennial } & \text { AMUT } & \text { Amelanchier }\end{array}$

tridentata ssp. tridentata

utahensis

\section{Short Shrubs (0.5-2 m)}

\begin{tabular}{|c|c|c|}
\hline Perennial & ARNO4 & Artemisia \\
\hline Perennial & EPVI & Ephedra \\
\hline Perennial & CHVIV2 & Chrysothamnus \\
\hline Perennial & ERMIS2 & Eriogonum \\
\hline Perennial & CHVIP4 & Chrysothamnus \\
\hline Perennial & PUTR2 & Purshia \\
\hline Perennial & ERNA7 & Ericameria \\
\hline Perennial & ATCAC & Atriplex \\
\hline Perennial & PUGL2 & Purshia \\
\hline Perennial & PUST & Purshia \\
\hline Perennial & EPNE & Ephedra \\
\hline Perennial & GRSP & Grayia \\
\hline Perennial & SYLO & Symphoricarpos \\
\hline Perennial & ERNAL & Ericameria \\
\hline Perennial & GUSA2 & Gutierrezia \\
\hline Perennial & SADOD3 & Salvia \\
\hline Perennial & ERNA10 & Ericameria \\
\hline Perennial & RIVEV & Ribes \\
\hline Perennial & ERFAP & Eriogonum \\
\hline Perennial & ERLI6 & Ericameria \\
\hline Perennial & KRLA2 & Krascheninnikovia \\
\hline Perennial & RICEC2 & Ribes \\
\hline Perennial & TEGL & Tetradymia \\
\hline Perennial & ATCO & Atriplex \\
\hline
\end{tabular}

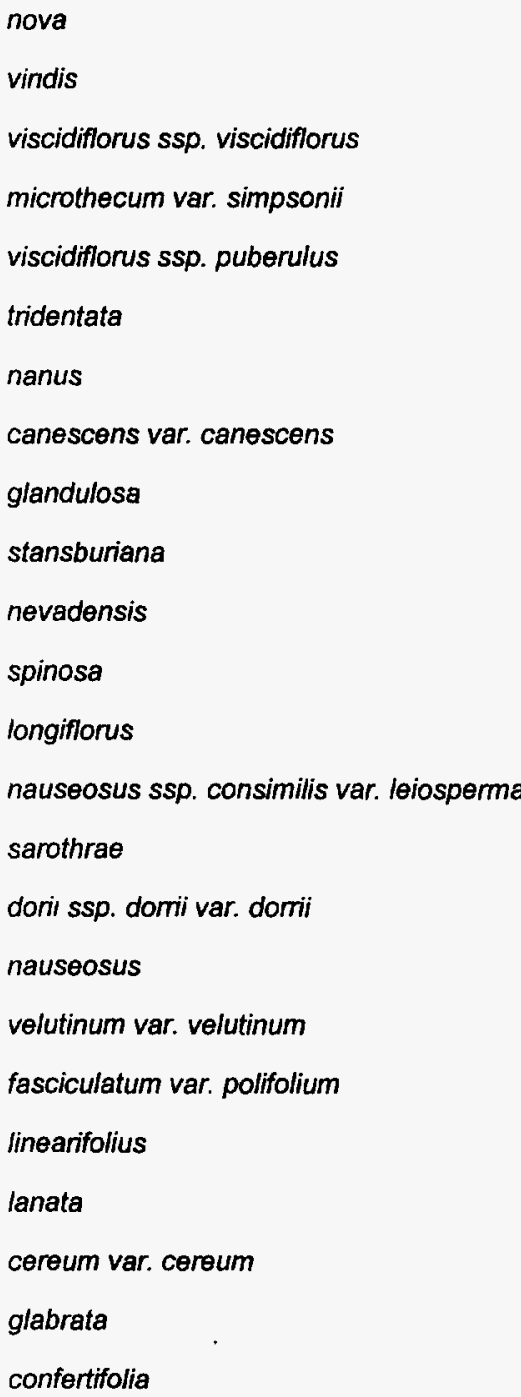

100.0

75.6

61.5

52.6

38.5

30.8

29.5

25.6

24.4

24.4

23.1

20.5

19.2

14.1

6.4 


$\begin{array}{cccl}\text { Association } & \begin{array}{c}\text { Longevity } \\ \text { Perennial }\end{array} & \text { BRMIW } & \text { Brickellia } \\ \text { Perennial } & \text { CORA } & \text { Coleogyne } \\ \text { Perennial } & \text { ERNAH } & \text { Ericameria } \\ \text { Perennial } & \text { ERPAN2 } & \text { Ericameria } \\ \text { Perennial } & \text { ERTE18 } & \text { Ericameria } \\ \text { Perennial } & \text { GLSPA } & \text { Glossopetalon } \\ \text { Perennial } & \text { KEROR } & \text { Keckiella } \\ \text { Perennial } & \text { LYAN } & \text { Lycium } \\ \text { Perennial } & \text { RHTRA } & \text { Rhus } \\ & \text { Perennial } & \text { STPIP } & \text { Stanleya } \\ \text { Perennial } & \text { TEAXA } & \text { Tetradymia } \\ \text { Perennial } & \text { TECA2 } & \text { Tetradymia }\end{array}$

\section{Species}

microphylla var. watsonii

ramosissima

nauseosus ssp. nauseosus var.

hololeuca

parnyi var. nevadensis

teretifolia

spinescens var. aridum

rothrockii ssp. rothrockii

andersonii

trilobata var. anisophylla

pinnata var. pinnata

axillaris var. axillaris

canescens
\% Frequency

1.3

1.3

1.3

1.3

1.3

1.3

1.3

1.3

1.3

1.3

1.3

1.3

\section{Dwarf Shrubs ( $<0.5 \mathrm{~m})$}

$\begin{array}{lll}\text { Perennial } & \text { LEPU } & \text { Leptodactylon } \\ \text { Perennial } & \text { ERMIL } & \text { Eriogonum } \\ \text { Perennial } & \text { ARSP5 } & \text { Artemisia }\end{array}$

pungens

microthecum var. lapidicola

spinescens

\section{Graminoids}

$\begin{array}{lcl}\text { Perennial } & \text { ELELE } & \text { Elymus } \\ \text { Annual } & \text { BRTE } & \text { Bromus } \\ \text { Perennial } & \text { POSE } & \text { Poa } \\ \text { Perennial } & \text { ACHY } & \text { Achnatherum } \\ \text { Perennial } & \text { HECOC8 } & \text { Hesperostipa } \\ \text { Perennial } & \text { POFE } & \text { Poa } \\ \text { Perennial } & \text { PLJA } & \text { Pleuraphis } \\ \text { Perennial } & \text { ACSP12 } & \text { Achnatherum } \\ \text { Perennial } & \text { KOMA } & \text { Koeleria } \\ \text { Perennial } & \text { ARPU9 } & \text { Aristida } \\ \text { Perennial } & \text { ACTH7 } & \text { Achnatherum } \\ \text { Perennial } & \text { AGGLL } & \text { Agoseris } \\ \text { Annual } & \text { BRRU2 } & \text { Bromus } \\ \text { Perennial } & \text { BOGR2 } & \text { Bouteloua } \\ \text { Annual } & \text { VUOC } & \text { Vulpia } \\ \text { Perennial } & \text { ACP12 } & \text { Achnatherum } \\ \text { Perennial } & \text { CADO2 } & \text { Carex } \\ \text { Perennial } & \text { LEC14 } & \text { Leymus }\end{array}$

$\begin{array}{lr}\text { elymoides ssp. elymoides } & 85.9 \\ \text { tectorum } & 79.5 \\ \text { secunda } & 79.5 \\ \text { hymenoides } & 69.2 \\ \text { comata ssp. comata } & 51.3 \\ \text { fendleriana } & 39.7 \\ \text { jamesii } & 30.8 \\ \text { speciosum } & 16.7 \\ \text { macrantha } & 15.4 \\ \text { purpurea } & 14.1 \\ \text { thurberiana } & 12.8 \\ \text { glauca var. laciniata } & 5.1 \\ \text { rubens } & 3.8 \\ \text { gracilis } & 2.6 \\ \text { octoflora } & 2.6 \\ \text { pinetorum } & 1.3 \\ \text { douglasii } & 1.3 \\ \text { cinereus } & 1.3\end{array}$




\section{Forbs}

\begin{tabular}{|c|c|c|}
\hline Perennial & ERCA8 & Eriogonum \\
\hline Perennial & PHST11 & Phlox \\
\hline Perennial & GIBRB & Gilia \\
\hline Annual & ASLEF2 & Astragalus \\
\hline Perennial & CAFL & Calochortus \\
\hline Perennial & EROVO5 & Eriogonum \\
\hline Perennial & ARCOS2 & Arenaria \\
\hline Perennial & CHDO & Chaenactis \\
\hline Perennial & MACAC & Machaeranthera \\
\hline Perennial & ERUM & Eriogonum \\
\hline Annual & PHVAV2 & Phacelia \\
\hline Perennial & STCOC & Streptanthus \\
\hline Perennial & CAAP4 & Castilleja \\
\hline Perennial & SEMU3 & Senecio \\
\hline Perennial & ASCAC5 & Astragalus \\
\hline Annual & CRGR3 & Cryptantha \\
\hline Perennial & HYCOC2 & Hymenoxys \\
\hline Perennial & CRFL6 & Cryptantha \\
\hline Annual & DEPIG & Descurainia \\
\hline Perennial & ERCOC3 & Erigeron \\
\hline Perennial & ASPUT & Astragalus \\
\hline Annual & ERER2 & Eriastrum \\
\hline Annual & PHSA & Phacelia \\
\hline Annual & CAPU16 & Camissonia \\
\hline Annual & LUSH & Lupinus \\
\hline Perennial & ARPUG & Arabis \\
\hline Perennial & CALI4 & Castilleja \\
\hline Perennial & DIPU3 & Dichelostemma \\
\hline Perennial & PEHUH & Penstemon \\
\hline Annual & PHFR2 & Phacelia \\
\hline Perennial & SPAMA & Sphaeralcea \\
\hline Annual & $\mathrm{CRCl} 2$ & Cryptantha \\
\hline Perennial & DEAN & Delphinium \\
\hline Perennial & LEKIK & Lesquere/la \\
\hline Annual & MEAL6 & Mentzelia \\
\hline
\end{tabular}

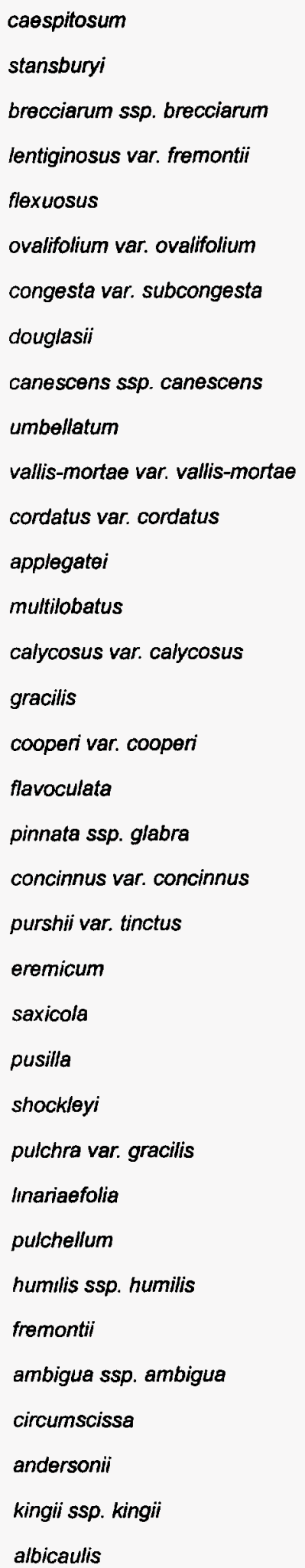




\begin{tabular}{|c|c|c|c|c|c|}
\hline \multirow[t]{37}{*}{ Association } & Longevity & $A C O D E$ & Genus & Species & $\%$ Frequency \\
\hline & Annual & CAPT & Camissonia & pterosperma & 1 \\
\hline & Perennial & LILE3 & Linum & lewisii & \\
\hline & Perennial & LONEN & Lomatium & nevadense var. nevadense & \\
\hline & Perennial & PHGRH & Phlox & gracills ssp. humilis & \\
\hline & Annual & CRPT & Cryptantha & pterocarya & \\
\hline & Annual & ERDI4 & Erigeron & divergens & \\
\hline & Perennial & CROCO2 & Crepis & occidentalis ssp. occidentalis & \\
\hline & Perennial & CRVI5 & Cryptantha & virginensis & \\
\hline & Annual & MISU2 & Mimulus & suksdorfii & \\
\hline & Perennial & ORFA & Orobanche & fasciculata & \\
\hline & Perennial & PEFLA2 & Penstemon & floridus var. austinii & \\
\hline & Annual & AMTE3 & Amsinckia & tessellata & \\
\hline & Perennial & DEPAP3 & Delphinium & parishii ssp. parishii & \\
\hline & Perennial & HEMUN & Heliomeris & multiflora var. nevadensis & \\
\hline & Perennial & PEPU7 & Petradoria & pumila & \\
\hline & Annual & MEVE5 & Mentzelia & veatchiana & \\
\hline & Annual & MISP & Mimulus & spissus & \\
\hline & Perennial & SPAMM & Sphaeralcea & ambigua ssp. monticola & \\
\hline & Annual & CHIN2 & Chenopodium & incanum & \\
\hline & Perennial & CRCO12 & Cryptantha & confertiflora & \\
\hline & Annual & GILIA & Gilia & & \\
\hline & Perennial & OECEM4 & Oenothera & caespitosa ssp. marginata & \\
\hline & Annual & ERNI4 & Eriogonum & nidularium & \\
\hline & Annual & LUFL & Lupinus & flavoculatus & \\
\hline & Annual & SYFR & Syntrichopappus & fremontii & \\
\hline & Perennial & ALNE & Allium & nevadense & \\
\hline & Perennial & ASNE6 & Astragalus & newberryi & \\
\hline & Annual & CHMA & Chaenactis & macrantha & \\
\hline & Annual & IPPO2 & Ipomopsis & polycladon & \\
\hline & Annual & ERSP3 & Eriastrum & sparsifforum & \\
\hline & Annual & LAOCO & Lappula & occidentalis var. occidentalis & \\
\hline & Perennial & LEREM & Lewisia & rediviva var. minor & \\
\hline & Annual & LUBR2 & Lupinus & brevicaulis & \\
\hline & Perennial & MIMUG & Mirabilis & multiflora var. glandulosa & \\
\hline & Annual & $\mathrm{PHCU}$ & Phacelia & curvipes & \\
\hline & Annual & SAPA8 & Salsola & paulsenii & \\
\hline
\end{tabular}




\begin{tabular}{|c|c|c|c|}
\hline Perennial & ANDI2 & Antennaria & dimorpha \\
\hline Annual & CETH3 & Centrostegia & thurberi \\
\hline Perennial & CHAL11 & Chamaesyce & albomarginata \\
\hline Annual & CHWA2 & Chorizanthe & watsonii \\
\hline Annual & ERESE & Eriogonum & esmeraldense var, esmeraldense \\
\hline Perennial & ERRA3 & Eriogonum & racemosum \\
\hline Annual & LIDI2 & Linanthus & dichotomus \\
\hline Perennial & LUARL5 & Lupinus & argenteus ssp. artenteus var. laxiflorus \\
\hline Annual & STEXE & Stephanomeria & exigua ssp. exigua \\
\hline Perennial & TOSC & Townsendia & scapigera \\
\hline Annual & URLI2 & Uropappus & linearifolia \\
\hline Perennial & ARPUM & Arabis & pulchra var. munciensis \\
\hline Annual & ASAC3 & Astragalus & acutirostris \\
\hline Perennial & ASBE 3 & Astragalus & beckwithii \\
\hline Perennial & ASBE5 & Astragalus & beatleyae \\
\hline Perennial & CACRG & Caulanthus & crassicaulis var. glaber \\
\hline Annual & CHST & Chaenactis & stevioides \\
\hline Biennial & CINE & Cirsium & neomexicanum \\
\hline Annual & CRAM3 & Cryptantha & ambigua \\
\hline Perennial & CRUT & Cryptantha & utahensis \\
\hline Annual & ERCI6 & Erodium & cicutarium \\
\hline Annual & GADIP & Gayophytum & diffusum ssp. parviflorum \\
\hline Perennial & GINY & Gilia & nyensis \\
\hline Perennial & IPCO5 & Ipomopsis & congesta \\
\hline Perennial & MIBI8 & Mirabilis & bigelovii \\
\hline Perennial & ORCO5 & Orobanche & corymbosa \\
\hline Perennial & PEPA23 & Penstemon & pahutensis \\
\hline Perennial & PERO10 & Penstemon & rostriflorus \\
\hline Annual & PHCRC3 & Phacelia & crenulata var. crenulata \\
\hline Perennial & STPA4 & Stephanomeria & pauciflora \\
\hline Perennial & STSP6 & Stephanomeria & spinosa \\
\hline Perennial & XYTOT & Xylorhiza & tortifolia var. imberbis \\
\hline Perennial & ZIPA2 & Zigadenus & paniculatus \\
\hline Perennial & ABEL & Abronia & elliptica \\
\hline Annual & AMAC2 & Ambrosia & acanthicarpa \\
\hline Perennial & ANRO2 & Antennaria & rosea \\
\hline
\end{tabular}




\section{Species}

holboellii var. pinetorum

kingii ssp. compacta

ludoviciana

macradenia

hookeri var. neglecta

boothii ssp. condensata

brevipes ssp. brevipes

parryi

leptophyllum

humulis

micrantha

aboriginum

brachyanthum

deflexum

inflatum

saxatile

wilcoxii

pahutensis

hutchinsifolia

vestita ssp. inyoensis

lasiocarpum

nuttallii ssp. nuttallii

foeniculaceum ssp. fimbriatum

glabrata

sonchoides

congesta

breweri

pusillum

palmeri

platycarpa

setosa

affinis

hoodii ssp. lanata

peirsoniana

patagonica

subspinosa
\% Frequency

1.3

1.3

1.3

1.3

1.3

1.3

1.3

1.3

1.3

1.3

1.3

1.3

1.3

1.3

1.3

1.3

1.3

1.3

1.3

1.3

1.3

1.3

1.3

1.3

1.3

1.3

1.3

1.3

1.3

1.3

1.3

1.3

1.3

1.3

1.3

1.3 
Association Longevity ACODE Genus

$\begin{array}{lll}\text { Perennial } & \text { SESP3 } & \text { Senecio } \\ \text { Perennial } & \text { SIVEA } & \text { Silene } \\ \text { Perennial } & \text { TRAN } & \text { Trifolium } \\ \text { Perennial } & \text { TRWA2 } & \text { Tricardia }\end{array}$

\section{Ferns}

Perennial PETR7 Pentagama

\section{Epiphytes}

Perennial ARDI3 Arceuthobium

\section{Succulents}

$\begin{array}{lll}\text { Perennial } & \text { OPERE } & \text { Opuntia } \\ \text { Perennial } & \text { OPPOR } & \text { Opuntia } \\ \text { Perennial } & \text { ESVIR2 } & \text { Escobaria } \\ \text { Perennial } & \text { YUBAV } & \text { Yucca } \\ \text { Perennial } & \text { ECEN } & \text { Echinocereus } \\ \text { Perennial } & \text { OPECE } & \text { Opuntia } \\ \text { Perennial } & \text { MATE4 } & \text { Mammillaria } \\ \text { Perennial } & \text { ECTRM } & \text { Echinocereus }\end{array}$

\section{Species}

spartioides

verecunda ssp. andersonii

andersonii

watsonii

triangularis

divaricatum

erinacea var. erinacea

polyacantha var. rufispina

29.5

vivipara var. rosea

19.2

baccata var. vespertina

16.7

engelmannii

10.3

echinocarpa var. echinocarpa

tetrancistra

triglochidiatus var. melanacanthus
6.4

2.6 


\section{Pinus monophylla/Artemisia tridentata Woodland}

\section{Trees (>5 m)}

$\begin{array}{lll}\text { Perennial } & \text { PIMO } & \text { Pinus } \\ \text { Perennial } & \text { JUOS } & \text { Juniperus } \\ \text { Perennial } & \text { QUGA } & \text { Quercus }\end{array}$

monophylla

\section{Tall Shrubs (2-5 m)}

$\begin{array}{ccl}\text { Perennial } & \text { ARTRT } & \text { Artemisia } \\ \text { Perennial } & \text { AMUT } & \text { Amelanchier } \\ \text { Perennial } & \text { CEGRV2 } & \text { Ceanothus } \\ \text { Perennial } & \text { AMPA2 } & \text { Amelanchier } \\ \text { Perennial } & \text { CEIN7 } & \text { Cercocarpus } \\ \text { Perennial } & \text { CELEL } & \text { Cercocarpus }\end{array}$

tridentata ssp. tridentata

utahensis

pallida

intricatus

Short Shrubs (0.5-2 m)

\begin{tabular}{|c|c|c|}
\hline Perennial & CHVIV2 & Chrysothamnus \\
\hline Perennial & PUTR2 & Purshia \\
\hline Perennial & EPVI & Ephedra \\
\hline Perennial & CHVIP4 & Chrysothamnus \\
\hline Perennial & SYLO & Symphoricarpos \\
\hline Perennial & ERMIS2 & Eriogonum \\
\hline Perennial & ARNO4 & Artemisia \\
\hline Perennial & PUST & Purshia \\
\hline Perennial & RIVEV & Ribes \\
\hline Perennial & RICEC2 & Ribes \\
\hline Perennial & SADOD3 & Salvia \\
\hline Perennial & ERNA7 & Ericameria \\
\hline Perennial & PUGL2 & Purshia \\
\hline Perennial & ATCAC & Atriplex \\
\hline Perennial & TEGL & Tetradymia \\
\hline Perennial & EPNE & Ephedra \\
\hline Perennial & GRSP & Grayia \\
\hline Perennial & RHTRA & Rhus \\
\hline Perennial & CHGR6 & Chrysothamnus \\
\hline Perennial & ERFAP & Eriogonum \\
\hline Perennial & ERLI6 & Ericameria \\
\hline
\end{tabular}

viscidiflorus ssp. viscidifforus

viridis

viscidiflorus ssp. puberulus

47.5

longiflorus

microthecum var. simpsonii

nova

stansburiana

velutinum var. velutinum

cereum var. cereum

15.3

dorii ssp. domi var. domii

nanus

glandulosa

canescens var. canescens

glabrata

nevadensis

spinosa

trilobata var. anisophylla

greenei 


$\begin{array}{lll}\text { Perennial } & \text { ERNA10 } & \text { Ericameria } \\ \text { Perennial } & \text { GUSA2 } & \text { Gutiemrezia } \\ \text { Perennial } & \text { KRLA2 } & \text { Krascheninnikovia } \\ \text { Perennial } & \text { ATCO } & \text { Atriplex } \\ \text { Perennial } & \text { CORA } & \text { Coleogyne } \\ \text { Perennial } & \text { ERCO23 } & \text { Ericameria } \\ \text { Perennial } & \text { ERNAH } & \text { Ericameria } \\ \text { Perennial } & \text { ERNAL } & \text { Ericameria } \\ \text { Perennial } & \text { ERPA29 } & \text { Ericameria } \\ \text { Perennial } & \text { ERPAN2 } & \text { Ericameria } \\ \text { Perennial } & \text { ERTE18 } & \text { Ericameria } \\ \text { Perennial } & \text { HODI } & \text { Holodiscus } \\ \text { Perennial } & \text { PRFA } & \text { Prunus } \\ \text { Perennial } & \text { TECA2 } & \text { Tetradymia }\end{array}$

nauseosus
sarothrae
lanata
confertifolia
ramosissima
cooperi
nauseosus ssp. nauseosus var.
hololeuca
nauseosus ssp. consimilis var. leiosperma
paniculata
parryi var. nevadensis
teretifolia
discolor
fasciculata
canescens

3.4 3.4 3.4 1.7 1.7 1.7 1.7 1.7 1.7 1.7 1.7 1.7 1.7 1.7

\section{Dwarf Shrubs $(<0.5 \mathrm{~m})$}

$\begin{array}{lll}\text { Perennial } & \text { LEPU } & \text { Leptodactylon } \\ \text { Perennial } & \text { ERMIL } & \text { Eriogonum } \\ \text { Perennial } & \text { ARSP5 } & \text { Artemisia } \\ \text { Perennial } & \text { ERWA8 } & \text { Ericameria }\end{array}$

\section{Graminoids}

$\begin{array}{lcl}\text { Perennial } & \text { POSE } & \text { Poa } \\ \text { Perennial } & \text { ELELE } & \text { Elymus } \\ \text { Annual } & \text { BRTE } & \text { Bromus } \\ \text { Perennial } & \text { POFE } & \text { Poa } \\ \text { Perennial } & \text { ACHY } & \text { Achnatherum } \\ \text { Perennial } & \text { HECOC8 } & \text { Hesperostipa } \\ \text { Perennial } & \text { ACTH7 } & \text { Achnatherum } \\ \text { Perennial } & \text { KOMA } & \text { Koeleria } \\ \text { Perennial } & \text { PLJA } & \text { Pleuraphis } \\ \text { Perennial } & \text { AGGLL } & \text { Agoseris } \\ \text { Perennial } & \text { ACSP12 } & \text { Achnatherum } \\ \text { Perennial } & \text { ARPU9 } & \text { Aristida } \\ \text { Perennial } & \text { LEC14 } & \text { Leymus } \\ \text { Perennial } & \text { ACCO21 } & \text { Achnatherum } \\ \text { Perennial } & \text { ACAR14 } & \text { Achnatherum }\end{array}$

pungens
microthecum var. lapidicola
spinescens
watsonii

secunda
elymoides ssp. elymoides
tectorum
fendleriana
hymenoides
comata ssp. comata
thurberiana
macrantha
Jamesii
glauca var. laciniata
speciosum
purpurea
cinereus
coronata
arida




\section{Species}

\% Frequency

$\begin{array}{lll}\text { Perennial } & \text { ACPI2 } & \text { Achnatherum } \\ \text { Annual } & \text { BRRU2 } & \text { Bromus } \\ \text { Perennial } & \text { CAOC2 } & \text { Carex } \\ \text { Perennial } & \text { CADO2 } & \text { Carex } \\ \text { Annual } & \text { VUMI } & \text { Vulpia }\end{array}$

\section{Forbs}

\begin{tabular}{|c|c|c|}
\hline Perennial & STCOC & Streptanthus \\
\hline Perennial & CAAP4 & Castilleja \\
\hline Perennial & SEMU3 & Senecio \\
\hline Annual & ASLEF2 & Astragalus \\
\hline Perennial & PHST11 & Phlox \\
\hline Perennial & ARCOS2 & Arenaria \\
\hline Perennial & CHDO & Chaenactis \\
\hline Perennial & ERCA8 & Eriogonum \\
\hline Perennial & CRFL6 & Cryptantha \\
\hline Perennial & MACAC & Machaeranthera \\
\hline Annual & MISP & Mimulus \\
\hline Perennial & PEHUH & Penstemon \\
\hline Perennial & ERUM & Eriogonum \\
\hline Annual & CAPU16 & Camissonia \\
\hline Annual & CRGR3 & Cryptantha \\
\hline Perennial & GIBRB & Gilia \\
\hline Annual & PHFR2 & Phacelia \\
\hline Perennial & CRVI5 & Cryptantha \\
\hline Perennial & EROVO5 & Eriogonum \\
\hline Perennial & PEPA23 & Penstemon \\
\hline Perennial & PEFLA2 & Penstemon \\
\hline Annual & PHVAV2 & Phacelia \\
\hline Perennial & $\mathrm{CROCO} 2$ & Crepis \\
\hline Annual & ERDI4 & Erigeron \\
\hline Perennial & ERRA3 & Eniogonum \\
\hline Perennial & ASCAC5 & Astragalus \\
\hline Annual & MEVE5 & Mentzelia \\
\hline Perennial & PEPU7 & Petradoria \\
\hline Annual & DEPIG & Descurainia \\
\hline Perennial & CAFL & Calochortus \\
\hline
\end{tabular}

$\begin{array}{ll}\text { pinetorum } & 3.4 \\ \text { rubens } & 3.4 \\ \text { occidentalis } & 3.4 \\ \text { douglasii } & 1.7 \\ \text { microstachys } & 1.7\end{array}$

cordatus var. cordatus $\quad \mathbf{7 4 . 6}$

applegatei $\quad 67.8$

multilobatus $\quad 62.7$

lentiginosus var. fremontii $\quad 50.8$

$\begin{array}{ll}\text { stansburyi } & 49.2\end{array}$

congesta var. subcongesta $\quad 47.5$

douglasii $\quad 45.8$

caespitosum $\quad 42.4$

$\begin{array}{ll}\text { flavoculata } & 40.7\end{array}$

$\begin{array}{ll}\text { canescens ssp. canescens } & 40.7\end{array}$

$\begin{array}{ll}\text { spissus } & 40.7\end{array}$

humilis $\mathrm{ssp}$. humilis $\quad 35.6$

umbellatum $\quad 33.9$

pusilla $\quad 32.2$

gracilis $\quad 32.2$

brecciarum ssp. brecciarum $\quad 32.2$

fremontii $\quad 32.2$

ovalifolium var. ovalifolium $\quad 30.5$

pahutensis $\quad 30.5$

floridus var. austinii $\quad 28.8$

vallis-mortae var. vallis-mortae $\quad 28.8$

occidentalis ssp. occidentalis $\quad 27.1$

divergens $\quad 25.4$

racemosum $\quad 23.7$

calycosus var. calycosus $\quad \mathbf{2 2 . 0}$

veatchiana $\quad 22.0$

pumila $\quad 22.0$

pinnata ssp. glabra $\quad 20.3$

flexuosus $\quad 18.6$ virginensis $\quad 30.5$ 


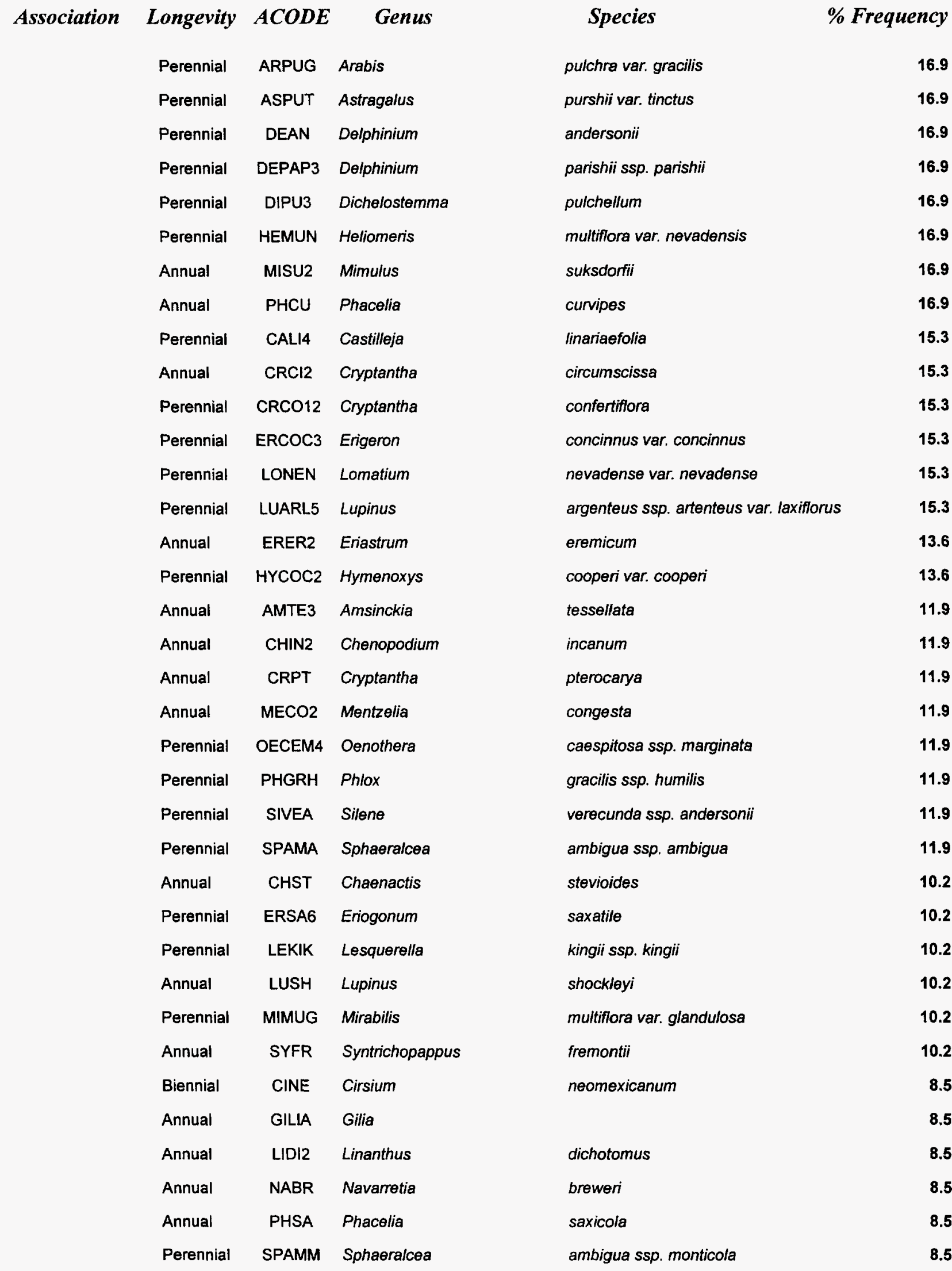




\begin{tabular}{|c|c|c|}
\hline Perennial & ABEL & Abronia \\
\hline Annual & COPA3 & Collinsia \\
\hline Annual & CRNEN & Cryptantha \\
\hline Annual & ERESE & Eriogonum \\
\hline Perennial & HUVEI & Hulsea \\
\hline Perennial & IPCO5 & Ipomopsis \\
\hline Perennial & LEREM & Lewisia \\
\hline Perennial & ORFA & Orobanche \\
\hline Perennial & PEPA8 & Penstemon \\
\hline Annual & PESE & Pectocarya \\
\hline Perennial & STSP6 & Stephanomeria \\
\hline Annual & THCU & Thysanocarpus \\
\hline Perennial & ALNE & Allium \\
\hline Perennial & ARMA3 & Arenaria \\
\hline Perennial & CACRG & Caulanthus \\
\hline Annual & CAPT & Camissonia \\
\hline Perennial & CYAB & Cymopterus \\
\hline Annual & ERN14 & Eriogonum \\
\hline Annual & ERSP3 & Eriastrum \\
\hline Annual & ERWI & Eriastrum \\
\hline Perennial & LILE3 & Linum \\
\hline Perennial & LINUN & Linanthus \\
\hline Annual & MEAL6 & Mentzelia \\
\hline Perennial & PENST & Penstemon \\
\hline Perennial & SPGRP2 & Sphaeralcea \\
\hline Perennial & ZIPA2 & Zigadenus \\
\hline Annual & ANAC & Anisocoma \\
\hline Perennial & ARPUM & Arabis \\
\hline Annual & CABRB4 & Camissonia \\
\hline Annual & CETH3 & Centrostegia \\
\hline Annual & CHAL7 & Chenopodium \\
\hline Perennial & CHGR13 & Chrysothamnus \\
\hline Annual & CHWA2 & Chorizanthe \\
\hline Annual & CLPAU2 & Claytonia \\
\hline Perennial & CRUT & Cryptantha \\
\hline Annual & ERCI6 & Erodium \\
\hline
\end{tabular}

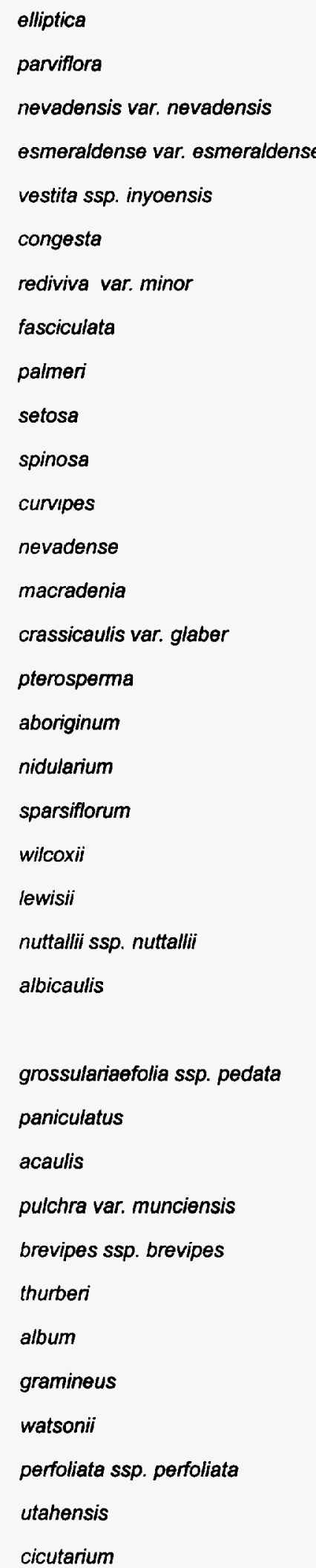




\begin{tabular}{|c|c|c|c|}
\hline \multirow[t]{37}{*}{ Association } & Longevity & $A C O D E$ & Genus \\
\hline & Perennial & GINY & Gilia \\
\hline & Perennial & HYFIM & Hymenopappus \\
\hline & Annual & LAOCO & Lappula \\
\hline & Perennial & MIBI8 & Mirabilis \\
\hline & Annual & PLPA2 & Plantago \\
\hline & Perennial & POSU & Polygala \\
\hline & Annual & URLI2 & Uropappus \\
\hline & Perennial & ARCO6 & Argemone \\
\hline & Perennial & ARDR4 & Artemisia \\
\hline & Perennial & ARKIC & Arenaria \\
\hline & Annual & CACLI & Camissonia \\
\hline & Perennial & CHAL11 & Chamaesyce \\
\hline & Annual & CHLE4 & Chenopodium \\
\hline & Annual & CHXA & Chaenactis \\
\hline & Annual & CRAM3 & Cryptantha \\
\hline & Perennial & CRIN4 & Crepis \\
\hline & Perennial & $\mathrm{EPCl}$ & Epilobium \\
\hline & Perennial & ERAP & Erigeron \\
\hline & Annual & ERDE6 & Eriogonum \\
\hline & Perennial & ERUMS2 & Eriogonum \\
\hline & Perennial & ERUMV & Eriogonum \\
\hline & Perennial & ERUMV2 & Eriogonum \\
\hline & Annual & GADIP & Gayophytum \\
\hline & Perennial & GIIN2 & Gilia \\
\hline & Annual & IPDE & Ipomopsis \\
\hline & Annual & IPPO2 & Ipomopsis \\
\hline & Perennial & LIRU4 & Lithospermum \\
\hline & Perennial & LOFOF & Lomatium \\
\hline & Perennial & LUCA & Lupinus \\
\hline & Perennial & LUPA3 & Lupinus \\
\hline & Perennial & OEPAP & Oenothera \\
\hline & Perennial & ORCO5 & Orobanche \\
\hline & Perennial & PER010 & Penstemon \\
\hline & Perennial & $\mathrm{PHCH} 2$ & Physaria \\
\hline & Annual & PHCRC3 & Phacelia \\
\hline & Perennial & POHE7 & Polygala \\
\hline
\end{tabular}

Species

nyensis

filifolius var. megacephalus

occidentalis var. occidentalis

bigelovii

patagonica

subspinosa

linearifolia

corymbosa

dracunculus

kingii ssp. compacta

claviformis ssp. integrior

albomarginata

leptophyllum

xantiana

ambigua

intermedia

ciliatum

aphanactis

deflexum

umbellatum var. subaridum

umbellatum var. vermum

umbellatum var, versicolor

diffusum ssp. parviflorum

inconspicua

depressa

polycladon

ruderale

foeniculaceum ssp. fimbriatum

caudatus

palmeri

pallida ssp. pallida

corymbosa

rostrifiorus

chambersii

crenulata var. crenulata

heteromyncha
\% Frequency

3.4

3.4

3.4

3.4

3.4

3.4

3.4

1.7

1.7

1.7

1.7

1.7

1.7

1.7

1.7

1.7

1.7

1.7

1.7

1.7

1.7

1.7

1.7

1.7

1.7

1.7

1.7

1.7

1.7

1.7

1.7

1.7

1.7

1.7

1.7

1.7 
Association Longevity ACODE

Genus

$\begin{array}{lll}\text { Annual } & \text { STEXE } & \text { Stephanomeria } \\ \text { Annual } & \text { STLO4 } & \text { Streptanthella } \\ \text { Perennial } & \text { STPA4 } & \text { Stephanomeria } \\ \text { Perennial } & \text { TRAN } & \text { Trifolium } \\ \text { Perennial } & \text { TRWA2 } & \text { Tricardia }\end{array}$

\section{Succulents}

$\begin{array}{lll}\text { Perennial } & \text { OPPOR } & \text { Opuntia } \\ \text { Perennial } & \text { OPERE } & \text { Opuntia } \\ \text { Perennial } & \text { YUBAV } & \text { Yucca } \\ \text { Perennial } & \text { ECEN } & \text { Echinocereus } \\ \text { Perennial } & \text { ESVIR2 } & \text { Escobaria } \\ \text { Perennial } & \text { SCPO4 } & \text { Sclerocactus } \\ \text { Perennial } & \text { YUBR } & \text { Yucca }\end{array}$

\begin{tabular}{lr}
\multicolumn{1}{c}{ Species } & \% Frequency \\
exigua ssp. exigua & 1.7 \\
longirostris & 1.7 \\
pauciflora & 1.7 \\
andersonii & 1.7 \\
watsonii & 1.7
\end{tabular}

$\begin{array}{lr}\text { polyacantha var. rufispina } & 61.0 \\ \text { eninacea var. erinacea } & 35.6 \\ \text { baccata var. vespertina } & 10.2 \\ \text { engelmannii } & 3.4 \\ \text { vivipara var. rosea } & 3.4 \\ \text { polyancistrus } & 1.7 \\ \text { brevifolia } & 1.7\end{array}$


This Page Intentionally Left Blank 


\section{Appendix $\mathrm{H}$}

Interspecific Association of Woody Vegetation on the NTS

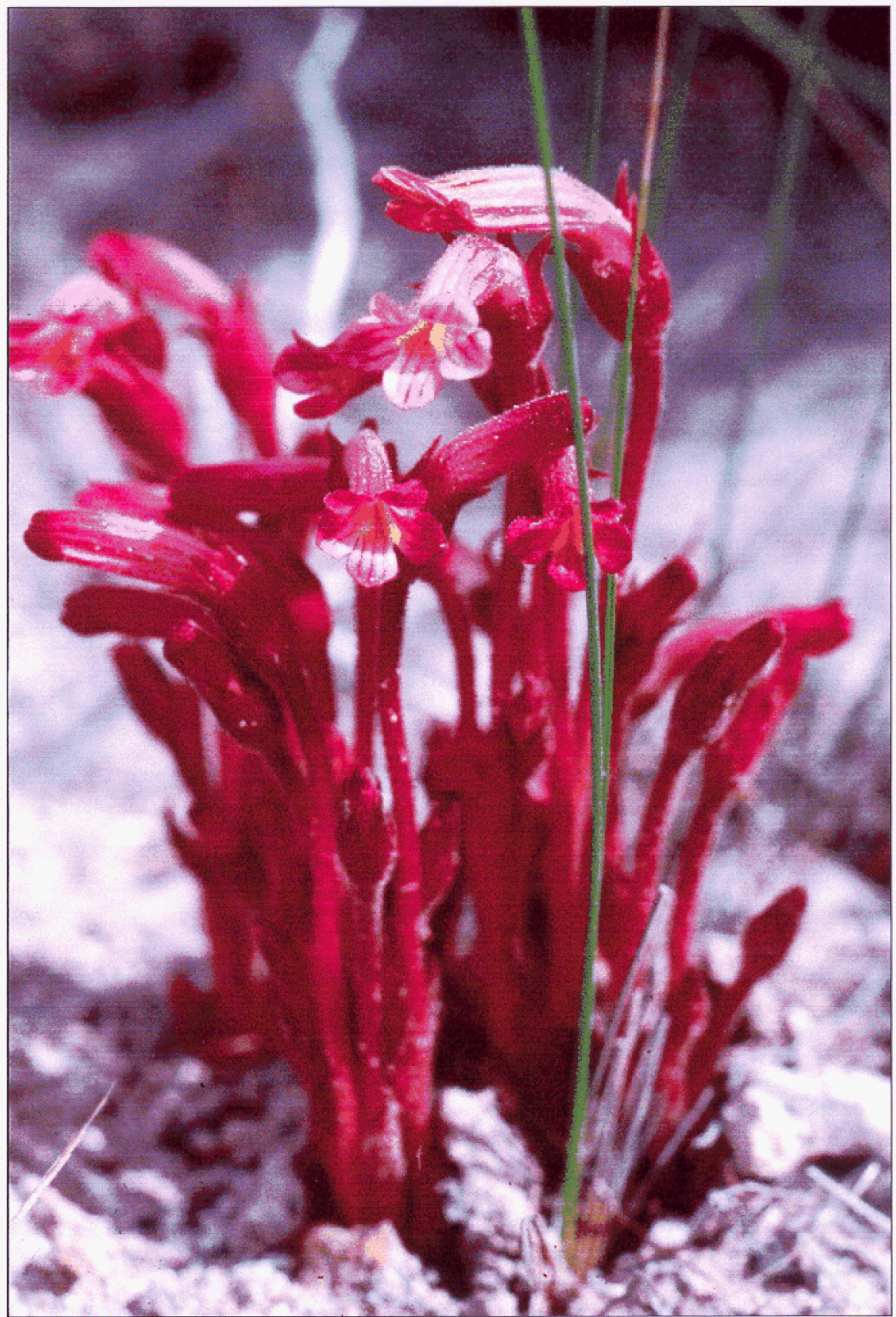

Clustered broomrape (Orobanche fasciculata) [photo by Susan Cochrane] 
This Page Intentionally Left Blank 


\section{Appendix $\mathrm{H}$ \\ Interspecific Association of Woody Vegetation on the NTS}

$A C O D E$

Genus

Species

Statistical Level

ACSH Acamptopappus shockleyi

$\begin{array}{llll}\text { AMDU2 } & \text { Ambrosia } & \text { dumosa } & \mathrm{P}<0.05 \\ \text { KRLA2 } & \text { Krascheninnikovia } & \text { lanata } & \mathrm{P}<0.05 \\ \text { LEFR2 } & \text { Lepidium } & \text { fremontii } & \mathrm{P}<0.05 \\ \text { MESP2 } & \text { Menodora } & \text { spinescens } & \mathrm{P}<0.05 \\ \text { STEL } & \text { Stanleya } & \text { elata } & \mathrm{P}<0.05 \\ \text { YUSC2 } & \text { Yucca } & \text { schidigera } & \mathrm{P}<0.05\end{array}$

ADCO2 Adenophyllum cooperi

HYSA

PSFRF

Hymenoclea

Psorothamnus

AMDU2 Ambrosia

\section{dumosa}

$\mathrm{ACSH}$

ATCO

EPFU

KRER

LATR2

LYPAO

PSFRF

YUSC2

Acamptopappus
Atriplex
Ephedra
Krameria
Larrea
Lycium
Psorothamnus
Yucca

AMER Ambrosia

BROBL

Brickellia

ERPA29

HYSA

Ericameria

Hymenoclea

\section{eriocentra}

salsola

fremontii var. fremontii

$P<0.05$

$P<0.05$
$P<0.05$

$P<0.05$

$P<0.05$

$P<0.05$

$P<0.05$

$P<0.05$

$P<0.05$

$P<0.05$ oblongifolia var. linifolia

paniculata

salsola
$P<0.05$

$P<0.05$

$P<0.05$

Page 1 of 37 


$\begin{array}{lllr}\text { ACODE } & \text { Genus } & \text { Species } & \text { Statistical Leve } \\ \text { PRFA } & \text { Prunus } & \text { fasciculata } & \mathrm{P}<0.05 \\ \text { PUST } & \text { Purshia } & \text { stansburiana } & \mathrm{P}<0.05\end{array}$

AMPA2 Amelanchier pallida

$\begin{array}{llll}\text { JUOS } & \text { Juniperus } & \text { osteosperma } & \mathrm{P}<0.05 \\ \text { PIMO } & \text { Pinus } & \text { monophylla } & \mathrm{P}<0.05 \\ \text { PUST } & \text { Purshia } & \text { stansbunana } & \mathrm{P}<0.05 \\ \text { QUGA } & \text { Quercus } & \text { gambelli } & \mathrm{P}<0.05\end{array}$

AMUT Amelanchier utahensis

$\begin{array}{llll}\text { EPVI } & \text { Ephedra } & \text { viridis } & \mathrm{P}<0.05 \\ \text { ERUMV } & \text { Eriogonum } & \text { umbellatum var. vemum } & \mathrm{P}<0.05 \\ \text { LEPU } & \text { Leptodactylon } & \text { pungens } & \mathrm{P}<0.05 \\ \text { PIMO } & \text { Pinus } & \text { monophylla } & \mathrm{P}<0.05 \\ \text { PUST } & \text { Purshia } & \text { stansburiana } & \mathrm{P}<0.05 \\ \text { QUGA } & \text { Quercus } & \text { gambelii } & \mathrm{P}<0.05 \\ \text { RHTRA } & \text { Rhus } & \text { trilobata var. anisophylla } & \mathrm{P}<0.05 \\ \text { SADOD3 } & \text { Salvia } & \text { dorii ssp. domii var. domii } & \mathrm{P}<0.05\end{array}$

\section{ARBI3 Artemisia bigelovii}

$\begin{array}{ll}\text { ERNAL } & \text { Enicameria } \\ \text { PUST } & \text { Purshia } \\ \text { SYLO } & \text { Symphoricarpos } \\ \text { TEAXA } & \text { Tetradymia }\end{array}$

nauseosus ssp. consimilis var. lejosperma

$P<0.05$

stansburiana

$P<0.05$

longiflorus

$P<0.05$

axillaris var. axillaris

$P<0.05$

\section{ARDR4 Artemisia dracunculus}

$\begin{array}{lll}\text { EPVI } & \text { Ephedra } & \text { viridis } \\ \text { PUGL2 } & \text { Purshia } & \text { glandulosa }\end{array}$

$P<0.05$

$P<0.05$ 
ACODE Genus Species Statistical Level

\section{ARLU Artemisia ludoviciana}

$\begin{array}{llll}\text { ARTRT } & \text { Artemisia } & \text { tridentata ssp. tridentata } & \mathrm{P}<0.05 \\ \text { BAEM } & \text { Baccharis } & \text { emoryi } & \mathrm{P}<0.05 \\ \text { EPVI } & \text { Ephedra } & \text { viridis } & \mathrm{P}<0.05 \\ \text { ERCUC } & \text { Ericameria } & \text { cuneatus } & \mathrm{P}<0.05 \\ \text { ERFAP } & \text { Eriogonum } & \text { fasciculatum var. polifolium } & \mathrm{P}<0.05 \\ \text { ERHEA } & \text { Eriogonum } & \text { heermannil var. argense } & \mathrm{P}<0.05 \\ \text { ERMIS2 } & \text { Eriogonum } & \text { microthecum var. simpsonii } & \mathrm{P}<0.05 \\ \text { ERTE18 } & \text { Ericameria } & \text { teretifolia } & \mathrm{P}<0.05 \\ \text { SYLO } & \text { Symphoricarpos } & \text { tongiflorus } & \mathrm{P}<0.05\end{array}$

\section{ARNO4 Artemisia}

\section{nova}

$\begin{array}{ll}\text { CHGR6 } & \text { Chrysothamnus } \\ \text { CHVIP4 } & \text { Chrysothamnus } \\ \text { EPVI } & \text { Ephedra } \\ \text { ERCA8 } & \text { Eriogonum } \\ \text { ERMIS2 } & \text { Eriogonum } \\ \text { ERNA7 } & \text { Ericameria } \\ \text { ERUMV2 } & \text { Eriogonum } \\ \text { GLSPA } & \text { Glossopetaion } \\ \text { JUOS } & \text { Juniperus } \\ \text { LEPU } & \text { Leptodactylon } \\ \text { OPPOR } & \text { Opuntia } \\ \text { PIMO } & \text { Pinus } \\ \text { YUBAV } & \text { Yucca }\end{array}$

greenei
viscidiflorus ssp. puberulus
viridis
caespitosum
microthecum var. simpsonii
nanus
umbellatum var. versicolor
spinescens var. aridum
osteosperma
pungens
polyacantha var. rufispina
monophylla
baccata var. vespertina

$P<0.05$

$P<0.05$

$P<0.05$

$P<0.05$

$P<0.05$

$P<0.05$

$P<0.05$

$P<0.05$

$P<0.05$

$P<0.05$

$P<0.05$

$P<0.05$

$P<0.05$

\section{ARSP5 Artemisia}

\section{spinescens}

$\begin{array}{ll}\text { ATCO } & \text { Atriplex } \\ \text { CHVIS5 } & \text { Chrysothamnus }\end{array}$

confertifolia

$P<0.05$

viscidifforus ssp. viscidiflorus var. stenophyllus

$P<0.05$ 


$\begin{array}{lllr}\text { ACODE } & \text { Genus } & \text { Species } & \text { Statistical Level } \\ \text { CHVIV2 } & \text { Chrysothamnus } & \text { viscidiflorus ssp. viscidiflorus } & \mathrm{P}<0.05 \\ \text { ERCO23 } & \text { Ericameria } & \text { cooperi } & \mathrm{P}<0.05 \\ \text { GRSP } & \text { Grayia } & \text { spinosa } & \mathrm{P}<0.05 \\ \text { KOAM } & \text { Kochia } & \text { americana } & \mathrm{P}<0.05 \\ \text { KRLA2 } & \text { Krascheninnikovia } & \text { lanata } & \mathrm{P}<0.05 \\ \text { LYAN } & \text { Lycium } & \text { andersonii } & \mathrm{P}<0.05 \\ \text { TEAXA } & \text { Tetradymia } & \text { axillaris var. axillaris } & \mathrm{P}<0.05\end{array}$

ARTRT Artemisia

ARLU

CHGR13

CHVIP4

CHVIV2

EPVI

ERHEA

ERUM

ERUMV

JUOS

LEPU

PIMO

PUTR2

QUGA

RICEC2

SYLO

$$
\text { Artemisia }
$$

Chrysothamnus

Chrysothamnus

Chrysothamnus

Ephedra

Eriogonum

Eriogonum

Eriogonum

Juniperus

Leptodactyion

Pinus

Purshia

Quercus

Ribes

Symphoricarpos tridentata ssp. tridentata

ludoviciana
gramineus
viscidifforus ssp. puberulus
viscidfforus ssp. viscidiflorus
viridis
heermannii var. argense
umbellatum
umbellatum var. vermum
osteosperma
pungens
monophylla
tridentata
gambelii
cereum var. cereum
longiflorus

$P<0.05$

$P<0.05$

$P<0.05$

$P<0.05$

$P<0.05$

$P<0.05$

$P<0.05$

$P<0.05$

$P<0.05$

$P<0.05$

$P<0.05$

$P<0.05$

$P<0.05$

$P<0.05$

$P<0.05$

\section{ATCAC Atriplex}

$\begin{array}{ll}\text { ERNU4 } & \text { Eriogonum } \\ \text { GRSP } & \text { Grayia } \\ \text { KRLA2 } & \text { Krascheninnikovia } \\ \text { LYAN } & \text { Lycium } \\ \text { OPBAB2 } & \text { Opuntia }\end{array}$

Thursday, September 09, 1999

\section{canescens var. canescens}

nummulare
spinosa
lanata
andersonii
basilaris var, basilaris

$P<0.05$

$P<0.05$

$P<0.05$

$P<0.05$

$P<0.05$

Page 4 of 37 


$\begin{array}{lllr}\text { ACODE } & \text { Genus } & \text { Species } & \text { Statistical Level } \\ \text { POSU } & \text { Polygala } & \text { subspinosa } & \mathrm{P}<0.05 \\ \text { PSPO } & \text { Psorothamnus } & \text { polydenius } & \mathrm{P}<0.05 \\ \text { TECA2 } & \text { Tetradymia } & \text { canescens } & \mathrm{P}<0.05\end{array}$

ATCO Atriplex

$\begin{array}{ll}\text { AMDU2 } & \text { Ambrosia } \\ \text { ARSP5 } & \text { Artemisia } \\ \text { ATHY } & \text { Atriplex } \\ \text { BRAT } & \text { Brickellia } \\ \text { BRLOM } & \text { Brickellia } \\ \text { BUUT } & \text { Buddleja } \\ \text { EPTO } & \text { Ephedra } \\ \text { ERHEH2 } & \text { Eriogonum } \\ \text { GAST } & \text { Galium } \\ \text { KOAM } & \text { Kochia } \\ \text { KRLA2 } & \text { Krascheninnikovia } \\ \text { LYAN } & \text { Lycium } \\ \text { MESP2 } & \text { Menodora } \\ \text { SENE5 } & \text { Senecio } \\ \text { YUSC2 } & \text { Yucca }\end{array}$

dumosa
spinescens
hymenelytra
atractyloides
longifolia var. multifora
utahensis
torreyana
heermannii var. heermannii
stellatum
americana
lanata
andersonii
spinescens
flaccidus var. douglasii
schidigera

$P<0.05$

$P<0.05$

$P<0.05$

$P<0.05$

$P<0.05$

$P<0.05$

$P<0.05$

$P<0.05$

$P<0.05$

$P<0.05$

$P<0,05$

$P<0.05$

$P<0.05$

$P<0.05$

$P<0.05$

$\begin{array}{llll}\text { ATCO } & \text { Atriplex } & \text { confertifolia } & \mathrm{P}<0.05 \\ \text { LEFR2 } & \text { Lepidium } & \text { fremontii } & \mathrm{P}<0.05\end{array}$

ATHY Atriplex

ATPO Atriplex

ERPA29

SAME

\section{hymenelytra}

fremontii paniculata

mexicana
$P<0.05$

$P<0.05$ 
ACODE Genus Species Statistical Level

BAEM Baccharis emoryi

$\begin{array}{llll}\text { ARLU } & \text { Artemisia } & \text { ludoviciana } & \mathrm{P}<0.05 \\ \text { ERNAH } & \text { Ericameria } & \text { nauseosus ssp. nauseosus var. hololeuca } & \mathrm{P}<0.05\end{array}$

BRAT Brickellia atractyloides

$\begin{array}{llll}\text { ATCO } & \text { Atriplex } & \text { confertifolia } & \mathrm{P}<0.05 \\ \text { BUUT } & \text { Buddleja } & \text { utahensis } & \mathrm{P}<0.05 \\ \text { EPFU } & \text { Ephedra } & \text { funerea } & \mathrm{P}<0.05 \\ \text { EPNE } & \text { Ephedra } & \text { nevadensis } & \mathrm{P}<0.05\end{array}$

BRCA3 Brickellia californica

PUGL2

Purshia

glandulosa

$P<0.05$

BRIN Brickellia

incana

HYSA

Hymenoclea

salsola

$P<0.05$

PSFRF

Psorothamnus

fremontii var. fremontii

$P<0.05$

BRLOMBrickellia

longifolia var. multiflora

ATCO

Atriplex

confertifolia

$P<0.05$

BRMIW Brickellia

LEFR2

Lepidium

fremontii

$P<0.05$

\section{BROBL Brickellia}

AMER

HYSA

\section{microphylla var. watsonii}

\section{oblongifolia var. linifolia}

Ambrosia

eriocentra

$P<0.05$

Hymenoclea

salsola

$P<0.05$ 


$\begin{array}{lllc}\text { ACODE } & \text { Genus } & \text { Species } & \text { Statistical Leve } \\ \text { RICEC2 } & \text { Ribes } & \text { cereum var. cereum } & \mathrm{P}<0.05 \\ \text { SAME } & \text { Salazaria } & \text { mexicana } & \mathrm{P}<0.05\end{array}$

\section{BUUT Buddleja utahensis}

$\begin{array}{llll}\text { ATCO } & \text { Atriplex } & \text { confertifolia } & \mathrm{P}<0.05 \\ \text { BRAT } & \text { Brickellia } & \text { atractyloides } & \mathrm{P}<0.05 \\ \text { EPTO } & \text { Ephedra } & \text { torreyana } & \mathrm{P}<0.05 \\ \text { GUSA2 } & \text { Gutierrezia } & \text { sarothrae } & \mathrm{P}<0.05 \\ \text { PRFA } & \text { Prunus } & \text { fasciculata } & \mathrm{P}<0.05\end{array}$

CEGRV2

$\begin{array}{ll}\text { CELEL } & \text { Cercocarpus } \\ \text { PIMO } & \text { Pinus } \\ \text { PUGL2 } & \text { Purshia } \\ \text { PUTR2 } & \text { Purshia } \\ \text { TEGL } & \text { Tetradymia }\end{array}$

\section{Ceanothus greggii ssp. vestitus}

ledifolius var. ledifolius

$P<0.05$

monophylla

$P<0.05$

$P<0.05$

$P<0.05$

tridentata

$P<0.05$

\section{CEIN7 Cercocarpus intricatus}

$\begin{array}{lll}\text { ERPAN2 } & \text { Ericameria } & \text { pamyi var. nevadensis } \\ \text { SYLO } & \text { Symphoricamos } & \text { longifiorus } \\ \text { TEGL } & \text { Tetradymia } & \text { glabrata }\end{array}$

$P<0.05$

$P<0.05$

$P<0.05$

\section{CELEL Cercocarpus ledifolius var. ledifolius}

$\begin{array}{lll}\text { CEGRV2 } & \text { Ceanothus } & \text { greggii ssp. vestitus } \\ \text { ERPAN2 } & \text { Ericameria } & \text { parryi var. nevadensis } \\ \text { SYLO } & \text { Symphoricarpos } & \text { longiflorus } \\ \text { TEGL } & \text { Tetradymia } & \text { glabrata }\end{array}$

$P<0.05$
$P<0.05$
$P<0.05$
$P<0.05$ 

ACODE
Genus
Species
Statistical Level

\section{CHGR13}

$\begin{array}{ll}\text { ARTRT } & \text { Artemisia } \\ \text { ERMIL } & \text { Eriogonum } \\ \text { LEPU } & \text { Leptodactylon } \\ \text { OPPOR } & \text { Opuntia } \\ \text { PERA4 } & \text { Peraphyllum } \\ \text { PIMO } & \text { Pinus } \\ \text { PUTR2 } & \text { Purshia } \\ \text { QUGA } & \text { Quercus } \\ \text { SADOD3 } & \text { Salvia }\end{array}$

\section{Chrysothamnus gramineus}

tridentata ssp. tridentata
microthecum var. lapidicola
pungens
polyacantha var. rufispina
ramosissimum
monophylla
tridentata
gambelii
dorii ssp. domii var. domi

$P<0.05$

$P<0.05$

$P<0.05$

$P<0.05$

$P<0.05$

$P<0.05$

$P<0.05$

$P<0.05$

$P<0.05$

\section{CHGR6 Chrysothamnus greenei}

$\begin{array}{lll}\text { ARNO4 } & \text { Artemisia } & \text { nova } \\ \text { ERUMS2 } & \text { Eriogonum } & \text { umbellatum var. subaridum } \\ \text { OPERE } & \text { Opuntia } & \text { erinacea var. erinacea } \\ \text { SYLO } & \text { Symphoricarpos } & \text { Iongiflorus }\end{array}$

$$
\begin{aligned}
& P<0.05 \\
& P<0.05 \\
& P<0.05 \\
& P<0.05
\end{aligned}
$$

\section{CHVIP4 Chrysothamnus viscidiflorus ssp. puberulus}

$\begin{array}{ll}\text { ARNO4 } & \text { Artemisia } \\ \text { ARTRT } & \text { Artemisia } \\ \text { EPVI } & \text { Ephedra } \\ \text { ERCA8 } & \text { Eriogonum } \\ \text { ERMIS2 } & \text { Eriogonum } \\ \text { ERNU4 } & \text { Eriogonum } \\ \text { ERUMS2 } & \text { Eriogonum } \\ \text { GUSA2 } & \text { Gutierrezia } \\ \text { JUOS } & \text { Juniperus } \\ \text { LEPU } & \text { Leptodactylon } \\ \text { OPPOR } & \text { Opuntia }\end{array}$

nova
tridentata ssp. tridentata
viridis
caespitosum
microthecum var. simpsonii
nummulare
umbellatum var. subaridum
sarothrae
osteosperma
pungens
polyacantha var. rufispina

$$
\begin{aligned}
& P<0.05 \\
& P<0.05 \\
& P<0.05 \\
& P<0.05 \\
& P<0.05 \\
& P<0.05 \\
& P<0.05 \\
& P<0.05 \\
& P<0.05 \\
& P<0.05 \\
& P<0.05
\end{aligned}
$$




$\begin{array}{lllc}\text { ACODE } & \text { Genus } & \text { Species } & \text { Statistical Leve } \\ \text { PERA4 } & \text { Peraphyllum } & \text { ramosissimum } & \mathrm{P}<0.05 \\ \text { PUST } & \text { Purshia } & \text { stansburiana } & \mathrm{P}<0.05\end{array}$

CHVIS5 Chrysothamnus viscidiflorus ssp. viscidiflorus var. stenophyllus

$\begin{array}{llll}\text { ARSP5 } & \text { Artemisia } & \text { spinescens } & P<0.05 \\ \text { MESP2 } & \text { Menodora } & \text { spinescens } & P<0.05 \\ \text { TEAXA } & \text { Tetradymia } & \text { axillaris var. axillaris } & P<0.05\end{array}$

CHVIV2 Chrysothamnus viscidiflorus ssp. viscidiflorus

$\begin{array}{llll}\text { ARSP5 } & \text { Artemisia } & \text { spinescens } & \mathrm{P}<0.05 \\ \text { ARTRT } & \text { Artemisia } & \text { tridentata ssp. tridentata } & \mathrm{P}<0.05 \\ \text { GRSP } & \text { Grayia } & \text { spinosa } & \mathrm{P}<0.05 \\ \text { HYCOC2 } & \text { Hymenoxys } & \text { cooperi var. cooperi } & \mathrm{P}<0.05 \\ \text { LEPU } & \text { Leptodactylon } & \text { pungens } & \mathrm{P}<0.05 \\ \text { STPA3 } & \text { Stephanomeria } & \text { parryi } & \mathrm{P}<0.05 \\ \text { SYLO } & \text { Symphoricarpos } & \text { longiflorus } & \mathrm{P}<0.05 \\ \text { TECA2 } & \text { Tetradymia } & \text { canescens } & \mathrm{P}<0.05 \\ \text { THMO } & \text { Thamnosma } & \text { montana } & \mathrm{P}<0.05 \\ \text { YUBR } & \text { Yucca } & \text { brevifolia } & \mathrm{P}<0.05\end{array}$

CORA Coleogyne ramosissima

$\begin{array}{llll}\text { ECPO2 } & \text { Echinocactus } & \text { polycephalus } & \mathrm{P}<0.05 \\ \text { ERNAL } & \text { Ericameria } & \text { nauseosus ssp. consimilis var. leiosperma } & \mathrm{P}<0.05 \\ \text { ERTE18 } & \text { Ericameria } & \text { teretifolia } & \mathrm{P}<0.05 \\ \text { TEAXA } & \text { Tetradymia } & \text { axillaris var. axillaris } & \mathrm{P}<0.05 \\ \text { YUBR } & \text { Yucca } & \text { brevifolia } & \mathrm{P}<0.05\end{array}$

ECENE Echinocereus enge/mannii var. engelmannii

ECPO2

Echinocactus

polycephalus

$P<0.05$ 


$\begin{array}{lllr}\text { ACODE } & \text { Genus } & \text { Species } & \text { Statistical Level } \\ \text { EPTO } & \text { Ephedra } & \text { torreyana } & \mathrm{P}<0.05 \\ \text { ERHEH2 } & \text { Eriogonum } & \text { heermannii var. heemannii } & \mathrm{P}<0.05 \\ \text { KOAM } & \text { Kochia } & \text { americana } & \mathrm{P}<0.05 \\ \text { OPERU } & \text { Opuntia } & \text { erinacea var. ursina } & \mathrm{P}<0.05 \\ \text { PSFRF } & \text { Psorothamnus } & \text { fremontii var. fremontii } & \mathrm{P}<0.05\end{array}$

ECPO2 Echinocactus polycephalus

$\begin{array}{lllr}\text { CORA } & \text { Coleogyne } & \text { ramosissima } & \mathrm{P}<0.05 \\ \text { ECENE } & \text { Echinocereus } & \text { engelmannii var. engelmannii } & \mathrm{P}<0.05 \\ \text { YUBR } & \text { Yucca } & \text { brevifolia } & \mathrm{P}<0.05\end{array}$

\section{ENVIV Encelia virginensis var. virginensis}

$\begin{array}{lllr}\text { ERFAP } & \text { Eriogonum } & \text { fasciculatum var. polifolium } & \mathrm{P}<0.05 \\ \text { ERNA7 } & \text { Ericameria } & \text { nanus } & \mathrm{P}<0.05 \\ \text { ERTE18 } & \text { Ericameria } & \text { teretifolia } & \mathrm{P}<0.05 \\ \text { HYSA } & \text { Hymenoclea } & \text { salsola } & \mathrm{P}<0.05 \\ \text { KRER } & \text { Krameria } & \text { erecta } & \mathrm{P}<0.05 \\ \text { PENI } & \text { Petalonyx } & \text { nitidus } & \mathrm{P}<0.05 \\ \text { PSFRF } & \text { Psorothamnus } & \text { fremontii var. fremontii } & \mathrm{P}<0.05 \\ \text { SAME } & \text { Salazania } & \text { mexicana } & \mathrm{P}<0.05 \\ \text { SENE5 } & \text { Senecio } & \text { flaccidus var. douglasii } & \mathrm{P}<0.05\end{array}$

\section{EPFU Ephedra funerea}

$\begin{array}{lllr}\text { AMDU2 } & \text { Ambrosia } & \text { dumosa } & \mathrm{P}<0.05 \\ \text { BRAT } & \text { Brickellia } & \text { atractyloides } & \mathrm{P}<0.05 \\ \text { EPTO } & \text { Ephedra } & \text { torreyana } & \mathrm{P}<0.05 \\ \text { KRER } & \text { Krameria } & \text { erecta } & \mathrm{P}<0.05 \\ \text { MESP2 } & \text { Menodora } & \text { spinescens } & \mathrm{P}<0.05 \\ \text { PSFRF } & \text { Psorothamnus } & \text { fremontii var. fremontii } & \mathrm{P}<0.05 \\ \text { YUSC2 } & \text { Yucca } & \text { schidigera } & \mathrm{P}<0.05\end{array}$


EPNE Ephedra

$\begin{array}{ll}\text { BRAT } & \text { Brickellia } \\ \text { ERCO23 } & \text { Ericameria } \\ \text { ERFAP } & \text { Eriogonum } \\ \text { ERTE18 } & \text { Ericameria } \\ \text { GRSP } & \text { Grayia } \\ \text { HYSA } & \text { Hymenoclea } \\ \text { KRER } & \text { Krameria } \\ \text { OPECE } & \text { Opuntia } \\ \text { PSFRF } & \text { Psorothamnus } \\ \text { PSPO } & \text { Psorothamnus } \\ \text { SAME } & \text { Salazaria } \\ \text { STEL } & \text { Stanleya } \\ \text { TEAXA } & \text { Tetradymia } \\ \text { THMO } & \text { Thamnosma } \\ \text { YUBR } & \text { Yucca }\end{array}$

\section{EPTO Ephedra}

$\begin{array}{ll}\text { ATCO } & \text { Atriplex } \\ \text { BUUT } & \text { Buddleja } \\ \text { ECENE } & \text { Echinocereus } \\ \text { EPFU } & \text { Ephedra } \\ \text { ERHEH2 } & \text { Eriogonum } \\ \text { LEFR2 } & \text { Lepidium } \\ \text { MESP2 } & \text { Menodora } \\ \text { OPERU } & \text { Opuntia } \\ \text { PSFRF } & \text { Psorothamnus } \\ \text { THMO } & \text { Thamnosma } \\ \text { YUSC2 } & \text { Yucca }\end{array}$

atractyloides
cooperi
fasciculatum var. polifolium
teretifolia
spinosa
salsola
erecta
echinocarpa var. echinocarpa
fremontii var. fremontii
polydenius
mexicana
elata
axillaris var. axillaris
montana
brevifolia

$P<0.05$

$P<0.05$

$P<0.05$

$P<0.05$

$P<0.05$

$P<0.05$

$P<0.05$

$P<0.05$

$P<0.05$

$P<0.05$

$P<0.05$

$P<0.05$

$P<0.05$

$P<0.05$

$P<0.05$

confertifolia
utahensis
engelmannii var. engelmannii
funerea
heermannii var. heermannii
fremontii
spinescens
erinacea var. ursina
fremontii var. fremontii
montana
schidigera

$P<0.05$

$P<0.05$

$P<0.05$

$P<0.05$

$P<0.05$

$P<0.05$

$P<0.05$

$P<0.05$

$P<0.05$

$P<0.05$

$P<0.05$ 


\section{EPVI Ephedra}

\section{viridis}

\begin{tabular}{ll} 
AMUT & Amelanchier \\
ARDR4 & Artemisia \\
ARLU & Artemisia \\
ARNO4 & Artemisia \\
ARTRT & Artemisia \\
CHVIP4 & Chrysothamnus \\
ERFAP & Eriogonum \\
ERHEA & Eriogonum \\
ERLI6 & Ericameria \\
ERMIS2 & Eriogonum \\
ERNAL & Ericameria \\
ERTE18 & Ericameria \\
JUOS & Juniperus \\
LEPU & Leptodactylon \\
PERA4 & Peraphyllum \\
PIMO & Pinus \\
PRFA & Prunus \\
PUGL2 & Purshia \\
PUST & Purshia \\
RHTRA & Rhus \\
SYLO & Symphoricarpos \\
YUBAV & Yucca \\
\hline
\end{tabular}

utahensis
dracunculus
ludoviciana
nova
tridentata ssp. tridentata
viscidiflorus ssp. puberulus
fasciculatum var. polifolium
heermannii var. argense
linearifolius
microthecum var. simpsonii
nauseosus ssp. consimilis var. leiosperma
teretifolia
osteosperma
pungens
ramosissimum
monophylla
fasciculata
glandulosa
stansburiana
trilobata var. anisophylla
longiflorus
baccata var. vespertina

$$
\begin{aligned}
& P<0.05 \\
& P<0.05 \\
& P<0.05 \\
& P<0.05 \\
& P<0.05 \\
& P<0.05 \\
& P<0.05 \\
& P<0.05 \\
& P<0.05 \\
& P<0.05 \\
& P<0.05 \\
& P<0.05 \\
& P<0.05 \\
& P<0.05 \\
& P<0.05 \\
& P<0.05 \\
& P<0.05 \\
& P<0.05 \\
& P<0.05 \\
& P<0.05 \\
& P<0.05 \\
& P<0.05
\end{aligned}
$$

\section{ERCA8 Eriogonum}

$$
\text { caespitosum }
$$

$\begin{array}{ll}\text { ARNO4 } & \text { Artemisia } \\ \text { CHVIP4 } & \text { Chrysothamnus }\end{array}$

$$
\begin{aligned}
& \text { nova } \\
& \text { viscidiflorus ssp. puberulus }
\end{aligned}
$$

$$
\begin{aligned}
& P<0.05 \\
& P<0.05
\end{aligned}
$$

\section{ERCO23}

\section{Ericameria cooperi}




$\begin{array}{lllr}\text { ACODE } & \text { Genus } & \text { Species } & \text { Statistical Level } \\ \text { ARSP5 } & \text { Artemisia } & \text { spinescens } & \mathrm{P}<0.05 \\ \text { EPNE } & \text { Ephedra } & \text { nevadensis } & \mathrm{P}<0.05 \\ \text { GRSP } & \text { Grayia } & \text { spinosa } & \mathrm{P}<0.05 \\ \text { HYSA } & \text { Hymenoclea } & \text { salsola } & \mathrm{P}<0.05 \\ \text { LYAN } & \text { Lycium } & \text { andersonii } & \mathrm{P}<0.05 \\ \text { YUBAV } & \text { Yucca } & \text { baccata var. vespertina } & \mathrm{P}<0.05\end{array}$

\section{ERCUC Ericameria}

\section{cuneatus}

$\begin{array}{ll}\text { ARLU } & \text { Artemisia } \\ \text { ERHEA } & \text { Eriogonum } \\ \text { ERMIS2 } & \text { Eriogonum } \\ \text { OPPOR } & \text { Opuntia }\end{array}$

Iudoviciana
heermannii var. argense
microthecum var. simpsonii
polyacantha var. rufispina

$P<0.05$

$P<0.05$

$P<0.05$

$P<0.05$

\section{ERFAP Eriogonum}

\section{fasciculatum var. polifolium}

$\begin{array}{ll}\text { ARLU } & \text { Artemisia } \\ \text { ENVIV } & \text { Encelia } \\ \text { EPNE } & \text { Ephedra } \\ \text { EPVI } & \text { Ephedra } \\ \text { ERTE18 } & \text { Ericameria } \\ \text { GUSA2 } & \text { Gutierrezia } \\ \text { SAME } & \text { Salazaria }\end{array}$

ludoviciana
virginensis var. virginensis
nevadensis
viridis
teretifolia
sarothrae
mexicana
$P<0.05$
$P<0.05$
$P<0.05$
$P<0.05$
$P<0.05$
$P<0.05$

$P<0.05$

\section{ERHEA Eriogonum}

\section{heermannii var. argense}

$\begin{array}{ll}\text { ARLU } & \text { Artemisia } \\ \text { ARTRT } & \text { Artemisia } \\ \text { EPVI } & \text { Ephedra } \\ \text { ERCUC } & \text { Ericameria } \\ \text { ERMIS2 } & \text { Eriogonum } \\ \text { ERNA7 } & \text { Ericameria } \\ \text { OPPOR } & \text { Opuntia }\end{array}$

ludoviciana
tridentata ssp. tndentata
viridis
cuneatus
microthecum var. simpsonii
nanus
polyacantha var. rufispina

$P<0.05$

$P<0.05$

$P<0.05$

$P<0.05$

$P<0.05$

$P<0.05$

$P<0.05$

Thursday, September 09, 1999

Page 13 of 37 
ACODE Genus Species Statistical Level

ERHEH2

$\begin{array}{ll}\text { ATCO } & \text { Atriplex } \\ \text { ECENE } & \text { Echinocereus } \\ \text { EPTO } & \text { Ephedra } \\ \text { ERNA10 } & \text { Ericameria } \\ \text { LEFR2 } & \text { Leprdium } \\ \text { MESP2 } & \text { Menodora } \\ \text { PRFA } & \text { Prunus } \\ \text { YUSC2 } & \text { Yucca }\end{array}$

\section{ERLI6 Ericameria}

$\begin{array}{ll}\text { EPVI } & \text { Ephedra } \\ \text { ERNAH } & \text { Ericameria } \\ \text { ERNAL } & \text { Ericameria } \\ \text { ERTE18 } & \text { Ericameria } \\ \text { PUGL2 } & \text { Purshia }\end{array}$

\section{Eriogonum heermannii var. heermannii}

confertifolia
engelmannir var. engelmannii
torreyana
nauseosus
fremontii
spinescens
fasciculata
schidigera

$P<0.05$

$P<0.05$

$P<0.05$

$P<0.05$

$P<0.05$

$P<0.05$

$P<0.05$

$P<0.05$

ERMIL Eriogonum

\section{microthecum var. lapidicola}

$\begin{array}{ll}\text { CHGR13 } & \text { Chrysothamnus } \\ \text { OPPOR } & \text { Opuntia } \\ \text { PIMO } & \text { Pinus } \\ \text { PUTR2 } & \text { Purshia } \\ \text { QUGA } & \text { Quercus }\end{array}$

gramineus
polyacantha var. rufispina
monophylla
tridentata
gambelii

$P<0.05$

$P<0.05$

$P<0.05$

$P<0.05$

$P<0.05$

\section{ERMIS2Eriogonum}

microthecum var. simpsonii

$\begin{array}{ll}\text { ARLU } & \text { Artemisia } \\ \text { ARNO4 } & \text { Artemisia } \\ \text { CHVIP4 } & \text { Chrysothamnus }\end{array}$

ludoviciana
nova
viscidiflorus ssp. puberulus

$P<0.05$

$P<0.05$

$P<0.05$ 


$\begin{array}{llll}\text { ACODE } & \text { Genus } & \text { Species } & \text { Statistical Level } \\ \text { EPVI } & \text { Ephedra } & \text { viridis } & \mathrm{P}<0.05 \\ \text { ERCUC } & \text { Ericameria } & \text { cuneatus } & \mathrm{P}<0.05 \\ \text { ERHEA } & \text { Eriogonum } & \text { heermannii var. argense } & \mathrm{P}<0.05 \\ \text { ERNA7 } & \text { Ericameria } & \text { nanus } & \mathrm{P}<0.05 \\ \text { ERNAL } & \text { Ericameria } & \text { nauseosus ssp. consimilis var. leiosperma } & \mathrm{P}<0.05 \\ \text { ERUMS2 } & \text { Eriogonum } & \text { umbellatum var. subaridum } & \mathrm{P}<0.05 \\ \text { GLSPA } & \text { Glossopetalon } & \text { spinescens var. aridum } & \mathrm{P}<0.05 \\ \text { JUOS } & \text { Juniperus } & \text { osteosperma } & \mathrm{P}<0.05 \\ \text { LEPU } & \text { Leptodactylon } & \text { pungens } & \mathrm{P}<0.05 \\ \text { OPERE } & \text { Opuntia } & \text { erinacea var. erinacea } & \mathrm{P}<0.05 \\ \text { PERA4 } & \text { Peraphyllum } & \text { ramosissimum } & \mathrm{P}<0.05 \\ \text { PIMO } & \text { Pinus } & \text { monophylla } & \mathrm{P}<0.05 \\ \text { PUST } & \text { Purshia } & \text { stansburiana } & \mathrm{P}<0.05 \\ \text { RHTRA } & \text { Rhus } & \text { trilobata var. anisophylla } & \mathrm{P}<0.05 \\ \text { RICEC2 } & \text { Ribes } & \text { cereum var. cereum } & \mathrm{P}<0.05 \\ \text { TARA } & \text { Tamarix } & \text { ramosissima } & \mathrm{P}<0.05 \\ \text { THMO } & \text { Thamnosma } & \text { montana } & \mathrm{P}<0.05\end{array}$

\section{ERNA10}

$\begin{array}{ll}\text { ERHEH2 } & \text { Eriogonum } \\ \text { ERNAL } & \text { Ericameria } \\ \text { HODI } & \text { Holodiscus } \\ \text { OPPOR } & \text { Opuntia } \\ \text { TECA2 } & \text { Tetradymia } \\ \text { TEGL } & \text { Tetradymia }\end{array}$

\section{Ericameria nauseosus}

heermannii var. heermannii
nauseosus ssp. consimilis var. leiosperma
discolor
polyacantha var. rufispina
canescens
glabrata

$P<0.05$
$P<0.05$
$P<0.05$
$P<0.05$
$P<0.05$
$P<0.05$

$P<0.05$

$P<0.05$

$P<0.05$

$P<0.05$ 
ACODE

Genus

Glossopetalon

Juniperus

JUOS

LEPU

PIMO

SYLO
Leptodactylon

Pinus

Symphoricarpos
Species

spinescens var. aridum

osteosperma

pungens

monophylla

longiflorus
Statistical Level

$P<0.05$

$P<0.05$

$P<0.05$

$P<0.05$

$P<0.05$
ERNAH Ericameria

BAEM

ERLI6

ERNAL

OPECE

PSPO

RIVEV

TARA

nauseosus ssp. nauseosus var. hololeuca

Baccharis
Ericameria
Ericameria
Opuntia
Psorothamnus
Ribes
Tamarix

emoryi

$P<0.05$

$P<0.05$

$P<0.05$

$P<0.05$

$P<0.05$

$P<0.05$

$P<0.05$

\section{ERNAL Ericameria}

$\begin{array}{ll}\text { ARBI3 } & \text { Artemisia } \\ \text { CORA } & \text { Coleogyne } \\ \text { EPVI } & \text { Ephedra } \\ \text { ERLI6 } & \text { Ericameria } \\ \text { ERMIS2 } & \text { Eriogonum } \\ \text { ERNA10 } & \text { Ericameria } \\ \text { ERNAH } & \text { Ericameria } \\ \text { GLSPA } & \text { Glossopetalon } \\ \text { GUSA2 } & \text { Gutiorrezia } \\ \text { PRFA } & \text { Prunus } \\ \text { PUGL2 } & \text { Purshia } \\ \text { SADOD3 } & \text { Salvia } \\ \text { SYLO } & \text { Symphoricarpos } \\ \text { TECA2 } & \text { Tetradymia } \\ \text { TEGL } & \text { Tetradymia }\end{array}$

nauseosus ssp. consimilis var. leiosperma

$$
\begin{aligned}
& P<0.05 \\
& P<0.05 \\
& P<0.05 \\
& P<0.05 \\
& P<0.05 \\
& P<0.05 \\
& P<0.05 \\
& P<0.05 \\
& P<0.05 \\
& P<0.05 \\
& P<0.05 \\
& P<0.05 \\
& P<0.05 \\
& P<0.05 \\
& P<0.05
\end{aligned}
$$




$\begin{array}{cccc}\text { ACODE } & \text { Genus } & \text { Species } & \text { Statistical Level } \\ \text { YUBR } & \text { Yucca } & \text { brevifolia } & \mathrm{P}<0.05\end{array}$

ERNU4 Eriogonum

$\begin{array}{ll}\text { ATCAC } & \text { Atriplex } \\ \text { CHVIP4 } & \text { Chrysothamnus }\end{array}$

ERPA29

$\begin{array}{ll}\text { AMER } & \text { Ambrosia } \\ \text { ATPO } & \text { Atriplex } \\ \text { HYSA } & \text { Hymenoclea }\end{array}$

ERPAN2

CEIN7

CELEL

SYLO

TEGL

ERSA6 Eriogonum

PSPO
PUST
TECA2

Psorothamnus

Purshia

Tetradymia

\section{Ericameria}

Cercocarpus

Cercocarpus

Symphoricarpos

Tetradymia

\section{saxatile}

\section{Ericameria teretifolia}

$\begin{array}{ll}\text { ARLU } & \text { Artemisia } \\ \text { CORA } & \text { Coleogyne } \\ \text { ENVIV } & \text { Encelia } \\ \text { EPNE } & \text { Ephedra } \\ \text { EPVI } & \text { Ephedra }\end{array}$

Thursday, September 09, 1999 polydenius

stansburiana

canescens

canescens var. canescens

$P<0.05$

$P<0.05$

$P<0.05$

$P<0.05$

$P<0.05$

$P<0.05$

$P<0.05$

$P<0.05$

$P<0.05$

$P<0.05$

$P<0.05$

$P<0.05$ 


$\begin{array}{lllr}\text { ACODE } & \text { Genus } & \text { Species } & \text { Statistical Leve } \\ \text { ERFAP } & \text { Eriogonum } & \text { fasciculatum var. polifolium } & \mathrm{P}<0.05 \\ \text { ERLI6 } & \text { Ericameria } & \text { linearifolius } & \mathrm{P}<0.05 \\ \text { TEAXA } & \text { Tetradymia } & \text { axillaris var. axillaris } & \mathrm{P}<0.05 \\ \text { THMO } & \text { Thamnosma } & \text { montana } & \mathrm{P}<0.05\end{array}$

\section{ERUM Eriogonum umbellatum}

$\begin{array}{llll}\text { ARTRT } & \text { Artemisia } & \text { tridentata ssp. tridentata } & \mathrm{P}<0.05 \\ \text { PUGL2 } & \text { Purshia } & \text { glandulosa } & \mathrm{P}<0.05\end{array}$

ERUMS2

\section{Eriogonum umbellatum var. subaridum}

$\begin{array}{llll}\text { CHGR6 } & \text { Chrysothamnus } & \text { greenei } & \mathrm{P}<0.05 \\ \text { CHVIP4 } & \text { Chrysothamnus } & \text { viscidiflorus ssp. puberulus } & \mathrm{P}<0.05 \\ \text { ERMIS2 } & \text { Eniogonum } & \text { microthecum var. simpsonii } & \mathrm{P}<0.05 \\ \text { JUOS } & \text { Juniperus } & \text { osteosperma } & \mathrm{P}<0.05 \\ \text { OPERE } & \text { Opuntia } & \text { erinacea var. erinacea } & \mathrm{P}<0.05 \\ \text { SYLO } & \text { Symphoricarpos } & \text { Iongiflorus } & \mathrm{P}<0.05\end{array}$

ERUMV Eriogonum

AMUT

ARTRT

PIMO

ERUMV2

ARNO4

PUST

GAST Galium

ATCO umbellatum var. vernum

Amelanchier
Artemisia
Pinus

utahensis

tridentata ssp. tridentata

monophylla

\section{Eriogonum umbellatum var. versicolor}

Artemisia

nova

stansburiana

\section{stellatum}

Atriplex

confertifolia

$P<0.05$
$P<0.05$

$P<0.05$
$P<0.05$

$P<0.05$

Page 18 of 37

$P<0.05$
$P<0.05$
$P<0.05$ 
GLSPA Glossopetalon spinescens var. aridum

$\begin{array}{llll}\text { ARNO4 } & \text { Artemisia } & \text { nova } & \mathrm{P}<0.05 \\ \text { ERMIS2 } & \text { Eriogonum } & \text { microthecum var. simpsonii } & \mathbf{P}<0.05 \\ \text { ERNA7 } & \text { Ericameria } & \text { nanus } & \mathbf{P}<0.05 \\ \text { ERNAL } & \text { Ericameria } & \text { nauseosus ssp. consimilis var. leiosperma } & \mathrm{P}<0.05 \\ \text { SYLO } & \text { Symphoricarpos } & \text { longiflorus } & \mathrm{P}<0.05\end{array}$

\section{GRSP Grayia}

\section{spinosa}

$\begin{array}{ll}\text { ARSP5 } & \text { Artemisia } \\ \text { ATCAC } & \text { Atriplex } \\ \text { CHVIV2 } & \text { Chrysothamnus } \\ \text { EPNE } & \text { Ephedra } \\ \text { ERCO23 } & \text { Ericameria } \\ \text { KRLA2 } & \text { Krascheninnikovia } \\ \text { LYAN } & \text { Lycium } \\ \text { STPA3 } & \text { Stephanomeria } \\ \text { TEAXA } & \text { Tetradymia } \\ \text { TECA2 } & \text { Tetradymia }\end{array}$

spinescens
canescens var. canescens
viscidiflorus ssp. viscidiflorus
nevadensis
cooperi
lanata
andersonii
parryi
axillaris var. axillaris
canescens

$P<0.05$

$P<0.05$

$P<0.05$

$P<0.05$

$P<0.05$

$P<0.05$

$P<0.05$

$P<0.05$

$P<0.05$

$P<0.05$

\section{GUSA2 Gutierrezia}

\section{sarothrae}

$\begin{array}{ll}\text { BUUT } & \text { Buddleja } \\ \text { CHVIP4 } & \text { Chrysothamnus } \\ \text { ERFAP } & \text { Eriogonum } \\ \text { ERNAL } & \text { Ericameria } \\ \text { YUBAV } & \text { Yucca }\end{array}$

\section{HODI Holodiscus discolor}

ERNA10

Ericameria utahensis

viscidiflorus ssp. puberulus

fasciculatum var. polifolium

nauseosus ssp. consimilis var. leiosperma

baccata var. vespertina
$P<0.05$

$P<0.05$

$P<0.05$

$P<0.05$

$P<0.05$
$P<0.05$ 


$\begin{array}{lllr}\text { ACODE } & \text { Genus } & \text { Species } & \text { Statistical Level } \\ \text { JUOS } & \text { Juniperus } & \text { osteosperma } & \mathrm{P}<0.05 \\ \text { OPPOR } & \text { Opuntia } & \text { polyacantha var. rufispina } & \mathrm{P}<0.05 \\ \text { PIMO } & \text { Pinus } & \text { monophylla } & \mathrm{P}<0.05 \\ \text { QUGA } & \text { Quercus } & \text { gambelii } & \mathrm{P}<0.05 \\ \text { SYLO } & \text { Symphoricarpos } & \text { longiflorus } & \mathrm{P}<0.05\end{array}$

HYCOC2

CHVIV2

\section{Hymenoxys cooperi var. cooperi}

\section{HYSA Hymenoclea salsola}

$\begin{array}{lll}\text { ADCO2 } & \text { Adenophyllum } & \text { cooperi } \\ \text { AMER } & \text { Ambrosia } & \text { eriocentra } \\ \text { BRIN } & \text { Brickellia } & \text { incana } \\ \text { BROBL } & \text { Brickellia } & \text { oblongifolia var. linifolia } \\ \text { ENVIV } & \text { Encelia } & \text { virginensis var. virginensis } \\ \text { EPNE } & \text { Ephedra } & \text { nevadensis } \\ \text { ERCO23 } & \text { Ericameria } & \text { cooperi } \\ \text { ERPA29 } & \text { Ericameria } & \text { paniculata } \\ \text { LEFR2 } & \text { Lepidium } & \text { fremontii } \\ \text { LYAN } & \text { Lycium } & \text { andersonii } \\ \text { SAME } & \text { Salazaria } & \text { mexicana }\end{array}$

$$
\begin{aligned}
& P<0.05 \\
& P<0.05 \\
& P<0.05 \\
& P<0.05 \\
& P<0.05 \\
& P<0.05 \\
& P<0.05 \\
& P<0.05 \\
& P<0.05 \\
& P<0.05 \\
& P<0.05
\end{aligned}
$$

\section{JUOS Juniperus}

\section{osteosperma}

$\begin{array}{ll}\text { AMPA2 } & \text { Amelanchier } \\ \text { ARNO4 } & \text { Artemisia } \\ \text { ARTRT } & \text { Artemisia } \\ \text { CHVIP4 } & \text { Chrysothamnus } \\ \text { EPVI } & \text { Ephedra } \\ \text { ERMIS2 } & \text { Eriogonum } \\ \text { ERNA7 } & \text { Ericameria }\end{array}$

pallida
nova
tridentata ssp. tridentata
viscidiflorus ssp puberulus
viridis
microthecum var. simpsonii
nanus

$P<0.05$

$P<0.05$

$P<0.05$

$P<0.05$

$P<0.05$

$P<0.05$

$P<0.05$ 


$\begin{array}{lll}\text { ACODE } & \text { Genus } & \text { Species } \\ \text { ERUMS2 } & \text { Eriogonum } & \text { umbellatum var. subaridum } \\ \text { HODI } & \text { Holodiscus } & \text { discolor } \\ \text { LEPU } & \text { Leptodactylon } & \text { pungens } \\ \text { OPERE } & \text { Opuntia } & \text { erinacea var. erinacea } \\ \text { OPPOR } & \text { Opuntia } & \text { polyacantha var. rufispina } \\ \text { PEPU7 } & \text { Petradoria } & \text { pumila } \\ \text { PIMO } & \text { Pinus } & \text { monophylla } \\ \text { PUST } & \text { Purshia } & \text { stansburiana } \\ \text { PUTR2 } & \text { Purshia } & \text { tridentata } \\ \text { QUGA } & \text { Quercus } & \text { gambelit } \\ \text { RICEC2 } & \text { Ribes } & \text { cereum var. cereum } \\ \text { RIVEV } & \text { Ribes } & \text { velutinum var. velutinum } \\ \text { SYLO } & \text { Symphoricarpos } & \text { longiflorus } \\ \text { YUBAV } & \text { Yucca } & \text { baccata var. vespertina }\end{array}$

Statistical Level

$$
\begin{aligned}
& P<0.05 \\
& P<0.05 \\
& P<0.05 \\
& P<0.05 \\
& P<0.05 \\
& P<0.05 \\
& P<0.05 \\
& P<0.05 \\
& P<0.05 \\
& P<0.05 \\
& P<0.05 \\
& P<0.05 \\
& P<0.05 \\
& P<0.05
\end{aligned}
$$

\section{KOAM Kochia}

\section{americana}

$\begin{array}{ll}\text { ARSP5 } & \text { Artemisia } \\ \text { ATCO } & \text { Atriplex } \\ \text { ECENE } & \text { Echinocereus }\end{array}$

KRER Krameria

\section{erecta}

$\begin{array}{ll}\text { AMDU2 } & \text { Ambrosia } \\ \text { ENVIV } & \text { Encelia } \\ \text { EPFU } & \text { Ephedra } \\ \text { EPNE } & \text { Ephedra } \\ \text { LATR2 } & \text { Larrea } \\ \text { LYPAO } & \text { Lycium } \\ \text { PSFRF } & \text { Psorothamnus } \\ \text { YUSC2 } & \text { Yucca }\end{array}$

$$
\begin{aligned}
& P<0.05 \\
& P<0.05 \\
& P<0.05
\end{aligned}
$$


KRLA2 Krascheninnikovi lanata

$\begin{array}{ll}\text { ACSH } & \text { Acamptopappus } \\ \text { ARSP5 } & \text { Artemisia } \\ \text { ATCAC } & \text { Atriplex } \\ \text { ATCO } & \text { Atriplex } \\ \text { GRSP } & \text { Grayia } \\ \text { LYAN } & \text { Lycium } \\ \text { TEAXA } & \text { Tetradymia }\end{array}$

shockleyt
spinescens
canescens var. canescens
confertifolia
spinosa
andersonii
axillaris var. axillaris

$P<0.05$

$P<0.05$

$P<0.05$

$P<0.05$

$P<0.05$

$P<0.05$

$P<0.05$

LATR2 Larrea

AMDU2

KRER

LYPAO

LYSH

PSFRF

YUSC2

\section{tridentata}

Ambrosia

Krameria

Lycium

Lycium

Psorothamnus

Yucca

\section{fremontii}

$\begin{array}{ll}\text { ACSH } & \text { Acamptopappus } \\ \text { ATHY } & \text { Atriplex } \\ \text { BRMIW } & \text { Brickellia } \\ \text { EPTO } & \text { Ephedra } \\ \text { ERHEH2 } & \text { Eriogonum } \\ \text { HYSA } & \text { Hymenoclea } \\ \text { MESP2 } & \text { Menodora } \\ \text { OPBAB2 } & \text { Opuntia } \\ \text { PEN1 } & \text { Petalonyx } \\ \text { PSFRF } & \text { Psorothamnus } \\ \text { SENE5 } & \text { Senecio }\end{array}$

dumosa

erecta

pallidum var. oligospermum

shockleyi

fremontij var. fremontii

schidigera
$P<0.05$

$P<0.05$

$P<0.05$

$P<0.05$

$P<0.05$

$P<0.05$

\section{LEFR2 Lepidium}

shockleyi
hymenelytre
microphylla var. watsonii
tomeyana
heermannii var. heermannii
salsola
spinescens
basilanis var. basilaris
nitidus
fremontii var. fremontii
flaccidus var. douglasii

$P<0.05$

$P<0.05$

$P<0.05$

$P<0.05$

$P<0.05$

$P<0.05$

$P<0.05$

$P<0.05$

$P<0.05$

$P<0.05$

$P<0.05$

Page 22 of 37 


$\begin{array}{lllr}\text { ACODE } & \text { Genus } & \text { Species } & \text { Statistical Leve } \\ \text { STEL } & \text { Stanleya } & \text { elata } & \mathrm{P}<0.05 \\ \text { THMO } & \text { Thamnosma } & \text { montana } & \mathrm{P}<0.05\end{array}$

\section{LEPU Leptodactylon pungens}

$\begin{array}{llll}\text { AMUT } & \text { Amelanchier } & \text { utahensis } & \mathrm{P}<0.05 \\ \text { ARNO4 } & \text { Artemisia } & \text { nova } & \mathrm{P}<0.05 \\ \text { ARTRT } & \text { Artemisia } & \text { tridentata ssp. tridentata } & \mathrm{P}<0.05 \\ \text { CHGR13 } & \text { Chrysothamnus } & \text { gramineus } & \mathrm{P}<0.05 \\ \text { CHVIP4 } & \text { Chrysothamnus } & \text { viscidiflorus ssp. puberulus } & \mathrm{P}<0.05 \\ \text { CHVIV2 } & \text { Chrysothamnus } & \text { viscidiflorus ssp. viscidiflorus } & \mathrm{P}<0.05 \\ \text { EPVI } & \text { Ephedra } & \text { viridis } & \mathrm{P}<0.05 \\ \text { ERMIS2 } & \text { Eriogonum } & \text { microthecum var. simpsonii } & \mathrm{P}<0.05 \\ \text { ERNA7 } & \text { Ericameria } & \text { nanus } & \mathrm{P}<0.05 \\ \text { JUOS } & \text { Juniperus } & \text { osteosperma } & \mathrm{P}<0.05 \\ \text { OPPOR } & \text { Opuntia } & \text { polyacantha var. rufispina } & \mathrm{P}<0.05 \\ \text { PEPU7 } & \text { Petradoria } & \text { pumila } & \mathrm{P}<0.05 \\ \text { PIMO } & \text { Pinus } & \text { monophylla } & \mathrm{P}<0.05 \\ \text { PUTR2 } & \text { Purshia } & \text { tridentata } & \mathrm{P}<0.05 \\ \text { QUGA } & \text { Quercus } & \text { gambelii } & \mathrm{P}<0.05 \\ \text { RHTRA } & \text { Rhus } & \text { trilobata var. anisophylla } & \mathrm{P}<0.05 \\ \text { SADOD3 } & \text { Salvia } & \text { dorii ssp. dormii var. domii } & \mathrm{P}<0.05\end{array}$

LYAN Lycium

$\begin{array}{ll}\text { ARSP5 } & \text { Artemisia } \\ \text { ATCAC } & \text { Atriplex } \\ \text { ATCO } & \text { Atriplex } \\ \text { ERCO23 } & \text { Ericameria } \\ \text { GRSP } & \text { Grayia } \\ \text { HYSA } & \text { Hymenoclea } \\ \text { KRLA2 } & \text { Krascheninnikovia } \\ \text { POSU } & \text { Polygala }\end{array}$

spinescens
canescens var. canescens
confertifolia
cooperi
spinosa
salsola
lanata
subspinosa

$$
\begin{aligned}
& P<0.05 \\
& P<0.05 \\
& P<0.05 \\
& P<0.05 \\
& P<0.05 \\
& P<0.05 \\
& P<0.05 \\
& P<0.05
\end{aligned}
$$

Page 23 of 37 


\begin{tabular}{lllr} 
ACODE & Genus & \multicolumn{1}{c}{ Species } & Statistical Level \\
TEAXA & Tetradymia & axillaris var. axillaris & $\mathrm{P}<0.05$ \\
& & \\
Lycium & \multicolumn{2}{c}{ pallidum var. oligospermum } & \\
AMDU2 & Ambrosia & dumosa & $\mathrm{P}<0.05$ \\
KRER & Krameria & erecta & $\mathrm{P}<0.05$ \\
LATR2 & Larrea & tridentata & $\mathrm{P}<0.05$ \\
PSFRF & Psorothamnus & fremontii var. fremontii & $\mathrm{P}<0.05$
\end{tabular}

LYSH Lycium

LATR2
LYPAO Lycium

MESP2 Menodora

ACSH

ATCO

CHVIS5

EPFU

EPTO

ERHEH2

LEFR2

OPECE

PSFRF

STEL

YUBR

YUSC2

\section{OPBAB2}

ATCAC
LEFR2
OPECE

\section{shockleyi}

tridentata

$P<0.05$

\section{spinescens}

Acamptopappus
Atriplex
Chrysothamnus
Ephedra
Ephedra
Eriogonum
Lepidium
Opuntia
Psorothamnus
Stanleya
Yucca
Yucca

shockleyi

$P<0.05$

confertifolia

$P<0.05$

viscidiflorus ssp. viscidifforus var. stenophyllus

$P<0.05$

funerea

$P<0.05$

torreyana

heermanni var. heermannii

fremontii

echinocarpa var. echinocarpa

$P<0.05$

$P<0.05$

$P<0.05$

$P<0.05$

$P<0.05$

$P<0.05$

elata

brevifolia

$P<0.05$

schidigera

$P<0.05$

\section{Opuntia basilaris var. basilaris}

Atriplex
Lepidium
Opuntia

canescens var. canescens

$P<0.05$

fremontii

$P<0.05$

echinocarpa var. echinocarpa 


$\begin{array}{lllr}\text { ACODE } & \text { Genus } & \text { Species } & \text { Statistical Leve } \\ \text { STPIP } & \text { Stanleya } & \text { pinnata var. pinnata } & \mathrm{P}<0.05 \\ \text { YUBR } & \text { Yucca } & \text { brevifolia } & \mathrm{P}<0.05\end{array}$

OPECE Opuntia

$\begin{array}{ll}\text { EPNE } & \text { Ephedra } \\ \text { ERNAH } & \text { Ericameria } \\ \text { MESP2 } & \text { Menodora } \\ \text { OPBAB2 } & \text { Opuntia } \\ \text { OPERU } & \text { Opuntia } \\ \text { OPRA } & \text { Opuntia } \\ \text { YUBR } & \text { Yucca } \\ \text { YUSC2 } & \text { Yucca }\end{array}$

\section{echinocarpa var. echinocarpa}

nevadensis

$P<0.05$

$P<0.05$

$P<0.05$

spinescens

$P<0.05$

$P<0.05$

$P<0.05$

$P<0.05$

$P<0.05$
OPERE Opuntia

$\begin{array}{ll}\text { CHGR6 } & \text { Chrysothamnus } \\ \text { ERMIS2 } & \text { Eriogonum } \\ \text { ERUMS2 } & \text { Eriogonum } \\ \text { JUOS } & \text { Juniperus } \\ \text { PIMO } & \text { Pinus } \\ \text { RICEC2 } & \text { Ribes } \\ \text { SYLO } & \text { Symphoricarpos }\end{array}$

\section{erinacea var. erinacea}

greenei
microthecum var. simpsonii
umbellatum var. subaridum
osteosperma
monophylla
cereum var. cereum
Iongiflorus

$P<0.05$

$P<0.05$

$P<0.05$

$P<0.05$

$P<0.05$

$P<0.05$

$P<0.05$

\section{OPERU Opuntia}

ECENE

EPTO

OPECE

PSFRF

THMO

\section{erinacea var. ursina}

Echinocereus
Ephedra
Opuntia
Psorothamnus
Thamnosma

engelmannii var. engelmannii
torreyana
echinocama var. echinocarpa
fremontii var. fremontii
montana

$\mathrm{P}<0.05$

$P<0.05$

$P<0.05$

$P<0.05$

$P<0.05$ 
OPPOR Opuntia

$\begin{array}{ll}\text { ARNO4 } & \text { Artemisia } \\ \text { CHGR13 } & \text { Chrysothamnus } \\ \text { CHVIP4 } & \text { Chrysothamnus } \\ \text { ERCUC } & \text { Ericameria } \\ \text { ERHEA } & \text { Eriogonum } \\ \text { ERMIL } & \text { Eriogonum } \\ \text { ERNA10 } & \text { Ericameria } \\ \text { HODI } & \text { Holodiscus } \\ \text { JUOS } & \text { Juniperus } \\ \text { LEPU } & \text { Leptodactylon } \\ \text { PIMO } & \text { Pinus } \\ \text { PUTR2 } & \text { Purshia } \\ \text { QUGA } & \text { Quercus }\end{array}$

polyacantha var. rufispina

nova
gramineus
viscidiflorus ssp. puberulus
cuneatus
heermannii var. argense
microthecum var. lapidicola
nauseosus
discolor
osteosperma
pungens
monophylla
tridentata
gambelii

$P<0.05$

$P<0.05$

$P<0.05$

$P<0.05$

$P<0.05$

$P<0.05$

$P<0.05$

$P<0.05$

$P<0.05$

$P<0.05$

$P<0.05$

$P<0.05$

$P<0.05$

\section{OPRA Opuntia}

OPECE

$$
\text { Opuntia }
$$

echinocarpa var. echinocarpa

$P<0.05$

\section{PENI Petalonyx}

$\begin{array}{ll}\text { ENVIV } & \text { Encelia } \\ \text { LEFR2 } & \text { Lepidium } \\ \text { PSFRF } & \text { Psorothamnus }\end{array}$

\section{PEPU7 Petradoria}

$\begin{array}{ll}\text { JUOS } & \text { Juniperus } \\ \text { LEPU } & \text { Leptodactylon } \\ \text { PIMO } & \text { Pinus } \\ \text { QUGA } & \text { Quercus }\end{array}$

\author{
virginensis var. virginensis \\ fremontii \\ fremontii var. fremontii
}

$P<0.05$

$P<0.05$

$P<0.05$

osteosperma
pungens
monophylla
gambeli

osteosperma

$P<0.05$

$P<0.05$

$P<0.05$

$P<0.05$

Page 26 of 37 
ACODE Genus Species Statistical Level

PERA4 Peraphyllum ramosissimum

$\begin{array}{llll}\text { CHGR13 } & \text { Chrysothamnus } & \text { gramineus } & \mathrm{P}<0.05 \\ \text { CHVIP4 } & \text { Chrysothamnus } & \text { viscidifforus ssp. puberulus } & \mathrm{P}<0.05 \\ \text { EPVI } & \text { Ephedra } & \text { viridis } & \mathrm{P}<0.05 \\ \text { ERMIS2 } & \text { Eriogonum } & \text { microthecum var. simpsonii } & \mathrm{P}<0.05\end{array}$

\section{PIMO Pinus monophylla}

$\begin{array}{llll}\text { AMPA2 } & \text { Amelanchier } & \text { pallida } & \mathrm{P}<0.05 \\ \text { AMUT } & \text { Amelanchier } & \text { utahensis } & \mathrm{P}<0.05 \\ \text { ARNO4 } & \text { Artemisia } & \text { nova } & \mathrm{P}<0.05 \\ \text { ARTRT } & \text { Artemisia } & \text { tridentata ssp. tridentata } & \mathrm{P}<0.05 \\ \text { CEGRV2 } & \text { Ceanothus } & \text { greggii ssp. vestitus } & \mathrm{P}<0.05 \\ \text { CHGR13 } & \text { Chrysothamnus } & \text { gramineus } & \mathrm{P}<0.05 \\ \text { EPVI } & \text { Ephedra } & \text { viridis } & \mathrm{P}<0.05 \\ \text { ERMIL } & \text { Eriogonum } & \text { microthecum var. lapidicola } & \mathrm{P}<0.05 \\ \text { ERMIS2 } & \text { Eriogonum } & \text { microthecum var simpsonii } & \mathrm{P}<0.05 \\ \text { ERNA7 } & \text { Ericameria } & \text { nanus } & \mathrm{P}<0.05 \\ \text { ERUMV } & \text { Eriogonum } & \text { umbellatum var. vermum } & \mathrm{P}<0.05 \\ \text { HODI } & \text { Holodiscus } & \text { discolor } & \mathrm{P}<0.05 \\ \text { JUOS } & \text { Juniperus } & \text { osteosperma } & \mathrm{P}<0.05 \\ \text { LEPU } & \text { Leptodactylon } & \text { pungens } & \mathrm{P}<0.05 \\ \text { OPERE } & \text { Opuntia } & \text { erinacea var. erinacea } & \mathrm{P}<0.05 \\ \text { OPPOR } & \text { Opuntia } & \text { polyacantha var. rufispina } & \mathrm{P}<0.05 \\ \text { PEPU7 } & \text { Petradoria } & \text { pumila } & \mathrm{P}<0.05 \\ \text { PUST } & \text { Purshia } & \text { stansburiana } & \mathrm{P}<0.05 \\ \text { PUTR2 } & \text { Purshia } & \text { tridentata } & \mathrm{P}<0.05 \\ \text { QUGA } & \text { Quercus } & \text { gambelii } & \mathrm{P}<0.05 \\ \text { RICEC2 } & \text { Ribes } & \text { cereum var. ceroum } & \mathrm{P}<0.05 \\ \text { RIVEV } & \text { Ribes } & \text { velutinum var. velutinum } & \mathrm{P}<0.05 \\ \text { SADOD3 } & \text { Salvia } & \text { donii ssp. dorrii var. domii } & \mathrm{P}<0.05\end{array}$

Thursday, September 09, 1999

Page 27 of 37 


$\begin{array}{cccc}\text { ACODE } & \text { Genus } & \text { Species } & \text { Statistical Level } \\ \text { SYLO } & \text { Symphoricarpos } & \text { longifforus } & \mathrm{P}<0.05\end{array}$

POSU Polygala

subspinosa

$\begin{array}{llll}\text { ATCAC } & \text { Atriplex } & \text { canescens var. canescens } & P<0.05 \\ \text { LYAN } & \text { Lycium } & \text { andersonii } & P<0.05\end{array}$

PRFA Prunus

\section{fasciculata}

$\begin{array}{llll}\text { AMER } & \text { Ambrosia } & \text { eriocentra } & \mathrm{P}<0.05 \\ \text { BUUT } & \text { Buddleja } & \text { utahensis } & \mathrm{P}<0.05 \\ \text { EPVI } & \text { Ephedra } & \text { viridis } & \mathrm{P}<0.05 \\ \text { ERHEH2 } & \text { Eriogonum } & \text { heermannii var. heermannii } & \mathrm{P}<0.05 \\ \text { ERNAL } & \text { Ericameria } & \text { nauseosus ssp. consimilis var. leiosperma } & \mathrm{P}<0.05 \\ \text { PUGL2 } & \text { Purshia } & \text { glandulosa } & \mathrm{P}<0.05 \\ \text { RHTRA } & \text { Rhus } & \text { trilobata var. anisophylla } & \mathrm{P}<0.05\end{array}$

\section{PSFRF Psorothamnus fremontii var. fremontii}

$\begin{array}{ll}\text { ADCO2 } & \text { Adenophyllum } \\ \text { AMDU2 } & \text { Ambrosia } \\ \text { BRIN } & \text { Brickellia } \\ \text { ECENE } & \text { Echinocereus } \\ \text { ENVIV } & \text { Encelia } \\ \text { EPFU } & \text { Ephedra } \\ \text { EPNE } & \text { Ephedra } \\ \text { EPTO } & \text { Ephedra } \\ \text { KRER } & \text { Krameria } \\ \text { LATR2 } & \text { Larrea } \\ \text { LEFR2 } & \text { Lepidium } \\ \text { LYPAO } & \text { Lycium } \\ \text { MESP2 } & \text { Menodora } \\ \text { OPERU } & \text { Opuntia }\end{array}$

coopen
dumosa
incana
engelmannii var. engelmannii
virginensis var. virginensis
funerea
nevadensis
torreyana
erecta
tridentata
fremontii
pallidum var. oligospermum
spinescens
erinacea var. ursina

$$
\begin{aligned}
& P<0.05 \\
& P<0.05 \\
& P<0.05 \\
& P<0.05 \\
& P<0.05 \\
& P<0.05 \\
& P<0.05 \\
& P<0.05 \\
& P<0.05 \\
& P<0.05 \\
& P<0.05 \\
& P<0.05 \\
& P<0.05 \\
& P<0.05
\end{aligned}
$$




$\begin{array}{lllc}\text { ACODE } & \text { Genus } & \text { Species } & \text { Statistical Leve } \\ \text { PENI } & \text { Petalonyx } & \text { nitidus } & \mathrm{P}<0.05 \\ \text { SAME } & \text { Salazaria } & \text { mexicana } & \mathrm{P}<0.05 \\ \text { STEL } & \text { Stanleya } & \text { elata } & \mathrm{P}<0.05 \\ \text { THMO } & \text { Thamnosma } & \text { montana } & \mathrm{P}<0.05 \\ \text { YUSC2 } & \text { Yucca } & \text { schidigera } & \mathrm{P}<0.05\end{array}$

\section{PSPO Psorothamnus polydenius}

$\begin{array}{ll}\text { ATCAC } & \text { Atriplex } \\ \text { EPNE } & \text { Ephedra } \\ \text { ERNAH } & \text { Ericameria } \\ \text { ERSA6 } & \text { Eriogonum }\end{array}$

canescens var. canescens

$P<0.05$

nevadensis

$P<0.05$

nauseosus ssp. nauseosus var. hololeuca

$P<0.05$

saxatile

$P<0.05$

PUGL2 Purshia

ARDR4
BRCA3

CEGRV2

EPVI

ERLI6

ERNAL

ERUM

PRFA

\section{glandulosa}

Artemisia

Brickellia

Ceanothus

Ephedra

Ericameria

Enicameria

Eriogonum

Prunus

dracunculus

califomica

greggii ssp. vestitus

viridis

linearifolius

nauseosus ssp. consimilis var. leiosperma

umbellatum

fasciculata
$P<0.05$

$P<0.05$

$P<0.05$

$P<0.05$

$P<0.05$

$P<0.05$

$P<0.05$

$P<0.05$
PUST Purshia

$\begin{array}{ll}\text { AMER } & \text { Ambrosia } \\ \text { AMPA2 } & \text { Amelanchier } \\ \text { AMUT } & \text { Amelanchier } \\ \text { ARBI3 } & \text { Artemisia } \\ \text { CHVIP4 } & \text { Chrysothamnus } \\ \text { EPVI } & \text { Ephedra } \\ \text { ERMIS2 } & \text { Eriogonum }\end{array}$

\section{stansburiana}

eriocentra
pallida
utahensis
bigelovii
viscidiflorus ssp. puberulus
viridis
microthecum var. simpsonii

$P<0.05$

$P<0.05$

$P<0.05$

$P<0.05$

$P<0.05$

$P<0.05$

$P<0.05$ 


$\begin{array}{llll}\text { ACODE } & \text { Genus } & \text { Species } & \text { Statistical Level } \\ \text { ERSA6 } & \text { Eriogonum } & \text { saxatile } & \mathrm{P}<0.05 \\ \text { ERUMV2 } & \text { Eriogonum } & \text { umbellatum var. versicolor } & \mathrm{P}<0.05 \\ \text { JUOS } & \text { Juniperus } & \text { osteosperma } & \mathrm{P}<0.05 \\ \text { PIMO } & \text { Pinus } & \text { monophylla } & \mathrm{P}<0.05 \\ \text { RHTRA } & \text { Rhus } & \text { trilobata var. anisophylla } & \mathrm{P}<0.05 \\ \text { TEGL } & \text { Tetradymia } & \text { glabrata } & \mathrm{P}<0.05\end{array}$

\section{PUTR2 Purshia tridentata}

$\begin{array}{ll}\text { ARTRT } & \text { Artemisia } \\ \text { CEGRV2 } & \text { Ceanothus } \\ \text { CHGR13 } & \text { Chrysothamnus } \\ \text { ERMIL } & \text { Eriogonum } \\ \text { JUOS } & \text { Juniperus } \\ \text { LEPU } & \text { Leptodactylon } \\ \text { OPPOR } & \text { Opuntia } \\ \text { PIMO } & \text { Pinus } \\ \text { QUGA } & \text { Quercus } \\ \text { RICEC2 } & \text { Ribes } \\ \text { RIVEV } & \text { Ribes } \\ \text { SADOD3 } & \text { Salvia } \\ \text { SYLO } & \text { Symphoricarpos }\end{array}$

tridentata ssp. tridentata
greggii ssp. vestitus
gramineus
microthecum var lapidicola
osteosperma
pungens
polyacantha var. rufispina
monophylla
gambelii
cereum var. cereum
velutinum var. velutinum
dorii ssp. domii var. dornii
longiflorus

$$
\begin{aligned}
& P<0.05 \\
& P<0.05 \\
& P<0.05 \\
& P<0.05 \\
& P<0.05 \\
& P<0.05 \\
& P<0.05 \\
& P<0.05 \\
& P<0.05 \\
& P<0.05 \\
& P<0.05 \\
& P<0.05 \\
& P<0.05
\end{aligned}
$$

\section{QUGA Quercus}

\section{gambelii}

$\begin{array}{ll}\text { AMPA2 } & \text { Amelanchier } \\ \text { AMUT } & \text { Amelanchier } \\ \text { ARTRT } & \text { Artemisia } \\ \text { CHGR13 } & \text { Chrysothamnus } \\ \text { ERMIL } & \text { Eriogonum } \\ \text { HODI } & \text { Holodiscus } \\ \text { JUOS } & \text { Juniperus } \\ \text { LEPU } & \text { Leptodactylon }\end{array}$

pallida
utahensis
tridentata ssp. tridentata
gramineus
microthecum var. lapidicola
discolor
osteosperma
pungens

$P<0.05$

$P<0.05$

$P<0.05$

$P<0.05$

$P<0.05$

$P<0.05$

$P<0.05$

$P<0.05$ 


$\begin{array}{llll}\text { ACODE } & \text { Genus } & \text { Species } & \text { Statistical Level } \\ \text { OPPOR } & \text { Opuntia } & \text { polyacantha var. rufispina } & \mathrm{P}<0.05 \\ \text { PEPU7 } & \text { Petradoria } & \text { pumila } & \mathrm{P}<0.05 \\ \text { PIMO } & \text { Pinus } & \text { monophylla } & \mathrm{P}<0.05 \\ \text { PUTR2 } & \text { Purshia } & \text { tridentata } & \mathrm{P}<0.05 \\ \text { RICEC2 } & \text { Ribes } & \text { cereum var. cereum } & \mathrm{P}<0.05 \\ \text { RIVEV } & \text { Ribes } & \text { velutinum var. velutinum } & \mathrm{P}<0.05 \\ \text { SADOD3 } & \text { Salvia } & \text { dorii ssp. domii var. domii } & \mathrm{P}<0.05 \\ \text { SYLO } & \text { Symphoricarpos } & \text { tongiflorus } & \mathrm{P}<0.05\end{array}$

RHTRA Rhus

$\begin{array}{ll}\text { AMUT } & \text { Amelanchier } \\ \text { EPVI } & \text { Ephedra } \\ \text { ERMIS2 } & \text { Eriogonum } \\ \text { LEPU } & \text { Leptodactylon } \\ \text { PRFA } & \text { Prunus } \\ \text { PUST } & \text { Purshia }\end{array}$

RICEC2Ribes

ARTRT

BROBL

ERMIS2

JuOS

OPERE

PIMO

PUTR2

QUGA

SYLO

\section{RIVEV Ribes}

ERNAH

Ericameria

\section{trilobata var. anisophylla}

utahensis

$P<0.05$

$P<0.05$

$P<0.05$

$P<0.05$

$P<0.05$

$P<0.05$

\section{cereum var. cereum}

$\begin{array}{ll}\text { Artemisia } & \text { tridentata ssp. tridentata } \\ \text { Brickellia } & \text { oblongifolia var. linifolia } \\ \text { Eriogonum } & \text { microthecum var. simpsonii } \\ \text { Juniperus } & \text { osteosperma } \\ \text { Opuntia } & \text { erinacea var. erinacea } \\ \text { Pinus } & \text { monophylla } \\ \text { Purshia } & \text { tridentata } \\ \text { Quercus } & \text { gambelii } \\ \text { Symphoricarpos } & \text { longiflorus }\end{array}$

$P<0.05$
$P<0.05$
$P<0.05$
$P<0.05$
$P<0.05$
$P<0.05$
$P<0.05$
$P<0.05$
$P<0.05$

velutinum var. velutinum

nauseosus ssp. nauseosus var. hololeuca

$P<0.05$

Thursday, September 09, 1999

Page 31 of 37 


$\begin{array}{lllc}\text { ACODE } & \text { Genus } & \text { Species } & \text { Statistical Leve } \\ \text { JUOS } & \text { Juniperus } & \text { osteosperma } & \mathrm{P}<0.05 \\ \text { PIMO } & \text { Pinus } & \text { monophylla } & \mathrm{P}<0.05 \\ \text { PUTR2 } & \text { Purshia } & \text { tridentata } & \mathrm{P}<0.05 \\ \text { QUGA } & \text { Quercus } & \text { gambelii } & \mathrm{P}<0.05 \\ \text { SADOD3 } & \text { Salvia } & \text { doni ssp. dorni var. domii } & \mathrm{P}<0.05 \\ \text { SYLO } & \text { Symphoricarpos } & \text { tongiflorus } & \mathrm{P}<0.05\end{array}$

\section{SADOD3}

AMUT

Amelanchier

Salvia dorii ssp. dorrii var. dorrii

CHGR13

Chrysothamnus

utahensis

$P<0.05$

ERNAL

Ericameria

gramineus

$P<0.05$

LEPU

Leptodactylon

nauseosus ssp. consimilis var. leiosperma

$P<0.05$

PIMO

Pinus

pungens

$P<0.05$

PUTR2

Purshia

monophylla

$P<0.05$

QUGA

Quercus

tridentata

$P<0.05$

RIVEV

Ribes

gambelii

$P<0.05$

SYLO

Symphoricarpos

velutinum var. velutinum

$P<0.05$

TECA2

Tetradymia

longiflorus

$P<0.05$

canescens

$P<0.05$

\section{SAME Salazaria}

\section{mexicana}

$\begin{array}{ll}\text { ATPO } & \text { Atriplex } \\ \text { BROBL } & \text { Brickellia } \\ \text { ENVIV } & \text { Encelia } \\ \text { EPNE } & \text { Ephedra } \\ \text { ERFAP } & \text { Eriogonum } \\ \text { HYSA } & \text { Hymenoclea } \\ \text { PSFRF } & \text { Psorothamnus } \\ \text { THMO } & \text { Thamnosma }\end{array}$

polycarpa
oblongifolia var. linifolia
virginensis var. virginensis
nevadensis
fasciculatum var. polifolium
salsola
fremontii var. fremontii
montana

$P<0.05$

$P<0.05$

$P<0.05$

$P<0.05$

$P<0.05$

$P<0.05$

$P<0.05$

$P<0.05$

\section{SENE5 Senecio}

flaccidus var. douglasii 


\begin{tabular}{|c|c|c|c|}
\hline$A C O D E$ & Genus & Species & Statistical Leve \\
\hline ATCO & Atriplex & confertifolia & $P<0.05$ \\
\hline ENVIV & Encelia & virginensis var. virginensis & $P<0.05$ \\
\hline LEFR2 & Lepidium & fremontii & $P<0.05$ \\
\hline
\end{tabular}

\section{STEL Stanleya elata}

$\begin{array}{lllr}\text { ACSH } & \text { Acamptopappus } & \text { shockleyi } & \mathrm{P}<0.05 \\ \text { EPNE } & \text { Ephedra } & \text { nevadensis } & \mathrm{P}<0.05 \\ \text { LEFR2 } & \text { Lepidium } & \text { fremontii } & \mathrm{P}<0.05 \\ \text { MESP2 } & \text { Menodora } & \text { spinescens } & \mathrm{P}<0.05 \\ \text { PSFRF } & \text { Psorothamnus } & \text { fremontii var. fremontii } & \mathrm{P}<0.05 \\ \text { YUBR } & \text { Yucca } & \text { brevifolia } & \mathrm{P}<0.05\end{array}$

\section{STPA3 Stephanomeria parryi}

$\begin{array}{lll}\text { CHVIV2 } & \text { Chrysothamnus } & \text { viscidiflorus ssp. viscidiflorus } \\ \text { GRSP } & \text { Grayia } & \text { spinosa } \\ \text { TEAXA } & \text { Tetradymia } & \text { axillaris var. axillaris }\end{array}$

$$
\begin{aligned}
& P<0.05 \\
& P<0.05 \\
& P<0.05
\end{aligned}
$$

STPIP Stanleya

OPBAB2
Opuntia

\section{pinnata var. pinnata}

basilaris var. basilaris
$P<0.05$

SYLO Symphoricarposlongiflorus

$\begin{array}{ll}\text { ARBI3 } & \text { Artemisia } \\ \text { ARLU } & \text { Artemisia } \\ \text { ARTRT } & \text { Artemisia } \\ \text { CEIN7 } & \text { Cercocarpus } \\ \text { CELEL } & \text { Cercocarpus } \\ \text { CHGR6 } & \text { Chrysothamnus } \\ \text { CHVIV2 } & \text { Chrysothamnus } \\ \text { EPVI } & \text { Ephedra }\end{array}$

bigelovit
ludoviciana
tridentata ssp. tridentata
intricatus
ledifolius var. ledifolius
greenei
viscidiflorus ssp. viscidiflorus
viridis

$P<0.05$

$P<0.05$

$P<0.05$

$P<0.05$

$P<0.05$

$P<0.05$

$P<0.05$

$P<0.05$ 


$\begin{array}{llll}\text { ACODE } & \text { Genus } & \text { Species } & \text { Statistical Level } \\ \text { ERNA7 } & \text { Ericameria } & \text { nanus } & \mathrm{P}<0.05 \\ \text { ERNAL } & \text { Ericameria } & \text { nauseosus ssp. consimilis var. leiosperma } & \mathrm{P}<0.05 \\ \text { ERPAN2 } & \text { Ericameria } & \text { parryi var. nevadensis } & \mathrm{P}<0.05 \\ \text { ERUMS2 } & \text { Eriogonum } & \text { umbellatum var. subaridum } & \mathrm{P}<0.05 \\ \text { GLSPA } & \text { Glossopetalon } & \text { spinescens var. aridum } & \mathrm{P}<0.05 \\ \text { HODI } & \text { Holodiscus } & \text { discolor } & \mathrm{P}<0.05 \\ \text { JUOS } & \text { Juniperus } & \text { osteosperma } & \mathrm{P}<0.05 \\ \text { OPERE } & \text { Opuntia } & \text { erinacea var. eninacea } & \mathrm{P}<0.05 \\ \text { PIMO } & \text { Pinus } & \text { monophylla } & \mathrm{P}<0.05 \\ \text { PUTR2 } & \text { Purshia } & \text { tridentata } & \mathrm{P}<0.05 \\ \text { QUGA } & \text { Quercus } & \text { gambelii } & \mathrm{P}<0.05 \\ \text { RICEC2 } & \text { Ribes } & \text { cereum var. cereum } & \mathrm{P}<0.05 \\ \text { RIVEV } & \text { Ribes } & \text { velutinum var. velutinum } & \mathrm{P}<0.05 \\ \text { SADOD3 } & \text { Salvia } & \text { dorii ssp. dorrii var. domii } & \mathrm{P}<0.05\end{array}$

\section{TARA Tamarix}

$\begin{array}{ll}\text { ERMIS2 } & \text { Eriogonum } \\ \text { ERNAH } & \text { Ericameria }\end{array}$

ramosissima

microthecum var. simpsonii
nauseosus ssp. nauseosus var. hololeuca

$$
\begin{aligned}
& P<0.05 \\
& P<0.05
\end{aligned}
$$

\section{TEAXA Tetradymia}

$\begin{array}{ll}\text { ARBI3 } & \text { Artemisia } \\ \text { ARSP5 } & \text { Artemisia } \\ \text { CHVIS5 } & \text { Chrysothamnus } \\ \text { CORA } & \text { Coleogyne } \\ \text { EPNE } & \text { Ephedra } \\ \text { ERTE18 } & \text { Ericameria } \\ \text { GRSP } & \text { Grayia } \\ \text { KRLA2 } & \text { Krascheninnikovia } \\ \text { LYAN } & \text { Lycium } \\ \text { STPA3 } & \text { Stephanomeria } \\ \text { YUBR } & \text { Yucca }\end{array}$

\section{axillaris var. axillaris}

bigelovii
spinescens
viscidiflorus ssp. viscidiflorus var. stenophyllus
ramosissima
nevadensis
teretifolia
spinosa
lanata
andersonii
parryi
brevifolia

$$
\begin{aligned}
& P<0.05 \\
& P<0.05 \\
& P<0.05 \\
& P<0.05 \\
& P<0.05 \\
& P<0.05 \\
& P<0.05 \\
& P<0.05 \\
& P<0.05 \\
& P<0.05 \\
& P<0.05
\end{aligned}
$$


ACODE Genus Species Statistical Level

TECA2 Tetradymia

canescens

$\begin{array}{ll}\text { ATCAC } & \text { Atriplex } \\ \text { CHVIV2 } & \text { Chrysothamnus } \\ \text { ERNA10 } & \text { Ericameria } \\ \text { ERNAL } & \text { Ericameria } \\ \text { ERSA6 } & \text { Eriogonum } \\ \text { GRSP } & \text { Grayia } \\ \text { SADOD3 } & \text { Salvia } \\ \text { YUBR } & \text { Yucca }\end{array}$

canescens var. canescens
viscidiflorus ssp. viscidiflorus
nauseosus
nauseosus ssp. consimilis var. leiosperma
saxatile
spinosa
dorii ssp. domii var. domii
brevifolia

$P<0.05$

$P<0.05$

$P<0.05$

$P<0.05$

$P<0.05$

$P<0.05$

$P<0.05$

$P<0.05$

\section{TEGL Tetradymia glabrata}

$\begin{array}{ll}\text { CEGRV2 } & \text { Ceanothus } \\ \text { CEIN7 } & \text { Cercocarpus } \\ \text { CELEL } & \text { Cercocarpus } \\ \text { ERNA10 } & \text { Ericameria } \\ \text { ERNAL } & \text { Ericameria } \\ \text { ERPAN2 } & \text { Ericameria } \\ \text { PUST } & \text { Purshia }\end{array}$

greggii ssp. vestitus
intricatus
ledifolius var. ledifolius
nauseosus
nauseosus ssp. consimilis var. leiosperma
parryi var. nevadensis
stansburiana

$P<0.05$

$P<0.05$

$P<0.05$

$P<0.05$

$P<0.05$

$P<0.05$

$P<0.05$

\section{THMO Thamnosma montana}

$\begin{array}{ll}\text { CHVIV2 } & \text { Chrysothamnus } \\ \text { EPNE } & \text { Ephedra } \\ \text { EPTO } & \text { Ephedra } \\ \text { ERMIS2 } & \text { Eriogonum } \\ \text { ERTE18 } & \text { Ericameria } \\ \text { LEFR2 } & \text { Lepidium } \\ \text { OPERU } & \text { Opuntia } \\ \text { PSFRF } & \text { Psorothamnus } \\ \text { SAME } & \text { Salazaria }\end{array}$

viscidiflorus ssp. viscidiflorus
nevadensıs
torreyana
microthecum var. simpsonii
teretifolia
fremontii
erinacea var. ursina
fremontii var. fremontii
mexicana

$P<0.05$

$P<0.05$

$P<0.05$

$P<0.05$

$P<0.05$

$P<0.05$

$P<0.05$

$P<0.05$

$P<0.05$ 
ACODE Genus Species Statistical Level

YUBAV Yucca

$\begin{array}{ll}\text { ARNO4 } & \text { Artemisia } \\ \text { EPVI } & \text { Ephedra } \\ \text { ERCO23 } & \text { Ericameria } \\ \text { GUSA2 } & \text { Gutierrezia } \\ \text { JUOS } & \text { Juniperus }\end{array}$

YUBR Yucca

CHVIV2

CORA

ECPO2

EPNE

ERNAL

MESP2

OPBAB2

OPECE

STEL

TEAXA

TECA2

\section{YUSC2 Yucca}

$\begin{array}{ll}\text { ACSH } & \text { Acamptopappus } \\ \text { AMDU2 } & \text { Ambrosia } \\ \text { ATCO } & \text { Atriplex } \\ \text { EPFU } & \text { Ephedra } \\ \text { EPTO } & \text { Ephedra } \\ \text { ERHEH2 } & \text { Eriogonum } \\ \text { KRER } & \text { Krameria } \\ \text { LATR2 } & \text { Larrea }\end{array}$

\section{brevifolia}

Chrysothamnus
Coleogyne
Echinocactus
Ephedra
Ericameria
Menodora
Opuntia
Opuntia
Stanleya
Tetradymia
Tetradymia

baccata var. vespertina

nova
viridis
cooperi
sarothree
osteosperma

$P<0.05$

$P<0.05$

$P<0.05$

$P<0.05$

$P<0.05$

viscidiflorus ssp. viscidiflorus
ramosissima
polycephalus
nevadensis
nauseosus ssp. consimilis var. leiosperma
spinescens
basilaris var. basilaris
echinocarpa var. echinocarpa
elata
axillaris var. axillaris
canescens

$P<0.05$

$P<0.05$

$P<0.05$

$P<0.05$

$P<0.05$

$P<0.05$

$P<0.05$

$P<0.05$

$P<0.05$

$P<0.05$

$P<0.05$

\section{schidigera}

shockleyi
dumosa
confertifolia
funerea
torreyana
heermannii var. heermannii
erecta
tridentata

$$
\begin{aligned}
& P<0.05 \\
& P<0.05 \\
& P<0.05 \\
& P<0.05 \\
& P<0.05 \\
& P<0.05 \\
& P<0.05 \\
& P<0.05
\end{aligned}
$$


ACODE

Genus

MESP2

OPECE

PSFRF
Menodora

Opuntia

Psorothamnus
Species

spinescens

echinocarpa var. echinocarpa

fremontii var. fremontii
Statistical Level

$P<0.05$

$P<0.05$

$\mathrm{P}<0.05$ 
This Page Intentionally Left Blank 


\section{Appendix I}

\section{Distribution on the NTS of the Top Dominant Woody Plant Species Based on Abundance}

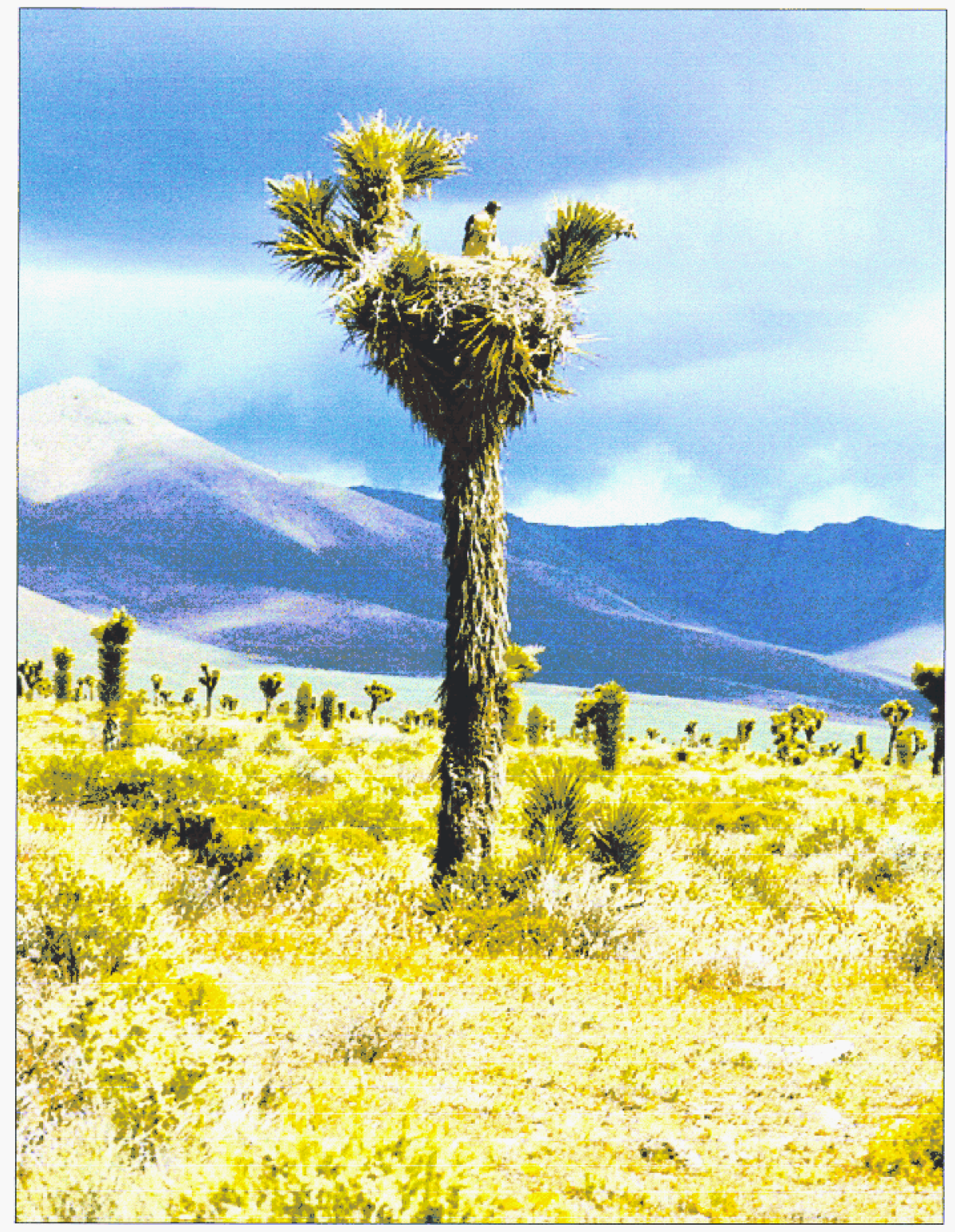

Joshua tree (Yucca brevifolia) with nesting red-tailed hawk (Buteo jamaicensis) [photo by Paul Greger] 
This Page Intentionally Left Blank 


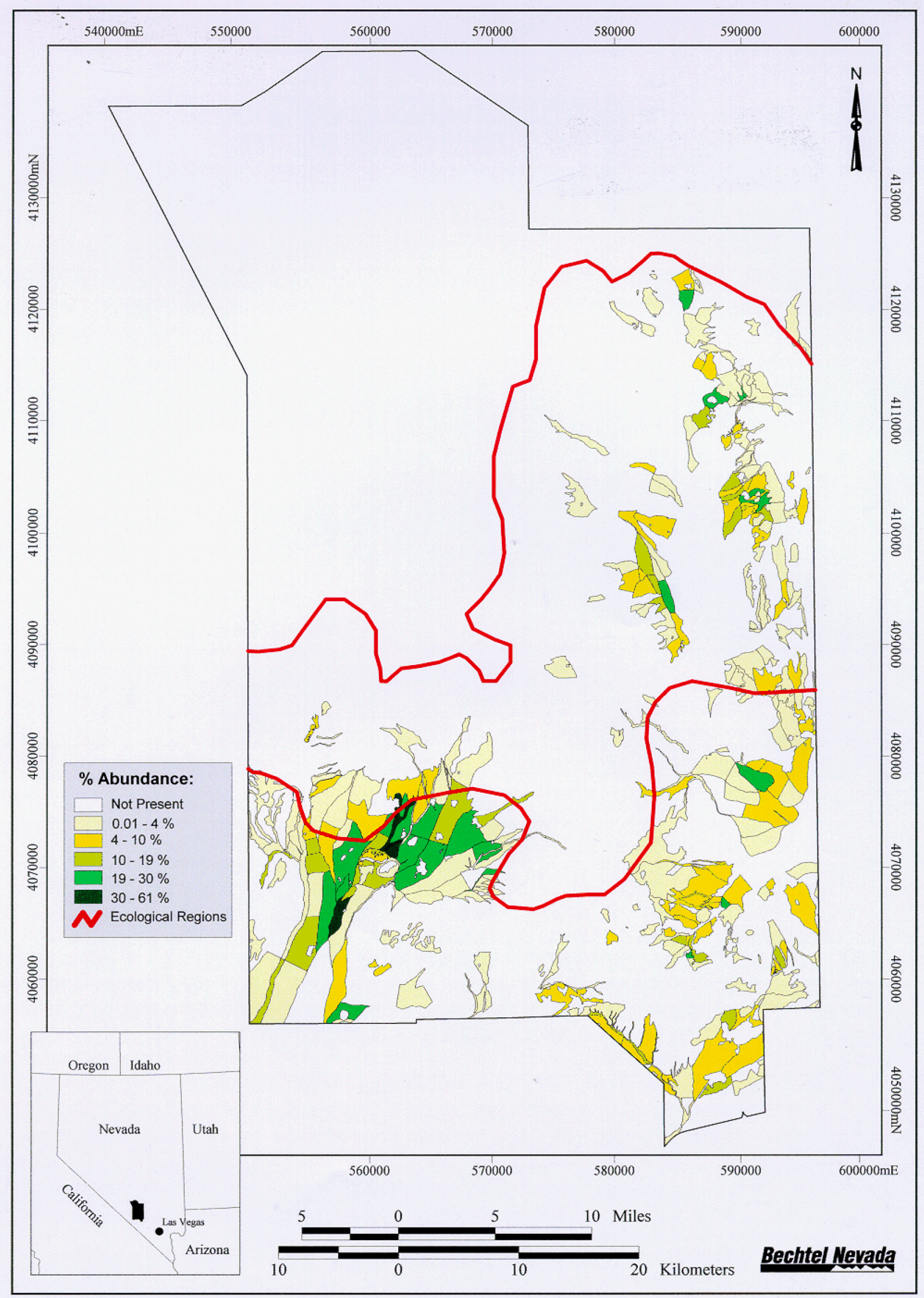

Figure 6-1 Percent Acamptopappus shockleyi abundance on the Nevada Test Site 


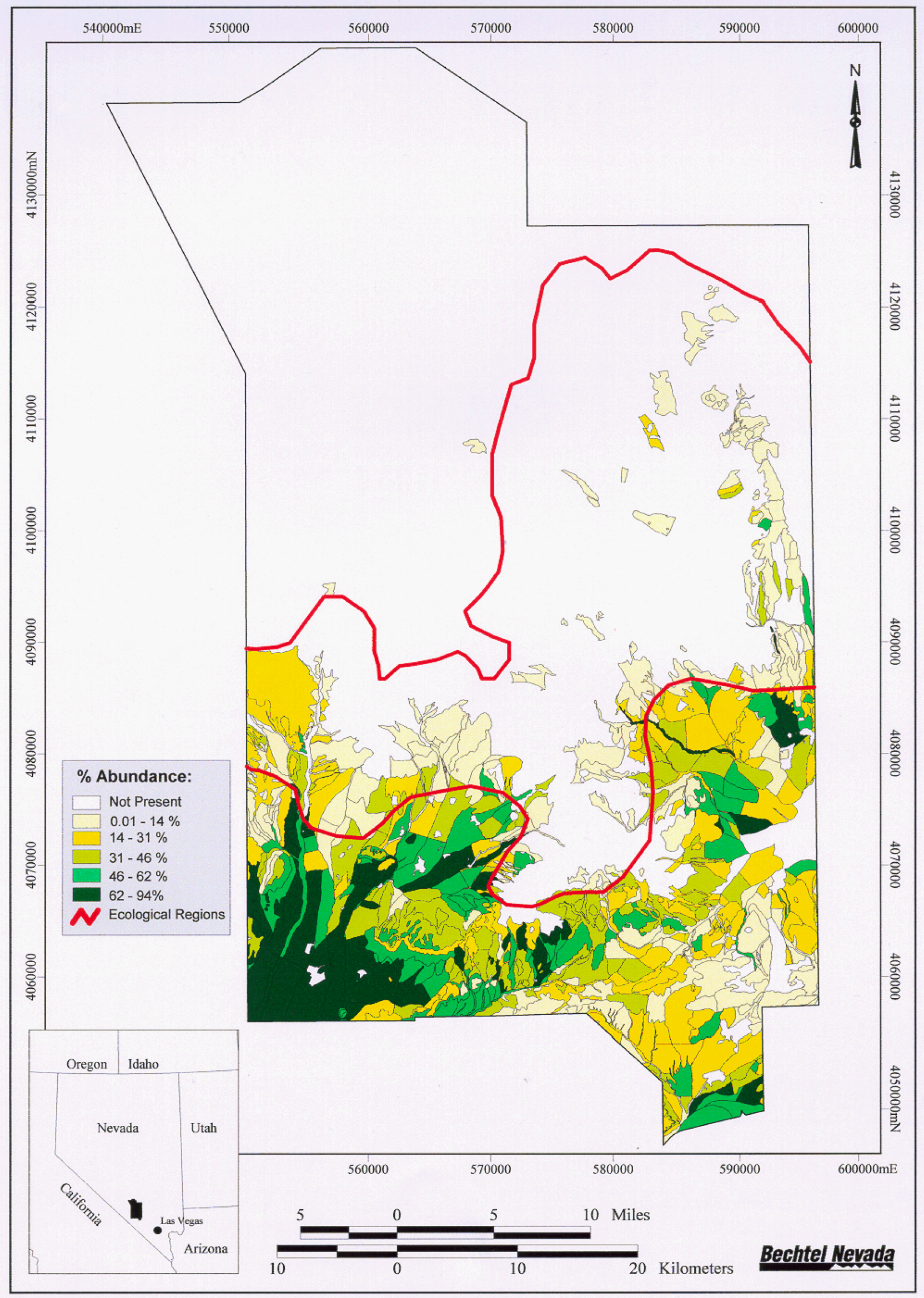

Figure 6-2 Percent Ambrosia dumosa abundance on the Nevada Test Site 


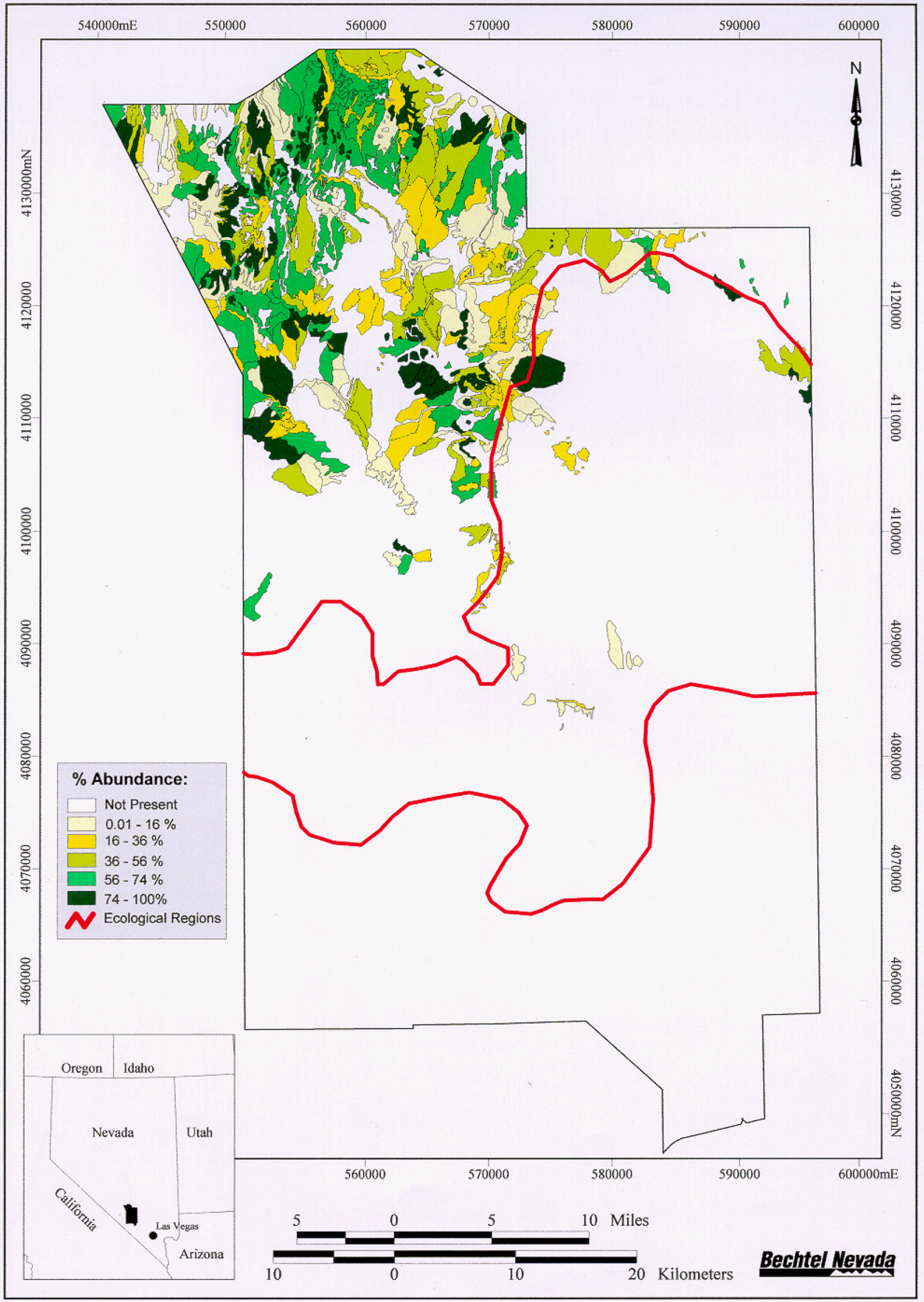

Figure 6-3 Percent Artemisia nova abundance on the Nevada Test Site 


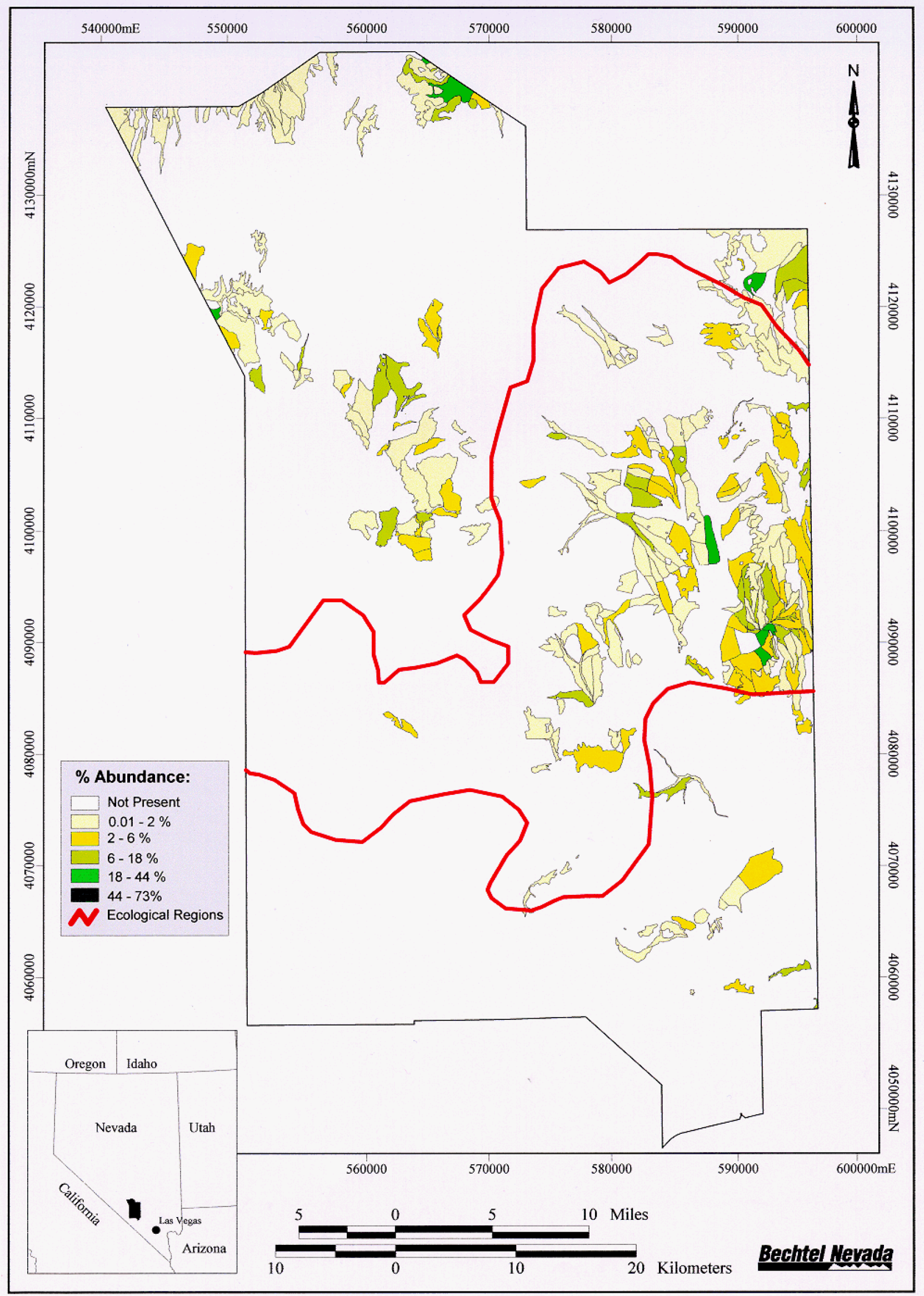

Figure 6-4 Percent Artemisia spinescens abundance on the Nevada Test Site 


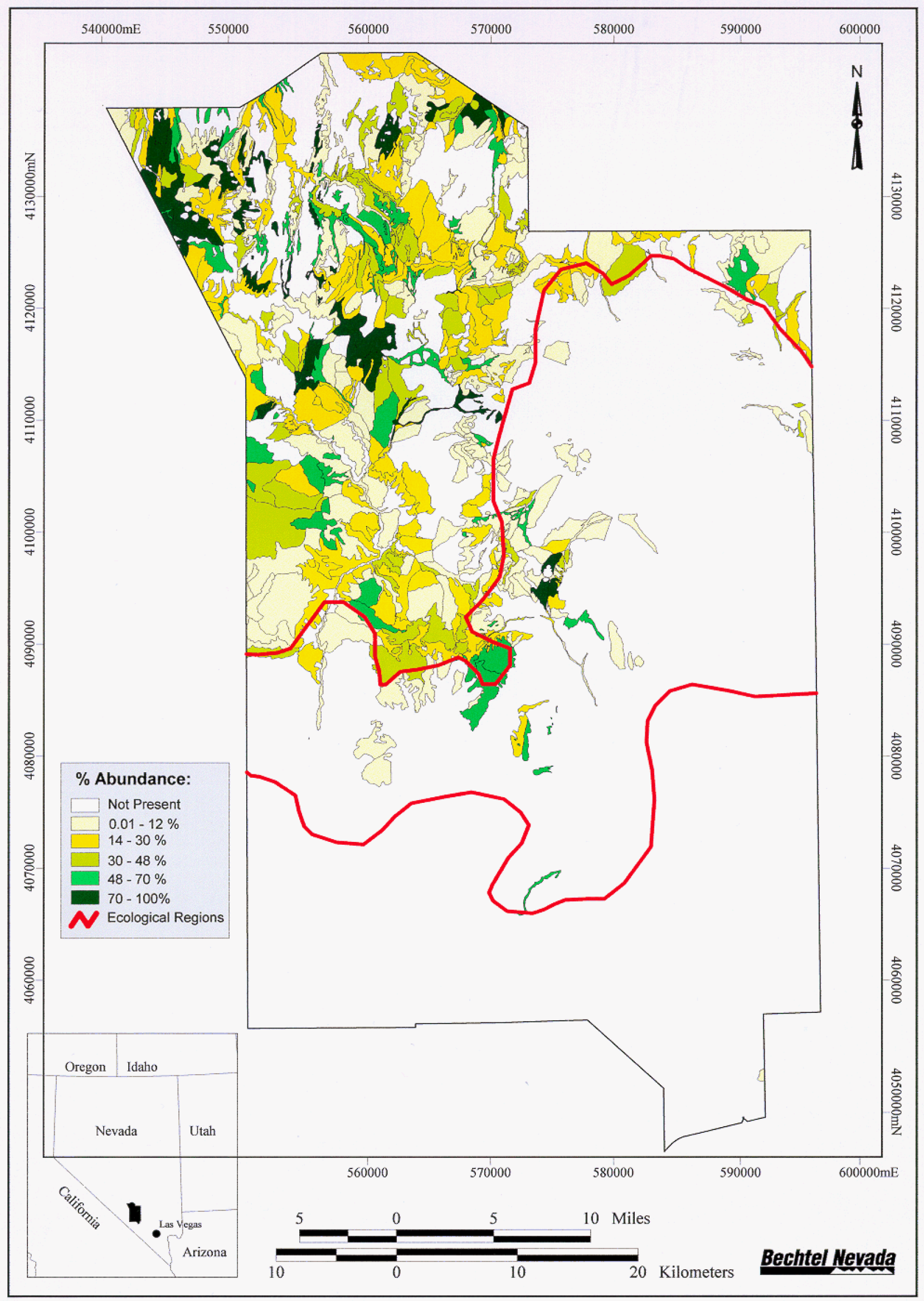

Figure 6-5 Percent Artemisia tridentata ssp. tridentata abundance on the Nevada Test Site 


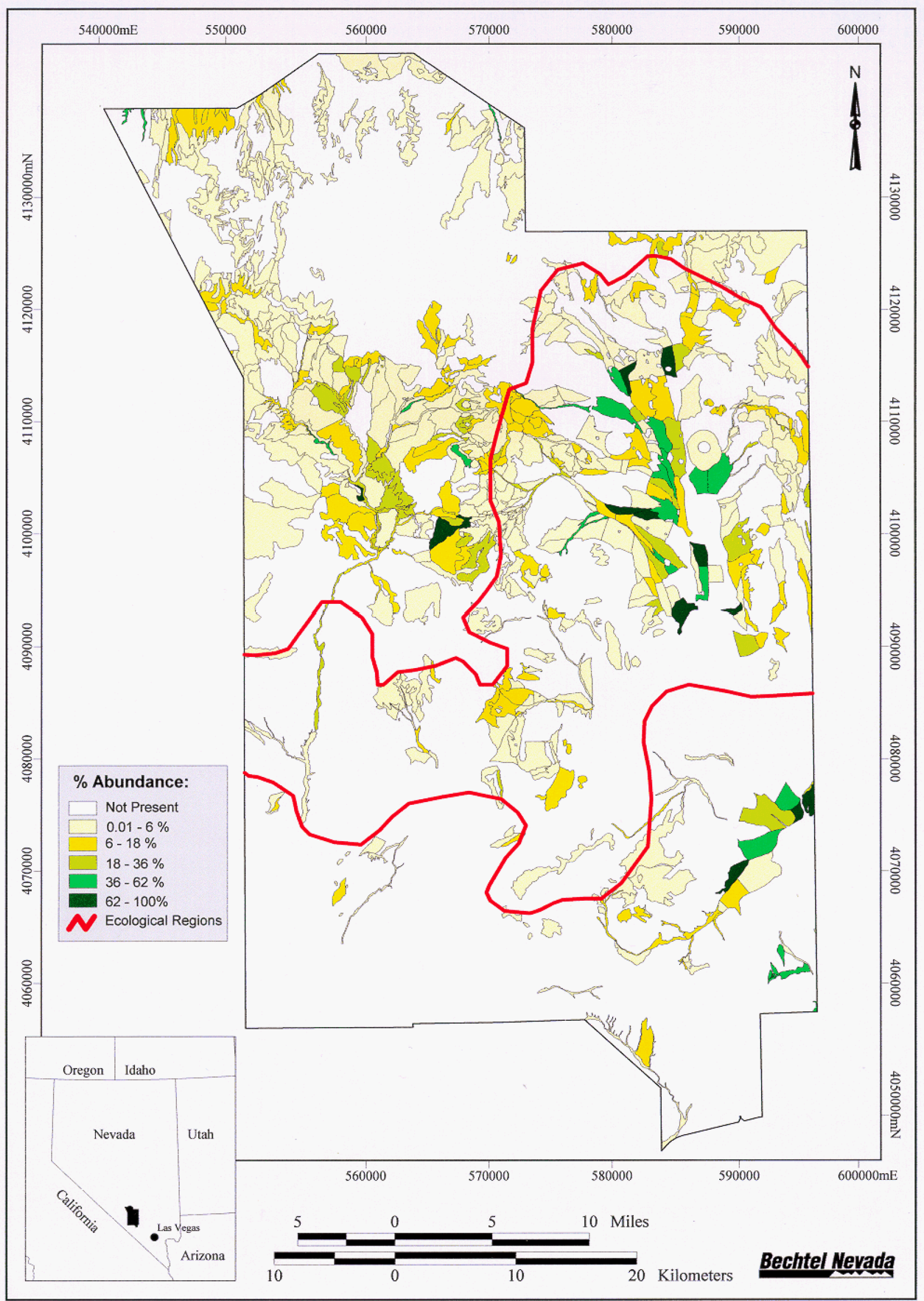

Figure 6-6 Percent Atriplex canescens var. canescens abundance on the Nevada Test Site 


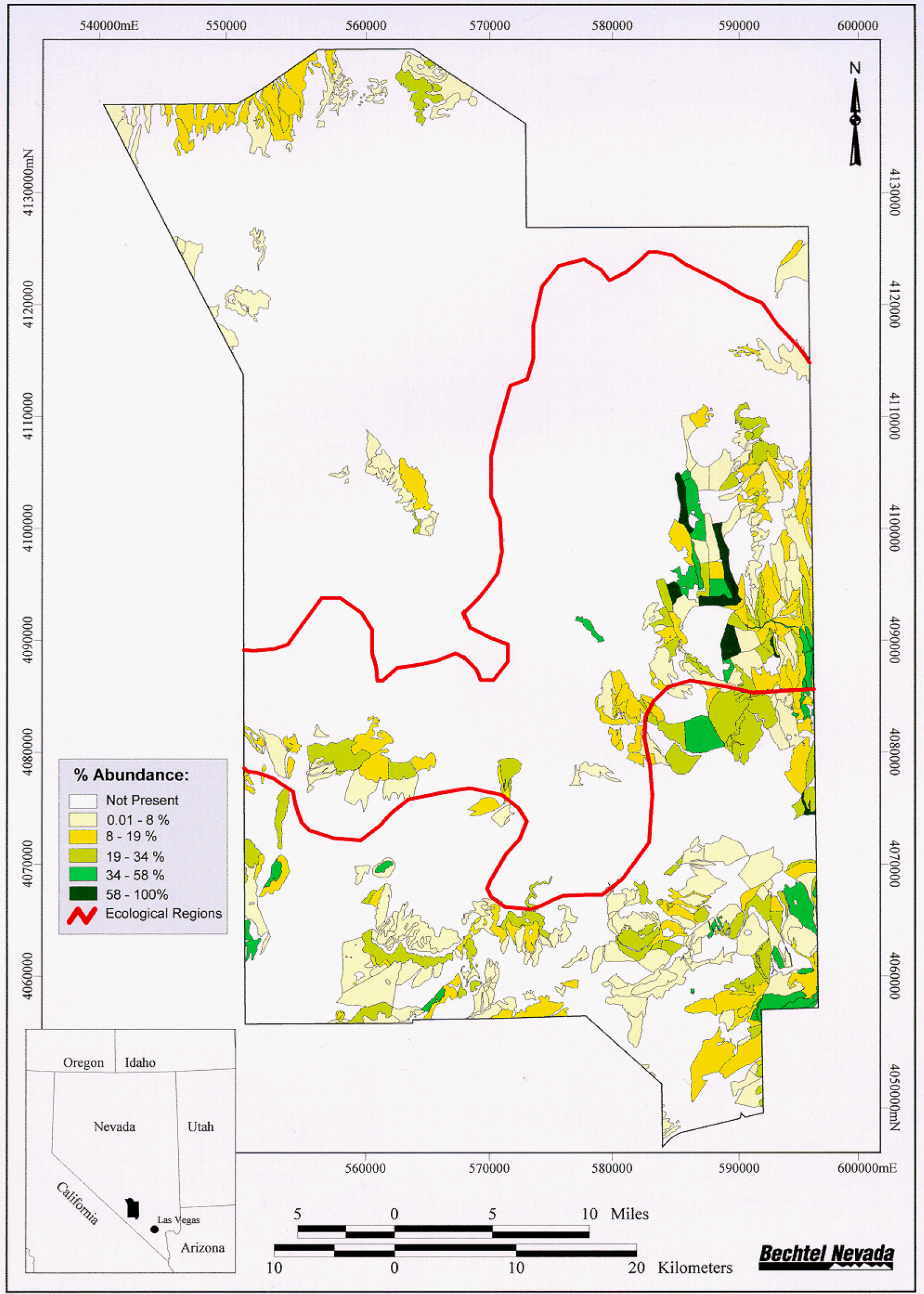

Figure 6-7 Percent Atriplex confertifolia abundance on the Nevada Test Site 


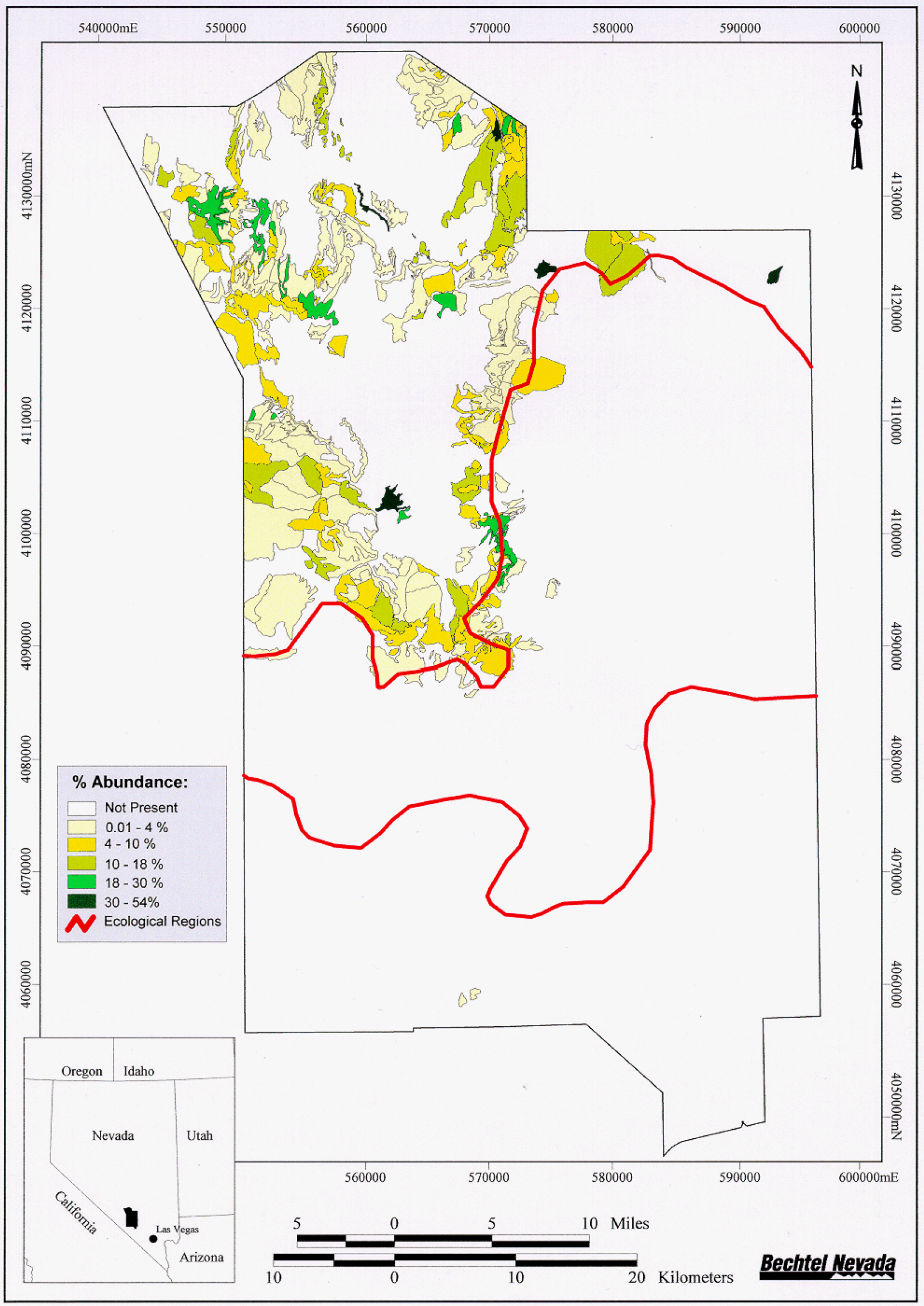

Figure 6-8 Percent Chrysothamnus viscidiflorus ssp. puberulus abundance on the Nevada Test Site 


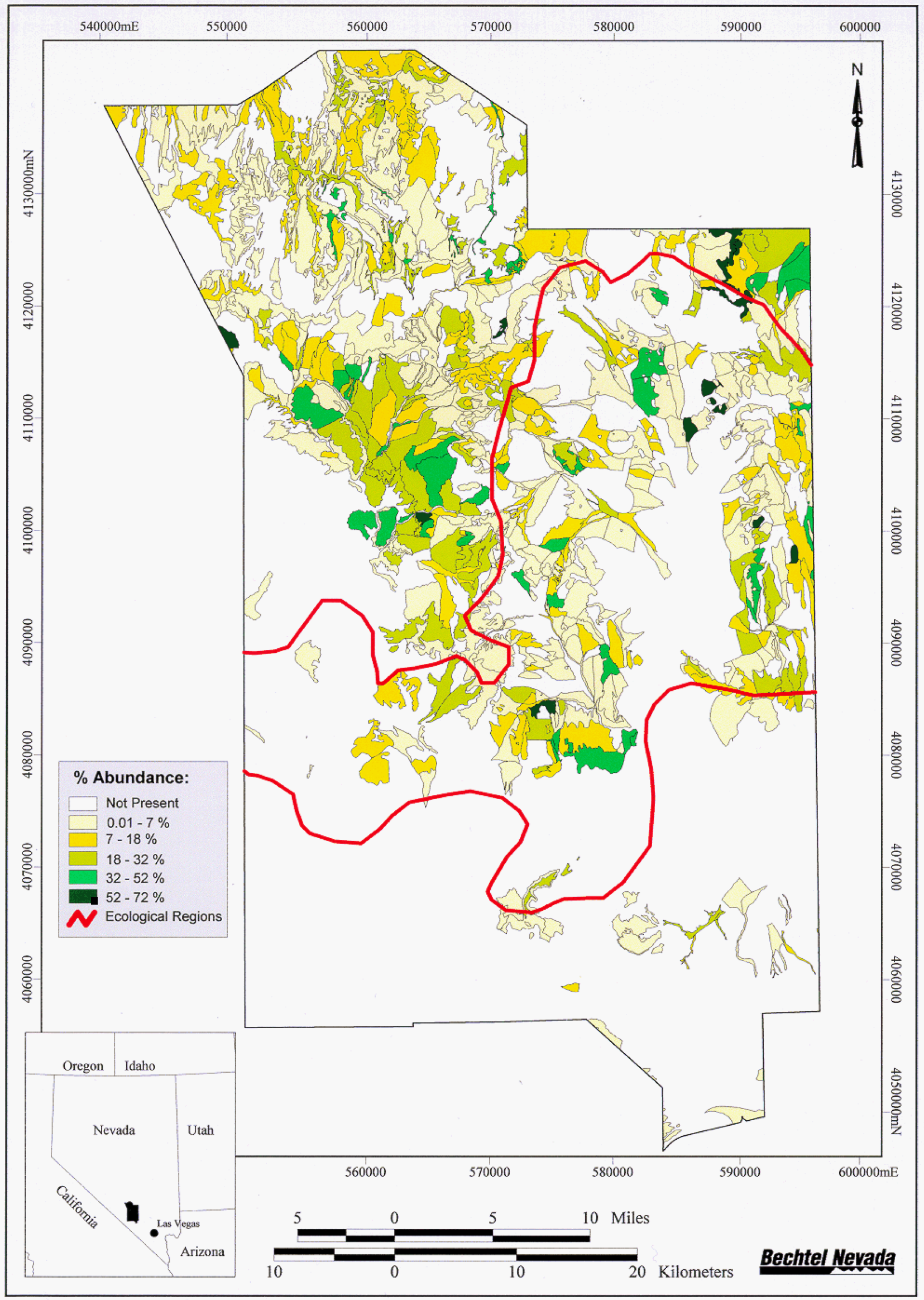

Figure 6-9 Percent Chrysothamnus viscidiflorus ssp. viscidiflorus abundance on the Nevada Test Site 


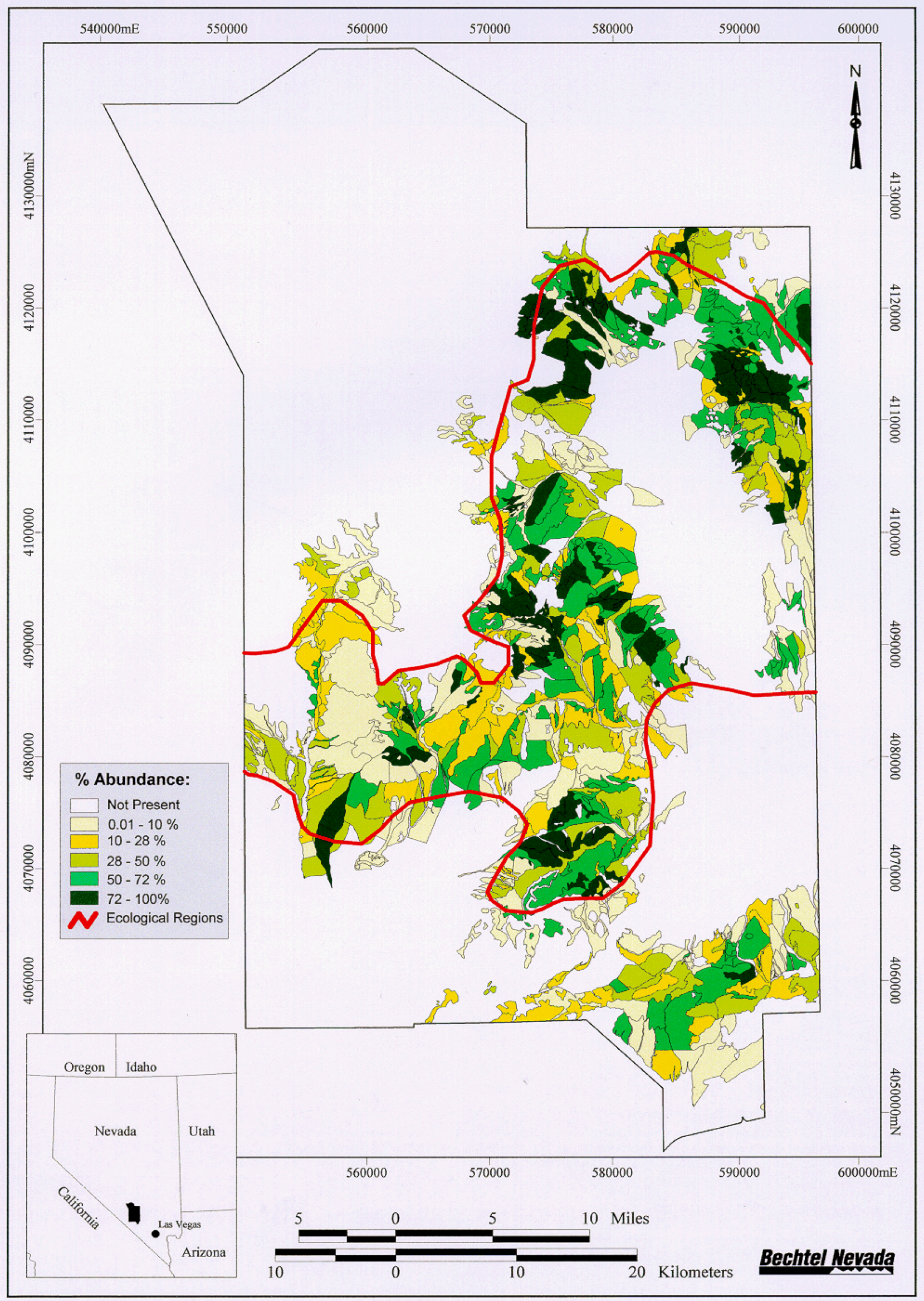

Figure 6-10 Percent Coleogyne ramosissima abundance on the Nevada Test Site 


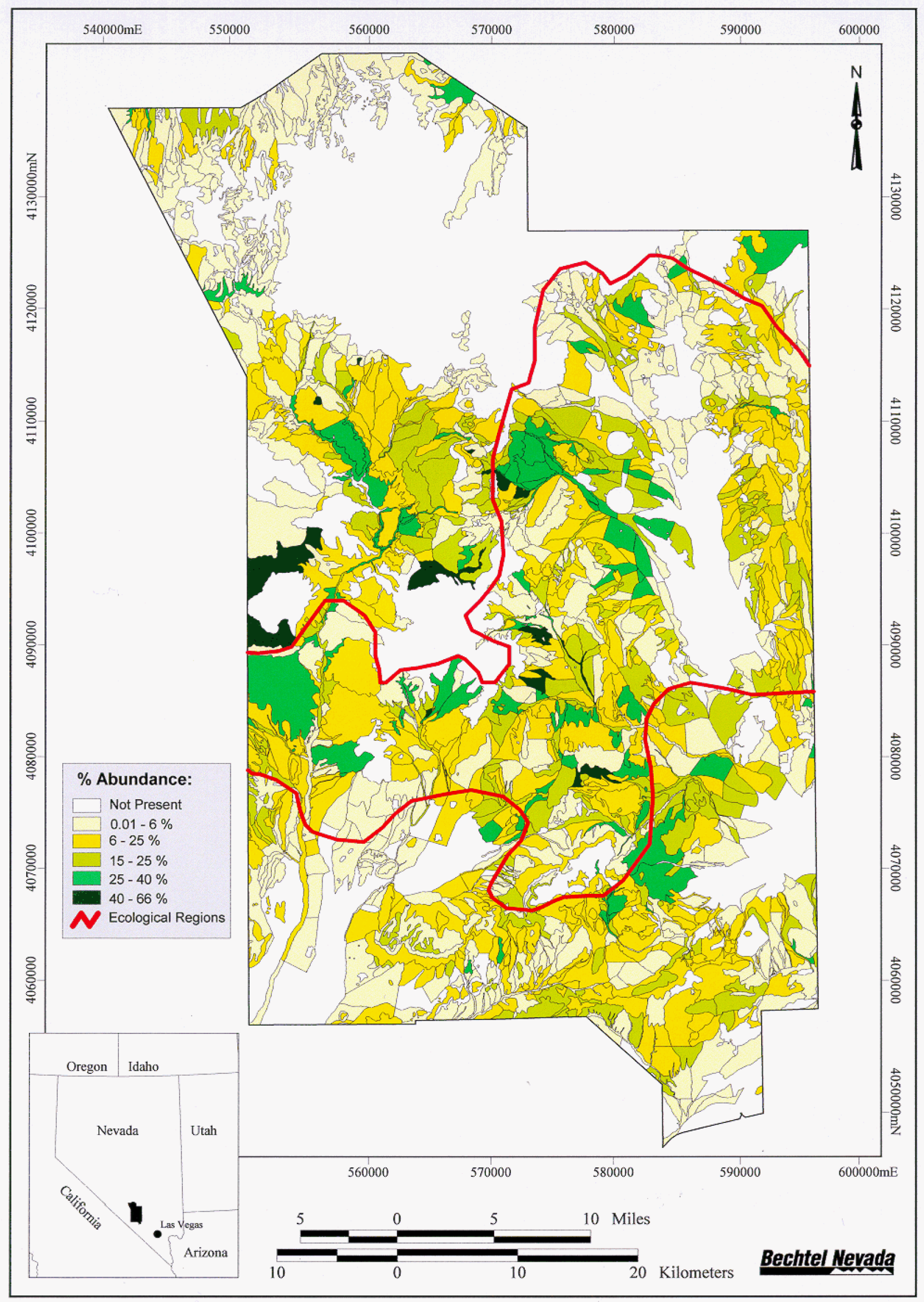

Figure 6-11 Percent Ephedra nevadensis abundance on the Nevada Test Site 


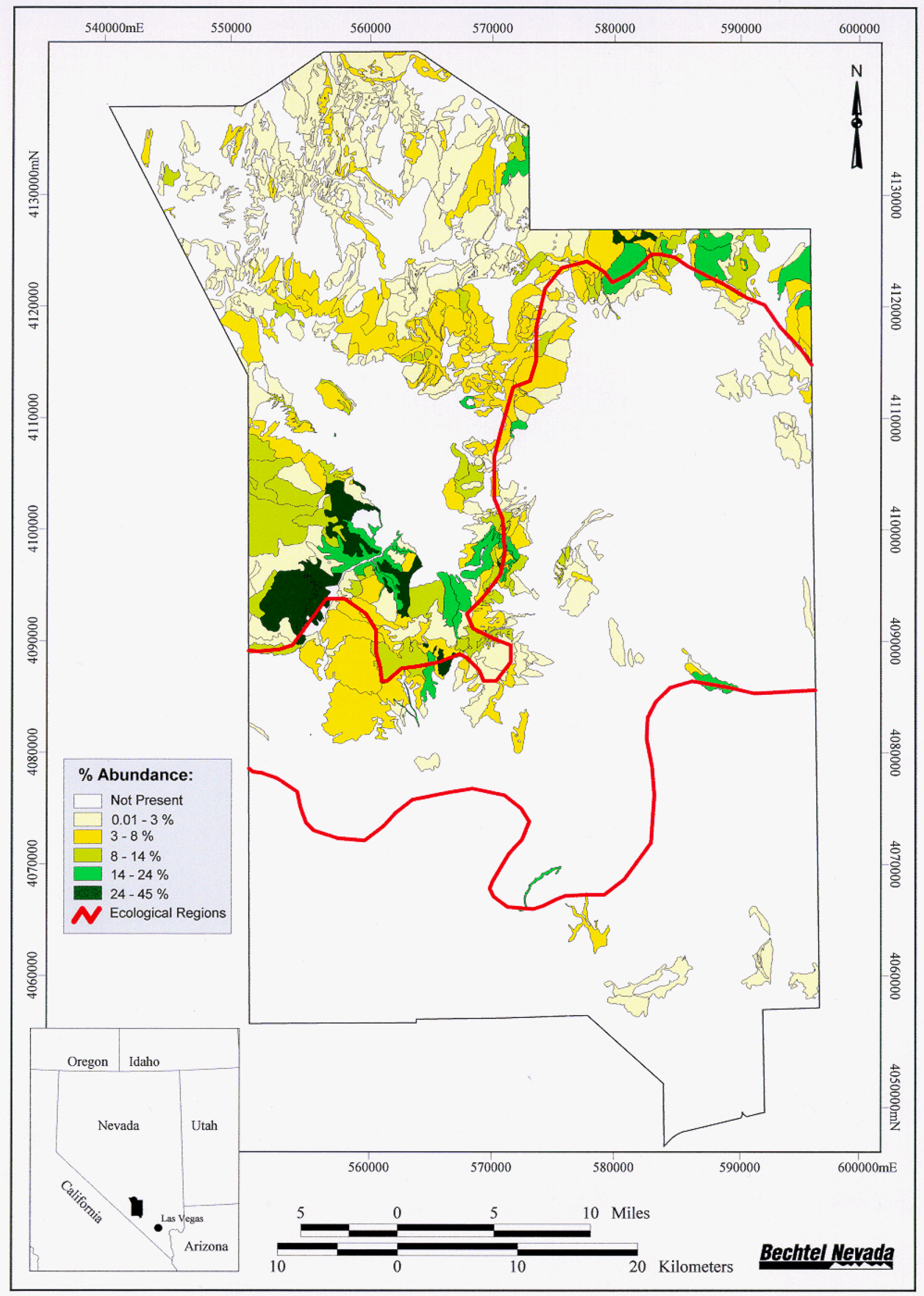

Figure 6-12 Percent Ephedra viridis abundance on the Nevada Test Site 


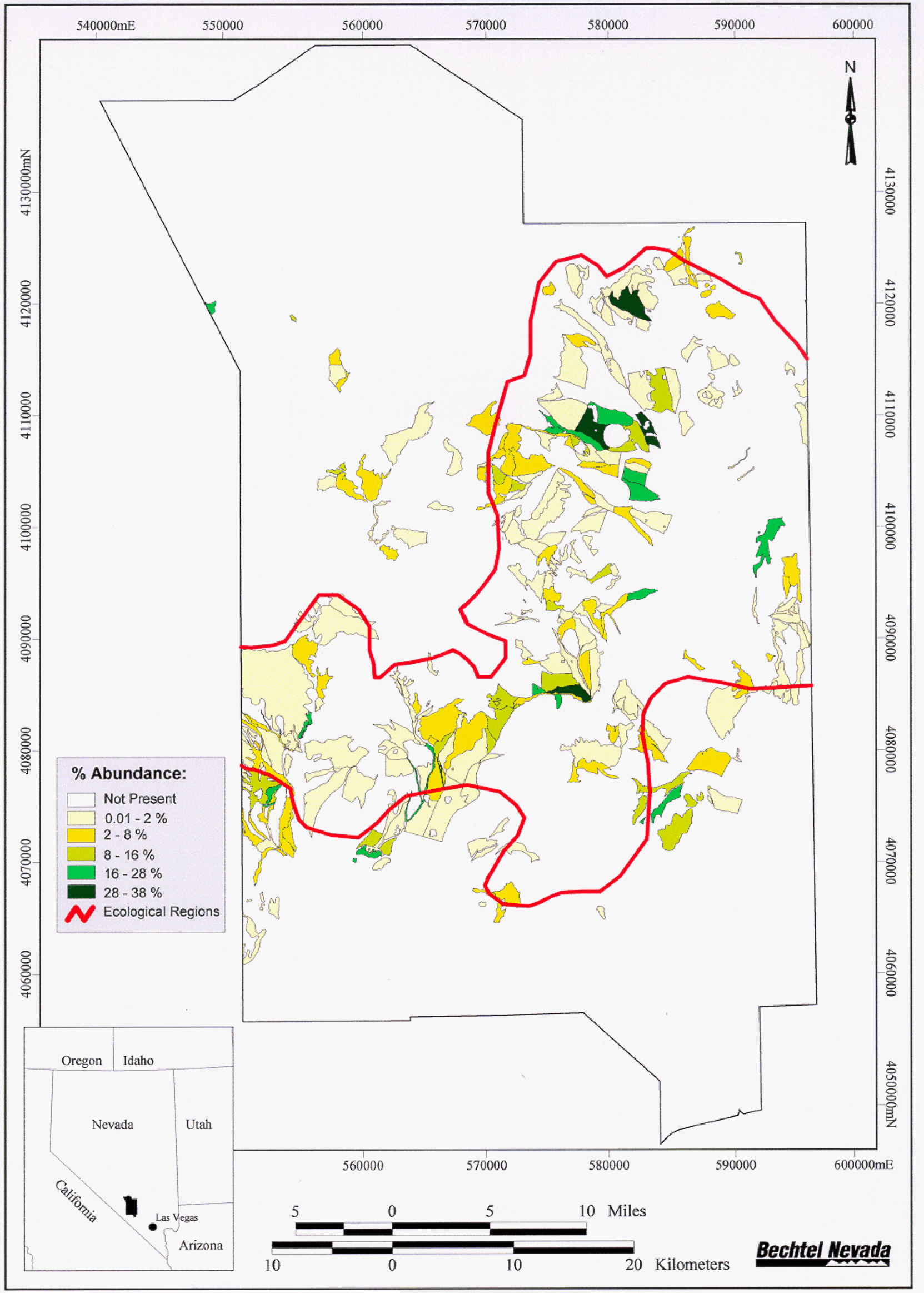

Figure 6-13 Percent Ericameria cooperi abundance on the Nevada Test Site 


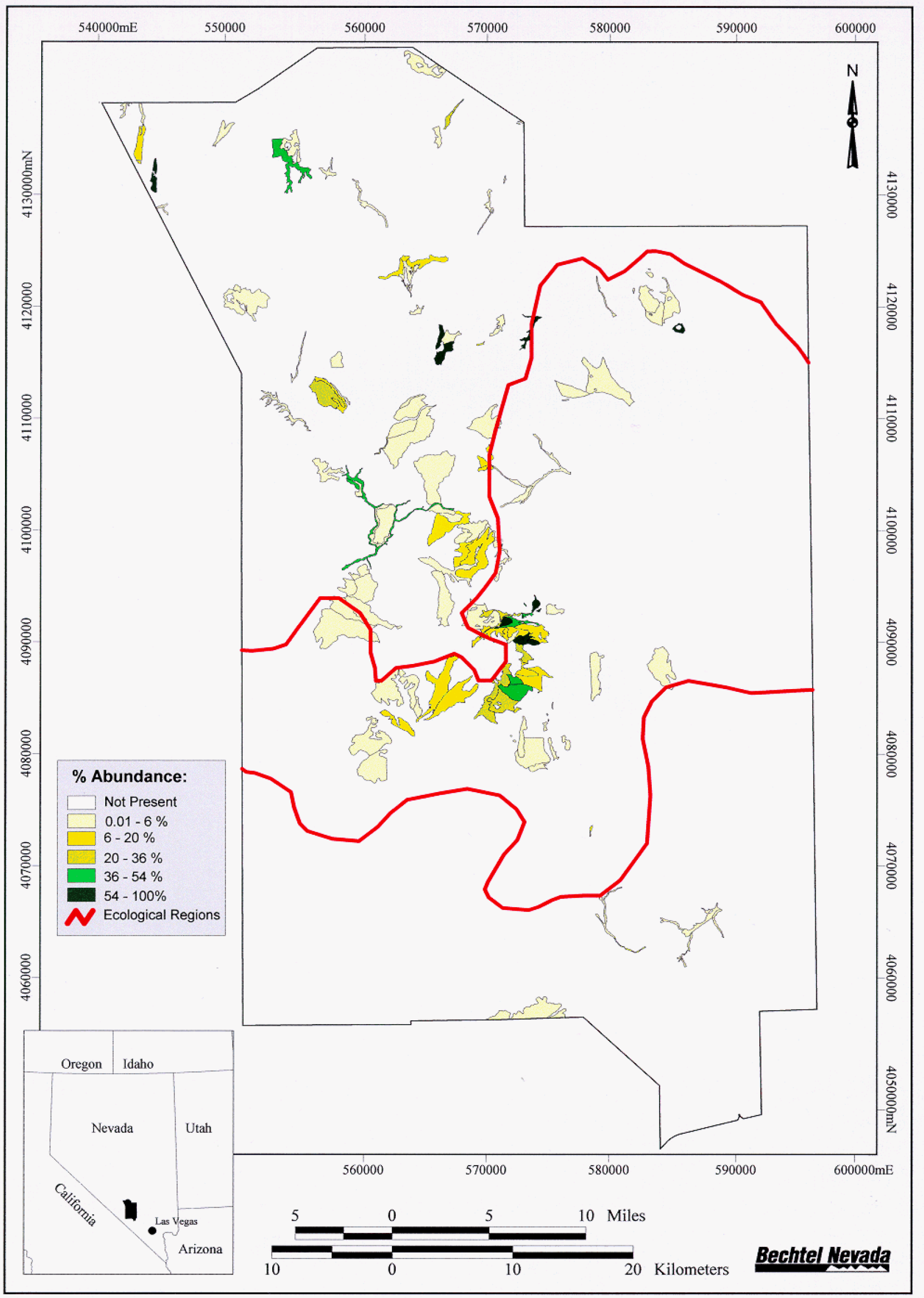

Figure 6-14 Percent Ericameria nauseosa ssp. nauseosa var. hololeuca abundance on the Nevada Test Site 


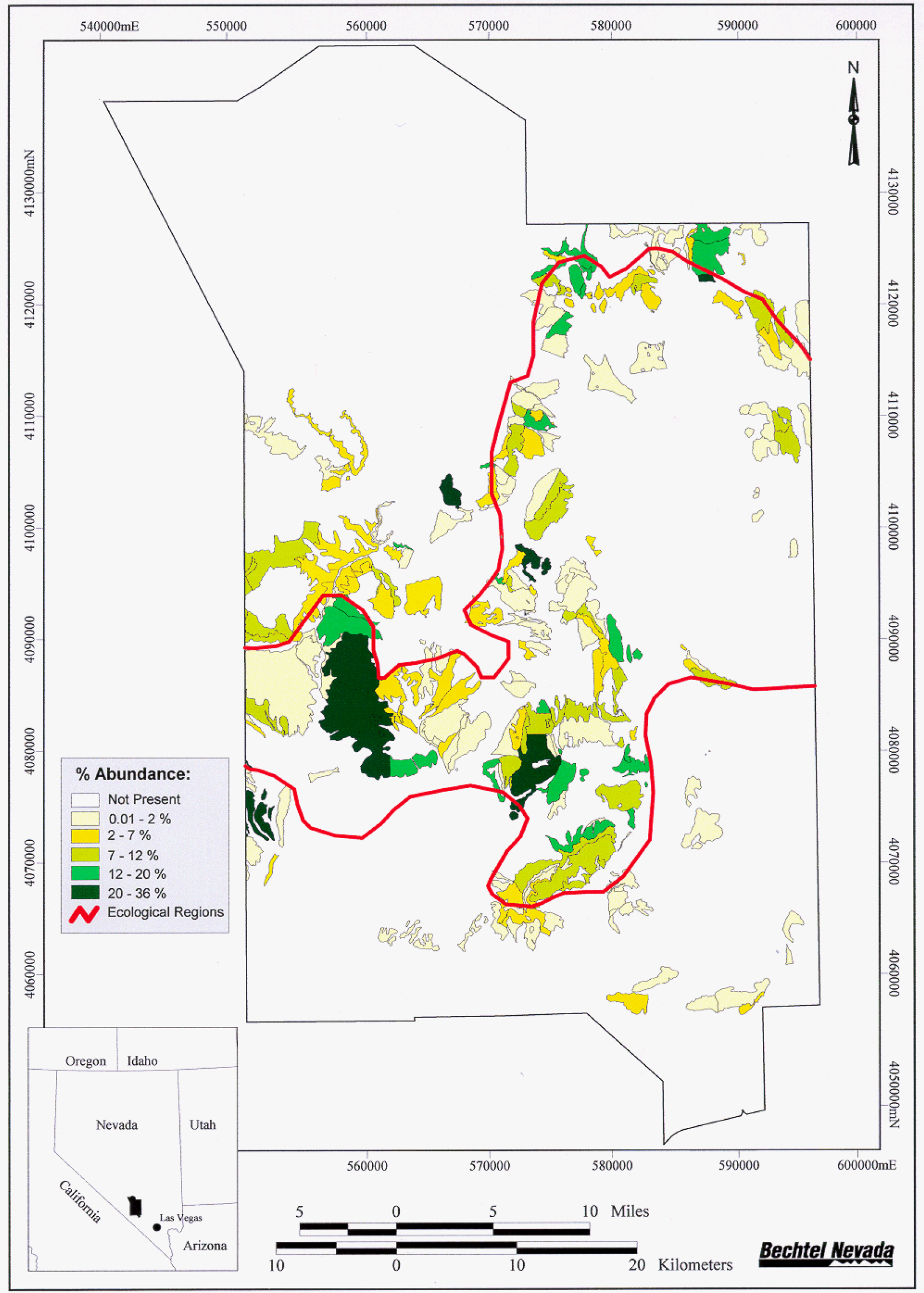

Figure 6-15 Percent Ericameria teretifolia abundance on the Nevada Test Site 


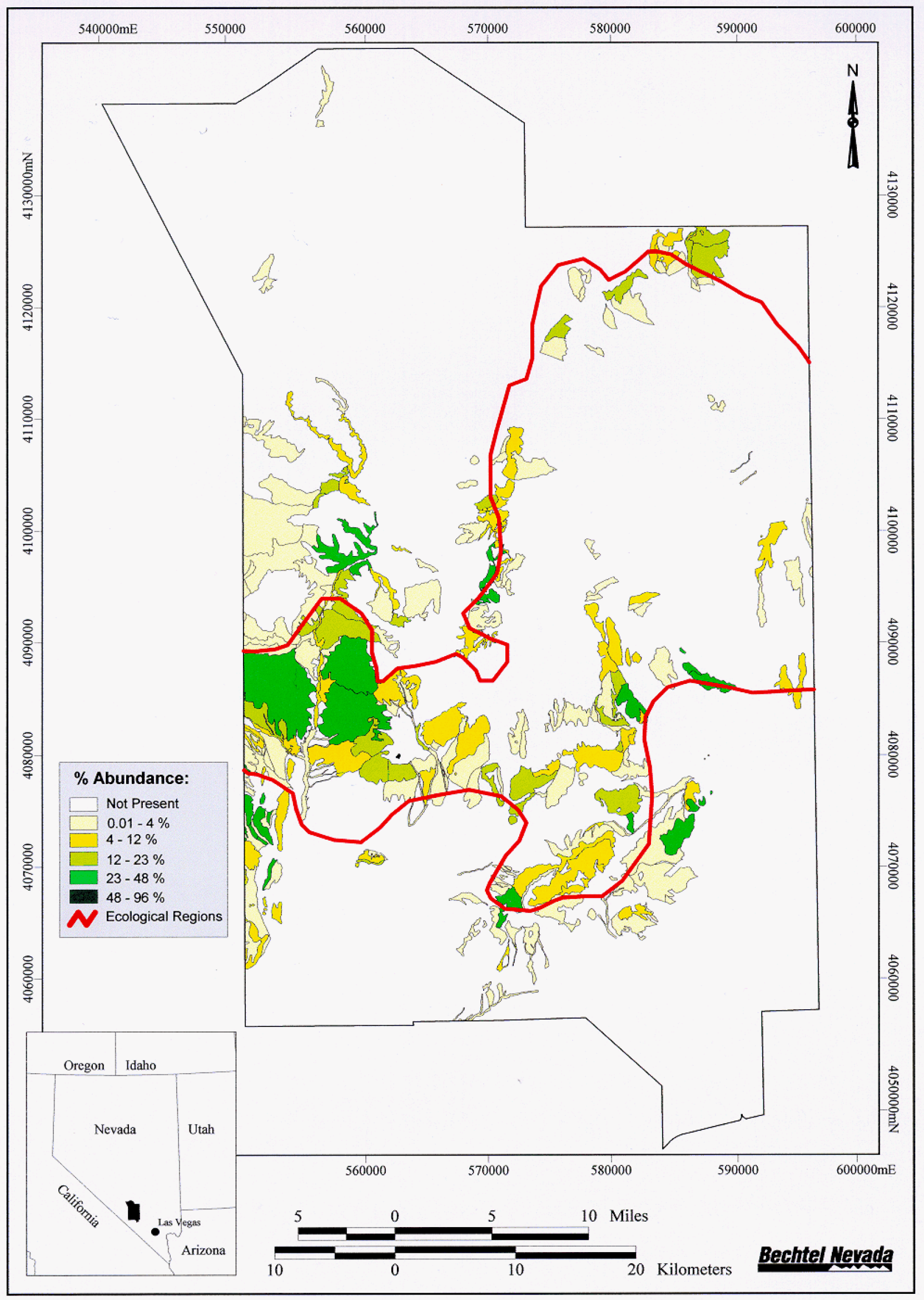

Figure 6-16 Percent Eriogonum fasciculatum var, polifolium abundance on the Nevada Test Site 


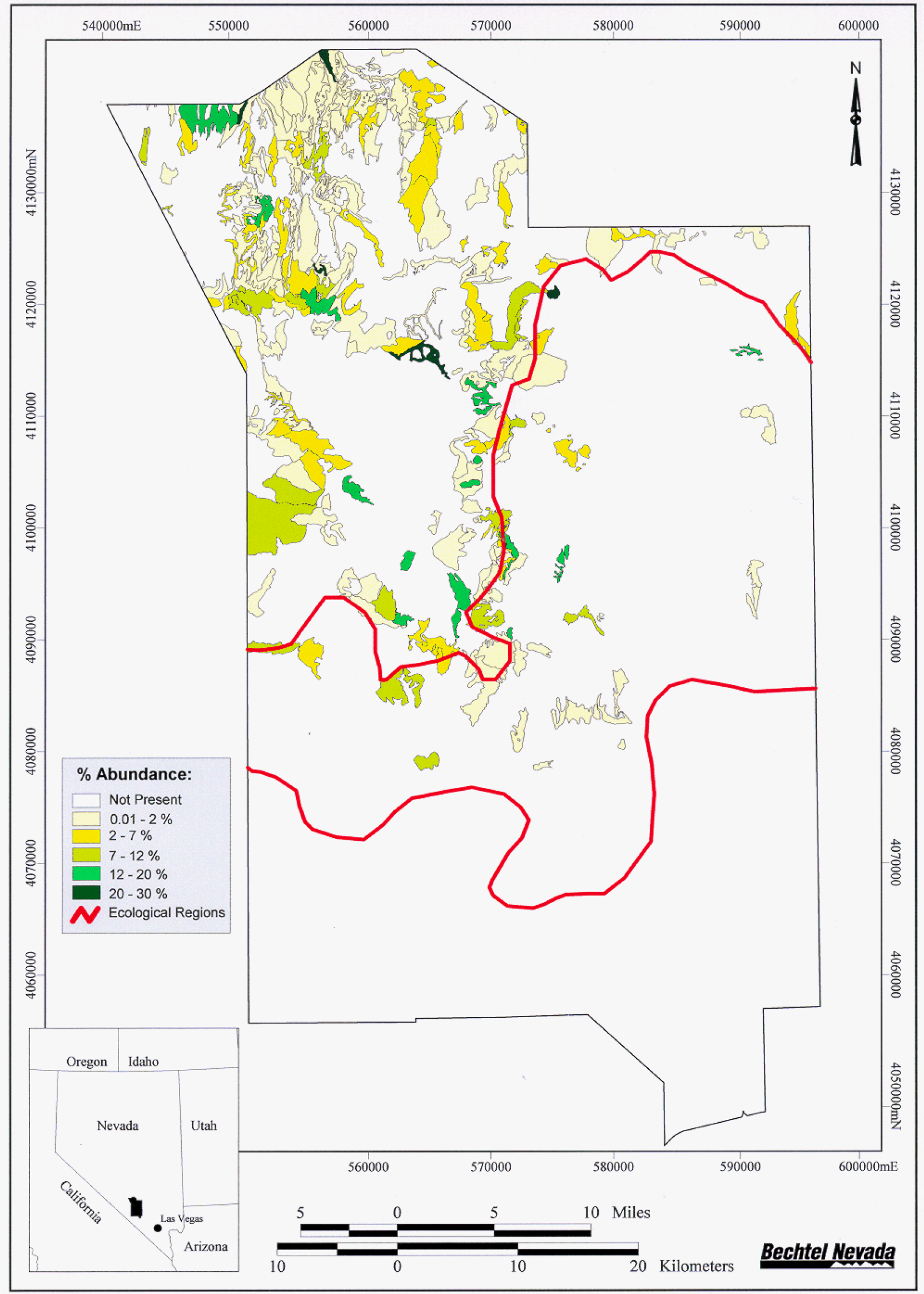

Figure 6-17 Percent Eriogonum microthecum var. lapidicola abundance on the Nevada Test Site 


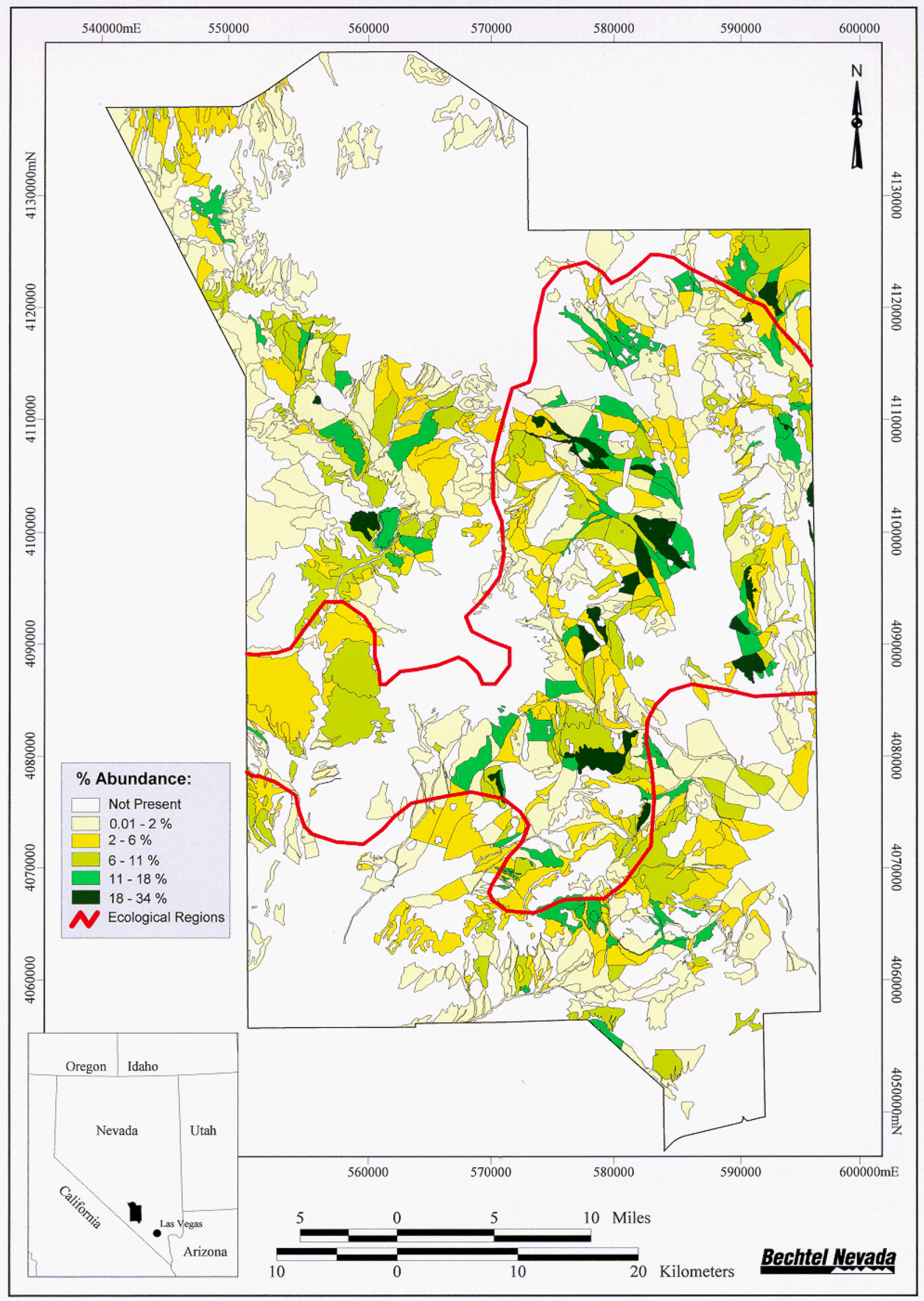

Figure 6-18 Percent Grayia spinosa abundance on the Nevada Test Site 


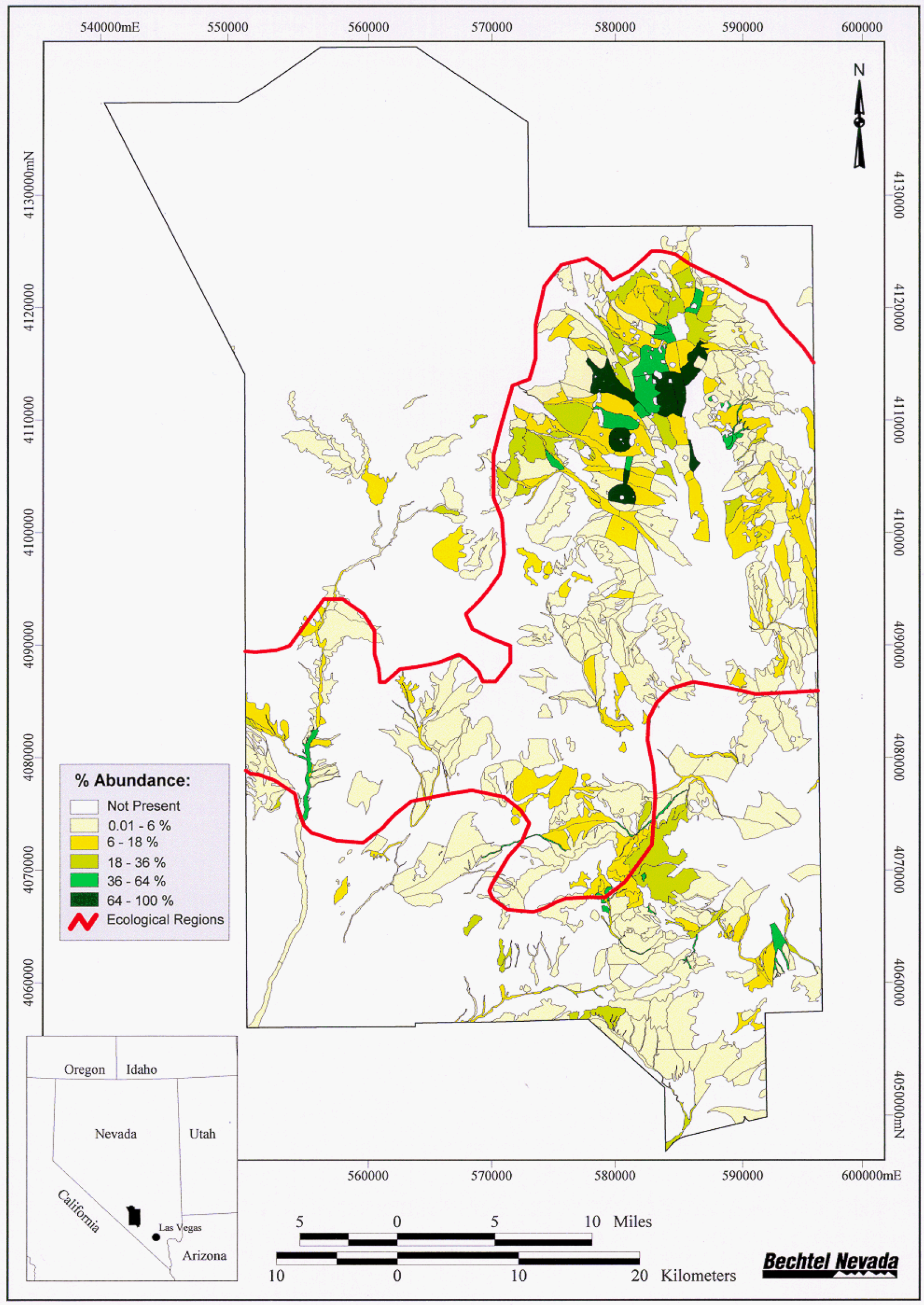

Figure 6-19 Percent Hymenoclea salsola abundance on the Nevada Test Site 


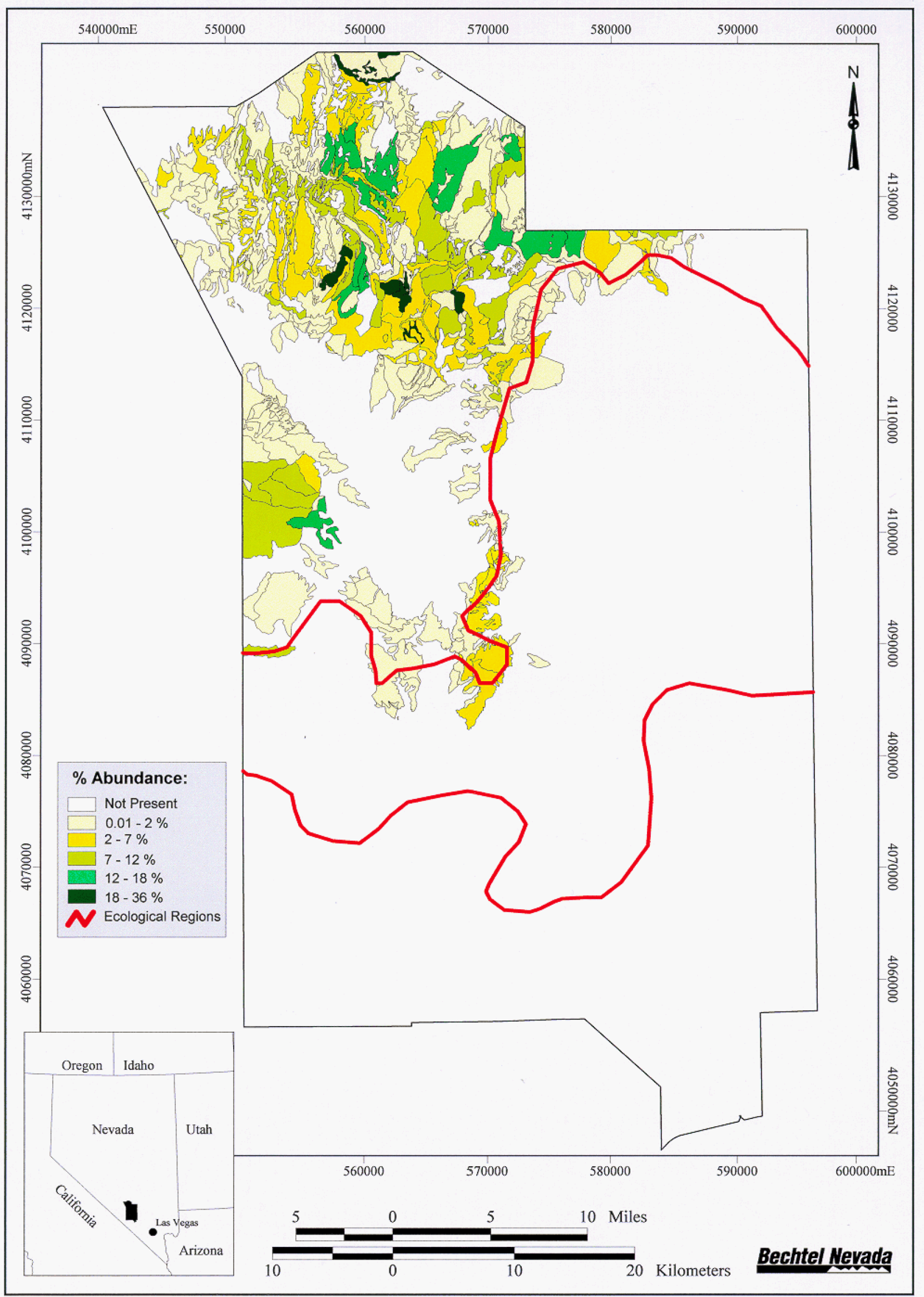

Figure 6-20 Percent Juniperus osteosperma abundance on the Nevada Test Site 


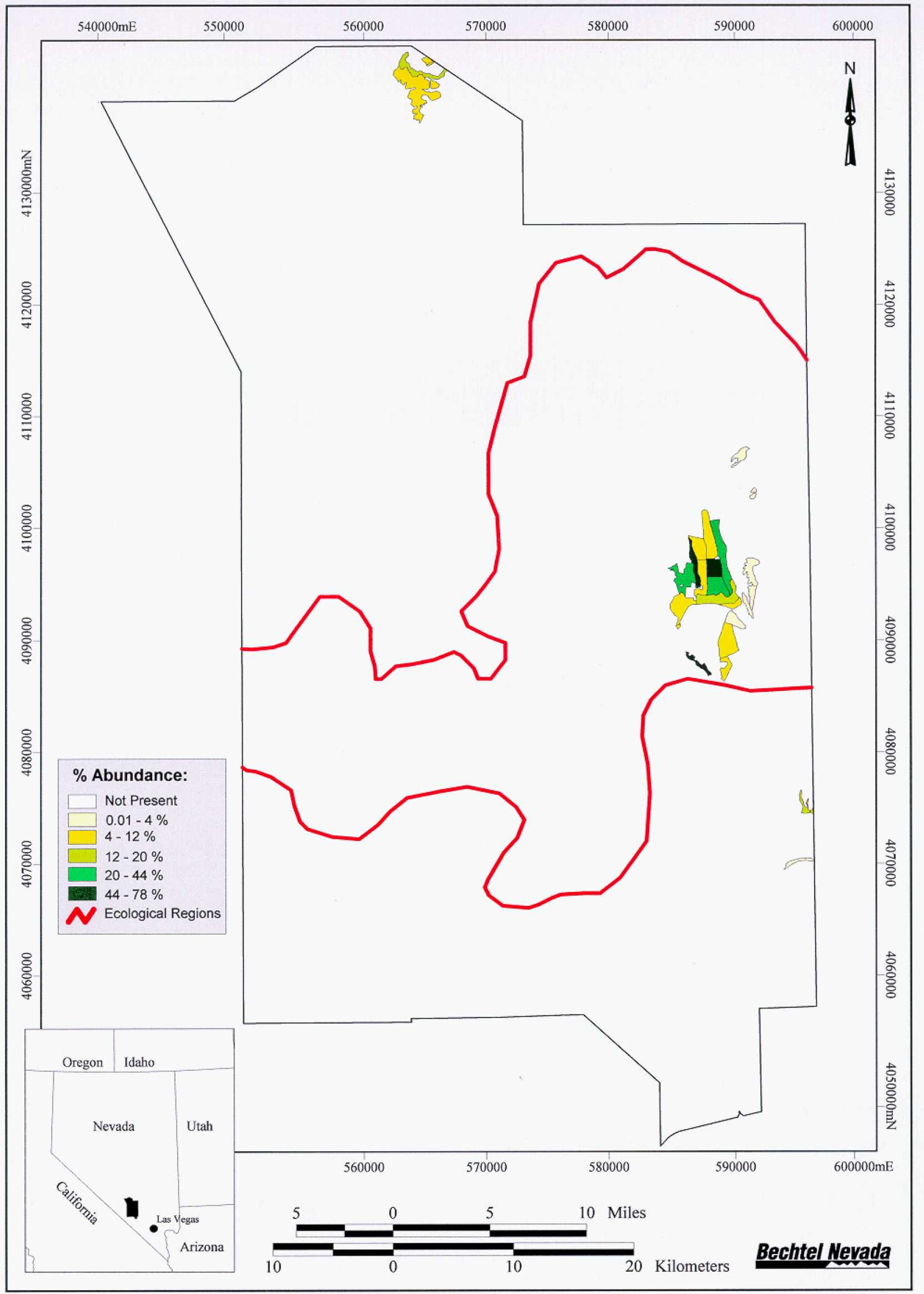

Figure 6-21 Percent Kochia americana abundance on the Nevada Test Site 


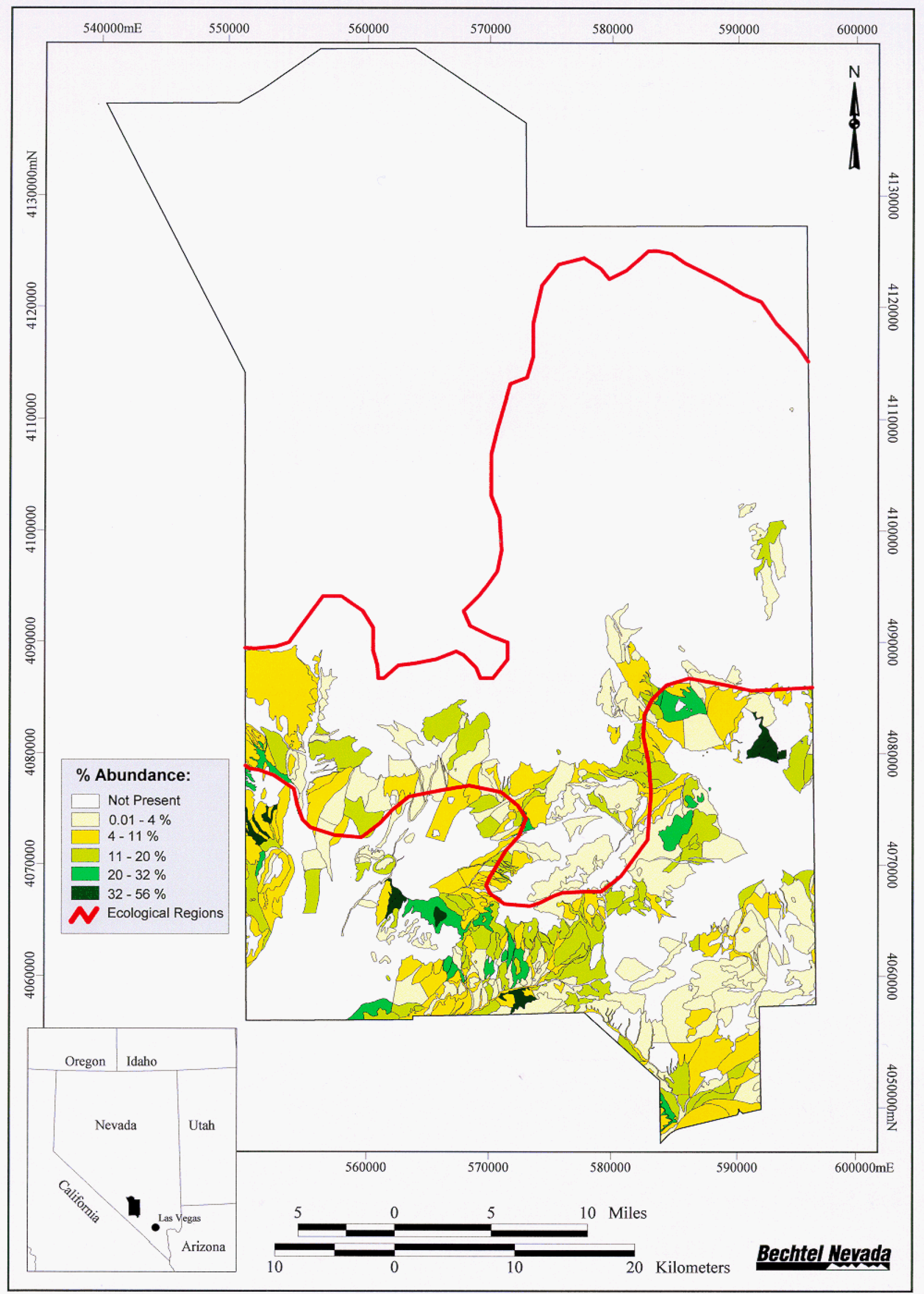

Figure 6-22 Percent Krameria erecta abundance on the Nevada Test Site 


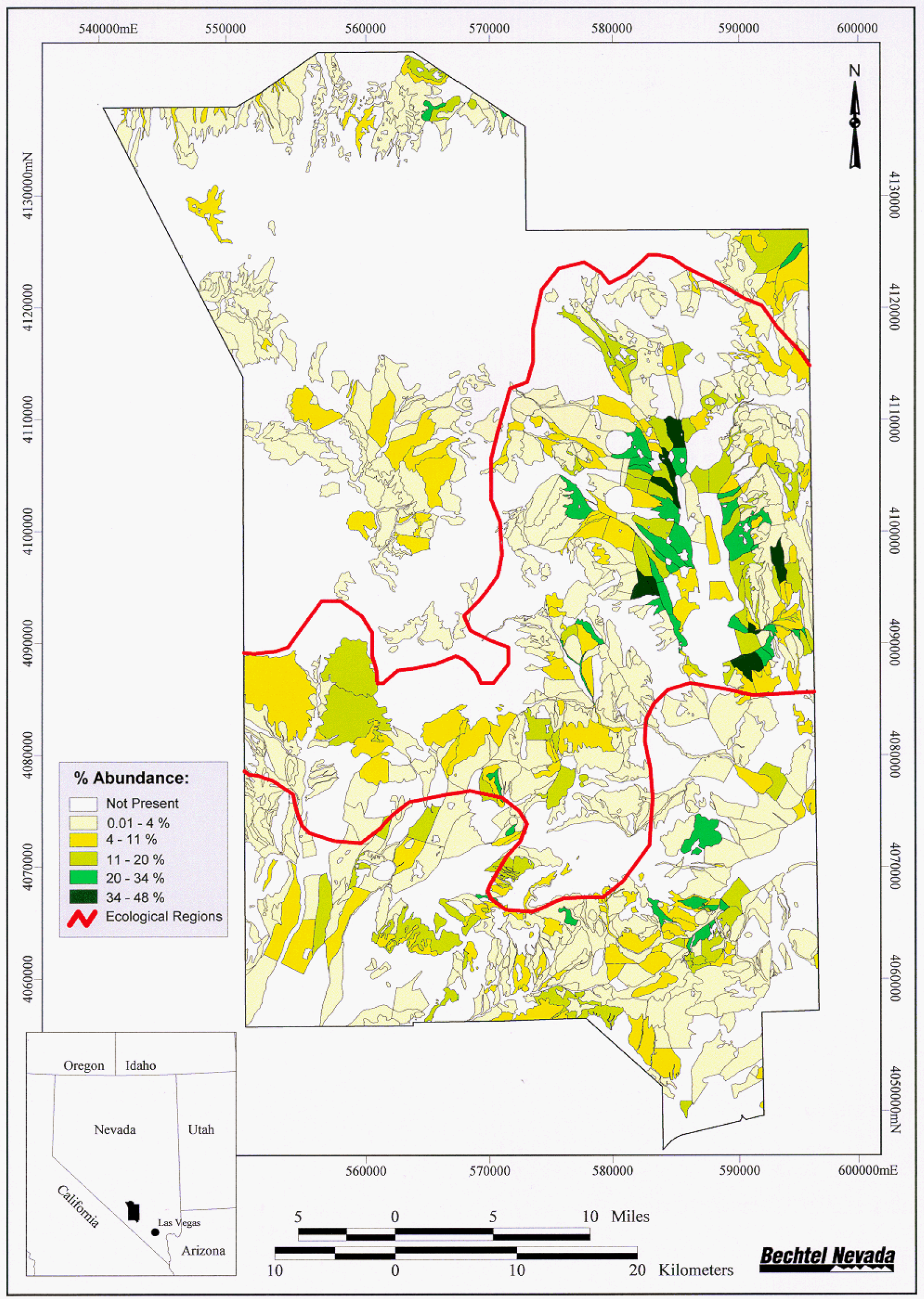

Figure 6-23 Percent Krascheninnikovia lanata abundance on the Nevada Test Site 


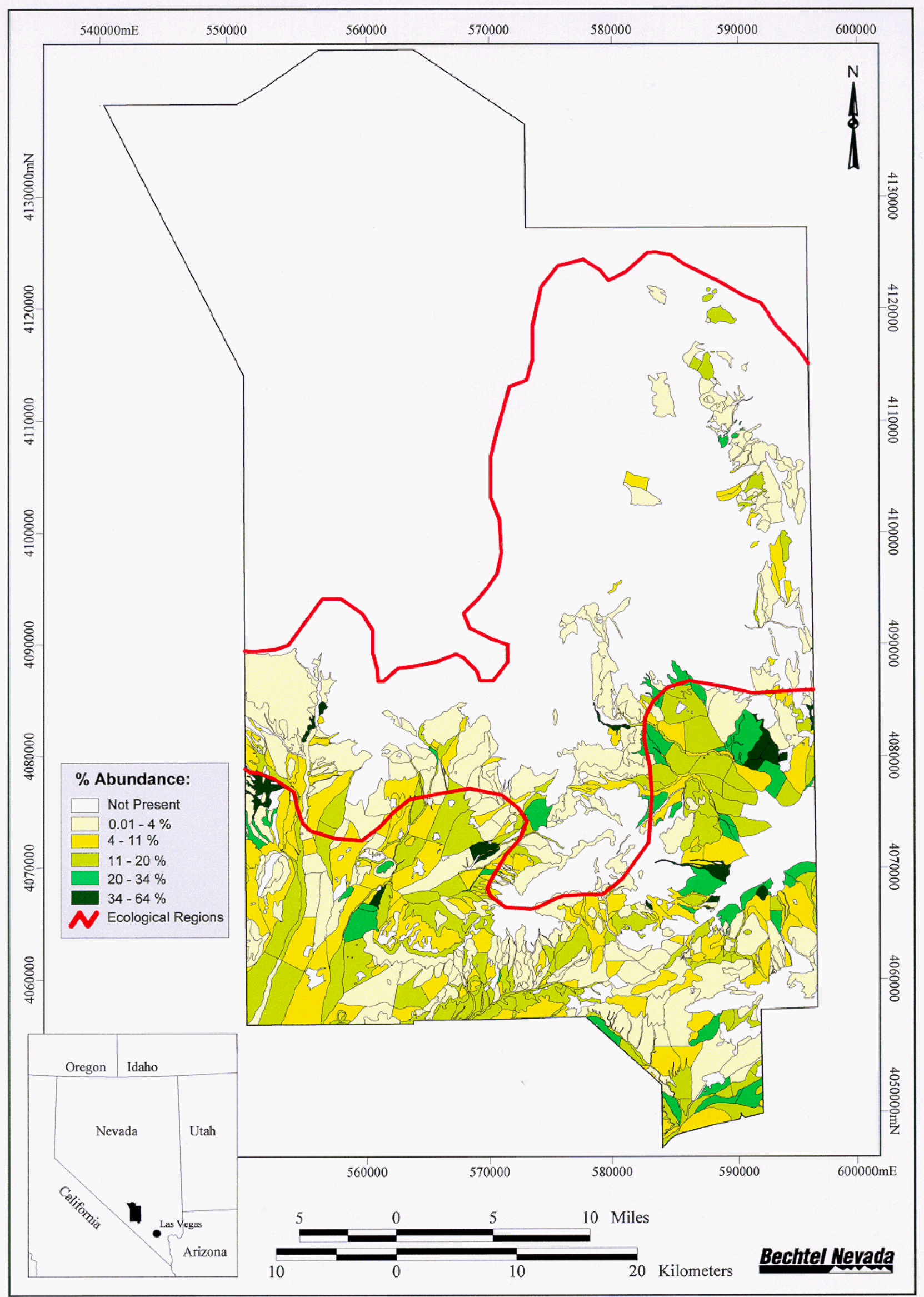

Figure 6-24 Percent Larrea tridentata abundance on the Nevada Test Site 


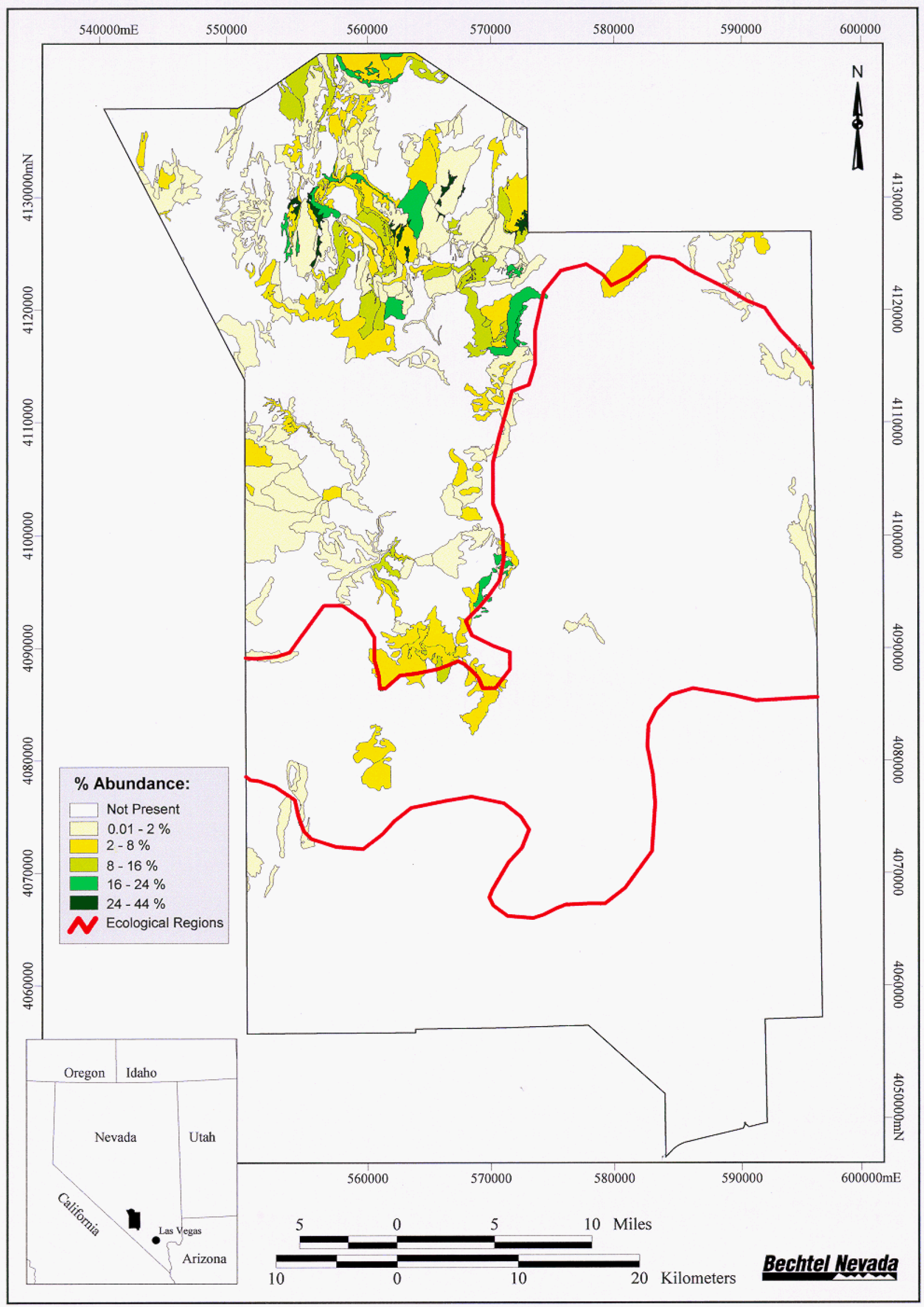

Figure 6-25 Percent Leptodactylon pungens abundance on the Nevada Test Site 


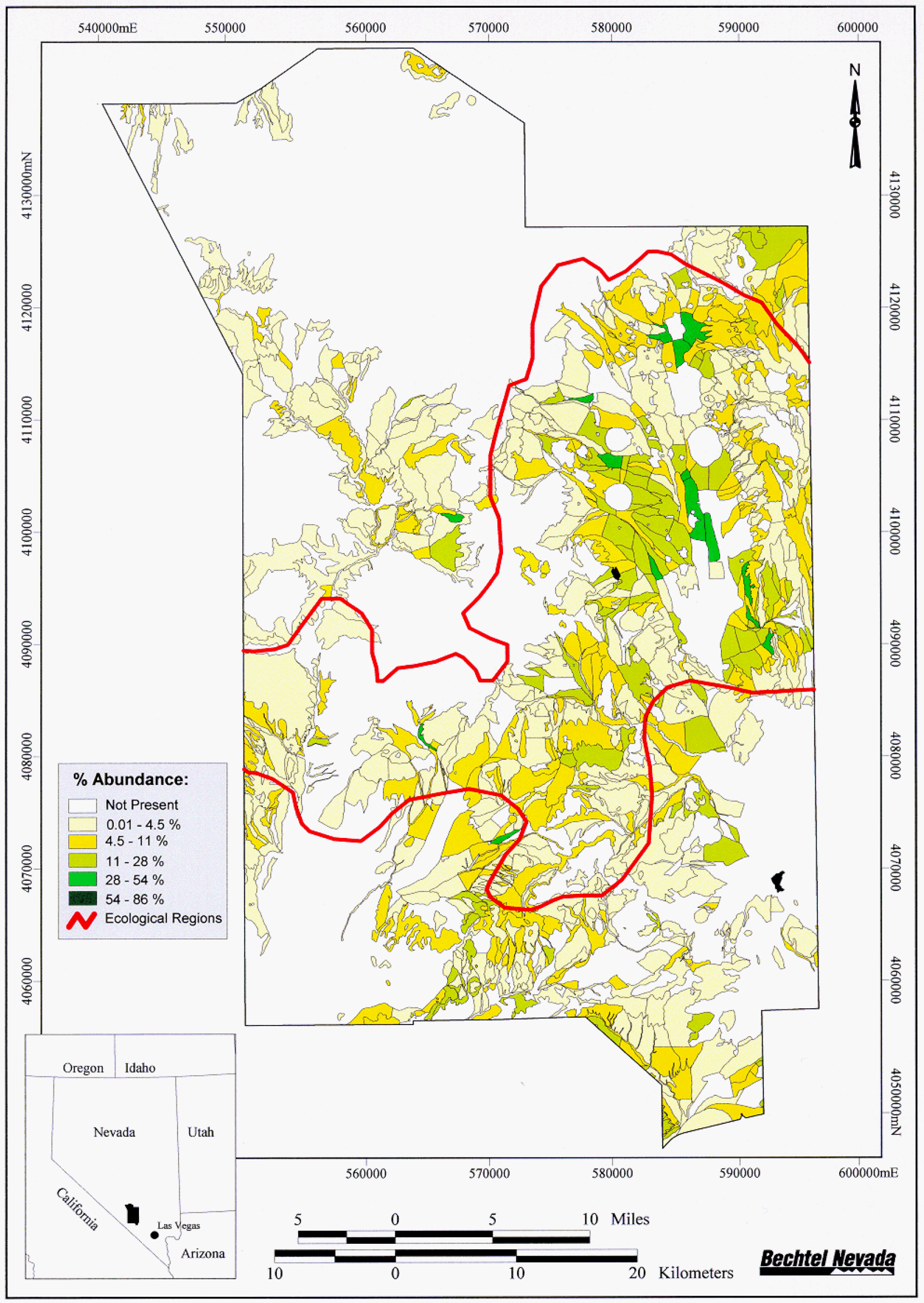

Figure 6-26 Percent Lycium andersonii abundance on the Nevada Test Site 


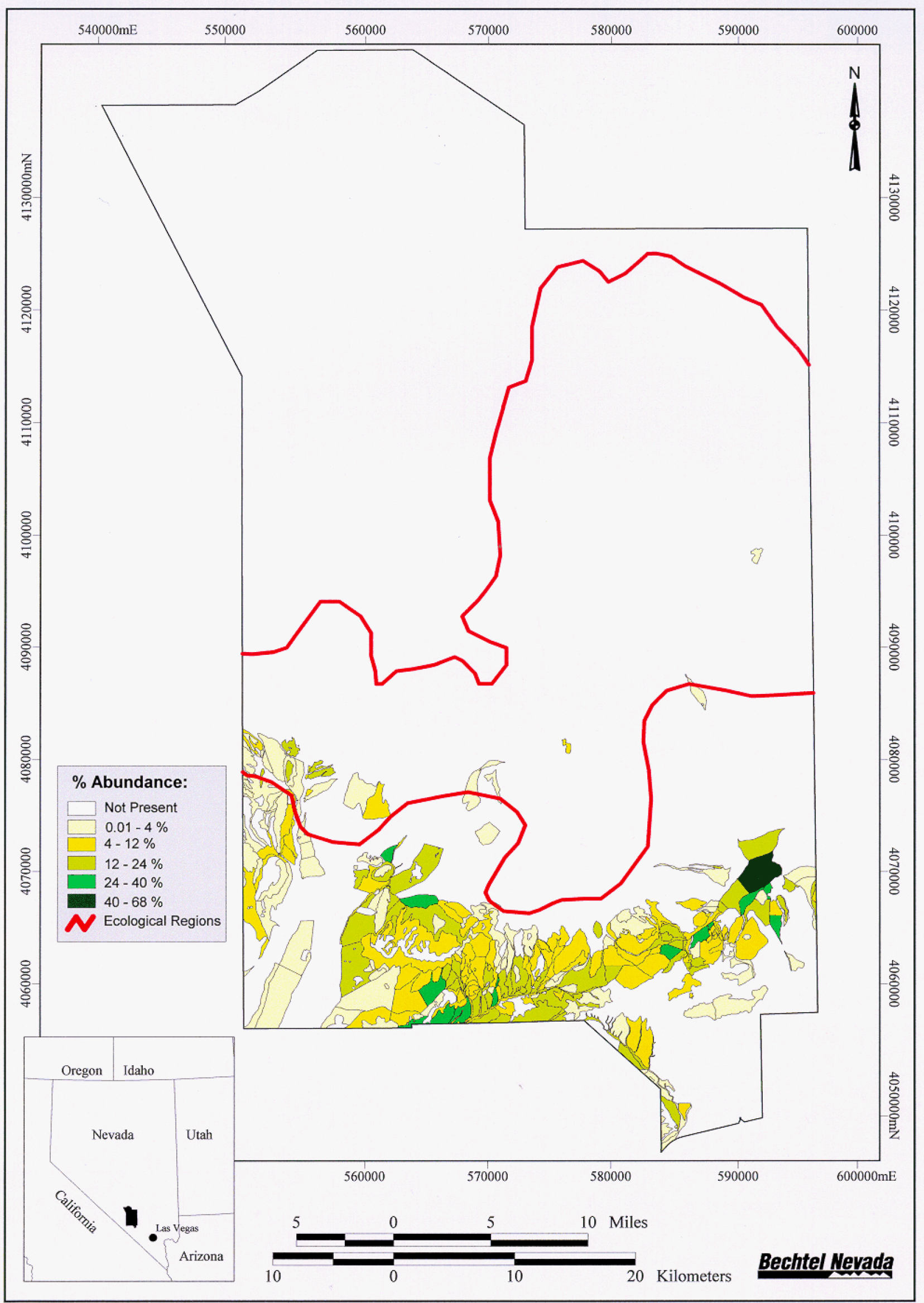

Figure 6-27 Percent Lycium pallidum var. oligospermum abundance on the Nevada Test Site 


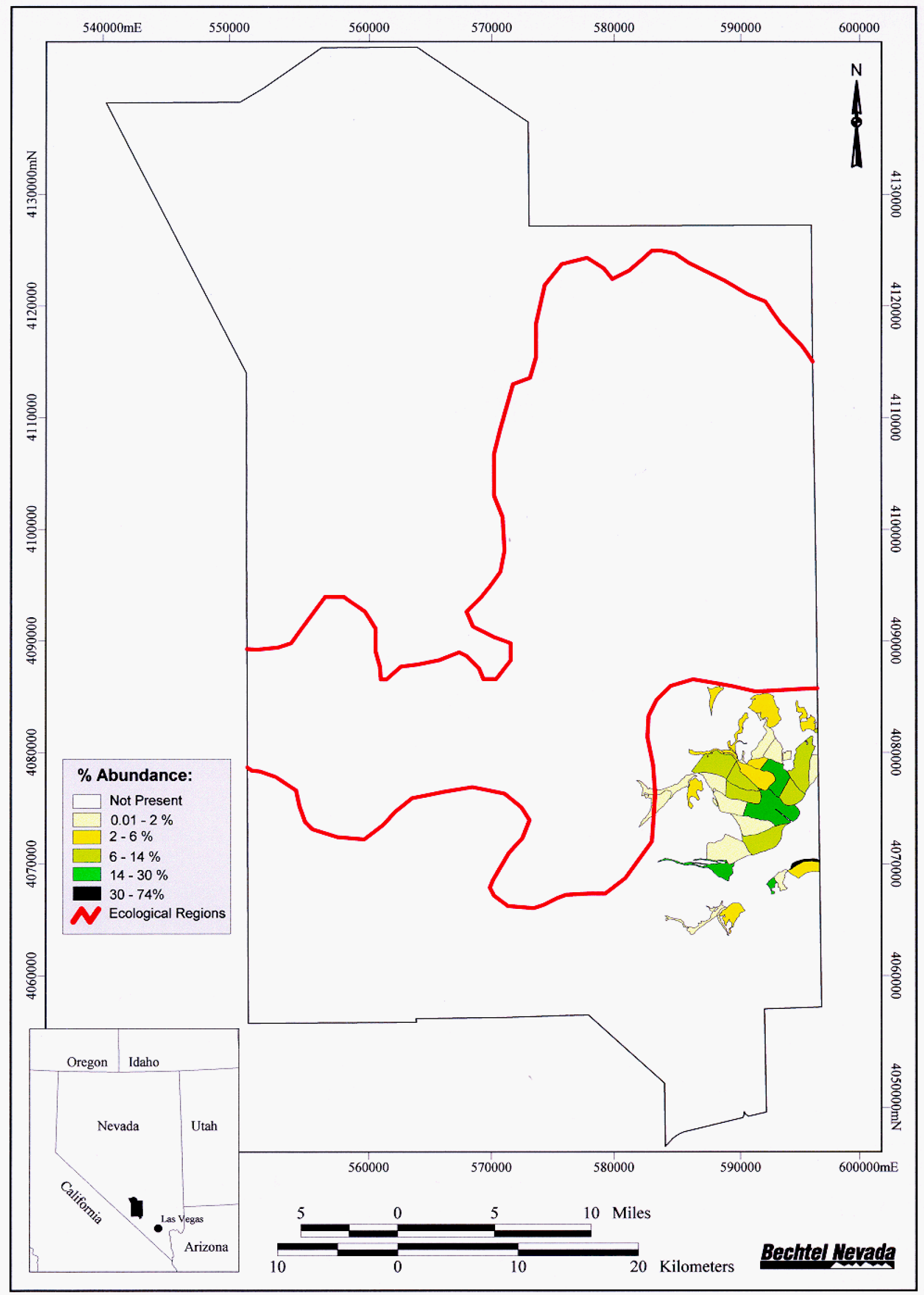

Figure 6-28 Percent Lycium shockleyi abundance on the Nevada Test Site 


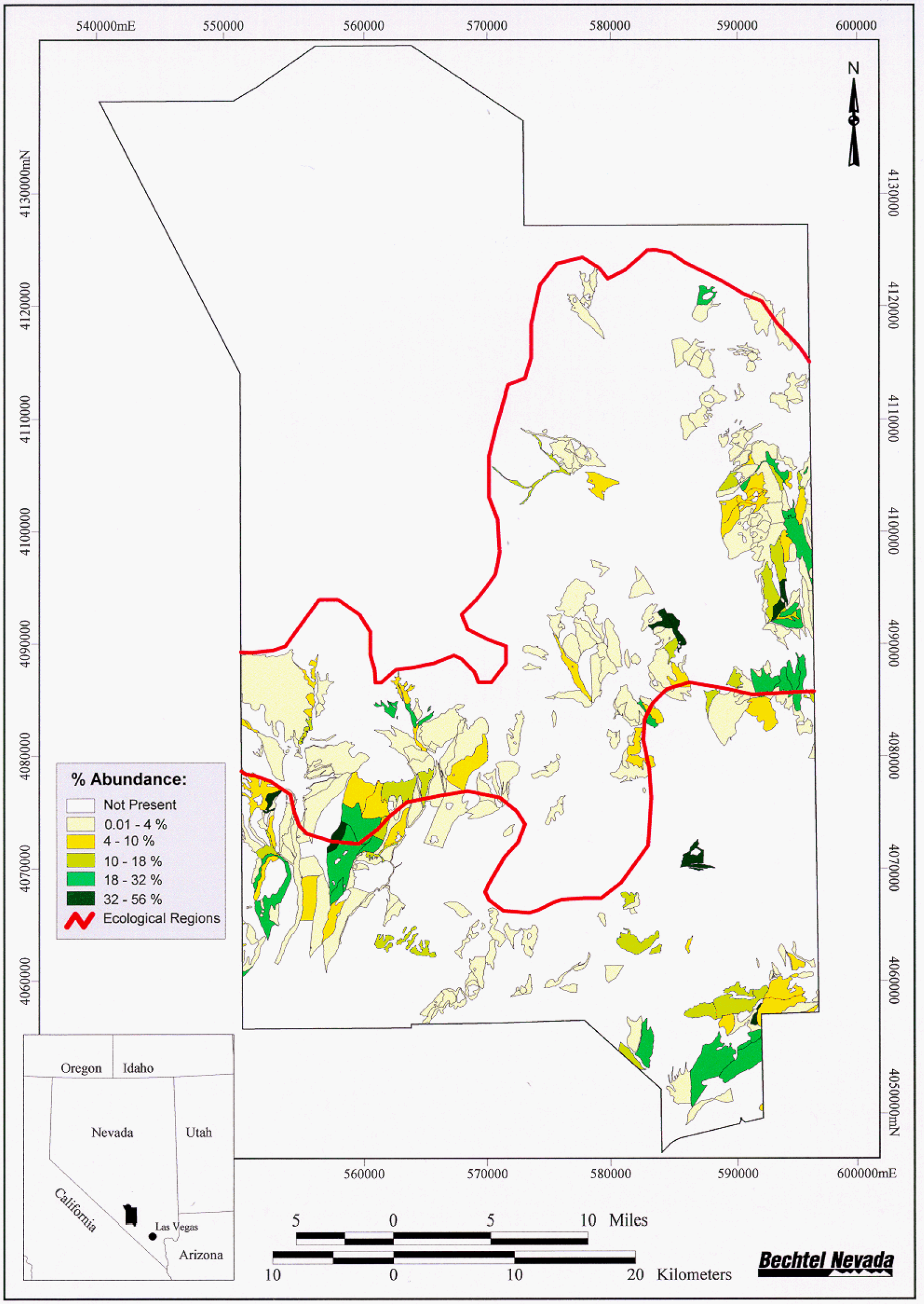

Figure 6-29 Percent Menodora spinescens abundance on the Nevada Test Site 


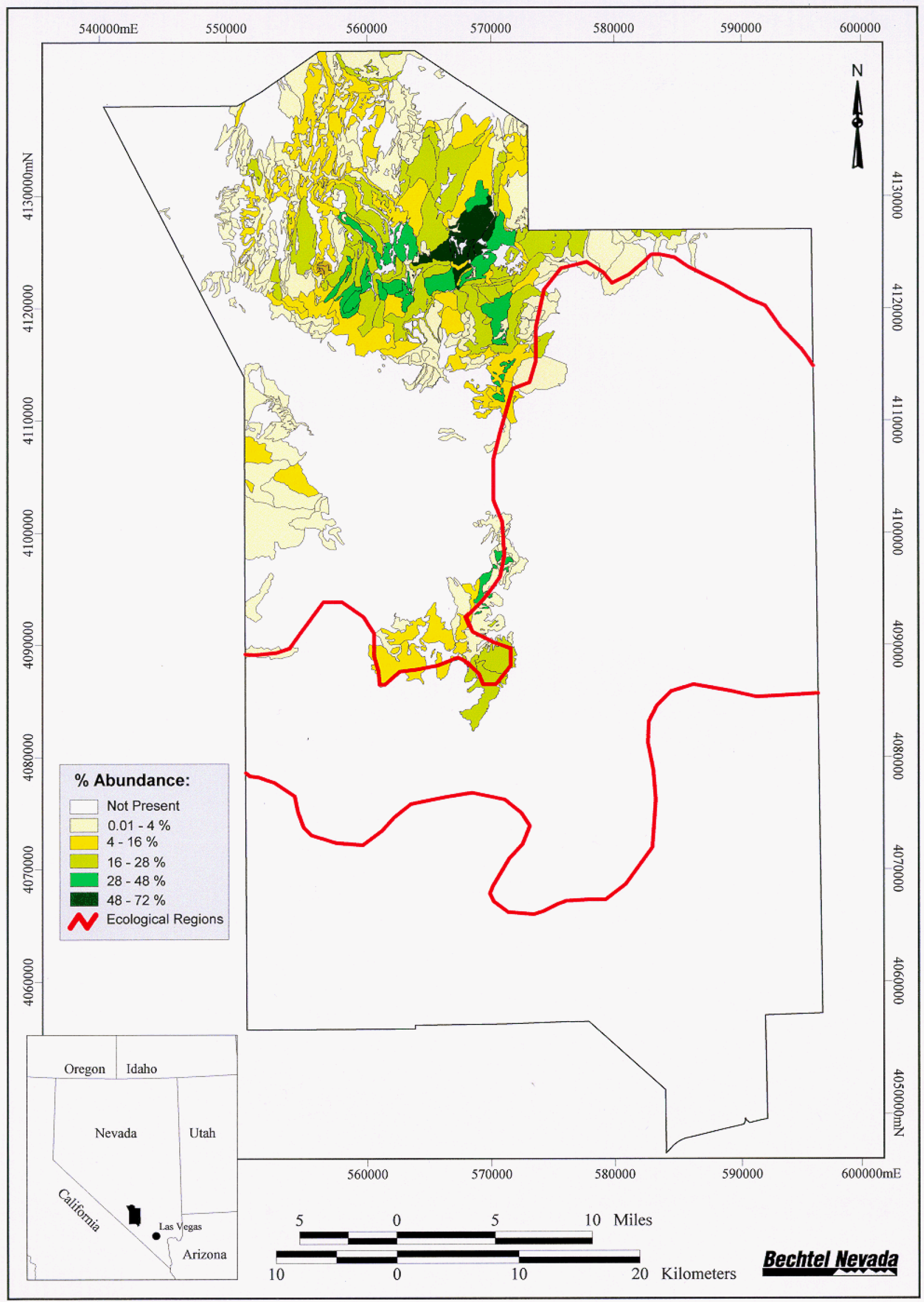

Figure 6-30 Percent Pinus monophylla abundance on the Nevada Test Site 


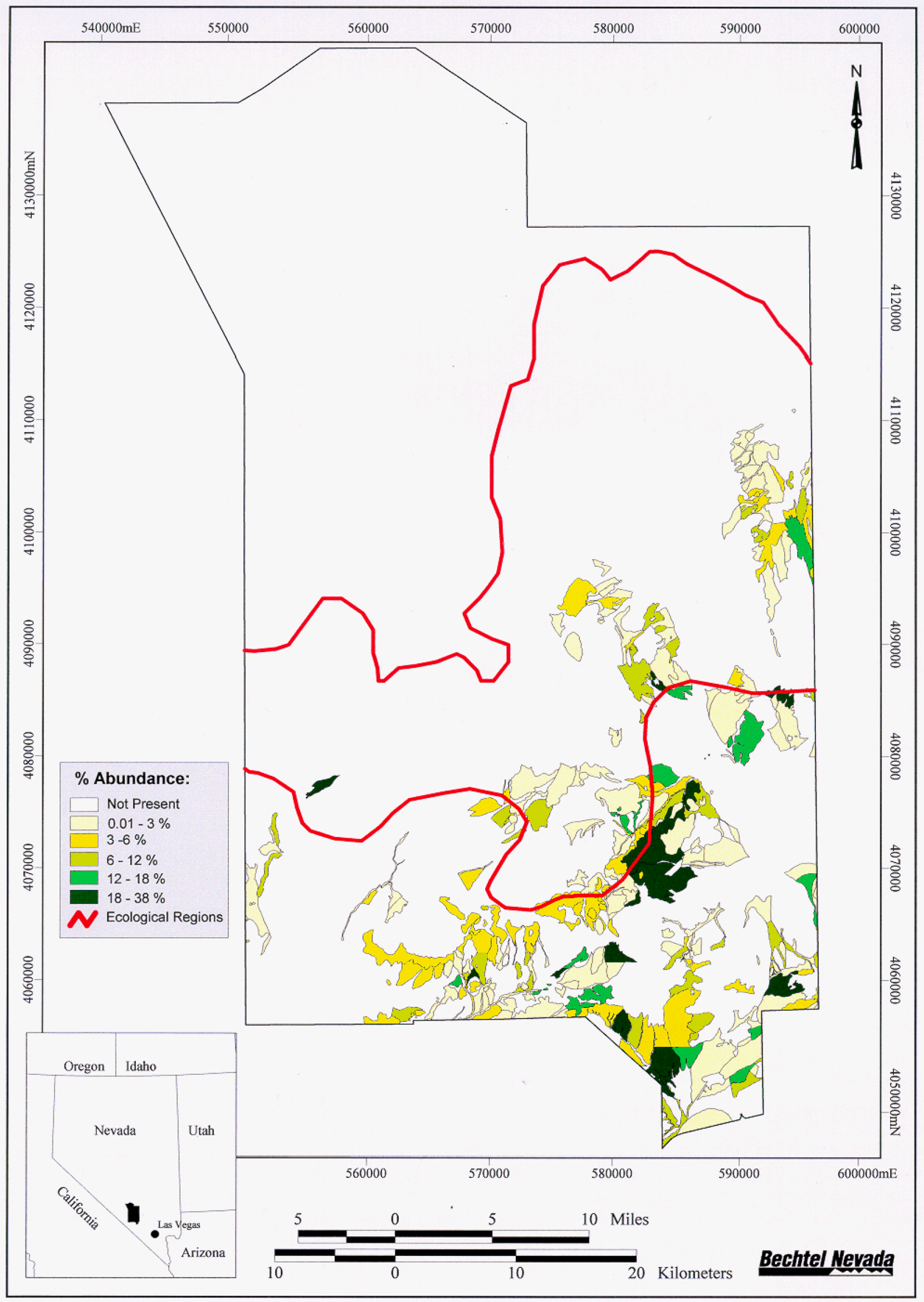

Figure 6-31 Percent Psorothamnus fremontii var. fremontii abundance on the Nevada Test Site 


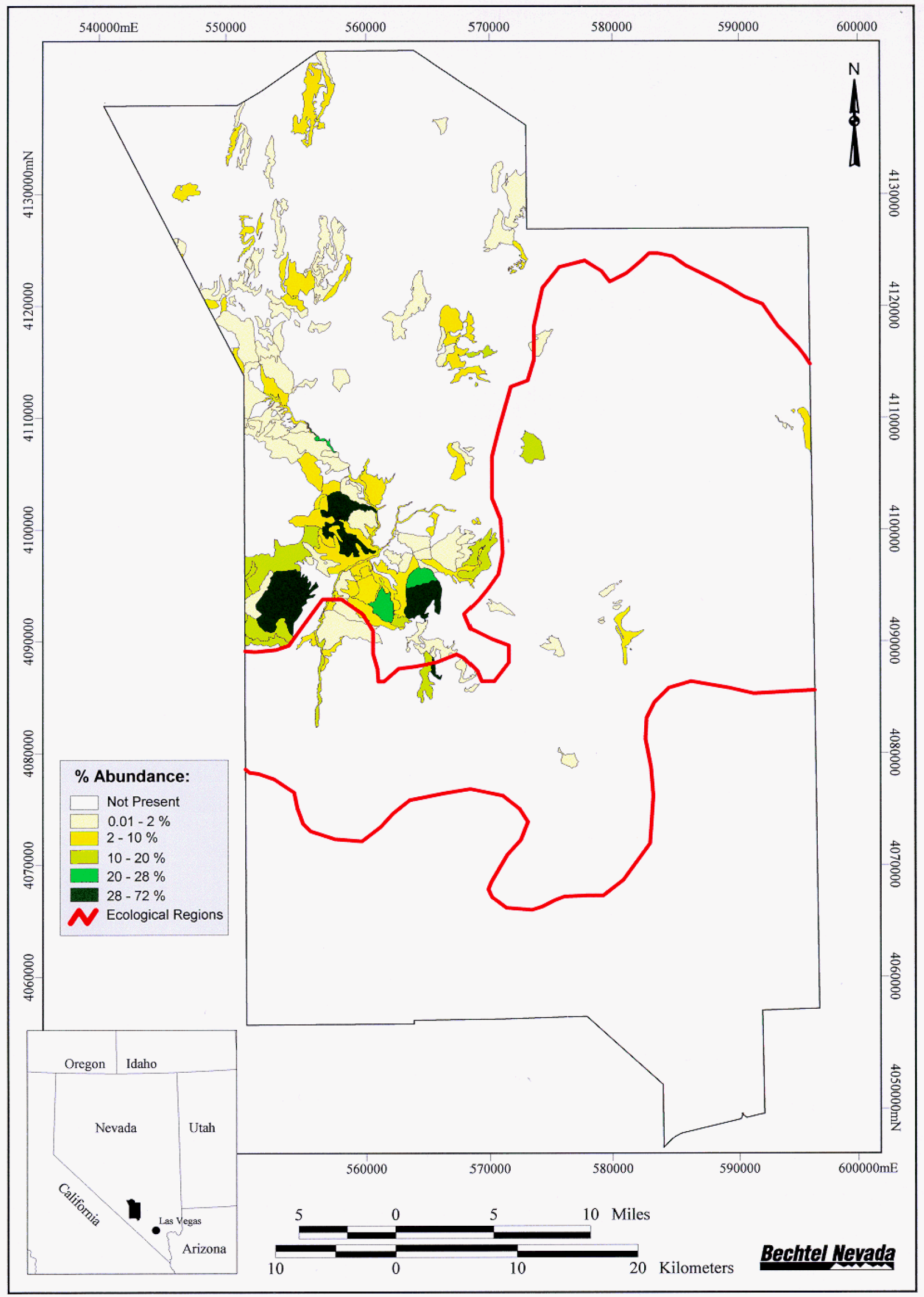

Figure 6-32 Percent Purshia glandulosa abundance on the Nevada Test Site 


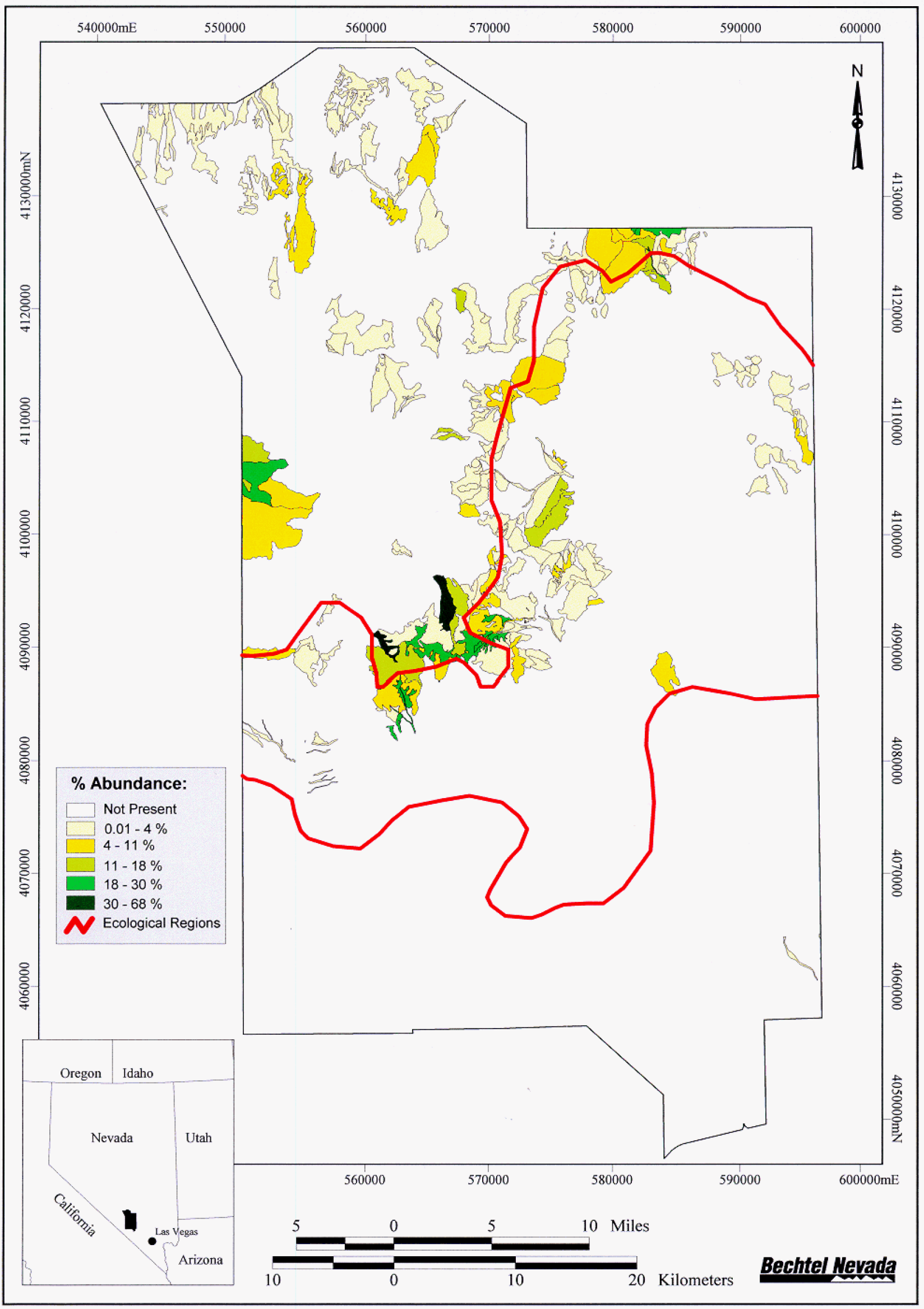

Figure 6-33 Percent Purshia stansburiana abundance on the Nevada Test Site 


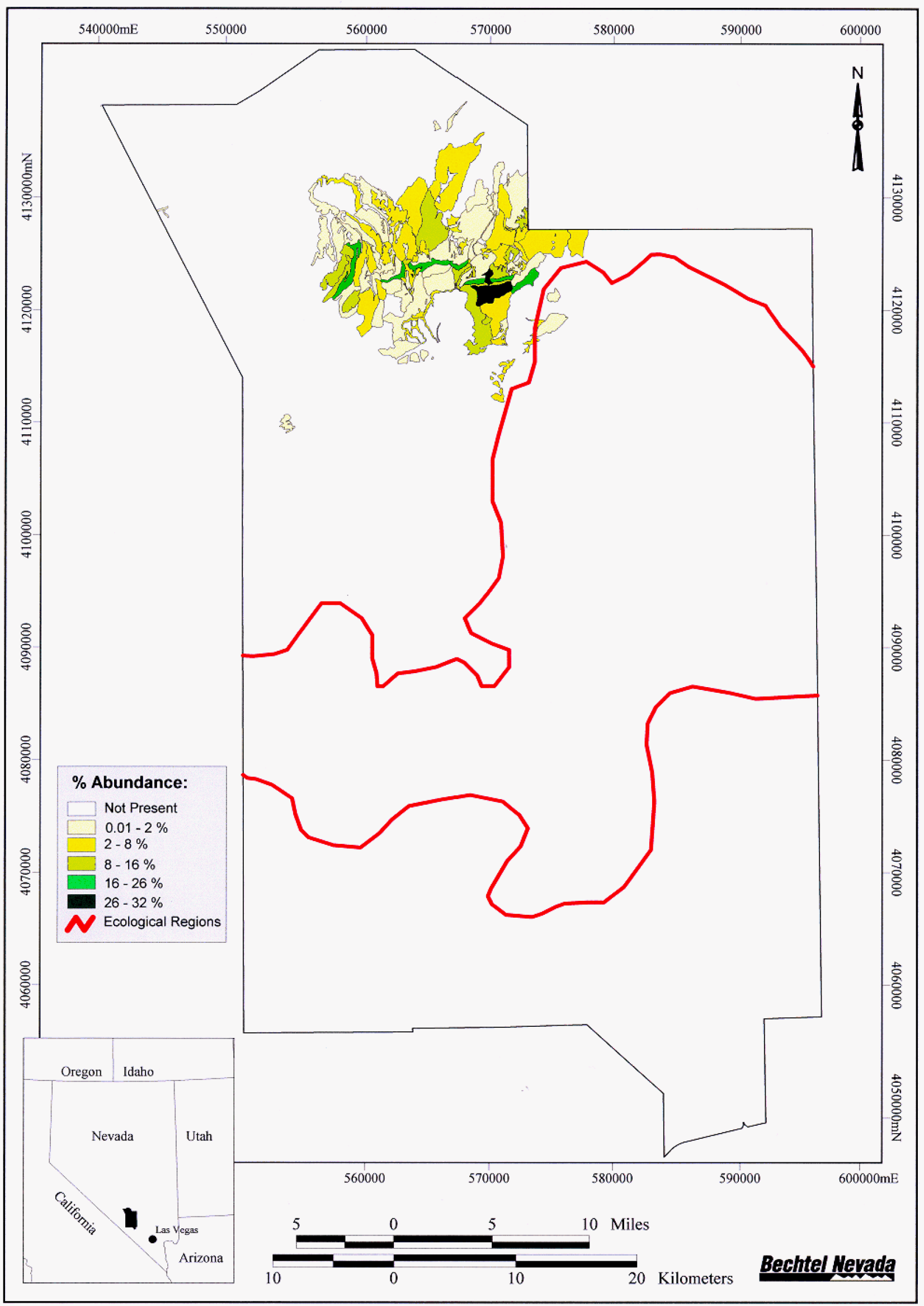

Figure 6-34 Percent Purshia tridentata abundance on the Nevada Test Site 


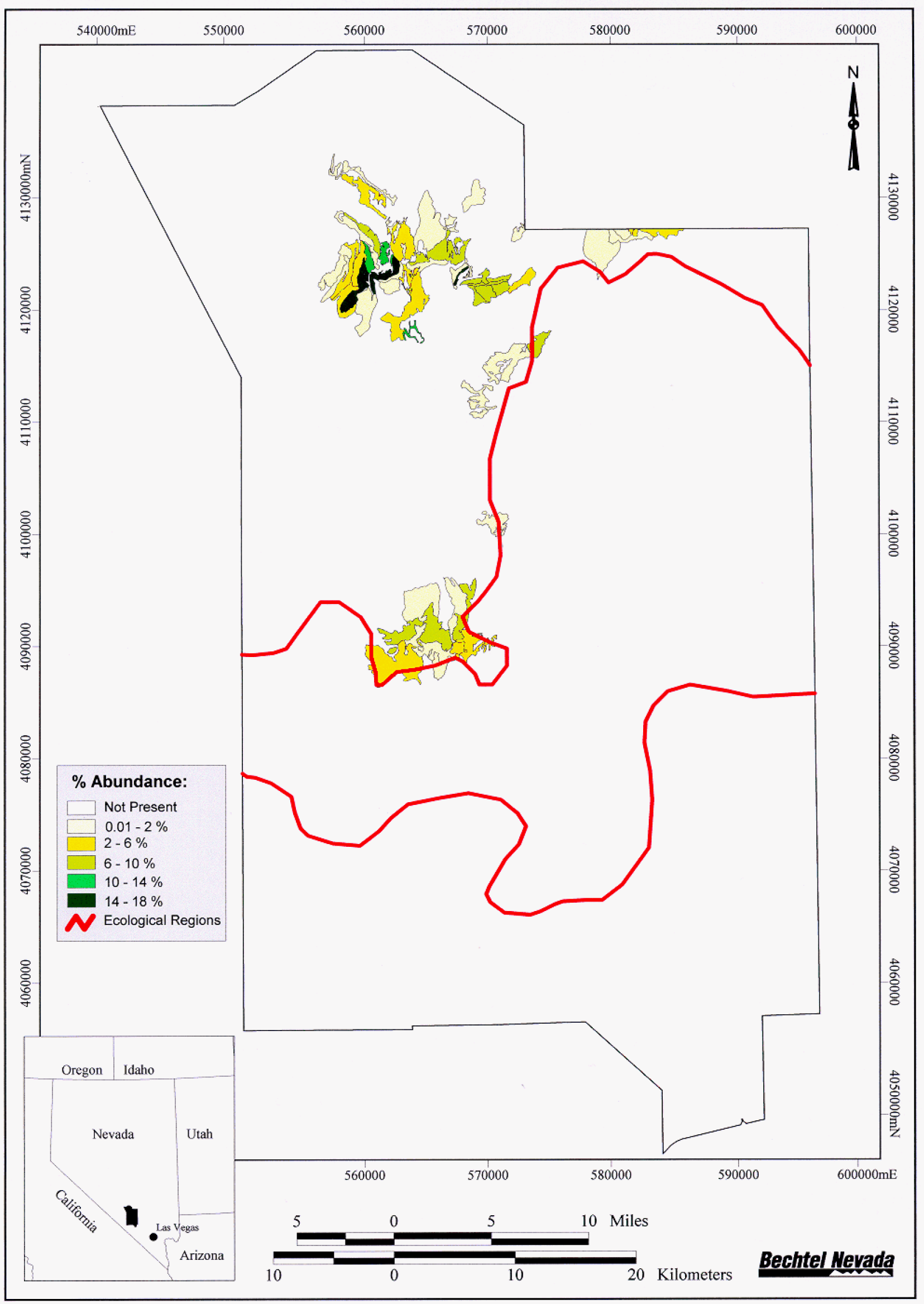

Figure 6-35 Percent Quercus gambelii abundance on the Nevada Test Site 


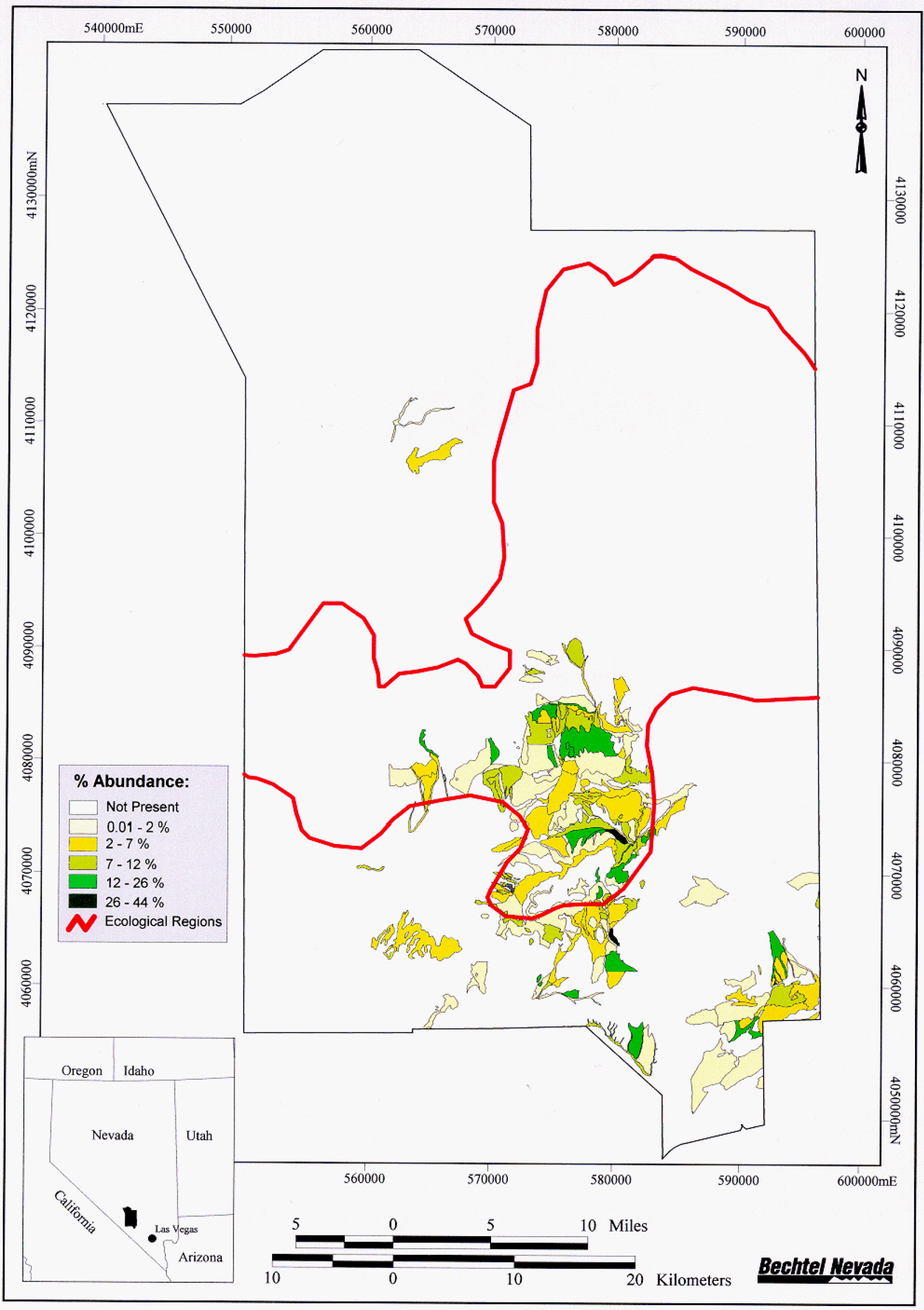

Figure 6-36 Percent Thamnosma montana abundance on the Nevada Test Site 


\section{Appendix $\mathrm{J}$}

Distribution on the NTS of the Top Dominant Grasses, Forbs, and Succulents Based on the Relative Ranking of Dominance

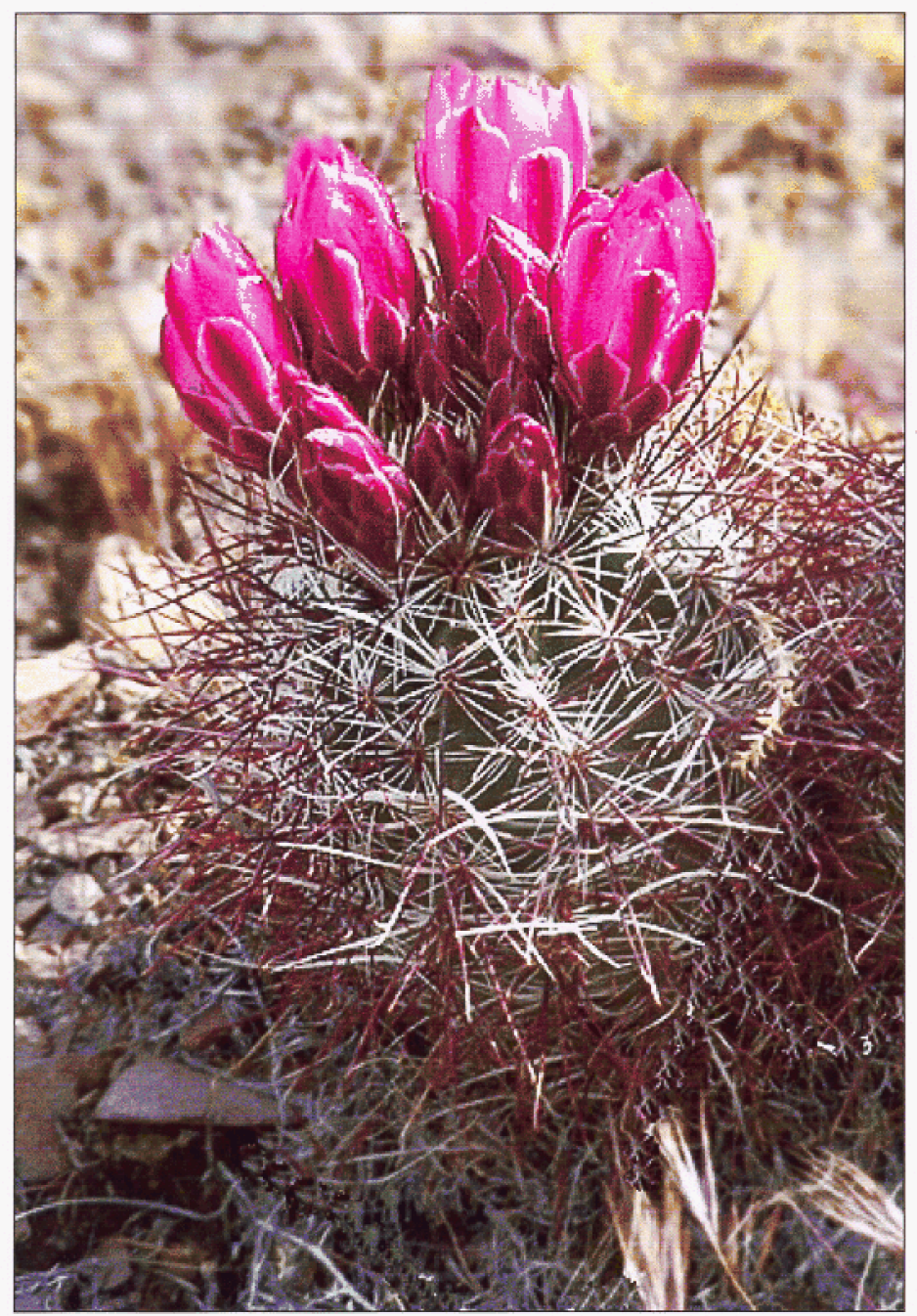

Redspined fishhook cactus (Sclerocactus polyancistrus) [photo by W. Kent Ostler] 
This Page Intentionally Left Blank 


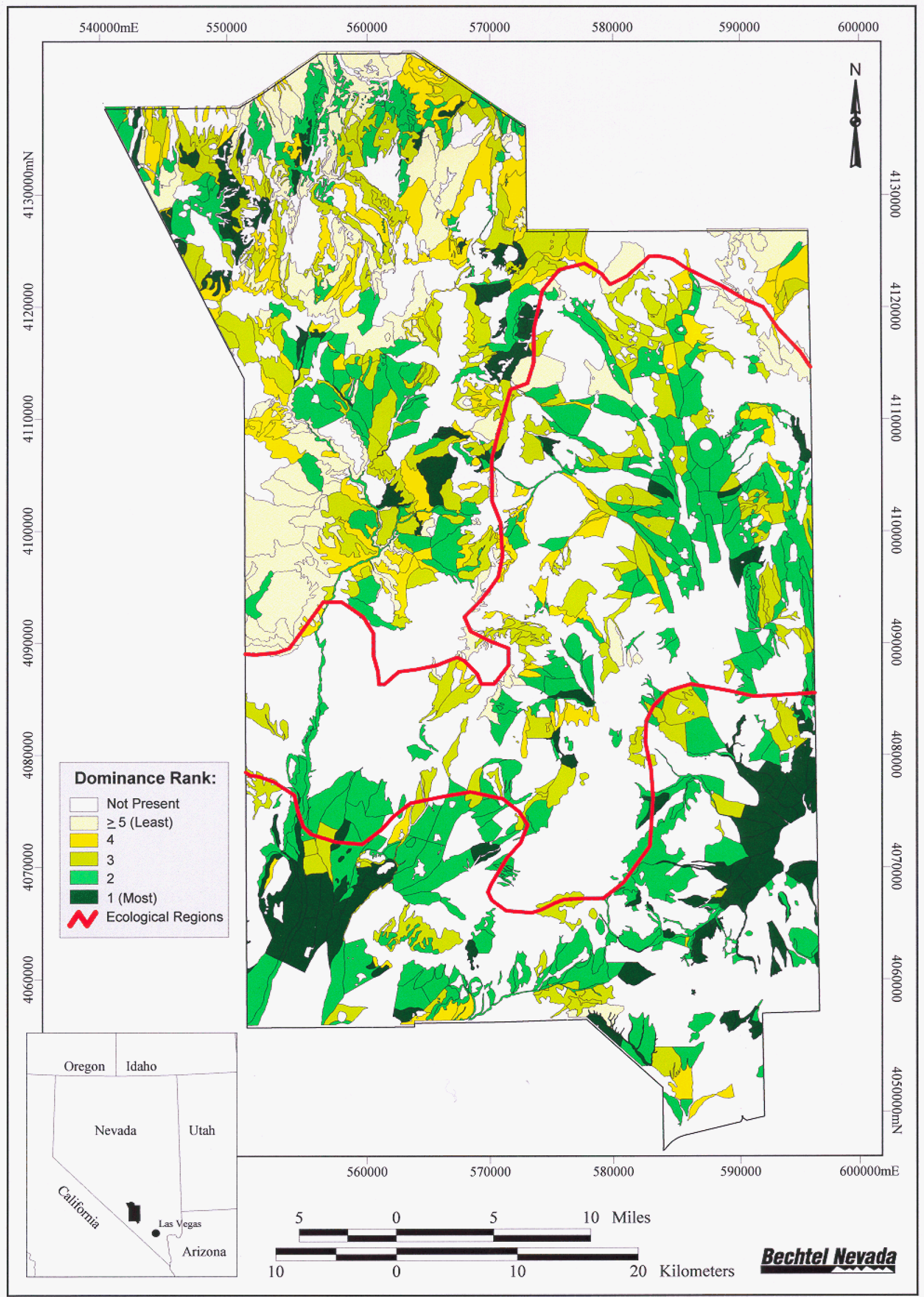

Figure 6-37 Relative ranking of dominance of Achnatherum hymenoides on the Nevada Test Site 


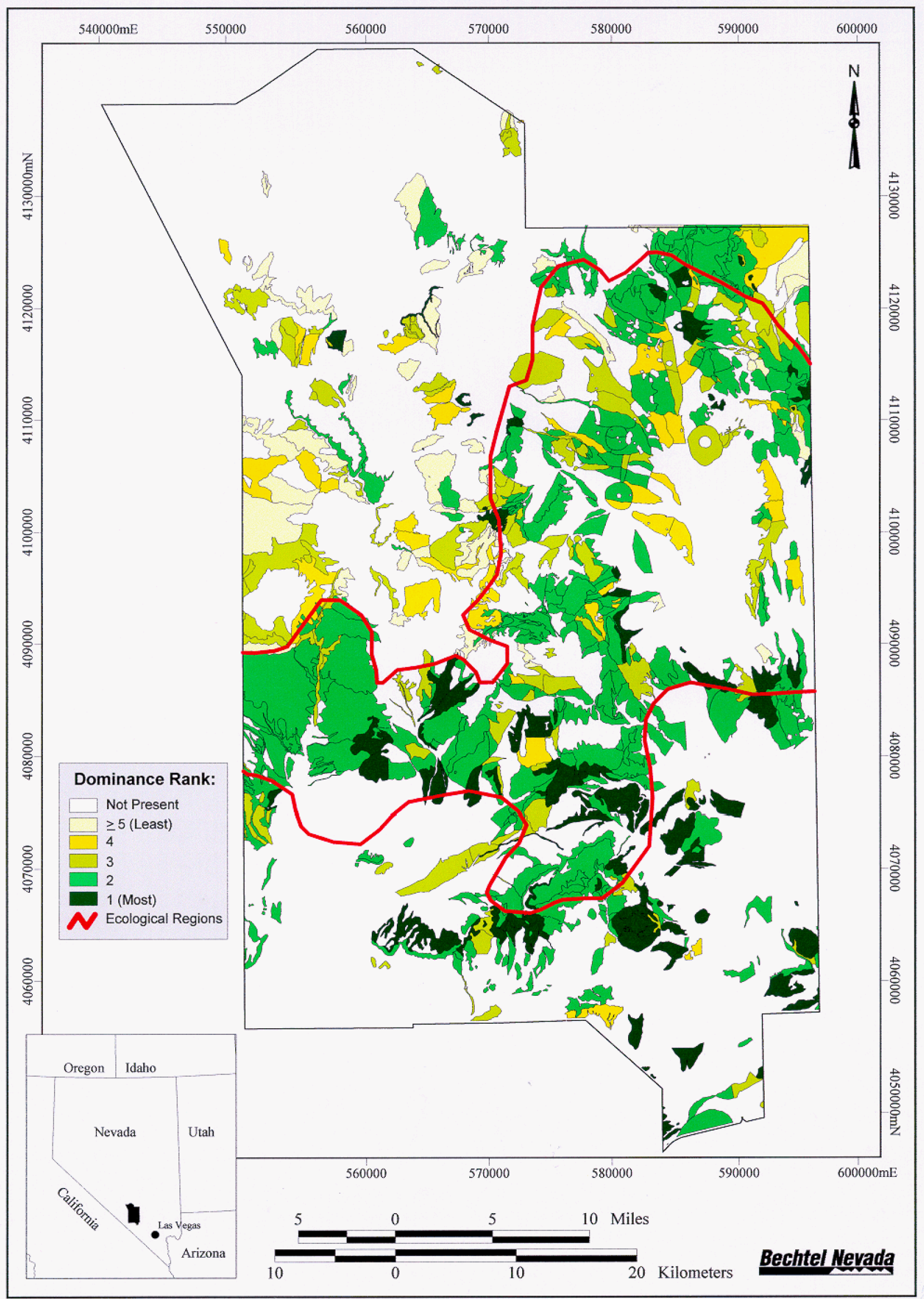

Figure 6-38 Relative ranking of dominance of Achnatherum speciosum on the Nevada Test Site 


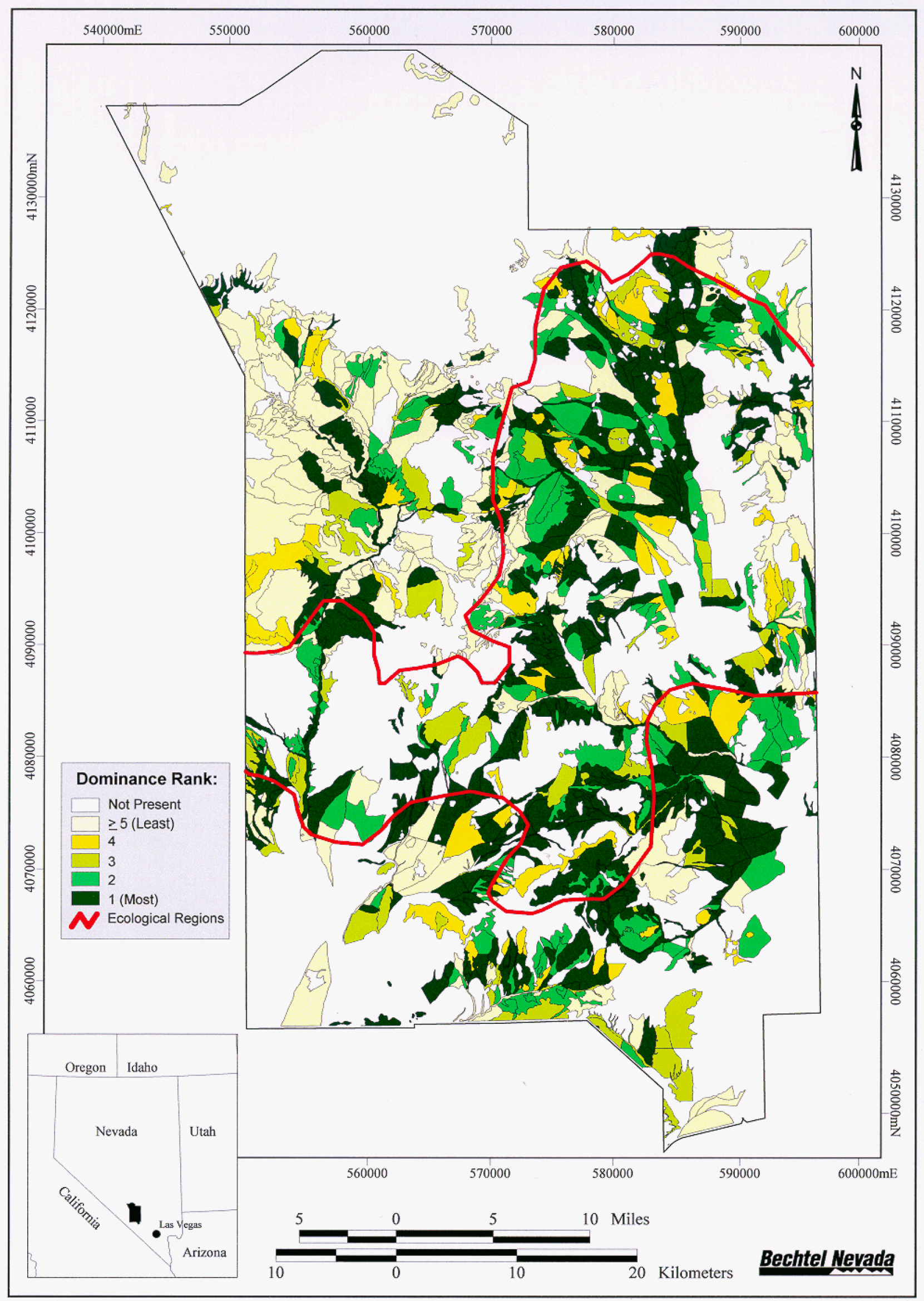

Figure 6-39 Relative ranking of dominance of Amsinckia tessellata on the Nevada Test Site 


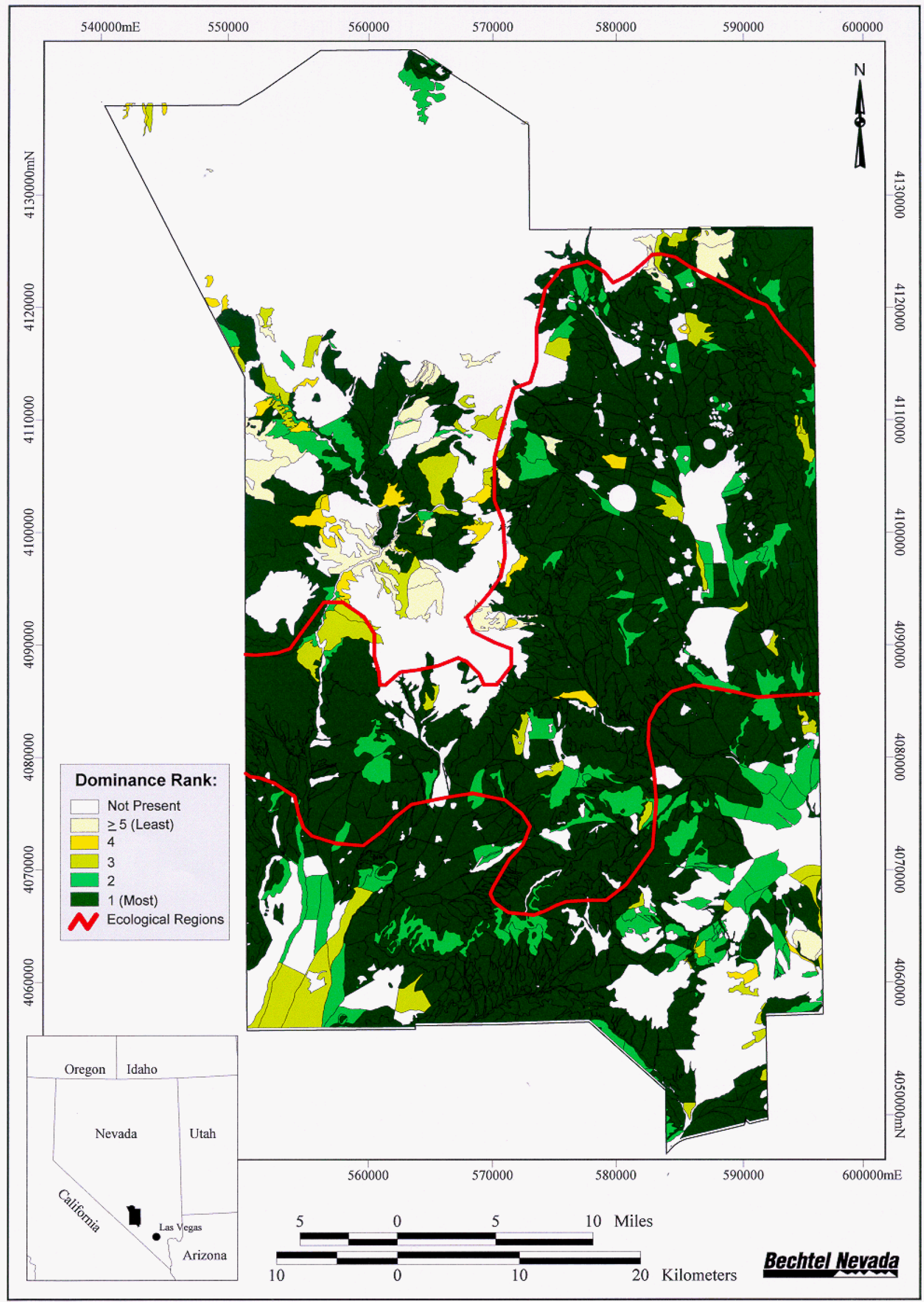

Figure 6-40 Relative ranking of dominance of Bromus rubens on the Nevada Test Site 


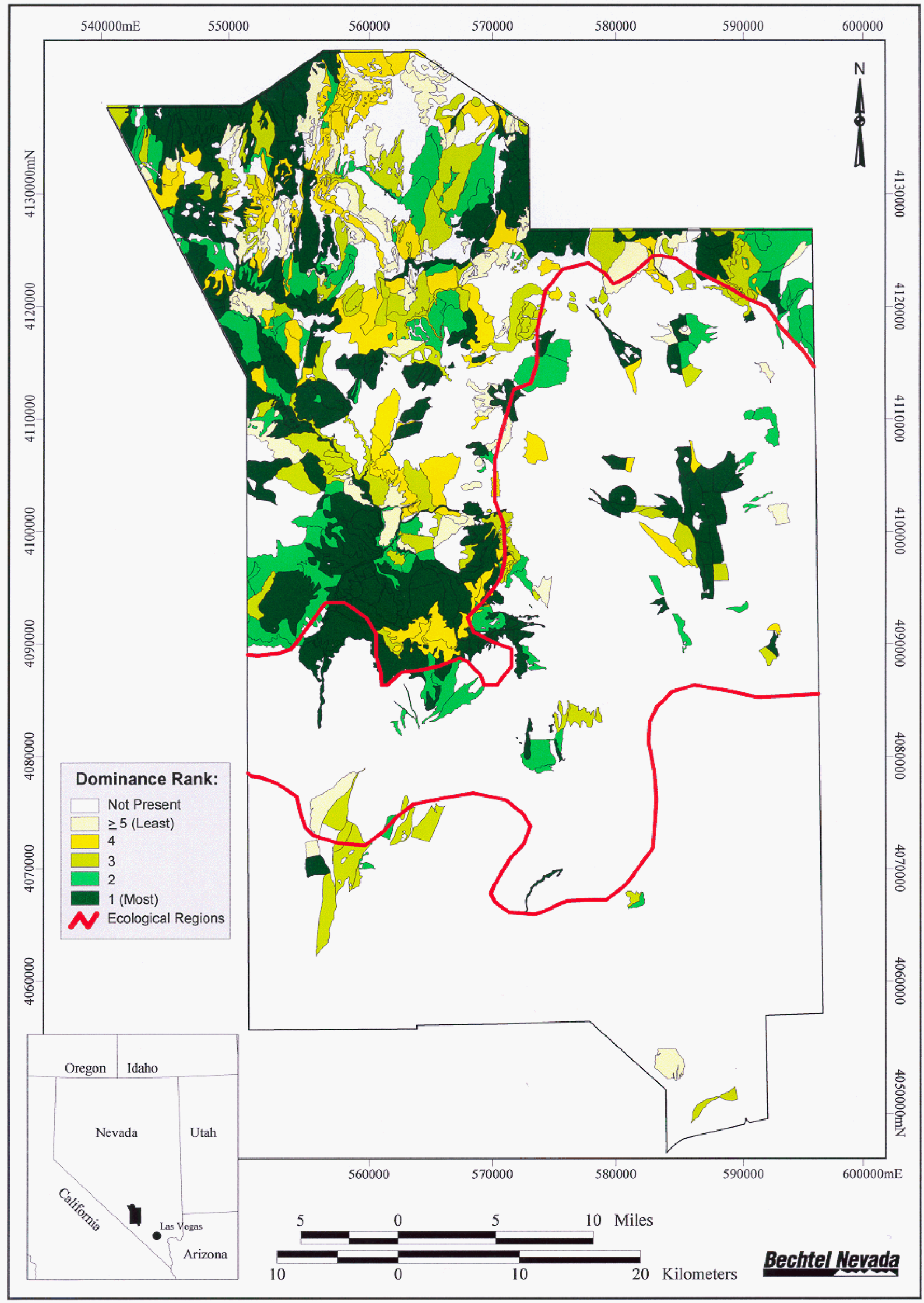

Figure 6-41 Relative ranking of dominance of Bromus tectorum on the Nevada Test Site 


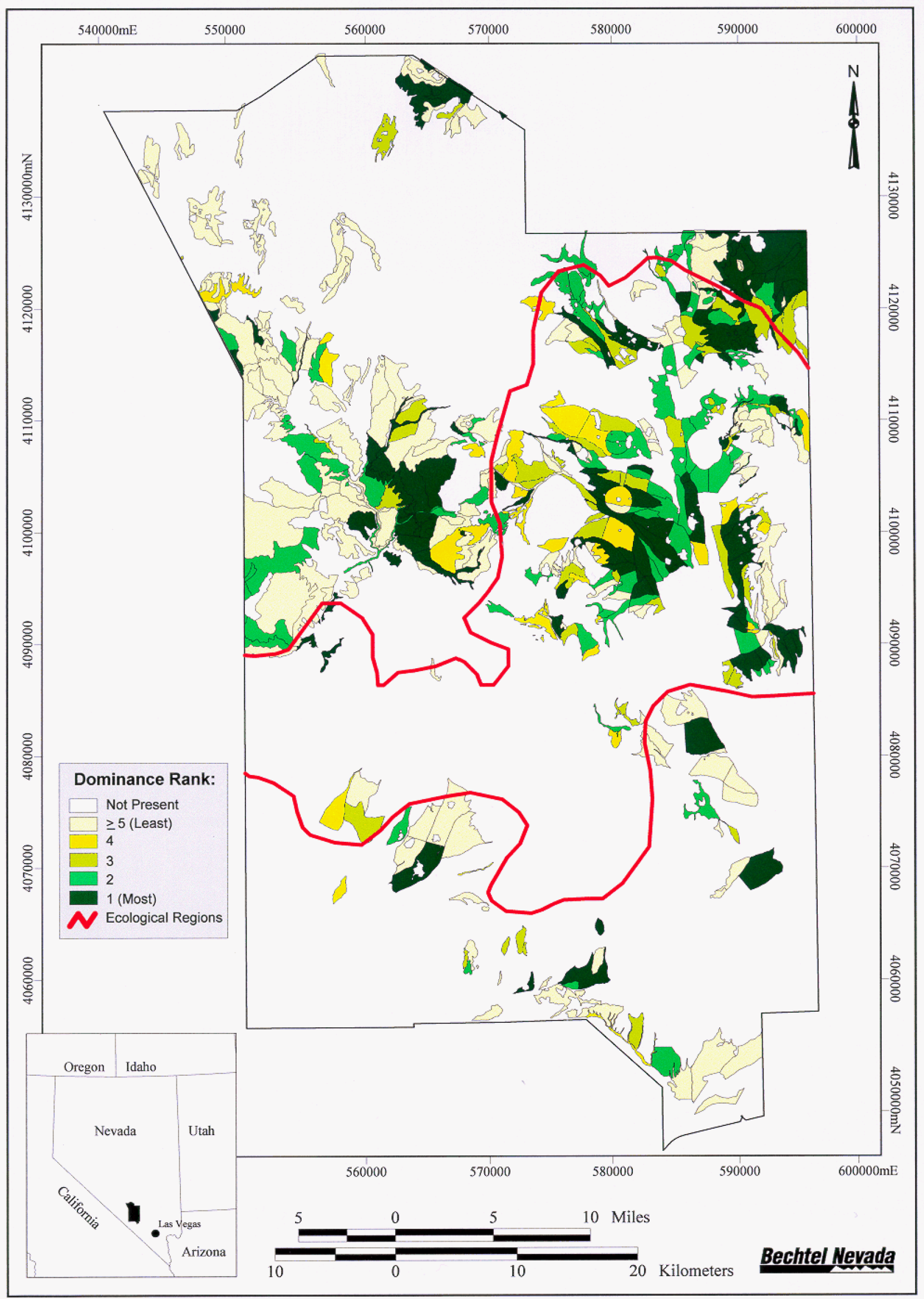

Figure 6-42 Relative ranking of dominance of Chaenactis stevioides on the Nevada Test Site 


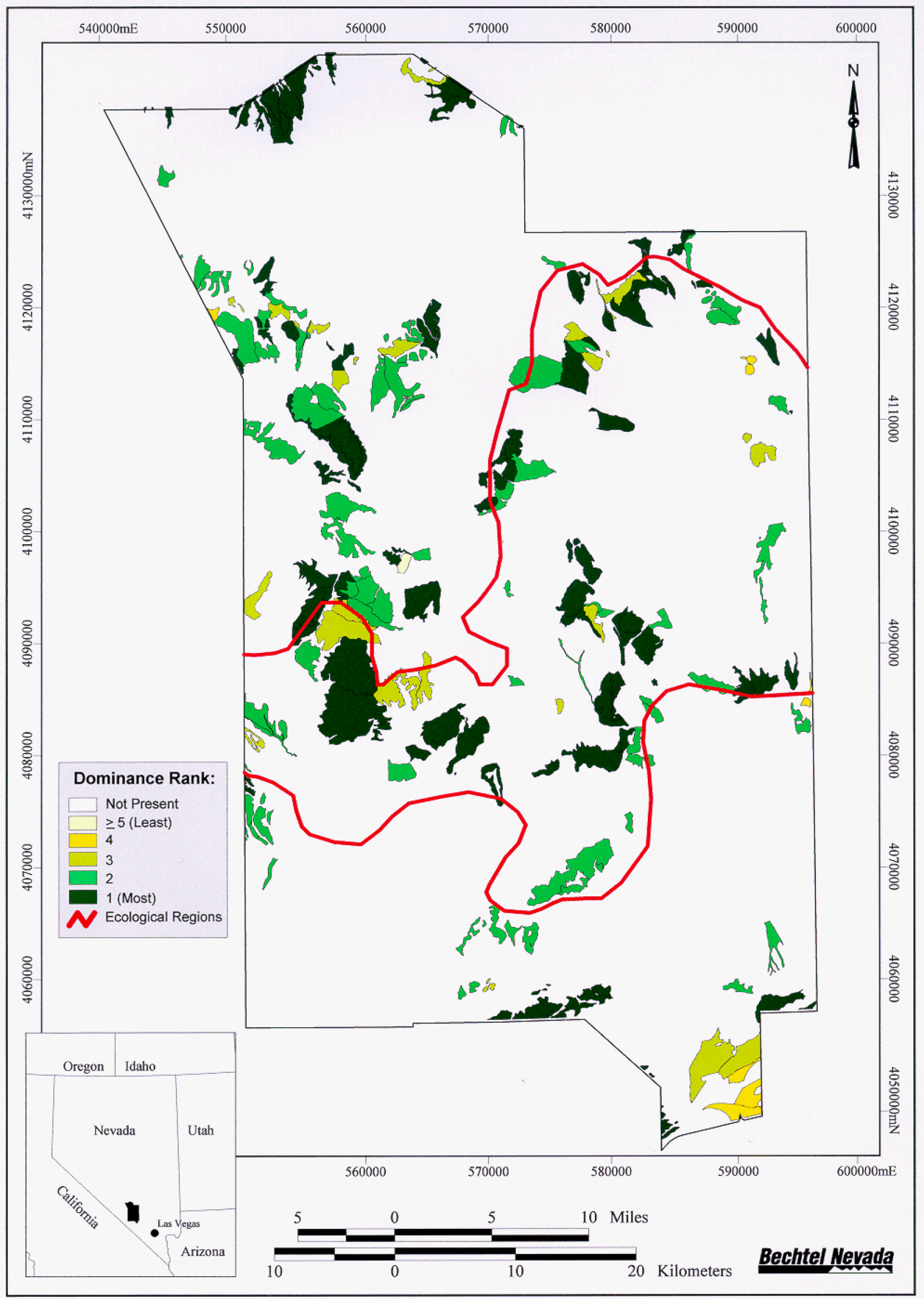

Figure 6-43 Relative ranking of dominance of Echinocereus engelmannii on the Nevada Test Site 


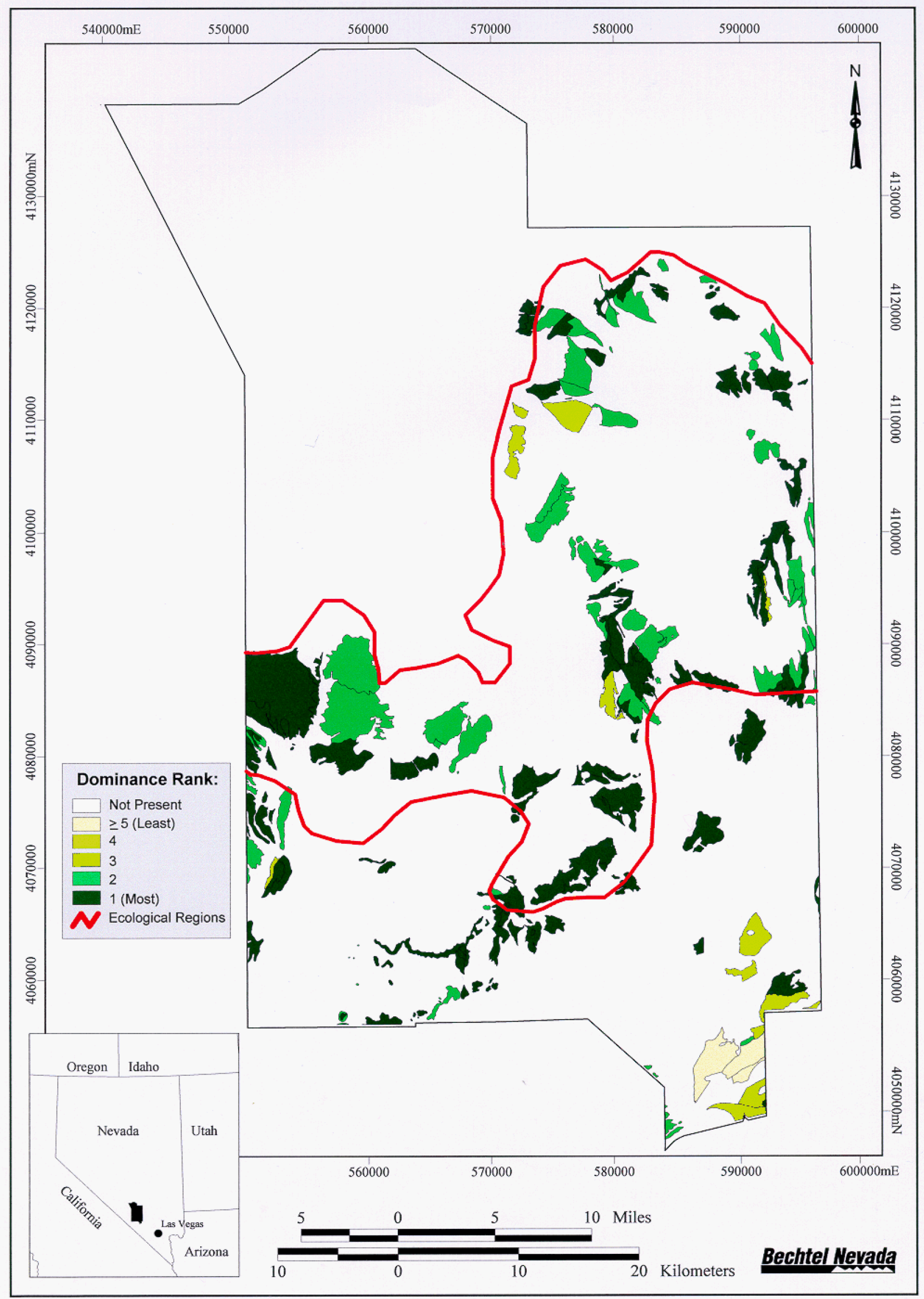

Figure 6-44 Relative ranking of dominance of Echinocactus polycephalus on the Nevada Test Site 


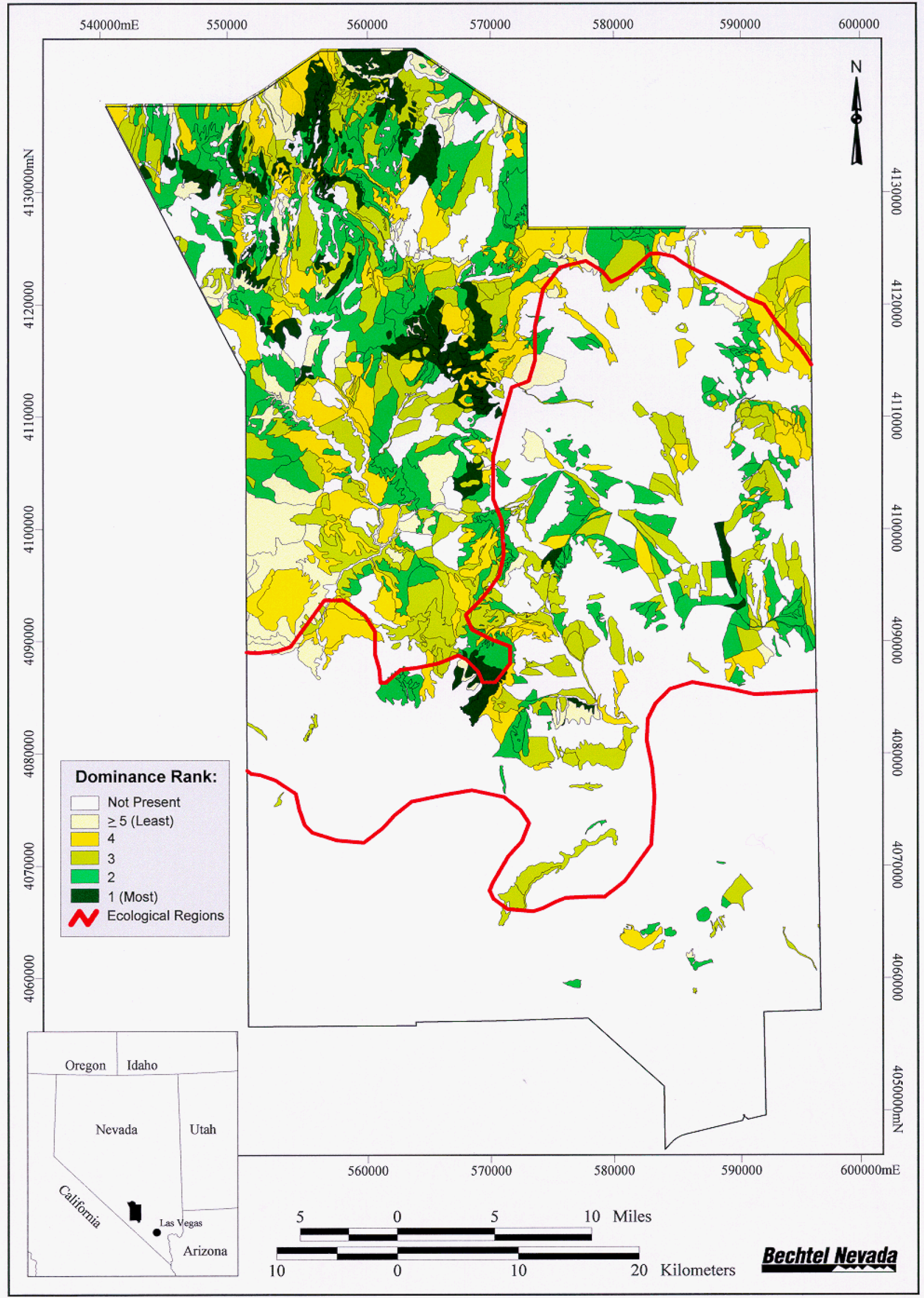

Figure 6-45 Relative ranking of dominance of Elymus elymoides ssp. elymoides on the Nevada Test Site 


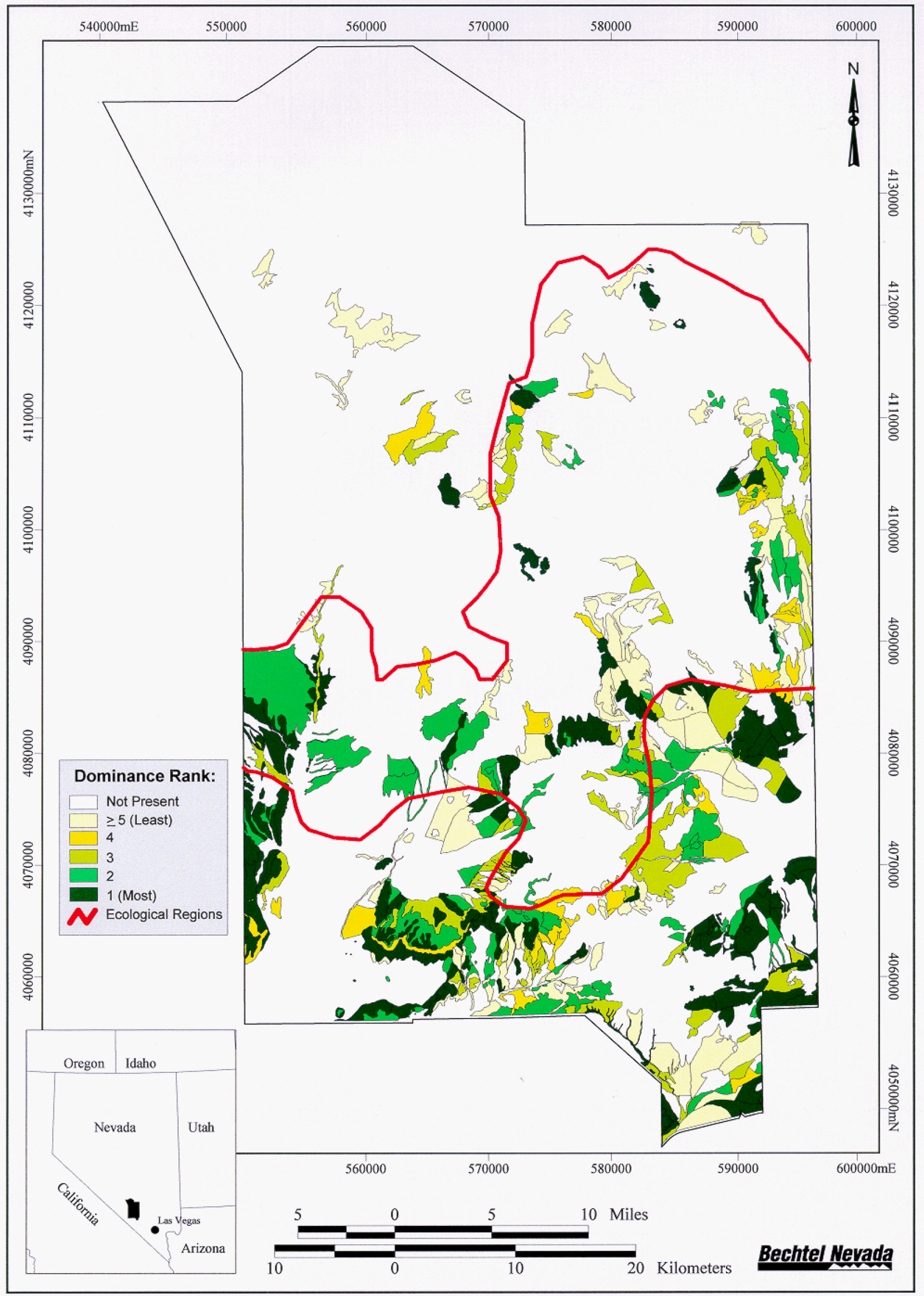

Figure 6-46 Relative ranking of dominance of Eriogonum inflatum on the Nevada Test Site 


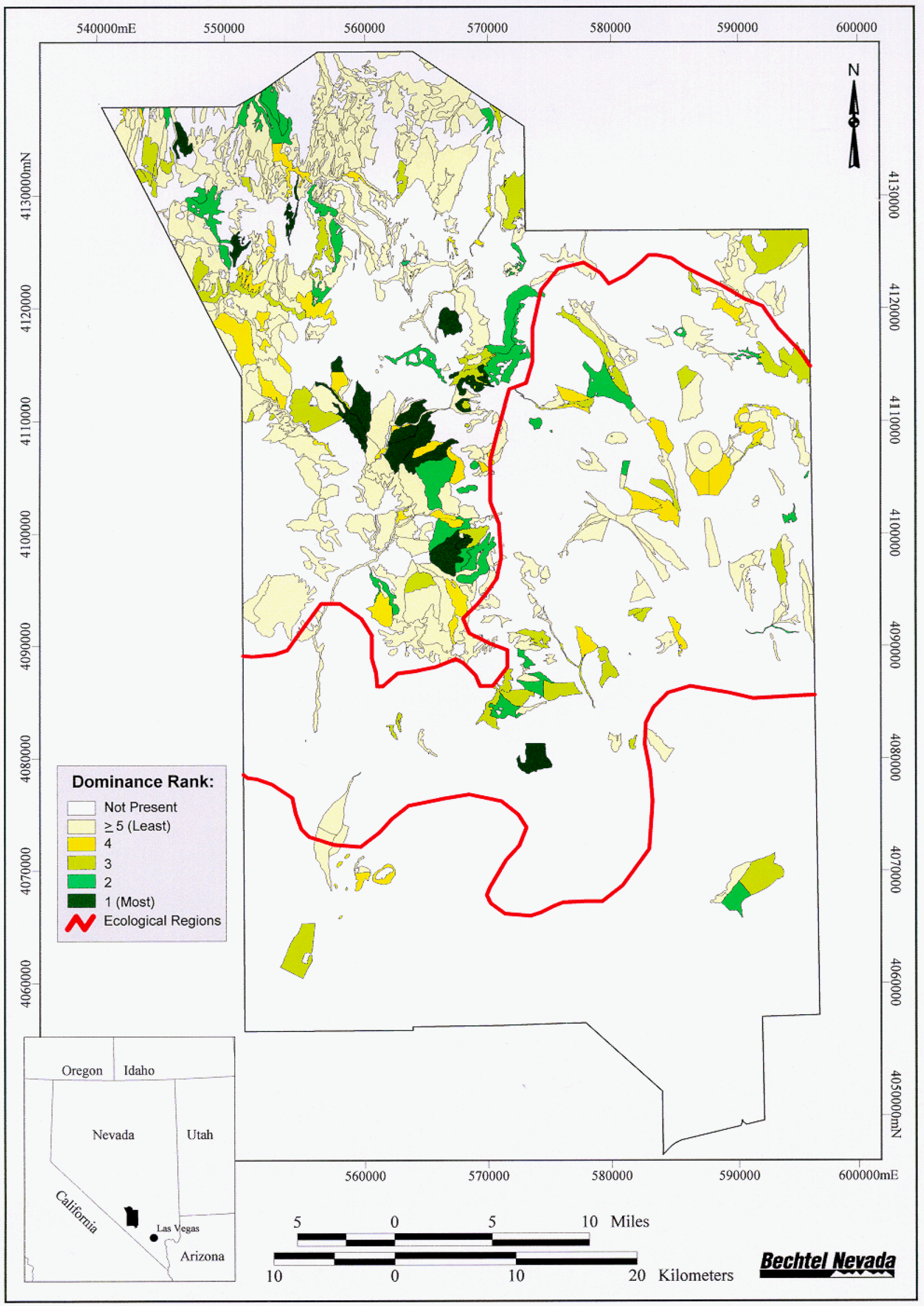

Figure 6-47 Relative ranking of dominance of Machaeranthera canescens ssp. canescens on the Nevada Test Site 


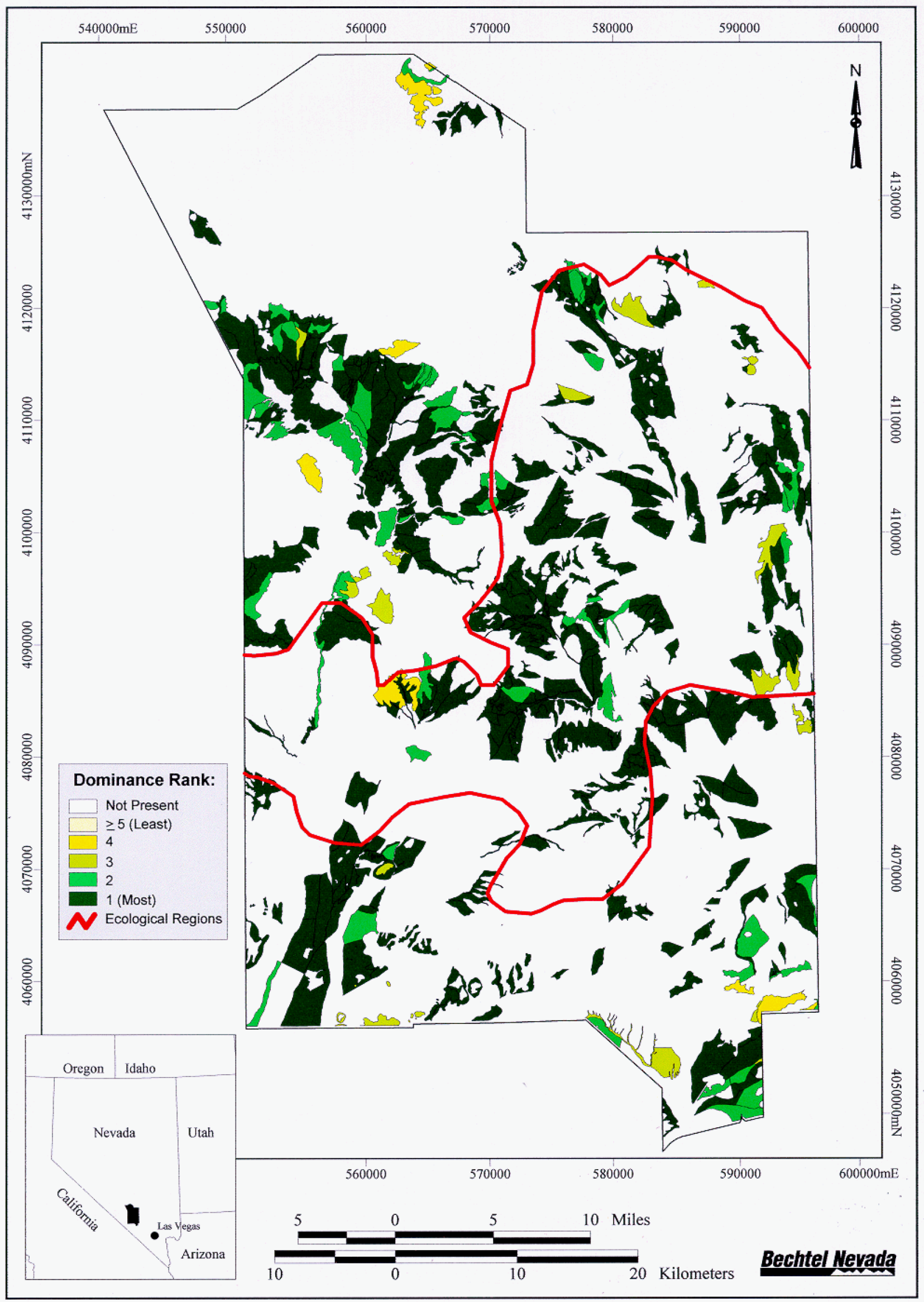

Figure 6-48 Relative ranking of dominance of Opuntia echinocarpa var. echinocarpa on the Nevada Test Site 


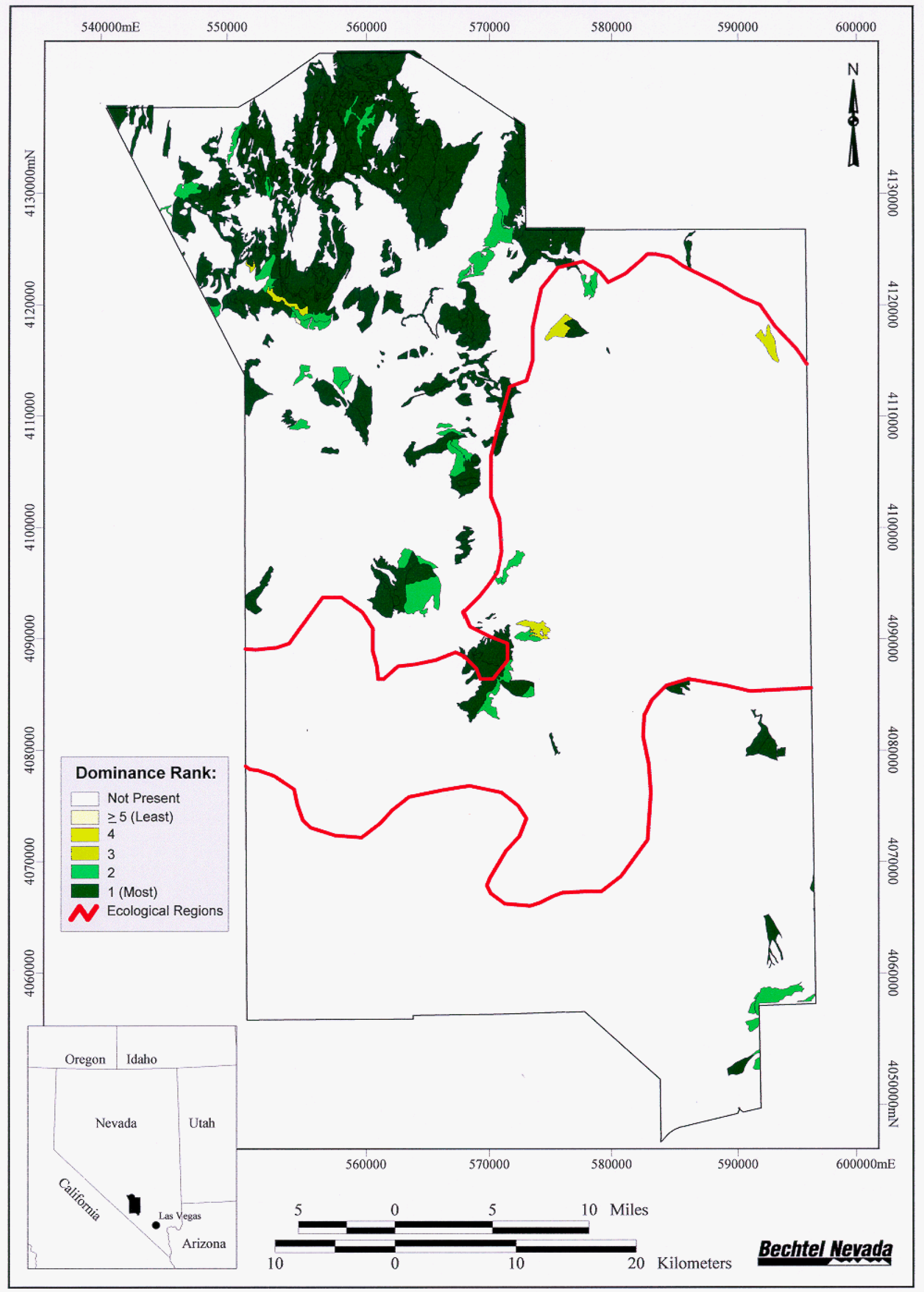

Figure 6-49 Relative ranking of dominance of Opuntia erinacea var. erinacea on the Nevada Test Site 


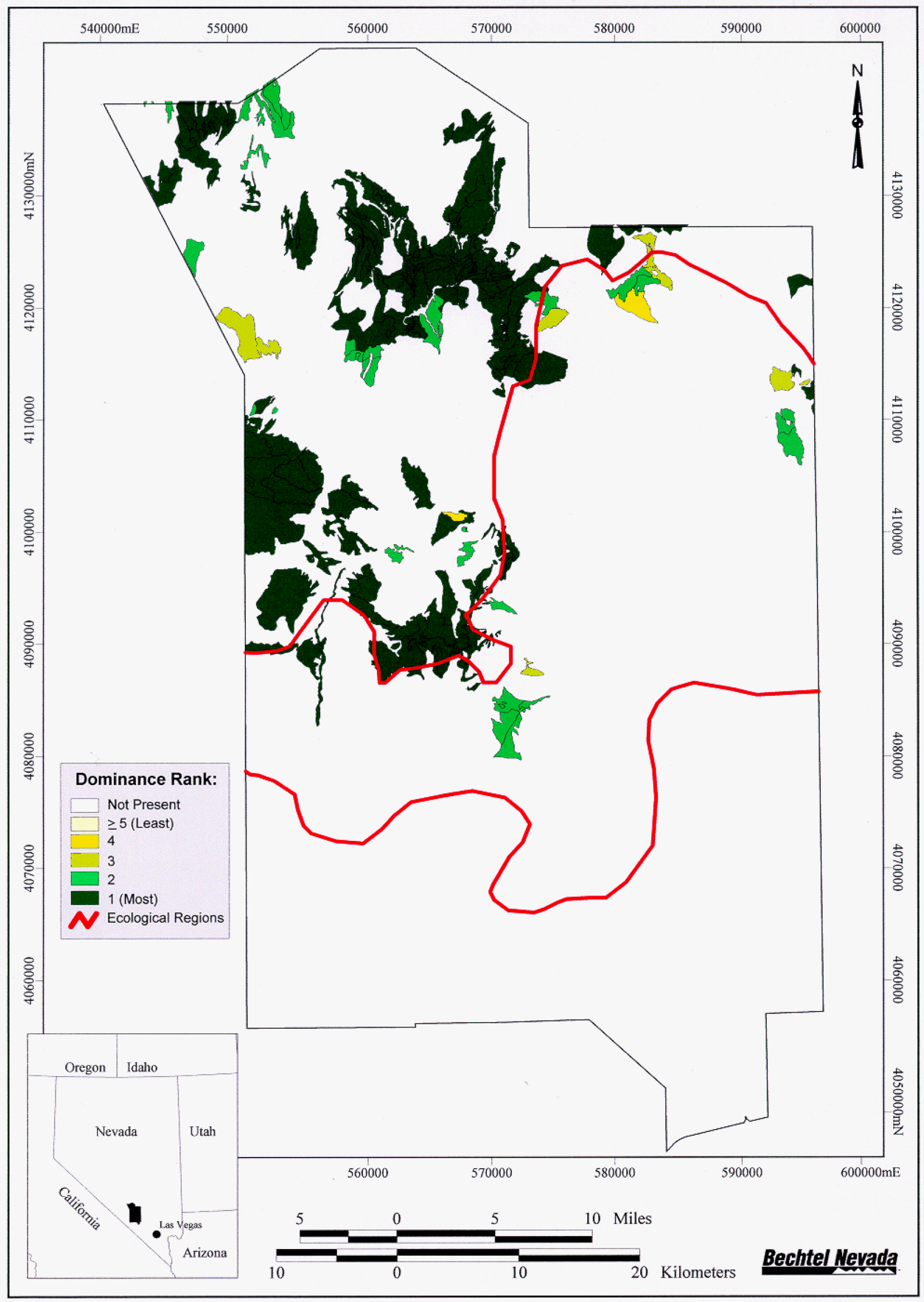

Figure 6-50 Relative ranking of dominance of Opuntia polyacantha var. rufispina on the Nevada Test Site 


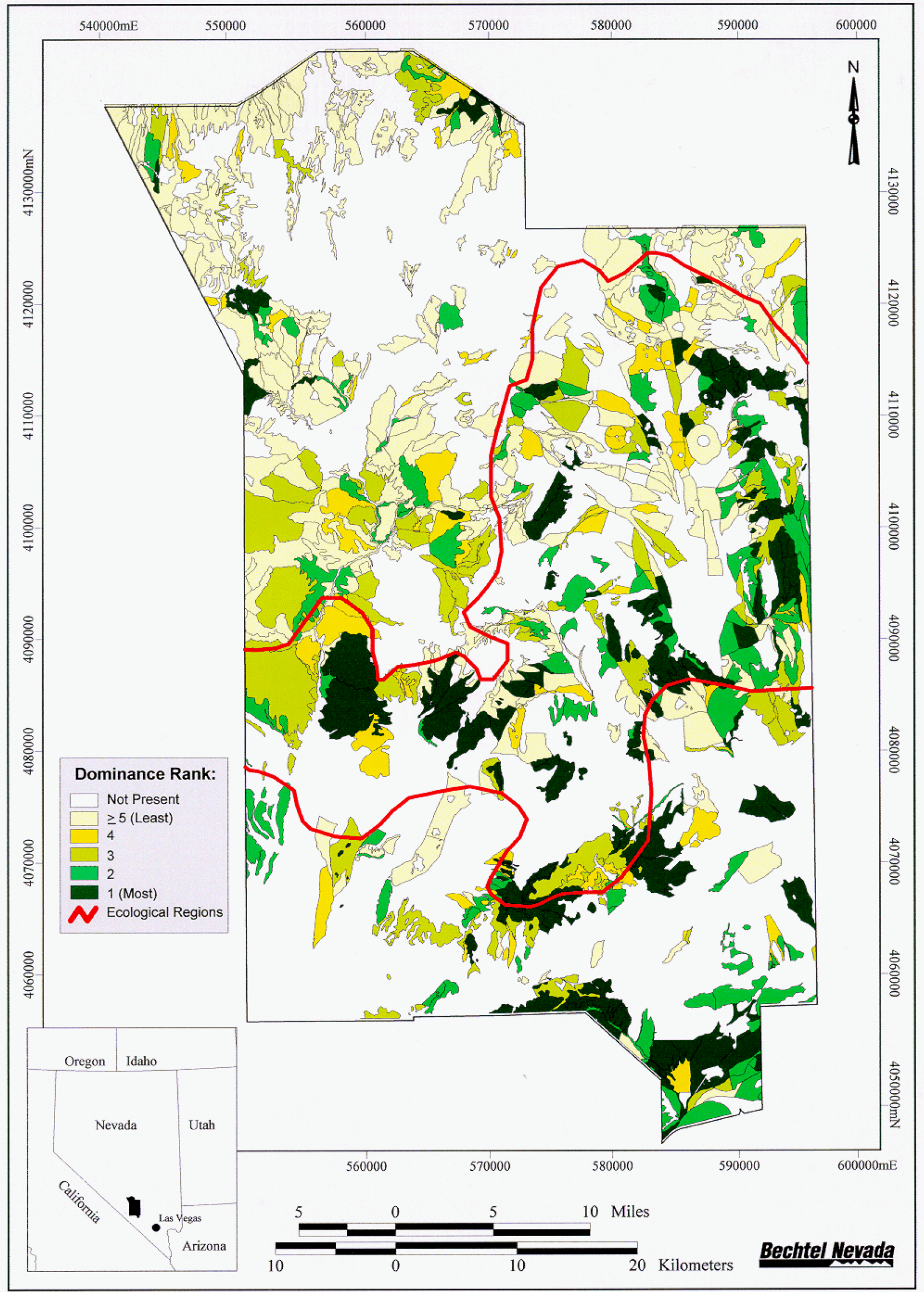

Figure 6-51 Relative ranking of dominance of Sphaeralcea ambigua ssp. ambigua on the Nevada Test Site 
This Page Intentionally Left Blank 